\title{
EFFEGTS OF ABANDONED MINE LAND RECLAMATION ON GROUND AND SURFAGE WATER QUALITY: RESEARCH AND CASE HISTORIES FROM INDIANA
}
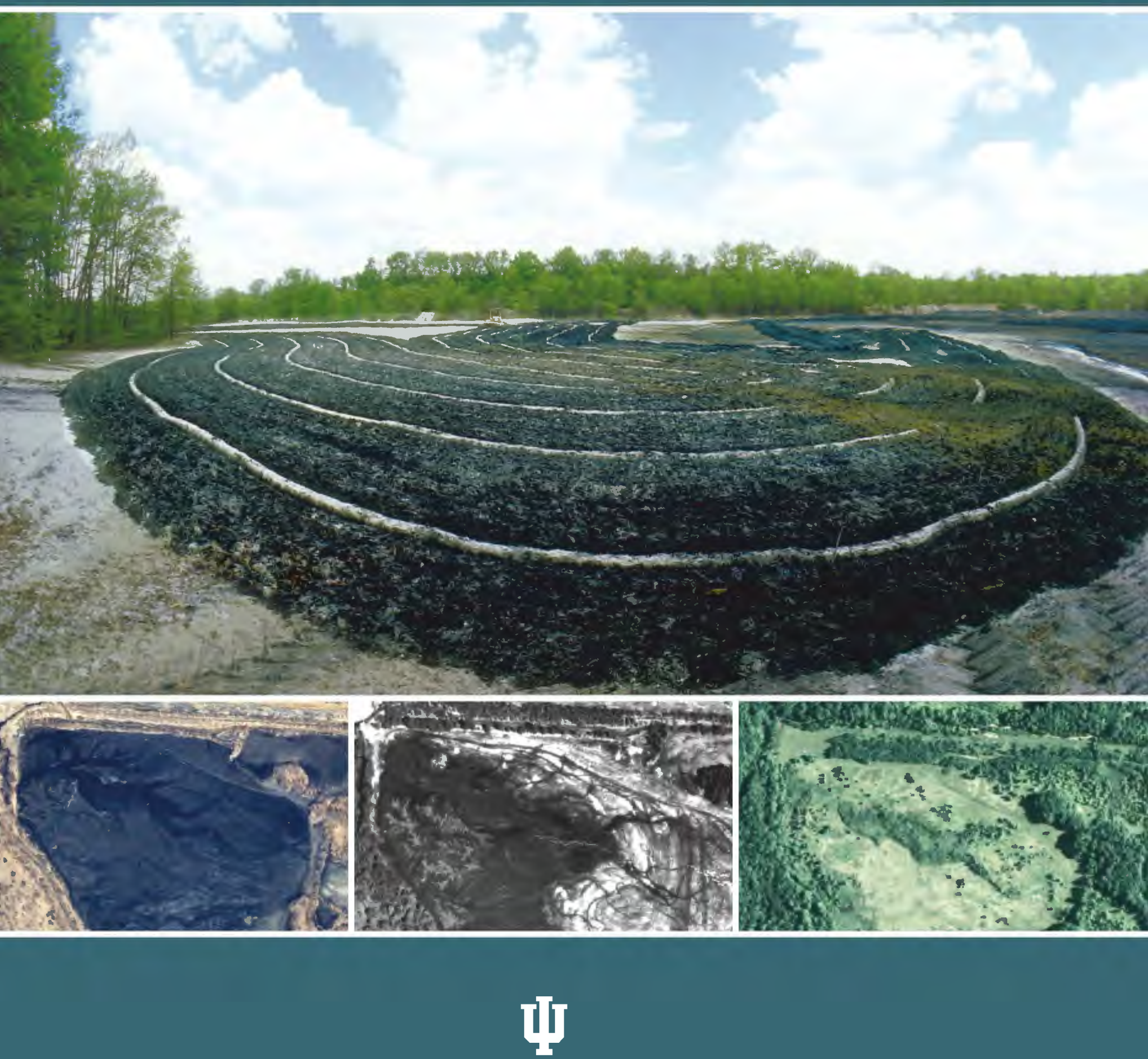

INDIANA

GEOLOGICAL SURVEY 


\section{Indiana Geological Survey Staff}

\section{Administration}

812.855.5067

Todd A. Thompson, Director and State Geologist

Tisa L. Bowden, Assistant Director for Business Affairs

\section{Division of Business Affairs}

812.855 .6446

Tisa L. Bowden, Assistant Director

Sherry K. Cazee, Administrative Support

Janis D. Fox, Publication Sales Supervisor

\section{Division of Information Services}

812.855 .3951

Richard T. Hill, Assistant Director

Michael S. Daniels, Systems Analyst/Programmer

Deborah A. DeChurch, Senior Editor

Chris R. Dintaman, Geologist and GIS Specialist

Kathleen M. Griffin, Network Support Specialist

\section{Division of Research}

812.855 .7428

Todd A. Thompson, Acting Assistant Director

Robert J. Autio, Geologic Field Assistant

Tracy D. Branam, Geochemist

Agnieszka Drobniak, Coal Geologist

Kevin M. Ellett, Senior Research Geophysicist/Hydrologist

Nancy R. Hasenmueller, Environmental Geologist

Walter A. Hasenmueller, Geologist

Barbara T. Hill, Photography and Imaging Coordinator

Sally L. Letsinger, Hydrogeologist

Henry M. Loope, Glacial Geologist
Richard T. Hill, Assistant Director for Information Services

DeAnn S. Reinhart, Licensed Professional Geologists Coordinator; Administrative Support

Donna M. Webb, Contracts and Grants Coordinator; Administrative Support

Matthew R. Johnson, Cartographic Coordinator Drew M. Packman, Laboratory and Field Assistant

Kevin P. Russell, Cartographic Analyst

Kathryn R. Shaffer, Minerals Statistician

Polly Sturgeon, Educational Outreach Coordinator
Maria D. Mastalerz, Coal Geologist

Patrick I. McLaughlin, Geologist

Cristian R. Medina, Research Geologist

Rebecca A. Meyer, GIS/Database Analyst

G. William Monaghan, Geologist

Shawn C. Naylor, Hydrogeologist

John A. Rupp, Senior Research Geologist

Robin F. Rupp, Geologist

John C. Steinmetz, State Geologist emeritus

Charles W. Zuppann, Petroleum Geologist

\section{Center for Geospatial Data Analysis $\quad \mathbf{8 1 2 . 8 5 5 . 5 0 6 7}$}

Shawn C. Naylor, Center Director; Hydrogeologist

\section{Research Affiliates}

Philip Ames

David L. Dilcher

Henry H. Gray

\author{
Edward W. Herrmann \\ Brian D. Keith \\ Richard W. Lahann
}

Greg A. Olyphant

Richard L. Powell

Licia A. Weber 


\section{EFFECTS OF ABANDONED MINE LAND RECLAMATION ON GROUND AND SURFACE WATER QUALITY: RESEARCH AND CASE HISTORIES FROM INDIANA}

Edited by John B. Comer

Indiana University

Indiana Geological Survey Special Report 72

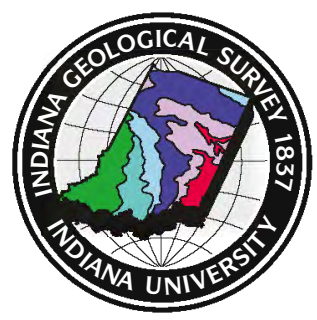


Generous contributions from the following sponsors allowed this volume to be published in color:

\section{Office of the Vice Provost for Research, Indiana University}

Indiana Department of Natural Resources, Division of Reclamation

Peabody Energy, Inc.

Solar Sources, Inc.

United Minerals, LLC

U.S. Office of Surface Mining Reclamation and Enforcement, Mid-Continent Region

Vigo Coal Operating Company, Inc.

\section{AUTHORS}

E. Randall Bayless, U.S. Geological Survey

Paul T. Behum, U.S. Office of Surface Mining Reclamation and Enforcement, Mid-Continent Region

Sandra S. Brake, Department of Earth and Environmental Systems, Indiana State University

Tracy D. Branam, Indiana Geological Survey

John B. Comer, Indiana Geological Survey (retired)

Erika R. Elswick, Department of Geological Sciences, Indiana University

Margaret V. Ennis, Indiana Geological Survey (retired)

Adam E. Flege, Apex Companies, LLC

Denver Harper, Indiana Geological Survey (retired)

Stephen T. Hasiotis, Department of Geology, University of Kansas

Dan R. Hause, Indiana Department of Natural Resources, Division of Reclamation

J. Barry Maynard, Department of Geology, University of Cincinnati

Shawn C. Naylor, Indiana Geological Survey

Greg A. Olyphant, Department of Geological Sciences, Indiana University and Indiana Geological Survey Jeanette K. Pope, Department of Geosciences, DePauw University

Nelson R. Shaffer, Indiana Geological Survey

Ronald T. Smith, Indiana Geological Survey

Mark A. Stacy, Indiana Department of Natural Resources, Division of Reclamation

Bruce A. Stevens, Indiana Department of Natural Resources, Division of Reclamation

Licia A. Weber, Indiana Geological Survey 


\section{CONTENTS}

Preface

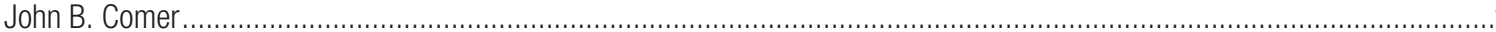

Overview of Indiana's Abandoned Mine Land Program and

Review of Environmental Challenges and Goals

Bruce A. Stevens

Indiana's Coal Mine Information System

Licia A. Weber

Reuses of Mined Land

Nelson R. Shaffer.....

Direct Revegetation and the Sustainability of Reclaimed Mine Lands:

The Story of the Friar Tuck Site, Indiana

Denver Harper, Greg A. Olyphant, and Tracy D. Branam

Effectiveness of Emerging Reclamation Methods

at an Abandoned Mine Land Site in Pike County, Indiana

Tracy D. Branam, Denver Harper, Ronald T. Smith, and Shawn C. Naylor

Impacts of Abandoned Mine Land Reclamation on Water Quality

within the South Fork Patoka River Watershed

Mark A. Stacy

Passive Treatment of Large-Flow, Net Acid Mine Drainage:

The Enos Reclamation Project, Indiana

Paul T. Behum, Dan R. Hause, Mark A. Stacy and Tracy D. Branam

Effects of Reclamation on the Water Quality of Augusta Lake

and Mill Creek, Pike County, Indiana

John B. Comer, Ronald T. Smith, Margaret V. Ennis, and Tracy D. Branam

Metals Removal in Acid Mine Drainage Wetlands

Ronald T. Smith.

The Role of Efflorescent Sulfate Salts in Indiana's Mine Water Quality

Jeanette K. Pope, E. Randall Bayless, Greg A. Olyphant, and Tracy D. Branam

Potential Metal Attenuation by Eukaryote-Dominated Biofilm Communities

in Acid Mine Drainage at the Green Valley Coal Mine Site, Indiana

Sandra S. Brake and Stephen T. Hasiotis.....

Sulfur Isotopes as Indicators of Remediation Efficacy in Constructed Wetlands

Receiving Acid Mine Drainage

Adam E. Flege, J. Barry Maynard, and Erika R. Elswick.

Passive Treatment of Low-pH, High-Aluminum Acid Mine Drainage:

A Critical Review of Sulfate-Reducing Bioreactor Technology

Paul T. Behum 


\section{PREFACE by John B. Comer}

Reclamation activities during the past few decades have provided numerous opportunities to gauge the effectiveness of various remediation designs and to conduct field experiments to quantify the impact of these efforts on water quality and hydrology. Studies conducted at Indiana mine sites and controlled experiments performed in the laboratory simulating these sites have produced considerable data and provided important insights into what processes are effective in converting barren land to productive uses and reducing the outflow of acid mine drainage that leaches toxic metals from mine refuse and overburden, sterilizes downstream water bodies, and contaminates downgradient aquifers. This volume gathers together under one cover the information learned and the insights gained over a period of decades by researchers at the Indiana Geological Survey and their colleagues who have studied the natural processes and environmental impacts of mine land reclamation.

Thirteen articles were contributed by 20 authors from federal and state agencies, private industry, and university research institutes and academic departments. The volume begins with three overviews. Stevens describes Indiana's Abandoned Mine Land Program, discusses the environmental impacts of abandoned coal mines, and reviews the AML Program's goals, accomplishments, and future directions. Weber describes the history and current status of the Indiana Geological Survey's Web-based Coal Mine Information System, a digital inventory of Indiana's surface and underground coal mines. The paper by Shaffer presents a look back and a look forward at the reuses of mined land and offers a number of innovative reuses that may be possible with appropriate planning and technological development.

The next five articles are case studies describing environmental impacts at specific coal mine reclamation sites. The history of reclamation at the Friar Tuck mine site, which straddles the Sullivan and Greene County line near Dugger, Indiana, is described by Harper and others. The site is one of the most complexly disturbed areas in the state and has experienced several phases of reclamation over a period of decades. By the early 1990s, reclamation efforts mostly succeeded in revegetating barren areas, reducing erosion, improving surface-water quality, and creating wildlife habitat. However, acid mine drainage from the site remains a problem. The authors use their experience at this site to discuss the long-term sustainability of reclaimed mine land.

Reclamation at the Midwestern abandoned mine site in Pike County, the first in Indiana using coal combustion byproducts (ash and fixated scrubber sludge), is presented in Branam and others. A 7.9-acre gob pile that generated extremely acidic water was capped with fixated scrubber sludge, successfully preventing infiltration of rainwater into the gob and reducing acid outflow. Leaching of metals from the ash and fixated scrubber sludge was evaluated and the data show that these materials did not degrade the quality of water leaving the site. A decade of monitoring has documented that water flowing from the site had lower acidity, iron, and aluminum concentrations and substantial alkalinity after reclamation.

Nine reclamation projects that dramatically improved the quality of water in the South Fork Patoka River watershed are documented by Stacy. These projects, which were funded by the Indiana Abandoned Mine Land Program during the last 20 years, reclaimed 1,541 acres of land disturbed by mining. Prior to this effort, the South Fork was considered the most severely affected stream in Indiana. Monitoring shows that water leaving each site had higher $\mathrm{pH}$ and alkalinity and lower acidity, iron, manganese, and sulfate after reclamation was completed.

The paper by Behum and others describes reclamation designed to improve the quality of highly acidic, metal-rich water discharged from the 200acre Enos gob pile and coal slurry deposits located near the South Fork Patoka River in Pike County. The constructions include a long drainageway that gathers all the acid mine drainage flowing from the gob and slurry, a large wetland that receives both the acid drainage and net alkaline dilution water from a separate impoundment, a collection pond that serves as a gathering point for the pretreated acid mine drainage, two vertical flow ponds (one with a limestone base, the other with a dolomite base) designed to increase alkalinity and decrease metals and sulfate, oxidation ponds to promote oxidation and precipitation of iron, and two large final-stage aerobic wetlands to further sequester metals. The vertical flow ponds were constructed to operate in parallel and receive pretreated acid mine drainage from a single source at the same flow rates so that their performances could be compared. The report documents changes in water quality at several sites along the flow path and discusses benefits and shortcomings of the various components of the treatment system.

The article by Comer and others documents improvements in the quality of water in Augusta Lake and Mill Creek that were accomplished by a variety of reclamation projects involving a number of different remediation strategies. These water bodies 
are located in Pike County, where acid mine drainage from coal mine refuse and spoil has degraded primary source tributaries that enter the Patoka River and adversely affected the water supplies of municipalities in the region. Water-quality data dating back to 1949 are presented and evaluated and these data are available in spreadsheet files on the $\mathrm{CD}$ that accompanies this volume.

The following three papers represent more innovative applied research based on data gathered at mine reclamation sites in Indiana. Smith's article documents the removal of metals from acid mine drainage in four constructed treatment wetlands. The partitioning of metals, including federally regulated toxic metals, is documented for acid mine drainage entering and leaving the wetlands and for wetland sediments at several locations along the effluent flow path. Of particular interest are the data documenting the accumulation of metals in wetland plants and the identification of plant tissues in which metals preferentially accumulate. This paper will be useful to land-use planners because it documents metal loads and potential toxicity for wetland sediments.

The significance of efflorescent sulfate salts that form when acid mine drainage evaporates is discussed by Pope and others. These salts contain a variety of metals in varying concentrations and they are chemically and structurally complex. They are highly soluble and cause abrupt deterioration of surface-water quality, including a sudden drop in $\mathrm{pH}$ and the release of metals, during storm flushes. This study shows that the chemistry of water affected by these salts depends on the chemical composition and history of the mine refuse pile with which they are associated. Failure to account for efflorescent sulfate salts during reclamation may lead to persistent acid mine drainage caused by their dissolution and may diminish the effectiveness of the remediation effort.

The role of eukaryotic microorganisms in remediating acid mine drainage is documented by Brake and Hasiotis. The microorganisms Euglena mutabilis, the diatom genus Nitzschia, and filamentous algae were observed living in acid mine drainage at the Green Valley Coal Mine in Vigo County, Indiana. They thrive in acid mine drainage channels where each dominates at different times of the year. These organisms take in iron and other contaminants as a means of detoxifying the cytoplasm, actively and passively accumulate iron phases on cell walls and membranes, precipitate iron and other elements through oxygenic photosynthesis, release iron granules and crusts after death that act as nucleation sites where additional iron minerals pre- cipitate, and biostabilize metal-rich chemical sediments through trapping and binding in filamentous biofilms and mucilage. The authors suggest that the beneficial effects of these microorganisms can be incorporated into the design of mine waste treatment systems. The authors also note that these same microbial processes may have operated early in Earth's history leading to the deposition of Precambrian iron formations and oxygenation of the atmosphere.

The final two articles focus on bacterial sulfate reduction as applied to acid mine drainage mitigation. Bacterial processes convert sulfate to sulfide, which reacts with metals to form stable precipitates that remain sequestered in the sediment. Flege and others demonstrate the advantages of using sulfur isotopes to measure the extent of sulfate reduction in constructed wetlands and to evaluate the effectiveness of wetland performance. Behum presents a detailed review of state-of-the-art technology and the design of sulfate-reducing bioreactors constructed to remediate acid mine drainage.

These thirteen papers represent the range of projects and the breadth of research being undertaken in Indiana's mine lands. By compiling them in one volume we hope that they will be easily accessible to the widest variety of interest groups. We also hope that the insights presented and the data included in the printed volume and on the accompanying CD-ROM will be useful to those who design and construct mine reclamation projects and to researchers actively involved in developing and refining today's and tomorrow's reclamation technologies.

The technical editor gratefully acknowledges the work of the Indiana Geological Survey editor, Deborah A. DeChurch, who oversaw the formatting and production of this volume and the accompanying CD-ROM. Figures were formatted by staff of the Graphics and Cartography group and the Photography and Imaging Section of the Indiana Geological Survey. The encouragement of the Indiana State Geologist, John C. Steinmetz, was key to the development and completion of this publication project and I am especially grateful for his support. Generous contributions from the following sponsors allowed this volume to be published in full color: Office of the Vice Provost for Research, Indiana University; Indiana Department of Natural Resources, Division of Reclamation; Peabody Energy, Inc.; Solar Sources, Inc.; United Minerals, LLC; U.S. Office of Surface Mining Reclamation and Enforcement, Mid-Continent Region; Vigo Coal Operating Company, Inc. 


\title{
Overview of Indiana's Abandoned Mine Land Program and Review of Environmental Challenges and Goals
}

\author{
Bruce A. Stevens \\ Indiana Department of Natural Resources, Division of Reclamation
}

\begin{abstract}
The Indiana Abandoned Mine Land Program was mandated when the United States Congress passed the Surface Mining Control and Reclamation Act in 1977. The Indiana Abandoned Mine Land Program was approved by the Department of Interior's Office of Surface Mining Reclamation and Enforcement in 1982 and its work is funded by fees collected from coal mining in Indiana. At its inception, the Indiana Abandoned Mine Land Program moved quickly to eliminate public safety hazards located in abandoned coal mines. Miles of guardrail were placed along public roads adjacent to unstable highwalls, dozens of open mine shafts were filled, and many open pits that had been used as trash dumps were cleaned up. Impoundments of acidic water have been successfully treated by directly applying chemicals such as hydrated lime and sodium hydroxide.
\end{abstract}

Treatment of chronic acid mine drainage requires thorough site evaluation and typically involves installation of multiple passive treatment systems such as aerobic and anaerobic wetlands, anoxic limestone drains, vertical flow ponds, and sulfate-reducing bioreactors. These systems promote the neutralization of acid, the removal of sulfate, and the deposition of toxic metals as acidic mine water passes through them. Although the cost of projects has increased since the Program's inception, success in remediating severe environmental impacts has improved significantly because of steady progress in understanding specific challenges in Indiana's abandoned mine land settings and because of continuing scientific and technological advances.

Future work will be required to maintain previously installed acid mine drainage treatment systems, improve the water quality of persistent acid seeps, mitigate hazardous emissions of methane and carbon dioxide from reclaimed mine sites, and remediate land subsidence and shaft failure in abandoned mine lands. The Indiana Abandoned Mine Land Program will provide an important public service as it continues to address these issues. 


\section{BACKGROUND}

\section{Inception of Abandoned Mine Land Program}

The federal Abandoned Mine Land (AML) Program came into being in 1977 with the passage by the United States Congress of the Surface Mining Control and Reclamation Act (SMCRA) (OSMRE, 2009). This law authorized the creation of the Office of Surface Mining Reclamation and Enforcement (OSMRE) under the Department of the Interior to administer the programs and regulations required by the Act, to oversee the funding for the AML Program, and to approve and assist state AML programs. The AML Program for Indiana was approved by OSMRE in 1982.

The federal AML Program provides funding for the proper reclamation of any coal mine site if the site has public safety, health, and environmental hazards resulting from past coal mining practices. Eligible sites are those that were mined for coal prior to August 3, 1977, and experienced occurrences of (1) mine-related deaths, serious personal injury, or where such occurrences appear imminent; (2) sites that adversely affect the public safety, health, or general welfare; and (3) sites that continue to cause environmental degradation. The funding for the AML Program comes from a fee paid by coal operators for each ton of coal produced during mining. Administrative expenses and costs for the construction of AML projects are reimbursed to the state through annual grants from the OSMRE.

\section{Scope of Indiana's AML Program}

According to the Final Environmental Statement (OSMRE, 1980) for the federal Abandoned Mine Lands Program, abandoned coal-mined areas alone have contributed to the environmental degradation of about one million acres across the nation. A much larger area of degradation was believed to exist because offsite problems caused by unreclaimed or inadequately reclaimed mine lands were not included in this estimate. While considering legislation for regulating coal mining in the 1970s, Congress determined that more than 1.5 million acres $(607,000$ hectares [ha]) of land in the nation had been directly disturbed by coal mining and more than 11,500 miles $(18,500 \mathrm{~km})$ of streams had been polluted by sedimentation or acidity from surface or underground coal mines. The report (OSMRE, 1980, Table 6, p. III-13) estimated that surface coal mining operations in Indiana resulted in 32,700 acres (13,233 ha) of abandoned mine land from 1930 to 1971. A review of the Indiana Geological Survey's Coal Mine Information System (IGS, 2009) indicates there are over 130,000 acres $(52,609 \mathrm{ha})$ of pre-SMCRA surface mines in Indiana.

Since 1982, the federal Abandoned Mine Land Program has provided more than 130 million dollars to the state of Indiana (Table 1) to correct and remedy public health, safety, and environmental problems resulting from the mining that took place prior to the reclamation standards required by SMCRA. Although costs to perform AML projects have increased because of increased costs of equipment, materials, and labor, the success of projects has improved significantly as a result of the efforts of many individuals within the Program and its local, state, and federal partners. Much of this improved success has resulted from scientific and technological advances that have evolved since

Table 1. Indiana Abandoned Mine Land Program projects and program construction expenditures through March 2012

\begin{tabular}{|l|c|c|}
\hline County & Number of sites & $\begin{array}{c}\text { Cost } \\
\text { (\$) }\end{array}$ \\
\hline Clay & 210 & $6,858,154$ \\
\hline Daviess & 28 & $4,583,789$ \\
\hline Dubois & 15 & 89,255 \\
\hline Fountain & 4 & 15,776 \\
\hline Gibson & 9 & 253,243 \\
\hline Greene & 150 & $8,824,989$ \\
\hline Knox & 33 & $11,943,740$ \\
\hline Martin & 7 & $1,542,795$ \\
\hline Owen & 5 & 17,289 \\
\hline Parke & 29 & 508,152 \\
\hline Perry & 7 & 372,136 \\
\hline Pike & 95 & $32,192,200$ \\
\hline Spencer & 28 & $2,016,225$ \\
\hline Sullivan & 107 & $10,016,226$ \\
\hline Vermillion & 25 & $1,084,330$ \\
\hline Vigo & 134 & $21,943,898$ \\
\hline Warrick & 173 & $28,945,691$ \\
\hline Total & 1,059 & $131,673,289$ \\
\hline
\end{tabular}


the time of the Program's inception and includes the use of alternative treatment methods to treat acidic drainage that resulted from previous coal mining activities.

\section{Coal production in Indiana}

Indiana's coal-producing region is located in the southwestern portion of the state and the coal resides in bedrock of the Pennsylvanian System (fig. 1). Coal was first discovered in Indiana along the Wabash River in 1736 (DOE, 1994) and was first reported in land surveys and located on maps in 1804 (OSMRE, 2000). By 1832, coal was being advertised for sale in many southern Indiana newspapers and by 1840 small quantities of coal were being shipped in flat boats from locations along the Ohio, Wabash, and White Rivers (OSMRE, 2000). Early mining was on a small scale and first accomplished along the outcrop using pick and shovel and later by horse and scraper (OSMRE, 2000). The first coal company was officially incorporated and granted a charter by the state of Indiana in 1837 (DOE, 1994) and the state's first underground mine shaft was constructed in 1850 at Newburgh, Indiana (OSMRE, 2000). Indiana's annual coal production rose rapidly from almost 9,700 tons in 1840 to more than 30 million tons in 1918 at the end of World War I (OSMRE, 2000).

In the middle 1800s, coal was produced primarily by drift mining techniques where the coal was accessed from outcrops or subcrops in hillsides. Room and pillar underground mining was common at the turn of the twentieth century (Weir, 1952). Coal mining in these early days was primitive and labor intensive (Harper and others, 2003). Slope, shaft, and drift mines became common and numerous communities arose nearby to support the coal mining activities. Because transportation was slow and difficult, these communities were often immediately adjacent to, and sometimes built upon, the underground mine workings. Many of these towns still exist today and subsidence of pre-SMCRA abandoned underground mines is common where the depth of coal was shallow or the rock overlying the coal was not competent.

As the demand for energy increased because of the growing population and the nation's move toward industrialization, demand for Indiana's coal increased (Harper and others, 2003). According to the U.S. Census Bureau, what is now the state of Indiana had a population of 2,632 in 1800 (Gibson and Jung, 2002). That number grew to more than 2.5 million by 1900 and to 3.9 million by 1950 (Gibson and Jung, 2002). Underground mining increased until it peaked at over 25 million tons annually around 1920 and then began to decline as surface mining techniques were employed (Harper and others, 2003). About 1940, surface mining techniques began producing more coal than underground methods (Harper and others, 2003). There has been a resurgence of underground coal mine production in Indiana over the past decade. Of the 37.3 million tons of coal extracted in Indiana in 2011, underground methods accounted for approximately 43 percent, up from approximately 10 percent at the turn of the twenty-first century (IDNR, 2012).

During the period before SMCRA was enacted producing coal was of overriding importance and reclamation was mostly ignored to ensure that limited resources were directed to production. While the nation benefited from the increase in production, coal-producing states and landowners were left to deal with the unreclaimed land. Because of the demand for coal, lack of regulations, and absence of scientifically tested methods for reclaiming the land, the public safety and environmental consequences were severe and long lasting. The result was a significant number of dangerous and environmentally degrading mine remnants that ultimately led policymakers to enact SMCRA and create the AML Program. Because of AML program activities and the mining regulations mandated by SMCRA, many new reclamation methods have been developed and present-day mining employs technologies that minimize adverse impacts to land, air, and water.

\section{ELIGIBILITY FOR FUNDING UNDER THE INDIANA AML PROGRAM}

Abandoned mine land projects may be approved for funding if they will improve public safety, health, and environmental conditions at pre-SMCRA coal mine sites (IDNR, 2009). Conditions at abandoned mine sites that meet eligibility requirements include the following subject headings. 


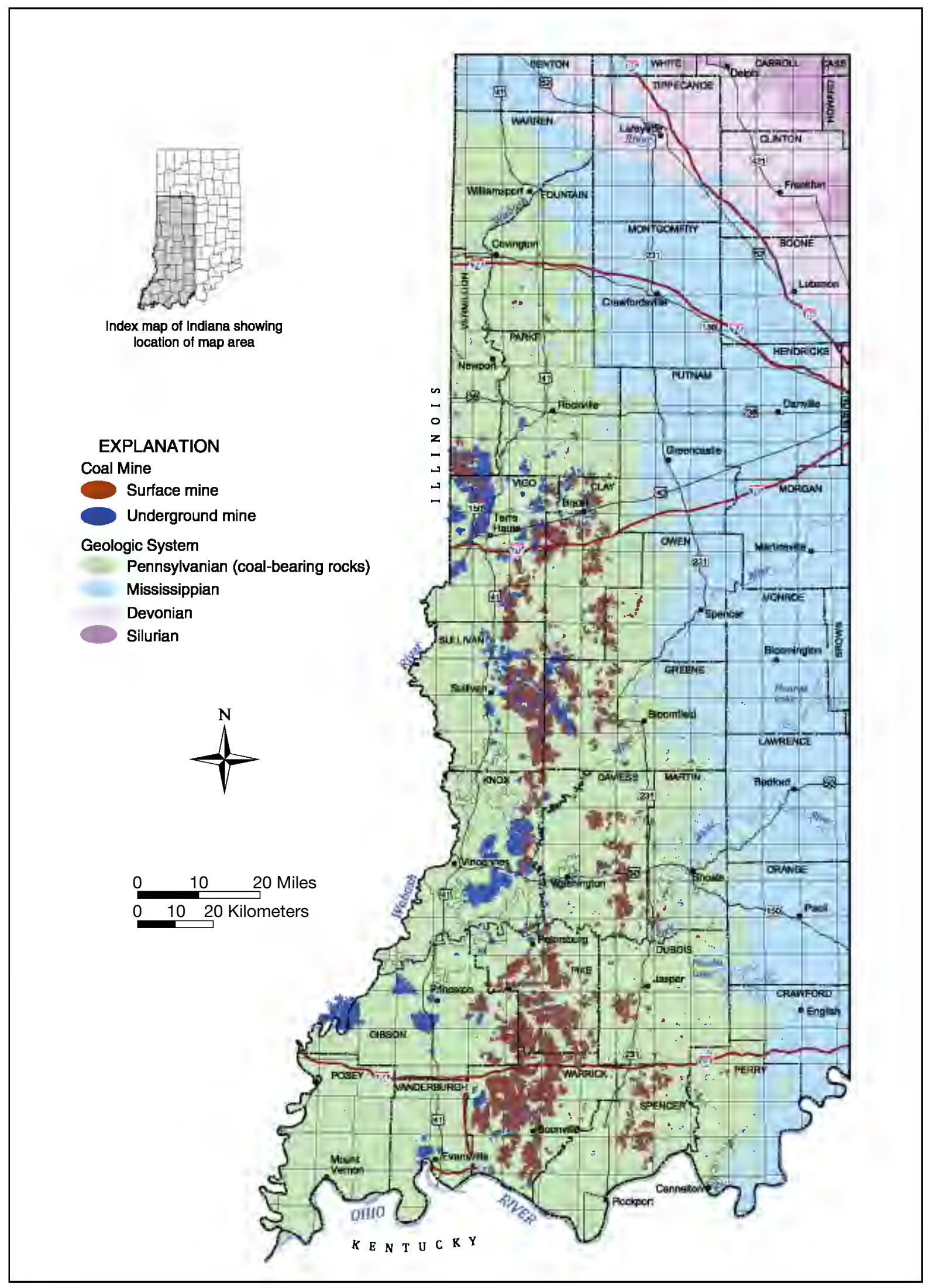

Figure 1. Map showing locations of surface and underground mines in southwestern Indiana; from Eaton and Weber (2000). 


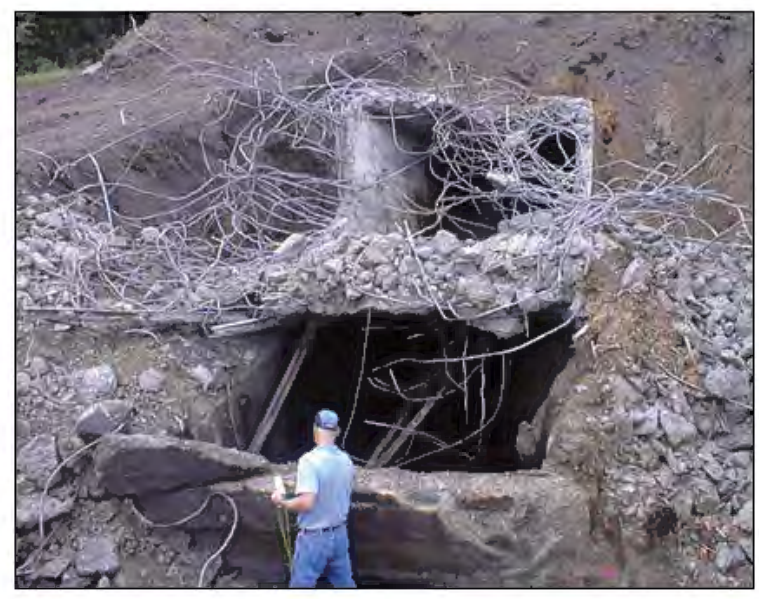

Figure 2. Photograph showing vertical entry to abandoned underground coal mine, Sullivan County, Indiana.

\section{Open vertical entries}

Open vertical entries to abandoned underground mines (fig. 2) are safety hazards as they may result in falls, especially when they are located in woods, are partially covered, or are not readily visible. These shafts and open workings can be hundreds of feet deep. If not sealed, drift entrances into underground mines can also pose serious risks as old timbers and roof rock may be very unstable and subject to collapse. Openings into underground mines afford public access and expose those who enter to oxygen deficiency, hazardous gases, and explosive mine atmospheres.

\section{Highwalls}

Highwalls (fig. 3) are potentially dangerous and unstable manmade cliffs along the boundaries of

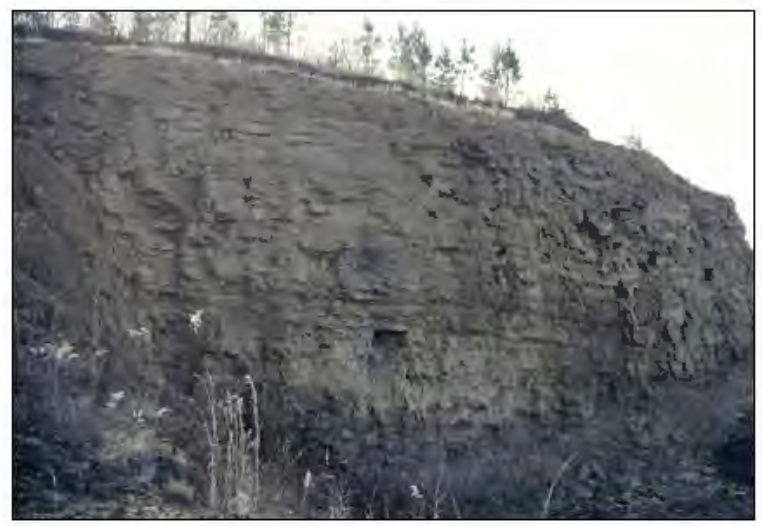

Figure 3. Photograph showing highwall from previous surface coal mining operation, Spencer County, Indiana. abandoned surface mines. They typically range in height in Indiana from $20 \mathrm{ft}(6 \mathrm{~m})$ to more than 100 $\mathrm{ft}(30.4 \mathrm{~m})$. Often highwalls exist adjacent to private housing or public roads presenting safety hazards to residents and travelers as a result of the steep slopes that are unstabilized and prone to rock falls and landslides.

\section{Physical and chemical erosion of mine spoils and coal refuse}

Erosion caused by stormwater runoff can be a severe problem, especially in the Midwest where rainfall is abundant and rainstorms are frequently heavy. Erosion occurs because the piles of mine spoils and coal refuse are often loose, highly permeable, steep-sloped, and unvegetated (fig. 4). Transported sediments may enter surrounding drainage channels, creeks, streams, and reservoirs and clogged stream channels can subsequently cause flooding. Heavy sediment loads can coat streambeds and have a profound negative impact on the health of fish and other aquatic organisms. Furthermore, mine spoils and coal refuse can be very difficult to build on because the substrate may be very unstable. During the mining operation, overburden rock and soil are removed to expose the coal and placed in previously mined areas. These materials are much looser and, therefore, much more easily eroded than the original materials. In addition, these materials can be poor growth media for plants because they often have low water-retention capacity, low $\mathrm{pH}$, low organic content, and high concentrations of toxic metals. Large numbers of pre-SMCRA surface mine sites and coal refuse disposal areas remained barren and lacked vegetative cover for decades. To return

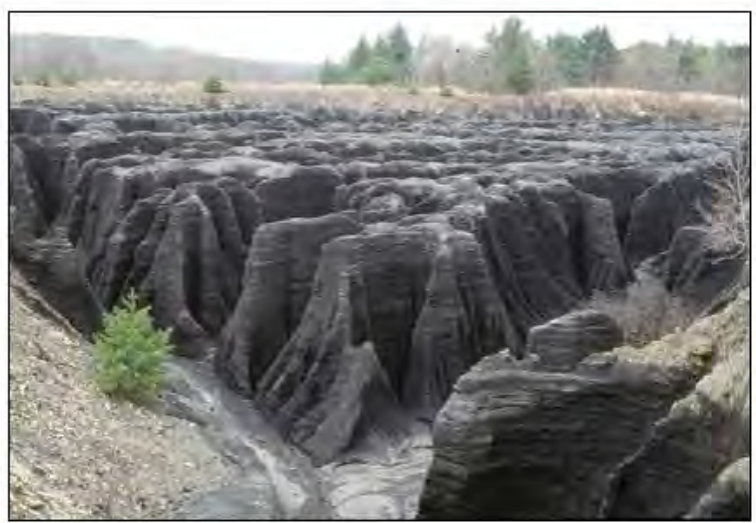

Figure 4. Photograph showing erosion of mine spoil and mine refuse, Pike County, Indiana. 
these mined lands to agricultural uses, wildlife habitat, forested areas, or native vegetation, it is often necessary to add significant amounts of amendments to neutralize acidity, fertilizers to restore basic nutrients, and organic matter to help replenish soil and increase its water-holding capacity.

\section{Abandoned buildings, structures, and mining equipment}

Abandoned buildings and equipment in dilapidated condition often are scattered around abandoned mine sites (fig. 5). Children or adults climbing on equipment or entering abandoned equipment and buildings can be subject to serious injury. Old abandoned coal preparation plants, mine hoists, mining equipment, vehicles, haul trucks, and other hardware related to the mining process may contain hazardous chemicals, such as solvents, metals, engine oils, transmission fluid, antifreeze, fuels, grease, and other lubricants, that might have been spilled or intentionally disposed at the site, thereby contaminating, soil, groundwater, and surface waters.

\section{Trash dumping}

Decades ago it was common practice for local citizens to dispose of trash and other wastes at abandoned mine sites (fig. 6). Trash placed in an abandoned pit or mine shaft may cause additional contamination concerns owing to its contact with surface water and groundwater.

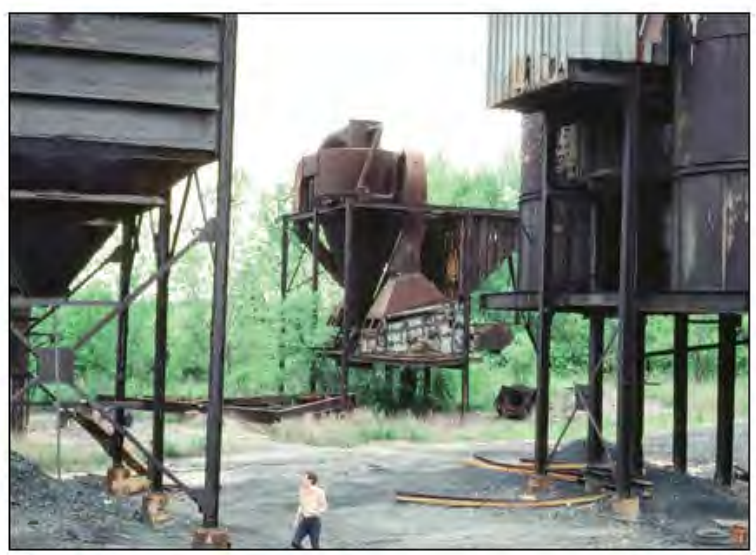

Figure 5. Photograph showing abandoned structures and equipment at previous coal mining operations in Warrick County, Indiana.

\section{Subsidence of the ground surface}

Subsidence occurs when the soil or rock above underground mine openings sinks or collapses into the mine void (figs. 7 and 8). Underground mines may have vertical shafts, slopes, drift openings, mine workings (including haulageways, and water and drainage tunnels), and other

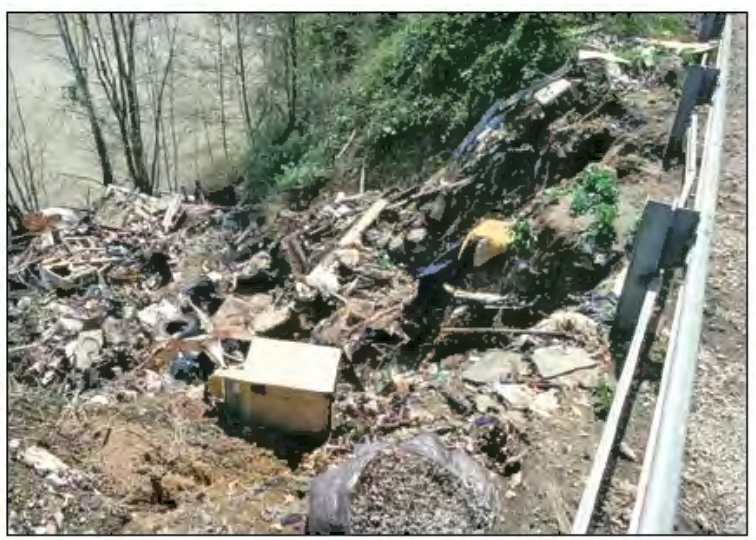

Figure 6. Photograph showing trash dumping and severe erosion at AML site immediately adjacent to county road, Greene County, Indiana.

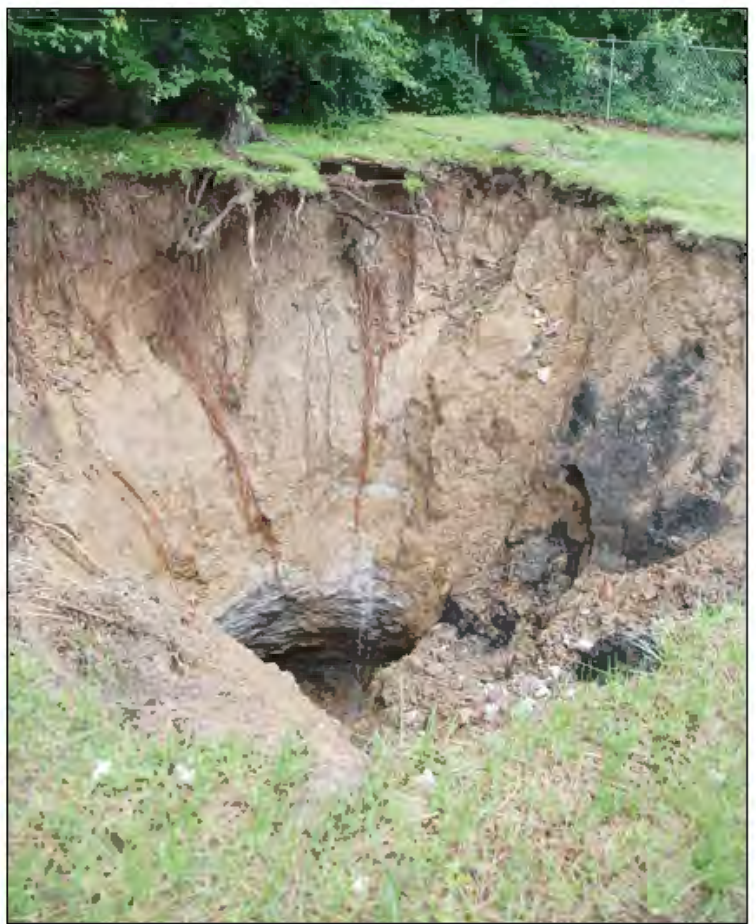

Figure 7. Photograph showing underground coal mine subsidence in residential yard, Sullivan County, Indiana. 


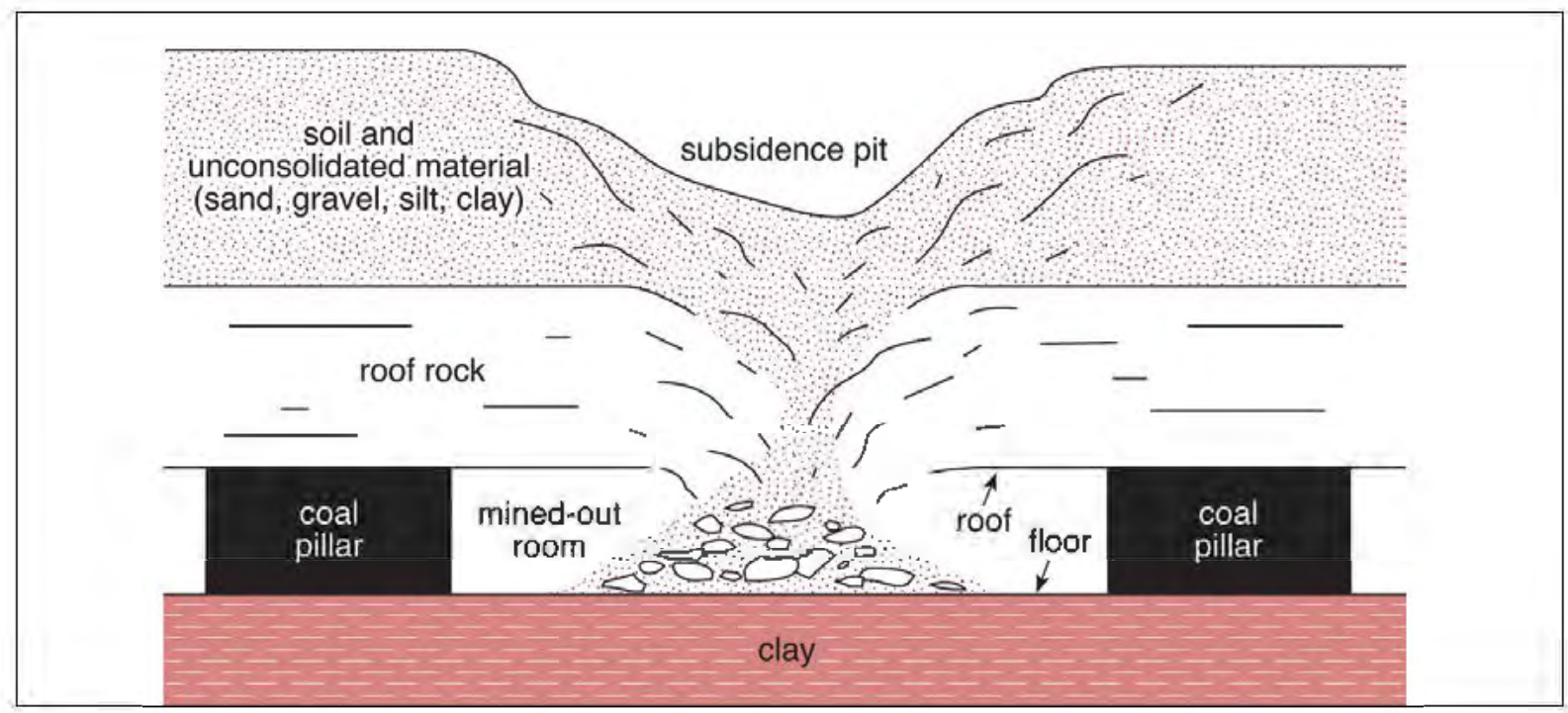

Figure 8. Diagramatic cross section illustrating typical subsidence resulting from mine roof collapse.

passageways excavated from the subsurface that are prone to subsidence. Buildings and other structures constructed on land undergoing active subsidence may crack, shift, tilt, and split. Damage to buildings can be so severe that they must be abandoned and demolished.

\section{Mine fires}

Mine fires are dangerous and commonly lead to the build-up of toxic levels of carbon dioxide and carbon monoxide (fig. 9). Underground fires may consume enough coal to cause land subsidence. Mine fires include coal seam fires and coal refuse burning; two common causes of mine fires are

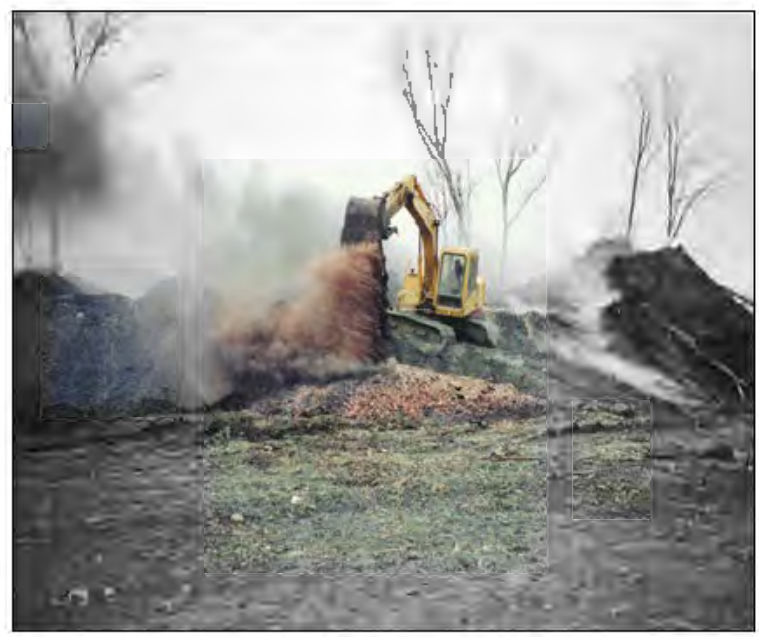

Figure 9. Photograph of a coal refuse fire, Parke County, Indiana. the burning of trash and methane gas explosions. Indiana has had a number of coal refuse fires over the years, however, underground coal seam fires have not been common.

\section{Acid mine drainage}

Acid mine drainage (AMD) is the most severe and well-recognized environmental problem related to abandoned coal mine sites and can affect surface waters, including lakes, ponds, streams, and even entire watersheds (fig. 10). AMD in Indiana is defined as water having a $\mathrm{pH}$ less than 6, commonly having high iron concentrations, and which drains from mine workings, mine spoils, and coal refuse. The low $\mathrm{pH}$ is a result of acid forming from the oxidation of sulfide minerals such as pyrite in the host rock as it is exposed to air and water. The acidic water solubilizes moderate to high concentrations of metals from disturbed overburden.

\section{ENVIRONMENTAL IMPACT OF ABANDONED COAL MINES}

Acid mine drainage is the most persistent source of environmental degradation at AML sites in Indiana and the most difficult problem to mitigate. The most severe environmental degradation caused by AMD is found at AML sites where largescale coal mining operations existed. Coal processing was commonly performed at the mine sites 


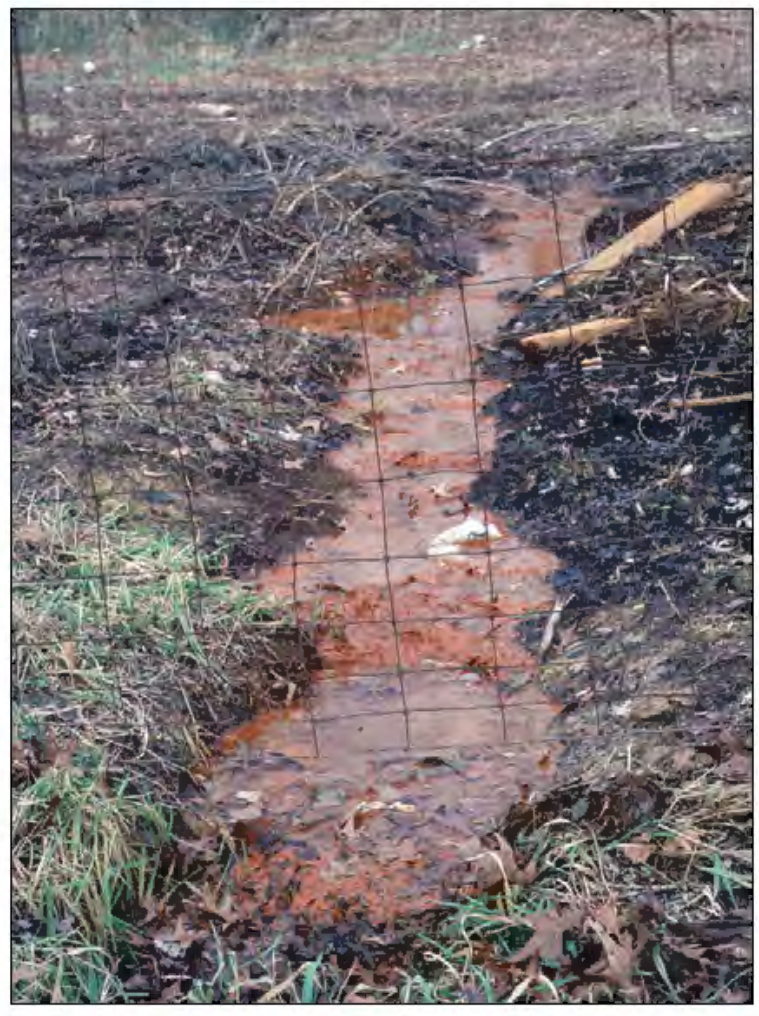

Figure 10. Photograph of acid mine drainage in Pike County, Indiana.

and these mining operations produced large volumes of pyritic spoil. Because coal processing involves the removal of impurities using water and flotation, the mines were typically located near a large stream and the coal refuse disposal areas were frequently placed immediately adjacent to the streams.

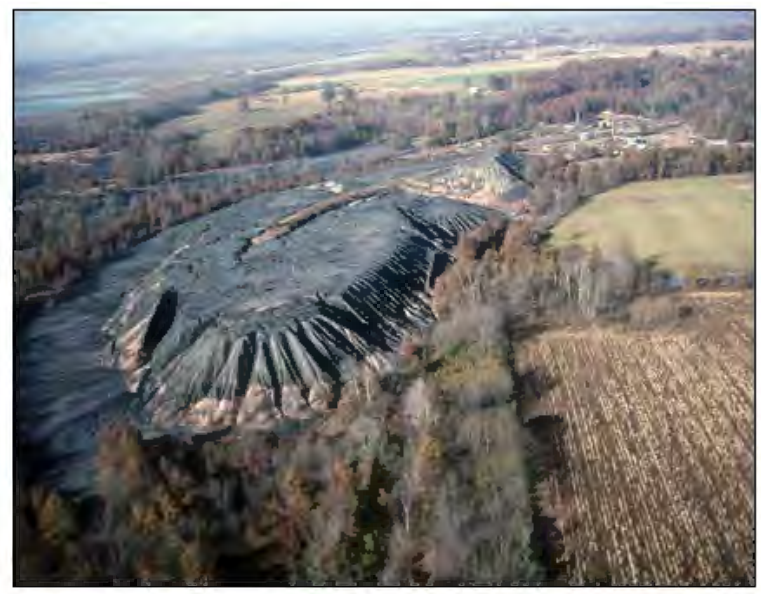

Figure 11. Aerial view of coarse coal refuse (gob) pile, Sullivan County, Indiana.
Coal processing resulted in two forms of waste materials: coarse-grained refuse known as "gob" and fine-grained refuse known as "slurry." Gob typically generates more AMD than slurry because it contains the larger percentage of pyritic materials. Very large piles of gob, sometimes covering hundreds of acres, existed across southwestern Indiana at the time the Abandoned Mine Land Program came into being (fig. 11). These piles were sometimes up to $100 \mathrm{ft}(30.4 \mathrm{~m})$ high. Because the material is coarse grained and highly permeable, there is efficient rainwater infiltration and groundwater mounding, which often lead to a constant flow of AMD at the toe, or bottom, of these piles (fig. 12). The acidic runoff killed whatever vegetion existed downslope and led to severe gullying and erosion. The AMD and sediment entering surface streamflow was extremely detrimental to the habitats of aquatic invertebrates, fish, and other biota.

Slurry is generally not as toxic as the coarser gob material. Unfortunately, the fine coal separators present at today's coal preparation plants were not employed in the early days of coal mining in Indiana. The earlier methods of separation were not very efficient and the resultant slurry contained large amounts of both coal and pyrite. As technologies improved, so too did the capture of this otherwise lost coal resource, and today's slurry is typically dominated by clays and silts that are generally not as toxic. Slurry was commonly discharged hydraulically into an impounding structure of some variety. These structures were often mine pits from which the coal had been removed by surface mining techniques, but numerous

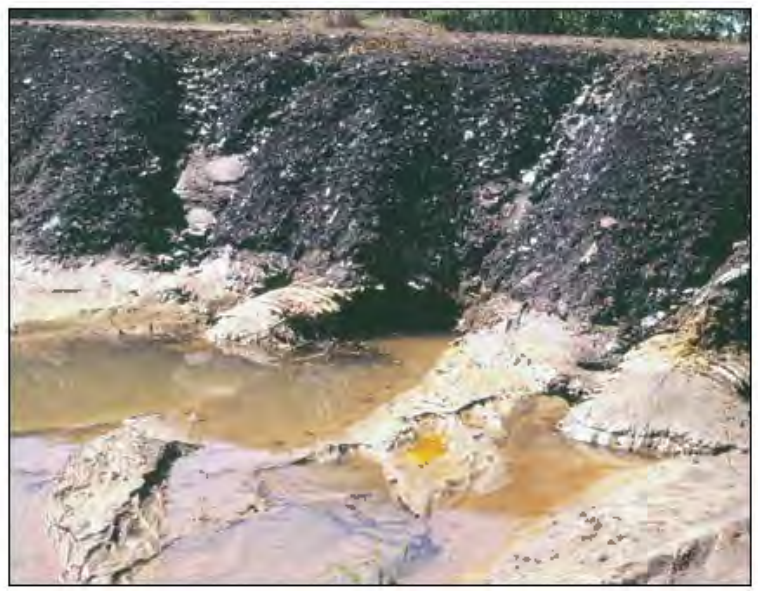

Figure 12. Photograph of an AMD seep at toe of coarse coal refuse (gob) pile, Pike County, Indiana. 
impounding structures were also constructed. Lack of maintenance following mine closure and lack of regulatory requirements often resulted in breaches or development of seeps discharging AMD into the local drainage system (fig. 13).

The toxicity of slurry from these early days varied considerably, depending upon the amount and type of coal present, the amount of pyritic sulfur in the coal and overburden that underwent the washing process, the location of the groundwater table, and the amount of water, if any, covering the slurry. Moreover, the type of coal and the environment of deposition of the rocks above and below the coal play a role in determining what environmental impacts ultimately occur. For instance, sediment deposited in a freshwater environment have much lower pyritic sulfur content than those deposited in brackish or saltwater environments. The quality of the slurry depends on the type and amount of chemical constituents it contains and the potential for oxidation and acid generation. Older slurry impoundments with fluctuating groundwater tables also lend themselves to higher impact than does a slurry impoundment that remains covered with water at all times. Water cover of slurry is a proven viable method of reclaiming these impoundments because it suppresses the oxidation of pyritic materials and, therefore, acid mine drainage cannot be generated.

When a watershed has been heavily mined, AMD can constitute the majority of water in the receiving surface waters. These water bodies can have

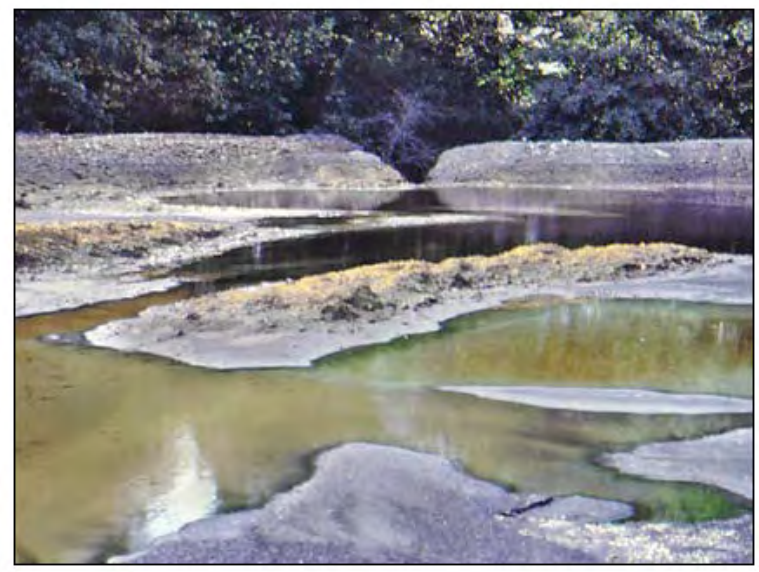

Figure 13. Photograph showing breach in fine coal refuse (slurry) impounding structure that allows AMD to discharge into the local drainage, Pike County, Indiana. Note that the retaining wall is made of coarse coal refuse (gob).
$\mathrm{pH}$ values between 2.0 and 5.0 and contain hundreds and even thousands of milligrams per liter $(\mathrm{mg} / \mathrm{L})$ of acidity and dissolved iron. Only a very limited number of animal and plant species can survive under these extreme conditions. Water bodies affected most severely are usually devoid of fish and other aquatic organisms. Hundreds of projects have been performed by the Indiana AML program in an attempt to evaluate and reclaim these watersheds and reestablish healthy aquatic habitats. Remediating AMD in a watershed can be extremely difficult. Often there is no simple at-source AMD abatement technique, such as completely alleviating the source of the AMD by conventional sealing or burying of the source material, that is feasible or cost-effective. In these cases, treatment of the AMD is sometimes the only alternative for improving water quality and aquatic habitats in the receiving water bodies.

\section{ACCOMPLISHMENTS OF THE ABANDONED MINE LAND PROGRAM IN INDIANA}

\section{Early priorities}

The early years of Indiana's Abandoned Mine Land Program were spent alleviating the most critical of public safety issues. Miles of guardrail were installed adjacent to highwalls along highly traveled public roadways. Dozens of open mine shafts, sometimes hundreds of feet in depth, were filled. Highwalls in remote locations adjacent to county roads that were often used as trash dumps were cleaned up and stabilized.

Efforts to mitigate impacts from toxic-forming spoil, gob, and slurry commenced during this time and those efforts became more predominant as the most serious public safety issues were resolved. Alleviating public safety concerns was typically accomplished without great difficulty. The solutions to the environmentally degrading conditions caused by AMD were not so easily attained. In the early years of the Program, the most common AMD remediation method employed was to bury and cover toxic-forming spoil, gob, and slurry with nontoxic earthen materials in order to establish vegetation and stop erosion. This often restored the land surface so that it could be productively used by the owner. These reclaimed sites were oftentimes and continue to be used for hay production. 


\section{Acid mine drainage mitigation}

Many AML sites in Indiana contained impoundments of acidic water having high concentrations of metals, the greatest of which was iron. These waters were treated to approved standards in accordance with the site's National Pollution Discharge Elimination System (NPDES) permit prior to discharge. Those sites in which an impoundment existed that had acidic mine waters to be treated and discharged and the impoundment regraded and vegetated were typically not difficult to mitigate. The sites having existing seeps of acidic mine waters were a different problem altogether and took considerable thought and design with continued modifications of the treatment systems based upon successes, failures, and lessons learned.

\section{Direct chemical applications}

Two typical methodologies were used early in the program to treat acidic mine waters. The first involved applying agricultural or hydrated lime $\left(\mathrm{CaCO}_{3}\right)$, which was usually injected into the impoundment by agricultural equipment. The other was applying liquid sodium hydroxide $(\mathrm{NaOH})$ in either 20 percent or 50 percent concentrations. These methods had several shortcomings, including a large formation of precipitate when using hydrated lime. Sodium hydroxide also led to formation of precipitate and was difficult to use during cool or cold weather, owing to its high freezing point. For instance, the 50 percent solution's freezing point was $56^{\circ} \mathrm{F}\left(13.3^{\circ} \mathrm{C}\right)$. The 20 percent solution's freezing point was lower, allowing work to occur in cooler weather, but a larger quantity of this more dilute solution was required to

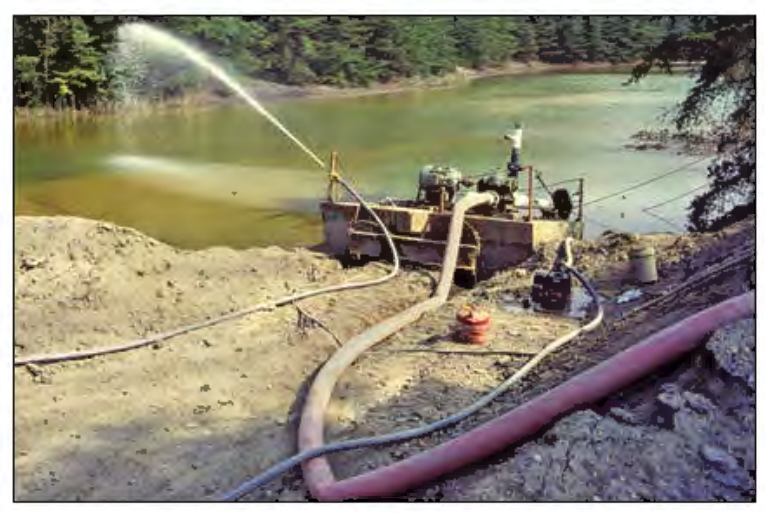

Figure 14. Photograph showing aeration during treatment of acid mine waters, Pike County, Indiana. neutralize the acid. Operators had to be vigilant during cool weather to ensure the dense sodium hydroxide did not simply sink to the bottom of the impoundment without mixing with the acidic water being treated.

Another problem with using these materials was achieving the proper aeration of the water mixed with the treatment additive. Early in the program this was often done simply by circulating these treatment solutions through large pumps. Sometimes large pieces of limestone, or rip rap, were added adjacent to the impoundment and the water from the discharge hose was allowed to shoot upward and land on the rip rap. This effort was predominately intended to add oxygen, which aided in precipitation of the metals rather than to add alkalinity from the dissolution of the limestone. Iron must be oxidized to the ferric ion $\left(\mathrm{Fe}^{3+}\right)$, from the ferrous ion $\left(\mathrm{Fe}^{2+}\right)$, so that hydrolization will take place and the ferric ions will precipitate as the iron hydroxide $\left(\mathrm{Fe}(\mathrm{OH})_{3}\right.$ ) compound. Circulation time varies according to the concentrations of metals that are dissolved in the water contained in the impoundment. Sometimes the water was simply shot into the air in an effort to add oxygen (fig. 14). These processes did work but were very labor intensive and, as mentioned, laden with difficulties.

A major breakthrough concerning the treatment of acidic mine waters was realized using a technology known as the in-line aeration system. One of the first times this was used at a large reclamation project was at the Enoco Mine site (AML Site \#297) near Bruceville, in Knox County (fig. 15). This project occurred from March 1987 through October 1988. Processing of underground mined coal had left behind 70 acres (28.3 ha) of gob, 30 acres (12.1

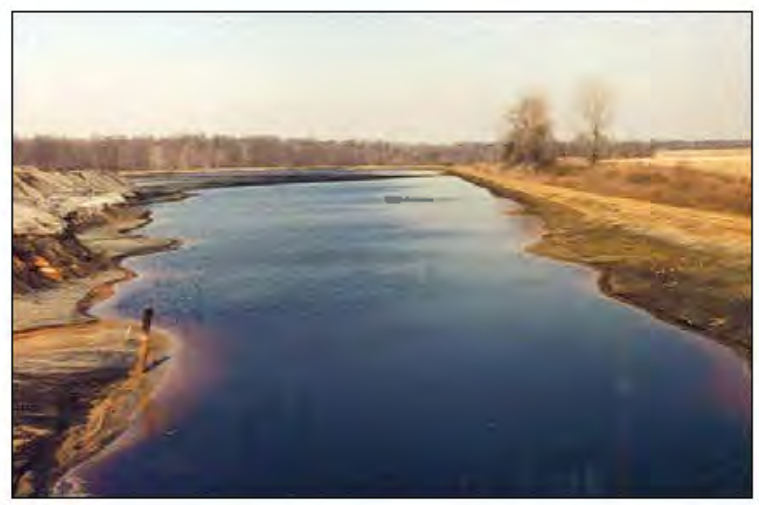

Figure 15. Photograph of impoundment containing acidic mine drainage at Enoco Mine, Knox County, Indiana. 


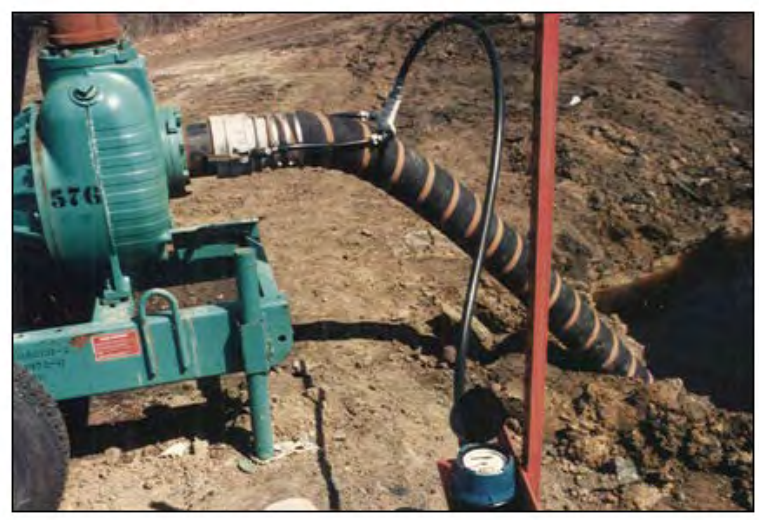

Figure 16. Photograph showing in-line aeration system chemical injection line and meter at Enoco Mine, Knox County, Indiana.

ha) of slurry, three shafts, and one structure. The area also contained a 5.7-acre (2.3-ha) impoundment containing acidic mine drainage. This onsite water was extremely acidic, having a $\mathrm{pH}$ below 3 and iron concentrations in the thousands of milligrams per liter.

The inline aeration system at this site consisted of a suction hose used to withdraw water via a pump from the AMD impoundment. The suction hose was fitted with a screen that restricted solids greater than 1 inch $(2.5 \mathrm{~cm})$ in size from entering the pump. The neutralizing agent, 50 percent sodium hydroxide, was injected directly into the suction hose before entering the pump. A meter was placed along the chemical injection line to regulate the injection of neutralizing agent (fig. 16). A jet pump, made of polyvinyl chloride pipe, was placed on the discharge hose directly behind the 6-inch (25.2$\mathrm{cm}$ ) pump. The jet pump is a nozzle which entrains oxygen by venturi action (fig. 17). As the water is discharged out of the pump, flow was restricted from 6 inches to 4 inches $(15.2-10.1 \mathrm{~cm})$ as the flow enters the jet pump. With this restriction in flow there is a rise in pressure and a proportional velocity increase. Immediately following the restriction, the discharge line flares and shoots the flow through an open suction chamber that forces air into the water from a vent, open to the atmosphere, by venturi action. As the water leaves the jet pump it is diffused back into the 6-inch $(15.2-\mathrm{cm})$ discharge hose which leads to the static mixer. The static mixer consisted of $25 \mathrm{ft} \quad(7.6 \mathrm{~m})$ of 12-inch $(30.4-\mathrm{cm})$ plastic corrugated pipe. Eighty percent of this pipe was filled with random media (fig. 18), a plastic screen product that agitates the product going through the mixer, thus oxygenating the water. The water was then discharged into a sediment pond (fig. 19). This pond acted as a detention basin designed to allow a settling time of 24 hours or more to allow precipitate to settle and not be discharged to streamflow. The water was then discharged from the sediment pond through a 4-inch $(10.1-\mathrm{cm})$ polyvinyl chloride pipe that was previously installed as part of the construction of the basin (fig. 20). The water was released by a drop inlet overflow structure controlled by a valve on the outfall side of the dam (fig. 21).

The inline aeration system at the Enoco site was a much more mobile piece of machinery than that used in earlier treatment efforts. The pump and its engine were mounted on a two-wheel trailer. The contractor was able to easily move it with a conventional pickup truck. The jet pump was mounted directly behind the discharge side of the pump, which allowed for initiation of the

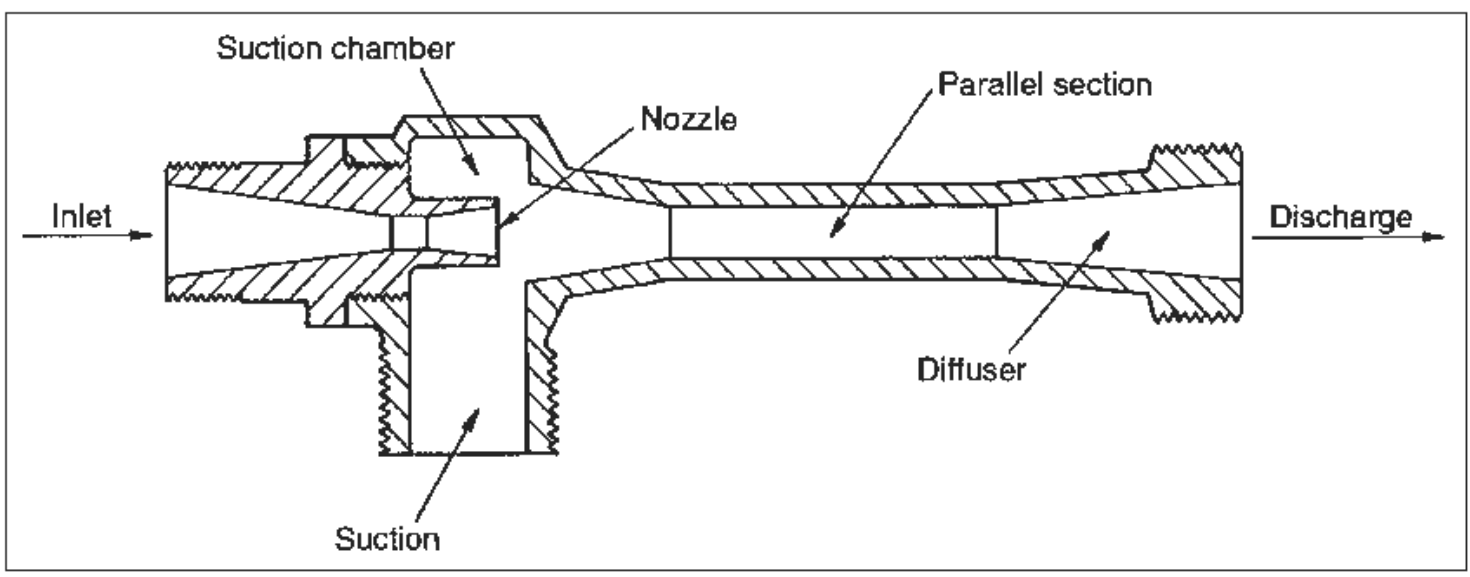

Figure 17. Schematic drawing of an inline aeration system jet pump. 


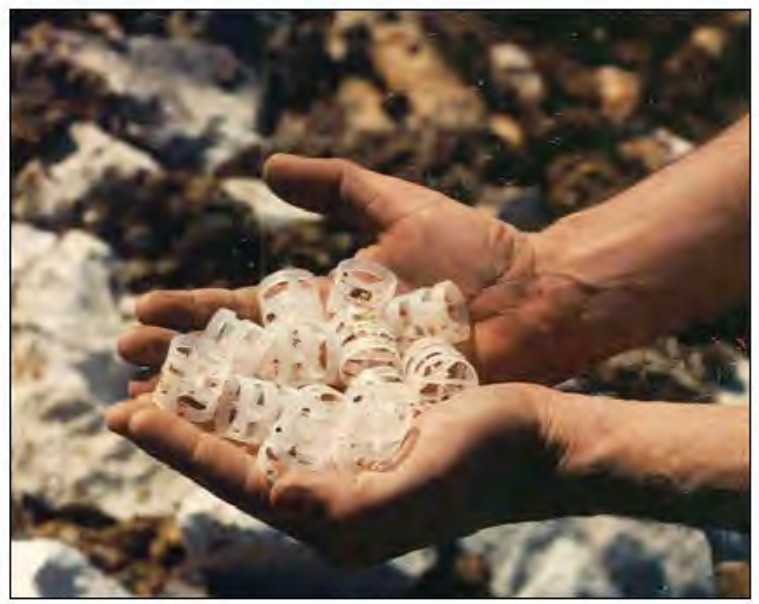

Figure 18. Photograph showing random media used in the inline aeration system.

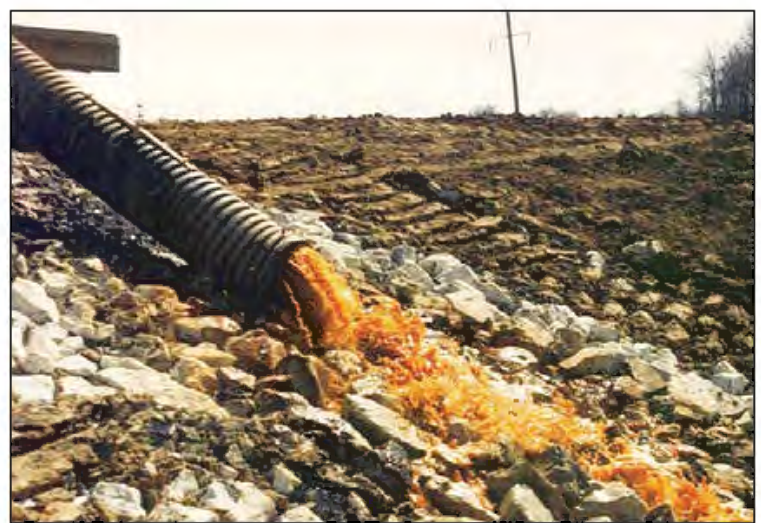

Figure 19. Photograph showing discharge of acidic mine drainage into settling basin following injection of sodium hydroxide via the inline aeration system, Enoco Mine, Knox County, Indiana.

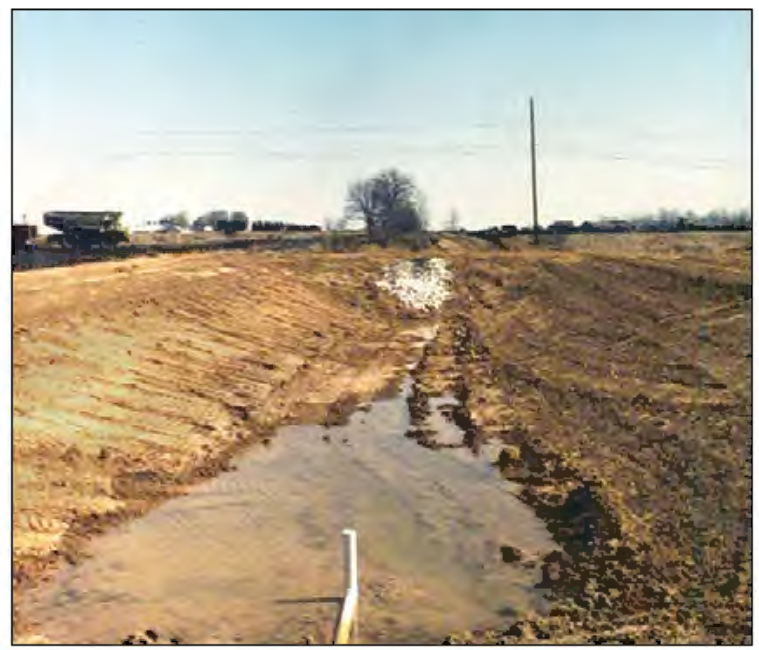

Figure 20. Photograph showing settling basin at Enoco Mine, Knox County, Indiana. chemical reaction as quickly as possible. The sodium hydroxide was stored in a tank mounted on a dual-axle flatbed truck that was positioned immediately adjacent to the pump. From the tank a relatively short chemical feed line was run to the intake side of the pump with the meter positioned approximately halfway down the line. This allowed a relatively quick relocation if it were deemed more efficient to pump from a different location in the impoundment.

Once this system was set up in the field, a few hours were expended in getting the treatment process working, chemical feed regulated, and proper pump discharge rate maintained at 700 gpm (2,649 Lpm). After this was accomplished, as long as there was sufficient volume in the impoundment to maintain a relatively uniform quality of the water to be treated, the system could function essentially unstaffed with intermittent checks to monitor fuel levels, chemical supply, and intake water level.

When the inline aeration system was first put into operation, it was necessary to achieve a balance between the pump discharge rate and the amount of chemical being metered into the intake. Although bench-scale studies had been conducted to determine the expected amount of chemical needed

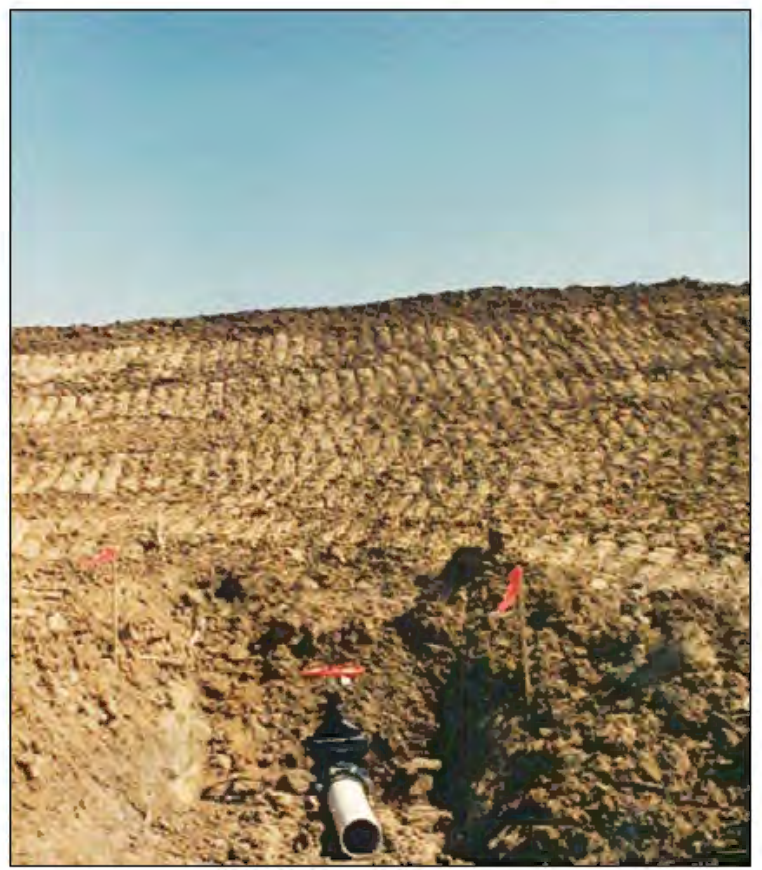

Figure 21. Photograph showing drop inlet discharge structure of settling basin at Enoco Mine, Knox County, Indiana. 


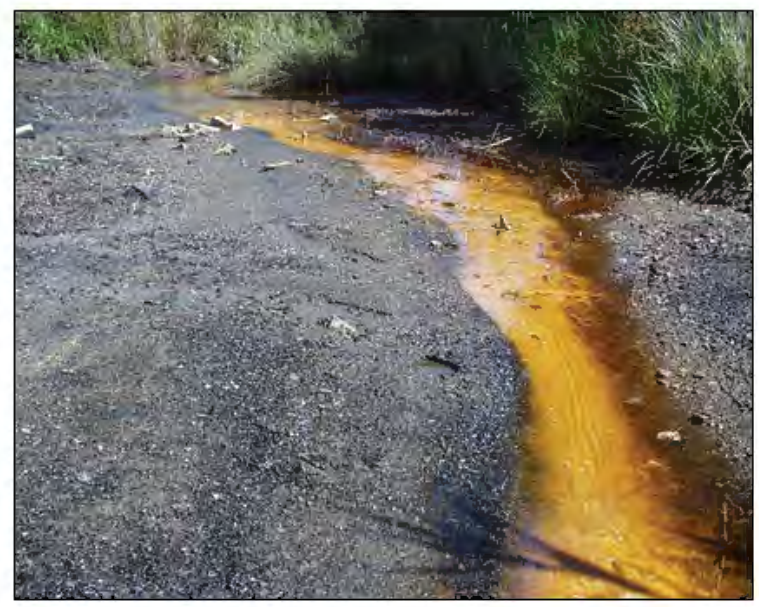

Figure 22. Photograph showing nonimpounded acid mine drainage, Sullivan County, Indiana.

to obtain optimum results, tests were conducted using trial and error onsite. So as to not use excessive chemicals, the chemical input line was regulated to produce a $\mathrm{pH}$ of approximately 7.0 at the discharge end. With time, it was determined that the iron precipitated most efficiently by maintaining a $\mathrm{pH}$ at the discharge end between 8.0 and 9.0 .

Results of the treated water versus the untreated water yielded staggering results. The untreated waters at this site had a $\mathrm{pH}$ of 2.4 and iron concentration of over $1,200 \mathrm{mg} / \mathrm{L}$, with manganese concentration over $10 \mathrm{mg} / \mathrm{L}$. The treated water, after the 24-hour settling period, had $\mathrm{pH}$ in excess of 8.0 with iron concentrations at less than $3 \mathrm{mg} / \mathrm{L}$ and manganese concentrations less than $1 \mathrm{mg} / \mathrm{L}$. As a result of the success at the Enoco site, the inline aeration system continues to be a methodology employed today.

\section{Passive treatment applications}

A more challenging problem was how to deal with nonimpounded acidic mine waters that discharged at varying flow rates from refuse piles, slurry ponds, slopes, shafts, and acid-forming overburden (fig. 22). Drift and slope entries to underground mines were often placed on the downdip extreme of the coal seam to allow water to discharge via gravity. This may have helped to keep the mines drier but certainly led to continual acid mine discharge problems to be dealt with by the Abandoned Mine Land Program years later.
Perpetual chemical treatment of these waters was not feasible because of high costs and maintenance, and so a new passive treatment technology began to evolve. Some passive treatment techniques employed by the Abandoned Mine Land Program include the construction of aerobic and anaerobic wetlands and the use of anoxic limestone drains (ALDs). Proper site and water characterization is critical in the determination of what technique to employ. Decisions must be based upon the amount of flow, $\mathrm{pH}$, the concentrations of metals, and the size of area in which construction can occur.

Aerobic wetlands are those having vegetation planted in earthen materials less than $1 \mathrm{ft}(0.3 \mathrm{~m})$ in thickness. The material making up the base of an aerobic wetland is clay, silt, mine spoil, or other material that forms a relatively impermeable layer. The treatment that takes place in an aerobic wetland occurs in the shallow layer.

Anaerobic wetlands consist of an organic substrate greater than $1 \mathrm{ft}(0.3 \mathrm{~m})$ in thickness. The material making up the base of an anaerobic wetland are those of a permeable nature and include things such as straw/manure, hay, corn stalks, compost, or other organic mixtures. This material is generally underlain with limestone. Treatment involves interactions within the substrate materials.

The earliest use of constructed wetlands in Indiana's Abandoned Mine Land Program was the Tecumseh Site (AML Site \#262) in Warrick County (fig. 23). The Tecumseh project included a 300-acre

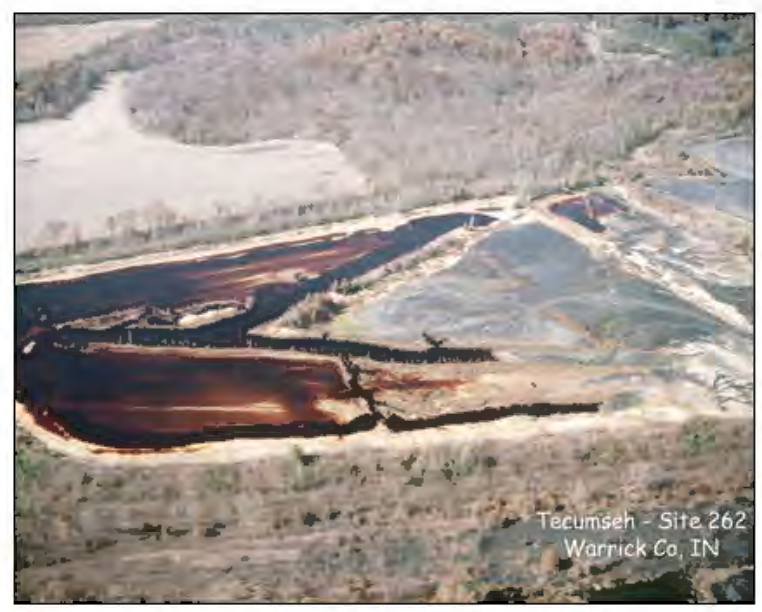

Figure 23. Photograph showing Tecumseh Site, Warrick County, Indiana, before reclamation. 
(121.4 ha) impoundment created by damming a valley using coarse coal refuse. Below this dam was fine coal refuse. Anoxic limestone drain technology was also utilized at the Tecumseh Site. As a result of the hydraulic head from the impoundment on the coarse coal refuse in the dam, an acid seep developed at the toe of the dam. Concentrations of these waters were in the range of $5,500 \mathrm{mg} / \mathrm{L}$ acidity, 1,700 mg/L iron, and $30 \mathrm{mg} / \mathrm{L}$ manganese.

Reclamation involved installing an anoxic limestone drain to add large quantities of alkalinity to the system. An anoxic limestone drain consists of a conduit that is filled with limestone and buried. The conduit is typically created by digging a trench, lining it with heavy plastic, filling the liner with limestone, wrapping the plastic over the limestone, and burying the trench. The process of wrapping the limestone in plastic and burying it precludes oxygen and maintains anoxic conditions. Alkalinity is added to AMD that flows through the anoxic limestone drain as the limestone gradually dissolves and the $\mathrm{pH}$ rises. By maintaining anoxic conditions, the limestone within the anoxic limestone drain does not armor with iron because the iron remains in the soluble ferrous form. The AMD then flows to a wetland area that was partitioned by berms to create a longer flow path and increase retention time for the water. The wetlands contained an organic substrate to promote microbial reactions that facilitate iron and sulfur removal, thus improving water quality.

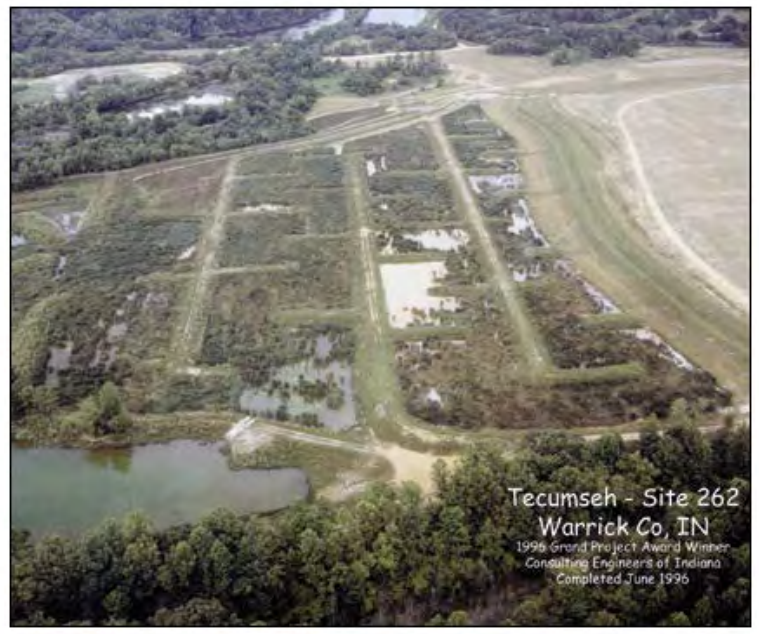

Figure 24. Photograph of the Tecumseh Site, Warrick County, Indiana, after reclamation.
The anoxic limestone drain failed shortly after the completion of the Tecumseh project. The failure occurred because of the formation of gypsum $\left(\mathrm{CaSO}_{4} \cdot 2 \mathrm{H}_{2} \mathrm{O}\right)$, which caused complete plugging of the anoxic limestone drain. Regardless of the failure of the anoxic limestone drain, the Tecumseh project is considered one of the most successful projects of the Indiana Abandoned Mine Land Program with the wetlands proving very efficient at alleviating the acid mine drainage. The quality of water exiting the wetlands remains good, having values in the range of $\mathrm{pH}$ of 7.0 to 8.5 and iron and manganese typically less than $1 \mathrm{mg} / \mathrm{L}$. The site today is a haven for wildlife and is an example of water-quality enhancement through the Indiana AML Program (fig. 24).

A more recent development in the passive treatment of acid mine drainage is the vertical flow pond. In a typical vertical flow pond, an organic layer, similar to that employed in the anaerobic wetland, is used to reduce any ferric iron to ferrous iron and to strip the dissolved oxygen as the acid mine drainage passes through. In the ferrous form, iron should not form a precipitate within the vertical flow pond. Sulfate reduction and consequent alkalinity generation should also occur in the organic layer. Next, the acid mine drainage enters a layer of limestone where dissolution of thelimestone causes the $\mathrm{pH}$ and alkalinity to increase, conditions that promote the precipitation of metals. This methodology, in conjunction with introducing naturally alkaline surface waters and constructing aerobic wetlands, was employed at the Enos Site (AML

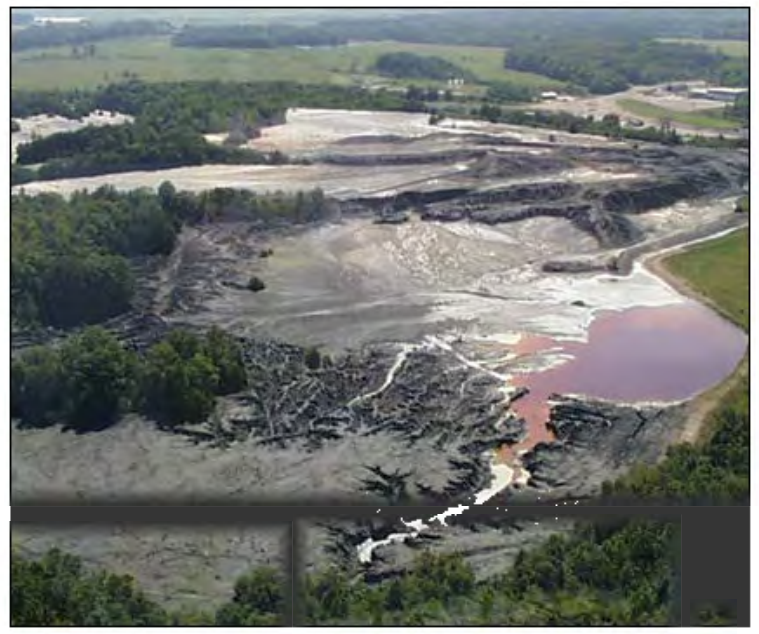

Figure 25. Photograph of the Enos Site, Pike County, Indiana. 
Sites \#898 and \#979) in Pike and Warrick Counties (fig. 25). Two vertical flow ponds were constructed. One utilized high-calcium limestone and the other used dolomitic limestone for alkalinity sources. Different materials were used to determine if dolomite might reduce the problems of plugging from the formation of gypsum that had occurred in the anoxic limestone drain at the Tecumseh Site. The eventual construction of these passive systems at the Enos Site led to the creation of a total of 63 acres $(25.5 \mathrm{ha})$ of wetlands (fig. 26). Additional work yet to be performed will add 26 additional acres (10.5 ha) of wetlands at this site. Water quality of the inflow had a $\mathrm{pH}$ of 2.79 and iron concentrations of $189.2 \mathrm{mg} / \mathrm{L}$. After passing through the vertical flow pond and wetland systems the $\mathrm{pH}$ was 7.13 and the iron concentration was below detection limits. The Enos Site project has led to continued enhancement of water quality in this watershed.

The most recent passive treatment technology advancement is known as sulfate-reducing bioreactors. A bioreactor utilizes naturally occurring sulfate-reducing bacteria to remove metals and add alkalinity to acid mine drainage. These bacteria can do so by converting the sulfate into sulfide, which then combines with the metals to form insoluble compounds. As a by-product, the bacteria also produce bicarbonate, which adds alkalinity. Abandoned Mine Land Program and Indiana Geological Survey staff conducted bench studies of various forms of bioreactors in 2006. Acid mine drainage was collected and routed

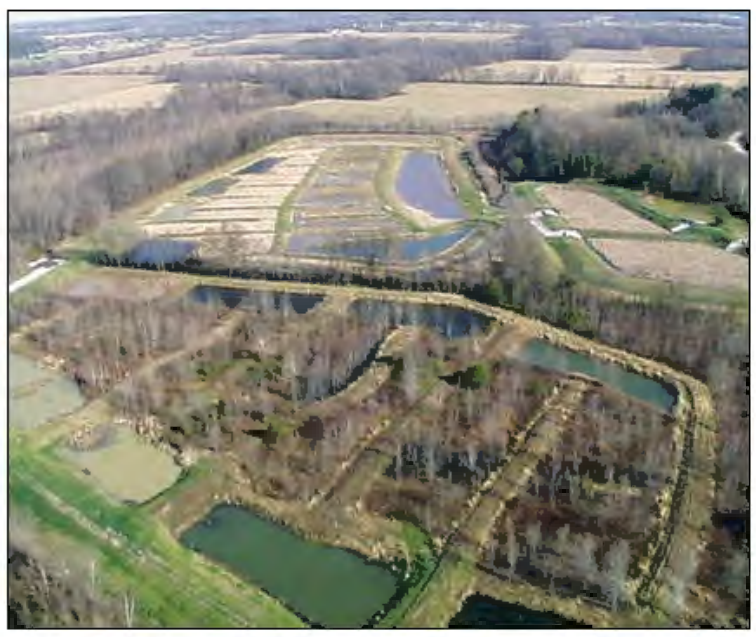

Figure 26. Photograph of the passive treatment wetland cells at the Enos Site, Pike County, Indiana. through barrels containing different organic components in an effort to determine optimum ratios of material to obtain the best water treatment result. These components included straw, wood chips, agricultural lime, and compost. Aged wood chips versus fresh wood chips were compared as was compost from vendors versus actual compost of wetland substrate from previously reclaimed abandoned mines.

The site that has been reclaimed the longest (since August 2007) using this technology is the Sunlight project (AML Site \#337) in Warrick County (fig. 27). Acid mine waters were routed through wetlands employing the bioreactor technology and having a weight ratio of 50 percent wood chips, 30 percent straw, 10 percent agricultural lime, and 10 percent compost. The inflowing waters have a $\mathrm{pH}$ value of 3.2 and iron concentrations of $653.19 \mathrm{mg} / \mathrm{L}$. The resultant outflow has thus far produced excellent results with waters of $\mathrm{pH} 7.7$ and iron below detection limits.

\section{FUTURE WORK OF THE AML PROGRAM}

The AML Program continues to develop projects that remediate abandoned coal mine sites in Indiana, particularly those affected by acid mine drainage. Also, the maintenance of previously installed acid mine drainage treatment structures is a continuing effort. Wetlands must be carefully monitored to ensure their performance. Eventually

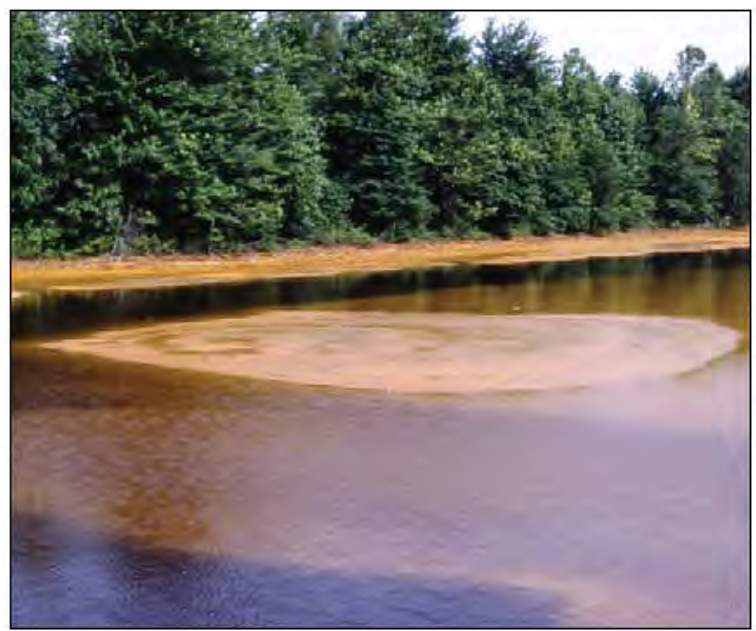

Figure 27. Photograph of the Sunlight Site, Warrick County, Indiana. 
most wetlands will need to be reworked and necessitate either adding additional organic or alkaline materials or removing the metal precipitate.

Other areas of concern continue to occur as well. Along with environmental issues, public roads adjacent to highwalls slough, typically after large rainfall events. Slopes and shafts that were sealed by mine operators decades ago occasionally fail, leaving open holes with vertical sides, often hundreds of feet in depth, and containing water and discharging dangerous volumes of methane gas. Other mine gases, such as carbon dioxide, continue to be of concern and the AML Program continues to research soltions to these issues and to mitigate these conditions when they present a public safety concern.

\section{SUMMARY AND CONCLUSIONS}

The Abandoned Mine Land Program has provided an important public service to the citizens of Indiana and, given the current needs, anticipates many years of future service. Since the inception of Indiana's AML Program in 1982, many AML projects mitigating numerous public safety issues have been completed. Years of effort have provided a much better understanding of abandoned mine lands issues and have resulted in improved reclamation techniques and acid mine drainage mitigation strategies. Much research has been done by our partners at the Indiana Geological Survey and other entities in an effort to determine the best and most cost-effective means for ongoing and future reclamation.

We learned lessons along the way as to the best technologies to employ to improve the quality of waters on a long-term basis at the lowest cost and with the least amount of maintenance possible. As demonstrated by the discussion concerning evolving technologies, AML staff and our partners at the Indiana Geological Survey and other institutions have directed significant effort to identifying and implementing the most efficient reclamation and AMD abatement technologies available, studying the successes and failures resultant thereof, and modifying treatment methods accordingly. Although the successes of Indiana's Abandoned Mine Land Program are many, these individuals consider it a work in progress and continue to add enhancements as new reclamation technologies develop.

\section{ACKNOWLEDGMENTS}

I would be remiss not to acknowledge each and every staff member involved in the Division of Reclamation's Abandoned Mine Land Program since its inception in 1982. The U.S. Department of Interior's Office of Surface Mining Reclamation and Enforcement (OSMRE) is the federal agency that funds the Abandoned Mine Land Program and they view their relationship with the states as a partnership. Staff of OSMRE have assisted not only with the administration of the Program but have also provided valuable training, assisted with specific design efforts, and worked closly with the states to solve ad hoc problems. Many staff members of the Indiana Geological Survey have been instrumental in providing expertise, research, and development of databases concerning abandoned coal mine sites. Indiana's Abandoned Mine Land Program would not be the model it is today without the shared commitment of all these entities.

Review, insight, and assistance in regard to this paper were provided by John Comer, former Geochemistry Section Head at the Indiana Geological Survey, of which I am very grateful. This manuscript was also reviewed by Andrew Gilmore, Indianapolis Area Office Chief of U.S. OSMRE; Ervin Barchenger, Mid-Continent Region Director of U.S. OSMRE; and Paul Ehret, Technical Services Supervisor for U.S. OSMRE, Mid-Continent Region. Their comments led to improvements of the technical presentation and are greatly appreciated. Mark Stacy, Environmental Specialist, Indiana Abandoned Mine Land Program, and Laura Montgrain, former GIS Inventory Specialist, Brock Mayes, Assistant Director of the Indiana Regulatory Program, and Jack McGriffin, Executive Assistant with the Division of Reclamation, provided technical input and organization and assistance in compiling the figures for this manuscript; their efforts are much appreciated. 


\section{REFERENCES}

Eaton, N., and Weber, L., 2000, Map of southwestern Indiana showing locations of surface and underground coal mines: Indiana Geological Survey Miscellaneous Map 67, scale 1:1,300,000.

Gibson, C., and Jung, K., 2002, Historical census statistics on population totals by race, 1790 to 1990, and by Hispanic origin, 1970 to 1990, for the United States, regions, divisions, and states: U.S. Census Bureau Web Site <http://census.gov/population/ www/documentation/twps0056/twps0056.html>, date accessed, Jan. 11, 2010.

Harper, D., Walls, C., and DeChurch, D. A., 2003, Coal mining history: Indiana Geological Survey Web site, <http://igs.indiana.edu/geology/coalOilGas/ coalMiningHistory/timelines.html $>$, date accessed, Nov. 3, 2009.

Indiana Department of Natural Resources (IDNR), 2009, Citizen's guide to Indiana's abandoned mine lands program: Indiana Department of Natural Resources Web site, <http://www.in.gov/dnr/reclamation/ files/re-CitizenGuideTo_IN_AML_Program.pdf $>$, date accessed, Nov. 11, 2009.

Indiana Department of Natural Resources (IDNR), 2012, Coal Production Internal Database.

Indiana Geological Survey (IGS), 2009, Indiana Coal Mine Information System [geographic information system]: Indiana Geological Survey Internet map server site, <http://igs.indiana.edu/geology/maps/ $\mathrm{coal} / \mathrm{cmis} /$ index.cfm>, date accessed, Sept. 25, 2009.

Office of Surface Mining Reclamation and Enforcement (OSMRE), 1980, Implementation of Program Policies for Federal, State, and Indiana Abandoned Mine Land Reclamation Under Title IV of the Surface Mining Control and Reclamation Act of 1977, Final Environmental Impact Statement: OSM-EIS-2.

Office of Surface Mining Reclamation and Enforcement (OSMRE), 2000, Annual evaluation summary report for the regulatory and abandoned mine lands programs administered by the State of Indiana: Office of Surface Mining Reclamation and Enforcement Web site, <http://www.osmre.gov/ Reports/EvalInfo/2000/indiana00.pdf $>$, date accessed Nov. 11, 2009.

Office of Surface Mining Reclamation and Enforcement (OSMRE), 2009, Surface mining law, Public Law 95-87, Surface Mining Control and Reclamation Act of 1977, An unofficial OSM compilation of P.L. 95-87 and all revisions through Dec. 31, 1993: Office of Surface Mining Reclamation and Enforcement Web site, <http://www.osmre.gov/topic/SMCRA/ SMCRA.shtm>, date accessed, Oct. 30, 2009.
U.S. Department of Energy (DOE), 1994, State coal profiles-state coal profile: Indiana: Energy Information Administration, Office of Coal, Nuclear, Electric and Alternate Fuels, U.S. Department of Energy, Department of Energy Web site, <http:// tonto.eia.doe.gov/ftproot/coal/0576.pdf $>$, date accessed, Nov. 11, 2009.

Weir, C. E., 1952, Geology and mineral deposits of the Jasonville quadrangle, Indiana: Indiana Department of Conservation, Geological Survey Bulletin 6, $34 \mathrm{p}$. 
INDIANA GEOLOGICAL SURVEY SPECIAL REPORT 72 


\section{Indiana's Coal Mine Information System}

Licia A. Weber

Indiana Geological Survey

ABSTRACT

The initial efforts to compile, organize, and analyze coal mine data for the state of Indiana began in 1981 with a cooperative agreement between the Indiana Geological Survey and the Indiana Division of Reclamation's Abandoned Mine Land Program. This and subsequent efforts have produced the Indiana Coal Mine Information System. The Coal Mine Information System is an integrated geographic information system and relational database management system that facilitates the compilation, preservation, management, analysis, and distribution of information related to Indiana's coal mines. The information contained in the Coal Mine Information System was collected from an extensive search of historic and contemporary coal mine information sources. Esri's ArcGIS and ArcGIS Server software is used to compile, analyze, and disseminate the collected data. The resulting geographic information system spatial data sets include raster images of underground mine maps, vector shapefiles of underground mine workings, surface and underground mine outlines, locations of underground mine entrances, known subsidence areas, and Abandoned Mine Land Program sites. This system promotes data accessibility and provides the Indiana Abandoned Mine Land Program with a comprehensive and powerful tool for use in evaluating abandoned mine sites and assessing subsidence risk. Continuous refinement and expanding functionality of the Coal Mine Information System products provide useful, accessible, and reliable resources for coal mine information, benefiting the public, industry, and government agencies. This information is readily accessible on the Internet through an Internet map server site on the Indiana Geological Survey's Web site, http://igs. indiana.edu, or directly at http://coalminemaps.indiana.edu.

\section{INTRODUCTION}

Indiana's Coal Mine Information System (CMIS) represents an ongoing effort to digitally preserve and archive information about coal mines in the state in as much detail as is technologically feasible and to make this information widely available to interested parties via the Internet (fig. 1). This paper summarizes the development of the Indiana CMIS from its inception, through several modifications of data and metadata gathering and verification, to the current procedures for capturing, archiving, and affording widespread accessibility to the comprehensive historic record of Indiana's coal mine information. By presenting this retrospective, together with accounts of specific difficulties encountered and 


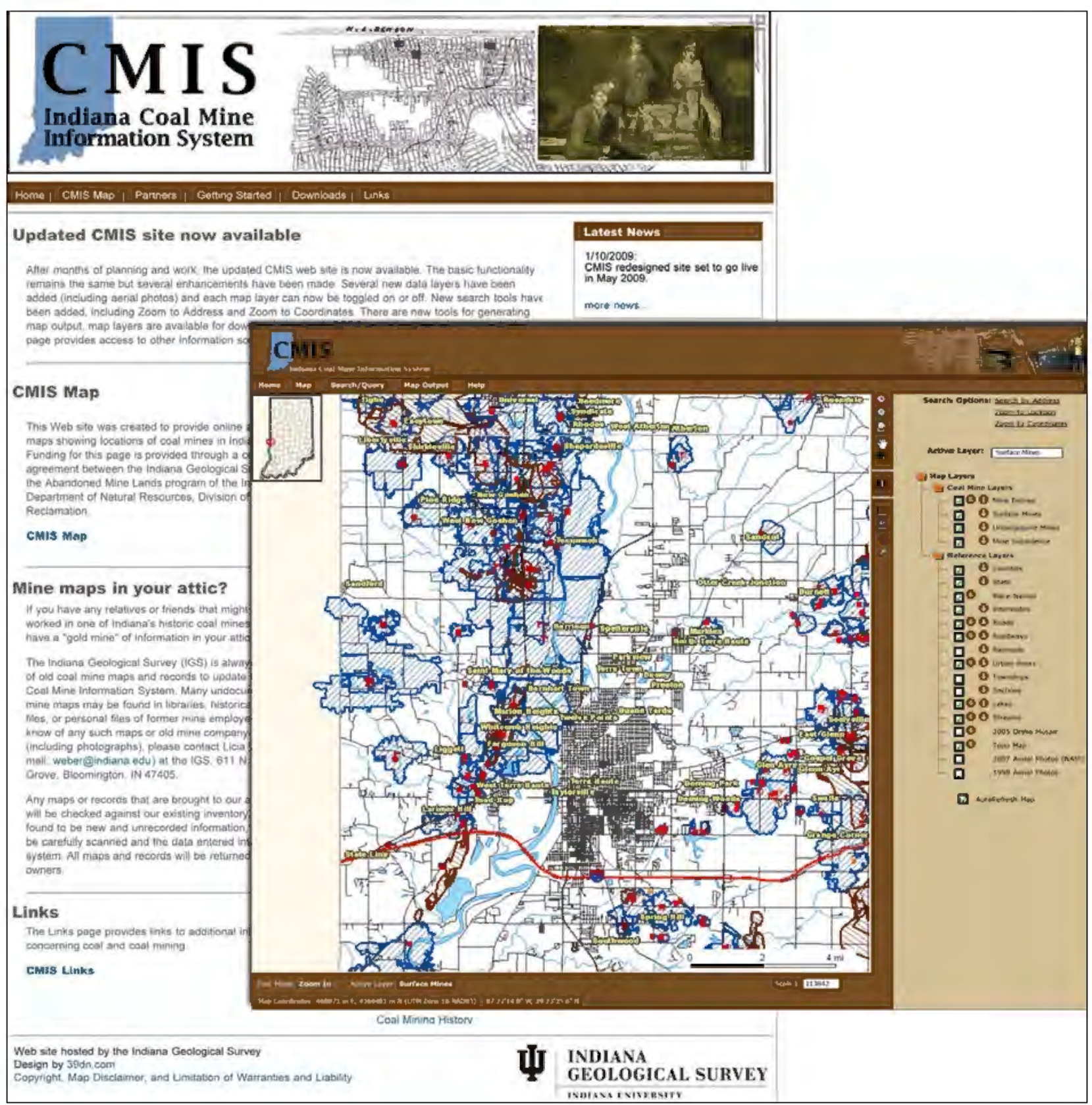

Figure 1. Indiana Coal Mine Information System home page (background) and an example of a map from the interactive map page (front). The map shows an area in Vigo County which includes the city of Terre Haute. Coal-mined areas are outlined in blue and brown.

how they were overcome, it is hoped that this discussion will serve as a useful guide to similar efforts for coal mine information preservation and that it also may be helpful for geologic data preservation efforts in general. All the coal mine maps and associated mine data in the Indiana CMIS is available through the Internet map server (IMS) from the Web site hosted by the Indiana Geological Survey (IGS).

\section{DEVELOPMENT OF THE CMIS: ACQUISITION AND PROCESSING OF MINE MAPS}

The IGS, funded by Indiana's Abandoned Mine Land (AML) Program, began a concerted effort in 1981 to collect, inventory, and compile all available existing information on Indiana coal mines, both surface and underground. The compilation 
included tabular data as well as map data. The U.S. Bureau of Mines (USBM) in Pittsburgh, Pennsylvania, began a national effort at about the same time to collect and produce microfilm $(40 \mathrm{~mm})$ copies of coal mine maps. All available Indiana coal mine maps (which were then housed at the Indiana Bureau of Mines and Mining in Terre Haute, Indiana) were included in this effort and copied to microfilm (fig. 2). As part of their process, the USBM assigned a unique six-digit number to each mine map image. The IGS then used this number as a key field to create a specific database entry and map outline for each mine. The USBM produced over 3,000 microfilm images representing all the paper maps then filed at the Indiana Bureau of Mines. The number of microfilm images does not represent the number of individual mines, as each coal mine can be represented by numerous workings maps. Indiana law requires that a workings map of a mine be submitted annually.

The initial IGS effort to compile mine data used the microfilm map image as the primary source of information. The abandonment map for each mine site was selected and the map image was printed from the film negative, the outline of the mine was digitized and scaled to 1:24,000, and the location of the mine outline was manually plotted on U.S. Geological Survey (USGS) 7.5-minute topographic quadrangle paper maps. In 1986 the IGS produced 97 quadrangle maps showing locations of abandoned underground coal mines and 115 quadrangle maps showing locations of abandoned surface coal mines. A database containing all available tabular information associated with these coal mines, such as the mine number, mine name, mine location, name of operator, dates of operation, name of coal bed mined, coal depth, and coal thickness, was also produced (fig. 3). Tabular data were obtained from numerous sources, including the original company mine map, IGS files, and historic documents such as reports of the State Mine Inspectors dating back to the late 1800 s.

The scaling and locating of the coal mine map images in this early mapping effort involved the careful assessment of each individual mine map (whether paper or film). In addition to mine survey orientation, surface features such as road intersections, railroad and road intersections, and township, range, and section information were used to precisely locate the position of the mines. The digitized mine outlines were scaled, oriented and hand-copied onto the paper USGS quadrangle base maps. The accuracy of the mine image locations and extents is dependent on the accuracy of the original mine map and the precision with which the microfilm image was created. Experience has shown that even when a mine map image has been carefully located and scaled, field verification is necessary to determine the accuracy of the location and extent of a given mine.

The microfilm images of the abandoned underground mine maps produced by the USBM were a crucial component to the early development of the

\section{4}

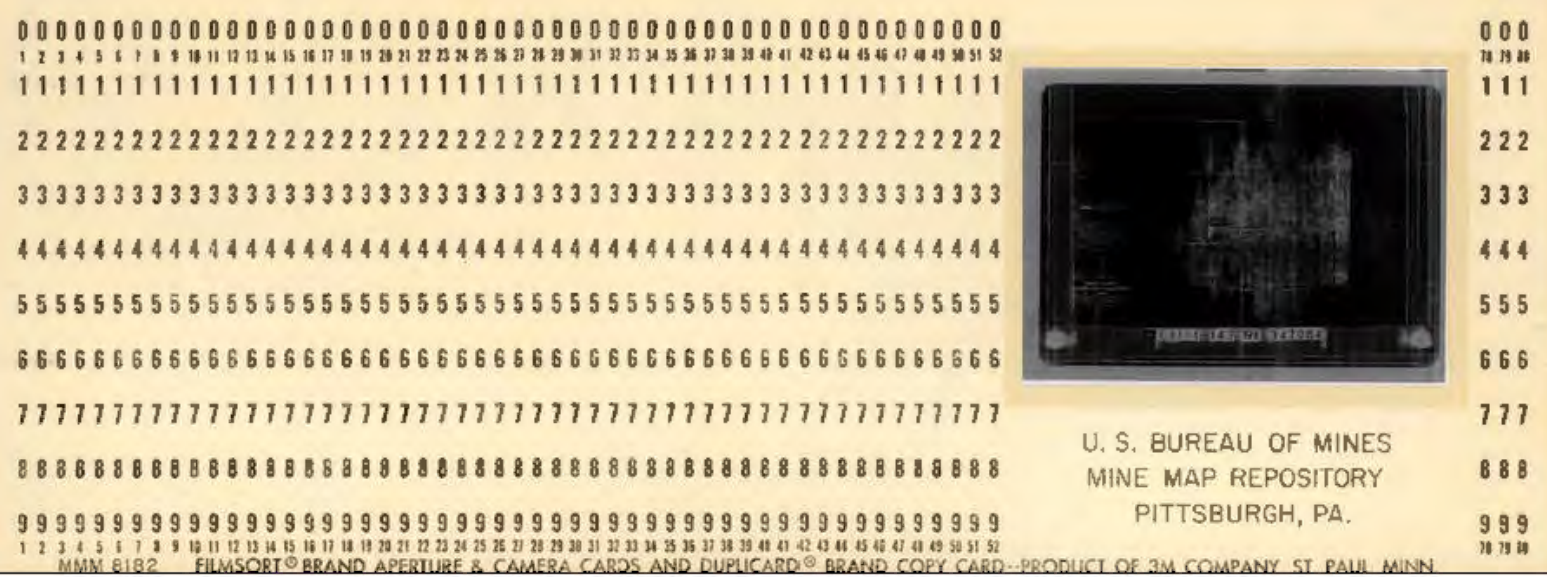

Figure 2. Example of aperture card produced by the U.S. Bureau of Mines containing $40 \mathrm{~mm}$ microfilm mine map image. 


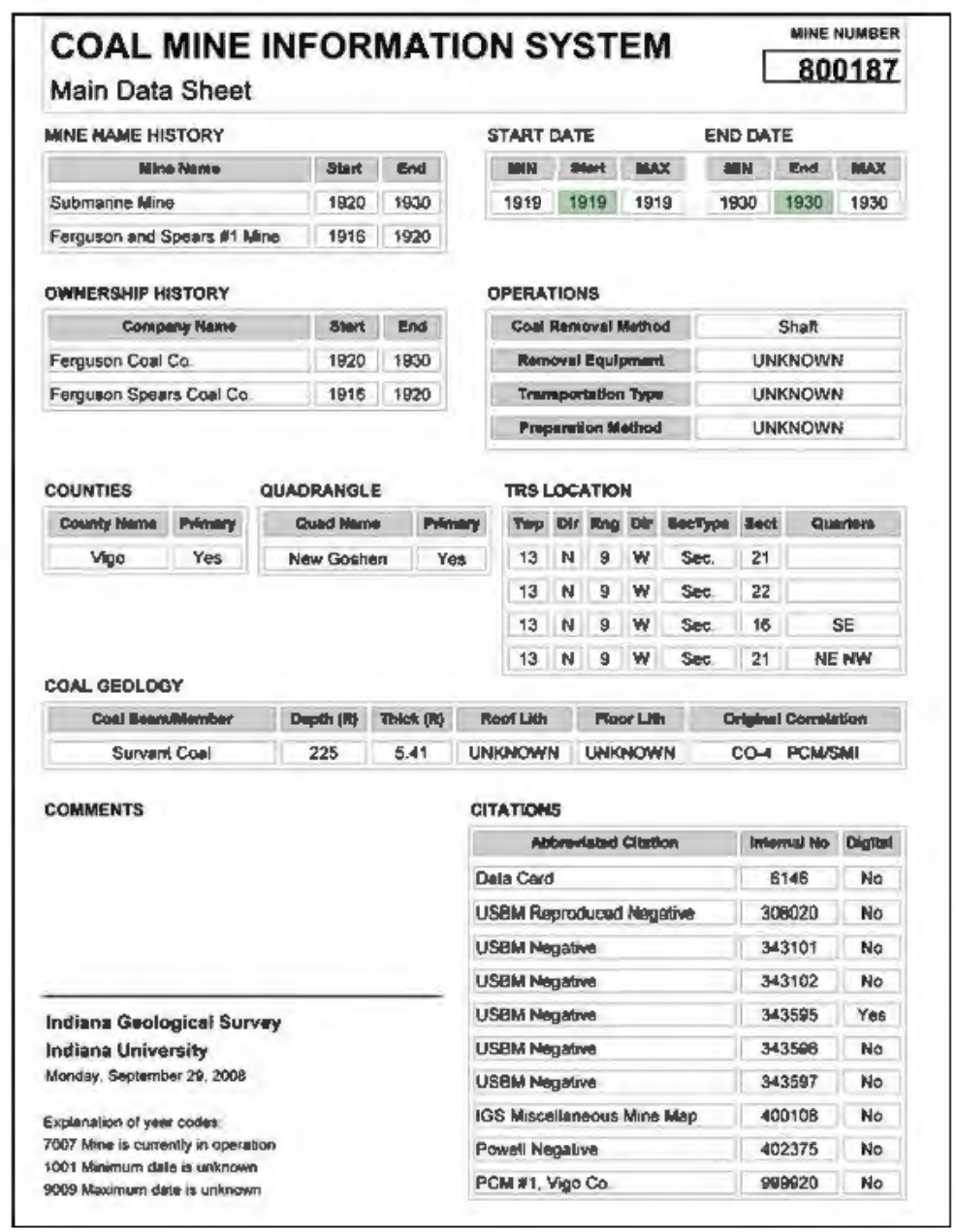

Figure 3. Example of mine data sheet for an abandoned underground coal mine located in Vigo County near Terre Haute. Data sheets like these are available from the Indiana Coal Mine Information System IMS Web site.

CMIS. They provided a comprehensive and consistent format for each mine map image and kept the handling of the original paper maps to a minimum. However, most of these USBM film copies of mine maps proved to be less than accurate to georeference (located using map coordinates) and collect information from because of the manner in which the copies were made. It was noted early in the process that these film images, as critical as they were, did not capture all the details from the paper maps. Because the accuracy of abandoned underground mine mapping is crucial to determining the impact of these voids on adjacent mining activities, surface structures, as well as assessing remediation measures that may be necessary, loss or distortion of detail in film images represented a significant problem. Small print from the paper maps, which could include drilling data, dates, or other important notes regarding the mine, was not always legible on the film copy. Faded areas of the mine workings maps did not receive the special lighting or treatment that might have allowed for recording all their details on the film copies. As a result, it can be difficult to confirm the exact extent of the mine workings on some of the film images.

Additionally, the maps were not flattened when photographed by the USBM, thus the map's folds often produced distortions in the film copy. This was especially true in the larger paper maps that contain dozens of folds. These larger maps required numerous microfilm views that were scanned and combined to create the whole map in one digital image. Overall, the information preserved on the microfilm images was still good enough, in spite of these flaws, to warrant their continued use to document the mine locations and extents. The main goal in the early phase of this project was to collect as 
much map information as possible and use that information to create a comprehensive resource showing abandoned mine locations.

Over the course of collecting and mapping the underground coal mine data, it became clear that the microfilm map images were not providing the level of accuracy required for mine remediation and public health and safety. Recent catastrophic mining-related events, as well as the deterioration and loss of the original historic paper mine maps, mandated a new effort to improve mapping accuracy and capture as much data as possible from the original paper maps. A digital "visual equivalent" of the original documents using the best current technology was required to alleviate problems that occurred in past efforts. The IGS began renewed efforts to gain access to the original historic mine maps housed at the Indiana State Archives in order to scan, archive, and incorporate all the information contained on those maps into the CMIS.

\section{PRESERVING AND DIGITALLY ARCHIVING INDIANA'S HISTORIC COAL MINE MAPS}

The original company mine maps that have been collected by the state of Indiana since the early 1900s contain extremely valuable data regarding the location, extent, and geologic details of coal mining activity in Indiana. The information contained in these maps is unique and the format is fragile and there is an urgent need to preserve this time-sensitive data from an historic resource. Unfortunately, the coal mine maps are not currently being stored in conditions favorable for keeping them structurally stable and legible; hence they are subject to continued deterioration.

Beginning in 2004, the IGS received funding from the U.S. Office of Surface Mining Reclamation and Enforcement (OSMRE) and Indiana's AML Program to undertake the important task of scanning and digitizing the original coal mine maps. Approximately 3,000 of these historic maps are known to exist. Since receiving initial funding in 2004, by early 2010 approximately 900 historic mine maps have been flattened, repaired, scanned, edited, and digitally archived (figs. 4 and 5). The newly scanned and edited digital map images are then georeferenced and the mine extent, entry locations, and other map information integrated into the CMIS. Past efforts to locate and map coal mine images were based on the best technology and resources available at the time; current GIS tools have improved map location accuracy because they are able to georeference the digital mine map images directly on the USGS quadrangle digital raster graphics (DRGs) (figs. 6 and 7).

\section{ADDITIONAL PRODUCTS AND REFINEMENT IN THE CMIS}

Advances in computer data storage and map dissemination technology in the 1990s brought about the restructuring of the Coal Mine Information System into a GIS with corresponding digital database. At that time, the CMIS GIS provided locations of underground mine entries, and surface and underground coal mine outlines. Advances in digital technology and data storage made the digital preservation of the map images feasible. This allowed for the addition of detailed information contained on Indiana's coal mine maps, including haulage roads, underground workings, and mine infrastructure (fig. 4). For this new effort, the microfilm images previously created by the USBM were scanned to create a digital image of each mine map. The five-step process that was developed to scan, enhance, edit, vectorize, and integrate the mine map images into a GIS was a significant effort, but the addition of the mine workings shown on the digital mine map image made a substantial improvement to the CMIS. The Esri GIS software allows a user to view georeferenced mine workings in vector format and to view the original coal company workings map in digital form. Adobe Photoshop software was used to enhance the images made from the original mine maps and preserve as much information as possible on each map (fig. 5). The georeferenced mine map images currently being produced (fig. 6) complement and enhance the previous efforts. They provide additional accuracy and show details contained on the mine workings maps that just the outline of the mine location previously plotted could not.

\section{CURRENT STATUS}

The CMIS project has made significant progress in recent years, using advancements made in GIS and database technology to increase the system's functionality and availability. The database and GIS has been restructured to make the system more 


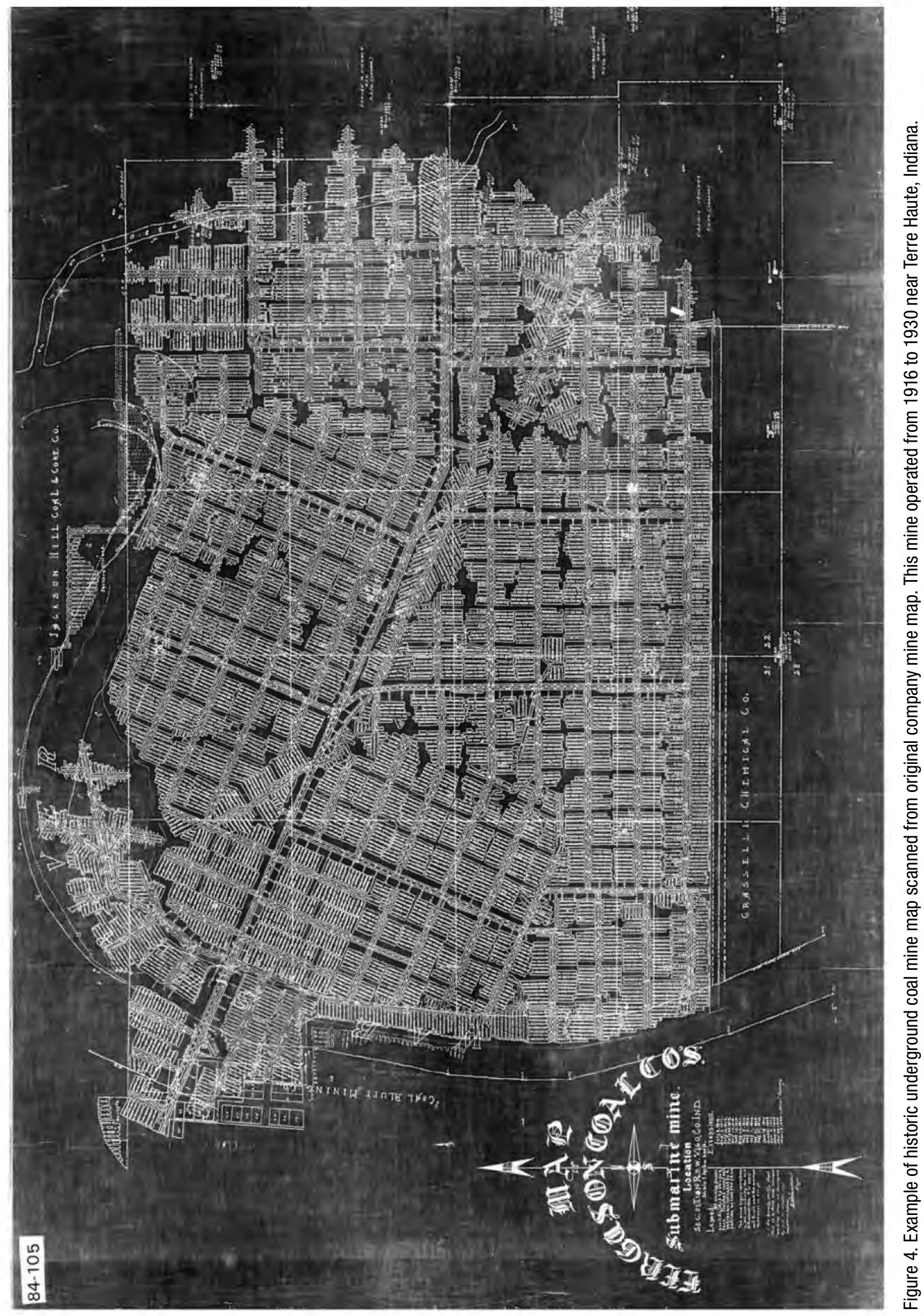




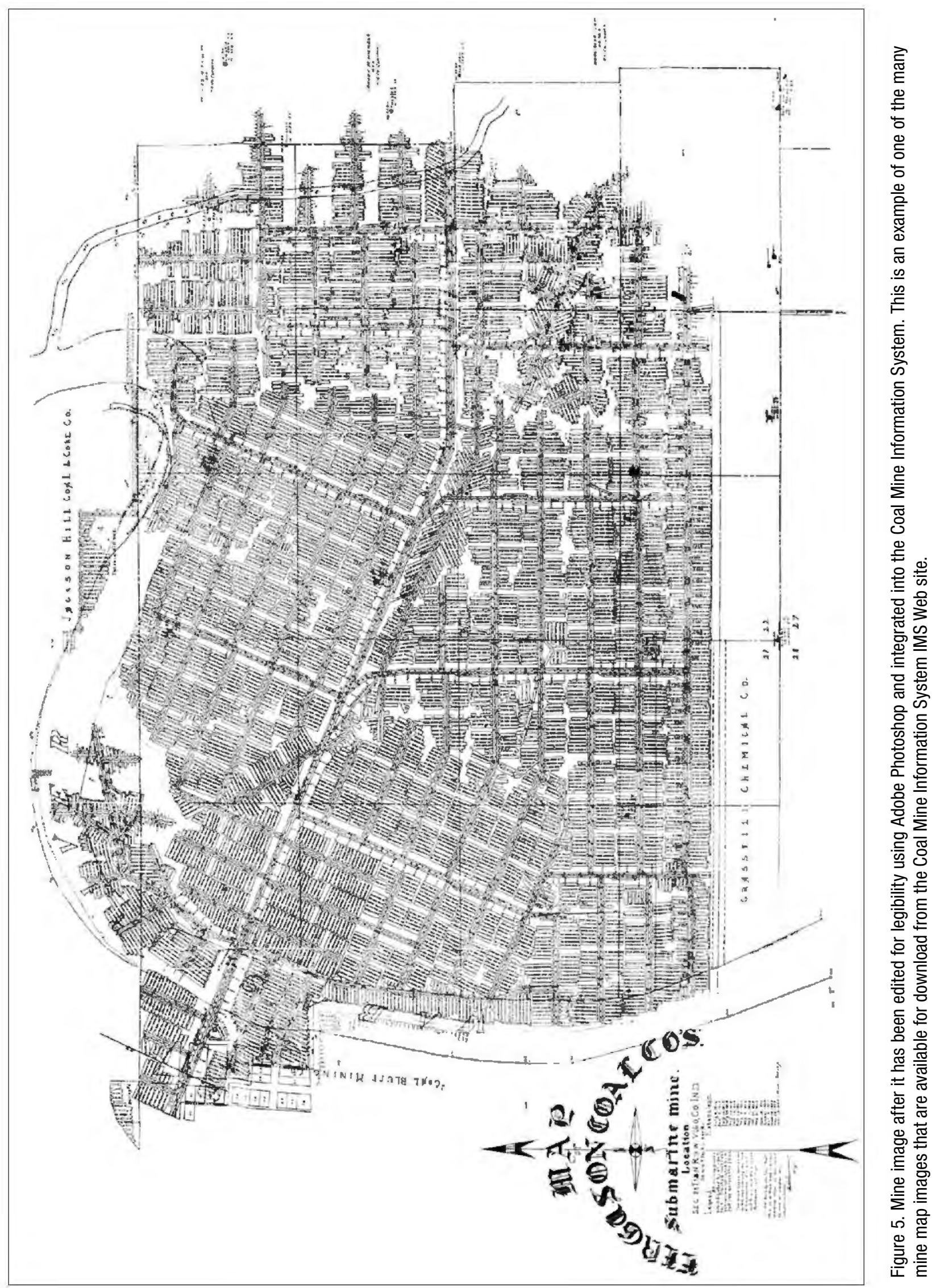




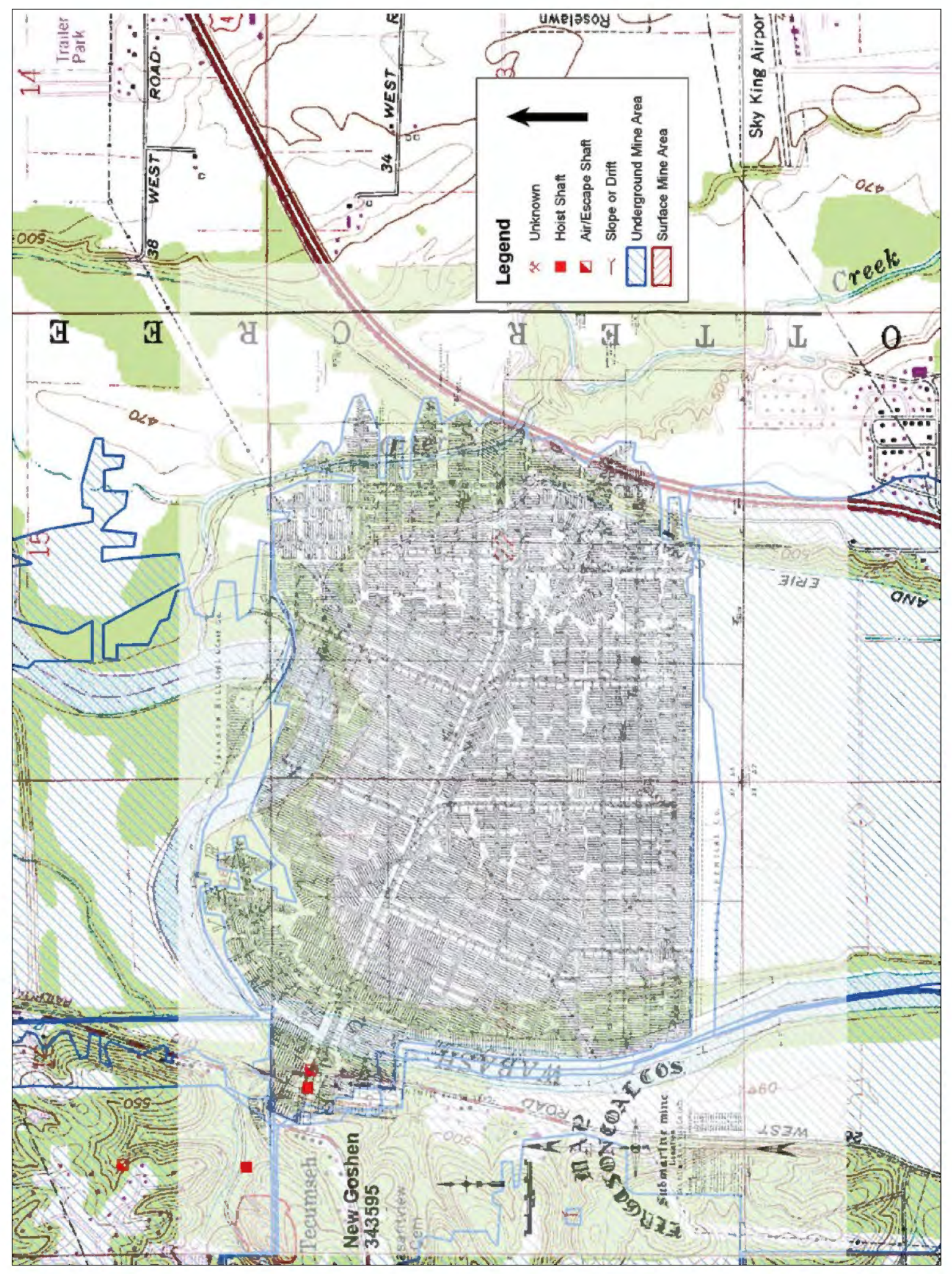

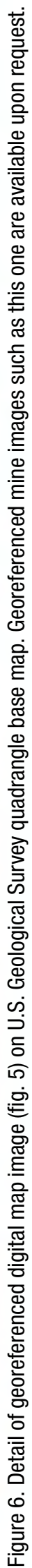







accessible and user-friendly. A major component of the project is the Indiana Coal Mine Maps IMS Web site, which makes Indiana coal mine data (location maps, mine data reports, and the digital company mine maps) available to the public through the Internet. This Web site continues to be refined for ease of use and functionality. Some of these new features, as well as a new look (fig. 1), were launched in 2009. New IMS functions include enhancements for (1) viewing mine location sy zooming in to address, street, county, city, quadrangle, township, section of interest, or coordinate system (Universal Transverse Mercator (UTM), Zone 16 North, NAD83, or decimal degrees); (2) accessing individual mine data reports (fig. 3); (3) downloading coal mine map images for underground mines (when available) (fig. 5); (4) turning map layers on or off; and (5) creating a customized map layout to send to a printer (figs. 6 and 7).

New information, such as coal depth and thickness from drilling records at the IGS and drill hole data that is sometimes present on the mine maps are now being added to the CMIS. Other data contained on the maps such as plat information, geologic conditions, or historical notes are also being cited in the data comments field. The georeferencing process provides an opportunity to examine each individual map for any unique information, which can then be added to the CMIS.

\section{STANDARDS}

The Indiana Geological Survey follows the USGS standards for surface coordinates and the Federal Geographic Data Committee Standard for Geospatial Metadata. The standard coordinate system is Universal Transverse Mercator (UTM) map projection, North American Datum of 1983 (NAD83). The USGS quadrangle maps (DRGs) are used as base maps, and the mine map data are referenced to these coordinates (figs. 3 and 6). The amount of detail shown on these topographic quadrangle maps is very useful in mapping mine locations. The maps show surface features, topography, and urban development, which help in analyzing mining impact. The IGS maintains metadata for all the spatial data in the CMIS. These metadata facilitate the exchange of GIS data sets among industry, local governments, and federal agencies and give credibility to data accuracy.

\section{ACCESSIBILITY}

Dissemination of mine information to government agencies and industry, as well as public awareness and education, has been a focus of the CMIS project in recent years. With the growing use of the Web by industry, the public, and educators, the IGS has found that serving these map data over the Internet has increased awareness and interest in the location and nature of coal mining and abandoned coal mines. The CMIS IMS Web site has proven the most effective vehicle for making coal mine data available. Since its launching in 2001, viewings of the Web site have increased significantly with 2,700 viewings in 2001, growing to 175,000 viewings in 2008. These numbers indicate that this information is an important resource, and feedback from Web site users has been very positive.

\section{CONCLUSIONS}

Indiana's CMIS is a dynamic and complex data management system. Initial efforts from the mid-1980s as well as ongoing efforts to compile, preserve, map, digitally archive, and distribute historic coal mine map information has resulted in the CMIS providing an important environmental management and planning resource for Indiana. The benefits of this project have been important and instrumental in mine reclamation, public education, land-use planning, hazard mitigation, and support of the coal mining industry in Indiana. The analytical capabilities of this system make the CMIS an especially useful tool in light of recent mine accidents. The CMIS, with its abilities for proximity and subsidence risk analyses, is instrumental in making reliable coal mine information and data analysis results readily available and provides an important resource for addressing public health and safety problems related to coal mining in Indiana.

An important aspect of the CMIS project has been the continued updating of the system as the technology and software improve. Advances in digital technology and the refinement of GIS software have allowed greater enhancement of the CMIS. For example, the CMIS database has been restructured into Microsoft Access database software and migrated to Esri's geodatabase model. This database is linked to the GIS using custom extensions that 
allow the user to access and query the large and growing amount of mine data while delivering detailed coal mine map image files for rapid downloading and viewing on an office desktop or laptop computer.

Additionally, CMIS personnel have played a major role in the U.S. Office of Surface Mining Reclamation and Enforcement's efforts to establish national mine mapping standards. Indiana's role in the national effort recognizes the long-term commitment and accomplishments of the Indiana CMIS project and the project's adoption of the highest standards of data documentation and accuracy. Starting in 2003, Indiana's contributions have included teaching OSMRE Technical Innovation and Professional Services classes: “Underground Mine Mapping with GIS," membership on OSMRE's Underground Mine Map Steering Committee, and participation in the development of agenda and topics for initial and follow-up Benchmarking Workshops on Underground Mine Mapping sponsored by the Interstate Mining Compact Commission and the OSMRE. These federally sponsored initiatives have promoted communication and technology transfer between those states that have taken on the work of mapping their abandoned underground coal mines. Indiana's CMIS program and products have had an important role in establishing important standards that have been embraced for these projects and have made the national mine mapping efforts a success.

\section{ACKNOWLEDGMENTS}

I would like to acknowledge the support of the Restoration Section, Abandoned Mine Land (AML) Program of the Indiana Department of Natural Resources, Division of Reclamation. Special thanks are given to the staff of the CMIS project at the Indiana Geological Survey: Rebecca Meyer, Robin Nolin, and Elke Pessl. I would also like to thank Jim Metzger and Mark Stacy of the AML Program, as well as the reviewers of this paper, John Comer, Denver Harper, and Rebecca Meyer of the Indiana Geological Survey, and Steve Herbert, Director, AML Program. 


\section{Reuses of Mined Land}

Nelson R. Shaffer

Indiana Geological Survey

\section{ABSTRACT}

Mined land has been reused beneficially for many decades. Abandoned mines are used for agriculture, silvaculture (cultivation of forests), wildlife habitat, residential and industrial development, recreation, storage, biomass cultivation (plant material grown for energy production), and less commonly for aquaculture (farming of fish, aquatic life, or plants) and other specialized farming. Unconventional uses of mined land are possible and should be considered in reclamation and land-use plans. Some mines are filled with water that, while often unsuitable for human consumption, could be used for irrigation and livestock, biofuels production, coal-to-liquid fuel production, integrated gasification combined cycle technologies, and cooling in industrial facilities. Water is an excellent heat-exchange medium, and, therefore, water-filled mines can enhance geothermal systems or be used as heat sinks. Water-filled mine voids could be modified to become very large and efficient geobioreactors and geobatteries. Geobioreactors are natural rockhosted areas where microbes perform a beneficial function or produce a useful product. For example, many mines could produce commercial amounts of methane. Geobatteries are large earth-based systems that can generate electrical current and store electrical energy. Underground mines can be used to store commercial commodities, generate and store electrical energy, and store liquids and gases. Biotechnology and research laboratories built in mine voids or pits are also possible. Careful consideration of geologic, hydrologic, and environmental conditions must be made to ensure public health and safety are protected and fluids, gases, or microbes are confined to an appropriate void space before any use can be safely attempted. Also, mine water must meet federal and state standards required for a particular use and must not contain contaminants in toxic concentrations. 


\section{INTRODUCTION}

My intention in this paper is to review ways that mined lands have been reused and speculate about how this land might be developed or better used in the future. Although I focus on mined land in Indiana, most of the reuses discussed here could be applied to other mined areas in the United States and throughout the world. A number of "blue sky" opportunities that will require vision and new technologies and techniques to implement are also offered and discussed to stimulate broader and more innovative thinking about the reuses of mined land.

Mining disturbs surface and near-surface land and may have serious negative impacts on both ground and surface water. Careful pre-planning for postmining land use can mitigate many potential environmental problems and open future uses to enhance sustainable mining. I discuss the opportunities for multiple, sequential, and sustainable reuses of mined lands and waters, provide examples of reused mine lands and waters, and suggest creative ways to restore mined lands and waters to productive uses. In this report the major reuses of mined land are presented under ten different categories. Under each category, current and potential uses for mined lands are discussed, including both well-established reuses and potential future reuses.

\section{MINING AND MINE REGULATIONS IN INDIANA}

Indiana is a major mining state, having gross revenues of more than $\$ 2$ billion annually from the extraction of mineral and energy resources (Tables 1 and 2). The state ranked twentieth-fifth nationally in 2009 in total value of industrial minerals and sixth in amount of coal produced. However, coal is the mined resource having the highest total value in Indiana, accounting for $\$ 1.38$ billion annually.

Coal was extracted mostly from underground mines in southwestern counties until the 1920s when surface mining became more efficient. Although surface mining remains dominant to this day, it is expected that underground mining will become more important as easily mined near-surface coal is depleted. This increase in underground mining is apparent in recent years (fig. 1). More than 186,000 acres $(75,271$ hectares [ha]) in Indiana

Table 1. Types of mines in Indiana

\begin{tabular}{|c|c|c|}
\hline \multicolumn{2}{|c|}{ Underground Mines } \\
\hline Type & Age & Number (in 2009) \\
\hline Coal & Pennsylvanian & 8 \\
\hline Gypsum & Mississippian & 9 \\
\hline Limestone/Dolomite $^{\star}$ & Ordovician to Mississippian & 0 \\
\hline Cement (past) & Ordovician to Devonian & 0 \\
\hline Clay (past) & Pennsylvanian & 2 \\
\hline
\end{tabular}

\begin{tabular}{|c|c|c|}
\hline \multicolumn{3}{|c|}{ Surface Mines } \\
\hline Type & Age & Number (in 2009) \\
\hline Coal & Pennsylvanian & 28 \\
\hline Limestone/Dolomite $^{\dagger}$ & Ordovician to Pennsylvanian & 104 \\
\hline Shale/Clay ${ }^{\ddagger}$ & Mississippian to Pennsylvanian & 14 \\
\hline Sandstone & Mississippian to Pennsylvanian & 5 \\
\hline Sand and Gravel & Quaternary & 150 \\
\hline Special sand & Quaternary & 1 \\
\hline Peat & Quaternary & 4 \\
\hline
\end{tabular}

* One is idled and may not return to production.

${ }^{\dagger}$ Four are captive for cement manufacture.

‡ Three are captive for cement manufacture. 
are underlain by underground coal mines; an additional 280,000 (111,311 ha) acres have been surface-mined for coal.

Indiana produces noncoal mineral commodities from mines located in all parts of the state from rocks of Cambrian to Pennsylvanian age plus unconsolidated Pleistocene deposits. These commodities include crushed stone, dimension stone, shale, clay, sand, gravel, gypsum, marl, and peat (fig. 2). Although mining of noncoal commodities is widespread, typically only relatively small areas are affected (figs. 3-5); a total of about 50,000 acres $(20,234 \mathrm{ha})$ in Indiana have been affected by the mining of noncoal minerals. Blasting, haulage, noise, dust, and operational hazards are associated with most industrial minerals mining but these effects are limited compared with the impacts of coal mining, which commonly affect much larger areas.

Active noncoal mines (fig. 3) are scattered widely around the state and some are short lived. Crushed and dimension stone operations are generally active for long periods. Sand and gravel pits and shale mines are small and quickly reclaimed by natural processes such as weathering, mass wasting, water fills, and plant growth; many noncoal mines are hard to recognize even a few years after mining ceased. Because many mines are near population centers, they frequently are reused for business development, housing, or recreation.

Coal has been mined in 20 southwestern counties of Indiana where rocks of Pennsylvanian age occur (fig. 6). Coal mines affect larger areas and are extended much faster than noncoal mines. These mines have different attributes-such as aerial size, depth, seam thickness, water quantity, water quality, interactions with surrounding bedrock, and hydrogeochemical connections to potential aquifers-hence they have different reuse potential. Detailed maps showing coal-mined areas can be obtained from the Indiana Geological Survey Web site's Coal Mine Information System (Weber, 2012 [this volume]).

A well-developed infrastructure exists for transporting goods and energy to and from the region having the largest density of mines in southwestern Indiana (figs. 7 and 8). Completion of Interstate 69 through this area from Indianapolis to Evansville will further support the development of these mined lands. Thus, given the transportation infrastructure and central location, Indiana is well positioned to benefit from the creative reuse of mined lands. Pre-engineering of mined lands before opening or special grading as they cease production could prepare them for many beneficial postmine uses.

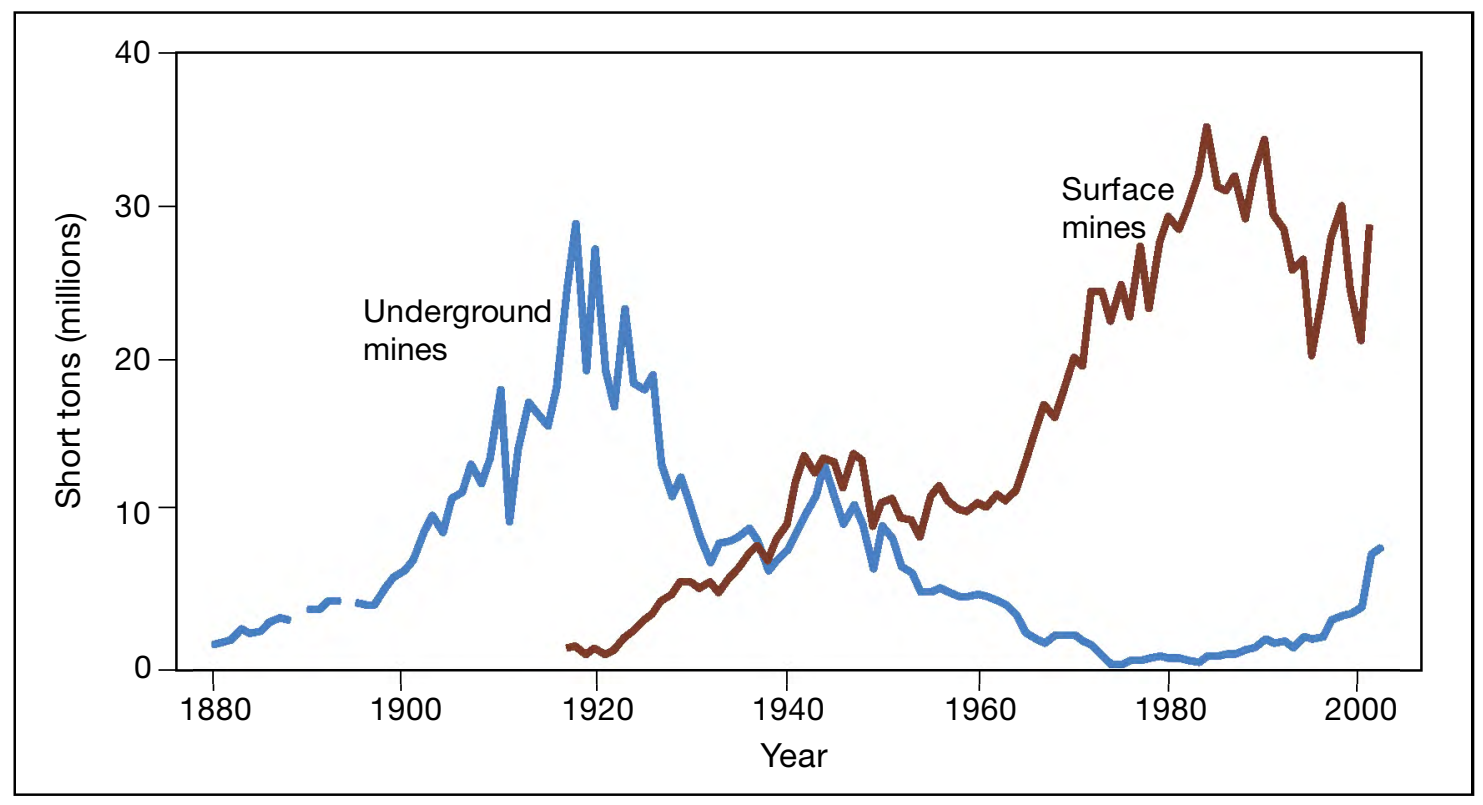

Figure 1. Graph showing coal production (short tons) for underground and surface mines in Indiana. 


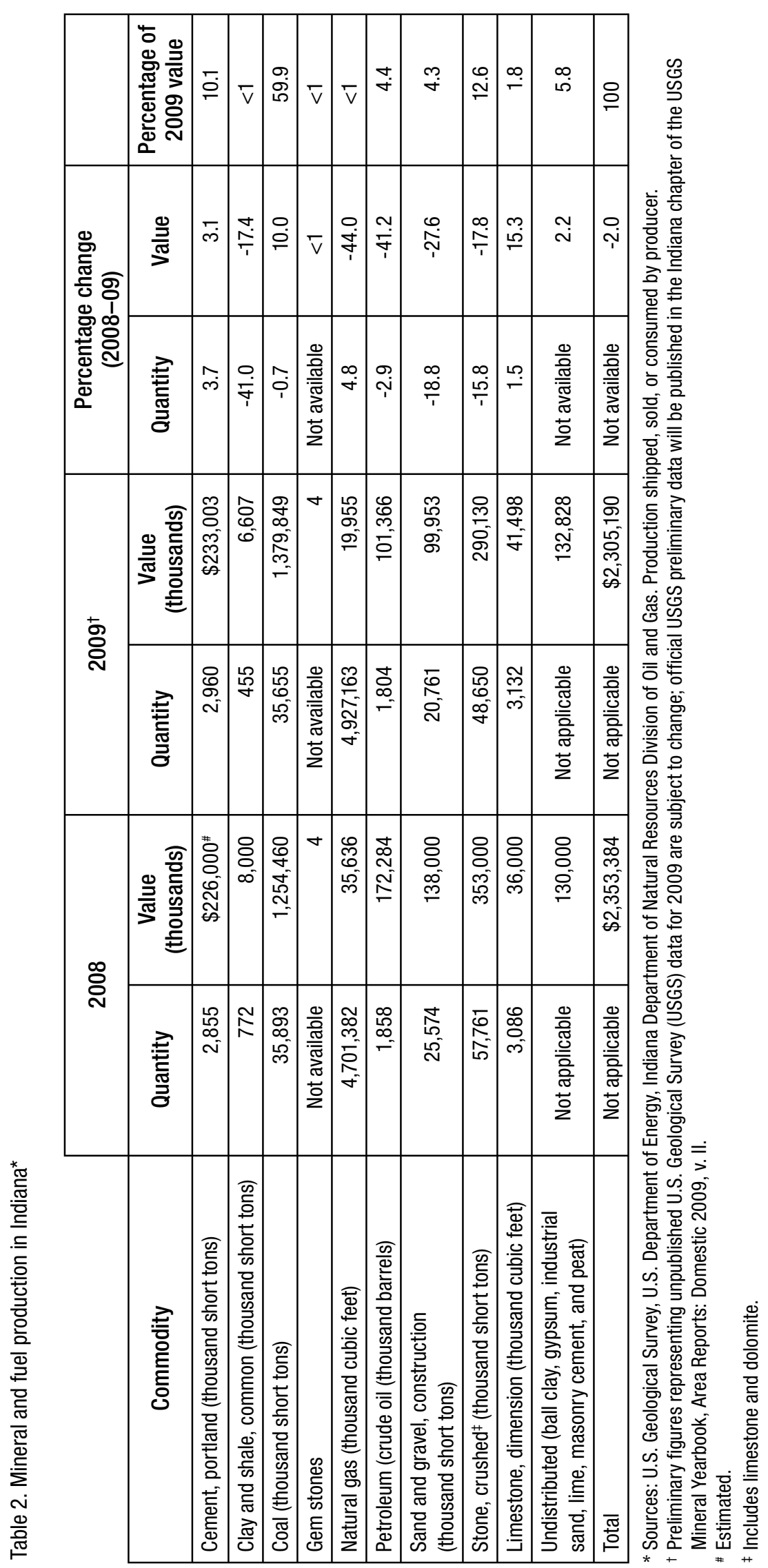




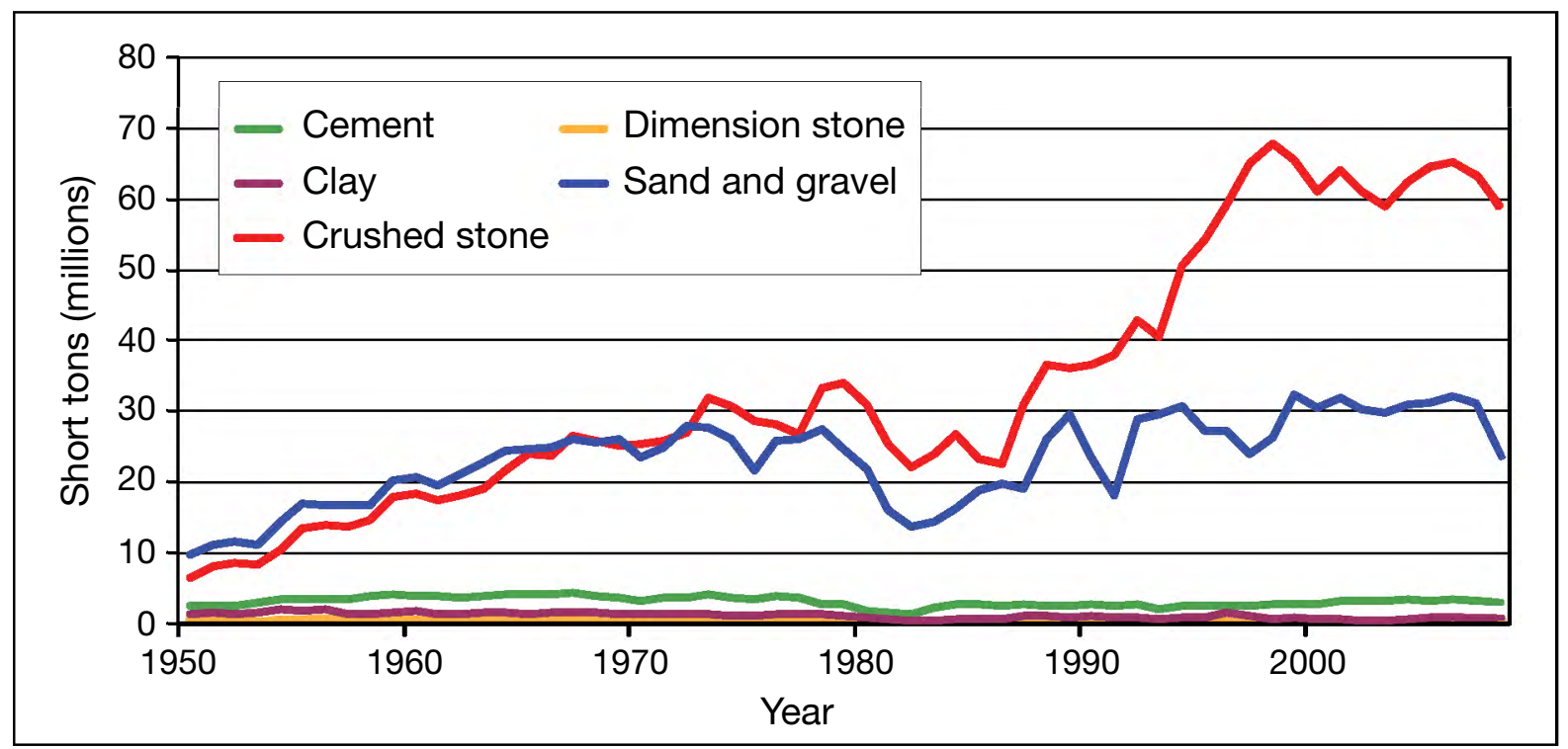

Figure 2. Graph showing industrial minerals production (short tons) in Indiana since 1950.

Rules that govern reclamation of surface-coalmined lands in Indiana evolved through a series of federal and state regulations (Table 3). The federal Surface Mining Control and Reclamation Act (SMCRA) of 1977 requires that postmining land use be specifically addressed as part of the permitting and bond release criteria. When assessing a mined area, an area to be mined, or when preparing to close a mine regulated by SMCRA, consideration must be given to potential uses of postmine surface land, underground voids left by mining, or water within the permit boundaries after legal SMCRA obligations have been met. In many cases, the land can be reclaimed and the byproducts of mining and waters affected by mining can be put to beneficial reuses.

Figure 9 and Table 4 (J. McGriffin, Indiana Department of Natural Resources, Division of Reclamation, written commun., Sept. 11, 2008) summarize the reuses of coal-mined lands that were implemented in Indiana after the completion of approved reclamation programs. These reuses include cropland (37\%), fish and wildlife habitat $(26 \%)$, pasture $(16 \%)$, and forest $(12 \%)$. Lesser amounts have been turned to industrial and residential development and a small, but important fraction has been reused for recreation $(<1 \%)$. Areas that are designated prime cropland must be restored after mining to produce crop yields that equal or surpass yields obtained before mining. Each site is required to meet this standard for at least 3 years out of 10 before the bond money, posted for reclamation prior to mining, is released (Indiana Department of Natural Resources, 2009).

Because there are no comparable laws for noncoal mines, they are not subject to the same level of required reclamation in Indiana. The mineral aggregates industry established voluntary reclamation practices and standards for its members through its trade organization, the Indiana Mineral Aggregates Association.

\section{AGRICULTURE}

\section{Forestation}

The term "forestation" refers here to the planting of forest; "reforestation" refers to the replanting of forest where a preexisting forest had been cleared. Since the beginning of mining, mined lands have been extensively used for forest and much reclaimed land is reforested. Prior to the 1977 enactment of SMCRA, most mined land was successfully reforested and midwestern mine lands were often forested or reforested after mining because cast overburden was generally not graded or compacted and topsoil was nonexistent or of poor quality (Burger, 1999). After SMCRA, the practice of reforestation became less common because the law focused on improving the hydrology, geochemistry, erosion (Vogel, 1981), and crop productivity of mined lands. 


\section{EXPLANATION}

Commodity Mined

A Cement

Clay and shale

Crushed stone

Dimension sand

Dimension stone

Gypsum

$\Delta$ Lime

Peat

- Sand (industrial)

Sand and gravel

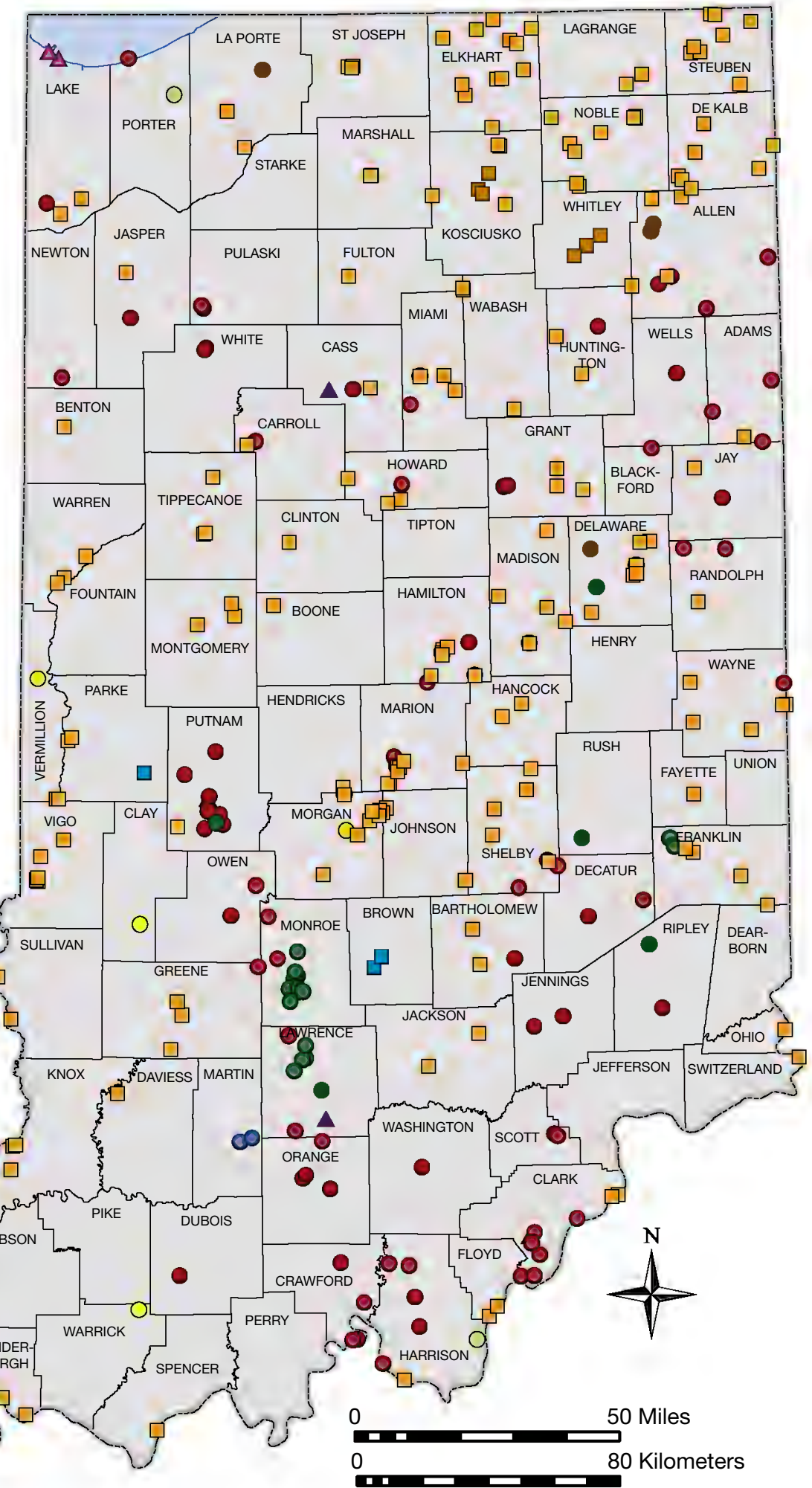

Figure 3. Map of Indiana showing active industrial mineral mines. 


\section{EXPLANATION}

- Abandoned industrial minerals mine

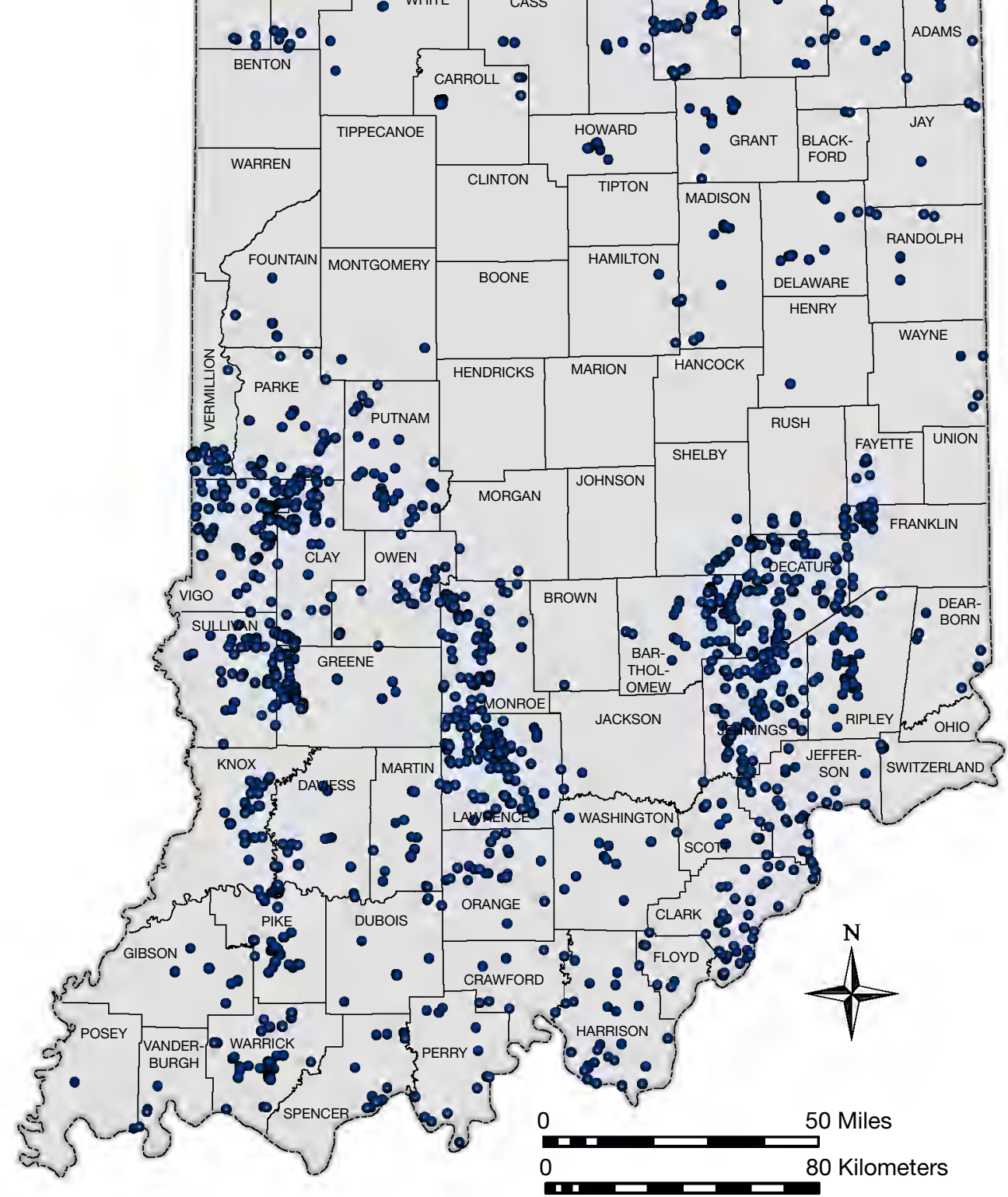

Figure 4. Map of Indiana showing abandoned industrial mineral mines. 


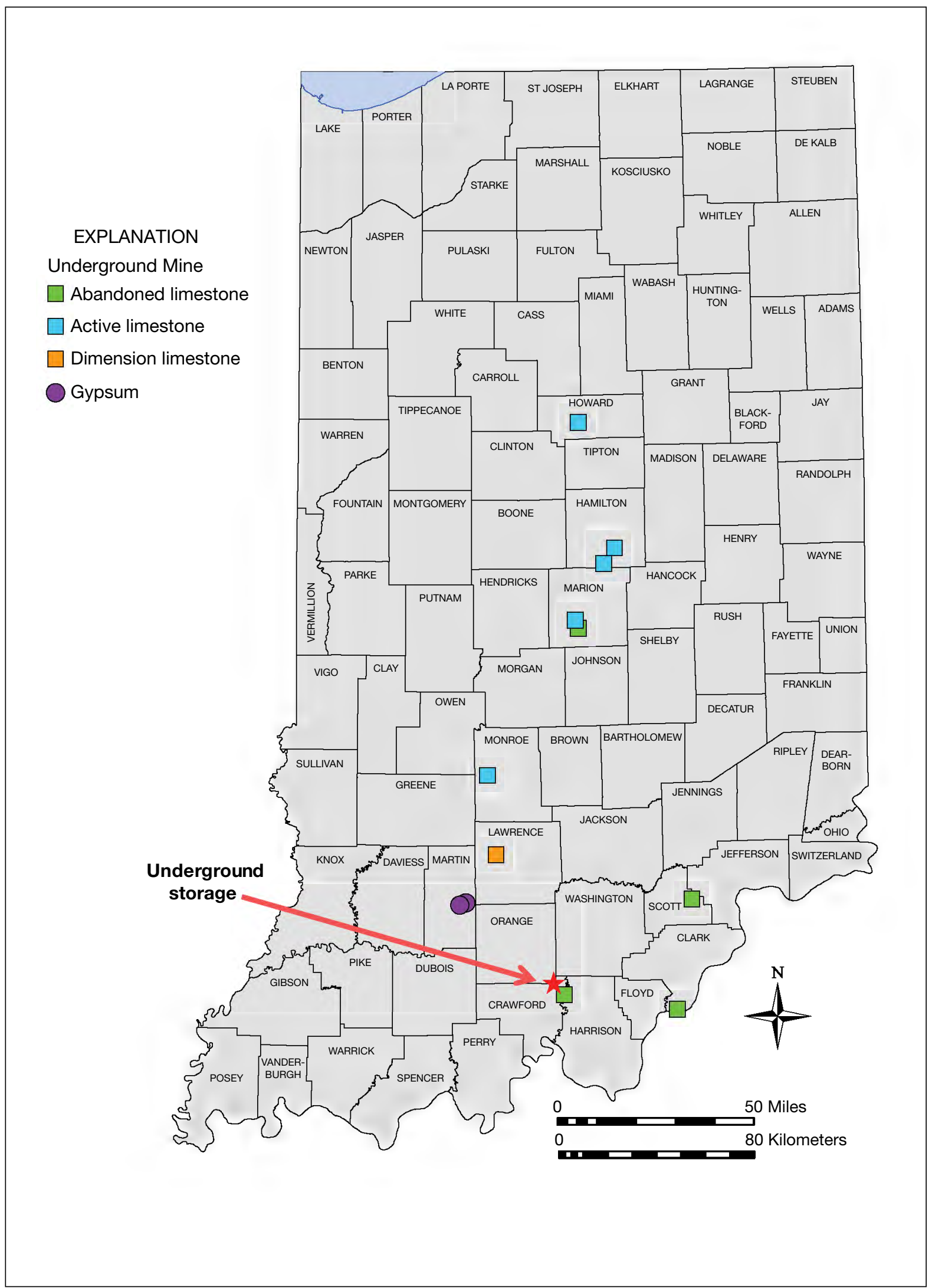

Figure 5. Map of Indiana showing industrial mineral underground mines. 


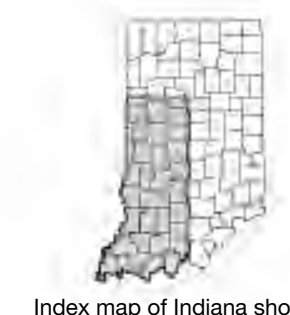

location of map area

\section{EXPLANATION}

Coal Mine

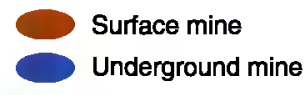

Geologic System

Pennsylvanian (coal-bearing rocks)

Mississippian

Devonian

Silurian
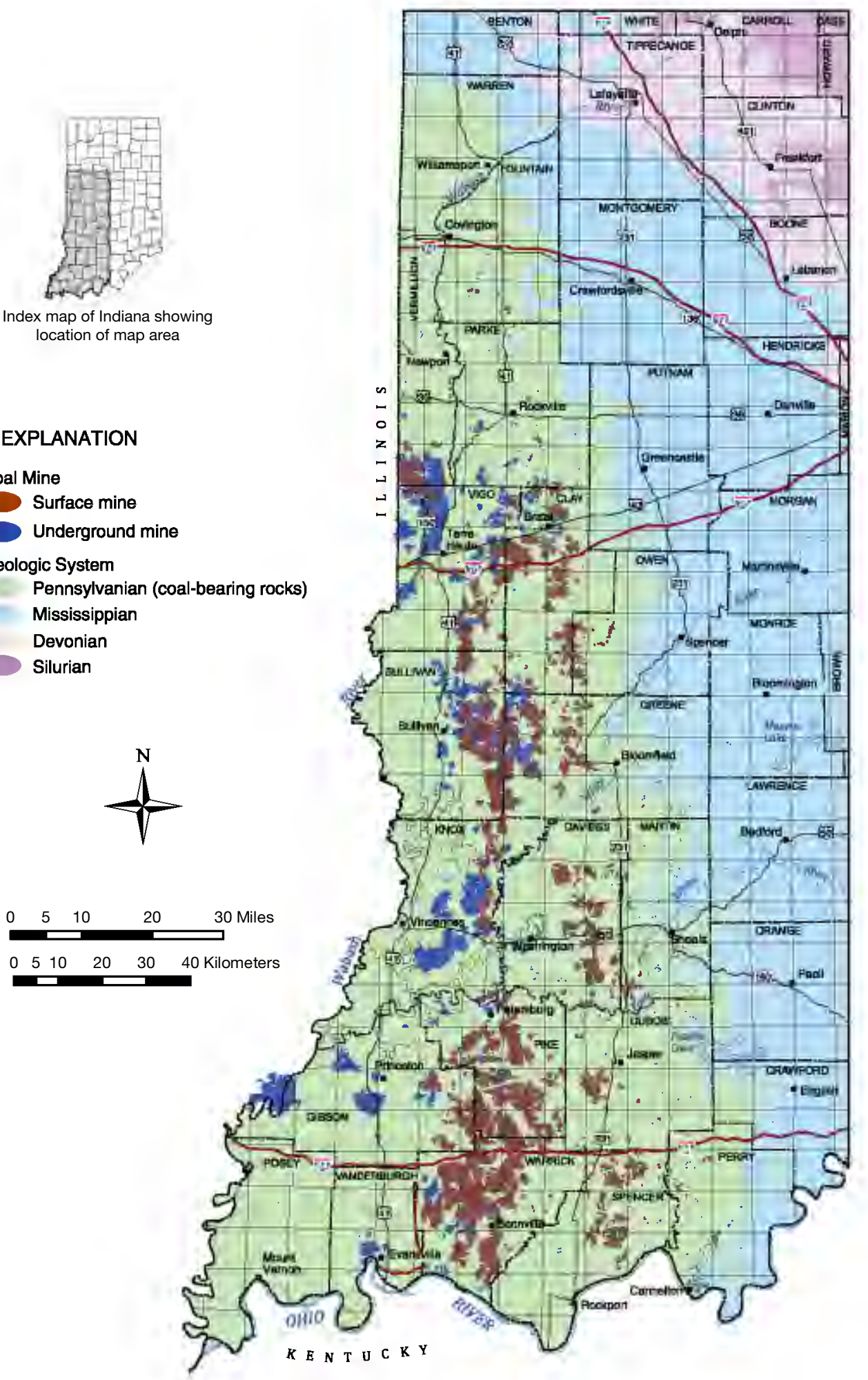

Figure 6. Map of Indiana showing locations of active coal mines (modified from Meyer, 2007). 


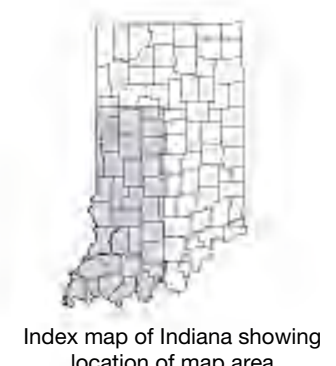
location of map area

\section{EXPLANATION}

_ Interstate and U.S. highway

+ Abandoned rail line

$\longrightarrow$ Active rail line

Surface mine

Underground mine

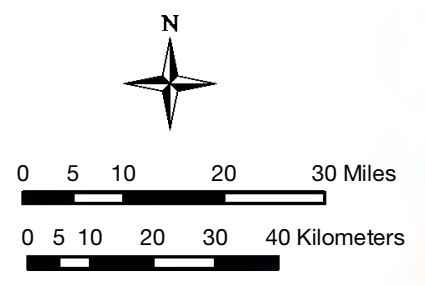

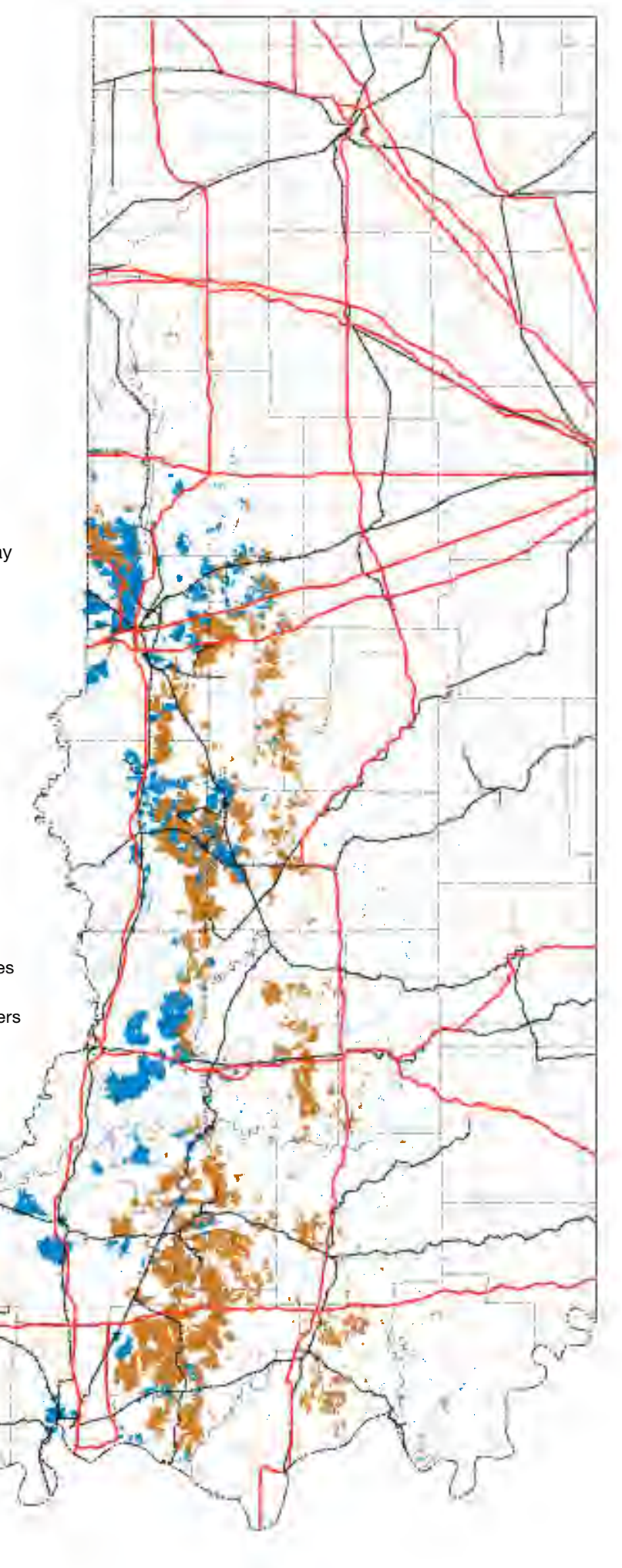

Figure 7. Map of southwestern Indiana showing major transportation routes. 


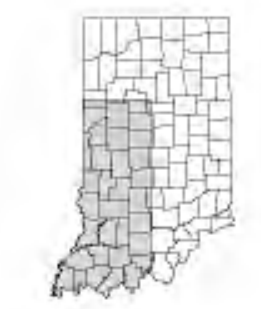

Index map of Indiana showing location of map area

EXPLANATION

_ Crude oil pipeline

Natural gas pipeline

Refined products pipeline

Transmission line

Surface mine

Underground mine
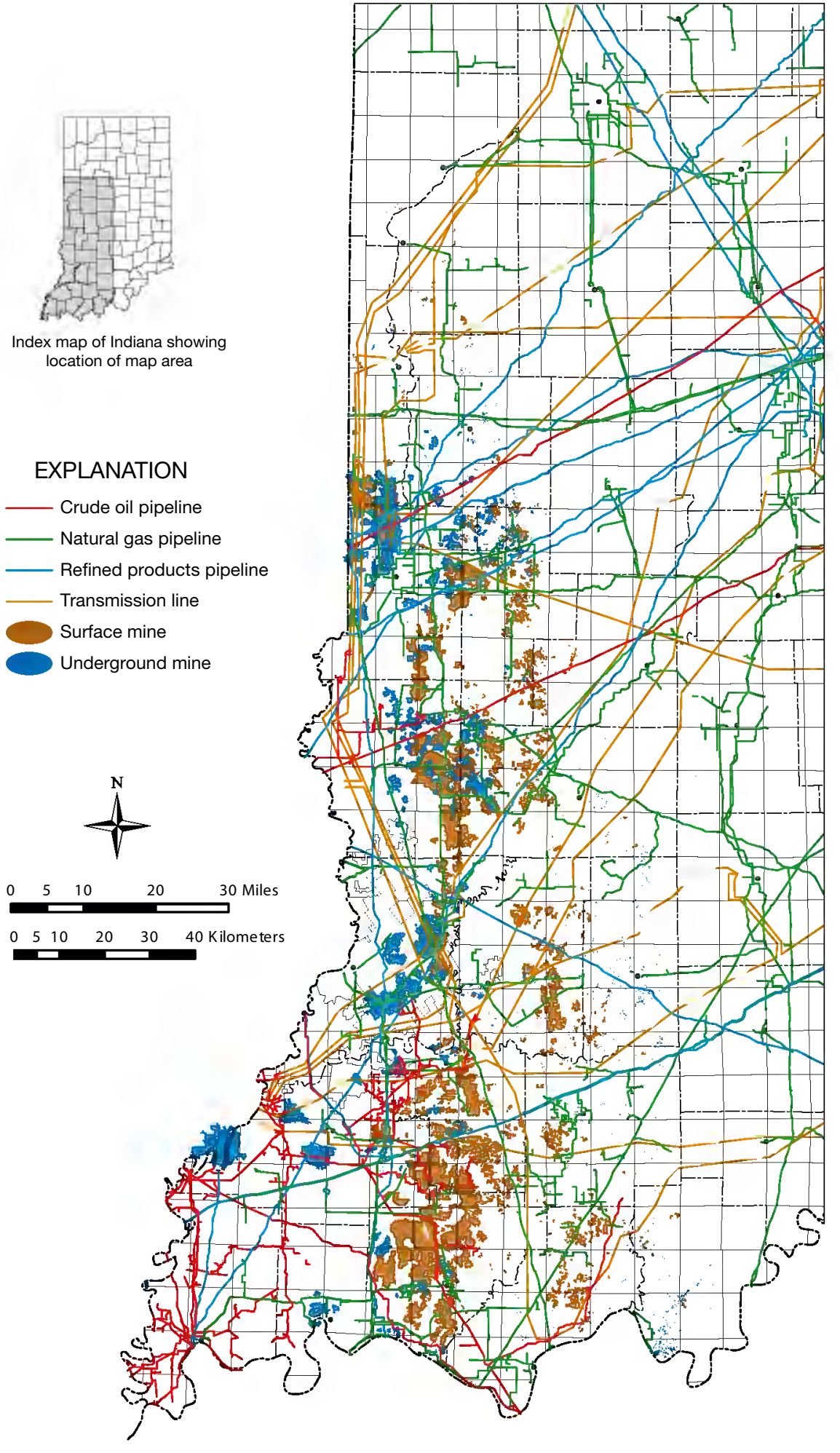

Figure 8. Map of southwestern Indiana showing pipelines and energy transmission lines. 
Table 3. Regulations that govern mine reclamation (IDNR, 2009)

\begin{tabular}{|l|l|}
\hline Federal Law & Public Law 95-87, the Surface Mining Control and Reclamation Act of 1977 \\
\hline Federal Regulations & 30 CFR Part 700 \\
\hline Indiana Law & $\begin{array}{l}\text { Indiana Code TItle 14: Natural and Cultural Resources: Article 34: Surface Coal Mining } \\
\text { and Reclamation }\end{array}$ \\
\hline Indiana Rules & $\begin{array}{l}\text { Indiana Administrative Code Title 312: Natural Resources Commission Article 25: Coal Mining } \\
\text { and Reclamation Operations }\end{array}$ \\
\hline
\end{tabular}

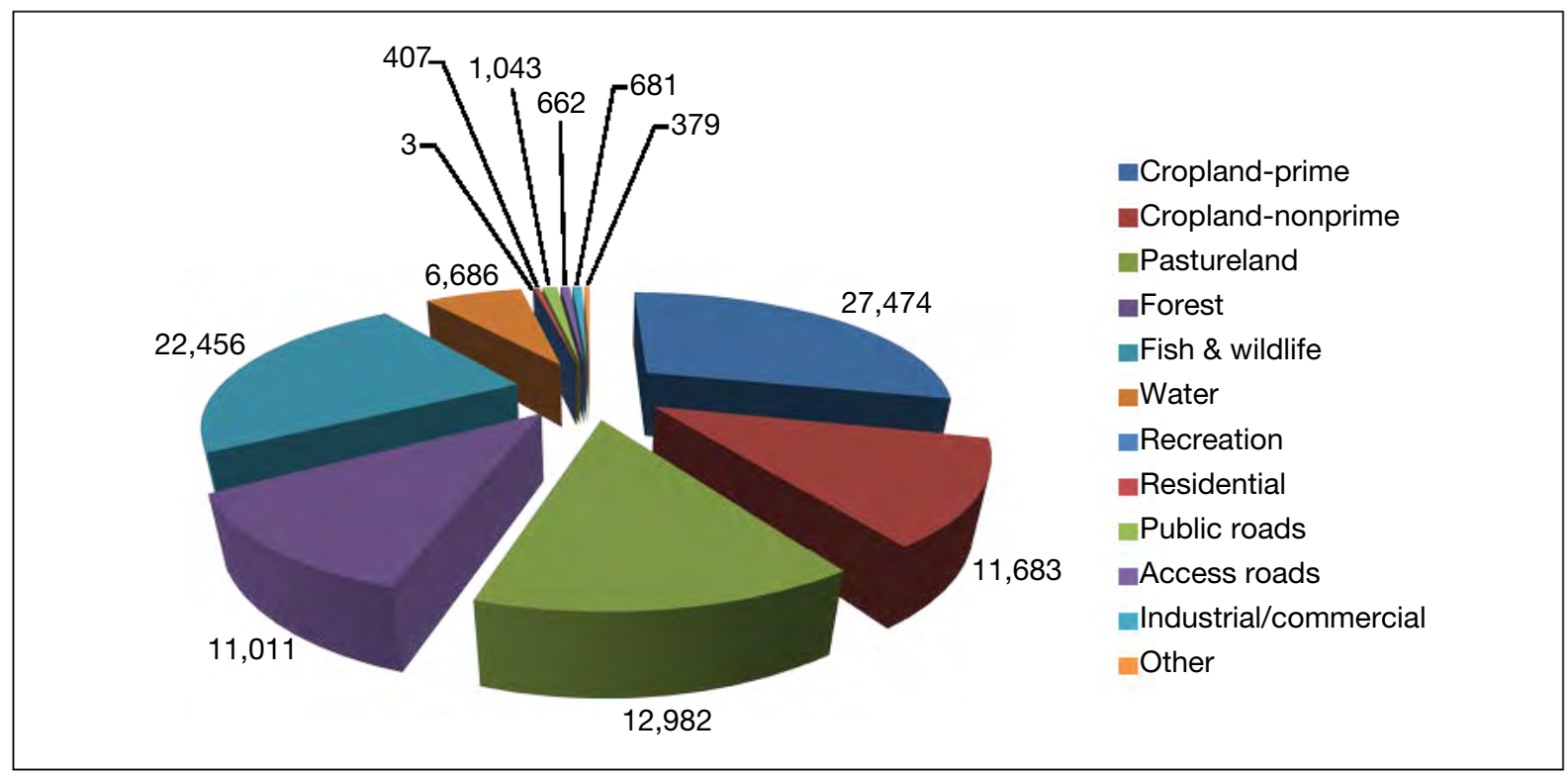

Figure 9. Pie chart showing current reuses of coal-mined lands in Indiana. Numbers represent permanent program final release acres (Table 4).

Early reforestation studies looked at tree species and survival rates, paying less attention to the soil (for example, Potter and others, 1951). Few longterm results were reported because trees generally take a long time to grow. More recent work (for example, Vories and Throgmorton, 1999) looked at results of growth, new techniques for planting, soil improvement, and the effects of ground cover. Lowcompaction grading was found to dramatically improve tree establishment and growth (Sweigard and others, 2007). Less-compacted soils are looser, resulting in easier planting, greater water infiltration, better air and water storage, and better root growth, all of which promote healthy tree growth. Selecting compatible soil amendments further enhances tree growth (Burger, 1999). Information on how to reforest surface-mined land can be found in Burger and Zipper (2002). A Purdue University study (Rathfon and others, 2005) noted that reclaimed forested lands are less productive, having less diverse flora than natural lands. They suggested a number of changes that could improve forestation outcomes including changes in ground cover, improved soil handling, better selection and availability of seed trees, avoiding compacting of soil, less grading, improved planting methods, and weed control.

Researchers are currently looking at new potential benefits of reforestation. Forest growth on mined land provides wood production, wildlife habitat, hydrologic improvements, erosion control, pollution mitigation, and recreational opportunities (Burger, 1999). Agroforestry is a relatively 
new reclamation technique in which woody perennials are deliberately integrated with crop or pasture lands. Agroforestry operates by using trees in spatial or temporal patterns. Combining standard agriculture and silvaculture techniques produces more diverse, productive, and sustainable land use. Although especially beneficial in less-developed countries, it could also provide more profitable reuses of mined lands in Indiana. Advantages of agroforestry include diversity of crops; improvement in nutrition for human populations; reduction of deforestation; improvement of soil fertility; carbon sequestration; longterm sustainability; more efficient use of sun, soil, and water; better wildlife habitat; and beautification. Agroforestry requires more attention to soil properties and its original implementation is more labor intensive, but it does represent a viable modern, environmentally friendly reclamation technique.

\section{Cropland}

Common agricultural crops-corn, soybeans, and forage crops-are often planted on reclaimed mine land in Indiana and elsewhere (Table 4). Successful agriculture requires water and mines frequently contain abundant water. However, the quality of water must be suitable for growing crops. Agricultural land use requires water that has been returned to a reasonable $\mathrm{pH}$ after mining and it must be low in components such as boron and toxic metals that can adversely affect plant growth.

The possibility for growing unusual or other highvalue crops exists in Indiana, but only one example is known. Experimental growing of genetically modified plants is being carried on underground in a reused limestone mine near Marengo, Indiana (Organic Consumers Association, 2005). Although this is a research effort, it does foreshadow potential future mine reuse possibilities in Indiana.

Some specialty crops can be grown underground. For example, mushrooms are grown in an abandoned limestone mine in Pennsylvania where certain species of mushrooms thrive in the moist, dark conditions (Earney, 1968). One Canadian company refits underground abandoned mines to grow tropical orchids, even in cold climes. The feasibility of growing such crops underground is also documented by orchids that are successfully grown in a cave under Kansas City, Missouri (Bile, 2008), and rice grown experimentally in an old underground bank vault in Japan (Trevi, 2008).

\section{Aquaculture}

Another possible reuse is aquaculture, the growing of fish or other aquatic biota in water bodies generated by mining. Many parts of the world have well-developed systems of aquaculture. Open ponds could be places to grow freshwater seaweed, algae, and other water-dependent plants for food, medicines, chemicals, fuels, or biomass. Although no example of such hydroponic growing on Indiana's mined lands was found during this study, good potential exists for establishing such water-based industries in the state, as has been demonstrated elsewhere at the Alliance Resource Partners, L.P. Mettiki Mine site in Maryland, where trout are raised.

Abundant water resources on or under mined areas can provide water for aquaculture. Water quality is important for raising fish, but some nonacidic mine lakes having low metal loadings should have adequately high-quality water to support fish cultivation. Sport fishing is already supported at a number of such lakes in Indiana, such as those at Greene-Sullivan or Shakamak State Parks. Aquaculture has been practiced in Minnesota (Axler and others, 1998) where more than 20 abandoned pits (mostly in abandoned iron mines) were used. Miller and others (2002) and Miller (2008) investigated using coal-mine water for aquaculture in West Virginia. Use of existing infrastructure such as roads, pipes, pits, utilities, and mine water of constant temperature benefits companies that raise fish commercially on mined lands (Smith, 1981). Based on these studies, prospects for aquaculture in Indiana are good and should be investigated further. Special attention will be needed to find mine waters suitable for fish production.

\section{ENERGY RESOURCES}

\section{Renewable carbon sources}

Plants grown on mined land can be harvested and burned to produce electrical energy or processed into transportation fuels or other materials. Trees and certain crops, such as switchgrass (Panicum virgatum) and rapeseed (Brassica napus), can be used to produce burnable mass or biofuels. Switchgrass is a currently used and promising renewable biomass (plant material used as energy sources) (Parrish and Fike, 2005). It grows 


\begin{tabular}{|c|c|c|c|c|c|c|c|c|c|c|c|c|c|c|}
\hline 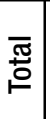 & & $\begin{array}{l}\text { o } \\
\text { 今. } \\
\text { Oे } \\
\text { N }\end{array}$ & 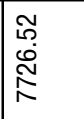 & \begin{tabular}{|l|} 
\\
+ \\
6 \\
0 \\
$\$$ \\
$\infty$ \\
\end{tabular} & 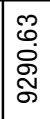 & $\begin{array}{l}\text { g } \\
\text { N } \\
\text { N } \\
\end{array}$ & 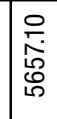 & 売 & $\begin{array}{l}\hat{\infty} \\
\text { D. } \\
\stackrel{D}{N}\end{array}$ & 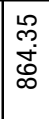 & $\begin{array}{l}\bar{\delta} \\
\stackrel{\tilde{े}}{ }\end{array}$ & 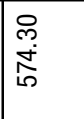 & & $\begin{array}{l}\bar{m} \\
\tilde{\rho} \\
o \\
g \\
\stackrel{\rho}{N}\end{array}$ \\
\hline $\bar{i}$ & & 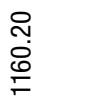 & 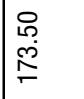 & $\begin{array}{l}\stackrel{8}{0} \\
\stackrel{\infty}{\sim}\end{array}$ & 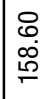 & 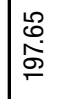 & 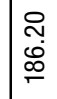 & $\stackrel{\circ}{\circ}$ & $\begin{array}{l}\text { 尺̊ } \\
\text { in }\end{array}$ & $\begin{array}{l}0 \\
0 \\
0\end{array}$ & $\frac{\circ}{\dot{m}}$ & 吕 & 웅 & 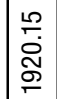 \\
\hline 을 & & 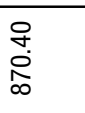 & 站 & 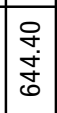 & \begin{tabular}{|l}
0 \\
\\
$\dot{j}$ \\
$\dot{\sigma}$
\end{tabular} & 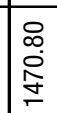 & $\frac{\mathcal{F}}{\dot{q}}$ & 迆 & 递 & \begin{tabular}{|l}
$\infty$ \\
$\infty$ \\
$\infty$ \\
$\infty$ \\
$\infty$
\end{tabular} & 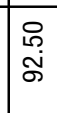 & $\begin{array}{l}\stackrel{R}{2} \\
\stackrel{\sim}{N}\end{array}$ & $\underset{\text { ָ̦ }}{\mathbb{N}}$ & 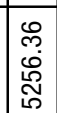 \\
\hline ¿্. & & $\begin{array}{l}8 \\
\stackrel{0}{\infty} \\
\stackrel{\infty}{0} \\
i\end{array}$ & $\begin{array}{l}\text { \& } \\
\stackrel{\text { }}{\text { jum }}\end{array}$ & $\begin{array}{l}\stackrel{0}{0} \\
o \\
o\end{array}$ & 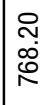 & 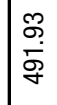 & $\begin{array}{l}\infty \\
\infty \\
\tilde{\sigma} \\
\dot{\sigma}\end{array}$ & 号 & 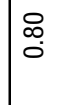 & 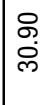 & $\begin{array}{l}\stackrel{P}{\mathbf{N}} \\
\dot{\sim}\end{array}$ & 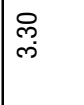 & ò & 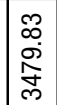 \\
\hline ڤ̊ & & $\begin{array}{l}\text { ల్ల } \\
\infty \\
\stackrel{\infty}{\infty} \\
\text { N }\end{array}$ & $\begin{array}{l}\frac{8}{0} \\
\frac{\bar{\sigma}}{0}\end{array}$ & 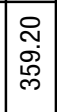 & 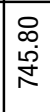 & 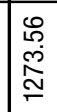 & F্ল & : & $\begin{array}{l}\stackrel{\infty}{\infty} \\
\sim \\
\sim\end{array}$ & $\mid$\begin{tabular}{c}
$\infty$ \\
\multirow{\infty}{\infty}{} \\
$\infty$
\end{tabular} & $\begin{array}{l}\stackrel{\odot}{~} \\
\dot{g}\end{array}$ & 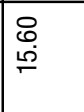 & $\begin{array}{l}0 \\
0 \\
0\end{array}$ & 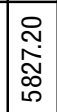 \\
\hline ڤ્. & & 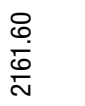 & 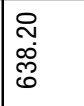 & $\mid \begin{array}{l}q \\
\stackrel{q}{0} \\
\stackrel{N}{0}\end{array}$ & 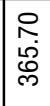 & \begin{tabular}{l}
$\infty$ \\
$\infty$ \\
\hdashline \\
$\mathscr{f}$
\end{tabular} & 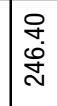 & $\underset{-}{\stackrel{0}{-}}$ & $\mid \begin{array}{l}\stackrel{P}{\$} \\
\stackrel{\infty}{\infty}\end{array}$ & 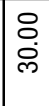 & $\begin{array}{l}\text { p్ల. } \\
\tilde{ల ్ ల ~}\end{array}$ & \begin{tabular}{|l}
$\circ$ \\
$\stackrel{0}{0}$ \\
d.
\end{tabular} & \& & 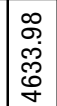 \\
\hline ஜ્̀ & & $\begin{array}{l}\text { ల్ల } \\
\underset{N}{\tilde{N}} \\
\text { N }\end{array}$ & 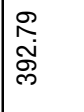 & $\mid \begin{array}{l}0 \\
\tilde{m} \\
0 \\
\bar{\sigma}\end{array}$ & 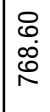 & 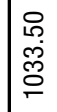 & 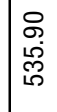 & 웅 & io & \begin{tabular}{|l}
$R$ \\
0 \\
0 \\
10
\end{tabular} & $\begin{array}{l}\text { న్ } \\
\text { న్ }\end{array}$ & $\begin{array}{l}\text { Oे } \\
0\end{array}$ & $\begin{array}{l}0 \\
10 \\
0 \\
0\end{array}$ & 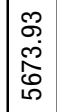 \\
\hline ڤి & & $\begin{array}{l}\stackrel{0}{0} \\
\stackrel{0}{0} \\
0\end{array}$ & $\begin{array}{l}\stackrel{q}{9} \\
\text { in }\end{array}$ & $\begin{array}{l}0 \\
\stackrel{8}{f} \\
\dot{f}\end{array}$ & $\begin{array}{l}R \\
R \\
\infty \\
m \\
m\end{array}$ & $\begin{array}{l}\text { Pof } \\
\dot{8} \\
\text { : }\end{array}$ & $\begin{array}{l}R \\
\stackrel{R}{0} \\
\stackrel{\sim}{\text { N }}\end{array}$ & 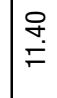 & 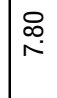 & 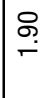 & 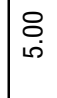 & 号 & 高 & $\begin{array}{l}0 \\
\text { of } \\
0 \\
0 \\
0\end{array}$ \\
\hline ఫે & & $\begin{array}{l}\underset{C}{\tilde{N}} \\
\stackrel{0}{N}\end{array}$ & $\begin{array}{l}0 \\
\infty \\
0 \\
0 \\
\dot{q}\end{array}$ & 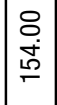 & 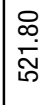 & 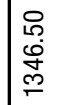 & 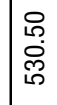 & 웅 & 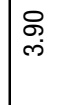 & \begin{tabular}{|l} 
g \\
$\dot{0}$ \\
d
\end{tabular} & $\begin{array}{l}\stackrel{\text { N }}{\text { I. }} \\
\end{array}$ & 号 & 号 & 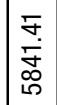 \\
\hline ֻి & & 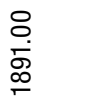 & 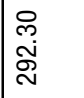 & \begin{tabular}{|c}
8 \\
0 \\
$\dot{j}$ \\
6
\end{tabular} & \begin{tabular}{|l}
0 \\
0 \\
0 \\
0 \\
0
\end{tabular} & 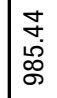 & $\begin{array}{l}\Delta \\
\dot{\sigma} \\
\dot{p} \\
\dot{m}\end{array}$ & 兑 & $\begin{array}{l}\stackrel{\leftrightarrow}{+} \\
\stackrel{\sim}{亡}\end{array}$ & 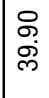 & $\begin{array}{l}\stackrel{8}{0} \\
\dot{m}\end{array}$ & \begin{tabular}{|l}
0 \\
吕 \\
in
\end{tabular} & 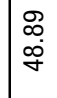 & 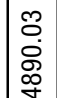 \\
\hline ๙ิ & & $\begin{array}{l}0 \\
0 \\
0 \\
0 \\
\Sigma\end{array}$ & \begin{tabular}{|l} 
\\
o \\
$\stackrel{+}{\sigma}$
\end{tabular} & $\begin{array}{l}\bar{f} \\
\dot{0} \\
\varnothing\end{array}$ & 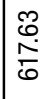 & \begin{tabular}{|l|l}
$\infty$ \\
0 \\
0 \\
0 \\
0
\end{tabular} & 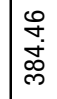 & 官 & \begin{tabular}{|l}
0 \\
$\stackrel{+}{\dot{\sigma}}$
\end{tabular} & $\begin{array}{l}\circ \\
0 \\
\dot{\theta}\end{array}$ & $\begin{array}{l}\text { న్ } \\
\text { g্ }\end{array}$ & $\underset{\mid}{\stackrel{8}{\circ}}$ & 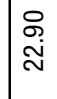 & $\begin{array}{l}\tilde{\gamma} \\
0 \\
0 \\
0\end{array}$ \\
\hline 호 & & \begin{tabular}{l}
$\stackrel{8}{0}$ \\
$\infty$ \\
$\dddot{9}$ \\
\multirow{f}{f}{}
\end{tabular} & 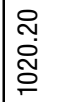 & 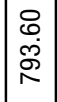 & 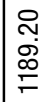 & $\begin{array}{l}\infty \\
\infty \\
\infty \\
\infty \\
\tilde{D} \\
\stackrel{2}{\alpha}\end{array}$ & $\begin{array}{l}\mathscr{m} \\
\infty \\
0 \\
0 \\
0 \\
0\end{array}$ & 迆 & $\begin{array}{l}\stackrel{8}{0} \\
\stackrel{0}{\circ}\end{array}$ & $\begin{array}{l}0 \\
0 \\
\dot{8}\end{array}$ & $\frac{0}{m}$ & 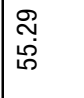 & $\begin{array}{l}0 \\
0 \\
0 \\
\infty \\
\end{array}$ & 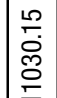 \\
\hline ్ㅗ & & 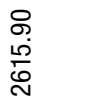 & 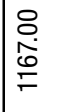 & $\begin{array}{l}\tilde{\omega} \\
\tilde{N} \\
\tilde{N} \\
\tilde{N}\end{array}$ & 竎 & 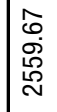 & 倠 & 迆 & $\begin{array}{l}\text { த } \\
\text { ণ }\end{array}$ & 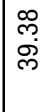 & 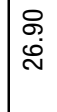 & $\begin{array}{l}\bar{\sigma} \\
\stackrel{\alpha}{\sigma}\end{array}$ & 帘 & 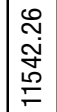 \\
\hline 용 & & 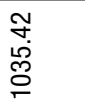 & \begin{tabular}{|l|}
$\frac{\infty}{20}$ \\
$\frac{0}{\infty}$
\end{tabular} & 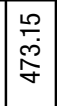 & 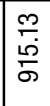 & 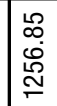 & 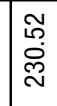 & O̊. & 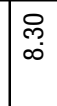 & $\begin{array}{l}\circ \\
\infty \\
\tilde{0} \\
\tilde{0}\end{array}$ & $\begin{array}{l}\circ \\
\infty \\
\infty \\
\infty\end{array}$ & 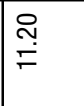 & 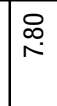 & 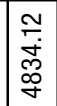 \\
\hline$\stackrel{\infty}{\stackrel{一}{\sigma}}$ & 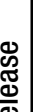 & 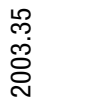 & \begin{tabular}{|l}
$\infty$ \\
$\infty$ \\
$\infty$ \\
$\infty$ \\
$\infty$ \\
$\infty$
\end{tabular} & 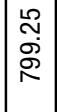 & 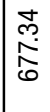 & 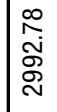 & 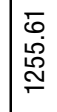 & 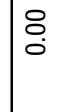 & 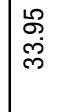 & 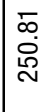 & $\begin{array}{l}\bar{\Sigma} \\
\dot{j}\end{array}$ & O̊. & $\stackrel{\circ}{\circ}$ & $\begin{array}{l}\infty \\
0 \\
0 \\
0 \\
0 \\
\infty \\
\infty\end{array}$ \\
\hline 홍 & 空 & $\begin{array}{l}\stackrel{8}{\circ} \\
\stackrel{0}{\imath}\end{array}$ & 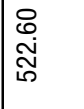 & $\mid \begin{array}{l}\stackrel{2}{\sim} \\
\vec{\sigma} \\
\sigma\end{array}$ & \begin{tabular}{|l}
$\stackrel{g}{\dot{d}}$ \\
J
\end{tabular} & $\mid \begin{array}{c}\stackrel{\Upsilon}{\tilde{~}} \\
\dot{\forall}\end{array}$ & $\begin{array}{l}\hat{5} \\
0 \\
0 \\
0\end{array}$ & 号 & 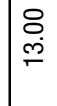 & 商 & $\begin{array}{l}\stackrel{\infty}{\infty} \\
\stackrel{\sim}{\sim}\end{array}$ & 号 & 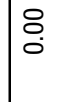 & 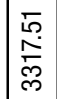 \\
\hline 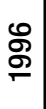 & | & 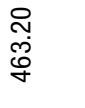 & 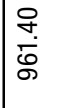 & 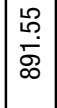 & $\begin{array}{l}0 \\
10 \\
0 \\
0 \\
\infty\end{array}$ & $\mid \begin{array}{l}0 \\
\stackrel{0}{+} \\
\stackrel{\infty}{\infty} \\
\stackrel{\infty}{0}\end{array}$ & $\mid \begin{array}{c}\tilde{m} \\
\stackrel{0}{0} \\
\infty \\
\infty\end{array}$ & ¿̊. & $\begin{array}{l}0 \\
\text { م. } \\
\text { ¿ }\end{array}$ & 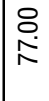 & 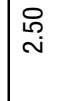 & $\begin{array}{l}8 \\
0 \\
\dot{0}\end{array}$ & 号 & 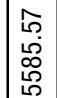 \\
\hline 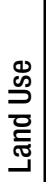 & | & 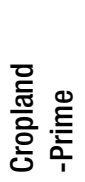 & 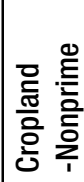 & 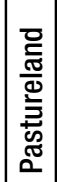 & 芯 & 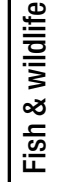 & 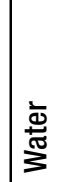 & 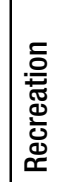 & 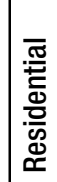 & 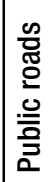 & 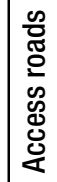 & 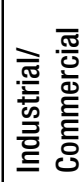 & |ᄒ & 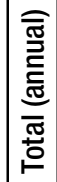 \\
\hline
\end{tabular}

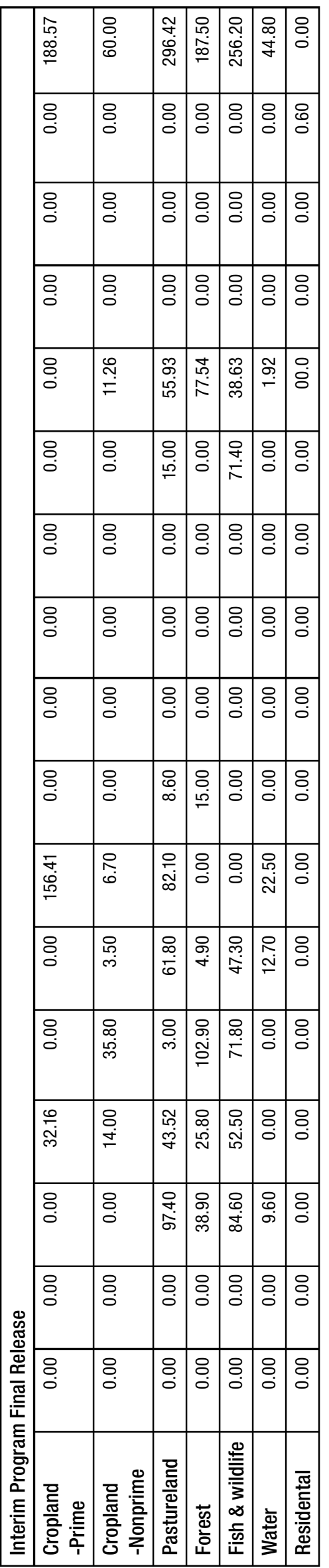




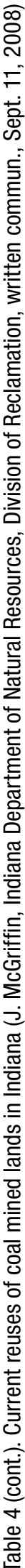

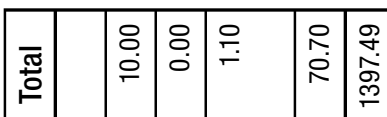

\begin{tabular}{|l|l|l|l|l|}
\hline$\circ$ & $\circ$ & 8 & 0 & 0 \\
\hline & 0 & 0 & 0 & 0 \\
\hline
\end{tabular}

둥

\begin{tabular}{|l|l|l|l|l|} 
& & & & \\
\hline$\circ$ & $\circ$ & $\circ$ & $\circ$ & $\circ$ \\
\hline
\end{tabular}

응

\begin{tabular}{llllll} 
& 0 & 0 & 0 & 0 & 0 \\
\hline & 0 & 0 & 0 & 0 \\
& & &
\end{tabular}

\begin{tabular}{|l|l|l|l|}
\hline 8 & 8 & 0 & 0 \\
\hline & 0 & 0 & 0 \\
\hline
\end{tabular}

융

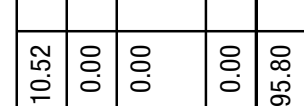

융

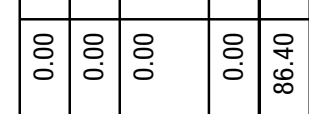

응

\begin{tabular}{|l|l|l|l|l|}
\hline$\circ$ & $\circ$ & $\circ$ & $\circ$ & $\circ$ \\
\hline & 0 & 0 & 0 \\
\hline
\end{tabular}

융

\begin{tabular}{|l|l|l|l|l|}
\hline$\circ$ & $\circ$ & $\circ$ & $\circ$ & $\circ$ \\
\hline & 0 & 0 & 0 & 0 \\
\hline
\end{tabular}

옹

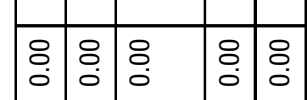

导

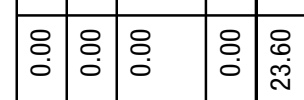

ஜํํ

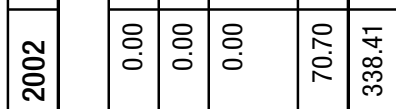

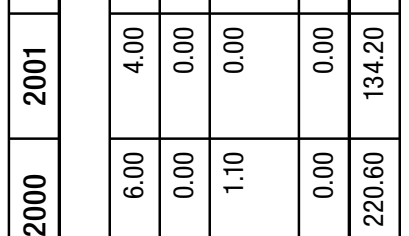

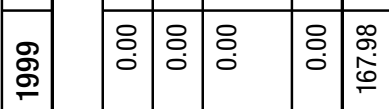

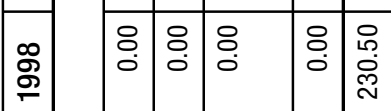

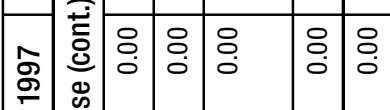

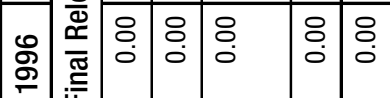

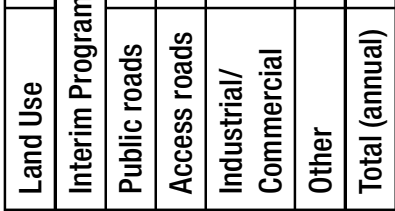

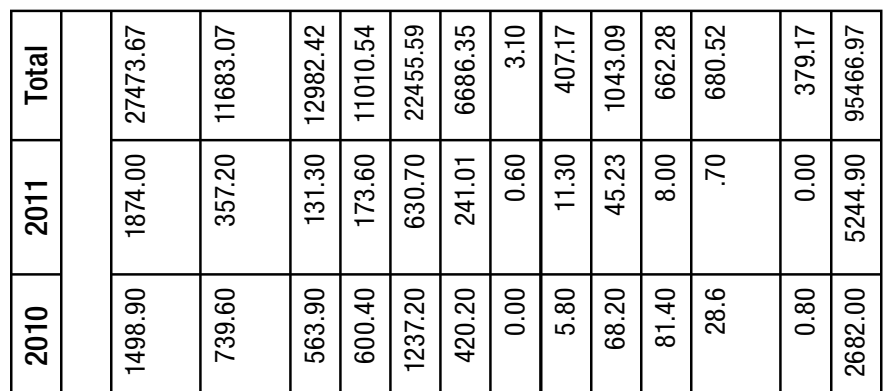

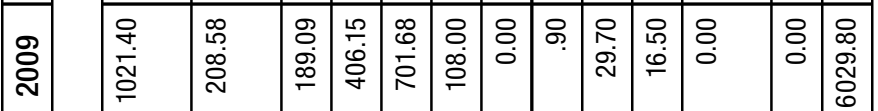

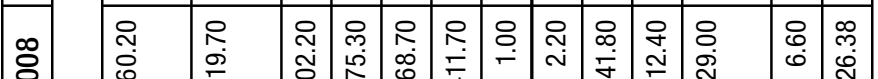

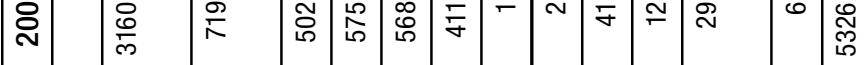

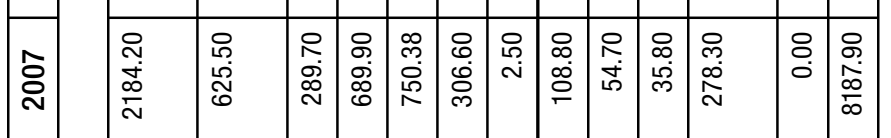

윰

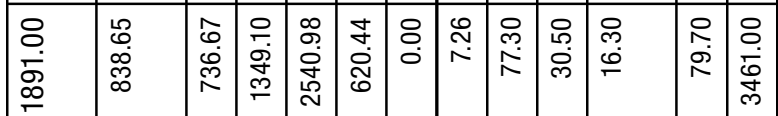

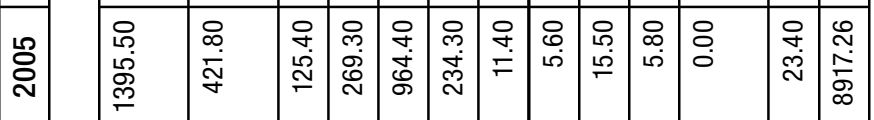

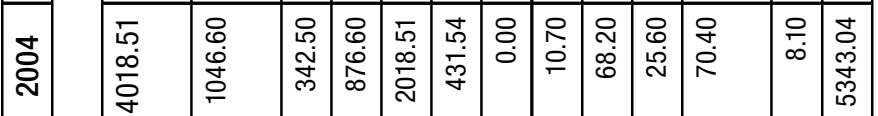

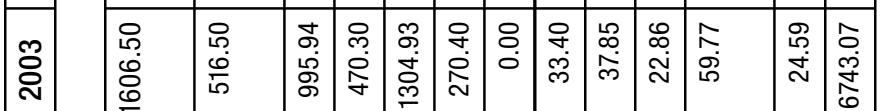

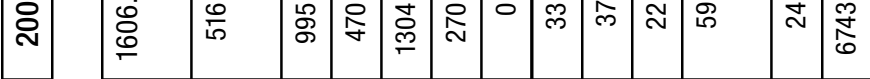

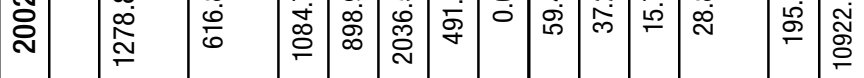

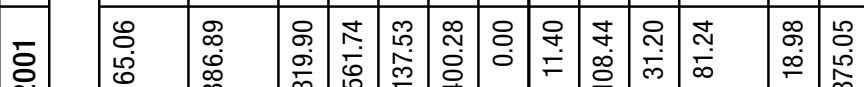

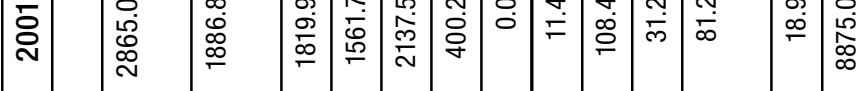

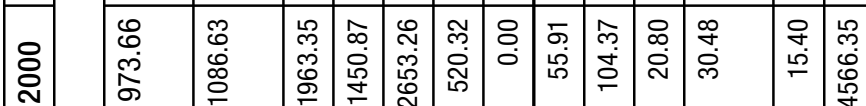

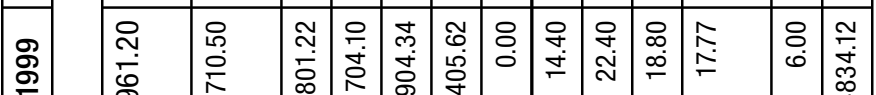

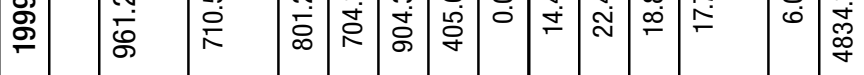

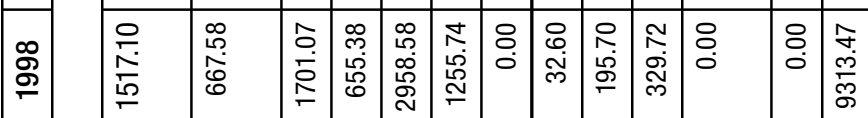

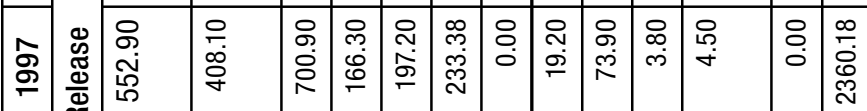

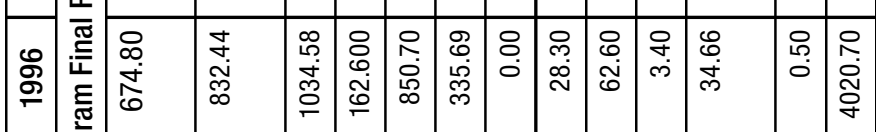

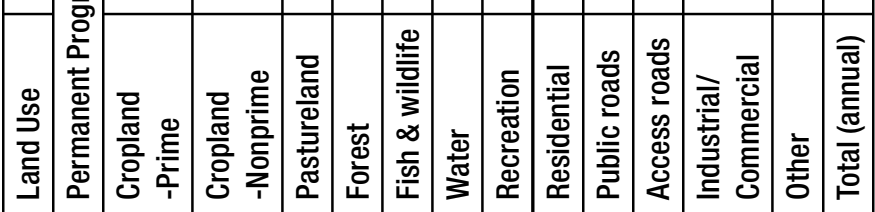


in the eastern United States and can adapt to lands having poor soils (Sokhansanj and others, 2009). Several recent papers deal with logistics and economics of energy production from grasses (USDOE, 2006; Schmer and others, 2008; Sokhansanj and others, 2009; Christensen and Koppenjan, 2010), and research supported by the U.S. Department of Energy showed it to be an efficient ethanol feedstock (Ehrlich, 2002). Ethanol is an alcohol that can be used as a fuel in vehicles. Biomass can also be turned into a flammable gas by gasification, a process that exposes carbon-bearing material to high temperature and controlled amounts of oxygen or steam without combustion. The resulting synthetic gas can be used for electric power generation (Jin and others, 2009; Larson and others, 2009). Corporations such as British Petroleum have announced research programs to develop commercial methods for producing biofuel (Childs, 2007). Rapeseed (Brassica napus) (Smith, 2007) and plants of the genus Miscanthus (McKendry, 2002) are also used for fuel production. Crop residue or waste wood are also viable biomass fuel sources. If technological barriers can be overcome, biofuel production from cellulose would further increase the need for more land dedicated to biofuel plant production.

\section{Carbon dioxide abatement}

Considerable potential exists for carbon dioxide $\left(\mathrm{CO}_{2}\right)$ sequestration through uptake by plants grown on mined lands. Planting new forest can sequester between 0.6 to 2.6 metric tons of carbon per acre per year (Birdsey, 1996). Lynd and others (2009) concluded that sugar-rich or starchrich plants have the best potential for $\mathrm{CO}_{2}$ removal.

Shrestha and Lal (2006) discussed carbon sequestration in mined soils and concluded that such soils show great potential to store carbon. Carbon dioxide is fixed when plant products are retained in the soil, when $\mathrm{CO}_{2}$ reacts with existing soil minerals, and when it forms new minerals, especially carbonates (Lee and Li, 2001). Akala and Lal (2000) estimated about 37 million grams/ha of carbon was sequestered in mined lands of Ohio in 25 years. While many unmined farm lands are near carbon saturation from long-term farming, mined lands are not and thus represent large potential carbon sinks as soil develops and new vegetation grows. Mined lands, which often contain little soil carbon owing to the lack of recent plant growth, sequester atmospheric $\mathrm{CO}_{2}$ when postmining planting is resumed (Lee and $\mathrm{Li}, 2001$ ). For instance, planting 2,000 to 4,000 trees per acre added approximately 50 percent of additional organic carbon, which was introduced into soils via tree roots. Reclaimed soils may be specifically prepared by adding growthpromoting chemicals, adjusting the $\mathrm{pH}$, or preventing erosion to enhance tree growth. With optimum applications, growth rates beyond those of natural soils may be achieved (Appalachian Regional Reforestation Initiative, 2010).

Abandoned underground mine voids and abandoned surface ponds could also be put to use for sequestering $\mathrm{CO}_{2}$ from power plants and other $\mathrm{CO}_{2}$-producing facilities. Algae and bacteria are used to capture $\mathrm{CO}_{2}$ and they can be processed into biofuels (Andrews and others, 2008; McGill, 2008; Grant, 2009; Ryan, 2009). Pilot plants are in operation and billions of dollars (Mascarelli, 2009; Sheridan, 2009) have been invested in more than 60 active or proposed operations. None are on mined lands at this point. A recent analysis (Viebahn and others, 2007) concludes that renewable energy based on $\mathrm{CO}_{2}$ removal could be cheaper than conventional carbon capture and sequestration technology, which requires expensive concentration of $\mathrm{CO}_{2}$, pressuring to supercritical conditions, and emplacement in deep geologic units.

Used mined lands, especially mine pool water or select surface sites, could be converted to geobioreactors to clean up $\mathrm{CO}_{2}$ and produce useful materials. For example, solid calcite can be produced by organisms from $\mathrm{CO}_{2}$ generated at power plants (Newall and others, 1999). The calcite could then be used in sulfur oxide scrubbers at coal-fired power plants. Surface mines can be contoured as part of final grading to form ponds suitable for lightdependent photosynthetic reactions that produce both organic biomass and mineral phases that sequester $\mathrm{CO}_{2}$. Mines are often near or even directly under electric power plants, making such operations feasible.

\section{Coal fines recovery}

During coal processing by washing, substantial amounts of fine coal particles commonly referred to as "coal slurry" were collected in large ponds. These deposits contain sizable amounts of mineral 
matter mixed with coal fines. Coal fines can be used for fluidized bed combustion and for gasification. Pennsylvania produces coal fines for electricpower generation at several sites and coal slurry is being re-mined to recover fine coal at two sites in Indiana, the abandoned Enos mine in Pike County and the closed Chinook mine in Clay County, south of I-70 near the Clay/Vigo County line. The Enos mine is being remined by $\mathrm{T} \& \mathrm{~T}$ Washing Company, and the Chinook Mine is being remined by Covol Engineered Fuels, LLC. In Indiana, coal processing wastes are estimated to contain 22 to 69 million tons of recoverable coal (Harper, Dintaman, Mastalerz, and Letsinger, 2009).

\section{Associated fossil carbon resources}

Substantial energy resources can be found in organic-rich black shales that lie directly above several commercial coal beds in Indiana mines (Shaffer and others, 1984; Shaffer and Leininger, 1985). These shales have high organic carbon content and can produce from 7 to almost 20 gallons of oil per ton of shale under conventional FischerTropsch process and more than 50 gallons per ton under special hydrogen-rich retorting. Such shales are commonly exposed in coal mine roof rocks. These organic-rich black shales locally produce commercial amounts of methane and, where present, they can increase the yield from underground gasification of coal (Shaffer and Mastalerz, 2009).

\section{Geothermal energy resources}

Abandoned underground mines usually fill with water to form mine pools. These waters have a nearly constant temperature unless there is rapid circulation and exchange with surface waters whose temperatures vary with seasons. In Indiana, most water isolated from the surface is at $52^{\circ}$ to $54^{\circ} \mathrm{F}\left(11 \cdot 1^{\circ}-12 \cdot 2^{\circ} \mathrm{C}\right)$. Approximately 170 billion gallons $\left(644 \times 10^{9}\right.$ liters [L]) of water of this temperature are in abandoned underground mine reservoirs (Harper, Dintaman, Mastalerz, and Letsinger, 2009). Although most current low-temperature geothermal energy applications use shallow groundwater, underground mine waters are a significant source of geothermal energy (Science Daily, 2007; Watzlaf and Ackman, 2007). This water represents an enormous energy resource that has been exploited primarily for heating and cooling in a number of creative ways.

Some direct geothermal use is made for greenhouses, aquaculture, various industrial heating processes, drying agricultural products, and snow and ice melting via embedded pipes. Direct or ground-coupled geothermal uses of mine waters are dominated by residential heating (70+ percent), heat pumps, and domestic hot water (fig. 10). It is estimated that even small voids could produce enough geothermal heat to support an average home's needs. A mine void a few feet thick with 50 percent extraction contains more than 2 acre-feet of water (approximately 652,000 gallons [2.5 million L]) for each acre mined. Heat from the mine water can be extracted in an open loop by pumping mine waters through a heat exchanger or heat pump at the surface (fig. 10) and discharging the water on the surface. Heat can also be extracted in closed loop systems by pumping the mine water through a surface heat exchanger and then sending the water back into the mine. It is also possible to extract the heat by using heat-transfer fluids that circulate through closed-loop pipes directly in the mine water or that pass through a secondary heat-exchange unit that actually resides in the mine. Use of heat exchange loops emplaced into one or a few vertical wells drilled into abandoned underground mines filled with water should be economically feasible using currently available technology. In closed systems, pipes filled with heat exchange fluids (water with antifreeze or a refrigerant) can be placed in drilled holes or into mine voids and the fluids pumped through the underground loop to surface heat exchangers.

Lund and Freeston (2001) and Lund (1997, 2005) reviewed worldwide use of geothermal energy from mine water and Lund (2003) focused on uses in the United States. Watzlaf and Ackman (2006) estimated that using coal mine waters in the Pittsburgh area to supply warm waters to surface heat pumps could reduce heating costs by 67 percent and cooling costs by 50 percent. Renz and others (2009) provided a numerical model for the optimum use of heat from mine waters. Banks (2009) coined the term "thermogeology" for the science of low-temperature geothermal waters and explained heat pump operations for lowtemperature systems. Rybach (2003), Hanova and Dowlatabadi (2007), Banks and others (2009), and Busby and others (2009), examined operational 


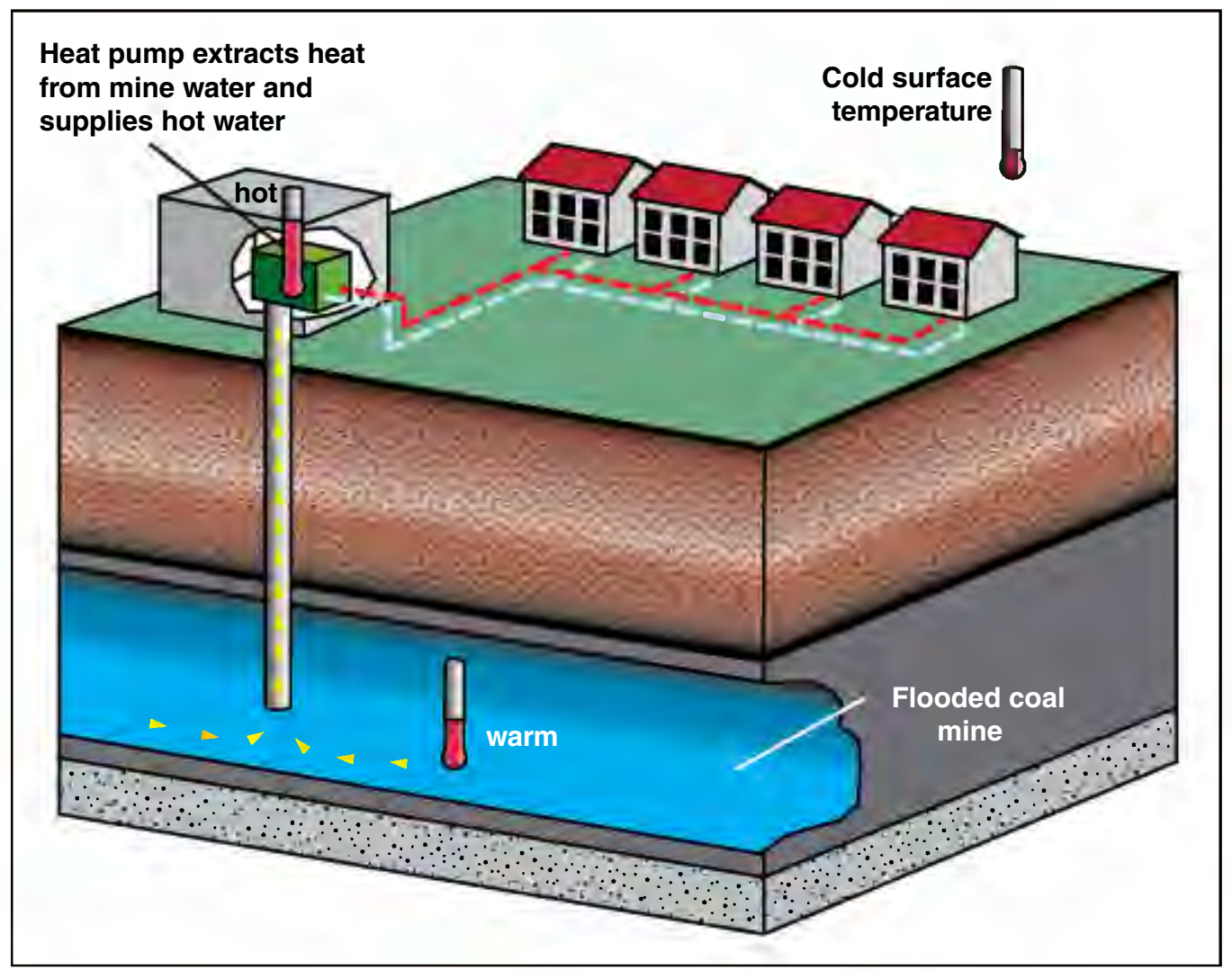

Figure 10. Diagram showing the configuration of a geothermal system developed using a flooded underground coal mine.

details of geothermal assisted heat pumps and encouraged extensive use of mine water. Rodriguez and Diaz (2009) stressed the renewable and sustainable aspects of mine water as a geothermal energy resource and suggested installing specialized large-diameter conduits, machine platforms, and stirring devices in preparation for using the geothermal energy in mine water before mine abandonment and flooding. Raymond and others (2008) noted that oxidization of coal wastes produces heat that contributes to the geothermal energy stored in mine water, thus contributing to the renewable nature of the resource. Other reports assess mine water geothermal resources in Europe (Malolepszy, 2000, 2003; Dickson, 2004; Midlothian Council, 2004; Malolepszy and others, 2005; McLoughlin, 2006; Bazargan Sabet and others, 2008; and Kranz and Dillenardt, 2009; Minewater Project, 2010). The Centre for the Analysis and Dissemination of Demonstrated Energy Technologies (CADDET, 2007) and Allen and others (2000) reviewed low-temperature geothermal potential of Canada, including mine waters. Locations where communities and residences use mine waters for heating include Springhill, Nova Scotia (Mason, 2009); Timmons, Ontario; Shettleston and other sites in Scotland; Yellowknife, Canada; several sites in Poland; and Butte, Montana and Pittsburgh, Pennsylvania in the United States. Others are planned for Asturias, Spain, and Cape Breton and Gaspe Mines in Canada. One of the most visible and successful operations is located in Heerlen in the Netherlands (Charter, 2008; Meinhold, 2008). This city is the lead partner of seven European countries promoting geothermal use from closed mines called the Minewater Project.

Information about exact locations and depths of mine pools, amounts of water, chemical and thermal characteristics of the water, general hydrology, effects of heat removal on rocks and water, and economics of water usage must be gathered and used in planning for the exploitation of this immense but mostly untapped resource. Technical issues such as aggressive (low-pH) water, scaling or precipitation of minerals, possible gas escapes $\left(\mathrm{CH}_{4}, \mathrm{CO}_{2}\right)$, and other unexpected difficulties may be overcome by pretreatment, using 
closed-loop systems with heat transfer fluids that do not come into direct contact with the mine waters, or choosing suitable waters. Mine water can lead to corrosion and mineral precipitation, but these can be controlled with filtration and additives (Rafferty, 2000). Banks and others (2003, 2009) identified mine water characteristics that are most compatible with heat pumps. Extensive removal of underground mine water by pumping may lead to subsidence (Waffel, 2008), but pump rates can be limited to maintain equilibrium and minimize such problems or the water can be reinjected into the mine. The most likely use for Indiana geothermal energy from mine water is as ground-coupled or ground-source heat pumps, because discharge of poor-quality mine waters at the surface would be problematic.

In the United States, many states, including Indiana, support programs that encourage the use of direct geothermal energy, mainly for heating and cooling homes, businesses, and civic buildings. A number of federal and state programs encourage use of low-temperature geothermal resources (Cappa and Hemborg, 1995; Allred, 2005; National Renewable Energy Laboratory, 2006; Lyons, 2009; Pennsylvania Department of Community and Economic Development, 2009; USDOE, 2009; Oak Ridge National Laboratory, 2011). Organizations such as the Geo-Heat Center (2011) or the International Geothermal Association (2011) provide background data and links to assistance programs. Indiana has a residential rebate program (Cummings, 2008), as well as other incentives for geothermal heating (North Carolina Solar Center, 2009). Use of geothermal mine water does not have a separate program at this time, but would be covered under existing programs.

An interesting new use of geothermal energy is the siting of computer-rich data centers inside abandoned underground mines (Trading Markets, 2007; Heimbuch, 2009; Mearian, 2009) and using mine waters to cool large computer centers (Miller, 2009). Ever increasing amounts of digital data and the need to have secure, energy-efficient data centers make underground data storage and geothermal cooling for data storage centers a viable option in some regions. Indiana has a number of potential sites (figs. 5 and 6) for this and other high-tech uses.

\section{Wind farms and solar arrays}

Coal-mined areas (fig. 6) are excellent candidates for renewable electric power production, such as wind turbine farms and solar energy arrays. Mined sites are being developed for renewable energy and future mines could even be designed in advance to maximize efficiency of wind or solar devices by constructing topographic features that encourage or focus winds or by placing solar arrays at more optimal orientation through sculpting the land during reclamation. However, a major problem with solar and wind power is the intermittent nature of energy production. Exploring good techniques to store energy for later use is critical for full development of these renewable sources (Moore and Douglas, 2006).

\section{ENERGY STORAGE}

\section{Energy smoothing}

Energy storage from existing coal-fired or renewable electric-generating plants is a major concern of electric companies (EPRI, 1976; Schaber, 2004; USDOE, 2007; Chen and others, 2009). Electric-generating plants function best if they keep operating at a very constant and high level. However, demand fluctuates and companies want to store energy that is produced during off-peak hours, a technique called "load leveling." Many techniques have been proposed for electrical storage (Lindley, 2010).

Underground thermal and energy storage is a new energy smoothing technique used by electric utilities in which seasonal temperatures or waste heat is stored by heating or cooling huge underground reservoirs of water or solids with electrical energy during times of low consumer demand. The freezing of water at the surface or in shallow underground aquifers can bank large amounts of energy, because energy from heat of fusion (144 $\mathrm{Btu} /$ pound) is tied up as a solid when ice forms and is then released when the ice melts. Manmade thermal energy, from electrical power generation, smelting, or other heat-generating processes, can thus be stored underground. Sanner and Paksoy (2002), Nielsen (2003), and MacCracken (2007) 
cited several commercial examples and showed that heat or cold could be stored in waters held in aquifers, boreholes, or caverns. Underground mine water could also function as underground thermal energy storage media. Mined lands can be used to store electrical energy as heat, potential energy in pumped hydraulic systems, compressed air storage, geobatteries or secure, inexpensive infrastructure for high-tech storage such as largescale capacitors.

\section{Pumped hydroelectric systems}

Under select circumstances, electricity can be stored by lifting water using electric pumps during low-demand hours then allowing the water to flow downward to turn generators when electricity is in high demand (Martin and Barnes, 2007). Pumped hydroelectric systems have been operating in many places throughout the world (ClimateTechWiki, 2011) and more than 40 pumped hydroelectric systems operate in the United States (Miller and Winters, 2009). Such pumped storage systems usually operate in regions where significant topographic differences occur. Surface storage reservoirs usually lie several hundred feet above generating units. In general, an elevation difference of several hundred feet is needed to make the system economical. Most open pit mines in the Midwest may not work well owing to low relief and, in Indiana, where topographic extremes can be $600 \mathrm{ft}(182.8 \mathrm{~m})$ but usually are much less, generally there are not sufficient topographic differences for pumped storage. However, some systems plan to pump water from underground reservoirs such as old mine works to the surface, for example, the Eagle Mountain Pumped Storage Project at Riverside, California (Eagle Mountain Energy, 2011), and iron mines in Minnesota (Severson, 2011) and in the Ruhr Valley, Germany (Deuse, 2011). There, generators are placed underground, resulting in extra costs and operational difficulties.

Depths of abandoned underground mines range from 12 to 600 or more feet (3.6-182.8 m) in Indiana. Consequently, it is not likely, using current technology, that pumped hydrologic storage is viable in Indiana except under very special circumstances. A power plant at river level along the Ohio where bluffs rise several hundred feet near the plant or a plant having a deep, large abandoned mine underneath or nearby might be workable, however. Two electric-generating stations and mined areas are located near Petersburg, Indiana (fig. 11). While pumped hydroelectric systems may not be viable energy storage systems in Indiana at present, miners, electric-generating companies, engineers, decision makers, and sustainability experts should keep the possibility of energy storage in mind when deciding the design and placement of future facilities.

\section{Compressed air energy storage}

Compressed air energy storage (CAES) is a method of smoothing electric production in which air is compressed and pumped into underground voids by electric pumps during times of low demand (fig. 12). When demand is high, the compressed air is released to drive generators that are assisted by gas-fired turbines. Compressed air energy storage is a viable way to store energy (Chen and others, 2009) and such systems are in use in Huntorf, Germany, and McIntosh, Alabama (van der Linden, 2006; London Research International, 2010). Current systems often use salt caverns (McIntosh, Alabama), hard rock mines, or quarries such as the Norton Limestone Mine in Ohio (Hydrodynamics Group, 2011) as compressed air reservoirs. Many opportunities for CAES operations exist in southwestern Indiana where some underground mine voids directly underlie electric-generating plants (fig. 11) and other underground mines occur near plants.

For CAES use, mines must hold high pressures and this may require plugging shafts, utility borings, and exploration holes. Care must also be exercised not to affect domestic water wells in the vicinity. It is important to assure that contaminated mine waters are not forced offsite by the high pressure, where they may degrade nearby water supply wells. If compressed air pressures are extreme, induced seismic disturbance may occur and structural stability issues must be addressed. The rate of methane release in the mine void may also pose a fire or explosion problem and repeated pressure changes may promote release of methane and other potentially harmful fluids.

In Indiana, the volume of underground mine voids varies greatly as do details of mine geometry and current conditions inside the mine. Consequently, available volumes of mine voids for potential CAES sites must be thoroughly assessed but, given the extent of underground mines, it is likely that suitable locations can be found. 


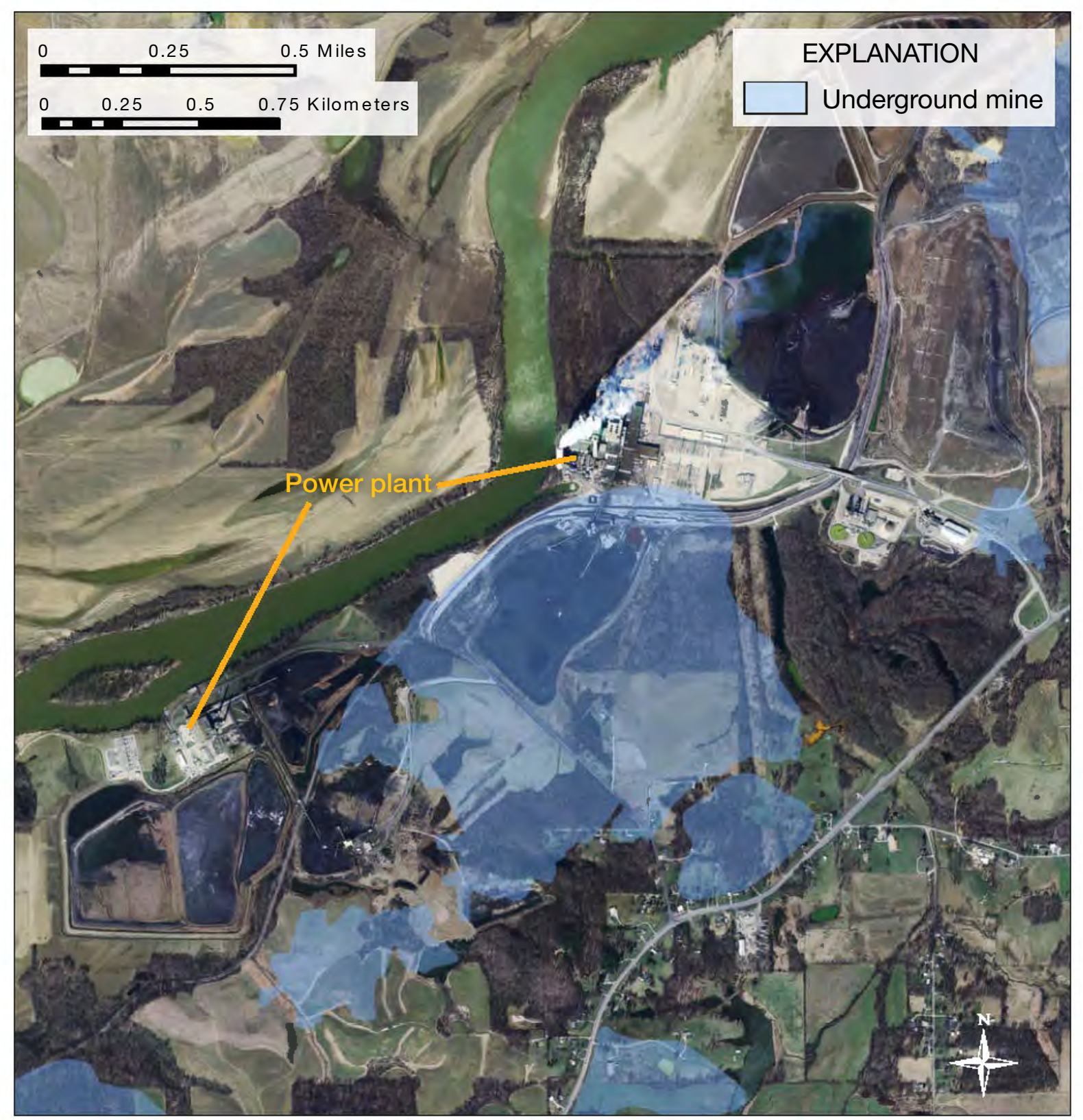

Figure 11. Aerial photograph of abandoned underground coal mines that underlie coal-fired electric-power-generating plants near Petersburg, Indiana.

\section{Geobatteries}

Another method for storing electricity is to store electrons themselves in large underground batteries, or geobatteries. Conventional storage batteries consist of a nonconductive case filled with an electrolyte, normally sulfuric acid, and plates that act as cathodes and anodes (fig. 13). Geobatteries are large earth-based systems capable of generating electric energy and releasing electric current; they can store electrical energy for extended periods of time. Underground mines commonly contain electrolyte-rich waters surrounded by nonconducting shales or underclays. All that is needed to make a battery is cathode and anode materials that act as electron donors and acceptors. Underclays and shales that commonly surround the mine voids generally are poor conductors or are nonconducting. While carbon is often a part of lead-acid batteries, it is not known if coal can act as an electrode. If so, one needs only to emplace metal electrodes to complete a conventional battery. Also, to draw 


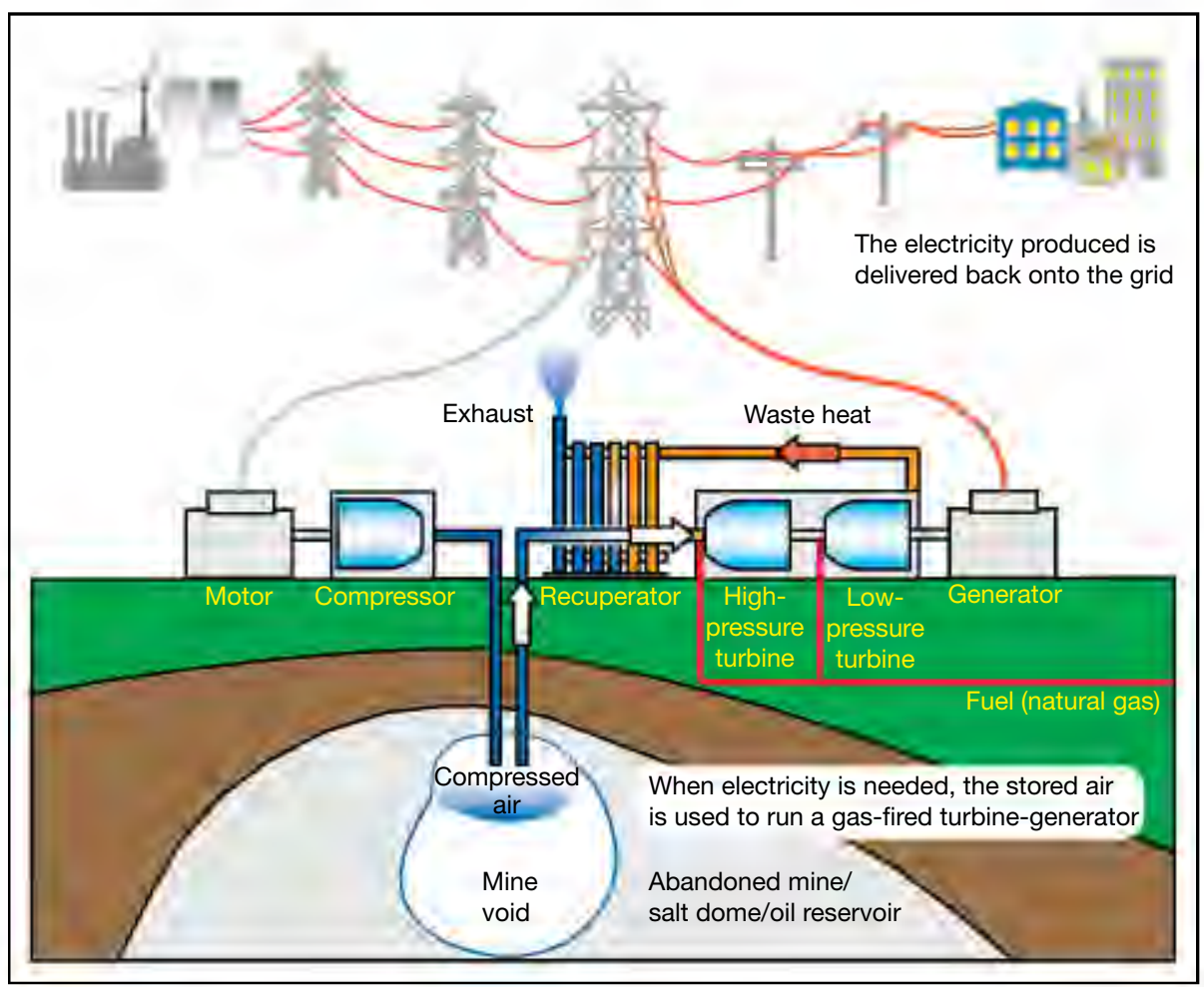

Figure 12. Diagram showing a compressed air energy storage (CAES) system that is used for energy storage.

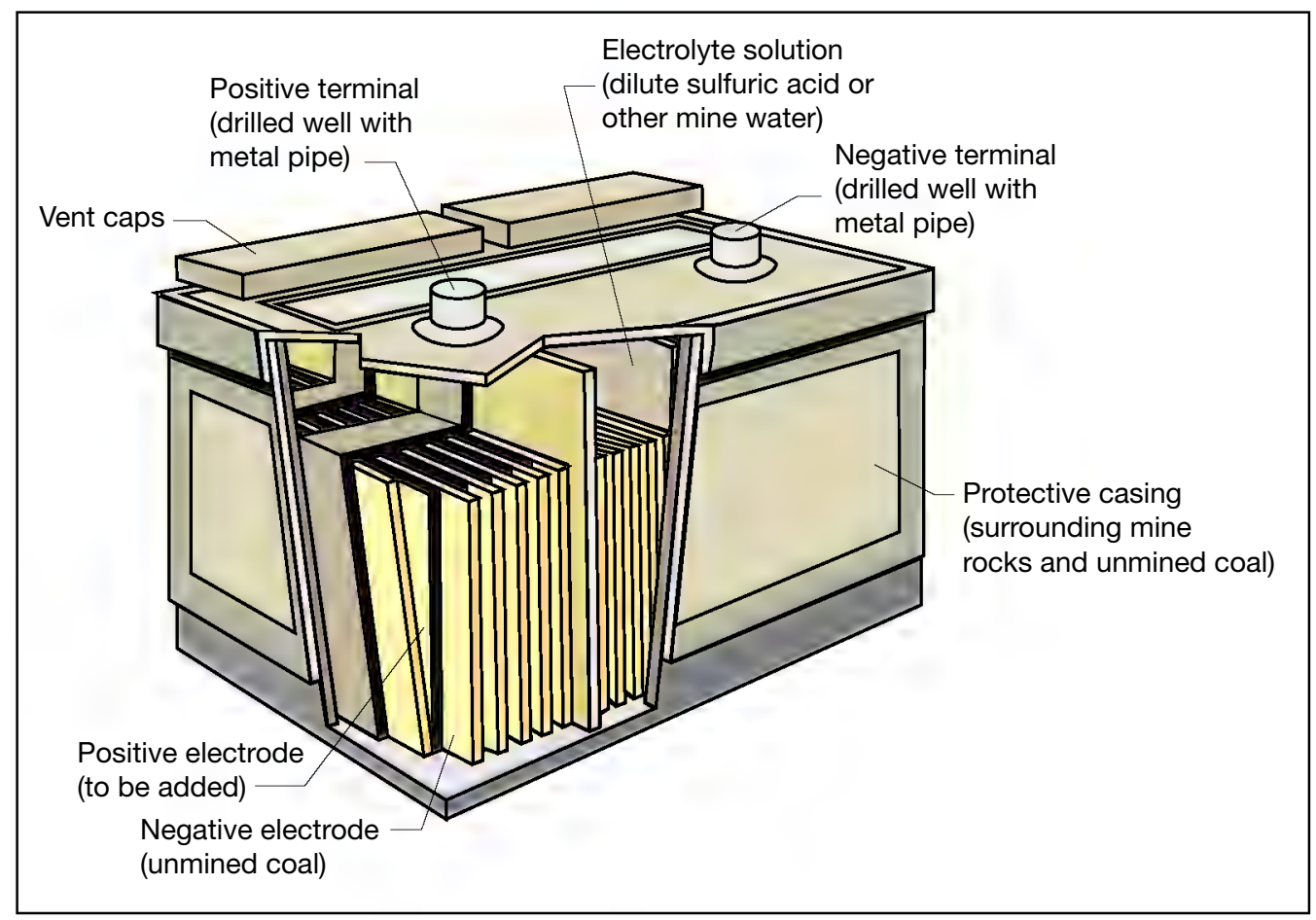

Figure 13. Diagram showing a model of a lead acid battery. Electrical energy production in geobatteries is similar to electrical energy produced by a lead acid battery. 
electricity from a geobattery an electrical circuit must be completed, allowing electricity to enter a grid where it can be distributed and used.

Conventional wet cell batteries consist of a metal cathode, an anode, and an electrolyte solution (usually sulfuric acid), and a nonconducting container (fig. 13). Underground mines have many elements of such a battery but on an enormous scale. Although the most common metal used in wet cell batteries is lead, introduction of metallic lead into underground mine water would not be acceptable or responsible. Other less perfect but functional materials could be used, such as lithium or carbon nanotubes. Additional research is needed to evaluate the potential for direct generation of electricity in water-filled underground mines.

A relatively new type of electric storage device, a flow battery, holds great promise. In a rechargeable flow battery two different liquids having the proper electrical properties reside in a cell (fig. 14, see inset). The liquids are separated by a membrane and the transfer of electrons through the membrane generates electric current. After discharge, introducing an electric current regenerates the electrolyte fluids. Many types of flow batteries exist, some of which could be developed in underground mines using the electrolytic fluids that are contained in them. Semipermeable membranes are required and may have to be inserted to separate fluids of different character or from different mined units. Such membranes could be emplaced through drill holes or perhaps by in-mine robots.

Often multiple coal seams have been mined at a site (fig. 14). Different mine levels could act as reservoirs for the electrolytes and the intervening rock could act as a membrane of a very large flow battery. Much research would be needed to turn underground mines into practical, efficiently functioning batteries, including research into optimum electrolyte characteristics and appropriate cathode materials.

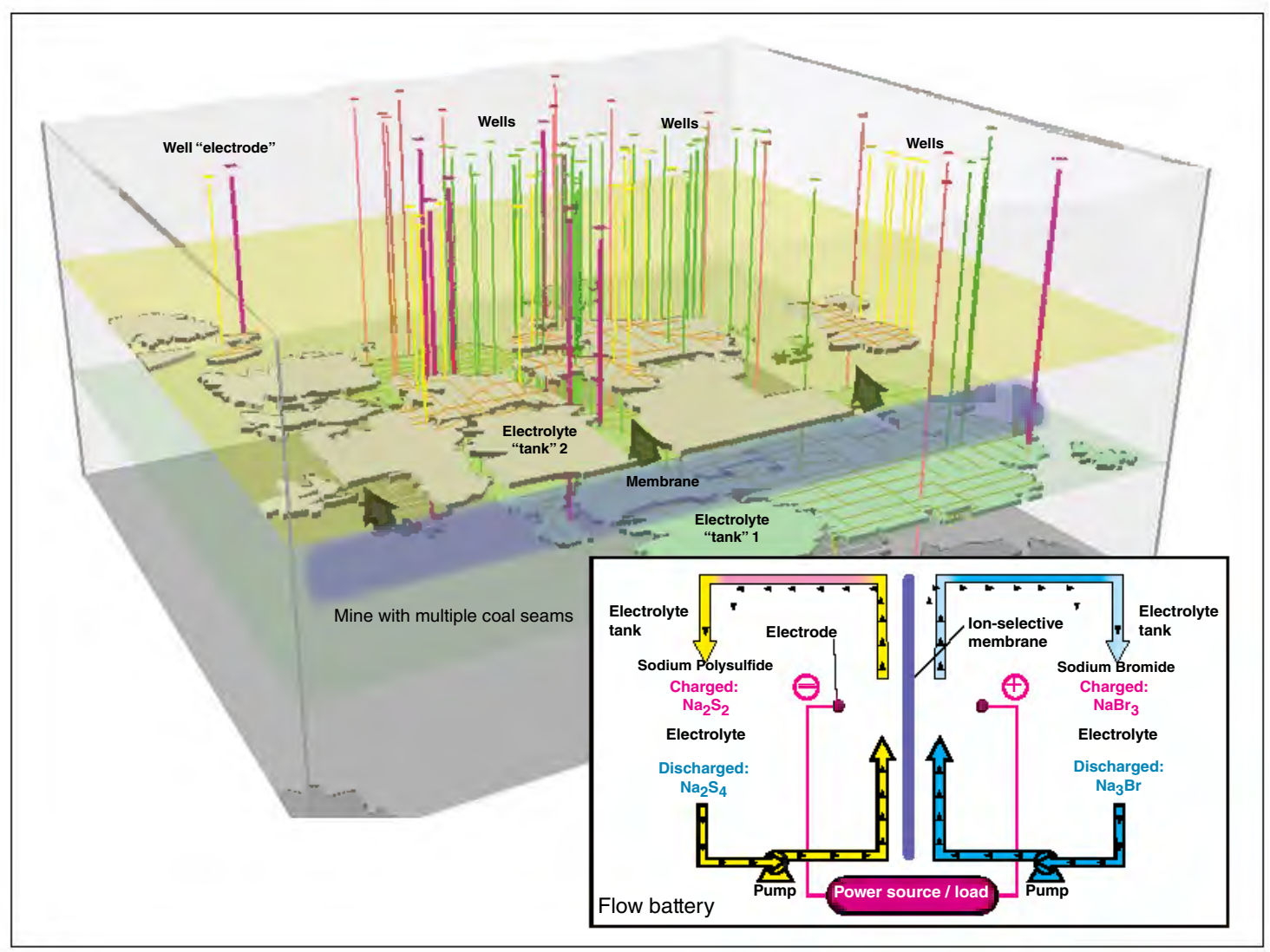

Figure 14. Flow battery diagram for the Friar Tuck multiseam mine. This "two electrode system" requires electrical energy input to start redox reactions and generate electrical current. Electrolyte is pumped through the geobattery "cells." Vertical lines represent wells that go through mines. 
Recent research has shown that the introduction of carbon nanotubes into conventional wet cell batteries improves performance dramatically (Williams, 2009). Nanotubes currently are relatively expensive but they soon may become common enough to use to create geobatteries in mined lands.

\section{Microbe batteries}

Microbe batteries are also known to exist in nature (for example, Malvankar and others, 2011) and it is very likely that these exist naturally in underground and perhaps surface mines (Richard, 2008). Proper geoengineering could develop such batteries or microbial fuel cells (Chang and others, 2006; Bullis, 2009) with the intent to generate or store electric current. Electricity has been generated with microbe fuel cells (Lovley and Nevin, 2008). In the future, underground space could be developed into such fuel cells.

\section{WATER}

\section{Need and availability}

Many energy-producing and industrial processes require large amounts of water for coolant, process fluids, or make-up water. Also, large volumes of water are used for agricultural applications and, in some areas, the use of surface and groundwater for irrigation is essential for agricultural sustainability. Water availability can be a major concern if large volumes are required and conventional sources are limited. Mine waters could be used for many purposes, including energy applications and perhaps even to transport coal in slurry pipelines (Table 5).

Large quantities of water are currently extracted from most active mines to accommodate removing the targeted resource, and large volumes of water are usually present in abandoned mines as well. The U.S. Geological Survey reported that active mine water withdrawals in 2000 equaled almost 3.5 billion gallons (13.25 billion L) per day (Hutson and others, 2004). Little of this water was reused and great potential exists for water as a byproduct of mining. At least $170 \times 10^{9}$ gallons $(644$ $\mathrm{X} 10^{9} \mathrm{~L}$ ) of water is estimated to occur in underground mines of Indiana (Harper, Branam, and
Table 5. Potential uses of mine waters

\begin{tabular}{|c|c|}
\hline $\begin{array}{c}\text { Energy production } \\
\text { (CAEstric storage }\end{array}$ & $\begin{array}{c}\text { Process water } \\
\text { Underground coal } \\
\text { gasification }\end{array}$ \\
\hline Irrigation & Enviromental \\
\hline Recreation & Metal recovery \\
\hline Cooling & Geothermal \\
\hline Aquaculture & Slurry pipelines \\
\hline Biotechnology & \\
\hline
\end{tabular}

Shaffer, 2009). This water is an important technical and economic resource. Harper and others (1996) reported on a number of mine pool studies in Indiana, and Harper and Olyphant (1993) and Harper and others (1990) suggested that there are hydrologic connections between underground mine pools and surrounding areas.

A great deal has been written about mine waters. The International Mine Water Association (IMWA) has sponsored meetings since 1998 (IMWA, 2011). Journals specifically focused on research about mine waters include the IMWA Journal and Mine Water and the Environment; many papers can be found in other journals (Wolkersdorfer, 2004). Studies in Europe were summarized by Wolkersdorfer and Bowell (2005). A synthesis of water needs for the entire United States has yet to be made.

Many questions must be answered about the chemical quality of waters, the amount and availability of water, interconnections of surface and underground deposits, and impacts of water withdrawal before specific usages can be undertaken. Changes in water levels may also lead to subsidence and structural instabilities and these possibities must be evaluated before withdrawals begin.

\section{Process water}

Process water is water used by industries or businesses to produce a product or affect a manufacturing process. Mines could provide water for industrial processes if the quality meets the standards of the specific application and state and federal regulations. For example, the U.S. Department of Energy recently issued a report on water needs for conventional and newer forms of electric 
energy generation such as gasification or liquefaction (USDOE, 2008). Coal to liquid or coal gasification processes also require abundant water to entrain coal particles for transport. There are even coal slurry pipelines that use water as a transport medium for coal. Mine water may be used for these applications provided the quantity and quality is acceptable. In Indiana, a stone mine in Portland provides 100 percent of the process water for an ethanol plant operated by POET (M. Basch, Indiana Department of Natural Resources, Division of Water, oral commun., 2006). A wide variety of applications are possible if the mine water meets regulatory standards.

\section{Cooling}

The amount of water used for cooling of thermoelectric power generation units in the United States was 195 billion gallons (738 billion L) per day in 2000. Veil and others $(2003 a, b)$ examined the use of mine pool waters and pointed out that six plants in Pennsylvania have used such water for power plant cooling. Veil and Puder (2006) reviewed mine pool water use in Pennsylvania and a new power plant at Maidsville, W. Va., will use mine water for cooling (Hopey, 2007). These authors concluded that use of mine pool water was technically possible and cost effective. They also pointed out the need to investigate locations and volumes of mine water, water quality, hydrologic features, potential geotechnical problems (for example, subsidence), long-term effects of using mine waters to transfer heat, water treatment details, and regulatory issues.

\section{Irrigation}

Mine waters can be used to irrigate conventional crops and to promote growth of biomass. Indiana generally has adequate water for crop growth, but increasing demand for water may make mine waters attractive for irrigation, especially if biomass is being grown on the mined lands. In water-poor areas such as South Africa (Jovanovic and others, 2002; Annandale and others, 2009) and Australia (Mercuri and others, 2005), mine waters have been used to grow crops. Many mine waters are rich in dissolved materials and water quality must be appropriate for the designated uses. Often, mine waters are treated with lime, limestone (Jovanovic and others, 1998), or municipal wastes (Mercuri and others, 2005) to improve crop growth. Careful monitoring of water-quality parameters is needed when irrigating with mine waters.

\section{Miscellaneous uses of mine water}

Some mine waters are adversely affected by pyrite oxidation and microbial processes that form acid mine drainage (AMD). Such water can be a source of various materials such as pigments (Banks and others, 1996), but is generally considered a problem. Good-quality mine waters are used to sustain AMD treatment in constructed wetlands and to dilute polluted waters. Cairney (1973) and Anderson (1999) suggested abandoned coal mines could be used as underground potable water sources or reservoirs. Exceptionally clean mine waters are currently being used for potable water in West Virginia, Kentucky, and Oklahoma (Varnell and others, 2004, 2009; Ghose and Lahiri-Dutt, 2007).

Mine water has been used to dissolve, leach, or bioleach soluble materials from sulfide ores, phosphates, coals, and industrial minerals (Edworthy and Puri, 1986). Such uses can contribute to both the economic recovery of important commodities and the mitigation of environmental impacts from mining.

\section{BIOREACTORS}

\section{Definitions and benefits}

Bioreactors are defined here as any system supporting biological activities used in biotechnology to produce carbon-based fuels, specialized chemicals, and drugs (Shaffer, 1994). Mines have large volumes or surface areas, are generally confined and supported, are typically secure and easy to monitor, and have basic infrastructure such as pipes, electricity, and surface buildings already in place. All these features can contribute to successful use of mined spaces for bioreactors. The lands, lakes, and voids created by mining could be used as bioreactors to produce methane in enormous quantities (figs. 15 and 16). Bioreactors can be designed to encourage and direct anaerobic microbial reactions that generate other fuels or products in watery areas either at depth or on the surface. 
They are capable of generating biofuels, transforming $\mathrm{CO}_{2}$ into biomass or minerals, and making other useful transformations of existing carbon compounds.

\section{Geobioreactors}

Geobioreactors are large-scale, natural rockhosted areas wherein microbes perform desired functions or generate useful products. Engineered wetlands are a type of geobioreactor that have been shown to be effective, long-term, low-energy use systems for mitigating acid mine drainage (Smith, 2012 [this volume]).

An example of an existing use of a large-scale geobioreactor is a landfill. Landfills demonstrate that large-scale biotechnology should be possible in abandoned mines, either at the surface or underground, especially in water-filled mines. Landfills, man-made bioreactors that degrade municipal wastes, generate methane and leachates naturally (fig. 17). Modern practice is to design landfills to maximize methane production and collection via properly spaced drill holes, and to contain leachates using controlled drainage, impervious liners, and sumps. Perhaps eventually usable byproducts can be extracted from the leachates. The Southside Landfill in Indianapolis, which used to be a sand and gravel mine, produces sufficient methane to heat large (6+ acres [2.4+ ha]) greenhouses where flowering plants are grown. Methane produced by microbial decay of the waste is collected through plastic pipes placed at different depths in the waste and used to heat the greenhouses.

Another example is the landfill south of Terre Haute, Ind., that provides enough methane to operate brick plant (Boral Brick) that produces more than 100 million bricks annually (fig. 18).

Many other landfills produce methane onsite for industrial use or for pipeline gas, and now most new landfills are designed to use indigenous methane. Large methane-producing engineered landfills operate in Buncombe County, N.C.; Gainesville, Fla.; Greenville, S.C.; Louisville, Ky.; King

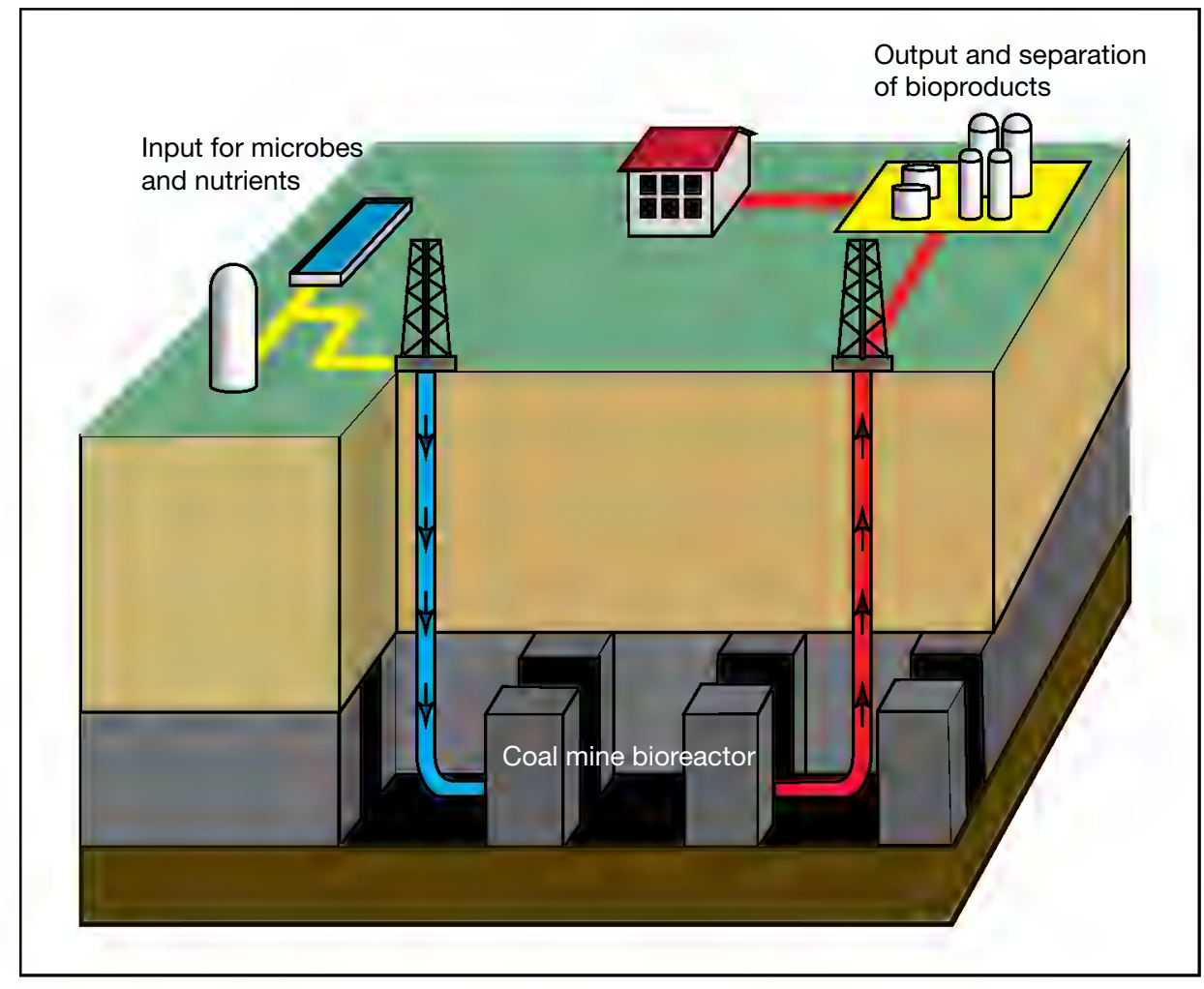

Figure 15. Diagram showing the use of flooded mines functioning as large bioreactors to produce bulk materials. 
George County, Va.; Shippensburg, Pa.; Harrison, Mich.; Williamson County, Tenn.; Yolo County, Calif.; Indianapolis, Ind.; near Terre Haute, Ind.; and near Sydney, Australia, where the landfill occupies an abandoned opencast coal mine.

\section{Environmental remediation}

Bioremediation uses organisms, usually microbes, to clean up polluted areas such as oil spills or industrial waste sites, often without moving soil or sediments. It has evolved into a very efficient, costeffective, and common technique (Shannon and Unterman, 1993; Bonaventura and Johnson, 1997; Vidali, 2001; Litchfield, 2005). Bioremediation sometimes relies on large geobioreactors such as the sand bioreactors used for wastewater treatment in Ohio (Banerji, 1997; Ohio State University, 1999). Bioreactors are also designed to accomplish reclamation goals (for example, Tenenbaum, 2004) and several bioreactor types have been developed to treat AMD (Behum, 2012 [this volume]). Tech- nology has allowed former waste disposal or polluted industrial sites to become valuable sources of methane while controlling pollutants, even greenhouse gases, by stabilizing organic waste, producing methane as a clean-burning fuel, and improving leachate characteristics (Reinhart and Townsend, 1997; Warith and others, 2005; National Solid Wastes Management Association, 2006).

\section{METHANE RECOVERY}

Methane has long been known to occur naturally in coal beds. Methane is an ongoing concern for miners and environmentalists, but methane can be a useful byproduct of coal mining. Occasional outbursts of methane in mines can be dangerous (Vogt, 2003). At least two companies in Indiana are collecting and selling methane from coal (Hite, 2007). Studies have documented existing deposits of coal-bed methane (CBM) all over

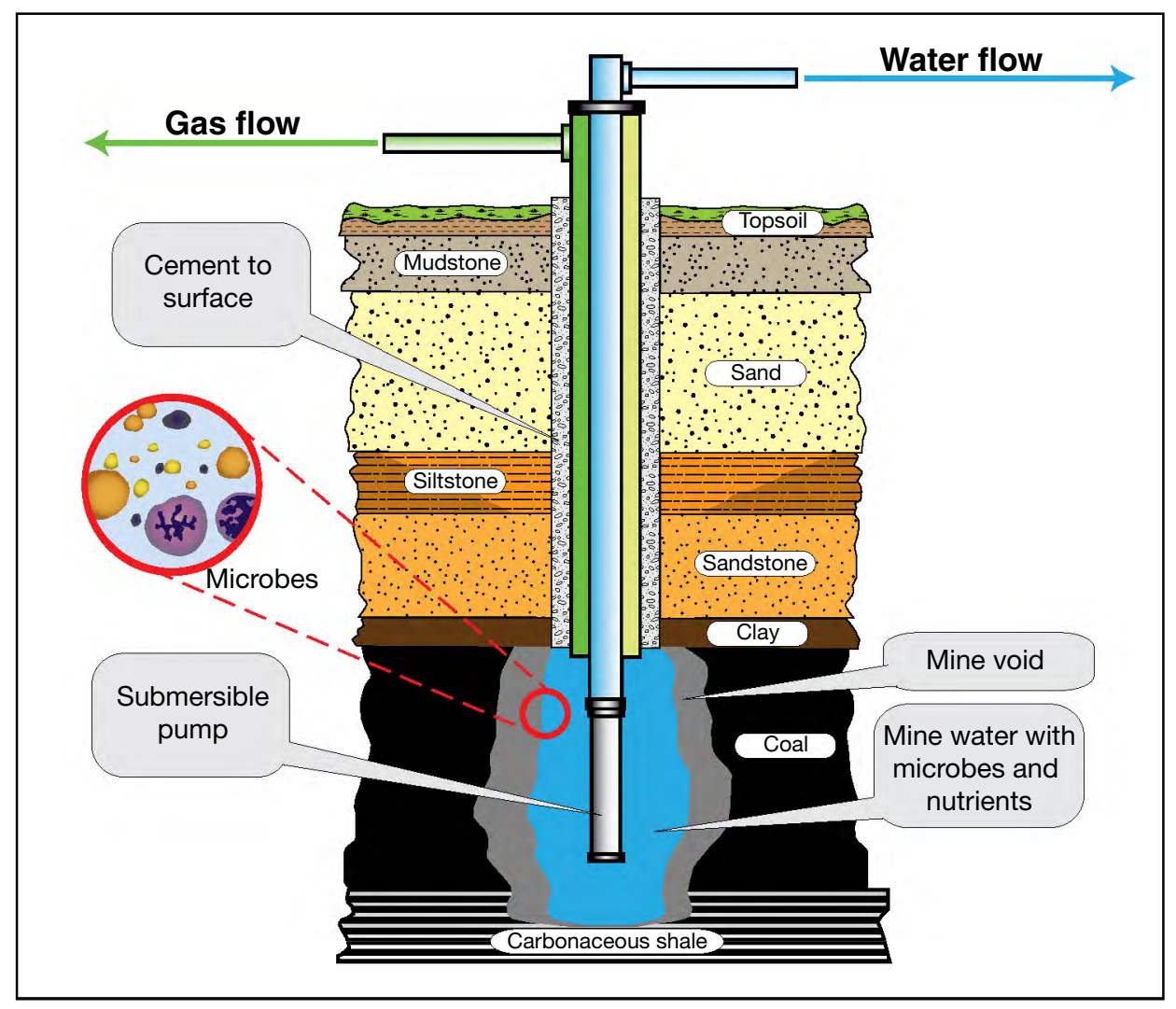

Figure 16. Diagram showing a generalized bioreactor. Modified from Ground Water Practitioners (2012). Specialized wells, like this one which produces methane by microbial processes, could be used as bioreactors. 


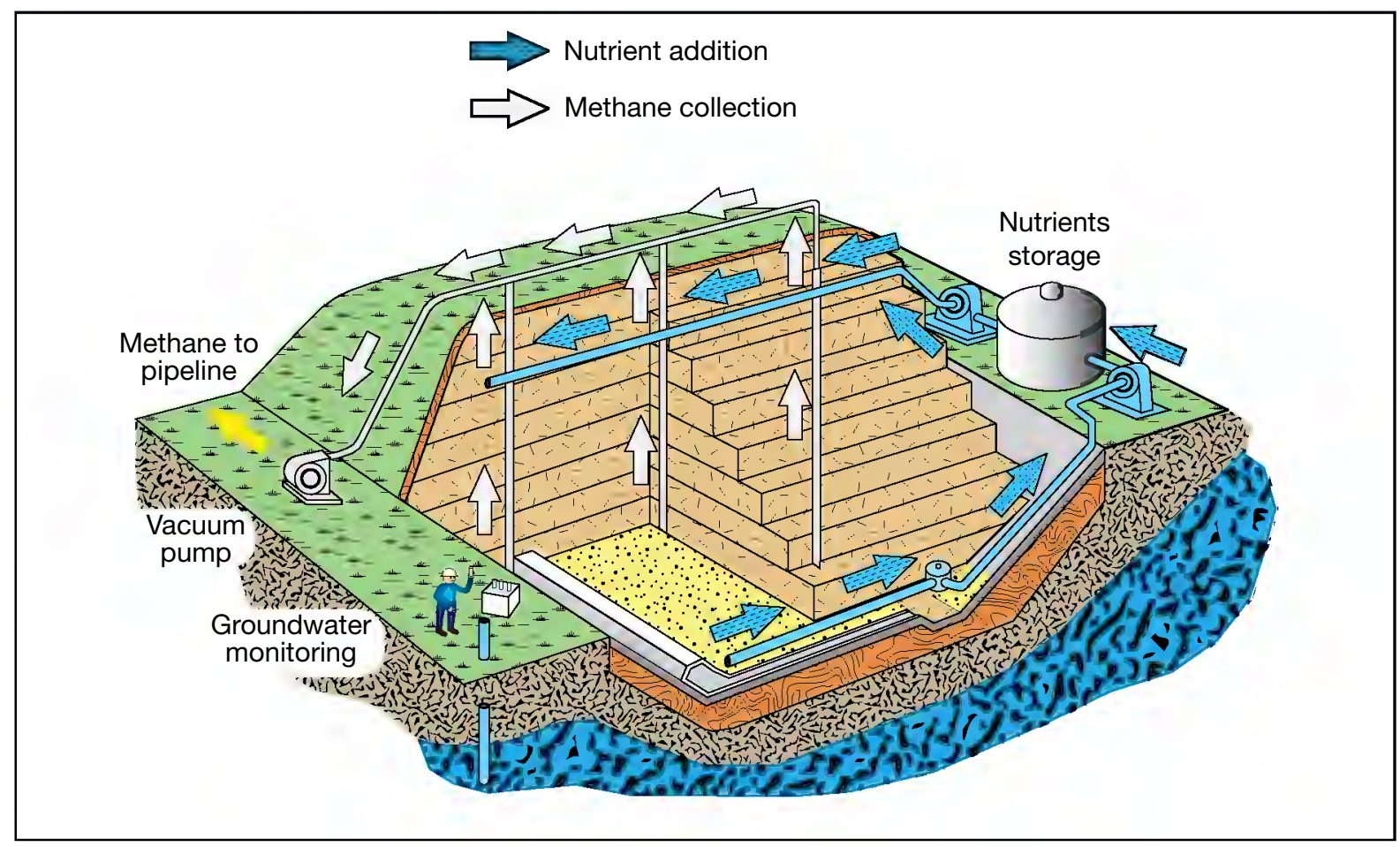

Figure 17. Diagram showing a very large bioreactor; bioreactors and geobioreactors can produce methane and other products. Modified with permission from Waste Management of Indiana, LLC (2012).

the world. Indiana Geological Survey publications and continuing research have detailed the CBM situation in Indiana and have determined sources of the methane (for example, Mastalerz and Kvale, 1998, 1999, 2000; Drobniak and others, 2004).

Methane is being actively produced from virgin coal beds and mined areas throughout the world (Bibler and others, 1998; Creedy and Tilley, 2003). Rightmire and others (1984) reviewed CBM resources in the United States and Archer and Kirr (1984) gave specifics for the Illinois Basin resource. Mastalerz and Kvale (1998, 1999, and 2000) and Drobniak and others (2004) outlined CBM potential in Indiana. The U.S. Environmental Protection Agency (2008a) cited opportunities for developing CBM in U.S. mines and the federal government has established programs that encourage CBM development (USEPA, 1992, 2008a, 2008b). Several general discussions of CBM basics have appeared (for example, Wheaton and Donato, 2004) and a number of special journal volumes dedicated to CBM are available. Coal-bed methane has progressed from a hazard to a commercial product. Abandoned mines offer great potential for long-term, renewable methane production (Thielemann and others, 2004), especially if natural microbial methanogenesis can be enhanced (Lin and Premuzic, 2003).

Coal mine voids can become enormous bioreactors that generate methane. Scott (1999), Budwill (2003), Gilcrease and Shurr (2007), Jadhav (2007), Strapoc and others (2007, 2008a, 2008b; 2011), and Ulrich and Bower (2008) have demonstrated that methane is being produced today by microbial processes. Smith and Pallasser (1996) and Strapoc and others $(2006,2008 b)$ showed that select anaerobic microbes produce methane by splitting coal molecules. Functioning of that system requires the mineral pyrite or some other sulfide as an electron receptor (Ramaswamy, 2002). No efforts have been made to enhance production in Indiana, but Australian researchers have suggested adding microbial nutrients to mines to enhance CBM production (Faiz and Hendry, 2006). Luca Technology has demonstrated the commercial viability of methane-generating geobioreactors and developed methods for introducing microbes and nutrients that greatly improved CBM production (Luca Technologies, 2011). They revivified oil deposits and have also enhanced production 


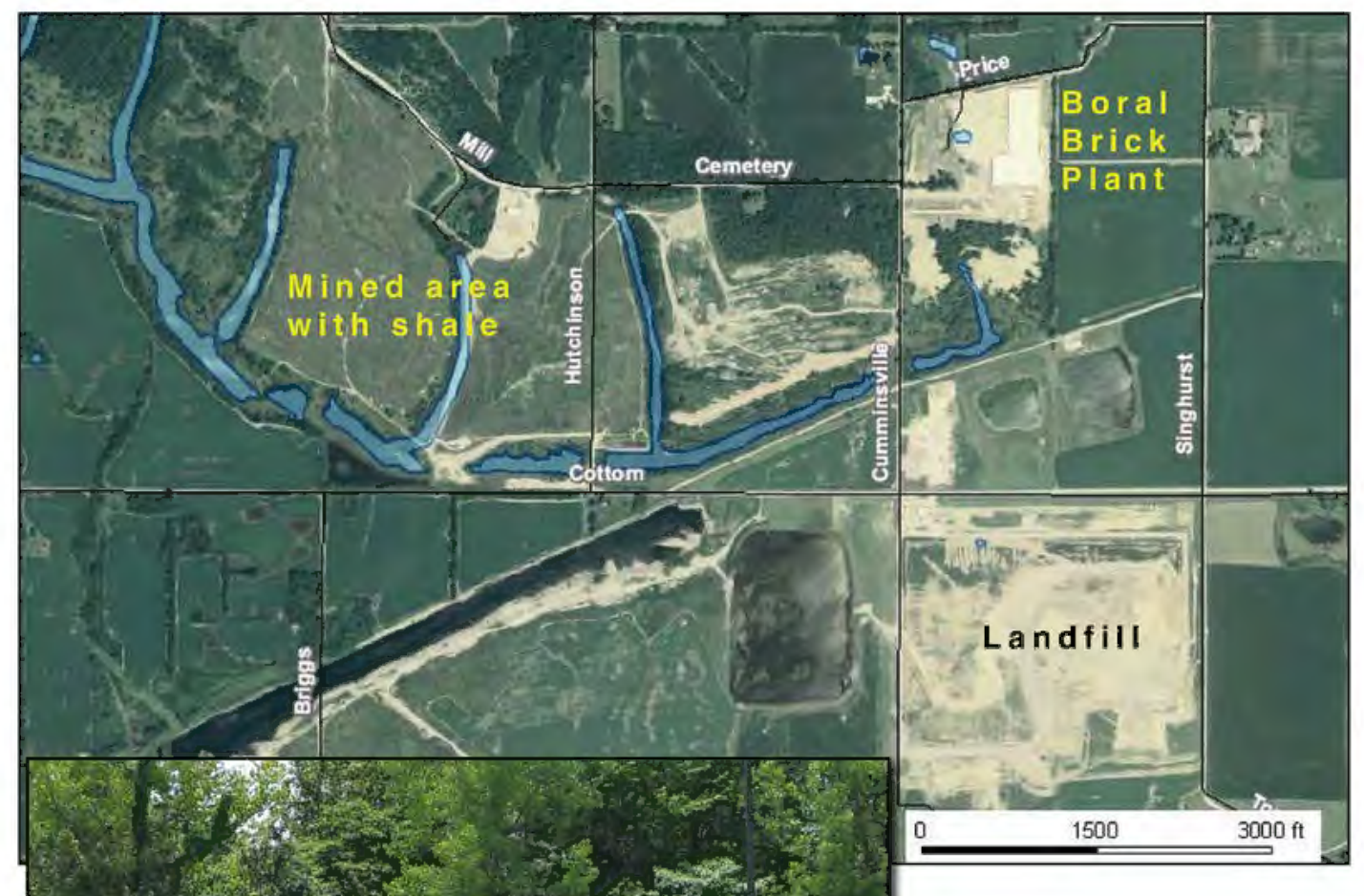

Figure 18. Aerial photograph of the Boral Brick Plant, located on an old strip mine in Vigo County,Ind. (top). The brick plant uses raw materials (shale cast overburden) from the old mine. Methane for the energy needs of the plant is produced from a geobioreactor at a nearby landfill (bottom).

of methane from coal beds in the Powder River Basin. Other researchers have reported on various experimental efforts to improve microbial methane generation from coals (Finkelstein and others, 2005; Winters, 2005; Mullin, 2006; Flores, 2008; Faiz and Hendry, 2009).

\section{MATERIALS}

Acid mine drainage in the Illinois Basin can be a relatively rich source of dissolved metals, containing as much as 1 percent dissolved iron and 0.2 percent aluminum by weight (Branam and Harper, 1994). Other valuable metals are present in AMD in varying concentrations, including copper, zinc, nickel, and molybdenum, as well as lanthanide rare earths. Some AMD sources contain reduced iron that is very difficult to remove by conventional treatment. Instead, the principles of hydrometallurgy may be employed to recover the iron and other elements in useful forms. By controlled neutralization and oxidation, the iron can be recovered in the form of soft, free-flowing powders that meet ASTM standards for iron oxide pigments (fig. 19) (Hedin, 2002; Glover, 2003; R. T. Smith, Indiana Geological Survey, written commun., 2004; Branan, 2009). A pilot-scale demonstration project, operated by the IGS Geochemistry Section, recovered more than 98 percent of the dissolved iron from solution. Acid mine drainage was further processed to isolate the iron from the aluminum and other elements. The resulting iron-rich sludge was converted into red 
and yellow pigments (fig. 19) (R. T. Smith, Indiana Geological Survey, written commun., 2004).

Kaksonen and Puhakka (2007) reviewed biological processes to treat acid mine drainage and recover metals. Leaching of low-grade mineral deposits with or without biological enhancements is practiced in many areas (Brandl, 2001; Ehrlich, 2002), but the techniques have not yet been applied to coal waste. However, coals and black shales are known to contain elevated amounts of a number of metals that are mostly bound in sulfide minerals or the organic fraction (Gluskoter, 1975; Hatch and others, 1976; Keefer and Sajwan, 1993; Shaffer, 1996; Brownfield, 2002). Some forms of remediation are designed to fix metals as insoluble minerals and there may be ways to excavate these areas and recover the metals by leaching. Leaching techniques could also be used to extract metals such as zinc, molybdenum, vanadium, gallium, and germanium from coal combustion products such as fly ash that accumulated in ponds or abandoned pits (Shaffer and Harvey, 2001).

\section{WAREHOUSING}

Many abandoned underground mines have found new life as storage facilities where environmental conditions are favorable, especially where transportation routes are nearby. The uniform temperatures offer excellent preservation potential and many archives have moved underground, especially in limestone mines (Benjamin, 1999). Large storage areas in abandoned mines already exist in many parts of the United States, such as those in limestone mines in the Kansas City, Mo., area (Parizek and others, 1975; Whitfield, 1981; Gentile, 1997; Seeger, 2004). Kansas also has storage facilities in a salt mine. Indiana has one major storage site, the Marengo Warehouse and Distribution Center, operating at Marengo in an abandoned underground limestone mine (Marengo Warehouse, 2011). This site has housed a wide variety of items (for example, tires; building materials; food) and has been used for cold storage with freezers for preserving perishable foods. There are 12 additional potential storage sites in limestone or gypsum mines in Indiana (fig. 5). Other underground stor- age sites exist in Pennsylvania (Associated Press, 2001) and Kentucky (Shafer, 2004). An inventory of all of Indiana's underground space should be made to properly assess the suitability for storage.

Currently most storage sites are not in coal mines but if certain geologic issues (water and gas infiltrations and collapse hazards) can be controlled, there very likely are a number of mines that could be used. Mines should be dry; generate little or no methane; and have low humidity, stable roof conditions, good ribs, floor, and back, accessible locations, and sufficient transport infrastructure.

Most storage operations are in dry mines (mostly adits) but liquids and gases are stored in some underground mines. In Jackson County, Ind., at least one underground mine site was constructed to store liquefied petroleum gas (LPG), confirming the feasibility of underground storage for LPG. Many mined sites could be outfitted to handle liquids. Sophisticated monitoring wells are required when fluids are stored underground. Although most coal mine voids are too shallow to be considered for gas storage and too "leaky" to hold dangerous liquids such as LPG, gasoline, or diesel fuel, bladders could be installed to prevent leakage. The U.S. Navy uses huge bladders, rugged enough to be towed by ships at sea, to store and deliver fuel to their fleet. Such bladders could be adapted for mine uses to isolate stored fluids from groundwater and assure that fluids are not lost from storage. A variety of grout, foams, concretes, or other sealants can be applied to the natural rock surfaces exposed in mines to eliminate interaction of stored goods and fluids with the host rock (Houlsby, 1990; Morrison, 1991; U.S. National Response Team, 1995; Naudts, 2004; U.S. Army Corps of Engineers, 2004; Warner, 2004).

Maps and records of underground coal mines in Indiana have been collected, standardized, and made available through the Coal Mine Information System (Weber, 2012 [this volume]). While locations of underground clay, limestone, gypsum or other mines have been collected at the Indiana Geological Survey, detailed maps are not readily available for these mines. Limestone mines are often near population centers or transportation routes and so have great potential as storage sites. 


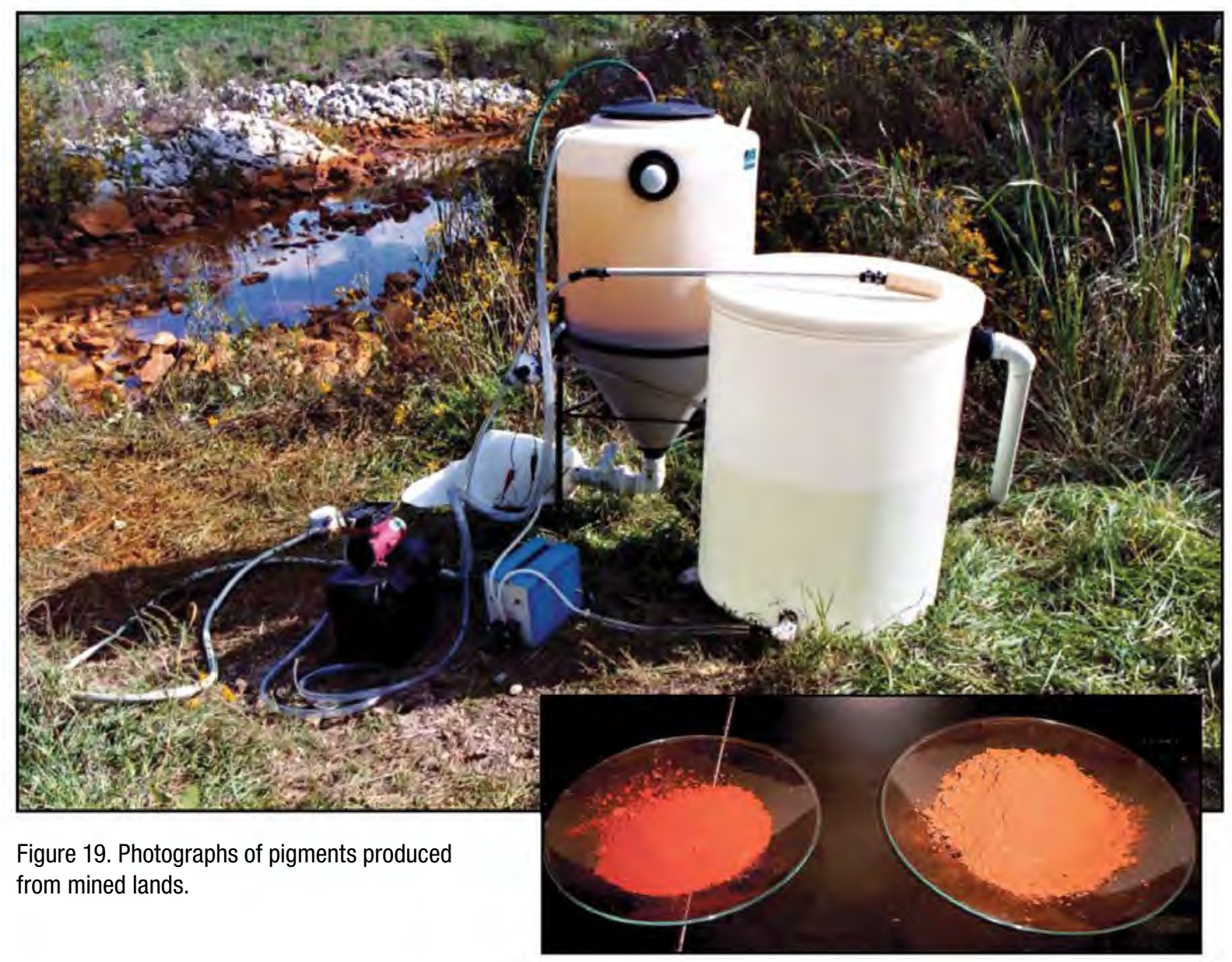

\section{RECREATION AND EDUCATION}

\section{Recreation}

Surface mines often can be reused as recreational facilities. Six large mines covering thousands of acres were donated to or purchased by the state of Indiana or local park groups who constructed buildings, roads, docks, or other recreational facilities to make sites easily accessible, attractive, and safe for public use. These mines are now included in Shakamak State Park, Lynnville City Park, Sugar Ridge State Fish and Wildlife Area, and Greene-Sullivan Wildlife area. Some highly acidic and barren mined areas, such as Augusta Lake in the Sugar Ridge State Fish and Wildlife Area in Pike County, have undergone limited changes and become known mainly as hunting sites. After extensive refurbishment, others have found use as golf courses, education centers, camping sites, wildlife parks, major sports venues, off-road vehicle areas, and all-terrain vehicle driving courses. Many thousands of visitors make use of such sites annually.
Many former mine sites across the country have been used for golf courses, hunting, boating, fishing, and athletic facilities. In Indiana, a former mine site (Victory Mine) and landfill in Vigo County east of Terre Haute is now the Wabash Valley Family Sports Center, a large community recreation center that includes the LaVern Gibson Championship Cross Country Course. Victoria Golf Course near Evansville (fig. 20) was developed on a small part of the abandoned Victoria Mine in Vanderburgh County. Music venues such as one near Dahalla, Sweden (fig. 21) and at San Antonio, Texas, attract music lovers. Other mines have been turned into civic attractions such as gardens (such as Buchart Gardens in Victoria, British Columbia), sport event venues, even one upscale tea garden (fig. 22). Recreational activities are ideally suited to mined lands because of the availability of large areas, interesting topography, water features, ease of access, and the potential to sculpt the land. Equestrian activities or competitive events would benefit from large flat areas, water courses, and interesting topography. Whitewater canoe or kayak courses on mined lands could be designed during reclamation. 
A man-made whitewater course in South Bend, Ind., attracts many enthusiasts. Hiking, orienteering, photography, or geocaching courses could be established on mined lands to attract outdoorsmen in addition to conventional activities such as fishing, hunting, bird watching, and off-roading.

\section{Education}

Mined lands can be made into attractive sites for education (Table 6A, B). Examples include the Eden Project, which transformed an abandoned clay mine in Cornwall, U.K., into a model for postmine use with environmental, educational, cultural displays and activities (Pearman, 2009). The project was sponsored by the Post-Mining Alliance (2011). In the United States similar use of mined land is exemplified by coal heritage trails, such as the one developed in Beckley, W. Va.

Many parks, museums, fishing, and wildlife areas are located in mined lands in Indiana (fig. 23). Fowler Park near Terre Haute is an excellent example of educational and recreational reuse of a mine that was operated by Peabody Coal Company until 1968 as the Chieftain \#20 Mine. Other educational heritage trail and mine tourism projects are possible because some communities in Indiana already maintain modest museums or parks (Table 6B) that celebrate mining or mine histories. The mined areas in the Dugger/Sullivan area, which has a long and rich mining history, are a potential location for mine tourism development (fig. 24A, B). Many documents, artifacts, and the personal recollections of miners in the region currently are being archived by a program called the Wabash Valley Visions and Voices, hosted by Indiana State University (Visions, 2009).

\section{Geotourism}

Mines can attract tourists and bring millions of dollars to an area. Geologic features, including active or abandoned mines, are a major part of geotourism (Dowling and Newsome, 2006; World Heritage Site Office, 2008; Garofano, 2010). Extreme mines such as the Bingham Canyon Copper Mine in Utah support a large range of amenities for tourists (Kennecott Utah Copper, 2011). Information about mining techniques, reclamation, importance of mined materials, geology, minerals, fossils, and local flora and fauna can be displayed to good advantage at parks developed at old mines. Weber Lake Park in Indiana is an excellent example of reclamation that stresses geotourism developed on an old strip mine. Signs and literature on the site explain previous mining and reclamation practices.

There are a number of tourism or "show mines" in the United States (fig. 25). Many are in the metalmining regions of the west, but a number of coal mines do entertain and educate tourists about mine operation and heritage. Several coal mine attractions occur in the East such as in Scranton, Pa., Lynch, Ky., and Beckley, W. Va. No specific tourist mine is known to exist in Indiana at this time, but there is potential to develop this type of attraction in Indiana. For example, an adit at Shakamak State Park was available, but is now blocked. A sign explains the mine's history at the portal.

European countries have a number of well-financed and well-visited tourist mines, including abandoned mines incorporated into large construction projects that provide interesting architectural and artistic elements. An excellent example is seen near Crazannes, France (Conan, 2004). A quarry used from Roman times until 1955 became the focal point of a highway rest stop. Special efforts included many artistic and educational displays. The site has become a tourist attraction bringing revenue to the area and enhancing public understanding of geology.

A few instances of successful fossil parks show the potential to protect and make publicly available the natural resource of traces of past life. Hanson Aggregates established Sylvania Fossil Park at an abandoned aggregate quarry near Sylvania, Ohio (Kaufman, 2001; Stoll, 2003). This park generated positive press and has also led to excellent community relations. An old mine site at Mineral Wells, Texas, is being turned into a fossil park with help from the Dallas Paleontological Society (Coyne, 2009). Mazonia Park in northern Illinois allows collection of fossil plants and animals of the Mazon Creek fauna at an old strip mine that was turned into a state park. Opportunities for federal, state, or local parks and commercial collecting sites occur in Indiana's abandoned mined lands, especially in spoil from strata overlying the Danville Coal Member. 


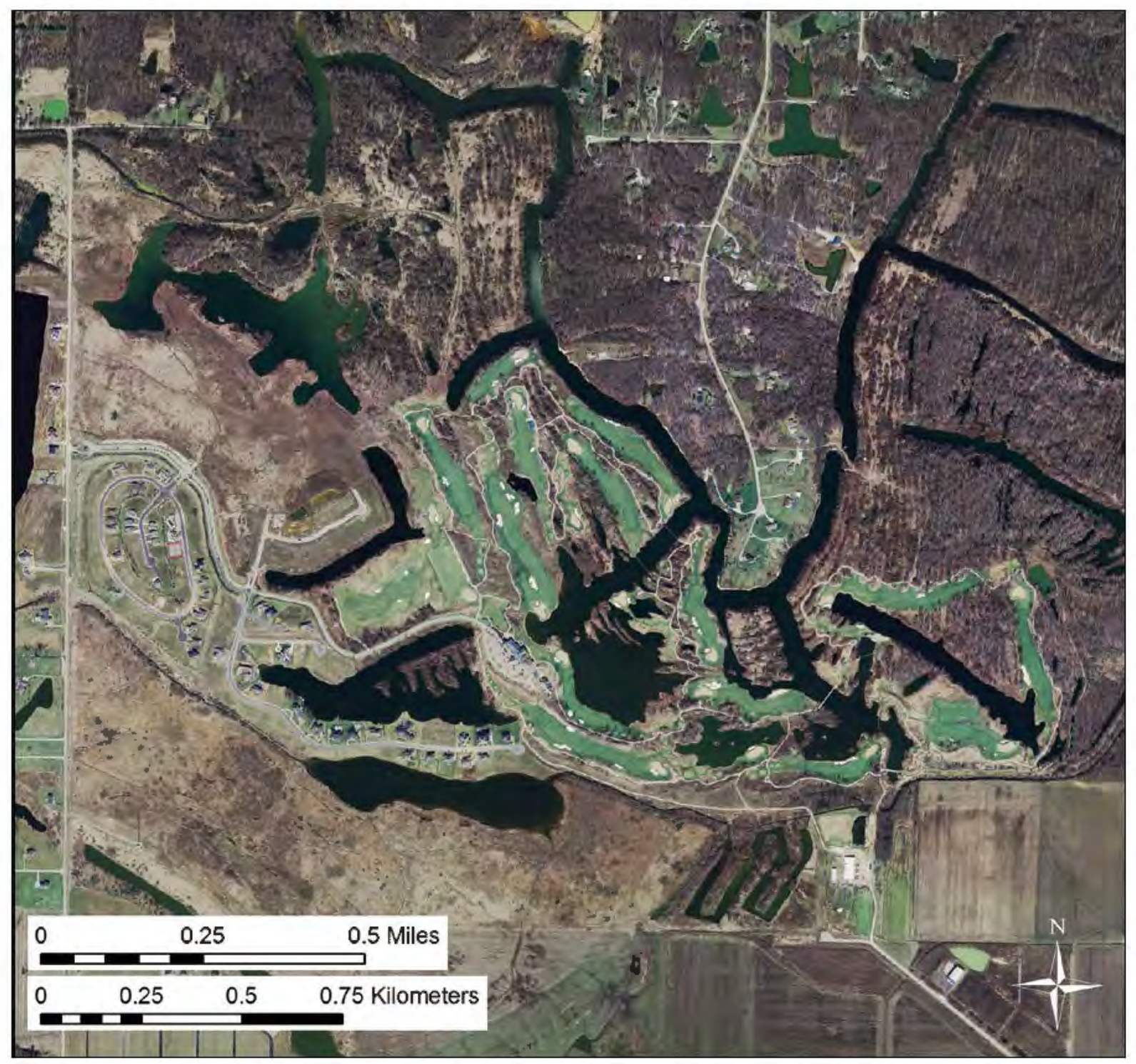

Figure 20. Aerial photograph showing the Evansville, Ind., Victoria Golf Course that was constructed on a coal-mined site.

\section{Films}

A more speculative use of mined land is for making films (Pearman, 2009). More than 30 movies have been filmed in Indiana and a larger number have been filmed featuring Indiana locales. A League of Their Own (1991) was shot in Huntingburg and Evansville and Breaking Away (1979) was set in the limestone district of Bloomington and Bedford and featured dimension stone quarries. Not only would movie making bring considerable money to the state, but positive portrayals could enhance the state's reputation as a place to conduct business, visits, or to target site events. Like most states, Indiana provides incentives to interested film companies. The overall mining culture, varied topography, and unique dimension stone buildings, could be attractive to filmmakers.

\section{LABORATORIES}

\section{Advantages of underground sites}

The underground space left by mining offers a very stable, secure environment for siting laboratories. Access can easily be restricted and controlled, limiting the possibility of trespass and creating an environment favorable for many hightech laboratories or manufacturing facilities. From huge physics experiments in deep gold mines 


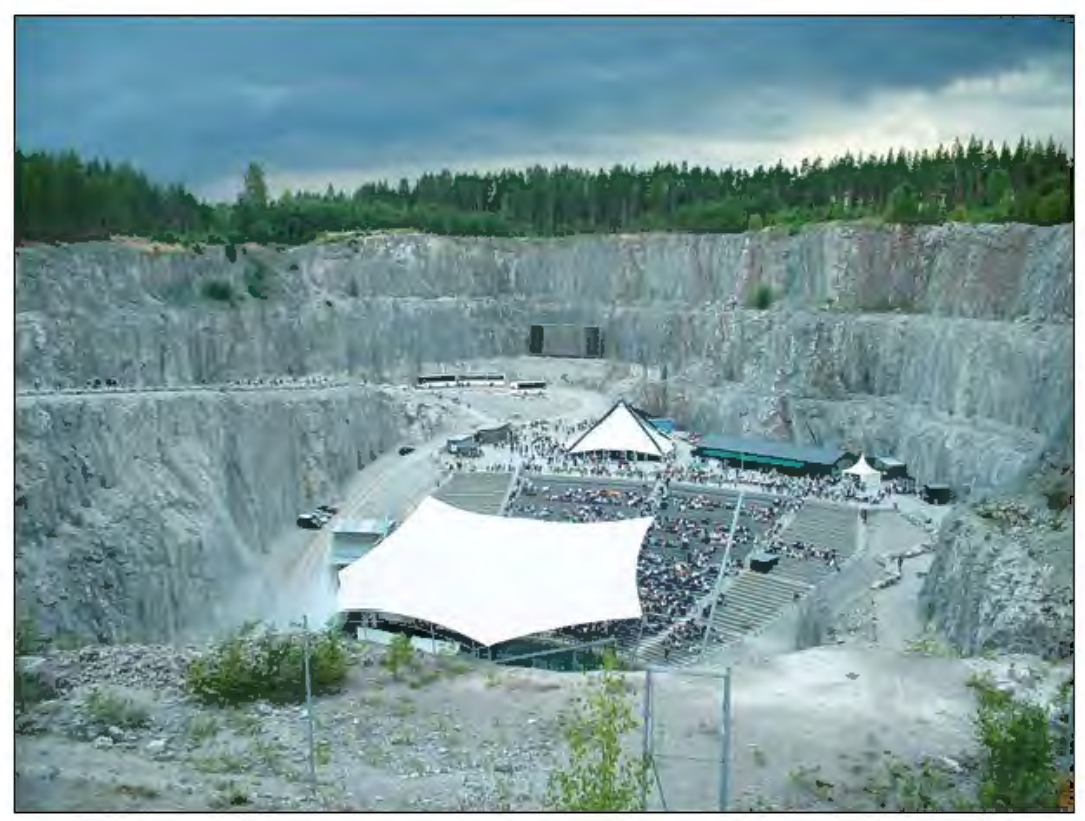

Figure 21. Photograph of an amphitheater built in an abandoned quarry in Dahalla, Sweden.

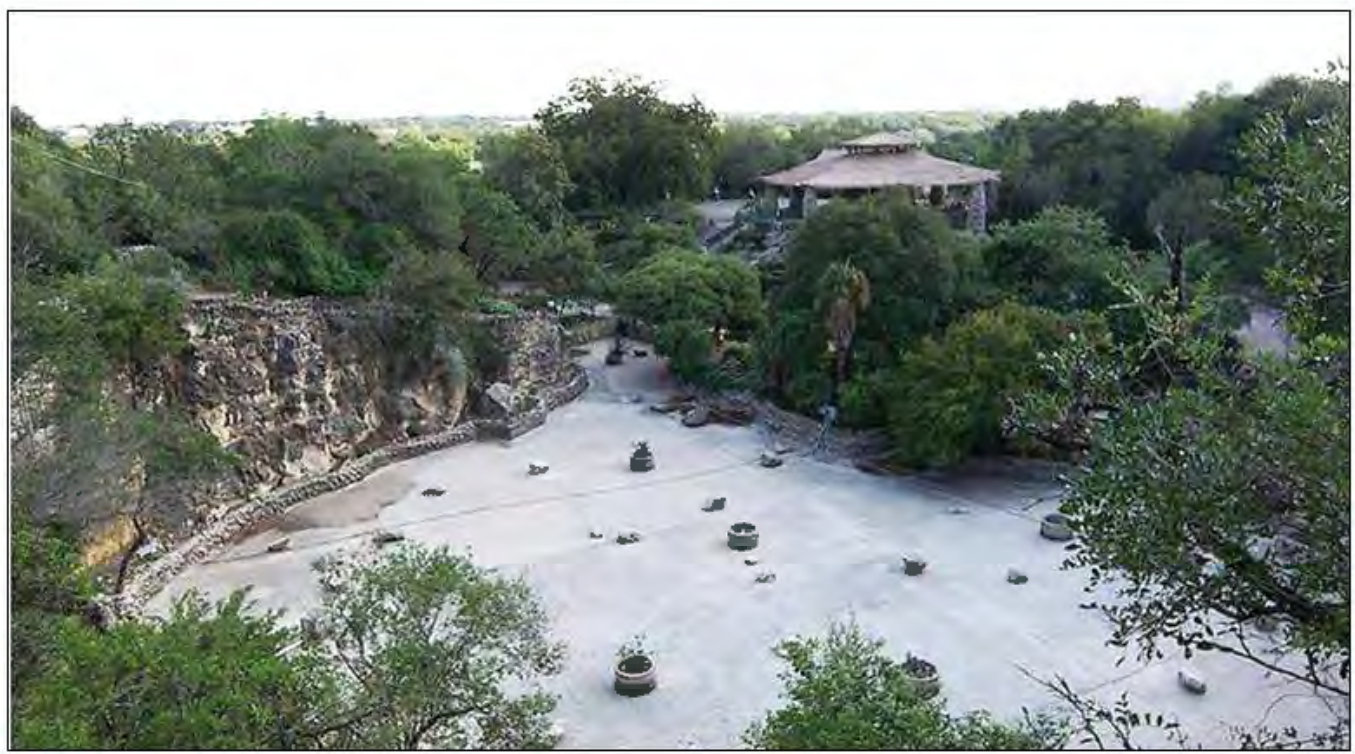

Figure 22. Photograph of a Japanese tea garden built in an abandoned quarry in San Antonio, Texas.

to constructed tunnels for particle accelerators, underground space has proved to be critical for certain important experiments. The stable temperature and excellent security of such spaces have been important to a number of high-tech uses (Table 7). Some applications such as subatomic particle beam acceleration experiments and applications depend upon shielding from virtually all types of radiation except neutrinos. The shielding provided by rock allows very delicate determinations of subatomic particles.

In Indiana, large, dry underground spaces that could be used for science can be found in underground gypsum mines near Shoals or in a number of unused limestone mines. Indiana mines are generally relatively shallow and are enclosed in relatively soft sedimentary rocks rather than dense crystalline rocks preferred for physics laboratories. 
Table 6A. Mine tourism or education sites*

\begin{tabular}{|c|c|c|c|}
\hline \multicolumn{4}{|c|}{ United States } \\
\hline Place/Name & Type & City, State & Web site \\
\hline Beckley exhibition coal mine & coal & Beckley, W.Va. & www.beckleymine.com \\
\hline Kansas Underground Salt Museum & salt & Hutchinson, Kans. & www.undergroundmuseum.org \\
\hline Kentucky Coal Museum & coal & Benham, Ky. & www.kingdomcome.org/museum \\
\hline Lacawanna Coal Mine & coal & Scranton, Pa. & $\begin{array}{l}\text { www.lackawannacounty.org/attractions_coal. } \\
\text { asp }\end{array}$ \\
\hline Mission Mine and Mineral Discovery Center & copper & Sahuarita, Ariz. & www.mineraldiscovery.com/ \\
\hline Morenci Copper Mine Tour & copper & Morenci, Ariz. & www.fcx.com \\
\hline No. 9 Coal Mine and Museum & coal & Lansford, $\mathrm{Pa}$. & no9mine.tripod.com \\
\hline Pioneer Tunnel Coal Mine & coal & Ashland, Pa. & www.pioneertunnel.com \\
\hline $\begin{array}{l}\text { Pocahontas Exhibition Coal Mine and } \\
\text { Museum }\end{array}$ & coal & Pocahontas, Va. & www.pocahontasva.org/museum.html \\
\hline Portal 31 & coal & Lynch, Ky. & www.portal31.org \\
\hline Seldom Seen Tourist Coal Mine & coal & Patton, Pa. & www.seldomseenmine.com \\
\hline Soudan Underground Mine & iron & Soudan, Minn. & $\begin{array}{l}\text { www.dnr.state.mn.us/state_parks/soudan_ } \\
\text { underground_mine/index.html }\end{array}$ \\
\hline $\begin{array}{l}\text { The Mining Museum and Rollo Jamison } \\
\text { Museum }\end{array}$ & lead, zinc & Platteville, Wisc. & mining.jamison.museum \\
\hline The Sterling Hill Mining Museum & zinc & Ogdensburg, N.J. & www.sterlinghillminingmuseum.org \\
\hline Tour-Ed Mine & coal & Tarentum, $\mathrm{Pa}$. & www.tour-edmine.com \\
\hline Vinegar Hill Historic Lead Mine and Museum & lead, zinc & Galena, III. & www.ohwy.com/il/v/vinegarh.htm \\
\hline \multicolumn{4}{|c|}{ World } \\
\hline National Coal Mining Museum for England & coal & Overton, Wakefield, UK & www.ncm.org.uk \\
\hline Scottish Mining Museum & coal & $\begin{array}{l}\text { Newtongrange, } \\
\text { Scotland }\end{array}$ & www.scottishminingmuseum.com \\
\hline Zollverein Coal Mine Industrial Complex & coal & Essen, Germany & whc.unesco.org/en/list/975 \\
\hline
\end{tabular}

* Many western United States ore mines not included.

\section{Military}

Mines have been useful in military research. A new type of secret bunker-buster bomb was tested in an Indiana limestone mine (Hambling and Shachtman, 2006). The U.S. Navy and others test weapons, sonar, and other sensing technologies at a reclaimed strip mine at Glendora Lake in Sullivan County (fig. 24A). Gypsum mines such as those at Shoals, Ind., are very dry and some are near a major military operation that might benefit from underground, very secure testing sites. Former surface mines are currently in use by the U.S. National Guard for field operations in both Illinois and Kentucky.

\section{Science}

Underground space has great potential to house and protect sensitive experiments. Unused mines have been put to work studying physics, cosmology, engineering, military science, water storage, and microbial reactions (fig. 26). The National Science Foundation (NSF) helped establish a Deep Underground Science and Engineering Laboratory (DUSEL, renamed the Sanford Underground Research Facility [SURF] in 2011), which involves some large mine sites and also supports more modestefforts in other mines. More than $\$ 100$ million have been spent to date to construct laboratories at a depth of about 7,000 ft $(2,133 \mathrm{~m})$ in unused 
Table 6B. Mining museums

\begin{tabular}{|l|l|l|l|}
\hline \multicolumn{1}{|c|}{ Name } & \multicolumn{1}{|c|}{ Type } & \multicolumn{1}{c|}{ Location } & \multicolumn{1}{c|}{ Web site } \\
\hline $\begin{array}{l}\text { Clinton Depot Coal Town and } \\
\text { Railroad Museum }\end{array}$ & coal & Clinton, Vermillion County & $\begin{array}{l}\text { visions.indstate.edu/visions/partners/ctm. } \\
\text { html }\end{array}$ \\
\hline Dugger Coal Museum & coal & Dugger, Clay County & $\begin{array}{l}\text { visions.indstate.edu/visions/partners/ } \\
\text { ominers/coaldcm.html }\end{array}$ \\
\hline Indiana State Museum & dimension stone, \\
& coal & Indianapolis, Marion County & indianamuseum.org \\
\hline Museum of the Coal Industry & coal & Lynnville, Vigo County & lynnvillecoalmuseum.org/ \\
\hline \multicolumn{1}{|c|}{ Name } & \multicolumn{1}{|c|}{ United States and Canada } \\
\hline Alabama Mining Museum & coal & \multicolumn{1}{c|}{ Location } & Web site \\
\hline Argo Gold Mill and Museum & gold & Dora, Ala. & www.alabamaminingmuseum.com/ \\
\hline Cape Breton Miner's Museum & coal & $\begin{array}{l}\text { Glace Bay, Nova Scotia, } \\
\text { Canada }\end{array}$ & www.historicargotours.com \\
\hline Cliff Shaft Mine Museum & iron & Ishpeming, Mich. & $\begin{array}{l}\text { www.me.mtu.edu/ jdschust/cliffs/ } \\
\text { csmhistory.html }\end{array}$ \\
\hline Joplin Museum Complex & lead, zinc minerals & Joplin, Mo. & www.joplinmuseum.org \\
\hline Minnesota Museum of Mining & iron & Chisholm, Minn. & $\begin{array}{l}\text { www.ironrange.org/attractions/mining/ } \\
\text { mining-museum/ }\end{array}$ \\
\hline New Mexico Mining Museum & uranium & Grants, N.Mex. & $\begin{array}{l}\text { www.grants.org/MiningMuseum/ } \\
\text { tabid/220/Default.aspx }\end{array}$ \\
\hline
\end{tabular}

parts of the Homestake gold mine. Scientists from SURF will study neutron details, proton decay, dark matter, rare radioactivity and other fundamental questions of nuclear physics (Deep Science, 2007). The Soudan underground mine laboratory has been in operation for 25 years at an unused iron mine in Minnesota. Instruments shielded from surface interferences, even cosmic rays, investigate dark matter, weakly interacting massive particles, the nature of fundamental forces, and other questions of basic science. Deep, underground science laboratories in refurbished mines also exist in Sudbury, Canada; Gran Sasso, Italy; Frejus, France; Canfranc, Spain; Pyhajarvi, Finland; and Kamioka, Japan. Many of these are very complex and represent a high investment of talent and money.

\section{Commercial}

Underground research facilities also exist for commercial businesses. KONE Elevator operates an elevator research and test tower in an old limestone mine of Lohja, Finland. Development of such specialized laboratories is possible in Indiana. The state has great ability and interest in biotechnology and one abandoned limestone mine is already at work as a biotechnology facility at the Marengo Warehouse. It is likely that others will develop. It is also likely that large wet void spaces of abandoned water-filled mines may be used as biotechnology and bioreactor research sites.

\section{INDUSTRIAL AND RESIDENTIAL DEVELOPMENT}

In Indiana, many mined areas have undergone development for industrial or business office uses. However, only a very small amount of reclaimed coal mines underlie industrial or commercial facilities. Mined lands near Pimento became a site for the Boral Brick Company. In addition to the location in an old mine site, the plant uses shale from the mine and methane generated by the nearby Terre Haute landfill (fig. 18). Sand and gravel mines often are reused for building sites, especially near population centers. The Precedent Office Park off 


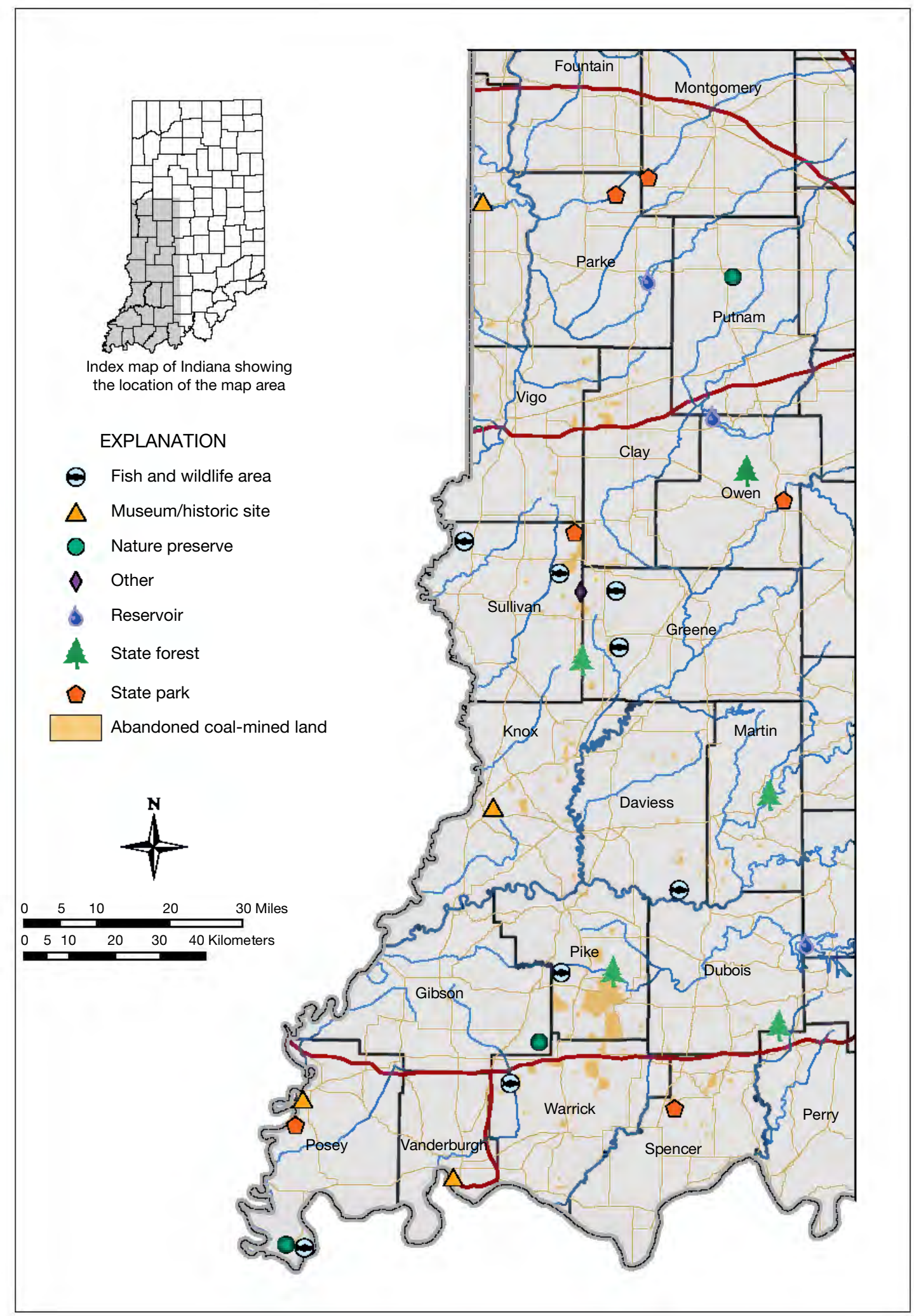

Figure 23. Map showing recreational areas on mined lands of Indiana. 

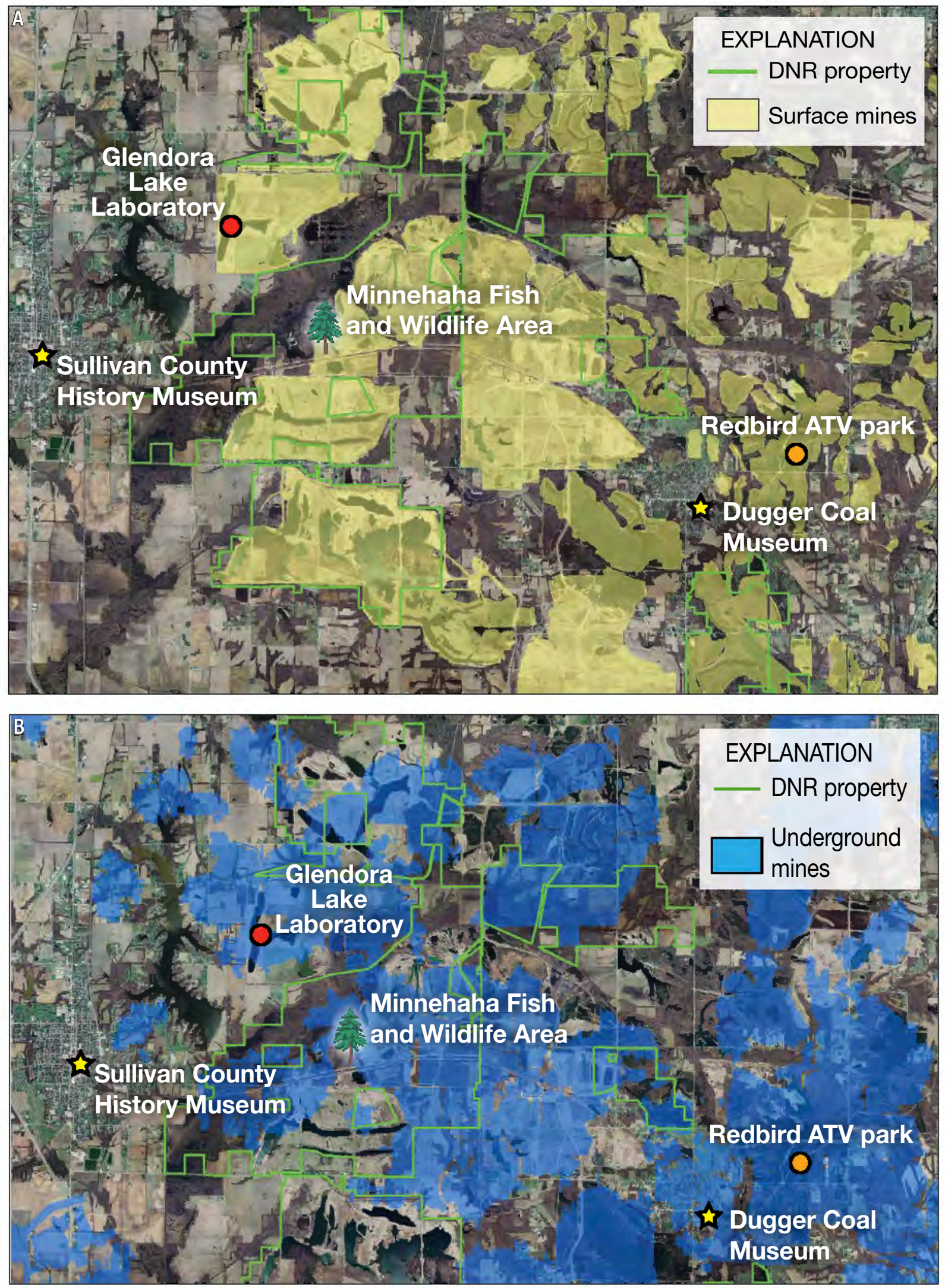

Figure 24. Aerial photograph of area surrounding Sullivan and Dugger, Indiana, that show mined areas and recreation sites superimposed on (A) surface-mined lands and (B) on underground-mined lands. 
$96^{\text {th }}$ Street north of Indianapolis was developed at an abandoned aggregate operation ( $\mathrm{C} 1$, fig. 27). It features very prestigious corporate office buildings and Indiana Wesleyan College.

Mine sites near urban centers have been turned into popular, expensive lakefront residential properties (sites C2, C3, C4, fig. 27). Examples of residential development include upscale subdivisions in Indianapolis, Mooresville, Kokomo, and Newburgh. Proper planning can result in final grading of a mine to assure aesthetic landscapes, proper drainageways for water, and pleasing topography, and thus can maximize potential for high-end development.

Caution is necessary when building homes on certain spoil materials because some overburden may produce gases, waters may leach toxic trace metals, and radon may be released if abundant black shales are present in the spoils. Erosion, subsidence hazards, and rarely, generation of $\mathrm{CO}_{2}$ gas or noxious fluids such as AMD also may be encountered. Buildings on coal spoil may experience $\mathrm{CO}_{2}$ buildups leading to health concerns (Robinson, 2009). However, if properly evaluated and prepared, mined lands can make excellent locations for real estate developments.

\section{CONCLUSIONS}

Many potential economically, environmentally, and culturally positive reuses for mined lands exist. Some are already in place in Indiana and elsewhere. Many additional reuses, some untested, should also be considered to help make the best uses of the world's growing inventory of mined lands. Indiana contains at least 516,000 acres (208,416 ha) of mined land. Recent reclamation practices have put much of this land to productive reuses as croplands, pastures, forests, and recreational sites but many unconventional or untried reuses are possible. Indiana's location and transport systems make underground storage in mines viable and some underground storage sites, like Marengo Cave, are already in operation. Abundant mine waters could be used for irrigation, geothermal heating and cooling, energy production, and process water in manufacturing. Underground space in coal mines could be modified to produce methane, make enormous bioreactors to produce fuels or bulk commodities or to remove atmospheric $\mathrm{CO}_{2}$, house science or military laboratories, and serve as compressed air storage or geobatteries for electric power load leveling. Surface-mined areas could be more extensively used for agriculture and aquaculture, $\mathrm{CO}_{2}$ sequestration, education, recreation, tourism, and to grow specialty crops or grasses for biomass.

The main problems in reusing mined areas are economic and environmental concerns. Implementing proper safeguards to protect surface and groundwater will present the most serious engineering constraints for most uses. Modern grouting techniques or development of bladders should be able to isolate areas subject to chemical, electrical, or physical changes from surrounding areas (Houlsby, 1990; Morrison, 1991; Naudts, 2004; U.S. Army Corps of Engineers, 2004; Warner, 2004). Economic incentives for geothermal uses are already in place and additional inducements could promote sustainable and renewable geothermal energy recovery in mined areas. Technological improvements, such as downhole imaging, infrared imaging, and improved pumps, will facilitate the development of new uses for underground space and societal pressures will encourage innovative approaches to reuse.

To fully utilize Indiana's mined areas, legal questions such as long-term responsibilities must be answered and economic and technical details concerning water quantity and quality must be settled. Most mine locations are already known and some data about geology, hydrology, and engineering are also known, but additional details have to be determined either from old records or renewed examination to learn details such as geologic structures; roof, wall, and floor conditions; the presence of plugged shafts, drill holes, utility access points, fractures; and actual or incipient subsidence features. Quantities and qualities of mine waters must be known. Certain processes can use waters of marginal quality while others, such as food growth or processing, require good quality water having low amounts of dissolved chemical constituents. Hydrologic connections, flow rates, and transmissivity should be known if large quantities of mine waters are used. Effects of water removal on structural stability of underground facilities could be critical and would need to be investigated.

Possible uses of new techniques such as directional or horizontal drilling to connect or move water masses should be explored. Methods to coat mine walls to prevent contamination or escape of stored 


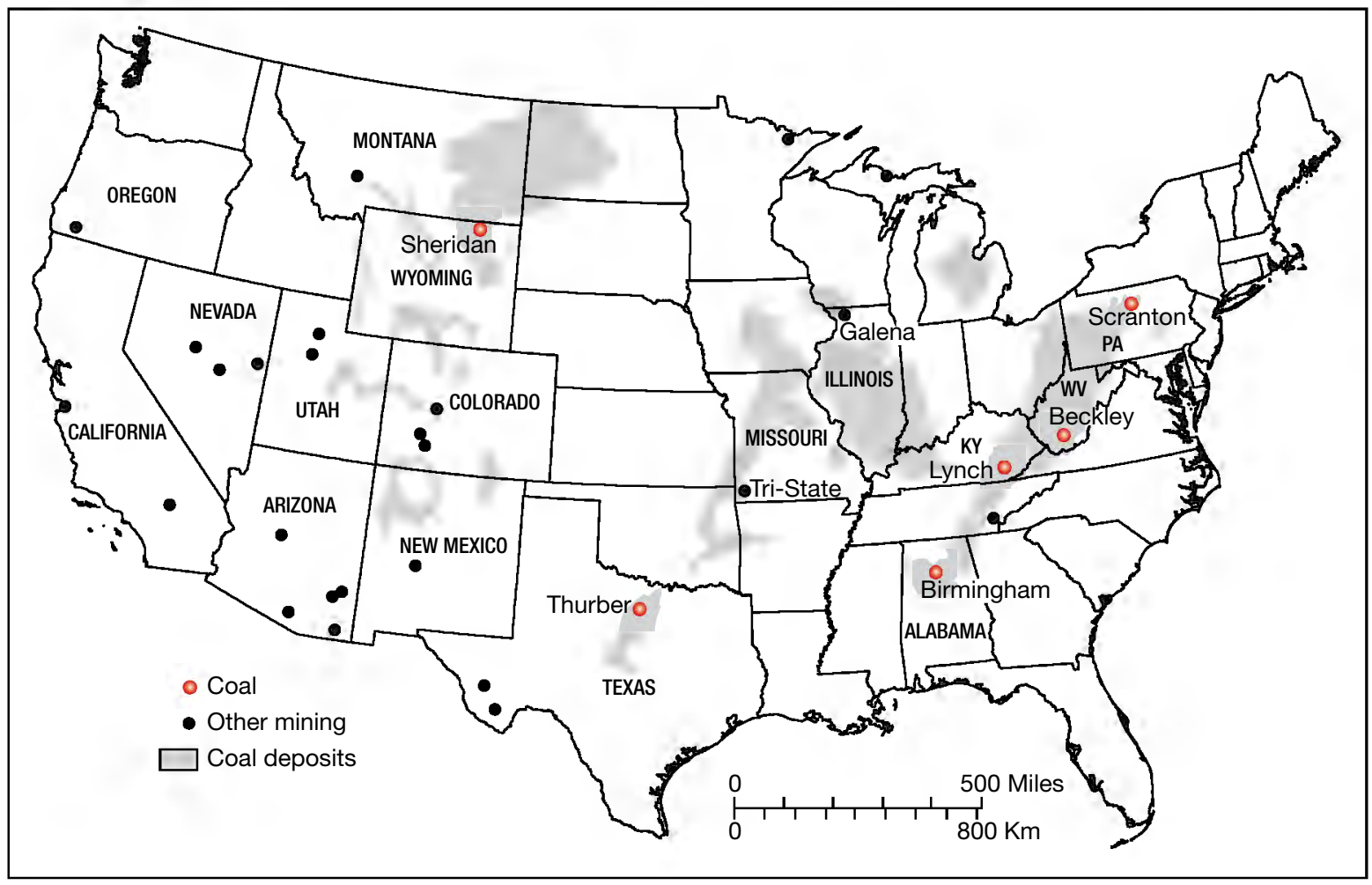

Figure 25. Map showing mine tourism sites in the United States.

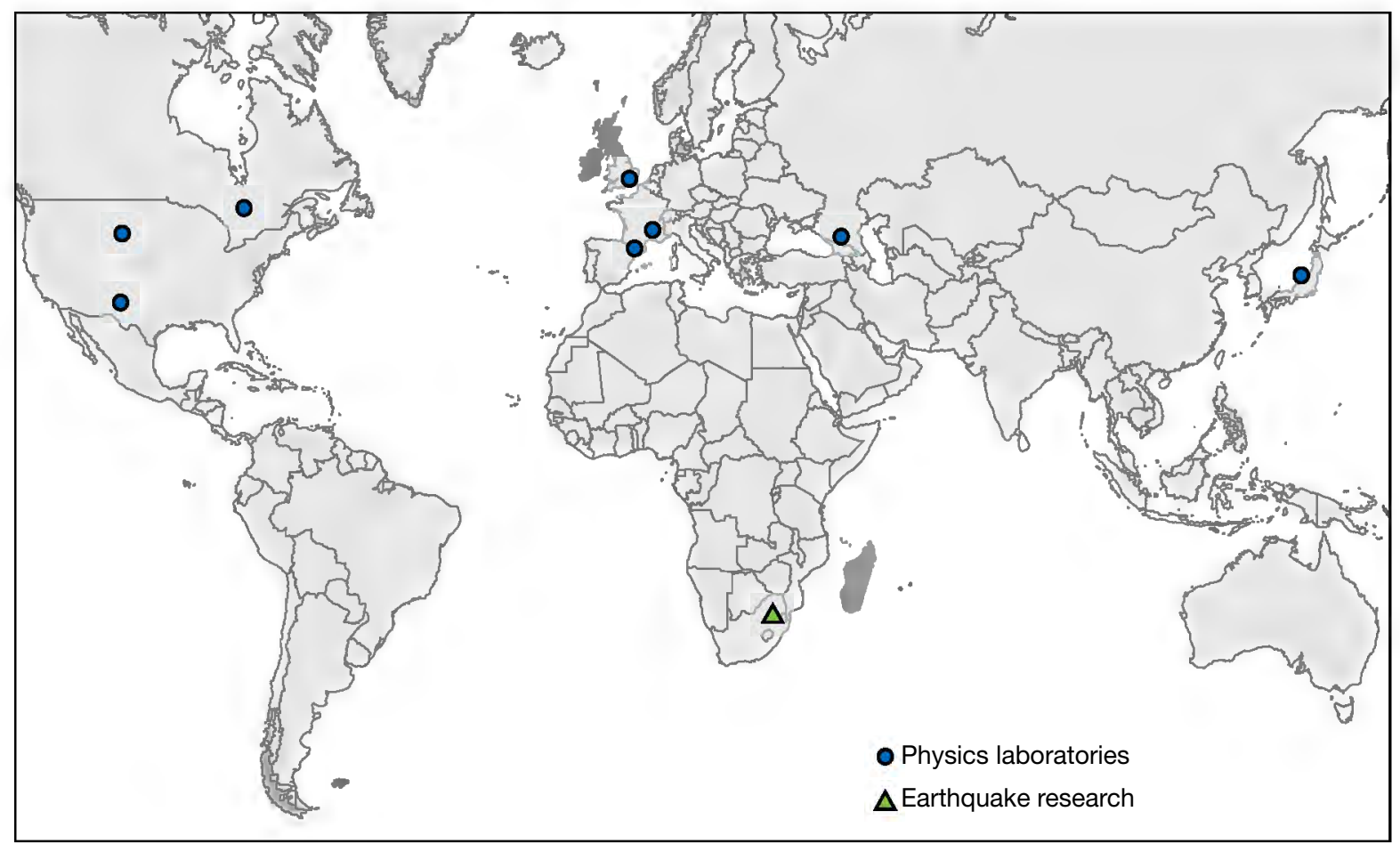

Figure 26. Map of the world showing the locations of known underground laboratories. 


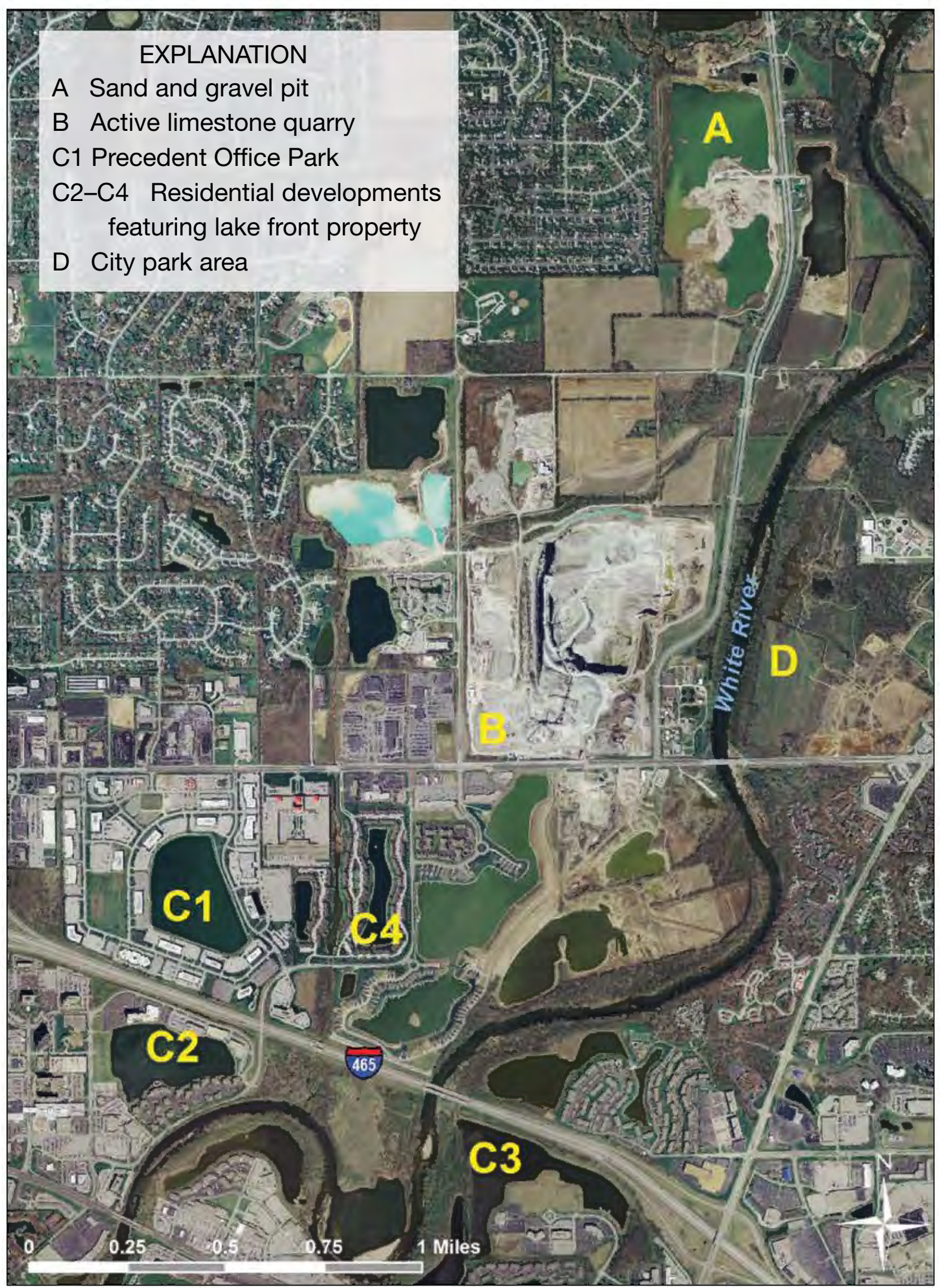

Figure 27. Aerial photograph of northern Indianapolis, Indiana, showing reuses of mined areas. 
Table 7. Science or military laboratories using mined lands

\begin{tabular}{|c|c|}
\hline Location & Type of Mine \\
\hline Boulby (Europe) & Metal \\
\hline SURF (South Dakota) & Metal \\
\hline Glendora Lake (Indiana) & Coal \\
\hline Lead (South Dakota) & Gold \\
\hline Marego Quarry (Indiana) & Limestone \\
\hline Mitchell Quarry (Indiana) & Limestone \\
\hline WIPP (New Mexico) & Evaporites \\
\hline Soudan (Minnesota) & Iron \\
\hline
\end{tabular}

or manufactured materials should be examined. Engineering barriers, installing plates or membranes, or modifying piping to provide needed infrastructure for techniques noted above could be done as mining ends. Educational programs about mined-land reuse should be undertaken by notfor-profit groups, trade associations, companies, and other interested organizations to alert decision makers, businessmen, and the public to the many opportunities to reuse mined areas in the best, most sustainable, ways.

\section{ACKNOWLEDGMENTS}

This work benefited from assistance by many others. The author wishes to acknowledge Jack McGriffin of the Indiana Department of Natural Resources (IDNR), Division of Reclamation in Indianapolis, and Brock Mayes of the IDNR, Division of Reclamation in Jasonville. Several members of the Indiana Department of Natural Resources at the main office in Indianapolis and at individual parks provided information. Tracy Branam, Licia Weber, Maria Mastalerz, and Denver Harper discussed various topics. Kathryn Shaffer of the Indiana Geological Survey provided production data and graphics. Barbara Hill, John Day, Denver Harper, Ronald Smith, and Kathryn Shaffer provided images. Kimberly Sowder perfected illustrations and three peer reviewers, Paul Ehret, Maria Mastalerz, and Penny Meighen, provided suggestions for improvements. John Comer and Deborah DeChurch edited the manuscript.

\section{REFERENCES}

Akala, V. A., and Lal, R., 2000, Potential of mine land reclamation for soil organic carbon sequestration in Ohio: Land Degradation and Development, v. 11, no. 3, p. 289-297.

Allen, D. M., Ghomshei, M. M., Sadler-Brown, T. L., Dakins, A., and Holtz, D., 2000, The current status of geothermal exploration and development in Canada: Proceedings World Geothermal Congress 2000, Kyushu-Tohoku, Japan, May 28-June 10, p. 55-58.

Allred, J., 2005, Promoting direct-use development of Utah's low-temperature geothermal resources: Utah Energy Office, Department of Natural Resources, prepared for the U.S. Department of Energy Grant Number DE-FG48026011, 36 p.

Anderson, E. T., 1999, Determining the sustainability of coal mine cavity discharge as a drinking water source: Blacksburg, Va., Virginia Polytechnic Institute and State University, master's thesis, $236 \mathrm{p}$.

Andrews, R., Liu, K., Crocker, M., Crofcheck, C., and Shea, A., 2008, Feasibility of capture and utilization of $\mathrm{CO}_{2}$ from Kentucky power plants by algae systems-technical review of the literature related to the cultivation and harvesting of algae for $\mathrm{CO}_{2}$ fixation and the co-production of fuels and chemicals: Kentucky Governor's Office of Energy Policy Seed Grant P02 8550700006898 1, final report, 21 p.

Annandale, J. G., Beletse, Y. G., Stirzaker, R.J., Bristow, K. L., and Aken, M. E., 2009, Is irrigation with coalmine water sustainable?: Abstracts of the International Mine Water Conference, Oct. 19-23, 2009, Pretoria, South Africa, p. 337-342.

Appalachian Regional Reforestation Initiative, 2010, Appalachian Regional Reforestation Initiative Web site, < http://arri.osmre.gov/>, date accessed, April 19, 2011.

Archer, P. L., and Kirr, J. N., 1984, Pennsylvanian geology, coal, and coalbed methane resources of the Illinois Basin-Illinois, Indiana, and Kentucky, in Rightmire, C. T., Eddy, G. E., and Kirr, J. N., eds., Coalbed methane resources of the United States: American Association of Petroleum Geologists Studies in Geology 17, p. 105-134.

Associated Press, 2001, Limestone mine keeps photos safe from climate, time, terrorism: The Herald, Sharon, Pa., Web site, Dec. 5, <http://www2.sharon herald.com/localnews/recentnews/0112/ln1205011. html >, date accessed, July 15, 2005.

Axler, R., Yokom, S., Tikkanen, C., McDonald, M., Runke, H., Wilcox, D., and Cady, B., 1998, Restoration of a mine pit lake from aquacultural nutrient enrichment: Restoration Ecology, v. 6, no. 1, p. 1-19. 
Banerji, S. K., 1997, Bioreactors for soil and sediment remediation: Annals of the New York Academy of Sciences, v. 829, p. 302-312.

Banks, D., 2009, An introduction to 'thermogeology' and the exploitation of ground source heat: Quarterly Journal of Engineering Geology and Hydrogeology, v. 42, p. 283-293.

Banks, D., Pumar, A. F., and Watson, I., 2009, The operational performance of Scottish minewater-based ground source heat pump systems: Quarterly Journal of Engineering Geology and Hydrogeology, v. 42, p. 347-357.

Banks, D., Skarphagen, H., Wiltshire, R., and Jessop, C., 2003, Mine water as a resource-space heating and cooling via use of heat pumps: Land Contamination and Reclamation, v. 11, no. 2, p. 191-198.

Banks, D., Younger, P. L., and Dumpleton, S., 1996, The historical use of mine-drainage and pyriteoxidation waters in central and eastern England, United Kingdom: Hydrogeology Journal, v. 4, no. 4, p. 55-68.

Bazargan Sabet, B., Demollin, E., Van Bergermeer, J.-J., 2008, Geothermal use of deep flooded mines: Post-Mining Symposium, Feb. 6-8, Nancy, France, p. 1-11.

Behum, P. T., 2012, Passive treatment of low-ph, highaluminum acid mine drainage-a critical review of sulfate-reducing bioreactor technology, in Comer, J. B., Effects of abandoned mine land reclamation on ground and surface water quality-research and case histories from Indiana: Indiana Geological Survey Special Report 72, p. 327-354.

Benjamin, T., 1999, Adaptation of underground space: National Archives Web site, Preservation and Archives Professionals, <http://www.archives.gov/ preservation/storage/underground-facilities.html date accessed, Sept. 4, 2007.

Bibler, C. J., Marshall, J. S., and Pilcher, R. C., 1998, Status of worldwide coal mine methane emissions and use: International Journal of Coal Geology, v. 35, issues 1-4, p. 283-310.

Bile, J., 2008, An orchid underground-Kansas City man grows thousands of exotic flowers and tropical plants in a climate-controlled cave: The Topeka, Kansas, Capital-Journal Web site, Jan. 20, <http:// www.cjonline.com/stories/012008/lif_238345190. shtml>, date accessed, Sept. 1, 2008.

Birdsey, R. A., 1996, Regional estimates of timber volume and forest carbon for fully stocked timberlandaverage management after final clearcut harvest, in Sampson, R. N., and Hair, D., eds., Forests and global changes, v. 2, Forest management opportunities for mitigating carbon emissions: Washington, D.C., American Forests, p. 309-334.
Bonaventura, C., and Johnson, F. M., 1997, Healthy environments for healthy people-bioremediation today and tomorrow: Environmental Health Perspectives, v. 105, no. S1, p. 5-20.

Branam, T., and Harper, D., 1994, Tabulated analytical data for water samples from the Friar Tuck site-final report to the Indiana Division of Reclamation concerning research and reclamation feasibility studies at the Friar Tuck site, Sullivan and Greene Counties, Indiana: Indiana Geological Survey Open-File Report 94-13, 169 p.

Branan, N., 2009, Mining for iron oxides in coal mine sludge: Earth Magazine, Apr. 30, <http://www. earthmagazine.org/earth/article/211-7d9-4-1e>, date accessed, November 27, 2011.

Brandl, H., 2001, Microbial leaching of metals, in Rehm, H. J., ed., Biotechnology, v. 10: Weinheim, WileyVCH, p. 191-224.

Brownfield, M. E., 2002, Characterization and modes of occurrence of elements in feed coal and fly ash-an integrated approach: U.S. Geological Survey Fact Sheet FS-038-02, 4 p.

Budwill, K., 2003, Microbial methanogenesis and its role in enhancing coalbed methane recovery: Canadian Society of Exploration Geophysicists Recorder, Nov., p. 41-46.

Bullis, K., 2009, Fuel from coal-eating microbes: Technology Review, Jan. 8, <http://skrconline.net/content/ images/stories/documents/mine_water_renewable_ energy_guide.pdf $>$, date accessed, Nov. 27, 2011.

Burger, J. A., 1999, Academic research perspective on experiences, trends, constraints, and needs related to reforestation of mined land, in Vories, K. C., and Throgmorton, D., eds., Proceedings, Enhancement of Reforestation at Surface Coal Mines-Technical Interactive Forum, March 23-24, 1999, Fort Mitchell, Ky., p. 63-74.

Burger, J. A., and Zipper, C. E., 2002, How to restore forests on surface-mined land: Virginia Polytechnic Institute and State University, Virginia Cooperative Extension Publication 460-123, 18 p.

Busby, J., Lewis, M., Reeves, H., and Lawley, R., 2009, Initial geological considerations before installing ground source heat pump systems: Quarterly Journal of Engineering Geology and Hydrogeology, v. 42, p. 295-306.

CADDET, 2007, Geothermal mine water as an energy source for heat pumps: Canada Natural Resources Web site, <http://oee.nrcan.gc.ca/Publications/ infosource/Pub/ici/caddet/english/pdf/R122.pdf >, date accessed, Nov. 16, 2007.

Cairney, T., 1973, Utilization of disused coal mines as water storage reservoirs: Journal of Hydrology, v. 19, p. 251-258. 
Cappa, J. A., and Hemborg, H. T., 1995, 1992-1993 low temperature geothermal assessment programColorado: Colorado Geological Survey Open-File Study 95-01, $20 \mathrm{p}$.

Chang, I. S., Moon, H., Bretschger, O., Jang, J. K., Park, H. I., Nealson, K. H., and Kim, B. H., 2006, Electrochemically active bacteria (EAB) and mediator-less microbial fuel cells: Journal of Microbiology and Biotechnology, v. 16, no. 2, p. 163-177.

Charter, D., 2008, Dutch city taps disused coalmines for clean, green heat: The Australian, Oct. 7, <http:// www.theaustralian.com.au/news/dutch-city-tapsdisused-coalmines/story-e6frg6to-1111117679138>, date accessed, Dec. 10, 2009.

Chen, H., Cong, T. N., Yang, W., Tan, C., Li, Y., and Ding, Y., 2009, Progress in electrical energy storage system-a critical review: Progress in Natural Science, v. 19, no. 3, p. 291-312.

Childs, D., 2007, BP funds biofuel research with \$500M: Cleantech Group Web site, Feb. 2, <http://cleantech. com/news/696/bp-funds-biofuel-research-with$500 \mathrm{~m}>$, date accessed, Jan. 19, 2009.

Christensen, C. A., and Koppenjan, G., eds., 2010, Planting and managing switchgrass as a dedicated energy crop, $2^{\text {nd }}$ ed.: Blade Energy Crops Web site, $<$ http://www.bladeenergy.com/Bladepdf/BladeSwitchgrass-Mgmt_2ed.pdf $>$, date accessed, Aug. 30, 2011.

ClimateTechWiki, 2011, Energy storage-pumped storage: ClimateTechWiki Web site, <http:// climatetechwiki.org/technology/jiqweb-ph>, date accessed, July 25, 2011.

Conan, M., 2004, The Crazannes quarries by Bernard Lassus, Dumbarton Oaks: Washington, D.C., Spacemaker Press, $95 \mathrm{p}$.

Coyne, C., 2009, Welcome to Mineral Wells Fossil Park: Mineral Wells Index Web site, February 16, $<$ http://www.mineralwellsindex.com/local/local_ story_047090701.html $>$, date accessed, March 1, 2009.

Creedy, D., and Tilley, H., 2003, Coalbed methane extraction and utilization, in Proceedings of the Institution of Mechanical Engineers, part A: Journal of Power and Energy, Professional Engineering Publishing, v. 217, no. 1, p. 19-25.

Cummings, P., 2008, Indiana residential geothermal heat pump rebate, program review: Indiana Office of Energy and Defense Development, 18 p., <http:// www.in.gov/oed/files/GHPProgramreport.pdf $>$, date accessed, Dec. 9, 2009.

Deep Science, 2007, Deep Science Web site: < http://www. DeepScience.org $>$, date accessed, Oct. 16, 2011.

Deuse, K., 2011, Coal mining company hopes to tap into green energy market: Deutsche Welle WORLD.DE
Web site, June 6, <www.dw-world.de/dw/article/0, 15143314,00.html $>$, date accessed, July 25, 2011.

Dickson, J., 2004, Using minewater as a heat source: Sustainable Development, issue 59, v. XIX, no. 3, Parsons Brinckerhoff Network.

Dowling, R. K., and Newsome, D., 2006, Geotourism: Oxford, U.K., Elsevier Butterworth-Heinemann, 260 p.

Drobniak, A., Mastalerz, M., Rupp, J., and Eaton, N., 2004, Coalbed gas potential of the Seelyville Coal in Indiana: International Journal of Coal Geology, v. 57 , p. 265-282.

Eagle Mountain Energy, 2011, Eagle Mountain pumped storage project represents a sustainable solution and the best of two worlds: Eagle Mountain Energy Co. Web site, <http://www.eaglemountainenergy. net/index2.html $>$, date accessed, July 25, 2011.

Earney, F. C., 1968, Mushrooms and mines-a study in horticulture: Journal of Geography, v. 67, no. 1, p. 42-48.

Edworthy, K. J., and Puri, S., 1986, Groundwater and aquifers; an overview of 'exotic' uses: Quarterly Journal of Engineering Geology, London, v. 19, p. 87-95.

Ehrlich, H. L., 2002, Geomicrobiology, 4th ed.: New York, Marcel Dekker, 768 p.

Electric Power Research Institute (EPRI), 1976, An assessment of energy storage systems suitable for use by electric utilities: Public Service Electric and Gas Company, Electric Power Research Institute Project 225 and Energy Research and Development Administration Contract No. E (11-1) -2501, v. I and II, July.

Faiz, M., and Hendry, P., 2009, Microbial activity in Australian CBM reservoirs: Search and Discovery Web site article \#80033, <http://www.searchanddiscovery. com/documents/2009/80033faiz/ndx_faiz.pdf $>$, date accessed, Oct. 2, 2009.

Faiz, M., and Hendry, P., 2006, Significance of microbial activity in Australian coal bed methane reservoirs-a review: Bulletin of Canadian Petroleum Geology, v. 54, issue 3, p. 261-272.

Finkelstein, M., DeBruyn, R. P., Weber, J. L., and Dodson, J. B., 2005, Buried hydrocarbons-a resource for biogenic methane generation: World Oil Online Web site, Aug., v. 226, <http://www.worldoil.com/ magazine/magazine_detail.asp?ART_ID=2657>, date accessed, Nov. 14, 2008.

Flores, R. M., ed., 2008, Microbes, methanogenesis, and microbial gas in coal: International Journal of Coal Geology, v. 76, no. 1-2, p. 1-186.

Garofano, M., 2010, Geotourism-the geological attractions of Italy for tourists: Italy, Geoturismo Edizioni, 138 p. 
Gentile, R. J., 1997, Geology and utilization of underground space in metropolitan Kansas City area, USA: Environmental Geology, v. 29, no. 1-2, Jan., p. 11-16.

Geo-Heat Center, 2011, Geo-Heat Center Web site: <http:// geoheat.oit.edu>, date accessed, Nov. 14, 2009.

Ghose, M. K., and Lahiri-Dutt, K., 2007, Reuse of coal mine discharge to meet the water crisis in Raniganj coalfield area: Indian Chemical Engineer, v. 49, no. 3, p. 237-250.

Gilcrease, P. C., and Shurr, G. W., 2007, Making microbial methane work-the potential for new biogenic gas: World Oil Online, Nov., <http://www.worldoil.com/ magazine/magazine_detail.asp?ART_ID=3335>, date accessed, Nov. 14, 2008.

Glover, L., 2003, Recovery process turns mine pollution into pigments: Pittsburgh Business Times, Oct. 20, <http://www.bizjournals.com/pittsburgh/ stories/2003/10/20/smallb1.html?s=print $>$, date accessed, Nov. 21, 2011.

Gluskoter, H. J., 1975, Mineral matter and trace elements in coal, in Babu, S., ed., Trace elements in fuel Washington, D.C., American Chemical Society, p. 1-22.

Grant, B., 2009, Future oil: The Scientist, v. 23, no. 2, p. 36 [available at $<$ http://www.the-scientist. com/2009/02/1/36/1/ >, date accessed, Oct. 10, 2009].

Ground Water Practitioners, 2012, Coal bed methane: Ground Water Practitioners Web site, < http://www. gwv.co.za/coal_bed_methane.shtm $>$, date accessed, Nov. 11, 2011.

Hambling, D., and Shachtman, N., 2006, Fire in the hole: Popular Mechanics, v. 183, no. 7, p. 28.

Hanova, J., and Dowlatabadi, H., 2007, Strategic GHG reduction through the use of ground source heat pump technology: Environmental Research Letters, v. 2, letter no. 044001, 8 p., <http://www.iop. org/EJ/article/1748-9326/2/4/044001/erl7_4_044001. pdf? request-id=1cb6421f-fce 9 - 470 a-9b2b25684d007952>, date accessed, Nov. 5, 2009.

Harper, D., and Olyphant, G. A., 1993, Statistical evaluation of hydrologic conditions in the vicinity of abandoned underground coal mines around Cannelburg, Indiana: Journal of Hydrology, v. 146, p. $49-71$.

Harper, D., and Olyphant, G. A., 1992, Requirements of a general operational model for the hydrologic response of flooded room-and-pillar mines to natural and man-made stresses, in Chugh, Y. P., and Beasley, G., eds., Proceedings of $4^{\text {th }}$ Conference on Ground Control for Midwestern U.S. Coal Mines, Nov. 2-4, 1992, Mt. Vernon, Ill., p. 1-12.

Harper, D., Branam, T., and Shaffer, N., 2009, Characterization of Indiana's coal mine aquifer: Indiana
Society of Mining and Reclamation $23^{\text {rd }}$ Annual Technology Transfer Seminar, Dec. 7-8, Jasper, Ind.

Harper, D., Dintaman, C., Mastalerz, M., and Letsinger, S., 2009, Reconnaissance of coal-slurry deposits in Indiana: Indiana Geological Survey Occasional Paper 69, 20 p., CD-ROM.

Harper, D., Olyphant, G. A., and Sjogren, D. R., 1996, Ground and surface-water interactions involving an abandoned underground coal mine in Pike County, Indiana: Proceedings of the $13^{\text {th }}$ Annual Meeting, American Society for Surface Mining and Reclamation, May 18-23, Knoxville, Tenn., p. 87-95.

Harper, D., Olyphant, G. A., and Hartke, E. J., 1990, Unexpected hydrologic perturbation in an abandoned underground coal mine-response to surface reclamation: Environmental Geolology and Water Sciences, v. 15, no. 3, p. 179-187.

Hatch, J. R., Gluskoter, H. J., and Lindahl, P. C., 1976, Sphalerite in coals from the Illinois Basin: Economic Geology, v. 71, no. 3, p. 613-624.

Hedin, R. S., 2002, Recovery of marketable iron oxide from mine drainage: National Meeting of the American Society of Mining and Reclamation, June 9-13, 2002, Lexington Ky., p. 517-526.

Heimbuch, J., 2009, 300 million-year-old limestone houses ultra efficient data center 22 stories underground: Treehugger Web site, <http://www. treehugger.com/files/2009/12/ultra-efficientdata-center-housed-22-stories-underground-inlimestone-cave.php $>$, date accessed, Dec. 28, 2009.

Hite, T., 2007, Coal bed methane (CBM) in Indiana: Center for Coal Technology Research Advisory Panel Meeting, Sept. 6, 2007, Vincennes University, Vincennes, Ind.

Hopey, D., 2007, Use of mine water may help avert pollution disaster: Pittsburgh Post-Gazette, Oct. 21, $<$ http://www.post-gazette.com/pg/07294/827175-85. stm>, date accessed, March 24, 2008.

Houlsby, A. C., 1990, Construction and design of cement grouting-a guide to grouting in rock foundations: House and Home, $442 \mathrm{p}$.

Hutson, S. S., Barber, N. L., Kenny, J. F., Linsey, K. S., Lumia, D. S., and Maupin, M. A., 2004, Estimated use of water in the United States in 2000: U.S. Geological Survey Circular 1268, 46 p.

Hydrodynamics Group, 2011, Hydrodynamics Group Web site: <http://www.hydrodynamics-group.net/>, date accessed, Nov. 13, 2008.

Indiana Department of Natural Resources (IDNR), 2009, Laws and regulations, <http://www.in.gov/dnr/ reclamation/2712.htm>, date accessed, June 28, 2009.

International Geothermal Association, 2011, International Geothermal Association Web site: <http:// 
www.geothermal-energy.org>, date accessed, Nov. 18, 2008.

International Mine Water Association (IMWA), 2011, International Mine Water Association Web site: <http://www.imwa.info/>, date accessed, Oct. 21, 2011.

Jadhav, M. V., 2007, Enhanced coal bed methane recovery using microorganisms: Society of Petroleum Engineers Middle East Oil and Gas Show and Conference, March 11-14, Kingdom of Bahrain, Conference Paper.

Jin, H., Larson, E. D., and Celik, F. E., 2009, Performance and cost analysis of future, commercially mature gasification-based electric power generation from switchgrass: Biofuels, Bioproducts and Biorefining, v. 3, no. 2, p. 142-173.

Jovanovic, N. Z., Annandale, J. G., Claassens, A. S., Lorentz, S. A., Tanner, P.D., Aken, M. E., and Hodgson, F. D. I., 2002, Commercial production of crops irrigated with gypsiferous mine water: Water SA, v. 28 , no. 4 , p. $413-422$.

Jovanovic, N. Z., Barnard, R. O., Rethman, N. F. G., and Annandale, J. G., 1998, Crops can be irrigated with lime-treated acid mine drainage: Water SA, v. 24, no. 2, p. 113-122.

Kaksonen, A. H., and Puhakka, J. A., 2007, Sulfate reduction based bioprocesses for the treatment of acid mine drainage and the recovery of metals: Engineering in Life Sciences, v. 7, no. 6, p. 541-564.

Kaufman, B. L., 2001, Fossil park invites visitors: Cincinnati Enquirer Web site, July 7, <http://www.enquirer.com/editions/2001/07/07/loc_fossil_park_park. html $>$, date accessed, March 1, 2009.

Keefer, R. F., and Sajwan, K. S., eds., 1993, Trace metals in coal and coal combustion residues-managing residue in electric power plants: Boca Raton, Fla., CRC Press, 308 p.

Kennecott Utah Copper, 2011, Bingham Canyon Mine Visitors' Center Web site: <http://www.kennecott. com/visitors-center $>$, date accessed, Oct. 20, 2011.

Kranz, K., and Dillenardt, J., 2009, Mine water utilization for geothermal purposes in Freiberg, Germany-determination of hydrogeological and thermophysical rock parameters: Mine Water and the Environment, v. 29 , p. 68-76, [available at <http://www.springerlink.com/content/1416337654551mh1/fulltext.pdf>, date accessed, Dec. 20, 2009].

Larson, E. D., Jin, H., and Celik, F. E., 2009, Large-scale gasification-based coproduction of fuels and electricity from switchgrass: Biofuels, Bioproducts and Biorefining, v. 3, no. 2, p. 174-194.

Lee, J. W., and Li, R., 2001, A novel strategy for $\mathrm{CO}_{2}$ sequestration and clean air protection, in Proceedings of the $1^{\text {st }}$ National Conference on Carbon
Sequestration, May 14-17, Washington, D.C.: U.S. Department of Energy Web site, <http://www.netl. doe.gov/publications/proceedings/01/carbon_seq/ p12.pdf $>$, date accessed, Nov. 11, 2011.

Lin, M. S., and Premuzic, E. T., 2003, Biochemical enhancement of coalbed methane (CBM) recovery and its potential for treatment of produced water: Preprint Papers-American Chemical Society, Division of Fuel Chemistry, v. 48, no. 2, p. 923-924.

Lindley, D., 2010, The energy storage problem: Nature, v. 463 , Jan. 7, p. 18-20.

Litchfield, C., 2005, Thirty years and counting-bioremediation in its prime?: BioScience, v. 55, no. 3 , p. 273-279.

London Research International, 2010, Survey of energy storage options in Europe: London Research International report, London, $25 \mathrm{p}$.

Lovley, D. R., and Nevin, K. P., 2008, Electricity production with electricigens, in Wall, J., Harwood, C. S., and Demain, A. L., eds., Bioenergy: Washington, D.C., ASM Press, p. 295-306.

Luca Technologies, 2011, Active biogenesis of methane in Wyoming's Powder River basin: Luca Technologies white paper, <http://www.lucatechnologies.com/ pdfs/whitepapers/Active-Biogensis-of-Methanein-Wyomings-Powder-River-Basin.pdf $>$, date accessed, Nov. 27, 2011.

Lund, J. W., 2005, Direct heat utilization of geothermal resources worldwide 2005: Klamath Falls, Ore., U.S. Department of Energy Efficiency and Renewable Energy Geothermal Technologies Program, GeoHeat Center, Oregon Institute of Technology.

Lund, J. W., 2003, Direct-use of geothermal energy in the USA: Applied Energy, v. 74, no. 1-2, p. 33-42.

Lund, J. W., 1997, Direct heat utilization of geothermal resources: Renewable Energy, v. 10, no. 2-3, p. 403-408.

Lund, J. W., and Freeston, D. H., 2001, World-wide direct uses of geothermal energy 2000: Geothermics, v. 30, no. 1, p. 29-68.

Lynd, L. R., Larson, E., Greene, N., Laser, M., Sheehan, J., Dale, B. E., McLaughlin, S., and Wang, M., 2009, The role of biomass in America's energy future-framing the analysis: Biofuels, Bioproducts and Biorefining, v. 3, no. 2, p. 113-123.

Lyons, K., 2009, A regulatory guide to low temperature geothermal development in Washington: Olympia, Wash., Washington State University Extension Energy Program WSUEEP09-015, 13 p.

MacCracken, M. M., 2007, Thermal energy storage and peak load reduction: National Association of Regulatory Utility Commissioners Summer Meeting, July 16, New York, N.Y. [available at <http:// www.naruc.org/meetingpresentations.cfm $>$, date accessed, Nov. 5, 2009]. 
Malolepszy, Z., 2003, Low temperature, man-made geothermal reservoirs in abandoned workings of underground mines: Proceedings, $28^{\text {th }}$ Workshop on Geothermal Reservoir Engineering, Jan. 27-29, Stanford University, Stanford, Calif., p. 259-265.

Malolepszy, Z., 2000, Low-enthalpy geothermal waters in coal-mines, Upper Silesia Coal Basin, Poland: Proceedings of the World Geothermal Congress 2000, May 28-June 10, 2000, Kyushu-Tohuku, Japan, p. 1,401-1,406.

Malolepszy, Z., Demollin-Schneiders, E., and Bowers, D., 2005, Potential use of geothermal mine waters in Europe: Proceedings of the World Geothermal Congress 2005, Antalya, Turkey, April 24-29, 2005, p. 1-3.

Malvankar, N. S., Vargas, M., Nevin, K. P., Franks, A. E., and others, 2011, Tunable metallic-like conductivity in microbial nanowire networks: Nature Nanotechnology, v. 6, p. 573-579.

Marengo Warehouse, 2011, Marengo Warehouse and Distribution Center Web site: <http://www.marengowarehouse.com/>, date accessed, Oct. 21, 2011.

Martin, G. D., and Barnes, F. S., 2007 Aquifer underground pumped hydroelectric energy storage: University of Colorado at Boulder, master's thesis, $90 \mathrm{p}$.

Mascarelli, A. L., 2009, Gold rush for algae: Nature, v. 461, Sept., p. 460-461.

Mason, T., 2009, Mining for energy: Ocean Resources, Aug./Sept., p. 22-23..

Mastalerz, M., and Kvale, E. P., 2000, Coal quality variation and coalbed gas content in boreholes SDH-383 and SDH-384 in Posey County, Indiana: Indiana Geological Survey Open-File Study 00-05, 30 p.

Mastalerz, M., and Kvale, E. P., 1999, Coalbed gas potential in Gibson County, Indiana: Indiana Geological Survey Open-File Study 99-17, 30 p.

Mastalerz, M., and Kvale, E. P., 1998, Coal-bed gas potential in Daviess County, Indiana: Indiana Geological Survey Open-File Report 98-07, 29 p.

McGill, R., 2008, Algae as feedstock for transportation fuels-the future of biofuels?: International Energy Agency Advanced Motor Fuels Implementing Agreement, Executive Committee Meeting, May, Vienna, Austria, 14 p. [available at <http://www.ieaamf.vtt.fi/pdf/annex34b_algae_white_paper.pdf $>$, date accessed, Sept. 10, 2009].

McKendry, P., 2002, Energy production from biomass (part 1)-overview of biomass: Bioresource Technology, v. 83, p. 37-46.

McLoughlin, N., 2006, Geothermal heat in Scotland: Scottish Parliament Information Centre Briefing 06/54, July 12, 14 p.
Mearian, L., 2009, 22 stories underground-Iron Mountain's experimental Room 48: Computerworld Web site, <http://www.computerworld.com/s/ article/9141765/22_stories_underground_Iron_ Mountain_s_experimental_Room_48>, date accessed, Dec. 24, 2009.

Meinhold, B., 2008, Old coal mines adapted to create geothermal energy: Inhabitat Web site, <http:// www.inhabitat.com/2008/12/10/heerlen-minewaterproject $\geqslant$, date accessed, Dec. 11, 2009.

Mercuri, A. M., Duggin, J. A., and Grant, C. D., 2005, The use of saline mine water and municipal wastes to establish plantations on rehabilitated open-cut coal mines, Upper Hunter Valley, NSW, Australia: Forest Ecology and Management, v. 204, no. 2-3, p. 195-207.

Meyer, R. A., 2007, Map showing locations of coal mines in Indiana 2007: Indiana Geological Survey OpenFile Study 00-12, scale: 1,300,000.

Midlothian Council, 2004, Shawfair Minewater Project, Scottish National Minewater Potential Study: Job no. 69211a/001, 54 p.

Miller, D., 2008, Using aquaculture as a post-mining land use in West Virginia: Mine Water and the Environment, Journal of the International Mine Water Association, <http:/www.springerlink.com/content/ q12gp757g27x2k09/fulltext.html , date accessed, July 9, 2008.

Miller, D., Semmens, K., and Sun, Q., 2002, Aquaculture as a post-mining land use in West Virginia: World Aquaculture Society meeting, Jan. 27, 2002, San Diego, Calif.

Miller, R., 2009, Geothermal data center is LEED platinum: Data Center Knowledge Web site, <http://www. datacenterknowledge.com/archives/2009/08/13/ geothermal-data-center-is-leed-platinum/?utmsource=feedburner\&utm-medium=feed\&utm-cam paign $=$ Feed $\% 3 \mathrm{~A}+$ DataCenterKnowledge+Data+Cen ter+Knowledge >, date accessed, Dec. 28, 2009.

Miller, R. R., and Winters, M., 2009, Opportunities in pumped storage hydropower-supporting attainment of our renewable energy goals: HydroWorld, July 1, <http://www. hydroworld.com/index/display/articledisplay/366365/articles/hydro-review/volume-28/ issue-5/Featured_Articles/energy-storageopportunities-for-pumped-storage-supportingrenewable-energy-goals.html>, date accessed, Aug. 29, 2011.

Minewater Project, 2010, Mine water as a renewable energy resource: Sustainable Keweenaw Resource Center Web site, <http://skrconline.net/content/ images/stories/documents/mine_water_renewable_ energy_guide.pdf $>$, date accessed, Nov. 27, 2011. 
Moore, T., and Douglas, J., 2006, Energy storage-big opportunities on a smaller scale: Electric Power Research Institute Journal, Spring issue, p. 16-23.

Morrison, W. C., 1991, Grouting in deep flooded mines: Land Subsidence, Proceedings of the $4^{\text {th }}$ International Symposium on Land Subsidence, May 1991, International Association of Hydrological Sciences Publication no. 200, p. 503-513.

Mullin, R., 2006, Microbial methane farming: Chemical and Engineering News, v. 84, no. 47, Web exclusive, <pubs.acs.org/cen/coverstory/84/8447cover4a.htmls, date accessed, Aug. 28, 2007.

National Renewable Energy Laboratory, 2006, Geothermal Heat Pumps for Homeowners: NREL Web site, <http://www.nrel.gov/learning/ho_geo_heat_ pumps.html $>$, date accessed, Dec. 9, 2009.

National Solid Wastes Management Association, 2006, Modern landfills-a far cry from the past: Environmentalists Every Day Web site, <http://www. environmentalistseveryday.org/docs/white-paperlandfill.pdf $>$, date accessed, Nov. 10, 2007.

Naudts, A., 2004, Irreversible changes in the grouting industry caused by polyurethane grouting-an overview of 30 years of polyurethane grouting: American Society of Civil Engineers, Proceedings of $3^{\text {rd }}$ International Specialty Conference on Grouting and Ground Treatment, p. 1,266-1,280.

Newall, P. S., Clarke, S. J., Haywood, H. M., Scholes, H., Clarke, N. R., and King, P. A., 1999, $\mathrm{CO}_{2}$ storage as carbonate minerals: Cheltenham, U.K., IEA.

Nielsen, K., 2003, Thermal energy storage-a state-of-theart: Trondheim, Norway, NTNU, 25 p. <http://www. energy.sintef.no/Prosjekt/Annex29/Publikasjoner/ GSHPs_ThermalStorageNO.pdf $>$, date accessed, Nov. 11, 2011.

North Carolina Solar Center, 2009, Indiana incentives for renewables and efficiency: Database of State Incentives for Renewables and Efficiency, North Carolina State University, <http://www.dsireusa.org/ incentives/index.cfm?re $=1 \&$ ee $=1 \& \mathrm{spv}=0 \& \mathrm{st}=0 \& \mathrm{srp}$ $=1 \&$ state $=\mathrm{IN} \geqslant$, date accessed, Nov. 15, 2009.

Oak Ridge National Laboratory, 2011, Federal Energy Management Program, <http://www.ornl.gov/ sci/eere/research_femp.shtml $>$ date accessed, Nov. 4, 2011.

Ohio State University, 1999, Sand bioreactors for wastewater treatment for Ohio Communities: Bulletin 876-99, <http://ohioline.osu.edu/b876/b876_3.html>, date accessed, Sept. 21, 2007.

Organic Consumers Association, 2005, Underground crops-the future of pharming: Organic Consumers Association Web site, April 20, <http://www. organicconsumers.org/ge/caves042505.cfm>, date accessed, Jan. 7, 2009.
Parizek, E. J., Stauffer, T., Sr., Vineyard, J. D., eds., 1975, Proceedings of the Symposium on the Development and Utilization of Underground Space, March 5-7, 1975, Kansas City, Mo., The University of Missouri-Kansas City: Washington, D.C., National Science Foundation, $196 \mathrm{p}$.

Parrish, D. J., and Fike, J. H., 2005, The biology and agronomy of switchgrass for biofuels: Critical Reviews in Plant Sciences, v. 24, nos. 5-6, p. 423-459.

Pearman, G., 2009, 101 things to do with a hole in the ground: Plymouth, U.K., Pepper Communications Ltd., $137 \mathrm{p}$.

Pennsylvania Department of Community and Economic Development, 2009, Renewable energy program geothermal and wind projects, program guidelines, 8 p.

Post-Mining Alliance, 2011, Post-Mining Alliance Web site: <www.postmining.org>, date accessed, Sept. 21, 2011.

Potter, H. S., Weitzman, S., and Trimble, G. R., Jr., 1951, Reforestation of strip-mined lands in West Virginia: U.S. Department of Agriculture, Forest Service, Northeastern Forest Experiment Station Paper No. 43, Upper Darby, Pa., 5 p.

Rafferty, K., 2000, Scaling in geothermal heat pump systems: GHC Bulletin, March, p. 11-15.

Ramaswamy, G., 2002, A field evidence for mineralcatalyzed formation of gas during coal maturation: Oil and Gas Journal, Sept. 16, p. 32-36.

Rathfon, R., Fillmore, S., and Groninger, J., 2005, Status of reforested mine sites in southwestern Indiana reclaimed under the Indiana Mining Regulatory Program: Purdue University Cooperative Extension Services Forestry and Natural Resources FNR$251,15 \mathrm{p}$.

Raymond, J., Therrien, R., and Hassani, F., 2008, Overview of geothermal energy resources in Quebec (Canada) mining environments: $10^{\text {th }}$ International Mine Water Association Congress-Mine Water and the Environment, June 2-5, Technical University of Ostrava, Karlovy Vary, Czech Republic, 13 p. [available at International Mine Water Association Web site, <http://www.imwa.info/docs/imwa_2008/ IMWA2008_039_Raymond.pdf>, date accessed, Nov. 15, 2009].

Reinhart, D. R., and Townsend, G., 1997, Landfill bioreactor design and operation: Boca Raton, Fla., CRC Press, 208 p.

Renz, A., Ruhaak, W., Schatzl, P., and Diersch, H.-J. G., 2009, Numerical modeling of geothermal use of mine water-challenges and examples: Mine Water and the Environment, Journal of the International Mine Water Association, Jan., <www.springerlink. 
com/content/92782p5843278470/fulltext.html $>$, date accessed, May 12, 2009.

Richard, M. G., 2008, MIT-move over batteries, here come the nanotube-enhanced capacitors: Treehugger Web site, <http://www.treehugger.com/ files/2008/03/mit-ultracapacitors-nanotubesnanowires.php $>$, date accessed, Dec. 12, 2009.

Rightmire, C. T., Eddy, G. E., and Kirr, J. N., eds., 1984, Coalbed methane resources of the United States: American Association of Petroleum Geologists Studies in Geology 17, 378 p.

Robinson, B., 2009, The accumulation and mitigation of carbon dioxide in residential structures: $23^{\text {rd }}$ Annual Surface Mined Land Reclamation Technology Transfer Seminar, Jasonville, Ind., Dec. 8, 2008, <http://www.in.gov/dnr/reclamation/5731.htm>, date accessed, April 22, 2011.

Rodriguez, R., and Diaz, M. B., 2009, Analysis of the utilization of mine galleries as geothermal heat exchangers by means a semi-empirical prediction method: Renewable Energy, v. 34, no. 7, p. $1,716-1,725$.

Ryan, C., 2009, Cultivating clean energy-the promise of algae biofuels: Ascension Publishing, Report for the Natural Resources Defense Council, 81 p., <http:// www.ascension-publishing.com/BIZ/cultivating. pdf $>$, date accessed, Dec. 1, 2009.

Rybach, L., 2003, Status and prospects of geothermal heat pumps (GHP) in Europe and worldwide; sustainability aspects of GHPs: Proceedings of International Geothermal Days, Bad Urach, Germany, Sept. 16-22, 2001, p. 85-100.

Sanner, B., and Paksoy, H., 2002, Possibilities for heating and cooling through underground thermal energy storage in the Mediterranean area: International Geothermal Days Greece 2002, Sept. 1-11, Aristoteles University, Thessaloniki, <http://www. bine.info/fileadmin/content/Publikationen/ProjektInfos/Zusatzinfos/2003-13_Vortrag.pdf $>$, date accessed, Nov. 5, 2009.

Schaber, C., 2004, Utility-scale storage of renewable energy: The Electricity Journal, v. 17, no. 6, p. 21-29.

Schmer, M. R., Vogel, K. P., Mitchell, R. B., and Perrin, R. K., 2008, Net energy of cellulosic ethanol from switchgrass: Proceedings of the National Academy of Sciences of the United States of America, v. 105, no. 2, p. 464-469.

Science Daily, 2007, 'Heat mining' backed in geothermal energy report: Science Daily Web site, Jan. 23, $<$ http://www.sciencedaily.com/releases/2007/01/ 070122122322.htm>, date accessed, Sept. 17, 2008.

Scott, A. R., 1999, Improving coal gas recovery with microbially enhanced coalbed methane, in Mastalerz, M., Glikson, M. V., and Golding, S. D., eds.,
Coalbed methane-scientific, environmental, and economic evaluations, p. 89-111.

Seeger, C. M., ed., 2004, Proceedings of the $38^{\text {th }}$ Forum on the Geology of Industrial Minerals, St. Louis, Missouri, April 28-May 3, 2002: Missouri Department of Natural Resources Geological Survey and Resource Assessment Division Report of Investigations No. 74, 310 p.

Severson, M. J., 2011, Preliminary evaluation of establishing an underground taconite mine, to be used later as a lower reservoir in a pumped hydro energy storage facility, on the Mesabi Iron Range, Minnesota: University of Minnesota Duluth, Natural Resources Research Institute Report of Investigations NRRI/RI-2011/02, 37 p.

Shafer, S., 2004, Louisville underground in line for grant, might store vital data: Louisville Courier-Journal, Sept. 29.

Shaffer, N. R., 1996, Lateral variations in mineralogy and geochemistry of Pennsylvanian black shale sequences related to contemporaneous fresh water channels, southwestern Indiana: Indiana Geological Survey Open-File Study 96-18, 402 p.

Shaffer, N. R., 1994, Biotechnical materials, in Industrial minerals and rocks, 6th ed., Carr, D. D., ed., Littleton, Colo., Society for Mining, Metallurgy, and Exploration, p. 157-169.

Shaffer, N. R., and Harvey, C., 2001, Ore for the askingcoal combustion byproducts, in Hagni, R. D., ed., Studies on ore deposits, mineral economics, and applied mineralogy with emphasis on Mississippi Valley-type base metal and carbonatite-related ore deposits: Rolla, Mo., University of Missouri-Rolla, p. 397-406.

Shaffer, N. R., and Mastalerz, M., 2009, Pennsylvanian black shales and underground coal gasification (UCG) considerations in Indiana: American Association of Petroleum Geologists Eastern Section Meeting, Sept. 20-22, Evansville, Ind.

Shaffer, N. R., and Leininger, R. K., 1985, Oil yields of fresh and weathered oil shales of Indiana: Proceedings 1985 Eastern Oil Shale Symposium, Nov. 18-20, Lexington, Ky., p. 275-282.

Shaffer, N. R., Leininger, R. K., and Ennis, M. V., 1984, Oil shale of Pennsylvanian Age in Indiana: Proceedings 1984 Eastern Oil Shale Symposium, Nov. 26-28, Lexington, Ky., p. 401-412.

Shannon, M. J. R., and Unterman, R., 1993, Evaluating bioremediation-distinguishing fact from fiction: Annual Review of Microbiology, v. 47, p. 715-738.

Sheridan, C., 2009, Making green: Nature Biotechnology, v. 27 , no. 12 , p. 1,074-1,076.

Shrestha, R. K., and Lal, R., 2006, Ecosystem carbon budgeting and soil carbon sequestration in reclaimed 
mine soil: Environment International, v. 32, no. 6, p. 781-796.

Smith, J. W., and Pallasser, R. J., 1996, Microbial origin of Australian coalbed methane: American Association of Petroleum Geologists Bulletin, v. 80, no. 6, p. 891-897.

Smith, K. C., 1981, A layman's guide to geothermal aquaculture: Klamath Falls, Ore., Technical Report to the Pacific NW Regional Commission, Geo-Heat Center, Oregon Institute of Technology, 8 p., <http:// geoheat.oit.edu/pdf/tp63.pdf $>$, date accessed, Jan. 7, 2009.

Smith, L., 2007, Rapeseed biofuel 'produces more greenhouse gas than oil or petrol': Times Online, Sept. 22, <http://www.timesonline.co.uk/tol/news/ uk/science/article2507851.ece $\gg$, date accessed, Sept. 22, 2007.

Smith, R. T., 2012, Metals removal in acid mine drainage treatment wetlands, in Comer, J. B., Effects of abandoned mine land reclamation on ground and surface water quality-research and case histories from Indiana: Indiana Geological Survey Special Report 72, p. 225-258.

Sokhansanj, S., Mani, S., Turhollow, A., Kumar, A., Bransby, D., Lynd, L., and Laser, M., 2009, Largescale production, harvest and logistics of switchgrass (Panicum virgatum L.)-current technology and envisioning a mature technology: Biofuels, Bioproducts and Biorefining, v. 3, no. 2, p. 124-141.

Stoll, J., 2003, Sylvania Fossil Park mine planning for the community: 2003 Society of Manufacturing Engineers Annual Meeting and Exhibit, Feb. 24-26, Cincinnati, Ohio, preprint 03-079.

Strapoc, D., Mastalerz, M., Dawson, K., Macalady, J., Callaghan, A. V., Wawrik, B., Turich, C., and Ashby, M., 2011: Biogeochemistry of microbial coal-bed methane: Annual Review of Earth and Planetary Sciences, v. 39, p. 617-656.

Strapoc, D., Mastalerz, M., Schimmelmann, A., Drobniak, A., Hedges, S., 2008a, Variability of geochemical properties in a microbially-dominated coalbed gas system from the eastern margin of the Illinois basin: International Journal of Coal Geology, v. 76, p. 98-110, <http://dx.doi.org/10.1016/j.coal.2008.02.002>, date accessed, Oct. 30, 2009.

Strapoc, D., Picardal, F. W., Turich, C., Schaperdoth, I., Macalady, J. L., Lipp, J. S., Lin, Y.-S., Ertefai, T. F., Schubotz, F., Hinrichs, K.-U., Mastalerz, M., and Schimmelmann, A., 2008b, Methane-producing microbial community in a coal bed of the Illinois Basin: Applied and Environmental Microbiology, v. 74 , no. 8 , p. 2,424-2,432.

Strapoc, D., Mastalerz, M., Eble C., and Schimmelmann, A., 2007, Characterization of the origin of coalbed gases from the southwestern Illinois Basin by compound-specific carbon and hydrogen stable isotope ratios: Organic Geochemistry, v. 38, p. 267-287, <http://dx.doi.org/10.1016/j. orggeochem.2006.09.005>, date accessed, Oct. 30, 2009.

Strapoc, D., Schimmelmann, A., and Mastalerz, M., 2006, Carbon isotopic fractionation of $\mathrm{CH}_{4}$ and $\mathrm{CO}_{2}$ during canister desorption of coal: Organic Geochemistry, v. 37, no. 2, p. 152-164.

Sweigard, R., Burger, J., Zipper, C., Skousen, J., Barton, C., and Angel, P., 2007, Low compaction grading to enhance reforestation success on coal surface mines: Appalachian Regional Reforestation Initiative (ARRI) Forest Reclamation Advisory No. 3, 6 p.

Tenenbaum, D. J., 2004, Constructed wetlands-borrowing a concept from nature: Environmental Health Perspectives, v. 112, no. 1, p. A44-A48.

Thielemann, T., Cramer, B., and Schippers, A., 2004, Coalbed methane in the Ruhr Basin, Germany-a renewable energy resource?: Organic Geochemistry, v. 35 , p. 1,537-1,549.

Trading Markets, 2007, 11 IT firms establish JV to create energy-efficient data center: Strataspace Web site, $<$ http://www.strataspace.com/strataspace-news/ news-releases.asp?id=49>, date accessed, Aug. 11, 2008.

Trevi, A., 2008, The subterranean farms of Tokyo: Pruned Web site, Feb. 12, <pruned.blogspot.com/2008/02/ subterranean-farms-of-tokyo.html $>$ date accessed, Jan. 7, 2009.

Ulrich, G., and Bower, S., 2008, Active methanogenesis and acetate utilization in Power River Basin coals, United States: International Journal of Coal Geology, v. 76, no. 1-2, p. 25-33.

U.S. Army Corps of Engineers, 2004, Grouting methods and equipment: Unified Facilities Criteria (UFC) 3-220-06, 86 p.

U.S. Department of Energy (USDOE), 2006, Distributed Energy Program-Biomass Power Web site: $<$ http:// www.eere.energy.gov/de/biomass_power.html>, date accessed, Sept. 1, 2008.

U.S. Department of Energy (USDOE), 2007, Basic research needsfor electrical energy storage: Report of the Basic Energy Sciences Workshop on Electrical Energy Storage, April 2-4, $82 \mathrm{p}$.

U.S. Department of Energy (USDOE), 2008, Estimating freshwater needs to meet future thermoelectric generation requirements: National Energy Technology Laboratory, DOE/NETL-400/2008/1339, 67 p., <http:// www.netl.doe.gov/technologies/coalpower/ewr/ pubs/2008_Water_Needs_Analysis-Final_10-2-2008. pdf $>$, date accessed, Dec. 11, 2009. 
U.S. Department of Energy (USDOE), 2009, Recovery Act-Geothermal Technologies Program-ground source heat pumps: Funding Opportunity Announcement Number DE-FOA-0000116, 39 p.

U.S. Environmental Protection Agency (USEPA), 1992, The impacts of FERC Order 636 on coal mine gas project development: April 8, <http://www.epa.gov/ cmop/docs/pol004.pdf $>$, date accessed, Nov. 1, 2009.

U.S. Environmental Protection Agency (USEPA) , 2008a, Identifying opportunities for methane recovery at U.S. coal mines-profiles of selected gassy underground coal mines 2002-2006: EPA 430-I-04-003.

U.S. Environmental Protection Agency (USEPA), 2008b, U.S. government accomplishments in support of the methane to markets partnership, Nov., <http:// www.epa.gov/methanetomarkets/accompreport. htm>, date accessed, March 31, 2009.

U.S. National Response Team, 1995, Temporary storage devices-towable: National Response TeamRegional Response Team Factsheet, <http:// www.nrt.org/production/NRT/NRTWeb.nsf/ AllAttachmentsByTitle/A-59Towable/\$File/towable. pdf?OpenElement $>$, date accessed, July 31, 2011.

van der Linden, S., 2006, Bulk energy storage potential in the USA, current developments and future prospects: Energy, v. 31, no. 15, p. 3,446-3,457.

Varnell, C. J., Brahana, J. V., and Steele, K., 2004, The influence of coal quality variation on utilization of water from abandoned coal mines as a municipal water source: Mine Water and Environment, v. 23, p. 204-208.

Varnell, C. J., Thawaba, S., and Van Brahana, J., 2009, Constructed wetlands for the pre-treatment of drinking water obtained from coal mines: The Open Environmental Engineering Journal, v. 2, p. 1-8.

Veil, J. A., and Puder, M. G., 2006, Update on use of mine pool water for power generation: Argonne National Laboratory Environmental Science Division for U.S. Department of Energy, National Energy Technology Laboratory, W-31-109-Eng-38, ANL/EVS/R-06/6, $26 \mathrm{p}$.

Veil, J. A., Kupar, J. M., and Puder, M. G., 2003a, Use of mine pool water for power plant cooling: U.S. Department of Energy National Energy Technology Laboratory, W-31-109-Eng-38, $52 \mathrm{p}$.

Veil, J. A., Kupar, J. M., Puder, M. G., and Feeley, T. J. III, 2003b, Beneficial use of mine pool water for power generation: Ground Water Protection Council Annual Forum, Sept. 13-17, Niagara Falls, N.Y. [available at National Energy Technology Laboratory, <http://www.netl.doe.gov/technologies/ coalpower/ewr/pubs/gwpc-mine\%20pool-anl.pdf>, date accessed, Dec. 10, 2009].
Vidali, M., 2001, Bioremediation-an overview: Pure Applied Chemistry, v. 73, no. 7, p. 1,163-1,172.

Viebahn, P., Nitsch, J., Fischedick, M., Esken, A., Schuwer, D., Supersberger, N., Zuberbuhler, U., and Edenhofer, O., 2007, Comparison of carbon capture and storage with renewable energy technologies regarding structural, economic, and ecological aspects in Germany: International Journal of Greenhouse Gas Control, v. 1, no. 1, p. 121-133.

Visions, 2009, Wabash Valley Visions and Voices-a digital memory project: <http://visions.indstate.edu>, date accessed, Nov. 13, 2008.

Vogel, W. G., 1981, A guide for revegetating coal minesoils in the eastern United States: United States Department of Agriculture Forest Service, Northeastern Forest Experiment Station General Technical Report NE-68, 23 p.

Vogt, M., 2003, Methane gas bursts from ground: Terre Haute [Ind.] Tribune Star, Sept. 5.

Vories, K. C., and Throgmorton, D., eds., 1999, Proceedings of Enhancement of Reforestation at Surface Coal Mines-technical interactive forum, March 2324, Fort Mitchell, Ky., 274 p.

Waffel, M., 2008, Buildings crack up as Black Forest town subsides: Spiegel Online, March 19, <https://www. spiegel.de/international/zeitgeist/0,1518,541296,00. html $>$, date accessed, Nov. 11, 2009.

Warith, M., Li, X., and Jin, H., 2005, Bioreactor landfillsstate-of-the-art review: Emirates Journal for Engineering Research, v. 10, no. 1, p. 1-14.

Warner, James, 2004, Practical handbook of groutingsoil, rock, and structures: John Wiley and Sons, $729 \mathrm{p}$.

Waste Management of Indiana, 2012, Bioreactor technologies: Waste Management Web site, <http://www. $\mathrm{wm} . c 0 m /$ sustainability/bioreactor-landfills/bioreactor-technologies.jsp >, date accessed, Nov. 11, 2011.

Watzlaf, G. R., and Ackman, T. E., 2006, Underground mine water for heating and cooling using geothermal heat pump systems: Mine Water and the Environment, v. 25, p. 1-14.

Watzlaf, G. R., and Ackman, T. E., 2007, Flooded underground coal mines-a significant source of inexpensive geothermal energy: Reclamation Matters, issue 1, p. 4-7.

Weber, L. A., 2012, Indiana's Coal Mine Information System, in Comer, J. B., Effects of abandoned mine land reclamation on ground and surface water qualityresearch and case histories from Indiana: Indiana Geological Survey Special Report 72, p. 19-30.

Wheaton, J., and Donato, T., 2004, Coalbed-methane basics-Powder River Basin, Montana: Montana Bureau of Mines and Geology Information Pamphlet 5, 20 p. 
Whitfield, J. W., 1981, Underground space resources in Missouri: Rolla, Missouri Department of Natural Resources Division of Geology and Land Survey Report of Investigations No. 65, 65 p.

Williams, M., 2009, Batteries get a boost in Rice lab: Rice University Web site, Feb. 5, <http:// www.media.rice.edu/media/NewsBot.asp? MODE=VIEW\&ID=12084>, date accessed, Dec. 12, 2009.

Winters, J., 2005, Deep seam farming: Mechnical Engineering, "Power and Energy," June, <www. memagazine.org/supparch/pejune05/deepseam/ deepseam.html $>$, date accessed, Oct. 5, 2007.

Wolkersdorfer, C., 2004, Mine water literature in ISI's science citation index expanded: Mine Water and the Environment, v. 23, p. 96-99.

Wolkersdorfer, C., and Bowell, R., 2005, Contemporary reviews of mine water studies in Europe: Mine water and the environment, v. 24, supplementary material, p. 1-76.

World Heritage Site Office, 2008, Mine and yoursan activity guide to the Cornish Mining World Heritage Site: Cornwall, England, Cornwall County Council, $64 \mathrm{p}$. 


\title{
Direct Revegetation and the Sustainability of Reclaimed Mine Lands: The Story of the Friar Tuck Site, Indiana
}

Denver Harper, Greg A. Olyphant, and Tracy D. Branam

Indiana Geological Survey

\begin{abstract}
Mines at the Friar Tuck Site near Dugger, Indiana, used both surface and underground methods to extract coal from four different beds at depths down to $150 \mathrm{ft}$ (46 m). A coalpreparation plant produced deposits of fine- and coarsegrained refuse ("tailings" and "gob," respectively). Before reclamation, the refuse areas, having an extent of approximately 230 acres (93 hectares), generated acid mine drainage and were largely barren of vegetation. Samples of surface water and groundwater had $\mathrm{pH}$ as low as 1.4 and concentrations of acidity, sulfate, and iron that ranged up to 170,000 $\mathrm{mg} / \mathrm{L}, 76,200 \mathrm{mg} / \mathrm{L}$, and 24,600 mg/L, respectively. Samples of water from abandoned underground mines had moderate $\mathrm{pH}$ (5.1-7.7), concentrations of acidity, sulfate, and iron that were less than $6,160 \mathrm{mg} / \mathrm{L}, 8,270 \mathrm{mg} / \mathrm{L}$, and 1,500 mg/L respectively, and some alkalinity (up to $790 \mathrm{mg} / \mathrm{L}$ ).
\end{abstract}

Reclamation by the Indiana Department of Natural Resources, Division of Reclamation commenced in 1989, and by 1992 much of the site had been reclaimed. A final reclamation phase was conducted between 2003 and 2005. Reclamation reestablished vegetation, reduced erosion, recreated wildlife habitat, and improved surface drainage. Several large refuse deposits were reclaimed by direct revegetation, while others were repaired by more conventional engineering methods that involved backfilling, terracing, capping with soil, and constructing artificial drainageways.

Between 1987 and 1992, more than 1,200 samples of water were collected from lakes, streams, the unsaturated zone, and monitoring wells. Also, storm runoff, sediment yield, chemistry of soil water and storm runoff, and morphologic evolution of gullies were intensively monitored within several small instrumented watersheds. In 2008, 15 additional water samples were collected to evaluate the long-term effectiveness of reclamation.

By the early 1990s, eroded sediment delivered to a nearby creek (formerly $2.1 \mathrm{lb} / \mathrm{ft}^{2}$ per year [10.4 $\mathrm{kg} / \mathrm{m}^{2}$ per year]) had been greatly reduced by reclamation. The yield of coarsegrained sediment was eliminated, and that of fine-grained sediment was reduced to as little as $0.06 \mathrm{lb} / \mathrm{ft}^{2}\left(0.3 \mathrm{~kg} / \mathrm{m}^{2}\right)$. The erosion and transport of as much as 4,400 tons $\left(4 \times 10^{6} \mathrm{~kg}\right)$ of sediment per year had been prevented.

Note: Spreadsheets containing the water-quality data on which this paper is based are located on the CD-ROM in the back of this book. 
In 2008, vegetation was thriving across more than 99 percent of the Friar Tuck Site. However, barren patches remained, which, though small and scattered, had the potential to enlarge and trigger the disintegration of artificial drainage networks. In contrast, those areas that were reclaimed by direct revegetation had developed a mature network of natural drainage in geomorphic equilibrium, so that even where vegetation might fail, aggressively eroding new gullies should not appear and some of the benefits of reclamation will be preserved.

The beneficial effects of reclamation on surface water quality continue to the present. However, some problems exist that threaten long-term sustainability. After reclamation in the early 1990s, about 440 tons $\left(4 \times 10^{5} \mathrm{~kg}\right)$ of acidity were still discharging annually as baseflow seeps from gob deposits. Additionally, about 2,200 tons $\left(2 \times 10^{6} \mathrm{~kg}\right)$ of acidity were being discharged annually from underground mines. These baseflow seeps and springs continue to discharge acid mine drainage, and a very large volume of contaminated water resides in the underground mines (approximately $1.3 \mathrm{x}$ $10^{9}$ gallons $\left.\left[5 \times 10^{9} \mathrm{~L}\right]\right)$ and the refuse deposits $\left(6.9 \times 10^{8}\right.$ gallons $\left.\left[2.6 \times 10^{9} \mathrm{~L}\right]\right)$.

At the Friar Tuck Site and elsewhere, greater consideration should be given to integrating groundwater in abandoned underground mines into reclamation designs. Such water has undeveloped potential as a beneficial dilutant of more concentrated baseflow seeps from gob deposits. By strategically emplacing artesian wells, it may be possible to create mixtures of water that are more chemically favorable for introduction into streams or inflows into passive treatment systems.

\section{INTRODUCTION}

Acid mine drainage (AMD) and the impacts of accelerated erosion represent significant challenges to persons involved with the reclamation of abandoned mine land (AML) sites, many of which are hydrologically complex. Methods of reclamation that have been widely used for the past 30 years have proven to be effective at stabilizing deposits of pyritic coal-preparation refuse and reducing AMD runoff. But large volumes of acidic groundwater are commonly stored within thick refuse deposits, giving rise to acidic baseflow seeps. Even greater volumes may be stored within the flooded workings of abandoned underground mines, which may produce artesian outflows of AMD onto the surface.

Since 1977, techniques for the reclamation of AML sites have experienced much refinement. From the beginning, the dominant approach has been based on engineering methods and involves grading pyritic refuse deposits, capping them with soil using large earth-moving equipment, and installing an artificial drainage system of terraces and rocklined drains. Vegetation is then established in the soil cap and much precipitation is either evapotranspired or captured and removed by the drainage system. When successful, such methods are effective at curtailing erosion because they produce stable slopes. However, with respect to sustainability, the artificial drainage system and the vegetative cover must be maintained in perpetuity. Owing to the unnatural morphology of the reclaimed landform, failure of the drainage system at even one point can result in erosion of the entire soil cap and reexposure of the pyritic refuse. Such failure, which can progress very rapidly, can be easily initiated by human activities such as unauthorized travel by off-road vehicles or by natural events such as unusually heavy rainfall and runoff where vegetative cover is thin or absent. 
An alternative and fundamentally different approach is referred to as "direct revegetation." This approach, developed by biologists and soil scientists, involves the establishment and maintenance of alkaline conditions in the weathered surficial layers of refuse deposits. Agricultural limestone is applied at very high rates (as much as 200 tons per acre [448 metric tons per hectare [ha]) using farming equipment and is incorporated directly into the uppermost 6 inches $(15.2 \mathrm{~cm})$ of the exposed pyritic refuse. Soil-building processes are then assisted by applying fertilizers and mulch. The method is appropriate only for older deposits that are deeply weathered, and grading of the deposit must be avoided to minimize the exposure of deeper unoxidized pyritic materials. Preexisting landforms are preserved wherever possible. Erosion-control structures, if absolutely necessary, are constructed by hand or light machinery wherever possible. Gullies and scattered barren patches on areas inaccessible to farm equipment must be tolerated or treated by hand. Because direct revegetation preserves preexisting landforms that may already be in geomorphic equilibrium with prevailing climatic conditions, there is less concern with perpetually maintaining the surface drainage system.

On refuse deposits reclaimed by grading and capping, some precipitation may still infiltrate the soil cap and underlying pyritic refuse and then reemerge at the base of the deposit as acidic seeps or springs. And on deposits reclaimed by direct revegetation, the incorporation of limestone by disking may actually increase the infiltration capacity of the surface layer, thereby augmenting groundwater recharge. Consequently, with either approach, acidic seeps and springs may persist, requiring additional treatment either by active chemical treatment or by passive systems such as wetlands, anoxic limestone drains (ALDs), or sulfate-reducing bioreactors. Although passive systems require relatively little maintenance, periodic removal of precipitates and replacement of substrates is still required (typically at intervals of 10 to 15 years) into the indefinite future. In periods of deep economic uncertainty and declining support for public services, the long-term sustainability of such efforts is uncertain.

The purpose of this paper is to provide a retrospective overview of reclamation methods used at the Friar Tuck Site (FTS). One of the most complexly disturbed areas in Indiana, the FTS has undergone several phases of reclamation involving a range of methods, including several variations on standard engineering methods and direct revegetation. Much data about the site were acquired over a period of decades, and the current state of environmental conditions is described herein. We make suggestions regarding hydrologic pathways and subsurface ground-water storages and how they may be more effectively integrated into future reclamation designs.

\section{CONDITIONS BEFORE RECLAMATION}

\section{Site history}

The FTS is located northeast of Dugger, Indiana, and occupies about 1.5 square miles $\left(3.9 \mathrm{~km}^{2}\right)$ in section 36, T. 8 N., R. 8 W., and the western part of section 31, T. 8 N., R. 7 W. (fig. 1). The reclamation area is bounded on the north by Mud Creek and on the west by a tributary of Mud Creek and it straddles the boundary between Greene and Sullivan Counties.

Coal was mined on or near the FTS from 1914 to 1993. Mining by both surface and underground methods was conducted in four different coal beds (Survant, Springfield, Hymera, and Danville Coal Members of the Carbondale Group, Desmoinesian Series) at depths down to $150 \mathrm{ft}(45.7 \mathrm{~m})$ (fig. 1). Between 1914 and 1993, shallow underground mining (less than $150 \mathrm{ft}$ [45.7 m] deep) was conducted in the Survant, Springfield, and Hymera Coal Members. Between 1921 and 1965, extensive arealtype surface mining was conducted in the Springfield, Hymera, and Danville coals. The surface mining, which was conducted prior to passage of the Surface Mining Control and Reclamation Act of 1977, created steeply ridged deposits of displaced overburden referred to as "spoil" (fig. 2). These deposits are not particularly enriched in pyrite and most were successfully reforested by coal companies, so that by the late 1980s they were covered by large stands of deciduous, coniferous, and mixed forests.

A power plant and a coal-preparation plant also operated on the site between about 1921 and 1965, producing deposits of ash and coal-preparation refuse. Fine-grained refuse (referred to as "tailings") was pumped as slurry from the preparation plant through pipes and deposited in a series of impoundments that were constructed along flat-lying floodplains of Mud Creek (North Tailings Deposit, fig. 2) and the tributary of Mud Creek (Main Tailings Deposit). The impoundments were separated 


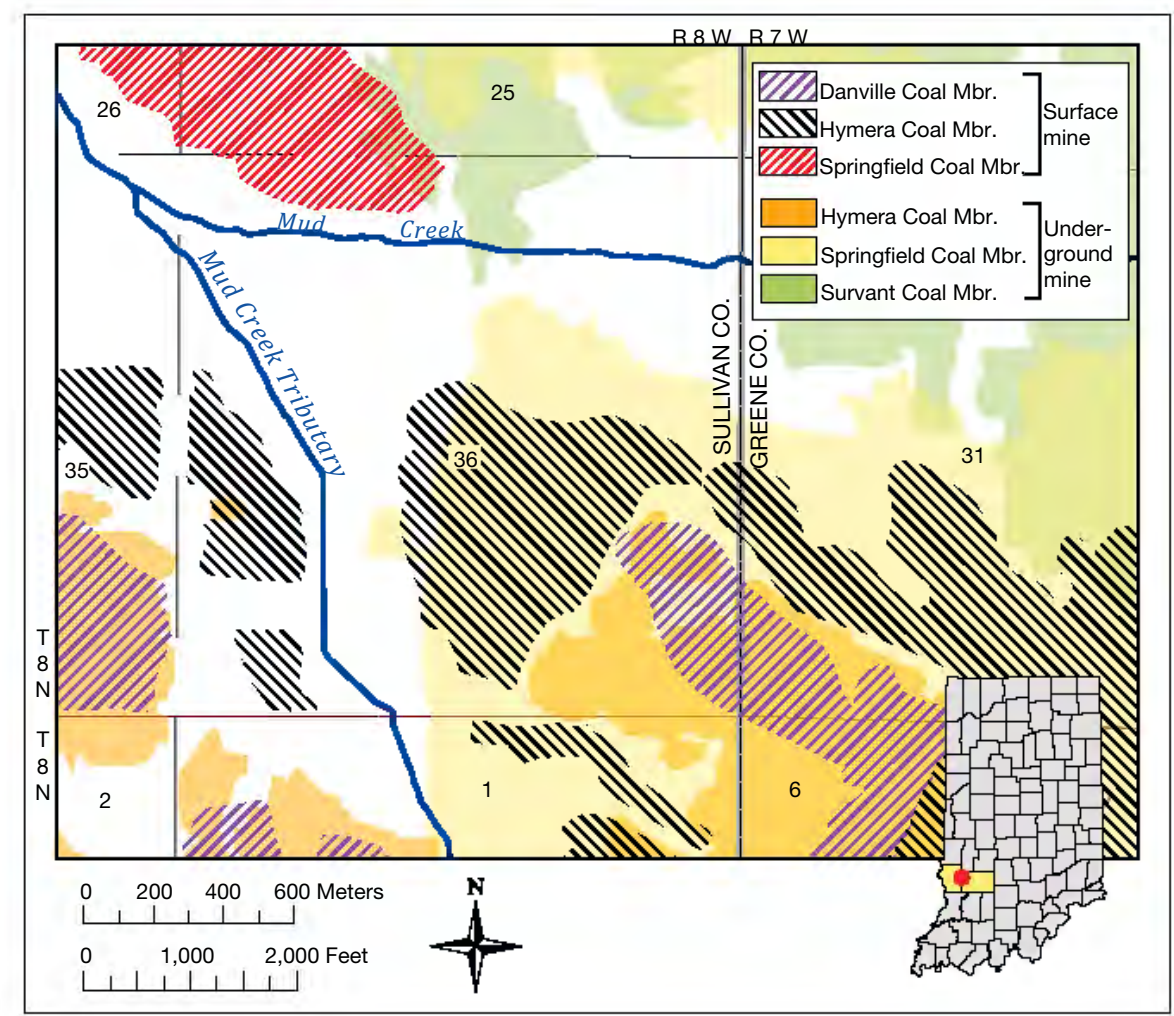

Figure 1. Map showing mined areas within the Friar Tuck Site. Data are derived from the Coal Mine Information System, a Web site hosted by the Indiana Geological Survey (see Weber, 2012 [this volume]).

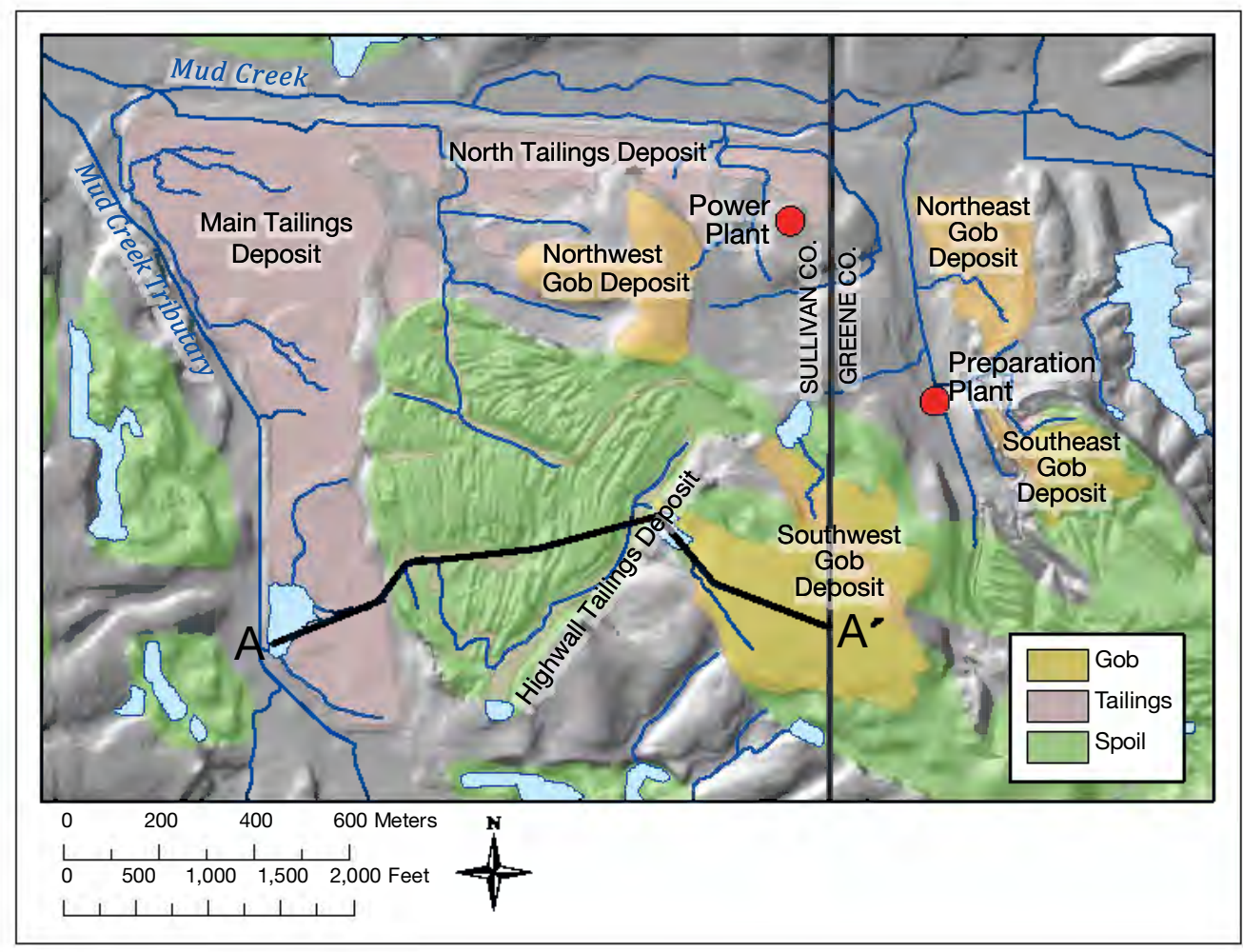

Figure 2. Map showing deposits of surface-mine spoil and coal-preparation-plant refuse ("gob" and "tailings") and their relationship to surface drainage. Cross section A-A' is shown in Figure 5. 
from the streams by low berms. Tailings were also deposited in a final-cut pit in a surface mine of the Hymera Coal (Highwall Tailings Deposit). Prior to commencement of reclamation in 1989, these areas, which had a total extent of approximately 140 acres (56.6 ha), were largely barren of vegetation.

The preparation plant also produced extensive deposits of coarse-grained refuse (referred to as "gob"), which have a total extent of approximately 90 acres (36.4 ha). Also, smaller gob deposits were scattered across the site, and gob was used extensively as roadbed material.

Large mounded deposits of gob form some of the highest topographic features in the area. Some of the gob piles were deposited on original ground (Northwest Gob Deposit and Northeast Gob Deposit, fig. 2), consisting of glacial loess and till, whereas others were deposited on spoil deposits (Southwest Gob Deposit and Southeast Gob Deposit). In the early to middle 1970 s as part of a failed attempt at reclamation, a coal company graded parts of the Northwest and Southwest Gob Deposits and covered portions of the Northwest, Southwest, and Northeast Gob Deposits with a thin veneer of soil. But vegetation was never successfully established, and by the late 1970s the soil caps were barren and undergoing severe erosion.

A power plant also operated at FTS. Ash from the power plant was disposed of on site, but the ash may have been mixed with gob, and no distinct deposits of ash were ever mapped.
Historical aerial photographs (Table 1) make it possible to observe and map many of the geomorphic, biological, and hydrologic changes that occurred over a period of almost 60 years.

\section{Chemistry of gob and tailings}

In 1988, as part of reclamation feasibility investigations, samples of tailings and gob were collected by personnel from the Indiana Geological Survey (IGS) and analyzed by A \& L Agricultural Laboratories, Inc. Most of the samples were obtained from the uppermost 6 inches $(15.2 \mathrm{~cm}$ ) (referred to as "shallow" refuse samples); others were obtained from depths of 30 to 36 inches $(76.2-91.4 \mathrm{~cm})$ below the surface ("deep" samples) (fig. 3).

In the decades before 1988, weathering of pyrite in the unsaturated zones of gob and tailings deposits had created chronically acidic conditions in the uppermost portions of those deposits. However, where long-term weathering had occurred without any disturbance, pyritic sulfur and potential acidity had been greatly reduced in both shallow and deep samples. By contrast, where deposits had been disturbed by the earlier, unsuccessful attempt at reclamation, values of pyritic sulfur and potential acidity were characteristic of preoxidation levels of pyrite.

A comparison of the chemical differences between refuse samples collected in 1988 from the Northwest and Southeast Gob Deposits demonstrates

Table 1. Aerial photographs showing the Friar Tuck Site

\begin{tabular}{|c|c|c|c|c|}
\hline Year & $\begin{array}{l}\text { Scale or } \\
\text { resolution }\end{array}$ & Source & File name & File size \\
\hline 2007 & $2 \mathrm{~m}$ & $\begin{array}{l}\text { National Agricultural Imagery Program } \\
\text { U.S. Department of Agriculture }\end{array}$ & Friar_Tuck_2007.pdf & $8 \mathrm{Mb}$ \\
\hline 2005 & $1 \mathrm{ft}$ & IndianaMap Orthophotography Project & Friar_Tuck_2005.pdf & $23 \mathrm{Mb}$ \\
\hline 2003 & \multirow{2}{*}{$1 \mathrm{~m}$} & $\begin{array}{l}\text { National Agricultural Imagery Program } \\
\text { U.S. Department of Agriculture }\end{array}$ & Friar_Tuck_2003.pdf & $16 \mathrm{Mb}$ \\
\hline 1998 & & $\begin{array}{l}\text { Digital Orthophoto Quarter Quads } \\
\text { U.S. Geological Survey }\end{array}$ & Friar_Tuck_1998.pdf & $6 \mathrm{Mb}$ \\
\hline 1989 & $1: 9,600$ & \multirow{3}{*}{$\begin{array}{l}\text { Indiana Department of Natural } \\
\text { Resources Division of Reclamation }\end{array}$} & Friar_Tuck_1989.pdf & $4 \mathrm{Mb}$ \\
\hline 1984 - west & \multirow{2}{*}{$1: 9,700$} & & Friar_Tuck_1984_west.pdf & $9 \mathrm{Mb}$ \\
\hline 1984 - east & & & Friar_Tuck_1984_east.pdf & $10 \mathrm{Mb}$ \\
\hline 1974 & $1: 42,000$ & \multirow{3}{*}{$\begin{array}{l}\text { Historical Aerial Photo Archive } \\
\text { Indiana Geological Survey }\end{array}$} & Friar_Tuck_1974.pdf & $4 \mathrm{Mb}$ \\
\hline 1954 & $1: 21,000$ & & Friar_Tuck_1954.pdf & $5 \mathrm{Mb}$ \\
\hline 1949 & & & Friar_Tuck_1949.pdf & $4 \mathrm{Mb}$ \\
\hline
\end{tabular}




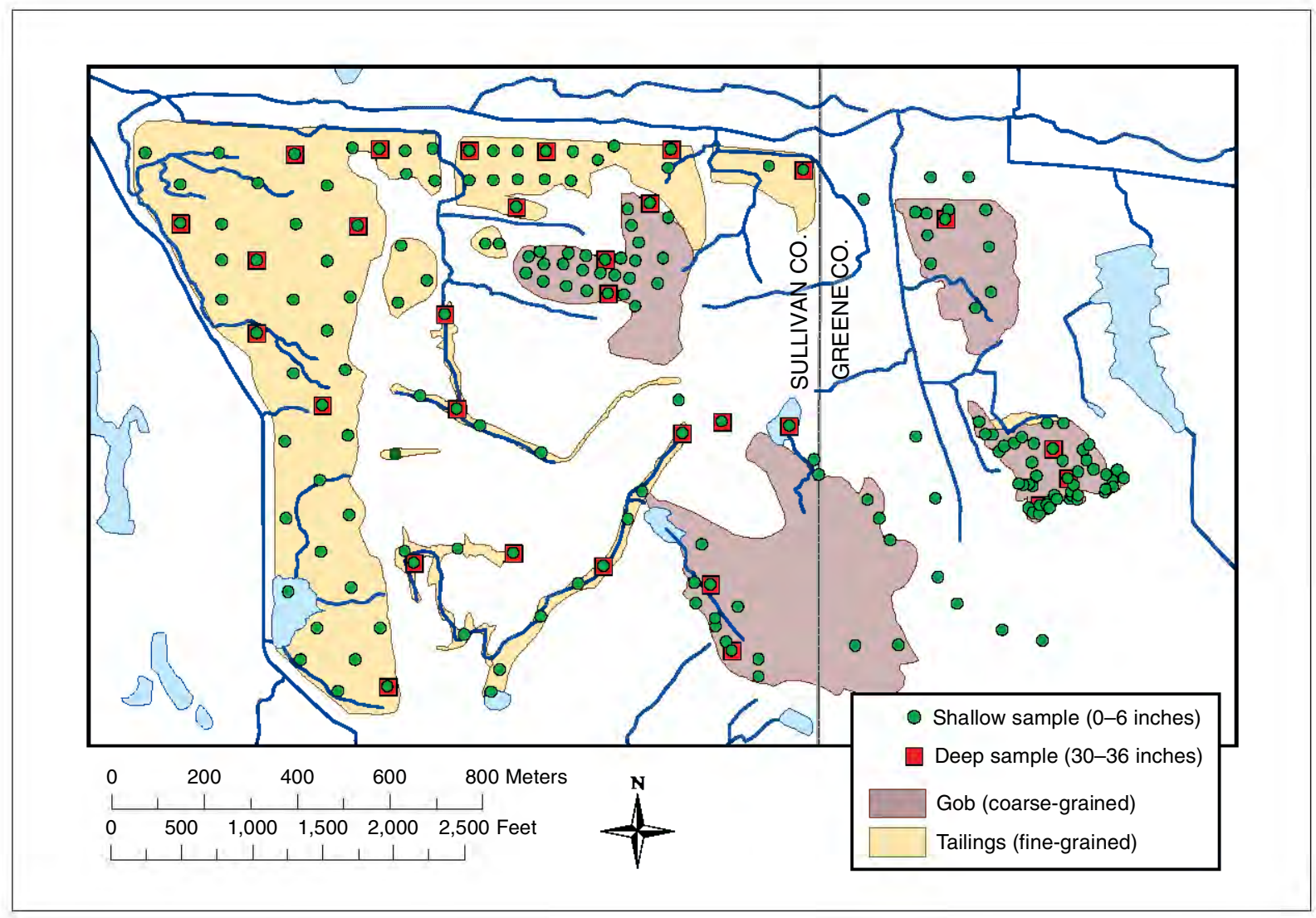

Figure 3. Map showing locations of samples of gob and tailings. Shallow samples were collected from depths of 0 to 6 inches $(0-15.2 \mathrm{~cm})$; deep samples from depths of 30 to 36 inches $(76.2-91.4 \mathrm{~cm})$. Data are from Harper and others $(1988,1989)$.

the effects of weathering and grading. The Southeast Gob Deposit had been undisturbed since its creation in the 1940s and 1950s, so that its surface layer was deeply weathered. In soil samples from this deposit, pyritic sulfur was generally less than 0.2 percent, and did not exceed 1 percent anywhere (fig. 4). In contrast, the Northwest Gob Deposit had been graded in the early 1970s during a coal company's unsuccessful attempt at reclamation. This grading had removed the weathered surficial layer and brought unweathered gob and fresh pyrite to the surface. Soil samples from this deposit commonly contained more than 0.5 percent pyritic sulfur and exceeded 4 percent in places. Values of soil $\mathrm{pH}$ for samples from the Northwest Gob Deposit were less than 2.0, but those for most samples from the Southeast Gob Pile exceeded 2.0 (fig. 4).

The extent of past weathering of the two gob deposits was also indicated by the relative abundances of iron and sulfate (products of the oxidation of pyrite) and calcium. In soil samples from the less weathered Northwest Gob Deposit, iron exceeded $1,000 \mathrm{ppm}$ in all samples while sulfate was usually less than 7,000 ppm (fig. 4). Conversely, in soil samples from the more weathered Southeast Gob Deposit, iron was typically less than 1,000 ppm, while sulfate exceeded 7,000 ppm in most samples. Furthermore, in the Southeast Gob Deposit, a positive correlation existed between sulfate and calcium, indicating the presence of gypsum $\left(\mathrm{CaSO}_{4} \cdot 2 \mathrm{H}_{2} \mathrm{O}\right)$, but such a correlation is less apparent for samples from the Northwest Gob Deposit (J. Nawrot, Southern Illinois University, written commun., 1989).

In general, the content of soluble salts in soil samples (as determined by standard soil-leaching tests) indicates that significant pyritic weathering is in progress (J. Nawrot, Southern Illinois University,

Figure 4 (opposite page). Maps showing analyses of soil samples collected from deposits of gob and tailings. Shallow samples were collected from depths of 0 to 6 inches $(0-15.2 \mathrm{~cm})$; deep samples were collected at depths of 30 to 36 inches (76.2-91.4 $\mathrm{cm})$. Data are from Harper and others $(1988,1989)$. 


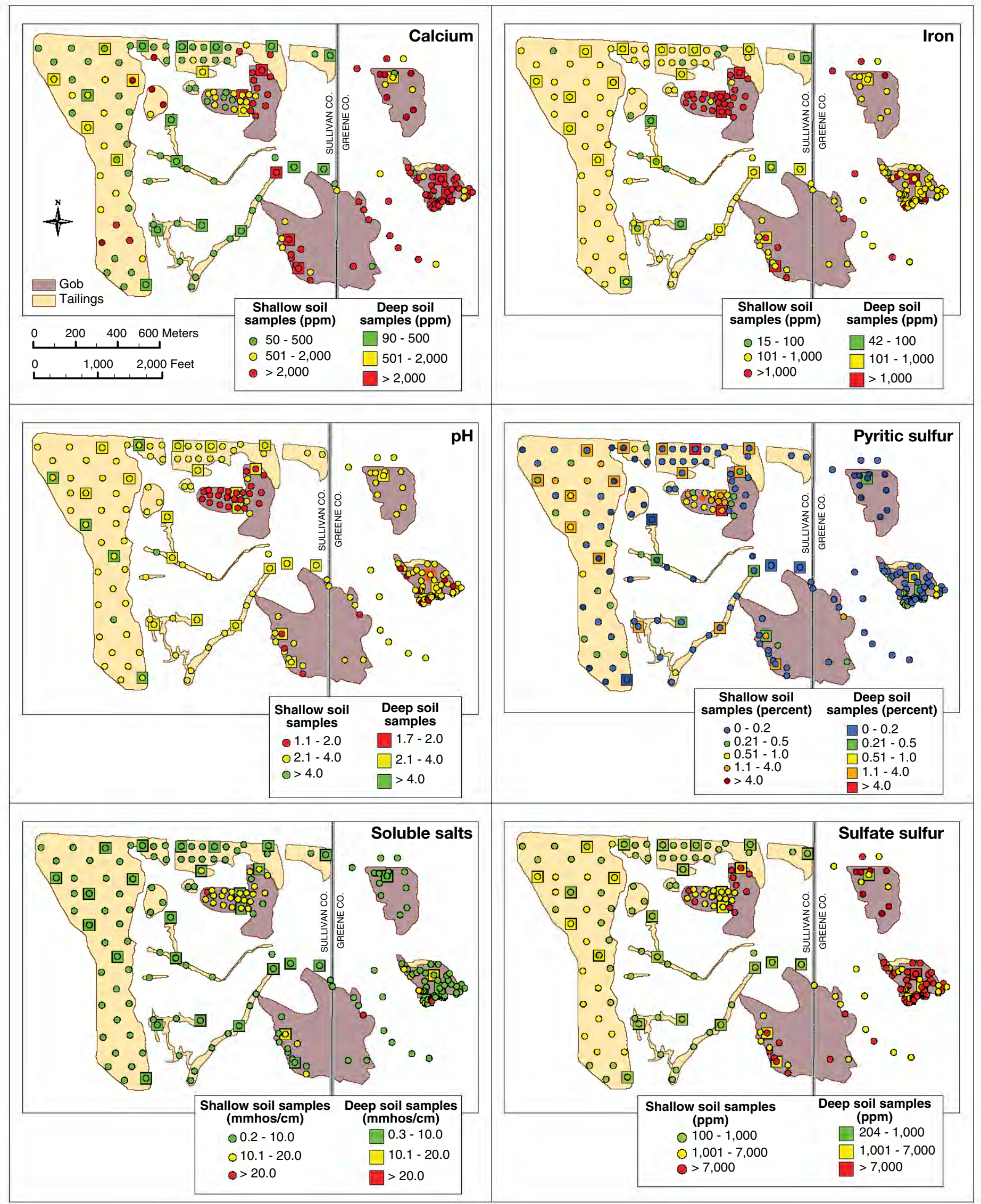


written commun., 1989). For samples from both the Northwest and Southeast Gob Deposits, this was reflected in a correlation between iron and salts, and the absence of any correlation between calcium and soluble salts (fig. 4).

Other chemical species that were more abundant in samples from the Northwest Gob Deposit than in samples from the Southeast Gob Deposit included manganese, aluminum, magnesium, zinc, copper, boron, and soluble salts. However, these differences may be attributable to differences in the original composition of the gob (related to the clay content of shales), as well as to differences in weathering. Consequently, this dissimilarity in the abundances of various trace metals of the two gob deposits could not be definitively interpreted (J. Nawrot, Southern Illinois University, written commun., 1989).

\section{Hydrogeology}

Many of the environmental problems associated with AMD from deposits of tailings and gob can be eliminated by revegetating the surface and developing soils, so precipitation that falls on the affected area is transpired by plants or shed directly into surface drainages without coming into contact with unreacted pyrite occurring at depth. However, mining and coal preparation activities at the FTS created a hydrogeologic and geochemical setting that is complex in three dimensions (fig. 5), and a strictly surficial approach to reclamation cannot address all the AMD problems in such an area.

At the FTS, the large deposits of gob are situated in some of the topographically highest portions of the site, and their unsaturated zones, where AMD is generated, are relatively thick, ranging from 11 to $40 \mathrm{ft}(3.3-12.1 \mathrm{~cm})$ (Harper and Olyphant, 1993, p. 7). Any rainwater that manages to infiltrate the gob, which contains very large amounts of pyrite, becomes acidified. This acidic water emerges as seeps near the bases of the deposits or it percolates as groundwater into adjacent and underlying materials, particularly the spoil deposits on which several gob deposits were emplaced. The groundwater may even enter abandoned underground mines through abandoned mine highwalls.

Compared with gob deposits, the deposits of tailings are generally low-lying and have much thinner unsaturated zones (ranging from 3 to $7 \mathrm{ft}$ [0.9-2.1 m]) (Harper and Olyphant, 1993, p. 7). Most tailings deposits were emplaced over preexisting natural materials, particularly alluvial deposits adjacent to streams. Some tailings deposits were emplaced in final-cut pits of surface mines, which, in turn, may be in close proximity to nearby underground mines in the same coal bed that was surface mined. In all cases, rainwater that infiltrates the tailings can still emerge as acid seeps that contaminate adjacent streams.

Much of the FTS is underlain by abandoned underground coal mines whose voids are now filled with water. At the FTS, several springs exist where water from underground mines emerges at the surface. Several of these are caused by artesian flow through poorly plugged drill holes.

\section{Chemistry of surface waters}

Samples of surface waters from the FTS were collected and analyzed as early as 1966 (Corbett and Agnew, 1968). Between 1987 and 1992, as part of reclamation feasibility investigations, more than 2,800 water samples were collected by personnel of the IGS from a variety of shallow and deep sources. These water samples were collected periodically from various seeps, springs, lakes, and perennial and ephemeral streams from across the study area (fig. 6). The samples were analyzed in the laboratories of the IGS (Branam and Harper, 1994). In 2008, IGS personnel revisited the FTS and collected water samples from many of the same sites that had been used in the earlier investigations.

Some of the most contaminated samples of lakes and streams were obtained from those that received drainage directly from gob deposits, where values of $\mathrm{pH}$ were as low as 1.7 , and where concentrations of acidity ranged up to $25,700 \mathrm{mg} / \mathrm{L}$ and alkalinity was generally absent (fig. 7). In these surface waters, concentrations of sulfate were as high as $29,800 \mathrm{mg} / \mathrm{L}$ and iron concentrations reached 6,380 mg/L (Branam and Harper, 1994).

Lakes and streams that received drainage directly from tailings deposits were somewhat less contaminated, having $\mathrm{pH}$ values as low as 2.5 , concentrations of acidity that ranged from 194 to 2,970 $\mathrm{mg} / \mathrm{L}$, and no alkalinity (fig. 7). Concentrations of sulfate sulfur were as high as $4,010 \mathrm{mg} / \mathrm{L}$ and iron was as high as $154 \mathrm{mg} / \mathrm{L}$.

Waters originating within the FTS degraded the water quality in Mud Creek and its principal tributary. Upstream of the FTS, water samples from 


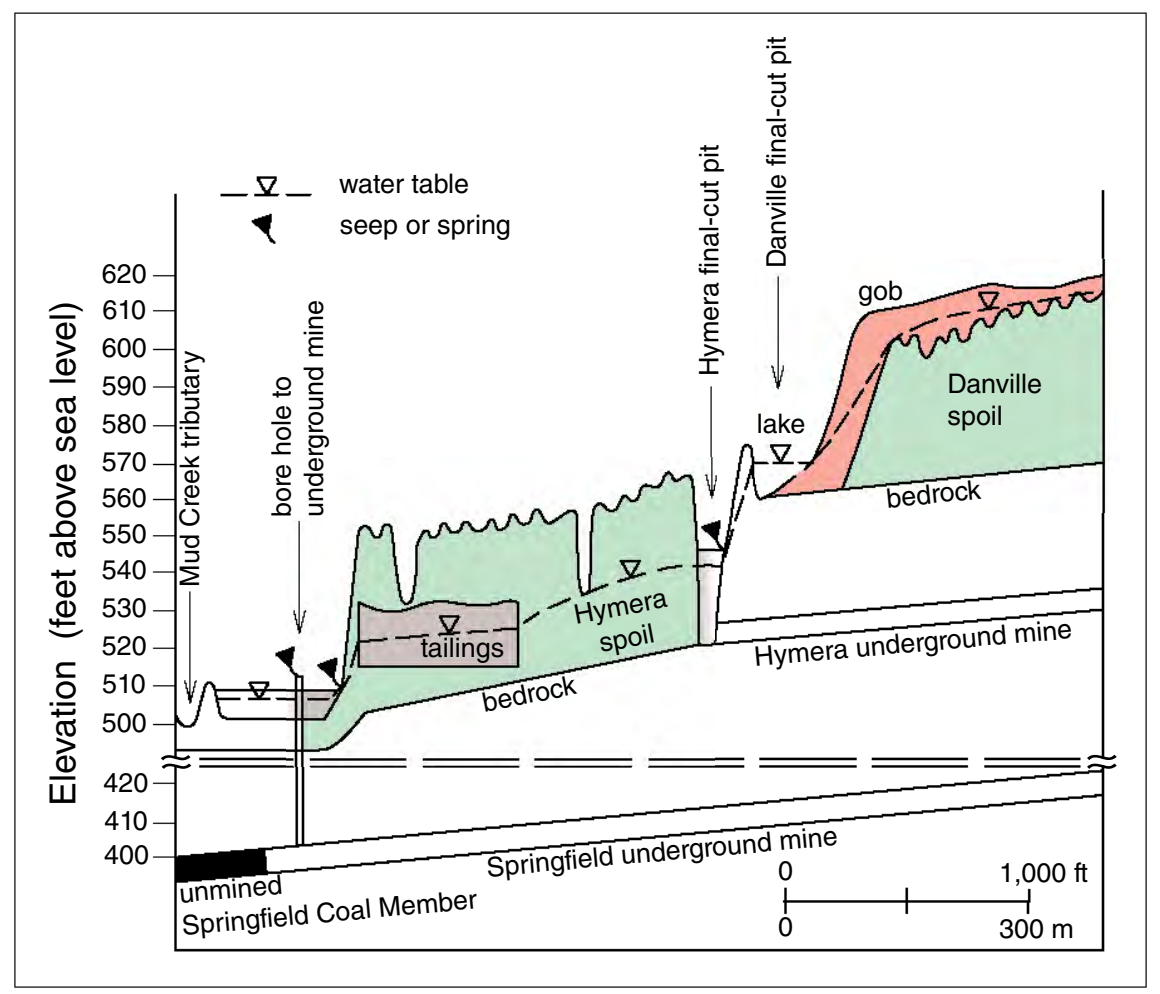

Figure 5. Cross section A-A' across the southwestern part of the Friar Tuck Site, showing contacts between gob, spoil, tailings, and bedrock for the Springfield, Hymera, and Danville Coal Members. The water table is indicated by the dashed line and triangles. See Figure 2 for location.

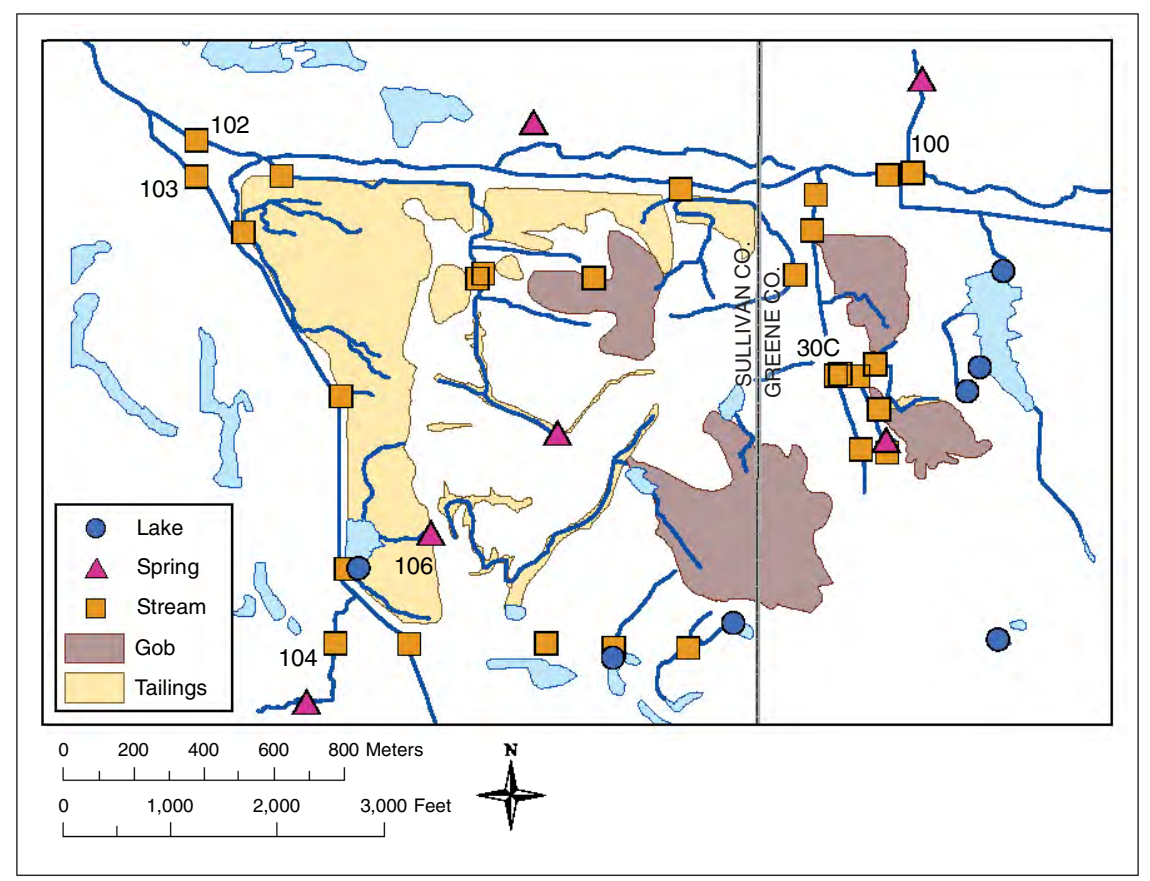

Figure 6. Map showing locations where water samples were collected from 1987 to 1992 from lakes, springs, and perennial and ephemeral streams. The sample sites are shown in relationship to major deposits of gob and tailings. Data are from Branam and Harper (1994). Selected features that are mentioned in this report are labeled with identifying designations. 


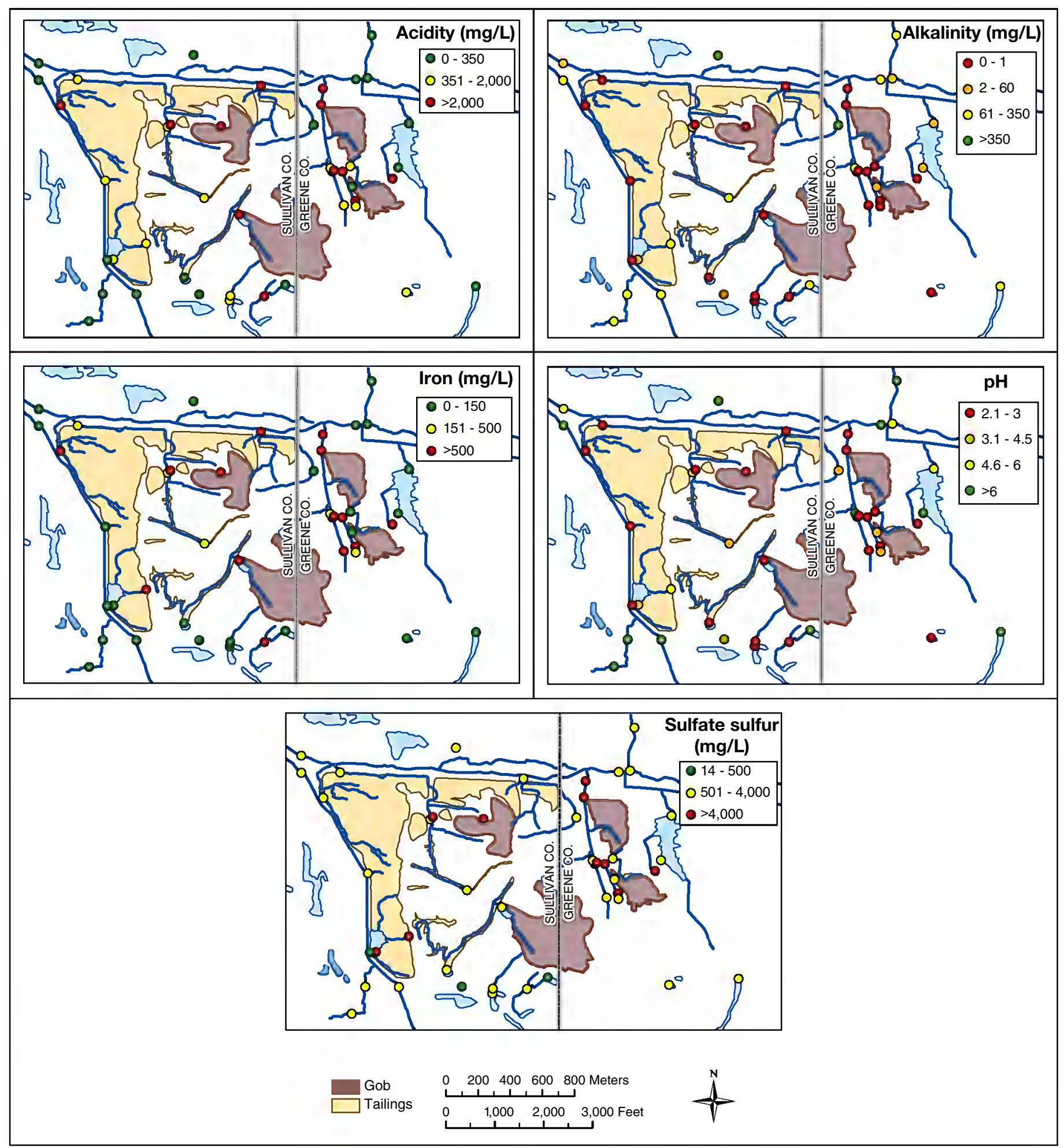

Figure 7. Maps showing average values and generalized ranges for analyses of water samples collected between 1987 and 1992 from lakes, springs, and perennial and ephemeral streams. The sample sites are shown in relationship to major deposits of gob and tailings. Data are from Branam and Harper (1994). 
Mud Creek that were collected during 1987 and 1988 had moderate $\mathrm{pH}$ values (6.2-7.2), and values of acidity (79-248 ppm) were comparable to values of alkalinity (39-217 ppm). However, comparing samples from upstream and downstream of the study area showed a trend of increasing acidity downstream, evidenced by increasing concentrations of acidity and sulfate and decreasing $\mathrm{pH}$ and concentrations of alkalinity.

Samples collected along the tributary of Mud Creek generally had moderate $\mathrm{pH}$ values (3.5-7.2) for both low- and high-flow conditions, but concentrations of alkalinity (0-160 ppm) were usually lower than concentrations of acidity (7-260 ppm), indicating that the tributary had little buffering capacity.

Between 1966 and 1988, trends in the quality of water in Mud Creek were also unfavorable. Mud Creek and its principal tributary were sampled in 1966 and 1967 (Corbett and Agnew, 1968), and several of the same sites were resampled in 1987 and 1988 (Harper and others, 1988). In both investigations, water samples that were collected downstream of the FTS indicated that the creek had moderately low $\mathrm{pH}$ values (less than 4.0), even during high-flow periods. But in samples taken during 1966 and 1967, values of alkalinity (400-3,800 ppm) exceeded values of acidity (270-2,000 ppm), while in samples taken during 1987 and 1988, values of alkalinity $(0-4 \mathrm{ppm})$ were lower than values of acidity (194-364 ppm).

\section{Chemistry of the unsaturated zone and runoff}

From 1987 to 1992, water samples were obtained from the unsaturated zones of deposits of gob, tailings, spoil, loess, and till by the use of clusters of pressure-vacuum (suction) lysimeters (fig. 8). In low-lying deposits of tailings, where water tables were usually close to the surface, most lysimeters were installed at depths of only 1.5 to $2 \mathrm{ft}(0.54-$ $0.6 \mathrm{~m}$ ). In the more elevated deposits of spoil and gob, some lysimeters were installed at depths of as much as $20 \mathrm{ft}(6 \mathrm{~m})$, whereas adjacent lysimeters within the cluster were installed at shallower depths. Differences in the chemical compositions of soil samples from the weathered zones of gob and tailings were reflected by differences in the chemistry of water samples from their unsaturated zones that were collected from 1987 to 1992. In the deeply weathered Southeast Gob Deposit, water samples were characterized by low $\mathrm{pH}$ (1.3-3.2), low alkalinity, and low to moderate acidity $(1,400-$ $23,000 \mathrm{mg} / \mathrm{L}$ ) that generally increased with depth. In contrast, water samples from the unsaturated zone of the Northwest Gob Deposit-disturbed by grading in the 1970s-were characterized by very low $\mathrm{pH}$ (0.7-4.2), low alkalinity, and high acidity $(9,000-160,000 \mathrm{mg} / \mathrm{L})$ that generally decreased with depth (Harper and Olyphant, 1993, p. 13).

Because of their low infiltration capacities, steep slopes, and high contents of pyrite, all the gob deposits were shedding large volumes of highly acidified storm runoff prior to reclamation. Nevertheless, runoff from the Northwest Gob Deposit was much more acidic than that from the Southeast Gob Deposit, and it was estimated that the total load of acidity in surface runoff from the former (110 tons [1 x $\left.10^{5} \mathrm{~kg}\right]$ ) was two orders of magnitude greater than the load from the latter (4.4 tons [ $4 \mathrm{x}$ $\left.10^{3} \mathrm{~kg}\right]$ ). On the other hand, the total acidic load of subsurface drainage (baseflow and seepage) from the Southeast Gob Deposit (176 tons [1.6 x 10 $\mathrm{kg}]$ ) exceeded that from the Northwest Gob Deposit (58 tons $\left[5.3 \times 10^{4} \mathrm{~kg}\right]$ ), so that total annual outflow of acidity from the two deposits were comparable (176 tons $\left[\sim 1.6 \times 10^{5} \mathrm{~kg}\right]$ ) (Harper and Olyphant, 1993, p. 13).

In contrast, samples of water from the unsaturated zone of the Main Tailings Deposit, although severely contaminated, were characterized by more moderate $\mathrm{pH}$ values (1.6-6.7) and lower acidity (0-58,000 mg/L) (Harper and Olyphant, 1993, p. 9).

\section{Chemistry of groundwater}

From 1987 to 1992, water samples were obtained from monitoring wells whose screens were installed in deposits of gob, tailings, and spoil, and in adjacent natural deposits of loess, till, and alluvium (fig. 9).

The most contaminated groundwater was associated with monitoring wells installed within or below gob deposits, where $\mathrm{pH}$ values were as low as 1.7, acidity was as much as $170,000 \mathrm{mg} / \mathrm{L}$, alkalinity was generally absent, and values of sulfate sulfur and iron reached concentrations of as much as 76,200 


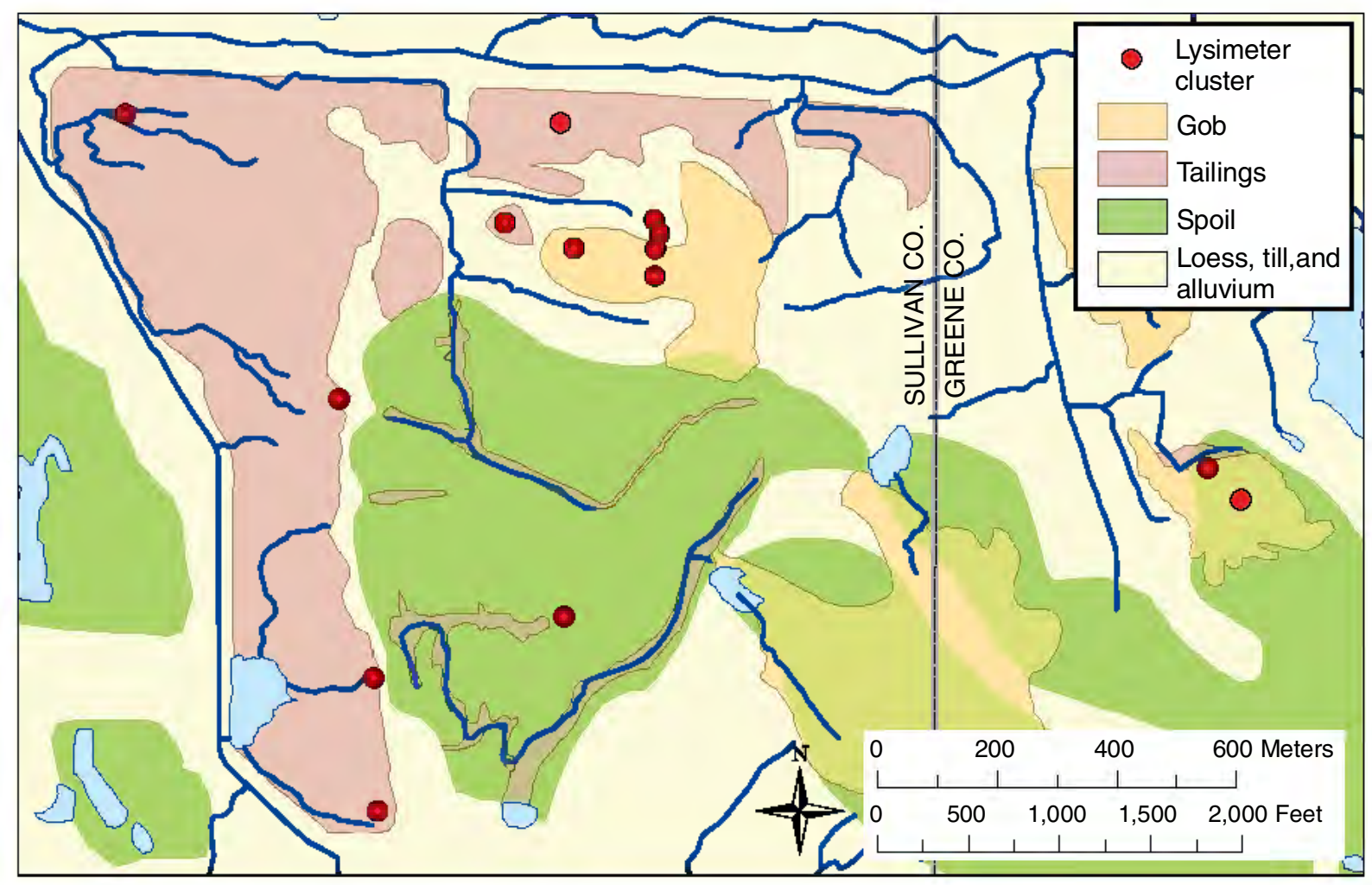

Figure 8. Map showing locations of clusters of pressure-vacuum (suction) lysimeters from which water samples were collected from 1987 to 1992. Lysimeters were installed in deposits of gob, tailings, spoil, loess, and till. Data are derived from Branam and Harper (1994).

and 24,600 mg/L, respectively (fig. 10). Groundwater associated with tailings had significantly better quality, relatively speaking, with maximum values of acidity of 9,540 mg/L and maximum values of sulfate and iron of 11,800 and $2,670 \mathrm{mg} / \mathrm{L}$, respectively (Branam and Harper, 1994).

Manganese, aluminum, magnesium, and zinc were more abundant in gob samples from the Northwest Gob Deposit than in gob samples from the Southeast Gob Deposit. With respect to samples of groundwater, however, concentrations of those elements were greater in water collected from monitoring wells installed in the Southeast Gob Deposit, with its thicker weathering profile, than in water collected from wells installed in the Northwest Gob Deposit. As with the soil samples, however, it is not possible to determine whether these differences are attributable to differences in the original composition of the gob or to differences in weathering.

Except where spoil deposits are overlain by gob or are immediately adjacent to gob, groundwater from spoil had values of acidity that were less than
$1,820 \mathrm{mg} / \mathrm{L}$ and a maximum value for sulfate that was $5,370 \mathrm{mg} / \mathrm{L}$. Similarly, except where they were receiving drainage directly from overlying or adjacent gob or tailings, groundwater from deposits of loess, till, and alluvium had values of acidity that were less than $1,690 \mathrm{mg} / \mathrm{L}$ and maximum values for sulfate and iron that were 5,220 and $340 \mathrm{mg} / \mathrm{L}$, respectively (Branam and Harper, 1994). An electromagnetic geophysical investigation indicated that, although water within the Northwest Gob Deposit was highly contaminated, a widespread contaminant plume had not developed in surrounding, undisturbed glacial till (Brooks and others, 1991).

\section{Chemistry of underground mine waters}

In 1987, as part of reclamation feasibility investigations, several monitoring wells were installed within the water-filled workings of abandoned underground mines (fig. 11). Measurements of the elevations of water levels in the monitoring wells indicated: 1) water levels associated with mines within the same coal bed are at the same elevation and are stable, exhibiting little seasonal variation, 


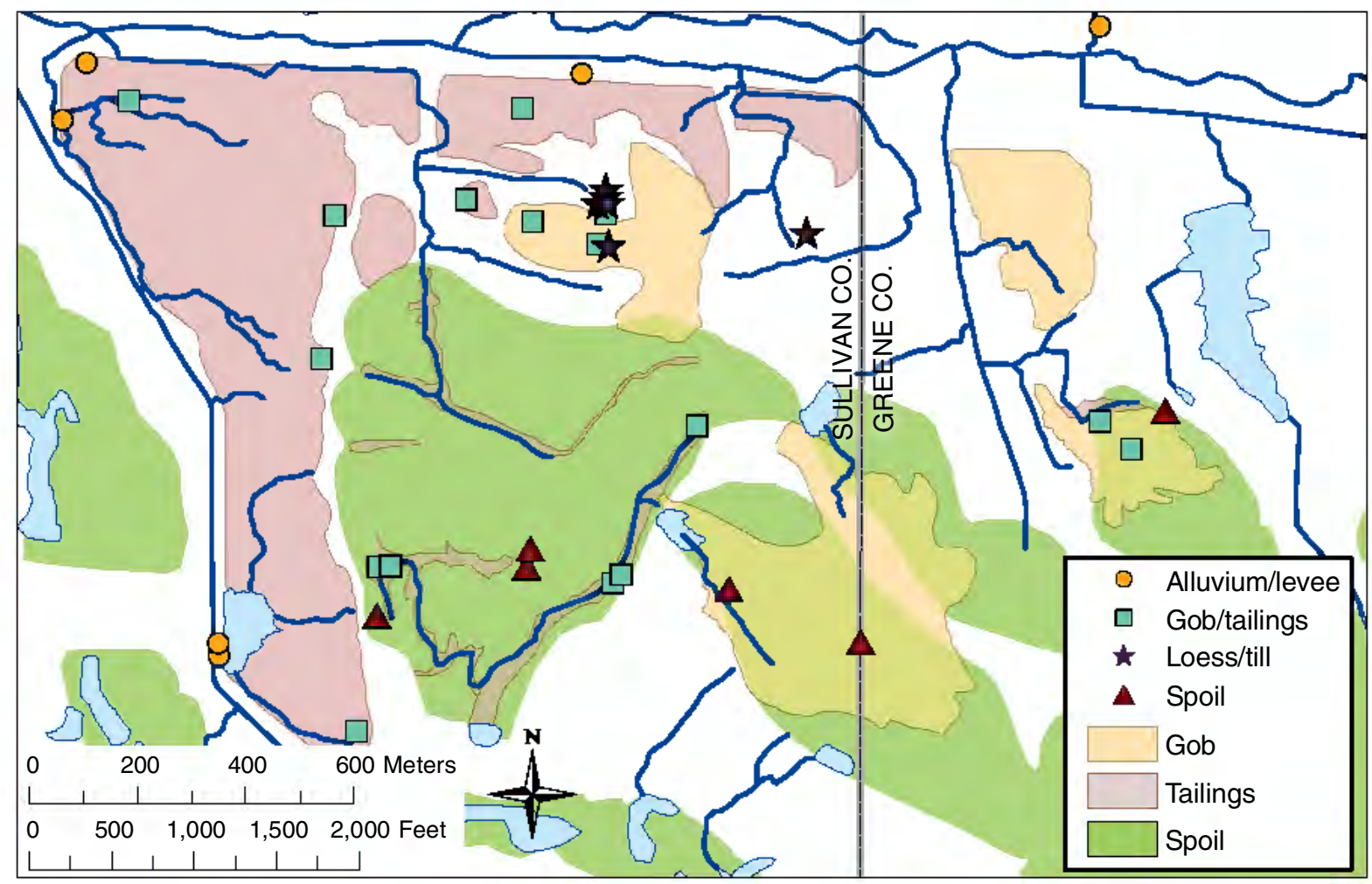

Figure 9. Map showing locations of monitoring wells from which water samples were collected from 1987 to 1992. Monitoring wells were installed in constructed levees, alluvium, loess, till, spoil, and gob and tailings. The sample sites are shown in relationship to major deposits of gob, tailings, and spoil. Data are from Branam and Harper (1994).

and 2) water levels associated with mines of the Springfield Coal are about $8 \mathrm{ft}(2.4 \mathrm{~m})$ lower than water levels associated with superjacent mines in the Hymera Coal.

In addition to the monitoring wells, there are several springs within the vicinity of the study area that are known to issue from workings of abandoned underground coal mines (fig. 11). Water samples collected from these springs and the monitoring wells during the period from 1987 to 1992 were characterized by moderate $\mathrm{pH}$ values (5.1-7.7) and values of acidity that were less than $6,160 \mathrm{mg} / \mathrm{L}$. Most of the waters associated with underground mines had some alkalinity (up to 790 $\mathrm{mg} / \mathrm{L}$ ). Maximum values of sulfate and iron were 8,270 and 1,500 $\mathrm{mg} / \mathrm{L}$, respectively (Branam and Harper, 1994). In this setting, it is unknown whether the dissolved iron and sulfate are derived from within the mines or from contamination by minerefuse deposits on the surface.

All the dissolved iron in these underground mine waters is present in the ferrous $\left(\mathrm{Fe}^{+2}\right)$ state. Such dissolved iron represents potential acidity. When high concentrations of ferrous iron are present, the iron rapidly oxidizes to the ferric $\left(\mathrm{Fe}^{+3}\right)$ state when the waters emerge onto the surface as springs. Ferric hydroxides ("yellow-boy") then precipitate, converting the potential acidity to active acidity $(\mathrm{H}+)$, neutralizing alkalinity and decreasing $\mathrm{pH}$.

\section{RECLAMATION METHODS}

\section{Recommendations}

Thomas (1978) made some very preliminary estimates regarding the costs of reclaiming the entire FTS area. The options that were considered included: 1) $\$ 90,000$ to $\$ 208,000$ (in 1978 dollars) for rechanneling nearby streams, without treatment of gob and slurry deposits, 2) $\$ 16$ million for complete removal of the gob and slurry and disposal in nearby active mines, and 3) $\$ 1.7$ million for grading gob deposits where necessary and applying a clay cap. It was estimated that the latter approach would be 85 percent effective and that annual maintenance costs would approximate $\$ 55,000$ per year. 


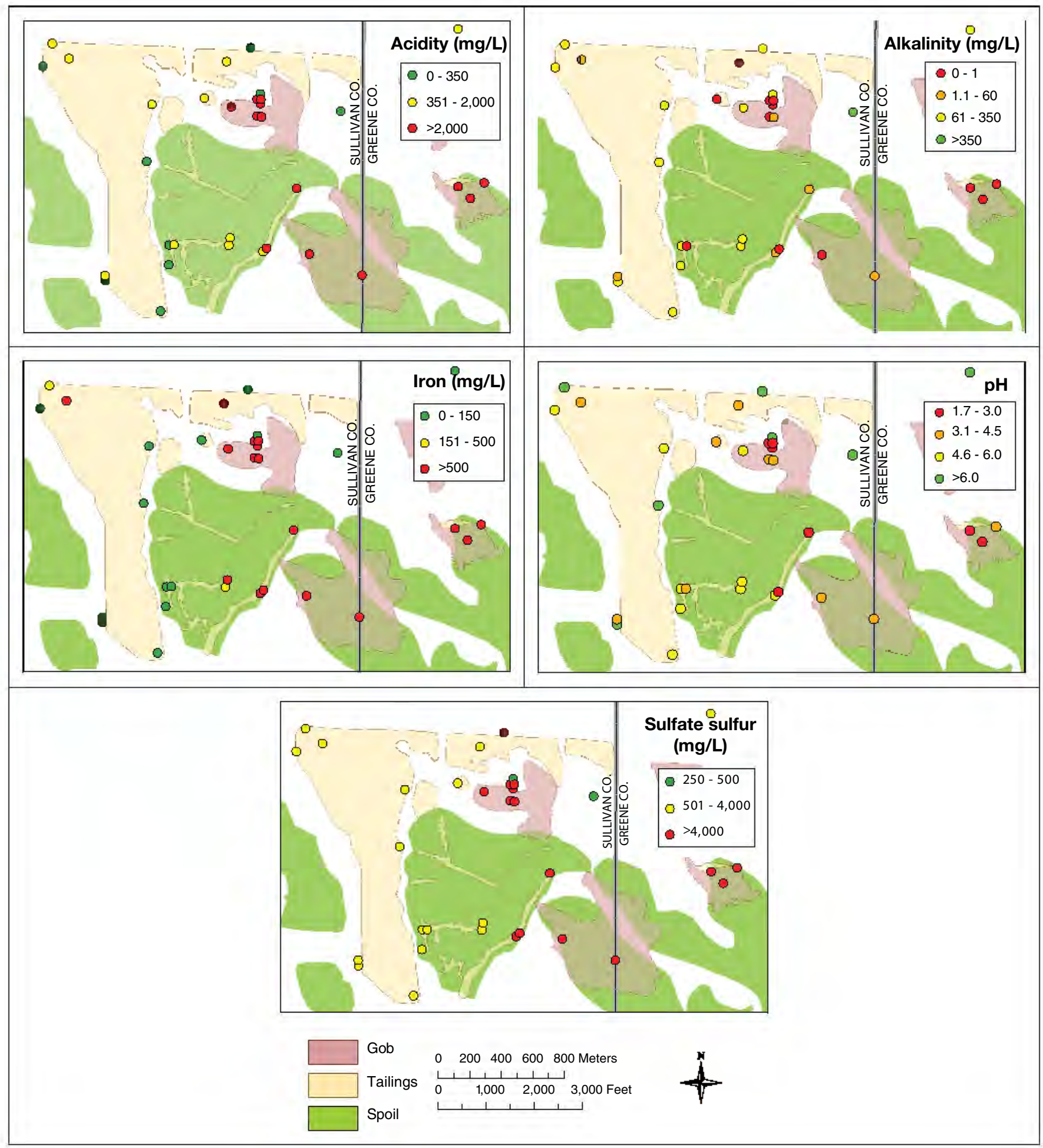

Figure 10. Maps showing average values for analyses of water samples collected between 1987 and 1992 from monitoring wells installed in constructed levees, alluvium, loess, till, spoil, gob, and tailings. Data are from Branam and Harper (1994). 


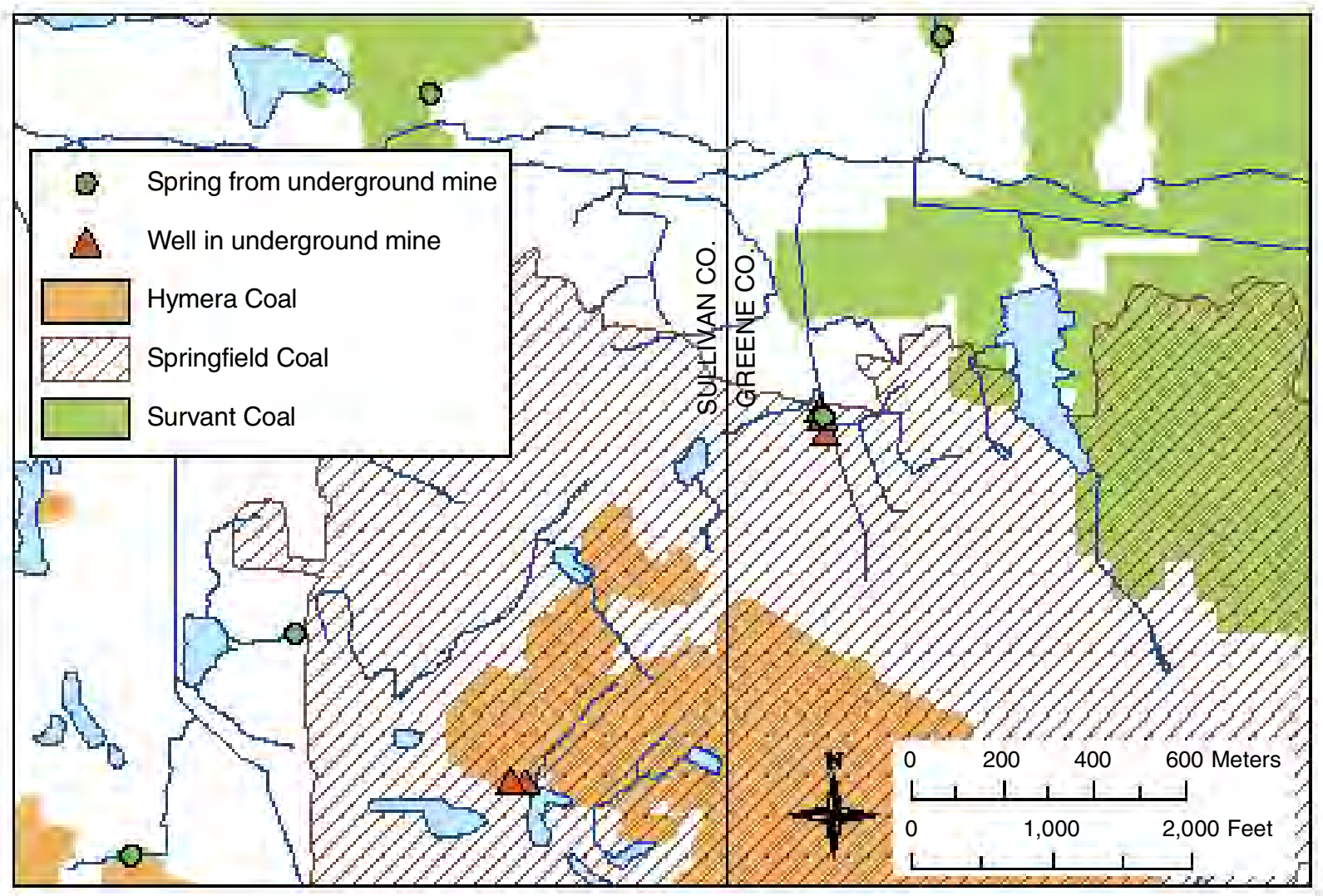

Figure 11. Map showing locations of water samples collected from 1987 to 1992 from springs issuing from underground mines and from monitoring wells installed in underground mines. Underground mines were developed in the Survant Coal, Springfield Coal, and Hymera Coal Members. Data are from Branam and Harper (1994).

Between 1987 and 1992, personnel of the IGS and Purdue University conducted a series of detailed reclamation feasibility studies that were funded through the Abandoned Mine Land (AML) Program of the U.S. Office of Surface Mining Reclamation and Enforcement (OSMRE), administered by the Indiana Department of Natural Resources, Division of Reclamation (IDNR-DOR).

Based on the analysis of soil samples collected in 1988, and in consultation with Jack Nawrot (Cooperative Wildlife Research Center, Southern Illinois University), it was suggested to personnel of IDNR-DOR that several deposits of tailings and gob at the FTS could be reclaimed by the method of direct revegetation (Nawrot and others, 1988). Recommendations were made for rates of application of agricultural limestone to various deposits, with greater rates generally being recommended for deposits having less favorable chemistry (fig. 12). It was suggested that the limestone amendments be applied over a period of several years and that the limestone be incorporated to depths of about 6 inches $(15.2 \mathrm{~cm})$.

At the FTS, long-term weathering and leaching in surface layers had ameliorated toxicity problems attributed to excessive soluble salts. Although concentrations of aluminum, copper, and zinc were moderate to high in the oxidized surficial layer, it was suggested that overtreatment with agricultural limestone would increase soil $\mathrm{pH}$, thereby decreasing the solubility of metallic ions and eliminating phytotoxic conditions.

Following the application of agricultural limestone, the promotion of soil-building processes would require supplemental amendments of phosphorus, potassium, and nitrogen to compensate for nutritional deficiencies. Low cation exchange capacity and droughtiness in the unsaturated zone would also require organic matter enhancements (mulch) to increase soil-moisture capacity and promote nutrient cycling. 


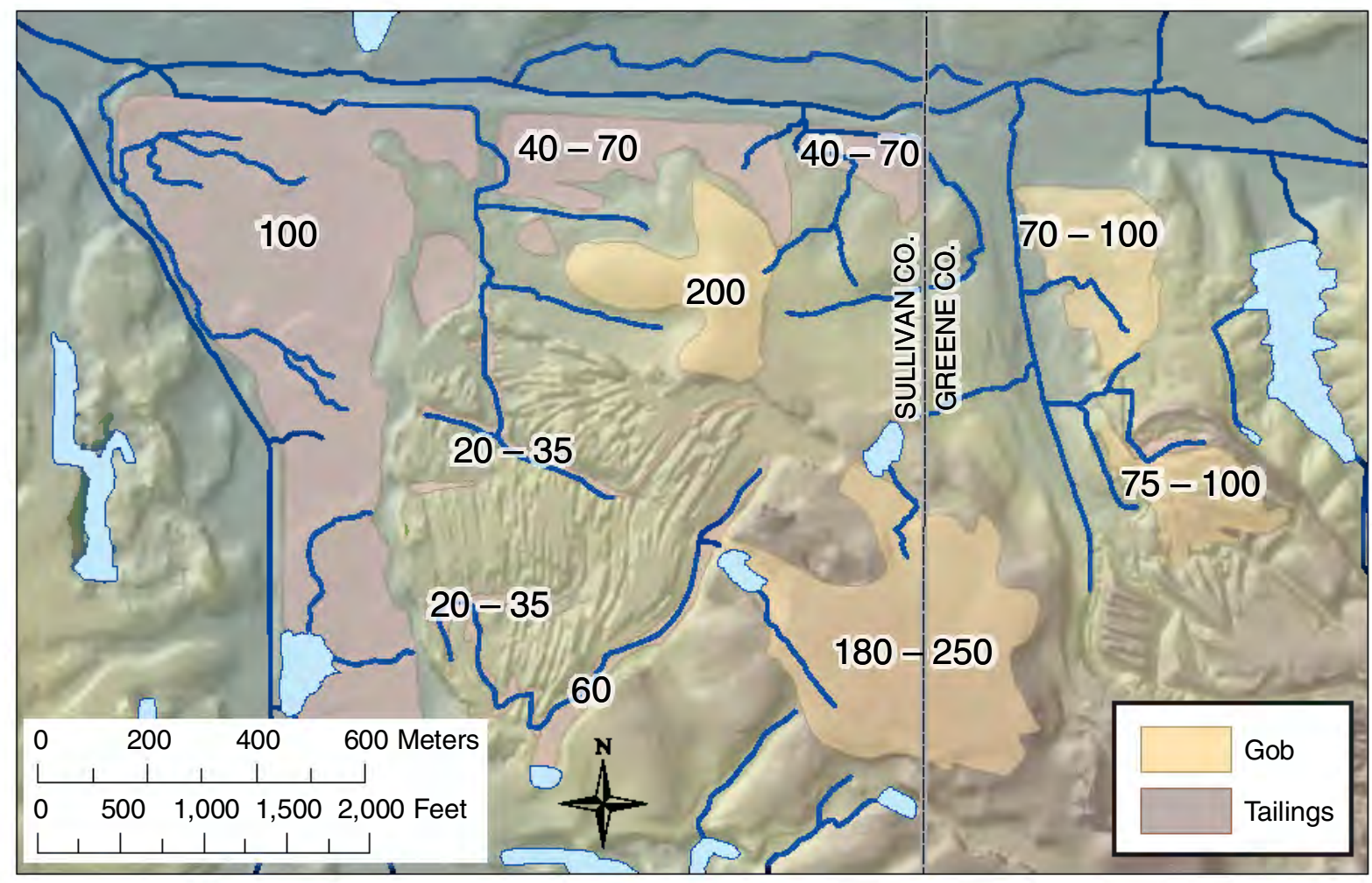

Figure 12. Map showing recommended application rates (total tons per acre) of agricultural limestone. Data are from Harper and others $(1988,1989)$.

Following the application of limestone, fertilizer, and mulch, it was recommended that treated areas be seeded with nurse crops (such as winter rye), followed in subsequent years by establishing grasses and legumes. Natural succession and associated soil-building processes would gradually establish a permanent vegetative cover.

Special problems were presented by the existence of very steep, deeply gullied edges along parts of the Southwest, Southeast, and Northeast Gob Deposits. Approaches to treating these areas included a combination of both conventional engineering methods and direct revegetation. It was suggested that gullies along the western edge of the Southwest Gob Deposit could be repaired by backfilling (without extensive grading), or by a combination of very large applications of limestone amendments (more than 300 tons per acre $[672$ metric tons per ha]), terracing, construction of drainage channels, and emplacement of a thin (18- to 24-inch [45.7- to $60.9-\mathrm{cm}]$ ) cover of soil. With regard to the western edge of the Southeast Gob Pile, it was recommended that the gob (which overlies spoil ridges) be buried in a pit where the pyritic refuse would remain below the water table. After removing and burying the gob-mantle, the underlying spoil could be graded, terraced, and amended with limestone (15 to 20 tons per acre [34-45 metric tons per ha]).

\section{Implementation}

Using funds from the Abandoned Mine Land Program of OSMRE, the IDNR-DOR commenced reclamation in 1989; by 1992 much of the FTS had been reclaimed. Based on the recommendations discussed previously, the large deposits of slurry were reclaimed using the direct revegetation method. A variety of approaches were used to reclaim the various gob deposits. Direct revegetation was used on the Northeast Gob Deposit and most of the Southwest Gob Deposit, except for its steep western slopes, where terraces and slope drains were emplaced. On the Northwest Gob Deposit, a hybrid approach was used that involved both direct revegetation and creation of an engineered drainage system without grading. Initially, direct revegetation was used on the upland portion of the Southeast Gob Deposit, and experiments were conducted to assess the applicability of the method to the deposit's steep western slopes. However, 
the Southeast Gob Deposit was subsequently reclaimed between 2003 and 2005 using engineering methods that involved grading and capping the entire deposit. The total cost of reclamation, including feasibility investigations, design, and construction, was approximately $\$ 3.3$ million (M. A. Stacy, IDNR-DOR, written commun., 2008).

\section{Main Tailings and North Tailings Deposits}

The appearance of the northern part of the Main Tailings Deposit before reclamation can be seen in an aerial photograph taken in 1984 (fig. 13). Reclamation of the Main Tailings Deposit and the North Tailings Deposit by direct revegetation was undertaken as a series of treatments in successive years, from 1989 to 1991 (fig. 14).

The original recommendations for the Main Tailings Deposit were modified on a yearly basis, as needed, by personnel of the IDNR-DOR who monitored the progress of revegetation. No efforts to stabilize the flat-lying surfaces were required. There was some difficulty in gaining access by limestone trucks to chronically wet, soft ground along the southern and western edges of the Main Tailings Deposit, and no specific measures were taken to reclaim an AMD pond in the southern part of the tailings deposit that received drainage from a perennial spring. Reclamation of the North Tailings Deposit was not begun until after the Northwest Gob Deposit, which discharged contaminated surface runoff and seepage to the tailings deposit, had been treated.

\section{Northwest Gob Deposit}

The appearance of the Northwest Gob Deposit before reclamation can be seen in an aerial photograph taken in 1984 (fig. 15). Reclamation of this deposit, which commenced in 1990, was based on plans developed by personnel from IDNRDOR and Purdue University. It was decided that the inability of lime trucks to access the gullied slopes of the Northwest Gob Deposit precluded direct revegetation of the entire deposit, so that a method involving elements of both direct revegetation and conventional engineering techniques was developed. The gullies were filled with spoil from a nearby ridge that had been created by surface mining operations in the Hymera Coal. Agricultural limestone was then incorporated directly into the upper surface of the gob. Using spoil, terraces were constructed on top of the gob with minimal grading (fig. $15 \mathrm{~B}$ and fig. 16), but a continuous soil cap was not applied across the entire deposit. Slope drains consisting of rock-lined ditches were emplaced to collect drainage from the terraces. Much of the southern lobe, which had been previously capped and was still partially vegetated, was preserved. The total construction cost for reclamation of the Main Tailings Deposit, North Tailings Deposit, and Northwest Gob Deposit was approximately $\$ 500,000$ (M. A. Stacy, IDNR-DOR, written commun., 2008).

\section{Southwest Gob Deposit and Highwall Tailings Deposit}

The appearance of the Southwest Gob Deposit before reclamation can be seen in an aerial photograph taken in 1984 (fig. 17A). Much of the central plateau and gentle northern slope of the Southwest Gob Deposit had been previously capped and was still partially vegetated, and those vegetated areas were preserved. However, it was decided by personnel of the IDNR-DOR that extensive grading of the steep western slopes, followed by construction of terraces and slope drains, was necessary to eliminate gullies. These terraces and slope drains are visible in an aerial photograph taken in 2005 (fig. 17B). Also, a pond near the northwest corner of the Southwest Gob Deposit, which was chronically contaminated before reclamation and whose level controlled the elevation of the water table in the deposit, was drained.

Concurrent with reclaiming the Southwest Gob Deposit, the Highwall Tailings Deposit (fig. 2), which receives surface drainage from the gob deposit, was reclaimed by direct revegetation. Reclamation of both deposits was completed by 1993. The total construction cost for reclamation of the two deposits was approximately $\$ 416,000$ (M. A. Stacy, IDNR-DOR, written commun., 2008).

\section{Northeast and Southeast Gob Deposits}

The appearance of the Southeast Gob Deposit before reclamation can be seen in an aerial photograph taken in 1984 (fig. 18A).

Initially, direct revegetation of both the Northeast and Southeast Gob Deposits, which are highly 
Figure 13. Aerial photographs showing the Main Taillings Deposit. For location, see Figure 2.

A. Aerial photograph (1984) showing the northern part of the Main Tailings Deposit. Prior to reclamation, the deposit was barren of vegetation. The image is derived from 1984 color aerial photographs obtained from IDNR-DOR.

B. Aerial photograph (1989) showing the northern part of the Main Tailings Deposit. Reclamation by direct revegetation was in progress when this photograph was taken. Agricultural limestone had been spread across the eastern portion of the area, but no limestone had yet been applied in the western portion. The red arrow indicates the location and direction of the photograph shown in Figure 14. The image is derived from aerial photographs obtained from IDNR-DOR.

C. Aerial photograph (2007) showing the northern part of the Main Tailings Deposit. The extent of vegetative cover can be seen in this photograph, taken 17 years after the completion of reclamation by direct revegetation. The red arrow indicates the location and direction of the photographs shown in Figure 22. The image is derived from color aerial photographs of the 2007 National Agricultural Imagery Program, U.S. Department of Agriculture.
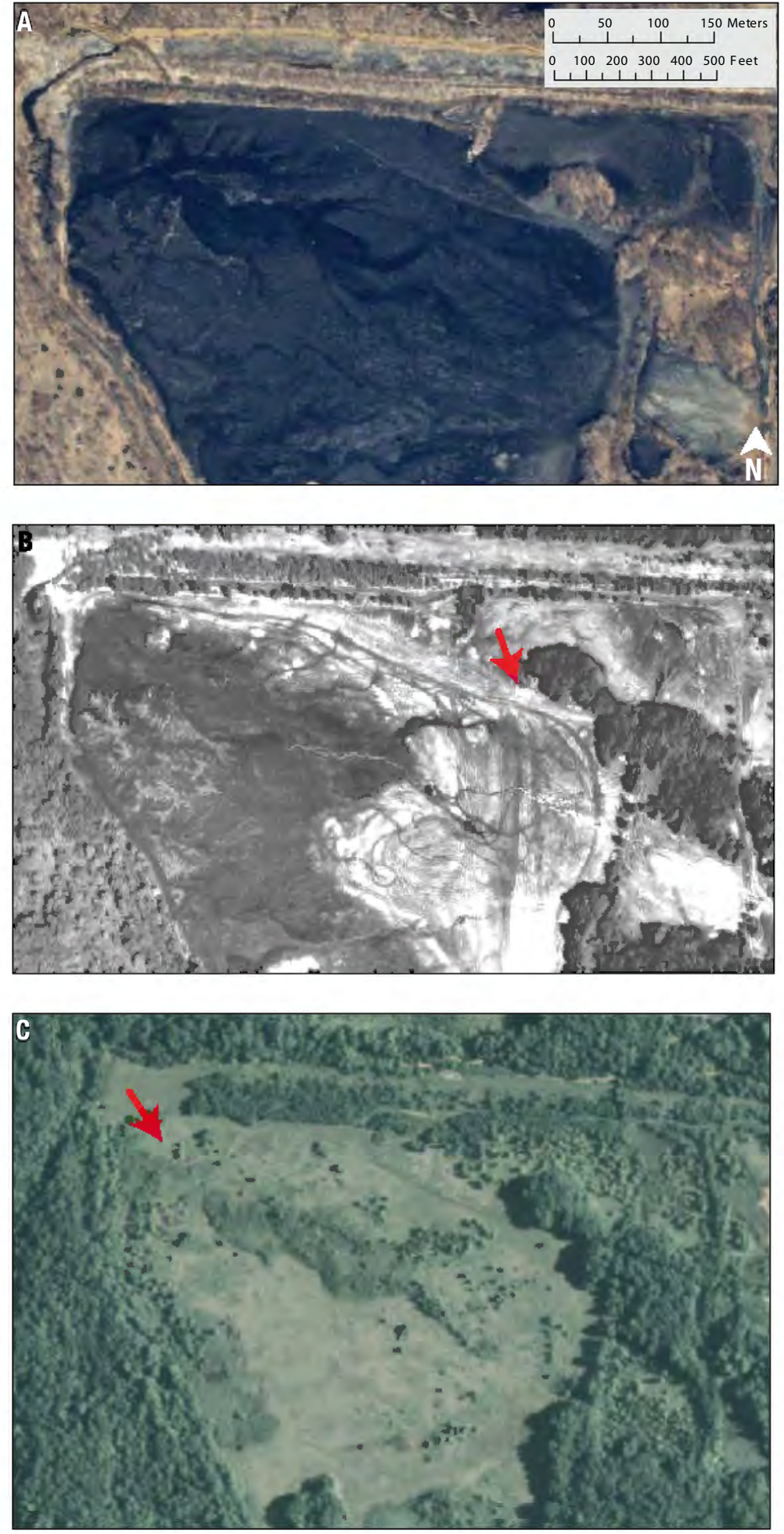


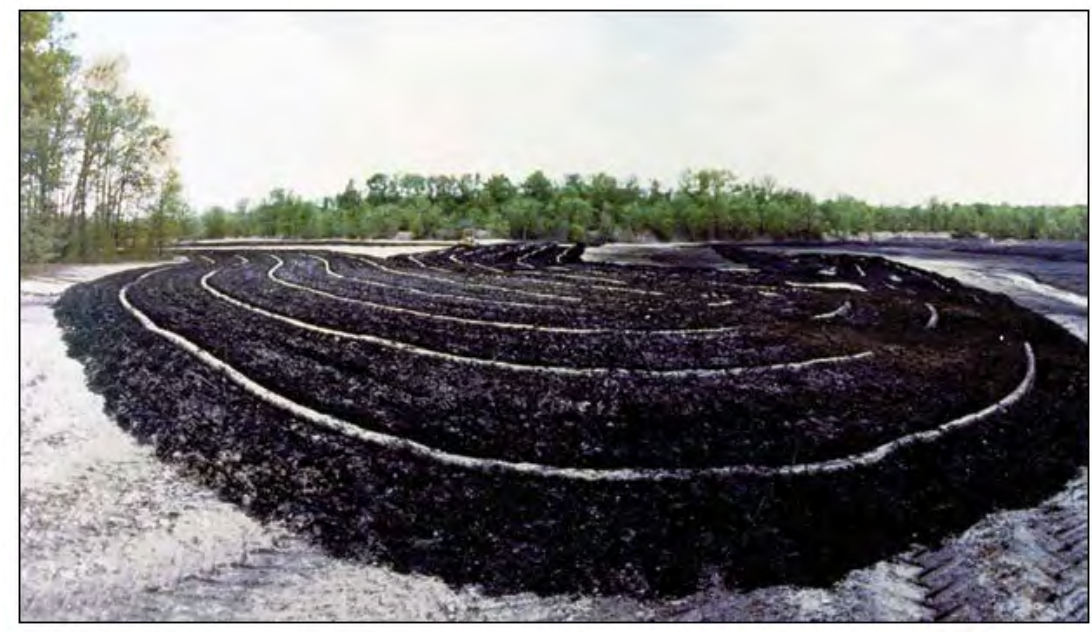

Figure 14. Photograph of the northeastern part of the Main Tailings Deposit showing the incorporation of agricultural limestone in September 1989. The approximate location and orientation of the photograph is indicated by the red arrow in Figure 13B.

weathered deposits, was considered potentially feasible. Although their soils were acidic ( $\mathrm{pH}$ less than 3.8), their relatively low values of pyritic sulfur (less than 0.84 percent) indicated little acidgenerating potential in the rooting zone of plants.

On the Southeast Gob Deposit, instruments were installed in three watersheds to test various combinations of amendments and different techniques for stabilizing slopes and gullies (fig. 19). One of the instrumented watersheds, referred to as "Watershed 1," was located on the relatively flat upland portion of the Southeast Gob Deposit (fig. 20). Instruments were installed to quantify the effects of the reclamation method on storm runoff, yield of coarse- and fine-grained sediment, chemistry ofsoil water and surface runoff, and morphologic evolution of gullies (fig. 20). On the steep western slope of the deposit, conditions were monitored simultaneously in a pair of twin watersheds, referred to as "Watersheds 2A and 2B" (fig. 19), of which the former was treated with agricultural limestone and other amendments and revegetated, whereas the latter was left untreated as a control. An additional interfluve surface near the boundary of Watershed 1 (fig. 19) was left undisturbed and continuously monitored so that it could serve as a standard for comparisons within and between the watersheds.

Large check-dams were emplaced by dumping truckloads of riprap (5 to 185 tons [4.5-168 metric tons]) at 9 locations in gullies that were scattered across the Northeast Gob Deposit and at 16 locations in gullies of the Southeast Gob Deposit (fig. 19). As sediment eroding from upland areas and gully walls accumulated behind the check-dams, it was anticipated that downcutting and seasonal flushing of the colluvium would be reduced. Headward and lateral erosion would be arrested by the burial of steep gully walls beneath accumulating colluvial mantles that were inclined at the angle of repose.

Beginning in 1990, agricultural limestone was applied to upland portions of the Northeast and Southeast Gob Deposits that could be accessed by conventional farming equipment. Most of the upland part of the Northeast Gob Deposit was treated with a total of 50 tons (45 metric tons) of agricultural limestone per acre, while most of the uplands of the Southeast Gob Deposit received a total of 100 to 110 tons (91-100 metric tons) of agricultural limestone per acre. Subsequently, various combinations of fertilizer, turkey manure, seed, and newspaper mulch were applied to different parts of the two gob deposits. In addition to grasses and legumes, trees and shrubs were planted as seedlings on portions of the two deposits.

Except for Watershed 2A, the steep western slopes of the Southeast Gob Deposit remained untreated and unvegetated following the cessation of the first major phase of reclamation in 1992.

In 2004 and 2005, as a second phase of reclamation, the entire Southeast Gob Deposit was reclaimed by the IDNR-DOR using conventional engineering methods. The result was a very large, grass-covered, mounded deposit with an engineered system of drainageways, as seen on an aerial photograph taken in 2005 (fig. 18C). The total construction cost 
Figure 15. Aerial photographs showing the Northwest Gob Deposit. For location, see Figure 2.

A. Aerial photograph (1984) showing the middle lobe of the Northwest Gob Deposit. During the 1970s, the deposit had been graded and capped with a thin layer of soil. This earlier attempt at reclamation had failed, and the soil cap and underlying gob eroded and deep gullies formed. The image is derived from 1984 color aerial photographs obtained from IDNRDOR.

B. Aerial photograph (2005) showing the middle lobe of the Northwest Gob Deposit. The system of terraces and slope drains that were created during reclamation in the early 1990s can be seen in this photograph, taken in spring (leaf off). Several barren areas, apparently related to intermittent acidic seeps, have developed along the flanks of the deposit. The red arrow indicates the location and direction of the photograph shown in Figure 16. The aerial photograph is derived from the 2005 IndianaMap Orthophotography Project.

C. Aerial photograph (2007) showing the middle lobe of the Northwest Gob Deposit. The extent of vegetative cover can be seen in this photograph, taken in summer (leaf on). The red arrow indicates the location and direction of the photographs shown in Figure 24. The image is derived from color aerial photographs of the 2007 National Agricultural Imagery Program, U.S. Department of Agriculture.
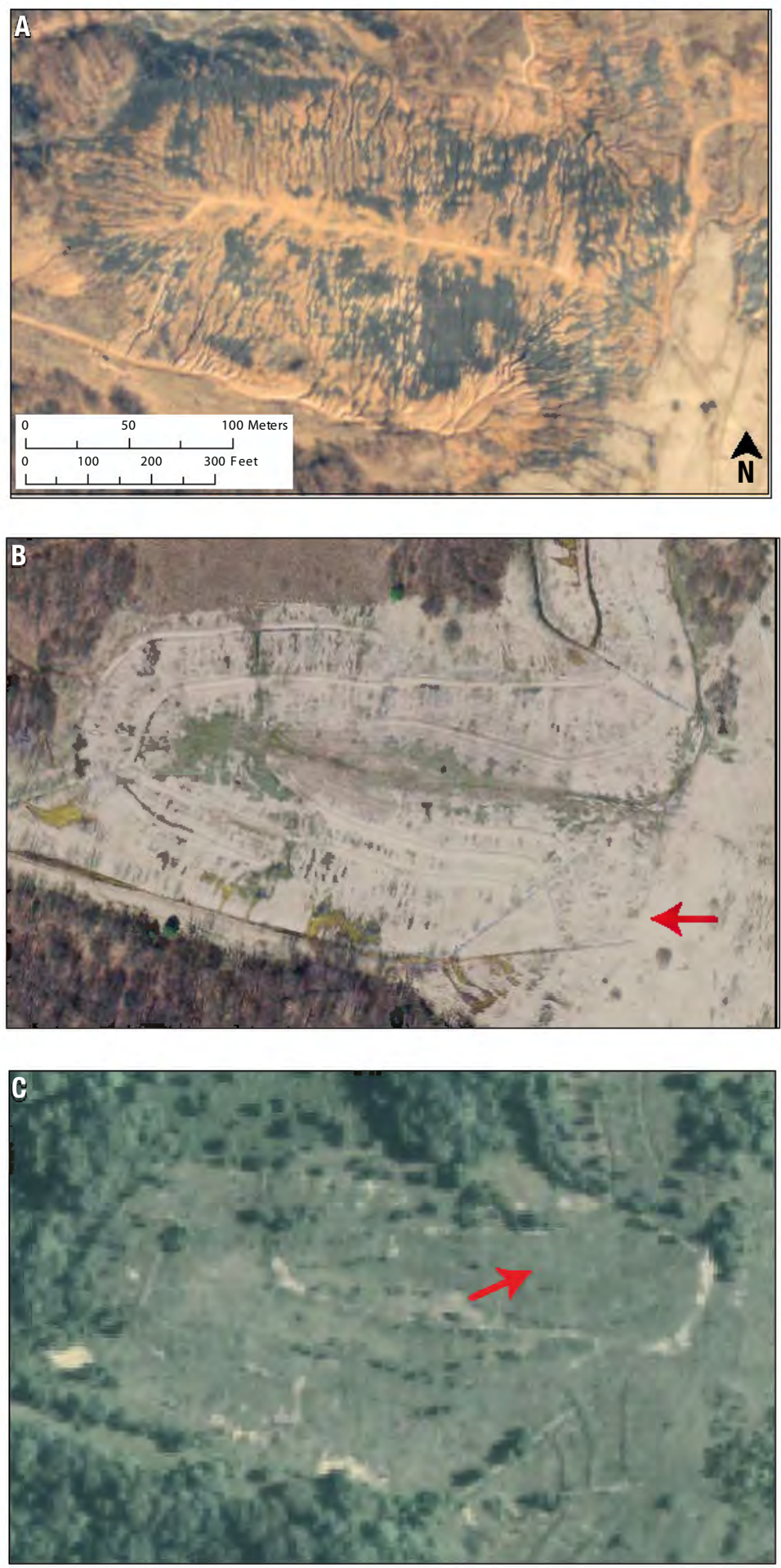


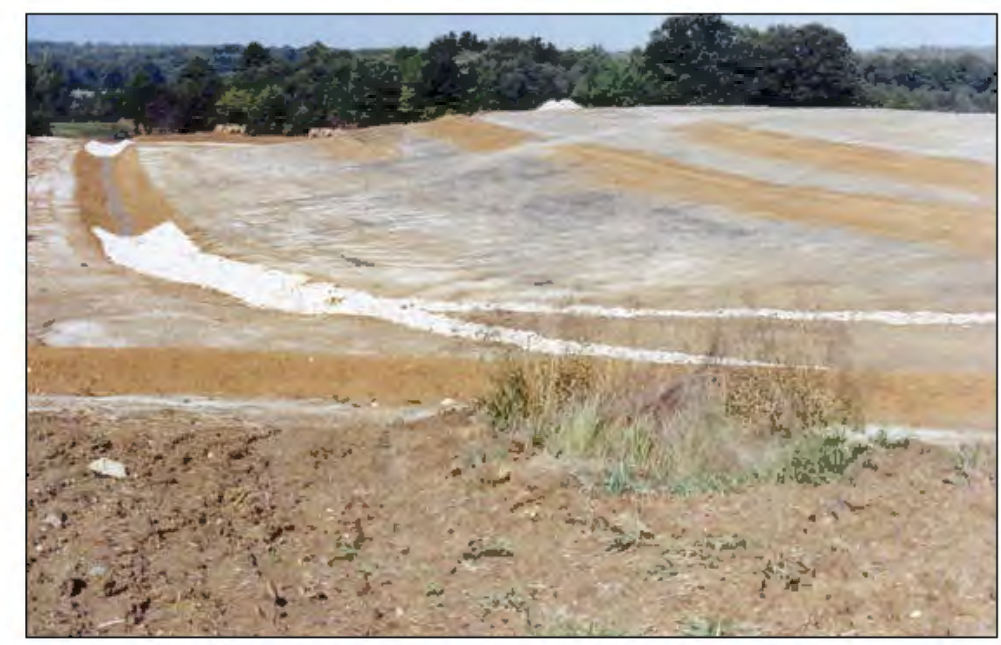

Figure 16. Photograph of the south slope of the middle lobe of the Northwest Gob Deposit, showing the installation of a drainage system of terraces and slope drains in 1990. The approximate location of the photograph is indicated by the red arrow in Figure 15B.

for reclamation of the Southeast Gob Deposit by conventional engineering methods was approximately $\$ 609,000$ (M. A. Stacy, IDNR-DOR, written commun., 2008).

A generalized depiction of changes in the overall topography and drainage of the FTS can be seen in Figure 21.

\section{CONDITIONS AFTER RECLAMATION}

Today, most of the FTS has been successfully revegetated using the combination of direct revegetation and conventional engineering methods described above, and the quality of surface runoff has greatly improved. Although vegetation now flourishes across most of the site, AMD continues to emerge locally as seeps and springs from the refuse deposits and the underground mines. The following discussion describes the improvements accomplished by reclamation between 1989 and 2005, as well as the remaining environmental problems.

\section{Main Tailings Deposit}

Before reclamation, the concentration of acidity in the shallow unsaturated zone (at a depth of $1.5 \mathrm{ft}$ [0.4 m]) of the Main Tailings Deposit exhibited a seasonal cycle that reached peak concentrations of more than 25,000 $\mathrm{mg} / \mathrm{L}$ in late summer and fall and declined to as little as $250 \mathrm{mg} / \mathrm{L}$ in late winter and early spring (Harper and Olyphant, 1993).

During the two years following reclamation (1990 and 1991), values of acidity gradually declined to less than $200 \mathrm{mg} / \mathrm{L}$ in parts of the deposit, and there was no observable peak during summer. No similar changes were observed in the saturated zone after reclamation, indicating that alkalinity from lime application reduced acidity within the uppermost $1.5 \mathrm{ft}(0.4 \mathrm{~m})$ of the deposit, in places, but that there was no observable influence on the acidity of the saturated zone.

By summer 1993, shallowly rooted vegetation had been established across all the treated areas of the Main Tailings Deposit, and a variety of volunteer species, including trees, were rapidly colonizing parts of the deposit. Similarly, direct revegetation of the North Tailings Deposit generally proceeded well, except in some areas that were adversely affected by AMD draining westward from the Northwest Gob Deposit. By 2008, the Main Tailings Deposit was well vegetated (fig. 22).

In the southern part of the Main Tailings Deposit, there is a spring that is referred to as "Spring 106" (see Figure 6 for location). This spring is characterized by moderate $\mathrm{pH}$ values (about 6.0), and, based on average values from 17 samples, by moderate values of acidity $(1,940 \mathrm{mg} / \mathrm{L})$ with some alkalinity (241 
Figure 17. Aerial photographs showing the Southwest Gob Deposit. For location, see Figure 2.

A. Aerial photograph (1984) showing the Southwest Gob Deposit. During the 1970s, the upland portion of the deposit had been graded and capped with a thin layer of soil. This earlier attempt at reclamation had failed. The soil cap and underlying gob eroded and deep gullies formed, especially along the southwestern edge of the deposit. The red arrow indicates the location and direction of the photograph shown in Figure 27A. The image is derived from 1984 color aerial photographs obtained from IDNR-DOR.

B. Aerial photograph (2005) showing the Southwest Gob Deposit. The system of terraces and slope drains that were created during reclamation in the early 1990s can be seen in this photograph, taken in spring (leaf off). The aerial photograph is derived from the 2005 IndianaMap Orthophotography Project.

C. Aerial photograph (2007) showing the Southwest Gob Deposit. The extent of vegetative cover can be seen in this photograph, taken in summer (leaf on). The arrow indicates the location and direction of the photograph shown in Figure 27B. The image is derived from color aerial photographs of the 2007 National Agricultural Imagery Program, U.S. Department of Agriculture.
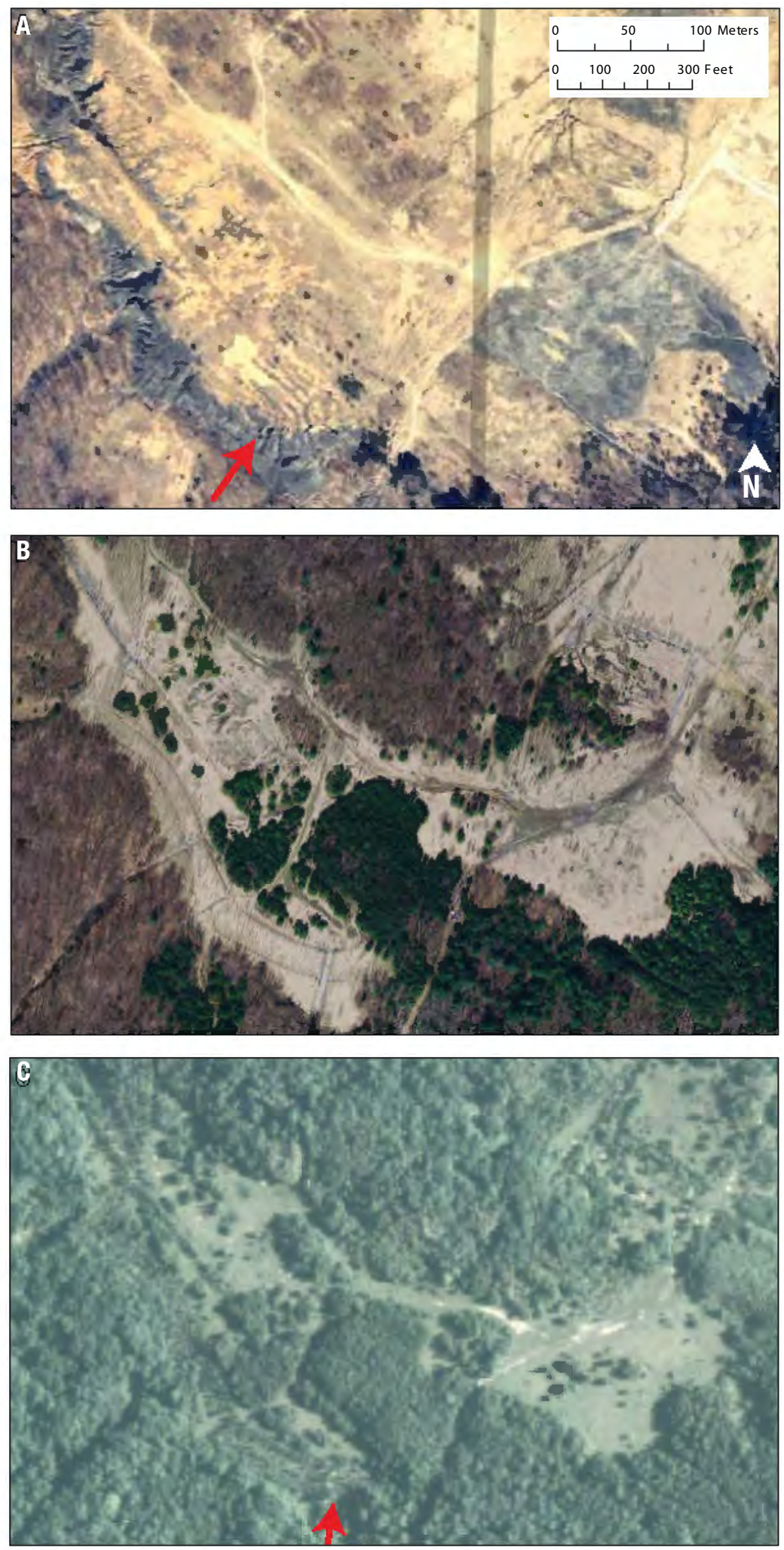

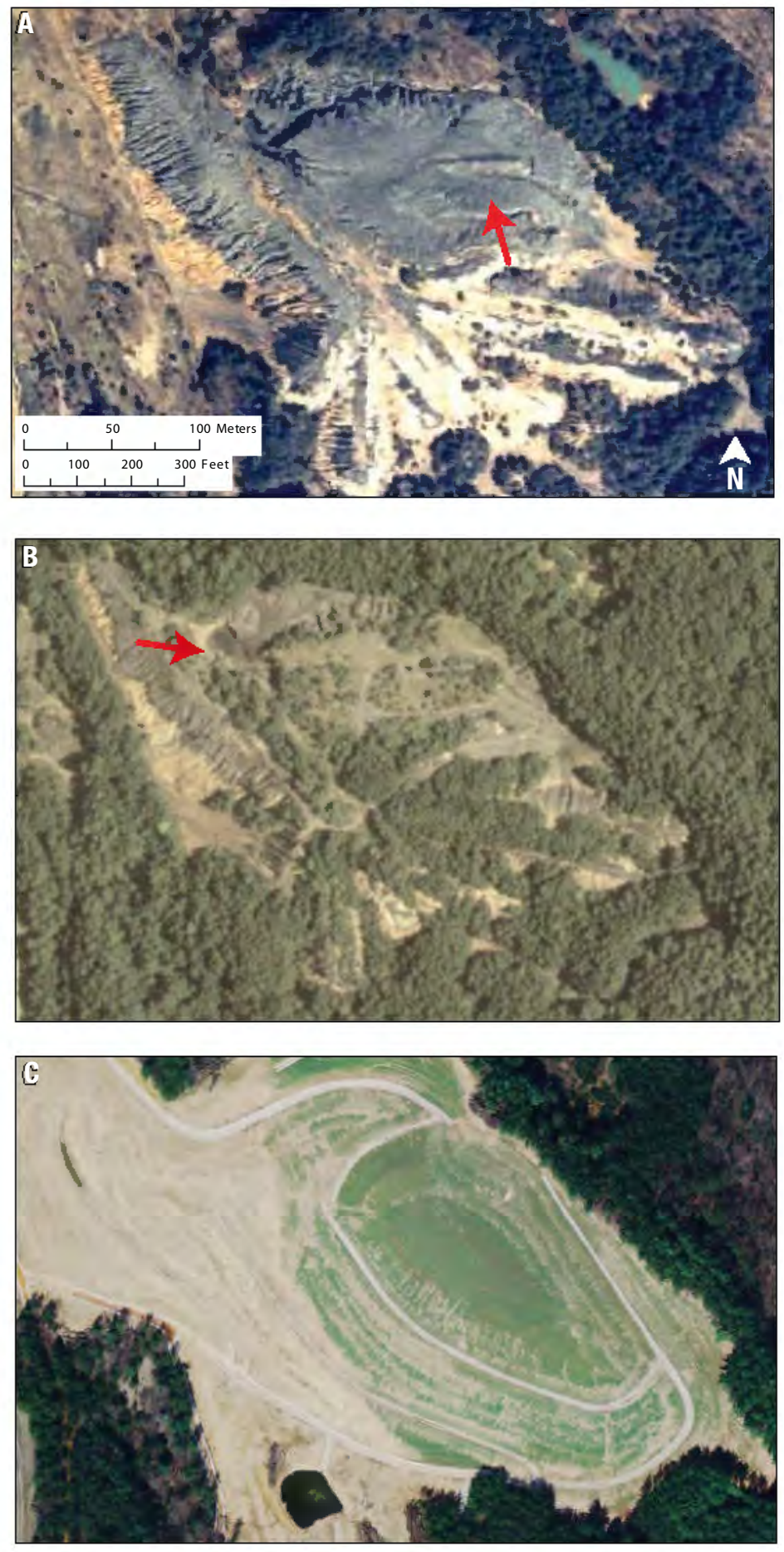

Figure 18. Aerial photographs showing the Southeast Gob Deposit. For location, see Figure 2.

A. Aerial photograph (1984) showing the Southeast Gob Deposit. Prior to reclamation, most of the deposit was barren, although a few volunteer pine trees had become established on burned and weathered southern portions of the deposit. The red arrow indicates the location and direction of the photographs shown in Figure 32. The image is derived from 1984 color aerial photographs obtained from IDNR-DOR.

B. Aerial photograph (2003) showing the Southeast Gob Deposit. In the late 1980s and early 1990s, direct revegetation was employed on the upland portions of the deposit. By 2003, these efforts, together with continued incursion of volunteer species, had established vegetation over much of the upland areas. However, the steep western slopes remained unvegetated. The red arrow indicates the location and direction of the photograph shown in Figure 31. The image is derived from color aerial photographs of the 2003 National Agricultural Imagery Program, U.S. Department of Agriculture.

C. Aerial photograph (2005) showing the Southeast Gob Deposit. By 2004, the results of direct revegetation were considered to be unsatisfactory by personnel of the Indiana Division of Reclamation, and the deposit was graded and capped using conventional engineering methods. The aerial photograph is derived from the 2005 IndianaMap Orthophotography Project. 


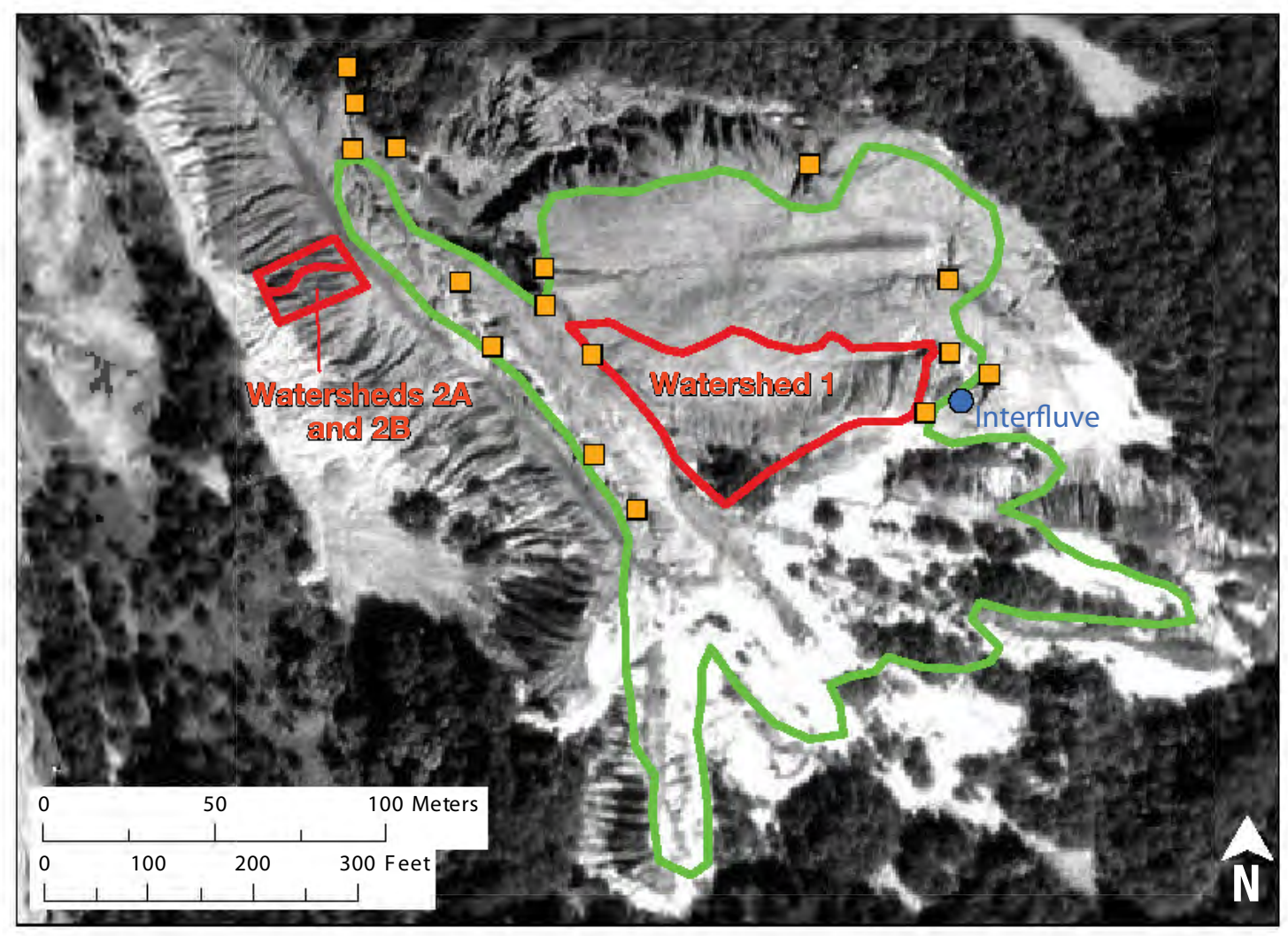

Figure 19. Aerial photograph of the Southeast Gob Deposit showing the locations of instrumented watersheds (red), locations of check-dams (orange squares), and upland areas that were accessible for direct revegetation (green). The image is derived from a 1989 aerial photograph obtained from IDNR-DOR.

$\mathrm{mg} / \mathrm{L})$, high concentrations of sulfate $(4,790 \mathrm{mg} / \mathrm{L})$, and low to moderate values of iron $(590 \mathrm{mg} / \mathrm{L})($ Branam and Harper, 1994). Sodium content is high (800 $\mathrm{mg} / \mathrm{L}$ ), which, based on other mine-water investigations by the IGS, may indicate that the water, in part, is derived from abandoned workings in the Springfield Coal (Harper and others, 1988). The spring directly overlies the western edge of an abandoned underground mine in that coal bed, and, based on inspection of mine maps, there is reason to believe that it may flow through a poorly plugged exploration drill hole associated with the mine. The spring may also be receiving subsurface drainage from the elevated deposit of spoil that is situated immediately to the east. The spring (fig. 23) and its receiving pond were largely unaffected by direct revegetation of the surrounding area, although, between 1993 and 2008, a community of cattails (genus Typha) that surrounded the spring and pond was largely supplanted by a thriving volunteer community of reeds (genus Phragmites).

\section{Northwest Gob Deposit}

Immediately following reclamation, seepages along the northern edge of the Northwest Gob Deposit temporarily dried up. However, there was no observable improvement of quality of water in the saturated-zone, and the water table remained at about the same elevation as before reclamation. Within a year, the seepages had returned, and as early as 1993, these seepages were having some adverse effects on vegetation in adjacent parts of the North Tailings Deposit (fig. 2).

Vegetation initially grew well over most of the Northwest Gob Deposit. By 2008, most of the deposit remained well vegetated with grasses (fig. 24). However, a series of small barren areas of exposed gob (readily identifiable as dark areas on high-resolution aerial photographs taken in 2005) had developed along the northern and southern portions of the middle lobe of the deposit (fig. 25). 

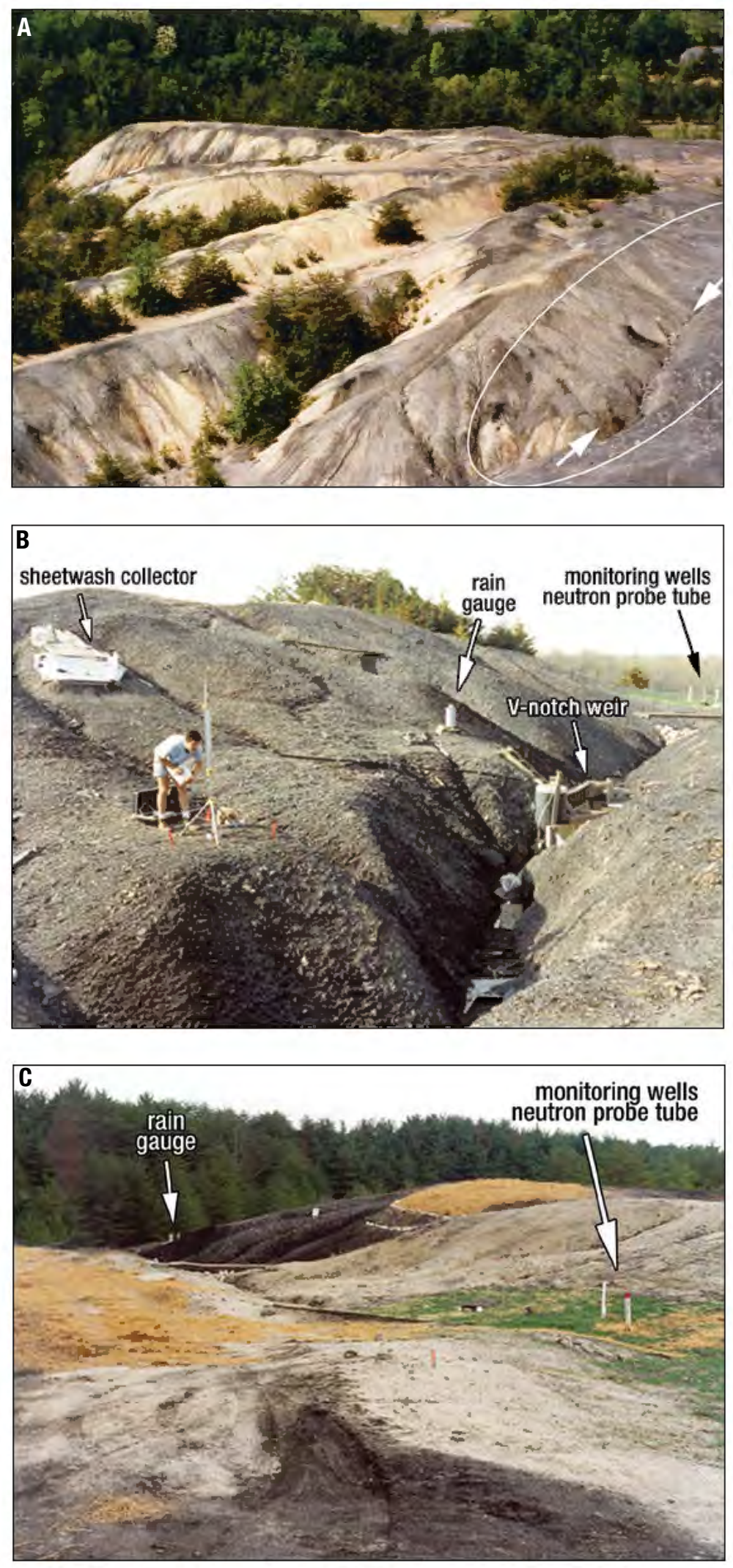

Figure 20. Photographs showing the Southeast Gob Deposit.

A. Photograph of the southern part of the Southeast Gob Deposit. Oblique aerial photograph showing most of Watershed 1 (white ellipse). The white arrows indicate the locations and directions of the photographs shown in Figures 20B and 20C.

B. Photograph of the southern part of the Southeast Gob Deposit. View of Watershed 1 , looking upslope (westward), showing instrumentation installed within the watershed in 1989. The location of the photo is indicated by the lower white arrow in Figure 20A.

C. Photograph of the southern part of the Southeast Gob Deposit. View of Watershed 1, looking downslope (eastward), showing the application in 1990 of agricultural limestone, straw mulch, and a nurse crop of rye grass. The location of the photo is indicated by the upper white arrow in Figure 20A. 


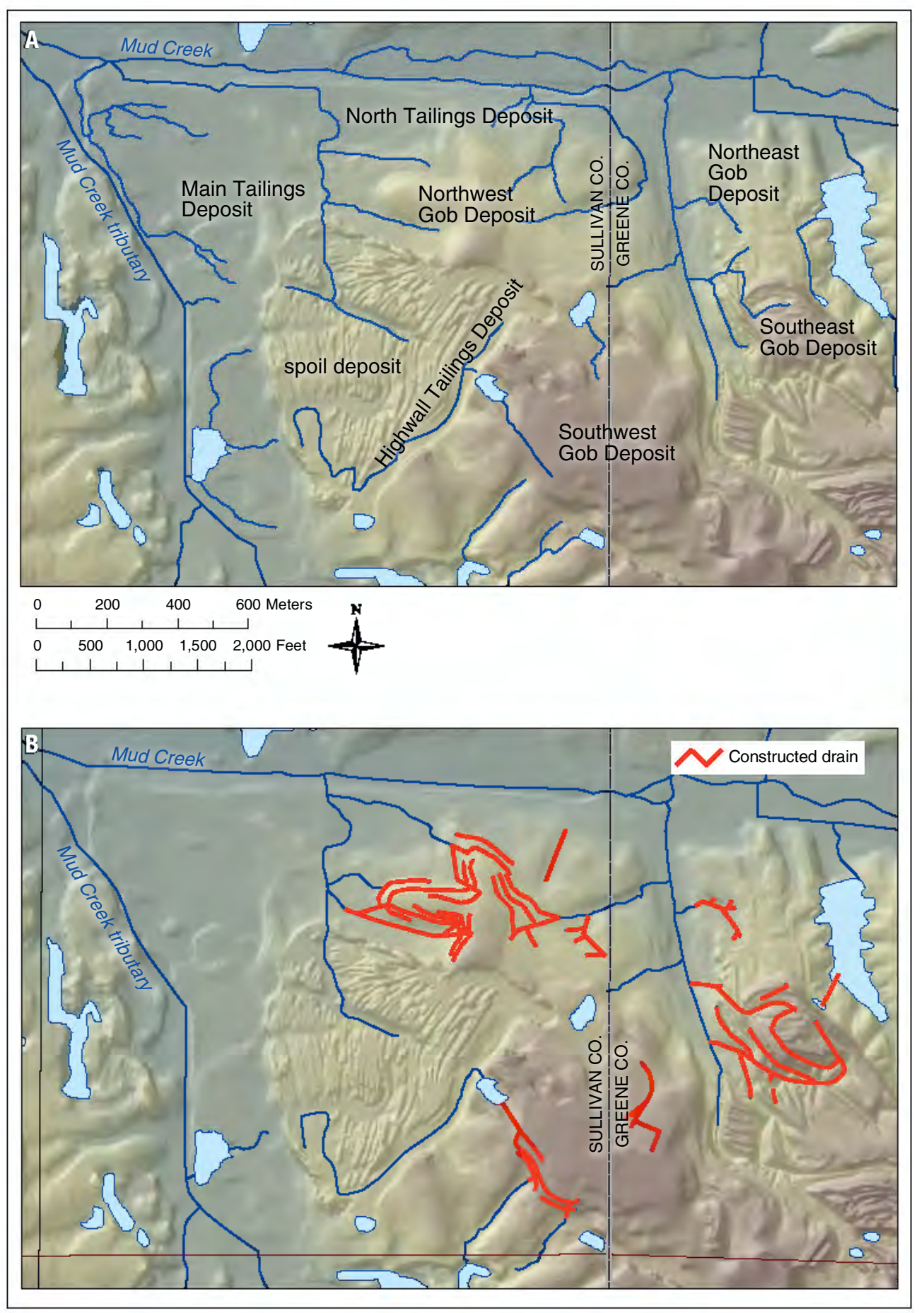

Figure 21. Hillshaded relief maps showing major changes in the topography and drainage of the Friar Tuck Site related to reclamation that occurred between 1989 and 2005. A. Generalized depiction of topography and drainage in 1989, before reclamation. The prereclamation topography is based on a detailed topographic map (scale $=1: 2,400$ ) provided by the IDNR-DOR. B. Topography and drainage in 2005, after reclamation. The red lines indicate engineered drainage systems (terraces and slope drains). The postreclamation topography is based on a digital elevation model derived from the 2005 IndianaMap Orthophotography Project (IMOP). The engineered drainage systems were digitized from the color orthophotography of the IMOP and black-and-white aerial imagery of 1998-1999 U.S. Geological Survey Digital Orthophoto Quarter Quadrangles. 
A more serious problem developed on the west slope of the north lobe of the Northwest Gob Deposit, where drainage sometimes ponds on a constructed terrace. AMD seepage reappeared in areas that were immediately downslope from the terrace, resulting in the loss of the vegetative cover and rendering the area susceptible to erosion (fig. 26). After inspecting the feature in the field, it is not immediately evident whether ponding within the terrace occurs because of some defect in the design of the terrace or from an obstruction within the drainageway, or if the problem is exacerbated by the reappearance of a spring that formerly existed about $100 \mathrm{ft}(30.4 \mathrm{~m})$ to the south, where drainage from the terrace flows into a slope drain.

Analysis of a sample of the ponded water that was collected on June 18, 2008, provided the following values: $\mathrm{pH}, 2.9$; acidity, 2,800 mg/L; sulfate, 5,140 $\mathrm{mg} / \mathrm{L}$; and total iron, $1,200 \mathrm{mg} / \mathrm{L}$. These values are characteristic of AMD produced from surface runoff from the Northwest Gob Deposit before it was reclaimed.

In contrast with the Main Tailings Deposit, there had been little growth of volunteer trees on the Northwest Gob Deposit in the 18 years since reclamation commenced, resulting, perhaps, from the persistence of acidic conditions in the thick unsaturated zone of the gob deposit.

\section{Southwest Gob Deposit}

In 2008, vegetation was doing well on both the central plateau and terraced western slopes of the Southwest Gob Deposit (fig. 27). However, several valleys that drain the western slopes remain filled with eroded gob from before reclamation and still continue to discharge acidic baseflow to surfacemine lakes that are situated immediately south of FTS.

Acidic baseflow from the Southwest Gob Deposit also continues to be discharged through a spring located at the northwestern edge of the deposit. By 2005, a large mass of iron oxihydroxide had precipitated from these waters (fig. 28). Analysis of a water sample collected from the spring on June 19, 2008, provided the following values: $\mathrm{pH}, 2.9$; acidity, 1,360 mg/L; sulfate, 4,380 mg/L; and total iron, $510 \mathrm{mg} / \mathrm{L}$.
Although the acid mine drainage flows southwestward along the Highwall Tailings Deposit as a narrow stream, vegetation was growing well on the tailings deposit by spring 1993, and continued to thrive thereafter. The AMD leaves the Highwall Tailings Deposit and enters the well-vegetated spoil deposit to the west. After infiltrating the spoil, it may contribute to AMD that seeps along the southwestern edge of the Main Tailings Deposit, where it may mix with AMD that issues from an underground coal mine through Spring 106.

Another baseflow seep exists along the southwestern edge of the Southwest Gob Deposit. It flows southwestward into a small stream that discharges into a surface-mine pond that is situated just off-site from the FTS. A water sample that was collected from the stream on June 19, 2008, was characterized as follows: $\mathrm{pH}, 2.9$; acidity, $917 \mathrm{mg} / \mathrm{L}$; sulfate, 2,430 mg/L; and total iron, $310 \mathrm{mg} / \mathrm{L}$.

\section{Northeast and Southeast Gob Deposits}

Direct revegetation of the Northeast Gob Deposit exhibited limited success, especially on the relatively steep northern slope. By 2008, extensive barren areas of various sizes were scattered across the northern edge, as well as the relatively flat upland portions (figs. 29 and 30).

After reclamation of the upland portions of the Southeast Gob Deposit by direct revegetation in 1990 to 1992, soil samples collected from the uppermost 4 inches $(10.1 \mathrm{~cm})$ of the uplands exhibited values of soil $\mathrm{pH}$ that were greatly improved compared with pre-reclamation samples (6.0 versus less than 3.0) (Harper and Olyphant, 1993). Alkalinity, which was absent before reclamation, fluctuated between 100 and $350 \mathrm{mg} / \mathrm{L}$ after reclamation. A broader reconnaissance across the gob deposit indicated that $\mathrm{pH}$ across less intensively treated parts of the deposit was somewhat lower (ranging from 3.8-5.8). Nevertheless, 84 percent of measurements exceeded 4.2, which is adequate for survival of acid-tolerant vegetation.

On the Southeast Gob Deposit and parts of the Northeast Gob Deposit, perennial ryegrass (Lolium perenne), Chinese lespedeza (Sericea lespedeza), and Kentucky 31 fescue (Festuca arundinacea) were used successfully to add organic matter to the soil and to 

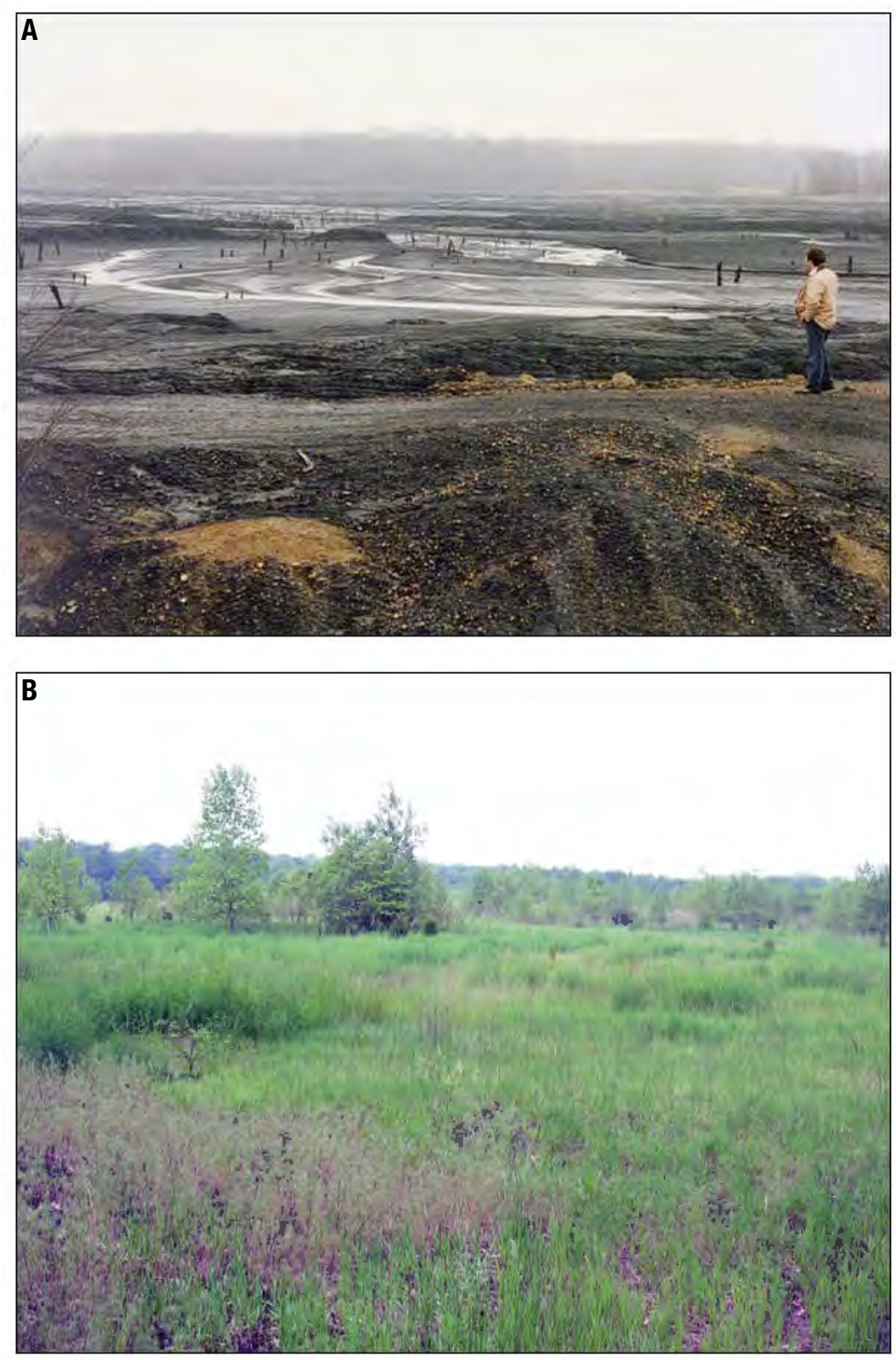

Figure 22. Photographs taken from the northwest corner of the Main Tailings Deposit, looking southeastward. Both photographs were taken from about the same location, which is indicated by the red arrow in Figure 13C. A. Photograph taken in 1987, 2 years before the commencement of reclamation. B. Photograph taken on May 27, 2008, almost 19 years after reclamation.

stabilize gullies. These acid- and drought-tolerant grasses and legumes proved effective in protecting against erosive downcutting by creating thick vegetative mats on gully floors and in the sediment that accumulated above check-dams. On the steep western slopes of the Southeast Gob Deposit where the seed was protected from transport by raking and mulching, fescue's aggressive root system increased the stability of interfluves, as well as gullies. Among the trees and shrubs that were planted, bristly locusts (Robinia hispida) and black locusts (Robinia pseudoacacia) were best suited for the initial stages of revegetation (Harper and Olyphant, 1993) (fig. 31).

In contrast, white pines (Pinus strobus) and Virginia pines (Pinus virginiana) showed little growth. The rapid incursion and proliferation of volunteer species also played a significant role in the early revegetation of the Southeast and Northeast Gob Deposits. By summer 1992, a dense and diverse vegetative cover had developed across much of the upland areas of both deposits (fig. 32C). 

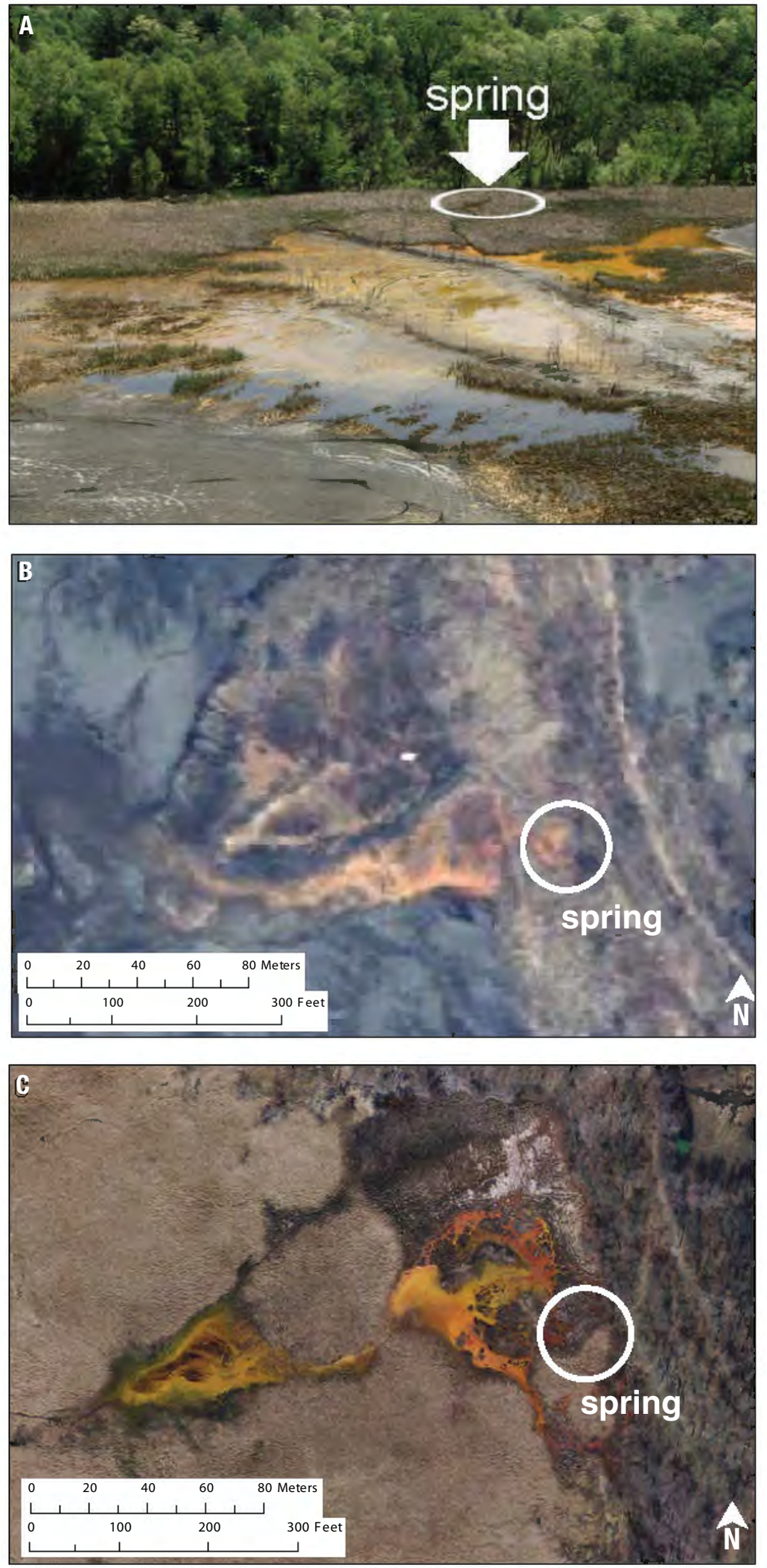

Figure 23. Photographs of a spring (referred to as "Spring 106"), located near the south end of the Main Tailings Deposit (see Figure 6 for location). The spring issues, in part, from an underground mine in the Springfield Coal Member.

A. Oblique aerial photograph taken in 1990, looking eastward.

B. Vertical aerial photograph taken on April 7, 1984 (leaf off). The aerial photograph was obtained from IDNR-DOR.

C. Vertical aerial photograph taken in April 2005 (leaf on). The aerial photograph is derived from the IndianaMap Orthophotography Project. 

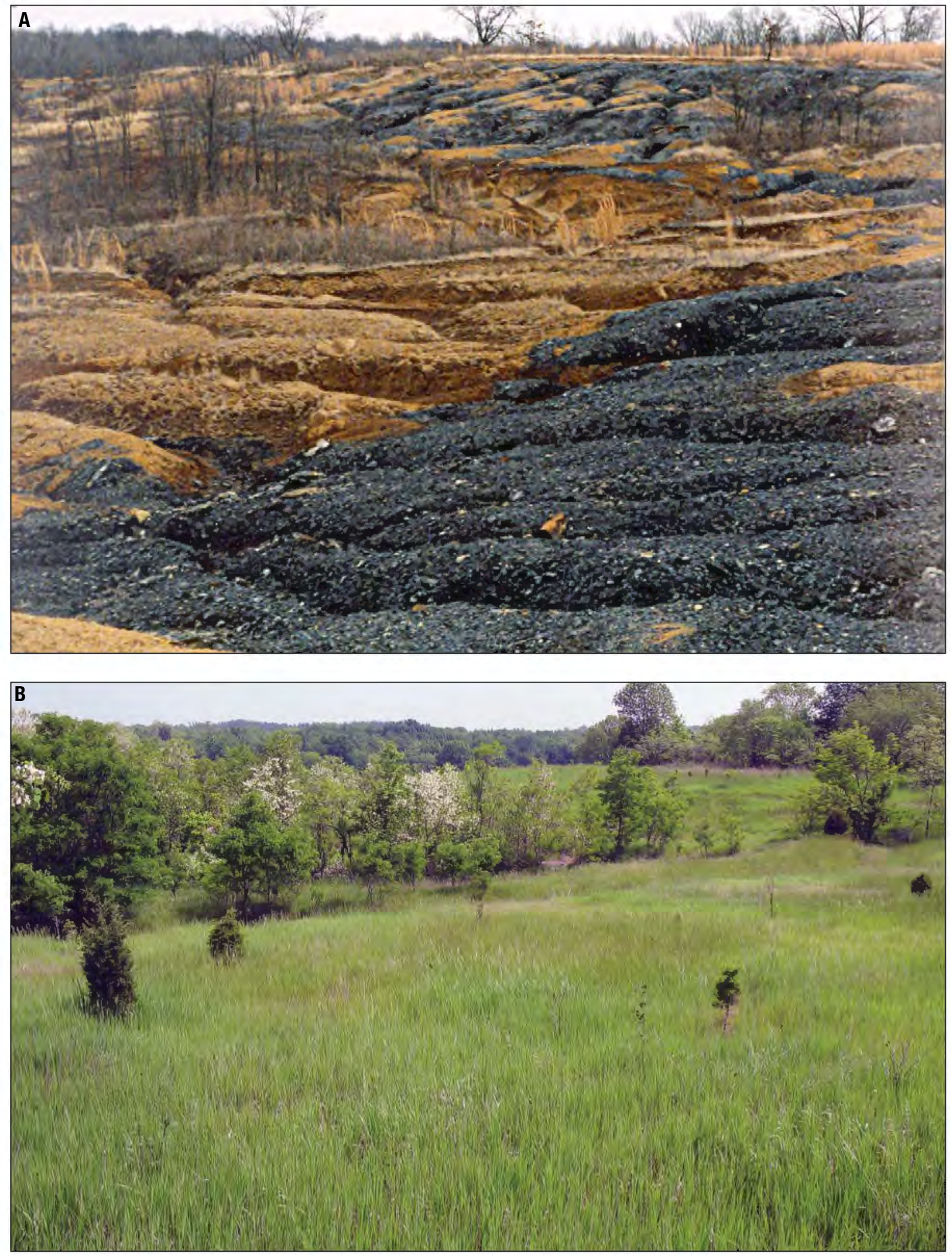

Figure 24. Photographs from near the center of the Northwest Gob Deposit, looking northeastward. Both photographs were taken from about the same location, which is indicated by the red arrow in Figure 15C. A. Photograph taken in 1987, 3 years before the commencement of reclamation. B. Photograph taken on May 27, 2008, almost 18 years after reclamation. 

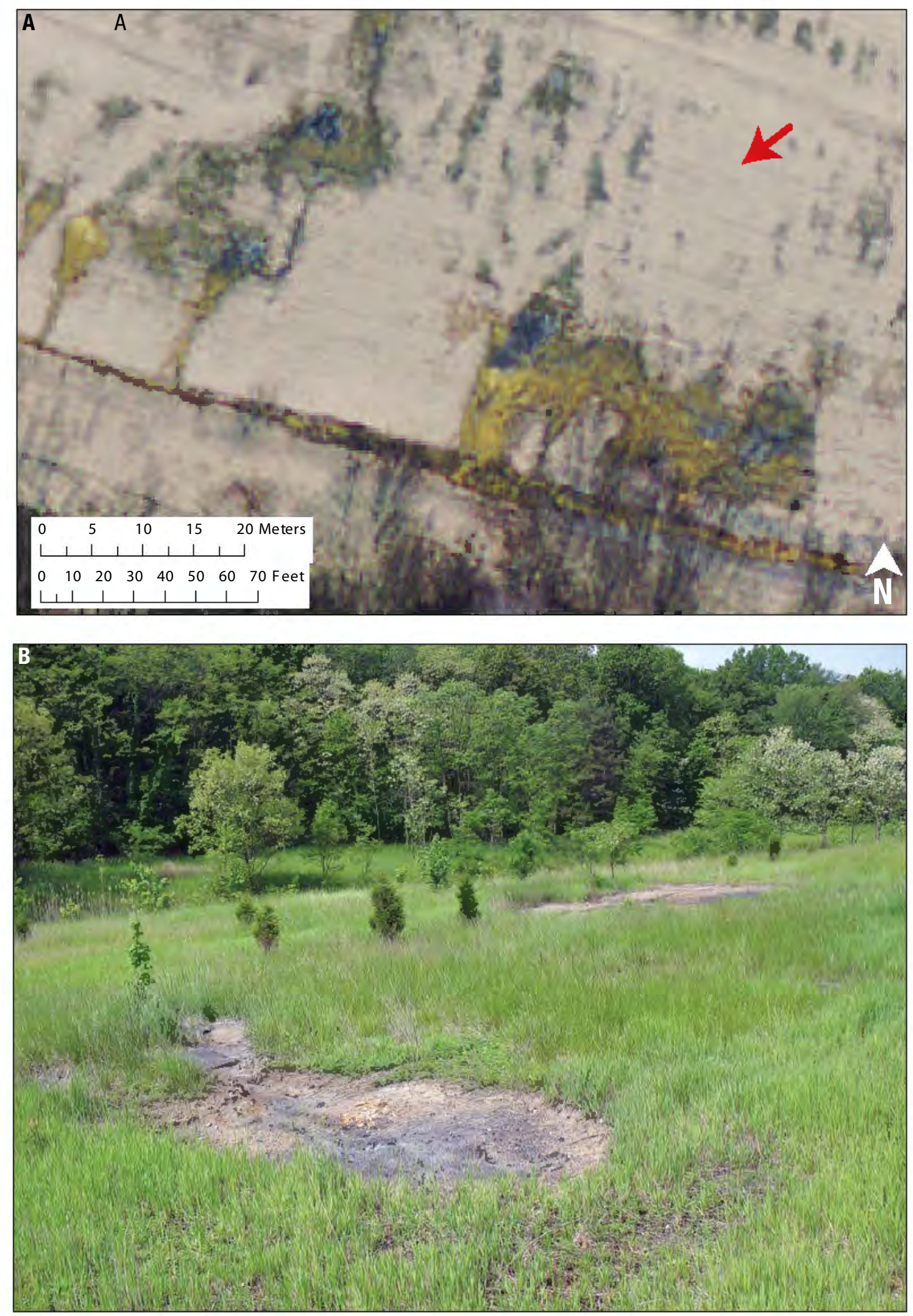

Figure 25. Photographs of the south slope of the middle lobe of the Northwest Gob Deposit, showing dark areas of exposed gob. A. Vertical aerial photograph showing several dark areas of exposed gob that were barren of vegetation in April 2005 (leaf off). The red arrow indicates the location and direction of the photograph shown in Figure 25B. The aerial photograph is derived from the 2005 IndianaMap Orthophotography Project. B. Photograph showing one of the barren areas of exposed gob on May 27, 2008. The approximate location of the photo is indicated by the red arrow in Figure 25A. 
Figure 26. Photographs of the west slope of the north lobe of the Northwest Gob Deposit showing barren areas.

A. Vertical aerial photograph showing dark areas of exposed gob that were barren of vegetation in April 2005 (leaf off). The red arrows indicate the locations and directions of the photographs shown in Figures 26B and 26C. The aerial photograph is derived from the 2005 Indiana Map Orthophotography Project.

B. Photograph showing a terrace with impounded acidic mine drainage on June 18, 2008. The approximate location of the photograph is indicated by the red arrow on the right in Figure 26A.

C. Photograph showing the barren area below the terrace. The approximate location of the photograph is indicated by the red arrow on the left in Figure 26A.
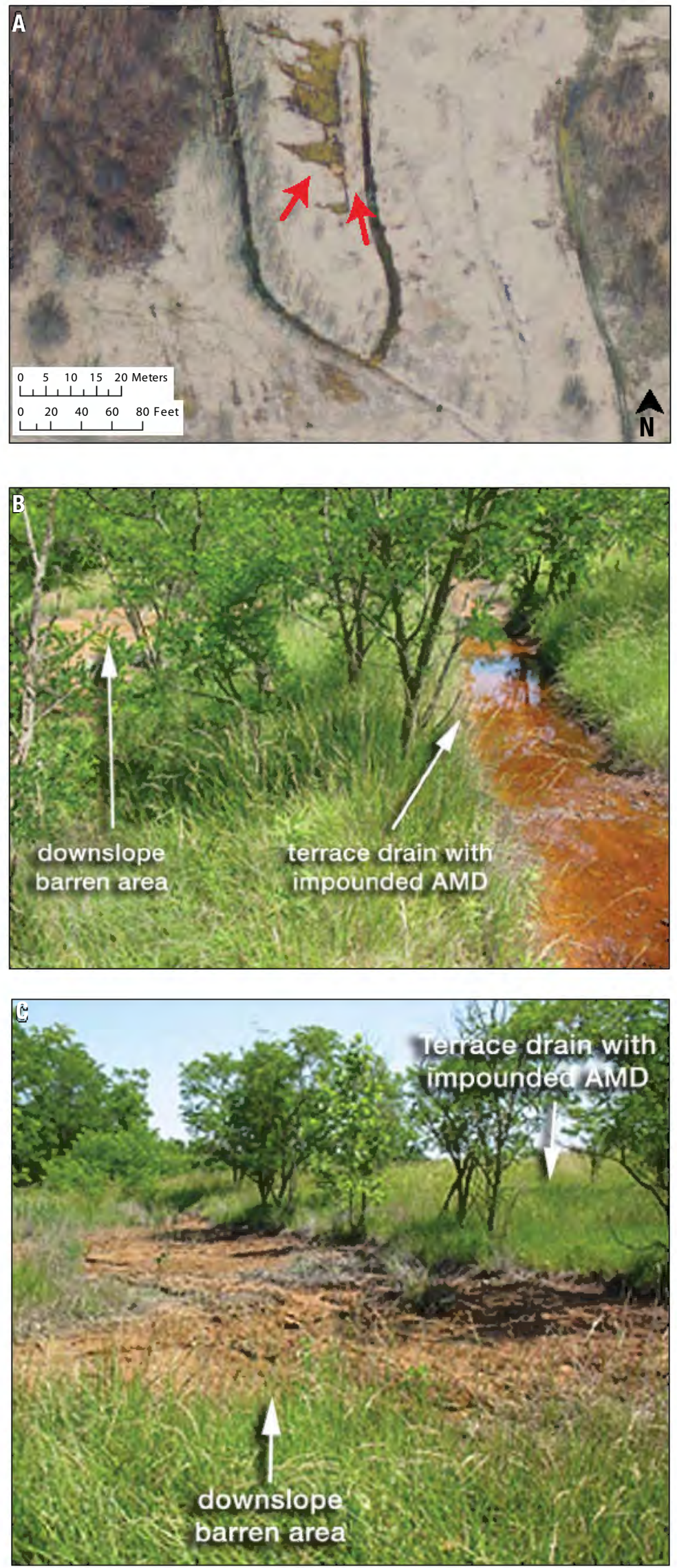
As determined by detailed monitoring within Watershed 1 on the Southeast Gob Deposit (fig. 19), the initial treatment of the upland portion of the deposit by disking and planting vegetation increased the proportion of water that infiltrated versus that which ran off. Before direct revegetation, about 34 percent of the warm-season rainfall was shed from the Southeast Gob Deposit as storm runoff. After reclamation, ratio of runoff to precipitation for the upland portion of the gob deposit declined to an average value of 0.14 (Harper and Olyphant, 1993). The increased infiltration promoted the growth of vegetation and decreased moisture stress by maintaining a higher soil-moisture content in the rooting zone during dry periods in summer. Prior to direct revegetation, there were periods during each growing season when the soil-water tension at a depth of 6 inches $(15.2 \mathrm{~cm})$ exceeded 1,000 cm $\mathrm{H}_{2} \mathrm{O}$ (indicating drought stress). After reclamation, periods when soil-water tension was indicative of moisture stress occurred only intermittently and for shorter periods (Harper and Olyphant, 1993).

Before reclamation of the Southeast Gob Deposit, interfluve surfaces were lowering at a rate of about $0.2 \mathrm{in} / \mathrm{yr}(0.4 \mathrm{~cm} / \mathrm{yr})$, and gullies were backwearing at a rate of about $1 \mathrm{in} / \mathrm{yr}(2.5 \mathrm{~cm} / \mathrm{yr})$, as determined by detailed monitoring within Watersheds $2 \mathrm{~A}$ and 2B (fig. 19) (Olyphant and Harper, 1995). The annual sediment yield was about $2.1 \mathrm{lb} / \mathrm{ft}^{2}\left(10.4 \mathrm{~kg} / \mathrm{m}^{2}\right)$, more than half of which was coarse grained and highly acidic. Significant in-filling behind checkdams occurred in the summer seasons of 1991 and 1992, when high-intensity rainfalls occurred during thunderstorms. After direct revegetation, however, the yield of coarse-grained sediment was virtually eliminated, and the annual yield of finegrained, suspended sediment was reduced from about 0.9 to $0.06 \mathrm{lb} / \mathrm{ft}^{2}\left(4.5-0.3 \mathrm{~kg} / \mathrm{m}^{2}\right)$. After September 1992, there was almost no sediment accumulation behind check-dams in drainages of areas that were subjected to direct revegetation, indicating that much of the trial plots had reached a state of stable geomorphic equilibrium. Diverse vegetation began growing vigorously in the alluvial sediments that collected behind many of the check-dams. Volunteer cottonwood trees (Populus deltoides) displayed the greatest growth during summer 1992, exceeding even the growth of locust trees. By June 1993, thick vegetation had become established in tributary gullies and flushing of colluvium had been largely eliminated, so that the gullies were also becoming less deeply incised.
Following direct revegetation of the Southeast Gob Deposit, water quality of the storm runoff improved, changing from acidic (acidities sometimes exceeded $700 \mathrm{mg} / \mathrm{L}$ prior to reclamation) to alkaline $(75 \mathrm{mg} / \mathrm{L}$ alkalinity, on average). On the other hand, groundwater in the gob deposit showed no evident improvements in acidity. Measurements of acidity were determined from samples of pore water that were collected from both the unsaturated and saturated zones. Before direct revegetation, acidity of groundwater increased with depth, reaching a maximum concentration of about 24,000 $\mathrm{mg} / \mathrm{L}$ in the saturated zone during late summer (Harper and Olyphant, 1993). Concentrations increased markedly at all levels during periods of drying in late summer and autumn. Limestone was applied in October 1990, and through February 1992, acidity in groundwater continued to vary seasonally as before. Also, it should be noted that increased infiltration may also result in the downward flushing of soluble salts into the saturated zone, which may eventually be manifested in worsening chemistry of baseflow and springs. These latter effects, if they occur, may be temporary or only related to seasons of exceptionally high recharge (Bayless and Olyphant, 1993).

After the experiments with direct revegetation of the Southeast Gob Deposit ceased in 1992, revegetation by volunteer species continued to occur, as can be seen on a 2003 aerial photograph (fig. 18B). The steep slopes remained barren, however, and in 2004 the entire Southeast Gob Deposit was reclaimed using conventional engineering methods. The result was a large mounded deposit capped with borrowed spoil and having an engineered drainage system of terraces and slope drains, as can be seen in a 2005 aerial photograph (fig. 18C).

Shortly after the Southeast Gob Deposit was reclaimed by conventional engineering methods, the seep of AMD that previously existed at the base of the deposit near its southwest corner reappeared close to the same location (fig. 33). Twentytwo analyses of water samples were collected from this baseflow seep between September 17, 1987, and December 16, 1992. These samples, collected before reclamation, can be compared with analysis of a water sample collected from the reemerged seep on June 18, 2008 (Table 2). While the quality of the water was somewhat better in 2008 than previously (perhaps owing, in part, to heavy rainfall that had occurred in the week before sampling), it 

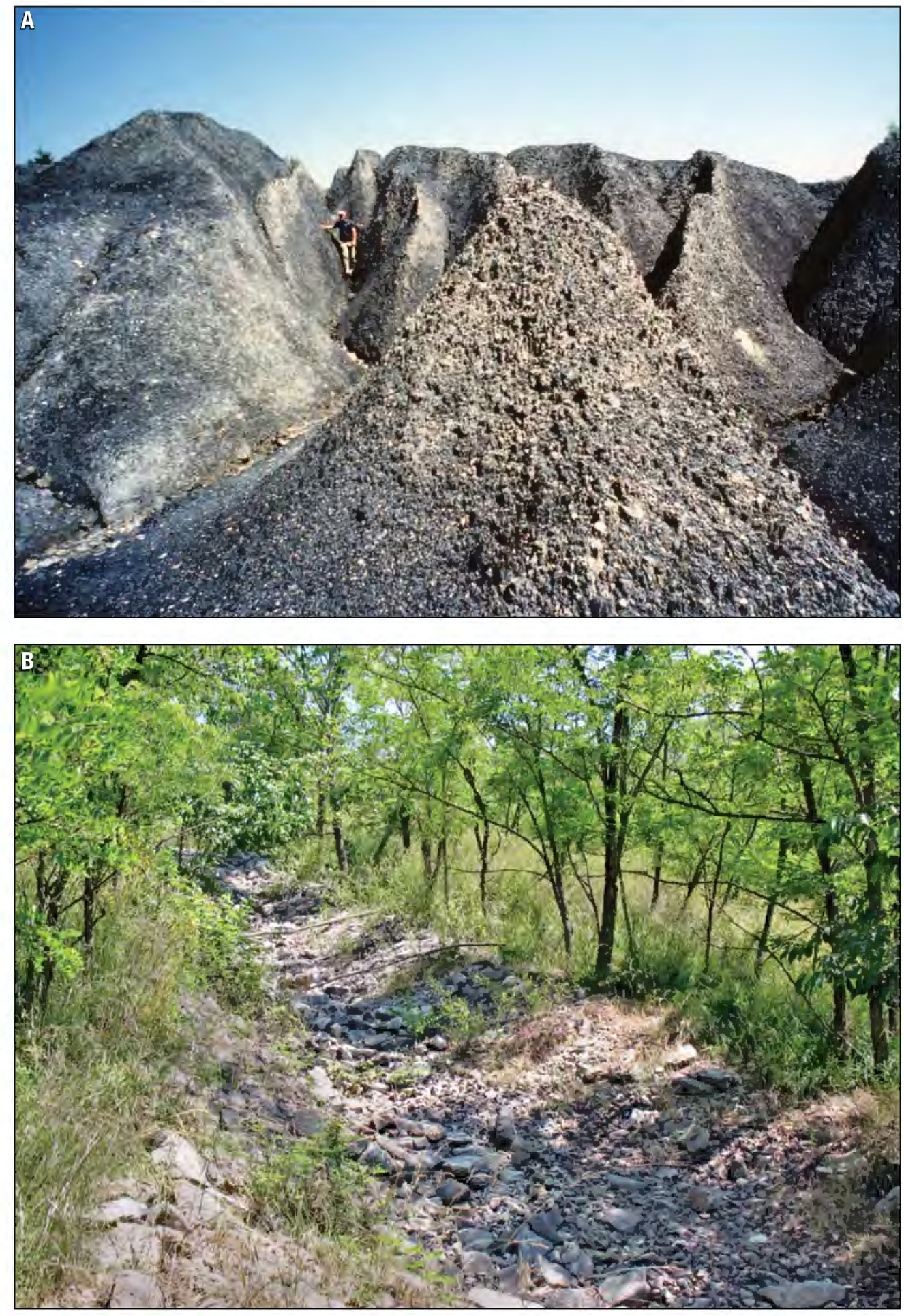

Figure 27. Photographs of the west slope of the Southwest Gob Deposit. A. Photograph taken in 1987, looking northeastward, showing the deeply eroded western slopes before reclamation. The approximate location of the photograph is indicated by the red arrow in Figure 17A. B. Photograph taken on June 18, 2008, looking northward, showing a rock-lined slope drain on the terraced and soil-capped western slope almost 15 years after reclamation. The approximate location of the photograph is indicated by the red arrow in Figure 17C. 


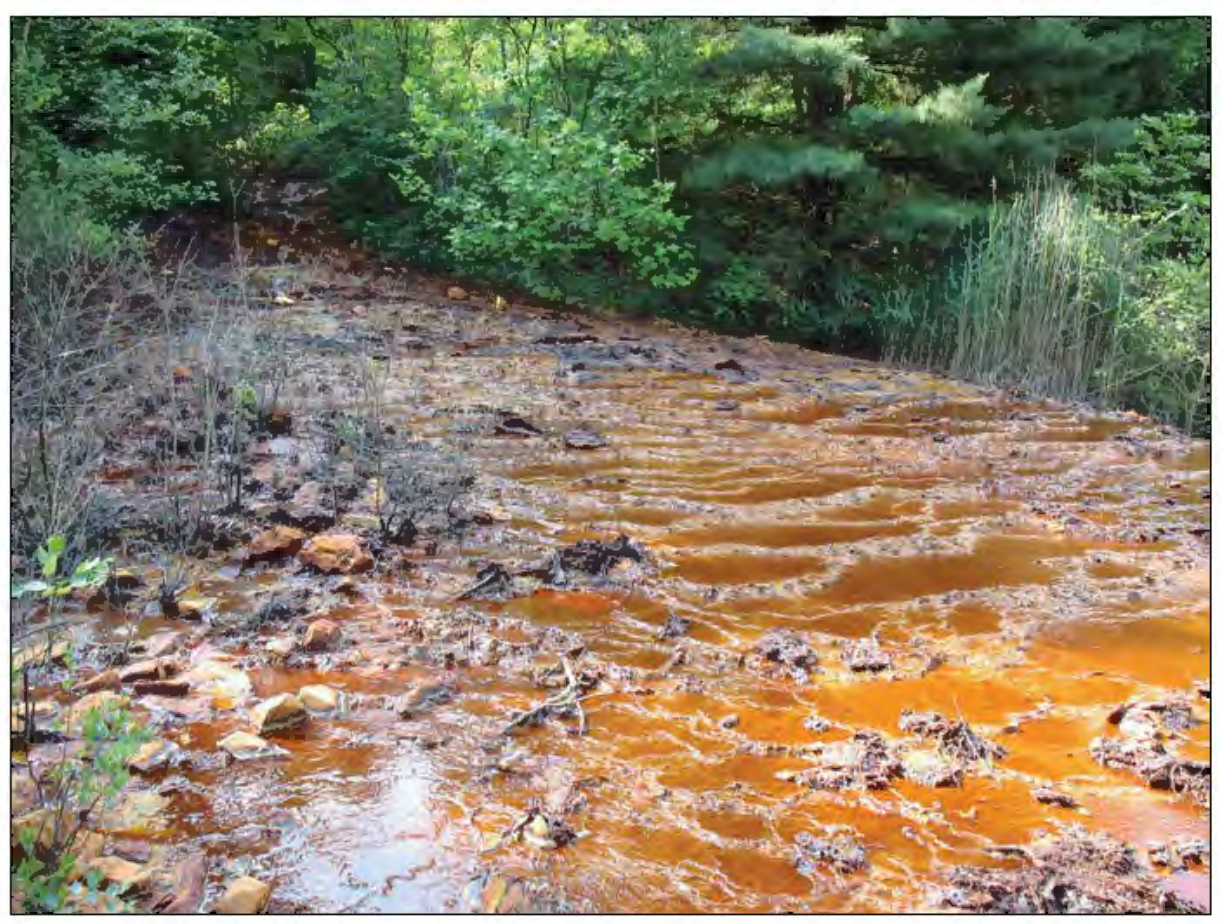

Figure 28. Photograph of the seep that discharges AMD from the Southwest Gob Deposit westward into the Highwall Tailings Deposit, showing a mass of iron oxihydroxide precipitates that had accumulated by 2008 . The spring is flowing toward the camera.

remained very contaminated. Treatment of such highly contaminated water with an anoxic limestone drain is not feasible because the drain would quickly become clogged with precipitates of iron, aluminum, and sulfate, and insufficient area is available downstream for treatment using an anaerobic wetland.

Another baseflow seep exists on the eastern edge of the Southeast Gob Deposit. While its chemistry is very similar to that of the western seep, its flow is much less. A preexisting reservoir having a surface area of about 9 acres (3.6 ha) was located less than $500 \mathrm{ft}(152.4 \mathrm{~m})$ northeast of the gob deposit (fig. 2). In the mid-1990s, the reservoir was drained and the lake bed was converted into a wetland, and in 1997, flow from the eastern seep was diverted into this wetland. Water draining from this wetland into Mud Creek is of significantly better quality than that of the eastern seep.

During the reclamation feasibility studies, a monitoring well, referred to as "Well 30C," was drilled into the water-filled workings of an abandoned underground mine in the Springfield Coal in an area that is $1,100 \mathrm{ft}(335.2 \mathrm{~m})$ downstream from the baseflow seep from the southwestern edge of the Southeast Gob Deposit (see Figure 6 for location). Four water samples were collected from Well 30C between March 3 and April 14, 1992 (Table 3). In the years following the cessation of monitoring, the portion of the well's casing that projected several feet above the ground was destroyed, and an artesian flow from the well subsequently developed (fig. 34). The analyses of water samples collected before reclamation can be compared with those of a water sample collected from the artesian spring on June 18, 2008. The quality of the water in 2008 is generally similar to its quality in 1992 (Table 3).

The artesian flow from Well 30C mixes with baseflow drainage from the Southeast Gob Deposit, including the western AMD seep, significantly diluting the concentrations of contaminants to levels that are more biologically tolerable. At a point that is $1,300 \mathrm{ft}$ (396.2 m) downstream from the artesian spring, a sample of the streamflow collected on June 18, 2008, is characterized as follows: $\mathrm{pH}, 2.7$; acidity, $1,130 \mathrm{mg} / \mathrm{L}$; sulfate, $3,920 \mathrm{mg} / \mathrm{L}$; total iron, $270 \mathrm{mg} / \mathrm{L}$; and aluminum, $59 \mathrm{mg} / \mathrm{L}$. 


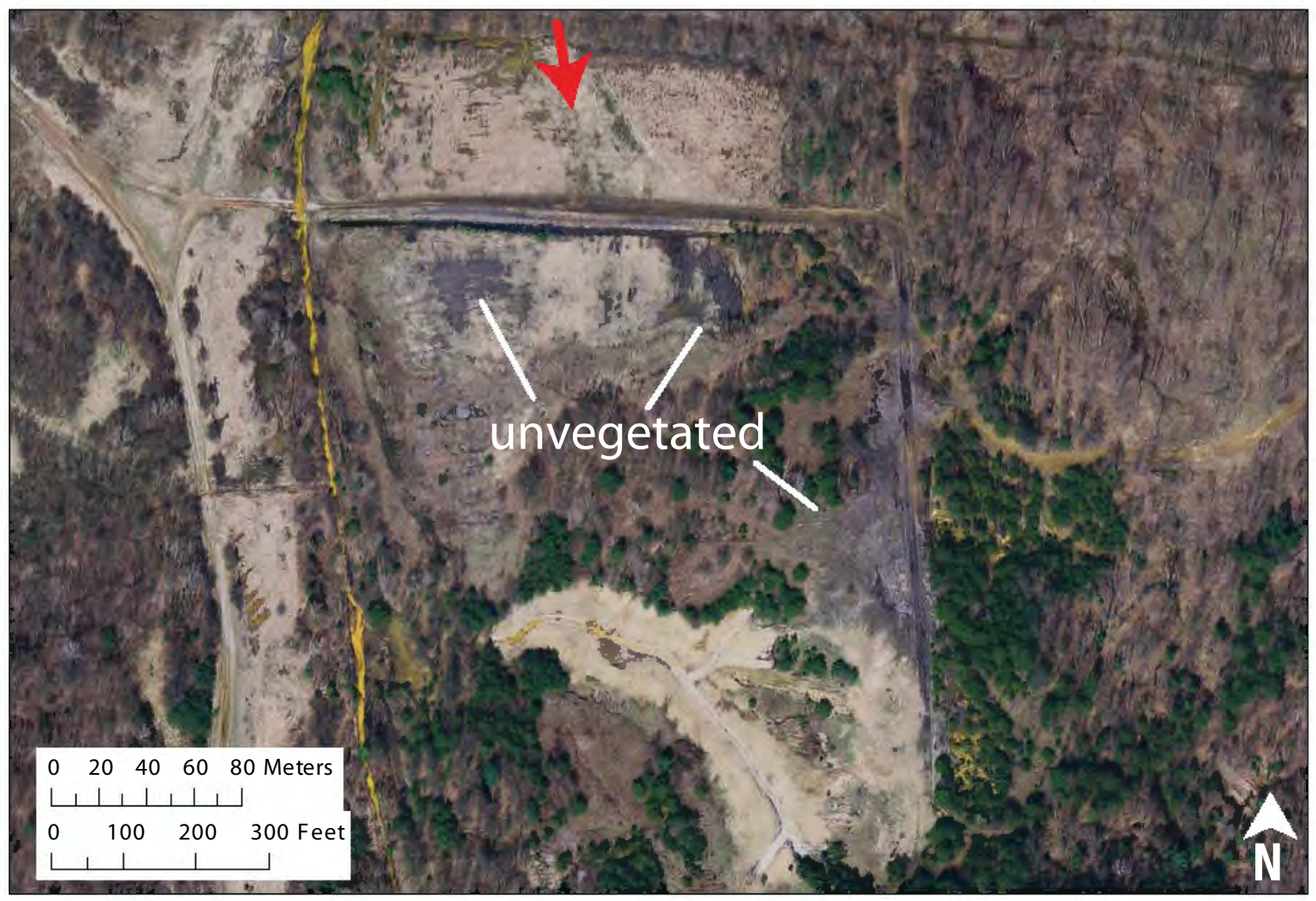

Figure 29. Vertical aerial photograph of the Northeast Gob Deposit, taken in April 2005 (leaf off). The red arrow indicates the location and direction of the photograph in Figure 30. The aerial photograph is derived from the IndianaMap Orthophotography Project.

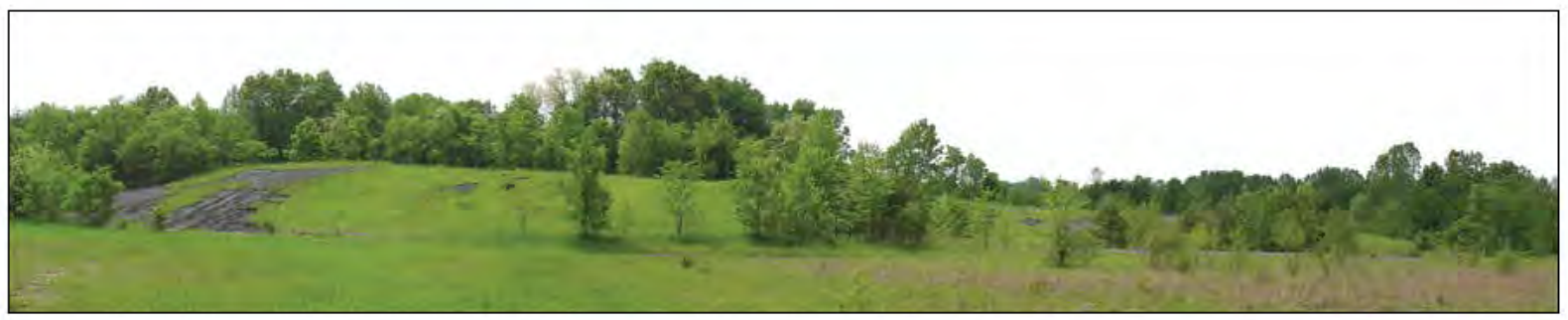

Figure 30. Panoramic photograph of the north slope of the Northeast Gob Deposit, taken on May 27, 2008. The location and direction of the photograph is indicated by the red arrow in Figure 29.

\section{Mud Creek and its tributary}

Water samples from Mud Creek and its tributary, obtained from both upstream and downstream of FTS, were collected on June 18, 2008. Although no definitive conclusions can be drawn from such a small number of samples, the analyses indicate that off-site benefits of reclamation persist almost 20 years later (Table 4). For water samples located upstream of FTS, note that changes were very small, as expected. But for samples located downstream, the sample collected in 2008 is markedly better than the average value of 17 samples collected from the same location between September 17, 1987, and December 9, 1992. For the downstream tributary of Mud Creek, which is influenced only by inflows from the Main Tailings Deposit, similar observations apply (Table 4). 


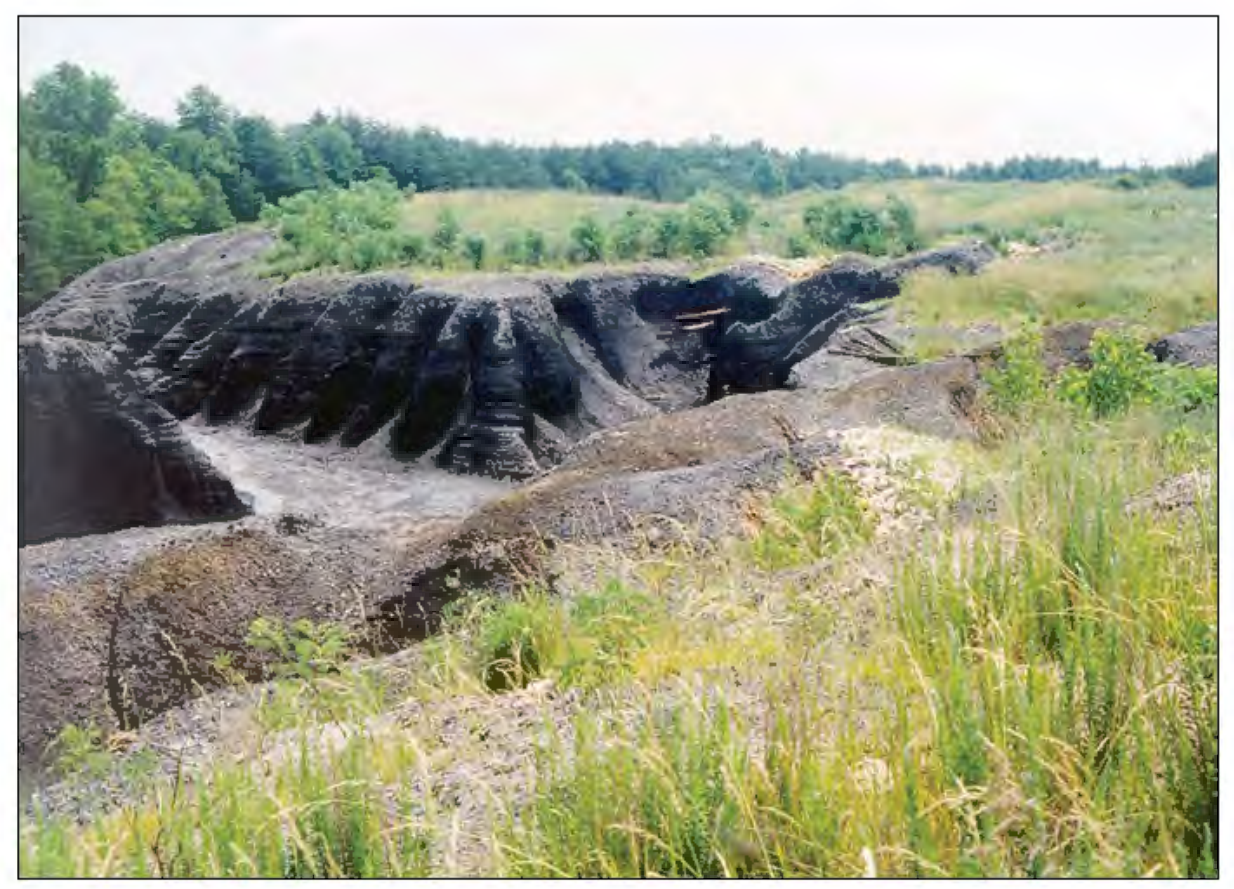

Figure 31. Photograph of the northern part of the Southeast Gob Deposit in 1992, showing the vegetative cover on the upland portion of the deposit. The shrubs and small trees are primarily black locust. The approximate location and orientation of the photograph is indicated by the red arrow in Figure 18B.

\section{SUMMARY AND CONCLUSIONS}

At the Friar Tuck Site, reclamation was directed toward establishing vegetation on barren areas, reducing erosion, creating wildlife habitat, and improving the quality of surface drainage. By the early 1990s, reclamation efforts had largely succeeded in attaining these goals. The sediment load that had formerly been delivered to Mud Creek $\left(2.1 \mathrm{lb} / \mathrm{ft}^{2}\left[0.4 \mathrm{~kg} / \mathrm{m}^{2}\right]\right.$ per year) had been greatly reduced by direct revegetation and the emplacement of check-dams (Olyphant and Harper, 1995). The yield of coarse-grained sediment was eliminated, and the yield of fine-grained sediment was reduced to as little as $0.06 \mathrm{lb} / \mathrm{ft}^{2}\left(0.3 \mathrm{~kg} / \mathrm{m}^{2}\right)$. As much as 4,400 tons $\left(4 \times 10^{6} \mathrm{~kg}\right)$ of sediment per year had been arrested (Harper and Olyphant, 1993). Revegetation also caused a large reduction in the mass of acidity entering adjacent streams. Prior to reclamation, storm runoff often had concentrations of acidity in excess of $700 \mathrm{mg} / \mathrm{L}$ during late summer and autumn. This acidic storm runoff was reduced in quantity and transformed into alkaline runoff (75 mg/L) (Olyphant and Harper, 1995).

Twenty years after the commencement of reclamation, vegetation is thriving across more than 99 percent of the FTS. Nevertheless, small barren patches (typically less than 0.2 acre [0.1 ha]) are scattered across the site. Although small and scattered, these barren patches will require constant vigilance. Particularly in areas such as the Northwest Gob Deposit, these barren patches may be especially vulnerable to erosion, which, once initiated, could cause breaches in nearby terraces. The terraces, as well as engineered drainage features on other gob deposits that were reclaimed by conventional engineering methods, are also vulnerable to breaches that might be caused by vehicular activity or by rare thunderstorms of exceptional intensity that occur after periods of drought stress when the vegetative cover is most susceptible to damage. If left unattended, any such breach could trigger the rapid disintegration of an artificial drainage network, followed soon thereafter by a loss of the soil cap and exposure of large areas of disturbed, unweathered, pyritic gob (Harper and Olyphant, 1993).

In those areas that were reclaimed by direct revegetation, a mature network of natural drainage had already developed and was left undisturbed by reclamation. The beneficial effects of long-term chemical weathering on the surficial layers of the refuse deposits have also been preserved and were left undisturbed by reclamation. In such areas, 

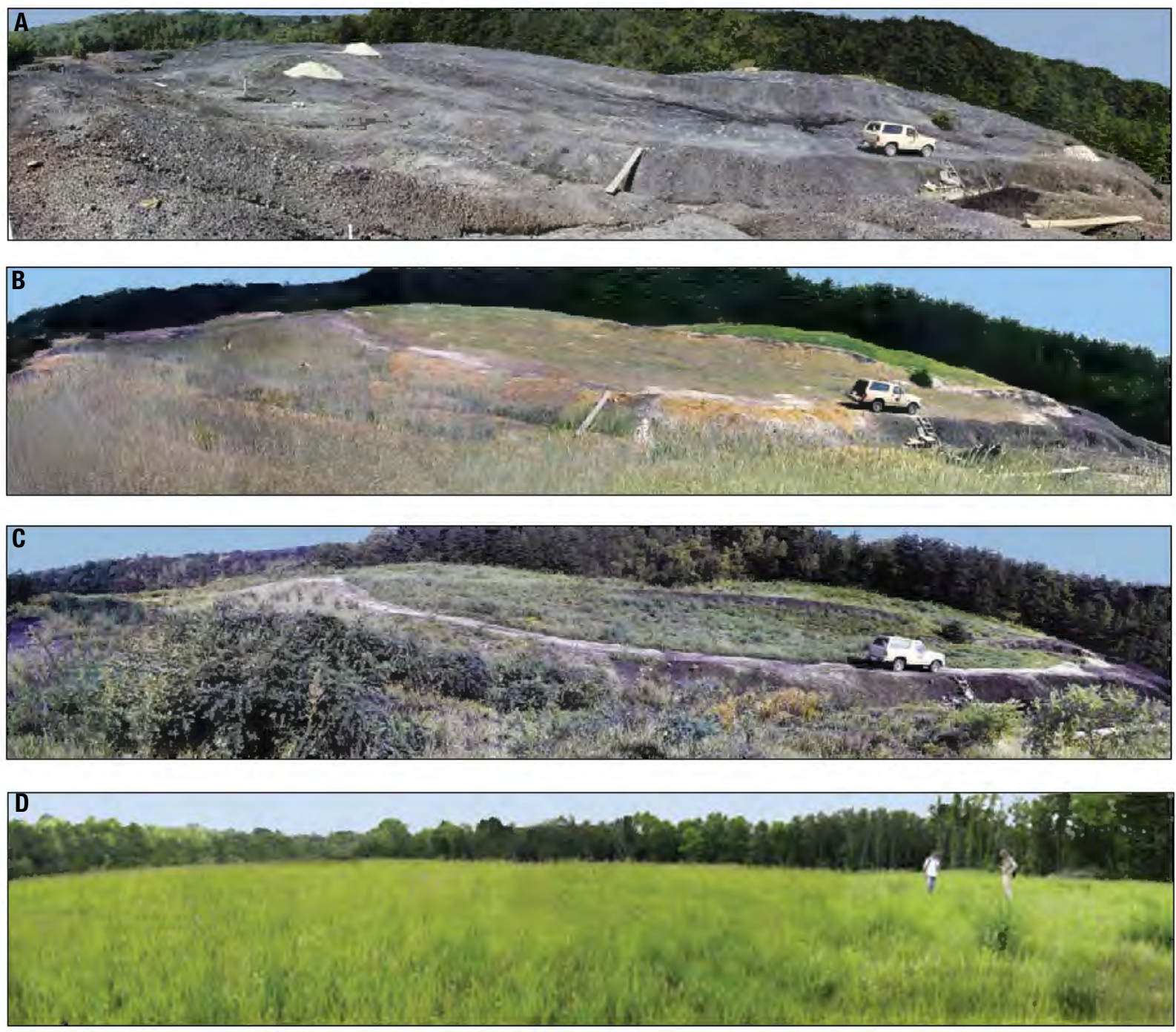

Figure 32. Panoramic photographs of the upland portion of the Southeast Gob Deposit. All the photographs were taken from approximately the same location, looking north, which is indicated by the red arrow in Figure 18A. A. September 20, 1990. B. May 30, 1991. C. September 10, 1992. D. May 27, 2008.

failures of check-dams might result in short-term increases of sediment yields, but aggressively eroding new gullies should not appear because the landscape has already developed a drainage density that is in equilibrium with prevailing climatic conditions. There may be areas where vegetation will fail because of inadequate limestone coverage, either as a result of the unevenness of the original application or loss through erosion. However, the upland portions of watersheds that have been reclaimed by direct revegetation should be relatively unaffected by failures in trunk gullies or local losses of vegetation. Thus, some of the benefits of reclamation will be preserved, even where there is failure of erosion-control structures caused by rare, extreme events, and even when there is no subsequent repair. This robustness of areas reclaimed by the method of direct revegetation represents a potentially important advantage over conventional engineering methods of reclamation (Harper and Olyphant, 1993).

Almost 20 years later, the beneficial effects of reclamation on erosion and surface-water quality continue. However, several significant problems exist that threaten the long-term sustainability of these improvements (fig. 35).

Harper and Olyphant (1993) estimated that 440 tons $\left(4 \times 10^{5} \mathrm{~kg}\right)$ of acidity were discharging from gob deposits each year through seeps and springs. In addition, they estimated that 2,200 tons $(2 \mathrm{x}$ 

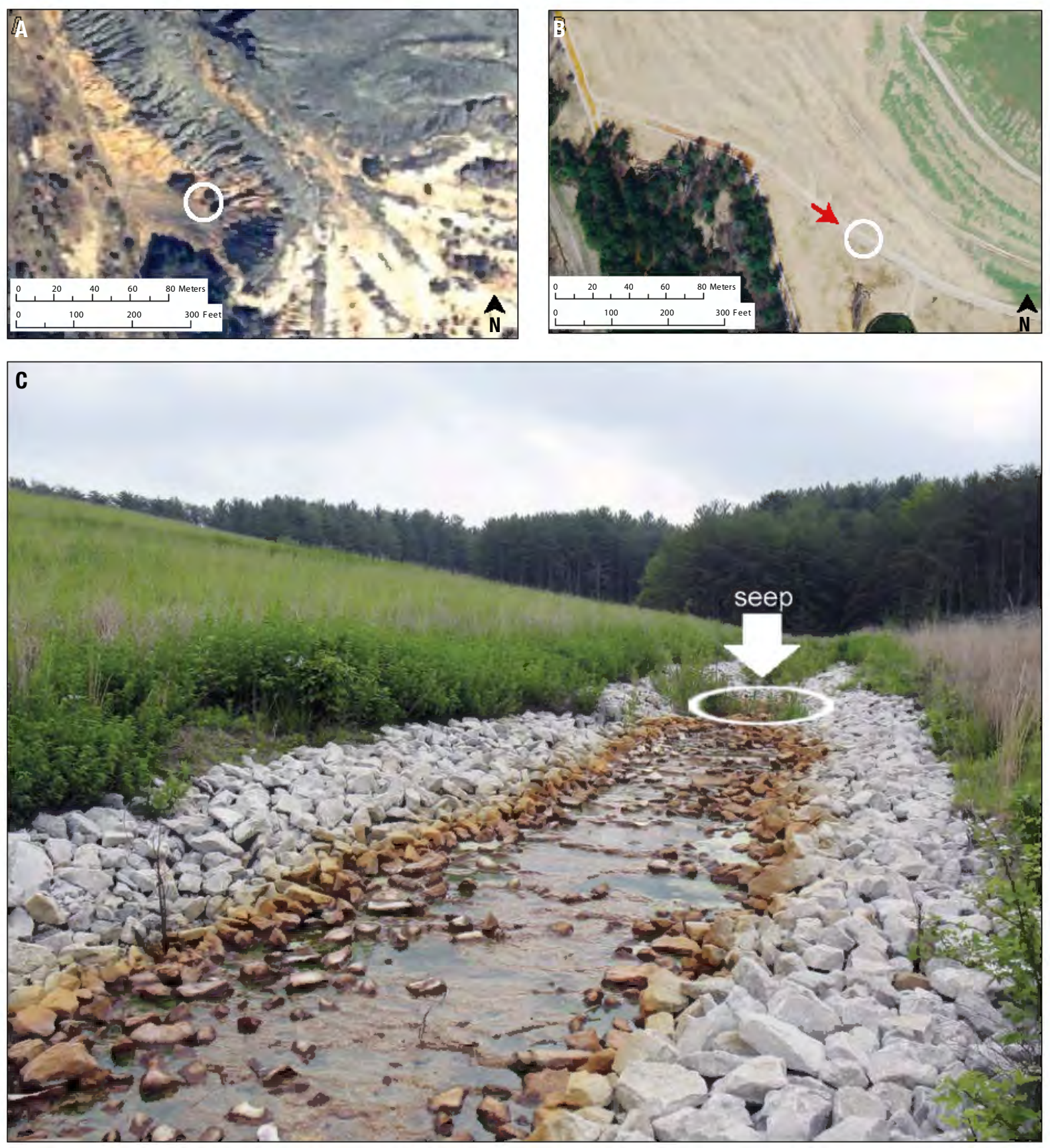

Figure 33. Photographs of a seep of acidic mine drainage at the base of the Southeast Gob Deposit. A. Vertical aerial photograph taken on April 7, 1984, showing the approximate location of the seep (white circle) before reclamation. The aerial photograph was obtained from IDNR-DOR. B. Vertical aerial photograph taken in April 2005 showing the approximate location of the seep (white circle) following reclamation. The aerial photograph is derived from the IndianaMap Orthophotography Project. C. Photograph taken on June 18, 2008. The location and orientation of the photograph is indicated by the red arrow in Figure 33B. 
Table 2. Analyses of water samples from a baseflow seep from the Southeast Gob Deposit

[For samples collected between 1987 and 1992, the upper number is the average value, and the lower numbers are the range of values.]

\begin{tabular}{|c|c|c|}
\hline & 1987 to 1992 & 2008 \\
\hline $\begin{array}{c}\text { Number of } \\
\text { samples }\end{array}$ & 22 & 1 \\
\hline pH (s.u.) & $\begin{array}{c}2.0 \\
1.8-2.6\end{array}$ & 3.0 \\
\hline acidity (mg/L) & $\begin{array}{c}23,800 \\
4,580-34,000\end{array}$ & 12,700 \\
\hline sulfate (mg/L) & $\begin{array}{c}29,300 \\
22,000-35,300\end{array}$ & 18,400 \\
\hline total iron (mg/L) & $\begin{array}{c}4,600 \\
2,300-6,000\end{array}$ & 3,200 \\
\hline aluminum (mg/L) & $\begin{array}{c}2,500 \\
760-3,600\end{array}$ & 1,400 \\
\hline
\end{tabular}

Table 3. Analyses of water samples from an artesian outflow from an abandoned underground mine in the Springfield Coal Member (Well 30C)

[For samples collected in 1992, the upper number is the average value, and the lower numbers are the range of value.]

\begin{tabular}{|c|c|c|}
\hline $\begin{array}{c}\text { Number of } \\
\text { samples }\end{array}$ & 1992 & 2008 \\
\hline pH (s.u.) & $\begin{array}{c}6.2 \\
6.1-6.4\end{array}$ & 1 \\
\hline acidity (mg/L) & $\begin{array}{c}607 \\
550-660\end{array}$ & 377 \\
\hline sulfate (mg/L) & $\begin{array}{c}257 \\
220-290\end{array}$ & 161 \\
\hline total iron (mg/L) & $\begin{array}{c}2,670 \\
2,620-2,700\end{array}$ & 2,860 \\
\hline aluminum (mg/L) & 2230 & 190 \\
$220-250$ & \\
\hline
\end{tabular}

$10^{6} \mathrm{~kg}$ ) of acidity were being discharged annually from the underground mines. Following reclamation, these springs and seeps from gob deposits and underground mines continued to discharge acid mine drainage, so that, even though 40 percent of the acid drainage associated with gob piles had been eliminated, this might represent as little as 10 percent of the total acid drainage from the site. This baseflow has its source in a vast reservoir of contamination that consists of existing dissolved solids and unreacted pyrite. Most of the remaining unreacted pyrite resides in the low-lying tailings, which have the largest volume of any of the deposits. But concentrations of acidity are far greater in the gob, because those elevated deposits have depressed water tables, and the water within their thick unsaturated zones is of the worst quality. From the volumetric standpoint, groundwater that is resident in the underground mines represents the greatest store of contamination (approximately $1.6 \times 10^{9}$ gallons ( $5 \times 10^{9}$ liters), compared with $6.9 \times 10^{8}$ gallons $\left(2.6 \times 10^{9}\right.$ liters $)$ in refuse and spoil deposits) (Harper and Olyphant, 1993).

To treat the remaining AMD seeps and springs in the future, the IDNR-DOR may consider installing passive treatment systems such as wetlands and anoxic limestone drains. But these methods all require maintenance work (such as replacement of substrates or removal of precipitates) at regular intervals into the distant future. And, depending upon particular chemical details of the AMD (such as the presence of high concentrations of aluminum), such systems might simply not be applicable at many sites.

For example, the western baseflow seep from the Southeast Gob Deposit is so highly contaminated that it is not susceptible to treatment by either an anoxic limestone drain, anaerobic wetland, or sulfate-reducing bioreactor. However, if water from this seep were mixed with less contaminated water from the artesian spring (Well 30C) that issues from the abandoned workings of the Springfield Coal, the mixture might be diluted enough to be susceptible to treatment using a downstream sulfate-reducing bioreactor. Before mixing, the water from the artesian spring might itself be improved by treatment using an anoxic limestone drain. Consideration might even be given to developing a new artesian well into abandoned underground workings of the Survant Coal; such an artesian flow already exists nearby (but on the north side of 

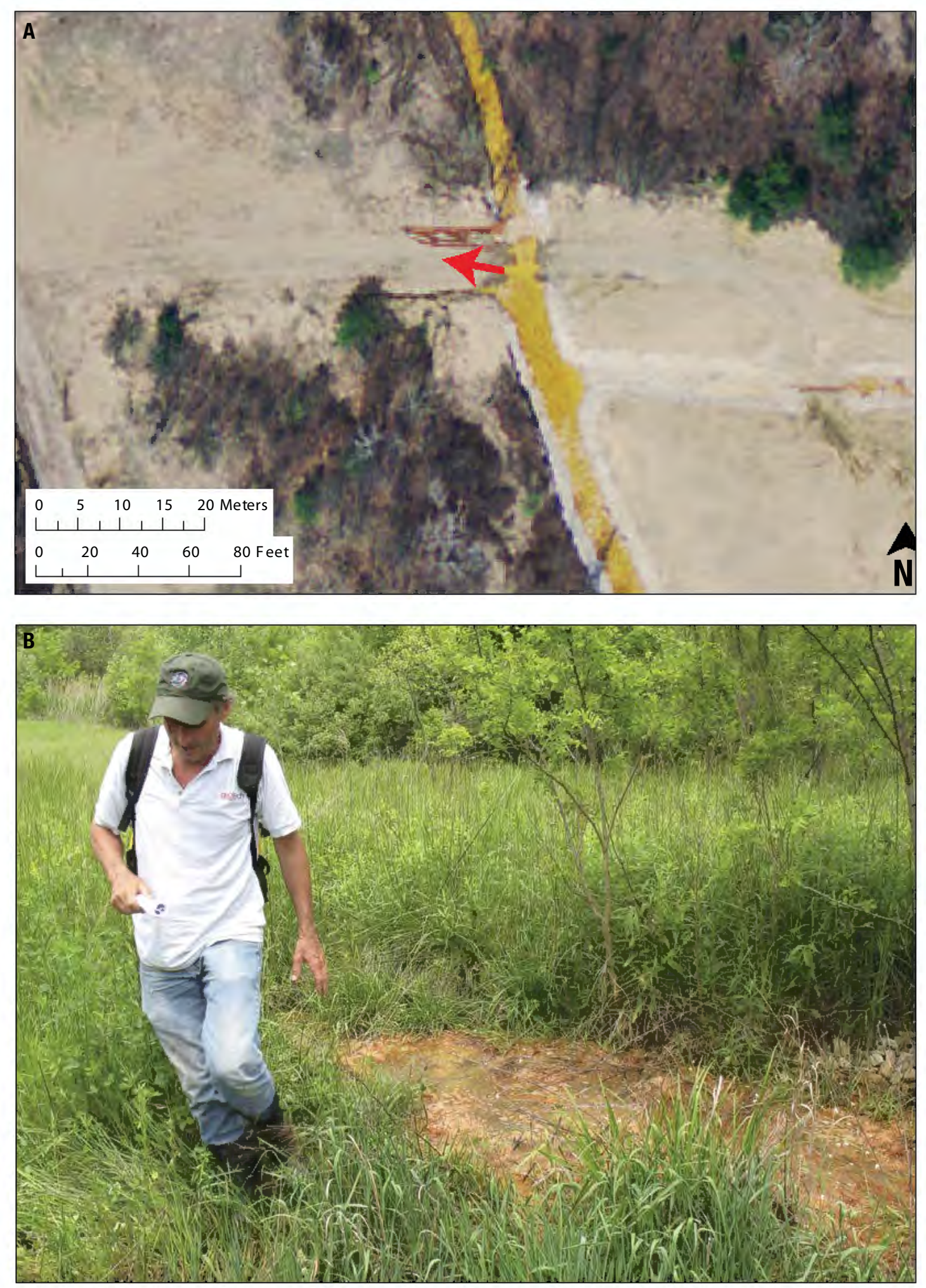

Figure 34. Photographs of an artesian spring of acid mine drainage. The spring is issuing through an incompletely plugged monitoring well (Well 30C) that was drilled into an abandoned underground coal mine in the Springfield Coal Member. See Figure 6 for the location of Well 30C.A. Vertical aerial photograph taken in April 2005. The aerial photograph is derived from IndianaMap Orthophotography Project. The red arrow indicates the location and direction of the photograph in Figure 34B. B. Photograph showing the spring on May 27, 2008. The approximate location of the photo is indicated by the red arrow in Figure 34A. 
Table 4. Analyses of water samples from Mud Creek and its tributaries

[For samples collected between 1987 and 1992, the upper number is the average value, and the lower numbers are the range of values.]

\begin{tabular}{|c|c|c|}
\hline & 1987 to 1992 & 2008 \\
\hline \multicolumn{3}{|c|}{ Mud Creek, upstream from Friar Tuck Site } \\
\hline Number of samples & 16 & 1 \\
\hline pH (s.u.) & $\begin{array}{c}6.6 \\
5.2-7.8\end{array}$ & 7.3 \\
\hline acidity (mg/L) & $\begin{array}{c}25 \\
0-248 \\
\end{array}$ & 29 \\
\hline alkalinity (mg/L) & $\begin{array}{c}111 \\
39-248\end{array}$ & 114 \\
\hline sulfate $(\mathrm{mg} / \mathrm{L})$ & $\begin{array}{c}1,100 \\
53-2,270\end{array}$ & 1,090 \\
\hline total iron $(\mathrm{mg} / \mathrm{L})$ & $\begin{array}{c}3.2 \\
<0.1-16\end{array}$ & 0.4 \\
\hline \multicolumn{3}{|c|}{ Mud Creek, downstream from Friar Tuck Site } \\
\hline Number of samples & 17 & 1 \\
\hline pH (s.u.) & $\begin{array}{c}5.2 \\
3.0-6.5\end{array}$ & 6.7 \\
\hline acidity $(\mathrm{mg} / \mathrm{L})$ & $\begin{array}{c}229 \\
6-720 \\
\end{array}$ & 52 \\
\hline alkalinity (mg/L) & $\begin{array}{c}14 \\
0-67 \\
\end{array}$ & 86 \\
\hline sulfate $(\mathrm{mg} / \mathrm{L})$ & $\begin{array}{c}1,180 \\
140-2,320\end{array}$ & 1,000 \\
\hline total iron (mg/L) & $\begin{array}{c}43 \\
1-130\end{array}$ & 9 \\
\hline \multicolumn{3}{|c|}{ Tributary of Mud Creek, upstream from Friar Tuck Site } \\
\hline Number of samples & 12 & 1 \\
\hline pH (s.u.) & $\begin{array}{c}6.7 \\
6.0-7.9\end{array}$ & 6.5 \\
\hline acidity (mg/L) & $\begin{array}{c}5 \\
0-55\end{array}$ & 29 \\
\hline alkalinity (mg/L) & $\begin{array}{c}144 \\
30-258\end{array}$ & 194 \\
\hline sulfate $(\mathrm{mg} / \mathrm{L})$ & $\begin{array}{c}952 \\
380-1,610\end{array}$ & 862 \\
\hline total iron (mg/L) & $\begin{array}{c}2 \\
<0.1-6.0 \\
\end{array}$ & 5 \\
\hline \multicolumn{3}{|c|}{ Tributary of Mud Creek, downstream from Friar Tuck Site } \\
\hline Number of samples & 15 & 1 \\
\hline pH (s.u.) & $\begin{array}{c}6.3 \\
3.4-7.6 \\
\end{array}$ & 7.3 \\
\hline acidity $(\mathrm{mg} / \mathrm{L})$ & $\begin{array}{c}30 \\
0-189 \\
\end{array}$ & 29 \\
\hline alkalinity (mg/L) & $\begin{array}{c}80 \\
0-160\end{array}$ & 136 \\
\hline sulfate $(\mathrm{mg} / \mathrm{L})$ & $\begin{array}{c}1,240 \\
572-2,730\end{array}$ & 845 \\
\hline total iron (mg/L) & $\begin{array}{c}3 \\
<0.1-20\end{array}$ & $<1$ \\
\hline
\end{tabular}

Mud Creek), where a sample obtained on June 19, 2008, was characterized by an even more favorable chemistry: $\mathrm{pH}, 6.1$; acidity, $88 \mathrm{mg} / \mathrm{L}$; alkalinity, 287 $\mathrm{mg} / \mathrm{L}$; sulfate, $1,550 \mathrm{mg} / \mathrm{L}$; total iron, $27 \mathrm{mg} / \mathrm{L}$; and aluminum, $<0.5 \mathrm{mg} / \mathrm{L}$.

If the baseflow seep from the Southeast Gob Deposit can be sufficiently diluted, an adequately large area is available along the southern bank of Mud Creek to install a bioreactor. Such integration of groundwater from flooded underground mines into reclamation designs will require more knowledge of the hydrogeologic regimes of the mines than we currently possess. But if integration could be successfully achieved at the FTS, the approach might be more widely applied at other reclamation sites across southwestern Indiana.

\section{ACKNOWLEDGMENTS}

The authors wish to recognize their colleagues at the Indiana Geological Survey; Terry West of Purdue University; students from the Department of Geological Sciences, Indiana University; and students from the Department of Earth and Atmospheric Sciences at Purdue University for their efforts in the execution of this research. The comments of John B. Comer and the reviewers were much appreciated. The efforts of the IGS graphics and cartography group, particularly Kimberly Sowder and Matt Johnson, and IGS photographers Barbara Hill and John Day were important to the dissemination of this research. A special thank you is extended to Deborah DeChurch, editor of the IGS. Funding for this project was provided by the Indiana Department of Natural Resources, Division of Reclamation.

\section{REFERENCES}

Bayless, E. R., and Olyphant, G. A., 1993, Acid-generating salts and their relationship to the chemistry of groundwater and storm runoff at an abandoned mine site in southwestern Indiana, U.S.A.: Journal of Contaminant Hydrology, v. 12, p. 313-328.

Branam, T. D., and Harper, D., 1994, Tabulated analytical data for water samples from the Friar Tuck site: Indiana Geological Survey Open-File Study 94-13, 177 p.

Brooks, G. A., Olyphant, G. A., and Harper, D., 1991, Application of electromagnetic techniques in a survey of contaminated groundwater at an abandoned 


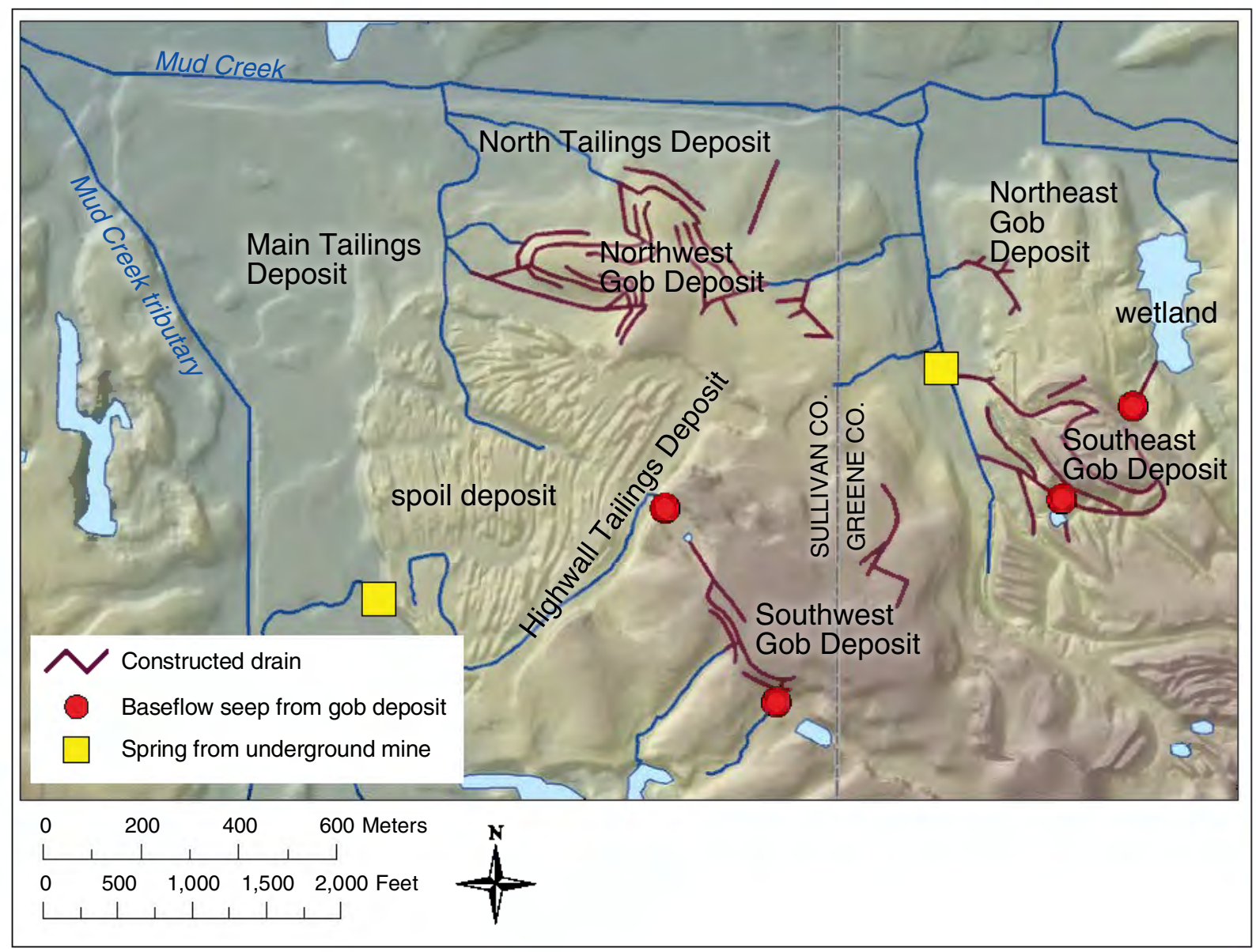

Figure 35. Map showing locations of major acidic baseflow seeps from gob deposits and springs from underground mines, as of 2008. Other smaller baseflow seeps are not shown.

mine complex in southwestern Indiana: Environmental Geology, v. 18, no. 1, p. 39-47.

Corbett, D. M., and Agnew, A. F., 1968, Coal mining effect on Busseron Creek Watershed, Sullivan County, Indiana: Bloomington, Ind., Indiana University Water Resources Research Center Report of Investigation No. 2, 185 p.

Harper, D., Hartke, E. J., Olyphant, G. A., and West, T. R., 1988, Research and reclamation feasibility studies at the Friar Tuck site, Sullivan and Greene Counties, Indiana, in First annual report to the Indiana Division of Reclamation: Indiana Geological Survey, 161 p., unpubl.

Harper, D., Hartke, E. J., Olyphant, G. A., and West, T. R., 1989, Research and reclamation feasibility studies at the Friar Tuck site, Sullivan and Greene Counties, Indiana, in Second annual report to the Indiana Division of Reclamation, part A-chemical analyses and hydrologic investigations: Indiana Geological Survey, 145 p., unpubl.

Harper, D., and Olyphant, G. A., 1993, Direct revegetation of abandoned coal-refuse deposits in Indiana-its ef- fects on hydrology, chemistry, and erosion: Indiana Geological Survey Open-File Study 93-09, 37 p.

Nawrot, J. R., Sandusky, J., and Klimstra, W. B., 1988, Acid soils reclamation-applying the principals: Proceedings of Mine Drainage and Surface Mine Reclamation Conference, U.S. Bureau of Mines, Pittsburgh, Pa., April 17-22, 1988.

Olyphant, G. A., and Harper, D., 1995, Effects of direct revegetation on hydrology, chemistry, and erosion of abandoned mine refuse: Geomorphology, v. 11, p. 261-273.

Thomas, T. C., 1978, An analysis of abandoned coal mines in west central Indiana and suggested reclamation techniques (with an inventory of active strip mines): Terre Haute, Ind., West Central Indiana Economic Development District, Inc., 231 p.

Weber, L. A., 2012, Indiana's Coal Mine Information System, in Comer, J. B., Effects of abandoned mine land reclamation on ground and surface water qualityresearch and case histories from Indiana: Indiana Geological Survey Special Report 72, p. 19-30. 
INDIANA GEOLOGICAL SURVEY SPECIAL REPORT 72 


\title{
Effectiveness of Emerging Reclamation Methods at an Abandoned Mine Land Site in Pike County, Indiana
}

\author{
Tracy D. Branam, Denver Harper, Ronald T. Smith, and Shawn C. Naylor \\ Indiana Geological Survey
}

\begin{abstract}
The Midwestern Mine Site in Pike County, Indiana, is an abandoned coal-mine site that was characterized by multiple sources of acid mine drainage, including three acidic springs from shallow underground mines and acidic runoff and baseflow from a deposit of coarse-grained refuse (gob) produced during coal preparation. In places, groundwater was extremely acidic ( $\mathrm{pH}$ as low as 1.1), and water discharging from the site had a $\mathrm{pH}$ of about 3 and concentrations of total mineral acidity and iron as great as $901 \mathrm{mg} / \mathrm{L}$ and $330 \mathrm{mg} / \mathrm{L}$, respectively. A multifaceted approach to reclamation has been employed that began with the use of pond ash from a nearby coal-burning power plant for structural fill and fixated scrubber sludge to cap the gob deposit (1995-1996). Subsequently, the three acidic springs have been treated by a variety of methods including an anoxic limestone drain (1996), an anoxic limestone drain with downgradient constructed wetland (1997), and a sulfate-reducing bioreactor cell (2008).
\end{abstract}

Use of the fixated scrubber sludge greatly reduced or eliminated the infiltration of rainwater into the gob deposit that led to a reduction in acid generation and the leaching of toxic metals from the gob. Toxic trace elements that were leached from the underside of the fixated scrubber sludge by groundwater that was resident in the gob deposit were rapidly attenuated, presumably by dilution, precipitation, and sorption. Since reclamation, most of the baseflow has been derived from the flooded underground mine workings, the largest of which has been effectively treated by one of the anoxic limestone drains.

During the first 5 years after its installation, the wetland was partially effective in neutralizing water from one of the acidic springs, but its effectiveness decreased over time. The wetland was more effective at sulfate removal in summer than in winter. During periods of very low flow, the sulfate-reducing bioreactor cell effectively removes sulfate and iron from the third acid mine drainage spring, but during periods of high flow, most of the water flows untreated across the surface of the cell, so that it does not

Note: Spreadsheets containing the water-quality data on which this paper is based are located on the CD-ROM in the back of this book. 
react with the bioreactor's substrate. It has not yet been determined whether bacterial activity can be sustained during winter months, and it is still too early to evaluate the sulfate-reducing bioreactor cell's overall performance. Compared with conditions before reclamation, concentrations of acidity and iron at the Midwestern Mine Site's outlet have been reduced more than 69 percent and more than 75 percent, respectively, through 2007 (to concentrations less than $280 \mathrm{mg} / \mathrm{L}$ and less than $83 \mathrm{mg} / \mathrm{L}$, respectively). Before reclamation, alkalinity was absent in the outflow from the site, but after reclamation, alkalinity concentrations as high as $140 \mathrm{mg} / \mathrm{L}$ have sometimes been present. Thus, the multifaceted approach, including the installation of emerging passive treatment systems and the strategic emplacement of coal combustion byproducts that has been applied between 1995 and 2008 significantly improved the quality of water discharging from the Midwestern Mine Site.

\section{INTRODUCTION}

Many abandoned mine land (AML) sites have multiple sources and pathways of acid mine drainage (AMD) that cannot be remediated by a single method. In such settings, a variety of reclamation methods may be needed to treat water before it is discharged from the site. The Midwestern Mine Site (MMS) in south-central Indiana is such a site. Before its reclamation, the MMS was discharging AMD with high concentrations of dissolved metals into an unnamed tributary of the Patoka River. The AMD was derived from a deposit of coarse-grained coal-preparation refuse (referred to as "gob") and from two small abandoned underground mines. In 1995, the Indiana Department of Natural Resources, Division of Reclamation (IDNR-DOR), commenced a multifaceted approach to reclamation of the MMS using a variety of emerging methods. Initially, highwall pits and the gob deposit were reclaimed by using coal combustion byproducts (CCBs) as structural fill and capping materials. This was the first time that CCBs were used in Indiana for the reclamation of abandoned surface mines or deposits of coal-preparation refuse. Subsequently, attempts were made to treat several springs and seeps from the underground mines by installing an anoxic limestone drain (ALD) in 1996, an ALD and an associated wetland in 1997, and a sulfate-reducing bioreactor in 2008.
In a series of investigations, the MMS has been intermittently studied from 1995 to the present by personnel of the Indiana Geological Survey (IGS) (Harper and Olyphant, 1999; Branam and others, 1999a, 1999b, 2001, 2005, 2010; Olyphant and others, 2002; Smith and others, 2003; Spindler and Olyphant, 2004; Naylor and others, 2010; Smith, 2012 [this volume]). Water samples have been analyzed for commonly used indicators of acid mine drainage, including acidity, alkalinity, iron, sulfate, aluminum, and $\mathrm{pH}$. Because of concerns regarding the susceptibility of CCBs to the leaching of toxic trace elements into groundwater, samples were also analyzed for antimony, arsenic, barium, boron, cadmium, calcium, chloride, chromium, copper, fluoride, lead, magnesium, manganese, mercury, molybdenum, nickel, nitrate, potassium, selenium, silicon, silver, sodium, strontium, and zinc. In this paper we summarize past investigations and present new data regarding the effects of using various materials and methods on the physical hydrology and hydrochemistry of the site.

\section{SITE LOCATION AND MINING HISTORY}

The MMS is located in section 22, T. 2 S., R. 7 W., Pike County, Indiana. The site is about 120 acres (49 hectares [ha]) in extent. In the vicinity of the MMS, 
mining by both surface and underground methods was conducted in the Springfield Coal Member (Petersburg Formation, Carbondale Group, Desmoinesian Series) at depths down to $55 \mathrm{ft}$ (16.8 $\mathrm{m})$. Small underground mines that were developed in the area included the Hartwell No. 1 Mine (active from 1895 to 1908), an unidentified mine referred to as “Unknown Mine No. 68” (1901 to 1905), and the undifferentiated Hartwell No. 2 and Caledonia No. 2 Mines (1908 to 1918) (fig. 1). The three mines underlie about 107 acres (43 ha) within and adjacent to the MMS. Large surface mines that operated in the vicinity included the Blackfoot No. 2 Mine (active from 1928 to 1950), the Ayrshire No. 1 Mine (1939 to 1953), and the undifferentiated Regal No. 1 and Midwestern No. 1 Mines (1978 to 1983).

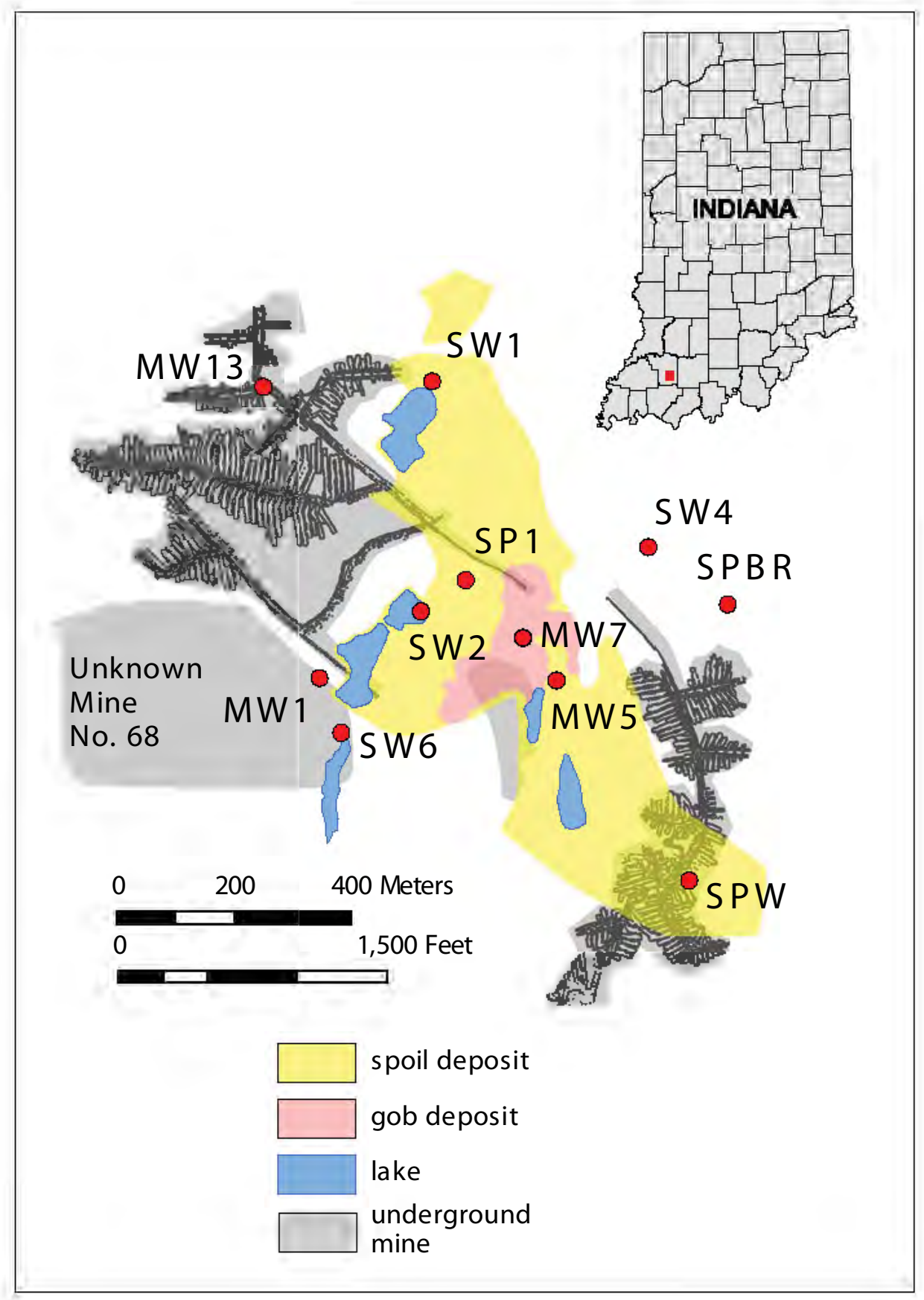

Figure 1. Map showing extent of gob and spoil deposits left by surface mining and their relationship to surface water-filled impoundments and the workings of abandoned, water-filled underground mines that underlie the MMS. Pre-reclamation monitoring sites associated with the mine aquifer are also shown (red points). 
The deposit of gob is located near the center of the MMS (fig. 1). Inspection of historical aerial photos indicates that deposition of the gob commenced sometime between 1966 and 1978. The gob was deposited along a wide haulage road and adjacent to deposits of displaced overburden (referred to as "spoil") that had been created sometime between 1939 and 1949 as part of the Ayrshire No. 1 Mine. The total extent of the gob deposit is about 7.9 acres (3.2 ha).

\section{CONDITIONS BEFORE RECLAMATION}

As part of the investigations that took place before reclamation began, a monitoring network was established at the MMS (fig. 1, Table 1). The network included wells into the flooded workings of the Hartwell No. 1 Mine (MW13) and the unmined barrier pillar between the Hartwell No. 1 Mine and Unknown Mine No. 68 (MW1). Water levels were also monitored in the highwall pit lakes adjacent to the underground mines (SW1, SW2, SW6), as was the discharge of springs that issued from the Hartwell No. 1 Mine (SP1) and the Hartwell No. 2 Mine (SPBR). Together, these monitoring stations were used to evaluate the hydrology of the aquifers associated with the abandoned underground mines. Another spring issued from the Hartwell No. 2 Mine (SPW), and water from this spring was sampled during an earlier evaluation of the site by a consultant (ATEC, 1984).

The spring that discharged from the Hartwell No. 1 Mine (SP1) was acidic, having a $\mathrm{pH}$ less

Table 1. Descriptions of monitoring sites

[The pre-reclamation period was from April 10 to October 25, 1995. The reclamation period was from January 11 to 0 ctober $7,1996$. The postreclamation period was from November 18, 1996, to June 13, 2007. "SW" designates a pond or stream; "SP" designates a spring; "MW" designates a monitoring well. See Figures 1 and 2 for locations.]

\begin{tabular}{|c|c|c|c|c|}
\hline Site ID & Description & $\begin{array}{l}\text { Pre- } \\
\text { reclamation }\end{array}$ & $\begin{array}{l}\text { Post- } \\
\text { reclamation }\end{array}$ & $\begin{array}{c}\text { Depth of screened } \\
\text { interval (meters) }\end{array}$ \\
\hline SW1 & Pond in final-cut pit & $\mathrm{X}$ & & \\
\hline SW2 & Pond in final-cut pit & $x$ & & \\
\hline SW4 & Stream at outlet to reclamation site & $\mathrm{X}$ & & \\
\hline SW6 & Pond in final-cut pit & $x$ & $x$ & \\
\hline SW8 & V-notch weir at outlet to reclamation site & & $x$ & \\
\hline SP1 & Spring issuing from underground mine & $x$ & & \\
\hline SP2A & Outlet from passive anoxic limestone drain (ALD) & & $\mathrm{X}$ & \\
\hline SPW & $\begin{array}{l}\text { Spring issuing from underground mine; } \\
\text { input to wetland }\end{array}$ & & & \\
\hline SPBR & $\begin{array}{l}\text { Spring issuing from underground mine; } \\
\text { input to SRBC }\end{array}$ & & $x$ & \\
\hline MW1 & Well in unmined coal bed & $x$ & $\mathrm{X}$ & 15.2 \\
\hline MW5 & Well in spoil deposit & $\mathrm{X}$ & & 5.5 \\
\hline MW5S & Well in spoil deposit below FSS & & $\mathrm{X}$ & 2.1 \\
\hline MW5M & Well in spoil deposit below FSS & & $\mathrm{X}$ & 4.3 \\
\hline MW5D & Well in spoil deposit below FSS & & $\mathrm{X}$ & 7.9 \\
\hline MW7 & Well in gob deposit & $\mathrm{X}$ & & 3.7 \\
\hline MW7S & Well in soil above gob deposit and FSS & & $\mathrm{X}$ & 1.2 \\
\hline MW7D & Well in gob deposit below FSS & & $\mathrm{X}$ & 4.1 \\
\hline MW8 & $\begin{array}{l}\text { Well in pond ash that filled a final-cut pit (SW2), } \\
\text { overlain by FSS }\end{array}$ & & $\mathrm{X}$ & 6.1 \\
\hline MW9 & Well in pond ash that filled final-cut pit (SW1) & & $\mathrm{X}$ & 11.3 \\
\hline MW13 & Well in void of underground mine & $\mathrm{X}$ & $\mathrm{X}$ & 30.5 \\
\hline
\end{tabular}


than 5.1 and total dissolved solids (TDS) averaging 2,033 mg/L (SP1, Table 2). SPBR was also acidic, having a $\mathrm{pH}$ less than 3 and average TDS greater than $3,700 \mathrm{mg} / \mathrm{L}$.

Monitoring indicated that the highest elevation of the water level in the Hartwell No. 1 mine aquifer was fixed by the elevation of an overflow point associated with one of the ponds (SW2). Also, the potentiometric level of the mine aquifer, as determined from the water levels in MW1 and MW13, was the same as the water level in a pond south of the MMS (SW6). This constituted evidence of a direct hydraulic connection between the ponds and the wells screened in the Hartwell No. 1 underground mine (Harper and Olyphant, 1999). To verify the hydrologic connection between the ponds and the wells, a pump test was conducted on October 4 and 5, 1995, that involved pumping water from pond SW2 while measuring the water levels in the monitoring wells, the water levels in the other ponds, and the flow from SP1. Throughout the test, the water level in the pond south of the MMS (SW6) responded identically to the level in the pond that was being pumped (SW2). Water levels in both MW1 and MW13 showed an immediate but dampened response to the pumping. The hydraulic head of the spring (SP1) did not show any response during pumping. A pond in the northern part of the MMS (SW1) also showed no response to the pumping (Harper and Olyphant, 1999). From mine maps, the total area of the Hartwell No. 1 and Unknown Mine No. 68 was estimated to be about $3.3 \times 10^{6} \mathrm{ft}^{2}\left(3.07 \times 10^{5} \mathrm{~m}^{2}\right)$. These measurements allowed us to calculate that the storativity of the mine aquifer, where storativity is a dimensionless quantity defined as the volume of water released from storage per unit decline in hydraulic head in the aquifer, per unit area of the aquifer. The calculated storativity of the Hartwell No. 1 Mine and Unknown Mine No. 68 was calculated to be about $2 \times 10^{3-}$. Typical values of storativity for confined aquifers range from $5 \times 10^{5-}$ to $5 \times 10^{3-}$ (Freeze and Cherry, 1979, p. 60), so that our calculated value for the mine aquifer is near the upper end of the range for such aquifers.

In addition to installations associated with the underground-mine aquifers, monitoring wells were also installed in the gob deposit (MW7, fig. 1) and in spoil that was immediately adjacent to the gob (MW5, fig. 1). A weir was placed in the channel of the stream that discharged surface water from the site (SW4), allowing continuous monitoring of the site's total discharge. The groundwater in the gob pile was extremely acidic ( $\mathrm{pH}$ less than 1.8 , average TDS greater than $23,000 \mathrm{mg} / \mathrm{L})(\mathrm{MW} 7$, Table 2 ), as was the water discharging from the MMS, which had a $\mathrm{pH}$ approximately equal to 3 , an iron concentration of about $240 \mathrm{mg} / \mathrm{L}$, and TDS averaging 3,650 mg/L (SW4, Table 2).

\section{RECLAMATION METHODS AND MATERIALS}

\section{Coal combustion byproducts}

Materials that are suitable for cover and fill are often scarce in surface-mined areas, and mine spoil, which is abundant, often has undesirable physical and chemical properties. In contrast, coal combustion byproducts (CCBs) are abundant and are being generated at an ever-increasing rate. However, the use of CCBs for reclaiming abandoned mine sites raises concerns that hazardous chemical constituents might leach from these materials and contaminate groundwater.

Under contract with IDNR-DOR, a private consulting company, ATEC Associates, Inc., determined that the MMS was well situated to demonstrate the potential beneficial use of coal combustion ash and fixated scrubber sludge (FSS) for the reclamation of AML sites (ATEC, 1984). Both of these CCBs were available from the Petersburg Generating Station of Indianapolis Power and Light (IPL), which is located about 17 miles $(27.3 \mathrm{~km})$ by highway from the reclamation site, and arrangements were made with IPL to contribute these CCBs to the MMS reclamation effort. FSS is a mixture of fly ash, gypsiferous flue-gas desulphurization sludge, and lime $(\mathrm{CaO})$ and it is highly alkaline. Because it undergoes pozzolanic reactions and develops a very low hydraulic conductivity and high shear strength (Soliman, 1990), FSS was used to cap the gob deposit and prevent vertical infiltration of rainwater into the underlying gob deposit. The long-term chemical stability of such an FSS cap was addressed in an earlier laboratory investigation, which concluded that deterioration of such a cap should not be a concern (Branam and others, 1999a). Given the severely impaired conditions at the MMS, the use of CCBs was therefore judged to be beneficial to the site's overall restoration and to the mitigation of its acidic discharge. 


\begin{tabular}{|c|c|c|c|c|c|c|c|}
\hline Site ID & $\begin{array}{c}\mathrm{SO}_{4} \\
(\mathrm{mg} / \mathrm{L})\end{array}$ & $\begin{array}{c}\mathrm{Fe} \\
(\mathrm{mg} / \mathrm{L})\end{array}$ & $\begin{array}{l}\text { Potential } \\
\text { acidity* }^{\star} \\
\text { (mg/L) }\end{array}$ & $\begin{array}{l}\text { Alkalinity } \\
\text { (mg/L) }\end{array}$ & $\begin{array}{c}\mathrm{pH} \\
\text { (s.u.) }\end{array}$ & $\begin{array}{c}\mathrm{SpC} \\
(\mu \mathrm{mhos} / \mathrm{cm})\end{array}$ & $\begin{array}{c}\text { TDS } \\
(\mathrm{mg} / \mathrm{L})\end{array}$ \\
\hline \multicolumn{8}{|c|}{ Pre-reclamation water chemistry (April-August 1995) } \\
\hline $\begin{array}{l}S P 1 \\
n=3\end{array}$ & $\begin{array}{c}1,380 \\
1,220-1,540\end{array}$ & $\begin{array}{c}76 \\
65-82\end{array}$ & $\begin{array}{c}369 \\
193-720\end{array}$ & $\begin{array}{c}11 \\
0-34\end{array}$ & $\frac{-}{3.7-5.1}$ & $\begin{array}{c}1,958 \\
1,927-1,988\end{array}$ & $\begin{array}{c}2,033 \\
1,900-2,100\end{array}$ \\
\hline $\begin{array}{l}\text { MW1 } \\
n=3\end{array}$ & $\begin{array}{c}907 \\
740-990\end{array}$ & $\begin{array}{c}16 \\
13-21\end{array}$ & $\begin{array}{c}35 \\
23-55\end{array}$ & $\begin{array}{c}110 \\
70-140\end{array}$ & $\frac{-}{6.0-6.1}$ & $\begin{array}{c}1,695 \\
1,643-1,737\end{array}$ & $\begin{array}{c}1,500 \\
1,300-1,600\end{array}$ \\
\hline $\begin{array}{l}\text { MW5 } \\
n=3\end{array}$ & $\begin{array}{c}2,690 \\
2,520-2,880\end{array}$ & $\begin{array}{c}273 \\
250-290\end{array}$ & $\begin{array}{c}885 \\
825-979\end{array}$ & $\begin{array}{c}0 \\
0-0\end{array}$ & $\frac{-}{3.0-3.4}$ & $\begin{array}{c}3,477 \\
3,390-3,640\end{array}$ & $\begin{array}{c}4,133 \\
3,700-4,600\end{array}$ \\
\hline $\begin{array}{l}\text { MW7 } \\
n=3\end{array}$ & $\begin{array}{c}12,967 \\
8,200-17,500\end{array}$ & $\begin{array}{c}4,333 \\
2,800-5,700\end{array}$ & $\begin{array}{c}11,732 \\
7,507-15,817\end{array}$ & $\begin{array}{c}0 \\
0-0\end{array}$ & $\overline{1.1-1.8}$ & $\begin{array}{c}22,093 \\
13,700-32,800\end{array}$ & $\begin{array}{c}23,333 \\
12,000-35,000\end{array}$ \\
\hline $\begin{array}{l}\text { MW13 } \\
n=2\end{array}$ & $\begin{array}{c}93 \\
35-150\end{array}$ & $\begin{array}{c}3 \\
3-4\end{array}$ & $\begin{array}{c}7 \\
6-10\end{array}$ & $\begin{array}{c}355 \\
260-450\end{array}$ & $\frac{-}{6.1-6.7}$ & $\begin{array}{c}854 \\
585-1,123\end{array}$ & $\begin{array}{c}685 \\
490-880\end{array}$ \\
\hline $\begin{array}{l}\text { SW1 } \\
n=4\end{array}$ & $\begin{array}{c}186 \\
94-240\end{array}$ & $\begin{array}{c}6 \\
1-18\end{array}$ & $\begin{array}{c}104 \\
11-350\end{array}$ & $\begin{array}{c}0 \\
0-0\end{array}$ & $\frac{-}{4.0-5.3}$ & $\begin{array}{c}460 \\
392-508\end{array}$ & $\begin{array}{c}338 \\
230-420\end{array}$ \\
\hline $\begin{array}{l}\text { SW2 } \\
n=4\end{array}$ & $\begin{array}{c}550 \\
370-690\end{array}$ & $\begin{array}{c}34 \\
6-80\end{array}$ & $\begin{array}{c}278 \\
92-523\end{array}$ & $\begin{array}{c}0 \\
0-0\end{array}$ & $\frac{-}{2.6-3.1}$ & $\begin{array}{c}1,479 \\
930-1,758\end{array}$ & $\begin{array}{c}848 \\
600-970\end{array}$ \\
\hline $\begin{array}{l}\text { SW4 } \\
n=4\end{array}$ & $\begin{array}{c}2,353 \\
2,280-2,500\end{array}$ & $\begin{array}{c}243 \\
190-330\end{array}$ & $\begin{array}{c}714 \\
451-901\end{array}$ & $\begin{array}{c}0 \\
0-0\end{array}$ & $\frac{-}{2.8-3.1}$ & $\begin{array}{c}3,215 \\
3,030-3,350\end{array}$ & $\begin{array}{c}3,650 \\
3,300-3,900\end{array}$ \\
\hline $\begin{array}{l}\text { SW6 } \\
n=1\end{array}$ & 1,570 & 5 & 87 & 0 & 3.3 & 2,470 & 2,400 \\
\hline \multicolumn{8}{|c|}{ Postreclamation water chemistry for comparable monitoring sites (November 1996-June 2007) } \\
\hline SP2A & $\begin{array}{c}1,463 \\
722-1,680 \\
n=20\end{array}$ & $\begin{array}{c}86 \\
64-120 \\
n=18\end{array}$ & $\begin{array}{c}159 \\
122-217 \\
n=20 \\
\end{array}$ & $\begin{array}{c}267 \\
218-323 \\
n=20 \\
\end{array}$ & $\begin{array}{c}-\overline{-} \\
6.0-7.3 \\
n=20\end{array}$ & $\begin{array}{c}2,531 \\
1,836-2,810 \\
n=20\end{array}$ & $\begin{array}{c}2,632 \\
2,336-3,000 \\
n=17\end{array}$ \\
\hline $\begin{array}{l}\text { MW1 } \\
n=9\end{array}$ & $\begin{array}{c}731 \\
620-1,000\end{array}$ & $\begin{array}{c}7 \\
4-12\end{array}$ & $\begin{array}{c}13 \\
8-24\end{array}$ & $\begin{array}{c}160 \\
120-190\end{array}$ & $\overline{6.1-7.1}$ & $\begin{array}{c}1,544 \\
990-2,030\end{array}$ & $\begin{array}{c}1,367 \\
1,000-1,800\end{array}$ \\
\hline MW5S & $\begin{array}{c}2,745 \\
2,175-4,740 \\
n=17\end{array}$ & $\begin{array}{c}275 \\
46-482 \\
n=17\end{array}$ & $\begin{array}{c}524 \\
110-913 \\
n=17\end{array}$ & $\begin{array}{c}110 \\
0-330 \\
n=16\end{array}$ & $\begin{array}{c}-\overline{-} \\
4.3-6.8 \\
n=17\end{array}$ & $\begin{array}{c}3,726 \\
2,872-4,950 \\
n=17\end{array}$ & $\begin{array}{c}5,019 \\
3,500-9,100 \\
n=15\end{array}$ \\
\hline MW5M & $\begin{array}{c}3,655 \\
2,680-5,840 \\
n=18\end{array}$ & $\begin{array}{c}626 \\
340-1,400 \\
n=17\end{array}$ & $\begin{array}{c}1646 \\
880-4160 \\
n=18\end{array}$ & $\begin{array}{c}0 \\
0-0 \\
n=18\end{array}$ & $\begin{array}{c}- \\
3.4-4.7 \\
n=18\end{array}$ & $\begin{array}{c}4,115 \\
3,002-6,080 \\
n=18\end{array}$ & $\begin{array}{c}5,966 \\
3,950-10,000 \\
n=17\end{array}$ \\
\hline MW5D & $\begin{array}{c}3,347 \\
2,688-4,130 \\
n=11\end{array}$ & $\begin{array}{c}537 \\
369-880 \\
n=10 \\
\end{array}$ & $\begin{array}{c}1190 \\
730-1850 \\
n=10 \\
\end{array}$ & $\begin{array}{c}0 \\
0-0 \\
n=11\end{array}$ & $\begin{array}{c}-\overline{-} \\
3.8-4.4 \\
n=11\end{array}$ & $\begin{array}{c}3,930 \\
2,971-4,890 \\
n=11\end{array}$ & $\begin{array}{c}5,775 \\
4,700-6,800 \\
n=8\end{array}$ \\
\hline MW7D & $\begin{array}{c}8,119 \\
2,192-15,900 \\
n=20\end{array}$ & $\begin{array}{c}2,578 \\
785-5,700 \\
n=19 \\
\end{array}$ & $\begin{array}{c}5,839 \\
1,560-13,413 \\
n=20\end{array}$ & $\begin{array}{c}0 \\
0-0 \\
\mathrm{n}=20\end{array}$ & $\begin{array}{c}- \\
1.6-4.0 \\
n=20\end{array}$ & $\begin{array}{c}8,890 \\
4,103-20,800 \\
n=20\end{array}$ & $\begin{array}{c}15,122 \\
6,405-29,000 \\
n=17\end{array}$ \\
\hline MW8 & $\begin{array}{c}2,117 \\
1,650-8,241 \\
n=20\end{array}$ & $\begin{array}{c}2 \\
0-6 \\
n=19\end{array}$ & $\begin{array}{c}20 \\
0-70 \\
n=20\end{array}$ & $\begin{array}{c}55 \\
29-123 \\
n=20\end{array}$ & $\begin{array}{c}- \\
6.2-8.7 \\
n=20\end{array}$ & $\begin{array}{c}3,014 \\
2,516-3,269 \\
n=20\end{array}$ & $\begin{array}{c}4,192 \\
2,686-6,823 \\
n=17\end{array}$ \\
\hline MW9 & $\begin{array}{c}1,687 \\
1,370-1,972 \\
n=18\end{array}$ & $\begin{array}{c}145 \\
16-197 \\
n=18 \\
\end{array}$ & $\begin{array}{c}266 \\
32-371 \\
n=18 \\
\end{array}$ & $\begin{array}{c}234 \\
104-460 \\
n=18 \\
\end{array}$ & $\begin{array}{c}-\overline{5.6}-7.1 \\
n=18\end{array}$ & $\begin{array}{c}2,740 \\
1,832-3,172 \\
n=18\end{array}$ & $\begin{array}{c}3,009 \\
2,400-3,600 \\
n=17\end{array}$ \\
\hline $\begin{array}{l}\text { MW13 } \\
n=9\end{array}$ & $\begin{array}{c}137 \\
110-210\end{array}$ & $\begin{array}{c}4 \\
1-7\end{array}$ & $\begin{array}{c}8 \\
2-15\end{array}$ & $\begin{array}{c}448 \\
420-480\end{array}$ & $\begin{array}{c}- \\
6.4-7.3\end{array}$ & $\begin{array}{c}1,026 \\
798-1,212\end{array}$ & $\begin{array}{c}913 \\
660-1,000\end{array}$ \\
\hline $\begin{array}{l}\text { SW6 } \\
n=9\end{array}$ & $\begin{array}{c}1,152 \\
89-2,260\end{array}$ & $\begin{array}{c}10 \\
1-20\end{array}$ & $\begin{array}{c}96 \\
1-265\end{array}$ & $\begin{array}{c}2 \\
0-12\end{array}$ & $\frac{-}{2.9-6.3}$ & $\begin{array}{c}1,653 \\
292-3,205\end{array}$ & $\begin{array}{c}1,762 \\
180-3,600\end{array}$ \\
\hline SW8 & $\begin{array}{c}1,579 \\
625-2,360 \\
n=20\end{array}$ & $\begin{array}{c}28 \\
2-83 \\
n=19\end{array}$ & $\begin{array}{c}87 \\
4-280 \\
n=20\end{array}$ & $\begin{array}{c}32 \\
0-140 \\
n=20\end{array}$ & $\begin{array}{c}--- \\
2.7-7.0 \\
n=20\end{array}$ & $\begin{array}{c}2,448 \\
1,408-3,389 \\
n=20\end{array}$ & $\begin{array}{c}2,452 \\
1,600-3,600 \\
n=17\end{array}$ \\
\hline
\end{tabular}


Table 2 (opposite page). Average values, ranges of values, and numbers of samples analyzed (n) at selected water-monitoring sites

[See Table 1 for descriptions of sites. See Figures 1 and 2 for locations of sites.]

*Alkalinity and acidity were determined using standard methods, with measured acidity being compared to calculated acidity using the equation described by Watzlaf and others (2004) for quality assurance purposes. These comparisons showed good agreement between measured and calculated acidity for all samples containing no alkalinity, generating typical deviations of less than 5 percent. When alkalinity was present, the difference between measured and calculated acidity was more commonly in the $10-30 \%$ range for net acid samples and up to $80 \%$ for net alkaline samples. Because of this discrepancy, calculated potential acidity was used for all water samples to define geochemical characterizations.

A product referred to as "pond ash" was used as structural fill, primarily to backfill the final-cut pits left by earlier surface mining. The pond ash used at the MMS is a mixture of fly ash (approximately 60 percent) and bottom ash (approximately 40 percent) that was disposed of in slurry cells ("ponds") located near the power plant. Prior to its use at MMS, the pond ash from the Petersburg Generating Station had been exposed to the atmosphere for an indeterminate period, during which it may have been subject to leaching. Hence, some of its leaching potential may have decreased owing to the natural processes of weathering that occurred prior to its use as structural fill at the MMS.

Emplacement of CCBs at the MMS commenced on Oct. 10, 1995. Water was first drained from the finalcut pits, and pond ash was used to fill the pits and to provide structural fill in other low-lying areas (fig. 2). The pond ash was emplaced across about 23 acres (9.3 ha). The FSS was emplaced across about 22 acres (8.9 ha), centered primarily over the gob deposit. Emplacement of the pond ash and FSS was completed by late autumn 1996. The FSS is approximately $5 \mathrm{ft}(1.5 \mathrm{~m})$ thick, with the minimum thickness being approximately $3 \mathrm{ft}(0.9 \mathrm{~m})$. A total of approximately $590,000 \mathrm{yd}^{3}\left(451,000 \mathrm{~m}^{3}\right)$ of CCBs were used (Branam and others, 2005). The CCBs were, in turn, covered with approximately $3 \mathrm{ft}(0.9 \mathrm{~m})$ of soil, consisting of a mixture of natural soils and mine spoil, to promote vegetation. Turkey manure was applied extensively as a fertilizer. A network of limestone riprap drainage channels was installed across the reclaimed area to capture surface runoff and direct it into a series of sediment ponds at the outlet from the site (fig. 2) to reduce the turbidity of water that was being discharged from the site.

\section{Anoxic limestone drain (ALD)}

An ALD consists of a trench filled with limestone and covered by an impervious cap that prevents the introduction of oxygen and the escape of carbon dioxide. An ALD works when the limestone dissolves and generates sufficient alkalinity to neutralize active acidity $\left(\mathrm{H}^{+}\right)$and, if there is enough excess alkalinity, to neutralize potential acidity. Potential acidity refers to the $\mathrm{H}^{+}$that would be released by oxidation of metals, which, in the case of $\mathrm{AMD}$, are mostly $\mathrm{Fe}^{+2}$. Anoxic limestone drain failures occur most commonly when mineral precipitates clog the drain or coat the limestone so that limestone dissolution is prevented. Oxygen entering the ALD will rapidly convert $\mathrm{Fe}^{+2}$ to $\mathrm{Fe}^{+3}$ and cause iron oxyhydroxides to precipitate, which may armor the limestone and prevent dissolution or clog the drain. The AMD that is being treated must be undersaturated with respect to gypsum $\left(\mathrm{CaSO}_{4} \cdot 2 \mathrm{H}_{2} \mathrm{O}\right)$ and dissolution of the limestone must not produce concentrations of dissolved calcium that are high enough to precipitate gypsum and clog the ALD. Also, ALDs are only suitable for AMD having low concentrations of aluminum, because aluminum will precipitate at low $\mathrm{pH}$ as aluminum hydroxides, resulting in clogging and drain failure.

An ALD was constructed in October 1996 to capture water flowing from the AMD spring that issued from the flooded workings of the abandoned underground Hartwell No. 1 Mine (SP1, fig. 1). Treatment with an ALD was considered appropriate because the spring's water contained no dissolved oxygen, ferric iron, or aluminum, and its potential acidity was low enough to be neutralized by alkalinity that would be generated within the ALD. The ALD is $250 \mathrm{ft}(76.2 \mathrm{~m})$ long, $30 \mathrm{ft}(9.1 \mathrm{~m})$ wide at the top, and $5 \mathrm{ft}(1.5 \mathrm{~m})$ deep. It is entrenched in pond ash, filled with Number 2 limestone, covered with a plastic liner, and buried beneath FSS and soil. Although aluminum, calcium, and ferric iron are all present in the pond ash, leaching of these elements was not expected to occur because they are in a chemically stable form within the ash. The plastic liner was used to 


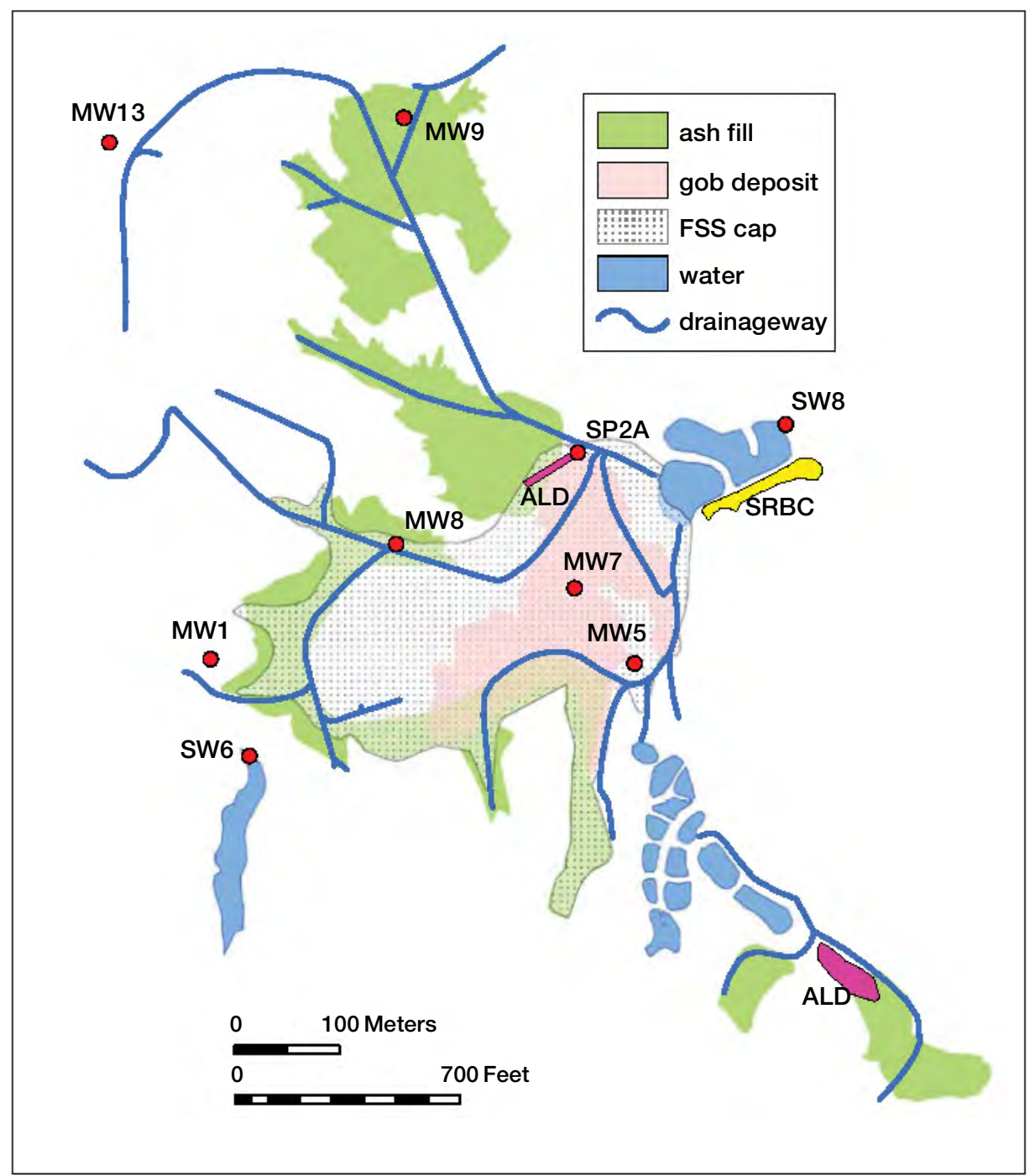

Figure 2. Map showing the extent of the gob deposit, FSS, and pond ash, together with the locations of sediment ponds and engineered drainageways constructed during reclamation. Also shown are the ALDs, the constructed wetland consisting of 13 cells, the sulfate-reducing bioreactor cell (SRBC), and the locations of postreclamation monitoring sites (red points). A cluster of wells including MW5S, MW5M, and MW5D was installed at pre-reclamation site MW5; Wells MW7S and MW7D were installed at pre-reclamation site MW7. In those areas where the green pattern for pond ash and the stippled pattern for FSS are superimposed, FSS overlies pond ash.

prevent the AMD from contacting the FSS because calcium in the FSS might otherwise leach into the water, causing precipitation of gypsum and plugging of the ALD. The ALD is equipped with a P-trap at its outlet, so that the mine water never comes into contact with the atmosphere until after it has been neutralized by the dissolving limestone. The treated water flows from the ALD (fig. 3) at a new postreclamation spring designated SP2A (Table 1; fig. 2). A flume was installed at the discharge point of the ALD so that its discharge could be continuously monitored. The success of the design is indicated by the fact that the ALD was still functioning as intended in 2009.

\section{Constructed wetland}

In 1997, a wetland (fig. 4) was constructed to passively treat AMD seeping from the flooded workings of the abandoned underground Hartwell No. 2 Mine (SPW, fig. 1). The seep first flows into a buried ALD and then through a series of 13 wetland cells. The series of cells include an anaerobic compost wetland, an oxidation pond, and a series of aerobic wetlands containing substrates that are composed of various combinations of hay, turkey manure, soil, wood-chip compost, fixated scrubber sludge, lime, and pond ash. The type and composition of each wetland cell is summarized in 


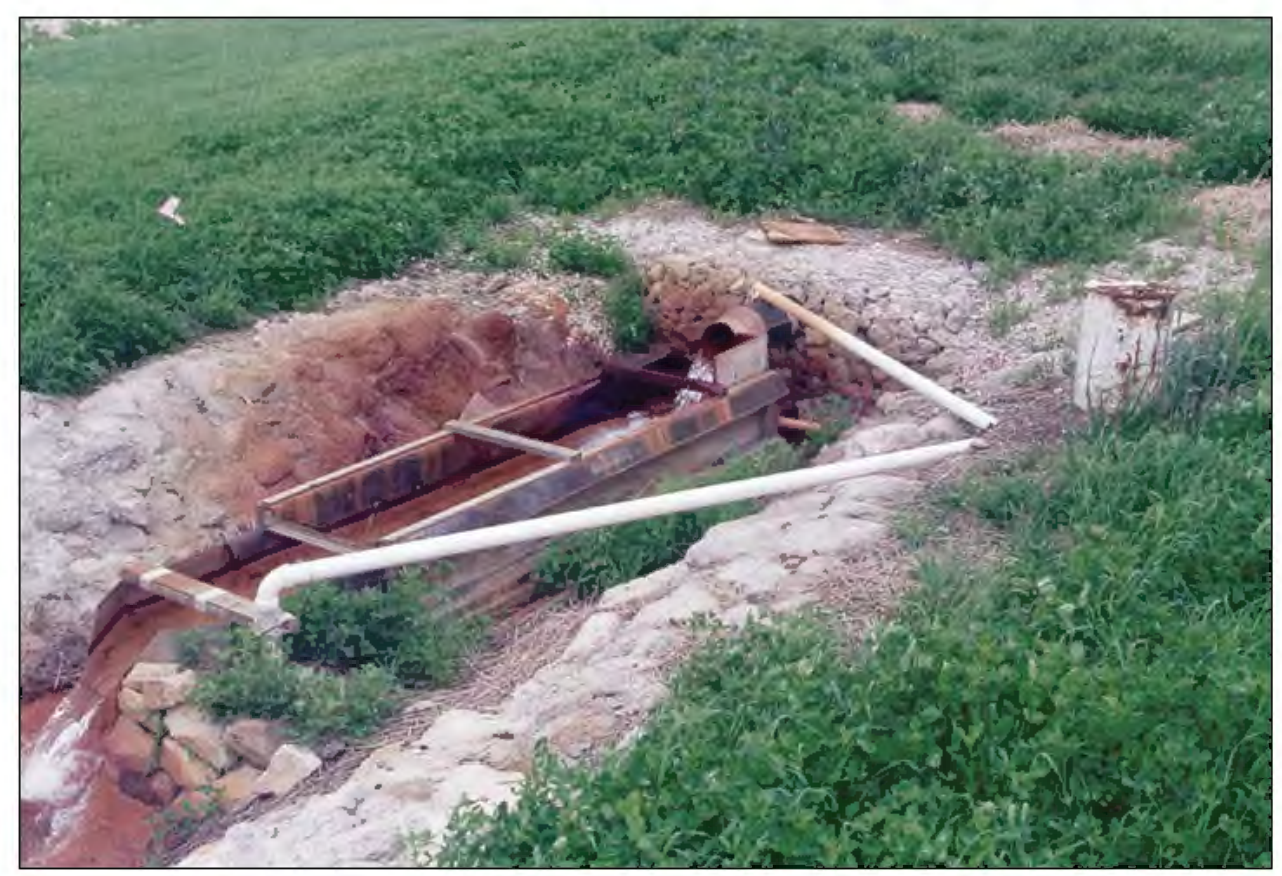

Figure 3. Photograph of outlet (SP2A) of anoxic limestone drain (ALD) constructed to capture drainage from spring SP1 (fig. 1). Water comes mostly from the flooded underground workings of the Hartwell No. 1 mine located on the Midwestern Mine Site. See Figure 2 for location of the ALD and SP2A.

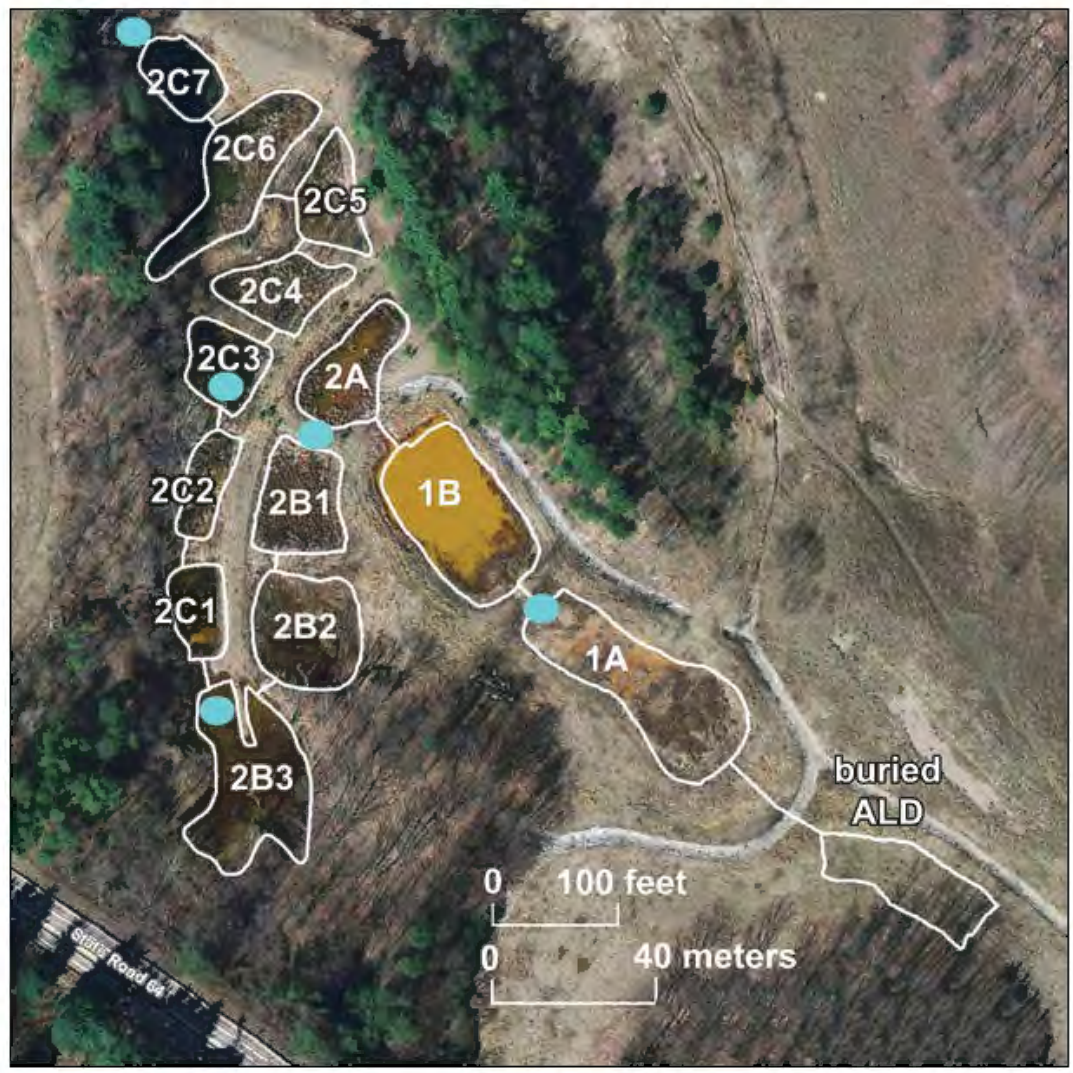

Figure 4. Aerial photograph of the constructed wetland showing locations of component cells and monitoring sites (blue dots). See Figure 2 for the location of the wetland. 
Table 3. After passing through the ALD, the mine seepage flows into the anaerobic compost wetland (Cell 1A), whose water level is maintained at a constant elevation by discharge through a standpipe. Water discharged through the standpipe is aerated in a steep limestone-lined channel before entering Cell 1B, where the water level is kept constant by a riser. The remainder of the wetland, where cells are arranged in a serpentine pattern, has only a slight gradient until water is discharged from Cell 2C7. The wetland was constructed in an area formerly occupied by a highwall pond containing acidic water that accumulated mostly from the underground Hartwell No. 2 mine (ATEC, 1984), but the wetland was sealed off from the original bed of the highwall pond by a layer of compacted pond ash. Within the wetland, berms and baffles were constructed of mine spoil and lined with limestone riprap. The surface area of the entire wetland is 2.5 acres $(1.0 \mathrm{ha})$.

At the time that the spring was captured and directed into an anoxic limestone drain, samples of its water had not been analyzed since 1984 (ATEC, 1984), and lack of access by the Indiana Geological Survey after construction of the ALD made it impossible to subsequently conduct direct sampling of the spring's water. As AMD passes through the wetland, dissolved chemical species (including toxic metals) precipitate and are sequestered in the wetland sediments. Sulfate and ferrous iron are removed from solution in the wetland cells, and along with the production of bicarbonate by sulfate reduction and by oxidation of organic carbon, this brings about a net increase in alkalinity (Smith and others, 2003).

\section{Sulfate-reducing bioreactor cell}

In 2008, a sulfate-reducing bioreactor cell (SRBC) was installed to capture and treat flow from an AMD spring (SPBR, fig. 1) that issues from the flooded workings of the Hartwell No. 2 Mine (fig. 5). The SRBC consists of a trench that is approximately $400 \mathrm{ft}(122 \mathrm{~m})$ long and $40 \mathrm{ft}(12.2 \mathrm{~m})$ wide, and is filled with a mixture of straw $(50 \%$ by volume), wood chips ( $30 \%$ by volume), compost ( $10 \%$ by volume), and crushed limestone $(10 \%$ by volume). The trench is about $7 \mathrm{ft}(2.1 \mathrm{~m})$ deep at the northeast end, but less than $3 \mathrm{ft}(0.9 \mathrm{~m})$ deep at the southwest end, where the treated water discharges into an adjacent sediment pond (Branam

Table 3. Type and composition of cells within the constructed wetland

\begin{tabular}{|c|c|c|c|}
\hline Cell & Type & Composition & Notes \\
\hline $1 \mathrm{~A}$ & $\begin{array}{l}\text { anaerobic } \\
\text { wetland }\end{array}$ & $\begin{array}{l}\text { manure to hay ratio }=4: 1 \\
\text { lime }=10 \%\end{array}$ & $\begin{array}{c}\text { surface covered with pea gravel and sparse } \\
\text { Typha }\end{array}$ \\
\hline $1 \mathrm{~B}$ & oxidation pond & manure to hay ratio $=4: 1$ & shallow end is vegetated with Typha \\
\hline $2 A$ & \multirow{11}{*}{ aerobic wetland } & \multirow{2}{*}{ manure to soil ratio $=1: 3$} & Typha in shallow areas \\
\hline $2 \mathrm{~B} 1$ & & & \\
\hline 2B2 & & \multirow{3}{*}{$\begin{array}{l}\text { manure to soil ratio }=1: 3 \\
\text { ponded ash base }\end{array}$} & \multirow[b]{4}{*}{ overgrown with Typha } \\
\hline $2 \mathrm{~B} 3$ & & & \\
\hline $2 \mathrm{C} 1$ & & & \\
\hline $2 \mathrm{C} 2$ & & $\begin{array}{c}\text { wood chip compost }=70 \% \\
\text { fixated scrubber sludge } \\
\text { and lime }=30 \% \\
\text { ponded ash base }\end{array}$ & \\
\hline $2 \mathrm{C} 3$ & & $\begin{array}{c}\text { manure to soil ratio }=1: 3 \\
\text { ponded ash base }\end{array}$ & Typha in shallow areas \\
\hline $2 \mathrm{C} 4$ & & \multirow{3}{*}{ manure to soil ratio $=1: 2$} & \multirow{2}{*}{ overgrown with Typha } \\
\hline $2 \mathrm{C5}$ & & & \\
\hline $2 \mathrm{CC} 6$ & & & Typha in shallow areas \\
\hline $2 \mathrm{C} 7$ & & manure to soil ratio $=1: 1.5$ & sparse Typha along fringes \\
\hline
\end{tabular}




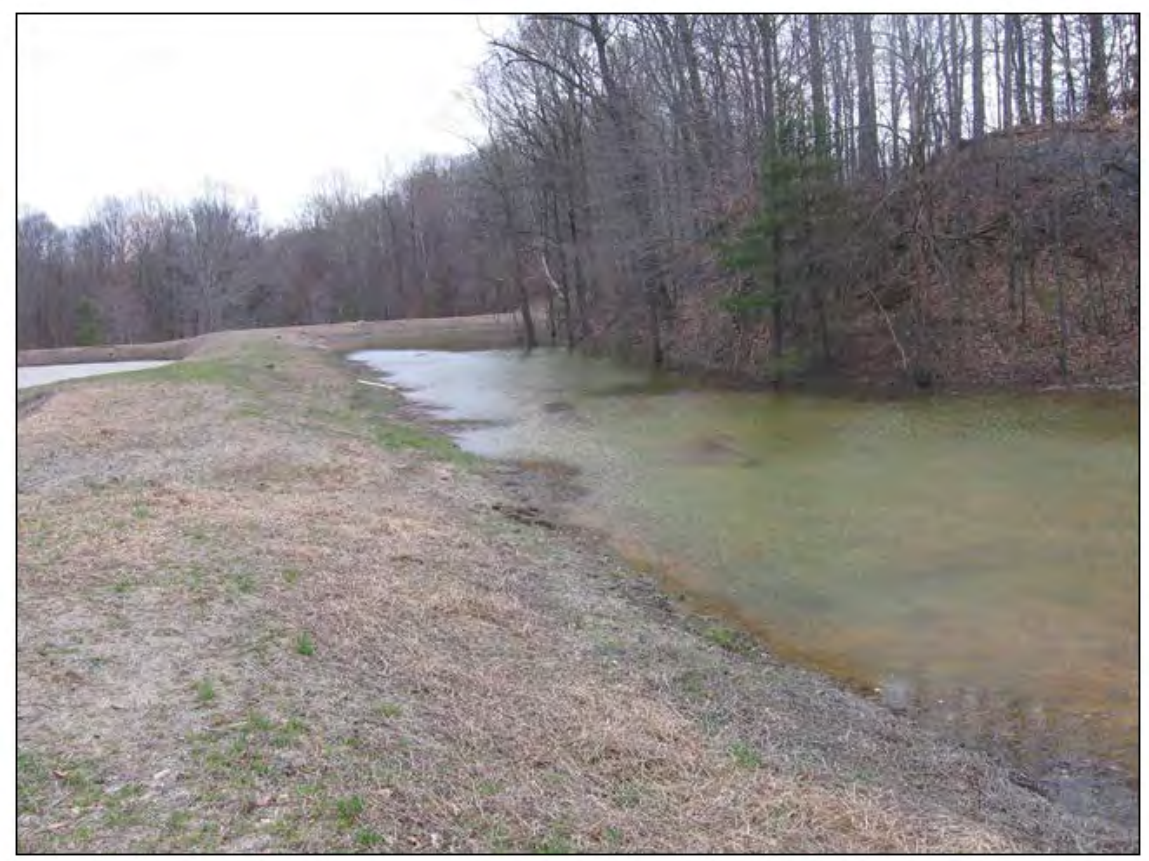

Figure 5. View of the sulfate-reducing bioreactor cell (SRBC) that was constructed to capture drainage from a spring (SPBR) that issues from the flooded workings of the underground Hartwell No. 2 Mine. At the time of this photograph, the SRBC was completely submerged. See Figure 2 for the location of the SRBC. View looking northeast along berm that separates the SRBC (on right) from the sediment ponds (on left). See Figure 2 for location.

and others, 2010). It was designed to handle an average flow of 30 gallons per minute (gpm) or 1.89 liters per second (Lps).

The bioreactor provides the organic-rich substrate required to maintaining an active community of anaerobic bacteria capable of sulfate reduction. The crushed limestone reacts with AMD to increase the $\mathrm{pH}$ to near-neutral conditions, which is essential because sulfate-reducing bacteria are inactive below a $\mathrm{pH}$ of 5 . The straw and wood chips provide a structural matrix that will minimize compaction and settling over time, and also serve as a place for bacteria to attach and establish colonies (Thomas and Romanek, 2002; Gusek, 2002).

Under the conditions established in the SRBC, sulfate-reducing bacteria oxidize available organic carbon sources $\left(\mathrm{CH}_{2} \mathrm{O}\right)$ to bicarbonate $\left(\mathrm{HCO}_{3}{ }^{-}\right)$and reduce sulfate sources $\left(\mathrm{SO}_{4}{ }^{2-}\right)$ to sulfide $\left(\mathrm{H}_{2} \mathrm{~S}\right)$. The bicarbonate that is generated increases the $\mathrm{pH}$ and net alkalinity of the system, and the $\mathrm{H}_{2} \mathrm{~S}$ readily reacts with dissolved metals to form insoluble sulfide minerals, thereby decreasing the water's toxicity. Divalent cations, such as iron, nickel, copper, and cadmium, precipitate as stable metal-sulfides that will be sequestered within the SRBC substrate material. The most important result of the bacterial sulfate reduction is a decrease in the acidity of the water by removal of iron and other metals and an increase in alkalinity by limestone dissolution and bicarbonate generation, leading to a higher $\mathrm{pH}$. Furthermore, the decrease of sulfate concentrations contributes to better water quality by lowering the content of total dissolved solids (Branam and others, 2010).

\section{MONITORING AFTER RECLAMATION}

During and after the initial reclamation work was completed in 1995 and 1996, monitoring stations were reinstalled or newly added in an effort to document any changes in physical hydrology and hydrochemistry that resulted from use of the CCBs and from the ALD treating effluent from the Hartwell No. 1 underground mine. Several of the wells installed prior to reclamation were unaffected by emplacement of the pond ash and FSS and continued to be sampled in the postreclamation period (MW1 and MW13). But other wells were destroyed during reclamation (MW5 and MW7) and closely spaced wells were reinstalled at the same geographic locations (MW5S, MW5M, MW5D in the vicinity of MW5, and MW7S and MW7D in the vicinity of MW7) in order to allow sampling from 
a three-dimensional array of monitoring wells in soil, pond ash, gob, and underlying spoil. MW7D was screened in the gob deposit beneath the FSS layer where it was thickest $(5 \mathrm{ft}[1.5 \mathrm{~m}])$ in order to assess whether any hazardous elements were leached from the FSS. MW7S was installed nearby with its screen in soil and resting on top of the FSS (fig. 2, Table 1). Three closely spaced wells were placed near the former site of MW5 to determine if any CCB leachate was moving vertically downward through the spoil. The shallowest of these wells (MW5S) was screened in spoil just below the overlying FSS, and the two other wells (MW5M and MW5D) were screened at greater depths within the spoil. MW8 was screened in pond ash and located along the thin northwestern edge of the FSS (fig. 2) in the vicinity of pre-reclamation monitoring site SW2 (fig. 1); it was installed in a former highwall pit lake, where pond ash had been used as structural fill. Similarly, MW9 was screened in a $16-\mathrm{ft}(4.9-\mathrm{m})$ thick section of pond ash used to fill the pond near pre-reclamation monitoring site SW1 (fig. 1), but no FSS had been used in this area.

Because reclamation activities were conducted episodically from 1995 to 2008, periods of monitoring were not the same at all monitoring stations. Following emplacement of CCBs (pond ash and FSS), construction of the ALD, and installation of sediment ponds, the first postreclamation monitoring period lasted from November 1996 through October 1998. A subsequent monitoring period lasted from February 2000 through October 2001. This later monitoring was done because of concerns raised about longer-term effects of the contact between CCBs and residual acidic groundwater and the potential for leaching of toxic metals from the CCBs.

Sampling of water in the wetland cells for water quality analysis was conducted on four occasions (Feb. 29, March 1, Sept. 1, and Sept. 19, 2000). Sampling, which was aimed at quantifying the removal of metals in the mine discharge (Smith and others, 2003), was conducted at the monitoring sites shown in Figure 4. Grab samples of water were taken at depths from 0.5 to $1 \mathrm{ft}(0.15-0.30 \mathrm{~m})$ along the edge of the cells just upstream from the outlet of each of the selected cells. The samples were collected in late winter (Feb. 29) and late summer (Sept. 19) to evaluate seasonal variations in water quality (Smith and others, 2003).

The SRBC, which was constructed with a threedimensional array of 38 sampling ports within the bioreactor, has been monitored from August 2008 through the present (Branam and others, 2010). The volume of AMD that is flowing from spring SPBR (fig. 1) is continuously monitored near its source. The volume of treated water is also continuously monitored. Since January 2009, water samples have been collected monthly for chemical analysis of the inflow, the outflow, and the internal flow from the 38 ports within the bioreactor.

\section{EFFECTS OF RECLAMATION}

\section{Impacts of CCBs}

At each location where CCBs were used, increases in $\mathrm{pH}$ and alkalinity occurred (Table 2; compare MW9 with SW1, and MW8 with SW2). The $\mathrm{pH}$ of water in well MW7D that was screened in the gob deposit below the FSS remained low initially but increased with time. Presumably, the generation of acid within the gob decreased because the downward percolation of oxygenated water was inhibited by the very low hydraulic conductivity of the FSS. Also, both the elevation of the water table and the hydrochemistry within the gob deposit, which had fluctuated greatly as a direct result of rainfall prior to reclamation, stabilized following reclamation. Acidity, iron, sulfate, aluminum, and trace elements all stabilized at lower concentrations (fig. 6). Together, these findings indicate that the FSS significantly reduced recharge, acid generation, and leaching of toxic metals from the gob.

Leaching of boron, potassium, and molybdenum from CCBs is inferred because the concentration of these elements increased significantly after reclamation in the water collected from monitoring wells screened in pond ash (MW8 and MW9) (fig. 7). The fact that much higher concentrations of these indicator elements were mostly observed in water collected from monitoring well MW8 (fig. 7), in which the screened pond ash interval is overlain by FSS, indicates that FSS releases these indicator elements more readily than pond ash (Branam and others, 1999a; Branam and others, 2001). Among the indicator elements, boron is the most conservative, in that it is least likely to be removed once it has entered the leachate. Although concentrations of boron in leachate from the FSS is higher than in leachate from pond ash, it is present only to depths of less than $14 \mathrm{ft}(4.3 \mathrm{~m})$ below the FSS (as determined from MW5S and MW5M), indicating that the leachate has little, if any, influence on underlying groundwater (MW5D) (Branam and others, 2005). 


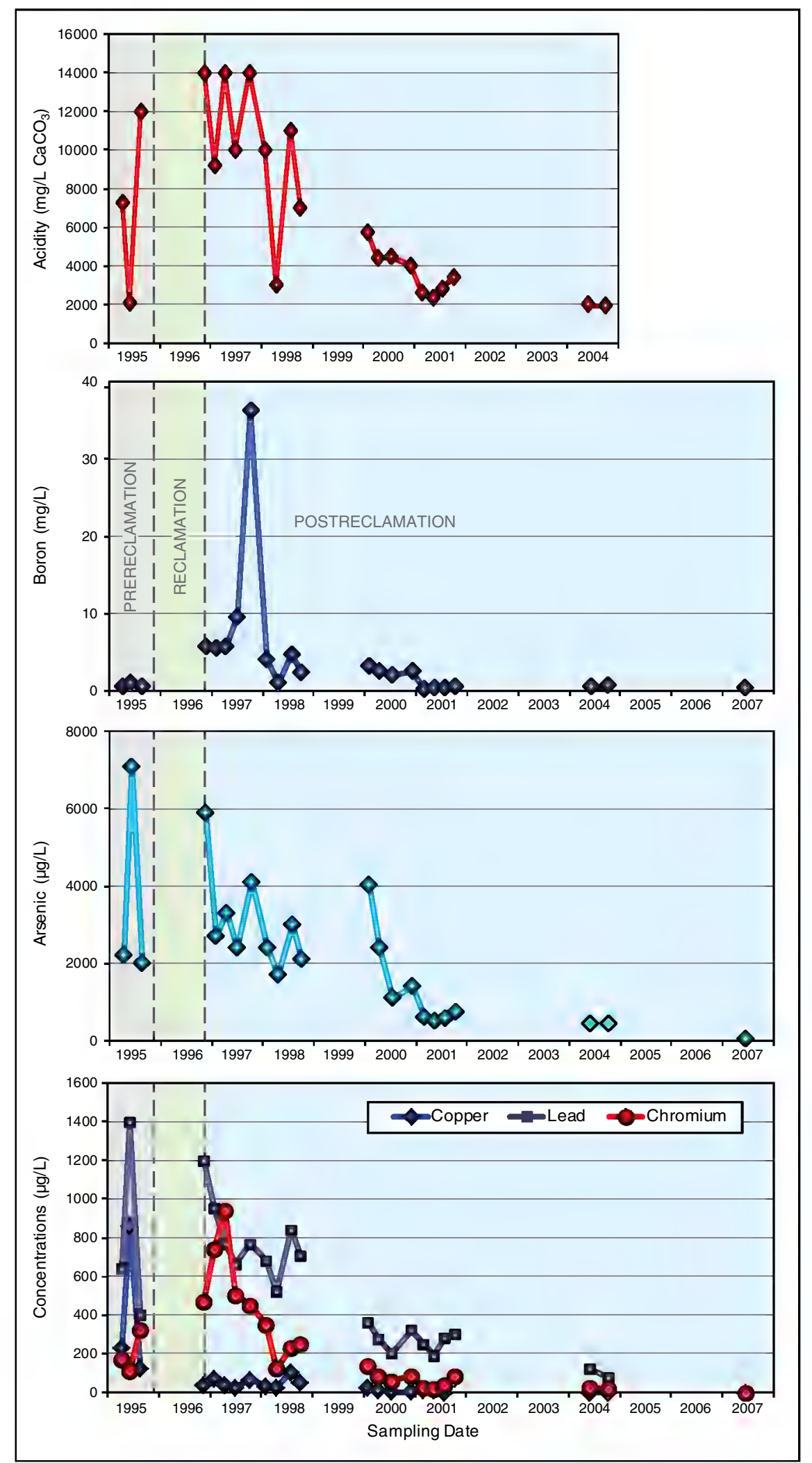

Figure 6. Graphs showing temporal trends in the concentrations of acidity, boron, arsenic, and trace metals (Cu, $\mathrm{Pb}$, and $\mathrm{Cr})$ in MW7, installed in gob before reclamation, and in MW7D, installed after reclamation in gob below the FSS. Pre- and postreclamation wells are at approximately the same location. Modified from Branam and others, 2005. 


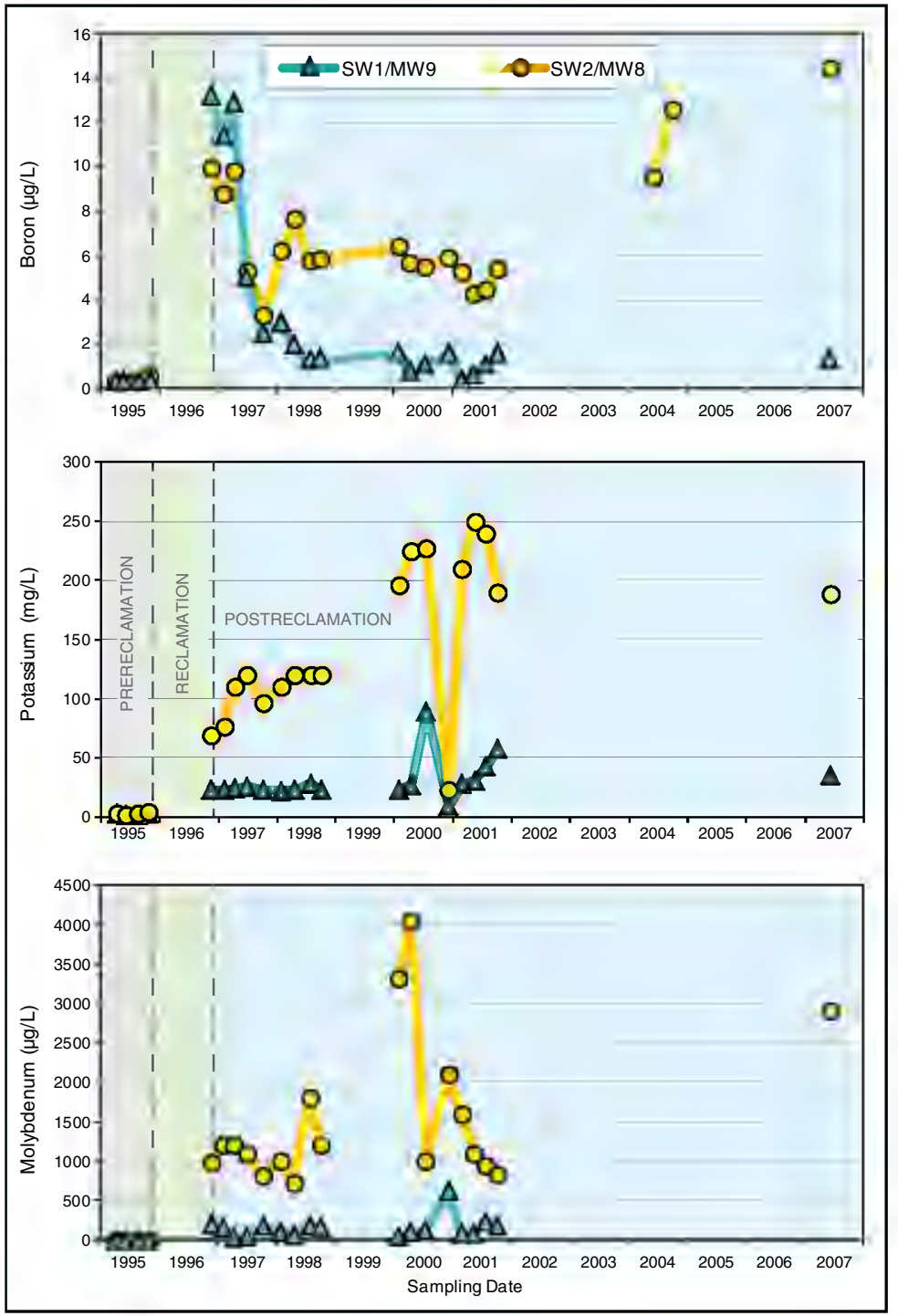

Figure 7. Graphs showing temporal trends in the concentrations of boron, potassium, and molybdenum in highwall ponds (SW1 and SW2) before reclamation and in monitoring wells (MW9 and MW8) installed in the pond ash and in pond ash beneath FSS, respectively, after reclamation. The screens for MW8 and MW9 were installed in approximately the same locations and at approximately the same elevations as the screens for SW2 and SW1, respectively. Modified from Branam and others, 2001.

\section{Impacts of ALD at SP2A}

After reclamation, for unknown reasons, flow from SP2A became significantly greater than flow from the preexisting SP1. From the time of its installation in 1996 through 2007, the ALD has functioned effectively to produce alkalinity that is sufficient to neutralize both the active and potential acidity of the spring's water (SP2A, Table 2). Samples collected from MW13 indicated that water quality within the Hartwell No. 1 Mine has remained unaffected by reclamation (Table 2 ).

\section{Hydrochemistry and hydrology changes at the MMS outlet}

Prior to reclamation, surface drainage that was leaving the MMS periodically had high concentrations (greater than 10 micrograms per liter) of selected trace elements such as cadmium and chromium (fig. 8). These intermittently high concentrations occurred during low-flow periods of high acidity and were presumably derived from leaching of trace elements from exposed gob. Elevated concentrations of cadmium and chromium also occurred after reclamation, although 


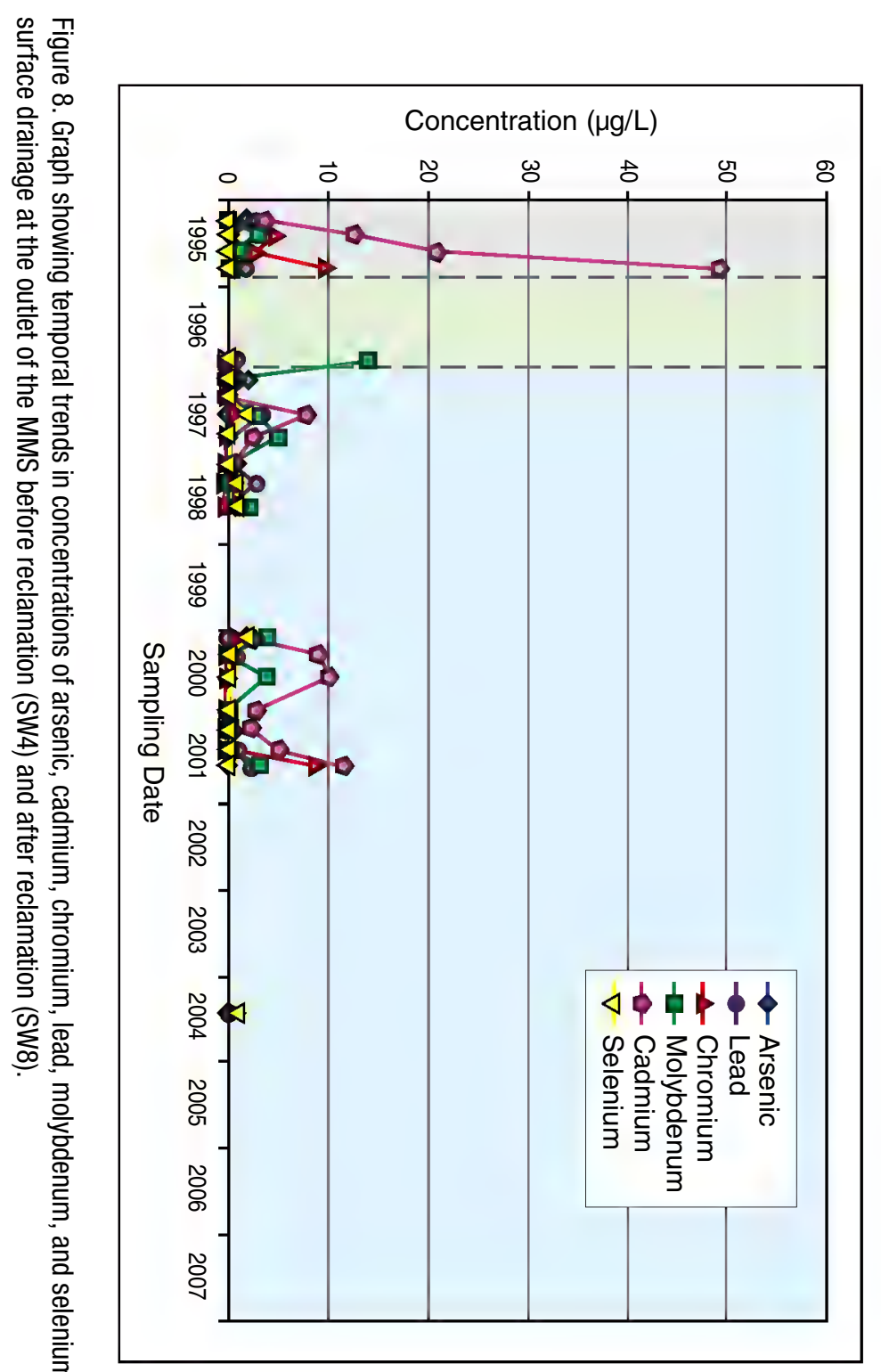

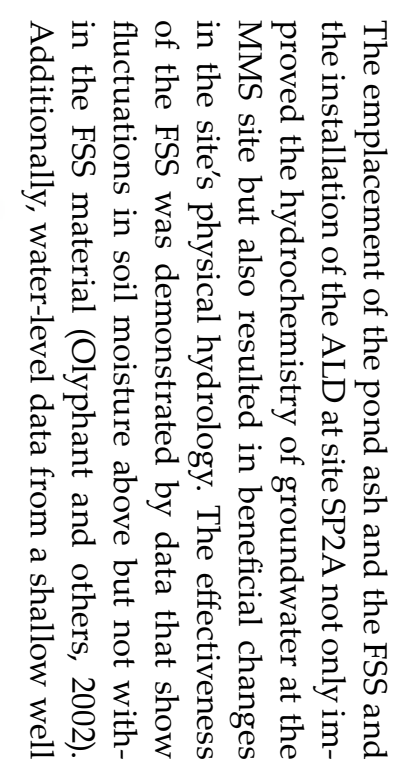

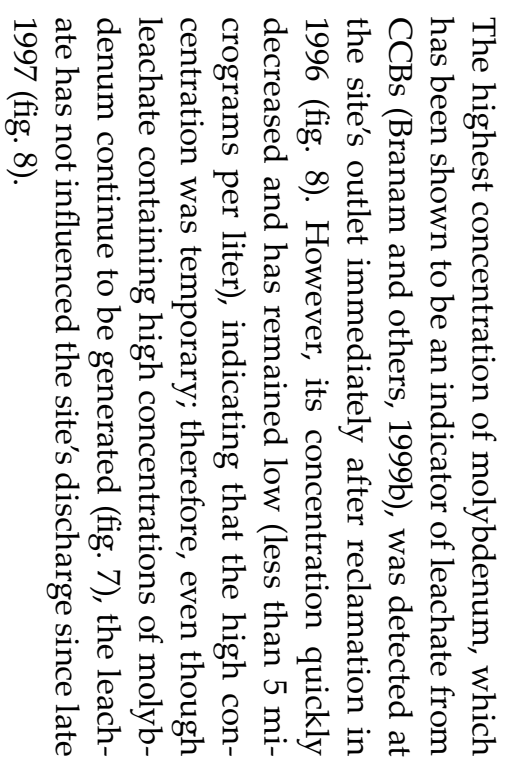

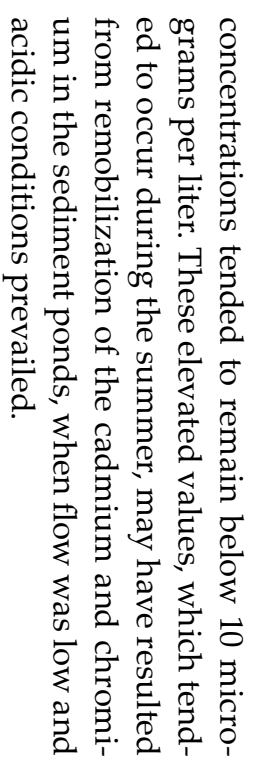

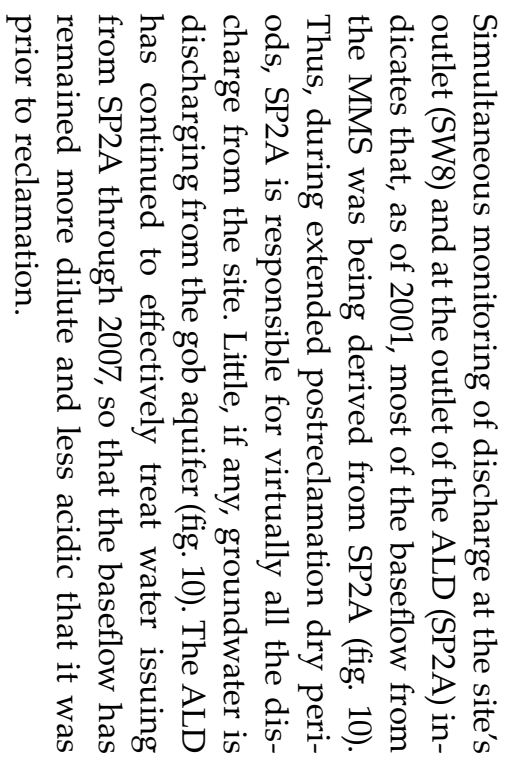

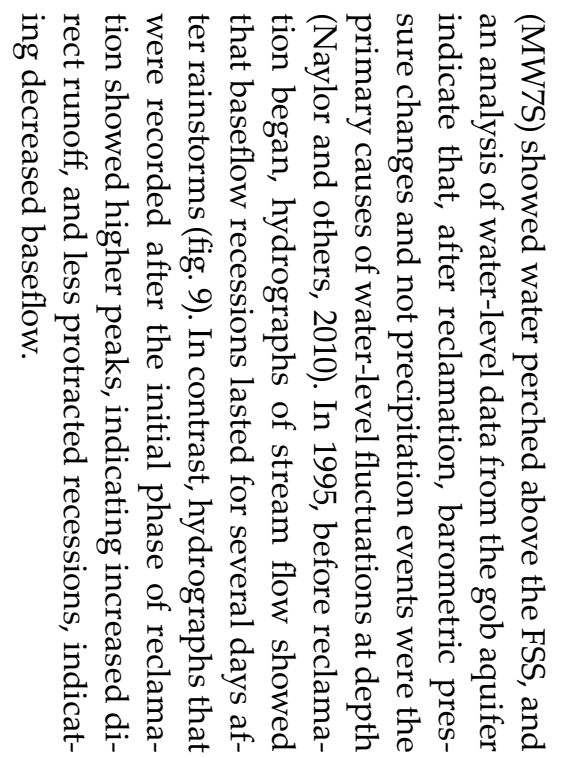




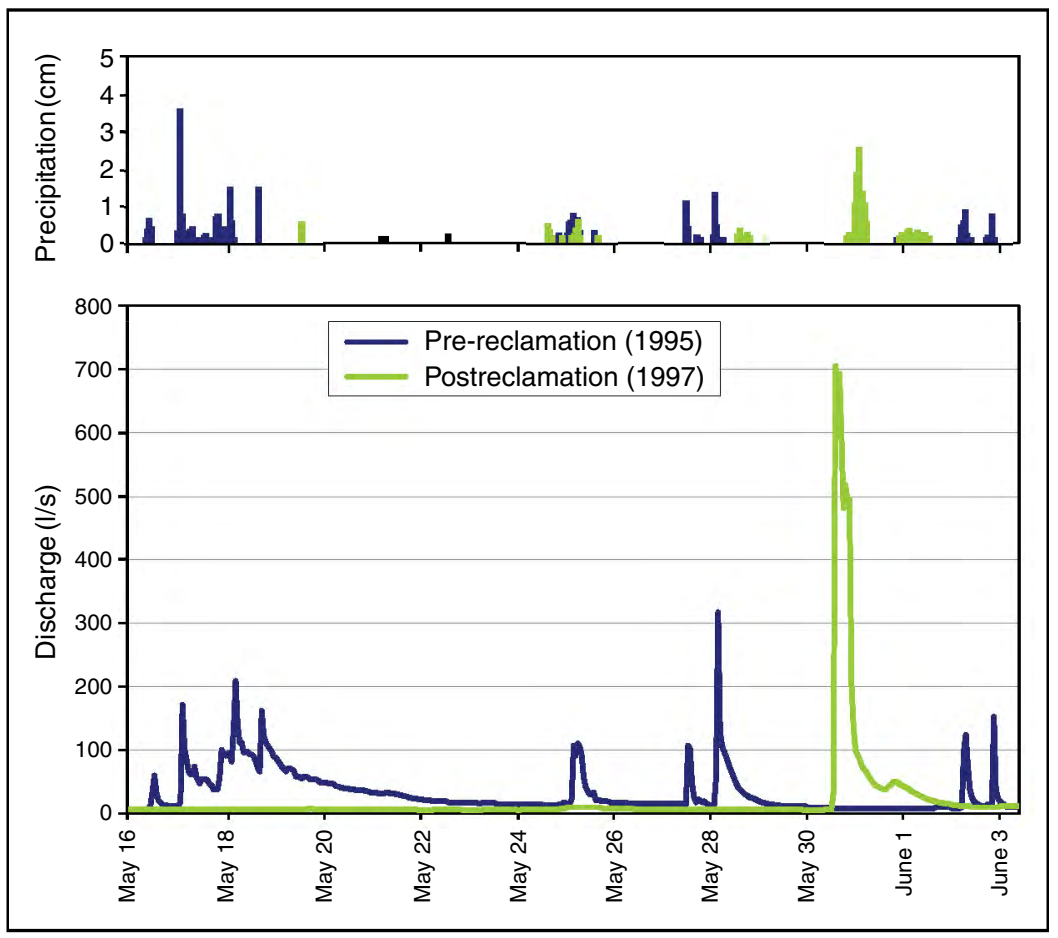

Figure 9. Hydrographs of MMS outflow during comparable periods before reclamation (May 16 to June 3, 1995; for location, see Figure 1, SW4) and after reclamation (May 16 to June 3, 1997; for location, see Figure 2, SW8). Precipitation during each period is also shown.

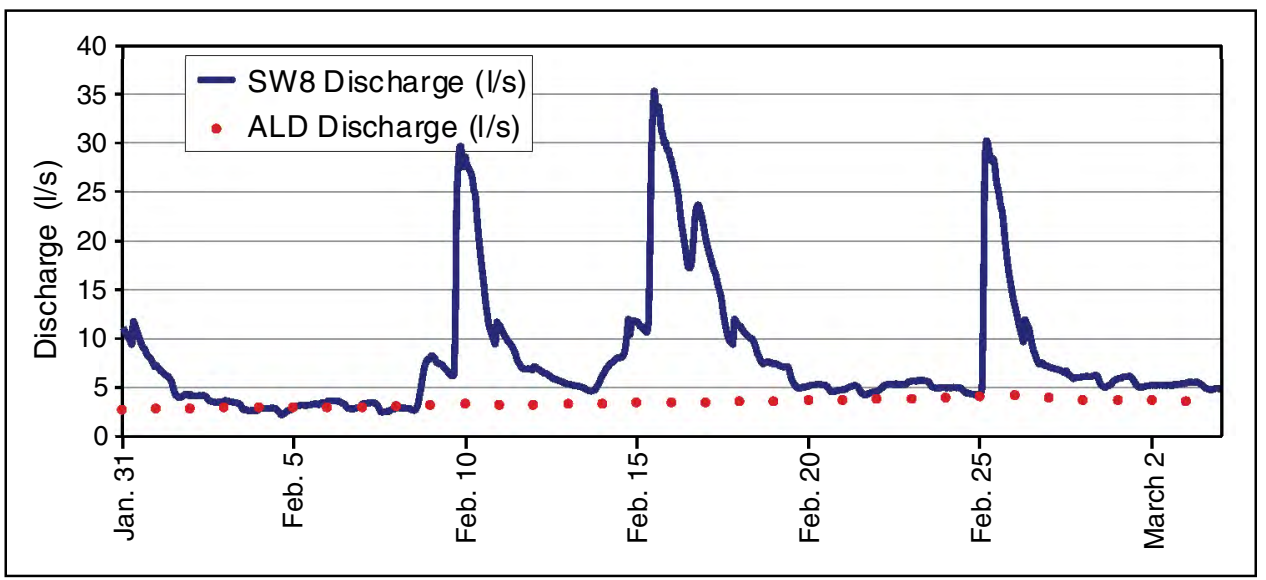

Figure 10. Graph showing daily discharge from the ALD (SP2A) and hourly discharge from the MMS (SW8) during February 2001. 
of acidity (290-840 mg/L) and iron (190-330 mg/L) (Table 2, SW4). During and after reclamation, acidity concentrations through June 2007 were generally lower $(0-350 \mathrm{mg} / \mathrm{L})$, as were iron concentrations (2$83 \mathrm{mg} / \mathrm{L}$ ) (Table 2, SW8). Also, before reclamation, alkalinity was absent in the outflow, but after reclamation, alkalinity has sometimes been present (0$140 \mathrm{mg} / \mathrm{L})$, particularly in the time period immediately following reclamation.

AMD from the site's outlet is typically most concentrated during the period of April to October. All available data on net acidity and alkalinity collected at the outlet were averaged for the periods of April 25 through October 10 in 1995 (pre-reclamation) and in 1997 and 2001 (postreclamation) (Table 4). These average values of acidity and alkalinity concentrations were combined with the stream flow totals to estimate the total outfalls of acidity during the pre- and postreclamation periods. Considering an average of the two postreclamation periods in Table 4, there was a net reduction of $6.8 \times 10^{4} \mathrm{~kg}$ of acidity $\left(\mathrm{CaCO}_{3}\right.$ equivalent) following reclamation for the April to June monitoring periods. This reduction persisted at least through 2001 and was accompanied by a similarly large reduction in the concentrations of iron as evidenced by average pre-and postreclamation iron concentrations at the site outlet shown in Table 2. Because water quality tends to be at its worst during the warm season, this calculation probably represents a minimum estimate of the improvement of water quality at the site.

\section{Impacts of the anaerobic wetland and ALD at SPW}

The anaerobic compost wetland and its associated ALD, which were constructed in 1997 to treat the AMD seep from the underground Hartwell No. 2 Mine (SPW, fig. 1), have produced significant changes in local vegetative cover and water quality. In the oxidation pond (Cell 1B, fig. 4), oxidation and precipitation of iron has been so rapid from the beginning that vegetation has never become established, except for some Typha in the shallow upper end. There, and throughout the central wetland cells, Typha had become established by 1998, although establishment of vegetation in Cells 2C5 through $2 \mathrm{C} 7$ was initially inhibited by excessively high concentrations of turkey manure. By 2009, Cells 2A through 2B2 had filled with sediment and were overgrown with Typha. Cells 2B3, 2C6, and $2 \mathrm{C} 7$, which are topographically lower, usually contain standing water and are only vegetated along their borders. The ALD and Cell 1A (fig. 4) have generated alkalinity that has been adequate to neutralize water from the AMD seep, so that samples obtained from the discharge of Cell 1A have been characterized by $\mathrm{pH}$ values that have been nearly neutral. Water quality has generally improved as the water flowed through successive downstream cells. Dissolved iron, manganese, and aluminum have all been greatly reduced at the outlet of Cell $2 \mathrm{C} 7$, compared with the water entering from Cell 1A. The rapid oxidation and precipitation of iron upon contact with the atmosphere is documented by the observation that the standpipe that controls discharge from Cell 1A has become encrusted with iron-oxide deposits that are several inches thick. In summer, when the flow of water entering the oxidation pond (Cell 1B) has been about 8 gpm $(0.5 \mathrm{Lps})$, the pond has collected more than 99 percent of the iron from the AMD seep. We estimate the net removal rate of iron has been about $4.3 \mathrm{~kg} /$ day. Because approximately 99 percent of the iron has been precipitated in Cell 1B, which has an area of 0.3 acre $(0.12 \mathrm{ha})$, the flux of iron into this aeration cell has been estimated to be about

Table 4. Hydrology and hydrochemistry of pre- and postreclamation outflows during comparable periods (April 25-0ct. 10)

\begin{tabular}{|l|c|c|c|}
\cline { 2 - 4 } \multicolumn{1}{c|}{} & 1995 & 1997 & 2001 \\
\hline Total precipitation (cm) & 48.41 & 42.98 & 40.08 \\
\hline Net acidity/alkalinity (mg/L) & 626 & 120 & 187 \\
\hline Total outflow (L) & $3.4 \times 10^{8}$ & $1.4 \times 10^{8}$ & $3.2 \times 10^{7}$ \\
\hline Total net acidity (kg) & $2.1 \times 10^{5}$ & $1.7 \times 10^{4}$ & $5.9 \times 10^{3}$ \\
\hline Net reduction of acidity from 1995 (kg) & & $1.9 \times 10^{5}$ & $2.0 \times 10^{5}$ \\
\hline
\end{tabular}


$3.5 \mathrm{~g} / \mathrm{m}^{2} /$ day (Smith, 2012 [this volume]). In winter, when the flow is about $11 \mathrm{gpm}(0.69 \mathrm{Lps})$, the pond has been far less effective. While many of the water samples have not contained measureable levels of dissolved arsenic, beryllium, chromium, copper, lead, or selenium, subsequent analysis of sediment samples have shown that these metals are present at significant levels throughout the wetland soils. In summer, concentrations of sulfate in waters from the outlet of Cell $2 \mathrm{C} 7$ have been about 51 percent of the concentrations in water from the outlet of Cell 1A (Smith, 2012 [this volume]). In winter, concentrations have been about 34 percent. If the reduction in sulfate levels were caused only by sulfate-reducing microbes, a greater reduction would be expected in summer than in winter because the warmer summer temperatures increase microbial metabolism. These results indicate that other processes, such as sorption to iron precipitates, may be involved in sulfate removal (Smith, 2012 [this volume]).

\section{Impacts of the SRBC}

In July 2008, the SRBC (fig. 2) was installed to remediate a previously untreated spring from the Hartwell No. 2 Mine (SPBR, fig. 1). At the time of construction, SRBCs had recently become popular for treating small AMD discharges where the area available for installation of passive treatment systems is limited. Before 2008, the flow from spring SPBR (fig. 1) did not enter the MMS but discharged into a different drainage from an area adjacent to the MMS. However, the SRBC and its contributing areas became part of the MMS when the SRBC's outlet was redirected so that it flowed into the preexisting sediment ponds.

Although the SRBC was designed to handle average flows of only $30 \mathrm{gpm}$ (1.89 Lps), flows from the AMD spring (SPBR) have varied from less than $2 \mathrm{gpm}(0.13 \mathrm{Lps})$ to as much as $40 \mathrm{gpm}(2.52 \mathrm{Lps})$. However, during and shortly after heavy precipitation, the flow is augmented by overland flow from adjacent areas, so that the total flow exceeds 76 gpm (4.79 Lps). During such periods, most of the water flows untreated across the surface of the SRBC, so that it does not interact with the SRBC's substrate. In contrast, during periods of very low flow, there is no discharge from the SRBC. During these periods, water samples collected from the three-dimensional array of sampling ports within the SRBC indicate that the sulfate-reducing bacteria are effectively removing sulfate and iron (Branam and others, 2010). Furthermore, no data are yet available regarding the performance of the SRBC during winter months, when bacterial activity may be reduced.

\section{SUMMARY AND CONCLUSIONS}

The multifaceted approach to reclamation-the use of coal combustion byproducts, anoxic limestone drains, a wetland, and a sulfate-reducing bioreactor cell-that was applied from 1995 to 2008 improved the quality of water discharged from the Midwestern Mine Site. The techniques that were employed have not only favorably affected the hydrochemistry of the MMS's discharge but have also resulted in beneficial changes in the site's physical hydrology. There is very little recharge through the pyritic gob, and baseflow discharge is now dominated by flow from an underground mine through a spring (SP2A) that is being successfully treated using an ALD. Storm runoff, which has increased because of reclamation, is now of relatively good quality (Harper and Olyphant, 1999). These improvements were achieved without significant leaching of hazardous trace elements from the CCBs that were emplaced at the MMS. Although some leaching may occur in the pond ash and especially near the base of the FSS where it contacts gob, concentrations of indicator elements are greatly attenuated over short distances, probably by dilution, precipitation, and sorption (Branam and others, 2005).

The system of an ALD followed by an anaerobic compost wetland generated alkalinity for more than 5 years after its construction, effectively neutralizing acidity in the seep from the abandoned underground Hartwell No. 2 Mine. The greatest benefits were observed during the summer months. Initially, during the winter, the wetland maintained some alkalinity, but values were far lower than in the summer. Within 5 years, iron oxyhydroxide precipitates filled in the lower wetland cells, greatly reducing or eliminating their storage capacity. The establishment of healthy stands of Typha has promoted soil building throughout much of the infilled wetland. Even though the overall efficiency of the anaerobic wetland has diminished, the ALD has continued to discharge water with a circum-neutral $\mathrm{pH}$ and measureable alkalinity (Smith, 2012 [this volume]). 
During periods of low flow, when no discharge is occurring from the SRBC, sulfate is being efficiently removed by bacterial action. Nevertheless, it is still too early to evaluate the overall seasonal performance of the bioreactor. Preliminary observations indicate that the plumbing system used to direct water into and through the system may not be optimally designed to ensure interaction of the AMD with the SRBC's substrate, because there is always standing water in the SRBC, and whenever there is any flow, water flows across the surface with minimal interaction with the substrate. Also, the fill material may not be of sufficient volume to treat the volume of contaminated influent entering the cell (Branam and others, 2010).

There has been a five-fold reduction in the amount of potential mineral acidity in waters leaving the MMS site, resulting from the large reduction in the concentrations of iron and aluminum (Harper and Olyphant, 1999). Concentrations of trace elements derived from the leaching of gob have decreased significantly in surface drainage that is leaving the site. Slightly elevated concentrations may occur intermittently during periods of low flow in late summer and early fall when acidic conditions may cause remobilization of those elements in the sediment ponds. Leaching of trace elements from CCBs, as indicated by concentrations of molybdenum in the site's outflow, increased for a short period immediately following reclamation, but concentrations soon decreased, and there is no evidence that any ongoing leaching of CCBs has resulted in elevated concentrations leaving the site.

In summary, the two ALDs that were installed at the MMS have been effective in treating a spring and a seep from the abandoned underground mines. Such ALDs are generally designed to have life spans of about 20 years, and those at the MMS are now more than 12 years old. It is not possible to predict how much longer they will remain effective, but, when they fail, the chemistry of water leaving the MMS will deteriorate noticeably if they are not reinstalled. The decrease of alkalinity observed in water leaving the ALD associated with SP2A could provide an early warning of that ALD's impending failure. In comparison with the two ALDs, the anaerobic wetland installed at the MMS was significantly effective for only a relatively short period of 5 years, and no judgments can yet be made regarding the effectiveness and longevity of the SRBC at this time because insufficient data have been collected.
Most importantly, the use of CCBs has produced significant improvements in the hydrology of the MMS. These benefits should persist, so long as the FSS, which covers the acid-generating gob deposit, maintains its structural and chemical integrity in the decades to come. To our knowledge, long-term monitoring of FSS covering gob under field conditions similar to those prevailing at the MMS has not been conducted. Changes in the quality of water in monitoring well MW7D, such as a steady or rapid increase in acidity, would provide an early warning of any deterioration of the FSS, increased vertical infiltration and recharge, and renewed leaching of the underlying gob deposit.

\section{ACKNOWLEDGMENTS}

Except for boron and mercury, the analyses of water samples were performed by personnel of the Geochemistry Section of the Indiana Geological Survey (IGS). Through 2001, mercury was analyzed by the Chemistry Department, Ball State University (BSU). Boron was initially analyzed by the Analytical Laboratory of the Department of Geological Sciences, Indiana University, but from April 1996 through 2001, this element was analyzed at BSU. After 2001, all analyses were performed at the IGS. Greg Olyphant, Associate Professor in the Department of Geological Sciences at Indiana University, directed much of the field work and analyses that were performed at the MMS and contributed significantly to the development and review of this article. Field work was performed by personnel of the Geochemistry Section and the Center for Geospatial Data Analysis of the IGS, and by graduate students of the Department of Geological Sciences at Indiana University.

\section{REFERENCES}

ATEC, 1984, Investigation of Mill Creek abandoned mine land site, Pike County, Indiana: Indianapolis, Ind., Report to Indiana Department of Natural Resources on Project No. E23-403 by ATEC Associates, Inc., Indiana ATEC Project No. 21-43037, 207 p.

Branam, T. D., Reeder, M., and Harper, D., 2010, Optimization of bioreactor cell design for treating lowflow acid mine drainage in the Midwest-model development and demonstration: Final report to the Office of Surface Mining, OSM Award Number S06PC12060, Indiana Geological Survey, 47 p. 
Branam, T. D., Smith, R. T., and Comer, J. B., 2005, Gauging success of coal-combustion byproducts utilization in Indiana abandoned mine land reclamation: Proceedings of the 2005 World of Coal Ash, April 11-15, Lexington, Ky.

Branam, T. D., Ennis, M. V., Smith, R. T., Comer, J. B., and Rybarczyk, J. P., 2001, Ground-water chemistry changes at an abandoned coal mine reclaimed with coal combustion byproducts, Pike County, Indiana: Proceedings of the 2001 National Association of Abandoned Mine Lands Annual Conference, Aug. 19-22, 2001, Athens, Ohio.

Branam, T. D., Maslowski, S., and Clark, H., 1999a, Analysis of chemical reactions between fixated scrubber sludge and simulated acid mine drainage of various compositions: Proceedings of the $13^{\text {th }}$ International Symposium on Use and Management of Coal Combustion Products (CCPs), v. 3, Jan. 11-15, 1999, Orlando, Fl., p. 74-1-74-14.

Branam, T. D., Smith, R. T., Ennis, M. V., Rybarczyk, J. P., and Comer, J. B., 1999b, Trace element partitioning in ground water at an abandoned mine-land site reclaimed with coal combustion byproducts: Proceedings of the 1999 International Ash Utilization Symposium, Oct. 18-20, 1999, Lexington, Ky.

Freeze, R. A., and Cherry, J. A., 1979, Groundwater: Englewood Cliffs, N.J., Prentice Hall, 604 p.

Gusek, J. J., 2002, Sulfate-reducing bioreactor design and operating issues-is this the passive treatment technology for your mine drainage?: Proceedings of the National Association of Abandoned Mine Land Programs, September 15-18, 2002, Park City, Utah. [Available at <http://www.ogm.utah.gov/amr/ naamlp/>, date accessed, July 29, 2010].

Harper, D., and Olyphant, G. A., 1999, Hydrology and water quality associated with the Midwestern Reclamation Site (Site No. 1087) Pike County, Indiana: Indiana Geological Survey Web site, <http://igs.indiana.edu/survey/projects/midwest/index.cfm>, date accessed, July 29, 2010].

Naylor, S., Olyphant, G. A., and Branam, T., 2010, Hydrochemical effects of using coal combustion byproducts as structural fill and capping material at an abandoned mine lands reclamation site, southwestern, Indiana: Proceedings of the 2010 National Meeting of the American Society of Mining and Reclamation, June 5-11, Pittsburgh, Pa.

Olyphant, G. A., Branam, T., and Harper, D., 2002, Midwestern project extension: Indiana Geological Survey Web site, <http://igs.indiana.edu/survey/projects/midwestExtension/midw2html/index.cfm>, date accessed, July 29, 2010].
Smith, R. T., 2012, Metals removal in acid mine drainage treatment wetlands, in Comer, J. B., ed., Effects of abandoned mine land reclamation on ground and surface water quality-research and case histories from Indiana: Indiana Geological Survey Special Report 72, p. 225-258.

Smith, R. T., Comer, J. B., Ennis, M. V., Branam, T. D., Butler, S. M., and Renton, P. M., 2003, Toxic metals removal in acid mine drainage treatment wetlands: Indiana Geological Survey Open-File Study 01-3, 48 p.

Spindler, K. M., and Olyphant, G. A., 2004, Geophysical investigations at an abandoned mine site subjected to reclamation using a fixated scrubber sludge cap: Environmental and Engineering Geoscience, v. 10, no. 3, p. 243-251.

Soliman, N. N., 1990, Laboratory testing of lime fixed flyash and FGD sludge, in Landva, A., and Knowles, G. D., eds., Geotechnics of waste fills-theory and practice: ASTM STP 1070, American Society for Testing and Materials, p. 168-184.

Thomas, R. C., and Romanek, C. S., 2002, Passive treatment of low-pH, ferric iron-dominated acid rock drainage in a vertical flow wetland II-metal removal: Proceedings of the National Meeting of the American Society of Mining and Reclamation, June 9-13, Lexington, Ky.

Watzlaf, G. R., Schroeder, K. T., Kleinmann, R. L. P., Kairies, C. L., and Nairn, R. W., 2004, The passive treatment of coal mine drainage: DOE/NETL-2004/1202, National Energy Technology Laboratory, U.S. Department of Energy, 72 p. [Available at $<$ http://www. netl.doe.gov/technologies/coalpower/ewr/water/ pdfs/Passive\%20Treatment.pdf $>$, date accessed, July 29, 2010.] 


\title{
Impacts of Abandoned Mine Land Reclamation on Water Quality within the South Fork Patoka River Watershed
}

\author{
Mark A. Stacy \\ Indiana Department of Natural Resources, Division of Reclamation
}

\begin{abstract}
Water quality in the South Fork Patoka River has dramatically improved as a direct result of the reclamation efforts of the Indiana Division of Reclamation's Abandoned Mine Land Program. Located in southwestern Indiana, the South Fork Patoka River was once considered the most severely affected stream in the state. These adverse impacts, owing to acid mine drainage from past coal mining activities, left the river devoid of most aquatic flora and fauna. The Indiana Abandoned Mine Land Program has spent much of the last 20 years funding and administering several reclamation projects within this watershed, completing nine large projects that reclaimed 1,541 acres (624 hectares) of disturbed land at a total cost of $\$ 16,409,402$. These nine reclamation projects (Blackfoot - Site 130, Stendal - Site 306, Wheeler Creek - Site 147, Blackfoot Tipple - Site 1101, Sugar Ridge Area 5 - Site 304, Enos - Sites 898 and 979, Log Creek Church - Sites 900 and 2040) have significantly improved water quality within the South Fork Patoka River.
\end{abstract}

Comparing historic water-quality data collected in the 1960s and 1980s and this recent water-quality data collected by the Indiana Abandoned Mine Land Program revealed the extent of water-quality improvements and also identified remaining acid mine drainage problems. The last major remaining source of acid mine drainage in this watershed is the Durham Ditch subwatershed. New passive treatment technologies, such as an experimental groundwater redirection project, are being evaluated and incorporated into reclamation projects to further improve water quality in the South Fork Patoka River.

\section{INTRODUCTION}

The South Fork Patoka River (South Fork) is located mainly in Pike County, with portions in Gibson and Warrick Counties, in southwestern Indiana (fig. 1). It is the largest tributary of the Patoka River, occupying 76.3 miles $^{2}\left(198 \mathrm{~km}^{2}\right)(48,832$ acres [19,761.6 hectares (ha)]) of drainage area. The channel of the South Fork was dredged and straightened in the 1920s and has a total length of nearly 17 miles $(27.3 \mathrm{~km})$. The South Fork watershed lies within the Boonville Hills physiographic unit (Gray, 2000, p. 7-8), south of the Illinoian Glacial boundary, and is characterized by bedrock hills of moderate relief. The gently rolling topography contains a mix of row-crop agriculture and woodlands, with coal mining being the other major land use in this area. Approximately 49.4 percent of the 
watershed has been affected by surface-mining activities (fig. 1).

Because the South Fork is the largest tributary of the Patoka River, any negative impacts in the South Fork watershed are also going to be felt in the Patoka River itself. This is important on several levels. As stated in the Log Creek Church Site Draft Ecosystem Restoration Report (The Bioengineering Group, 2002, p. 1-1):

"The Patoka River Watershed has received national attention for the development of the Patoka River National Wildlife Refuge and Management Area (PRNWR). With 30 miles of riverine corridor and almost 13,000 acres of existing wetlands, the PRNWR offers habitat refuge and ecosystem protection to endangered species and important forested wetland systems. The South Fork is within the boundaries of the PRNWR for the last 2.5 miles before it enters the Patoka River. Valuable wetland habitat within the refuge is hydrologically linked to the South Fork."

Therefore, acid mine drainage originating in the South Fork watershed could adversely affect this important National Wildlife Refuge.

Coal mining has been a major industry in Pike County since the 1830s. Underground mining techniques were used initially, but by the 1920s, surface

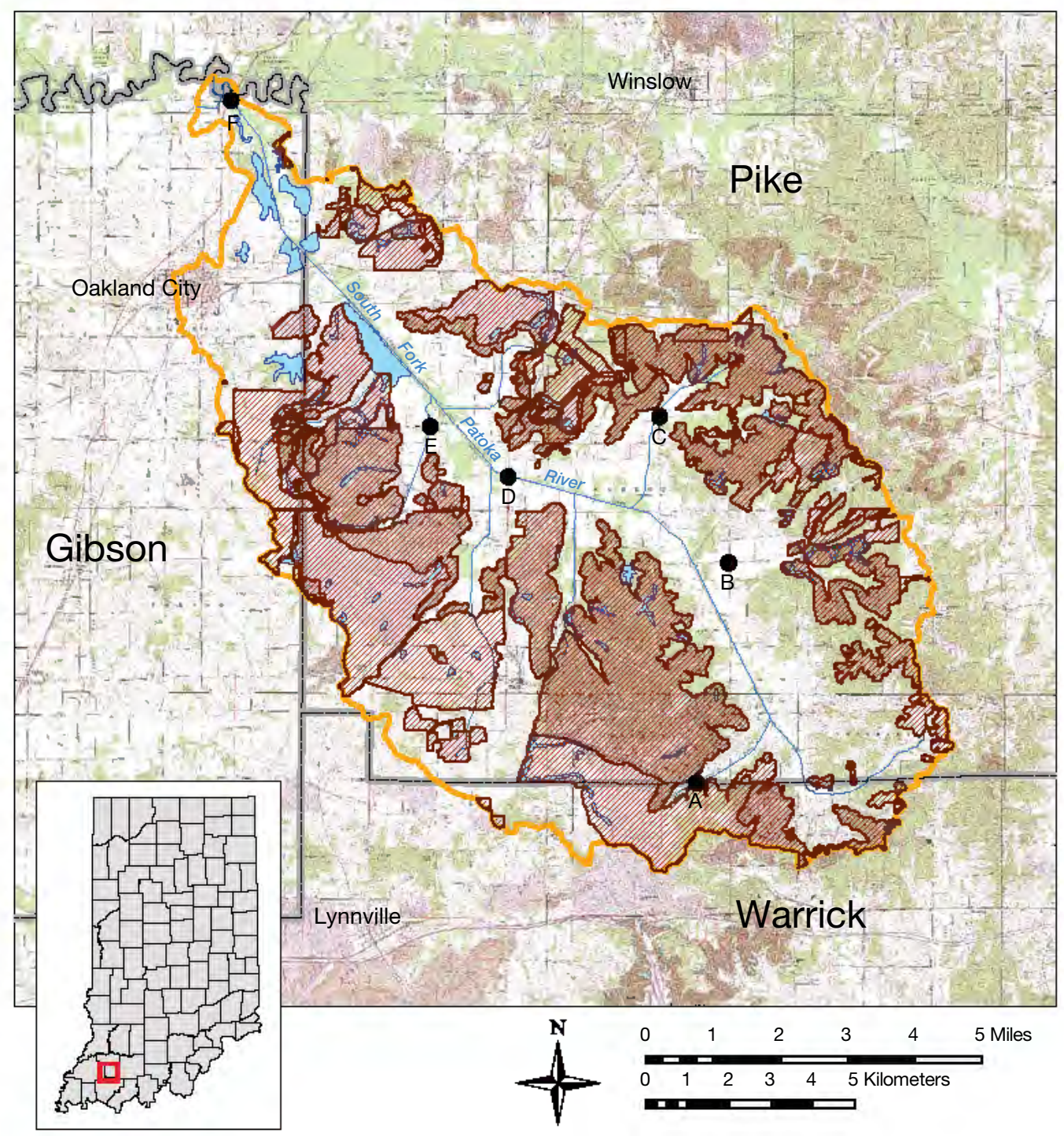

Figure 1. Map of the South Fork Patoka River Watershed (yellow line) showing water sampling locations (black dots) and mined areas (brown) within the watershed. 
mining became the predominate method of coal extraction. During the next 50 years, more than 20,000 acres (8,093.7 ha) of land was mined and left in an unreclaimed state. Much of this land was planted with trees as part of early reclamation efforts and has since become valuable wildlife habitat. Vast areas of forested spoil have become state fish and wildlife areas and state forests, however, a large portion of this unreclaimed land was left in a derelict condition. Hundreds of acres of gob piles, slurry ponds, barren spoil, acid impoundments, and miles of impaired streams were the result. For many years, the entire length of the South Fork was so heavily damaged that fish and other aquatic flora and fauna could not survive.

Prior to the enactment of the Surface Mining Control and Reclamation Act of 1977, Public Law 9587 (SMCRA), coal mining operations were not required to prevent the production or discharge of acid mine drainage into local waterways. Therefore, watersheds having a high concentration of coal mining activity, such as the South Fork watershed, were severely affected by acid mine drainage (fig. 2). Acid mine drainage is formed by the chemical weathering of minerals (mostly pyrite); mined areas most prone to its production are gob piles and slurry ponds, railroad grades and haul roads built with coal refuse, tipple areas and preparations plants, large accumulations of acidic coal spoil, and abandoned underground coal mines.

A great deal of water-quality research has taken place over the years in the coal mining region of Indiana, particularly in Pike County and the Patoka River Watershed. This is primarily due to the extensive mining operations and subsequent waterquality impairment that occurred in this region prior to the enactment of SMCRA. Since then, waterquality impairments from active coal mining have largely disappeared, at least on a large scale. Two major studies took place here, the first in the mid1960s (Corbett, 1969), the second in the mid-1980s (Renn, 1989). Both were designed to assess stream

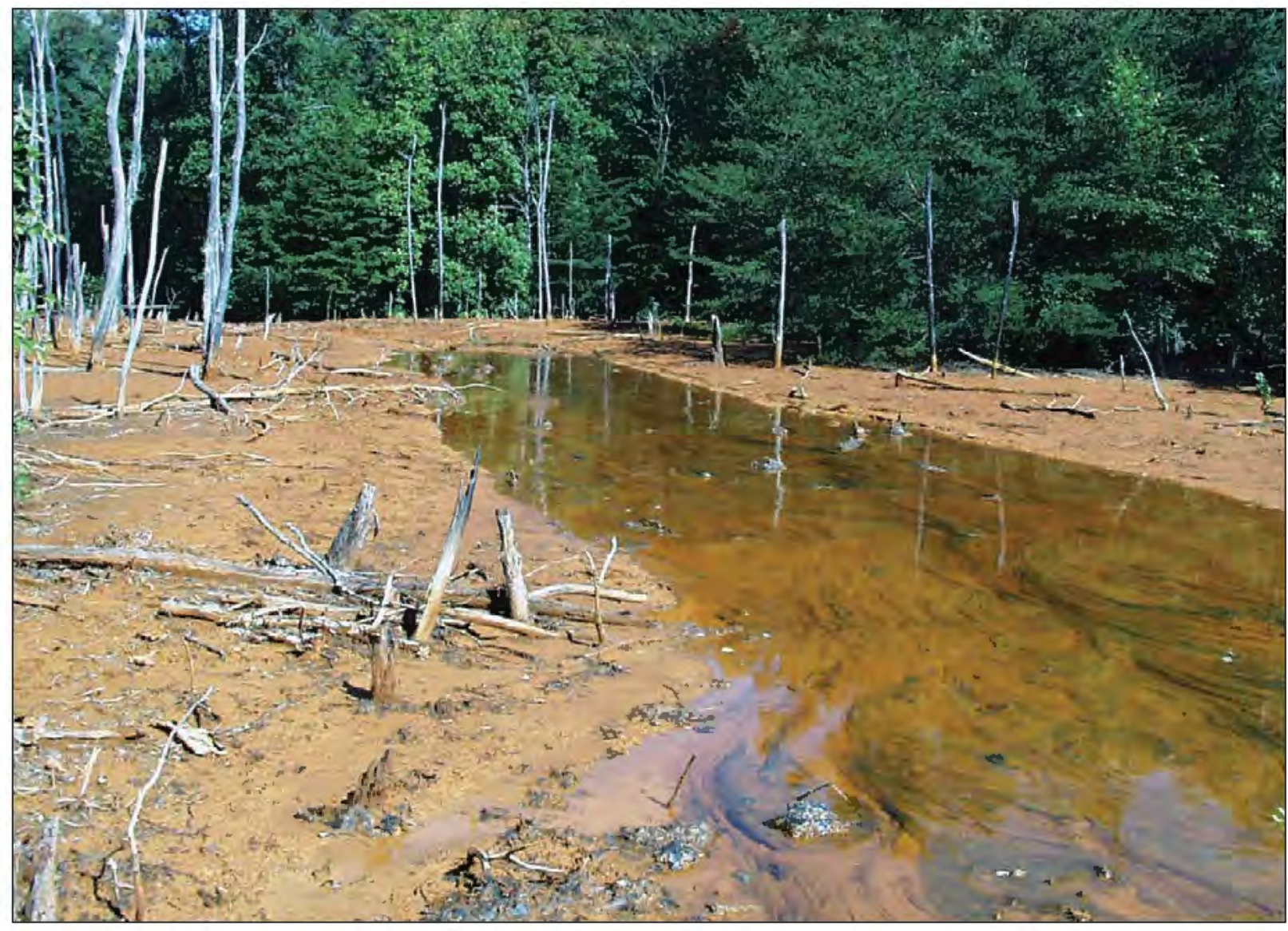

Figure 2. Photograph showing the impact of acid mine drainage in Durham Ditch, a subwatershed of the South Fork Patoka River, Pike County, Indiana. 
water quality and evaluate the impacts of acid mine drainage on the Patoka River and major tributaries, including the South Fork.

Corbett sampled 100 different sites within the South Fork watershed on 436 occasions over 4 years and analyzed the following parameters: temperature, conductivity, $\mathrm{pH}$, alkalinity, acidity, total hardness, chloride, calcium, magnesium, total iron, manganese, and sulfate. Renn collected samples four times at 29 surface water sites within the Patoka River basin, including the South Fork and its tributaries, and analyzed for the following parameters: temperature, specific conductance, $\mathrm{pH}$, alkalinity, acidity, dissolved oxygen, total iron and manganese, dissolved solids, and suspended sediment. Many of Renn's samples were collected at the same locations as Corbett's. These data sets have provided the Indiana Abandoned Mine Land (AML) Program with invaluable water-quality data that predates any reclamation activities. This paper will compare these pre-reclamation water-quality data sets with recently collected data, and so will show the changes in water quality in the South Fork.

Of the many sites that Corbett and Renn sampled, six were selected (fig. 1) to characterize water quality within the South Fork. One site is in the headwaters area (A, fig. 1), one is near the center of the reach at a former U.S. Geological Survey gauging station (D, fig. 1), three are on main tributaries (Houchin Ditch [B, fig. 1], Durham Ditch [C, fig. 1], Wheeler
Creek [E, fig. 1]) and one is near the mouth of the river (F, fig. 1). Four water-quality parameters $(\mathrm{pH}$, acidity, alkalinity, and sulfate) were selected as indicators of the effects of acid mine drainage on the South Fork and its tributaries. Table 1 shows that in the past, the entire length of the South Fork, from the headwaters to the mouth and all major tributaries, were adversely affected by acid mine drainage.

\section{PAST PROJECTS OF THE INDIANA ABANDONED MINE LAND PROGRAM IN THE SOUTH FORK WATERSHED}

The Indiana AML Program ensures the proper reclamation of previously mined sites that were abandoned prior to the enactment of SMCRA. The purpose of the reclamation is to alleviate the health, safety, and environmental hazards of past coal mining practices while improving land productivity and enhancing the environmental landscape. Examples of this type of reclamation include filling mine shafts and subsidences, backfilling dangerous highwalls, eliminating hazardous structures, grading and covering barren coal refuse and spoil, treating acid water, and revegetating all disturbed areas.

The problems associated with the abandoned mines located in the South Fork watershed were so vast and numerous that it was necessary to divide this large area into smaller, more manageable

Table 1. Historic water quality of South Fork Patoka River and its tributaries, as reported by Corbett (1969) and Renn (1989)

[NA = not analyzed]

\begin{tabular}{|c|c|c|c|c|c|c|}
\hline Sample location & Source & $\begin{array}{c}\mathrm{pH} \\
\text { (s.u.) }\end{array}$ & $\begin{array}{l}\text { Acidity } \\
\text { (mg/L) }\end{array}$ & $\begin{array}{c}\text { Alkalinity } \\
(\mathrm{mg} / \mathrm{L})\end{array}$ & $\begin{array}{l}\text { Sulfate } \\
\text { (mg/L) }\end{array}$ & Sample dates \\
\hline A-Headwaters & Corbett & 2.8 & 280 & NA & 3,400 & $08 / 02 / 66$ \\
\hline \multirow{3}{*}{ B-Houchin Ditch } & \multirow{3}{*}{ Renn } & $\begin{array}{ll}4.7 \\
\end{array}$ & 233 & 0.0 & 1,100 & $07 / 18 / 84$ \\
\hline & & 3.7 & 179 & 0.0 & 520 & $12 / 05 / 84$ \\
\hline & & 3.8 & 99 & 0.0 & 410 & $02 / 26 / 85$ \\
\hline C-Durham Ditch & Corbett* & $2.5-3.0$ & $\begin{array}{l}1,810- \\
8,800\end{array}$ & 0.0 & $\begin{array}{c}3,350- \\
22,000\end{array}$ & $03 / 03 / 62-10 / 03 / 68$ \\
\hline D-Main channel & Corbett $^{\dagger}$ & $2.7-4.6$ & $314-1,860$ & 0.0 & $700-5,300$ & $03 / 24 / 65-07 / 08 / 68$ \\
\hline \multirow{3}{*}{ E-Wheeler Creek } & \multirow{3}{*}{ Corbett } & 2.8 & 1,130 & NA & NA & $10 / 13 / 65$ \\
\hline & & 2.3 & 1,960 & NA & NA & $10 / 27 / 65$ \\
\hline & & 2.8 & 1,920 & NA & NA & $06 / 27 / 67$ \\
\hline F-Near mouth & Corbett $^{\dagger}$ & $2.6-5.5$ & $38-554$ & $0.0-4$ & $188-4,400$ & $04 / 09 / 62-07 / 08 / 68$ \\
\hline
\end{tabular}

* Data comprise a range of 19 samples collected during this period.

† Data comprise a range of 37 samples collected during this period. 
reclamation projects. To date, nine reclamation projects (fig. 3) have been completed within the South Fork watershed. These include: Blackfoot-Site 130; Stendal-Site 306; Wheeler Creek-Site 147; Blackfoot Tipple-Site 1101; Sugar Ridge Area 5-Site 304; EnosSites 898 and 979; and Log Creek Church-Sites 900 and 2040. Each of these projects has had a positive effect on water quality within the South Fork and will be discussed individually.

\section{Blackfoot Reclamation Project-AML Site 130}

This site is located in Pike County approximately 1.5 miles $(2.4 \mathrm{~km})$ south of Augusta, Indiana, and comprised 125 acres (50.5 ha) of gob, 146 acres (59 ha) of slurry, 292 acres (118.1 ha) of spoil, 41 acres (16.6 ha) of acid lakes, and 1,762 linear ft $(537 \mathrm{~m})$ of highwalls (fig. 4). TenEch Environmental Engineers, Inc., completed the original feasibility study

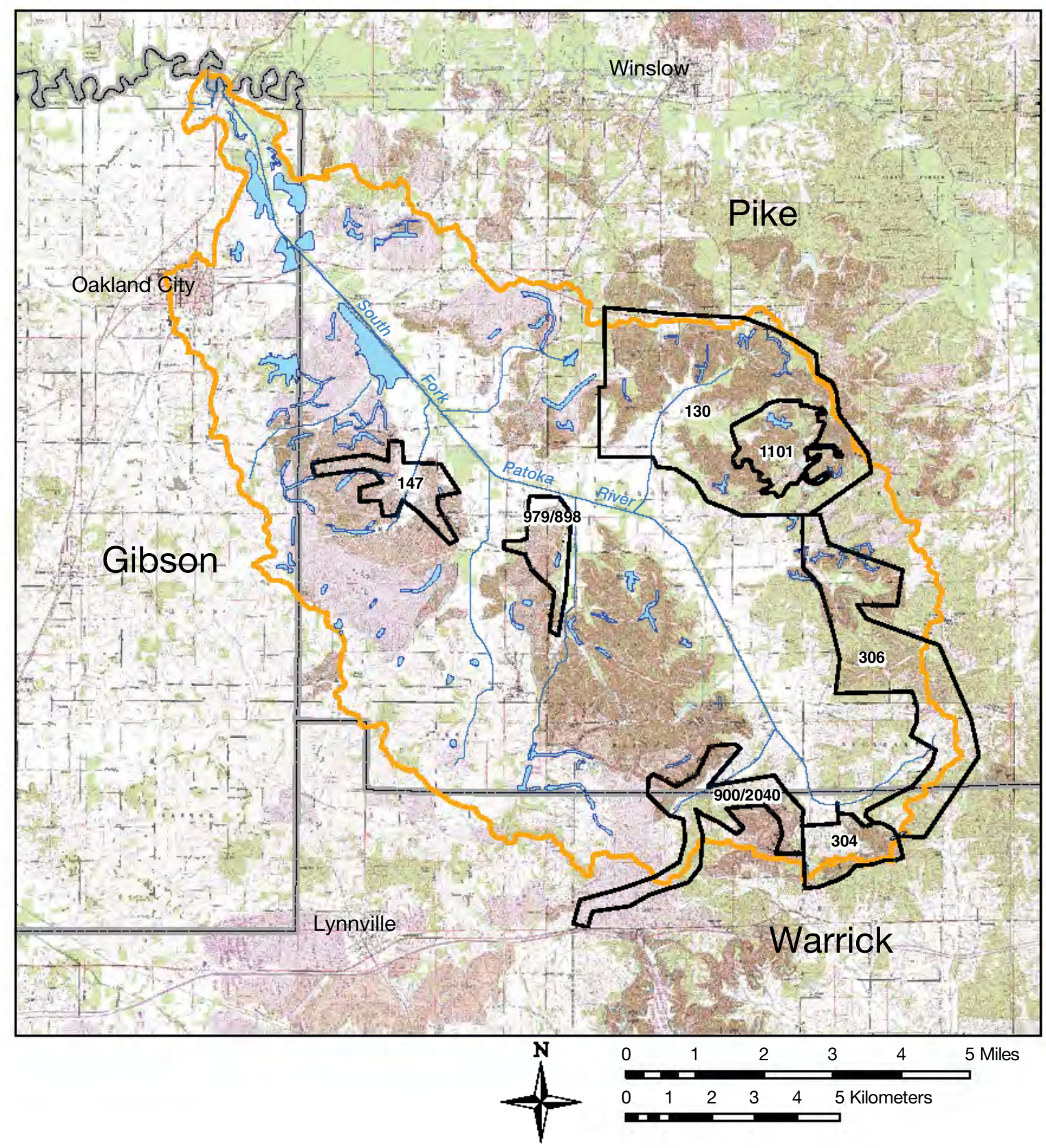

Figure 3. Map of the South Fork Patoka River Watershed (yellow line) showing locations of abandoned mine land reclamation projects. 


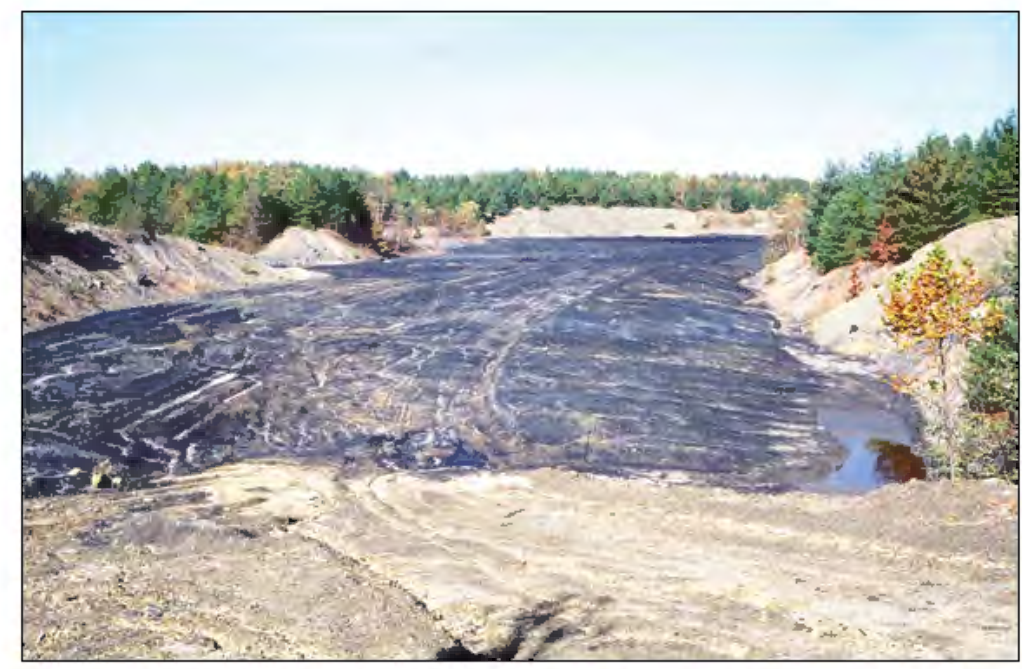

Figure 4. Photograph of AML Site 130 prior to reclamation showing a large area of barren and eroding gob, barren spoil, and acid water surrounded by vegetated spoils, Pike County, Indiana.

and project design; Rogers Group, Inc., was the construction contractor. This reclamation project began in October 1986 and was completed by June 1988 at a total cost of $\$ 3,434,376$.

In an attempt to enhance the environmental landscape and improve the quality of water leaving the site, state-of-the-art reclamation techniques were utilized, including: grading, consolidating, and covering all barren spoil and coal refuse (including 20.6 miles $(33.1 \mathrm{~km})$ of roads built with gob); treating and discharging impounded acid water; backfilling dangerous highwalls; establishing positive drainage; and revegetating 521 acres (210.8 ha), for a total completed project of 521 acres (210.8 ha).

This large, complex site was not only the first reclamation project undertaken within the South Fork watershed, but was one of the first big projects completed by the young Indiana AML Program. Consequently, the services of an engineering firm to complete a feasibility study as well as the project design and specifications were solicited. A general discussion of the problems associated with this area was succinctly presented in the Blackfoot Abandoned Mine Lands Feasibility Study (TenEch, 1985, p. 86) as follows:

"The problems associated with the coal mining industry are not new and are likely to be with us for some time. Fortunately, as time passes, technologies, methods and laws are upgraded to reflect the general awareness of the potential problems associated with the mining of coal. Unfortunately, this general awareness has not always been present and its results are all too evident. The project in question, the Blackfoot abandoned mine land site, is one example of the general lack of awareness and concern that existed in the past. Techniques to treat problems that were created due to mining activities were incomplete or nonexistent, and the problems created then persist to this day. The problem of greatest concern is the generation of acid mine drainage." More than 20 years later, these statements are still all too relevant.

The Blackfoot reclamation area is wholly contained within the Durham Ditch tributary watershed of the South Fork, which comprises 6.34 miles $^{2}\left(16.42 \mathrm{~km}^{2}\right)$ of drainage area. At the time of Corbett's investigation, 52.4 percent of this area had been disturbed by surface mining (Corbett, 1969). That percentage is much greater today. Table 2 lists historic and recent water-quality data and shows how impaired Durham Ditch has been over the years. These data also demonstrate a legacy of acid mine drainage problems within this subwatershed that, to a certain degree, continues to this day.

When this project was completed, the reclamation activities were generally viewed as being very successful, with the revegetation of over 500 acres (202.3 ha) of drastically disturbed land. However, it soon became apparent that not all acid mine drainage was eliminated, because, for a variety of reasons, not all the AML problems in the area were addressed by this initial project. Even though water quality had improved as a result of the project, the Durham Ditch subwatershed was still impaired and in need of additional reclamation (fig. 2). 


\section{Stendal Reclamation Project-AML Site 306}

This site is located in Pike County approximately 1.5 miles $(2.4 \mathrm{~km})$ northwest of Stendal, Indiana, and consisted of 56 acres (22.6 ha) of gob, 46 acres (18.6 ha) of slurry, 31 acres (12.5 ha) of spoil, 40 acres (16.1 ha) of acid lakes, and 1,688 linear $\mathrm{ft}$ (514.5 m) of highwalls. Snell Environmental Group, Inc., completed the original project design; Aigner Construction, Inc., was the construction contractor. This reclamation project began in June 1993 and was completed by January 1995 at a total cost of $\$ 2,089,108$.

The site consisted primarily of acid impoundments, barren pit bottoms, a series of dangerous highwalls, and 9.3 miles $(14.9 \mathrm{~km})$ of county roads that were built using coal refuse (fig. 5). Reclamation included removing coal refuse and reconstructing county roads with drainage structures and side ditches; burying coal refuse, fire clays and contaminated soils with adjacent soil/spoil material; treating and dewatering acid impoundments and filling with spoil material; and revegetating 271 acres (109.6 ha), for a total completed project of 291 acres (117.7 ha).

This was another large and complex site that necessitated retaining the services of a design firm to evaluate the nature and extent of the exposed coal refuse, mine spoil, and acid mine drainage associated with this area. The study area encompassed approximately 535 total acres (216.5 ha), the vast majority of which resides within the Sugar Ridge State Fish and Wildlife Area. Although a portion of the site drains to the east via Cup Creek (a tributary of the Patoka River), the majority of the drainage flows west via Houchin Ditch and two unnamed tributaries of the South Fork.

Corbett (1969, p. 52) found that:

"The principal sources of acid mine drainage in the Houchin Ditch Watershed are concentrated in three areas: (1) the north tributary, the upper reaches of which contain the abandoned Blackfoot Coal Preparation Plant, (2) the southeastern tributary area which contains considerable acreage of shallow mined open pits, some containing acidic ponds and others with dry floors covered with pyritic material which, after oxidation, is later flushed into the ponds during wet weather, and (3) abandoned haul roads and some currently traveled roads constructed of mine waste."

In the early 1990s, the Preliminary Reclamation Study for AML Site 306 found that:

"The majority of drainageways and small impoundments within the reclamation area display $\mathrm{pH}$ in the $2-4$ range with an average high conductivity. All major drainage outfalls leaving the site have shown low $\mathrm{pH}$ and high conductivities. In conclusion, the surface water

Table 2. Historic and recent water quality of Durham Ditch, selected locations

[NA = not analyzed; BDL = below detectable limits. $]$

\begin{tabular}{|c|c|c|c|c|c|c|c|}
\hline Source & $\begin{array}{l}\mathrm{pH} \\
\text { (s.u.) }\end{array}$ & $\begin{array}{l}\text { Acidity } \\
\text { (mg/L) }\end{array}$ & $\begin{array}{l}\text { Alkalinity } \\
\text { (mg/L) }\end{array}$ & $\begin{array}{c}\text { Total Fe } \\
\text { (mg/L) }\end{array}$ & $\begin{array}{c}\text { Total Mn } \\
\text { (mg/L) }\end{array}$ & $\begin{array}{l}\text { Sulfate } \\
\text { (mg/L) }\end{array}$ & Sample dates \\
\hline Corbett $^{\star \dagger}$ & $\begin{array}{l}2.5- \\
3.0\end{array}$ & $\begin{array}{l}1,810- \\
8,800\end{array}$ & $0.0-0.0$ & NA & NA & $\begin{array}{l}3,350- \\
22,000\end{array}$ & 03/03/62-10/03/68 \\
\hline \multirow{3}{*}{$\begin{array}{l}\text { TenEch } \\
\text { Feasibility } \\
\text { Study }{ }^{\ddagger}\end{array}$} & 3.08 & $2,868.0$ & 0.0 & 176.3 & 55.68 & $4,535.0$ & $10 / 13 / 65-01 / 07 / 66$ \\
\hline & 2.6 & 870 & $<0.7$ & 95.650 & 25.175 & 8,895 & $04 / 26 / 84$ \\
\hline & 2.4 & 1,875 & $<0.7$ & 173.150 & 47.500 & 5,430 & $09 / 21 / 84$ \\
\hline \multirow{5}{*}{ Renn ${ }^{\S}$} & 3.1 & 387 & 0.0 & 25 & 24 & 3,200 & $08 / 23 / 83$ \\
\hline & 3.2 & $N A$ & $\mathrm{NA}$ & $N A$ & NA & $N A$ & $06 / 07 / 84$ \\
\hline & 3.1 & $N A$ & 0.0 & 39 & 22 & 3,100 & $07 / 18 / 84$ \\
\hline & 3.5 & 318 & 0.0 & 37 & 20 & 1,800 & $12 / 05 / 84$ \\
\hline & 3.8 & 268 & 0.0 & 26 & 16 & 1,900 & $02 / 26 / 85$ \\
\hline Stacy $^{\dagger}$ & 3.50 & 383 & $\mathrm{BDL}$ & 9.48 & 12.06 & 933 & $04 / 21 / 09$ \\
\hline Stacy ${ }^{\S}$ & 4.60 & 280 & $\mathrm{BDL}$ & 4.41 & 9.64 & 979 & $04 / 21 / 09$ \\
\hline
\end{tabular}

* Data comprise a range of 19 samples collected during this period.

+ Sample taken where Durham Ditch crosses Scottsburg Road; Sample Point C.

‡Sample taken near mouth of Durham Ditch, 1.51 miles $(2.4 \mathrm{~km})$ downstream of Sample Point C.

$\S$ Sample taken where Durham Ditch crosses County Road 875 South, 1.24 miles (1.9 km) downstream of Sample Point C. 


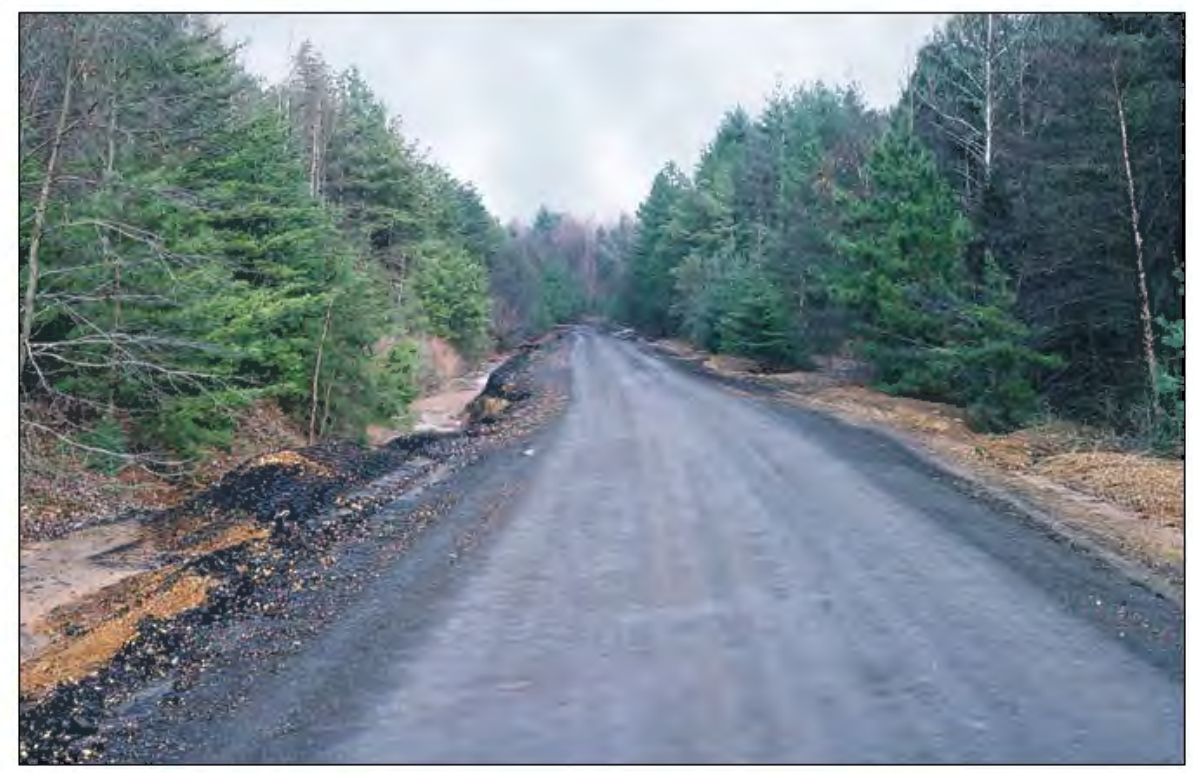

Figure 5. Photograph of AML Site 306 prior to reclamation showing one of many roads built with coal refuse. This portion of road was being used and maintained as a public road, Pike County, Indiana.

samples analyzed have indicated a range typical of abandoned mine lands consisting of poor water quality within the reclamation and outfall areas and fairly good water quality in the stabilized areas adjacent to the limits of reclamation." (Snell Environmental Group, 1992, p. 6-7)

A comparison of pre- and postreclamation waterquality data for Houchin Ditch (Table 3) shows that water quality has improved as a result of the reclamation efforts conducted within this subwatershed. Generally speaking, this waterway now supports the typical aquatic flora and fauna one would expect in a small southern Indiana stream and is nearly indistinguishable from other nearby streams in areas that were not mined.

\section{Wheeler Creek Reclamation Project-AML Site 147}

This site is located in Pike County approximately 3.5 miles $(5.6 \mathrm{~km})$ southeast of Oakland City, Indiana, and comprised 55 acres (22.2 ha) of gob, 75 acres (30.3 ha) of spoil, 5 acres (2.02 ha) of acid lakes, and 4,862 linear $\mathrm{ft}(1,482.9 \mathrm{~m})$ of highwalls. RQAW and Associates, Inc., completed the original project design; Foertsch Construction Company, Inc., was the construction contractor. This reclamation project began in June 1994 and was completed by September 1995 at a total cost of $\$ 1,342,372$.
This site contained barren spoil, acid impoundments, and nearly a mile of dangerous highwalls, and 5.3 miles $(8.5 \mathrm{~km})$ of roads built with coal refuse $(2.5$ miles $[3.2 \mathrm{~km}]$ of which were active county roads) (fig. 6). In general, reclamation activities included: excavating exposed coal refuse, burying this material in designated fill areas, establishing positive drainage, treating acid water, and revegetating 142 acres (57.4 ha), for a total completed project of 142 acres (57.4 ha).

Taking place roughly at the same time as the Stendal Reclamation Project, the Wheeler Creek Reclamation Project was another large site that required the services of an outside firm for field engineering data collection and development of a final design of reclamation methods. The majority of the site is drained by the Wheeler Creek subwatershed of the South Fork. A small, northern portion of the site is drained by Lick Creek, also a tributary of the South Fork.

Corbett (1969, p. 79) concluded:

"that Wheeler Creek...is a wet-weather stream which produces highly acidic water during, and immediately following storms of sufficient magnitude and intensity to produce either a partial or complete flush out from areas known to contain exposed pyritic material."

During the preparation of the Abandoned Mine Land Restoration Design Development Phase Report (RQAW, 1991, p. 1-2), it was determined that: 
Table 3. Historic and recent water quality of Houchin Ditch, selected locations

[NA = not analyzed; $\mathrm{BDL}=$ below detectable limits. $]$

\begin{tabular}{|c|c|c|c|c|c|c|c|}
\hline Source & $\begin{array}{l}\text { pH } \\
\text { (s.u.) }\end{array}$ & $\begin{array}{l}\text { Acidity } \\
\text { (mg/L) }\end{array}$ & $\begin{array}{l}\text { Alkalinity } \\
\text { (mg/L) }\end{array}$ & $\begin{array}{c}\text { Total Fe } \\
\text { (mg/L) }\end{array}$ & $\begin{array}{c}\text { Total Mn } \\
(\mathrm{mg} / \mathrm{L})\end{array}$ & $\begin{array}{l}\text { Sulfate } \\
\text { (mg/L) }\end{array}$ & Sample dates \\
\hline Corbett* & 2.9 & 300 & 0.0 & NA & NA & 930 & $06 / 21 / 67$ \\
\hline \multirow{3}{*}{ Renn $^{\dagger}$} & 4.7 & 233 & 0.0 & 0.680 & 5.4 & 1,100 & $07 / 18 / 84$ \\
\hline & 3.7 & 179 & 0.0 & 31 & 9.7 & 520 & $12 / 05 / 84$ \\
\hline & 3.8 & 99 & 0.0 & 21 & 4.5 & 410 & $02 / 26 / 85$ \\
\hline SEG* & 4.91 & NA & $<1.5$ & 19 & 7.7 & 1,620 & 10/17/91 \\
\hline ATC $^{\ddagger \neq}$ & 7.0 & 0.0 & 48 & 2.5 & 3.1 & 473 & $\begin{array}{l}08 / 03 / 01 \\
01 / 31 / 02 \\
04 / 18 / 02\end{array}$ \\
\hline Stacy $^{\dagger}$ & 6.81 & $\mathrm{BDL}$ & 61 & 1.03 & 3.79 & 511 & $01 / 13 / 09$ \\
\hline
\end{tabular}

* Sample taken in Houchin Ditch adjacent to Haul Road, 1.27 miles $(2.04 \mathrm{~km})$ upstream of Sample Point B.

+ Sample taken where Houchin Ditch crosses County Road 400 East, Sample Point B.

$\ddagger$ Data comprise an average of three samples collected during this period.

"Runoff from the coal refuse has caused all of the contamination of the surrounding vegetation and water bodies. It is estimated that approximately 149,000 cubic yards of coal refuse is present on the site and the total area of contamination is approximately 137 acres. There are seven water bodies within the proposed reclamation site limits that have a total volume of approximately 4.6 million gallons of water and require treatment due to contamination by runoff from the coal refuse."

A comparison of pre- and postreclamation waterquality data for Wheeler Creek (Table 4) shows that water quality improved as a result of the reclamation efforts conducted within this subwatershed. RQAW did not collect water samples in Wheeler Creek itself during their design process, so data

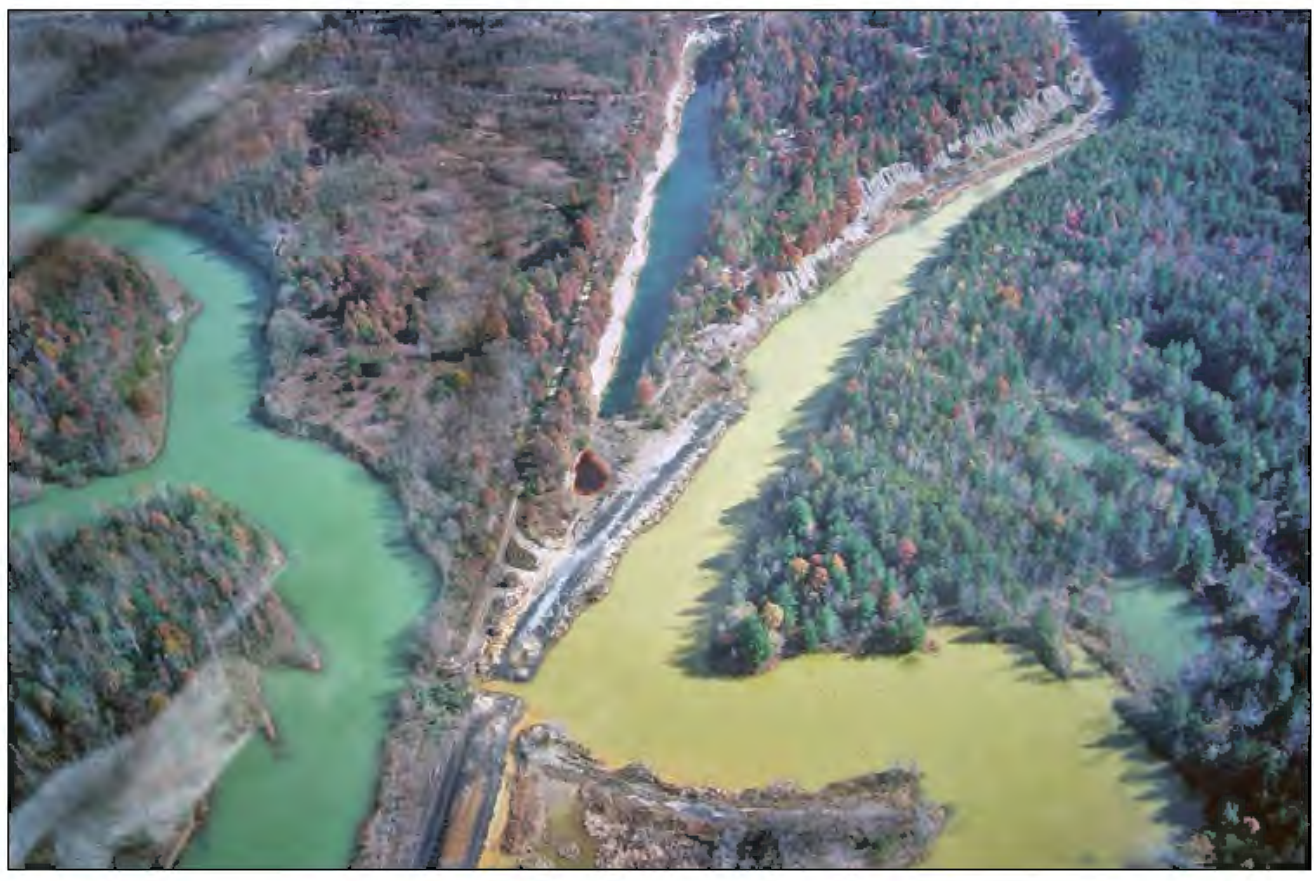

Figure 6. Photograph of AML Site 147 prior to reclamation showing multiple highwalls, scattered coal refuse, and impaired water surrounded by vegetated spoils, Pike County, Indiana. 
Table 4. Historic and recent water quality of Wheeler Creek, selected locations

[NA = not analyzed.]

\begin{tabular}{|l|c|c|c|c|c|c|c|}
\hline Source & $\begin{array}{c}\mathrm{pH} \\
\text { (s.u.) }\end{array}$ & $\begin{array}{c}\text { Acidity } \\
\text { (mg/L) }\end{array}$ & $\begin{array}{c}\text { Alkalinity } \\
(\mathrm{mg} / \mathrm{L})\end{array}$ & $\begin{array}{c}\text { Total Fe } \\
(\mathrm{mg} / \mathrm{L})\end{array}$ & $\begin{array}{c}\text { Total Mn } \\
(\mathrm{mg} / \mathrm{L})\end{array}$ & $\begin{array}{c}\text { Sulfate } \\
\text { (mg/L) }\end{array}$ & Sample dates \\
\hline \multirow{3}{*}{ Corbett* $^{*}$} & 2.8 & 1,130 & $\mathrm{NA}$ & $\mathrm{NA}$ & $\mathrm{NA}$ & $\mathrm{NA}$ & $10 / 13 / 65$ \\
\cline { 2 - 8 } & 2.3 & 1,960 & $\mathrm{NA}$ & $\mathrm{NA}$ & $\mathrm{NA}$ & $\mathrm{NA}$ & $10 / 27 / 65$ \\
\cline { 2 - 8 } & 2.8 & 1,920 & $\mathrm{NA}$ & $\mathrm{NA}$ & $\mathrm{NA}$ & $\mathrm{NA}$ & $06 / 27 / 67$ \\
\hline \multirow{3}{*}{ Renn $^{*}$} & 7.3 & $\mathrm{NA}$ & $\mathrm{NA}$ & $\mathrm{NA}$ & $\mathrm{NA}$ & $\mathrm{NA}$ & $06 / 07 / 84$ \\
\cline { 2 - 8 } & 3.3 & 134 & 0.0 & 22 & 11 & 1,500 & $12 / 04 / 84$ \\
\cline { 2 - 8 } & 6.5 & 70 & 86 & 14 & 6 & 1,500 & $02 / 27 / 85$ \\
\hline \multirow{2}{*}{ RQAW ${ }^{\dagger}$} & 3.4 & 540 & $<10$ & 26 & 25 & 1,400 & $08 / 90$ \\
\cline { 2 - 8 } & 3.3 & 540 & $<10$ & 18 & 9.8 & 850 & $11 / 90$ \\
\hline Stacy* & 7.03 & 40 & 111 & 4.72 & 2.59 & 1,303 & $01 / 13 / 09$ \\
\hline
\end{tabular}

* Sample taken where Wheeler Creek crosses Couty Road 775 South; Sample Point E.

† Sample taken in impoundments near Wheeler Creek.

collected in nearby impoundments are included for that time period. Although metal concentrations are currently still slightly elevated, generally speaking this waterway is now net alkaline and supports the typical aquatic flora and fauna one would expect in a small southern Indiana stream.

\section{Blackfoot Tipple Reclamation Project- AML Site 1101}

This site is located in Pike County approximately 2 miles $(3.2 \mathrm{~km})$ south of Augusta, Indiana, and consisted of 55 acres (22.2 ha) of gob, 90 acres (36.4 ha) of slurry, and 70 acres (28.3 ha) of spoil. Indiana Department of Natural Resources (IDNR), Division of Reclamation engineers completed the original project design; Foertsch Construction Company, Inc., was the construction contractor. This reclamation project began in November 1998 and was completed by September 2000 at a total cost of $\$ 4,578,580$.

In general, this project consisted of large, scattered areas of barren gob and slurry, spoil, and multiple acidic impoundments (fig. 7). Reclamation consisted primarily of consolidating, grading, and covering barren coal refuse; treating and discharging $45,000,000$ gallons $(170,343,630$ liters [L]) of acid water; and revegetating 290 acres (117.3 ha) for a total completed project of 294 acres (118.9 ha).

As discussed earlier, the original Blackfoot Reclamation Project (AML Site 130) did not address all abandoned mine land problems within the extremely large Blackfoot complex. The AMD problems

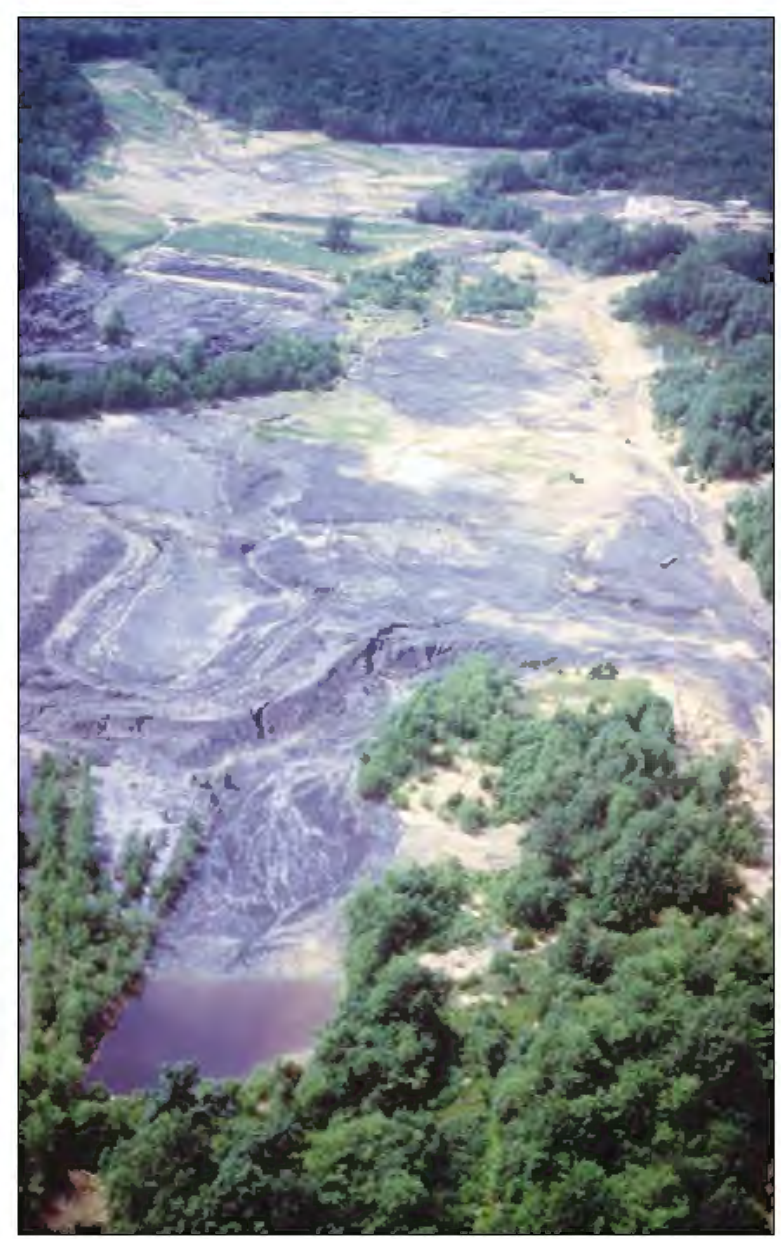

Figure 7. Photograph of AML Site 1101 prior to reclamation showing a large area of scattered coal refuse, barren spoil, and acidic impoundments, Pike County, Indiana. 
in Durham Ditch, although improved, were still prevalent. Additional reclamation in this area was needed, for nearly 300 acres (121.4 ha) of unreclaimed land continued to contribute AMD to Durham Ditch. The Blackfoot Tipple Reclamation Project was designed to address most of the remaining problem areas.

The Blackfoot Tipple Project area is wholly drained by the Durham Ditch subwatershed; Table 2 lists historic and recent water-quality data for this project area. After the successful reclamation of over 800 acres ( $323.7 \mathrm{ha}$ ) of abandoned mine lands at both Blackfoot projects (AML Sites 130 and 1101), Durham Ditch was still being affected by AMD. However, as stated in the Design Feasibility ReportPhase 1, Blackfoot/Midwestern Site (ATC, 2003, p. 71):

"Based on the available data, it appears that the reclamation activities conducted in the West Watershed (the Blackfoot Reclamation Area) since 1984 have resulted in a significant improvement in the water quality discharging to the South Fork Patoka River. It should also be noted that the acid load discharging from Durham Ditch has been reduced by 62 percent as a result of previous reclamation efforts."

This reduction in acid load is quite significant, especially considering how seriously impaired this waterway was. And the fact that there are still AMD problems associated with the area points out how heavily affected this subwatershed has been; even after both projects were completed, additional reclamation is still needed. The Blackfoot Tipple Project was viewed by many as "Phase 2" of a multi-part project.

\section{Sugar Ridge Area 5 Reclamation Project - AML Site 304}

This site is located in Pike County approximately 1.5 miles $(2.4 \mathrm{~km})$ northeast of Scalesville, Indiana, and consisted of 5 acres (2.02 ha) of gob, 20 acres (8.09 ha) of spoil, and 12 acres ( $4.8 \mathrm{ha}$ ) of acid lakes. IDNR, Division of Reclamation engineers completed the original project design; Aigner Construction, Inc., was the construction contractor. This reclamation project began in February 2000 and was completed by May 2001 at a total cost of $\$ 817,755$.

Reclamation of this relatively small site ( 100 acres [ 40 ha]) was the next step in the AML Program's attempt to alleviate the abandoned mine land problems within the South Fork watershed. The site consisted primarily of exposed coal refuse, including 0.8 miles $(1.3 \mathrm{~km})$ of roads built with gob, multiple acid impoundments, barren and acidic pit bottoms, and barren spoils (fig. 8), all contributing acid mine drainage into an unnamed tributary of the South Fork in the headwaters region. Reclamation included grading and covering the exposed coal refuse and acidic pit bottoms, treating and discharging $1,200,000$ gallons $(4,542,494.14 \mathrm{~L})$ of acid water, and revegetating 92 acres ( $37.2 \mathrm{ha})$, for a total completed project of 104 acres (42.08 ha).

This site was one of the first of Indiana AML Program's reclamation projects to incorporate a series of small passive treatment wetlands to help alleviate the acid mine drainage problems. Because this site is also located within the Sugar Ridge State Fish and Wildlife Area, several pits having marginal water quality were treated and maintained and several other wetlands were created using drop-log structures to serve as passive treatment systems and to provide excellent wildlife habitat.

The quality of water leaving this area has been quite variable over the years (Table 5). Most likely, water quality decreased rapidly during "flush-out events" where storms of sufficient magnitude and intensity would readily oxidize exposed pyritic material and dissolve acid salts in coal refuse and transport it directly to the receiving stream. The degraded water that resulted from these events may have lingered for some time after the actual storm event as stored groundwater seeped out of the surrounding acid spoils. The source of normal flow, however, may have been from impoundments or groundwater of good quality. Also, much of this subwatershed has not been mined, therefore some of the surface water would emanate from undisturbed areas. This project was designed to isolate and cover the exposed acid-forming materials that caused those periodic flushes of poor-quality water.

\section{Enos Reclamation Projects - AML Sites 898 and 979}

These two sites are located in Pike County approximately 2 miles $(3.2 \mathrm{~km})$ north of Spurgeon, Indiana. AML Site 898 consisted of only 1 acre ( 0.4 ha) of gob. U.S. Department of Interior (DOI), Office of Surface Mining Reclamation and Enforcement and IDNR, Division of Reclamation engineers designed the 


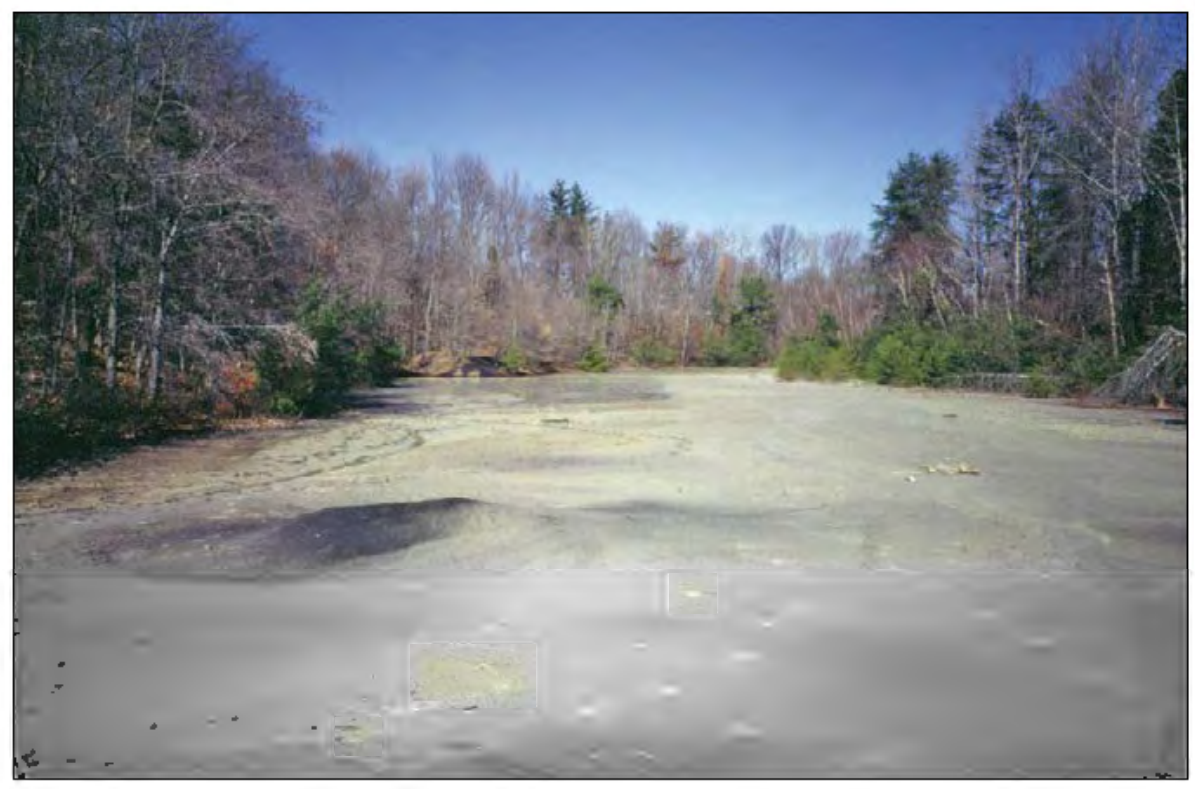

Figure 8. Photograph of AML Site 304 prior to reclamation showing a barren pit bottom and adjacent vegetated spoils, Warrick County, Indiana.

project; Blankenberger Brothers, Inc., was the construction contractor. This reclamation project began in January 2005 and was completed by September 2005 at a total cost of $\$ 996,233$. AML Site 979 consisted of only 1 acre ( 0.4 ha) of gob and 5 acres (2.02 ha) of acid lakes. DOI, U.S. Office of Surface Mining Reclamation and Enforcement and IDNR, Division of Reclamation engineers designed the project; Blankenberger Brothers, Inc., was the construction contractor. This reclamation project began in April 2005 and was completed by October 2005 at a total cost of $\$ 1,011,432$.

Reclamation of Site 898 included treating and discharging 3,500,000 gallons $(13,248,941.2 \mathrm{~L})$ of acid water, creating 28 acres (11.3 ha) of passive treatment wetlands, and revegetating 21 acres ( $8.4 \mathrm{ha})$, for a total completed project of 37 acres (14.9 ha). Reclamation of Site 979 included treating and discharging $3,500,000$ gallons $(13,248,941.2 \mathrm{~L})$ of acid water, creating 35 acres (14.1 ha) of passive treatment wetlands, and revegetating 20 acres (8.09 ha), for a total completed project of 41 acres (16.5 ha).

This very unique project consists of two separate AML sites (898 and 979) that were intended to work in tandem with each other. They were originally designed as one project, but split into two construction projects for logistical reasons. The same contractor, however, retained both contracts and built both projects at virtually the same time. What makes these projects so unique is the fact that both

Table 5. Historic and recent water quality of unnamed tributary in the headwaters of the South Fork, selected locations

[NA $=$ not analyzed. $]$

\begin{tabular}{|c|c|c|c|c|c|c|c|}
\hline Source & $\begin{array}{l}\mathrm{pH} \\
\text { (s.u.) }\end{array}$ & $\begin{array}{l}\text { Acidity } \\
\text { (mg/L) }\end{array}$ & $\begin{array}{c}\text { Alkalinity } \\
\text { (mg/L) }\end{array}$ & $\begin{array}{c}\text { Total Fe } \\
\text { (mg/L) }\end{array}$ & $\begin{array}{c}\text { Total Mn } \\
\text { (mg/L) }\end{array}$ & $\begin{array}{l}\text { Sulfate } \\
(\mathrm{mg} / \mathrm{L})\end{array}$ & Sample dates \\
\hline Corbett* & 4.0 & 420 & 0.0 & NA & NA & 1,200 & $08 / 08 / 68$ \\
\hline \multirow{4}{*}{$\operatorname{Renn}^{\dagger}$} & 7.6 & 48 & 270 & 0.330 & 4.1 & 3,500 & $08 / 24 / 83$ \\
\hline & 7.9 & 0.0 & 307 & 0.470 & 3.5 & 2,600 & $07 / 17 / 84$ \\
\hline & 3.7 & 65 & 0.0 & 27 & 4.9 & 1,000 & $12 / 03 / 84$ \\
\hline & 5.7 & 40 & 2 & 23 & 3.4 & 820 & $02 / 26 / 85$ \\
\hline Stacy* & 6.74 & 10 & 23 & 0.25 & 0.69 & 407 & 04/22/08 \\
\hline
\end{tabular}

*Sample taken where tributary crosses County Road 1350 North.

†Sample taken where tributary crosses County Road 500 East, 1.02 miles $(1.64 \mathrm{~km})$ downstream of County Road 1350 North sampling location. 
sites consisted solely of the construction of a large passive treatment system (fig. 9) to treat acid mine drainage emanating from an adjacent 200 acre $(80.9$ ha) coal refuse area (AML Site 978) known as the Enos Gob Pile. Actually, much of the area where Site 898 was constructed was never disturbed by mining-a very unusual situation for this program.

This multi-stage passive treatment system, totaling approximately 63 acres (25.4 ha), included the addition of naturally alkaline water from an existing mine impoundment, the construction of two vertical flow ponds for additional alkalinity enhancement, and the excavation of a series of oxidation ponds and aerobic wetlands for metal precipitation. This project was designed to treat 375 gallons $(1,419.5 \mathrm{~L})$ per minute of acid mine drainage. This long, linear passive treatment system is so convoluted that from the point where AMD enters the uppermost part of the treatment system to the point where it discharges into the receiving stream, the water will have traveled over 4 miles $(6.4 \mathrm{~km})$. To date, this is the largest, most complex passive treatment system built by the Indiana AML Program.
The other aspect that made this project so unique was the fact that prior to reclamation, acid mine drainage from the coal refuse area was not leaving the site. Although located very near the South Fork, all water seeping or draining off the Enos Gob Pile was collected in a drainage channel and impoundment and was pumped to an adjacent, active tipple operation. It was very fortunate that the tipple, although having no reclamation responsibility for that water, was not allowing any to leave the site. However, it became known that the mining company operating the tipple was in the process of closing the mine and would ultimately shut off the pumps. This would eventually result in all surface and seep water from the Enos Gob Pile flowing directly into the South Fork Patoka River.

To prevent this from happening, the Indiana AML Program installed the passive treatment system before the tipple operation was shut down. The entire system was constructed and completely operational before the pumps were turned off; therefore, no acid mine drainage has ever left the site. Table 6 compares influent and effluent water quality; the data

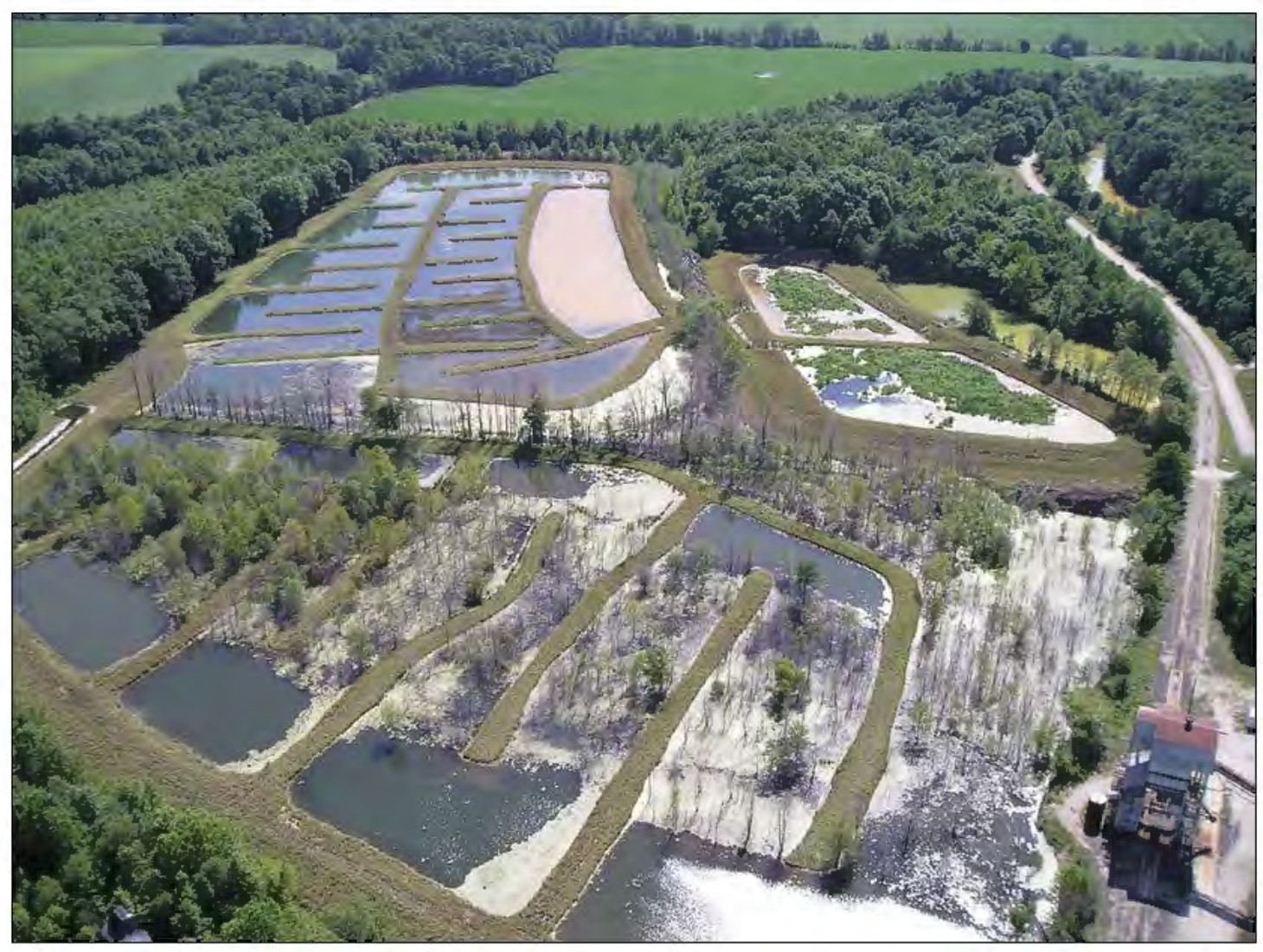

Figure 9. Photograph of AML Site 898 showing the completed passive treatment wetland system three years after construction, Pike County, Indiana. 
Table 6. Water quality of the Enos Reclamation Project (AML Sites 898 and 979) passive treatment system

[BDL $=$ below detectable limits.]

\begin{tabular}{|c|c|c|c|c|c|c|c|c|}
\hline Location & $\begin{array}{c}\mathrm{pH} \\
\text { (s.u.) }\end{array}$ & $\begin{array}{l}\text { Acidity } \\
\text { (mg/L) }\end{array}$ & $\begin{array}{l}\text { Alkalinity } \\
\text { (mg/L) }\end{array}$ & $\begin{array}{c}\text { Total Al } \\
(\mathrm{mg} / \mathrm{L})\end{array}$ & $\begin{array}{c}\text { Total Fe } \\
\text { (mg/L) }\end{array}$ & $\begin{array}{c}\text { Total Mn } \\
\text { (mg/L) }\end{array}$ & $\begin{array}{l}\text { Sulfate } \\
(\mathrm{mg} / \mathrm{L})\end{array}$ & Sample date \\
\hline System in & 2.79 & 660 & $\mathrm{BDL}$ & 14.17 & 189.20 & 4.59 & 2,497 & \multirow{2}{*}{ 10/29/08 } \\
\hline System out & 7.13 & $\mathrm{BDL}$ & 105 & 0.06 & $\mathrm{BDL}$ & 1.57 & 1,910 & \\
\hline
\end{tabular}

show a dramatic improvement in quality as a result of this passive treatment system. A detailed report on the design and effectiveness of this project is presented by Behum (2012 [this volume]).

\section{Log Creek Church Reclamation Projects - AML Sites 900 and 2040}

These two sites are located in Pike and Warrick Counties approximately 2 miles $(3.2 \mathrm{~km})$ north of Scalesville, Indiana. AML Site 900 consisted of 36 acres (14.5 ha) of gob, 30 acres (12.1 ha) of spoil, 18 acres (7.2 ha) of acid lakes, and 1,570 linear $\mathrm{ft}(478.5$ $\mathrm{m})$ of highwall. IDNR, Division of Reclamation engineers designed the project; Foertsch Construction Company, Inc., was the construction contractor. This reclamation project began in May 2006 and was completed by November 2006 at a total cost of $\$ 1,565,719$. AML Site 2040 consisted of 8 acres (3.2 ha) of gob, 11 acres (4.4 ha) of spoil, 10 acres (4.04 ha) of acid lakes, and 2,863 linear $\mathrm{ft}(872.6 \mathrm{~m})$ of highwall. IDNR, Division of Reclamation engineers designed the project; Boyd and Sons Excavating was the construction contractor. This reclamation project began in April 2007 and was completed by July 2007 at a total cost of $\$ 573,827$.

These two sites (900 and 2040) were designed as one project but split into two construction projects for financial reasons. Reclamation of both sites consisted of grading, consolidating, and covering coal refuse, including 3 miles $(4.8 \mathrm{~km})$ of roads built with gob; backfilling dangerous highwalls; treating and discharging 35,400,000 gallons $(134,003,577 \mathrm{~L})$ of acid water; constructing a 17-acre (6.8-hectare), 3-cell, passive treatment wetland system; and revegetating 96 acres (38.8 ha), for a total completed project of 114 acres (46.1 ha). Prior to reclamation, the largest of the acidic impoundments on this site drained directly into the very beginning of the South Fork channel. Essentially, the headwaters of the South Fork Patoka River was an acidic impoundment surrounded by acid-producing, barren coal refuse (fig.
10). The project was designed to ameliorate the last remaining major source of acid mine drainage in the South Fork headwaters region.

The Draft Ecosystem Restoration Report (The Bioengineering Group, 2002, p. 3-6) for this site found that:

"The most active source of pyritic material impacting adjacent and downstream water quality is coal refuse found on the site. This refuse consists of low-grade coal, gob, and black shale, all of which have a high pyritic content. These materials are often mixed and contribute chemically to the generation of acid runoff. In the past, gob was used extensively for road building on coal property, and is also found in stockpiles randomly across the site." Water quality in the headwaters of the South Fork was negatively affected by the widespread presence of acid-forming material and the complete alteration of natural surface flow.

Corbett (1969) stated that 47 percent of this area had been disturbed by surface mining as of June 30, 1968, and the then-active Enos Log Church Mine would eventually mine out most of the headwaters to the west, which it and subsequent mining operations did. While sampling in this area, he also noted that "there was indication that acid concentrations progressively increased during the six-year (sampling) period" (Corbett, 1969, p. 47). Unfortunately, the U.S. Geological Survey (Renn, 1989) did not collect samples in the area during their study; consequently, no data is available from that source for comparison purposes. Table 7 summarizes the historic and recent water quality for this area and shows a dramatic improvement in water quality. Figure 11 shows water-quality data collected by the author before and after reclamation activities at the same sampling location, which is now where the passive treatment wetland system discharges to the headwaters of the South Fork channel. These data display a very rapid and dramatic improvement in water quality as a direct result of reclamation activities. 


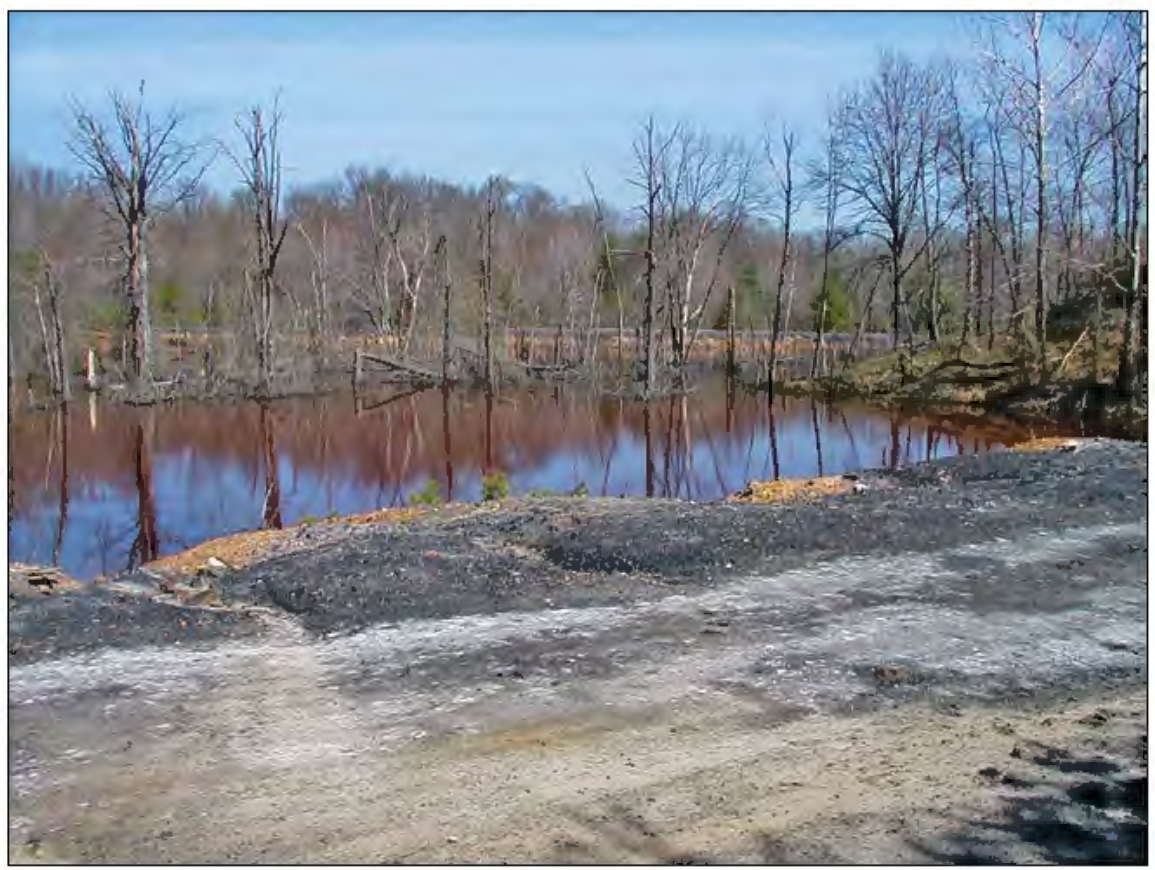

Figure 10. Photograph of AML Site 900 prior to reclamation showing an acidic impoundment surrounded by barren coal refuse. Water from this impoundment flowed directly into the headwaters of the South Fork Patoka River but is now part of the passive treatment wetland system, Warrick County, Indiana.

\section{Current Indiana AML Program projects in the South Fork watershed}

The Indiana Abandoned Mine Land Program conducts a quarterly water sampling program at a multitude of sites, not only to document waterquality improvement, but also to recognize areas where additional reclamation is necessary. Table 8 presents historic and recent water-quality data at selected points along the length of the South Fork and displays an overall improvement in water quality. However, it also indicates that the Durham Ditch subwatershed, although improved, continues to be impaired by AMD. These data are being used by the AML Program to develop additional projects within this subwatershed to address these issues and has led to the development of an experimental reclamation technique at the original Blackfoot project, AML Site 130. This project will constitute the third reclamation project in the Blackfoot Reclamation Area, the tenth in the South Fork Watershed.

One of the main sources of AMD in Durham Ditch is a unique acid seep located at the edge of the surface-mined area in the Blackfoot Reclamation Area (fig. 12). This distinctive feature consists of two large seeps that emanate from the ground within a few feet of each other, each having drastically different water qualities. These two seeps form a channel that is the headwaters of Durham Ditch. As can be seen in Table 9, one seep has chemical characteristics that are typical of acid mine drainage. The other seep, although still impaired, is actually net alkaline.

After an extensive review of the original surface mine maps from the early 1950s, it has been determined that these seeps are located at the lowest elevation of both the surficial topography and

Table 7. Historic and recent water quality in the headwaters of the South Fork

[NA = not analyzed; $B D L=$ below detectable limits. $]$

\begin{tabular}{|l|c|c|c|c|c|c|c|}
\hline Source & $\begin{array}{c}\mathrm{pH} \\
(\mathrm{s} . \mathrm{u} .)\end{array}$ & $\begin{array}{c}\text { Acidity } \\
(\mathrm{mg} / \mathrm{L})\end{array}$ & $\begin{array}{c}\text { Alkalinity } \\
(\mathrm{mg} / \mathrm{L})\end{array}$ & $\begin{array}{c}\text { Total Fe } \\
(\mathrm{mg} / \mathrm{L})\end{array}$ & $\begin{array}{c}\text { Total Mn } \\
(\mathrm{mg} / \mathrm{L})\end{array}$ & $\begin{array}{c}\text { Sulfate } \\
(\mathrm{mg} / \mathrm{L})\end{array}$ & Sample dates \\
\hline Corbett $^{\star}$ & 2.8 & 280 & $\mathrm{NA}$ & $\mathrm{NA}$ & $\mathrm{NA}$ & 3,400 & $08 / 08 / 66$ \\
\hline Stacy* $^{*}$ & 7.71 & $\mathrm{BDL}$ & 193 & 0.21 & 0.17 & 2,165 & $02 / 02 / 09$ \\
\hline
\end{tabular}

* Sample taken where South Fork crosses main haul road; Sample Point A. 


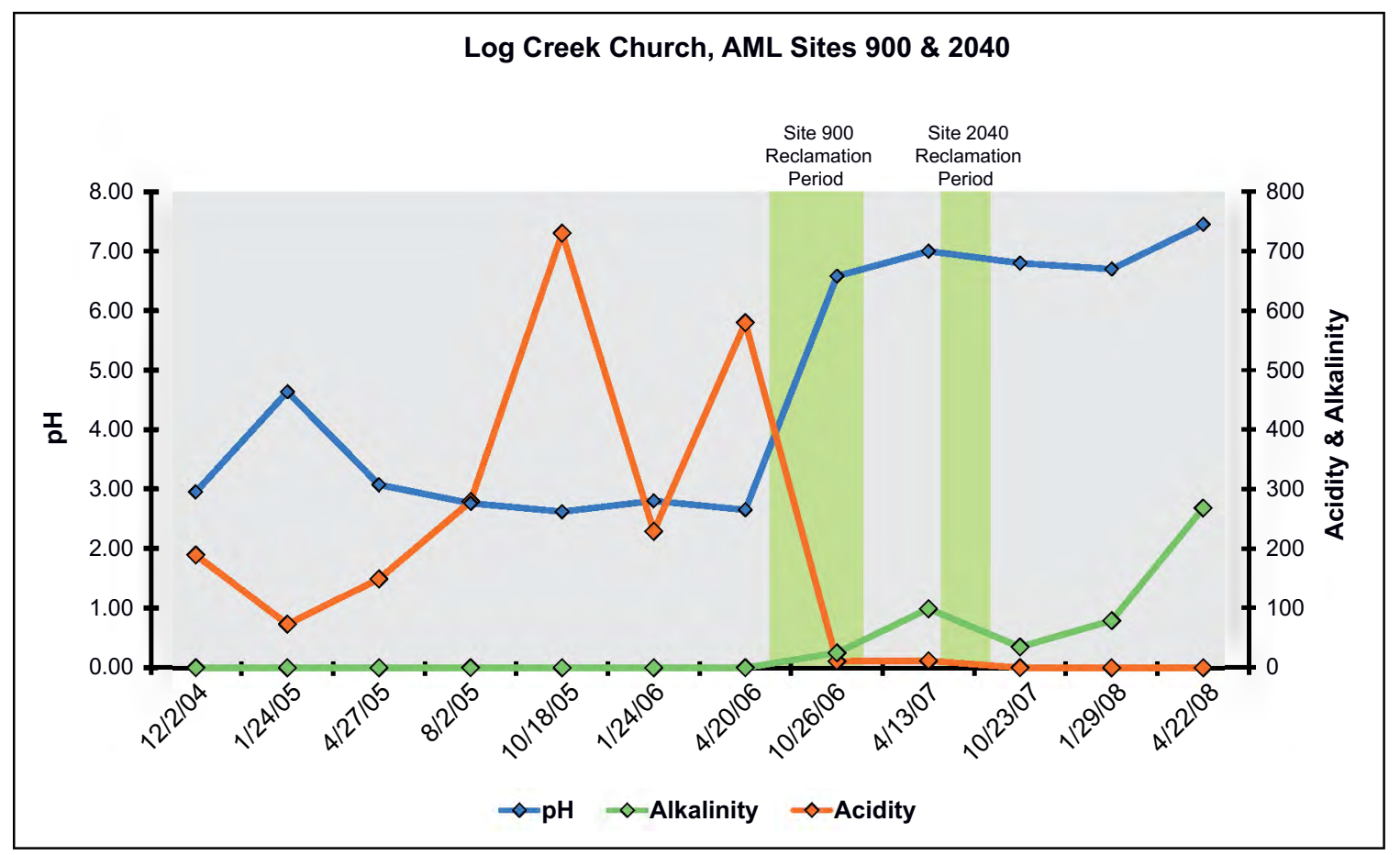

Figure 11. Graph showing water-quailty data before and after reclamation activities at the Log Creek Church, AML sites 900 and 2040 .

Table 8. Historic and recent water quality of the South Fork Patoka River and its tributaries, as reported by Corbett (1969), Renn (1989), and Stacy (unpublished data, 1989)

[NA = not analyzed; $B D L=$ below detectable limits. $]$

\begin{tabular}{|c|c|c|c|c|c|c|}
\hline $\begin{array}{l}\text { Sample } \\
\text { Iocation }\end{array}$ & Source & $\begin{array}{c}\mathrm{pH} \\
\text { (s.u.) }\end{array}$ & $\begin{array}{l}\text { Acidity } \\
(\mathrm{mg} / \mathrm{L})\end{array}$ & $\begin{array}{c}\text { Alkalinity } \\
(\mathrm{mg} / \mathrm{L})\end{array}$ & $\begin{array}{l}\text { Sulfate } \\
\text { (mg/L) }\end{array}$ & Sample dates \\
\hline \multirow{2}{*}{$\begin{array}{c}\text { A } \\
\text { Headwaters }\end{array}$} & Corbett & 2.8 & 280 & NA & 3,400 & $08 / 02 / 66$ \\
\hline & Stacy & 7.71 & BDL & 193 & 2,165 & $02 / 02 / 09$ \\
\hline \multirow{4}{*}{$\begin{array}{c}\text { B } \\
\text { Houchin } \\
\text { Ditch }\end{array}$} & \multirow{3}{*}{ Renn } & 4.7 & 233 & 0.0 & 1,100 & $07 / 18 / 84$ \\
\hline & & 3.7 & 179 & 0.0 & 520 & $12 / 26 / 85$ \\
\hline & & 3.8 & 99 & 0.0 & 410 & $02 / 26 / 85$ \\
\hline & Stacy & 6.81 & $\mathrm{BDL}$ & 61 & 511 & $01 / 13 / 09$ \\
\hline \multirow{2}{*}{$\stackrel{\text { C }}{\text { Durham Ditch }}$} & Corbett $^{*}$ & $2.5-3.0$ & $1,810-8,800$ & $0.0-0.0$ & $3,350-22,000$ & $03 / 03 / 62-10 / 03 / 68$ \\
\hline & Stacy & 3.50 & 383 & $\mathrm{BDL}$ & 933 & $04 / 21 / 09$ \\
\hline \multirow{2}{*}{$\begin{array}{c}\text { D } \\
\text { Main channel }\end{array}$} & Corbett $^{\dagger}$ & $2.8-4.6$ & $314-1,860$ & $0.0-0.0$ & $700-5,300$ & $03 / 24 / 65-07 / 08 / 68$ \\
\hline & Stacy & 7.11 & BDL & 50 & 534 & $04 / 21 / 09$ \\
\hline \multirow{4}{*}{$\begin{array}{c}\text { E } \\
\text { Wheeler Creek }\end{array}$} & \multirow{3}{*}{ Corbett } & 2.8 & 1,130 & NA & NA & $10 / 13 / 65$ \\
\hline & & 2.3 & 1,960 & NA & NA & $10 / 27 / 65$ \\
\hline & & 2.8 & 1,920 & NA & NA & $06 / 27 / 67$ \\
\hline & Stacy & 7.03 & 40 & 111 & 1,303 & $01 / 13 / 09$ \\
\hline \multirow{2}{*}{$\begin{array}{c}\mathbf{F} \\
\text { Near mouth }\end{array}$} & Corbett $^{\dagger}$ & $2.6-5.5$ & $38-554$ & $0.0-4$ & $188-4,400$ & $04 / 09 / 62-07 / 08 / 68$ \\
\hline & Stacy & 7.28 & $\mathrm{BDL}$ & 127 & 915 & $01 / 13 / 09$ \\
\hline
\end{tabular}

* Data comprise a range of 19 samples collected during this period.

† Data comprise a range of 37 samples collected during this period. 


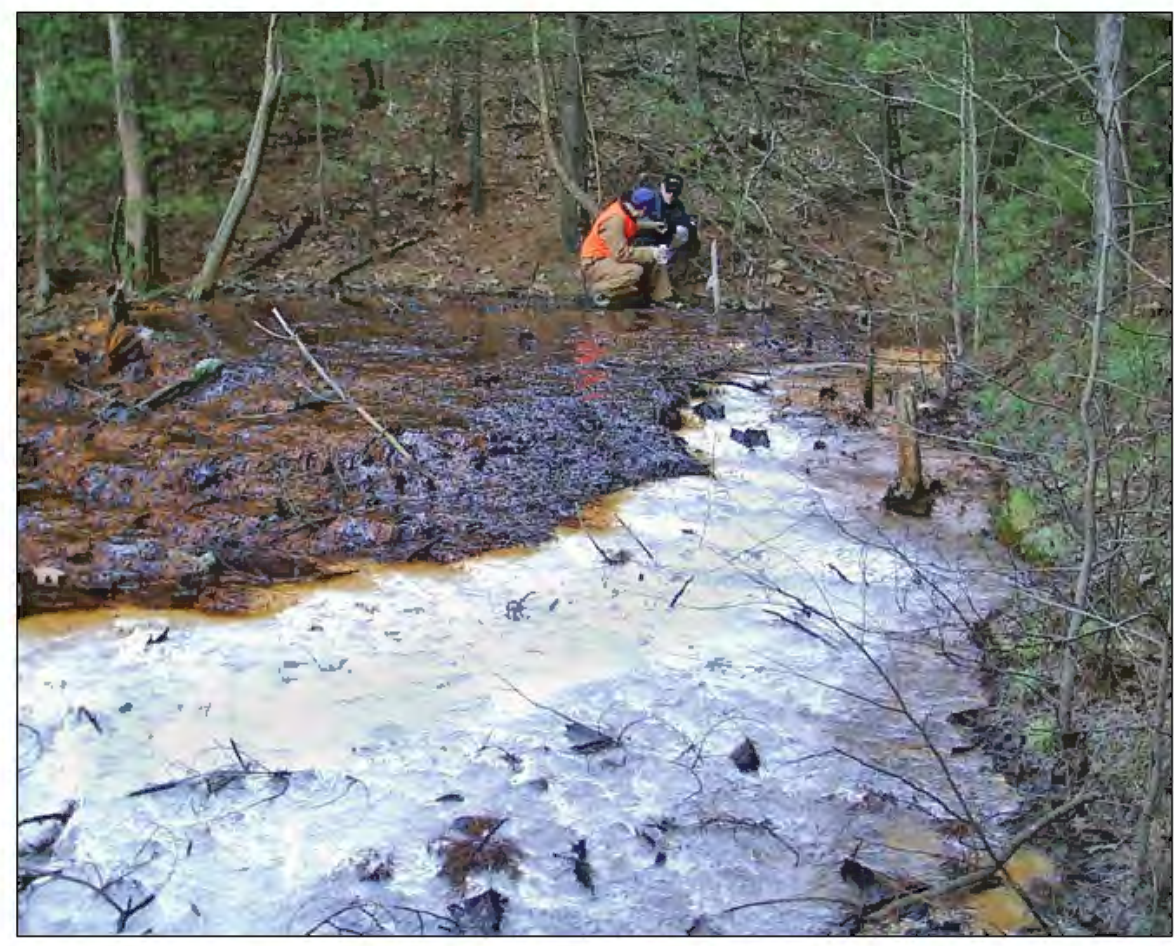

Figure 12. Photograph of AML Site 130 showing the combined flow of two seeps. The acid seep in the left center of the photograph shows the typical red staining of an iron precipitate. The alkaline seep in the bottom center of the photograph shows the white flocculent of an aluminum precipitate, Pike County, Indiana.

the subsurface mine floor topography. Therefore, all groundwater from the surrounding spoils in this area "wants" to flow toward this one location. It was postulated that the acid seep is emanating from an area of typical acidic spoils to the east and the alkaline seep is emanating from spoils to the west which contain an alkaline component, most likely a limestone layer. It was also speculated that these two spoil areas are bisected by some form of subsurface "dam," possibly a remnant of the original mining operation, preventing the groundwater from mixing prior to reaching the surface.

The overriding problem was that the combined seeps created such high flows of very poor quality water that typical passive treatment systems were not practical. Prior to this project, plugging acid seeps had generally been discouraged because seep water has a tendency to reemerge at other locations, possibly creating greater negative impacts than originally existed. However, this site offered the opportunity to utilize the alkaline spoil zone to ameliorate the acidic seep water. For the first time in Indiana's AML Program, this project was designed to purposefully plug an acid seep and force it to discharge at another predetermined location, passing through alkaline spoil on its way. Theoretically, by passing through the alkaline spoil zone, the acid water is "pretreated" to such a level that the resulting seep could be effectively remediated using conventional passive treatment technologies.

This project was built in the summer of 2008, and as of this writing, has not yet been fully evaluated. Because of the ambitious experimental nature of this project, the Indiana Geological Survey was retained to complete a detailed hydrologic monitoring and groundwater flow modeling study to evaluate, optimize, and diagnose the reasons for success or failure. If water quality is improved as a result of this project, the next phase will be to design and implement a more typical passive treatment system downstream to further improve water quality.

\section{SUMMARY}

This paper outlines the successful reclamation efforts of the Indiana Abandoned Mine Land Program in the South Fork Patoka River Watershed and the impacts on water quality within that watershed as compared to historic water-quality data collected in the 1960s and 1980s. With great foresight, Corbett 
Table 9. Water quality of two adjacent seeps, Blackfoot Project, AML Site 130, as reported by ATC (2003)

\begin{tabular}{|c|c|c|c|c|c|c|c|c|}
\hline Seep & $\begin{array}{c}\mathrm{pH} \\
\text { (s.u.) }\end{array}$ & $\begin{array}{l}\text { Acidity } \\
\text { (mg/L) }\end{array}$ & $\begin{array}{c}\text { Alkalinity } \\
\text { (mg/L) }\end{array}$ & $\begin{array}{c}\text { Total Al } \\
(\mathrm{mg} / \mathrm{L})\end{array}$ & $\begin{array}{c}\text { Total Fe } \\
(\mathrm{mg} / \mathrm{L})\end{array}$ & $\begin{array}{c}\text { Total Mn } \\
(\mathrm{mg} / \mathrm{L})\end{array}$ & $\begin{array}{l}\text { Sulfate } \\
\text { (mg/L) }\end{array}$ & $\begin{array}{c}\text { Sample } \\
\text { dates }\end{array}$ \\
\hline Acid $^{*}$ & 4.3 & 883 & 0 & 77.3 & 126.9 & 29.7 & 2,600 & 08/01/01 \\
\hline Alkaline $^{\dagger}$ & 6.1 & 150 & 195 & 0.7 & 19.6 & 19.0 & 2,350 & $04 / 25 / 02$ \\
\hline
\end{tabular}

* Data comprise an average of three samples collected during this period.

${ }^{\dagger}$ Data comprise an average of two samples collected during this period.

(1969, p. 10) concluded that "The water chemist, geologist, hydrologist, biologist, forester, and reclamation manager, both in government and industry, must pool their talents and work together with a common objective in mind, if the desired results in the Patoka River Watershed are to be achieved." Some 40 years later, that is almost exactly what has transpired.

The South Fork was one of the most heavily impaired waterways in the state of Indiana because of acid mine drainage from past coal mining activities. To date, nine large reclamation projects were completed, reclaiming 1,541 acres (623.6 ha) of drastically disturbed lands at a total cost of $\$ 16,409,402$. These reclamation projects significantly improved water quality within the South Fork Patoka River. The Durham Ditch subwatershed was identified, through a quarterly water sampling program, as the last remaining major source of acid mine drainage in the South Fork Watershed. An experimental groundwater redirection project was completed in the Durham Ditch headwaters to address this issue. Future reclamation projects will be implemented by the Indiana Abandoned Mine Land Program as necessary to further improve water quality in the South Fork Patoka River Watershed.

\section{ACKNOWLEDGMENTS}

The author would like to thank the following people for their significant contributions in the preparation of this paper; without their knowledge and generosity, this paper would not have been possible. Dan Hause, Carolyn Sluder, and Craig Wolfe of the Indiana Department of Natural Resources provided site-specific information. Rebecca Meyer and Kimberly Sowder of the Indiana Geological Survey, Dan Hause, and Carolyn Sluder assisted with creating the maps and figures. Ramona Briggeman of the Indiana Department of Natural Resources, John Comer and Margaret Ennis of the Indiana Geological
Survey, and Russ Miller of the U.S. Office of Surface Mining Reclamation and Enforcement reviewed this paper. E. Randall Bayless of the U.S. Geological Survey provided a technical review.

\section{REFERENCES}

ATC Associates, Inc. (ATC), 2003, Design feasibility report-phase 1, Blackfoot/Midwestern Site, Pike County, Indiana: ATC Associates, Inc., 190 p.

Behum, P. T., Hause, D. R., Stacy, M. A., and Branam, T. D., 2012, Passive treatment of large-flow, net-acid mine drainage, in Comer, J. B., ed., Effects of abandoned mine land reclamation on ground and surface water quality-research and case histories from Indiana: Indiana Geological Survey Special Report 72, p. $165-185$.

Corbett, D. M., 1969, Acid mine-drainage problem of the Patoka River Watershed, southwestern Indiana: Water Resources Research Center Report of Investigations No. 4, 173 p.

Gray, H. H., 2000, Physiographic divisions of Indiana: Indiana Geological Survey Special Report 62, p. 7-8.

Renn, D. E., 1989, Streamflow and stream quality in the coal-mining region, Patoka River basin, southwestern Indiana, 1983-85: U.S Geological Survey WaterResources Investigations Report 88-4150, 68 p.

RQAW and Associates, Inc. (RQAW), 1991, Abandoned mine land restoration design development phase report, Reclamation Site 147: RQAW and Associates, Inc., $47 \mathrm{p}$.

Snell Environmental Group, Inc., 1992, Preliminary reclamation study, Abandoned Mine Lands Site \#306, Pike County, Indiana: Snell Environmental Group, Inc., 9 p.

TenEch Environmental Engineers, Inc. (TenEch), 1985, Blackfoot abandoned mine lands feasibility study: Final report, TenEch Environmental Engineers, Inc., $118 \mathrm{p}$.

The Bioengineering Group, Inc., 2002, Draft ecosystem restoration report/environmental assessment, Log Creek Church Site, southwestern Indiana: The Bioengineering Group, Inc., 131 p. 


\title{
Passive Treatment of Large-Flow, Net Acid Mine Drainage: The Enos Reclamation Project, Indiana
}

\author{
Paul T. Behum, ${ }^{*}$ Dan R. Hause, ${ }^{\dagger}$ Mark A. Stacy, ${ }^{\dagger}$ and Tracy D. Branam ${ }^{\ddagger}$ \\ *U.S. Office of Surface Mining Reclamation and Enforcement, Mid-Continent Region \\ ${ }^{\dagger}$ Indiana Department of Natural Resources, Division of Reclamanation \\ ${ }^{\ddagger}$ Indiana Geological Survey
}

\begin{abstract}
The Enos Gob Pile, located in Pike County, Indiana, is a 200-acre (80.9-hectare) refuse disposal area emplaced prior to the August 3, 1977, enactment of the Surface Mining Control and Reclamation Act. Two passive treatment systems totaling approximately 63 acres (25.4 hectares) were constructed in 2005 by the Indiana Department of Natural Resources, Division of Reclamation, with the assistance of the U.S. Office of Surface Mining Reclamation and Enforcement, Mid-Continent Region, to treat acid mine drainage discharging from the refuse disposal area. The passive treatment system at the site includes: 1) addition of alkaline water from adjacent mine impoundments, 2) construction of two vertical flow ponds for additional alkalinity enhancement, and 3) excavation of a series of oxidation ponds and aerobic wetlands for metal precipitation. The system was designed to handle a large amount of net acidic runoff during storm events ranging from 674 to 869 gallons per minute (42.5 to 54.6 liters per second). The water entering each vertical flow pond is relatively low in iron $(18 \mathrm{mg} / \mathrm{L})$, manganese $(3.0 \mathrm{mg} / \mathrm{L})$, and total acidity $\left(92 \mathrm{mg} / \mathrm{L}\right.$ as $\mathrm{CaCO}_{3}$ equivalent). This is the result of prior treatment by mixing dilution water added from a freshwater impoundment with the acid mine drainage in a surface wetland. However, the designers were required to consider the impact of low $\mathrm{pH}(4.0)$ and a significant amount of aluminum $(2.9 \mathrm{mg} / \mathrm{L})$ on the life expectancy of the vertical flow ponds. One of these structures was constructed in a conventional manner using high-calcium limestone and the second using dolomitic limestone as the source of alkalinity. A postconstruction evaluation indicated nearly complete iron removal by the system (total iron $=0.25 \mathrm{mg} / \mathrm{L}$ ) and a net alkaline discharge (alkalinity exceeds acidity by about $69 \mathrm{mg} / \mathrm{L}$ ). Although no specific structures were incorporated in the design for manganese removal, some manganese is being removed by the large wetland system that follows the vertical flow ponds $(3.0 \mathrm{mg} / \mathrm{L}$ in the vertical flow pond inlet, $0.8 \mathrm{mg} / \mathrm{L}$ at the system outlet). Unfortunately, as a
\end{abstract}


result of a sudden large influx of acid mine drainage in 2008, both vertical flow ponds began to fail and required reconstruction during the summer of 2009. Repair of the dolomitic limestone-based vertical flow pond cell required removal of the degraded organic material and replacement with a 4-ft-thick (1.2-m-thick) layer consisting of a blend of agricultural limestone and organic material. The limestone-based cell was rehabilitated simply by adding additional straw to the compost layer. Sulfate declined 19 percent and 8 percent in the limestone and dolomite vertical flow ponds, respectively, which indicates that only a minor amount of sulfate reduction is occurring within these cells.

\section{INTRODUCTION}

The Office of Surface Mining Reclamation and Enforcement, Mid-Continent Region (OSMRE-MCR) and the Indiana Department of Natural Resources, Division of Reclamation (IDNR-DOR) began a joint study of the acid mine drainage (AMD) problems at the abandoned Enos Gob Pile (EGP) in Pike County, Indiana, in September 2004 (fig. 1). The project site is located approximately 34 miles northeast of Evansville (fig. 1). The area is within the Boonville Hills physiographic province and the watershed of the South Fork Patoka River (hereafter, South Fork). The South Fork bisects an extensively mined portion of Pike County and is significantly affected by coal mining conducted before the enactment of the Surface Mining Control and Reclamation Act (SMCRA) in August 1977 (Stacy, 2007).

The Indiana Department of Natural Resources, Division of Reclamation has undertaken extensive reclamation and watershed-based water-quality remediation in the South Fork Patoka River watershed (Stacy, 2007, 2012 [this volume]). Most of the coal produced in the watershed was surface mined, including the coal produced by the Enos Coal Company at Enos Corner. Coal mining at the Enos site began in 1921. In 1963 Interlake Steel and Iron Company purchased the Enos Coal Company, and then sold the mining operation to Old Ben Coal Company in 1965 (Endress, 1999). The 200-acre (80.9-hectare [ha]) EGP was used for fine and coarse coal refuse disposal between 1921 and the imposition of the reclamation requirements of the Surface Mining Control and Reclamation Act of 1977 and it is the source of AMD in the project area (figs. 2 and 3). Because mining activity and gob pile construction ceased prior to the enactment of SMCRA, expenditure for reclamation from the Abandoned Mine Land (AML) Fund is permissible. The EGP overlies an area that was previously surface mined by area methods. Combined, the refuse and mine spoil are piled to a height of $80 \mathrm{ft}$ $(24.4 \mathrm{~m})$ above the nearby floodplain. Prior to reclamation, water that infiltrated through the EGP emerged as AMD in a series of seeps along a preexisting 2,000-ft (610-m) north-south-trending drainage channel (fig. 2, Canal) immediately east of the refuse pile. This drainage flowed northward and was collected in a 7.7-acre (3.1-ha) impoundment termed the "acid lake" located immediately north of the EGP (figs. 2 and 3).

Pumping of the acid lake to prevent discharge ceased in 2006 following the bankruptcy of the old wash plant operator. In anticipation of pumping termination in 2004, the IDNR-DOR and OSMREMCR designed a passive treatment system to treat AMD that discharged from the acid lake, thereby preventing an additional pollution load from reaching the South Fork.

\section{CONDITIONS BEFORE RECLAMATION}

Between 1978 and 2006 an adjacent active operation prevented the AMD in the acid lake from discharging into the South Fork by pumping excess water to a post-SMCRA slurry cell located south of the old wash plant and southwest of the EGP (figs. 2 and 4) (Endress, 1999). During heavy rainfall, highly metal-laden AMD, which normally pooled in a large slurry cell north of the EGP, discharged through an emergency spillway directly into the acid lake (figs. 2 and 3, site F). This incursion of highly acidic water periodically degrades the AMD in this impoundment. Another 


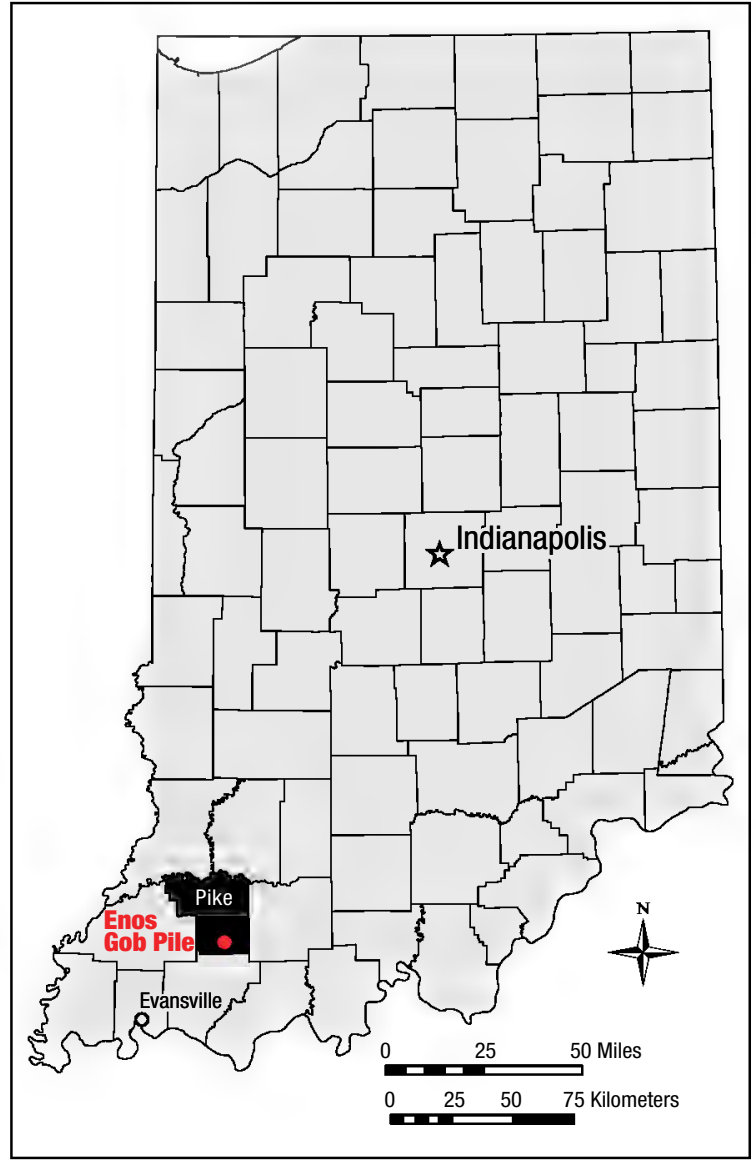

Figure 1. Map of Indiana showing the location of the Enos Gob Pile site.

acidic impoundment, a 1.9-acre (0.78-ha) structure referred to as the "truck wash pond," also collected runoff and seepage from the north side of EGP and discharged poor quality water into the acid lake (figs. 2 and 3). A series of interconnected abandoned mine impoundments located south of the EGP previously served as a secondary source of fresh water for the preparation plant (fig. 2, dilution source lake). The discharge from the post-SMCRA slurry impoundment recharged this dilution water source and formed a closed loop during the old wash plant pumping operation.

\section{BASELINE STUDIES}

From 2001 to 2004, IDNR-DOR and OSMRE-MCR collected baseline water-quality data of acidic discharges from the EGP, two monitoring wells, and the water source believed to be suitable for dilution (figs. 2 and 3). The monitoring wells were developed to evaluate water table depth, soil conditions, groundwater quality, and the stability of an existing freshwater impoundment structure. Additional baseline data were provided by the former mining company that occupied the site (Endress, 1999) and the National Mine Land Reclamation Center (P. Ziemkiewicz, written commun., 2001) (Table 1).

Discharge from the impoundments south of the EGP (fig. 3, south of C) was also evaluated as a source of dilution water during the baseline study. These impoundments are an excellent source of dilution water for passive treatment, having an alkalinity of nearly $220 \mathrm{mg} / \mathrm{L}$ ( $\mathrm{CaCO}_{3}$ equivalent) and low metals content (Table 1). However, this dilution water also contains elevated concentrations of calcium, magnesium, and sulfate, which are characteristic of mine drainage neutralized by disturbed calcareous overburden within the mine spoil. This is important because elevated levels of calcium and sulfate could lead to the precipitation of gypsum on limestone surfaces within passive treatment system structures, such as reducing and alkalinity-producing systems and successive alkalinity-producing systems, with a deleterious effect on system performance (Maynard and Helton, 2005; Huminicki, 2006; Rimstidt and Huminicki, 2006; Rose and others, 2007; Huminicki and Rimstidt, 2008).

\section{DESIGN AND CONSTRUCTION OF THE TREATMENT SYSTEM}

The design team considered two different passive treatment options. Option 1 was based on diluting the AMD by the regulated addition of alkalinity-bearing water from impoundments in the south to improve the quality of the AMD prior to its introduction into a passive treatment system consisting of a series of oxidation ponds and surface-flow (aerobic) wetlands. Option 2 also pre-treats the AMD with alkaline dilution water from the surface impoundments, but alkalinity is further enhanced by two reducing and alkalinityproducing vertical flow ponds (VFP) connected in parallel. The VFPs would not only boost alkalinity but also decrease the concentration of sulfate through bacterial sulfate reduction (Hedin and others, 1994). Effluent from the VFPs would discharge into a series of oxidation ponds and 


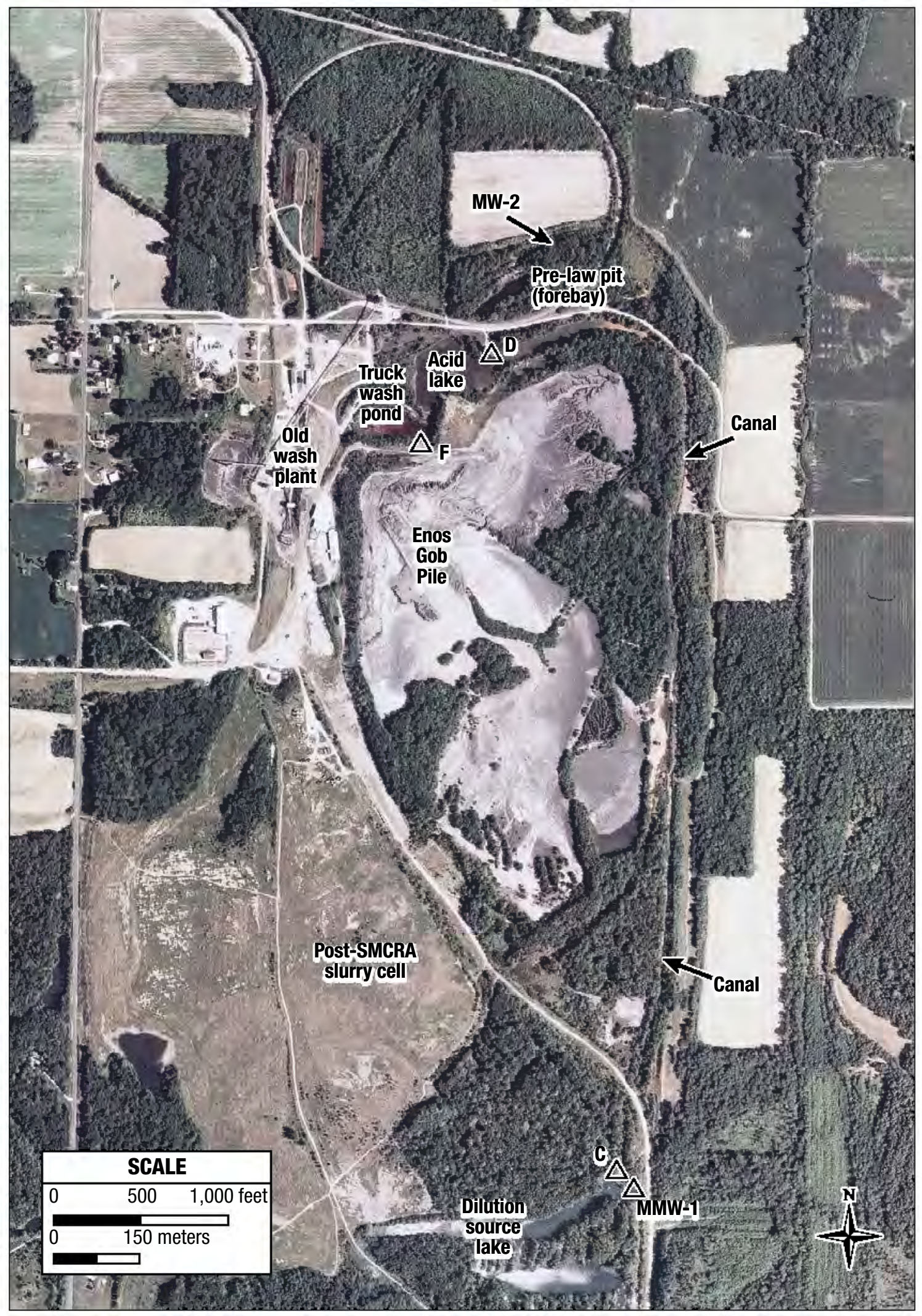

Figure 2. Aerial photograph (2004) showing the Enos Gob Pile prior to reclamation and remining. 


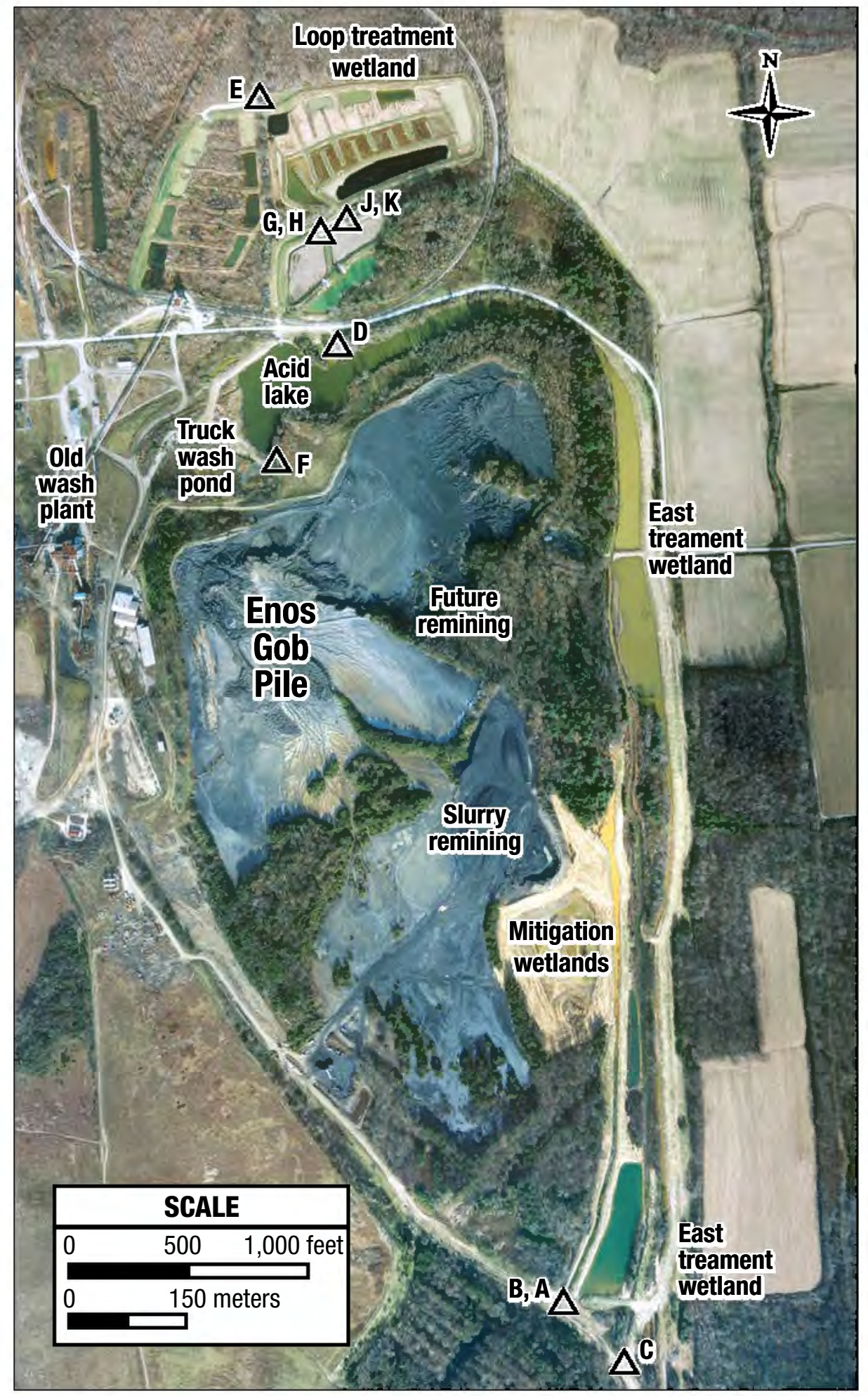

Figure 3. Aerial photograph (2007) showing the Enos Gob Pile site, treatment wetlands, and water monitoring sites (A-K). A. Weir: East ditch on the southeast side of the Enos Gob Pile. B. Weir: West ditch on southwest side of gob pile. C. Dilution water source outlet and well. D. Old pump location (fig. 4) at the acid lake. E. Weir at final outlet of passive treatment system. F. Acidic slurry impoundment of gob pile discharge. G. Discharge from west (limestone) vertical flow pond. H. Discharge from east (dolomite) vertical flow pond. J. West (limestone) vertical flow pond flush pipe. K. East (dolomite) vertical flow pond flush pipe. 


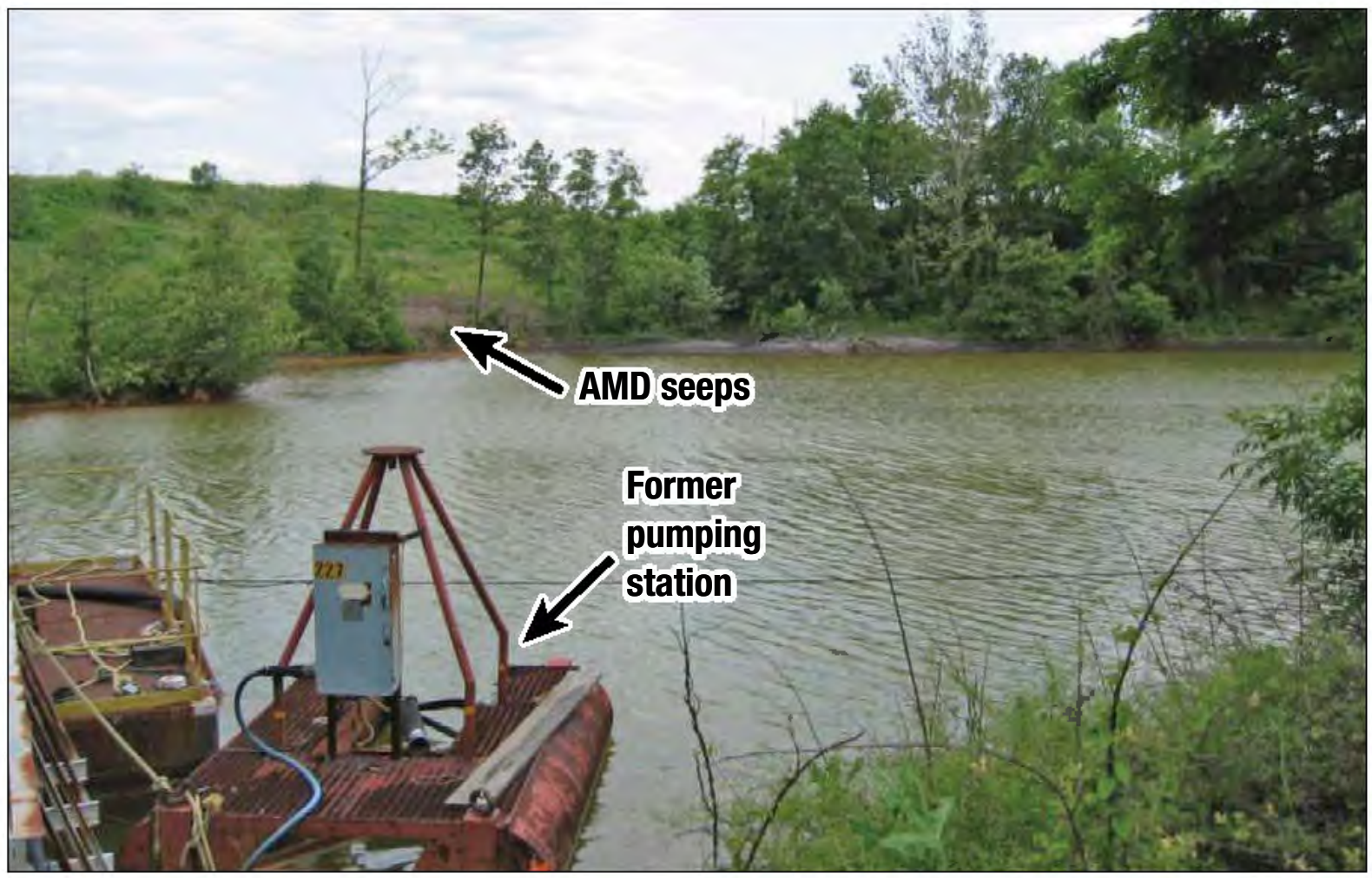

Figure 4. Photograph of the former pumping station at the acid lake; note the Enos Gob Pile in the background and acid mine drainage seepage along the far bank.

surface-flow wetlands where metals would precipitate. Option 1 has been successfully employed at other AML projects in Indiana (Flege, 2001; Flege and Maynard, 2001; and Smith and others, 2003). However, dilution water flow is limited to 0.5 cubic $\mathrm{ft}$ per second (cfs) (225 gallons per minute [gpm], 14.2 liters per second [Lps]) at the Enos site by a use agreement with the landowner to protect water rights in the event of future preparation plant operations.

Option 2 was selected with the VFPs designed to split $1.5 \mathrm{cfs}$ (675 gpm, $42.6 \mathrm{Lps})$ of diluted AMD (0.5 cfs [225 gpm, $14.2 \mathrm{Lps}$ ] of alkaline dilution water and a total of AMD-impacted runoff of $1.0 \mathrm{cfs}$ [450 gpm, $28.4 \mathrm{Lps}]$ ). This design applied passive treatment sizing criteria developed by the U.S. Bureau of Mines (Hedin and others, 1994; Watzlaf, 1997; Watzlaf and others, 2004), which dictated that a large treatment system would be required for effective acidity and metal removal. Two separate contracts were necessary to construct passive treatment facilities at the EGP: one for the east treatment wetland (AML Site 979) and another for the loop treatment wetland (AML Site 898) (fig. 3).
Option 2 provides an additional benefit in that sulfate reduction will occur in the organic compost layer of the vertical flow ponds.

\section{East treatment wetland}

The 16-acre (6.5-ha) east treatment wetland is a series of oxidation ponds and surface-flow aerobic wetlands constructed along the eastern side of the EGP replacing the older AMD collection canal (figs. 2 and 3). This system is intended to pre-treat the AMD by removing most of the iron and aluminum before the water enters the vertical flow ponds in the loop treatment wetland (fig. 3). Two AMD sources feed into the wetland system at the upstream (southern) end, the east ditch (fig. 3, site A), which collects AMD from the east side of the EGP, and the west ditch (fig. 3, site B), which collects AMD from the southwestern part of the EGP. Fresh dilution water, regulated by a gate valve and a weir structure located at site C (fig. 3), enters the wetland from the impoundment that lies south of the EGP (fig. 2). 
Table 1. Summary of 2001-2004 baseline water-quality data

[D. = dissolved; D.O. = dissolved oxygen; F = field measurement or test; NC = not calculated; ND = not determined; NM = not measured; NT = not tested; S.C. $=$ specific conductance; $\mathrm{T} .=$ total; TDS $=$ total dissolved solids. $]$

\begin{tabular}{|c|c|c|c|c|c|c|}
\hline Parameter & $\begin{array}{c}\text { Ferruginous } \\
\text { seep along } \\
\text { canal }\end{array}$ & $\begin{array}{c}\text { Enos Gob Pile } \\
\text { slurry cell } \\
\text { discharge } \\
\text { (Site F) }\end{array}$ & $\begin{array}{c}\text { Acid lake @ } \\
\text { pump platform } \\
\text { (Site D, } \\
\text { median*) }\end{array}$ & $\begin{array}{l}\text { Truck wash } \\
\text { pond } \\
\text { (median*) }\end{array}$ & 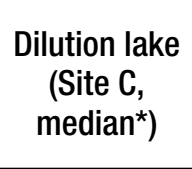 & Units \\
\hline $\mathrm{pH}(\mathrm{F})$ & 7.2 & 2.32 & 3.0 & 4.5 & 7.6 & s.u. \\
\hline S.C. (F) & 3,243 & NM & 3,033 & 3,139 & 3,301 & $\mu \mathrm{S} / \mathrm{cm}$ \\
\hline D.0. (F) & NM & NM & 6.0 & 3.32 & 3.4 & $\mathrm{mg} / \mathrm{L}$ \\
\hline D. Fe (F) & NT & NT & 25.90 & 33.70 & 0.32 & $\mathrm{mg} / \mathrm{L}$ \\
\hline D. $\mathrm{Fe}^{2+}(\mathrm{F})$ & NT & NT & 2.46 & 9.60 & 0.13 & $\mathrm{mg} / \mathrm{L}$ \\
\hline D. $\mathrm{Fe}^{3+}(\mathrm{F})$ & NT & NT & 22.29 & 1.10 & 0.23 & $\mathrm{mg} / \mathrm{L}$ \\
\hline Alkalinity (F) & NT & NT & $<1$ & NT & 217 & $\mathrm{mg} / \mathrm{L}$ \\
\hline Sulfate & 840 & 4,890 & 1,300 & 1,050 & 1,600 & $\mathrm{mg} / \mathrm{L}$ \\
\hline Chloride & NT & NT & 2.7 & NT & 3.5 & $\mathrm{mg} / \mathrm{L}$ \\
\hline $\mathrm{HCO}_{3 \text { calc }}^{-}{ }^{\ddagger}$ & NC & $\mathrm{NC}$ & 0.6 & 3.0 & 3.4 & $\mathrm{mg} / \mathrm{L}$ \\
\hline T. Fe & 100 & 961 & 16.10 & 36.25 & 0.22 & $\mathrm{mg} / \mathrm{L}$ \\
\hline T. Al & $<0.07$ & 54.0 & 5.20 & 1.45 & 0.10 & $\mathrm{mg} / \mathrm{L}$ \\
\hline T. Mn & 4.92 & 11.6 & 7.00 & 2.65 & 0.28 & $\mathrm{mg} / \mathrm{L}$ \\
\hline D. Ca & NT & NT & 357.0 & NT & 404 & $\mathrm{mg} / \mathrm{L}$ \\
\hline D. Mg & NT & NT & 135.3 & NT & 260 & $\mathrm{mg} / \mathrm{L}$ \\
\hline D. $\mathrm{Na}$ & NT & NT & 26.90 & NT & 70.9 & $\mathrm{mg} / \mathrm{L}$ \\
\hline D. Fe & 15.0 & NT & 18.39 & 34.35 & 0.22 & $\mathrm{mg} / \mathrm{L}$ \\
\hline D. Al & $<0.07$ & NT & 5.20 & 1.33 & 0.04 & $\mathrm{mg} / \mathrm{L}$ \\
\hline D. Mn & 3.10 & NT & 7.21 & 2.78 & 0.40 & $\mathrm{mg} / \mathrm{L}$ \\
\hline Alkalinity (lab) & NT & $<10$ & $<1$ & 2.5 & 239 & $\mathrm{mg} / \mathrm{L}$ \\
\hline Acidity $_{\text {calc }}^{\dagger}$ & 37.7 & $\mathrm{NC}$ & 126.7 & 90.2 & 1.7 & $\mathrm{mg} / \mathrm{L}$ \\
\hline Acidity (lab) & NT & 3,080 & 200 & NT & $<10$ & $\mathrm{mg} / \mathrm{L}$ \\
\hline TDS (lab) & NT & 8,030 & 1,800 & NT & 3,300 & $\mathrm{mg} / \mathrm{L}$ \\
\hline TDS $_{\text {calc }} \S$ & NC & $\mathrm{NC}$ & 1,770 & ND & 2,516 & $\mathrm{mg} / \mathrm{L}$ \\
\hline
\end{tabular}

${ }^{*}$ Lab alkalinity and acidity are arithmetic mean values and reported as a $\mathrm{CaCO}_{3}$ equivalent ${ }^{\dagger}$ Acidity $_{\text {calc }}=50\left[2 \mathrm{Fe}^{2+} / 56\right.$

$\left.+3 \mathrm{Fe}^{3+} / 56+3 \mathrm{Al} / 27+2 \mathrm{Mn} / 55+1000\left(10^{-\mathrm{pH}}\right)\right]$.

₹ Calculation method from Deutsch (1997).

$\S$ Calculated using AquaChem ver. 3.7 by Waterloo Hydrogeologic.

\section{Loop treatment wetland}

The 30-acre loop treatment wetland was constructed entirely within the preparation plant railroad loop (fig. 5). Prior to reclamation, only 2 acres $(0.8$ ha) were affected by previous mining activities. Most of the remaining area previously was used for agriculture. The total inflow to the proposed passive treatment system from the acid lake (figs. 3 and 5) was estimated by calculating the water balance. A peak flow of $1.0 \mathrm{cfs}(450 \mathrm{gpm}, 28.4 \mathrm{Lps})$ was estimated for a combination of runoff and groundwater base flow to the passive treatment system.
This inflow could be supplemented by a variable amount of water from the dilution source with the rate controlled by a gate valve structure (Site C, fig. 3).

Acid mine drainage from the acid lake (figs. 3 and 4) feeds a smaller abandoned mine pit within the railroad loop that serves as a flow distribution pond (forebay) (fig. 5). Here AMD flow is partitioned into the two vertical flow ponds arranged in parallel (fig. 5) by a flow control valve and stop$\log$ structure at the south end of each VFP. Water that flows through the VFPs discharges into the 
nearest oxidation pond, located south of wetland 1, which discharges into the oxidation pond to the east. From there the water is directed into wetland 2. Wetland 1 remediates any AMD that bypasses the vertical flow ponds by overflowing stop-log structures located on the north side of each VFP (fig. 5). The oxidation ponds total 4.3 acres (1.7 ha), 2.8 acres (1.1 ha) for the upstream pond and 1.5 acres ( $0.6 \mathrm{ha})$ for the downstream pond, while setland 1 is 4.2 acres (1.7 ha), wetland 2 is 7.1 acres (2.9 ha), and wetland 3 is 14.4 acres (5.8 ha).

The two VFPs were constructed to facilitate maintenance and to evaluate alternative alkaline materials. The west VFP was built in a more conventional manner whereby water and compost overlies a 2-ft-thick (0.6-m-thick) layer of high-calcium limestone (Kepler and McCleary, 1994; Watzlaf, 1997; and Behum and others, 2008, 2010). The east VFP substituted dolomitic limestone $\left(\mathrm{CaMg}\left(\mathrm{CO}_{3}\right)_{2}\right)$ for high-calcium stone to evaluate the resistance of dolomitic stone to plugging caused by the formation gypsum coatings. Laboratory research funded by IDNR-DOR found that, under certain geochemical conditions encountered in treatment systems, coatings of gypsum $\left(\mathrm{CaSO}_{4} \cdot 2 \mathrm{H}_{2} \mathrm{O}\right)$ form on limestone $\left(\mathrm{CaCO}_{3}\right)$ surfaces, reducing alkalinity generation from the stone (Maynard and Helton, 2005). More recent research confirmed that gypsum does coat limestone in constructed passive treatment beds (Rose and others, 2007) and in bench-scale tests (Huminicki, 2006; Rimstidt and Huminicki, 2006; and Huminicki and Rimstidt, 2008).

The organic material used in 2006 to construct the VFPs was also unconventional. Because suitable

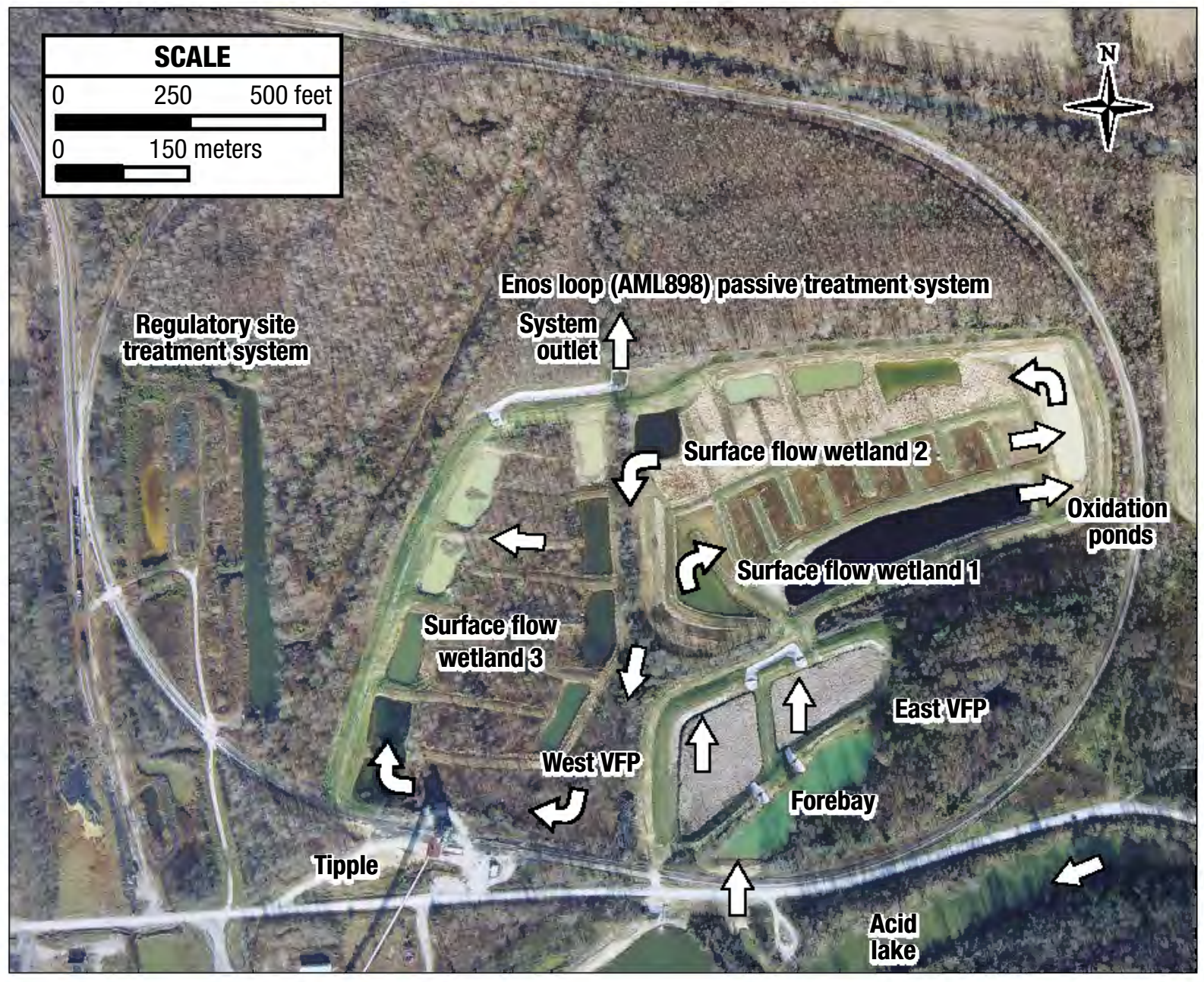

Figure 5. Aerial photograph of the Enos loop treatment wetland (arrows show flow direction). Acid mine drainage that flows over the vertical flow ponds (VFP) during periods of excessive discharge and heavy rainfall is diverted to the pond located west of surface flow wetland 1 and is passively treated as it flows through this wetland system. 
organic material, such as spent mushroom compost or yard waste compost (Kepler and McCleary, 1994; Watzlaf, 1997; Behum and others, 2002; Neculita and others, 2007; and Zagury and Neculita, 2007), was not readily available, bailed straw (dried grain stalks) was substituted (fig. 6). In addition, several 20-ton truckloads of wetland substrate were transplanted from an established wetland (the Tecumseh Mine treatment wetland) (Flege and Maynard, 2001; Flege and others, 2012 [this volume]). This transplanted substrate serves as inoculants for the establishment of both sulfate-reducing bacteria (SRB) and compostdegrading bacteria. Straw-based organic material used in VFP construction had high hydraulic conductivity but is bulky. Therefore, as constructed, the organic layer was 2 to $3.5 \mathrm{ft}$ ( 0.6 to $2 \mathrm{~m}$ ) thick, which is considerably thicker than the 2-ft $(0.6-\mathrm{m})$ thickness in the original design plans. Because of the organic layer thickness, most of the water column that typically forms the upper surface of a VFP was eliminated (figs. 7 and 8).

The loop treatment wetland was constructed between January 2005 and September 2005; the east treatment wetlands was constructed between April 2005 and October 2005. Although the east rreatment wetland received AMD and dilution water immediately upon completion, a break-in period was allowed for the loop treatment wetland,

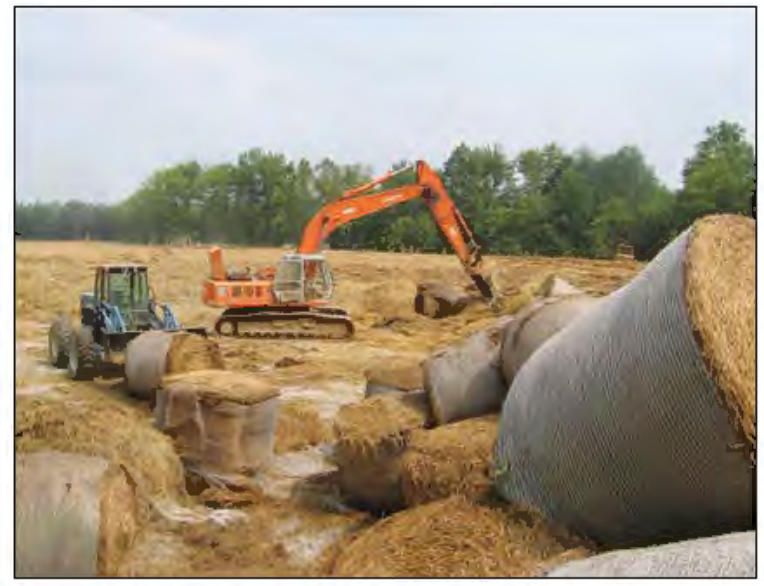

Figure 6. Photograph of excavators spreading straw to construct organic layer.

which did not receive AMD until the fall of 2006. This delay was necessary to allow partial composting of the straw-based organic layer in the VFPs and the establishment of a health microbiologic community.

\section{POSTCONSTRUCTION SYSTEM EVALUATION}

The completed system is monitored by a team that includes personnel from the IDNR-DOR, with

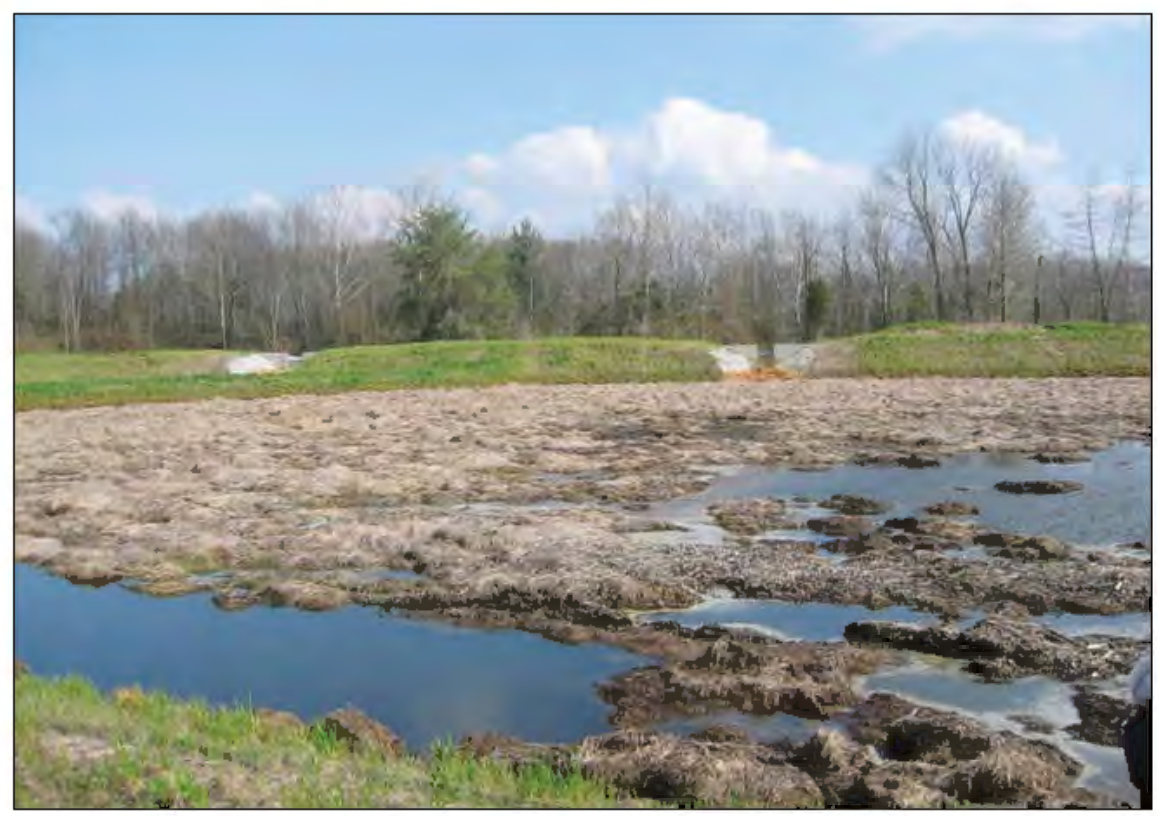

Figure 7. Photograph of dolomite vertical flow pond as originally constructed, showing straw-based compost and thin water layer; note the vertical flow pond inlet stop-log structures in the background. 
assistance on an as-needed basis by personnel of the Indiana Geological Survey (IGS) and OSMREMCR. Most of the water-quality information presented in this paper is based on a series of quarterly water-quality analyses for water samples collected at monitoring sites D and E (fig. 3). This effort was supplemented by more detailed sampling of individual treatment components (fig. 5) and analysis of all the major physical and chemical parameters required to facilitate geochemical modeling (Table 2).

\section{Postconstruction performance: Preliminary findings}

The data in Table 2 shows that the system typically removed most of the iron and aluminum between 2006 and mid-2009 (the system discharged between 0.02 and $9.1 \mathrm{mg} / \mathrm{L}$ and between less than 0.05 (below the detection limit) and $5.35 \mathrm{mg} / \mathrm{L}$, respectively); median values for iron and aluminum are $0.25 \mathrm{mg} / \mathrm{L}$ and $0.13 \mathrm{mg} / \mathrm{L}$, respectively. Significant sulfate removal was also observed from 1,900 to $1,510 \mathrm{mg} / \mathrm{L}$, a 20.5 percent reduction (Table 2). During this period the discharge was net alkaline (alkalinity exceeded acidity by about $69 \mathrm{mg} / \mathrm{L}$ at the system outlet) (Table 2, fig. 5). Aluminum is mostly removed in the VFPs owing to the increase in $\mathrm{pH}$ from 4.0 to 6.4 within these structures. The increase in $\mathrm{pH}$ and alkalinity by the VFPs along with aeration in the oxidation pond and wetlands promoted the precipitation of iron.

During the 2006 through mid-2009 period, aluminum concentration declined from 2.94 to $0.13 \mathrm{mg} / \mathrm{L}$ (Table 2), a 95.6 percent reduction, and the iron concentration declined from 18.3 to $0.25 \mathrm{mg} / \mathrm{L}$ (Table 2), a 98.6 percent decrease. Improvements in metal removal occurred in late 2006 when aquatic vegetation developed. These improvements are presumably because of the adsorption of metals onto organic matter and the precipitation of Fe and Mn hydroxides that began to accumulate at that time.

Between 2006 and mid-2009 the concentration of manganese was reduced 71.8 percent in the loop treatment wetland (from $2.98 \mathrm{mg} / \mathrm{L}$ at the VFP

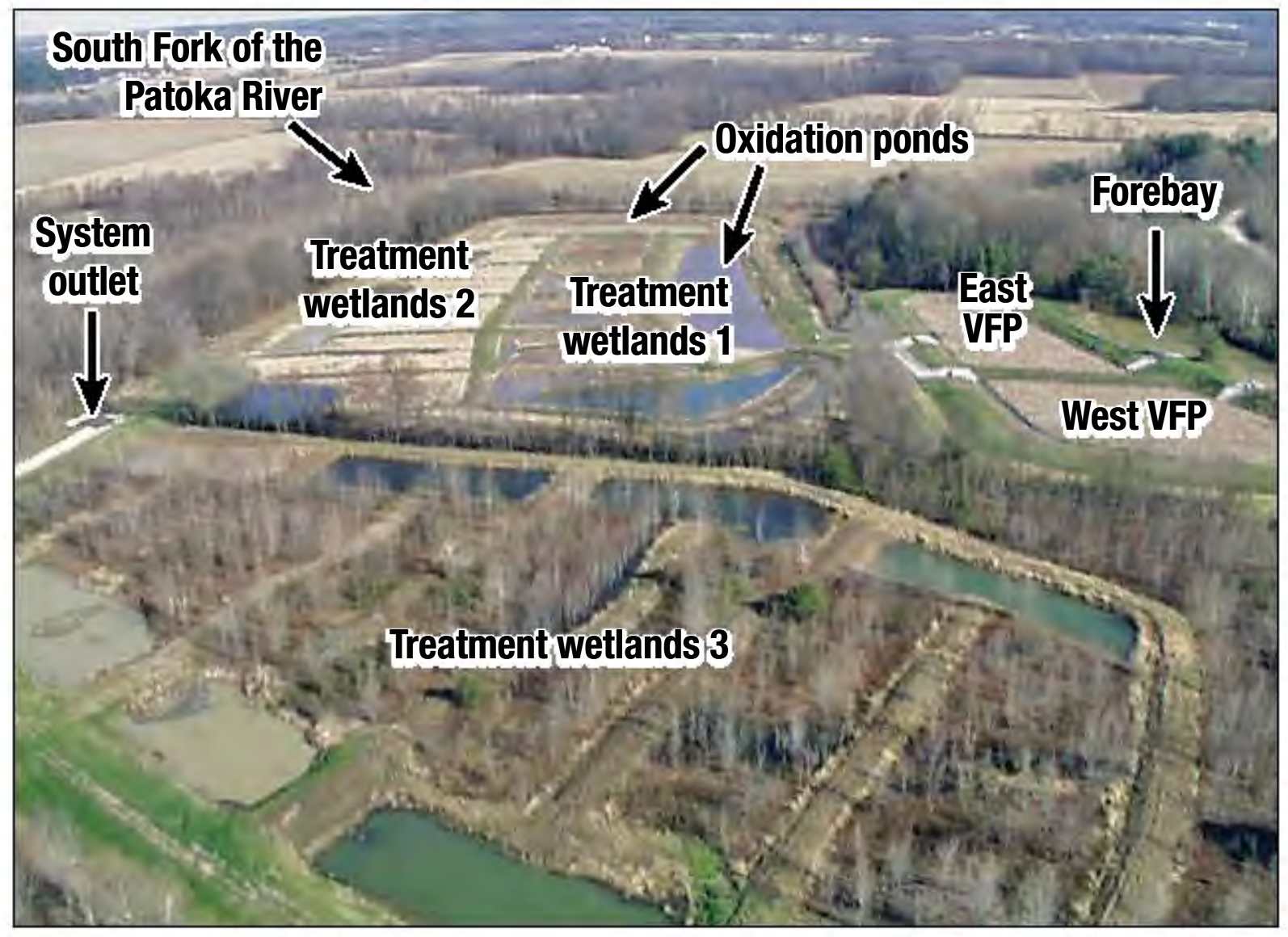

Figure 8. Oblique aerial photograph looking east at the Enos loop treatment wetland system. 
Table 2. Median water quality (2006-mid-2009) before repair, Enos loop treatment wetland system

[ $\mathrm{n}=$ number of samples; $\mathrm{NM}=$ not measured; $\mathrm{T} .=$ total. $]$

\begin{tabular}{|c|c|c|c|c|c|c|c|c|c|c|c|}
\hline $\begin{array}{l}\text { Sample } \\
\text { location }\end{array}$ & $\begin{array}{l}\text { Flow } \\
\text { (Lps) }\end{array}$ & $\begin{array}{l}\text { pH } \\
\text { (s.u.) }\end{array}$ & $\begin{array}{l}\mathrm{T} . \mathrm{Fe} \\
\text { (mg/L) }\end{array}$ & $\begin{array}{l}\text { T. Mn } \\
\text { (mg/L) }\end{array}$ & $\begin{array}{c}\mathrm{T} . \mathrm{Al} \\
\text { (mg/L) }\end{array}$ & $\begin{array}{c}\mathrm{Ca}^{*} \\
(\mathrm{mg} / \mathrm{L})\end{array}$ & $\begin{array}{c}\mathrm{Mg}^{*} \\
(\mathrm{mg} / \mathrm{L})\end{array}$ & $\begin{array}{c}\mathrm{SO}_{4} \\
(\mathrm{mg} / \mathrm{L})\end{array}$ & $\begin{array}{c}\text { TDS } \\
\text { (mg/L) }\end{array}$ & $\begin{array}{l}\text { Acidity }^{\dagger} \\
\text { (mg/L) }\end{array}$ & $\begin{array}{c}\text { Alkalinity }{ }^{\dagger} \\
(\mathrm{mg} / \mathrm{L})\end{array}$ \\
\hline $\begin{array}{l}\text { East AMD } \\
\text { ditch }\end{array}$ & $\begin{array}{l}4.42 \\
n=8\end{array}$ & $\begin{array}{c}7.10 \\
n=16\end{array}$ & $\begin{array}{l}0.33 \\
n=14\end{array}$ & $\begin{array}{l}1.88 \\
n=14\end{array}$ & $\begin{array}{l}0.45 \\
n=15\end{array}$ & $\begin{array}{c}579.7 \\
n=1\end{array}$ & $\begin{array}{c}300.0 \\
n=1\end{array}$ & $\begin{array}{l}2,193 \\
\mathrm{n}=13\end{array}$ & $\begin{array}{l}3,590 \\
n=12\end{array}$ & $\begin{array}{c}0.5 \\
n=13\end{array}$ & $\begin{array}{l}230.0 \\
n=13\end{array}$ \\
\hline $\begin{array}{l}\text { West AMD } \\
\text { ditch }\end{array}$ & $\begin{array}{l}2.44 \\
n=6\end{array}$ & $\begin{array}{l}0.50 \\
n=13\end{array}$ & $\begin{array}{c}17.0 \\
n=15\end{array}$ & $\begin{array}{l}20.72 \\
n=13\end{array}$ & $\begin{array}{l}3.64 \\
n=13\end{array}$ & $\begin{array}{l}580 \\
n=1\end{array}$ & $\begin{array}{l}170 \\
n=1\end{array}$ & $\begin{array}{l}1,800 \\
n=13\end{array}$ & $\begin{array}{l}2,740 \\
n=11\end{array}$ & $\begin{array}{l}75.0 \\
n=13\end{array}$ & $\begin{array}{c}<1.0 \\
n=13\end{array}$ \\
\hline $\begin{array}{l}\text { Dilution } \\
\text { water }\end{array}$ & $\begin{array}{c}13.09 \\
\mathrm{n}=4\end{array}$ & $\begin{array}{l}7.28 \\
n=13\end{array}$ & $\begin{array}{l}0.376 \\
n=12\end{array}$ & $\begin{array}{l}0.105 \\
n=12\end{array}$ & $\begin{array}{l}0.05 \\
\mathrm{n}=15\end{array}$ & $\begin{array}{l}450 \\
n=1\end{array}$ & $\begin{array}{l}280 \\
n=1\end{array}$ & $\begin{array}{l}1,800 \\
n=13\end{array}$ & $\begin{array}{l}2,560 \\
n=11\end{array}$ & $\begin{array}{l}13.0 \\
n=12\end{array}$ & $\begin{array}{c}238 \\
n=12\end{array}$ \\
\hline $\begin{array}{l}\text { Acid pond/ } \\
\text { VFP inlet }\end{array}$ & $\begin{array}{c}19.30 \\
\mathrm{n}=2\end{array}$ & $\begin{array}{c}4.02 \\
n=21\end{array}$ & $\begin{array}{c}18.3 \\
n=24\end{array}$ & $\begin{array}{c}2.98 \\
\mathrm{n}=22\end{array}$ & $\begin{array}{c}2.94 \\
\mathrm{n}=22\end{array}$ & $\begin{array}{c}438.5 \\
n=2\end{array}$ & $\begin{array}{c}190.7 \\
\mathrm{n}=2\end{array}$ & $\begin{array}{l}1,900 \\
n=18\end{array}$ & $\begin{array}{l}2,750 \\
n=14\end{array}$ & $\begin{array}{l}92.0 \\
n=17\end{array}$ & $\begin{array}{r}5.0 \\
\mathrm{n}=17\end{array}$ \\
\hline $\begin{array}{l}\text { Limestone } \\
\text { VFP outlet }\end{array}$ & $\begin{array}{l}9.65 \\
n=2\end{array}$ & $\begin{array}{l}6.40 \\
n=9\end{array}$ & $\begin{array}{l}29.4 \\
\mathrm{n}=7\end{array}$ & $\begin{array}{l}3.25 \\
n=6\end{array}$ & $\begin{array}{l}0.50 \\
n=5\end{array}$ & $\begin{array}{c}408.8 \\
\mathrm{n}=3\end{array}$ & $\begin{array}{c}168.4 \\
n=3\end{array}$ & $\begin{array}{l}1,471 \\
\mathrm{n}=6\end{array}$ & $\begin{array}{c}3,228 \\
n=5\end{array}$ & $\begin{array}{l}88.5 \\
n=6\end{array}$ & $\begin{array}{l}106.0 \\
n=6\end{array}$ \\
\hline $\begin{array}{l}\text { Dolomite } \\
\text { VFP outlet* }\end{array}$ & $\begin{array}{l}9.65 \\
n=2\end{array}$ & $\begin{array}{l}6.35 \\
n=8\end{array}$ & $\begin{array}{c}36.28 \\
\mathrm{n}=8\end{array}$ & $\begin{array}{l}3.88 \\
n=5\end{array}$ & $\begin{array}{c}0.626 \\
\mathrm{n}=8\end{array}$ & $\begin{array}{c}470.6 \\
n=2\end{array}$ & $\begin{array}{c}184.5 \\
\mathrm{n}=2\end{array}$ & $\begin{array}{c}2,080 \\
\mathrm{n}=8\end{array}$ & $\begin{array}{c}3,179 \\
\mathrm{n}=4\end{array}$ & $\begin{array}{c}104.6 \\
\mathrm{n}=5\end{array}$ & $\begin{array}{l}124.0 \\
n=5\end{array}$ \\
\hline $\begin{array}{l}\text { Oxidation } \\
\text { pond outlet }\end{array}$ & NM & $\begin{array}{l}5.32 \\
n=2\end{array}$ & $\begin{array}{l}9.31 \\
n=2\end{array}$ & $\begin{array}{l}4.66 \\
n=2\end{array}$ & $\begin{array}{l}2.29 \\
n=2\end{array}$ & $\begin{array}{c}386.4 \\
n=2\end{array}$ & $\begin{array}{c}145.2 \\
n-2\end{array}$ & $\begin{array}{l}1,917 \\
\mathrm{n}=2\end{array}$ & $\begin{array}{c}2,945 \\
\mathrm{n}=2\end{array}$ & $\begin{array}{l}52.7 \\
n=2\end{array}$ & $\begin{array}{l}16.0 \\
n=2\end{array}$ \\
\hline $\begin{array}{l}\text { Wetland } 2 \\
\text { outlet }\end{array}$ & NM & $\begin{array}{l}3.50 \\
n=3\end{array}$ & $\begin{array}{c}0.293 \\
n=3\end{array}$ & $\begin{array}{l}1.89 \\
n=3\end{array}$ & $\begin{array}{l}0.74 \\
n=3\end{array}$ & $\begin{array}{c}386.1 \\
n=1\end{array}$ & $\begin{array}{c}147.4 \\
n=1\end{array}$ & $\begin{array}{c}1,648 \\
n=2\end{array}$ & $\begin{array}{c}2,811 \\
\mathrm{n}=2\end{array}$ & $\begin{array}{l}13.7 \\
n=3\end{array}$ & $\begin{array}{l}87.3 \\
n=3\end{array}$ \\
\hline $\begin{array}{l}\text { Wetland 3/ } \\
\text { system outlet }\end{array}$ & $\begin{array}{l}24.60 \\
n=13\end{array}$ & $\begin{array}{c}6.92 \\
n=27\end{array}$ & $\begin{array}{l}0.250 \\
n=27\end{array}$ & $\begin{array}{c}0.84 \\
\mathrm{n}=25\end{array}$ & $\begin{array}{c}0.13 \\
\mathrm{n}=19\end{array}$ & $\begin{array}{c}436.2 \\
n=3\end{array}$ & $\begin{array}{c}184.0 \\
n=3\end{array}$ & $\begin{array}{l}1,510 \\
n=26\end{array}$ & $\begin{array}{l}2,102 \\
n=19\end{array}$ & $\begin{array}{c}7.1 \\
\mathrm{n}=26\end{array}$ & $\begin{array}{r}76.5 \\
\mathrm{n}=26\end{array}$ \\
\hline
\end{tabular}

${ }^{*}$ Assumes flow to each vertical flow pond is equally split.

${ }^{\dagger}$ Calcium carbonate $\left(\mathrm{CaCO}_{3}\right)$ equivalent.

inlet to $0.84 \mathrm{mg} / \mathrm{L}$ at the system outlet) (Table 2). The data indicate that the loop treatment wetland oxidation pond and surface flow wetlands 2 and 3 (Table 2, fig. 5) are large enough to remove iron to low levels and then allow significant manganese removal. Most manganese removal occurred in the final treatment stage, surface flow wetland 3. This is consistent with the understanding that aerobic wetlands are capable of removing manganese to low levels but at a rate 20 to 40 times less than iron and only after ferrous iron has been removed (Hedin and others, 1994; Watzlaf and others, 2004). Manganese is most likely removed by biologically aided oxidation/precipitation in oxic portions of the surface-flow wetland system and through adsorption onto organic matter, $\mathrm{MnO}_{2}$, and iron hydroxide $(\mathrm{FeOOH})$ (Hedin and others, 1994; Hong and others, 1995; Watzlaf and others, 2004; Hallberg and Johnson, 2005). Watzlaf and others (2004) suggest that sequential removal of iron and manganese is due to the reduction of manganese precipitates $\left(\mathrm{MnO}_{2}\right.$ and $\left.\mathrm{MnOOH}\right)$ by ferrous iron (reactions 1 and 2).

$$
\mathrm{MnO}_{2}+\mathrm{Fe}^{2+} \rightarrow 2 \mathrm{FeOOH}+\mathrm{Mn}^{2+}+2 \mathrm{H}
$$

$$
\mathrm{MnOOH}+\mathrm{Fe}^{2+} \rightarrow 2 \mathrm{FeOOH}+\mathrm{Mn}^{2+}
$$

The treated discharge from the VFPs had a very high hardness (dolomite VFP $=1,933 \mathrm{mg} / \mathrm{L}$ calcium carbonate equivalent (CCE) $(\mathrm{n}=2)$; limestone VFP $=1,619 \mathrm{mg} / \mathrm{L} \mathrm{CCE}(\mathrm{n}=3) ;$ and system outlet $=1,855$ $\mathrm{mg} / \mathrm{L} \mathrm{CCE}(\mathrm{n}=3))$. This is due to elevated calcium and magnesium, which are presumably derived from dissolution of carbonate minerals.

\section{VFP reconstruction and preliminary postreconstruction performance}

Following a period of extreme metal loading in 2008 and early 2009 (fig. 9), the slightly smaller dolomite VFP failed (outlet $\mathrm{pH}<5$ and alkalinity $=0)$ and performance declined in the limestone VFP (alkalinity <100). Because of these problems, reconstruction of the VFPs was necessary to restore treatment function. During reconstruction of the dolomite VFP, the research team observed that the carbonate layer was relatively free of precipitates and coatings. This may be due to remobilization of the iron by the high volume of 


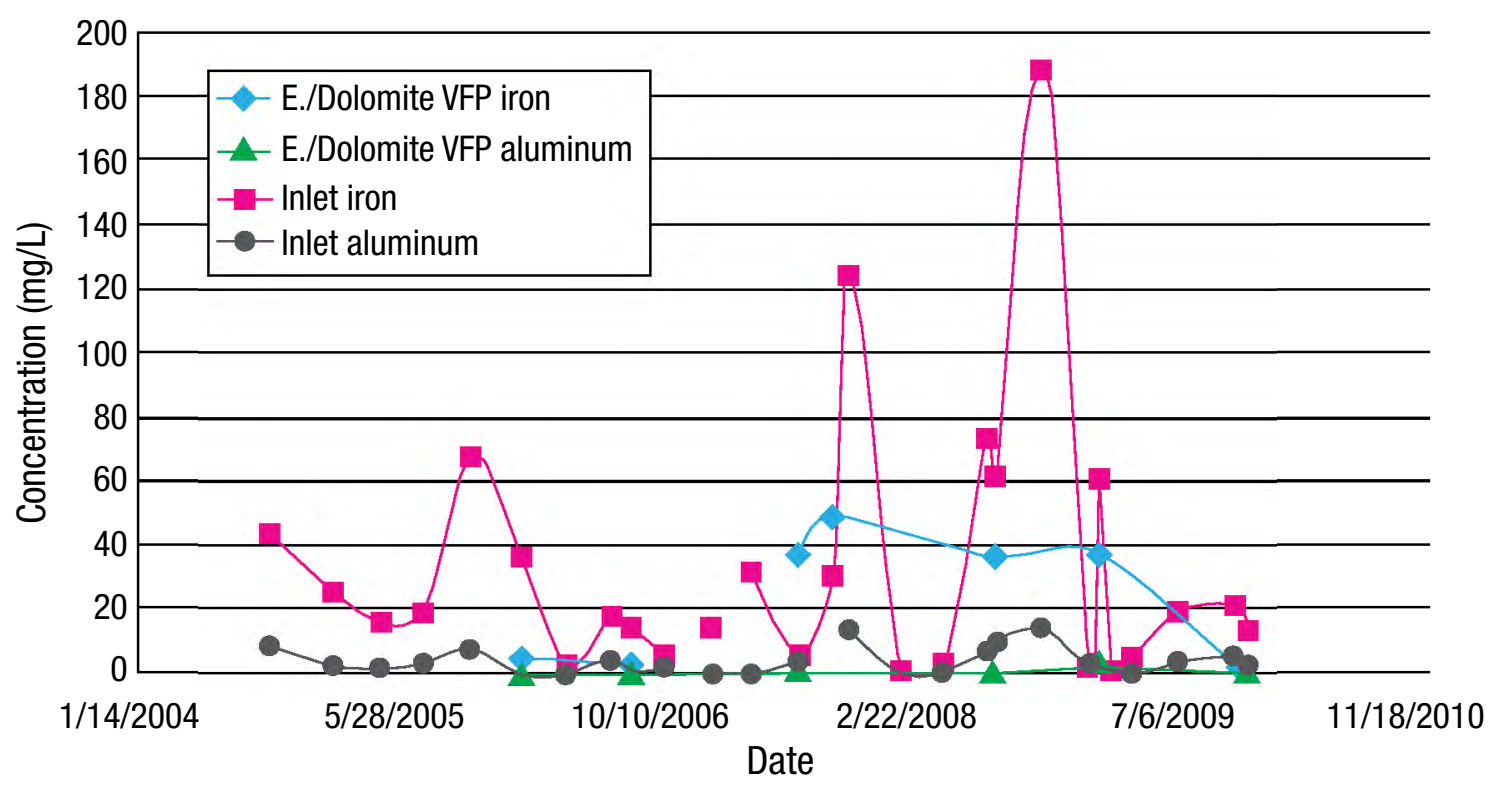

Figure 9. Graph showing metal concentrations of the dolomite verticle flow pond over time, prior to reconstruction.

low-pH water that flowed through the structure. Repair of the dolomite VFP cell required removing the spent organic material (compost resistant to digestion by the cellulose-degrading bacteria) and replacing it with a 4 -ft-thick (1.2-m-thick) layer consisting of a blend of agricultural limestone and organic material, which in this case was composted yard waste, wood chips, and straw. Some researchers have termed this blend "limestonebuffered organic substrate" (Thomas, 2002; Thomas and Romanek, 2002a).

This reconstruction converted the conventional reducing and alkalinity-producing system VFP to a sulfate-reducing or anaerobic bioreactor design (a type of VFP with a 4- to 6-ft-thick [1.2- to 1.8-m-thick] limestone-amended organic substrate). A simpler rehabilitation method was chosen for the limestone-based VFP. In this case, the existing straw-based organic layer was leveled and additional straw was placed on top of the old substrate. The increased thickness of organic material in both VFP cells virtually eliminates the open water layer. This allows emergent vegetation to be established and organic material to be replenished seasonally.

Also, during reconstruction of the VFPs, the aerobic wetland (fig. 5, surface flow wetland 1) was replaced with a large anaerobic (compost) wetland designed to treat AMD that overflowed the two VFP structures. The substrate consisted of the same blend of agricultural limestone, composted yard waste, wood chips, and straw used in the reconstructed dolomite VFP. This was done to provide comparable treatment for AMD that bypassed the VFPs and AMD that flowed through them.

A preliminary assessment of the reconstructed VFP performance (Table 3) found that the system's discharge mostly met or exceeded the water quality prior to the premature failure. Elevated sulfate in the discharge from the limestone VFP may be attributed to the mobilization of sulfate minerals that formed when the VFP was taken offline and the compost was allowed to desiccate. During reconstruction, the limestone VFP organic layer was exposed to oxygen and both wet and dry cycles. This may have oxidized the previously accumulated iron sulfide minerals (possibly pyrite, $\mathrm{FeS}_{2}$, or mackinawite $\left((\mathrm{Fe}, \mathrm{Ni})_{1+\mathrm{x}} \mathrm{S}\right)$ to more easily mobilized iron sulfate minerals such as schwertmannite $\left(\mathrm{Fe}_{8} \mathrm{O}_{8}(\mathrm{OH})_{6}\left(\mathrm{SO}_{4}\right) \cdot \mathrm{nH}_{2} \mathrm{O}\right.$ or $\mathrm{Fe}^{3+}{ }_{16} \mathrm{O}_{16}\left(\mathrm{OH}, \mathrm{SO}_{4}\right)_{12-13}$ - $10-12 \mathrm{H}_{2} \mathrm{O}$ ). The presence of a dense, black precipitate (possibly iron-rich monosulfide) in the reconstructed VFP discharge and a strong hydrogen sulfide gas odor were noted and are typically suggestive of sulfate-reducing bacteria activity. Because of the sudden surge of low-pH water into the reconstructed dolomite VFP, the SRB 
Table 3. Median water quality (2009-2011) after repair, Enos loop treatment wetland system

[n = number of samples; $\mathrm{NM}=$ not measured; $\mathrm{T}$. = total. $]$

\begin{tabular}{|c|c|c|c|c|c|c|c|c|c|c|c|}
\hline $\begin{array}{l}\text { Sample } \\
\text { Iocation }\end{array}$ & $\begin{array}{l}\text { Flow } \\
\text { (Lps) }\end{array}$ & $\begin{array}{l}\mathrm{pH} \\
\text { (s.u.) }\end{array}$ & $\begin{array}{l}\text { T. Fe } \\
(\mathrm{mg} / \mathrm{L})\end{array}$ & $\begin{array}{l}\text { T. Mn } \\
(\mathrm{mg} / \mathrm{L})\end{array}$ & $\begin{array}{c}\text { T. Al } \\
(\mathrm{mg} / \mathrm{L})\end{array}$ & $\begin{array}{c}\mathrm{Ca} \\
(\mathrm{mg} / \mathrm{L})\end{array}$ & $\underset{(\mathrm{mg} / \mathrm{L})}{\mathrm{Mg}}$ & $\begin{array}{c}\mathrm{SO}_{4} \\
(\mathrm{mg} / \mathrm{L})\end{array}$ & $\begin{array}{c}\text { TDS } \\
(\mathrm{mg} / \mathrm{L})\end{array}$ & $\begin{array}{l}\text { Acidity }^{\dagger} \\
(\mathrm{mg} / \mathrm{L})\end{array}$ & $\begin{array}{l}\text { Alkalinity }^{\dagger} \\
\text { (mg/L) }\end{array}$ \\
\hline $\begin{array}{l}\text { Acid pond/ } \\
\text { VFP inlet }\end{array}$ & $\begin{array}{l}24.23 \\
* n=3\end{array}$ & $\begin{array}{l}3.18 \\
n=8\end{array}$ & $\begin{array}{l}27.9 \\
n=8\end{array}$ & $\begin{array}{c}2.0 \\
n=8\end{array}$ & $\begin{array}{l}4.46 \\
n=3\end{array}$ & $\begin{array}{l}3.81 \\
n=8\end{array}$ & $\begin{array}{l}341 \\
n=3\end{array}$ & $\begin{array}{c}1,887 \\
n=8\end{array}$ & $\begin{array}{c}2,537 \\
n=3\end{array}$ & $\begin{array}{c}151.2 \\
n=8\end{array}$ & $\begin{array}{c}1.8 \\
n=8\end{array}$ \\
\hline $\begin{array}{l}\text { Limestone VFP } \\
\text { outlet }^{\star}\end{array}$ & $\begin{array}{c}17.12 \\
* n=3\end{array}$ & $\begin{array}{l}6.46 \\
n=9\end{array}$ & $\begin{array}{l}11.0 \\
n=9\end{array}$ & $\begin{array}{l}2.26 \\
n=9\end{array}$ & $\begin{array}{l}0.36 \\
n=9\end{array}$ & $\begin{array}{l}487 \\
n=3\end{array}$ & $\begin{array}{l}185 \\
n=3\end{array}$ & $\begin{array}{c}1,750 \\
n=9\end{array}$ & $\begin{array}{c}3,729 \\
n=4\end{array}$ & $\begin{array}{l}114.1 \\
n=9\end{array}$ & $\begin{array}{c}309.0 \\
n=9\end{array}$ \\
\hline $\begin{array}{l}\text { Dolomite VFP } \\
\text { outlet }^{\star}\end{array}$ & $\begin{array}{r}17.12 \\
* n=3\end{array}$ & $\begin{array}{l}6.77 \\
n=7\end{array}$ & $\begin{array}{l}2.24 \\
n=7\end{array}$ & $\begin{array}{l}3.24 \\
n=7\end{array}$ & $\begin{array}{l}0.27 \\
n=7\end{array}$ & $\begin{array}{l}459 \\
n=3\end{array}$ & $\begin{array}{l}166 \\
n=7\end{array}$ & $\begin{array}{c}1,590 \\
n=7\end{array}$ & $\begin{array}{c}2,669 \\
n=2\end{array}$ & $\begin{array}{c}101.3 \\
n=7\end{array}$ & $\begin{array}{c}322.0 \\
n=7\end{array}$ \\
\hline $\begin{array}{l}\text { Oxidation pond } \\
\text { outlet }\end{array}$ & NM & $\begin{array}{l}7.06 \\
n=2\end{array}$ & $\begin{array}{l}3.31 \\
n=2\end{array}$ & $\begin{array}{l}3.48 \\
n=2\end{array}$ & $\begin{array}{l}0.83 \\
n=2\end{array}$ & $\begin{array}{l}491 \\
n=2\end{array}$ & $\begin{array}{l}171 \\
n=2\end{array}$ & $\begin{array}{c}1,787 \\
n=2\end{array}$ & $\begin{array}{c}2,707 \\
n=2\end{array}$ & $\begin{array}{c}368.9 \\
n=2\end{array}$ & $\begin{array}{l}112.1 \\
n=2\end{array}$ \\
\hline Wetland 2 outlet & NM & NM & NM & NM & NM & NM & NM & NM & NM & NM & NM \\
\hline $\begin{array}{l}\text { Wetland 3/ } \\
\text { system outlet }\end{array}$ & $\begin{array}{c}18.14 \\
n=7\end{array}$ & $\begin{array}{l}7.48 \\
n=9\end{array}$ & $\begin{array}{l}0.48 \\
n=9\end{array}$ & $\begin{array}{l}2.05 \\
n=9\end{array}$ & $\begin{array}{l}0.05 \\
n=9\end{array}$ & $\begin{array}{c}403.8 \\
n=3\end{array}$ & $\begin{array}{c}156.2 \\
n=3\end{array}$ & $\begin{array}{c}1,383 \\
n=9\end{array}$ & $\begin{array}{c}2,671.5 \\
n=3\end{array}$ & $\begin{array}{c}5.5 \\
n=9\end{array}$ & $\begin{array}{c}215.0 \\
n=9\end{array}$ \\
\hline
\end{tabular}

* Assumes flow to each vertical flow pond is equally split.

${ }^{+}$Calcium carbonate $\left(\mathrm{CaCO}_{3}\right)$ equivalent.

community appeared to be in a stressed condition upon start up. This, along with the dissolution of sulfate minerals in the limestone cell, may account for the low amount of sulfate removal from both reconstructed VFP cells immediately following reconstruction (Table 3).

\section{Performance comparison: Limestone VFP versus dolomite VFP}

The limestone-based VFP was expected to outperform the dolomitic limestone VFP for two reasons:
1) calcium carbonate (calcite), the major mineral of a high-Ca limestone, is more soluble than calcium-magnesium carbonate (dolomite), and 2) the dolomite-based VFP is 8 percent smaller. However, based on the limited 2006 through mid2009 data set, the median discharge of alkalinity from the limestone-based VFP was $106 \mathrm{mg} / \mathrm{L} \mathrm{CCE}$, whereas the median discharge from the dolomitic limestone-based system was $124 \mathrm{mg} / \mathrm{LCCE}$ (Table 2, fig. 10). After reconstruction of the VFPs, during which additional straw was added to the limestone VFP and the compost above the dolomite in the dolomitic limestone-based system was replaced by

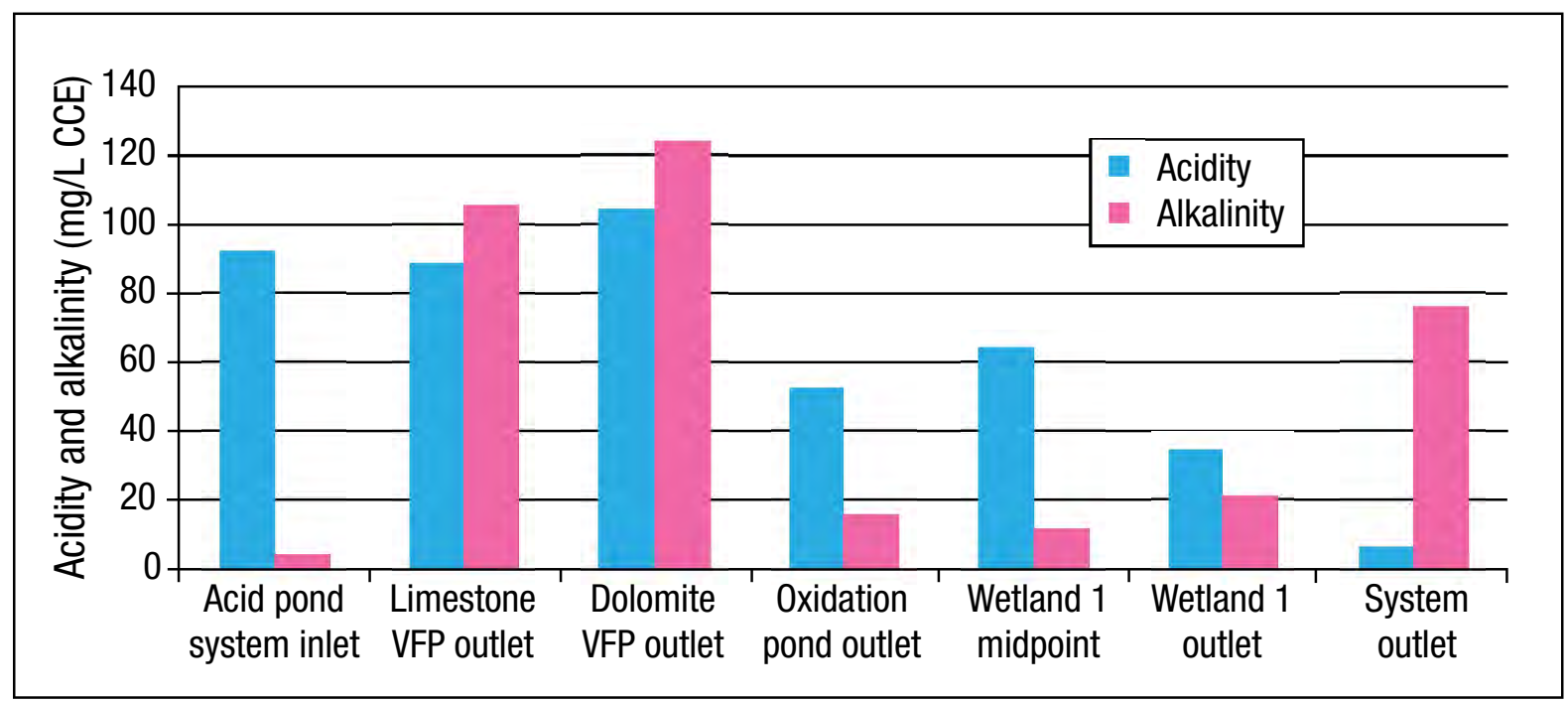

Figure 10.Graph showing alkalinity and acidity within the Enos loop treatment wetland system from 2006-mid-2009 data (Table 2); the acid pond is the forebay impoundment shown in Figures 5 and 8. (CCE = calcium carbonate equivalent.) 
a straw/wood chip/yard waste/agricultural limestone blend, alkalinity from the limestone-based VFP was $309 \mathrm{mg} / \mathrm{L} \mathrm{CCE} \mathrm{(n=9)} \mathrm{and} \mathrm{the} \mathrm{alkalinity}$ generated by the dolomitic limestone-based VFP

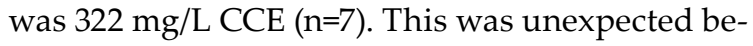
cause calcite is greater than eight orders of magnitude more soluble than dolomite at $25^{\circ} \mathrm{C}$ (calcite $\mathrm{K}_{\mathrm{SP}}=10^{-8.40}$ vs. dolomite $\mathrm{K}_{\mathrm{SP}}=10^{-17}$ ) (Drever, 1997). Dissolution of agricultural limestone in the fresh compost layer may account for the higher alkalinity in the outflow from the reconstructed dolomitic limestone-based VFP.

The observation that carbonate dissolution is directly proportional to retention time (Watzlaf, 1997; Watzlaf and others, 2004) also suggests that calcium levels should be higher in the discharge from the slightly larger limestone-based system. However, VFP size and retention time may not be the controlling factors because: 1 ) the assumption that VFP inlet flow is completely balanced has not been verified, and 2) a limited number of samples ( $\mathrm{n}=$ 2-3) have been analyzed over a relatively short period of time. Although research by Maynard and Helton (2005), Huminicki (2006), Rimstidt and Huminicki (2006), Rose and others (2007), and Huminicki and Rimstidt (2008) suggest that a dolomitic limestone-based VFP will outperform a limestonebased cell over the long term where sulfate levels are elevated $(>1,500 \mathrm{mg} / \mathrm{L})$ because of gypsum precipitation in the limestone-based system, this effect was not observed in the relatively short operational lives of the Enos loop VFPs (2006-2011).

\section{Vertical flow pond longevity}

Operational experience with the Enos loop wetlands demonstrated that vertical flow ponds treating surface water runoff must be managed to maintain a flow rate close to optimum design specifications to avoid overstressing the bacterial populations required to maintain the desired biochemical reactions (namely, cellulose degradation and sulfate reduction) and overloading the system (namely, reduced retention time and excessive precipitation of metal-bearing coatings that clog the compost layer). Additional design features were included in the 2005 construction to accommodate both normal and low-flow conditions during most of the year and excessive flow during seasonal increases in rainfall and severe storms (Behum and others, 2008). During normal flow conditions, untreated AMD enters the top of the vertical flow ponds, percolates downward, collects in the underdrain pipe system, and discharges into the nearest oxidation pond (fig. 5). Under normal and lowflow conditions, two 6-inch $(15.2-\mathrm{cm})$ pipes with valves balance flow between the two VFPs. During high-flow conditions, excess AMD flows over the surface of each VFP though a stop-log structure equipped with a v-notch weir to monitor flow rate (fig. 7). A similar stop-log system allows monitoring of the surface outflow from each VFP (fig. 8, north side of VFPs). During periods of overflow, a portion of the AMD bypasses VFP treatment. The excess surface flow from the VFPs discharges over stop logs of the outlet flow control structures and is redirected to the holding pond that feeds into surface flow wetland 1 (fig. 5). Subsequently, the discharge from surface flow wetland 1 is mixed with treated, net-alkaline VFP outlet water that discharged directly to the oxidation ponds (fig. 5).

Prior to the mid-2009 failure, the Enos loop wetland encountered a period of excessive metal loading (fig. 9). This undoubtedly placed an additional stress on the VFPs by reducing the retention time (increased flow velocity) and creating a high rate of metal accumulation (increased metal load). Excavation of the failed dolomite VFP during the 2009 reconstruction showed that the buoyant, strawbased organic layer shifted toward the eastern or downwind side of the east VFP where more than $3 \mathrm{ft}(0.9 \mathrm{~m})$ had accumulated. Conversely, the straw layer on the western side of the east VFP was only about 6 to 18 inches $(15.25-45.7 \mathrm{~cm})$ thick. Those areas where the organic layer was thin undoubtedly experienced a certain amount of short-circuited flow of the untreated AMD, shortened retention time, and ineffective treatment. Other possible failure mechanisms include clogging by metal precipitates and exhaustion of the organic substrate by bacterial activity.

\section{Metal accumulation}

The excess alkalinity derived from the VFPs, large oxidation pond, and wetland areas (Table 3) allows for a significant removal of AMD metal contaminants ( $\mathrm{Al}$ and Fe) (figs. 11 and 12). Both iron and aluminum are typically removed to low levels (<1.0 mg/L) (Table 3; system outlet). Nearly all the aluminum and a significant proportion of the iron are removed in the vertical flow ponds (fig. 11); this 


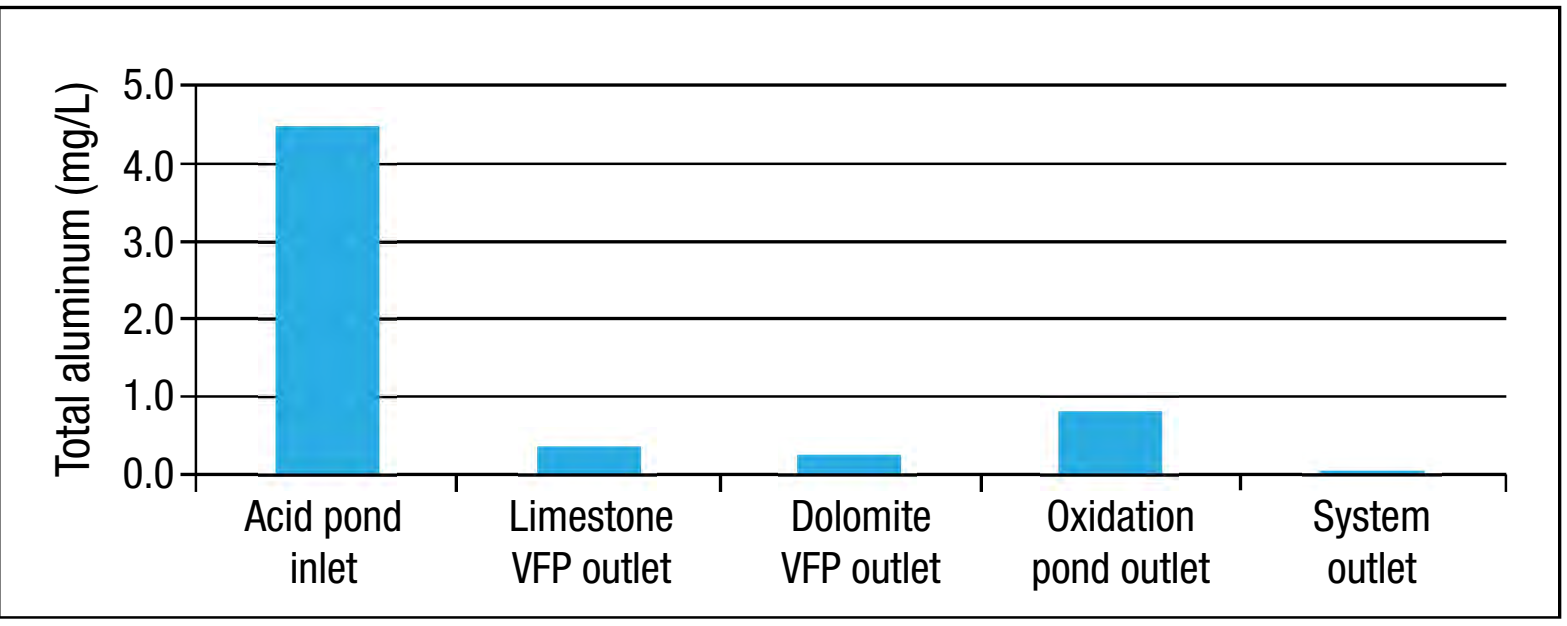

Figure 11. Graph showing median postreconstruction aluminum content within the Enos loop treatment wetland system; the acid pond is the forebay impoundment shown in Figures 5 and 8. Data are from Table 3.

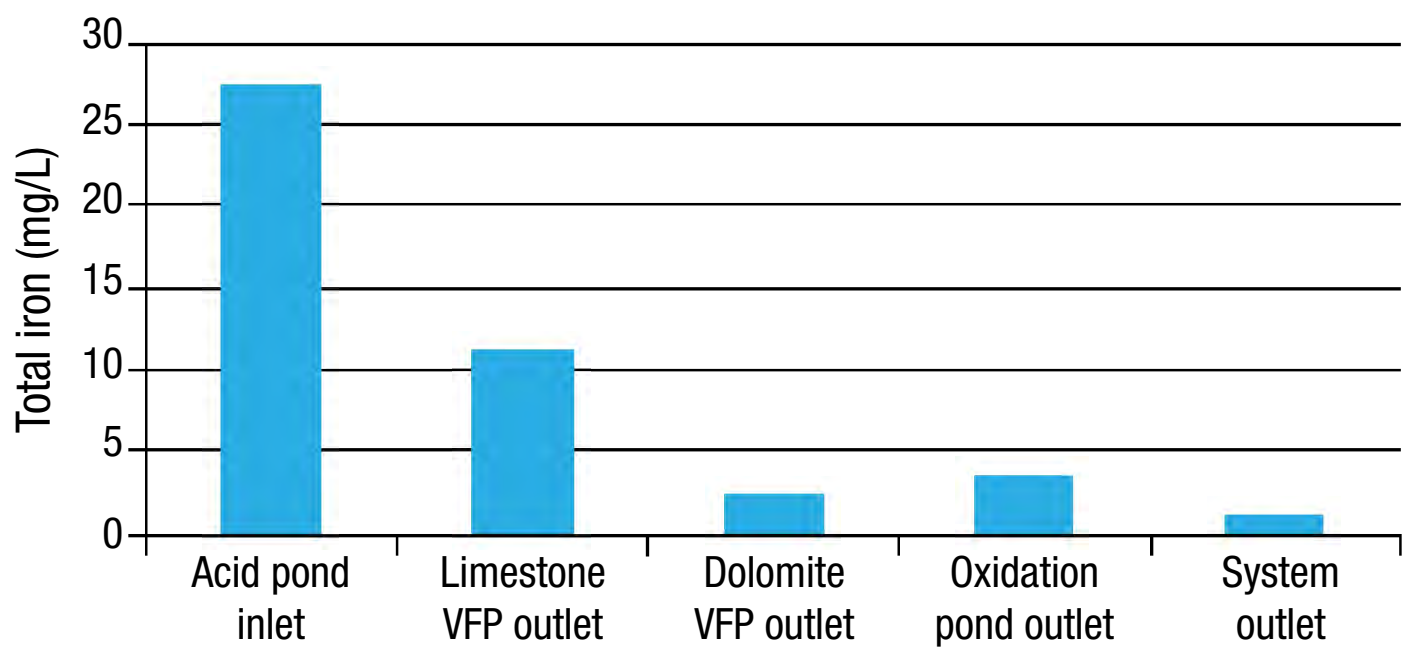

Figure 12.Graph showing median postreconstruction iron content within the Enos loop treatment wetland system; the acid pond is the forebay impoundment shown in Figures 5 and 8. Data are from Table 3.

suggests that clogging of the substrate with aluminum and iron precipitates may explain the 2009 failure of the VFPs. The increase in both aluminum and iron in the discharge from the oxidation pond (figs. 11 and 12) may be due to the fact that discharge from the VFPs is filtered through the substrate, whereas discharge from the oxidation pond was unfiltered and includes suspended sediment from which metals could be released.

The following discussion evaluates whether ironand aluminum-bearing minerals found in similar settings are likely to form at the Enos site based on geochemical modeling. Note that the geochemical modeling data presented in this discussion evaluates the equilibrium chemistry and not the kinetics of the possible reactions. As such, the discussion only partially evaluates mineral formation potential within the confines of the Enos loop treatment wetland system. The modeling software used for this discussion was Geochemist's Workbench (ver. 6.0 standard; C. Bethke, University of Illinois at Urbana-Champaign). Precipitation of a specific solid phase was evaluated by calculating the saturation index (SI). As an example, the SI may be calculated for the mineral gibbsite $\left(\mathrm{Al}(\mathrm{OH})_{3}\right)$ 
by the following equation:

$$
\mathrm{SI}=\log \left[\frac{\left(\alpha_{\mathrm{Al}^{3+}} \cdot \alpha_{\mathrm{OH}}\right)_{\text {solution }}}{\mathrm{K}_{\mathrm{sp}}}\right]
$$

Here $\alpha_{\mathrm{Al}^{3+}}$ and $\alpha_{\mathrm{OH}^{-}}$are the activities of aluminum and hydroxide in the solution, respectively, and $\mathrm{K}_{\mathrm{sp}}$ is the solubility product of the solid phase, in this case gibbsite (Drever, 1997). If the SI is greater than zero, the solid phase should precipitate; if the SI is less than zero, metal ions should remain in solution.

Geochemical conditions ( $\mathrm{pH}>4.5)$ dictate that aluminum will be removed to low levels in carbonate-based passive treatment systems such as anoxic limestone drains (ALD). This is because aluminum will typically precipitate at a $\mathrm{pH}$ greater than 4.5 as the aluminum hydroxide mineral gibbsite (Mitchell and Wildeman, 1996; Drever, 1997; Gusek and Wildeman, 2002). Gusek and Wildeman (2002), Thomas (2002), and Thomas and Romanek (2002b) report that aluminum precipitates as compact sulfate minerals such as the aluminum-potassium sulfate mineral alunite $\left(\mathrm{KAl}_{3}\left(\mathrm{SO}_{4}\right)_{2}(\mathrm{OH})_{6}\right)$ in the organic layer, whereas aluminum hydroxide tends to precipitate within and clog the limestone layer. At the Enos site, potassium is relatively low in the AMD at the VFP inlet $($ median $=7.3 \mathrm{mg} / \mathrm{L}$ ). Because the sodium concentration is somewhat higher in the AMD (median $=26.5 \mathrm{mg} / \mathrm{L})$, the sodium-rich equivalent, natroalunite $\left(\mathrm{NaAl}_{3}\left(\mathrm{SO}_{4}\right)_{2}(\mathrm{OH})_{6}\right)$, may form.

Computer modeling using pre-failure waterquality data for the VFP inlet (Table 2) suggested unsaturated conditions for several possible mineral precipitates including Na-jarosite $(\mathrm{SI}=-0.2542$ to $-0.0986)$, gibbsite (-3.0015 to -3.704), gypsum $\left(\mathrm{CaSO}_{4} \cdot 2 \mathrm{H}_{2} \mathrm{O}, \mathrm{SI}=-0.3767\right.$ to -0.4376$)$, anhydrite $\left(\mathrm{CaSO}_{4}, \mathrm{SI}=-0.5548\right.$ to -0.6156$)$, siderite $\left(\mathrm{FeCO}_{3} \mathrm{SI}=\right.$ -8.360 to -9.022$)$, and $\mathrm{Fe}(\mathrm{OH})_{3}$ precipitate $(\mathrm{SI}=$ -2.5347 to -0.6178$)$. Note, however, that a thick (2-inch +/- [50.8-mm +/-]) accumulation of orange precipitate (presumably iron-rich) covered the VFP surface by late 2009, suggesting water quality changed upon entering the VFPs and oxic conditions occurred in the upper portion of the VFP. One possible mineral that forms on the VFP surface at this moderately low $\mathrm{pH}$ (median $=4.0$ ) is jarosite. However, geochemical modeling of the inlet's AMD (acid pond/forebay) indicates the inlet AMD is normally undersaturated with respect to the mineral K-jarosite ( $\mathrm{SI}=-0.2542$ to -9.099). Subsequently, the chemistry of the water changes: the redox potential decreases as the water passes though the organic layer and $\mathrm{pH}$ and alkalinity increase as water flows through the carbonate rock within the VFPs. The nature of aluminum precipitation in the VFP substrate warrants study. Additional water-quality and mineralogy data are needed to understand the geochemical processes that operate in these treatment cells.

Geochemical reaction modeling indicates that discharge from the limestone VFP was typically saturated with respect to K-jarosite (SI = 1.349 to 4.871 ). A number of mineral species were identified that vary from saturated to undersaturated. These include: alunite (SI $=-4.3591$ to 4.1655$)$, Na-jarosite (SI $=-3.6512$ to 1.539$)$, gibbsite $(-0.3915$ to 2.234$)$, and $\mathrm{Fe}(\mathrm{OH})_{3}(\mathrm{SI}=-2.304$ to 2.305$)$. The minerals gypsum (SI $=-0.2134$ to -0.3488$)$, anhydrite $(\mathrm{SI}=-0.3915$ to $-0.5115)$, siderite (SI $=-0.8026$ to -7.999$)$, and calcite $(\mathrm{SI}=-0.5349$ to -8.7199$)$ were always undersaturated in all the water samples collected to date.

Reaction modeling indicates that discharge from the dolomitic limestone VFP was also saturated with respect to K-jarosite (SI $=2.5610$ to 4.8533 ). As with the limestone VFP, a number of mineral species alternate between saturated and undersaturated. These include: alunite (SI $=-3.0154$ to 0.1165$)$, Najarosite ( $\mathrm{SI}=-1.218$ to 1.552 ), gibbsite (SI $=-2.434$ to 1.641), calcite ( $\mathrm{SI}=-8.159$ to 0.4283 ), and $\mathrm{Fe}(\mathrm{OH})_{3}$ (SI $=-0.1953$ to 2.483$)$. Again, the minerals gypsum $(\mathrm{SI}=$ -0.2190 to -0.3255$)$, anhydrite (SI $=-0.0598$ to -0.5036 ), and siderite (SI $=-1.3038$ to -7.6608 ) are always undersaturated in all the samples collected to date.

\section{Sulfate reduction}

Sulfate removal was determined by converting concentrations to mass ( $\mathrm{kg}$ per day) to normalize for flow (Table 4). Flow measurements from the system outlet (wetland 3) were used because they are the most accurately gauged readings. It was assumed that half the flow at the system outlet passed through the limestone VFP and half through the dolomite VFP. Sulfate concentrations and flow rates used in the calculations are based on all data collected from January 2006 to February 2011. 
Table 4. Median values (2006-2011) used to determine sulfate removal

[Data for the acid pond (forebay) represent the input into the VFPs at the upstream end of the Enos loop treatment wetland system.]

\begin{tabular}{|c|c|c|c|c|c|c|c|}
\hline \multirow{2}{*}{$\begin{array}{l}\text { Sample } \\
\text { location }\end{array}$} & \multirow{2}{*}{$\begin{array}{l}\text { Flow } \\
\text { (Lps) }\end{array}$} & \multicolumn{2}{|c|}{$\mathrm{SO}_{4}$ output } & \multicolumn{2}{|c|}{$\mathrm{SO}_{4}$ input } & \multicolumn{2}{|c|}{$\mathrm{SO}_{4}$ removed } \\
\hline & & $(\mathrm{mg} / \mathrm{L})$ & 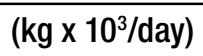 & $(\mathrm{mg} / \mathrm{L})$ & $\left(\mathrm{kg} \times 10^{3} / \mathrm{day}\right)$ & $\left(\mathrm{kg} \times 10^{3} / \mathrm{day}\right)$ & $(\%)$ \\
\hline Acid pond & 22.6 & 1,880 & 3.67 & - & - & - & \\
\hline Limestone VFP & 11.3 & 1,528 & 1.49 & 1,880 & 1.84 & 0.35 & 19 \\
\hline Dolomite VFP & 11.3 & 1,732 & 1.69 & 1,880 & 1.84 & 0.15 & 8 \\
\hline Wetland $3 /$ system outlet & 22.6 & 1,452 & 1.69 & 1,880 & 3.67 & 0.84 & 23 \\
\hline
\end{tabular}

During the operation of the loop treatment wetlands, sulfate declined 19 percent and 8 percent in the limestone and dolomite VFPs, respectively, which indicates that only a relatively minor amount of sulfate reduction is occurring within these cells. This corresponds to a removal rate of 0.436 and 0.250 moles of $\mathrm{SO}_{4} / \mathrm{m}^{3} /$ day for the limestone and dolomite VFPs, respectively (assuming a 3.5-ft-thick [1.06-m-thick] compost layer). Sulfate removal was expected to be higher than achieved to date and the low removal rate is somewhat unexpected for the reducing and alkalinity-producing system design. The original dolomite and limestone VFP size was based on inorganic reactions (dissolution of carbonate rock) and did not consider contributions from biologic processes (Watzlaf, 1997; Watzlaf and others, 2004). However, a significant amount of sulfate reduction was expected. The lower removal rate may be due to a lower than anticipated retention time as the result of higher flow rates or may be related to the long-term efficiency of a straw-based organic layer compared with more conventional blends of organic materials. A higher sulfate-removal rate and corresponding higher alkalinity was expected from the reconstructed dolomite VFP, which was designed as a sulfate-reducing bioreactor with a thick limestoneamended organic substrate to optimize sulfate reduction and alkalinity generation. Samples to date show that sulfate levels are lower and alkalinity higher in the discharge from the reconstructed dolomite-based VFP (compare data in Tables 2 and 3). However, using the entire 2006-2011 data set for the concentration of sulfate in water entering the VFPs and water flowing from wetland 3, the overall treatment system removal of sulfate is a more significant 23 percent (Table 4). Additional sulfate reduction appears to be occurring in deep portions of the oxidation pond and surface-flow wetlands of the loop treatment wetland system.

\section{Manganese removal and retention}

Manganese removal in a VFP is typically limited because: 1 ) the $\mathrm{pH}$ of VFP-based systems is mostly less than 6.5 and, therefore, is too low for removal of this metal as an oxide, and 2) the solubility of manganese sulfide and manganese carbonate are higher than the corresponding iron minerals (for example, the MnS solubility product $=5.6$ $\times 10^{-16}$ and the FeS solubility product $=1.0 \times 10^{-19}$ ) (Hedin and others, 1994) thus favoring the precipitation of iron rather than manganese. Also, geochemical modeling for this study found that the VFP discharge was undersaturated with respect to rhodochrosite $\left(\mathrm{MnCO}_{3} ; \mathrm{SI}=-0.2275\right.$ to -9.078$)$. However, manganese can be removed by adsorption onto organic ligands (complex formation) in VFPs and perhaps by biologically aided oxidation (oxide mineral formation) in surface-flow wetland treatment systems (Hong and others, 1995; Drever, 1997; Hallberg and Johnson, 2005). Research conducted by the U.S. Bureau of Mines indicates that inorganic processes dominate (adsorption of manganese onto ferric iron solid phases and oxidation by ferrous iron) and the empirically based removal

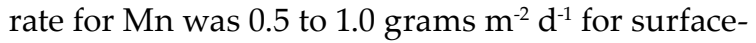
flow aerobic wetlands (Hedin and others, 1994; Watzlaf and others, 2004). However, the inorganic and biologic processes responsible for manganese removal in these surface-flow wetlands are not completely understood.

In the loop treatment wetland system, iron was removed in the VFPs and the wetlands (fig. 12) and a short-term study documented removal to a low

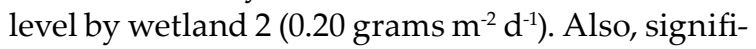
cant manganese removal was observed in wetland $3\left(0.16\right.$ grams $\left.\mathrm{m}^{-2} \mathrm{~d}^{-1}\right)$ (fig. 13 ; system outlet). The increase in manganese concentrations in the discharge from the VFPs and the oxidation pond (fig. 


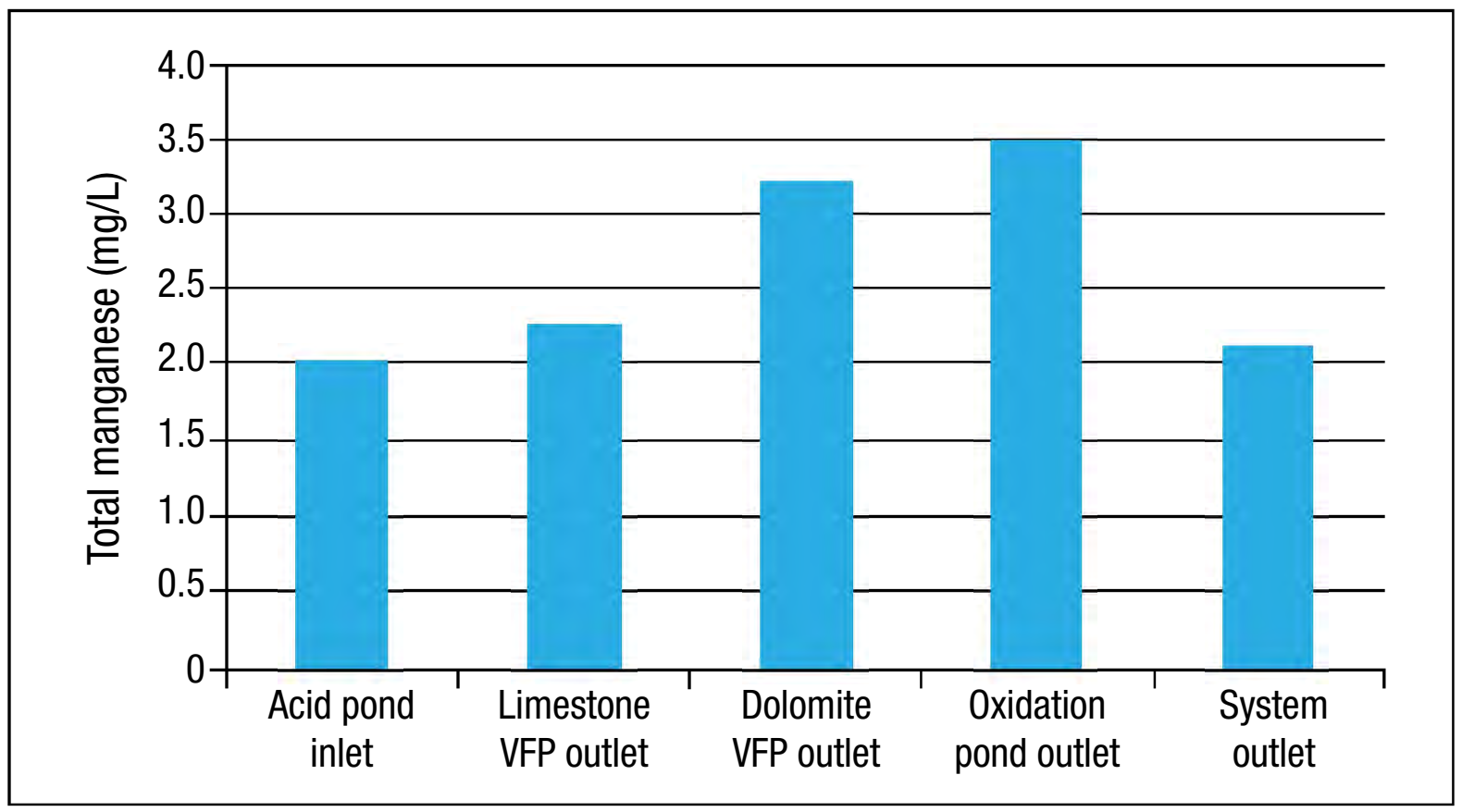

Figure 13.Graph showing median postreconstruction manganese content within the Enos loop treatment wetland system; the acid pond is the forebay impoundment shown in Figures 5 and 8. Data are from Table 3.

13) may be explained by the release of manganese from iron-rich sediment that accumulated in the VFPs and by release of manganese from dolomite, which is commonly less pure than limestone. The short-term study found that manganese was being removed in the wetlands downstream from the oxidation ponds (fig. 13) and primarily by the 14.4acre (5.8-ha) surface flow wetland 3. Manganese increased in the preceding stage, the 7.1-acre (2.8-ha) wetland 2. Although the removal rate for manganese is relatively low, the large size of the system allows effective manganese removal. Lower removal rates than classical designs may relate to the specific parameters of these wetlands. In general, the Enos site wetlands have greater water depths than conventional surface-flow wetlands and a significant portion of the water can pass through these deep areas without interacting with the sediment. Both wetland 2 and wetland 3 contain numerous deep ( $>10-\mathrm{ft}[>3.05-\mathrm{m}])$ pools that served as borrow pits for embankment material.

The sudden influx of low-pH water into the treatment wetlands 2 and 3 during the winter of 20082009 revealed a problem inherent with metal retention in these systems (fig. 14). Both benchscale research and field observations by Watzlaf and Casson (1990) found that iron and manganese associated with iron hydroxide precipitates that were submerged continuously below water tended to remobilize when $\mathrm{pH}$ was lowered to less than 3 . Manganese, in particular, may be weakly bound to the substrate, possibly adsorbed onto organic material or iron hydroxides (Hong and others, 1995; Drever, 1997; Hallberg and Johnson, 2005). Vertical flow pond reconstruction in 2009 improved both the $\mathrm{pH}$ and metal retention in these cells.

\section{CONCLUSIONS AND LESSONS LEARNED}

To date, the passive treatment system constructed at the EGP has, under most conditions, improved the quality of water discharged into the South Fork Patoka River. Because of the low metal content and surplus alkalinity of the discharge, an improvement in the downstream South Fork water quality may be expected for most parameters at least during low-flow conditions. However, for the entire data set (2006-2011), sulfate concentration in the discharge, which ranged from $<250$ to $2,320 \mathrm{mg} / \mathrm{L}$ (median $=1,452 \mathrm{mg} / \mathrm{L}$ ), indicates that sulfate loading remains significant.

Lessons learned during the course of this project included the benefits of obtaining data from geochemical modeling and preconstruction, bench- 


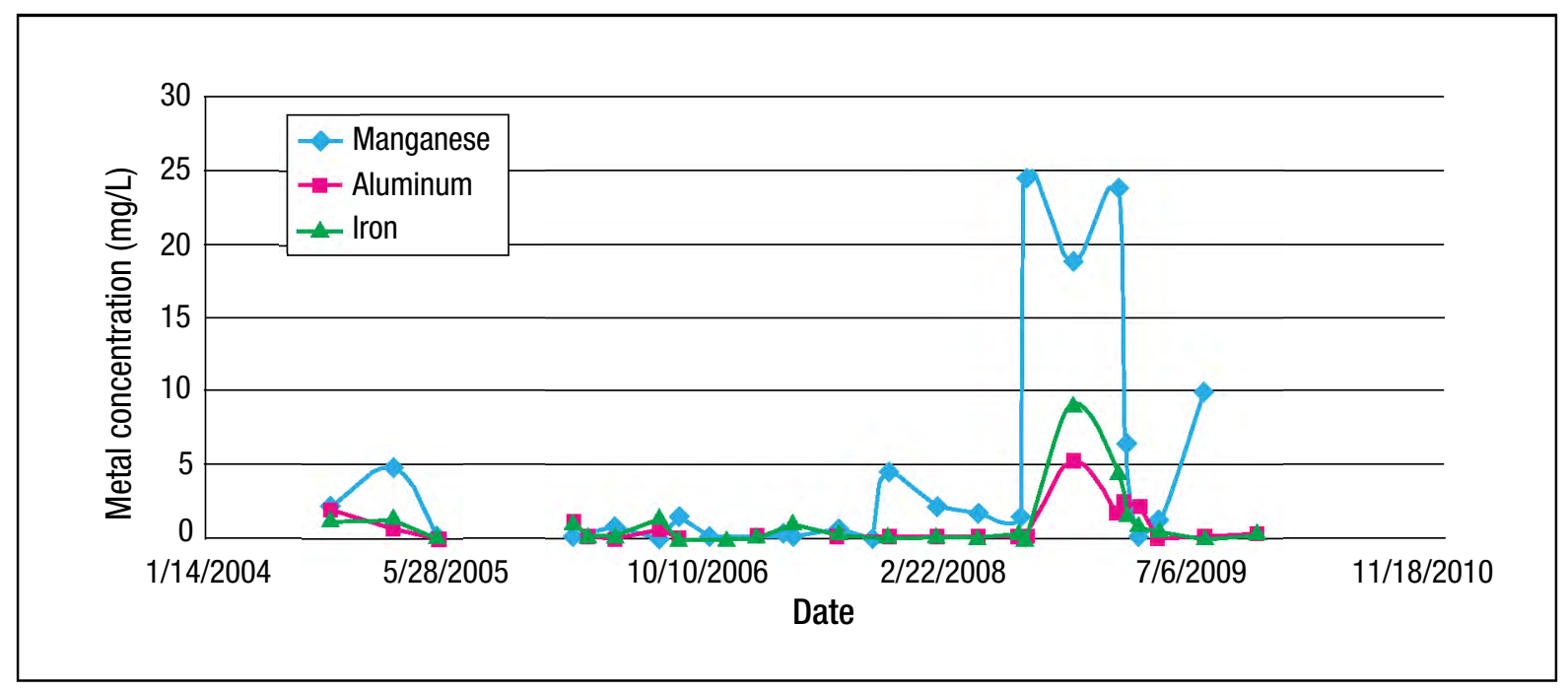

Figure 14.Graph showing mobilization of metals upon vertical flow pond failure before reconstruction.

scale kinetic testing of the actual mine drainage, and incorporating this information in AMD remediation designs. Analysis of the major cations and anions in drainage from the site is necessary for the suggested geochemical modeling and assessment. In the case of the Enos project, the preconstruction investigation documented the availability of alkaline water for diluting AMD, and this alkaline water was effectively used for AMD abatement.

One problem encountered during construction was the lack of locally available compost. Since 2005, IDNR-DOR has negotiated agreements with local landfill authorities and municipalities to develop new sources for yard waste and tree removal debris. The project team continues to evaluate alternative sources such as agricultural byproducts for use in passive treatment system construction. These sources were successfully employed in more recent Indiana reclamation projects, such as the large anaerobic bioreactor constructed at the Sunlight Mine project site in 2007 (OSMRE, 2010).

Large fluctuations in the quality and quantity of the AMD are observed in response to seasonal variations and heavy rainfall during severe storms. From 2008 through early 2009, both VFP cells at the Enos site were stressed by extremely high flow that accompanied a period of abnormally high rainfall. During this period, the $\mathrm{pH}$ gradually decreased from about 6.3 to $<6.0$ and the amount of alkalinity gradually declined. Also, the cold weather of the winter of 2008-2009 provided an additional stress, resulting in low $\mathrm{pH}$ and net acid discharge from both VFPs. Improvements are suggested for the Enos site and similar facilities treating AMD that have large and variable flow rates. These systems should be equipped with a surface-flow control structure on the discharge side of the vertical flow pond that drains away excessive surface overflow from the VFP and limits overloading of the system. This design would require a large anaerobic (compost) wetland (figs. 5 and 8; surface flow wetland 1) to treat this overflow.

The 2009 reconstruction of the VFPs at the Enos site included these improvements and should increase performance and extend the life of this passive treatment system. In addition, completion of re-mining of coal slurry (fig. 3) and final grading should drastically lower the pollution loading from the EGP. The research team will continue to monitor this large reclamation project with the goals of maintaining system performance and evaluating options for system improvements. Additional testing and evaluation including: 1) geochemical reaction modeling, 2) investigating trace metal remov$\mathrm{al}$, and 3) evaluating receiving stream impacts.

\section{ACKNOWLEDGMENTS}

Craig Wolfe, IDNR-DOR Project Manager, was instrumental in ensuring high-quality construction and maintenance of reclamation projects at the Enos site. Steve Herbert, Director of the AML 
Program for IDNR-DOR, provided guidance and funding for this project and the follow-up studies. John Endress of Buckridge Environmental Engineering, Inc., of Newburg, Ind., and landowners Kindill Mining, Inc., and Roy Jeffcoat provided access to the facilities and guidance in the history and water quality of the site. The Patoka South Fork Watershed Steering Committee (PSFWSC), particularly Tom Mosley, assisted in the early planning effort. Paul Ziemkiewicz of the National Mine Land Reclamation Center provided waterquality data acquired during projects assisting the PSFWSC. Office of Surface Mining Reclamation and Enforcement personnel Kwang (Min) Kim, David Best, Joy Schieferstein, Ken Foit (retired), and Kevin Garnett, assisted in the hydrologic investigations. Julie LaBar, Matthew Reeder, and Denver Harper reviewed the manuscript and provided suggestions that led to improvements.

\section{REFERENCES}

Behum, P. T., Kim, K., Garnett, K. W., Meier, L., Glascock, L. A., Mueller, M., and Phillips, M., 2002, Rehabilitation of the Old Bevier passive treatment wetland, Macon County, Missouri, in Proceedings of the $24^{\text {th }}$ Annual National Association of Abandoned Mine Land Programs Conference, Sept. 15-18, 2002, Park City, Utah, 21 p.

Behum, P. T., Hause, D. R., Stacy, M. A., and Branam, T. D., 2008, Passive treatment of acid mine drainagethe Enos Reclamation Project, Indiana-preliminary results, in Proceedings of the $25^{\text {th }}$ Annual Meeting of the American Society of Mining and Reclamation, June 14-19, 2008, Richmond, Va., 24 p.

Behum, P. T., Hause, D. R., Stacy, M. A., and Branam, T. D., 2010, Passive treatment of high volume net acidic mine drainage-the Enos Reclamation Project, Indiana, in Proceedings of the 2010 National Association of Abandoned Mine Lands Programs Conference, Sept. 19-22, 2010, Scranton, Pa.

Deutsch, W. J., 1997, Groundwater geochemistry fundamentals and applications to contamination: Boca Raton, Fla., Lewis Publishers, 221 p.

Drever, J. I., 1997, The geochemistry of natural waters, third edition: Upper Saddle River, N.J., PrenticeHall, 436 p.

Endress, J., 1999, The Enos Gob Pile-a summary of problems and potential solutions: Unpublished report for the Patoka South Fork Watershed Steering Committee, Nov. 15, 1999: Oakland City, Ind., 34 p.
Flege, A. E., 2001, Sulfate reduction in five constructed wetlands receiving acid mine drainage: Cincinnati, Ohio, University of Cincinnati, master's thesis, <http://etd.ohiolink.edu/send-pdf.cgi/Flege $\% 20$ Adam\%20Eric.pdf?ucin991680380>, date accessed, Nov. 2, 2011.

Flege, A. E., Maynard, J. B., and Elswick, E. R., 2012, Sulfur isotopes as indicators of remediation efficacy in constructed wetlands receiving acid mine drainage, in Comer, J. B., Effects of abandoned mine land reclamation on ground and surface water qualityresearch and case histories from Indiana: Indiana Geological Survey Special Report 72, p. 299-324.

Flege, A. E., and Maynard, J. B., 2001, Sulfate reduction in three Indiana wetlands receiving acid mine drainage: $35^{\text {th }}$ Annual Meeting, Geological Society of America, North-CentralSection, April 2324, Normal, Ill., <http:/gsa.confex.com/gsa/2001NC/ final program/abstract 4335.htm>, date accessed, Nov. 2, 2011.

Gusek, J. J., and Wildeman, T. R., 2002, Passive treatment of aluminum-bearing acid rock drainage, in Proceedings of the $23^{\text {rd }}$ Annual West Virginia Surface Mine Drainage Task Force Symposium, April 16-17, 2002, Morgantown, W. Va., 9 p.

Hallberg, K. B., and Johnson, D. B., 2005, Biological manganese removal from acid mine drainage in constructed wetlands and prototype bioreactors: Science of the Total Environment, v. 338, p. 115-124.

Hedin, R. S., Narin, R. W., and Kleinmann, R. L. P., 1994, passive treatment of coal mine drainage: U.S. Bureau of Mines Information Circular IC 9389, $35 \mathrm{p}$.

Hong, J., Calmaro, W., and Forester, U., 1995, Interstitial waters, in Salbu, B., and Steinnes, E., eds., Trace elements in natural waters: Boca Raton, Fla., CRC Press, p. 117-150.

Huminicki, D. M. C., 2006, Effect of coatings on mineral reaction rates in acid mine drainage: Blacksburg, Va., Virginia Tech, Ph.D. dissertation, 98 p.

Huminicki, D. M. C., and Rimstidt, J. D., 2008, Neutralization of sulfuric acid solutions by calcite dissolution and the application to anoxic limestone drain design: Applied Geochemistry, v. 23, no. 2, p. $148-165$.

Kepler, D. A., and McCleary, E. C., 1994, Successive alkalinity producing systems (SAPS) for the treatment of acidic mine drainage, in Proceedings of the International Land Reclamation and Mine Drainage Conference and the $3^{\text {rd }}$ International Conference of the Abatement of Acidic Drainage, April 1994, Pittsburgh, Pa., p. 195-204.

Maynard, J. B., and Helton, A. M., 2005, Improving the performance of constructed wetlands for the treat- 
ment of acid mine drainage-a pilot scale study of the use of dolostone instead of limestone for anoxic drains: Final Report on Indiana Division of Reclamation SMART Grant, $32 \mathrm{p}$.

Mitchell, K. G., and Wildeman, T. R., 1996, Solubility of Fe (III) and Al in AMD by modeling and experiment, in Proceedings of the 1996 National Meeting of the American Society for Surface Mining and Reclamation, May 18-23, Knoxville, Tenn., p. 682-689.

Neculita, C., Zagury, G. J., and Bussière, B., 2007, Passive treatment of acid mine drainage in bioreactors using sulfate-reducing bacteria-critical review and research needs: Journal of Environmental Quality, v. 36, p. 1-16.

Office of Surface Mining Reclamation Enforcement (OSMRE), 2010, Indiana AML site 337 (Sunlight), in Acid Mine Drainage Workshop, April 13-14, Evansville, Ind., p. 18-19.

Rimstidt, J. D., and Huminicki, D. M. C., 2006, The effect of gypsum coatings on the hydrodynamic factors on ALD performance, in Proceedings of the $27^{\text {th }}$ Annual West Virginia Surface Mine Drainage Task Force Symposium, Morgantown, W. Va., 2 p.

Rose, A. W., Morrow, T., Dunn, M., and Denholm, C., 2007, Mode of gypsum precipitation in vertical flow ponds, in Barnhisel, R. I., ed., Proceedings of the 2007 National Meeting of the American Society of Mining and Reclamation, 30 Years of SMCRA and Beyond, Gillette, Wyom., June 2-7, 2007: Lexington, Ky., American Society of Mining and Reclamation, p. 678-691.

Smith, R. T., Comer, J. B., Ennis, M. V., Branam, T. D., Butler, S. M., and Renton, P. M., 2003, Toxic metals removal in acid mine drainage treatment wetlands: Indiana Geological Survey Open-File Report 01-03, $52 \mathrm{p}$.

Stacy, M. A, 2007, AML reclamation activities, past, present and future in the Southern Fork Patoka River watershed: Indiana Society of Mining and Reclamation $21^{\text {st }}$ Annual Surface Mine Reclamation Technology Transfer Seminar, December 3-4, 2007, Jasper, Ind.

Stacy, M. A., 2012, Impacts of abandoned mine land reclamation on water quality within the South Fork Patoka River watershed, in Comer, J. B., Effects of abandoned mine land reclamation on ground and surface water quality-research and case histories from Indiana: Indiana Geological Survey Special Report 72, p. 147-164.

Thomas R. C., 2002, Passive treatment of low-pH, ferric iron-dominated acid rock drainage: Athens, University of Georgia, Ph.D. dissertation, 365 p.
Thomas R. C., and Romanek, C. S., 2002a, Passive treatment of low-pH, ferric iron-dominated acid rock drainage in a vertical flow wetland-acidity neutralization and alkalinity generation, in Proceedings of the 2002 National Meeting of the American Society of Mining and Reclamation, June 9-13, 2002: Lexington, Ky., American Society of Mining and Reclamation, p. 723-748.

Thomas, R. C., and Romanek, C. S., 2002b, Passive treatment of low-pH, ferric-iron dominated acid rock drainage in a vertical flow wetland II-metal removal, in Proceedings of the $19^{\text {th }}$ Annual Meeting, American Society of Mining and Reclamation, June 9-13, Lexington, Ky., p. 752-775.

Watzlaf, G. R., 1997, Passive treatment of acid mine drainage in down-flow limestone systems, in Proceedings of the National Meeting of the American Society of Surface Mining and Reclamation, May 10-15, 1997, Austin, Texas, p. 611-622.

Watzlaf, G. R., and Casson, L., 1990, Chemical stability of manganese and iron in mine drainage treatment sludge; effects of neutralization chemical, iron concentration and sludge age, in Skousen, J. J., Sencindiver, J., and Samuel, D., eds., Proceedings of the 1990 Mining and Reclamation Conference and Exhibition, April 23-26, 1990, Charleston, W. Va.: Morgantown, West Virginia University, p. 3-9.

Watzlaf, G. R., Schroeder, K. T., Kleinmann, R. L., Kairies, C. L., and Nairn, R. W., 2004, The passive treatment of coal mine drainage: Department of Energy/National Energy Technology Laboratory Publication 2004/1202, $72 \mathrm{p}$.

Zagury, G. J., and Neculita, C., 2007, Passive treatments of acid mine drainage in bioreactors-short review, applications, and research needs, in Proceedings of the OttawaGeo2007 Conference, Oct. 21-25, 2007, Ottawa, p. 1,439-1,446. 
INDIANA GEOLOGICAL SURVEY SPECIAL REPORT 72 


\title{
Effects of Reclamation on the Water Quality of Augusta Lake and Mill Creek, Pike County, Indiana
}

John B. Comer, Ronald T. Smith, Margaret V. Ennis, and Tracy D. Branam

Indiana Geological Survey

\begin{abstract}
Augusta Lake is a 55-acre (22.25-hectare) man-made lake located on Mill Creek, a tributary of the Patoka River in the coal-mining region of south-central Pike County, Indiana. The lake is strongly acidic (mean $\mathrm{pH}=3.1$, range $=1.8-6.3$ ) and has been barren of aquatic life throughout most of its history. Mill Creek receives the majority of its base flow from Augusta Lake and also has been predominantly acidic (mean $\mathrm{pH}=3.1$, range $=2.4-7.8$ ) since monitoring data were first acquired in 1949. Oxidation of pyrite in the disturbed overburden from coal mining is the principal source of acid in the Augusta Lake-Mill Creek watershed.
\end{abstract}

Augusta Lake was created in 1950 in an attempt to mitigate acid mine drainage entering Mill Creek and the Patoka River by impounding a large body of diluted water in the most highly impacted part of the watershed. From 1993 to 1997, a staged passive treatment system was constructed adjacent to Augusta Lake in the northeast drainage area because most of the acid discharged into the lake was from this part of the watershed. The staged passive treatment system included anoxic limestone drains, aerobic wetlands, and successive alkalinity-producing systems, which together generate alkalinity, promote metals deposition, and raise the $\mathrm{pH}$ of the effluent. From 1999 to 2006, alkaline chemicals $\left(\mathrm{Ca}(\mathrm{OH})_{2}, \mathrm{NaOH}, \mathrm{CaCO}_{3}, \mathrm{Na}_{2} \mathrm{CO}_{3}\right)$ were used to directly neutralize surface water entering the lake and to increase the $\mathrm{pH}$ and buffer capacity of groundwater before it contacted pyritic spoil. For the groundwater application, alkaline chemicals were placed in concentrated alkaline recharge pits and alkaline recharge trenches in the groundwater flow path. These applications of alkaline chemicals were designed to improve the quality of water sufficiently so that Augusta Lake would become a recreational lake supporting fish.

Monitoring data show that the quality of water discharged from the northeast drainage area into Augusta Lake, the water discharged from Augusta Lake, and the water in Mill Creek has improved during the last six decades. This improvement is documented by comparing the mean values of analytes from the earliest to the latest monitoring

Note: Appendices for this paper are located on the CD-ROM in the back of this book; the CD-ROM also contains spreadsheets of the water-quality data on which this paper is based. 
periods between 1949 and 2008. For all parameters except sulfate, the greatest changes occurred in water discharged from Augusta Lake. These changes included the largest increases in $\mathrm{pH}$ (from 2.8 to 3.8) and calcium (47\%) and the largest decreases in iron (96\%), hydrogen ion activity (91\%), acidity $(90 \%)$, aluminum (52\%), manganese (43\%), magnesium $(33 \%)$, specific conductance $(26 \%)$, and total dissolved solids (20\%). Mill Creek experienced the smallest increases in $\mathrm{pH}$ (from 2.7 to 3.1 ) and calcium concentration (35\%), the smallest decreases in hydrogen ion activity (54\%) and magnesium concentration (10\%), and the largest decrease in sulfate concentration (26\%). Discharge from the northeast drainage into Augusta Lake experienced the smallest decreases in the concentrations of iron (65\%), acidity (54\%), and sulfate $(6.5 \%)$.

The increase in $\mathrm{pH}$ and decrease in acidity and sulfate concentrations prior to the intensive reclamation work in the northeast drainage that began in the 1990s are most likely a response to the dilution of acid outflows accomplished by the construction of Augusta Lake, the depletion of oxidizable pyrite in spoil through weathering, and a natural increase in vegetative cover on mined land which promoted stability, reduced erosion, and limited exposure of fresh pyrite to weathering. The observed increase in calcium concentration in surface water before 1993 indicates an increased contribution from calcium-bearing materials in the watershed over time and may reflect increased use of limestone $\left(\mathrm{CaCO}_{3}\right)$ for road grading and related activities in the Augusta Lake-Mill Creek watershed. After the construction of the staged passive treatment system beginning in 1993, some of the increased calcium in the watershed is attributed to the dissolution of limestone in anoxic limestone drains and successive alkalinity-producing systems as the limestone reacted with the acid mine drainage formed in mine spoil. After the application of calciumbearing alkaline chemicals beginning in 1999, calcium concentration in Augusta Lake increased as a result of dissolution of these chemicals when they were discharged directly into surface water entering the lake and when they dissolved in groundwater that passed through the concentrated alkaline recharge pits and alkaline recharge trenches prior to being discharged into the lake.

The large decrease in iron concentration in Augusta Lake during the first year after the initial filling of the reservoir represents the time when iron precipitation became a predominant geochemical reaction in the newly developing lake system. Subsequently, the continued decline in iron concentration indicates that the process of scavenging iron from aqueous solution and fixing it in the lake sediments is extremely efficient in Augusta Lake. The decline in the concentration of iron and other metals ( $\mathrm{Al}, \mathrm{Mn}, \mathrm{Mg}$ ) indicates that, although Augusta Lake may not be suitable for recreational uses, it does serve the important function of cleaning dissolved metals from mine effluent. 


\section{INTRODUCTION}

\section{Background and purpose}

Augusta Lake and Mill Creek are located near the center of the Patoka River watershed in the coal-mining region of south-central Pike County, Indiana (figs. 1 and 2). During the eighteenth century, the Patoka River watershed was part of an extensive riparian floodplain wetland that connected the White River and the lower Wabash River. Anthropogenic changes, including ditching, channelization, levee construction, coal mining, and oil and gas production, have dramatically altered Patoka River drainage and water quality (Simon and others, 2005). In the nineteenth and twentieth centuries, surface water was a major source of drinking water for towns located in the Patoka River watershed and concerns about degraded water quality led to investigations into the causes of impairment, attempts to mitigate degradation, and programs to improve water quality. A review of the historical evidence indicates that approximately 61 percent of the Patoka River watershed was degraded by anthropogenic changes and that acid mine drainage (AMD) resulting from the weathering of pyrite in disturbed overburden from coal mining was a major cause of this degradation. Acid mine damage caused a decline of biological diversity throughout the watershed and all aquatic fauna were lost in some headwater streams during the last century (Simon and others, 2005).

This report briefly presents an overview of the history of coal mining in the Augusta Lake-Mill Creek watershed, discusses early AMD abatement efforts, presents and analyzes data from waterquality monitoring studies, and evaluates the various water-quality improvement efforts. The brief overview of the history of coal mining in the Augusta Lake and Mill Creek drainage provides insight into the primary cause of water-quality degradation in this highly impacted watershed. Because this case study includes data collected over a period of nearly six decades, it provides a rare long-term perspective on the effectiveness of both historical and modern approaches to improving water quality in Indiana's abandoned mine lands.

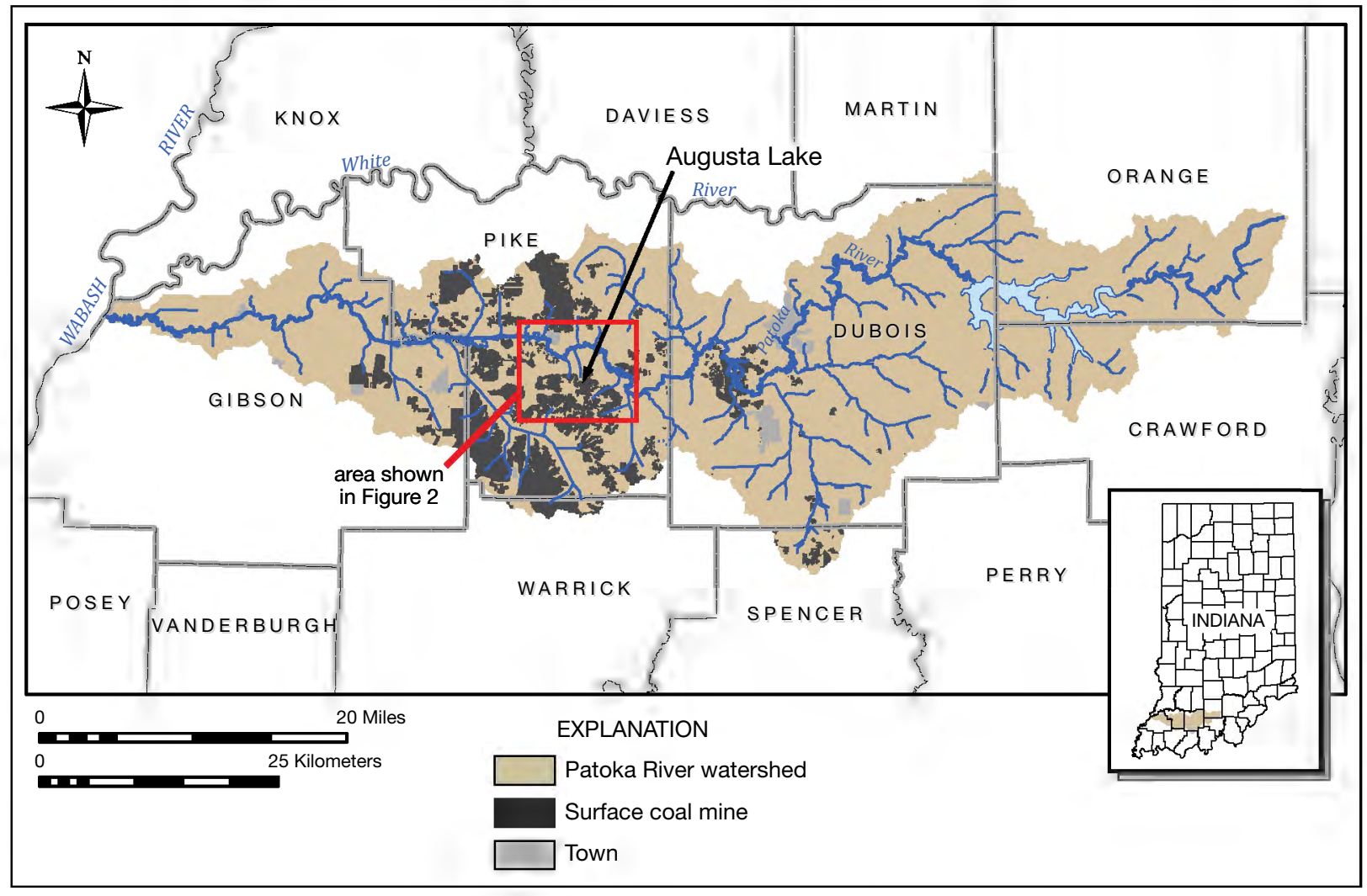

Figure 1. Map showing location of the Patoka River watershed including rivers and streams, counties, towns, and areas mined for coal. Arrow indicates the location of Augusta Lake. 


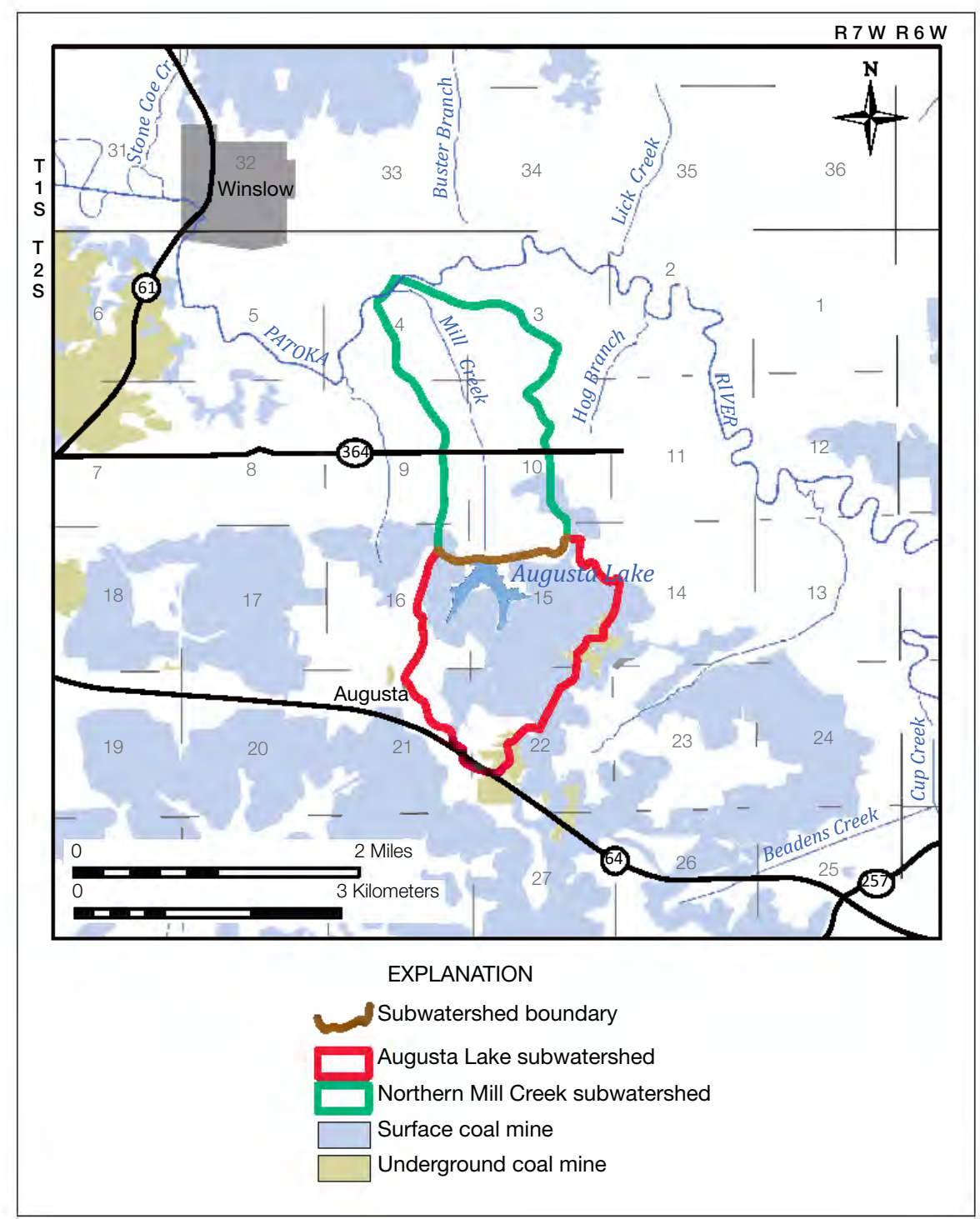

Figure 2. Map showing location of Augusta Lake and Mill Creek subwatersheds with rivers and streams, towns, state roads, surface and underground coal mines, and sections.

\section{Geographic area}

Augusta Lake is a 55-acre (22.25-hectare) manmade lake located on Mill Creek, a tributary of the Patoka River (fig. 2). Augusta Lake is located in sections 15 and 16, T. 2 S., R. 7 W., and is part of the Sugar Ridge Fish and Wildlife Refuge, Area 4, of the Indiana Department of Natural Resources (IDNR). The drainage areas for the lake and Mill Creek are contained in sections $3,4,9,10,14,15,16$, 21, and 22 of T. 2 S., R. 7 W. Abandoned mine lands located in sections 15 and 16, T. 2 S., R. $7 \mathrm{~W}$. are the source for most of the acidic water that degrades Augusta Lake and Mill Creek.
The drainage area for Augusta Lake is $1.45 \mathrm{mi}^{2}$ $\left(3.76 \mathrm{~km}^{2}\right)($ Corbett, 1965) and the drainage area for Mill Creek below the dam is $1.57 \mathrm{mi}^{2}\left(4.07 \mathrm{~km}^{2}\right)$. Abandoned mine lands (AML) account for 62 percent of the Augusta Lake subwatershed and 5 percent of the Mill Creek subwatershed below the dam. These estimates of drainage area are somewhat imprecise because the delineation of watershed boundaries is difficult where the land has been heavily disturbed by surface mining. Surface mining recontours the land, causing the breaching of natural divides in some areas and the construction of barriers to surface flow in others. In addition, underground mining alters the flow of groundwater in the subsurface. 
Changes to the land surface caused by mining in the most highly impacted part of the Augusta Lake-Mill Creek watershed are illustrated in Figure 3. This series of six aerial photographs shows the landscape in 1937, before extensive surface mining (fig. 3A); during active surface mining, before construction of the Augusta Lake dam (fig. 3B); after construction of the Augusta Lake dam and after closure of the Ayrshire No. 1 Mine (fig. 3C); during a period of intermittent surface mining in 1966 (fig. 3D); after most of the mines in the area had been abandoned and during reclamation activities in 1998 (fig. 3E); and recent conditions in 2005 showing the distribution of spoil ridges, final-cut lakes, and tributaries that discharge AMD (fig. 3F). These orthophotos document the extent of coal mining near Augusta Lake, the complexity of disturbance of the land surface, and the large area of acid-generating mine spoil adjacent to the lake. Water-quality monitoring sites were established throughout the watershed for various studies that were completed to assess the impacts of mine effluent and the effects of reclamation on the environment. Locations of the monitoring sites discussed in this report are plotted on the orthophoto of the study area shown in Figure 4.

\section{Mining history}

Commercial underground coal mining (fig. 2) began near the study area in 1895 when Caledonia Coal Company opened the Hartwell No. 1 Mine in section 22, T. 2 S., R. 7 W. (IGS, 2007). From 1908 to 1922, underground mining extended northward into section 15, where most of Augusta Lake and its subwatershed are located. The last underground coal mining occurred during 1951 in sections 16 and 21 in the Augusta Mine, operated by Augusta Coal Company. All the underground mines recovered coal from the Springfield Coal Member (Petersburg Formation, Carbondale Group, Pennsylvanian).

The first surface mining of coal in the study area began in 1939 when Ayrshire Collieries Corporation opened the Ayrshire No. 1 Mine and recovered coal from the Springfield coal in nine sections of T. 2 S., R. 7 W., including sections 15 and 16 (IGS, 2007). The Ayrshire No. 1 Mine closed in 1953, after which mining near the study area was intermittent. From 1979 to 1980, Shelton Paul Company recovered coal from the Springfield Coal by surface mining methods in the Cherokee No. 2 Mine located in sections 15 and 22. From 1981 to 1983, Midwestern Mining Consultants produced coal by surface mining from the Survant Coal Member (Linton Formation, Carbondale Group, Pennsylvanian) in the Midwestern No. 1 Mine located in sections 14 and 23, and from 1981 to 1988, Parke Coal Company produced coal from the Springfield Coal in the Augusta Pit located in sections 21 and 22. In 2002, Triad Mining of Indiana began surface mining of the Springfield Coal and the Bucktown Coal Member (Dugger Formation, Carbondale Group, Pennsylvanian) in the Augusta Mine (Pike) in four sections, including section 16 . Surface mining by Triad is ongoing.

\section{Environmental impacts and reclamation efforts}

The first record of coal mine reclamation activities in the Augusta Lake area is contained in a report by the U.S. Public Health Service documenting an effort to seal abandoned coal mines in southern Indiana (Mershon, 1940). The report tallied 2,679 coal mines that discharged an annual load of 116,463 tons of sulfuric acid to streams and tributaries in Indiana. An acid abatement effort was implemented between 1935 and 1940 by the Works Progress Administration (WPA) and supervised by the U.S. Public Health Service. The goal was to prevent acidic water in mined lands from entering primary streams. Twenty-eight surface-mine pits in Pike County were sealed by constructing dams to form small lakes and the spoil around the lakes was reforested.

Reclamation during the height of surface mining in the Augusta Lake-Mill Creek watershed from 1939 to 1953 (fig. 3B) followed mining and generally progressed from the northwest to the east and southeast (ATEC, 1984). When mining operations ceased in an area, the county agronomist inspected exposed spoil to determine if it would support vegetation. Nontoxic spoil was revegetated primarily by planting pine trees, whereas no revegetation was attempted for spoil determined to be toxic (ATEC, 1984) (fig. 3C-F).

In 1939, the city of Princeton in Gibson County abandoned the Patoka River as its public water supply because the water was too acidic for domestic use and the town did not have the financial resources for treatment (Corbett, 1969). In 1949, the Indiana State Board of Health (ISBH) investigated a complaint from the town of Winslow in 

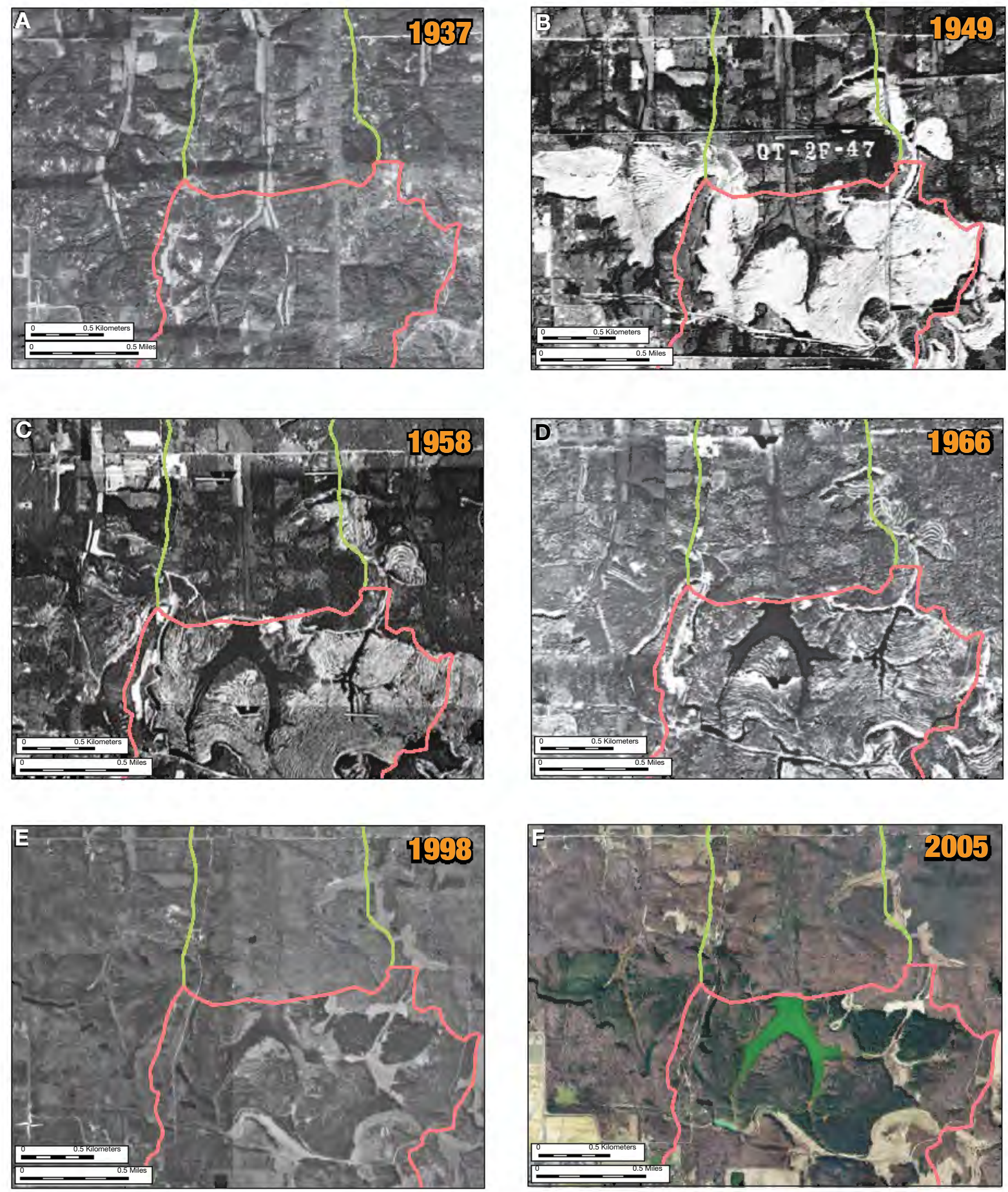

Figure 3. Orthophoto time series of the study area showing conditions during and after mining and before and after Augusta Lake was constructed. Pink and green lines are the subwatershed boundaries shown in Figure 2. A. 1937 - Conditions prior to extensive surface mining. B. 1949 - Pre-lake conditions during active surface mining. C. 1958 - After lake construction and after closure of the Ayrshire No. 1 mine. Note impoundment of surface water in the northeast drainage area and the growth of pine trees planted on abandoned spoil of surface-mined areas in the west. D. 1966 - Absence of mining activity during extended period of intermittent late-stage mining. E. 1998 - During reclamation activities under regulations of the Indiana Abandoned Mine Land Program. F. 2005 - Present-day conditions. The pale green color of the southernmost final-cut lake (fig. 3F) is due to $\mathrm{Ca}(\mathrm{OH})_{2}$ that was discharged directly into the water from tanker trucks on the access road located at the top of the highwall at the west end of this impoundment. 


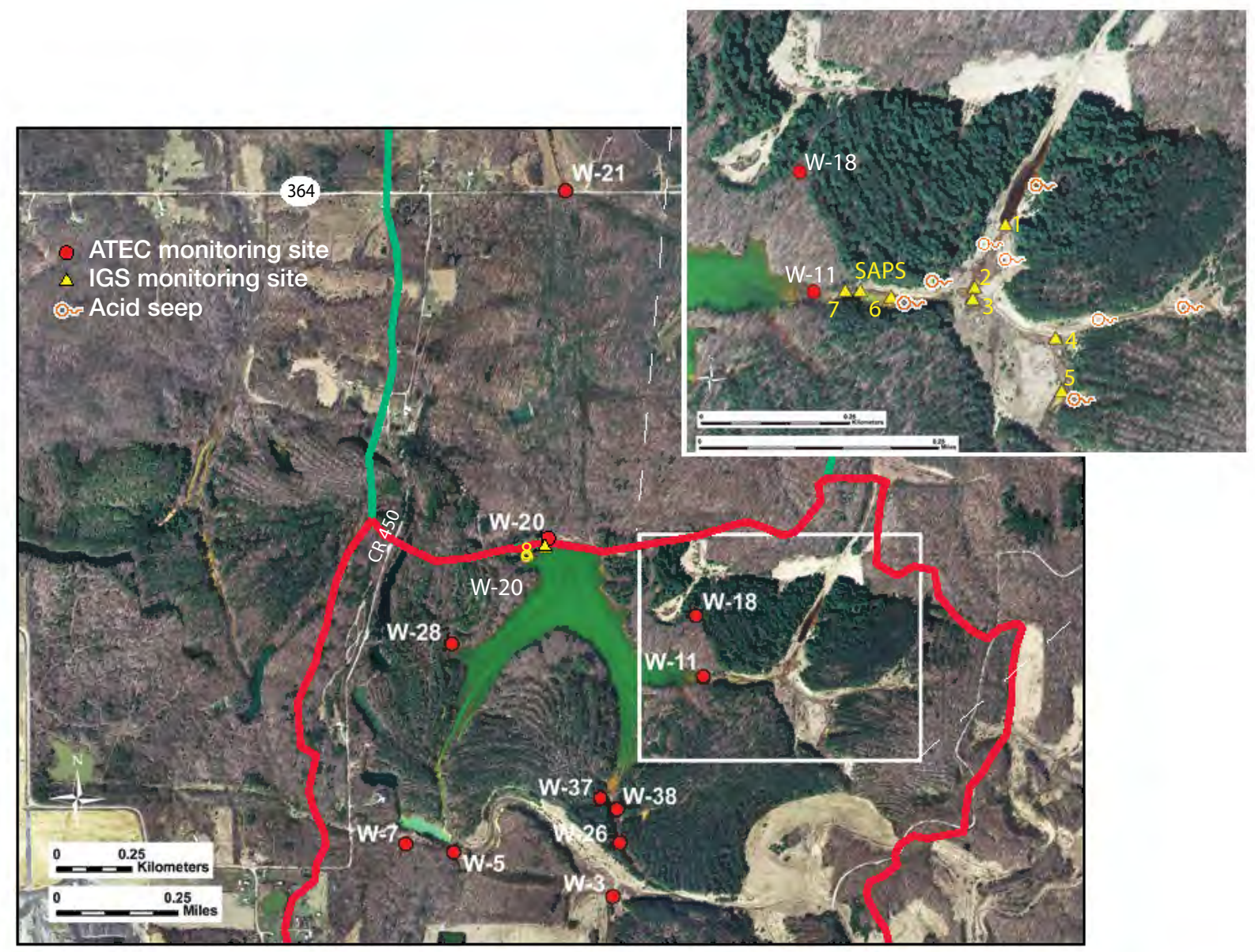

Figure 4. Orthophoto mosaic of Augusta Lake showing the location of hydrology and water-quality monitoring sites discussed in this report. Red dots are monitoring sites reported in Appendix A (ATEC, 1984), yellow triangles are monitoring sites reported in Appendix B (Comer and others, 2000), and orange circles represent the major acid seeps reported prior to construction of the staged passive treatment system (Ryu, 1997). The location of monitoring site 1302A in Appendix $C$ is essentially the same as monitoring site W-20 (M. A. Stacy, IDNR-DOR, written commun., 2008). (Appendices are available on CD-ROM included with this volume.) Red and green lines are the subwatershed boundaries shown in Figure 2.

Pike County that operations at Ayrshire Colleries Corporation No. 1 Mine were polluting the Patoka River, the town's domestic water supply, with acid and excess iron (Corbett, 1969). In November 1949 ISBH tested the water quality ( $\mathrm{pH}$ and acidity) and measured the flow rate for Mill Creek at State Road (S.R.) 364 to document the problems identified in the complaint. Based on the results of these tests, ISBH recommended the construction of four dams to inundate the acid-forming materials in the Augusta Lake-Mill Creek watershed (Corbett, 1969). Ayrshire Colleries Corporation developed an alternate plan, later approved by ISBH, to construct one dam on Mill Creek for the purpose of remediating acid discharge from the watershed.

In the late fall of 1950, an earth-filled dam was constructed on Mill Creek that created a lake (origi- nally named "Ayrshire Lake," now "Augusta Lake") to dilute the AMD generated in mine spoil in the Augusta Lake-Mill Creek watershed and reduce the concentration of acid in the Patoka River at Winslow (Corbett, 1969). Reclamation practices at that time favored submerging mine spoil under water to prevent pyrite oxidation and acid production. The spillway for the lake, which controlled the normal pool elevation, was a drop inlet riser with a 48 -inch $(121.9-\mathrm{cm})$ diameter corrugated metal pipe located at the west end of the dam (ATEC, 1984). The fixed normal pool elevation of Augusta Lake of $480 \mathrm{ft}$ (146.3 m) (mean sea level) was, however, not sufficient to submerge all the mine spoil in the area and the lake became a barren, acid lake devoid of aquatic life. Augusta Lake filled for the first time during the early part of 1951 (Corbett, 1969) and Ayrshire Collieries Corporation 
monitored water quality $(\mathrm{pH}$, acidity, iron, sulfate, and calcium) of the lake's outflow from January 1951 through August 1954 (ATEC, 1984).

Based on hydrology and water-quality monitoring from May 1963 to July 1968, Corbett (1969) documented that most of the water flowing into the Patoka River from a 270 mile $^{2}\left(699.3 \mathrm{~km}^{2}\right)$ area of the watershed in the coal mining region of Pike County drained from coal-mine spoil and that this water was highly acidic. Water quality $(\mathrm{pH}$, acidity, alkalinity, and sulfate) and the flow rates for water entering the Patoka River and exiting Augusta Lake and Mill Creek were surveyed periodically during this period and the results were reported by Corbett $(1965,1969)$. Corbett (1969) noted an improvement in the acidity of Mill Creek during these studies and concluded that draining acidic water from spoil, small ponds, and WPA lakes feeding into Augusta Lake and allowing lower levels of the spoil to be leached would result in greatly improved water quality in the Augusta Lake-Mill Creek watershed. Furthermore, a managed plan to grade acid-generating spoil, cover it, and drain acidic water from the spoil and feeder lakes was proposed to improve the water quality in Augusta Lake sufficiently to support harvestable fish (Corbett, 1969). The notion that Augusta Lake could be converted, with the appropriate reclamation effort, into a recreational lake originated with this work.

From 1976 through 1980, AMAX Coal Company conducted monthly water-quality monitoring of Mill Creek at S.R. 364 (ATEC, 1984). The data included discharge, water temperature, specific conductance, $\mathrm{pH}$, and the concentrations of total dissolved solids (TDS), acidity, alkalinity, chloride, sulfate, calcium, magnesium, sodium, total iron, and manganese. Mill Creek water was mostly acidic during the monitoring period (ATEC, 1984). The water also contained high concentrations of sulfate and iron, the telltale signature in surface water flowing from AML settings indicative of pyrite oxidation.

In 1979, the U.S. Geological Survey (USGS) conducted a reconnaissance survey to assess the hydrology and water quality of surface water in the coal-mining region of southwestern Indiana. This survey was intended to be the initial phase of a project to create a data collection network that would provide hydrologic and water-quality data for coal-mining permits, as stipulated in the Surface Mining Control and Reclamation Act of
1977. Water collected from Mill Creek at the S.R. 364 bridge was confirmed to be highly acidic during this survey (Renn and others, 1980). Subsequent monitoring showed that water collected from Mill Creek at the S.R. 364 bridge during relatively high flow remained strongly acidic (Renn, 1989).

In 1984 a report was submitted to the Indiana Department of Natural Resources (IDNR) describing the comprehensive investigation of 6,000 acres $\left(24.3 \mathrm{~km}^{2}\right)$ near Augusta, Indiana, to determine the sources of AMD that had seriously degraded the quality of surface water and groundwater in the area (ATEC, 1984). More than 500 surface water samples, 50 groundwater samples from 19 test borings, 100 samples of mine spoil, and 17 samples of coal refuse were collected during this study. Disturbed overburden from surface mining, coal refuse used in constructing rail grades and haul roads, exposed coal, acidic overburden in highwalls, and seepage from underground mines were identified as the main sources of AMD in the study area (Corbett, 1969; ATEC, 1984). The surface waters that drained from areas where Springfield coal was mined were found to be more acidic than those draining from areas where other coal beds were mined. The study also noted serious structural problems with the Augusta Lake dam and recommended that repairs to the discharge pipe begin immediately to prevent breaching failure of the embankment. The Augusta Lake-Mill Creek watershed was identified as one of the worst AMDimpacted areas during this study and the highest discharge of AMD into the Augusta Lake was documented as coming from the northeast drainage area (ATEC, 1984).

In 1991, a project to treat AMD issuing from seeps in the northeast drainage of Augusta Lake was initiated by the U.S. Fish and Wildlife Service and passive reclamation technologies were chosen to treat water from eight seepage areas. The first passive treatment installation was an anoxic limestone drain (ALD) constructed in 1993 to treat the poorest quality acidic water seeping from mine spoil. This ALD failed after about 1 year, owing to clogging of the limestone bed by what was assumed to be aluminum precipitates (W. McCoy, Patoka River National Wildlife Refuge, written commun., 2008). Also, in 1993 a successive alkalinity-producing system (SAPS) was constructed in the upper reach of the northeast drainage, where it received water from the first ALD. The SAPS failed after 2 months because of clogging and subsequent work in 1995 failed to improve its performance. A 
staged passive treatment system consisting of 4 cells of aerobic wetlands, 15 ALDs, and a new SAPS was constructed from 1995 to 1997 with funding from the Indiana Department of Environmental Management. Preconstruction water-quality monitoring was done in August and September 1992 (Ryu, 1997) and postconstruction monitoring was conducted in 1997 and 1998 (Comer and others, 2000). The new SAPS failed after 6 months owing to clogging of the substrate. Postconstruction monitoring documented that alkaline water flowed from the SAPS standpipe near the mouth of the northeast drainage and mixed with surface water before entering Augusta Lake (Comer and others, 2006). After mixing, water discharged into the lake remained strongly acidic (Comer and others, 2006).

In 1996, the Patoka South Fork Watershed Steering Committee was formed and identified Augusta Lake among their list of sites for AMD remediation (Kalagian and Simmons, 2002). The committee oversaw a program to directly neutralize the acidity in Augusta Lake and in acid seeps entering the lake by introducing alkaline chemicals at selected locations within the drainage basin. The alkaline chemicals used during this program included calcium hydroxide $\left(\mathrm{Ca}(\mathrm{OH})_{2}\right), 50$ percent caustic soda $(\mathrm{NaOH})$, calcium carbonate $\left(\mathrm{CaCO}_{3}\right)$, and soda ash $\left(\mathrm{Na}_{2} \mathrm{CO}_{3}\right)$ (Kalagian and Simmons, 2002). The goal of the program was to convert Augusta Lake into a recreational lake that supported fish. Besides discharging alkaline chemicals from tanker trucks into the southernmost final-cut lake, which feeds directly into Augusta Lake (fig. 3F), a concept was developed to introduce alkalinity into the upstream groundwater system before the water entered mine spoil and became acidic. Maps showing the groundwater flow paths produced by ATEC (1984) were used to guide the construction of concentrated alkaline recharge pits (CARPs) and alkaline recharge trenches (ARTs), which were filled with $\mathrm{Ca}(\mathrm{OH})_{2}$ paste or $\mathrm{CaCO}_{3}$ powder and covered with riprap to collect surface-water runoff and promote the generation and infiltration of highly alkaline water into the groundwater flow system. This effort was funded by four Clean Water Action Plan Challenge Grants from the U.S. Fish and Wildlife Service Regional Office; partners in the project included the Patoka River National Wildlife Refuge, Jack Nawrot (Southern Illinois University), Rose Disposal Services, IDNR, Division of Reclamation, and IDNR Division of Fish and Wildlife. The direct neutralization program reported a reduction in the acid concentration for Augusta Lake and a reduc- tion in acid load to Mill Creek, based on data collected from September 1999, when the first applications began, until December 2001 (Kalagian and Simmons, 2002). In 2000, aquatic life was reported in Augusta Lake for the first time and darters were observed downstream in Mill Creek (Simon and others, 2005). A biological survey of Mill Creek at the S.R. 364 bridge in 2001 identified eight aquatic species that were not present during earlier surveys (Kalagian and Simmons, 2002). There is no longer a Patoka South Fork Watershed Steering Committee and no water-quality monitoring designed to evaluate the effects of direct neutralization on water quality of Augusta Lake has been reported since 2001. The last ART was installed in 2006 and no new funding has been requested for additional construction at this time.

In 2007, the Augusta Lake dam underwent reconstruction. The spillway was rebuilt with acidresistant polymer concrete (Polycrete ${ }^{\circledR}$ ) and a new emergency spillway was excavated into the native bedrock. Also, the embankment was raised to a crest elevation of $486 \mathrm{ft}$ (148.1 m) (mean sea level) and the downstream slope was flattened using spoil from the emergency spillway. The original spillway was undersized and the embankment unstable, allowing seepage to develop during the years since original construction. These deficiencies and the threat of a catastrophic release of acidic water from the lake prompted IDNR to fund the reconstruction effort. The normal pool elevation of Augusta Lake after reconstruction is $479 \mathrm{ft}$ (146 m) (mean sea level).

Future reclamation plans for the Augusta Lake subwatershed have been prepared by the IDNRDOR to eliminate remaining public safety hazards and to further improve the quality of surface water in Augusta Lake and Mill Creek. As part of the current mining operations by Triad, the old highwalls immediately west of Augusta Lake along County Road 450 were eliminated and five finalcut impoundments were backfilled (fig. 5). A stream, which discharges into the southwestern tributary of the lake, was constructed along these backfilled impoundments. Future plans include the construction of a new passive treatment system that will intercept AMD flowing from the northeast drainage area and divert it through a sulfate-reducing bioreactor into a wetland (fig. 5). Treated effluent exiting the wetland will flow westward and enter the southwestern tributary of Augusta Lake (fig. 5). The preliminary plans call 


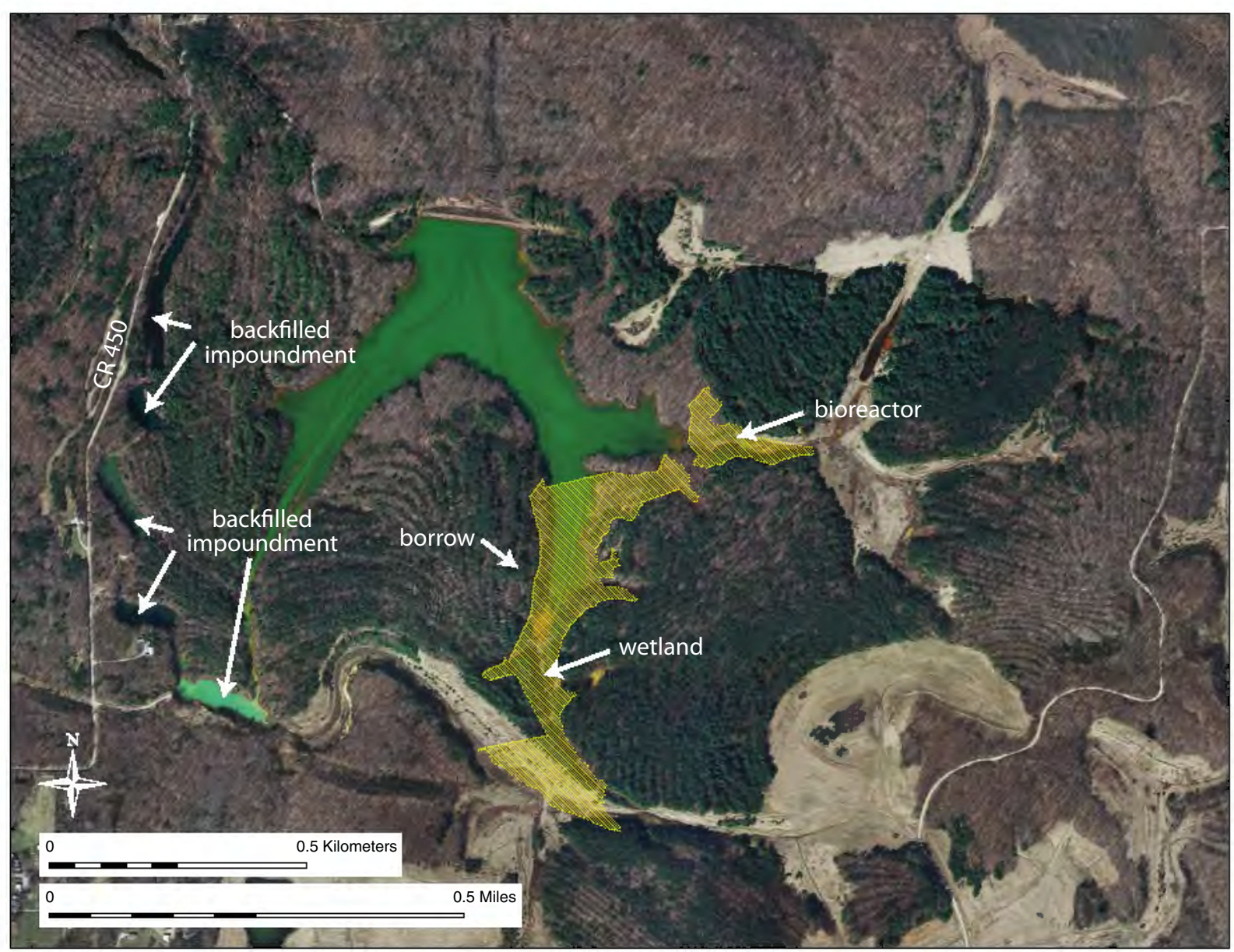

Figure 5. Orthophoto of Augusta Lake showing impoundments that have been backfilled and preliminary future construction sites for a sulfate-reducing bioreactor and wetland.

for the borrow material required for construction of the new passive treatment system to be taken from a location west of the southeastern tributary adjacent to the proposed wetland (fig. 5). The Indiana Department of Natural Resources will use funds from the Indiana Abandoned Mine Land Program to pay for the new construction. Design plans will be finalized by the IDNR, Division of Reclamation (DOR) and construction is anticipated to begin in 2014.

\section{DATA AND METHODS}

The primary sources of water-quality data from the Augusta Lake-Mill Creek watershed are the reports by ATEC (1984), the Indiana Geological Survey (IGS) (Comer and others, 2000), and the IDNR (M. A. Stacy, IDNR-DOR, written commun., 2008). The water-quality and hydrologic data for
Augusta Lake and its tributaries and for Mill Creek compiled by ATEC (1984) and Renn (1989) for the period from 1949 to 1985 are tabulated in Appendix A (on CD-ROM), water-quality data collected during monitoring in 1997 and 1998 (Comer and others, 2000) are presented in Appendix B (on CD$\mathrm{ROM})$, and water-quality data from monitoring at the Augusta Lake spillway by the IDNR-DOR, during the period from 1999 to 2008 (M.A. Stacy, IDNR-DOR, written commun., 2008) are tabulated in Appendix C (on CD-ROM). All these data are reproduced in an Excel spreadsheet on the CD-ROM that accompanies this volume. Some information about the methods of analysis is given in the ATEC report (1984) and detailed information about analytical methods and quality assurance is presented in the IGS report (Comer and others, 2000).

The data reported in Appendix A include the sample location, site identification number as listed in the original source, date when the water was collected, 
flow in liters per second (Lps), water temperature when collected, specific conductance $(\mathrm{SpC}), \mathrm{pH}$ measured in the field, $\mathrm{pH}$ measured in the laboratory, total dissolved solids (TDS), total suspended solids (TSS), acidity, alkalinity, the concentrations of chloride $(\mathrm{Cl})$, sulfate $\left(\mathrm{SO}_{4}\right)$, calcium $(\mathrm{Ca})$, magnesium $(\mathrm{Mg})$, sodium $(\mathrm{Na})$, total iron $(\mathrm{Fe})$, and manganese $(\mathrm{Mn})$, and a numbered note identifying the original source of the data. The locations of monitoring sites reported in Appendix A are shown in Figure 4. Flow rates published in previous studies, which were variously reported in units of gallons per minute (gpm), gallons per day (gpd), or cubic feet per second (cfs), have all been converted and are reported as liters per second in Appendix A. Concentrations of acidity and alkalinity were originally reported in units of milligrams per liter $(\mathrm{mg} / \mathrm{L})$. Concentrations of other components (TDS, TSS, $\mathrm{Cl}, \mathrm{SO}_{4^{\prime}} \mathrm{Ca}, \mathrm{Mg}$, Na, $\mathrm{Fe}, \mathrm{Mn}$ ), which were originally reported in parts per million (ppm), are reported in $\mathrm{mg} / \mathrm{L}$ in Appendix A. The conversion was accomplished using the relationship ppm $x$ density $\left(\mathrm{g} / \mathrm{cm}^{3}\right)=\mathrm{mg} / \mathrm{L}$, where density was calculated using the TDS and temperature of the water sample. For the 25 water samples that reported no values for temperature or TDS, the missing values were estimated based on values recorded at the monitoring site during the same season and with similar flow rates. For most of the water samples reported here, there is no significant difference between the numerical values for $\mathrm{ppm}$ and $\mathrm{mg} / \mathrm{L}$. Concentrations of chemical components that are reported as $0 \mathrm{mg} / \mathrm{L}$ in Appendix A faithfully represent the values recorded in the original data source (ATEC, 1984). However, it should be noted that components in aqueous solution that are not detected during an analysis are conventionally reported as less than the detection limit of the analytical method. Because detection limits were not provided in the original data source, concentrations reported as $0 \mathrm{mg} / \mathrm{L}$ were not amended.

The data reported in Appendix B is divided into four tables containing field data, acidity and anion data, cation and minor element data, and calculated data. Each table contains the sample site identification number and the sampling date, which together uniquely identify the water sample. The locations of monitoring sites are shown in Figure 4. Specific data include the following: Table B1 in Appendix B contains temperature of the water when collected, specific conductance $(\mathrm{SpC})$, turbidity, salinity, dissolved oxygen (DO), oxidationreduction potential (Eh), field $\mathrm{pH}$, and alkalinity; Table B2 in Appendix B contains acidity, and the concentrations of bicarbonate $\left(\mathrm{HCO}_{3}\right)$, carbonate $\left(\mathrm{CO}_{3}\right)$, chloride $(\mathrm{Cl})$, nitrate $\left(\mathrm{NO}_{3}\right)$, and sulfate $\left(\mathrm{SO}_{4}\right)$; Table B3 in Appendix B contains the concentrations of calcium $(\mathrm{Ca})$, magnesium $(\mathrm{Mg})$, potassium $(\mathrm{K})$, sodium $(\mathrm{Na})$, total iron $(\mathrm{Fe}(\mathrm{tot}))$, ferrous iron $\left(\mathrm{Fe}^{+2}\right)$, manganese $(\mathrm{Mn})$, zinc $(\mathrm{Zn})$, nickel $(\mathrm{Ni})$, strontium (Sr), barium (Ba), aluminum ( $\mathrm{Al})$, silicon $(\mathrm{Si})$, and copper $(\mathrm{Cu})$; Table B4 in Appendix B contains total dissolved solids, anion sum, cation sum, and the charge balance in equivalents per million (EPM balance). Total dissolved solids were calculated by adding the mass in milligrams (mg) contributed by each constituent analyzed. The anion and cation sums are the algebraic sum of negatively and positively charged ions, respectively, in terms of milliequivalents per liter (meq/L). The EPM balance was computed as the percent difference between the anion and cation sums and represents the net ionic charge for a water sample. The EPM balance is an indication of the overall validity of the chemical analysis, and values within the range of \pm 10 percent are considered acceptable. An EPM balance of 0.0 percent represents the perfect equality between anions and cations and is the theoretical value for all natural water samples. Less than 5 percent of the data in Appendix B had EPM balances outside the \pm 10 percent range.

The data reported in Appendix $\mathrm{C}$ are for the monitoring at the Augusta Lake spillway from 1999 to 2008 (M. A. Stacy, IDNR-DOR, written commun., 2008) and include the sample location description, site identification number (Site ID), sampling date, $\mathrm{pH}$ measured in the laboratory, TDS, acidity, alkalinity, and concentrations of sulfate $\left(\mathrm{SO}_{4}\right)$, total iron $(\mathrm{Fe})$, manganese $(\mathrm{Mn})$, and aluminum (Al). Some of the values listed in Appendix $C$ were modified from those in the original IDNR data set so that they are consistent with the accuracy of the analytical methods and conform to the rules for significant digits. The location of the monitoring site for these data (1302A) is essentially the same as the location of monitoring site W-20 shown in Figure 4. Statistical analysis of the data includes the range, mean, and standard deviation of values for various measurements over time. These statistics are sufficient to document changes in water quality that have taken place during nearly six decades of monitoring in the study area. It should be noted that the mean and standard deviation for $\mathrm{pH}$ cannot be computed directly by adding or subtracting the measured values because $\mathrm{pH}$ is an exponent $\left(\mathrm{pH}=-\log \left[\mathrm{H}^{+}\right]\right)$. The mean and standard deviation of a population of $\mathrm{pH}$ values must be considered and computed from the hydrogen ion activity $\left[\mathrm{H}^{+}\right]$. 
Thus, the mean and standard deviation for $\mathrm{pH}$ values of $2.8,4.2$, and 3.0 is not $3.3 \pm 0.76$, rather the mean $\mathrm{pH}$ is $3.1\left(-\log \left[\mathrm{H}^{+}{ }_{\text {mean }}\right]\right)$ with a $1 \sigma$ range from $2.8\left(-\log \left[\mathrm{H}_{\text {mean }}^{+}+\mathrm{H}_{10}^{+}\right]\right)$to $3.9\left(-\log \left[\mathrm{H}_{\text {mean }}^{+}-\mathrm{H}_{10}^{+}\right]\right)$. In many cases, the data reported here give statistical ranges for hydrogen ion activity that are below zero on the low end, which is theoretically impossible. Since the logarithm of a negative number does not exist, no $\mathrm{pH}$ value can be given for a negative hydrogen ion activity. Because of these issues, the mean and standard deviation for $\mathrm{pH}$ are presented and discussed in terms of hydrogen ion activity in this report.

\section{DATA ANALYSIS AND INTERPRETATION}

\section{Hydrology}

Discharge in Mill Creek and from the Augusta Lake spillway is summarized in Table 1 and illustrated in Figure 6. Flow data for Mill Creek at S.R. 364 have been compiled in Appendix A for the period from 1949 through 1985 (ATEC, 1984; Renn, 1989) and discharge from the Augusta Lake spillway has been compiled in Appendix A for the period from
1951 through 1984 (ATEC, 1984). Flow recorded for Mill Creek was highly variable (fig. 6A), with a minimum discharge of 0 Lps during winter freeze conditions in January 1978 and January 1979 and during very dry conditions in September 1978 and May 1979, a maximum discharge of 2,550 Lps during intense rainfall in March 1977, and a mean discharge of 120 Lps (Table 1; Appendix A). Flow from the Augusta Lake spillway was less variable than in Mill Creek (fig. 6B), with a minimum lake discharge of 7.6 Lps in October 1964, a maximum lake discharge of 297 Lps in April 1984, and a mean lake discharge of 69 Lps (Table 1; Appendix A). Flow data collected on the same day for Mill Creek and the Augusta Lake spillway (fig. 6C) show that discharge in Mill Creek is consistently higher and more variable than discharge from Augusta Lake, reflecting the larger drainage area of Mill Creek and reduction of the amplitude of discharge from the upper part of the watershed because of the presence of the Augusta Lake dam.

Discharge data for nine of the most prominent tributaries that flow into Augusta Lake are reported in Appendix A, summarized in Table 1, and illustrated in Figure 7. The data show that discharge

Table 1. Discharge statistics for the Mill Creek-Augusta Lake watershed based on the data in Appendix A (ATEC, 1984)

[The symbol $1 \sigma$ refers to the standard deviation and $\mathrm{n}$ refers to the number of measurements taken at a monitoring site. Monitoring sites are indicated by the site number and their locations are plotted on the orthophoto in Figure 4. Site W-21 includes all discharge data for Mill Creek at S.R. 364, site W-20 includes all discharge data for the Augusta Lake spillway, and the remaining sites are where the major tributaries and seeps discharge into Augusta Lake.]

\begin{tabular}{|c|c|c|c|c|c|}
\hline $\begin{array}{c}\text { Site } \\
\text { number }\end{array}$ & $\begin{array}{c}\text { Minimum } \\
(\text { Lps })\end{array}$ & $\begin{array}{c}\text { Maximum } \\
(\text { Lps) }\end{array}$ & $\begin{array}{c}\text { Mean } \\
(\text { Lps })\end{array}$ & $\begin{array}{c}1 \sigma \\
(\mathbf{L p s})\end{array}$ & $\mathbf{n}$ \\
\hline W-21 & 0 & 2,550 & 120 & 284 & 86 \\
\hline W-20 & 7.6 & 297 & 69 & 63 & 22 \\
\hline W-3 & 8.5 & 37 & 22 & 11 & 5 \\
\hline W-5 & 1 & 46 & 15 & 21 & 4 \\
\hline W-7 & 0.6 & 16 & 8.8 & 11 & 2 \\
\hline W11 & 24 & 50 & 38 & 11 & 5 \\
\hline W18 & 0 & 0.6 & 0.3 & 0.3 & 4 \\
\hline W-26 & 1 & 6.9 & 4 & 3 & 4 \\
\hline W-28 & 3 & 11 & 6 & 4 & 4 \\
\hline W-37 & 0.6 & 1 & 0.6 & 0.3 & 4 \\
\hline W-38 & 0.3 & 0.9 & 0.5 & 0.3 & 4 \\
\hline
\end{tabular}




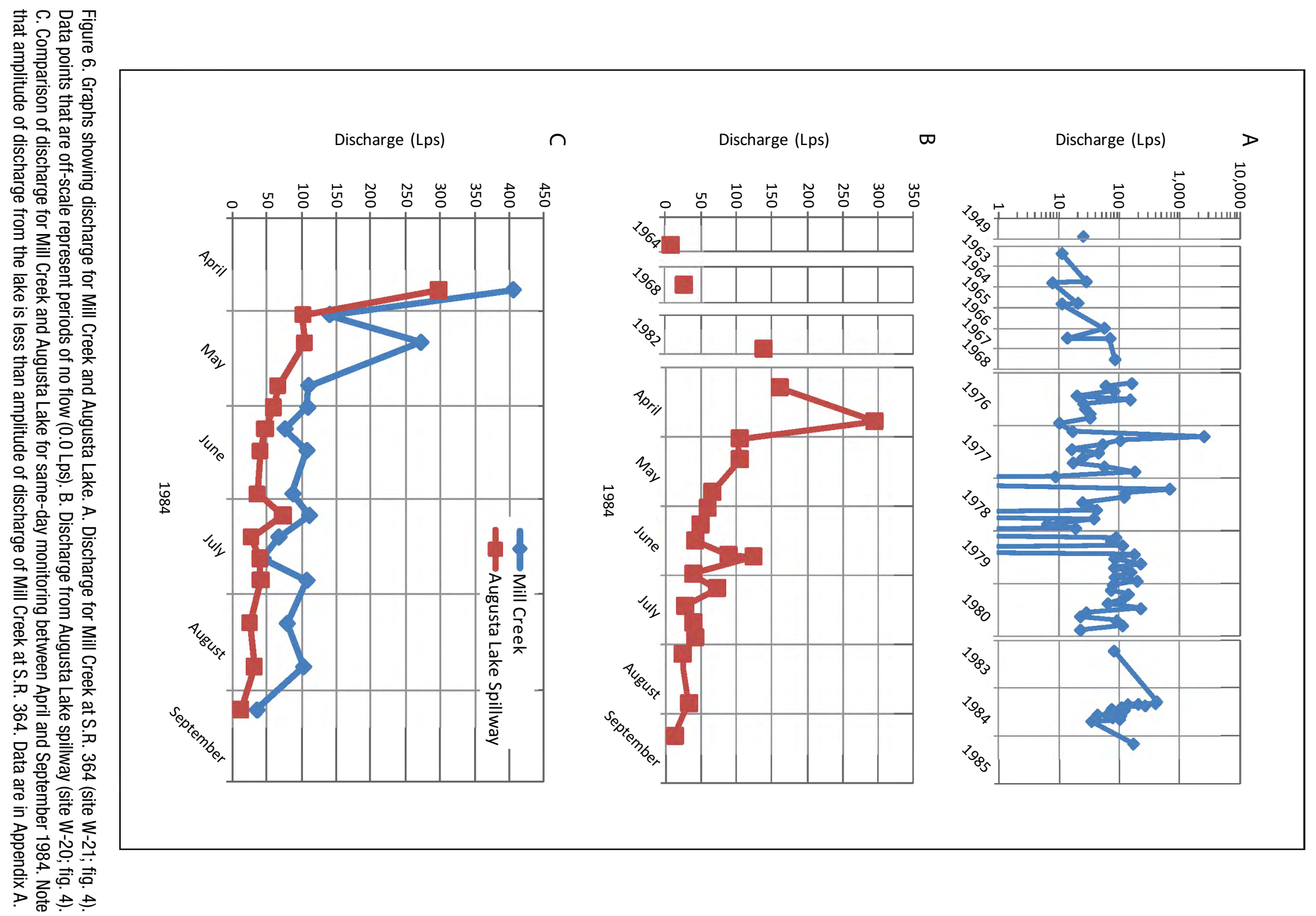


at these sites generally declined from April to September 1984 (fig. 7A) and the decline corresponded to the transition from seasonally wet spring conditions to dry summer conditions. The more frequently collected data from the lake spillway (site W-20) clearly show the effects on lake discharge that resulted from spring rains in April and storms in June and July (fig. 7A; Appendix A). The order of decreasing mean flow from the tributaries, based on the data in Table 1, is as follows: 1) The northeast drainage (monitoring site $W-11$ ) discharged at a maximum rate of $50 \mathrm{Lps}$, a minimum rate of $24 \mathrm{Lps}$, and a mean rate of $38 \mathrm{Lps}$; 2 ) the south tributary (monitoring site $\mathrm{W}-3$ ) discharged at a maximum rate of $37 \mathrm{Lps}$, a minimum rate of 8.5 Lps, and a mean rate of 22 Lps; 3) the southwest (SW) lake arm tributary (monitoring site $\mathrm{W}-5$ ) discharged at a maximum rate of $46 \mathrm{Lps}$, a minimum rate of $1 \mathrm{Lps}$, and a mean rate of $15 \mathrm{Lps}$; 4 ) the southwest final-cut tributary (monitoring site $\mathrm{W}-7$ ) discharged at a maximum rate of $16 \mathrm{Lps}$, a minimum rate of $0.6 \mathrm{Lps}$, and a mean rate of $8.8 \mathrm{Lps}$; 5) the northwest tributary (monitoring site W-28) discharged at a maximum rate of 11 Lps, a minimum rate of $3 \mathrm{Lps}$, and a mean rate of $6 \mathrm{Lps} ; 6$ ) the southeast (SE) lake arm tributary (monitoring site W-26) discharged at a maximum rate of $6.9 \mathrm{Lps}$, a minimum rate of $1 \mathrm{Lps}$, and a mean rate of $4 \mathrm{Lps} ; 7$ ) the west seep along the southeast (SE) lake arm tributary (monitoring site W-37) discharged at a maximum rate of $1 \mathrm{Lps}$, a minimum rate of $0.6 \mathrm{Lps}$, and a mean rate of $0.6 \mathrm{Lps}$; 8 ) the east seep along the southeast (SE) lake arm tributary (monitoring site W-38) discharged at a maximum rate of 0.9 Lps, a minimum rate of $0.3 \mathrm{Lps}$, and a mean rate of 0.5 Lps; and 9) the northeast tributary (monitoring site $\mathrm{W}-18$ ) discharged at a maximum rate of $0.6 \mathrm{Lps}$, a minimum rate of $0 \mathrm{Lps}$, and a mean rate of 0.3 Lps. The data clearly show that the greatest flows come from the northeast drainage through site W-11 (fig. 7B).

The percent of discharge illustrated in Figure 7C was computed using the flow from the Augusta Lake spillway (site W-20) for data collected on May 25, 1984 (ATEC, 1984). On this date, discharge from the nine tributaries totaled 150 percent of the discharge from the spillway and reflected losses of water from the lake owing to low flow through the emergency spillway (drop inlet) at the east end of the dam, seepage through the dam, seepage into the groundwater system, and errors in flow measurements (ATEC, 1984). The estimated flow percentages suggest that the northeast drainage may account for roughly 70 percent of the total discharge into Augusta Lake (fig. 7C). These data guided the intensive reclamation efforts that were implemented in the northeastern drainage during the 1990s.

\section{Water quality}

\section{Northeast drainage}

In 1992 prior to construction of the staged passive treatment system in the northeast drainage, preconstruction monitoring of the eight major AMD seeps (fig. 4) documented ranges for $\mathrm{pH}$ from 2.2$6.0($ mean $=2.8)$, acidity from $35-1,060 \mathrm{mg} / \mathrm{L}$ (mean $=330 \pm 280 \mathrm{mg} / \mathrm{L})$, TDS concentration from 156-636 $\mathrm{mg} / \mathrm{L}($ mean $=350 \pm 154 \mathrm{mg} / \mathrm{L})$, sulfate concentration from $61-241 \mathrm{mg} / \mathrm{L}($ mean $=110 \pm 58 \mathrm{mg} / \mathrm{L})$, total iron concentration from $2.8-319 \mathrm{mg} / \mathrm{L}$ (mean $=160 \pm 100$ $\mathrm{mg} / \mathrm{L}$ ), ferrous iron from $1.9-268 \mathrm{mg} / \mathrm{L}$ (mean = $140 \pm 86 \mathrm{mg} / \mathrm{L}$ ), manganese concentration from $26-$ $72 \mathrm{mg} / \mathrm{L}$ (mean $=49 \pm 14 \mathrm{mg} / \mathrm{L}$ ), and aluminum concentration from $2.3-216 \mathrm{mg} / \mathrm{L}($ mean $=34 \pm 52 \mathrm{mg} / \mathrm{L})$ (Ryu, 1997).

All the preconstruction monitoring sites were significantly disturbed or destroyed during construction of the staged passive treatment system that began in 1993. Consequently, the postconstruction monitoring sites, marked by yellow triangles in Figure 4, do not coincide with the preconstruction monitoring sites described by Ryu (1997). The locations of postconstruction monitoring sites were selected to document the effect on water quality of individual passive treatment elements as AMD from the various areas of seepage flowed through the staged passive treatment system. Locations of the postconstruction monitoring sites are described as follows: Site 1 is located at the outflow of the northeasternmost pond constructed in the staged passive treatment system; site 2 is located at the outflow of the last pond constructed along the northeastern tributary downstream from site 1; site 3 is located in the wetland at the downstream end of the eastern tributary; site 4 is located at the outflow of a pond constructed downstream from the confluence of the easternmost and southeasternmost tributaries; site 5 is located at the outflow of the southeasternmost pond constructed upstream from site 4; site 6 is located at the upstream head of the westernmost pond constructed downstream from sites 1-5; site SAPS is located northwest of the surface outflow from the westernmost 

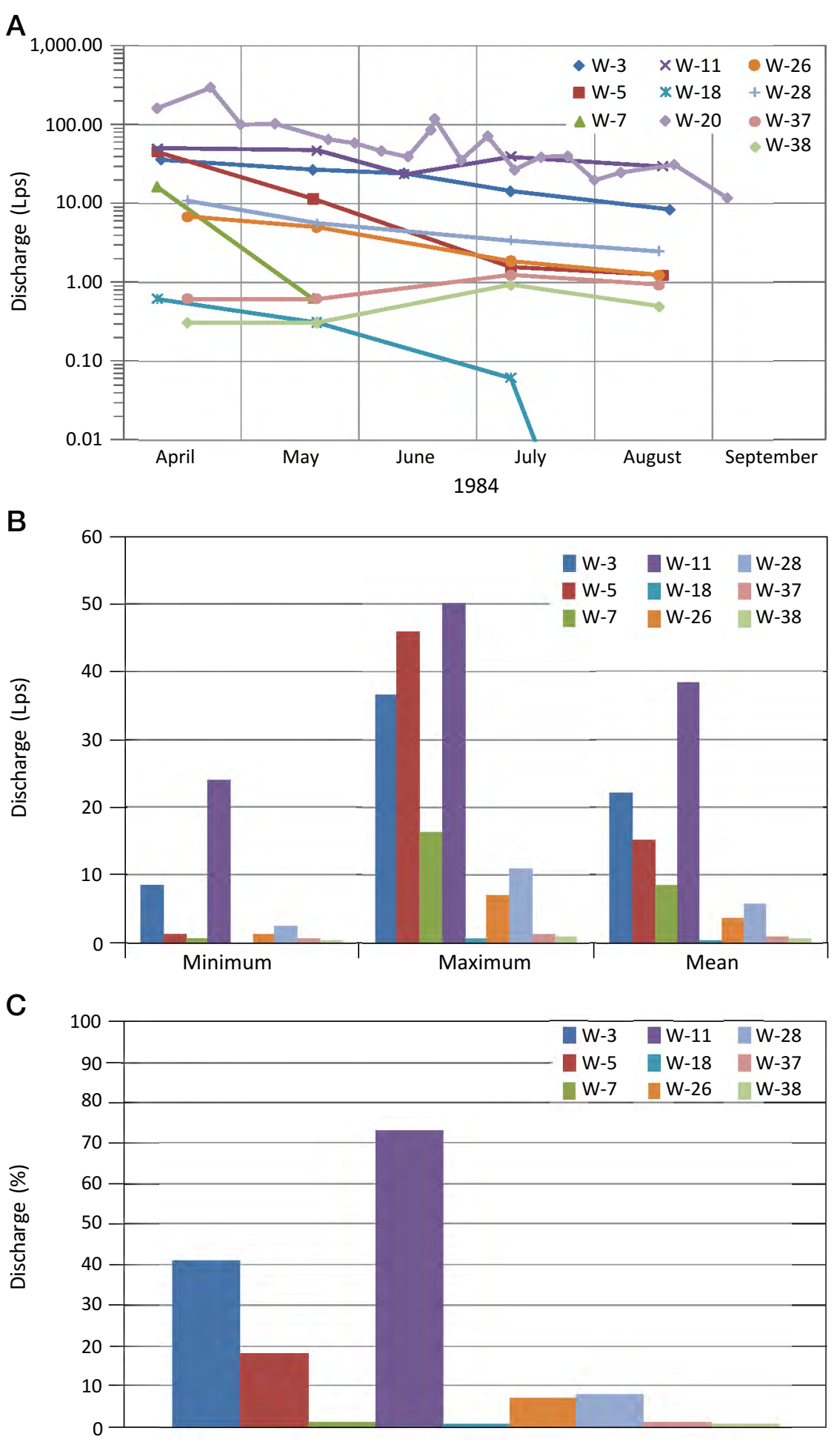

Figure 7. Graphs showing discharge from Augusta Lake spillway (site W-20) and from the nine major tributaries that flow into the lake. Locations of the monitoring sites are shown in Figure 4. A. Discharge in liters per second (Lps). B. Minimum, maximum, and mean discharge (Lps) for each of the nine tributaries. C. Percent of total discharge entering Augusta Lake based on gauging at the lake spillway and the nine tributaries on May 25, 1984 (ATEC, 1984). The greatest discharge of surface water into Augusta Lake is from the northeast drainage through site $\mathrm{W}-11$. 
pond and represents the vertical standpipe that carries outflow from the SAPS buried under the westernmost pond; site 7 is located at the western end of the staged passive treatment system and represents the combined outflow from the northeast drainage.

Postconstruction monitoring occurred from 1997 through 1998 (Comer and others, 2000) and these data are tabulated in Appendix B, summarized in Table 2, and illustrated graphically in Figure 8. The data show that surface water at sites 1-6 was consistently acidic, with $\mathrm{pH}$ values ranging from a low of 2.3 at site 4 to a high of 6.5 at site 5; the lowest mean $\mathrm{pH}$ was 3.0 at site 1 and the highest mean $\mathrm{pH}$ was 4.2 at sites 3 and 5 (Table 2). The highest $\mathrm{pH}$ values for sites 1 through 6 were recorded mostly in February and March during seasonally cool, wet conditions (Appendix B). Water flowing from the SAPS standpipe was alkaline, with $\mathrm{pH}$ values ranging from 10.3 to 12.4 and a mean $\mathrm{pH}$ of 10.8 (Table 2; fig. 8A). The highest $\mathrm{pH}$ values recorded at the SAPS discharge pipe were in April and May during warm spring conditions (Appendix B). Acidity concentrations (Table 2; fig. 8B) ranged from a low of $22 \mathrm{mg} / \mathrm{L}$ at site 5 to a high of 1,900 $\mathrm{mg} / \mathrm{L}$ at site 1 . The lowest mean acidity concentration was $130 \mathrm{mg} / \mathrm{L}$ at the SAPS discharge pipe and the highest mean acidity concentration was 730 at site 1 . The highest acidity concentrations were recorded in late summer and early fall during hot, dry conditions (Appendix B). Alkalinity was measured for most water samples having $\mathrm{pH}$ greater than 4.5. No alkalinity would have been detected and no measurements were attempted for water having $\mathrm{pH}$ less than 4.5 because the analytical method is based on titration to a $\mathrm{pH}$ endpoint of 4.5. For water samples having measurable alkalinity, values ranged from a low of $2 \mathrm{mg} / \mathrm{L}$ at site 3 to $1,600 \mathrm{mg} / \mathrm{L}$ at the SAPS discharge (Table 2; Appendix B).

Total dissolved solids and sulfate concentrations varied similarly at each monitoring site (fig. 8C-D). Total dissolved solids concentrations (Table 2; fig. 8C) ranged from a low of $490 \mathrm{mg} / \mathrm{L}$ at site 1 to a high of $4,300 \mathrm{mg} / \mathrm{L}$ at sites $1,3,4$, and SAPS (Table 2). The lowest mean TDS concentration was $2,800 \mathrm{mg} / \mathrm{L}$ at site 1 and the highest mean TDS concentration was 3,600 at sites 4 and 6 . Sulfate concentrations (Table 2; fig. 8D) ranged from a low of $308 \mathrm{mg} / \mathrm{L}$ at site 1 to a high of 3,000 mg/L at site 4 . The lowest mean sulfate concentration was $1,920 \mathrm{mg} / \mathrm{L}$ at site 1 and the highest mean sulfate concentration was 2,410 at site 4 . Total dissolved solids and sulfate concentrations at site SAPS were inversely related during the spring of 1997, with TDS increasing from $2,300 \mathrm{mg} / \mathrm{L}$ to $4,200 \mathrm{mg} / \mathrm{L}$ and sulfate falling from $2,190 \mathrm{mg} / \mathrm{L}$ to 1,980 mg/L between April 8 and June 19 (Appendix B). Decreasing sulfate coincident with increasing TDS indicates that sulfate was being removed in the successive alkalinity-producing system at increasing rates by bacterial sulfate-reduction stimulated by the seasonal rise in temperature.

The concentration of all the metals analyzed varied seasonally. Iron concentrations (Table 2; fig. $8 \mathrm{E})$ ranged from a low below the detection limit $(<1 \mathrm{mg} / \mathrm{L})$ at the SAPS discharge pipe and at site 3 to a high of $230 \mathrm{mg} / \mathrm{L}$ at site 1 . The lowest mean iron concentration was less than $1 \mathrm{mg} / \mathrm{L}$ at the SAPS discharge pipe and the highest mean iron concentration was $130 \mathrm{mg} / \mathrm{L}$ at site 2 . The highest iron concentrations for sites 1, 2, 4, 5, and 6 were recorded in February and March during cool, wet conditions and high iron concentrations were also recorded in July and September for sites 1, 2, and 3 during hot, dry conditions (Appendix B). Manganese concentrations (Table 2; fig. 8F) ranged from a low below the detection limit $(<0.1 \mathrm{mg} / \mathrm{L})$ at the SAPS discharge pipe to a high of $49 \mathrm{mg} / \mathrm{L}$ at sites 1 and 2 . The lowest mean manganese concentration was less than $0.1 \mathrm{mg} / \mathrm{L}$ at site SAPS and the highest mean manganese concentration was $41 \mathrm{mg} / \mathrm{L}$ at site 2 . The highest manganese concentrations were recorded mostly in July and September during hot, dry conditions (Appendix B). Aluminum concentrations (Table 2; fig. 8G) ranged from a low of less than $0.5 \mathrm{mg} / \mathrm{L}$ at all but two sites to a high of $76 \mathrm{mg} / \mathrm{L}$ at site 1 . The lowest mean aluminum concentration was $0.5 \mathrm{mg} / \mathrm{L}$ at site SAPS and the highest mean aluminum concentration was $41 \mathrm{mg} / \mathrm{L}$ at site 1 . The highest aluminum concentrations were recorded mostly in July and September during hot, dry conditions (Appendix B). Calcium concentrations (Table 2; fig. $8 \mathrm{H}$ ) ranged from a low of $69 \mathrm{mg} / \mathrm{L}$ at site 1 to a high of 1,400 $\mathrm{mg} / \mathrm{L}$ at site SAPS. The lowest mean calcium concentration was $340 \mathrm{mg} / \mathrm{L}$ at site 1 and the highest mean calcium concentration was $1,000 \mathrm{mg} / \mathrm{L}$ at site SAPS. The highest calcium concentrations for sites 1 through 6 were recorded mostly in July and August during hot, dry conditions and the highest calcium concentrations for site SAPS were recorded in the spring during warm, wet conditions (Appendix B). Magnesium concentrations (Table 2; fig. 8I) ranged from a low of less than $0.05 \mathrm{mg} / \mathrm{L}$ at 
Table 2. Water-quality statistics for seven monitoring sites in the northeast drainage

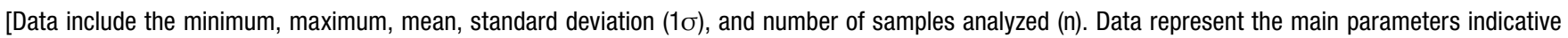
of AMD from AML sites and materials commonly used in reclamation construction (for example limestone); they include $\mathrm{pH}$, hydrogen ion activity (H), specific conductance ( $\mathrm{SpC}$ ), total dissolved solids (TDS), acidity, alkalinity, bicarbonate $\left(\mathrm{HCO}_{3}\right)$, sulfate $\left(\mathrm{SO}_{4}\right)$, iron ( $\left.\mathrm{Fe}\right)$, manganese (Mn), aluminum (Al), calcium (Ca), and magnesium (Mg). Based on data collected during monitoring in 1997 and 1998 (Appendix B). Locations of monitoring sites are shown in Figure 4 (yellow triangles). $N A=$ not analyzed.]

\begin{tabular}{|c|c|c|c|c|c|c|c|c|c|c|c|c|c|c|}
\hline $\begin{array}{c}\text { Site } \\
\text { number }\end{array}$ & Statistic & $\mathrm{pH}$ & $\begin{array}{c}\mathrm{H} \\
\text { activity }\end{array}$ & $\begin{array}{c}\mathrm{SpC} \\
(\mu \mathrm{mhos} / \\
\mathrm{cm})\end{array}$ & $\begin{array}{c}\text { TDS } \\
(\mathrm{mg} / \mathrm{L})\end{array}$ & $\begin{array}{l}\text { Acidity } \\
\text { (mg/L) }\end{array}$ & $\begin{array}{c}\text { Alkalinity } \\
\text { (mg/L) }\end{array}$ & $\begin{array}{l}\mathrm{HCO}_{3} \\
(\mathrm{mg} / \mathrm{L})\end{array}$ & $\begin{array}{c}\mathrm{SO}_{4} \\
(\mathrm{mg} / \mathrm{L})\end{array}$ & $\begin{array}{c}\mathrm{Fe} \\
(\mathrm{mg} / \mathrm{L})\end{array}$ & $\begin{array}{c}\mathrm{Mn} \\
(\mathrm{mg} / \mathrm{L})\end{array}$ & $\begin{array}{c}\mathrm{Al} \\
(\mathrm{mg} / \mathrm{L})\end{array}$ & $\begin{array}{c}\mathrm{Ca} \\
(\mathrm{mg} / \mathrm{L})\end{array}$ & $\begin{array}{c}\mathrm{Mg} \\
(\mathrm{mg} / \mathrm{L})\end{array}$ \\
\hline \multirow{5}{*}{1} & Minimum & 2.7 & $2.5 \mathrm{E}-02$ & 370 & 490 & 80 & NA & NA & 308 & 1 & 4.1 & 3.4 & 69 & 19 \\
\hline & Maximum & 4.6 & $1.9 \mathrm{E}+00$ & 4,180 & 4,300 & 1,900 & NA & $N A$ & 2,970 & 230 & 49 & 76 & 490 & 190 \\
\hline & Mean & 3.0 & $9.2 \mathrm{E}-01$ & 2,470 & 2,800 & 730 & NA & $N A$ & 1,920 & 73 & 31 & 41 & 340 & 120 \\
\hline & $1 \sigma$ & $\begin{array}{l}2.8- \\
3.6^{\star}\end{array}$ & $6.5 \mathrm{E}-01$ & 1,170 & 1,200 & 560 & NA & NA & 813 & 57 & 14 & 20 & 130 & 51 \\
\hline & $n$ & 17 & 17 & 17 & 17 & 15 & NA & NA & 17 & 17 & 17 & 17 & 17 & 17 \\
\hline \multirow{5}{*}{2} & Minimum & 2.7 & $8.3 \mathrm{E}-04$ & 1,630 & 2,400 & 270 & 24 & 29 & 1,220 & 81 & 27 & 1.6 & 340 & 140 \\
\hline & Maximum & 6.1 & $2.2 \mathrm{E}+00$ & 3,900 & 4,200 & 1,400 & 34 & 42 & 2,880 & 190 & 49 & 39 & 580 & 250 \\
\hline & Mean & 3.3 & $5.0 \mathrm{E}-01$ & 2,930 & 3,400 & 520 & 29 & 36 & 2,250 & 130 & 41 & 15 & 460 & 200 \\
\hline & $1 \sigma$ & $3.0-^{\star}$ & $5.8 \mathrm{E}-01$ & 710 & 580 & 260 & 7 & 9 & 480 & 29 & 6.5 & 9.3 & 71 & 32 \\
\hline & $n$ & 17 & 17 & 17 & 17 & 15 & 2 & 2 & 17 & 17 & 17 & 17 & 17 & 17 \\
\hline \multirow{5}{*}{3} & Minimum & 3.5 & $3.6 \mathrm{E}-04$ & 1,850 & 2,600 & 53 & 2 & 2 & 1,590 & $<1$ & 7.8 & $<0.5$ & 450 & 190 \\
\hline & Maximum & 6.4 & $2.9 \mathrm{E}-01$ & 4,000 & 4,300 & 450 & 130 & 160 & 2,900 & 110 & 32 & 6.7 & 610 & 310 \\
\hline & Mean & 4.2 & $6.1 \mathrm{E}-02$ & 2,700 & 3,500 & 140 & 36 & 44 & 2,300 & 15 & 25 & 1.1 & 520 & 240 \\
\hline & $1 \sigma$ & $3.8-^{\star}$ & $9.0 \mathrm{E}-02$ & 630 & 440 & 96 & 45 & 55 & 318 & 30 & 5.5 & 1.8 & 43 & 32 \\
\hline & $n$ & 14 & 14 & 14 & 14 & 14 & 7 & 7 & 14 & 14 & 14 & 14 & 14 & 14 \\
\hline \multirow{5}{*}{4} & Minimum & 2.3 & $1.2 \mathrm{E}-03$ & 1,930 & 3,100 & 130 & 3 & 3 & 2,090 & 11 & 31 & $<0.5$ & 440 & 190 \\
\hline & Maximum & 5.9 & $4.5 \mathrm{E}+00$ & 3,730 & 4,300 & 280 & 25 & 30 & 3,000 & 72 & 39 & 11 & 570 & 250 \\
\hline & Mean & 3.2 & $5.8 \mathrm{E}-01$ & 2,860 & 3,600 & 210 & 12 & 15 & 2,410 & 38 & 35 & 3.4 & 520 & 220 \\
\hline & $1 \sigma$ & $2.7-^{\star}$ & $1.2 \mathrm{E}+00$ & 600 & 280 & 44 & 8 & 10 & 228 & 22 & 2.4 & 2.6 & 35 & 18 \\
\hline & $n$ & 17 & 17 & 17 & 17 & 17 & 8 & 8 & 17 & 17 & 17 & 17 & 17 & 17 \\
\hline \multirow{5}{*}{5} & Minimum & 3.3 & $3.1 \mathrm{E}-04$ & 2,010 & 160 & 22 & 41 & 50 & 1,040 & 14 & 9.5 & $<0.5$ & 280 & 58 \\
\hline & Maximum & 6.5 & $5.4 \mathrm{E}-01$ & 3,420 & 3,900 & 560 & 150 & 180 & 2,600 & 65 & 38 & 33 & 590 & 250 \\
\hline & Mean & 4.2 & $6.0 \mathrm{E}-02$ & 2,780 & 3,300 & 210 & 110 & 130 & 2,170 & 36 & 21 & 4.4 & 510 & 210 \\
\hline & $1 \sigma$ & $3.7-^{\star}$ & $1.6 \mathrm{E}-01$ & 520 & 600 & 130 & 40 & 48 & 394 & 16 & 7.3 & 9.3 & 75 & 55 \\
\hline & $n$ & 17 & 17 & 17 & 17 & 17 & 12 & 12 & 17 & 17 & 17 & 17 & 17 & 17 \\
\hline \multirow{5}{*}{6} & Minimum & 3.0 & $3.8 \mathrm{E}-04$ & 1,920 & 2,400 & 210 & 11 & 13 & 1,660 & 30 & 24 & $<0.5$ & 340 & 140 \\
\hline & Maximum & 6.4 & $9.3 \mathrm{E}-01$ & 3,730 & 4,200 & 450 & 22 & 26 & 2,980 & 100 & 40 & 16 & 560 & 260 \\
\hline & Mean & 3.7 & $2.0 \mathrm{E}-01$ & 2,830 & 3,600 & 290 & 16 & 20 & 2,400 & 71 & 34 & 7.0 & 490 & 230 \\
\hline & $1 \sigma$ & $3.3-^{\star}$ & $2.8 \mathrm{E}-01$ & 520 & 430 & 70 & 5 & 5 & 317 & 22 & 3.8 & 4.4 & 54 & 28 \\
\hline & $n$ & 17 & 17 & 17 & 17 & 17 & 4 & 4 & 17 & 17 & 17 & 17 & 17 & 17 \\
\hline \multirow{5}{*}{ SAPS } & Minimum & 10.3 & $3.7 \mathrm{E}-10$ & 2,210 & 2,300 & 26 & 220 & 37 & 1,780 & $<1$ & $<0.1$ & $<0.5$ & 790 & $<0.05$ \\
\hline & Maximum & 12.4 & $5.5 \mathrm{E}-08$ & 7,940 & 4,300 & 180 & 1,600 & 95 & 2,190 & $<1$ & $<0.1$ & 0.8 & 1,400 & 140 \\
\hline & Mean & 10.8 & $1.6 \mathrm{E}-08$ & 3,770 & 3,400 & 130 & 680 & 72 & 2,020 & $<1$ & $<0.1$ & 0.5 & 1,000 & 31 \\
\hline & $1 \sigma$ & $10.4-^{\star}$ & $2.1 \mathrm{E}-08$ & 2,330 & 690 & 60 & 550 & 26 & 142 & NA & $N A$ & 0.3 & 240 & 61 \\
\hline & $\mathrm{n}$ & 6 & 6 & 6 & 6 & 6 & 6 & 4 & 6 & 5 & 5 & 5 & 5 & 5 \\
\hline
\end{tabular}

* Upper and lower pH limits (range) are derived from the mean and standard deviation $(1 \sigma)$ of the hydrogen ion activity $(\mathrm{H})$, where the lower pH limit = $-\log \left[\mathrm{H}_{\text {mean }}+\mathrm{H}_{1 \sigma}\right]$ and the upper $\mathrm{pH}$ limit $=-\log \left[\mathrm{H}_{\text {mean }}-\mathrm{H}_{1 \sigma}\right]$. Where no upper pH limit is recorded, the logarithm does not exist because $\left[\mathrm{H}_{\text {mean }}-\mathrm{H}_{1 \sigma}\right]$ is a negative number. 

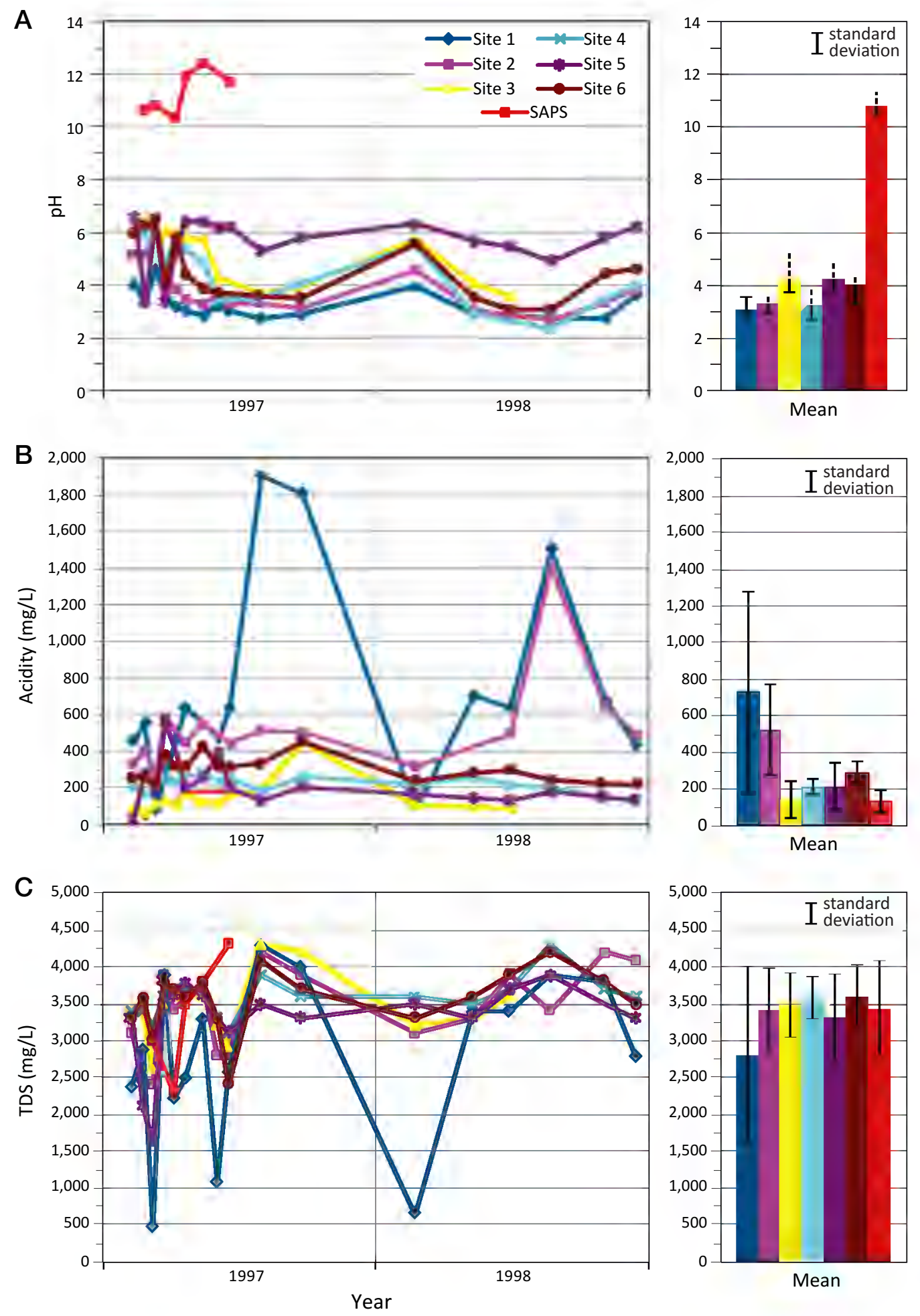

Figure 8. Graphs showing the water quality for monitoring sites 1-6 and SAPS in the northeast drainage of Augusta Lake. Means for each monitoring site are shown in the bar graph at the right. The location of monitoring sites is shown by the yellow triangles in Figure 4. A. pH. B. Acidity. C. Total dissolved solids (TDS). Data are tabulated in Appendix B. See Table 2 for statistical summary of the data. 


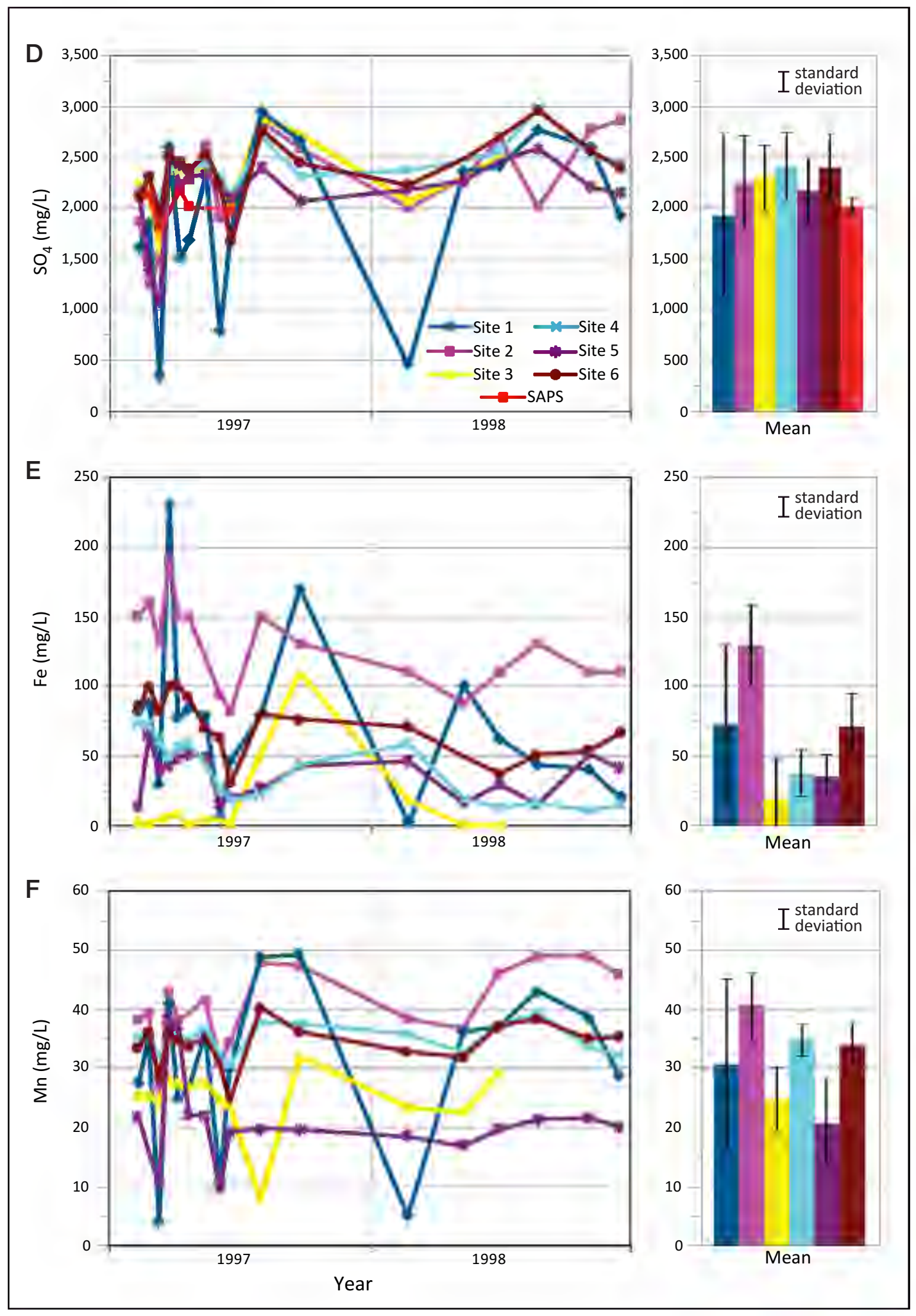

Figure 8 (cont.). Graphs showing the water quality for monitoring sites 1-6 and SAPS in the northeast drainage of Augusta Lake. Means for each monitoring site are shown in the bar graph at the right. The location of monitoring sites is shown by the yellow triangles in Figure 4. D. Sulfate $\left(\mathrm{SO}_{4}\right)$. E. Iron (Fe). F. Manganese (Mn). Data are tabulated in Appendix B. See Table 2 for statistical summary of the data. 




Figure 8 (cont.). Graphs showing the water quality for monitoring sites 1-6 and SAPS in the northeast drainage of Augusta Lake. Means for each monitoring site are shown in the bar graph at the right. The location of monitoring sites is shown by the yellow triangles in Figure 4. G. Aluminum (Al). H. Calcium (Ca), I. Magnesium (Mg). Data are tabulated in Appendix B. See Table 2 for statistical summary of the data. 
site SAPS to a high of $310 \mathrm{mg} / \mathrm{L}$ at site 3 . The lowest mean magnesium concentration was $31 \mathrm{mg} / \mathrm{L}$ at site SAPS and the highest mean magnesium concentration was $240 \mathrm{mg} / \mathrm{L}$ at site 3 . The highest magnesium concentrations for sites 1 through 6 were recorded mostly in the late summer during hot, dry conditions and the highest magnesium concentrations for site SAPS were recorded in the winter during cold, damp conditions (Appendix B).

The quality of water discharged from the northeast drainage into Augusta Lake was monitored at site W-11 during 1984 (ATEC, 1984), before construction of the staged passive treatment system, and at site 7 from 1997 through 1998 (Comer and others, 2000), after the staged passive treatment system was completed. The data are tabulated in Appendices A and B, summarized in Table 3, and illustrated in Figure 9. The data show that water quality varied significantly through time and that, on average, water quality of effluent from the northeast drainage improved after the staged passive treatment system was completed. Before construction, mean $\mathrm{pH}$ of the surface-water outflow was 3.1, with a range from 3.0 to 3.6; after construction, mean $\mathrm{pH}$ was 4.0 , with a range from 3.3 to 7.8 (Table 3; fig. 9A). The increase in mean $\mathrm{pH}$ from 3.1 to 4.0 represents a decrease in the hydrogen ion activity of 85 percent. Mean acidity before construction was $350 \mathrm{mg} / \mathrm{L}$, with a range of 314 $\mathrm{mg} / \mathrm{L}$ to $395 \mathrm{mg} / \mathrm{L}$; after construction, mean acidity was $160 \mathrm{mg} / \mathrm{L}$, with a range from 19 to $410 \mathrm{mg} / \mathrm{L}$ (Table 3; fig. 9B). High acidities correspond with low $\mathrm{pHs}$ and they consistently occur during hot, dry summer months (Appendices A and B). The large concentration range for data collected from 1997 through 1998 (Table 3; fig. 9A-B) may reflect incomplete mixing of acidic surface water which bypassed the SAPS and the highly alkaline water discharged from the SAPS standpipe. These two separate flows enter a marshy area immediately east of the lake through multiple small, ephemeral

Table 3. Water-quality statistics for discharge from the northeast drainage area

[Statistical parameters are the same as those in Table 2; water-quality parameters are the same as those in Table 2 except for aluminum (Al), which is not included because it was not analyzed during the 1984 monitoring. This tabulation includes statistics for all data (at top) and data for two subsequent monitoring periods. Based on data from monitoring site W-11 in Appendix A and monitoring site 7 in Appendix B. Location of monitoring sites is shown in Figure 4.]

\begin{tabular}{|c|c|c|c|c|c|c|c|c|c|c|c|c|c|}
\hline $\begin{array}{l}\text { Monitoring } \\
\text { dates }\end{array}$ & Statistic & $\mathrm{pH}$ & $\begin{array}{c}\mathrm{H} \\
\text { activity }\end{array}$ & $\begin{array}{c}\text { SpC } \\
(\mu \mathrm{mhos} / \\
\mathrm{cm})\end{array}$ & $\begin{array}{c}\text { TDS } \\
(\mathrm{mg} / \mathrm{L})\end{array}$ & $\begin{array}{l}\text { Acidity } \\
\text { (mg/L) }\end{array}$ & $\begin{array}{c}\text { Alklainity } \\
\text { (mg/L) }\end{array}$ & $\begin{array}{c}\mathrm{HCO}_{3} \\
(\mathrm{mg} / \mathrm{L})\end{array}$ & $\begin{array}{c}\mathrm{SO}_{4} \\
(\mathrm{mg} / \mathrm{L})\end{array}$ & $\begin{array}{c}\mathrm{Fe} \\
(\mathrm{mg} / \mathrm{L})\end{array}$ & $\begin{array}{c}\mathrm{Mn} \\
(\mathrm{mg} / \mathrm{L})\end{array}$ & $\begin{array}{c}\mathrm{Ca} \\
(\mathrm{mg} / \mathrm{L})\end{array}$ & $\begin{array}{c}\mathrm{Mg} \\
(\mathrm{mg} / \mathrm{L})\end{array}$ \\
\hline \multirow{5}{*}{$\begin{array}{l}\text { 1984-1998 } \\
\text { (all data) }\end{array}$} & Minimum & 3.0 & $1.5 \mathrm{E}-05$ & 2,030 & 3,100 & 19 & 0 & 0 & 2,070 & $<1$ & 0.1 & 450 & $<0.05$ \\
\hline & Maximum & 7.8 & $1.0 \mathrm{E}+00$ & 4,010 & 4,400 & 410 & 1,500 & 1,820 & 3,200 & 130 & 40 & 1,400 & 300 \\
\hline & Mean & 3.5 & $3.5 \mathrm{E}-01$ & 3,320 & 3,670 & 230 & 140 & 170 & 2,500 & 37 & 28 & 640 & 200 \\
\hline & $1 \sigma$ & $3.1-^{*}$ & $3.8 \mathrm{E}-01$ & 606 & 420 & 130 & 390 & 480 & 300 & 35 & 11 & 240 & 73 \\
\hline & $\mathrm{n}$ & 18 & 18 & 16 & 16 & 18 & 14 & 14 & 16 & 16 & 16 & 14 & 14 \\
\hline \multirow{5}{*}{1984} & Minimum & 3.0 & $2.5 \mathrm{E}-01$ & 2,475 & 3,500 & 314 & 0 & 0 & 2,200 & 47 & 31 & 450 & 240 \\
\hline & Maximum & 3.6 & $1.0 \mathrm{E}+00$ & 3,850 & 4,260 & 395 & 0 & 0 & 3,200 & 130 & 39 & 510 & 300 \\
\hline & Mean & 3.1 & $7.3 \mathrm{E}-01$ & 3,450 & 3,980 & 350 & 0 & 0 & 2,620 & 66 & 35 & 490 & 270 \\
\hline & $1 \sigma$ & $\begin{array}{l}3.0- \\
3.3^{\star}\end{array}$ & $2.6 \mathrm{E}-01$ & 560 & 310 & 35 & 0 & 0 & 363 & 36 & 4 & 32 & 31 \\
\hline & $\mathrm{n}$ & 7 & 7 & 5 & 5 & 6 & 6 & 6 & 5 & 5 & 5 & 3 & 3 \\
\hline \multirow{5}{*}{ 1997-1998 } & Minimum & 3.3 & $1.5 \mathrm{E}-05$ & 2,030 & 3,100 & 19 & 15 & 20 & 2,070 & $<1$ & 0.1 & 520 & $<0.05$ \\
\hline & Maximum & 7.8 & $5.5 \mathrm{E}-01$ & 4,010 & 4,400 & 410 & 1500 & 1820 & 2,870 & 78 & 40 & 1,400 & 260 \\
\hline & Mean & 4.0 & $1.1 \mathrm{E}-01$ & 3,260 & 3,500 & 160 & 240 & 290 & 2,450 & 23 & 25 & 690 & 190 \\
\hline & $1 \sigma$ & $3.5-^{\star}$ & $1.9 \mathrm{E}-01$ & 643 & 390 & 115 & 510 & 620 & 265 & 27 & 13 & 2,600 & 70 \\
\hline & $\mathrm{n}$ & 11 & 11 & 11 & 11 & 12 & 8 & 8 & 11 & 11 & 11 & 11 & 11 \\
\hline
\end{tabular}

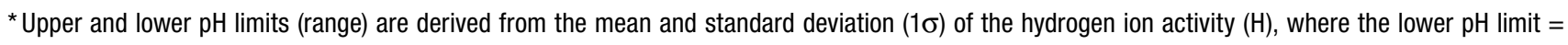
$-\log \left[\mathrm{H}_{\text {mean }}+\mathrm{H}_{1 \sigma}\right]$ and the upper pH limit $=-\log \left[\mathrm{H}_{\text {mean }}-\mathrm{H}_{1 \sigma}\right]$. Where no upper pH limit is recorded, the logarithm does not exist because $\left[\mathrm{H}_{\text {mean }}-\mathrm{H}_{\sigma}\right]$ is a negative number. 

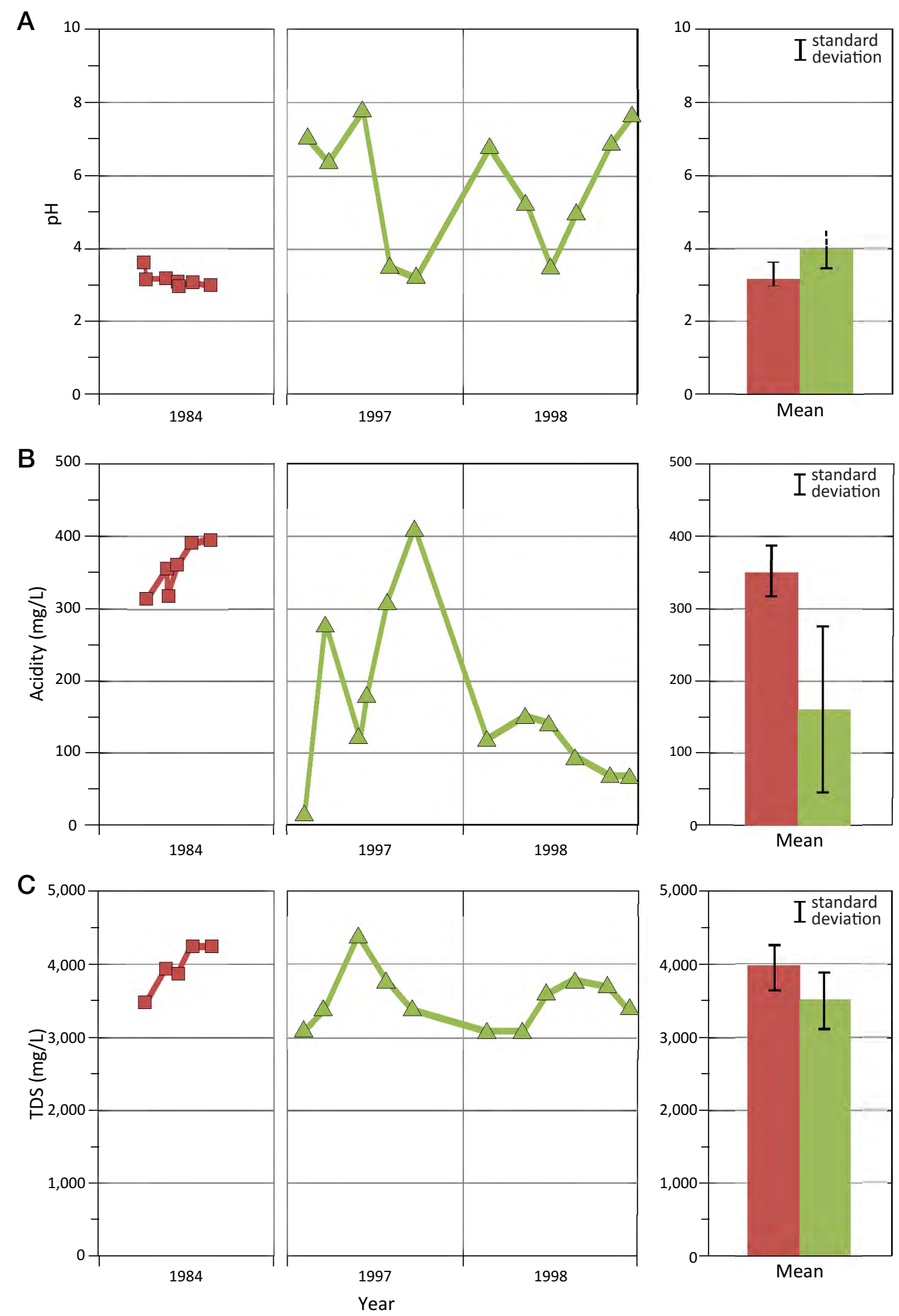

Figure 9. Graphs showing the quality of surface water discharged from the northeast drainage into Augusta Lake. Means for each monitoring period are shown in the bar graph at the right. Surface water samples were collected at site W-11 in 1984 and at site 7 in 1997-1998 (fig. 4). A. pH. B. Acidity. C. Total dissolved solids (TDS). Data are tabulated in Appendix A and B. See Table 3 for statistical summary of the data. 


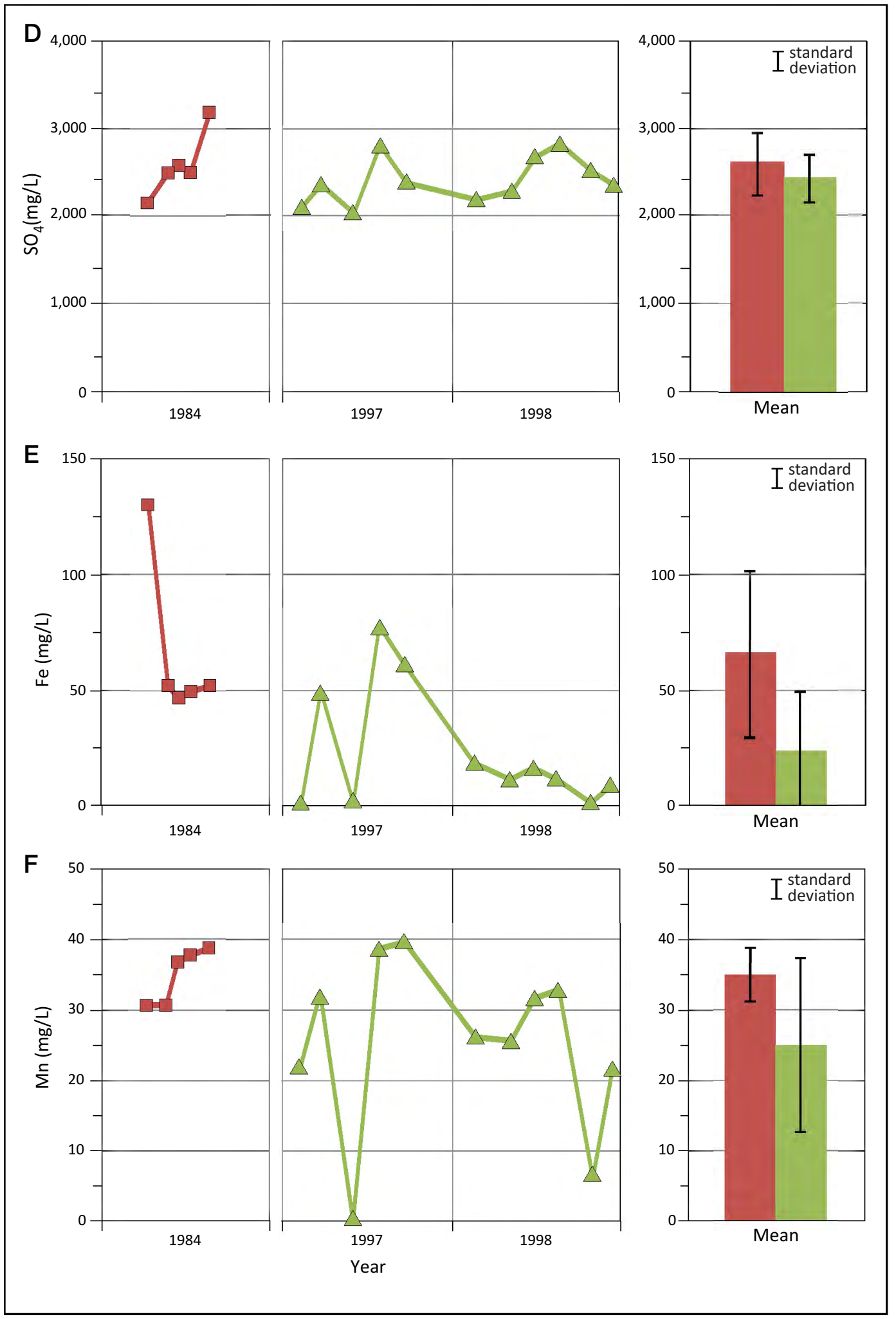

Figure 9 (cont.). Graphs showing the quality of surface water discharged from the northeast drainage into Augusta Lake. Means for each monitoring period are shown in the bar graph at the right. Surface water samples were collected at site W-11 in 1984 and at site 7 in 1997-1998 (fig. 4). D. Sulfate $\left(\mathrm{SO}_{4}\right)$. E. Iron (Fe). F. Manganese (Mn). Data are tabulated in Appendix A and B. See Table 3 for statistical summary of the data. 


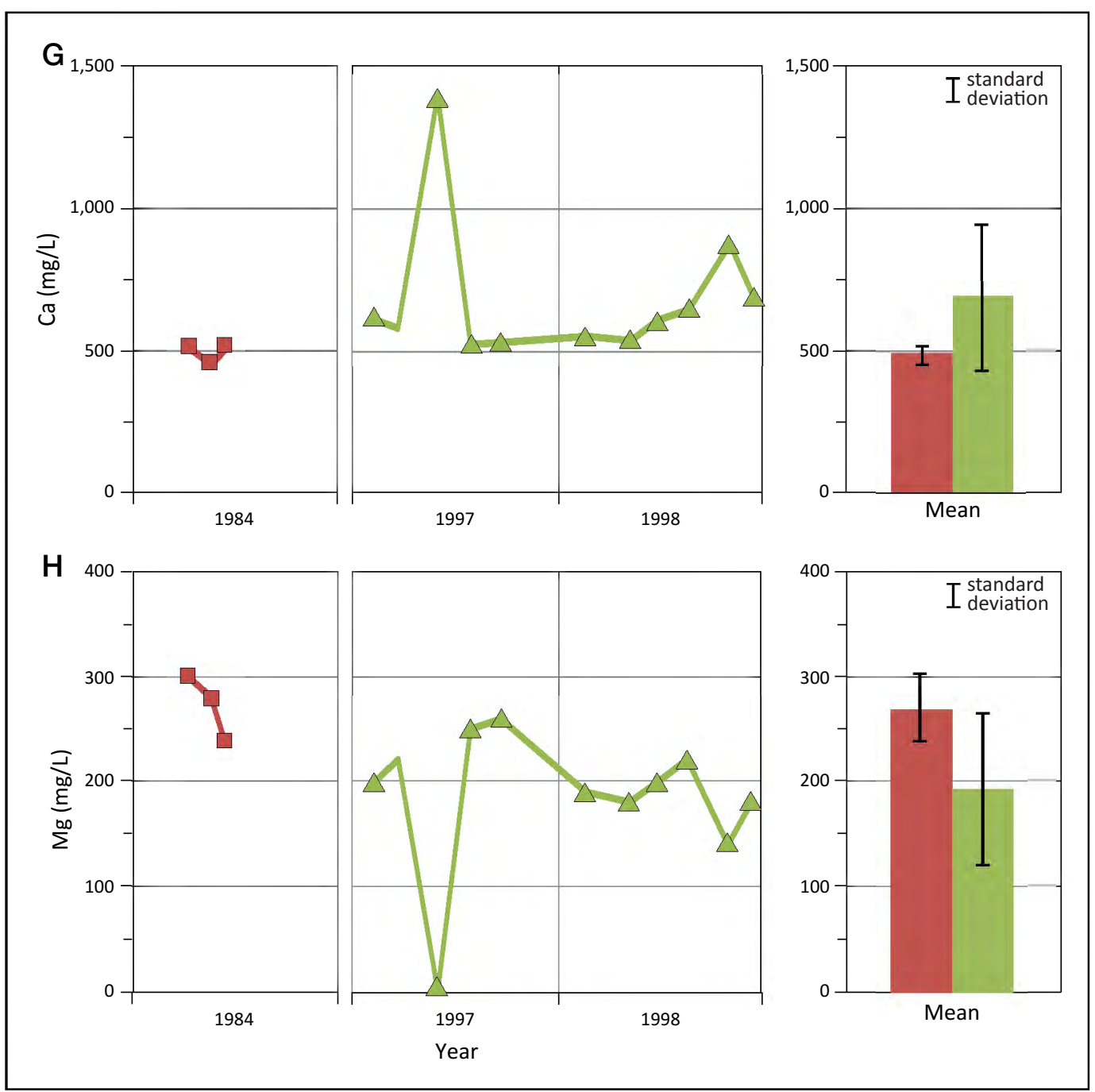

Figure 9 (cont.). Graphs showing the quality of surface water discharged from the northeast drainage into Augusta Lake. Means for each monitoring period are shown in the bar graph at the right. Surface water samples were collected at site W-11 in 1984 and at site 7 in 1997-1998 (fig. 4). G. Calcium (Ca), H. Magnesium (Mg). Data are tabulated in Appendix A and B. See Table 3 for statistical summary of the data.

rivulets and there is no well-defined channel in which mixing takes place.

Mean concentrations of TDS and sulfate decreased after the staged passive treatment system was constructed (Table 3; fig. 9C-D). Before construction, mean TDS concentration was $3,980 \mathrm{mg} / \mathrm{L}$, with a range of 3,500-4,260 mg/L; after construction, mean TDS concentration was $3,500 \mathrm{mg} / \mathrm{L}$, with a range of 3,100-4,400 mg/L (Table 3; fig. 9C). Before construction, mean sulfate concentration was $2,620 \mathrm{mg} / \mathrm{L}$, with a range of $2,200-3,200 \mathrm{mg} / \mathrm{L}$; after construction, mean sulfate concentration was $2,450 \mathrm{mg} / \mathrm{L}$, with a range of 2,070-2,870 mg/L (Table 3; fig. 9D). The data show that sulfate ions account for most of the dissolved solids in effluent from the northeast drainage. Total dissolved solids and sulfate concentrations vary seasonally and are consistently higher in warm, dry months (Appendices A and B).

Mean concentrations of the metals iron and manganese also decreased after the staged passive treatment system was constructed (Table 3; fig. $9 \mathrm{E}-\mathrm{F})$. Before construction, mean iron concentration was $66 \mathrm{mg} / \mathrm{L}$, with a range of $47-130 \mathrm{mg} / \mathrm{L}$; after construction, mean iron concentration was 23 $\mathrm{mg} / \mathrm{L}$, with a range of less than $1 \mathrm{mg} / \mathrm{L}$ (below the detection limit) to $78 \mathrm{mg} / \mathrm{L}$ (Table 3; fig. 9E). Before construction, mean manganese concentration was $35 \mathrm{mg} / \mathrm{L}$, with a range of 31-39 mg/L; after construction, mean manganese concentration was 25 $\mathrm{mg} / \mathrm{L}$, with a range of $0.1-40 \mathrm{mg} / \mathrm{L}$ (Table 3; fig. 9F). 
The monitoring data also show that calcium and magnesium are inversely related and that mean calcium concentration was generally higher after construction of the staged passive treatment system (Table 3; fig. 9G-H). Before construction, mean calcium concentration was $490 \mathrm{mg} / \mathrm{L}$, with a range of $450-510 \mathrm{mg} / \mathrm{L}$; after construction, mean calcium concentration was $690 \mathrm{mg} / \mathrm{L}$, with a range of 520 $1,400 \mathrm{mg} / \mathrm{L}$ (Table 3; fig. 9G). Before construction, mean magnesium concentration was $270 \mathrm{mg} / \mathrm{L}$, with a range of $240-300 \mathrm{mg} / \mathrm{L}$; after construction, mean magnesium concentration was $190 \mathrm{mg} / \mathrm{L}$, with a range of less than $0.05-260 \mathrm{mg} / \mathrm{L}$ (Table 3; fig. $9 \mathrm{H}$ ). These trends document the release of calcium as AMD percolated through the limestone used in the ALDs and SAPS of the staged passive treatment system. This observation is supported by the fact that alkalinity (reported as the equivalent of $\mathrm{CaCO}_{3}$ ) increased from $0 \mathrm{mg} / \mathrm{L}$ before construction to a mean of $240 \mathrm{mg} / \mathrm{L}$ (range, $15-1,500$ $\mathrm{mg} / \mathrm{L}$ ) after construction (Table 3). This corresponds to an increase in bicarbonate $\left(\mathrm{HCO}_{3}\right)$ concentration from $0 \mathrm{mg} / \mathrm{L}$ before construction to a mean of $290 \mathrm{mg} / \mathrm{L}$ (range, $20-1,820 \mathrm{mg} / \mathrm{L}$ ) after construction (Table 3).

It should be noted that the maximum concentrations recorded for calcium $(1,400 \mathrm{mg} / \mathrm{L})$, alkalinity $(1,500 \mathrm{mg} / \mathrm{L})$, and bicarbonate $(1,820 \mathrm{mg} / \mathrm{L})$ are unusually high and that all these high values, along with the highest $\mathrm{pH}(7.8)$ and the lowest magnesium concentration $(<0.05 \mathrm{mg} / \mathrm{L})$, occurred in the sample collected on June 4, 1997 (Appendix B). The values for calcium, magnesium, and alkalinity are comparable to those recorded for water flowing from the SAPS standpipe (site SAPS, Table 2, Appendix B) and indicate that there was minimal mixing of SAPS water with overland outflow from the northeast drainage at the time this sample was collected. The $\mathrm{pH}$ of this sample is significantly lower than the $\mathrm{pH}$ of SAPS water, most likely because of some minimal mixing with overland flow and reactions with the wetland sediment. Bicarbonate concentrations are low in SAPS water (Table 2$)$ because at high $\mathrm{pH}($ mean $=10.8)$ carbonate ions $\left(\mathrm{CO}_{3}^{2-}\right)$ predominate over bicarbonate ions $\left(\mathrm{HCO}_{3}^{-}\right)$in aqueous solutions. By reducing the $\mathrm{pH}$ to 7.8 , the chemical equilibrium will shift, causing bicarbonate to become the dominant carbonatebearing ion in solution.

\section{Augusta Lake}

Water-quality records for Augusta Lake from 1951, shortly after the dam was constructed, to April
2008 are included in Appendices A, B, and C. Highfrequency water-quality monitoring at the spillway was conducted by Ayrshire Collieries Corp. from 1951 to 1954 (Appendix A, numbered note 3), in 1984 for an environmental assessment (ATEC, 1984), from 1997 to 1998 for an evaluation of the staged passive treatment system (Appendix B) (Comer and others, 2000), and from 1999 to 2008 as part of the IDNR AML Program (Appendix C). Additional water-quality data were collected in 1968 to assess acid mine drainage problems (Corbett, 1969) and in 1982 for a coal mine permit application (ATEC, 1984) (Table 4, fig. 10). The data show that lake water remained acidic throughout its history, with a mean $\mathrm{pH}$ of 3.1, a minimum $\mathrm{pH}$ of 1.8, and a maximum $\mathrm{pH}$ of 6.3 (Table 4). The data also show that, on average, lake $\mathrm{pH}$ increased through time (fig. 10A). During the period from 1951-1968, water discharged from Augusta Lake had a mean $\mathrm{pH}$ of 2.8 , a minimum $\mathrm{pH}$ of 1.8 , and a maximum $\mathrm{pH}$ of 4.7; from 1982-1984, the mean $\mathrm{pH}$ was 3.1 , minimum $\mathrm{pH}$ was 2.7 , and maximum $\mathrm{pH}$ was 3.3; from 1997-1998, mean $\mathrm{pH}$ was 3.6, minimum $\mathrm{pH}$ was 3.1 , and maximum $\mathrm{pH}$ was 4.4 ; and from 1999-2008, mean $\mathrm{pH}$ was 3.8, minimum $\mathrm{pH}$ was 3.3 , and maximum $\mathrm{pH}$ was 6.3 (Table 4 ).

The cause of the three high-pH values in the modern data that occurred in January 2001, January 2002, and October 2006 (Appendix C) is unknown but may be related to the direct neutralization program that began in 1999, which involved discharging alkaline chemicals directly into surface water entering the lake and emplacement in ARTs and CARPs at a number of locations around the Augusta Lake subwatershed (Kalagian and Simmons, 2002). Between 1999 and 2001, approximately 844 metric tons of $\mathrm{Ca}(\mathrm{OH})_{2}, 48$ metric tons of $\mathrm{CaCO}_{3}, 9$ metric tons of $\mathrm{Na}_{2} \mathrm{CO}_{3}$, and $416 \mathrm{~L}$ of $\mathrm{NaOH}$ were distributed at more than 40 sites throughout the subwatershed (Kalagian and Simmons, 2002). The direct neutralization program continued until 2006 when the last ART was installed in the Augusta Lake subwatershed (W. McCoy, Patoka River National Wildlife Refuge, written commun., 2008). The periodic emplacement and episodic dissolution of these alkaline materials in the surface and groundwater could explain the observed spikes in $\mathrm{pH}$ during this time.

The 1951-2008 monitoring showed that water flowing from Augusta Lake mostly had high acidity, with a mean concentration of $190 \mathrm{mg} / \mathrm{L}$ and a concentration range from less than $10 \mathrm{mg} / \mathrm{L}$ (below the detection limit) to $710 \mathrm{mg} / \mathrm{L}$ (Table 4). The lake had 


\section{Table 4. Water-quality statistics for Augusta Lake}

[Statistical parameters are the same as those in Table 2; water-quality parameters are the same as those in Table 2 except for alkalinity and bicarbonate $\left(\mathrm{HCO}_{3}\right)$, which were not analyzed or not detected in all but four samples. This table includes statistics for all data (at top) and data for four subsequent monitoring periods. Based on data tabulated for Augusta Lake spillway in Appendix A, site 8 in Appendix B, and site 1302A in Appendix C. Location of the monitoring sites is shown in Figure 4; for the data in Appendix A and C, the location is designated "W-20" and for the data in Appendix $B$, the location is designated "8." NA = not analyzed.]

\begin{tabular}{|c|c|c|c|c|c|c|c|c|c|c|c|c|}
\hline $\begin{array}{c}\text { Monitoring } \\
\text { dates }\end{array}$ & Statistic & $\mathrm{pH}$ & $\begin{array}{c}\text { H } \\
\text { activity }\end{array}$ & $\begin{array}{l}\text { Acidity } \\
\text { (mg/L) }\end{array}$ & $\begin{array}{c}\mathrm{SpC} \\
(\mu \mathrm{mhos} / \mathrm{cm})\end{array}$ & $\begin{array}{c}\text { TDS } \\
(\mathrm{mg} / \mathrm{L})\end{array}$ & $\begin{array}{c}\mathrm{SO}_{4} \\
(\mathrm{mg} / \mathrm{L})\end{array}$ & $\begin{array}{c}\mathrm{Fe} \\
(\mathrm{mg} / \mathrm{L})\end{array}$ & $\begin{array}{c}\mathrm{Mn} \\
(\mathrm{mg} / \mathrm{L})\end{array}$ & $\begin{array}{c}\mathrm{Al} \\
(\mathrm{mg} / \mathrm{L})\end{array}$ & $\begin{array}{c}\mathrm{Ca} \\
(\mathrm{mg} / \mathrm{L})\end{array}$ & $\begin{array}{c}\mathrm{Mg} \\
(\mathrm{mg} / \mathrm{L})\end{array}$ \\
\hline \multirow{5}{*}{$\begin{array}{c}\text { 1951-2008 } \\
\text { (all data) }\end{array}$} & Minimum & 1.8 & $5.0 \mathrm{E}-04$ & $<10$ & 240 & 88 & 6.7 & $<1$ & 0 & 0.7 & 160 & 70 \\
\hline & Maximum & 6.3 & $1.6 \mathrm{E}+01$ & 710 & 3,170 & 3,090 & 3,270 & 40 & 35 & 8.9 & 390 & 230 \\
\hline & Mean & 3.1 & $7.8 \mathrm{E}-01$ & 190 & 2,200 & 1,990 & 1,430 & 6.4 & 17 & 4.4 & 290 & 150 \\
\hline & $1 \sigma$ & $2.6^{-*}$ & $1.6 \mathrm{E}+00$ & 150 & 720 & 650 & 510 & 9.2 & 7.1 & 2.1 & 69 & 36 \\
\hline & $n$ & 106 & 106 & 83 & 38 & 41 & 64 & 56 & 49 & 34 & 31 & 29 \\
\hline \multirow{5}{*}{$1951-1968$} & Minimum & 1.8 & $2.0 \mathrm{E}-02$ & 276 & NA & $\mathrm{NA}$ & 1,216 & 2.6 & NA & NA & 188 & $N A$ \\
\hline & Maximum & 4.7 & $1.6 \mathrm{E}+01$ & 710 & NA & NA & 2,500 & 40 & NA & NA & 196 & NA \\
\hline & Mean & 2.8 & $1.7 \mathrm{E}+00$ & 410 & NA & $\mathrm{NA}$ & 1,680 & 26 & NA & NA & 190 & $N A$ \\
\hline & $1 \sigma$ & $2.3-^{\star}$ & $3.1 \mathrm{E}+00$ & 100 & NA & NA & 709 & 11 & NA & NA & 6 & NA \\
\hline & $n$ & 26 & 26 & 20 & NA & $\mathrm{NA}$ & 3 & 7 & NA & NA & 2 & $N A$ \\
\hline \multirow{5}{*}{ 1982-1984 } & Minimum & 2.7 & $5.0 \mathrm{E}-01$ & 145 & 240 & 88 & 6.7 & 0.11 & 0 & NA & 160 & 160 \\
\hline & Maximum & 3.3 & $1.9 \mathrm{E}+00$ & 386 & 3,170 & 3,090 & 2,100 & 17 & 35 & NA & 390 & 230 \\
\hline & Mean & 3.1 & $8.5 \mathrm{E}-01$ & 200 & 2,490 & 2,280 & 1,580 & 9.4 & 23 & NA & 320 & 180 \\
\hline & $1 \sigma$ & $2.9-3.3^{*}$ & $2.9 \mathrm{E}-01$ & 57 & 750 & 820 & 620 & 4.0 & 9 & NA & 70 & 18 \\
\hline & $n$ & 35 & 35 & 19 & 21 & 16 & 16 & 15 & 15 & NA & 13 & 13 \\
\hline \multirow{5}{*}{ 1997-1998 } & Minimum & 3.1 & $4.3 \mathrm{E}-02$ & 92 & 730 & 930 & 658 & $<1$ & 8.7 & 3.3 & 170 & 70 \\
\hline & Maximum & 4.4 & $8.5 \mathrm{E}-01$ & 200 & 2,710 & 2,200 & 1,690 & 4 & 22 & 8.9 & 370 & 170 \\
\hline & Mean & 3.6 & $2.5 \mathrm{E}-01$ & 140 & 1,850 & 1,800 & 1,360 & 1 & 15 & 6.1 & 280 & 120 \\
\hline & $1 \sigma$ & $3.3-4.4^{*}$ & $2.1 \mathrm{E}-01$ & 26 & 520 & 370 & 288 & 1 & 3.5 & 1.4 & 58 & 27 \\
\hline & $n$ & 17 & 17 & 17 & 17 & 16 & 16 & 16 & 16 & 16 & 16 & 16 \\
\hline \multirow{5}{*}{ 1999-2008 } & Minimum & 3.3 & $5.0 \mathrm{E}-04$ & $<10$ & NA & 1,030 & 510 & 0.4 & 6.9 & 0.7 & $N A$ & $N A$ \\
\hline & Maximum & 6.3 & $5.0 \mathrm{E}-01$ & 190 & NA & 2,600 & 3,270 & 1.9 & 17 & 5.8 & NA & NA \\
\hline & Mean & 3.8 & $1.5 \mathrm{E}-01$ & 41 & NA & 1,820 & 1,370 & 1.0 & 13 & 2.9 & NA & NA \\
\hline & $1 \sigma$ & $3.6-4.7^{*}$ & $1.3 \mathrm{E}-01$ & 37 & NA & 550 & 524 & 0.4 & 3.2 & 1.4 & NA & NA \\
\hline & $n$ & 28 & 28 & 27 & NA & 9 & 29 & 18 & 18 & 18 & NA & $N A$ \\
\hline
\end{tabular}

* Upper and lower pH limits (range) are derived from the mean and standard deviation $(1 \sigma)$ of the hydrogen ion activity $(\mathrm{H})$, where the lower pH limit $=-\log \left[\mathrm{H}_{\text {mean }}+\mathrm{H}_{1 \sigma}\right]$ and the upper pH limit $=-\log \left[\mathrm{H}_{\text {mean }}-\mathrm{H}_{1 \sigma}\right]$. Where no upper pH limit is recorded, the logarithm does not exist because $\left[\mathrm{H}_{\text {mean }}-\mathrm{H}_{1 \sigma}\right]$ is a negative number.

no measurable alkalinity except on four occasions in January 2001, January 2002, October 2006, and April 2008 when alkalinity ranged from $2 \mathrm{mg} / \mathrm{L}$ to $26 \mathrm{mg} / \mathrm{L}$ (Appendix C). The data also show that, on average, acidity decreased through time (fig. 10B; Table 4). During the monitoring period from 19511968, water discharged from Augusta Lake had a mean acidity of $410 \mathrm{mg} / \mathrm{L}$, with a range between 276-710 mg/L; from 1982-1984, the mean acidity was $200 \mathrm{mg} / \mathrm{L}$, with a range between $145-386 \mathrm{mg} / \mathrm{L}$; from 1997-1998, mean acidity was $140 \mathrm{mg} / \mathrm{L}$, with a range between $92-200 \mathrm{mg} / \mathrm{L}$; and from 1999-2008, mean acidity was $41 \mathrm{mg} / \mathrm{L}$, with a range between $<10 \mathrm{mg} / \mathrm{L}$ (below the detection limit) and $190 \mathrm{mg} / \mathrm{L}$ (Table 4). These data document the long-term decrease in acidity of Augusta Lake water since construction of the dam in 1950.

Total dissolved solids and sulfate $\left(\mathrm{SO}_{4}\right)$ concentrations vary through time (fig. 10C-D) and comparison of the concentrations indicates that most of the dissolved solids in lake water are accounted for by dissolved sulfate ions. The monitoring records show that water flowing from Augusta Lake had a 

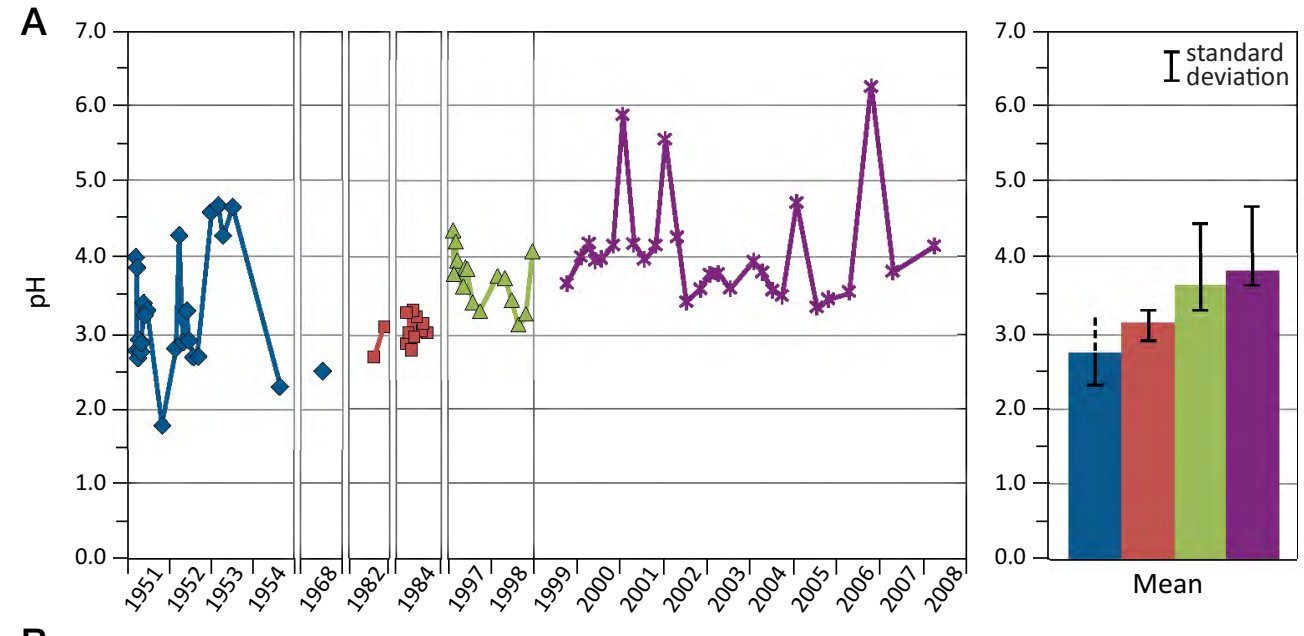

\section{B}
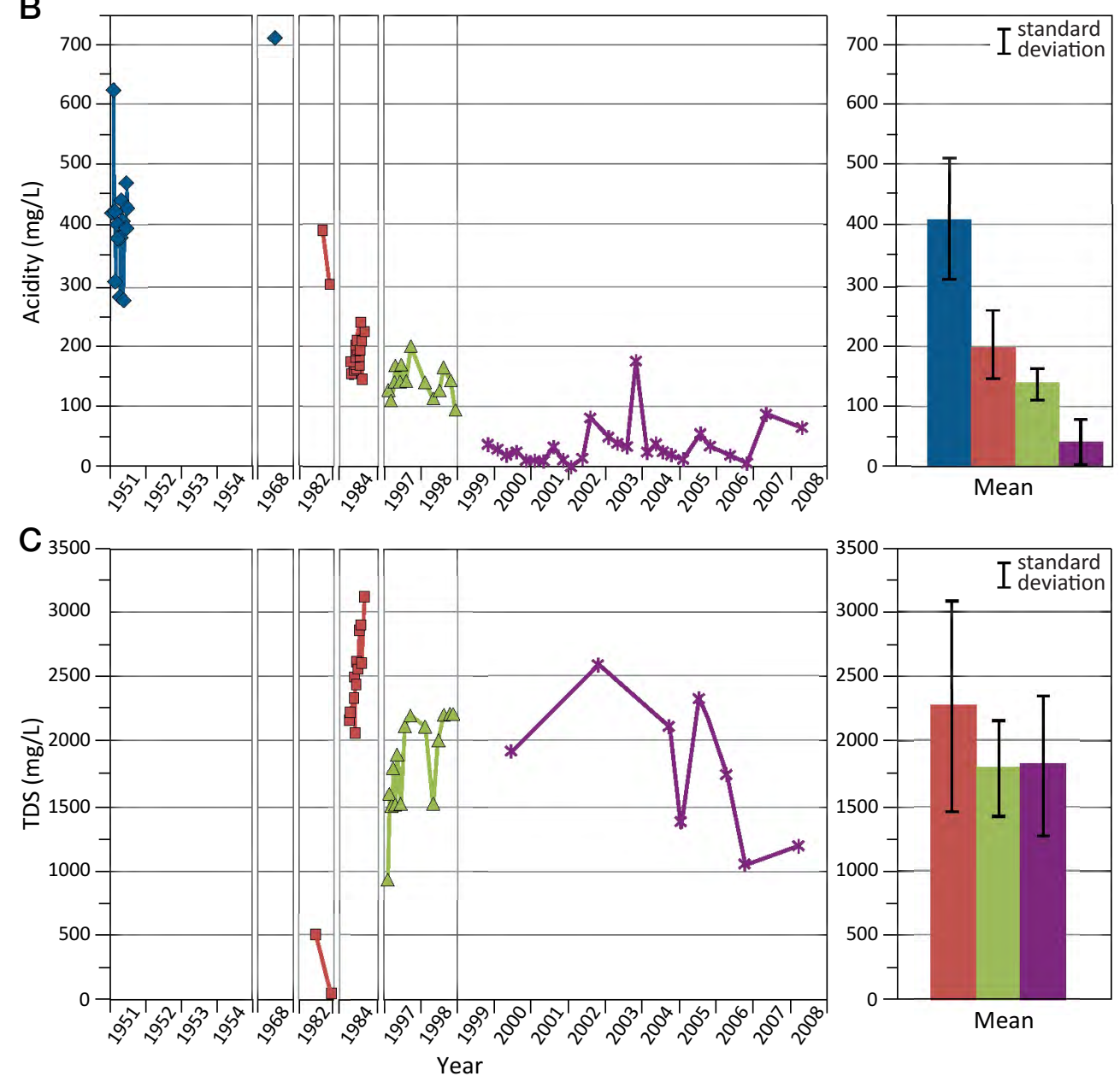

Figure 10. Graphs showing the quality of water discharged from Augusta Lake. Data are grouped into four different monitoring periods spanning nearly six decades. Means for each monitoring period are shown in the bar graph at the right. Surface water samples were collected at site W-20 and at site 8 (fig. 4). A. pH. B. Acidity. C. Total dissolved solids (TDS). Data are tabulated in Appendices A-C. See Table 4 for statistical summary of the data. 


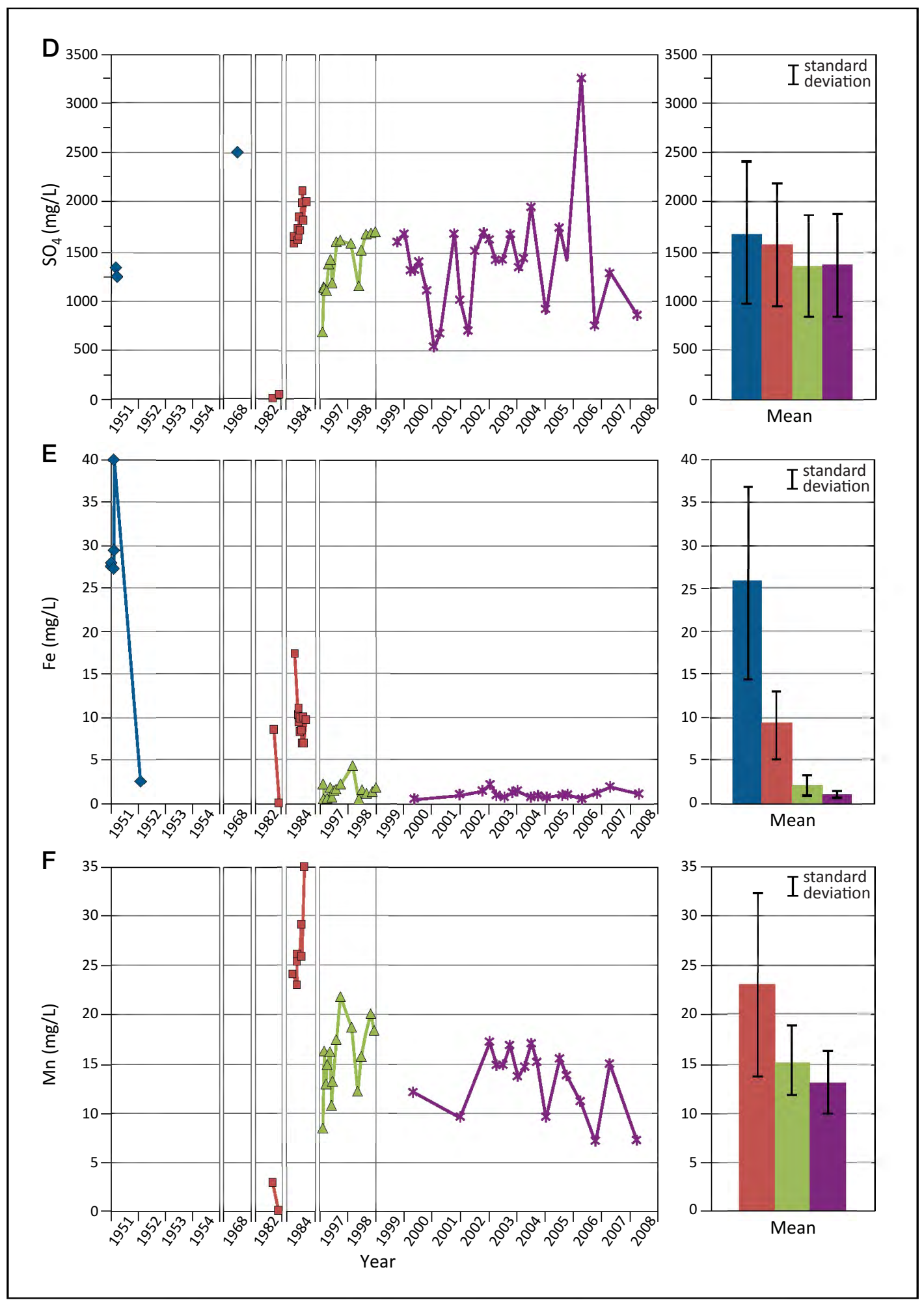

Figure 10 (cont.). Graphs showing the quality of water discharged from Augusta Lake. Data are grouped into four different monitoring periods spanning nearly six decades. Means for each monitoring period are shown in the bar graph at the right. Surface water samples were collected at site W-20 and at site 8 (fig. 4). D. Sulfate $\left(\mathrm{SO}_{4}\right)$. E. Iron (Fe). F. Manganese (Mn). Data are tabulated in Appendices A-C. See Table 4 for statistical summary of the data. 

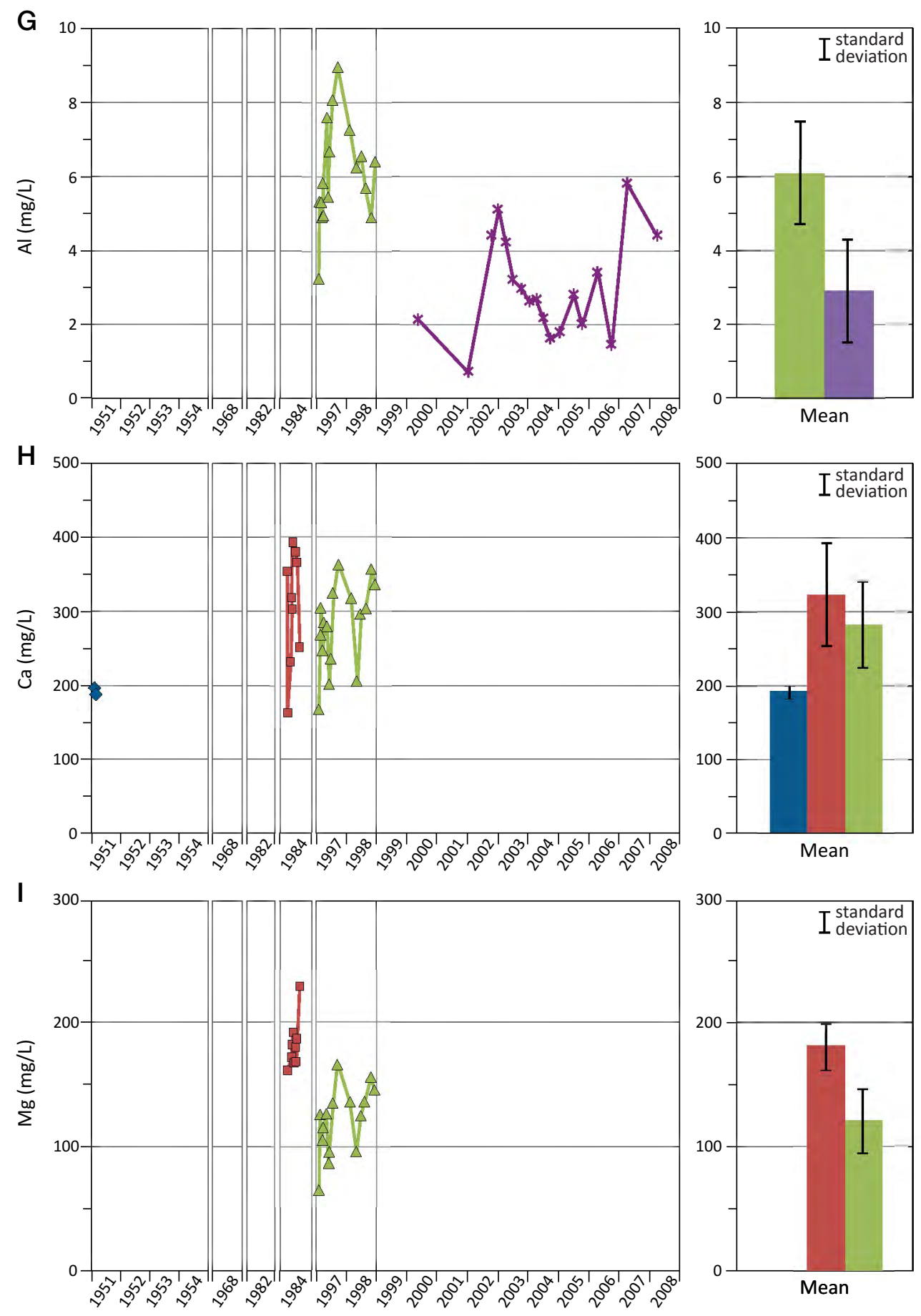

Figure 10 (cont.). Graphs showing the quality of water discharged from Augusta Lake. Data are grouped into four different monitoring periods spanning nearly six decades. Means for each monitoring period are shown in the bar graph at the right. Surface water samples were collected at site W-20 and at site 8 (fig. 4). G. Aluminum (Al). H. Calcium (Ca). I. Magnesium (Mg). Data are tabulated in Appendices A-C. See Table 4 for statistical summary of the data. 
mean TDS of $1,990 \mathrm{mg} / \mathrm{L}$, with a range from $88-$ 3,090 mg/L (Table 4). The data show that TDS was mostly lower on average during the 1997-1998 and the 1999-2008 monitoring periods compared to the 1982-1984 monitoring period (Table 4; fig. 10C). From 1982-1984, water discharged from Augusta Lake had a mean TDS of 2,280 mg/L, with a range between $88-3,090 \mathrm{mg} / \mathrm{L}$; from 1997-1998, mean TDS was $1,800 \mathrm{mg} / \mathrm{L}$, with a range between 930 2,200 mg/L; and from 1999-2008, mean TDS was $1,820 \mathrm{mg} / \mathrm{L}$, with a range between $1,030-2,600$ $\mathrm{mg} / \mathrm{L}$ (Table 4). Total dissolved solids concentrations were essentially unchanged on average during the 1997-1998 and the 1999-2008 monitoring periods, with standard deviations of $370 \mathrm{mg} / \mathrm{L}$ and $550 \mathrm{mg} / \mathrm{L}$, respectively, and the difference between means of $20 \mathrm{mg} / \mathrm{L} \mathrm{(1.1 \% )} \mathrm{(Table} \mathrm{4).}$

Similarly, the monitoring records show that water flowing from Augusta Lake had a mean sulfate concentration of $1,430 \mathrm{mg} / \mathrm{L}$, with a range from $6.7-$ $3,270 \mathrm{mg} / \mathrm{L}$ (Table 4). The data show that sulfate decreased, on average, from the 1951-1968 monitoring period through the 1982-1984 monitoring period to the 1997-1998 monitoring period (fig. 10D). From 1951-1968, water discharged from Augusta Lake had a mean sulfate concentration of $1,680 \mathrm{mg} / \mathrm{L}$, with a range between $1,216-2,500 \mathrm{mg} / \mathrm{L}$; from $1982-$ 1984, mean sulfate concentration was $1,580 \mathrm{mg} / \mathrm{L}$, with a range between $6.7-2,100 \mathrm{mg} / \mathrm{L}$; from 19971998 , mean sulfate concentration was $1,360 \mathrm{mg} / \mathrm{L}$, with a range between $658-1,690 \mathrm{mg} / \mathrm{L}$; and from 1999-2008, mean sulfate concentration was 1,370 $\mathrm{mg} / \mathrm{L}$, with a range between $510-3,270 \mathrm{mg} / \mathrm{L}$ (Table 4). These data document the long-term decrease in sulfate concentrations in Augusta Lake water since construction of the dam in 1950. Sulfate concentration was essentially unchanged on average during the 1997-1998 and the 1999-2008 monitoring periods, with standard deviations of $288 \mathrm{mg} / \mathrm{L}$ and $524 \mathrm{mg} / \mathrm{L}$, respectively, and the difference between means of $10 \mathrm{mg} / \mathrm{L}(0.7 \%)$ (Table 4$)$.

The monitoring data showed that concentrations of the metals iron, manganese, and aluminum in water flowing from Augusta Lake were initially high and, on average, decreased through time (fig. 10E-G; Table 4). For all monitoring from 1951-2008, mean iron concentration was $6.4 \mathrm{mg} / \mathrm{L}$, with a range from less than 1-40 mg/L (Table 4). From 1951-1968, water discharged from Augusta Lake had a mean iron concentration of $26 \mathrm{mg} / \mathrm{L}$, with a range between $2.6-40 \mathrm{mg} / \mathrm{L}$; from $1982-1984$, the mean iron concentration was $9.4 \mathrm{mg} / \mathrm{L}$, with a range between 0.11-17 mg/L; from 1997-1998, mean iron concentration was $1 \mathrm{mg} / \mathrm{L}$, with a range of less than $1 \mathrm{mg} / \mathrm{L}$ to $4 \mathrm{mg} / \mathrm{L}$; and from 1999-2008, mean iron concentration was $1.0 \mathrm{mg} / \mathrm{L}$, with a range between $0.4-1.9 \mathrm{mg} / \mathrm{L}$ (Table 4). These data show that mean iron concentration decreased in each of the three earliest monitoring periods and that the decline was roughly geometric, with a large early decrease that diminished through time (fig. 10E). Although the mean iron concentration remained the same at $1 \mathrm{mg} / \mathrm{L}$ in the $1997-1998$ monitoring period and the 1999-2008 monitoring period (Table 4), the maximum, range, and standard deviation decreased, documenting that less iron was discharged from Augusta Lake during the 1991-2008 monitoring period. The large drop in iron concentration that occurred after February 1951 (Appendix A) may represent the time during the initial filling of the lake when iron precipitation became a predominant geochemical reaction in the newly developing lake system.

The mean concentration of manganese in water flowing from Augusta Lake decreased through time during three monitoring periods (fig. 10F). For all monitoring, mean manganese concentration was $17 \mathrm{mg} / \mathrm{L}$, with a range from $0-35 \mathrm{mg} / \mathrm{L}$ (Table 4). From 1982-1984, the mean manganese concentration was $23 \mathrm{mg} / \mathrm{L}$, with a range between 0-35 $\mathrm{mg} / \mathrm{L}$; from 1997-1998, mean manganese concentration was $15 \mathrm{mg} / \mathrm{L}$, with a range of $8.7-22 \mathrm{mg} / \mathrm{L}$; and from 1999-2008, mean manganese concentration was $13 \mathrm{mg} / \mathrm{L}$, with a range between $6.9-17$ $\mathrm{mg} / \mathrm{L}$ (Table 4). The fluctuations characteristic of the 1997-1998 and the 2000-2008 manganese data (fig. 10F) represent seasonal variations, with high concentrations mostly occurring in the warm late summer and early fall months and low concentrations occurring in the cool winter and spring months (Appendices B and C).

The mean concentration of aluminum in water flowing from Augusta Lake also decreased through time during two monitoring periods (fig. 10G). For all monitoring, mean aluminum concentration was $4.4 \mathrm{mg} / \mathrm{L}$, with a range from $0.7-8.9 \mathrm{mg} / \mathrm{L}$ (Table 4 ). From 1997-1998, mean aluminum concentration was $6.1 \mathrm{mg} / \mathrm{L}$, with a range of $3.3-8.9 \mathrm{mg} / \mathrm{L}$; and from 1999-2008, mean aluminum concentration was $2.9 \mathrm{mg} / \mathrm{L}$, with a range between $0.7-5.8 \mathrm{mg} / \mathrm{L}$ (Table 4). Fluctuations in aluminum concentration (fig. 10G) represent seasonal variations, with the highest concentration occurring in late September 1997 and the lowest concentration occurring in January 2002 (Appendices B and C). 
Other changes include mostly increased calcium concentration and decreased magnesium concentration during successive monitoring periods (Table 4; fig. 10H-I). The mean calcium concentration for all monitoring was $290 \mathrm{mg} / \mathrm{L}$, with a range from $160-390 \mathrm{mg} / \mathrm{L}$ (Table 4). From the 1951-1968 to the 1982-1984 monitoring period, mean calcium increased 68 percent from $190 \mathrm{mg} / \mathrm{L}$ to $320 \mathrm{mg} / \mathrm{L}$; for the 1997-1998 monitoring period, mean calcium concentration decreased to $280 \mathrm{mg} / \mathrm{L}$ (Table 4; fig. $10 \mathrm{H}$ ). For all monitoring, mean magnesium was $150 \mathrm{mg} / \mathrm{L}$, with a range from 70-230 mg/L. From the 1982-1984 to the 1997-1998 monitoring period, mean magnesium concentration decreased 33 percent from $180 \mathrm{mg} / \mathrm{L}$ to $120 \mathrm{mg} / \mathrm{L}$ (Table 4; fig. 10I).

All these data represent an improvement of the quality of water in Augusta Lake through time. This improvement reflects the increased use of limestone and alkaline chemicals during reclamation activities in the Augusta Lake subwatershed, dilution by rainfall and less impaired runoff, and the deposition of metals (especially iron) in Augusta Lake sediments. These processes, along with improvements in the quality of water discharged from the northeast drainage, the depletion of pyrite in mine spoil resulting from weathering over time, and decreased exposure of pyrite resulting from the stabilization of spoil by increased vegetative cover (fig. 3 ), served to mitigate the impact of AMD and improve the water quality in Augusta Lake.

\section{Mill Creek}

Water-quality records from 1949 to 1985 for Mill Creek at the S.R. 364 bridge are summarized in Table 5 and illustrated in Figure 11. The data show that $\mathrm{pH}$ remained mostly acidic, with a mean $\mathrm{pH}$ of 3.1, a minimum $\mathrm{pH}$ of 2.5, and a maximum $\mathrm{pH}$ of 7.8 (Table 5). Conversely, acidity was high during this time, having a maximum concentration of $1,000 \mathrm{mg} / \mathrm{L}$, a minimum concentration of $0 \mathrm{mg} / \mathrm{L}$, and a mean concentration of $230 \mathrm{mg} / \mathrm{L}$ (Table 5). The lowest $\mathrm{pH}$ and highest acidity were recorded between 1949 and 1967. Mean $\mathrm{pH}$ increased from 2.7 during the 1949-1967 monitoring to 3.3 during the 1976-1980 monitoring and 3.1 during the 1983-1985 monitoring (Table 5; fig. 11A). Mean acidity concentration decreased from $660 \mathrm{mg} / \mathrm{L}$ during the earlier monitoring to $200 \mathrm{mg} / \mathrm{L}$ during the 1976-1980 monitoring and $190 \mathrm{mg} / \mathrm{L}$ during the 1983-1985 monitoring (Table 5; fig. 11B). Neither parameter exhibited a consistent long-term trend toward improvement or degradation after 1967 (Table 5; fig. 11A-B).

Two episodes of high $\mathrm{pH}$ occurred during the 1976-1980 monitoring period that were abrupt and short-lived (fig. 11A), one between December 1978 and April 1979 when the $\mathrm{pH}$ varied between 6.9 and 7.8 and another in November 1980 when the $\mathrm{pH}$ reached 7.6 (Appendix A). The earlier anomaly was interrupted in March 1979 by an abrupt drop to $\mathrm{pH} 3.2$, which represents a return to the more normal trend (fig. 11A). During both anomalies, high $\mathrm{pH}$ values were accompanied by absence of acidity (fig. 11B) and an increase in alkalinity, with the earlier anomaly involving a decrease in sulfate concentration and the later anomaly showing no change in sulfate concentration (Appendix A). The cause of these $\mathrm{pH}$ anomalies is unknown but may have resulted from construction work on S.R. 364 involving limestone. Although maintenance records generally are not kept beyond 5 years, the Indiana Department of Transportation confirmed that road construction did take place along S.R. 364 during the period from December 1978 to April 1979 and that limestone was included in the materials used during this construction (A. C. Evans, Vincennes District Office, Indiana Department of Transportation, written commun., 2008). Dissolution of the limestone construction materials could account for this episode of anomalous water chemistry observed in Mill Creek at the S.R. 364 bridge. The cause of the abrupt drop to pH 3.2 in March 1979 is also unknown. Although no flow data are available, discharge of highly impaired water from Augusta Lake during a spring storm may account for the sudden $\mathrm{pH}$ drop. However, the data are not sufficient to provide a conclusive explanation.

Specific conductance and TDS were recorded from 1976 to 1985 and vary similarly (fig. 11C-D). Both minima occurred during a storm in late February 1985 (680 $\mu \mathrm{mhos} / \mathrm{cm}$ and $460 \mathrm{mg} / \mathrm{L})$ and both maxima occurred during late summer, the maximum specific conductance in September $1976(3,700$ $\mu \mathrm{mhos} / \mathrm{cm})$ and the maximum TDS in September $1980(3,589 \mathrm{mg} / \mathrm{L})$ (Appendix A; Table 5). Lower values coincided with seasonal wet conditions mostly in the spring months and higher values coincided with seasonal dry conditions in the summer months (Appendix A).

Sulfate concentrations recorded from 1949-1985 ranged between $330 \mathrm{mg} / \mathrm{L}$ and 2,750 $\mathrm{mg} / \mathrm{L}$, with 
Table 5. Water-quality statistics for Mill Creek

[Statistical and water-quality parameters are the same as those in Table 4 except for aluminum (Al), which was not analyzed during the monitoring at this location. This tabulation includes statistics for all data (at top) and data for three subsequent monitoring periods. Based on data tabulated for Mill Creek at S.R. 364 in Appendix A. Location of the monitoring site is designated W-21 in Figure 4. NA= not analyzed.]

\begin{tabular}{|c|c|c|c|c|c|c|c|c|c|c|c|}
\hline $\begin{array}{l}\text { Monitoring } \\
\text { dates }\end{array}$ & Statistic & $\mathrm{pH}$ & $\begin{array}{c}\text { H } \\
\text { activity }\end{array}$ & $\begin{array}{l}\text { Acidity } \\
\text { (mg/L) }\end{array}$ & $\begin{array}{c}\mathrm{SpC} \\
(\mu \mathrm{mhos} / \\
\mathrm{cm})\end{array}$ & $\begin{array}{c}\text { TDS } \\
(\mathrm{mg} / \mathrm{L})\end{array}$ & $\begin{array}{c}\mathrm{SO}_{4} \\
(\mathrm{mg} / \mathrm{L})\end{array}$ & $\begin{array}{c}\mathrm{Fe} \\
(\mathrm{mg} / \mathrm{L})\end{array}$ & $\begin{array}{c}\mathrm{Mn} \\
(\mathrm{mg} / \mathrm{L})\end{array}$ & $\begin{array}{c}\mathrm{Ca} \\
(\mathrm{mg} / \mathrm{L})\end{array}$ & $\begin{array}{c}\mathrm{Mg} \\
(\mathrm{mg} / \mathrm{L})\end{array}$ \\
\hline \multirow{5}{*}{$\begin{array}{r}\text { 1949-1985 } \\
\text { (all data) }\end{array}$} & Minimum & 2.5 & $1.6 \mathrm{E}-05$ & 0 & 680 & 460 & 330 & 0.1 & 0.1 & 78 & 28 \\
\hline & Maximum & 7.8 & $3.2 \mathrm{E}+00$ & 1,000 & 3,700 & 3,589 & 2,750 & 1,585 & 35.5 & 456 & 389 \\
\hline & Mean & 3.1 & 7.7E-01 & 230 & 2,500 & 2,510 & 1,610 & 38 & 22 & 290 & 200 \\
\hline & $1 \sigma$ & $2.9-3.7^{*}$ & $5.5 \mathrm{E}-01$ & 170 & 700 & 685 & 543 & 190 & 8 & 82 & 54 \\
\hline & $n$ & 97 & 97 & 86 & 71 & 69 & 75 & 70 & 69 & 47 & 47 \\
\hline \multirow{5}{*}{ 1949-1967 } & Minimum & 2.5 & $5.0 \mathrm{E}-01$ & 354 & NA & NA & 1,700 & NA & NA & NA & NA \\
\hline & Maximum & 3.3 & $3.2 \mathrm{E}+00$ & 1,000 & NA & NA & 2,750 & NA & NA & NA & $N A$ \\
\hline & Mean & 2.7 & $1.8 \mathrm{E}+00$ & 660 & NA & NA & 2,340 & NA & NA & NA & NA \\
\hline & $1 \sigma$ & $2.6-3.0^{*}$ & 7.1E-01 & 290 & NA & NA & 410 & NA & NA & NA & NA \\
\hline & $n$ & 9 & 9 & 7 & NA & NA & 6 & NA & NA & NA & NA \\
\hline \multirow{5}{*}{ 1976-1980 } & Minimum & 2.9 & $1.6 \mathrm{E}-05$ & 0 & 730 & 632 & 369 & 0.1 & 0.1 & 78 & 28 \\
\hline & Maximum & 7.8 & $1.3 \mathrm{E}+00$ & 355 & 3,700 & 3,589 & 2,550 & 1,585 & 35.5 & 456 & 389 \\
\hline & Mean & 3.3 & $5.6 \mathrm{E}-01$ & 200 & 2,480 & 2,510 & 1,500 & 48 & 21 & 260 & 200 \\
\hline & $1 \sigma$ & $3.0-3.7^{*}$ & $3.5 \mathrm{E}-01$ & 86 & 709 & 702 & 518 & 220 & 9 & 79 & 62 \\
\hline & $n$ & 54 & 54 & 53 & 53 & 53 & 53 & 53 & 53 & 33 & 33 \\
\hline \multirow{5}{*}{ 1983-1985 } & Minimum & 2.7 & $5.0 \mathrm{E}-02$ & 40 & 680 & 460 & 330 & 3.5 & 5 & 260 & 150 \\
\hline & Maximum & 4.3 & $2.0 \mathrm{E}+00$ & 305 & 3,180 & 3,120 & 2,230 & 11 & 34 & 420 & 230 \\
\hline & Mean & 3.1 & $8.3 \mathrm{E}-01$ & 190 & 2,560 & 2,510 & 1,720 & 6.8 & 26 & 350 & 180 \\
\hline & $1 \sigma$ & $2.9-3.3^{*}$ & $3.5 \mathrm{E}-01$ & 51 & 702 & 648 & 443 & 1.8 & 6 & 45 & 22 \\
\hline & $\mathrm{n}$ & 34 & 34 & 26 & 18 & 16 & 16 & 17 & 16 & 14 & 14 \\
\hline
\end{tabular}

* Upper and lower pH limits (range) are derived from the mean and standard deviation $(1 \sigma)$ of the hydrogen ion activity $(\mathrm{H})$, where the lower $\mathrm{pH}$ limit $=-\log \left[\mathrm{H}_{\text {mean }}+\mathrm{H}_{1 \sigma}\right]$ and the upper pH limit $=-\log \left[\mathrm{H}_{\text {mean }}-\mathrm{H}_{1 \sigma}\right]$. Where no upper pH limit is recorded, the logarithm does not exist because $\left[\mathrm{H}_{\text {mean }}-\mathrm{H}_{1 \sigma}\right]$ is a negative number.

a mean of $1,610 \mathrm{mg} / \mathrm{L}$ (Table 5). The sample having the lowest sulfate concentration, which also contained the lowest TDS concentration and lowest specific conductance, was collected in February 1985 (Appendix A) when Mill Creek was greatly diluted by a late winter storm. The highest sulfate concentration was recorded in August 1966 (Appendix A). Mean sulfate concentration decreased from 2,340 $\mathrm{mg} / \mathrm{L}$ during the 1949-1967 monitoring period to $1,500 \mathrm{mg} / \mathrm{L}$ during the $1976-$ 1980 monitoring period (Table 5; fig. 11E). Mean sulfate concentration increased from $1,500 \mathrm{mg} / \mathrm{L}$ to $1,720 \mathrm{mg} / \mathrm{L}$ between the $1976-1980$ and the $1983-$ 1985 monitoring periods.

Iron and manganese concentrations were recorded from 1976 to 1985 (Appendix A). Iron concentrations ranged between $0.1 \mathrm{mg} / \mathrm{L}$ and $1,585 \mathrm{mg} / \mathrm{L}$, with a mean of $38 \mathrm{mg} / \mathrm{L}$ (Table 5). The lowest concentration occurred in September 1977 and the highest concentration occurred in December 1977 during a period of low flow (8.8 Lps) (Appendix A). The mean concentration of iron decreased 86 percent from $48 \mathrm{mg} / \mathrm{L}$ during the 1976-1980 monitoring period by AMAX Coal Company to $6.8 \mathrm{mg} / \mathrm{L}$ during the 1983-1985 monitoring period (Table 5). However, the two anomalously high iron values recorded in December 1977 and January 1978 (Appendix A) skew the mean for the 1976-1980 monitoring period. If these two values are removed, the mean iron concentration for the 1976-1980 monitoring period is $13 \mathrm{mg} / \mathrm{L}$ and the decrease between the monitoring periods is from $13 \mathrm{mg} / \mathrm{L}$ to $6.8 \mathrm{mg} / \mathrm{L}$ $(48 \%)$. Manganese concentrations ranged between 0.1-35.5 mg/L, with a mean of $22 \mathrm{mg} / \mathrm{L}$ (Table 5; fig. 11G). The lowest manganese concentration occurred in September 1977 in the same sample that had the lowest iron concentration, and the highest 
A

동
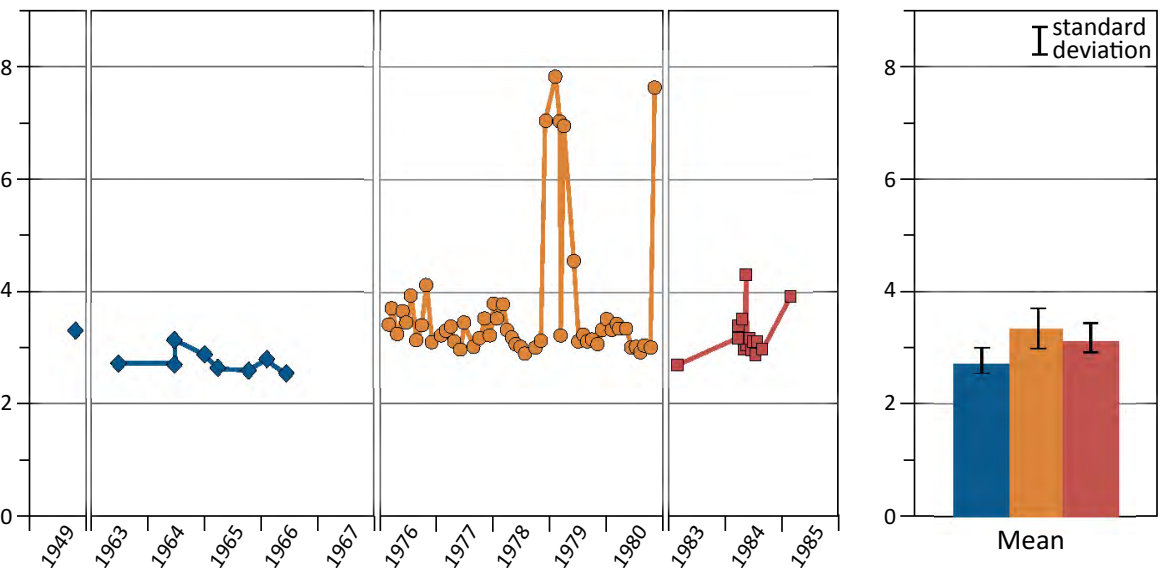

$\mathbf{B}_{1,200}$
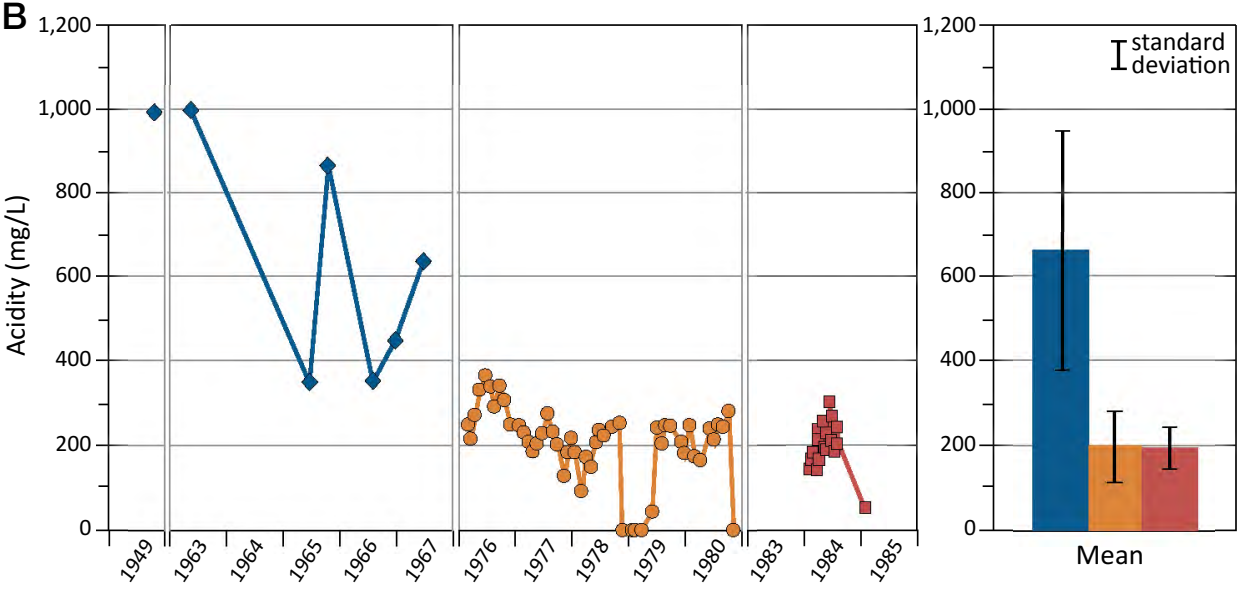

$\mathrm{C}_{4,0}$

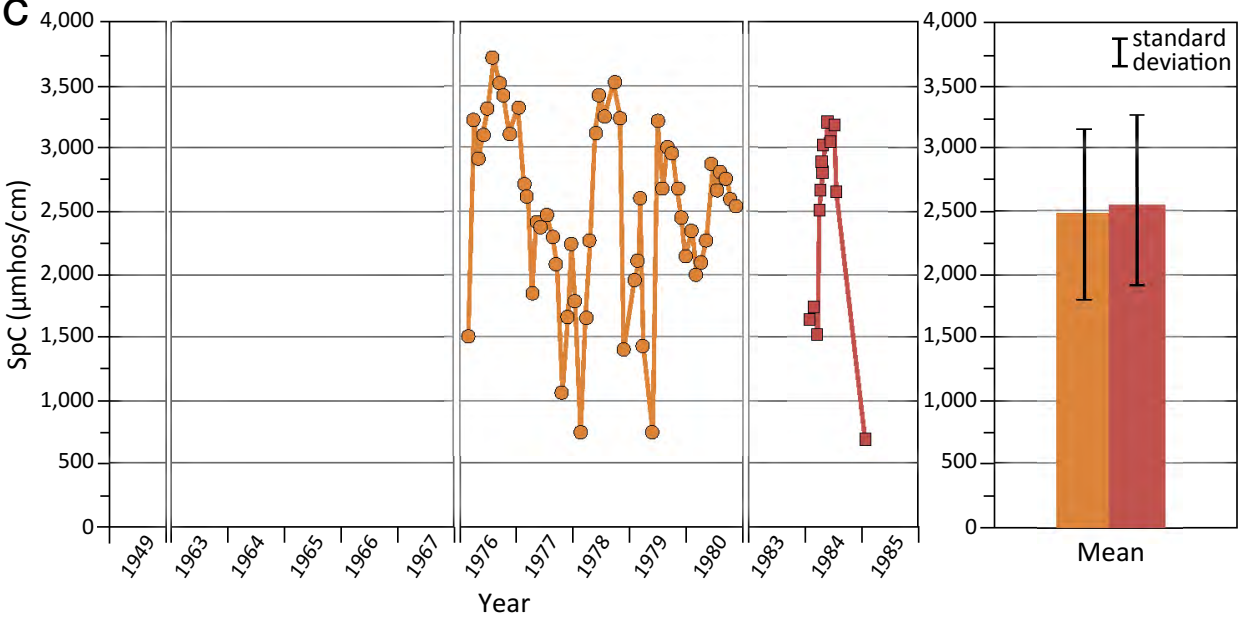

Figure 11. Graphs showing water quality of Mill Creek at the S.R. 364 bridge for monitoring that took place from 1949 through 1985. Surface-water sampling sites are represented by the red dot designated W-21 in Figure 4. A. pH. B. Acidity. C. Specific conductance (SpC). Data are tabulated in Appendix A. See Table 5 for statistical summary of the data. 


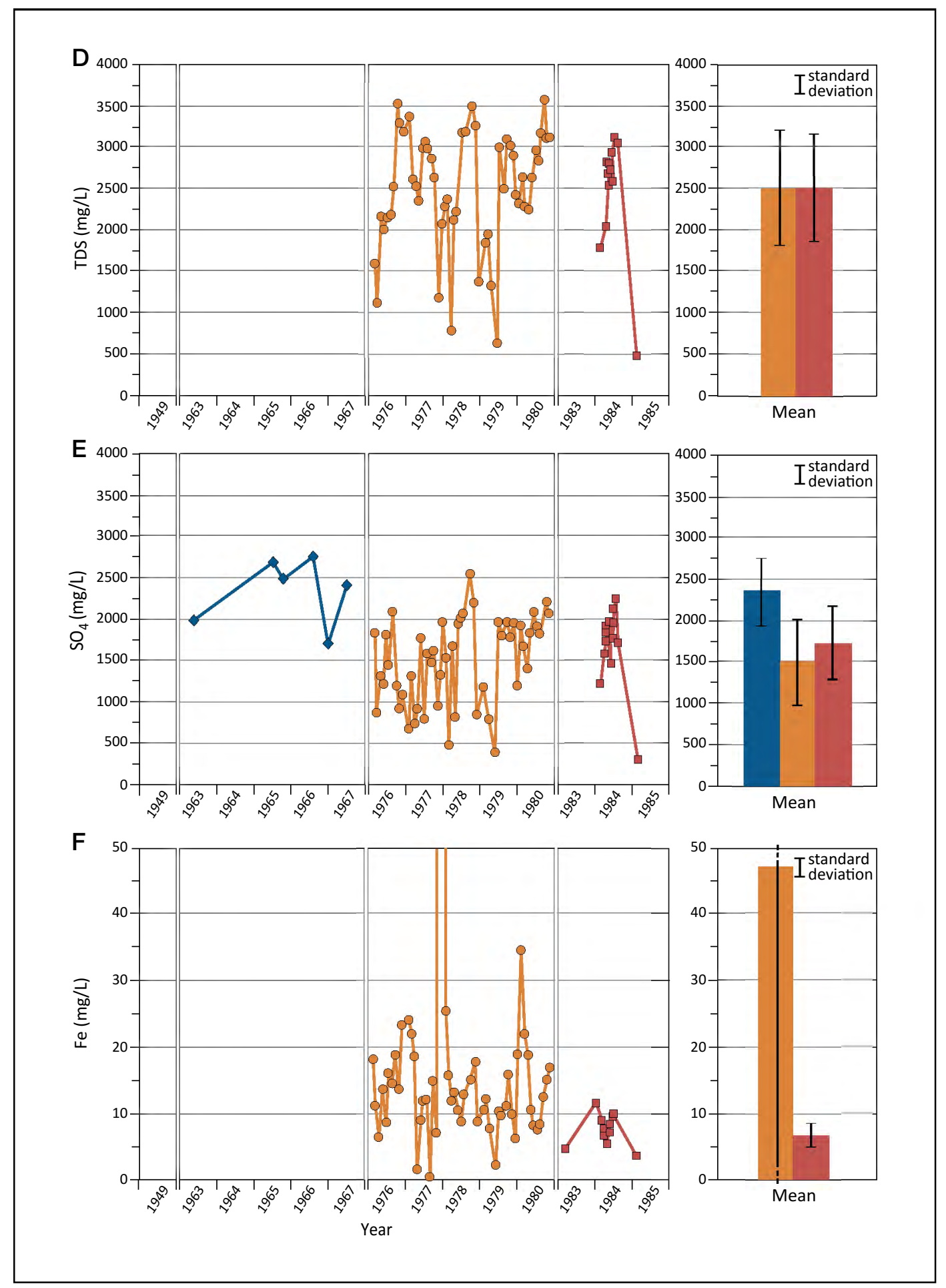

Figure 11 (cont.). Graphs showing water quality of Mill Creek at the S.R. 364 bridge for monitoring that took place from 1949 through 1985. Surface-water sampling sites are represented by the red dot designated W-21 in Figure 4. D. Total dissolved solids (TDS). E. Sulfate $\left(\mathrm{SO}_{4}\right)$. F. Iron $(\mathrm{Fe})$. Data are tabulated in Appendix A. See Table 5 for statistical summary of the data. 

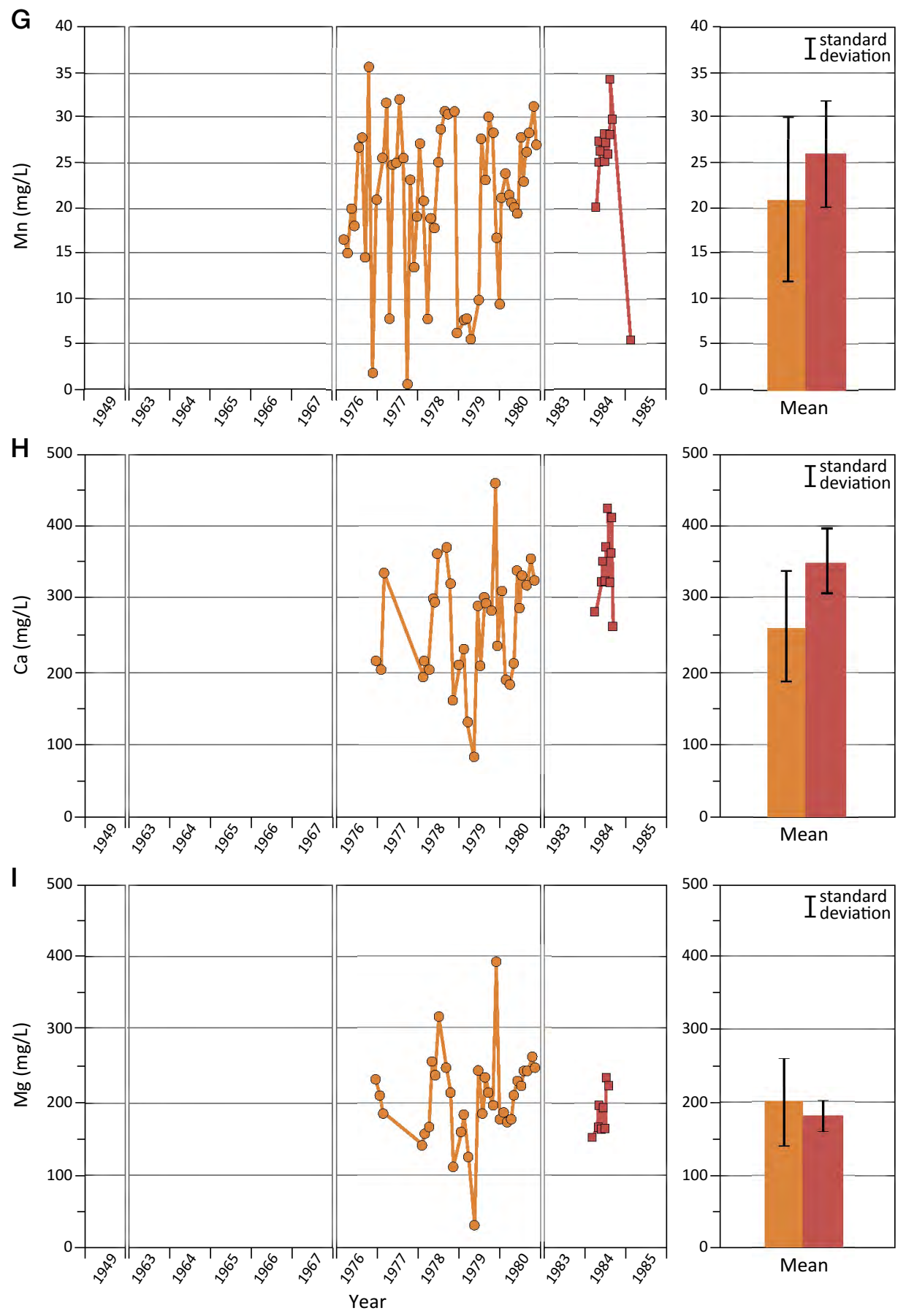

Figure 11 (cont.). Graphs showing water quality of Mill Creek at the S.R. 364 bridge for monitoring that took place from 1949 through 1985. Surface-water sampling sites are represented by the red dot designated W-21 in Figure 4. G. Manganese (Mn). H. Calcium (Ca). I. Magnesium (Mg). Data are tabulated in Appendix A. See Table 5 for statistical summary of the data. 
manganese concentration occurred in October 1976 in the sample that had the third highest TDS $(3,514$ $\mathrm{mg} / \mathrm{L}$ ) (Appendix A). Manganese concentrations were highly variable between the maximum and minimum until January 1980 (fig. 11G; Appendix A) when the concentration range narrowed between $19.5 \mathrm{mg} / \mathrm{L}$ and $34 \mathrm{mg} / \mathrm{L}$, with a mean of $26 \mathrm{mg} / \mathrm{L}$. The sharp decrease in concentration of manganese at the end of the curve (fig. 11G) reflects dilution during a storm in February 1985.

Calcium and magnesium concentrations recorded from 1976 through 1985 vary similarly (fig. 11H-I), with both minima occurring in June 1979 and both maxima occurring in December 1979 (Appendix A). Calcium concentrations ranged from $78-456$ $\mathrm{mg} / \mathrm{L}$, with a mean concentration of $290 \mathrm{mg} / \mathrm{L}$, and magnesium concentrations ranged from 28$389 \mathrm{mg} / \mathrm{L}$, with a mean of $200 \mathrm{mg} / \mathrm{L}$ (Table 5). The mean concentration of calcium increased from 260 $\mathrm{mg} / \mathrm{L}$ to $350 \mathrm{mg} / \mathrm{L}$ and the mean concentration of magnesium decreased from $200 \mathrm{mg} / \mathrm{L}$ to $180 \mathrm{mg} / \mathrm{L}$ between the 1976-1980 monitoring period and the 1983-1985 monitoring period (Table 5; fig. 11H-I).

The data indicate the water quality of Mill Creek at S.R. 364 improved from 1949 to 1985 (Table 5), with significant improvement mostly occurring between the 1949-1967 and the 1976-1980 monitoring periods. This improvement reflects the depletion of pyrite in mine spoil resulting from weathering over time, the increased use of limestone for road grading and related activities in the watershed, and the decline of surface mining activity in the Augusta Lake-Mill Creek watershed. The decline in mining activity was accompanied by increased growth of vegetation in the mine spoil (fig. 3), which resulted in increased stability, decreased erosion, less exposure of fresh pyrite to weathering, and decreased surface runoff in the mined areas.

\section{SUMMARY AND CONCLUSIONS}

Acid conditions dominate the water quality of Mill Creek and Augusta Lake and oxidation of pyrite in disturbed overburden from surface mining is the primary source of acid in these water bodies. Attempts to mitigate acid drainage and to improve water quality in this part of the coal mining region of Indiana are many and varied. They include damming headwater streams to seal abandoned coal mines (1935-1940), creating Augusta Lake to dilute the acid in Mill Creek (1950), constructing a staged passive treatment system in the area of greatest acid discharge (1993-1997), adding alkaline chemicals directly to surface waters entering Augusta Lake to neutralize acidity (1999-2006), and introducing alkalinity by placing alkaline chemicals in the groundwater flow system upgradient from mine spoil (1999-2006).

While these water bodies remain seriously impaired, the water quality has improved during the last six decades. The greatest discharge of acidic water into Augusta Lake is from the northeast drainage, an area of spoil ridges and numerous acid seeps. Construction of a staged passive treatment system in this drainage area resulted in a significant overall improvement in the quality of water discharged to the lake. This improvement is documented by the changes in water chemistry shown in Table 3, including an increase in mean $\mathrm{pH}$ (from 3.1 to 4.0 ), an 85 percent decrease in mean hydrogen ion activity (from 0.73 to 0.11 ), a 54 percent decrease in mean acidity (from $350 \mathrm{mg} / \mathrm{L}$ to $160 \mathrm{mg} / \mathrm{L}$ ), a 12 percent decrease in mean TDS (from 3,980 mg/L to $3,500 \mathrm{mg} / \mathrm{L})$, a 6.5 percent decrease in mean sulfate concentration (from $2,620 \mathrm{mg} / \mathrm{L}$ to $2,450 \mathrm{mg} / \mathrm{L}$ ), a 65 percent decrease in mean iron concentration (from $66 \mathrm{mg} / \mathrm{L}$ to $23 \mathrm{mg} / \mathrm{L}$ ), a 29 percent decrease in mean manganese concentration (from $35 \mathrm{mg} / \mathrm{L}$ to $25 \mathrm{mg} / \mathrm{L})$, a 41 percent increase in calcium concentration (from $490 \mathrm{mg} / \mathrm{L}$ to $690 \mathrm{mg} / \mathrm{L}$ ), and a 30 percent decrease in magnesium concentration (from $270 \mathrm{mg} / \mathrm{L}$ to $190 \mathrm{mg} / \mathrm{L}$ ) (Table 3). Also, there was no alkalinity before construction of the staged passive treatment system, but there was a mean alkalinity of $240 \mathrm{mg} / \mathrm{L}$ after construction (Table 3). The increase in calcium concentration and the introduction of alkalinity resulted from the dissolution of limestone by AMD that percolated through ALDs and SAPS in the staged passive treatment system. Also, the dissolution of calcium-bearing chemicals placed in CARPs and ARTs in this area accounts for some of the increased concentration of calcium in the surface water.

Analytical data for outflow collected at the spillway confirm that the quality of water in Augusta Lake also improved significantly over time. This improvement is documented by the changes in water chemistry for successive monitoring periods from 1951-2008 (Table 4). The data show that mean $\mathrm{pH}$ increased from 2.8 to 3.8 , mean hydrogen ion activity decreased 91 percent (from 1.7 to 0.15 ), 
mean acidity decreased 90 percent (from $410 \mathrm{mg} / \mathrm{L}$ to $41 \mathrm{mg} / \mathrm{L}$ ), mean TDS decreased 20 percent (from $2,280 \mathrm{mg} / \mathrm{L}$ to $1,820 \mathrm{mg} / \mathrm{L}$ ), mean sulfate concentration decreased 18 percent (from 1,680 mg/L to $1,370 \mathrm{mg} / \mathrm{L}$ ), mean iron concentration decreased 96 percent (from $26 \mathrm{mg} / \mathrm{L}$ to $1.0 \mathrm{mg} / \mathrm{L}$ ), mean manganese concentration decreased 43 percent (from 23 $\mathrm{mg} / \mathrm{L}$ to $13 \mathrm{mg} / \mathrm{L}$ ), mean aluminum concentration decreased 52 percent (from $6.1 \mathrm{mg} / \mathrm{L}$ to $2.9 \mathrm{mg} / \mathrm{L}$ ), mean magnesium concentration decreased 33 percent (from $180 \mathrm{mg} / \mathrm{L}$ to $120 \mathrm{mg} / \mathrm{L}$ ), and mean calcium concentration increased 47 percent (from 190 $\mathrm{mg} / \mathrm{L}$ to $280 \mathrm{mg} / \mathrm{L}$ ). Most dramatic was the abrupt decrease in iron concentration (fig. 10E) after February 1951, a few months after Augusta Lake filled for the first time. The abrupt decrease and continued slow decline in iron concentration indicate that the process of scavenging iron from aqueous solution and fixing it in the lake sediments is extremely efficient in Augusta Lake.

The quality of water in Mill Creek also improved over time and this improvement is documented by changes in water chemistry (Table 5). For Mill Creek, mean $\mathrm{pH}$ increased from 2.7 to 3.1, mean hydrogen ion activity decreased 54 percent (from 1.8 to 0.83 ), mean acidity decreased 71 percent (from $660 \mathrm{mg} / \mathrm{L}$ to $190 \mathrm{mg} / \mathrm{L}$ ), mean sulfate concentration decreased 26 percent (from $2,340 \mathrm{mg} / \mathrm{L}$ to $1,720 \mathrm{mg} / \mathrm{L}$ ), mean iron concentration decreased 86 percent (from $48 \mathrm{mg} / \mathrm{L}$ to $6.8 \mathrm{mg} / \mathrm{L}$ ), mean calcium concentration increased 35 percent (from $260 \mathrm{mg} / \mathrm{L}$ to $350 \mathrm{mg} / \mathrm{L}$ ), and mean magnesium decreased 10 percent (from $200 \mathrm{mg} / \mathrm{L}$ to $180 \mathrm{mg} / \mathrm{L}$ ). The increase in $\mathrm{pH}$ and decrease in acidity and sulfate concentrations are mostly consequences of the depletion of oxidizable pyrite in coal spoil over time through weathering, increased use of limestone within the watershed, and growth of vegetation on the barren mined land (fig. 3) that stabilized spoil, reduced erosion, and limited the amount of pyrite exposed to weathering. The increase in calcium and decrease in magnesium also reflect the increased use of limestone in the watershed. Additional evidence of water-quality improvement is found in published reports documenting the biological recovery of aquatic species in Mill Creek during monitoring in 2000 (Simon and others, 2005) and in 2001 (Kalagian and Simmons, 2002).

Construction of the Augusta Lake dam effectively attenuated the discharge from headwater areas of Mill Creek. Discharge for Mill Creek at S.R. 364 and from Augusta Lake varied with rainfall and generally increased in wet spring seasons and during storms and decreased in dry summer seasons. Rapidly increased discharge resulted from storms and increased flow rates commonly coincided with notable dilution of dissolved constituents, increased $\mathrm{pH}$, and decreased acidity. Conversely, very low discharge was mostly observed during seasonal dry conditions in late summer to early fall, during drought, or occasionally during a hard freeze in winter. Low discharge commonly coincided with increased concentrations of dissolved constituents, decreased $\mathrm{pH}$, and increased acidity. The data show that lake water remained acidic throughout its history and was devoid of aquatic life for most of its history. The data also show that water quality improved on average over time and, in 2000, aquatic life was reported in Augusta Lake for the first time (Kalagian and Simmons, 2002; Simon and others, 2005).

Seasonal variations in water quality are also apparent in the monitoring data from the northeast drainage area. During wet conditions, mostly in the spring and during storms, $\mathrm{pH}$ increased and concentrations of dissolved constituents and acidity decreased. During dry conditions, mostly in late summer and early fall, $\mathrm{pH}$ decreased and dissolved constituents and acidity increased. The magnitude of these seasonal variations was greater in this headwater area of spoil ridges and acid seeps than in Augusta Lake and Mill Creek. This occurred because lake water was diluted by direct rainfall and less-impaired runoff and because Mill Creek water included diluted lake water plus runoff from unmined areas of the watershed.

\section{ACKNOWLEDGMENTS}

The author is indebted to Licia A. Weber who retrieved information about the mining history in T. 2 S., R. 7 W., from the Indiana Geological Survey Coal Mine Information System database. Kimberly Sowder drafted the figures and created the GIS coverages of the Patoka River watershed, Megan Divine formatted the tables and appendices, and Deborah DeChurch edited the manuscript and accomplished the final formatting. The manuscript benefited from technical reviews by James P. Rybarczyk, Ball State University Chemistry Department, and Nancy R. Hasenmueller and Denver Harper of the Indiana Geological Survey. William McCoy, Manager of 
the Patoka River National Wildlife Refuge, provided information about the various reclamation efforts that were implemented beginning in 1993. The Indiana Geological Survey, Indiana University Department of Geological Sciences, Indiana University Department of Recreation and Park Administration, and the U.S. Fish and Wildlife Service collaborated to execute the 1997-1998 monitoring and chemical analyses documented in this report (Appendix B).

\section{REFERENCES}

ATEC, 1984, Investigation of Mill Creek abandoned mine land site, Pike County, Indiana: Indianapolis, Indiana, ATEC Associates, Inc., Indiana Department of Natural Resources Project No. E23-403, ATEC Project No. 21-43037, 207 p.

Comer, J. B., Smith, R. T., Ennis, M. V., Branam, T. D., Welp, L. R., Morales, N. E., Sobiech, S. A., and Simon, T. P., 2000, Effects of passive reclamation on water quality in the northeastern drainage of Augusta Lake, Pike County, Indiana-chemical analyses and QA/QC: Indiana Geological Survey Open-File Study 00-2, 19 p.

Comer, J. B., Smith, R. T., Ennis, M. V., Branam, T. D., Welp, L. R., and Simon, T. P., 2006, Effects of passive reclamation on water quality in the northeastern drainage of Augusta Lake, Pike County, Indiana: $26^{\text {th }}$ International Symposium of the North American Lake Management Society, Nov. 8-10, Indianapolis, Indiana. [Available at Indiana University ScholarWorks, <http://hdl.handle.net/2022/454>, date accessed, Nov. 20, 2006.]

Corbett, D. M., 1965, Runoff contributions to streams from cast overburden of surface mining operations for coal, Pike County, Indiana: Bloomington, Indiana, Water Resources Research Center, Report of Investigations No. 1, 67 p.

Corbett, D. M., 1969, Acid mine-drainage problem of the Patoka River watershed, southwestern Indiana: Bloomington, Ind., Water Resources Research Center, Report of Investigations No. 4, 173 p.

Indiana Geological Survey (IGS), 2007, Indiana Coal Mine Information System: Indiana Geological Survey Internet map server site, <http://igs.indiana. edu/CMIS/>, date accessed, July 25, 2011.

Kalagian, M., and Simmons, J. S., 2002, Acid mine neutralization at Augusta Lake, Indiana: 2002 West Virginia Surface Mine Drainage Task Force Symposium, Morgantown, W. Va., 8 p. [Available at $<$ http:// wvmdtaskforce.com/proceedings/02/Kalagian. pdf $>$, date accessed, July 29, 2008.]
Mershon, R. W., 1940, Report on sealing abandoned coal mines in Indiana: Vincennes, Ind., U.S. Public Health Service, $14 \mathrm{p}$.

Renn, D. E., 1989, Streamflow and stream quality in the coal-mining region, Patoka River basin, southwestern Indiana, 1983-85: U.S. Geological Survey WaterResources Investigations Report 88-4150, 68 p.

Renn, D. E., Ragone, S. E., and Wilber, W. G., 1980, Quality of surface water in the coal-mining region, southwestern Indiana, March and May 1979: U.S. Geological Survey Open-File Report 80-970, 69 p.

Ryu, J.-H., 1997, A study of effectiveness of anoxic limestone drains, aerobic wetlands, and successive alkalinity producing systems for treatment of acid mine drainage in Augusta Lake area, Indiana: Bloomington, Indiana University, Department of Geological Sciences, $38 \mathrm{p}$.

Simon, T. P., Dufour, R. L., and Fisher, B. E., 2005, Changes in the biological integrity of fish assemblages in the Patoka River drainage as a result of anthropogenic disturbance from 1888 to 2001, in Rinne, J. N., Hughes, R. M., and Calamusso, B., eds., Historical changes in large river fish assemblages of the Americas: Bethesda, Md., American Fisheries Society Symposium 45, p. 202-212. 


\title{
Metals Removal in Acid Mine Drainage Treatment Wetlands
}

\author{
Ronald T. Smith \\ Indiana Geological Survey
}

\begin{abstract}
Constructed wetlands are commonly used to improve the quality of metal-rich, acidic water originating from disturbed mine lands. The mineral acidity of such water is generated by dissolved iron, aluminum, and manganese, and the water's acidity cannot be successfully mitigated without removing these metals. Natural processes that remove these metals also remove trace metals that account for much of the toxicity of mine drainage. The removal of metals from acid mine drainage was studied in four constructed wetlands on abandoned mine lands in southwestern Indiana.
\end{abstract}

Water and sediments were analyzed for their physicochemical characteristics, major ions, and the trace metals arsenic, beryllium, boron, cadmium, chromium, copper, lead, molybdenum, nickel, selenium, and vanadium. As, Be, Cd, and Se were generally not detectable in the wetland effluent. $\mathrm{Cr}$, $\mathrm{Cu}$, and $\mathrm{Pb}$ appeared in the effluent at levels less than 10 $\mu \mathrm{g} / \mathrm{L}$. Ni levels ranged from 7 to $422 \mu \mathrm{g} / \mathrm{L}$ in the wetland effluents, the greater values being found in wetlands that experienced greater inputs of nickel. Manganese levels decreased from $32.2 \mathrm{mg} / \mathrm{L}$ to $23.8 \mathrm{mg} / \mathrm{L}$ (26\%) along the course of the Augusta Lake wetland in winter; in summer the decrease was only from $20.5 \mathrm{mg} / \mathrm{L}$ to $18.7 \mathrm{mg} / \mathrm{L}$ (9\%). Manganese was generally found at levels greater than $1 \mathrm{mg} / \mathrm{L}$ throughout the Friar Tuck and Midwestern wetlands, while the Tecumseh wetland received only a few $\mathrm{mg} / \mathrm{L}$ in its influent and discharged from 0.2 to $0.3 \mathrm{mg} / \mathrm{L}$ in its effluent. Except for manganese and nickel, the levels of dissolved metals in the effluents did not suggest that metals had accumulated in the sediments or biota along the flow path through the wetlands.

Sequential extraction of wetland sediment revealed that several metals had been sequestered in this environmental compartment. The metals As, Be, Cd, Cr, and Mo had accumulated in sediments at the four wetlands at levels ranging from a few $\mathrm{mg} / \mathrm{kg}$ to greater than $10 \mathrm{mg} / \mathrm{kg}$. The elements $\mathrm{Cu}, \mathrm{Pb}$, and V had accumulated to levels as great as $250 \mathrm{mg} / \mathrm{kg}$, while nickel and zinc were present at levels that approached 1,000 $\mathrm{mg} / \mathrm{kg}$. The sediments contained Mn that ranged from a few $\mathrm{mg} / \mathrm{kg}$ to 16.6 percent by weight. Aluminum levels varied from less than 0.1 percent to 9 percent by weight, while the iron concentration ranged from about 0.2 percent to 43 percent by weight. The flux of iron into wetland sediments was calculated to be within the range of 1 to $8 \mathrm{~g} / \mathrm{m}^{2} /$ day.

Note: Appendices for this paper are located on the CD-ROM in the back of this book. 
Metals levels were determined in Typha, Phragmites, Potamogeton, spike rush, and square stem rush collected from the Tecumseh wetland to evaluate interspecies differences in metals uptake. All these species were found to bioconcentrate trace metals. The metals burden was primarily concentrated in the root tissue, and the submerged species Potamogeton accumulated metals in its leaves as well. Manganese partitioning between the sediments and plants was calculated to determine to what extent bioaccumulation affected the overall fate of metals entering the wetland. It was found that the $9 \mathrm{~kg}$ of manganese stored in the biological compartment constitutes only about 5 percent of the $191 \mathrm{~kg}$ of manganese stored in wetland sediments each year.

Comparison of the metals concentrations in the water, plants, aerobic precipitates, and chemically reduced sediments showed that the constructed wetlands were an effective means of improving water quality in mine land settings. The greatest removal of dissolved metals was found in those wetlands where alkalinity was present. Although most of the toxic metals are removed by wetland processes, nickel and manganese pass through the wetlands at levels that are a significant fraction of their concentrations in the AMD that enters the wetland.

The aerobic processes responsible for removing iron generate large volumes of sludge, which means that the wetlands must be designed with ample space for storing precipitates. Because the flow path is not confined as it is in buried anaerobic treatment structures, wetlands are less prone to fail when a large volume of precipitates has accumulated. Potentially toxic metals stored in the sediments present a disposal challenge when the sediments are excavated. Landuse planners should be aware of the potential ecologic impacts associated with these metals burdens when determining future uses for abandoned mine lands.

\section{INTRODUCTION}

\section{Background and objectives}

The acid mine drainage (AMD) associated with coal mining in the Illinois Basin of the midwestern United States generally contains dissolved toxic metals. These metals can be removed in constructed wetlands by a variety of physical and chemical processes such as precipitation, co-precipitation, ion exchange, complexation with sulfate, adsorption to solid phases, and biological uptake. Toxic metals are sufficiently abundant that they may pose a threat to water quality downstream even when other adverse water characteristics such as high acidity, total dissolved solids, and iron have been mitigated. The intent of the work described here is to track the abundance and distribution of metals through four AMD treatment wetlands and to identify the mechanisms that account for their removal from solution.

Metals that enter a wetland system in AMD must either remain dissolved and pass through the wetland in its effluent, pass from solution into solid phases, or be taken up by wetland organisms. 
These three possible fates can be viewed as three environmental compartments, which include the aqueous phase, the sediment, and the biological compartment. To evaluate the relative importance of the three compartments, metals concentrations were measured in water samples, sediments, and the aquatic plants which make up most of the biomass in wetlands.

\section{Chemical origins of acid mine drainage}

The oxidation of pyritic materials is the primary source of acidity in disturbed mine lands. Most coal beds throughout the midwestern United States contain several percent by weight of pyrite in the form of fine crystals that rapidly oxidize in the presence of water and oxygen as shown by the following equation (Evangelou, 1995):

$$
4 \mathrm{FeS}_{2}+14 \mathrm{O}_{2}+4 \mathrm{H}_{2} \mathrm{O} \rightarrow 4 \mathrm{Fe}^{2+}+8 \mathrm{SO}_{4}{ }^{2-}+8 \mathrm{H}^{+}
$$

Above $\mathrm{pH}$ 4.0, ferrous iron leached from the mine spoil spontaneously oxidizes to ferric iron in the presence of air, according to the following chemical equation (Langmuir, 1997):

$$
4 \mathrm{Fe}^{2+}+\mathrm{O}_{2}+4 \mathrm{H}^{+} \rightarrow 4 \mathrm{Fe}^{3+}+2 \mathrm{H}_{2} \mathrm{O}
$$

Ferric ions rapidly hydrolyze water and form a yellow precipitate while generating acidity:

$$
4 \mathrm{Fe}^{3+}+12 \mathrm{H}_{2} \mathrm{O} \rightarrow 4 \mathrm{Fe}(\mathrm{OH})_{3 \text { (solid) }}+12 \mathrm{H}^{+}
$$

The net reaction for the transformation of pyrite to solid ferric hydroxide releases 2 moles of sulfate and 5 moles of hydrogen ion for every mole of iron sulfide oxidized. The resulting aqueous solution is defined as acid because it contains an excess of hydrogen ions (protons). When the $\mathrm{pH}$ is below 5.0, iron-oxidizing bacteria such as Thiobacillus ferrooxidans thrive, converting pyritic materials into ferric iron at a far more rapid rate and producing additional acidity (Evangelou, 1995). The oxidation of pyritic materials initiates a cascade of proton-producing reactions that promote further dissolution of acidic materials resulting in acid mine drainage. The presence of calcareous rock can help neutralize the acidity generated by pyritic rock. But in a typical Indiana coal mine setting, pyritic material can yield several orders of magnitude more acid than the available calcareous rock can neutralize (ATEC, 1984).

\section{Dissolved metals and mineral acidity}

Because the metal-bearing phases are more soluble under acidic conditions than under neutral conditions, the generation of acid by pyrite weathering leads to high levels of dissolved metals in drainage from the mined land. These metals originate either in the coal or in adjacent rock strata disturbed during mining and are leached from mine spoil and refuse during weathering. Acidic water picks up metals either by direct dissolution of minerals or by cation exchange. Cation exchange involves the displacement of metal ions by the hydrogen ions (protons) that are abundant in acidic water. The chemical equilibria governing reactions that precipitate the relevant metal cations indicate that, as the hydroxide $\left(\mathrm{OH}^{-}\right)$concentration increases, the tendency of the metals to form insoluble hydroxides increases (Stumm and Morgan, 1970). Therefore, raising the $\mathrm{pH}$ toward neutrality results in the precipitation of metal cations from solution.

Acidity is a measure of the capacity of a solution to react with an alkaline species and render it neutral. The total acidity of an aqueous solution is defined as the sum total of its proton acidity $\left(\mathrm{H}^{+}\right)$, its mineral acidity owing to dissolved metals, and its organic acidity owing to dissolved organic compounds. Equation 3 illustrates how mineral acidity, represented by dissolved iron, reacts with water to generate proton acidity. Similarly, manganese and aluminum represent mineral acidity because they also react with water to generate proton acidity, as shown below (Stumm and Morgan, 1970). Equations 4-6 illustrate how divalent manganese and manganese oxyhydroxides and oxides react to release additional protons:

$$
4 \mathrm{Mn}^{2+}+\mathrm{O}_{2}+6 \mathrm{H}_{2} \mathrm{O} \rightarrow 4 \mathrm{Mn}(\mathrm{OOH})_{\text {(solid) }}+8 \mathrm{H}^{+}
$$

Manganese oxyhydroxide is unstable in the presence of ferrous iron and re-dissolves upon reaction with ferrous iron:

$$
\mathrm{Mn}(\mathrm{OOH})+\mathrm{Fe}^{2+} \rightarrow \mathrm{FeOOH}_{\text {(solid) }}+\mathrm{Mn}^{2+}
$$

When oxygen is available, the manganese oxyhydroxide is transformed into manganese dioxide, which also can re-dissolve in the presence of ferrous iron:

$$
\begin{aligned}
& \mathrm{MnO}_{2}+2 \mathrm{Fe}^{2+}+2 \mathrm{H}_{2} \mathrm{O} \rightarrow 2 \mathrm{FeOOH}_{\text {(solid) }} \\
& +\mathrm{Mn}^{2+}+2 \mathrm{H}^{+}
\end{aligned}
$$


In sum, as long a ferrous iron remains in the water, manganese can re-dissolve from sediment and propagate mineral acidity downstream.

Likewise, aluminum is leached from shales and clays by AMD (Behum and Kim, 1999). Dissolved aluminum generates acidity as follows:

$$
\mathrm{Al}^{3+}+3 \mathrm{H}_{2} \mathrm{O} \rightarrow \mathrm{Al}(\mathrm{OH})_{3(\text { solid })}+3 \mathrm{H}^{+}
$$

At $\mathrm{pH}$ values below the range of 4 to 4.5 , aluminum hydroxide is soluble, allowing aluminum to remain in solution or re-dissolve and transfer its potential acidity downstream.

As long as sufficient acid-generating metals remain in solution, acidity can recur by hydrolysis interactions described in equations 2 through 7. Other dissolved heavy metals are capable of generating acidity as well, but their contributions to mineral acidity are insignificant because their concentrations in AMD are generally orders of magnitude less than those of iron, manganese, and aluminum.

The dissolved metals responsible for generating mineral acidity must be removed from solution or the $\mathrm{pH}$ of partially treated water will decline over time. The high solubility of ferrous iron and manganese make them the most problematic sources of mineral acidity. Ferrous iron does not completely precipitate from solution at $\mathrm{pH}$ values below 10 units and manganese requires a $\mathrm{pH}$ of 9 units or higher before it precipitates completely in a stable form (Franco and Balouskus, 1974). On the other hand, ferric iron precipitation begins around $\mathrm{pH}$ 3 , with the most effective $\mathrm{pH}$ value for its removal is 6.5 units (Dietz and Dempsey, 1980). For this reason, aeration is used in addition to raising the $\mathrm{pH}$ as a means of removing iron.

\section{Wetlands for treating acid mine drainage}

Constructed wetlands are widely used for the long-term treatment of acid mine drainage (McCleary and Keppler, 1994). The Indiana Department of Natural Resources, Division of Reclamation has constructed more than 15 AMD treatment wetlands in areas where AMD is a significant problem. The decision to install a wetland for AMD treatment is usually based on site-specific factors and well-established treatability criteria. The U.S. Bureau of Mines has published a multistep treatability model that distinguishes different types of AMD and reclamation settings and facilitates choosing the most appropriate means of treatment (Bureau of Mines, 1994). The first step involves sampling and the chemical characterization of the AMD and the flow volume. The second step is to classify the water as net alkaline or net acidic. This distinction is based upon the concentration of dissolved iron relative to the water's alkalinity. In order for water to be classified as net alkaline there must be at least $1.8 \mathrm{mg} / \mathrm{L}$ of alkalinity for every $1 \mathrm{mg} / \mathrm{L}$ of dissolved iron (Hedin and Nairn, 1992).

When the water to be treated is net alkaline, the use of a wetland is indicated. Water classified as net acidic must be rendered alkaline by pretreatment before introduction to an aerobic wetland. If the acidity is not exceptionally high and there is very little dissolved oxygen in the AMD, then a compact structure such as an anoxic limestone drain (ALD) can produce the required alkalinity (Hedin and Nairn, 1992). Other types of alkalinity-generating structures installed in treatment wetlands in Indiana include compost wetlands, successive alkalinity-producing systems, limestone ponds, and concentrated alkaline recharge pits. Once a means of introducing alkalinity has been established, the later treatment stages generally provide for aeration and the collection and storage of precipitated metals.

Ultimately, the success of metals removal depends upon the original chemical composition of the AMD, the maintenance of alkalinity, the surface area of the wetland, and the retention time of the AMD in the wetland (Behum and Kim, 1999). The establishment of vegetation is also a factor because it stabilizes sediments, baffles water flow, and reduces water velocity and wind damage (Prasad, 2001). Submerged stems and roots support microbes and algae that aid in AMD oxidation and metals removal (Emerson and others, 1999).

\section{STUDY AREAS}

\section{Augusta Lake wetland}

Augusta Lake is located in sections 15 and 16, T. 2 S. and R. 7 W. in Pike County, Indiana (fig. 1). Most of the Augusta Lake watershed has been disturbed by surface and underground mining and was identified as a source of AMD as early as 1949 


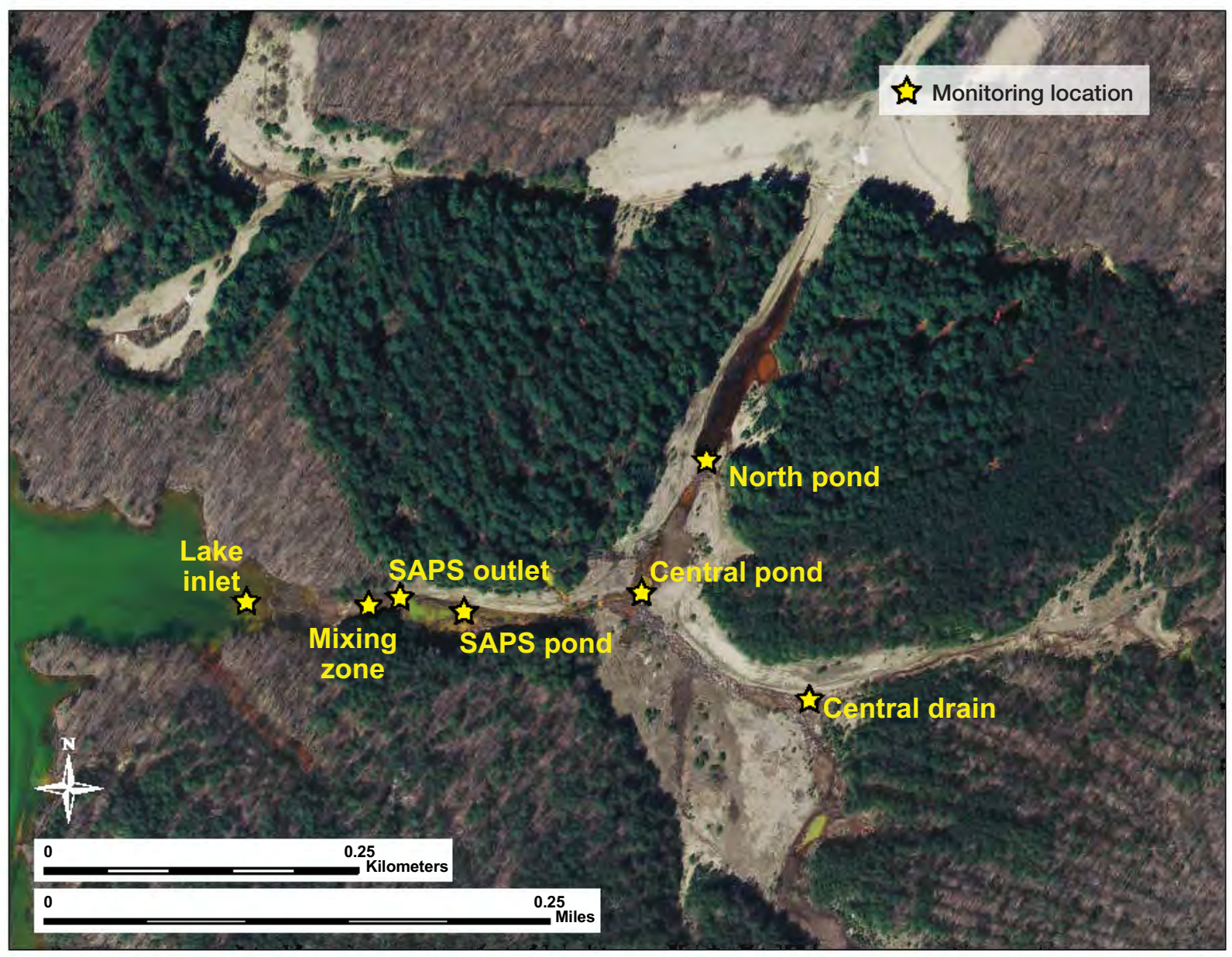

Figure 1. Orthophoto showing the Augusta Lake wetland and the location of sampling sites.

(Comer and others, 2012 [this volume]). Augusta Lake is a large impoundment that was constructed in 1950 as a holding pond for impaired water from the upper watershed (Comer and others, 2000, 2012 [this volume]). The surface features within the study area are composed entirely of disturbed overburden from the Dugger Formation (Carbondale Group, Pennsylvanian), and the bed of Augusta Lake is in contact with the Springfield (V) Coal Member (Petersburg Formation, Carbondale Group, Pennsylvanian) (ATEC, 1984). Augusta Lake discharges highly acidic water northward into Mill Creek and the Patoka River. Spoil ridges and abandoned underground mines have been found to be the major sources of acidity, sulfate, iron, and manganese in the lake (ATEC, 1984; Comer and others, 2000, 2012 [this volume]).

The treatment system studied during this investigation (fig. 1) was constructed in the 1990s, and included a series of 15 anoxic limestone drains that intercepted seeps originating in the spoil ridges and the outflow from the abandoned underground mine located to the southeast. A large ALD was installed in 1993 to treat the major acid seep in the northeastern drainage of the Augusta Lake watershed. A prior study by the Indiana Geological Survey showed that the AMD from this seep contained up to $76 \mathrm{mg} / \mathrm{L}$ of aluminum (Comer and others, 2000). This ALD and some others installed along this channel became clogged with aluminum within the first 6 months of operation (W. McCoy, U.S. Fish and Wildlife Service, written commun., August 5, 2008).

The ALDs installed at Augusta Lake vary in size from about $6 \mathrm{ft}$ by $50 \mathrm{ft}(1.8$ by $15.2 \mathrm{~m})$ to three times these dimensions. The ALDs discharge into wetland oxidation ponds, then flow through stands of Typha, until the combined flows merge into a single stream that feeds into a successive alkalinityproducing system (SAPS). The SAPS is $40 \mathrm{ft}$ by 140 ft (12.2 by $42.7 \mathrm{~m})$ long, and six segments of perforated PVC pipe are embedded in its base. Acid 
mine drainage is meant to percolate downward through a submerged bed containing 6 inches $(15 \mathrm{~cm})$ of wood waste and sewage sludge, then a 2 -ft $(0.6-\mathrm{m})$ layer of lime-stabilized compost, and finally a layer of 2-inch $(5-\mathrm{cm})$ crushed limestone on the bottom. In the bottom layer of crushed limestone, the AMD is collected by the perforated PVC pipes and conveyed to a 4 -inch $(10-\mathrm{cm})$ pipe that discharges downstream from the spillway. The majority of the AMD flows over the spillway and mixes with the treated water in a Typha wetland below, then enters Augusta Lake.

The Augusta Lake system of scattered wetlands was sampled at four locations in late winter of 2000 (Table 1; fig. 1). Sampling points were: North pond, which drains the problematic northern spoils deposits; Central pond, which collects drainage from the North pond and additional AMD seepage from spoil to the east and northwest; SAPS pond, which collects the combined flow from the northern, central, and southern tributaries; and Lake inlet, which is the wetland below the SAPS near its confluence with Augusta Lake and represents the effluent from the wetland system.

A second sampling was conducted on September 28, 2000. For the second sampling, the Central pond sampling point was moved to the Central drain (fig. 1) on the eastern tributary, where prior work had established the presence of alkalinity. The move was intended to gather information on the shortage of alkalinity throughout the system by observing the fate of the alkaline waters present in this part of the watershed. In an effort to determine why metals were not precipitating completely before leaving the system, the Lake inlet sampling point was moved to the Mixing zone (fig. 1), where the water that percolates through the SAPS mixes with surface water that flows over the SAPS pond weir.

\section{Friar Tuck wetland}

The Friar Tuck wetland is located northeast of Dugger, Ind., in T. 8 N., R. 7 W., Wright Township section 31, Greene County (fig. 2). The wetland occupies the bed of an artificial lake whose dam was breached after its water became too acidic to support aquatic life. Formerly, extensive surface and underground mines, a power plant, and a coal processing plant were operated on the property (Harper and others, 2012 [this volume]). Four coal beds were mined in the past; the spoil was heaped in a series of steep ridges and large deposits of coarse refuse (gob) were created (fig. 2). During the preceding decades, these features were directly revegetated with pine trees. The Southeast Gob Deposit (Harper and others, 2012 [this volume]) stores a large volume of acidic water, some of which slowly seeps into the study area. Prior to 1998, much of this AMD was retained by a berm and diverted along a perimeter drain into a containment area. During the years when this AMD was diverted, a wetland of Typha and Phragmites became established in the bed of the preexisting lake. The primary source of water for the wetland is a freshwater stream that flows northward and enters the site from reclaimed land at a higher elevation in watershed (fig. 2).

In 1998, the dam that formed the original lake was reconstructed at its former location, creating a flooded zone with a pond surface elevation several feet lower than that of the original lake. Subsequently, the berm that retained the AMD seeping from the Southeast gob deposit was breached and the drainage was diverted through a channel lined with limestone riprap into the central part of the wetland where it mixed with the freshwater stream. The AMD from the breached berm is severely acidic but its flow is relatively small in comparison to that of the freshwater feeder stream.

Although the water at the reconstructed dam and spillway remains somewhat acidic $(\mathrm{pH} 5)$, there is considerable use of the open-water area by wildlife. A beaver dam situated atop the spillway has raised the surface level of the impounded water by approximately 18 inches $(45.7 \mathrm{~cm})$. The effluent from the wetland flows northward through a channel eroded in an expanse of bottom land before entering Mud Creek, the primary stream which flows westward along the northern edge of the Friar Tuck Reclamation Site (Harper and others, 2012 [this volume]).

The Friar Tuck wetland was sampled at four locations (fig. 2): feeder stream, which is the alkalinity-bearing stream where it enters the wetland; AMD seep, which is the major acid seep issuing from the base of the southeast gob deposit at the discharge point of the riprap channel; mixing zone, where acidic and alkaline waters mix and metals precipitate; and Weir, which is the point where water flows from the wetland pond at the discharge weir of the reconstructed dam. 


\section{Midwestern wetland}

The Midwestern Reclamation Site is located north of State Highway 64 in Pike County southeast of Augusta Lake and represents the southern portion of Reclamation Site 1087 (Midwestern) (fig. 3). It lies entirely within secs. 22 and 27 of T. 2 S. and R. 7 W. Site 1087 consists of about 550 acres (222.6 hectares [ha]) of surface-mined land that adjoins and, in some cases, intersects underground mine workings (Bryenton and Gasper, 1994, p. 6). Although the central portion of the Midwestern site was regraded during reclamation work in 1995, vegetated spoil ridges and gob piles remain that discharge acidic drainage.

The Midwestern wetland (fig. 3) was constructed in 1997 to passively treat AMD seeping from the flooded workings of the abandoned underground Hartwell No. 2 mine. The wetland was constructed in an area formerly occupied by a highwall pond containing acidic water that accumulated mostly from the underground mine (ATEC, 1984; Branam and others, 2012 [this volume]). The wetland was sealed off from the original bed of the highwall pond by a layer of compacted pond ash from a nearby power plant (Branam and others, 2012 [this volume]). Within the wetland, berms and baffles were constructed of mine spoil and lined with limestone riprap. The surface area of the entire wetland is 2.5 acres (1.0 ha).

The underground mine discharge flows into a buried ALD before entering the constructed wetland (fig. 3). The water is directed from the ALD into an anaerobic compost wetland (Cell 1A), whose water level is maintained at a constant elevation by discharge through a standpipe. Water discharged through the standpipe is aerated in a steep limestone-lined channel before entering Cell 1B, an oxidation pond where the water level is kept constant by a riser. Rapid iron oxidation and precipitation is evident in Cell $1 \mathrm{~B}$ in the large volume of red sediment that is seen throughout the cell. The remainder of the wetland consists of 11 more cells arranged in a serpentine pattern. The cells contain substrates composed of various combinations of hay, turkey manure, soil, over a bed composed of pond ash. About halfway through the sequence of aeration cells lies Cell 2C2, where the substrate was changed to a mixture of 70 percent wood chip compost and 30 percent fixated scrubber sludge and lime, placed over a base of ponded coal ash.
The final four segments of Cell $2 \mathrm{C}$ received a mixture of the soil and manure substrate at a progressively greater ratio of turkey manure to soil. The ratio of manure to soil gradually increased from an initial 3 parts soil for every part of manure to a ratio of 1.5 parts soil to 1 part manure in the final cell. The high ratios of turkey manure to soil in the final cells inhibited the establishment of vegetation. At present, Typha is established throughout most of the lower wetland, but remains sparse in the final cell. The wetland apparently is successful, as iron oxidation and precipitation are evident in the upper cells, vegetation predominates, and wildlife, including frogs, is plentiful.

The sampling locations chosen (fig. 3) were: upper Cell 1, where water flows from the buried ALD; Cell 1A, where water discharges from the Cell 1A standpipe into an oxidation pond; Cell $1 \mathrm{~B}$, where water discharges from Cell 1B; Cell 2A, at the baffle between Cell 2A and 2B1; Cell 2B2, where water discharges from Cell 2B2; Cell 2B3, where water discharges from Cell 2B3 downstream from where an intermittent seep enters the system; Cell 2C2, downstream from the wood chip and sewage sludge substrate; Cell 2C4, where water discharges at the weir from Cell 2C4; and Outlet, where water exits the final treatment cell (2C7).

An effort was made to sample the upper part of Cell 1A where the ALD discharges by digging a hole in the pea gravel and allowing the water to settle. The sediment here consisted of a thin coating of iron precipitate on pea gravel. It was too difficult to separate this layer from the gravel and was impossible to obtain an interstitial water sample from the thin layer of iron oxide, therefore, this sampling point (upper Cell 1) was abandoned.

\section{Tecumseh wetland}

The Tecumseh wetland occupies the site of the abandoned Tecumseh Mine and coal processing plant in Owen Township section 17, R. 7 W., T. 4 S., Warrick County, Ind. (fig. 4). A broad, gently contoured mound of spoil and gob and low-lying tailings dominates the site. The mound impounds the water of upper Barren Fork, forming a freshwater lake. Water percolates through the mound, oxidizes pyrite, and emerges from its toe, creating at least four acid seeps. Anoxic limestone drains have been installed within the mound to intercept these seeps. The DNR constructed an AMD treatment wetland in the broad flood plain below the Tecumseh spoil 
Table 1. Data documenting the quality of surface water in the four wetlands

[NA = not analyzed. Site locations are shown in Figures 1-4.]

\begin{tabular}{|c|c|c|c|c|c|c|c|c|c|c|c|c|c|c|c|}
\hline Site & Sampling & $\begin{array}{c}\mathrm{pH} \\
\text { (s.u.) }\end{array}$ & $\begin{array}{c}\text { Eh } \\
\text { (mV) }\end{array}$ & \begin{tabular}{|c} 
TDS \\
(mg/L)
\end{tabular} & \begin{tabular}{|l} 
Acidity \\
(mg/L)
\end{tabular} & $\begin{array}{l}\text { Alka- } \\
\text { linity } \\
\text { (mg/L) }\end{array}$ & $\begin{array}{c}\mathrm{SO}_{4} \\
(\mathrm{mg} / \mathrm{L})\end{array}$ & $\begin{array}{c}\mathrm{Al} \\
(\mathrm{mg} / \mathrm{L})\end{array}$ & $\begin{array}{c}\mathrm{Ca} \\
(\mathrm{mg} / \mathrm{L})\end{array}$ & $\begin{array}{c}\mathrm{Mg} \\
(\mathrm{mg} / \mathrm{L})\end{array}$ & $\begin{array}{c}\mathrm{K} \\
(\mathrm{mg} / \mathrm{L})\end{array}$ & $\begin{array}{c}\mathrm{Na} \\
(\mathrm{mg} / \mathrm{L})\end{array}$ & $\begin{array}{c}\mathrm{Fe} \\
(\mathrm{mg} / \mathrm{L})\end{array}$ & $\begin{array}{c}\mathrm{Mn} \\
(\mathrm{mg} / \mathrm{L})\end{array}$ & $\begin{array}{c}\mathrm{Zn} \\
(\mathrm{mg} / \mathrm{L})\end{array}$ \\
\hline \multicolumn{16}{|c|}{ Augusta Lake wetland } \\
\hline North pond & winter & 2.7 & 672 & 3,572 & NA & 0 & 2,787 & 0.2 & 444 & 194 & 7 & 2 & 104.4 & 32.2 & 0.9 \\
\hline Central pond & winter & 2.5 & 749 & 3,449 & NA & 0 & 2,670 & 0.3 & 420 & 181 & 7 & 5 & 133.6 & 31.9 & 1.0 \\
\hline SAPS pond & winter & 2.6 & 643 & 3,068 & 233 & 0 & 2,310 & 4.1 & 432 & 230 & 6 & 11 & 49.8 & 23.2 & 1.0 \\
\hline Lake inlet & winter & 3.4 & 551 & 3,046 & 151 & 0 & 2,344 & 5.3 & 446 & 205 & 7 & 5 & 8.5 & 23.8 & 0.9 \\
\hline North pond & summer & 3.5 & 501 & 2,852 & 178 & 0 & 2,031 & $<0.1$ & 640 & 141 & 6 & 6 & 7.1 & 20.5 & 0.7 \\
\hline Central drain & summer & 6.8 & 270 & 2,913 & 89 & 102 & 2,052 & $<0.1$ & 641 & 151 & 9 & 10 & 33.1 & 15.4 & 0.4 \\
\hline SAPS outlet & summer & 9.1 & 185 & 2,780 & 24 & 140 & 1,936 & $<0.1$ & 645 & 147 & 6 & 4 & 38.7 & 2.1 & 0.4 \\
\hline Mixing zone & summer & 5.6 & 372 & 2,538 & 82 & 19 & 1,977 & 0.4 & 371 & 126 & 6 & 8 & 30.2 & 18.7 & 0.8 \\
\hline \multicolumn{16}{|c|}{ Friar Tuck wetland } \\
\hline Feeder stream & winter & 7.3 & 388 & 1,653 & 30 & 173 & 1304 & $<0.1$ & 208 & 108 & 5 & 22 & 4.1 & 2.0 & 0.1 \\
\hline AMD seep & winter & 2.9 & 605 & 2,666 & 6,220 & 0 & $>11,000$ & 422.8 & 807 & 241 & 8 & 30 & $1,045.8$ & 92.0 & 19.1 \\
\hline Mixing zone & winter & 4.6 & 446 & 1,583 & 32 & 132 & 1,252 & 0.3 & 198 & 90 & 4 & 19 & 14.7 & 4.0 & 0.3 \\
\hline Weir & winter & 5.3 & 438 & 1,222 & 34 & 85 & 930 & 0.4 & 170 & 88 & 5 & 15 & 4.7 & 8.3 & 0.2 \\
\hline Feeder stream & summer & 7.6 & 428 & 1,637 & 55 & 301 & 1,126 & $<0.1$ & 389 & 91 & 5 & 17 & 7.9 & 1.5 & 0.3 \\
\hline AMD seep & summer & 2.6 & 607 & 11,365 & 6,093 & 0 & 8,620 & 381.0 & 789 & 371 & 18 & 33 & $1,100.2$ & 37.0 & 16.3 \\
\hline Mixing zone & summer & 5.8 & 326 & 1,541 & 57 & 19 & 949 & $<0.1$ & 391 & 174 & 5 & 16 & \begin{tabular}{|l|}
0.7 \\
\end{tabular} & 4.6 & 0.6 \\
\hline Weir & summer & 6.1 & 246 & 1,814 & 70 & 28 & 1,075 & $<0.1$ & 455 & 244 & 5 & 22 & 7.8 & 4.7 & 0.4 \\
\hline \multicolumn{16}{|c|}{ Midwestern wetland } \\
\hline Cell 1A & winter & 6.5 & 172 & 2,230 & 122 & 310 & 1,720 & $<0.1$ & 236 & 190 & 9 & 16 & 49.9 & 8.7 & 0.1 \\
\hline Cell 1B & winter & & & 2,499 & & & 1,852 & $<0.1$ & 259 & 263 & 7 & 23 & 78.6 & 15.6 & 0.6 \\
\hline Cell 2A & winter & 7.1 & 317 & 1,914 & 35 & 188 & 1,451 & $<0.1$ & 245 & 184 & 11 & 16 & 0.3 & 7.3 & 0.1 \\
\hline Cell 2B2 & winter & 7.3 & 297 & 1,666 & 36 & 158 & 1,263 & $<0.1$ & 213 & 161 & 11 & 13 & 0.6 & 4.6 & 0.1 \\
\hline Cell 2B3 & winter & 5.5 & 351 & 1,521 & 40 & 17 & 1,132 & 1.2 & 211 & 137 & 9 & 17 & 7.2 & 6.8 & 0.3 \\
\hline Cell 2C2 & winter & 6.3 & 337 & 1,542 & 26 & 42 & 1,160 & 0.2 & 210 & 137 & 8 & 17 & 0.4 & 7.8 & 0.8 \\
\hline Outlet & winter & 7.0 & 320 & 1,059 & 15 & 76 & 763 & $<0.1$ & 187 & 85 & 9 & 10 & 4.0 & 0.7 & 0.6 \\
\hline Cell $1 \mathrm{~A}$ & summer & 6.1 & 131 & 3,485 & 142 & 248 & 2,413 & $<0.1$ & 697 & 202 & 9 & 25 & 124.4 & 13.8 & 0.5 \\
\hline Cell 1B & summer & 6.6 & 241 & 2,950 & 30 & 201 & 2,093 & $<0.1$ & 644 & 183 & NA & 23 & 0.2 & 6.3 & 0.4 \\
\hline Cell 2B2 & summer & 6.6 & 232 & 2,849 & 64 & 205 & 1,980 & $<0.1$ & 656 & 173 & 12 & 23 & 0.2 & 4.1 & 0.4 \\
\hline Cell 2B3 & summer & 6.3 & 271 & 2,176 & 32 & 186 & 1,443 & $<0.1$ & 566 & 126 & 12 & 22 & 0.2 & 6.2 & 0.3 \\
\hline Cell 2C2 & summer & 6.5 & 325 & 2,126 & 63 & 196 & 1,414 & 0.6 & 556 & 115 & 14 & 20 & 0.2 & 6.6 & 0.3 \\
\hline Outlet & summer & 6.4 & 341 & 1,825 & 28 & 217 & 1,172 & $<0.1$ & 510 & 97 & 18 & 20 & 0.2 & 8.4 & 0.3 \\
\hline \multicolumn{16}{|c|}{ Tecumseh wetland } \\
\hline Cell 1 & winter & 6.1 & 248 & 1,976 & 22 & 123 & 1,522 & $<0.1$ & 198 & 230 & 6 & 13 & 6.0 & 0.7 & 0.5 \\
\hline Cell 2 & winter & 6.6 & 209 & 2,216 & 24 & 84 & 1,608 & $<0.1$ & 242 & 233 & 10 & 117 & 5.1 & 0.8 & 0.1 \\
\hline Cell 4A & winter & 3.1 & 590 & 4,759 & 1,304 & 0 & 3,358 & 12.7 & 314 & 231 & 18 & 110 & 708.0 & 5.8 & 1.0 \\
\hline Cell 4B & winter & 6.9 & 236 & 2,085 & 27 & 111 & 1,520 & $<0.1$ & 196 & 235 & 8 & 121 & 4.6 & 0.6 & 0.1 \\
\hline Cell 5 & winter & 7.2 & 424 & 2,009 & 18 & 82 & 1,442 & $<0.1$ & 223 & 222 & 8 & 113 & 0.1 & 0.3 & 0.5 \\
\hline Cell 2 & summer & 7.4 & 255 & 2,163 & 56 & 128 & 1,466 & $<0.1$ & 414 & 158 & 10 & 114 & 0.9 & 0.3 & 0.1 \\
\hline Cell 4A & summer & 2.9 & 622 & 12,112 & NA & 0 & 8,191 & 51.8 & 1021 & 228 & 27 & 111 & $2,462.0$ & 17.3 & 2.8 \\
\hline Cell 4B & summer & 4.6 & 515 & 3,045 & 73 & 12 & 2,294 & $<0.1$ & 437 & 160 & 11 & 119 & 20.7 & 2.2 & 0.1 \\
\hline Cell 5 & summer & 8.3 & 342 & 2,309 & 39 & 103 & 1,405 & $<0.1$ & 701 & 89 & 8 & 106 & 0.3 & 0.2 & 0.1 \\
\hline
\end{tabular}


Table 1 (cont.). Data documenting the quality of surface water in the four wetlands

[NA = not analyzed. Site locations are shown in Figures 1-4.]

\begin{tabular}{|c|c|c|c|c|c|c|c|c|c|c|c|c|}
\hline Site & Sampling & $\begin{array}{c}\text { As } \\
(\mu \mathrm{g} / \mathrm{L})\end{array}$ & $\begin{array}{c}\text { B } \\
(\mathrm{mg} / \mathrm{L})\end{array}$ & $\begin{array}{c}\mathrm{Be} \\
(\mu \mathrm{g} / \mathrm{L})\end{array}$ & $\begin{array}{c}\mathrm{Cd} \\
(\mu \mathrm{g} / \mathrm{L})\end{array}$ & $\begin{array}{c}\mathrm{Cr} \\
(\mu \mathrm{g} / \mathrm{L})\end{array}$ & $\begin{array}{c}\mathrm{Cu} \\
(\mu \mathrm{g} / \mathrm{L})\end{array}$ & $\begin{array}{c}\text { Mo } \\
(\mu \mathrm{g} / \mathrm{L})\end{array}$ & $\begin{array}{c}\mathrm{Ni} \\
(\mu \mathrm{g} / \mathrm{L})\end{array}$ & $\begin{array}{c}\mathrm{Pb} \\
(\mu \mathrm{g} / \mathrm{L})\end{array}$ & $\begin{array}{c}\mathrm{Se} \\
(\mu \mathrm{g} / \mathrm{L})\end{array}$ & $\begin{array}{c}V \\
(\mu g / L)\end{array}$ \\
\hline \multicolumn{13}{|c|}{ Augusta Lake wetland } \\
\hline North pond & winter & $<1$ & 0.2 & 19 & 4.8 & 4 & $<1$ & 11 & 750 & 1.9 & $<1$ & $<1$ \\
\hline Central pond & winter & $<1$ & 0.2 & 18 & 6.7 & 5 & $<1$ & 13 & 924 & 1.4 & $<1$ & $<1$ \\
\hline SAPS pond & winter & $<1$ & NA & 5 & 3.4 & 1 & 4 & 9 & 371 & 0.8 & $<1$ & $<1$ \\
\hline Lake inlet & winter & $<1$ & 0.2 & 4 & 3.2 & $<1$ & 10 & 6 & 418 & 1.5 & $<1$ & $<1$ \\
\hline North pond & summer & 1 & NA & 5 & 3.8 & $<1$ & 5 & $<1$ & 391 & 32.9 & $<1$ & $<1$ \\
\hline Central drain & summer & 2 & 0.3 & $<1$ & 5.2 & 2 & $<1$ & $<1$ & 297 & 0.7 & $<1$ & $<1$ \\
\hline SAPS outlet & summer & $<1$ & 0.2 & $<1$ & $<0.4$ & $<1$ & 0 & 5 & 398 & 0.4 & $<1$ & $<1$ \\
\hline Mixing zone & summer & $<1$ & 0.2 & 1 & 0.2 & 3 & $<1$ & $<1$ & 422 & 2.1 & $<1$ & $<1$ \\
\hline \multicolumn{13}{|c|}{ Friar Tuck wetland } \\
\hline Feeder stream & winter & $<1$ & 0.3 & $<1$ & $<0.4$ & $<1$ & $<1$ & 13 & 17 & $<0.5$ & $<1$ & 3 \\
\hline AMD seep & winter & $<1$ & 3.0 & 56 & 30.4 & 42 & 47 & 8 & 1,088 & 3.8 & $<1$ & 168 \\
\hline Mixing zone & winter & $<1$ & 0.2 & $<1$ & 0.8 & $<1$ & 3 & 4 & 31 & $<0.5$ & $<1$ & 10 \\
\hline Weir & winter & $<1$ & 0.2 & $<1$ & 0.7 & 1 & $<1$ & 5 & 9 & $<0.5$ & $<1$ & 24 \\
\hline Feeder stream & summer & $<1$ & 0.3 & $<1$ & 0.2 & $<1$ & $<1$ & $<1$ & 5 & 0.3 & $<1$ & $<1$ \\
\hline AMD seep & summer & $<1$ & 2.9 & 25 & 28.8 & 40 & 11 & $<1$ & 1,307 & 0.8 & $<1$ & 320 \\
\hline Mixing zone & summer & $<1$ & 0.3 & $<1$ & 0.3 & $<1$ & $<1$ & $<1$ & 13 & 0.6 & $<1$ & $<1.0$ \\
\hline Weir & summer & $<1$ & 0.3 & 1 & 0.2 & 4 & 2 & $<1$ & 7 & 5.3 & $<1$ & 11 \\
\hline \multicolumn{13}{|c|}{ Midwestern wetland } \\
\hline Cell 1A & winter & 2 & 0.5 & $<1$ & $<0.4$ & $<1$ & 1 & 8 & 47 & $<0.5$ & $<1$ & $<1$ \\
\hline Cell 1B & winter & $<1$ & 0.6 & $<1$ & $<0.4$ & 1 & $<1$ & 9 & 260 & $<0.5$ & $<1$ & $<1$ \\
\hline Cell 2A & winter & $<1$ & 0.5 & $<1$ & 0.6 & $<1$ & $<1$ & 7 & 54 & $<0.5$ & $<1$ & $<1$ \\
\hline Cell 2B2 & winter & $<1$ & 0.4 & $<1$ & 0.4 & $<1$ & $<1$ & 6 & 37 & $<0.5$ & $<1$ & $<1$ \\
\hline Cell 2B3 & winter & $<1$ & 0.3 & $<1$ & 5.5 & $<1$ & $<1$ & 4 & 179 & $<0.5$ & $<1$ & $<1$ \\
\hline Cell 2C2 & winter & 1 & 0.3 & $<1$ & 4.4 & $<1$ & $<1$ & 5 & 163 & $<0.5$ & 2 & $<1$ \\
\hline Outlet & winter & 1 & 0.2 & $<1$ & 0.6 & $<1$ & $<1$ & 4 & 37 & $<0.5$ & 1 & $<1$ \\
\hline Cell 1A & summer & 1 & 0.0 & $<1$ & $<0.4$ & 6 & $<1$ & $<1$ & 250 & $<0.1$ & $<1$ & $<1$ \\
\hline Cell 1B & summer & 1 & 0.5 & $<1$ & $<0.4$ & $<1$ & $<1$ & $<1$ & 18 & $<0.1$ & $<1$ & $<1$ \\
\hline Cell 2B2 & summer & 2 & 0.4 & $<1$ & 0.4 & $<1$ & $<1$ & $<1$ & 233 & 5.2 & $<1$ & $<1$ \\
\hline Cell 2B3 & summer & $<1$ & 0.3 & $<1$ & 0.2 & $<1$ & $<1$ & $<1$ & 53 & $<0.1$ & $<1$ & $<1$ \\
\hline Cell 2C2 & summer & 1 & 0.3 & $<1$ & 0.1 & $<1$ & $<1$ & $<1$ & 20 & $<0.1$ & 1 & $<1$ \\
\hline Outlet & summer & 1 & 0.2 & $<1$ & 1.4 & 1 & $<1$ & $<1$ & 13 & 1.1 & $<1$ & $<1$ \\
\hline \multicolumn{13}{|c|}{ Tecumseh wetland } \\
\hline Cell 1 & winter & 1 & 0.4 & $<1$ & $<0.4$ & $<1$ & $<1$ & 5 & 10 & $<0.5$ & $<1$ & 4 \\
\hline Cell 2 & winter & $<1$ & 0.4 & $<1$ & $<0.4$ & $<1$ & $<1$ & 4 & 14 & 1.2 & 1 & $<1$ \\
\hline Cell 4A & winter & $<1$ & 1.2 & 3 & 0.9 & 2 & 2 & 5 & 106 & 1.0 & $<1$ & 16 \\
\hline Cell 4B & winter & $<1$ & 0.4 & $<1$ & $<0.4$ & $<1$ & $<1$ & 6 & 6 & $<0.5$ & 2 & $<1$ \\
\hline Cell 5 & winter & $<1$ & 0.4 & $<1$ & $<0.4$ & $<1$ & $<1$ & 5 & 5 & $<0.5$ & 1 & 1 \\
\hline Cell 2 & summer & $<1$ & 0.4 & $<1$ & 3.4 & $<1$ & $<1$ & $<1$ & 37 & 0.6 & $<1$ & $<0.1$ \\
\hline Cell 4A & summer & $<1$ & 3.0 & 18 & 4.5 & 5 & 3 & $<1$ & 343 & 0.1 & $<1$ & 45 \\
\hline Cell 4B & summer & 1 & 0.4 & $<1$ & 0.2 & 4 & 1 & $<1$ & 29 & $<0.1$ & $<1$ & $<1$ \\
\hline Cell 5 & summer & 1 & 0.4 & $<1$ & 0.3 & 1 & $<1$ & $<1$ & 15 & $<0.1$ & $<1$ & $<1$ \\
\hline
\end{tabular}




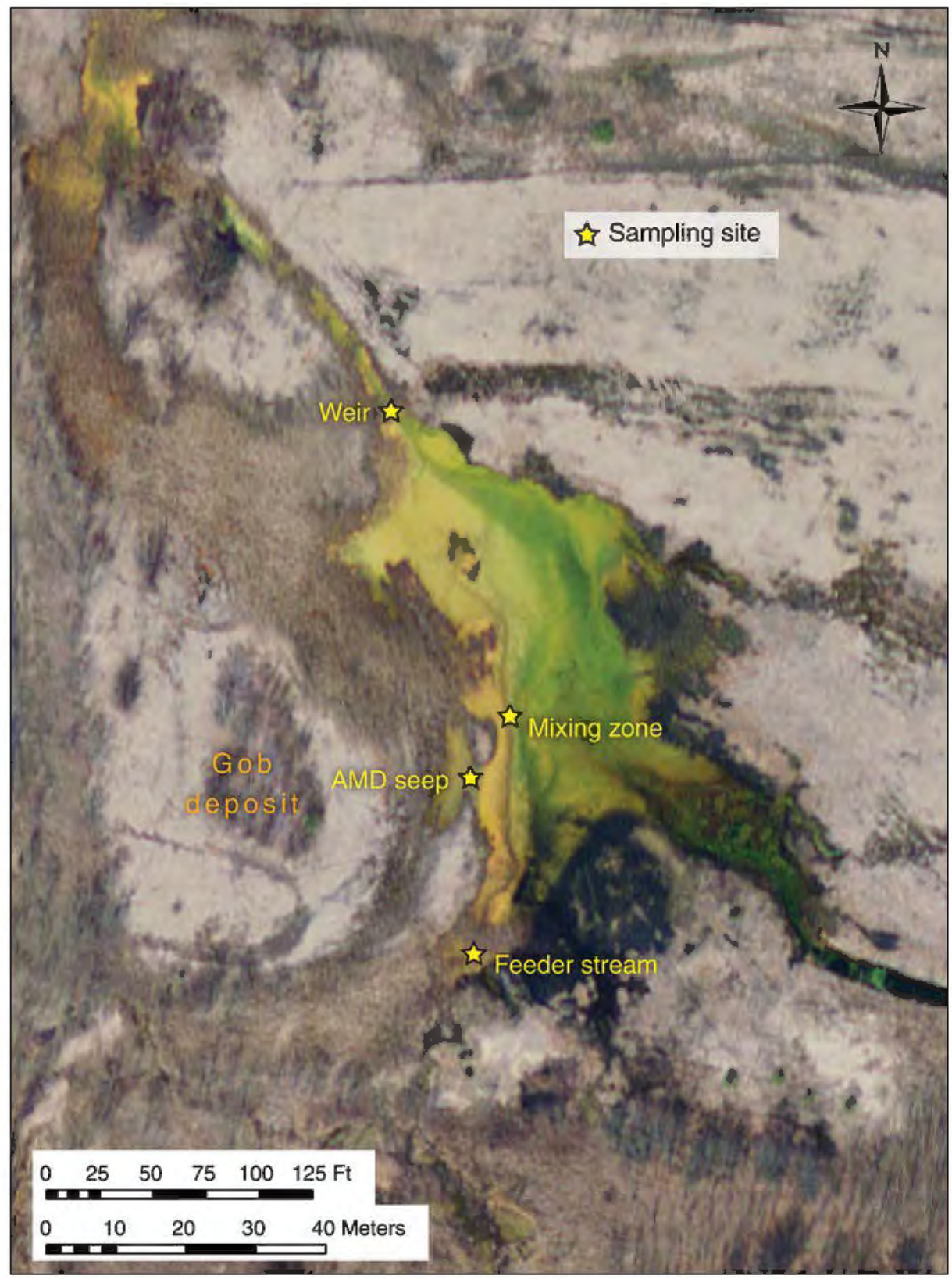

Figure 2. Orthophoto showing the Friar Tuck wetland and the location of sampling sites.

mound to collect the discharges from these ALDs and other seeps. Fresh water from the lake is introduced along the west side of the mound and flows laterally through Cell 1 along the toe of the hill to collect the drainage (fig. 4). The combined water then follows a serpentine path through a sequence of baffles, forming a series of four long, narrow cells. In addition to the AMD generated by the main spoil deposit, AMD from another large seep is directed through a limestone drain into the cell designated "4A." Its water mixes with that of Cell 4B, which is a conduit for the water from the upper serpentine wetland cells (fig. 4). The combined effluent from these two sources enters the upper portion of the large pond designated "Cell 5" on the former site of a coal slurry pond that occupied the flood plain of Barren Fork. The lower part of Cell 5 has been sloped to drain and contains a number of islands and other structures meant to baffle flow.

The base of the entire wetland system consists of a bottom layer of sand covered with a 1-ft-thick (30.5-cm-thick) layer of turkey manure compost. The turkey manure compost is a mixture of three 


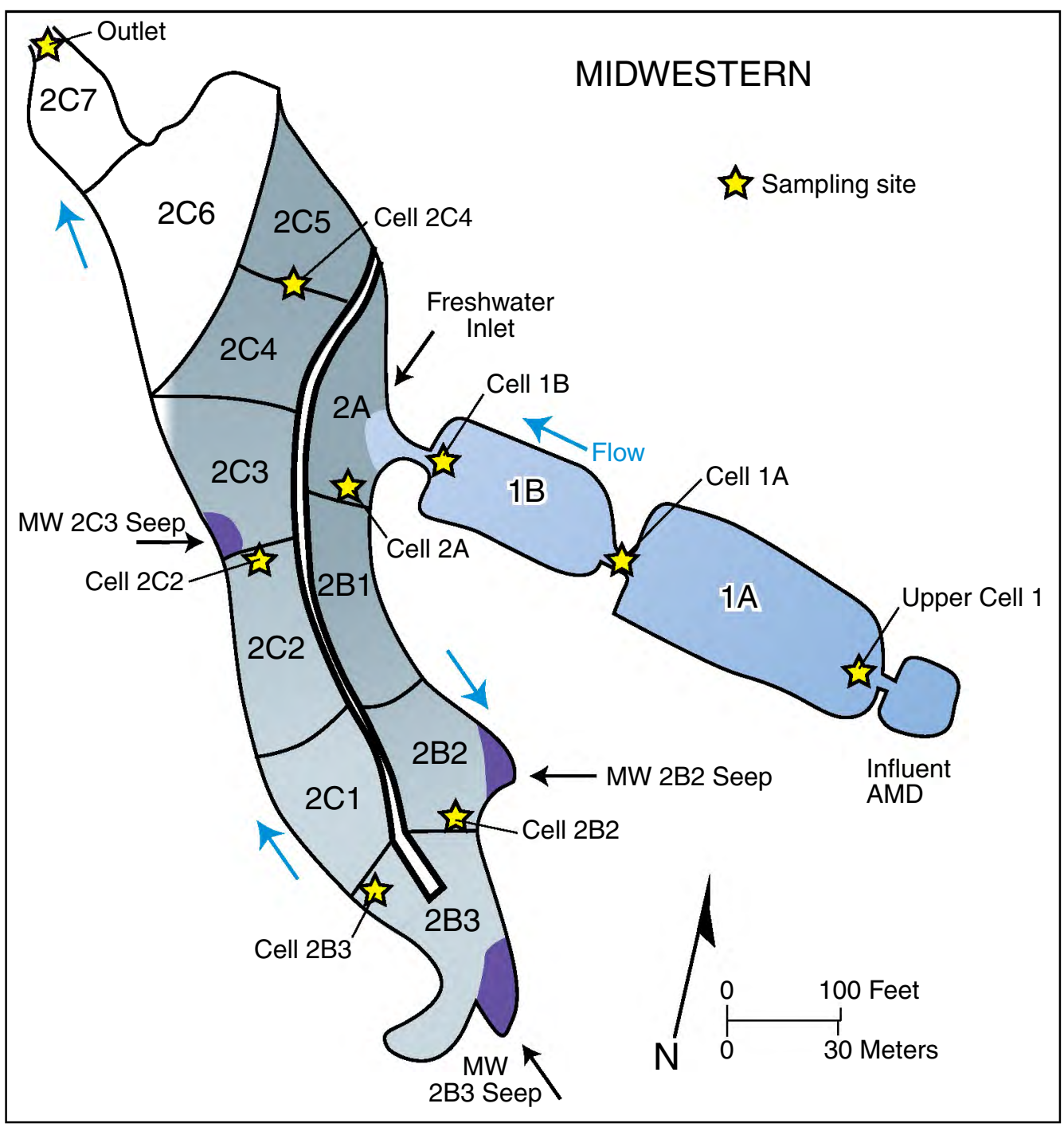

Figure 3. Map showing the Midwestern wetland and the location of sampling sites (modified from Flege and others, 2012 [this volume]).

parts soil to one part turkey manure. Agricultural lime was applied to the cell base at a rate of 200 tons per acre. The largest acid seep enters the wetland in Cell 4A. The upper four treatment cells are shallow and support dense stands of Typha; in the final cell Typha are found only in shallow zones along the bank of Cell 5.

The wetland was sampled at the following points (fig. 4): Cell 1 at the base of the dam near the freshwater supply source; Cell 2 at the outlet from the second wetland cell; Cell $4 \mathrm{~A}$ at the end of the western berm of treatment Cell 4; Cell 4B at the end of the eastern berm of Cell 4 where effluent from the upper wetland flows into Cell 5; and Cell 5 at the outfall from the wetland.
The Cell 1 sampling point was determined to contain AMD as well as fresh water and was abandoned after the first (winter) sampling.

\section{METHODS}

\section{Water-quality analysis}

Field measurements were taken at each location prior to sampling. Field parameters, including $\mathrm{pH}$, dissolved oxygen, redox potential (Eh), temperature, and specific conductivity, were measured using a YSI 600XL sonde and a YSI Model 610DM data logger calibrated as specified in the U.S. 


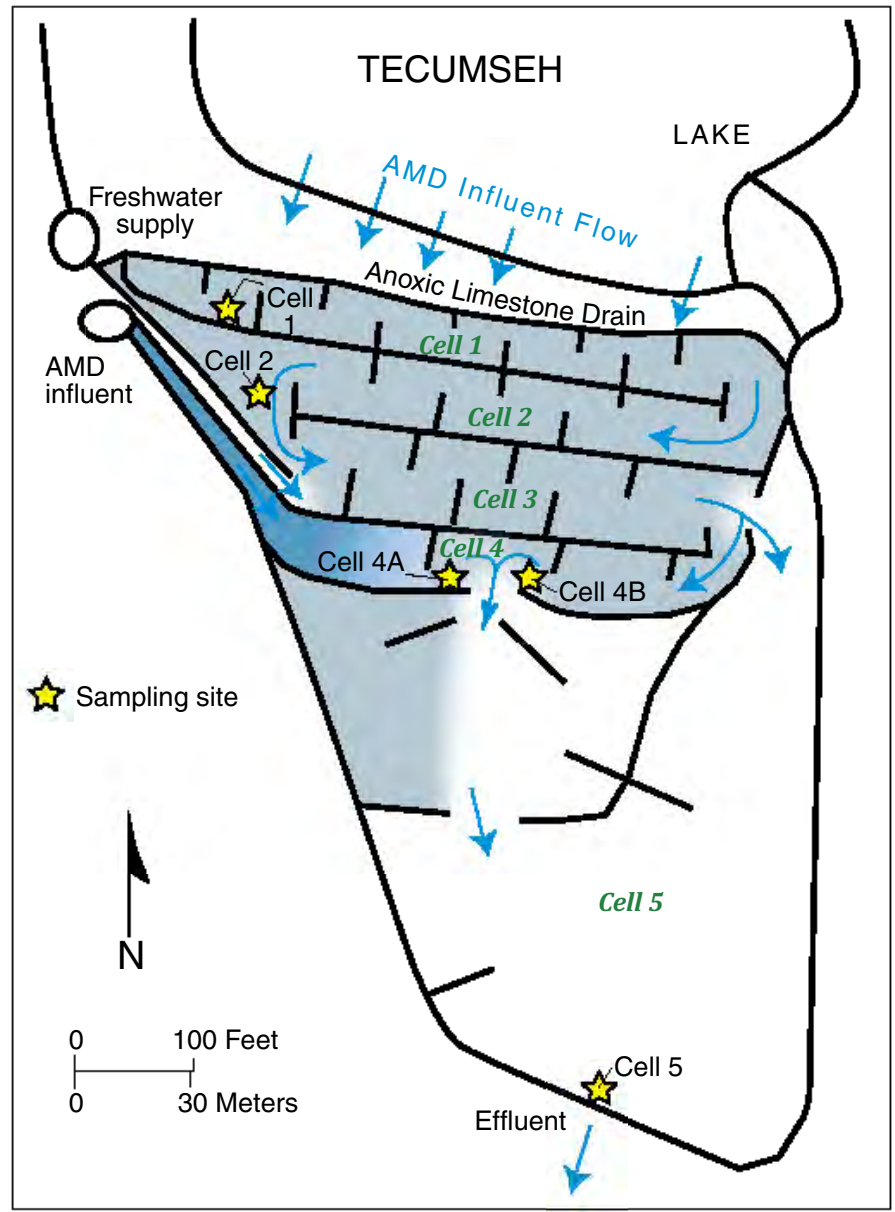

Figure 4. Map showing the Tecumseh wetland and the location of sampling sites (modified from Flege and others, 2012 [this volume]).

Environmental Protection Agency's (USEPA) Methods for Chemical Analysis of Water and Wastes (USEPA, 1979). Alkalinity was measured using a Hach Model 16900-01 digital titrator according to the method presented in Hach's Water Analysis Handbook (Hach Co., 1992). Acidity was measured using the APHA standard method (APHA, 1985). Ferrous iron was determined using the Cerium-IV titration method adapted to a Radiometer TIM900 electronic titrator (Peters and others, 1974).

Water samples were collected in precleaned 1-liter polyethylene bottles with Teflon-lined caps. The samples were collected approximately 10 inches $(25.4 \mathrm{~cm})$ below the water surface, as close as possible to the exit point of the wetland cell being sampled. Sediment samples were collected at the same locations such that the surficial sediment layer was placed into a precleaned wide-mouth $500-\mathrm{ml}$ polyethylene jar with a Teflon-lined cap. The remainder of the container was filled to the top from the water column and the lid was replaced while the jar remained immersed so that all air was excluded from the container. All samples were immediately placed in coolers precooled with cold-packs. Filtration of water samples took place as soon as possible after sampling. Alkalinity determinations were performed immediately after filtration.

Samples were divided into aliquots to meet the requirements of the various analytical methods and preserved as appropriate. Aliquots of filtered water for metals analysis were acidified with concentrated nitric acid to below $\mathrm{pH} 2$. All water aliquots and sediment samples were preserved by refrigeration at $45^{\circ} \mathrm{F}\left(7.2^{\circ} \mathrm{C}\right)$ prior to extraction and analysis. The aliquots were stored in the Indiana Geological Survey walk-in refrigeration unit, which is equipped with 24-hour temperature monitors and alarms. 
Chloride, nitrate, and sulfate were determined by ion chromatography. A Dionex AS40 Autosampler introduced the samples to a DX100 chromatograph controlled and monitored by a computer running Dionex AI-450 software. The separation of ions was performed using an AS-4A column and the results were quantified using a five-point calibration curve constructed from certified reference standards according to the procedures set forth in (USEPA) Method 300 (Pfaff and others, 1991).

\section{Metals analysis}

Three types of analytical techniques were available for metals determinations: flame atomic absorption (AA), graphite furnace atomic absorption (GF/AA), and inductively coupled plasma atomic emission spectrometry (ICP). The choice of techniques was based upon both the suitability of the technique for the element in question and the concentration at which the element was present.

Aluminum, barium, sodium, strontium, and silicon were analyzed using ICP. Samples were introduced to the plasma by a Rainin peristaltic pump and a Hildebrand nebulizer as described in EPA Method 6010A (USEPA, 1992a). The ICP used was a Jarrell Ash Atomcomp II Model 975 simultaneous instrument modified with an ADAM-II 30 channel, high-speed digital data acquisition system. Results from the major cation analyses were checked on a second ICP, the Leeman Labs PS900 ICP/Echelle Spectrophotometer, located at the Center for Earth and Environmental Science at Indiana University-Purdue University, Indianapolis.

Flame atomic absorption was used to determine calcium, iron, magnesium, manganese, nickel, potassium, and zinc. The atomic absorption spectrophotometer used was a Perkin Elmer 5100PC Zeeman Corrected Graphite Furnace Atomic Absorption Spectrophotometer interfaced to a PCbased data station running PE Winlab software. Flame atomic absorption methods were taken from USEPA's Methods for the Analysis of Water and Wastes, (USEPA, 1979) and the USEPA Solid Waste Manual, SW-846, (USEPA, 1992a).

Trace metals were analyzed by GF/AA techniques described in the above-referenced USEPA manuals, as well as methods published by the instrument's manufacturer. Analyses were performed on the furnace for the following metals: arsenic, beryllium, cadmium, chromium, copper, lead, molybdenum, nickel, selenium, and vanadium. All AA analyses were done in triplicate, except for the refractory metals vanadium and molybdenum, which were sometimes done in duplicate to minimize attrition of the analytical system's graphite components. Arsenic and selenium values were checked using the PE Model 5100's hydride generation system.

\section{Sediment analysis}

The chemistry of wetland sediments changes rapidly when the material is brought from an anaerobic to an aerobic environment. Because of this, sediment samples were prepared while wet, so that their alteration by drying and exposure to air would be minimized. Wet sediments were quantitatively extracted for 2 hours at $\mathrm{pH} 3$ with ammonium oxalate/oxalic acid buffer $(0.175 \mathrm{M}$ ammonium oxalate with $0.1 \mathrm{M}$ oxalic acid) (Schwertmann and Cornell, 1991). This oxalate extract contains the exchangeable metals and metals bound to soluble phases such as ferrihydrite and schwertmannite (Pickering, 1986).

The remaining solids were heated with 30 percent hydrogen peroxide to oxidize the organic materials, then gently heated to drive off excess liquid. The moist residue was then extracted with $0.5 \mathrm{M}$ hydrochloric acid $(\mathrm{HCl})$. This peroxide/hydrochloric acid extract contains organic bound metals and metals that were mineralized as oxides and sulfides (Pickering, 1986). Any residue that did not dissolve during the second extraction was regarded as being detrital in nature and totally immobile.

The extracts were analyzed for major cations using USEPA Method 6000, ICPES (USEPA 1992a). The elements manganese and calcium were analyzed by flame atomic absorption using the USEPA 200 series of methods (USEPA, 1979). Trace metals were analyzed using graphite furnace atomic absorption methods derived from the USEPA 200 series. The results of the extract analyses were then corrected to reflect the concentration of the metal in the original sediment.

The results from the sequential extraction and subsequent analyses appear in Appendix A (on CD$\mathrm{ROM}$ ). This table presents the concentrations as available metals in the oxalate extract, and residual metals in the hydrochloric acid extract. Both types 
of values are corrected so that the concentrations show the metals concentrations in the sediment as it is found in the wetlands. Appendix B (on CDROM) represents the values in terms of dry weight, which is necessary in order to compare the values to established sediment quality criteria. The line in the table entitled OSWER shows reference values published by USEPA and its significance is discussed below (USEPA, 1996).

To determine the equivalent dry weight concentration, the percentage of solid matter in the sample had to be calculated. Percent solids values were gravimetrically determined by drying aliquots of the sediments using Standard Method 209 A (APHA, 1985). The total mass of metals measured in the wet sediment was attributed to the mass of solid material in each sample based on the percent solids. The values for the two extracts from each sample were summed for use in determining the total metals burden.

The sequential extraction was designed to provide two types of information: it allowed the relative abundance of metals to be tracked as the water passed through the course of the wetlands and it allowed the relative distribution of metals between the available and residual compartments to be assessed. The oxalate extraction procedure selectively dissolves ferrihydrite, schwertmannite, and other poorly crystalline hydrous oxides while leaving the organic and more crystalline oxides intact (Schwertmann and Cornell, 1991). Large amounts of iron and lesser amounts of aluminum and manganese are associated with the oxalate extracts (Appendices A and B), which signifies an abundance of metals in amorphous and poorly crystalline forms.

\section{Analysis of aquatic plants}

The large standing crop of biomass visible in the AMD wetlands studied here suggests that the bioaccumulation of trace metals should be a significant contributor to metals removal in wetlands. Samples of plant tissue were tested for trace metals concentrations to test this hypothesis and to examine differences among the species in metals uptake. The inundated areas of the wetlands were informally surveyed for the distribution and diversity of aquatic vegetation. Because of the diversity of species available, plants at the
Tecumseh wetland were chosen for sampling for metals analysis.

One specimen of each of the selected species was harvested from shallow water along the berm separating Tecumseh Cell 4A from Cell 5, adjacent to the channel that carried the AMD (fig. 4). In order to remove soil and iron deposits from the surface of roots, the material was washed first in deionized water and subsequently using the ammonium oxalate/oxalic acid procedure referenced above (Schwertmann and Cornell, 1991). The washed plant material was digested using acid digestion on a hot plate according to USEPA method 3050A and subsequently analyzed by atomic absorption using USEPA method 7000A (USEPA, 1992a). Iron oxide plaque continued to adhere tightly to most of the root tissue. The results for exterior root tissue are reported as "root plus plaque," to indicate that some of the iron-rich plaque continued to adhere to these samples prior to analysis. As a result, the values for plaque-encrusted root tissue are not directly comparable to other tissue values because they include some metals that are external to the plant itself.

\section{RESULTS AND DISCUSSION}

\section{Water quality in the four wetlands}

Each wetland described above was sampled once in late winter and again in the first week of autumn to evaluate seasonal changes in the water chemistry. The results of field measurements and laboratory analysis of these water samples appear in Table 1. Differences in the design, hydrology, water chemistry, and geological setting appeared to influence the water chemistry in each wetland. At the Augusta Lake wetland (fig. 1), the treatment approach relied upon ALDs to provide alkalinity at several AMD sources in the watershed. The oxidation and settling ponds downstream from the ALDs have accumulated a large amount of iron while the $\mathrm{pH}$ value of their water remains quite acidic (from 2.5 to 3.5 units). The intent of these ponds was to allow the precipitation of iron before the water reached the final successive alkalinity-producing structure. No alkalinity could be detected in these ponds during the winter sampling. During the autumn sampling, water was collected at the Central drain (fig. 1) to test drainage in the eastern 
tributary, and $102 \mathrm{mg} / \mathrm{L}$ of alkalinity was found in this branch, although no alkalinity could be found at this site when it had been sampled in the spring. The lack of alkalinity generation in the oxidation ponds feeding into the SAPS allowed dissolved metals to remain in solution and enter the porous media of the SAPS structure. Flow measurements made in 2000 indicated that the ratio of water passing over the weir to that passing through the SAPS bed is 170 to 1 . While some alkalinity continued to be generated in the SAPS, as evinced by a $\mathrm{pH}$ above 9 in the underflow, there was not enough flow to effectively neutralize the large volume of untreated AMD flowing over the weir. Net acidity downstream from the SAPS ranged from 82 to $151 \mathrm{mg} / \mathrm{L}$.

The failure of the SAPS and the ALDs emplaced in nearby ridges has contributed to high acidity values downstream and the removal of metals from the water is inconsistent at best with manganese, cadmium, and nickel remaining in the effluent, as shown in Table 1. Manganese levels decreased from $32.2 \mathrm{mg} / \mathrm{L}$ to $23.8 \mathrm{mg} / \mathrm{L}$ along the course of the Augusta Lake wetland in winter and in summer the decrease was only from $20.5 \mathrm{mg} / \mathrm{L}$ to 18.7 $\mathrm{mg} / \mathrm{L}$. In winter the Cd levels only decreased from about $7 \mu \mathrm{g} / \mathrm{L}$ to $3 \mu \mathrm{g} / \mathrm{L}$, while no $\mathrm{Cd}$ was detected in the effluent in summer. The nickel level decreased from $924 \mu \mathrm{g} / \mathrm{L}$ to $418 \mu \mathrm{g} / \mathrm{L}$ during the winter sampling, but during the summer sampling the level increased along the flow path from $297 \mu \mathrm{g} / \mathrm{L}$ to $422 \mu \mathrm{g} / \mathrm{L}$.

At Friar Tuck (fig. 2), the feeder stream provides 173 to $301 \mathrm{mg} / \mathrm{L}$ of alkalinity at a flow volume that is relatively large compared with the small flow volume of the AMD seep. Acidity in AMD from the seep is very high, ranging from 6,093 to 6,220 $\mathrm{mg} / \mathrm{L}$. The interaction of the two flows is not direct, since both sources enter a dense stand of Phragmites where the water sinks and diffuses into the detrital layer. Processes that take place beneath the surface of the inundated Phragmites stand were not investigated. Water that emerges in diffuse flow along the lower elevation of the stand was taken as representing a mixing zone. The data in Table 1 show that the $\mathrm{pH}$ values for the water in this zone are intermediate between the value measured for the AMD and that of the lower pond near the weir. The $\mathrm{pH}$ was 4.6 in the winter and 5.8 in the summer. The pooled water representing the mixing zone forms the upper end of the pond created by the dam at the lower end of the wetland. Water from the mixing zone ranges in alkalinity from 19 to 132 $\mathrm{mg} / \mathrm{L}$. At the dam, the impounded water has a $\mathrm{pH}$ value of 5.3 in the winter and 6.1 in the summer. All the parameters measured in the pond water are similar in magnitude to the values measured in the feeder stream, so it appears that the water quality in the pond is dominated by the influence of this stream.

At Midwestern (fig. 3), the anaerobic wetland cell designated Cell 1A was built over the subsurface outlet of the ALD that treats the water from the abandoned underground mine workings. This design provided a constant water level inside the structure and excluded air from entering the drain. A consistent flow of water is discharged from the standpipe at the end of Cell 1A with alkalinity values from 248 to $310 \mathrm{mg} / \mathrm{L}$ and $\mathrm{pH}$ values ranging from 6.1 to 6.5 units.

The flow from Cell 1A was not mixed with water from other surface streams. Dilution of the AMD within this wetland is limited to that provided by runoff from precipitation within the watershed and any dilute groundwater that may be flushed from spoil ridges within the watershed during precipitation events. The sole additional flow was that of a small ephemeral seep observed entering Cell 2B3 during the winter. Immediately downstream from this seep, the iron level increased from 0.6 to 7.2 $\mathrm{mg} / \mathrm{L}$, manganese increased from 4.6 to $6.8 \mathrm{mg} / \mathrm{L}$, cadmium increased from 0.4 to $5.5 \mu \mathrm{g} / \mathrm{L}$, and nickel increased from 37 to $179 \mu \mathrm{g} / \mathrm{L}$. The $\mathrm{pH}$ dropped from 7.3 in the previous cell to 5.5 units. These changes can be seen as an indication that the seep consisted of AMD. Although the water quality was impaired in the cell that received this seep, all the affected metals levels and the $\mathrm{pH}$ had improved by the time the water reached the wetland outlet. Iron dropped to $4.0 \mathrm{mg} / \mathrm{L}$, manganese decreased to 0.7 $\mathrm{mg} / \mathrm{L}$, cadmium decreased to $0.6 \mu \mathrm{g} / \mathrm{L}$, and nickel decreased to $37 \mu \mathrm{g} / \mathrm{L}$.

At Tecumseh (fig. 4), the readings for Cell 4A can be taken as the AMD source, and the other cells represent a channeled flow path into the final polishing pond, Cell 5. In the winter, the water along this flow path ranged from $\mathrm{pH} 6.1$ to 6.9 units; the Eh ranged from 248 to $236 \mathrm{mV}$, acidity ranged from 22 to $27 \mathrm{mg} / \mathrm{L}$; and the alkalinity ranged from 123 
to $111 \mathrm{mg} / \mathrm{L}$. All the dissolved species measured changed very little along the course of the first four cells during the winter, except for zinc, which decreased from 0.5 to $0.1 \mathrm{mg} / \mathrm{L}$. This suggests that the volume of flow out of Cell 4A was too low to affect the overall character of the wetland water. In summer, the $\mathrm{pH}$ of water discharged from the Cell $4 \mathrm{~B}$ was 4.6 units and the acidity was $73 \mathrm{mg} / \mathrm{L}$. This indicates that the flow from Cell $4 \mathrm{~A}$ was more significant and that its influence extended into Cell 4B where it mixed with the water from the Cells 1, 2, and 3 (fig. 4).

Despite the fact that Cell 4A discharged water that was severely acidic ( $\mathrm{pH}$ 2.9-3.1), the water leaving the wetland outlet maintained an alkalinity between 82 and $103 \mathrm{mg} / \mathrm{L}$, and a circum-neutral $\mathrm{pH}$ ranging from 7.2 to 8.3 units. The amount of iron in the wetland effluent from Cell 5 is very low and averaged only $0.2 \mathrm{mg} / \mathrm{L}$. In winter, the sulfate level dropped from 1,520 to $1,442 \mathrm{mg} / \mathrm{L}$ as the water passed through Cell 5. In summer, the sulfate level decreased from 2,294 to $1,405 \mathrm{mg} / \mathrm{L}$ between the two sampling points. The improvement in water quality provided by final treatment Cell 5 is due at least in part to the large amount of agricultural lime incorporated in its base.

\section{Wetland hydrology and retention time}

There was a considerable difference in the surface area of the four wetlands studied. The surface area of the inundated zones in the wetlands appears in Table 2, along with the area of the oxidation cells where the initial aeration of AMD takes place. The largest wetland, Tecumseh, was almost five times larger than the smallest wetland, Augusta Lake. Almost all the Augusta Lake wetland served as oxidation ponds, as did all of the inundated area of Friar

Table 2. Total area of the four wetlands and their oxidation cells

\begin{tabular}{|l|c|c|}
\hline \multicolumn{1}{|c|}{ Site } & $\begin{array}{c}\text { Total cell area } \\
\left(\mathbf{~}^{2}\right)\end{array}$ & $\begin{array}{c}\text { 0xidation cell area } \\
\left(\mathbf{~ m}^{2}\right)\end{array}$ \\
\hline Augusta Lake & 5,390 & 4,487 \\
\hline Friar Tuck & 11,753 & 11,753 \\
\hline Midwestern & 9,978 & 1,223 \\
\hline Tecumseh & 25,548 & 8,055 \\
\hline
\end{tabular}

Tuck. The areas of the oxidation ponds at the other two wetlands were only a fraction of the total area.

The four wetlands also differed considerably in the volume of AMD and other surface water that entered them. Flow rates were measured during the summer between rain events to determine the base flows into the wetlands. The quantity of water in low-volume flows was determined using the bucket and stopwatch method. This method was used to measure discharge from the Augusta Lake SAPS outlet standpipe and the Midwestern Cell 1A standpipe. At Friar Tuck, a V-notch weir was installed to measure the seep volume. At the other locations, the flow was determined by measuring the cross-sectional area of the flow, the depth of the water column, and its velocity (Table 3).

The precipitation of metals, particularly iron, occurs at a rate that is influenced by the water chemistry. In the case of the primary metal, iron, the reactions are expressed in equations 2 and 3 above, which are not instantaneous. Because time is a factor, the length of time that the water resides in a water body affects the cell's capacity to remove iron from solution. The metric for this parameter is the hydraulic retention time, which is determined by dividing the volume of the cell by the quantity of flow passing through the cell. The volume of the cells was determined by estimating the areal extent of each cell and estimating the cell depth from the map contours and the water level. The depth estimates were verified by using meter sticks.

Each wetland was designed such that the AMD initially enters an oxidation pond or aerobic cell so that the iron can react with atmospheric oxygen. The concentrations of iron presented in Table

Table 3. Estimated flow rates in the four wetlands

\begin{tabular}{|l|l|c|}
\hline \multicolumn{1}{|c|}{ Wetland } & \multicolumn{1}{|c|}{ Gauging site } & $\begin{array}{c}\text { Discharge } \\
\text { (Lps) }\end{array}$ \\
\hline \multirow{2}{*}{ Augusta Lake } & SAPS outlet standpipe & 0.06 \\
& SAPS bypass weir & 10.70 \\
\hline \multirow{3}{*}{ Friar Tuck } & AMD seep & 0.15 \\
& AMD feeder stream & 13.0 \\
& Weir & 17.0 \\
\hline Midwestern & Cell 1A standpipe & 0.60 \\
\hline \multirow{2}{*}{ Tecumseh } & Cell 4A AMD inflow & 0.13 \\
& Cell 5 & 58.50 \\
\hline
\end{tabular}


1 indicate that there is a dramatic decrease in dissolved iron between the levels in the influent and effluent of these oxidation ponds and cells. These data indicate that iron precipitation takes place primarily in the zones where fresh water mixes with AMD. Table 1 also shows that there is little change in the iron levels in the cells downstream.

Table 4 shows the hydraulic characteristics of the oxidation ponds along with their retention times. It was expected that the hydraulic retention time would correlate with the decrease in iron levels in the water; however, such an effect is not clear from the data (Table 4). While the wetland that was the most effective at removing iron, Midwestern, had the greatest retention time, the Tecumseh wetland was also highly effective at removing iron, even though it had the shortest retention time.

\section{Iron levels throughout the four wetlands}

At Augusta Lake in winter, the iron concentration decreased from $133.6 \mathrm{mg} / \mathrm{L}$ to $49.8 \mathrm{mg} / \mathrm{L}$ above the SAPS pond, and then continued to decrease to 8.5 $\mathrm{mg} / \mathrm{L}$ as the water flowed through the pond and the channel downstream (Table 1). However, in the summer, there was a much less significant decrease in the iron level from its initial value of 33.1 $\mathrm{mg} / \mathrm{L}$. The level increased as the water crossed the SAPS pond to $38.7 \mathrm{mg} / \mathrm{L}$, then fell to $30.2 \mathrm{mg} / \mathrm{L}$ in the flow below the weir. The data do not provide a clear reason for the release of iron from the pond during the summer.

At Friar Tuck, iron removal or filtration by detritus largely took place in the main Phragmites stand. The water entering the stand in winter from the freshwater stream contained $4.1 \mathrm{mg} / \mathrm{L}$ of iron. The water leaving the stand showed a net increase in iron to $14.7 \mathrm{mg} / \mathrm{L}$, indicating that the influx of AMD containing $1,045.8 \mathrm{mg} / \mathrm{L}$ had only a small impact on the mixed water leaving the stand (Table 1). The iron level decreased in the summer from $7.9 \mathrm{mg} / \mathrm{L}$ to $0.7 \mathrm{mg} / \mathrm{L}$ as it traveled through the Phragmites stand. At the weir where the effluent was sampled, the iron level was $4.7 \mathrm{mg} / \mathrm{L}$ in winter, and $7.8 \mathrm{mg} / \mathrm{L}$ in summer.

At Midwestern, the iron level decreased from 78.6 $\mathrm{mg} / \mathrm{L}$ to $0.3 \mathrm{mg} / \mathrm{L}$ between the standpipe and the second oxidation pond in winter (Table 1). In summer, the difference was even greater, as the iron concentration fell from $124.4 \mathrm{mg} / \mathrm{L}$ to $0.2 \mathrm{mg} / \mathrm{L}$.
In this wetland, there are no additional inputs of fresh water to provide for dilution, so the decrease in the iron level can be attributed to precipitation.

At Tecumseh in winter, very little increase in the iron level was observed where diluted water from Cells 1, 2, and 3 mixed with the AMD in Cell 4A (Table 1). The iron level in water flowing from Cell 2 was $5.1 \mathrm{mg} / \mathrm{L}$ and the iron level in water flowing from Cell 4B was $4.6 \mathrm{mg} / \mathrm{L}$. In summer, water from Cell $4 \mathrm{~B}$ was affected more significantly by the AMD from Cell 4A and the iron level rose from 0.9 $\mathrm{mg} / \mathrm{L}$ in Cell 2 to $20.7 \mathrm{mg} / \mathrm{L}$ at the confluence between Cell 4A and Cell 4B. In winter the effluent from final Cell 5 contained $0.1 \mathrm{mg} / \mathrm{L}$ of iron, while in summer the effluent contained $0.3 \mathrm{mg} / \mathrm{L}$. This large, final cell served as an effective iron precipitation zone, probably because of the presence of alkalinity and the circum-neutral $\mathrm{pH}$ (winter $\mathrm{pH}=$ 7.2 , summer $\mathrm{pH}=8.3$; Table 1 ). These nearly neutral water conditions may have resulted from the initial application of agricultural lime at a rate of 200 tons per acre at the base of the constructed wetland system.

\section{Manganese and nickel levels}

Table 1 indicates that manganese and nickel are regularly found in the wetland effluents.

Manganese was generally found at levels greater than $1 \mathrm{mg} / \mathrm{L}$ throughout the wetland systems at Augusta Lake, Friar Tuck, and Midwestern and it appeared in the wetland effluents at levels as great as $23.8 \mathrm{mg} / \mathrm{L}$. This was not the case for the Tecumseh wetland, which received only a few $\mathrm{mg} / \mathrm{L}$ of manganese in its influent and discharged from 0.2

Table 4. Hydraulic retention times for water in the oxidation cells

\begin{tabular}{|l|c|c|c|}
\hline \multicolumn{1}{|c|}{ Site } & $\begin{array}{c}\text { Flow } \\
\text { rate } \\
\text { (Lps) }\end{array}$ & $\begin{array}{c}\text { Estimated } \\
\text { depth } \\
\text { (m) }\end{array}$ & $\begin{array}{c}\text { Reten- } \\
\text { tion time } \\
\text { (days) }\end{array}$ \\
\hline $\begin{array}{l}\text { Augusta Lake } \\
\text { oxidation pond }\end{array}$ & 10.7 & 0.77 & 3.7 \\
\hline $\begin{array}{l}\text { Friar Tuck } \\
\text { oxidation pond }\end{array}$ & 17.0 & 0.62 & 8.0 \\
\hline Midwestern Cell 1A & 0.63 & 1.0 & 23.6 \\
\hline $\begin{array}{l}\text { Tecumseh } \\
\text { Cell 4A + Cell 5 }\end{array}$ & 58.5 & 1.0 & 1.6 \\
\hline
\end{tabular}


to $0.3 \mathrm{mg} / \mathrm{L}$ in its effluent. As seen in equations $4-6$ above, the presence of manganese contributes to the propagation of mineral acidity downstream. In mildly aerated, high-sulfate waters, manganese is associated with sulfur as $\mathrm{MnSO}_{4}^{0}$ (aa)' cies which remains soluble at $\mathrm{pH}$ values below 9 (Nordstrom and Munoz, 1994). In waters that are highly aerated, the mineral pyrolusite, $\mathrm{MnO}_{2^{\prime}}$ can form and it precipitates more readily than $\mathrm{MnSO}_{4}$ (Nordstrom and Munoz, 1994). This explains the practical observation that the simplest way to achieve manganese removal is by active aeration under alkaline conditions (Behum and Kim, 1999).

The dissolved manganese levels throughout the Augusta Lake wetland range from 23.2 to 32.2 $\mathrm{mg} / \mathrm{L}$ in the winter and from 15.4 to $20.5 \mathrm{mg} / \mathrm{L}$ in the summer. However, the water draining from the SAPS shows a relatively low value for manganese of $2.1 \mathrm{mg} / \mathrm{L}$. The $\mathrm{pH}$ of the SAPS water is 9.1 units, which lies within the range where $\mathrm{MnSO}_{4}$ precipitation is feasible.

At Friar Tuck, the manganese levels varied from a minimum of $1.5 \mathrm{mg} / \mathrm{L}$ in the feeder stream to a maximum of $92 \mathrm{mg} / \mathrm{L}$ in the AMD source. The values at the weir varied from 4.7 to $8.3 \mathrm{mg} / \mathrm{L}$. As previously seen, the iron levels were reduced from two to three orders of magnitude in the wetland, but the difference was about tenfold between the manganese in the AMD and that in the Friar Tuck effluent. At Midwestern the manganese level usually exceeded $1 \mathrm{mg} / \mathrm{L}$ and ranged from 4.1 to 15.6 $\mathrm{mg} / \mathrm{L}$ throughout the wetland cells; the exception was that in winter the manganese level fell to 0.7 $\mathrm{mg} / \mathrm{L}$ at the outlet (Table 1 ). In summer the relatively high level of $8.4 \mathrm{mg} / \mathrm{L}$ at the outlet highlights the difficulty of removing manganese in wetlands unless the $\mathrm{pH}$ can be elevated to about 9 units.

The data in Table 1 indicate that nickel has a tendency to pass through the AMD treatment wetlands and to contaminate receiving streams. Under the chemical conditions found in the wetland waters, nickel behaves similarly to manganese in that it is unlikely to precipitate as $\mathrm{NiO}$ unless the $\mathrm{pH}$ is raised above 8.8 units (Nordstrom and $\mathrm{Mu}$ noz, 1994). Some acid mine waters contain $\mathrm{SO}_{4}$ activities that are within the range where nickel will bind to sulfate, forming aqueous $\mathrm{NiSO}_{4}{ }^{0}$ (aq) $\mathrm{com}$ plex; however, this species is highly soluble and unlikely to precipitate as a solid phase. The high solubility of the divalent nickel ion and nickel sulfate explains the tendency for nickel to pass through aerobic wetlands.

\section{Significance of metals concentrations in reclamation design}

Apart from their ability to generate mineral acidity, the concentrations of major metals are important in treatment settings because metal oxides can form precipitates that clog AMD treatment structures. The ALDs and SAPS that generate alkalinity in the wetland treatment settings are designed to thwart armoring from iron oxides by eliminating air. However, even when iron precipitation is avoided, ALDs and SAPS are vulnerable to clogging because of the precipitation of other minerals. For instance, aluminum does not require oxygen when it forms precipitates as in equation 7 , so aluminum can precipitate in response to an increase in $\mathrm{pH}$ alone.

The historical data from a prior study indicated that aluminum was present in the AMD at $\mathrm{Au}-$ gusta Lake wetland at levels ranging up to 76 $\mathrm{mg} / \mathrm{L}$ (Comer and others, 2000). When the SAPS at Augusta Lake failed, site managers concluded that aluminum precipitation inside the structure was responsible (W. McCoy, U.S. Fish and Wildlife Service, written commun., Aug. 5, 2008).

In other instances, the drains are vulnerable to clogging because of the chemistry of bicarbonate generation. During the reaction of calcium carbonate with AMD inside an ALD, one mole of calcium is released for every mole of bicarbonate. The successful generation of alkalinity by limestone dissolution results in elevated amounts of dissolved calcium. Gypsum, a hydrated form of calcium sulfate, forms when calcium and sulfate concentrations reach the point of gypsum saturation. A useful generalization based on chemical equilibrium is that if the water in the drain contains more than 1,500 $\mathrm{mg} / \mathrm{L}$ sulfate, sufficient limestone will dissolve under acidic conditions to make the water saturated with respect to gypsum and gypsum will precipitate from solution (Behum and Kim, 1999). The significance of this reaction is illustrated by the observation that when failed ALDs in the Tecumseh spoil mound were excavated, gypsum was the dominant secondary mineral phase found inside the drain (T. D. Branam, Indiana Geological Survey, written commun., 2008). 


\section{Effluent water quality}

Comparison of winter and summer levels of sulfate and metals in the water throughout the four wetlands (Table 1) does not show that contaminant removal is necessarily less effective in the winter, even though biological activity decreases during cold weather. Rather, the same general trend of decreasing metals and sulfate levels along the flow path is seen during both winter and summer (Table 1). During the winter, abiotic contaminant removal processes must prevail of a magnitude comparable to biological processes in their effectiveness at removing sulfate and metals from the water column. The nature of these processes was not investigated, but it may be assumed that precipitation and sorption to solid phases are among the most important of them (Gambrell, 1994).

In areas where iron is abundant and its precipitation rate is high, other metals tend to be entrained with the iron and co-precipitate from solution (Schwertmann and Cornell, 1991). Hydrous metal oxide precipitates that accumulate in the submerged zones of wetlands also scavenge trace metals from solution by sorptive and ion-exchange mechanisms. Iron-rich solids and colloids absorb sulfate as well as metals, so these phases can remove sulfate even when sulfate is not fixed in the iron oxide's crystalline structure (Elliot and others, 1990). Sulfate that is bound to solid phase surfaces serves as a ligand for binding additional metals. Such an assemblage is known as a "ternary complex." Iron oxyhydroxides that contain abundant ternary complexes tend to contain higher concentrations of $\mathrm{Pb}, \mathrm{Cu}$, and $\mathrm{Zn}$ than other iron hydroxides (Webster and others, 1998). Sorptive mechanisms are less effective at low $\mathrm{pH}$ because of proton competition for binding sites (Webster and others, 1998).

Potentially toxic trace metals that appear in the effluents include cadmium and copper, which were discharged at Augusta Lake in winter at concentrations of $3.2 \mu \mathrm{g} / \mathrm{L}$ and $10 \mu \mathrm{g} / \mathrm{L}$ respectively. Beryllium was also discharged at Augusta Lake in winter at a level of $4 \mu \mathrm{g} / \mathrm{L}$. Zinc was measurable in all the effluents, reaching a maximum value of $0.9 \mathrm{mg} / \mathrm{L}$ at Augusta Lake in winter. In winter, molybdenum appeared in all the effluents at values ranging from 4 to $6 \mu \mathrm{g} / \mathrm{L}$. Vanadium was discharged from the Friar Tuck wetland at $24 \mu \mathrm{g} / \mathrm{L}$ in winter and $11 \mu \mathrm{g} / \mathrm{L}$ in summer. During the summer, chromium was slightly more abundant in the effluents, ranging from 1 to $4 \mu \mathrm{g} / \mathrm{L}$. Lead increased to $5.3 \mu \mathrm{g} / \mathrm{L}$ at Friar Tuck in summer. Otherwise, potentially toxic metals in the effluents were either not detectable or found at very low concentrations on the order of $1 \mu \mathrm{g} / \mathrm{L}$.

\section{Metals levels in interstitial water}

Much of the water in the wetlands at any given time is runoff from precipitation (Flege, 2001). The open water in a wetland may not be in equilibrium with wetland sediments because of poor mixing, short residence time, low permeability of the sediment, or the isolation of water from sediment by chemically-formed crusts and plant detritus in the sediment. In contrast, pore water is more likely to be in equilibrium with the solid phases in the sediment: interstitial water has very close proximity to sediments and its contact time with the solid phases is long because movement of dissolved material into and out of sediments is driven mainly by diffusion, a process that proceeds at a much slower rate than open column flow (Freeze and Cherry, 1979).

The results of the analyses for trace metals in wetland sediment pore water appear in Table 5. In general, arsenic, copper, chromium, molybdenum, and lead are elevated in the interstitial water (Table 5) relative to the surface water collected at the same sites (Table 1). The frequency at which cadmium was detected was also greater in the pore water. Except for the samples from Augusta Lake, beryllium remained scarce in the pore water. Nickel and zinc were abundant in the surface water and their levels in interstitial water were comparable, with the nickel level in the surface water sometimes exceeding that of the pore water.

The pore water levels of metals were usually greater than those of the surface water at locations where the AMD enters the wetland (Tables 1 and 5). However, the relationship between the pore water values and the surface water values is not straightforward at sampling stations that are distant from the AMD sources, and the surface water values occasionally exceed the values for the pore water at these locations. Pore water and surface water values for trace metals in the samples from 
Table 5. Dissolved metals concentrations in interstitial water extracted from wetland sediments

[NA = not analyzed].]

\begin{tabular}{|c|c|c|c|c|c|c|c|c|c|c|}
\hline $\begin{array}{c}\text { Sample } \\
\text { ID }\end{array}$ & $\begin{array}{l}\text { Sampling } \\
\text { date }\end{array}$ & $\begin{array}{c}\text { As } \\
(\mu \mathrm{g} / \mathrm{L})\end{array}$ & $\begin{array}{c}\mathrm{Be} \\
(\mu \mathrm{g} / \mathrm{L})\end{array}$ & $\begin{array}{c}\text { Cd } \\
(\mu g / L)\end{array}$ & $\begin{array}{c}\mathrm{Cr} \\
(\mu \mathrm{g} / \mathrm{L})\end{array}$ & $\begin{array}{c}\mathrm{Cu} \\
(\mu \mathrm{g} / \mathrm{L})\end{array}$ & $\begin{array}{c}\text { Mo } \\
(\mu \mathrm{g} / \mathrm{L})\end{array}$ & $\begin{array}{c}\mathrm{Ni} \\
(\mu \mathrm{g} / \mathrm{L})\end{array}$ & $\begin{array}{c}\mathrm{Pb} \\
(\mu \mathrm{g} / \mathrm{L})\end{array}$ & $\begin{array}{c}\mathrm{Zn} \\
(\mathrm{mg} / \mathrm{L})\end{array}$ \\
\hline \multicolumn{11}{|c|}{ Augusta Lake wetland } \\
\hline North pond & 03/07/00 & $<1$ & 29 & 9.4 & 6 & 11 & 13 & 194 & 4.5 & 4.2 \\
\hline SAPS pond & 03/07/00 & $<1$ & 9 & 12.3 & 1 & 4 & 14 & 394 & 15.6 & 2.8 \\
\hline Lake inlet & 03/07/00 & $<1$ & $<1$ & $<0.2$ & $<1$ & $<2$ & 15 & 116 & 1.6 & 0.5 \\
\hline \multicolumn{11}{|c|}{ Friar Tuck wetland } \\
\hline Weir & 02/28/00 & 6 & $<1$ & 0.4 & $<1$ & $<2$ & 9 & 9 & 3.6 & 0.4 \\
\hline \multicolumn{11}{|c|}{ Midwestern wetland } \\
\hline Cell $1 A$ & $02 / 29 / 00$ & 2 & $<1$ & 0.5 & $<1$ & 31 & 18 & 52 & 9.3 & 0.1 \\
\hline Cell 1B & $02 / 29 / 00$ & 1 & $<1$ & $<0.2$ & $<1$ & 2 & 20 & 18 & $<0.5$ & 0.2 \\
\hline Cell 2B2 & $02 / 29 / 00$ & 4 & $<1$ & $<0.2$ & $<1$ & 13 & 57 & 16 & 6.0 & 1.5 \\
\hline Cell 2B3 & $02 / 29 / 00$ & 3 & $<1$ & $<0.2$ & $<1$ & 2 & 22 & 13 & 4.2 & 0.1 \\
\hline Cell 2C2 & $02 / 29 / 00$ & 6 & 2 & 2.0 & $<1$ & 3 & 180 & 211 & 2.4 & 0.9 \\
\hline Outlet & $02 / 29 / 00$ & 6 & $<1$ & 1.0 & $<1$ & $<2$ & 55 & 131 & 1.2 & 0.1 \\
\hline \multicolumn{11}{|c|}{ Tecumseh wetland } \\
\hline Cell 4A & $02 / 29 / 00$ & 3 & 12 & 4.0 & 3 & 11 & 17 & 105 & 13.6 & 3.4 \\
\hline Cell 4B & 02/29/00 & 4 & $<1$ & 0.5 & $<1$ & $<2$ & 60 & 6 & 3.6 & 0.1 \\
\hline \multicolumn{11}{|c|}{ Augusta Lake wetland } \\
\hline Central drain & 09/28/00 & $<1$ & $<1$ & 0.7 & 12 & $<2$ & $<1$ & 11 & 0.5 & 0.2 \\
\hline SAPS pond & 09/28/00 & $<1$ & 6 & 3.3 & 20 & 15 & $<1$ & 262 & 11.6 & 3.6 \\
\hline SAPS pond (replicate) & $09 / 28 / 00$ & $<1$ & 7 & NA & 21 & 14 & $<1$ & 273 & 11.7 & 3.4 \\
\hline Mixing zone & 09/28/00 & $<1$ & $<1$ & 1.1 & 14 & 5 & $<1$ & 88 & 0.8 & 0.5 \\
\hline \multicolumn{11}{|l|}{ Friar Tuck wetland } \\
\hline Feeder stream & $09 / 22 / 00$ & 2 & $<1$ & 0.2 & $<1$ & 3 & 3 & 8 & 0.7 & 0.1 \\
\hline AMD seep & 09/22/00 & 2 & $<1$ & 2.0 & 1 & $<2$ & 19 & 96 & 0.3 & 10.1 \\
\hline Weir & $09 / 22 / 00$ & $<1$ & $<1$ & 2.1 & 8 & 5 & 5 & 2 & 1.4 & 0.1 \\
\hline Mixing zone & $09 / 22 / 00$ & 2 & $<1$ & 6.1 & 7 & 13 & 7 & 559 & 0.9 & 3.2 \\
\hline \multicolumn{11}{|c|}{ Midwestern wetland } \\
\hline Cell 1B & 09/19/00 & 1 & $<1$ & 0.3 & 5 & 3 & $<1$ & 107 & 1.1 & 1.3 \\
\hline Cell 2B2 & 09/19/00 & 7 & $<1$ & 1.2 & 1 & 11 & $<1$ & 5 & 3.7 & 1.6 \\
\hline Cell 2B3 & $09 / 19 / 00$ & 3 & $<1$ & 0.4 & $<1$ & 7 & $<1$ & 12 & 1.5 & 0.1 \\
\hline Cell 2C2 & 09/19/00 & 3 & $<1$ & $<0.2$ & 0 & 2 & $<1$ & 28 & 1.0 & 1.5 \\
\hline Outlet & 09/19/00 & 15 & $<1$ & $<0.2$ & 3 & 3 & 5 & 7 & 4.7 & 0.1 \\
\hline \multicolumn{11}{|c|}{ Tecumseh wetland } \\
\hline Cell 2 & 09/19/00 & 2 & $<1$ & 0.2 & 2 & 3 & 10 & 10 & 1.2 & 0.2 \\
\hline Cell 4A & $09 / 19 / 00$ & 1 & $<1$ & 9.9 & 7 & $<2$ & 87 & 27 & 0.6 & 6.3 \\
\hline Cell 4B & 09/19/00 & 2 & $<1$ & 0.3 & 12 & 9 & 7 & 155 & 0.6 & 1.4 \\
\hline Cell 5 & 09/19/00 & $<1$ & $<1$ & 0.8 & 4 & 9 & 9 & 35 & 3.8 & 0.2 \\
\hline
\end{tabular}


Midwestern have been plotted in Figure 5. The chart shows spikes in the molybdenum and nickel levels in pore water at Cell 2C2. The concentrations of nickel in winter surface water at Cell 2B3 and Cell $2 \mathrm{C} 2$ are comparable to those in pore water at Cell 2C2.

Figure 6 shows the $\mathrm{pH}$ of the pore water from the cells at Midwestern. The $\mathrm{pH}$ value of the pore water dipped at Cell 2C2, the same location where the molybdenum and nickel spikes occurred. The increase in these metals corresponded to the slightly lower $\mathrm{pH}$, and metal cations are somewhat more soluble at lower $\mathrm{pH}$ values. The origin of the elevated metals and $\mathrm{pH}$ deviation in the pore water at Cell 2C2 is unclear. This cell differed from the others in that municipal sludge was incorporated over a base of coal ash and wood chips. The cause for the lower $\mathrm{pH}$ and elevated metals levels could be either the ephemeral AMD seep in Cell 2B3 upstream or the leaching of solutes from the municipal sludge. The observation that nickel concentration in winter surface water spikes at Cell 2B3 and Cell 2C2 suggests that the seep is the source of the nickel in Cell 2C2 pore water.

Although the concentrations of metals in the surface water and the associated pore water samples are not always similar, the levels of trace metals in the pore water do correspond with sediments that contain greater levels of leachable metals. The concentrations of metals in wetland sediments are discussed in detail below.

\section{Analysis of wetland sediments}

Sediments formed in AMD treatment wetlands serve as both a sink and a source for metals (Chapman and others, 1999). Although the specific routes of dissolution and biological uptake can be complex, a basic distinction can be made between available and unavailable metals based upon the strength of the metal's bond to insoluble matter in the sediment. If a metal is so tightly bound to a solid phase that it cannot be freed under the conditions it is likely to encounter within its natural setting, then it can be considered unavailable. As described in the methods section, a sequential extraction was used to assess the amount of metals in both the available and unavailable fractions. The oxalate extract represents metals that are absorbed to solid surfaces or bound to metastable phases such as ferrihydrite or schwertmannite. The hydrogen peroxide/0.5 M hydrochloric acid extract contains metals that are more tightly bound to organics in sulfides (Pickering, 1986).

The metals data obtained from the sequential extractions appear in Appendices A and B. Appendix A contains the total extractable metals expressed on a dry weight basis. This consists of the sum of the oxalate and hydrochloric acid levels per unit mass of dry sediment. Because these values are not subject to a variable weight of water contained in the sediment, their values are more uniform than wet weight values, and they may be compared with published sediment quality criteria. Appendix $B$ contains the values for each sediment extract on a wet weight basis. The Appendix $B$ values are useful for assessing the relative distribution of metals between the readily available and residual components of the sediment.

Examination of Appendix A shows that metals that have toxic potential are present at total concentrations greater than $1 \mathrm{mg} / \mathrm{kg}$. The dissolved metals concentrations in Table 1 reflect values that are orders of magnitude less. Certain elements were below the detection limit in the water samples, yet their concentrations in the associated sediments were more than a thousand fold above the detection limit. For example, arsenic, beryllium, chromium, copper, lead, selenium, and vanadium were not detected in the water samples from several locations, yet they were enriched in the sediment.

The metals in the oxalate and $\mathrm{HCl}$ extracts can be summed and the proportion of the elements in each fraction compared (Table 6). Oxalate extractable iron constitutes from 85 to 99 percent of the total iron found in summer samples. The distribution of iron into the oxalate extract is characteristic of locations where AMD is most rapidly oxidized, creating an abundance of freshly formed precipitates. At Augusta Lake (SAPS pond) and Friar Tuck (AMD seep), the winter samples did not show such a great abundance of iron in the oxalate extract; only 81 to 89 percent of the iron was present in the oxalate fraction. This can be attributed to the finding that the $\mathrm{pH}$ of the AMD was below 3.0 at these sampling stations. Other researchers have observed that jarosite forms at this $\mathrm{pH}$ rather than schwertmannite or ferrihydrite (Bigham and Schwertmann, 1996). Jarosite is not soluble in the oxalate extractant, whereas the other phases that form above $\mathrm{pH} 3.0$ are oxalate-soluble. 


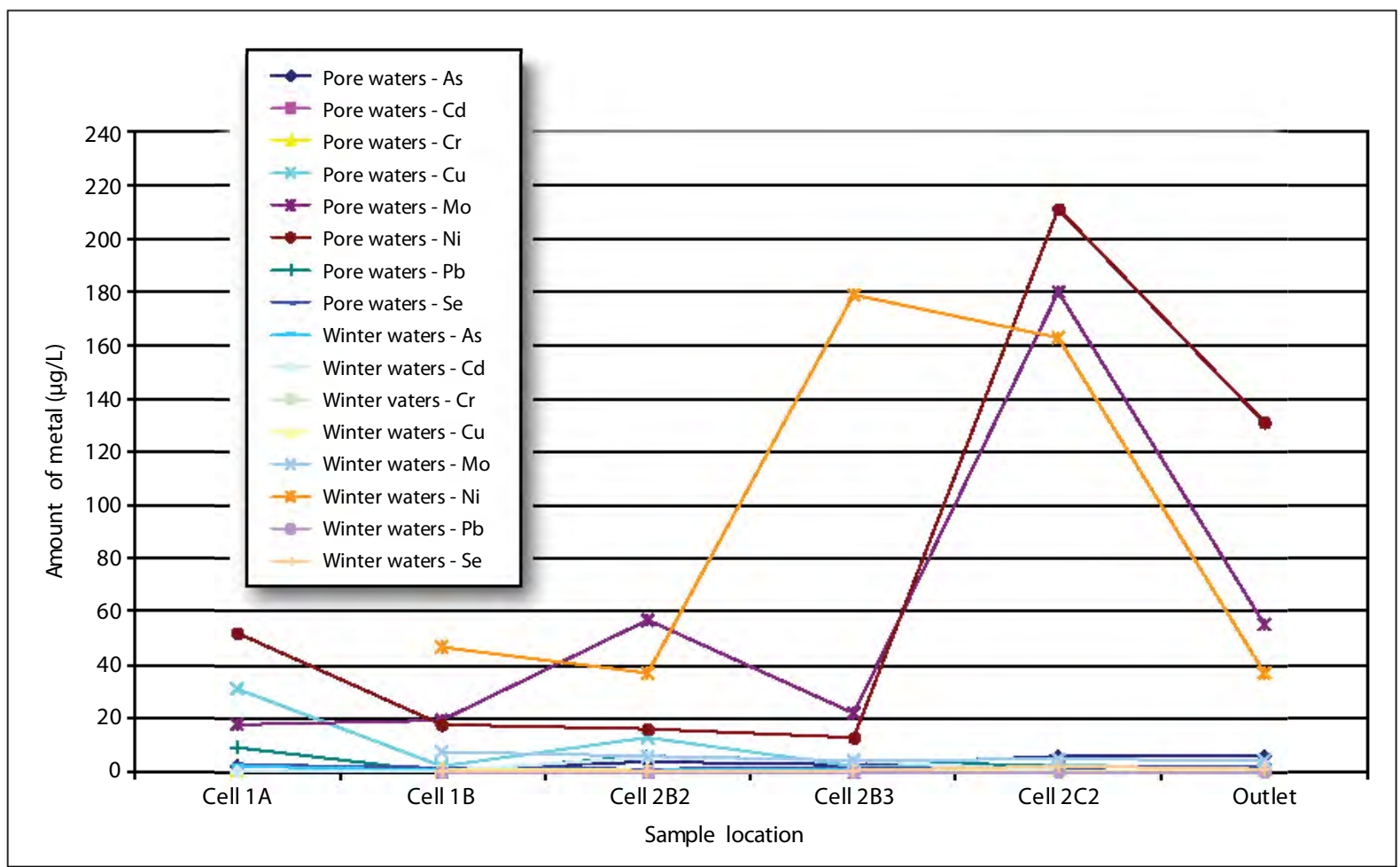

Figure 5. Graph showing the concentration of trace metals in pore water and surface water collected from the Midwestern wetland. Sampling sites are arranged from left to right in order from the AMD source toward the lower wetland.

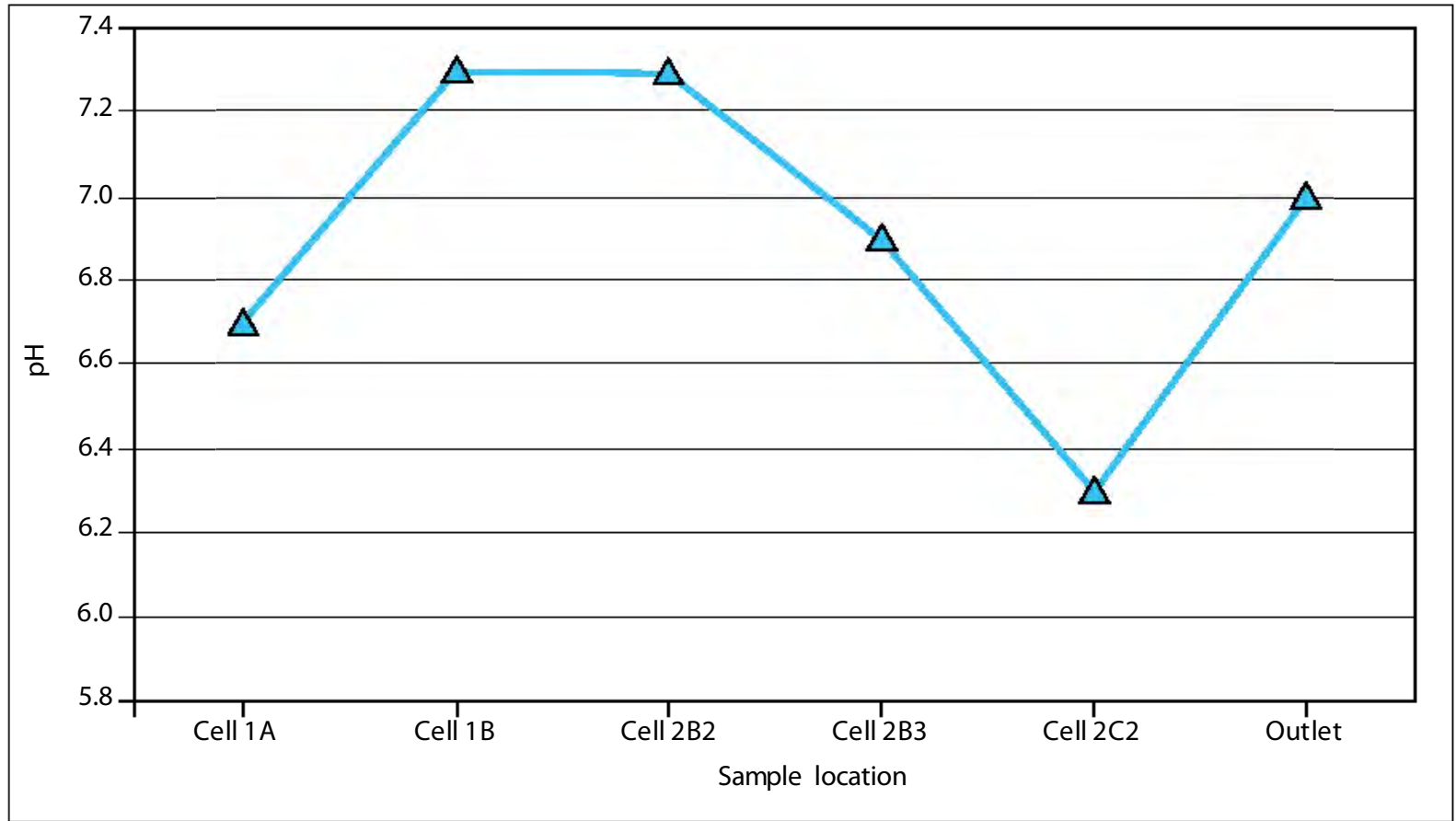

Figure 6. Graph showing the $\mathrm{pH}$ of pore water collected from the Midwestern wetland. Sampling sites are arranged from left to right in order from the AMD source toward the lower wetland. 
The distribution of iron into the $\mathrm{HCl}$ extract varies over a wide range from 1 to 37 percent of the total sediment-bound iron. The sediments showing the greatest percentage of iron in this residual fraction are those collected from the downstream treatment areas where the substrate contains a high concentration of organic matter, as in the final cells in the Midwestern wetland. In contrast, the data in Appendix B show that at places where AMD enters the wetland, the concentration of most trace metals is greater in the oxalate (available) fraction than in the $\mathrm{HCl}$ (residual) fraction. As, $\mathrm{Be}, \mathrm{Cd}, \mathrm{Ni}$, and $\mathrm{Zn}$ are found at high concentrations in the zones of rapid precipitation where the AMD is introduced to the wetland. These zones include oxidation ponds North pond at Augusta Lake, the AMD seep at Friar Tuck, Cell 1A at Midwestern, and Cell $4 \mathrm{~A}$ at Tecumseh.

Appendices A and B show that the cells following the oxidation zones tend to contain relatively lower concentrations of metals. It is likely that, after most of the iron has precipitated and settled, co-precipitation is less likely to occur. However, at sampling stations located closer to the wetland outlet, the levels of trace metals increase once again.

The trace metals found in the oxalate extracts of the lower wetland cells probably reflect the influence of high surface area phases such as schwertmannite and ferrihydrite, which are predicted to form in the $\mathrm{pH}$ range from 3.5 to 7.0 units (Bigham and Schwertmann, 1996). Accumulation in the lower wetland oxalate-soluble phases is most readily apparent for $\mathrm{As}, \mathrm{Be}, \mathrm{Cr}, \mathrm{Ni}$, Se, and $\mathrm{V}$. For the other trace elements, the trend of increasing metals levels in oxalate extracts of the lower wetland sediments is less pronounced. Metals in these oxalate fractions from the lower wetlands may result either from scavenging by schwertmannite and ferrihydrite, which were identified in preliminary X-ray diffraction analysis, or from the flushing of these less dense and easily suspended iron phases from the oxidation ponds into the lower wetlands during rain events. However, the observation that only certain elements are enriched in the lower cells suggests that the accumulation is due to a selective process such as sorption rather than bulk transport of solids.

Appendices A and B show that chromium is abundant in sediments throughout the wetlands. The mechanisms for the removal of this element are particularly complex. Chromium may exist in the
Table 6. The distribution of iron between oxalic acid buffer and hydrochloric acid extractants for sediments collected from the four wetlands

\begin{tabular}{|c|c|c|c|}
\hline Winter sample & $\% \mathrm{Fe}$ & Summer sample & $\% \mathrm{Fe}$ \\
\hline \multicolumn{4}{|c|}{ Augusta Lake wetland } \\
\hline No sample & & North pond $(0 x)$ & 99 \\
\hline No sample & & North pond $(\mathrm{HCl})$ & 1 \\
\hline SAPS pond (0x) & 89 & SAPS pond (0x) & 98 \\
\hline SAPS pond $(\mathrm{HCl})$ & 11 & SAPS pond $(\mathrm{HCl})$ & 2 \\
\hline Lake inlet (0x) & 87 & Mixing zone $(0 x)$ & 97 \\
\hline Lake inlet (HCl) & 13 & Mixing zone $(\mathrm{HCl})$ & 3 \\
\hline \multicolumn{4}{|c|}{ Friar Tuck wetland } \\
\hline No sample & & Feeder stream (0x) & 93 \\
\hline No sample & & Feeder stream (HCl) & 7 \\
\hline AMD seep (0x) & 81 & AMD seep (0x) & 97 \\
\hline AMD seep $(\mathrm{HCl})$ & 19 & AMD seep $(\mathrm{HCl})$ & 3 \\
\hline Mixing zone $(0 x)$ & 89 & Mixing zone (0x) & 99 \\
\hline Mixing zone $(\mathrm{HCl})$ & 11 & Mixing zone $(\mathrm{HCl})$ & 1 \\
\hline Weir (0x) & 90 & Weir (0x) & 97 \\
\hline Weir $(\mathrm{HCl})$ & 10 & Weir $(\mathrm{HCl})$ & 3 \\
\hline \multicolumn{4}{|c|}{ Midwestern wetland } \\
\hline Upper Cell 1 (0x) & 98 & Upper Cell 1 (0x) & 97 \\
\hline Upper Cell 1 (HCl) & 2 & Upper Cell 1 (HCl) & 3 \\
\hline Cell 1A (0x) & 80 & No sample & \\
\hline Cell 1A (HCl) & 20 & No sample & \\
\hline Cell 1B (0x) & 84 & Cell 2A (0x) & 85 \\
\hline Cell 1B (HCl) & 16 & Cell 2A (HCl) & 15 \\
\hline Cell 2B2 (0x) & 63 & Cell 2B (0x) & 97 \\
\hline Cell 2B2 (HCl) & 37 & Cell 2B (HCl) & 3 \\
\hline Cell 2B3 (0x) & 87 & Cell 2C4 (0x) & 92 \\
\hline Cell 2B3 (HCl) & 13 & Cell 2C4 (HCl) & 8 \\
\hline Outlet (0x) & 91 & Outlet (0x) & 86 \\
\hline Outlet (HCl) & 9 & Outlet $(\mathrm{HCl})$ & 14 \\
\hline \multicolumn{4}{|c|}{ Tecumseh wetland } \\
\hline Cell $1(0 x)$ & 96 & No sample & \\
\hline Cell 1 (HCl) & 4 & No sample & \\
\hline Cell 2 (0x) & 98 & Cell $2(0 x)$ & 97 \\
\hline Cell 2 (HCl) & 2 & Cell 2 (HCl) & 3 \\
\hline Cell 4A (0x) & 89 & Cell 4A (0x) & 96 \\
\hline Cell 4A (HCl) & 11 & Cell 4A (HCl) & 4 \\
\hline Cell 4B (0x) & 96 & Cell 4B (0x) & 99 \\
\hline Cell 4B (HCl) & 4 & Cell 4B (HCl) & 1 \\
\hline Cell 5 (0x) & 89 & Cell $5(0 x)$ & 95 \\
\hline Cell $5(\mathrm{HCl})$ & 11 & Cell 5 (HCl) & 5 \\
\hline
\end{tabular}


toxic, highly soluble form, Cr VI, or as the less toxic Cr III species, which is easily adsorbed to hydrous iron oxides. Together, these two valence states can exist as any of six different aqueous species $\left(\mathrm{HCrO}_{4}^{-}, \mathrm{CrO}_{4}^{2-}, \mathrm{CrO}_{2}^{-}, \mathrm{Cr}(\mathrm{OH})_{2}^{+}, \mathrm{Cr}(\mathrm{OH})^{2+}\right.$, and $\mathrm{Cr}^{3+}$ ), which in turn may undergo a number of possible redox reactions with other solutes and with iron and manganese hydrous oxides and humic substances (Makos and Hrncir, 1995). Because the chromium species were not determined during this study, the mechanism by which $\mathrm{Cr}$ accumulates in the sediments cannot be inferred.

Although the oxalate extracts collected near the final wetland cells contain more trace metals than those found just upstream, Appendix B shows that there are even greater concentrations of metals in the $\mathrm{HCl}$ (organic/residual metals) extracts than in the oxalate extracts.

This is especially the case in the final cells of the Tecumseh and Midwestern wetlands. In these final cells, the organic-bound, $\mathrm{HCl}$-soluble fraction contained greater levels of the toxic metals cadmium and lead than did the oxalate extracts. Lead and cadmium are known to have high affinities for the organic component of wetland sediment (Pickering, 1986). The accumulation of trace metals in the organic/residual phase of the lower part of the wetlands is consistent with the findings of Bhumbla and others (1990) that greater than 50 percent of the metals retention in AMD wetlands occurs because of exchange reactions and organic complexation. The greatest concentrations of As, $\mathrm{Cd}, \mathrm{Cu}$, and $\mathrm{Pb}$ in any of the wetlands were found in the organic/residual fraction of the final wetland cell at Midwestern. This cell was built with the highest ratio of organic material in its substrate (Bryenton and Gasper, 1994). The accumulation of high levels of lead in the hydrochloric acid extracts from the final cells at Midwestern is probably due, in part, to its adsorption to the rich organic substrate and to the sulfides that are presumably abundant there.

The incorporation of organic material at Augusta Lake and Friar Tuck is not as well-documented as at Midwestern. However, the accumulation of plant detritus is plainly visible in some areas as opposed to others. At these two wetlands, the most plant detritus was present at the AMD/fresh water mixing zones, namely, at the confluence of the north and eastern tributaries at Augusta Lake, and the Phragmites stand in the upper pond at Friar Tuck. Appendix A shows that the greatest concentrations of $\mathrm{As}, \mathrm{Cd}, \mathrm{Cr}, \mathrm{Cu}, \mathrm{Ni}$, and $\mathrm{Pb}$ were found in these mixing zones where organic detritus had accumulated. Similarly, Tecumseh Cell 5 had received the greatest input of manure to its base and held a large standing crop of vegetation. The sediment at Tecumseh Cell 5 also contained elevated levels of $\mathrm{As}, \mathrm{Cd}, \mathrm{Cr}, \mathrm{Cu}, \mathrm{Ni}$, and $\mathrm{Pb}$. Appendix A shows the same trend of accumulation for $\mathrm{V}$, with the exception that Midwestern Cell 2A rather than the final cell contained the most V. While Midwestern Cell 2A did not contain the richest blend of organic substrate, it represents the first cell where the oxidized AMD encountered organic material under neutral $\mathrm{pH}$ conditions.

The oxalate extractable metals levels in Augusta Lake wetland sediment during the summer sampling appear in Figure 7. The oxalate extractable metals in Midwestern wetland sediments collected in the summer appear in Figure 8. The graphs contrast the pattern of metals accumulation in sediments generated at low $\mathrm{pH}$ in an organic-poor setting (Augusta Lake) with the pattern of accumulation generated at circumneutral $\mathrm{pH}$ in an organic-rich setting (Midwestern).

Figure 7 shows that, relative to the major species iron, the trace metals are not particularly enriched in the oxidation pond sediments. The levels at the oxidation pond are not noticeably greater than at the other sampling stations. This implies that coprecipitation is not the major driving force for precipitation here. Trace metals in the extracts from Midwestern wetland (fig. 8) show a more complex pattern of distribution. As noted above, the elements lead and chromium are highly concentrated in the final cells. Several other elements show greater concentrations in the lower wetland cells. This may result from scavenging by precipitated iron phases or absorption by organic substances. These processes are more favorable at the circumneutral $\mathrm{pH}$ of the Midwestern wetland than at the acidic $\mathrm{pH}$ of the Augusta Lake wetland.

\section{Environmental impact of sediment-bound metals}

In general, all the wetlands serve the desirable goal of relocating acid-generating deposits from areas of high relief to low-lying areas where they can be 
isolated from oxidation by burial or by submersion beneath the water table. The inundated surfaces in the wetlands were usually observed to be covered with precipitated iron. While these precipitates impair the growth of aquatic organisms, it is preferable to collect such iron deposits on site, rather than to allow them to pass into vulnerable waterways downstream. Sediment deposits become more compact and uniform as they age and exhibit less pore space as water is gradually expelled under hydrostatic pressure (Webster and others, 1998). The greater density of aged sediment and the chemical reduction of entrained sulfate to sulfide tend to inhibit the release of metals, since most metal sulfides are less soluble than oxyhydroxides or carbonates.

In most cases, metals sequestered in anoxic sediments remain stable and subsequent changes in the redox state that accompany drying are not enough to release most of the metals bound in the sediments (Gambrell, 1994). However, this is not the case for wetland soils that become acidified or oxidized upon drying. Sulfidic sediments in AMD

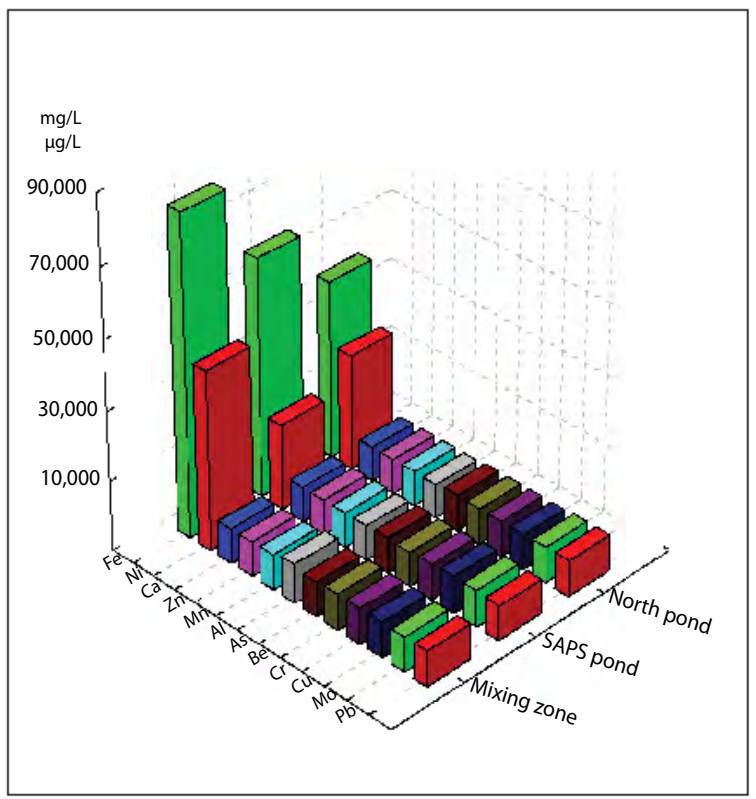

Figure 7. Graph of metals levels in the Augusta Lake wetland oxalic acid extracts of sediments from the summer sampling. Sampling sites are arranged from right to left in order from the AMD source toward the lower wetland. The sample names correspond to those that appear elsewhere in this report (fig. 1); the data are tabulated in Appendix B, Table B2, and the concentration units are $\mathrm{mg} / \mathrm{L}$ for the more abundant metals and $\mu \mathrm{g} / \mathrm{L}$ for the less abundant metals. wetlands are highly susceptible to oxidation upon exposure to the air, and the berms that maintain the water level in some constructed wetlands are built from coarse and porous onsite materials that may be unstable and prone to leakage. The use of such construction materials can render the wetland cells vulnerable to hydrologic changes, including sudden drainage caused by breaching of the berm.

\section{Sediment toxicity criteria}

The practical significance of the metals concentrations in wetland sediments is open to interpretation and depends in part upon the land-use goals of the wetland's setting (Webster and others, 1998). USEPA's Office of Solid Waste and Emergency Response (OSWER) has published sediment ecotoxicological screening criteria for metals (Hellyer and Balog, 1999). These screening values provide a framework for assessing the potential impact of the metals found in sediments collected at the outlets of the four treatment wetlands. Because a variety of factors can affect the ecological toxicity

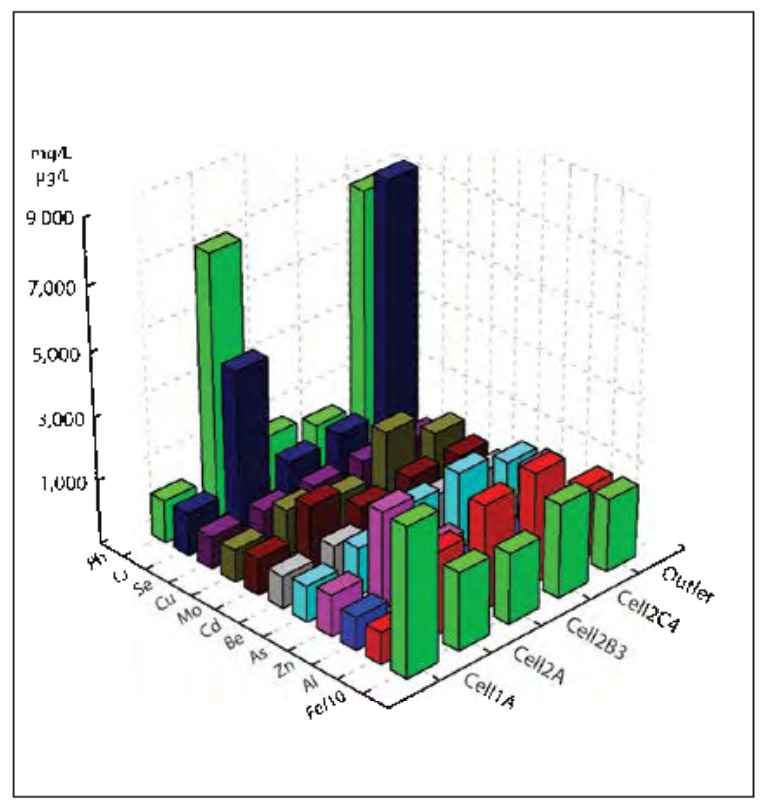

Figure 8. Graph of metals levels in the Midwestern wetland oxalic acid extracts of sediments from the summer sampling. Sampling sites are arranged from left to right from the oxidation pond to the wetland outfall. The sample names correspond to those that appear elsewhere in this report (fig. 3); the data are tabulated in Appendix B, Table B2, and the concentration units are $\mathrm{mg} / \mathrm{L}$ for the more abundant metals and $\mu \mathrm{g} / \mathrm{L}$ for the less abundant metals. The iron concentration has been divided by a factor of 10 to allow the trace metals to be more visible. 
of sediment, the values are considered to be benchmarks rather than universally applicable sediment quality standards (Jones and others, 1996).

The sediment quality benchmarks appear in Appendix A on the line labeled "OSWER Limit." The data show that virtually all the sediments exceeded the toxicity threshold for nickel. About onehalf of the sediments exceeded the cadmium standard. Significant numbers of samples surpassed the threshold values for copper, zinc, and arsenic, as well. While the Midwestern wetland produced some of the best final water quality, the metals that have accumulated in its sediment, particularly the final treatment cells, show potential ecotoxicity.

In conclusion, the spatial distribution of trace metals in the wetlands and their relative distribution between the available and residual fractions suggest that the processes of co-precipitation, scavenging by hydrous iron oxides, and organic complexation must all contribute to metals removal. While the metals in the $\mathrm{HCl}$ fraction are not readily available for biological uptake, the tendency for the metals to accumulate to high concentrations in the final cells indicates that the wetland sediments could potentially serve as a source of contamination should they be drained or disturbed.

\section{Metals accumulation in aquatic plants}

The concept of phyto-remediation (metals removal by plant uptake) is an established component of AMD treatment plans (Prasad, 2001). Aquatic macrophytes can remove metals by bio-accumulating them to concentrations that are often three or four orders of magnitude greater than that of the surrounding water (St.-Cyr and others, 1994). Rooted aquatic plants take up nutritive metals such as calcium, magnesium, potassium, and sodium directly from the water column through their leaves, but, for the most part, potentially toxic metals are absorbed through the plant's roots (Chambers and others, 1989; Barko and others, 1991). Therefore, the metals must be trapped in pore water or precipitate from AMD and accumulate in the sediment where they equilibrate with the pore water before most species of plants take them up through their root cell membranes.

An alternative path for metals uptake by aquatic plants is through the layers of iron oxides and hydroxides that develop on the submerged surfaces of exposed root masses. Dense populations of acidophilic iron-oxidizing bacteria are found on wetland plants grown in waters with a $\mathrm{pH}<4$ (King and Garey, 1999). The density of these populations $\left(10^{5}\right.$ bacteria per gram of wet root mass) indicates that plaque microbes must contribute substantially to the precipitation and cycling of iron, manganese, and phosphorus in wetlands (King and Garey, 1999). The activities of bacteria present in these iron-rich plaques can contribute significantly to the plant's ability to utilize these metals (Emerson and others, 1999). Heat generated from the metabolism of dense microbial communities in subsurface water may help extend biological processes into periods of colder temperatures (Price and Sowers, 2004).

Once potentially toxic metals have been taken into a plant, they tend to bind to cellulosic cell walls or to proteins known as "phytochelatins" (Siedlecka and others, 2001). Metals bound to internal structures within the plants are usually considered to have been phyto-remediated and effectively removed from the eco-system, though they may be released into ground and surface water when plants die and decay (Prasad, 2001).

Not all the functions of aquatic plants are helpful for fixating metals. Since nutrients are often scarce in aquatic systems, aquatic plants have developed mechanisms to increase the solubility of nutritional elements and these mechanisms may cause release of metals from sediments (Chambers and others, 1989). The roots of aquatic plants, particularly Typha, can reduce ferric iron oxyhydroxides at a very high rate (King and Garey, 1999; Schmidt, 1999) and plant roots can secrete protons, generating acidity and increasing metal solubility (Schubert and Mengel, 1986).

While the physiological mechanisms of aquatic plants may not always be beneficial, the presence of plants generally improves the overall metals removal rates. Established stands of Phragmites and Typha can be relied upon to stabilize sediments and provide a self-renewing barrier to water flow, thereby increasing the residence time of AMD in the wetland. Overall, wherever sufficient aquatic plants become established in an AMD wetland, increases in the iron removal rate offset the increases in iron dissolution brought about by physiological processes in the roots. 
The four Indiana wetlands are dominated by stands of Typha and Phragmites that have been introduced to stabilize the sediments. Because of the physiological stresses presented by AMD, there is little plant diversity at most of these sites. At Augusta Lake, Friar Tuck, and Midwestern, the emergent aquatic species were limited to monocultures of Typha and Phragmites. At Tecumseh, a few opportunistic native species were found to colonize hydric zones along the fringe areas. The Tecumseh wetland also held several species of submerged plants.

Throughout the four wetlands, no native species of submerged plants were found in any inundated area where the $\mathrm{pH}$ was below 4.5 units. Emergent stands of Typha were found in Cell $4 \mathrm{~A}$ of the Tecumseh wetland in water having a $\mathrm{pH}$ of 3.5 units; but flow from a nearby acid seep that influenced the $\mathrm{pH}$ was seen to be intermittent, so the $\mathrm{pH}$ there may vary seasonally.

The plants were collected from Tecumseh wetland Cell 5, where the large surface area, nutrient-rich substrate, and circumneutral water conditions support a wide range of species. The sampling point was along the western edge of the berm that separates Cell 4A from Cell 5, adjacent to the main inflow of AMD into the cell. In addition to Typha and Phragmites, emergent aquatic plants found here include square stem rush, bulrush, sedges, arrowheads, and horsetails. The submerged plants identified include spike rush, naiads, and pondweed. The genera selected for sampling were Typha (cattail), Phragmites (reed), Potamogeton (pondweed), Eleocharis (spike rush and square stem rush). Plant species were confirmed using the guidelines provided in Godfrey and Wooten (1979) and Magee (1981).

The results of metals analysis of the plant tissues appears in Table 7. As the data show, the aquatic plants all tend to concentrate the phytotoxic metals aluminum, cobalt, copper, and lead in their roots. Sequestration of these metals serves to protect the plant's photosynthetic apparatus from interference by metals toxicity (Siedlecka and others, 2001). Cadmium was sequestered in the root mass of the Potamogeton and rush species. Less toxic metals like iron, chromium, manganese, and zinc were also concentrated in the roots. Arsenic and selenium levels were generally less than $1 \mathrm{mg} / \mathrm{kg}$, and these metals were primarily limited to the lower parts of the plants. On the other hand, boron was widely distributed throughout the plant tissues. Phragmites translocated the nutritional elements chromium, manganese, molybdenum, and zinc, to their upper leaves, as well as potentially toxic aluminum and copper. Typha translocated aluminum, boron, manganese, and zinc to their upper shoots. Potamogeton concentrated manganese, zinc, and lead in their leaves. Phragmites, Potamogeton, and Typha accumulated nickel in their leaves.

\section{Implications for phytoextraction remediation in wetlands}

Plants may be classified as exhibiting three different strategies in response to potentially toxic metals, making them excluders, indicators, or accumulators (Prasad, 2001). In response to metals exposure, excluders restrict their uptake of excess metals. Indicator species take up metals at levels that reflect the ambient concentration of the metal, and they show symptoms when the metals reach toxic levels in their tissues. Accumulators readily take up metals and employ physiological mechanisms to mitigate the potential toxicity.

The plant's response to external metals determines the role it can play in site remediation and the fate of metals at the site. The remedial role of plants may be phytostabilization, which involves storage of the metals on the site, or phytoremediation, which involves removal of the metals from the ecosystem. When phytostabilization is the goal, plants that sequester metals in their roots are preferable because the root tissue and its burden of metals tend to remain buried and fixed in the sediments. Alternatively, species that translocate metals to their upper tissues are preferable for bioremediation, because this removes the metals from the sediment for harvesting. Indicator and accumulator species which translocate metals to their leaves may cause remobilization of metals from the site when vegetation dies and the material is washed downstream. These types of plants also make metals available for uptake by herbivores.

An alternative for dealing with metals absorbed by accumulator and indicator species of plants is to harvest them, which removes the metals from the ecosystem. Harvesting plant biomass is a form of phytoremediation known as phytoextraction, and this technology is now widely practiced in a number of countries as an inexpensive alternative to engineering options (Mukherjee, 2001). The U.S. 


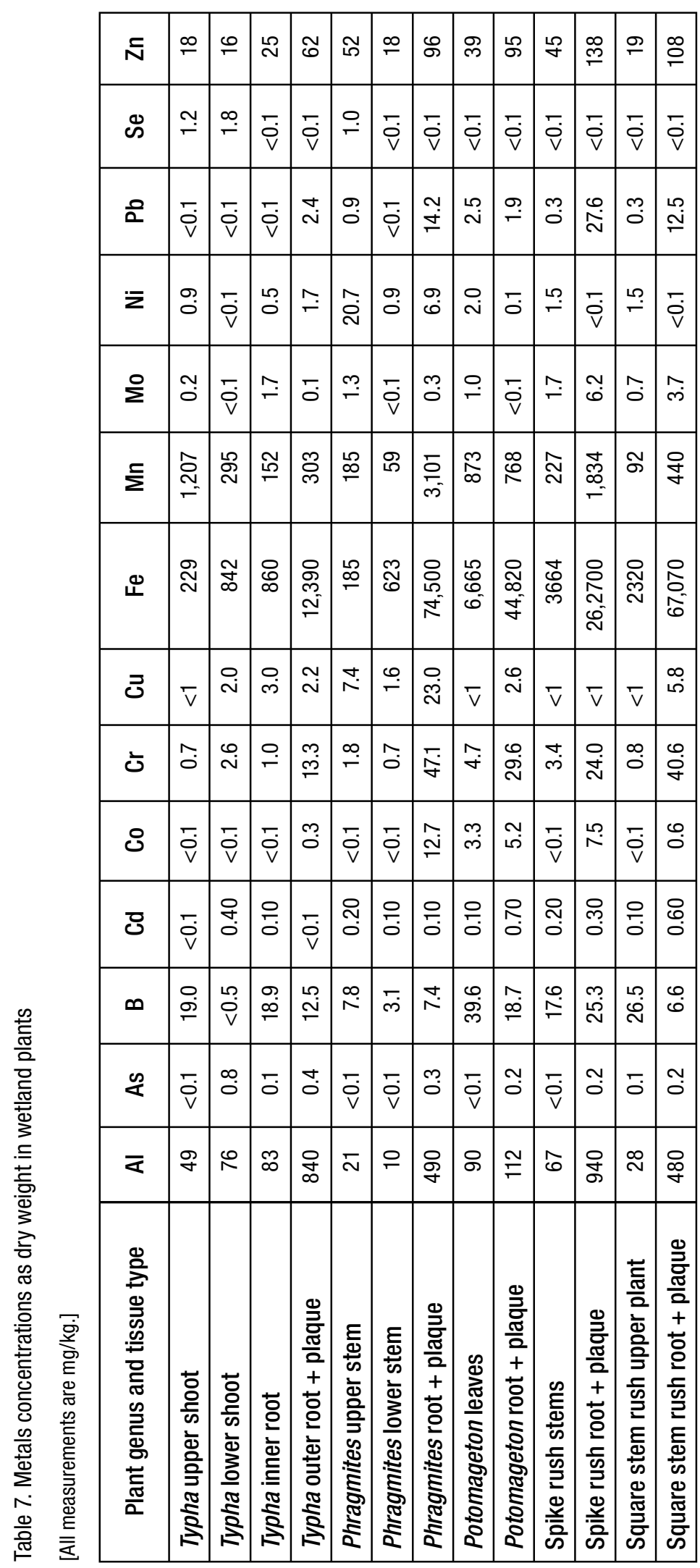


Environmental Protection Agency has suggested that harvesting aquatic plants is justifiable in situations where the majority of metals are associated with the plant biomass rather the sediment (Marble and others, 2002).

To gauge whether phytoextraction might be a viable option for remediating Indiana wetlands, an estimate was made of the mass of manganese in the standing crop of Typha relative to the mass deposited in sediment over a growing season. Manganese was chosen because it is readily taken up by plants and plant tissues can accumulate very high levels of manganese before showing visible symptoms (Prasad, 2001).

The Midwestern site was chosen for this exercise because most of its surface area supports dense stands of Typha. The AMD influent to the wetland contains an average of $14.7 \mathrm{mg} / \mathrm{L}$ of manganese while its effluent contains an average of $4.6 \mathrm{mg} / \mathrm{L}$ of manganese. The flow of water through the wetland averages $36 \mathrm{~L}$ per minute; and multiplication of the concentration by water volume indicates that the mass of Mn removed in the wetland each year is $191 \mathrm{kgs}$. Typha covers about 90 percent of the wetland's surface area (Table 2), meaning that the vegetated area is 0.9 hectare ( 2.2 acres). At this latitude, Typha is likely to produce at most 16 tons $(\sim 14,690 \mathrm{~kg})$ of dry biomass in this area (Prasad, 2001). From the weighted average of $\mathrm{Mn}$ values in Table 7, the mean manganese concentration measured for the plant tissue taken from these wetlands was calculated to be about $600 \mathrm{mg}(0.02 \mathrm{oz})$ manganese per dry $\mathrm{kg}(2.2 \mathrm{lbs})$. Therefore, the standing crop of Typha holds about $9 \mathrm{~kg}$ (19.8 lbs) of $\mathrm{Mn}$. So at best, the standing crop of Typha in this highly productive wetland contains only about 4.7 percent of the total manganese removed by the wetland each year.

In this case, plant harvesting is not justified because the plant biomass represents a relatively minor environmental compartment for Mn storage; the mass of metal stored does not approach the aforementioned criterion of containing most (or more than half) of the metals burden of the total mass within the system. However, harvesting the biomass of emergent species could be beneficial in cases where the overall flux of toxic metals into the system will eventually result in the future increase of toxicity either onsite or downstream. Such a situation could arise when toxic metals concentrations in the biota and the sediment already exceed ecotoxicity criteria and the influx of metals continues unabated. The metals to be mitigated would have to be among those shown to be translocated into the upper tissues of the plants: aluminum, boron, manganese, zinc, and possibly nickel. Ultimately, the decision to employ phytoextraction should be based upon projected land use and other environmental impact considerations.

While phytoextraction does not appear practical at this time, the phytostabilization of toxic metals does take place wherever these plants become established. The data in Table 7 indicate that all the plants studied here accumulate metals in their root mass and that the translocation of metals to the leaves and upper shoots is less common. To the extent that metals are chemically bound to proteinaceous matter and internal structures within the plant, the metals can be considered to have been effectively phytostabilized.

Dense thickets of Potamogeton and smaller thickets of Eleocharis (spike rush) were observed throughout Tecumseh Cell 5. While reeds and cattails dominate these wetlands, the submerged plants occupy significant portions of wetland cells in those zones where their metabolic needs can be met. The establishment of submerged plants is considered very beneficial because they act as a physical barrier to flow and reduce water velocity, attenuate waves, baffle the water flow pattern, and provide surfaces on which metals may precipitate (Prasad, 2001).

In the upper area of the Friar Tuck wetland, dense reeds have caused so much organic material and sediment to accumulate that the channels of both the freshwater stream and the AMD source are broadly dispersed and sink beneath the surface. The highly acidic flow that enters the area of the reed bed reacts with this unconsolidated, lowdensity sediment so that the water emerging from the ground downstream is much closer to neutral $\mathrm{pH}$ and far less impaired than the AMD at its source (Table 1).

Taken as a whole, the primary contribution to metals removal by the abundant emergent and submerged plants lies not so much in the direct absorption of toxic metals, but in their ability to stabilize sediment, baffle the flow, and improve the retention time so that the wetlands physically capture and retain metal precipitates. 


\section{CONCLUSIONS}

The removal of dissolved metals is an important aspect of AMD remediation both in terms of eliminating mineral acidity and in mitigating the impact of toxic trace metals. Comparison of the levels of potentially toxic trace metals found in the AMD with the levels that appear in the effluents show that the concentrations are generally reduced by passage through the wetlands (Table 1). There were a few exceptions to this trend. Manganese does not precipitate from water with a $\mathrm{pH}$ less than 9, and its level was only slightly decreased by passage through the Augusta Lake wetland, being discharged at $23.8 \mathrm{mg} / \mathrm{L}$ in winter and $18.7 \mathrm{mg} / \mathrm{L}$ in summer. The summer value of $18.7 \mathrm{mg} / \mathrm{L}$ for manganese in the effluent actually exceeded the value of $15.4 \mathrm{mg} / \mathrm{L}$ that was found in one of the oxidation ponds located closer to the AMD source. Calcium, potassium, and other alkaline earth metals decreased very little in the effluents, and occasionally increased throughout the wetlands, but this was not considered a cause for concern because these elements have nutritive value and are not toxic at the levels detected.

Dissolved iron concentrations decreased mostly by more than 96 percent between the initial AMD and the wetlands effluent, and most of this decrease can be attributed to precipitation and dilution effects. However, the iron level at Augusta Lake wetland during the summer saw only a small decrease from $33.1 \mathrm{mg} / \mathrm{L}$ to $30.2 \mathrm{mg} / \mathrm{L}$ (8.8\%). Other significant metals discharges include manganese, which was discharged from the Friar Tuck wetland at $8.3 \mathrm{mg} / \mathrm{L}$ in winter and $4.7 \mathrm{mg} / \mathrm{L}$ in summer. Nickel was abundant at levels as great as 1,307 $\mu \mathrm{g} / \mathrm{L}$ in the AMD entering the four wetlands, and it was always detectable in the effluents at levels that ranged from 5 to $422 \mu \mathrm{g} / \mathrm{L}$.

In more than 50 percent of the water samples, the elements arsenic, beryllium, copper, molybdenum, and selenium were not detected. Arsenic was never found above its detection limit of $1 \mu \mathrm{g} / \mathrm{L}$ in any of the effluents. In winter, molybdenum appeared in all the effluents at values ranging from 4 to $6 \mu \mathrm{g} / \mathrm{L}$. Zinc was measurable in all the effluents, reaching a maximum value of $0.9 \mathrm{mg} / \mathrm{L}$ at Augusta Lake in winter. Vanadium was discharged from the Friar Tuck wetland at $24 \mu \mathrm{g} / \mathrm{L}$ in winter and $11 \mu \mathrm{g} / \mathrm{L}$ in summer. Beryllium was most abundant at the Augusta Lake wetland, but its level was reduced from $19 \mu \mathrm{g} / \mathrm{L}$ in the upper watershed to $4 \mu \mathrm{g} / \mathrm{L}$ in the effluent. The Augusta Lake wetland also discharged low levels of cadmium $(3.2 \mu \mathrm{g} / \mathrm{L})$ and copper $(10 \mu \mathrm{g} / \mathrm{L})$ in the winter. During the summer, chromium was slightly more abundant $(1-4 \mu \mathrm{g} / \mathrm{L})$ in the effluents than in the winter $(<1-1 \mu \mathrm{g} / \mathrm{L})$. Lead was more frequently detected in the winter than in the summer, but its maximum discharge level was $5.3 \mu \mathrm{g} / \mathrm{L}$ at Friar Tuck in summer. Otherwise, potentially toxic metals in the effluents were either not detectable or found at very low levels on the order of $1 \mu \mathrm{g} / \mathrm{L}$.

The low levels of trace metals in many of the surface water samples are consistent with the large amount of rainfall in these wetland watersheds. That the surface waters were not completely equilibrated with the solid phases abundant in the wetlands is confirmed by the greater levels of metals found in the pore waters. Of the elements arsenic, beryllium, copper, molybdenum and selenium, which were detected in more than 50 percent of the surface water samples, beryllium was the only element that was not detected in more than 50 percent of the pore waters. In addition to more frequent detection of trace metals in pore water, the concentrations of trace metals in pore water were generally greater in magnitude than their concentrations in the surface water.

The wetland sediments were found to contain toxic metals; however, only nickel was commonly present at levels that exceed EPA's published ecotoxicity guidelines. The elements aluminum, boron, cadmium, and lead were found in these AMD sediments at levels that could exceed ecotoxicity guidelines if they continue to accumulate in the sediments and become further enriched.

Arsenic, cadmium, chromium, copper, nickel, lead, and vanadium were found to accumulate in downstream cells of the constructed wetlands, where, if remobilized, they could potentially pose an environmental threat to areas farther downstream. In the distal cells, these elements accumulated in relatively insoluble forms that represent organic and sulfide-bound metals. In contrast, the extracts from sediments collected in the initial upstream oxidation cells where iron oxidation is rapid indicate that trace metals are more soluble and biologically available in this part of the wetland.

In the initial oxidation ponds, toxic metals are deposited by processes such as oxidation, co-precipitation, and adsorption to iron phase surfaces. In 
the lower downstream cells, the metals are increasingly abundant in less soluble phases that require very acidic conditions to dissolve. The change in the distribution of metals between the available and residual phases suggests that metals removal processes progress from the initial stage of rapid precipitation and co-precipitation, in which metals are weakly bound, to later stages of complexation and sorption, during which metals are bound in organic matter and incorporated into the crystal structure of hydrous iron oxides and sulfides.

While the metals in the residual (HCl-extracted) fraction are less readily available for biological uptake, the tendency for the metals to accumulate to high concentrations in the final cells indicates that these wetland sediments could potentially serve as a source of contamination should they be drained or disturbed. If the wetlands are allowed to remain inundated, the sediments will most likely remain stable and these toxic metals will remain much less mobile than under upland conditions (Gambrell, 1994). Hence, the wetlands serve the practical function of reconcentrating metals in lowlying areas where they are less likely to become mobilized. However, when the treatment cells become filled with solid matter, the flow must either be directed to new cells or the sediment must be excavated. Where space is constrained, excavation is the only option.

If the excavated material is placed on higher ground, it will be subject to weathering, oxidation, and leaching. However, metal precipitates that have accumulated in wetland sediments usually coexist with organic matter and carbonate emplaced during construction. This association may deter acidification by buffering the groundwater. As long as there is enough alkalinity and organic matter present, the saturated zone within the landfilled wetland sediment should not become acidified below $\mathrm{pH}$ 5, a condition that would promote microbially mediated oxidation by the pyrite-oxidizing bacteria such as T. ferrooxidans. Consequently, the release of acidity and metals from these reburied deposits should be greatly diminished compared to the acidity generated from mine spoil. To ensure this, if AMD wetland sediments are to be excavated and re-interred elsewhere, alkaline material should be emplaced with the sediment as a safeguard.
A significant standing crop of biomass is readily apparent in all four wetlands and analysis of plant tissues showed that the plants readily absorbed metals, sequestering most of the toxic metals in their root mass. While wetland plants accumulate elevated levels of toxic metals in their tissues, the overall mass of metals sequestered in plant tissue is small relative to the mass deposited in sediment. In addition to accumulating metals in their roots, the emergent species Typha and Phragmites were shown to translocate aluminum, boron, manganese, molybdenum, nickel, and zinc into their upper shoots and leaves. Metals in these tissues are potentially available for ingestion by herbivores and for offsite transport after the seasonal die-off of the plants.

Root tissues that were covered with plaque contained elevated levels of iron and other metals. The accumulation of metal-bearing plaque on the outside of submerged plant tissues underscores the multifaceted role that aquatic species play in these wetlands. Although only a small amount of metals accumulate in plant tissues, wetland plants enhance metals removal mainly by increasing effluent residence time, baffling flow, stabilizing sediments, and providing surfaces on which highly absorptive iron oxide plaques can grow and interact with the pore water.

There may be economic pressure for reclaimed mine land to be redeveloped for agricultural, commercial, recreational, or residential use. When developing reclaimed land, it is important for planners to show appropriate consideration for the environmental consequences of draining wetlands that have been affected by acidic mine drainage, because it is possible for toxic metals to be remobilized and released from these wetlands. In light of the potentially ecotoxic metals burden contained in the wetland sediments, the role that aquatic macrophytes play in stabilizing the sediments can be quite important. While it is advantageous to maintain AMD treatment wetland sediments in an undisturbed state, it is also important to allow aquatic plant communities to continue to thrive, because these plants serve to phytostabilize the metals that accumulate in the wetland sediments. 


\section{ACKNOWLEDGMENTS}

The author wishes to acknowledge the efforts of the Geochemistry Section of the Indiana Geological Survey (IGS) and the research assistants who contributed to the acquisition of the data that are reported here. Sarah Butler, Jessica Deli, Patricia Renton, and Jill Tutlewski aided in the preparation of plant tissues, the analyses of metals by atomic absorption spectrometry, and the titrations for ferrous iron and acidity. Margaret Ennis performed many of the major cation analyses and Tracy Branam was responsible for the provision and calibration of the field equipment. Barry Maynard and Adam Flege of the Department of Geology, University of Cincinnati corroborated the field measurements and published the sulfur isotope data used to evaluate the role of precipitation in the hydrologic regime of the sites. I wish to thank John Comer of the IGS for his guidance, editorial assistance, and administrative support.

\section{REFERENCES}

American Public Health Association (APHA) and American Water Works Association, 1985, Standard methods for the examination of water and wastewater, $16^{\text {th }}$ ed.: Washington, D.C., $1,268 \mathrm{p}$.

ATEC Associates, 1984, Investigation of Mill Creek Abandoned Mine Land Site, Pike County, Indiana: ATEC Associates, Indiana Department of Natural Resources Project No. E23-403, 207 p.

Barko, J., Gunnison, D., and Carpenter, S., 1991, Sediment interactions with submerged macrophyte growth and community dynamics: Aquatic Botany, v. 41, no. 1-3, p. 41-65.

Behum, P., and Kim, K., 1999, Workshop for the application of passive technology to the treatment of acid mine drainage: Alton, Ill., U.S. Office of Surface Mining Reclamation and Enforcement, $73 \mathrm{p}$.

Bhumbla, D., Calabrese, J., Sencindiver, J., Sexstone, A., and Bissonnette, G., 1990, Attenuation of Fe and Mn in AMD applied to constructed wetlands: Agronomy Abstracts 1990, p. 33.

Bigham, J., and Schwertmann, U., 1996, Influence of $\mathrm{pH}$ on mineral speciation in a bioreactor simulating acid mine drainage: Applied Geochemistry, v. 11, no. 6, p. $845-849$.

Branam, T. D., Harper, D., Smith, R. T., and Naylor, S. C., 2012, Effectiveness of emerging reclamation methods at an abandoned mine and site in Pike County,
Indiana, in Comer, J. B., ed., Effects of abandoned mine land reclamation on ground and surface water quality-research and case histories from Indiana: Indiana Geological Survey Special Report 72, p. 127-146.

Bryenton, D. L., and Gasper, J. H., 1994, Design and construction guidelines for coal combustion by-product utilization in abandoned mine land settings-a case study: Indianapolis, Ind., ATEC Associates, Inc.

Bureau of Mines, 1994, Passive mine drainage treatment systems: U.S. Department of the Interior, Bureau of Mines, Technology News, no. 407A, AML \#12A reissue, $4 \mathrm{p}$.

Chambers, P. A., Prepas, E. E., Bothwell, M. L., and Hamilton, H. R., 1989, Roots versus shoots in nutrient uptake by aquatic macrophytes in flowing waters: Canadian Journal of Fisheries and Aquatic Sciences, v. 46, no. 3, p. 435-439.

Chapman, P., Wang, F., Adams, W., and Green, A., 1999, Appropriate applications of sediment quality values for metals and metalloids: Environmental Science and Technology, v. 33, no. 22, p. 3,937-3,941.

Comer, J. B., Smith, R. T., Ennis, M. V., Branam, T. D., Welp, L. R., Morales, N. E., Sobiech, S. A, and Simon, T. P., 2000, Effects of passive reclamation on water quality in the northeastern drainage of Augusta Lake, Pike County, Indiana-chemical analyses and QA/QC: Indiana Geological Survey Open-File Study 00-02, $19 \mathrm{p}$.

Comer, J. B., Smith, R. T., Ennis, M. V., and Branam, T. D., 2012, Effects of reclamation on the water quality of Augusta Lake and Mill Creek, Pike County, Indiana, in Comer, J. B., ed., Effects of abandoned mine land reclamation on ground and surface water quality-research and case histories from Indiana: Indiana Geological Survey Special Report 72, p. $187-224$.

Dietz, J., and Dempsey, B., 1980, Oxygenation kinetics of ferrous iron in aqueous media: Environmental Science and Technology, v. 14, no. 5, p. 562-568.

Elliot, H. A., Dempsey, B. A., and Maille, P. J., 1990, Content and fractionation of heavy metals in water treatment sludges: Journal of Environmental Quality, v. 19, p. 330-334.

Emerson, D., Weiss, J., and Megonigal, J., 1999, Ironoxidizing bacteria are associated with ferric hydroxide precipitates (Fe-plaque) on the roots of wetland plants: Applied Environmental Microbiology, v. 65 , no. 6 , p. 2,758-2,761.

Evangelou, V. P., 1995, Pyrite oxidation and its control: New York, CRC Press, 293 p.

Flege, A. E., 2001, Sulfate reduction in five constructed wetlands receiving acid mine drainage: Cincinnati, 
Ohio, University of Cincinnati, master's thesis, $148 \mathrm{p}$.

Flege, A. E., Maynard, J. B., and Elswick, E. R., 2012, Sulfur isotopes as indicators of remediation efficacy in constructed wetlands receiving acid mine drainage, in Comer, J. B., ed., Effects of abandoned mine land reclamation on ground and surface water qualityresearch and case histories from Indiana: Indiana Geological Survey Special Report 72, p. 299-324.

Franco, N., and Balouskus, R., 1974, Electrochemical removal of heavy metals from acid mine drainage: U.S. Environmental Protection Agency, EPA-670/274-023, $87 \mathrm{p}$.

Freeze, R. A., and Cherry, J. A., 1979, Groundwater: Englewood Cliffs, N.J., Prentice-Hall, 604 p.

Gambrell, R. P., 1994, Trace and toxic metals in wetlands-a review: Journal of Environmental Quality, v. 23, p. $883-891$.

Godfrey, R. K., and Wooten, J. W., 1979, Aquatic and wetland plants of southeastern United States: Athens, Ga., University of Georgia Press, 712 p.

Hach Company, 1992, Water analysis handbook, $2^{\text {nd }}$ ed.: Loveland, Colo., Hach Company, p. 70-73.

Harper, D., Olyphant, G. A., and Branam, T. D., 2012, Direct revegetation and the sustainability of reclaimed mine lands-the story of the Friar Tuck Site, Indiana, in Comer, J. B., ed., Effects of abandoned mine land reclamation on ground and surface water quality-research and case histories from Indiana: Indiana Geological Survey Special Report 72, p. $83-125$.

Hedin, R. S., and Nairn, R. W., 1992, Designing and sizing passive mine drainage treatment systems, in Proceedings of the $13^{\text {th }}$ Annual West Virginia Surface Mine Drainage Task Force Symposium, West Virginia Mining and Reclamation Association, Morgantown, W. Va.

Hellyer, G. M., and Balog, G. E., 1999, Derivation, strengths and limitations of sediment ecotoxicological screening benchmarks, ESBs: U.S. Environmental Protection Agency, Lexington, Mass., New England Regional Laboratory.

Jones, D. S., Hull, R. N., and Suter II, G. W, 1996, Toxicological benchmarks for screening potential contaminants of concern for effects on sedimentassociated biota, 1996 revision: Oak Ridge, Tenn., Oak Ridge National Laboratory, ES/ER/TM-95/ $\mathrm{R} 2,33 \mathrm{p}$.

King, G. M., and Garey, M. A., 1999, Ferric iron reduction by bacteria associated with the roots of freshwater and marine macrophytes: Applied and Environmental Microbiology, v. 65, no. 10, p. 4,393-4,398.
Langmuir, D., 1997, Aqueous environmental geochemistry: Englewood Cliffs, N.J., Prentice Hall, 600 p.

Magee, D. W., 1981, Freshwater wetlands-a guide to common indicator plants of the northeast: Amherst, Mass., University of Massachusetts Press, $245 \mathrm{p}$.

Makos, J. D., and Hrncir, D. C., 1995, Chemistry of Cr (VI) in a constructed wetland: Environmental Science and Technology, v. 29, p. 2,414-2,419.

Marble, J. C., Corley, T. L., and Conklin, M. H., 2002, Representative metals uptake in plants and algae near Globe, Arizona: U.S. Geological Survey Toxic Substance Hydrology Program Web site, $<$ http://toxics.usgs.gov/pubs/wri99-4018/Volume1/ sectionC/1411_Marble/pdf/1411_Marble.pdf $>$, date accessed, July 26, 2011.

McCleary, E. C., and Kepler, D. A., 1994, Ecological benefits of passive wetland treatment systems designed for acid mine drainage with emphasis on watershed restoration, in International Land Reclamation and Mine Drainage Conference and $3^{\text {rd }}$ International Conference on the Abatement of Acidic Drainage, v. 3: U.S. Bureau of Mines Special Publication 06C94, p. 111-119.

Mukherjee, A. B., 2001, Behavior of heavy metals and their remediation in metalliferous soils, in Prasad, M. N. V., ed., Metals in the environment-analysis by biodiversity: Basel, Switzerland, Marcel Dekker, p. 433-472.

Nordstrom, D., and Munoz, J., 1994, Geochemical thermodynamics, $2^{\text {nd }}$ ed.: Boston, Mass., Blackburn Press, $493 \mathrm{p}$.

Peters, D. G., Hayes, J. M., and Hieftje, G. M., 1974, The cerium (IV)-iron (II) titration, in Chemical separations and measurements: Philadelphia, Pa., W.B. Saunders Co., p. 280-286.

Pfaff, J. D., Brockhoff, C. A., and O'Dell, J. W., 1991, Test method-the determination of inorganic anions in water by ion chromatography-method 300.0: U.S. Environmental Protection Agency, Environmental Monitoring and Systems Laboratory, Office of Research and Development, Cincinnati, Ohio, p. 300.0-1-300.0-13.

Pickering, W., 1986, Metal ion speciation in soils and sediments-a review: Oregon Geology Reviews, v. 1, p. 83.

Prasad, M. N. V., 2001, Aquatic macrophytes, in Prasad, M. N. V., ed., Metals in the environment-analysis by biodiversity: Basel, Switzerland, Marcel Dekker, p. 259-288.

Price, T., and Sowers, T., 2004, Temperature dependence of microbial rates for growth, maintenance, and survival: Proceedings of the National Academy of Sciences, v. 101, no. 13, p. 4,631-4,636. 
Schmidt, W., 1999, Mechanisms and regulation of reduction-based iron uptake in plants: New Phytologist, v. 141, no. 1, p. 1-26.

Schubert, S., and Mengel, K., 1986, Effect of light intensity on proton extrusion by roots of intact maize plants: Physiologia Plantarum, v. 67, no. 4, p. 614-619.

Schwertmann, U., and Cornell, R. M., 1991, Iron oxides in the laboratory: preparation and characterization: New York, VCH, 137 p.

Siedlecka, A., Tukendorf, A., Skorzynska-Polit, E., Maksymiec, W., Wojcik, M., Basjzynski, T., and Krupa, Z., 2001, Angiosperms, in Prasad, M. N. V., ed., Metals in the environment-analysis by biodiversity: Basel, Switzerland, Marcel Dekker, p. 171-217.

St.-Cyr, L., Campbell, P., and Guertin, K., 1994, Evaluation of the role of submerged plant beds in the metal budget of a fluvial lake: Hydrobiologica, v. 291, p. 141-156.

Stumm, W., and Morgan, J. J., 1970, Aquatic chemistry: New York, Wiley-Interscience, 583 p.

U.S. Environmental Protection Agency, (USEPA), 1979, Methods for the chemical analysis of water and wastes: EPA-600/4-79-020.

U.S. Environmental Protection Agency, (USEPA), 1992a, Test methods for evaluating solid waste, physical/ chemical methods: SW-846, 538 p.

U.S. Environmental Protection Agency, (USEPA), 1992b, Relationship with sediment criteria, interim guidance on interpretation and implementation of aquatic life criteria for metals, health and ecological criteria division: U.S. Environmental Protection Agency, $24 \mathrm{p}$.

U.S. Environmental Protection Agency (USEPA), 1996, ECOTOX thresholds: 540/F-95/038, 12 p.

Webster, J., Swedlund, P., and Webster, K., 1998, Trace metal adsorption onto an acid mine drainage iron (III) oxy hydroxide sulfate: Environmental Science and Technology, v. 32 , no. 10 , p. $1,361-1,368$. 


\title{
The Role of Efflorescent Sulfate Salts in Indiana's Mine Water Quality
}

\author{
Jeanette K. Pope, ${ }^{*}$ E. Randall Bayless, ${ }^{\dagger}$ Greg A. Olyphant, ${ }^{\ddagger}$ and Tracy D. Branam ${ }^{\S}$ \\ *Department of Geosciences, DePauw University \\ ${ }^{+}$U.S. Geological Survey \\ ${ }^{\ddagger}$ Department of Geological Sciences, Indiana University \\ Indiana Geological Survey
}

\begin{abstract}
Efflorescent sulfate salts, which form from evaporating acid mine drainage and occur in a wide variety of environments, can significantly alter water quality and are, therefore, important considerations for remediation strategies at coal refuse sites. Many efflorescent sulfate salts, including melanterite, rozenite, siderotil, copiapite, halotrichite, coquimbite, epsomite, potash alum, and gypsum, are known to occur in Indiana. Because they build up on the gob-pile surface during dry periods and release acidity and metals in storm flushes, it is essential to understand the mineralogical and geochemical parameters that control efflorescent sulfate salts formation and dissolution in mine settings.
\end{abstract}

The Friar Tuck Site, in southwestern Indiana, is an ideal location for demonstrating the role of efflorescent sulfate salts in the generation of acid mine drainage and is included as a case study in this report. Examination of two gob piles at the site (northwest and southeast), in the same setting but with different mineralogies and depositional and reclamation histories, provides a unique opportunity to consider the transferability of lessons learned about the efflorescent sulfate salts between different sites.

Hydraulic and chemical data, including data on aqueous and solid states (coal refuse and efflorescent sulfate salts), were collected from streams (adjacent to the gob piles and further downstream), seeps, surface runoff, and saturated and unsaturated groundwater at the Northwest and Southeast Gob Piles during 1988-89 and 1990-92, respectively. Samples were analyzed in the field for bulk indicators and in a laboratory (Indiana Geological Survey, Geochemistry Section) for concentrations of major and trace elements.

Values of $\mathrm{pH}$ and specific conductance at the Southeast Gob Pile indicated a trend of declining water quality with duration of the dry season, followed by dilution and improved water quality during the wet season; similar observations were made at the Northwest Gob Pile. Concentrations of key water-quality indicators for the Northwest and Southeast Gob Piles show that acidity and concentrations of sulfate and iron are notably lower in the surface runoff and groundwater in saturated and unsaturated refuse at the Southeast Gob Pile compared to the Northwest Gob Pile. The dissolution of efflorescent sulfate salts is likely the cause for the 
decrease in water quality at both gob piles, but it has a greater effect at the Northwest Gob Pile.

The results of this study indicate that some generalizations about the effect of efflorescent sulfate salts on water quality (for example, the conditions that favor the precipitation of specific efflorescent sulfate salts; the development of acidic, metal-rich drainage; and so on) can be transferred from one coal-waste site to another. However, the specific geochemistry of the gob pile, the age and history of refuse, the source rock, and the coal-processing and reclamation activities at the specific site will determine the extent to which the processes described in this and other papers can be applied to unstudied gob piles.

\section{INTRODUCTION}

A ubiquitous feature of lands impacted by acid mine drainage is a rainbow of colors on soil and spoil surfaces and along drainageways from the myriad minerals that form via oxidation and dehydration reactions. The most common colors, of course, are the ochre reds, oranges, and purplebrowns of iron oxyhydroxide phases (for example, goethite, lepidocrocite, ferrihydrite) that dominate the mineralogy. But upon closer inspection, encrustations or "blooms" of pale yellow, blue-green, and white minerals can be found coating rocks along the banks of streams or in otherwise bare patches of sediment (fig. 1). These minerals, called efflorescent sulfate salts (ESS) because they form in blooms (efflorescences), until recently have been overlooked in acid mine drainage settings (Nordstrom and Alpers, 1999). However, they can significantly alter water quality, and they are, therefore, important considerations for remediation strategies at coal refuse sites.

The reason that ESS are so common is that they can occur in virtually any environment where iron sulfide minerals are weathering at the near surface. Iron is the fourth most abundant element, and sulfur (as sulfide) is the second most abundant anion (after oxygen) in the Earth's crust; therefore, iron sulfide minerals occur in a wide variety of geologic environments. These environments include sulfide ore bodies, coal deposits, and other sedimentary deposits. As such, ESS have been reported to associate with massive sulfide deposit mines (Jerz and Rimstidt, 2003; Hammarstrom and others, 2003, 2005), coal mines (Cravotta, 1994), pyritic shale (Joeckel and Ang Clement, 2005), and even landscaping materials (Mrozek and others, 2006).
Because this book is about environmental impacts of coal mining and reclamation, we will focus our comments on the occurrence and implications of ESS in coal-refuse settings. For additional discussions of the role of ESS associated with other types of deposits, see Alpers and others (1994a), Jambor and Blowes (1994), Cabri and Vaughan (1998), and Plumlee and Logsdon (1999).

Under the same anoxic conditions that allow coal formation, detrital iron-bearing minerals and hydrogen sulfide gas $\left(\mathrm{H}_{2} \mathrm{~S}\right)$ react to form pyrite $\left(\mathrm{FeS}_{2}\right.$, isometric) or the less common polymorph marcasite $\left(\mathrm{FeS}_{2}\right.$, orthorhombic) (Berner, 1984). Additionally, minor or trace elements such as arsenic, cadmium, and manganese can be incorporated into the sulfide minerals. When pyrite or marcasite is exposed to water and oxygen in the nearsurface environment, it will undergo a series of complex reactions that collectively produce acid mine drainage (AMD). For a more complete description of the AMD process, see Brady and others (1998), Nordstrom and Alpers (1999), and references therein. Although the stoichiometric equation below misses some of the subtlety of the intermediate steps and mechanisms, the overall reaction that describes the process is:

$$
\mathrm{FeS}_{2}+5 / 2 \mathrm{H}_{2} \mathrm{O}+15 / 4 \mathrm{O}_{2}=\mathrm{FeOOH}+4 \mathrm{H}^{+}+2 \mathrm{SO}_{4}^{2-}
$$

In addition to the acid that is produced, the minor and trace elements that were incorporated into the pyrite or marcasite are released to the environment during this process. The acid can also leach other minor and trace elements from surrounding minerals. In sum, AMD produces acidic, ironsulfate-rich solutions that can contain elevated concentrations of several toxic elements. 

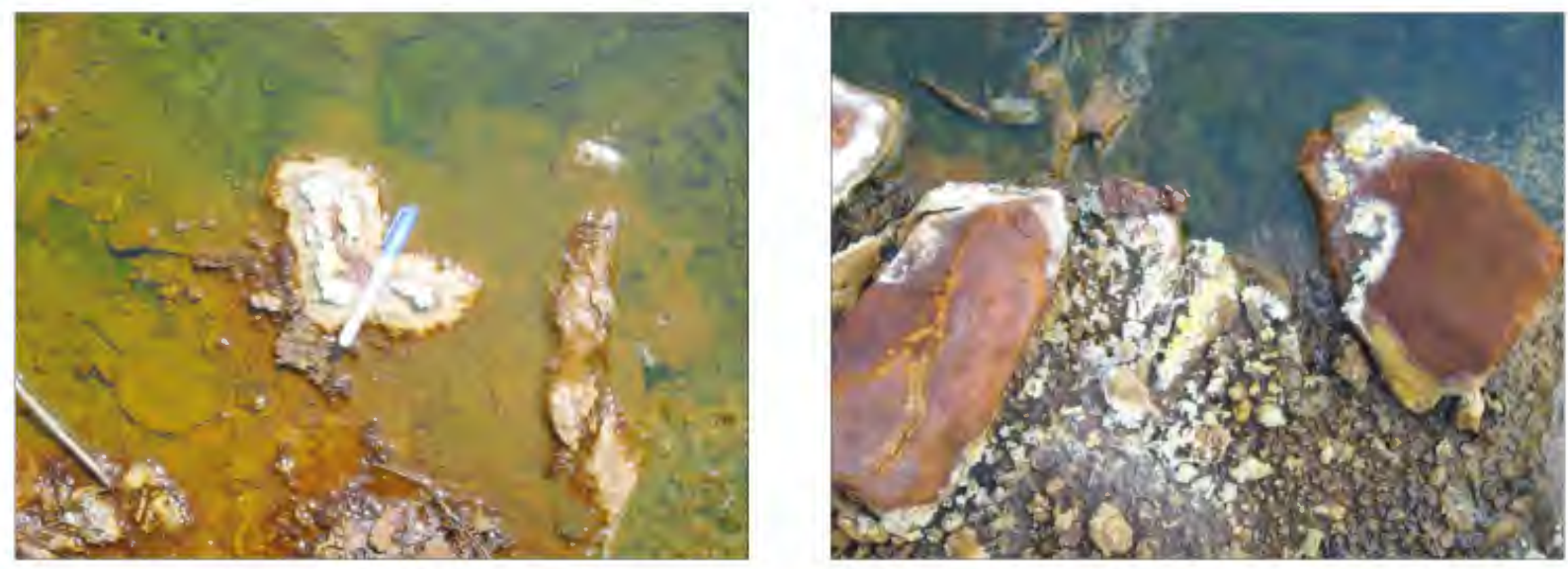

Figure 1. Photographs of efflorescent sulfate salts growing from an acidic, ferrous iron-rich solution at Green Valley Mine, Indiana (fig. 2).

Efflorescent sulfate salts such as melanterite and copiapite form from these iron-sulfate rich solutions as they dehydrate and oxidize. In doing so, ESS can temporarily store acidity and toxic metals in their structure. However, because ESS are highly soluble, the acidity and metals are rapidly released during storm events, negatively affecting water quality.

Because ESS accumulate in the near-surface environment during dry periods and release acidity and metals in storm flushes, it is essential to understand the mineralogical and geochemical parameters that control their formation and dissolution in mine settings. To address some of the principal unanswered questions, several recent studies have investigated the seasonal variation in water quality owing to the influence of ESS dissolution (Romero and others, 2006; Cánovas and others, 2008; Salvarredy-Aranguren and others, 2008; Carmona and others, 2009). Lessons from these studies can be helpful in understanding the role of ESS in contributing to AMD and managing runoff when they are present.

The occurrences of ESS in Indiana are relatively well known and were originally described in the early nineteenth century (Cramer, 1811, referenced in Erd and Greenberg, 1960). These minerals are found associated with pyritic shale and "coal brass" (pyrite- and marcasite-rich coal units). The most common salts are melanterite, rozenite, siderotil, copiapite, halotrichite, coquimbite, epsomite, potash alum, and gypsum (Erd and Greenberg, 1960). Additionally, exotic ESS minerals such as xitieshanite $\left(\mathrm{Fe}\left(\mathrm{SO}_{4}\right) \mathrm{Cl} \cdot 6 \mathrm{H}_{2} \mathrm{O}\right)$ also have been found in association with coal mine drainage in Indiana
(Melchiorre and others, 2005). Although there has not been a systematic study of ESS minerals in Indiana, a 1960 study of Indiana minerals reported melanterite and copiapite in Carroll, Clark, Crawford, Floyd, Morgan, Parke, Perry, Pike, Pulaski, and Wells Counties (Erd and Greenberg, 1960). Additionally, ESS are known to occur in Vigo and Sullivan Counties (Olyphant and others, 1992; Bayless and Olyphant, 1993; Smith, 1993; Amt and Jerz, 2004).

Because ESS are associated with coal weathering, are known to occur in Indiana, and can contribute to poor water quality, the goal of this paper is to briefly describe their mineralogy and geochemistry so that they can be better understood. We provide additional references along with these descriptions for more detailed information about ESS. We also include a case study demonstrating how formation and dissolution of ESS influence water quality at the Friar Tuck abandoned mine site in Indiana (fig. 2). Conclusions from this case study should be particularly helpful to those considering the impact of ESS on the remediation process.

\section{MINERALOGY AND GEOCHEMISTRY}

Efflorescent sulfate salts form when iron sulfatesulfuric acid rich solutions evaporate. The evolution from ferrous sulfate minerals to iron oxyhydroxide minerals occurs by a series of oxidation, dehydration, and neutralization reactions (Jerz and Rimstidt, 2003). The mineralogy that develops at any particular site will be controlled by the relative rates of each of these types of reactions. 


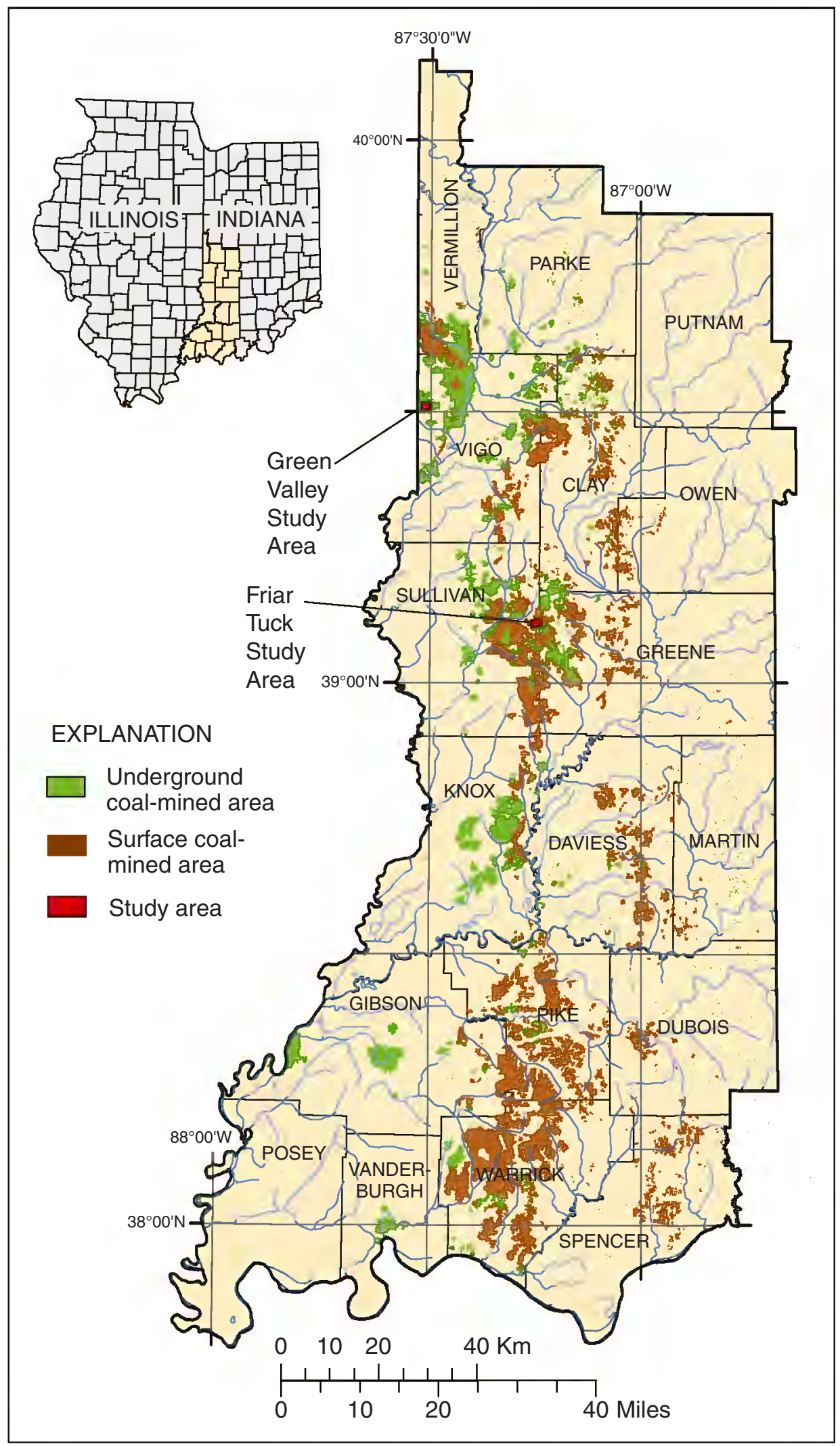

Figure 2. Map showing location of coal-mined areas in southwestern Indiana. 
The number and variety of ESS that occur in acid mine environments can be quite complex. For example, Table 1 contains a list of the ESS that have been reported in the literature and generally contain iron as the only cation in their mineralogical formulae. Additional ESS that contain other cations such as $\mathrm{Al}^{3+}, \mathrm{Zn}^{2+}, \mathrm{Cu}^{2+}$, and $\mathrm{Mg}^{2+}$ also have been reported. Of these, some commonly occurring salts include halotrichite $\left(\mathrm{FeAl}_{2}\left(\mathrm{SO}_{4}\right)_{4} \cdot 22 \mathrm{H}_{2} \mathrm{O}\right)$, chalcanthite $\left(\left(\mathrm{CuSO}_{4}\right)_{5} \cdot \mathrm{H}_{2} \mathrm{O}\right)$, and epsomite $\left(\mathrm{MgSO}_{4} \cdot 7 \mathrm{H}_{2} \mathrm{O}\right)$. For a complete review of the occurrence of sulfate minerals, especially in AMD environments, see Jambor (1994) and Jambor and others (2000).

Although all the minerals in Table 1 (and more) have been observed, they are not all equally likely to occur. We can predict the order in which the minerals are likely to form by examining their stoichiometries in light of three types of reactions. The axes of Figure 3, which are based on the atomic ratios of chemical constituents found in iron-bearing ESS, are designed to show how the minerals are related by oxidation, neutralization, and dehydration reactions. Values plotted along each axis were calculated by using the stoichiometries of the minerals listed in Table 1. The oxidation axis expresses the amount of positive charge provided by ferric iron divided by the total cationic charge in each mineral. This number increases when ferrous iron oxidizes to ferric iron. For example, minerals that contain only ferric iron have a value of 1 and plot to the left along this axis, whereas minerals that

Table 1. Names, formulae, and relative abundance of iron sulfate minerals found in acid mine drainage environments

[Relative abundances are based on the frequency with which different minerals have been reported in the literature. The abbreviations apply to Figure 3.]

\begin{tabular}{|c|c|c|c|}
\hline \multicolumn{2}{|c|}{ Name and abbreviation } & Formula & Relative abundance \\
\hline Quenstedtite & que & $\mathrm{Fe}_{2}\left(\mathrm{SO}_{4}\right)_{3} \cdot 10 \mathrm{H}_{2} \mathrm{O}$ & \\
\hline Coquimbite & $\operatorname{coq}$ & $\mathrm{Fe}_{2}\left(\mathrm{SO}_{4}\right)_{3} \cdot 9 \mathrm{H}_{2} \mathrm{O}$ & \\
\hline Paracoquimbite & pcoq & $\mathrm{Fe}_{2}\left(\mathrm{SO}_{4}\right)_{3} \cdot 9 \mathrm{H}_{2} \mathrm{O}$ & \\
\hline Kornelite & kor & $\mathrm{Fe}_{2}\left(\mathrm{SO}_{4}\right)_{3} \cdot 7 \mathrm{H}_{2} \mathrm{O}$ & \\
\hline Lausenite & lau & $\mathrm{Fe}_{2}\left(\mathrm{SO}_{4}\right)_{3} \cdot 6 \mathrm{H}_{2} \mathrm{O}$ & \\
\hline Hohmannite & hoh & $\mathrm{Fe}_{2}\left(\mathrm{SO}_{4}\right)_{2}(\mathrm{OH})_{2} \cdot 7 \mathrm{H}_{2} \mathrm{O}$ & \\
\hline Metahohmannite & mhoh & $\mathrm{Fe}_{2}\left(\mathrm{SO}_{4}\right)_{2}(\mathrm{OH})_{2} \cdot 3 \mathrm{H}_{2} \mathrm{O}$ & \\
\hline Fibroferrite & fib & $\mathrm{Fe}\left(\mathrm{SO}_{4}\right)(\mathrm{OH}) \cdot 5 \mathrm{H}_{2} \mathrm{O}$ & somewhat common \\
\hline Amerantite & amer & $\mathrm{Fe}\left(\mathrm{SO}_{4}\right)(\mathrm{OH}) \cdot 3 \mathrm{H}_{2} \mathrm{O}$ & \\
\hline Butlerite & but & $\mathrm{Fe}\left(\mathrm{SO}_{4}\right)(\mathrm{OH}) \cdot 2 \mathrm{H}_{2} \mathrm{O}$ & \\
\hline Parabutlerite & pbut & $\mathrm{Fe}\left(\mathrm{SO}_{4}\right)(\mathrm{OH}) \cdot 2 \mathrm{H}_{2} \mathrm{O}$ & \\
\hline Bilinite & bil & $\mathrm{Fe}^{2+} \mathrm{Fe}_{2}^{3+}\left(\mathrm{SO}_{4}\right)_{4} \cdot 22 \mathrm{H}_{2} \mathrm{O}$ & very rare \\
\hline Römerite & rom & $\mathrm{Fe}^{2+} \mathrm{Fe}_{2}^{3+}\left(\mathrm{SO}_{4}\right)_{4} \cdot 14 \mathrm{H}_{2} \mathrm{O}$ & rare \\
\hline Copiapite & cop & $\mathrm{Fe}^{2+} \mathrm{Fe}_{4}^{3+}\left(\mathrm{SO}_{4}\right)_{6}(\mathrm{OH})_{2} \cdot 2 \mathrm{H}_{2} \mathrm{O}$ & common \\
\hline Ferricopiapite & fcop & $\mathrm{Fe}_{5} \mathrm{O}\left(\mathrm{SO}_{4}\right)_{6} \mathrm{OH} \cdot 2 \mathrm{OH}_{2} \mathrm{O}$ & common \\
\hline Melanterite & mel & $\mathrm{FeSO}_{4} \cdot 7 \mathrm{H}_{2} \mathrm{O}$ & common \\
\hline Ferrohexahydrite & fhex & $\mathrm{FeSO}_{4} \cdot 6 \mathrm{H}_{2} \mathrm{O}$ & \\
\hline Siderotil & sid & $\mathrm{FeSO}_{4} \cdot 5 \mathrm{H}_{2} \mathrm{O}$ & \\
\hline Rozenite & $\mathrm{rOz}$ & $\mathrm{FeSO}_{4} \cdot 4 \mathrm{H}_{2} \mathrm{O}$ & common \\
\hline Szomolnokite & szo & $\mathrm{FeSO}_{4} \cdot \mathrm{H}_{2} \mathrm{O}$ & somewhat common \\
\hline Rhomboclase & rhom & $\mathrm{H}_{3} \mathrm{OFe}\left(\mathrm{SO}_{4}\right)_{2} \cdot 3 \mathrm{H}_{2} \mathrm{O}$ & \\
\hline Jarosite & jar & $\mathrm{KFe}_{3}\left(\mathrm{SO}_{4}\right)_{2}(\mathrm{OH})_{6}$ & somewhat common \\
\hline Borgstromite & borg & $\mathrm{H}_{3} \mathrm{OFe}_{3}\left(\mathrm{SO}_{4}\right)_{2}(\mathrm{OH})_{6}$ & \\
\hline Voltaite & & $\mathrm{K}_{2} \mathrm{Fe}_{5}^{2+}{ }_{5} \mathrm{Fe}_{4}^{3+}\left(\mathrm{SO}_{4}\right)_{12} \cdot 18 \mathrm{H}_{2} \mathrm{O}$ & \\
\hline
\end{tabular}


contain only ferrous iron have a value of 0 and plot to the right along this axis. The neutralization axis expresses the ratio of anionic charge provided by hydroxide to the total charge provided by all anions. This number increases as minerals incorporate hydroxide from solution or as sulfate is lost to solution as $\mathrm{H}_{2} \mathrm{SO}_{4}$. The dehydration axis expresses the number of moles of water molecules per total moles of positive charge. This ratio decreases as water is lost by dehydration. The heavy arrow shows the general trend of compositions as ferrous sulfates evolve to iron oxyhydroxides. The diagram shows that minerals like lausenite (lau) are relatively rare because they form only in very acid environments. More common minerals, like copiapite (cop), fall near the most direct path leading from melanterite (mel) to goethite (goe). By examining the geochemistry, mineralogy, and occurrence of these phases, we can begin to map out the important reactions that result in the overall transformation processes.

Although more than a hundred different types of ESS have been reported in the literature, the most common in Indiana are a suite of hydrated ferrous sulfate minerals (melanterite, rozenite, and

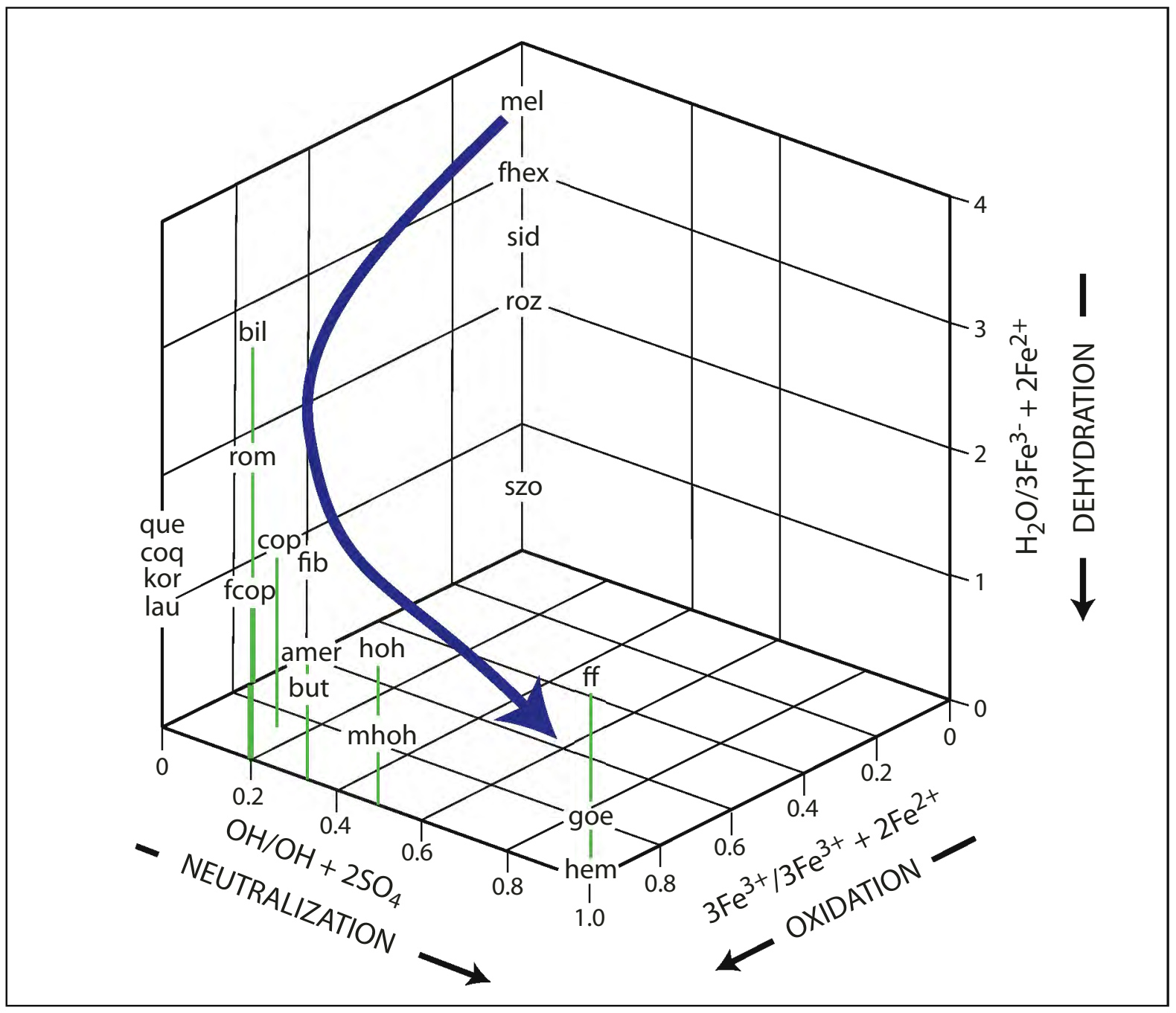

Figure 3. Graph showing chemical relationships among efflorescent sulfate salts. This diagram shows how the stoichiometry of iron sulfate and iron oxide minerals found in acid mine drainage environments relates to reactions that transform one phase into another. Most of the abbreviated mineral names are explained in Table 1 ; hem $=$ hematite, goe $=$ goethite, $\mathrm{ff}=$ ferrihydrite . Changes in the ratio along the axes correspond to processes observed in acid mine drainage environments, specifically (z) dehydration, (y) neutralization, and $(x)$ oxidation. The blue line indicates a generalized reaction path involving these three processes that converts ferrous sulfates to iron oxyhydroxides. Minerals that plot close to the line are likely to be found in acid mine drainage areas, whereas those with extreme ratios are likely to be rare. Adapted from Jerz and Rimstidt, 2003. 
szomolnokite) and copiapite. Although studies like that of Melchiorre and others (2005) show that rare ESS can be found in Indiana, the more common ESS are likely to be most important for remediation and water-quality considerations. With this in mind, we briefly describe the ESS most likely to be encountered in Indiana's coal mining regions.

\section{Ferrous sulfate salts: Melanterite, rozenite, szomolnokite}

The first sulfate phase to form from acidic mine drainage solutions is melanterite $\left(\mathrm{FeSO}_{4} \cdot 7 \mathrm{H}_{2} \mathrm{O}\right)$; however, melanterite is stable only at relatively high humidity and can dehydrate to rozenite $\left(\mathrm{FeSO}_{4} \cdot 4 \mathrm{H}_{2} \mathrm{O}\right)$ and eventually szomolnokite $\left(\mathrm{FeSO}_{4} \cdot \mathrm{H}_{2} \mathrm{O}\right)$. These transformations can occur relatively rapidly. Melanterite (also known as "copperas") is a blue-green, monoclinic mineral in the space group $\mathrm{P}_{1} / \mathrm{c}$ (Baur, 1964); its color is helpful for identification. Melanterite is usually found with stubby prismatic or blocky to tabular crystals. It is a soft mineral (hardness of 2) and has a glassy luster. Melanterite is relatively unstable and tends to deliquesce or dehydrate with varying humidity. Some solid solution in the mineral structure of melanterite allows for the substitution of several divalent elements $\left(\mathrm{Ni}^{2+}<\mathrm{Zn}^{2+}<\mathrm{Mg}^{2+}<\mathrm{Co}^{2+}<\mathrm{Cu}^{2+}\right)$ for iron in the mineral structure (Aslanian and Balarew, 1977). Rozenite is a white, monoclinic mineral in the space group $\mathrm{P} 2_{1} / \mathrm{n}$ (Baur, 1962). It forms as the direct dehydration product of melanterite. Rozenite has a hardness of 2 to 3 and an earthy luster. Solid solution limits are not known, but natural samples have been reported to contain trace metals (Jambor and others, 2000). Szomolnokite is the ferrous iron member of the kieserite group (the namesake, kieserite, has the mineralogical formula $\mathrm{MgSO}_{4} \cdot \mathrm{H}_{2} \mathrm{O}$ ). It is a tan to brown, monoclinic mineral in the space group C2/c (Le Fur and others, 1966). It is found in dry, acidic environments, most likely from the dehydration of melanterite. It has a hardness of 2.5 and a vitreous luster. Natural samples of szomolnokite have been reported to contain significant $\mathrm{Mg}^{2+}$ (Kubisz, 1960) and $\mathrm{Zn}^{2+}$ (Jamieson and others, 1999).

\section{Mixed ferrous/ferric sulfate salts: Copiapite}

Minerals of the copiapite group are the most common mixed divalent-trivalent hydrated sulfate minerals found in AMD environments. There are seven members of the copiapite group (see Table 2), and most natural samples are likely to be a mixture of these different compositions. As such, we will use the term "copiapite" as a substitute for "copiapite group minerals" and refer to the ideal formula $\mathrm{Fe}^{2+} \mathrm{Fe}^{3+}{ }_{4}\left(\mathrm{SO}_{4}\right)_{6}(\mathrm{OH})_{2} \cdot 20 \mathrm{H}_{2} \mathrm{O}$. Copiapite is a yellow, triclinic mineral in the Pì space group (Süsse, 1972). It forms platy or scaly crystals that are easily identified with SEM. Macroscopically, it forms as a massive crust coating rocks and sediments near acidic, iron sulfate-rich solutions. It has a hardness of 2.5 and a pearly to earthy luster. Jamieson and others (2005) provide information about the formation of and trace element substitution, including As, in several copiapite group members from Iron Mountain, California.

Because of the importance of iron sulfate minerals in AMD, a number of field and laboratory studies of their paragenesis have been done (Bandy, 1938; Bol'shakov and Ptushko, 1971; Zodrow and others, 1979; Nordstrom and Alpers, 1999; Jerz and Rimstidt, 2003). Generally, phases have been observed to: 1) evolve from all ferrous iron to mixed ferrous/ ferric iron to all ferric iron phases, and 2) dehydrate through the loss of structural water. Jambor and others (2000) compared the results of selected field and laboratory paragenetic sequences, as summarized in Table 3.

Knowledge of the ESS mineralogy and evolution at an AMD site is important because different sulfate minerals carry different amounts of trace elements and produce different amounts of acid upon dissolution. The dissolution of iron sulfate minerals during rain events can dramatically affect aquatic ecosystems. Dagenhart (1980) showed a very clear relationship between stream discharge and stream chemistry during rain events (fig. 4). His data show that during the initial phase of a rain event, $\mathrm{pH}$

Table 2. Names and formulae of the copiapite group

\begin{tabular}{|l|l|}
\hline \multicolumn{1}{|c|}{ Mineral name } & \multicolumn{1}{c|}{ Formula } \\
\hline Aluminocopiapite & $\mathrm{Al}_{2 / 3} \mathrm{Fe}_{4}\left(\mathrm{SO}_{4}\right)_{6}(\mathrm{OH})_{2} \cdot 20 \mathrm{H}_{2} \mathrm{O}$ \\
\hline Magnesiocopiapite & $\mathrm{MgFe}_{4}\left(\mathrm{SO}_{4}\right)_{6}(\mathrm{OH})_{2} \cdot 20 \mathrm{H}_{2} \mathrm{O}$ \\
\hline Calciocopiapite & $\mathrm{CaFe}_{4}\left(\mathrm{SO}_{4}\right)_{6}(\mathrm{OH})_{2} \cdot 20 \mathrm{H}_{2} \mathrm{O}$ \\
\hline Copiapite & $\mathrm{Fe}^{2+} \mathrm{Fe}^{3+}{ }_{4}\left(\mathrm{SO}_{4}\right)_{6}(\mathrm{OH})_{2} \cdot 20 \mathrm{H}_{2} \mathrm{O}$ \\
\hline Ferricopiapite & $\mathrm{Fe}^{3+}{ }_{2 / 3} \mathrm{Fe}^{3+}{ }_{4}\left(\mathrm{SO}_{4}\right)_{6}(\mathrm{OH})_{2} \cdot 20 \mathrm{H}_{2} \mathrm{O}$ \\
\hline Cuprocopiapite & $\mathrm{CuFe}_{4}\left(\mathrm{SO}_{4}\right)_{6}(\mathrm{OH})_{2} \cdot 2 \mathrm{H}_{2} \mathrm{O}$ \\
\hline Zincocopiapite & $\mathrm{ZnFe}_{4}\left(\mathrm{SO}_{4}\right)_{6}(\mathrm{OH})_{2} \cdot 2 \mathrm{H}_{2} \mathrm{O}$ \\
\hline
\end{tabular}


Table 3. Paragenesis of iron sulfate minerals in acid mine drainage (from Jambor and others, 2000)

\begin{tabular}{|c|c|l|l|}
\cline { 2 - 4 } \multicolumn{1}{c|}{} & $\begin{array}{c}\text { Alcaporrosa, Chile } \\
\text { (Bandy, 1938) }\end{array}$ & $\begin{array}{c}\text { Laboratory } \\
\text { (Burman, 1975) }\end{array}$ & $\begin{array}{c}\text { Iron Mountain, Calif. } \\
\text { (Nordstrom and Alpers, } \\
\text { 1999) }\end{array}$ \\
\hline early & Pyrite & Pyrite & Pyrite \\
\hline \multirow{6}{*}{} & & Melanterite & \multicolumn{1}{|c|}{} \\
\cline { 3 - 4 } & & Siderotil & Rozenite \\
\cline { 2 - 4 } & & Rozenite & Szomolnokite \\
\cline { 2 - 4 } & Szomolnokite & Szomolnokite & Copiapite \\
\cline { 2 - 4 } & Römerite & Rhomboclase & Römerite \\
\cline { 2 - 4 } & Quenstedtite & & Coquimbite \\
\cline { 2 - 4 } & Coquimbite & Coquimbite & Kornelite \\
\cline { 2 - 4 } & Pickeringite & Römerite & Rhomboclase \\
\cline { 2 - 4 } & Copiapite & & Voltaite \\
\cline { 2 - 4 } & Parabutlerite & Voltaite & Halotrichite-bilinite \\
\hline late & Jarosite & & \\
\hline
\end{tabular}

decreased markedly and dissolved solids concentration increased as iron sulfate minerals dissolved and the acid sulfate solutions were carried by overland flow into the stream. With time, $\mathrm{pH}$ rose and the dissolved solids concentration declined as the water draining the sulfate-rich area was diluted by cleaner water from upstream and the ESS were depleted. During a later storm event, no significant change in water chemistry was observed because the soluble sulfates had been washed away by earlier events.

Bayless and Olyphant (1993) and Alpers and others (1994b) observed changes in sulfate mineral chemistry as a result of wet and dry periods. Keith and others (1999) and Keith and others (2001) reported that iron sulfate minerals accumulate during dry periods and that their rapid dissolution during the first rain in the wet season released high concentrations of metals into local streams. In addition, they noted that the degree of trace element and acid release could be related to the mineralogy of the iron sulfates. Stewart and others (1997) observed similar effects by using a leaching column in a laboratory setting. They found that coal wastes having a 4 percent pyritic sulfur content produced enhanced acidity, as well as high iron and sulfate concentrations, in the leachate when the columns were leached after long periods of drying and efflorescent salts had formed. These laboratory and field studies provide evidence that the dissolution of iron sulfate phases can rapidly contribute acid and metals to receiving waters upon their dissolution.
Another effect of the dissolution of iron sulfate minerals is the promotion of pyrite oxidation. Ferric iron oxidizes pyrite faster in aqueous systems than does dissolved oxygen (McKibben and Barnes, 1986; Williamson and Rimstidt, 1994). At low $\mathrm{pH}$, however, the oxidation rate of ferrous iron is slow (Singer and Stumm, 1970). The dissolution of ferric-rich sulfate minerals near the top of the gob piles can release ferric iron solutions that will infiltrate the wastes, where the ferric iron solutions will cause pyrite oxidation at levels deeper than oxygen can penetrate. Therefore, the dissolution of ferric sulfate minerals creates a positive feedback mechanism for the further generation of acid mine drainage (Cravotta, 1994).

\section{CASE STUDY: THE FRIAR TUCK SITE}

The Friar Tuck Site (FTS) in southwestern Indiana is an ideal place to demonstrate the role of ESS in the formation of AMD and degradation of water quality. In the 1990s, researchers at Indiana University and the Indiana Geological Survey installed a series of monitoring devices to characterize the hydrogeology and water chemistry of this site (Olyphant and others, 1992). In particular, the role of ESS in the reclamation process was considered. Bayless and Olyphant (1993) found that two distinct suites of ESS minerals, which formed at different times, controlled the chemistry of surface runoff as overland flow. They concluded that 


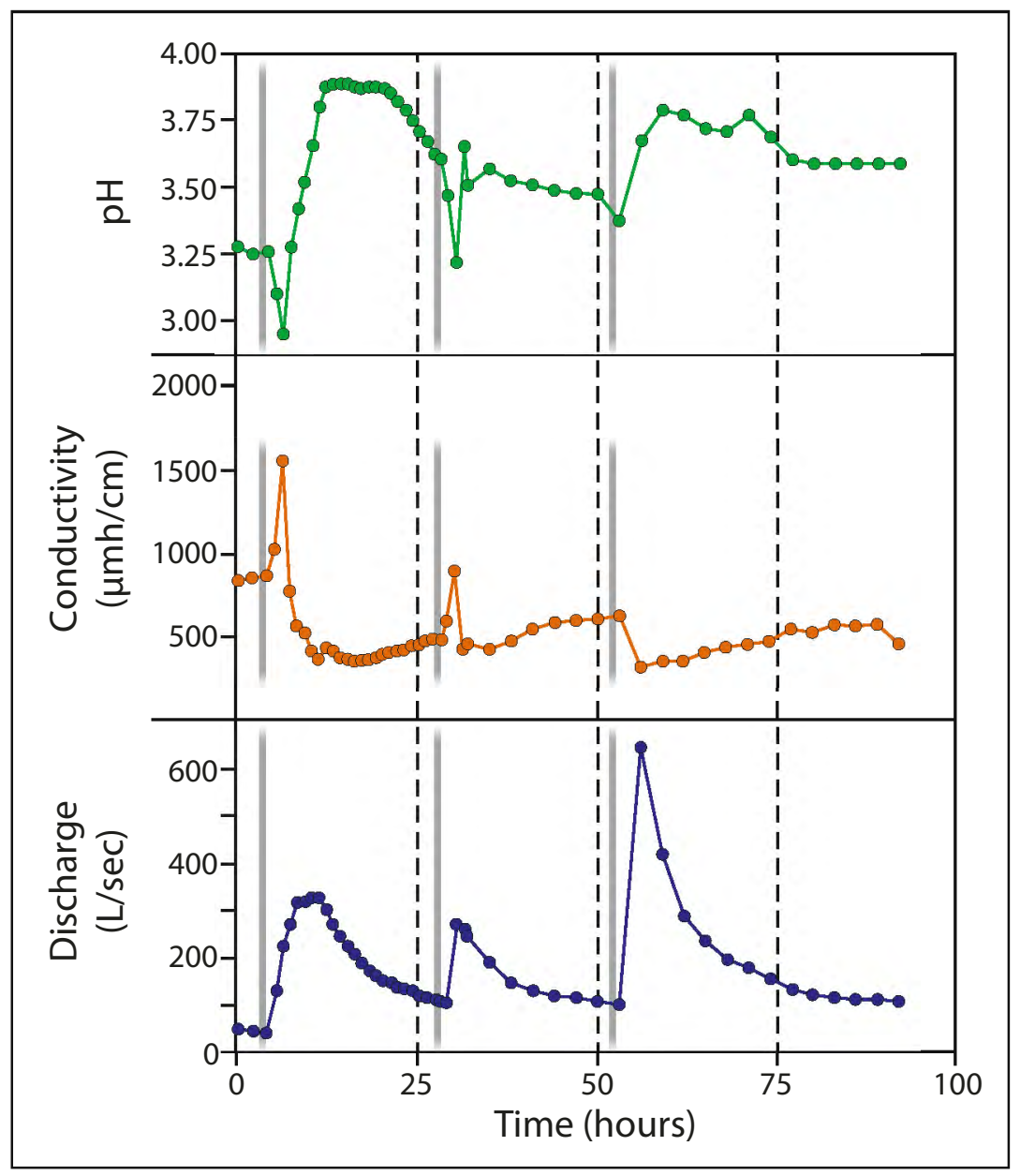

Figure 4. Graphs of pH, conductivity, and discharge in Contrary Creek, Virginia, for rain events in June 1978, showing the effect of storm-runoff-derived inputs of sulfate from efflorescent sulfate salt dissolution on acidity and conductivity (Dagenhart, 1980; as adapted from Jerz and Rimstidt, 2003). The bold vertical lines represent rain events. Runoff from the first rain event dissolved sulfate minerals and carried the resulting acidic, sulfate-rich solution to the stream, causing an increase in acidity and conductivity. After a short time, relatively fresher water from upstream diluted the surface water, decreasing acidity and conductivity. Later storm events produced smaller changes in conductivity and $\mathrm{pH}$ because most of the sulfate minerals had been previously washed away.

the formation of ESS has the potential to negatively affect ecosystem health and diminish the effectiveness of the remediation process. Similar conclusions have been reached at other Indiana mine sites (for example, Brake and others, 2001).

An interesting feature of the FTS is the presence of two different gob piles at this site (the northwest and southeast) that have differing source rocks, reclamation histories, and depositional histories. In this case study, we compare the results of the Bayless and Olyphant (1993) study of the Northeast Gob Pile with the Olyphant and Harper (1995) study and previously unpublished data collected from the Southeast Gob Pile to determine how ESS influence on water quality may differ between the two gob piles. Examination of two gob piles approximately 0.6 miles $(0.96 \mathrm{~km})$ apart but otherwise at the same site allowed the elimination of some site-specific variables, such as climate, that could confuse comparisons and interpretations of process transferability. Aqueous and solid samples from both gob piles were collected and analyzed by means of identical methods. Prereclamation data from the Southeast and Northwest Gob Piles are compared in the following sections, and preand post-reclamation changes in water quality and mineralogy at the Southeast Gob Pile also are examined. This study provides a unique opportunity to evaluate the transferability of lessons learned about ESS between different sites. 


\section{Site description and reclamation history}

The FTS is near the town of Dugger, in southwestern Indiana. The areal extent of the site is approximately 1.5 miles $^{2}\left(2.4 \mathrm{~km}^{2}\right)$. Mining-related deposits at the site include gob piles, tailings ponds, spoil ridges, and other rubbish related to mining and coal processing (fig. 5). The FTS is bounded on the north by Mud Creek and on the east by a tributary of Mud Creek; however, these waterways do not directly contact the studied gob piles (Harper and others, 2012 [this volume], fig. 2). A humid continental climate in this region provides cool winters and warm summers. ${ }^{1}$ Rainfall intensity is lowest during fall and winter, and runoff events are less common during those seasons (Clark, 1980). Rainfall intensity is generally highest during spring and summer storms; runoff events are more common during this period and stream discharge is more episodic. The mean annual rainfall for this region is approximately 44 inches $(111.76 \mathrm{~cm}$ ) (PRISM Climate Group, 2010).

Surface and underground mines operated at the FTS and produced bituminous coal from the 1930s through the 1960s. Coal was mined from surface and underground workings and processed at the land surface. Mined coal beds included the Survant Coal Member of the Linton Formation (formerly Indiana Coal IV), the Springfield Coal Member of the Petersburg Formation (Indiana Coal V), the Hymera Coal Member of the Dugger Formation (Indiana Coal VI), and the Danville Coal Member of the Dugger Formation (Indiana Coal VII) (Harper and others, 1989). Mining operations ceased in 1965 (Harper and others, 1989). Gob was deposited at the Northwest Gob Pile during the 1940s and at the Southeast Gob Pile during the 1950s (Olyphant

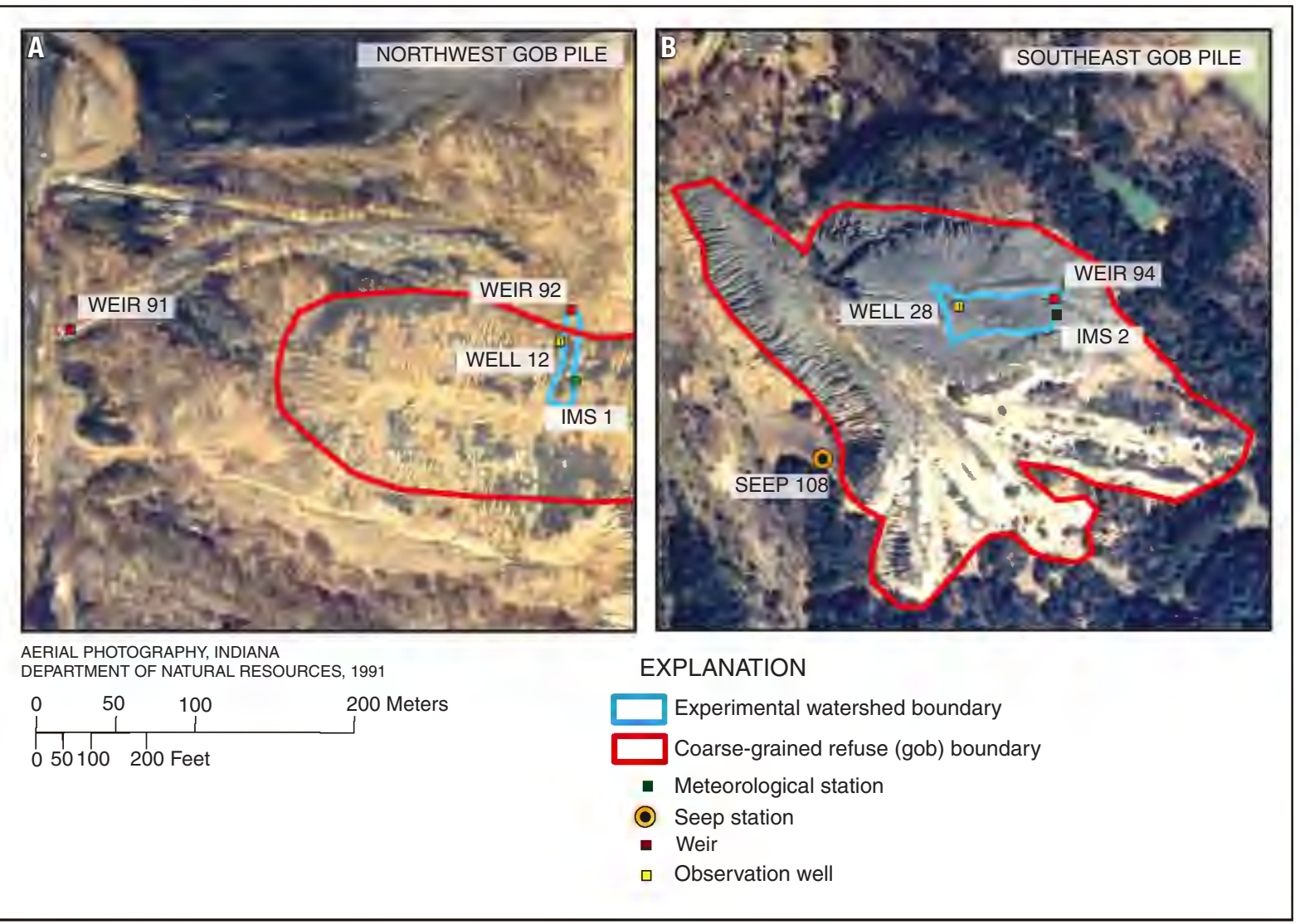

Figure 5. Aerial photographs of the two study areas at the Friar Tuck Site, southwestern Indiana: A. Northwest Gob Pile and sampling sites; B. Southeast Gob Pile and sampling sites.

${ }^{1}$ The average daytime high is 86.3 degrees Fahrenheit $\left(30.16^{\circ} \mathrm{C}\right)$ in July and 36.6 degrees Fahrenheit $\left(2.5^{\circ} \mathrm{C}\right)$ in January (PRISM Climate Group, 2010). 
and others, 1992). At the Northwest Gob Pile, waste material was placed on the original land surface that consisted of loess and till overlying bedrock. At the Southeast Gob Pile, refuse was placed over spoil ridges formed by a surface mine of the Hymera Coal (Harper and others, 1989).

A spatially distributed sampling of gob from the surface (0 to 6 inches [0-15.2 cm]) of the two piles indicated compositional similarities and differences (Harper and others, 1989). A few cores also were collected to improve gob characterization. In general, the gob was described as "primarily pyritic black shale, and contained smaller amounts of coal, limestone, and sandstone. Grain sizes of gob samples varied from fine-grained to boulder sized fragments" (Harper and others, 1989). The two gob piles displayed notable heterogeneity in vertical and horizontal dimensions. Chemical analyses of gob from the two gob piles indicated that the solids were geochemically dissimilar (Table 4). In general, lower $\mathrm{pH}$, higher concentrations of pyritic sulfur and most metals, and higher abundance of soluble salts indicated more acidic conditions at the Northwest Gob Pile than at the Southeast Gob Pile.

In addition to having different geochemical constituents, the gob piles also have different reclamation histories. During the 1970s, the Northwest Gob Pile was reclaimed by use of the traditional cap-andseed method, by which a layer of glacial drift was placed on the gob surface to decrease infiltration of precipitation and was seeded with grasses to prevent erosion. That reclamation was largely unsuccessful because acidic groundwater, wicked to the surface by evapotranspiration, killed the grasses and, eventually, the cap was almost completely eroded. Excavation during the reclamation likely exposed previously unweathered pyrite and thereby exacerbated the generation of acid mine drainage.

The Northwest Gob Pile was reclaimed more effectively with direct revegetation methods, as described below for the Southeast Gob Pile, after completion of the hydrologic investigations described in Olyphant and others (1992) and Bayless and Olyphant (1993). The Southeast Gob Pile was reclaimed with a direct revegetation method during late 1990. Direct revegetation requires the incorporation of agricultural limestone into the gob-pile surface to a depth of 15 centimeters at a rate of 22 kilograms per square meter. Fertilizer, straw, mulch, and rye seed were then applied to the prepared surface. Seedlings appeared within a few months and were well established within one year. The data discussed in this paper were collected at the site from January 1990 through November 1992, as discussed in the methods section below, and include pre- and postreclamation efforts. A small section of the Southeast Gob Pile was not reclaimed because this area was used to establish a microwatershed for research purposes. However, the remainder of the Southeast Gob Pile, which completely surrounded the microwatershed, was reclaimed.

Table 4. Chemical data for solid samples (0-6 inches depth) from the Northwest and Southeast Gob Piles at the Friar Tuck Site, near Dugger, Indiana, 1989 (summarized from Harper and others, 1989)

[ppm = parts per million; $\mathrm{mS}=$ millisiemens; $\mathrm{cm}=$ centimeter. $]$

\begin{tabular}{|l|c|c|c|c|c|c|}
\cline { 2 - 7 } \multicolumn{1}{c|}{} & \multicolumn{5}{c|}{ Chemical indicator } \\
\cline { 2 - 7 } & $\begin{array}{c}\text { Pyritic sulfur, } \\
\text { mean and range } \\
\text { (\% solid mass) }\end{array}$ & $\begin{array}{c}\mathrm{pH} \\
\text { (s.u.) }\end{array}$ & $\begin{array}{c}\text { Calcium } \\
\text { (ppm) }\end{array}$ & $\begin{array}{c}\text { Iron } \\
\text { (ppm) }\end{array}$ & $\begin{array}{c}\text { Aluminum } \\
\text { (ppm) }\end{array}$ & $\begin{array}{c}\text { Soluble salts* } \\
\text { (mS/cm) }\end{array}$ \\
\hline $\begin{array}{l}\text { Northwest Gob } \\
\text { Pile (0-6 inch } \\
\text { depth) }\end{array}$ & $\begin{array}{c}0.88 \\
0.0-4.17\end{array}$ & $\begin{array}{c}1.8 \\
1.1-2.2\end{array}$ & $\begin{array}{c}1,840 \\
220-4,600\end{array}$ & $\begin{array}{c}2,600 \\
930-6,800\end{array}$ & $\begin{array}{c}250 \\
100-590\end{array}$ & $7.4-24.5$ \\
\hline $\begin{array}{l}\text { Southeast Gob } \\
\text { Pile (0-6 inch } \\
\text { depth) }\end{array}$ & $\begin{array}{c}0.14 \\
0.0-0.84\end{array}$ & $\begin{array}{c}2.6 \\
1.7-3.8\end{array}$ & $\begin{array}{c}3,780 \\
370-5,480\end{array}$ & $\begin{array}{c}690 \\
150-3,500\end{array}$ & $25-500$ & $3.0-25.8$ \\
\hline
\end{tabular}

* The measurement is made on the extract of a 1:1 soil-to-water ratio by using a conductivity meter with the conductivity reported in mS/ $\mathrm{cm}$ compensated for temperature differences. A table such as the one available at $<$ http://ag.udel.edu/EXTENSION/agnr/pdf/soiltesting/ CP10-95.pdf $>$ (Table 10-2) is used to determine the degree of salinity in the sample based on the soil composition and conductivity reading. 


\section{Field and laboratory methods}

Hydraulic and chemical data were collected from most environmental compartments at the Northwest and Southeast Gob Piles during 1988-89 and 1990-92, respectively. These environmental compartments included streams (adjacent to the gob piles and further downstream), seeps, runoff as overland flow, and saturated and unsaturated groundwater. Solid-phase analyses examined coal refuse and ESS at the Northwest Gob Pile but only coal refuse at the Southeast Gob Pile. Data and interpretations presented herein for the Southeast Gob Pile were not previously published; they include pre- and postreclamation conditions. Data and interpretations for the Northwest Gob Pile were previously published in Harper and others (1988; 1989), Olyphant and others (1992), and Bayless and Olyphant (1993).

Instrumentation at the Northwest and Southeast Gob Piles included monitoring wells, nested suction lysimeters, sediment and runoff collectors, and seep and stream samplers. Samples were collected periodically and after storm events but no less than monthly; however, no samples were collected during the periods December through March 1991 and 1992. Water samples were analyzed in the field for bulk indicators and in the laboratory (Indiana Geological Survey, Geochemistry Section) for concentrations of major and trace elements (Table 5). Precipitation and surface discharge data were also off to rainfall ratios.

Runoff was collected from an experimental microwatershed (IMS) ${ }^{2}$ within the Southeast Gob Pile that was similar to the one established during studies at the Northwest Gob Pile. The equipment used to collect data from this area was identical to that used at the Northwest Gob Pile and is described in Bayless (1993). Land-surface area of the IMS was $4.65 \mathrm{~m}^{2}$. The IMS was not disturbed during reclamation of the Southeast Gob Pile and surface drainage of the IMS was hydrologically isolated from the remainder of the Southeast Gob Pile. Runoff was not available for other sites at the Southeast Gob Pile. Chemical analyses of runoff were collected after 33 storms and represent integrated runoff for the entire storm. Mineralogical identification of collected for both sites and used to determine run-

samples from the Northwest Gob Pile was done by using X-ray diffraction analysis and chemical constituency was determined by dissolving the sample in deionized water and analyzing the resulting solution (Bayless and Olyphant, 1993). Samples of ESS were collected and analyzed for mineralogy and chemical content at the Northwest Gob Pile but were not sampled at the Southeast Gob Pile. As a result, conclusions about ESS at the Southeast Gob Pile were inferred from the chemistry of runoff collected at the site. The justification for using runoff chemistry to predict ESS mineralogy at the Southeast Gob Pile was based on previous studies at the Northwest Gob Pile, which determined that the chemistry of runoff there was controlled by the mineralogy of and trace elements in ESS at land surface (Bayless and Olyphant, 1993); elsewhere, other researchers have made similar observations (Keith and others, 1999; 2001; Cánovas and others, 2008). Identical analytical methods were used for samples collected at the Northwest and Southeast Gob Piles (Harper and others, 1989). The analytical procedures and quality-assurance data are also described in Branam and Harper (1994).

\section{Water-quality data at the Northwest and Southeast Gob Piles}

Groundwater and surface water at the Northwest and Southeast Gob Piles was of poor quality, with

Table 5. Field and laboratory analyses of water collected at the Northwest (1988-1989) and Southeast Gob Piles (19901992), Friar Tuck Site, southwestern Indiana.

\begin{tabular}{|l|ll|}
\hline Field parameters & \multicolumn{2}{|c|}{ Laboratory analyses } \\
\hline Water temperature & Acidity & Sodium \\
Specific & Alkalinity & Iron (ferrous and \\
conductance & Bicarbonate & total) \\
pH & Carbonate* & Manganese \\
Eh & Chloride & Zinc \\
& Nitrate* & Copper* \\
& Sulfate & Nickel $^{*}$ \\
& Calcium & Strontium* \\
& Magnesium & Aluminum \\
& Potassium & Cadmium* \\
& & Silicon \\
\hline Indicates that constituent was analyzed at Southeast Gob Pile \\
only. & & \\
\hline
\end{tabular}

${ }^{2}$ The microwatershed is referred to as the Interfluve Monitoring Site (IMS) in Olyphant and Harper (1995) and labeled "IMS 2" in Figure 5. 
low $\mathrm{pH}$ and high concentrations of sulfate and iron (Table 6). Water quality was notably better in the runoff and saturated and unsaturated refuse at the Southeast Gob Pile compared to the Northwest Gob Pile. These data reflect different source rock for the two gob piles and different pile histories. The Southeast Gob Pile has not been disturbed since it was deposited and, as a result, pyrite has been relatively depleted at land surface and in the shallow unsaturated zone. The land surface and shallow unsaturated zone at the Northwest Gob Pile was reworked by reclamation during the 1970 s and fresh, unoxidized pyrite was brought to land surface (Harper and others, 1989). A lower pyritic content or relatively advanced weathering profile (or both) may be plausible explanations for more dilute concentrations of elements derived from pyrite oxidation at the Southeast Gob Pile, particularly in runoff and the shallow unsaturated zone (Table 4). The presence of carbonate minerals in the spoil and gob at the Southeast Gob Pile also may be responsible for generally better water quality in runoff and the unsaturated zone.

The water-quality data indicated the influence of seasonal weather patterns on the local hydrology. Values of $\mathrm{pH}$ and specific conductance at the Southeast Gob Pile showed a trend of declining water quality with duration of the dry season, followed by dilution and improved water quality during the wet season (fig. 6). Similar observations were made at the Northwest Gob Pile (Olyphant and others, 1992). The $\mathrm{pH}$ of runoff from the Southeast Gob Pile during spring and summer generally ranged from 2.2 to 2.7 , and specific conductance ranged from 1,700 to 3,800 microsiemens per centimeter $(\mu \mathrm{S} / \mathrm{cm})$. In winter, $\mathrm{pH}$ was greater than 2.7, and specific conductance was less than 1,700 $\mu \mathrm{S} /$ $\mathrm{cm}$. Runoff measurements were a composite of the entire storm and do not reveal the extremes in $\mathrm{pH}$, specific conductance, and other water-quality indicators that likely occurred early in the history of the storm event. Those spikes may represent acute events for delicate stream ecosystems. The seasonal trends were not limited to prereclamation conditions at the Southeast Gob Pile; however, the data extremes were muted during 1991-92.

\section{Influence of ESS on water chemistry}

Studies of the Northwest Gob Pile during the 1990s indicated that two hydrated iron-sulfate mineral suites, one composed of copiapite and the other composed of melanterite-rozenite-szomolnokite, formed from evaporating surface water after summer rain events or from pore waters that were brought to land surface (interfluves and gully walls) in response to dry summer conditions. The mineral suites were highly soluble, ubiquitous,

Table 6. Ranges of $\mathrm{pH}$ and sulfate and iron concentrations from specific sampling locations within the Northwest and Southeast Gob Piles, Friar Tuck Site, southwestern Indiana, 1988-93

\begin{tabular}{|c|c|c|c|}
\hline & $\begin{array}{c}\mathrm{pH} \\
\text { (s.u.) }\end{array}$ & $\begin{array}{l}\text { Sulfate } \\
\text { (mg/L) }\end{array}$ & $\begin{array}{c}\text { Iron } \\
\text { (mg/L) }\end{array}$ \\
\hline \multicolumn{4}{|l|}{ Runoff: } \\
\hline Northwest (unnamed) & $2.0-2.6$ & $100-5,970$ & $10-1,970$ \\
\hline Southeast (IMS) & $2.1-4.3$ & $40-1,780$ & $1-170$ \\
\hline \multicolumn{4}{|l|}{ Unsaturated zone: } \\
\hline Northwest (Well 12, $2.0 \mathrm{ft}$ ) & $1.0-1.8$ & $15,000-112,000$ & $5,100-37,000$ \\
\hline Northwest (Well 12, $8.0 \mathrm{ft}$ ) & $1.1-2.6$ & $38,200-125,000$ & $13,600-34,400$ \\
\hline Northwest (Well 12, 14 ft) & $1.9-3.1$ & $26,300-43,000$ & $10,000-13,200$ \\
\hline Southeast (Well 28, $1.5 \mathrm{ft}$ ) & $1.5-2.7$ & $1,600-9,800$ & $70-1,700$ \\
\hline Southeast (Well 28, $4.5 \mathrm{ft}$ ) & $1.5-2.5$ & $2,600-11,400$ & $200-2,500$ \\
\hline Southeast (Well 28, $18 \mathrm{ft}$ ) & $1.6-3.2$ & $8,000-13,900$ & $70-750$ \\
\hline \multicolumn{4}{|l|}{ Saturated zone: } \\
\hline Northwest (Well 12) & $1.8-4.2$ & $30,800-39,700$ & $11,000-19,300$ \\
\hline Southeast (Well 28) & $1.4-2.5$ & $14,700-30,800$ & $2,300-4,800$ \\
\hline
\end{tabular}




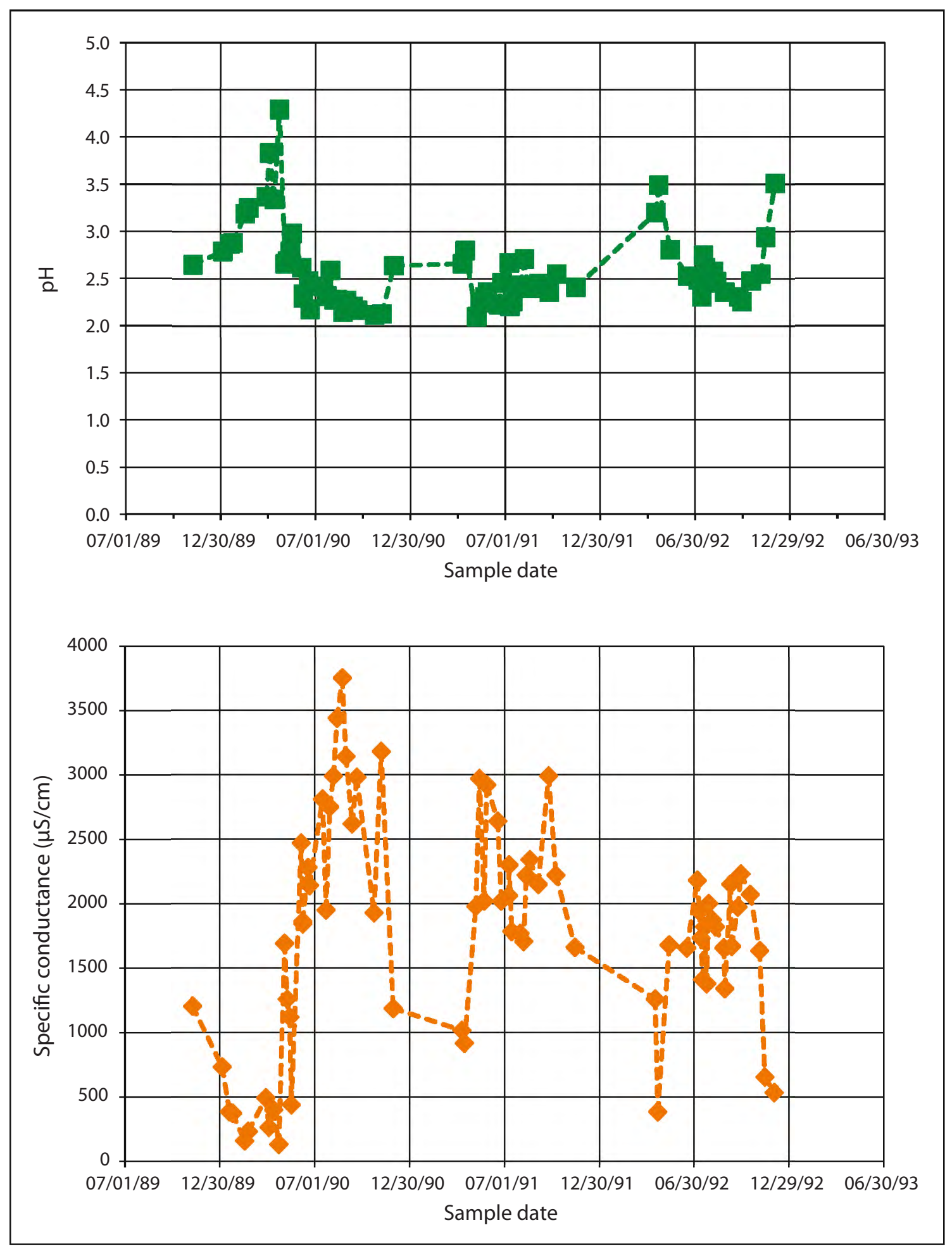

Figure 6. Graphs showing pH and specific conductance of runoff collected at the Southeast Gob Pile, Friar Tuck Site, southwestern Indiana, 1990-92. 
and likely responsible for acidic runoff. Mixingcurve analyses indicated that the water chemistry could be created by combining variable masses of the two minerals. The metal and trace element composition of the two minerals was notably different. The median chemistry of the melanteriterozenite-szmolnokite suite was:

$$
\begin{aligned}
& \mathrm{Al}_{3.12} \mathrm{Ca}_{0.0} \mathrm{Fe}_{93.22} \mathrm{Mg}_{1.75} \mathrm{Mn}_{.07} \mathrm{Na}_{0.0} \mathrm{Ni}_{.13} \\
& \mathrm{Si}_{0.0} \mathrm{Zn}_{0.0}\left(\mathrm{SO}_{4}\right)_{\mathrm{x}} \cdot(1-7)\left(\mathrm{H}_{2} \mathrm{O}\right)
\end{aligned}
$$

the hydration state being the only feature distinguishing the predominant mineral in the suite. The median copiapite chemistry was:

$$
\begin{aligned}
& \mathrm{Al}_{11.68} \mathrm{Ca}_{2.75} \mathrm{Fe}_{81.50} \mathrm{Mg}_{2.05} \mathrm{Mn}_{14} \mathrm{Na}_{0.0} \\
& \mathrm{Ni}_{.10} \mathrm{Si}_{.23} \mathrm{Zn}_{.15}\left(\mathrm{SO}_{4}\right)_{\mathrm{x}}(\mathrm{OH})_{2} \cdot 20\left(\mathrm{H}_{2} \mathrm{O}\right)
\end{aligned}
$$

The copiapite chemistry, by virtue of the divalent and trivalent cation positions in its mineral structure, generally contained greater concentrations of most trace elements and less iron than did the melanterite-rozenite-szmolnokite mineral suite.

The acidification of runoff at the Northwest Gob Pile was facilitated by relatively large amount of runoff from the pile. This runoff resulted from an armoring of the surface by platy coal and shale rock fragments and an absence of vegetation. Runoff-to-rainfall ratios at the Northwest Gob Pile ranged from less than 25 percent to about 79 percent, depending on the rainfall intensity of individual storms. The ratio of runoff to rainfall for the entire Southeast Gob Pile before reclamation was about 73 percent. After reclamation (1991-92), however, the ratio decreased to about 24 percent. This difference was likely due to disruption of the compacted and imbricated surface materials and the initiation of a vegetative cover. In addition to decreasing the amount of runoff from the Southeast Gob Pile, reclamation produced a significant increase of net infiltration and gob-pile recharge. The IMS runoff-to-rainfall ratio was not altered by reclamation activities and appeared to be highest during "stormy" 1992. The mean annual runoff-torainfall ratios at the IMS watershed were 73 percent or higher during the monitoring period.

The concentrations of most trace elements in runoff from the Southeast Gob Pile were higher during summer months. This may indicate further deleterious effects of salt dissolution, in addition to acute low-pH conditions, on local ecosystems. Interestingly, elevated concentrations of trace metals in the runoff did not occur simultaneously during all three years. Maximum concentrations occurred during 1990-92 for aluminum, manganese, and silicon, during 1990-91 for nickel, during 1992 for strontium, and during 1991 for zinc. These trace elements are likely the result of ESS dissolution, as well as dissolution of other minerals that contain trace elements (for example, clay and carbonate minerals). Iron oxyhydroxides and secondary iron phases that are common byproducts of pyrite oxidation were likely present on the surface at the IMS; however, the solubilities of those minerals are low relative to ESS and likely had less drastic and instantaneous impacts on the chemistry of runoff.

Iron was the most abundant cation released by dissolution of ESS at the Northwest Gob Pile. Concentrations (mole percent) in the unsaturated zone typically ranged from 64 to 84 percent. At the Southeast Gob Pile, the mole percentage of iron was greater than 50 percent in only a few samples collected during late summer and fall of 1990 from the shallow lysimeters ( 1.5 and $4.5 \mathrm{ft}$ ) (0.45 and $1.37 \mathrm{~m}$ ) (fig. 7). Reclamation likely caused later water samples to contain an even lower concentration of iron. The relatively low proportion of iron in shallow lysimeters is significant because ESS formation is largely dependent on the supply of iron and other constituents from upward-moving pore fluids. Calcium was the cation of greatest relative concentration in most groundwater and surfacewater samples at the Southeast Gob Pile.

Interestingly, although the IMS was not reclaimed and was hydrologically isolated at land surface, the iron abundance in runoff samples collected during 1991 and 1992 also decreased. These observations imply that horizontal pore-water flow from reclaimed parts of the gob pile could influence the chemistry of soil moisture beneath the IMS and may change the mineral composition of ESS in the microwatershed. Alternatively, windblown reclamation amendments may reach the surface of the IMS and affect the chemistry of runoff and the shallow unsaturated zone. The distinction between these two scenarios is significant because the latter possibility would affect runoff chemistry without involving the formation of ESS, whereas the former scenario would be more likely to form ESS and other soluble mineral phases as pore waters are drawn to the land surface by evaporation. 


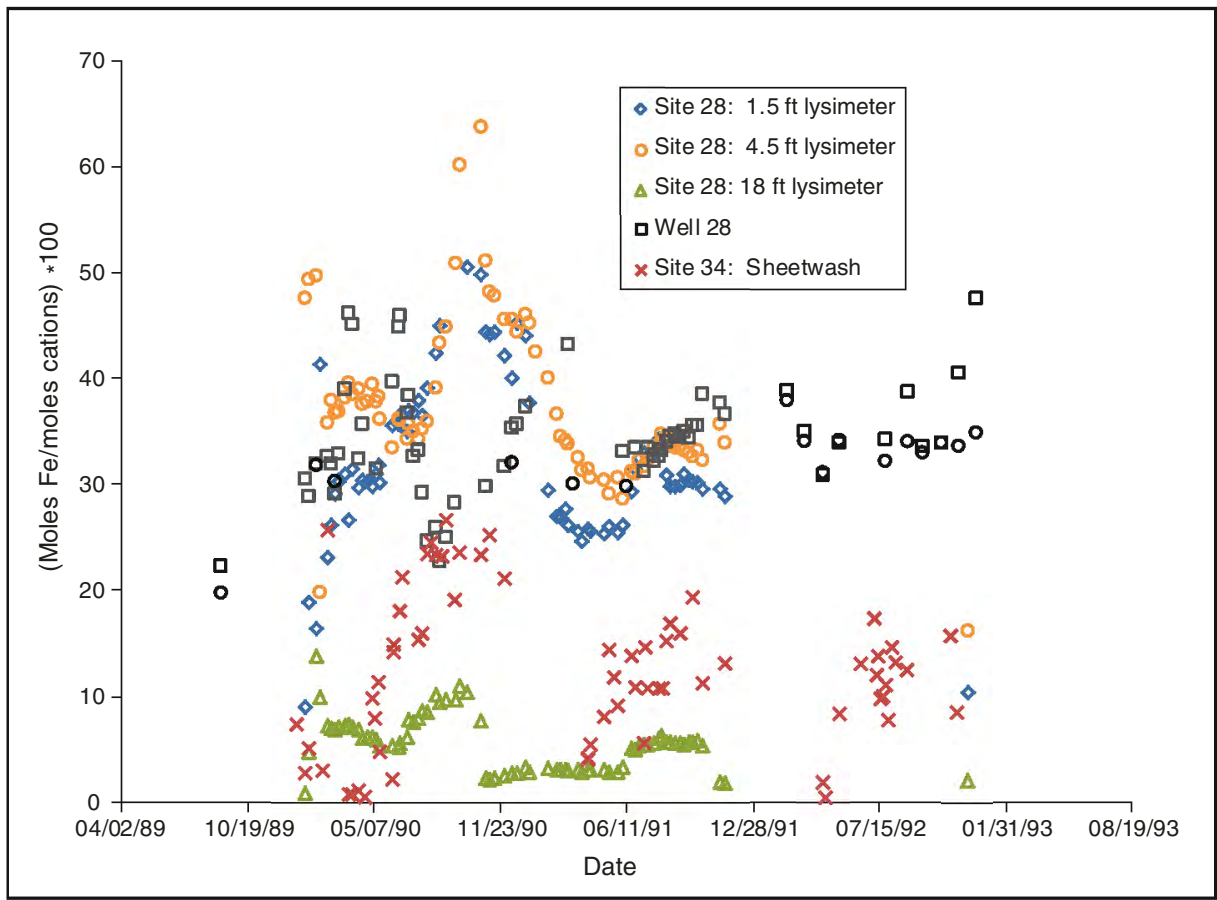

Figure 7. Graph showing ratio of moles of total iron to total moles of all cations, expressed as percent, in water samples from the unsaturated zone at the Southeast Gob Pile, Friar Tuck site, southwestern Indiana.

Assuming ESS dissolution is the only influence on runoff chemistry and that dissolution is stoichiometric, the average salt chemistries at the Southeast Gob Pile for years 1990, 1991, and 1992, are represented by the following formulae, respectively:

$$
\begin{aligned}
& \mathrm{Al}_{11.84} \mathrm{Ca}_{62.92} \mathrm{Cd}_{01} \mathrm{Cu}_{1.23} \mathrm{Fe}_{15.33} \mathrm{~K}_{.35} \mathrm{Mg}_{1.91} \mathrm{Mn}_{.09} \\
& \mathrm{Na}_{1.82} \mathrm{Ni}_{.04} \mathrm{Si}_{2.45} \mathrm{Sr}_{0.01} \mathrm{Zn}_{1.99}\left(\mathrm{SO}_{4}\right)_{\mathrm{X}}(\mathrm{Cl})_{1-\mathrm{X}} \cdot \mathrm{n}\left(\mathrm{H}_{2} \mathrm{O}\right) \\
& \mathrm{Al}_{8.30} \mathrm{Ca}_{72.63} \mathrm{Cd}_{.01} \mathrm{Cu}_{.00} \mathrm{Fe}_{11.55} \mathrm{~K}_{.88} \mathrm{Mg}_{2.10} \mathrm{Mn}_{.04} \\
& \mathrm{Na}_{14} \mathrm{Ni}_{.02} \mathrm{Si}_{1.09} \mathrm{Sr}_{01} \mathrm{Zn}_{2.87}\left(\mathrm{SO}_{4}\right)_{\mathrm{x}} \cdot(\mathrm{Cl})_{1-\mathrm{x}} \cdot \mathrm{n}\left(\mathrm{H}_{2} \mathrm{O}\right) \\
& \mathrm{Al}_{7.84} \mathrm{Ca}_{76.19} \mathrm{Cd}_{.01} \mathrm{Cu}_{.01} \mathrm{Fe}_{10.13} \mathrm{~K}_{.78} \mathrm{Mg}_{1.91} \mathrm{Mn}_{05} \\
& \mathrm{Na}_{.23} \mathrm{Ni}_{.01} \mathrm{Si}_{1.40} \mathrm{Sr}_{.01} \mathrm{Zn}_{.39}\left(\mathrm{SO}_{4}\right)_{\mathrm{x}} \cdot(\mathrm{Cl})_{1-\mathrm{x}} \cdot \mathrm{n}\left(\mathrm{H}_{2} \mathrm{O}\right)
\end{aligned}
$$

The high concentrations of calcium indicate that processes affecting runoff chemistry at the Southeast Gob Pile are different from those described at the Northwest Gob Pile. If calcium-rich calciocopiapite were the sole ESS determining the chemistry of the runoff at the IMS, the calcium-to-iron ratio would be 1:4. Clearly the calcium-to-iron ratio is significantly higher, suggesting that the chemistry of runoff at the Southeast Gob Pile is more likely explained by the dissolution of a mixture of ESS and calcium-bearing minerals such as calcite, gypsum, and clay minerals. These calciumbearing phases may be of natural occurrence or associated with the application of agricultural lime on the surrounding gob. Detailed solid sampling and analysis are the best ways to determine that ESS and other soluble minerals are forming on the Southeast Gob Pile and affecting the chemistry of runoff from the IMS.

The notably different chemistries of runoff for 1990, 1991, and 1992 indicate the relative changes in cation chemistry between data taken before reclamation (1990) and after reclamation (1991-92). In general, the postreclamation chemistry is characterized by greater quantities of calcium and lesser quantities of iron and several other cations. These data are interesting because pre- and postreclamation data are not commonly available, particularly where the test watershed was not actually reclaimed but is surrounded by gob that was reclaimed (by direct revegetation). These data may improve understanding of the geochemical response of unreclaimed gob piles to the reclamation of adjacent gob deposits.

The hypothetical mineral formulae interpreted from the runoff chemistry at the Southeast Gob Pile are notably dissimilar to the chemistry of the salts observed at the Northwest Gob Pile. Most striking is the abundance of calcium at the 
Southeast Gob Pile. The source of calcium in runoff at the Southeast Gob Pile is likely agricultural limestone applied to the surface of the pile or mixed into the spoil during remediation. Transport of calcium to the surface of the IMS could be from wind drift or horizontal transport in the shallow unsaturated zone. The $\mathrm{pH}$ of runoff samples collected at the Southeast Gob Pile was similar to the $\mathrm{pH}$ at the Northwest Gob Pile, indicating that the oxidation of pyrite and the dissolution of ESS, which is a byproduct of pyrite oxidation, are significant processes at the Southeast Gob Pile.

The available data indicated that chemistry of runoff at the Southeast Gob Pile was seasonally variable. This observation was also made at the Northwest Gob Pile. Calcium is the dominant cation in solution at the Southeast Gob Pile, generally accounting for 70 to 90 percent during the winter months but decreasing in relative abundance (50 to 70 percent) during late summer and early autumn. For other metals, the reverse trend was observed. The abundances of most trace metals, iron, and aluminum increased with the progression of summer. Mole percentages of iron and aluminum increased from less than 5 percent to more than 25 percent. In most samples, sulfate accounted for 94 to 100 percent of the anion mass, with a small amount of chloride also present.

The causes of the seasonal trends observed in the chemistry of runoff at the Southeast Gob Pile are uncertain and likely are multiple. As summer months become hotter and the dry season progresses, various factors may influence runoff chemistry:

1. As the net volume of water (as soil moisture) is reduced by evaporation, concentrations of solutes should increase;

2. Hydraulic gradients in the unsaturated zone increase and induce flow from progressively greater depths toward land surface, which causes new sources of water (for example, water from dead-end pores, tight and poorly connected rock partings and fractures, deposits with relatively low hydraulic coductivity, and water from greater depths) with different relative chemical abundances to be brought toward land surface; and

3. The formation of ESS at the land surface creates a reservoir of chemical elements that are available for dissolution by the next rainfall event.
Rock fragments and gob deposits having relatively low permeability and those that are poorly connected to actively flowing pore waters are not regularly flushed with recharging water. Resident pore waters in these environments may have relatively high concentrations of metals and trace elements that are present in relative abundances that differ from those observed during the wet season, when the source of solutes is hydrologically well connected and regularly flushed. The same principle applies to the entrainment of progressively deeper pore waters that occurs as summer progresses and surfacedirected hydraulic gradients in the unsaturated zone reach progressively greater depths. The chemistry of ESS will be controlled by the composition of the fluids from which they form and may vary seasonally as the sources of water at the land surface also changes.

\section{Conclusions from the Friar Tuck case study}

The results of this study indicate that some generalizations about the impact of iron-sulfate minerals on water quality can be transferred from one coal-refuse site to another. However, the specific geochemistry of the gob pile, age and history of refuse, source rock, coal-processing and reclamation activities will determine the extent to which the processes described in this and other papers can be applied to unstudied refuse piles.

Data collected at the Southeast Gob Pile indicated that ESS and perhaps other highly soluble minerals substantially affected the chemistry of runoff, particularly during intense rain events, prior to direct revegetation of the pile. Modifications to the gob-pile surface as a result of direct revegetation, however, eliminated runoff from the pile and allowed almost all precipitation to infiltrate into the unsaturated zone of the pile. The impact of ESS on the chemistry of surface water being discharged from the Southeast Gob Pile was thereby reduced. Despite reclamation, ESS continue to form at the land surface and in the shallow subsurface and to dissolve during rainfall events, allowing ESSaffected water to be transported into the gob pile.

Although there were some similarities between the Friar Tuck gob piles (for example, climatic inputs), dissimilarities between the sites caused notable differences in the ESS formation and in the chemistry of runoff and groundwater. The 
chemistry of runoff at both gob piles was characterized by poor water quality (namely, low $\mathrm{pH}$ and high concentrations of metals) during the dry season when ESS minerals were forming at the land surface. Groundwater and runoff at the Southeast Gob Pile contained substantially higher concentrations of calcium and lower concentrations of iron than were observed at the Northwest Gob Pile. Either the dissolution of ESS and geochemical reaction with calcium-bearing minerals-such as calcite, gypsum, and clay minerals-that were codeposited with the coal refuse or the dissolution of limestone added to the gob pile during the reclamation process could explain these observations. Greater abundances of noncoal minerals may result from different source rock, coal-processing techniques, or depositional histories. These minerals likely reacted with dissolved ESS constituents to produce the water chemistry observed in runoff from the IMS; this water was generally less acidic than runoff from the Northwest Gob Pile and indicates that mixing coal refuse with other rock debris produced during mining, especially carbonate rocks, may lessen the deleterious effects of ESS on water quality. That being said, only prereclamation data were available for the Northwest Gob Pile, and these were expected to reflect more caustic water, whereas pre- and postreclamation data were evaluated for the Southeast Gob Pile.

\section{SUMMARY}

Efflorescent sulfate salts are important environmental minerals because they are commonly found in mining regions and they impact water quality upon dissolution. However, because of their transient nature, they are frequently overlooked or misunderstood. This paper has provided an overview of the geochemistry and mineralogy of ESS in order to help rectify this situation.

As shown through the case study, the specific ESS found at a given site are a strong control on aqueous chemistry. Because different ESS minerals have different capacities to incorporate trace elements into their structure, an understanding of ESS mineralogy and geochemistry is important to the remediation of coal mined areas. We have provided an elementary discussion of important features of ESS that can be expected in Indiana as well as key references where addition information can be found.
Although certain impacts of ESS may be expected at most pyrite-bearing coal gob piles, this case study indicates that the precise chemistry created by dissolution and transport of ESS-impacted runoff will reflect the chemical content and history of the pile. Therefore, a thorough characterization of a site prior to remediation is important to determine what ESS minerals are present or capable of forming. Failure to account for ESS during remediation may lead to continued acid mine drainage from ESS dissolution, thus marginalizing the impact of the reclamation process.

\section{REFERENCES}

Alpers, C. N., Blowes, D. W., Nordstrom, D. K., Jambor, J. L., 1994a, Secondary minerals and acid mine-water chemistry, in Jambor, J. L., and Blowes, D. W., eds., Environmental geochemistry of sulfide minewastes: Mineralogical Association of Canada Short Course Series, v. 22, p. 247-270.

Alpers, C. N., Nordstrom, D. K., and Thompson, J. M., $1994 b$, Seasonal variations of $\mathrm{Zn} / \mathrm{Cu}$ ratios in acid mine water from Iron Mountain, California, in Alpers, C. N., and Blowes, D. W., eds., Environmental geochemistry of sulfide oxidation: Washington, D.C., American Chemical Society Symposium Series, v. 550, p. 324-344.

Amt, E., and Jerz, J. K., 2004, Analysis of sediment from West Little Sugar Creek impacted by acid mine drainage from the Green Valley Mine in Vigo County, IN, USA: Proceedings of the National Conference on Undergraduate Research, 2004, Indianapolis, Ind.

Aslanian, S., and Balarew, C., 1977, On the crystal structure differences of the $\mathrm{MeSO}_{4} \mathrm{nH}_{2} \mathrm{O}$ salt-types: Kristall und Technik, v. 12, p. 435-446 [in German].

Bandy, M. C., 1938, Mineralogy of three sulphate deposits of northern Chile: American Mineralogist, v. 23, p. 669-760.

Baur, W. H., 1962, On the crystal chemistry of salt hydrates-crystal structure of $\mathrm{MgSO}_{4} \cdot 4 \mathrm{H}_{2} \mathrm{O}$ (leonhardtite) and $\mathrm{FeSO}_{4} \cdot 4 \mathrm{H}_{2} \mathrm{O}$ (rozenite): Acta Crystallographica, v. 15, p. 815-826 [in German].

Baur, W. H., 1964, On the crystal chemistry of salt hydrates III-crystal structure of $\mathrm{FeSO}_{4} \cdot 7 \mathrm{H}_{2} \mathrm{O}$ (melanterite): Acta Crystallographica, v. 17, p. 1,167-1,174 [in German].

Bayless, E. R., 1993, Acid-generating salts and their relationship to the chemistry of groundwater and storm runoff at a pyritic coal refuse deposit in southwestern Indiana: Bloomington, Indiana University, Ph.D. dissertation, 129 p. 
Bayless, E. R., and Olyphant, G. A., 1993, Acid-generating salts and their relationship to the chemistry of groundwater and storm runoff at an abandoned mine site in southeastern Indiana, U.S.A.: Journal of Contaminant Hydrology, v. 12, p. 313-328.

Berner, R. A., 1984, Sedimentary pyrite formation-an update: Geochimica et Cosmochimica Acta, v. 48, no. 4, p. 605-615.

Bol'shakov, A. P., and Ptushko, L. I., 1971, Alteration products of melanterite from Nikitov mercury ore deposits: International Geology Review, v., 13, no. 6, p. 849-854.

Brady, B. C., Kania, T., Smith, W. M., and Hornberger, R. J., eds., 1998, Coal mine drainage prediction and pollution prevention in Pennsylvania: Pennsylvania Department of Environmental Protection, 398 p.

Brake, S. S., Connors, K. A., and Romberger, S. B., 2001, A river runs through it-impact of acid mine drainage on the geochemistry of West Little Sugar Creek pre- and post-reclamation at the Green Valley coal mine, Indiana, USA: Environmental Geology, v. 40, no. $11-12$, p. 1,471-1,481.

Branam, T. D., and Harper, D., 1994, Tabulated analytical data for water samples from the Friar Tuck Site: Indiana Geological Survey Open-File Study 94-13, 169 p.

Burman, P., 1975, In vitro weathering of pyrite: Geologie en Mijinbouw, v. 54, p. 101-105.

Cabri, L. J., and Vaughan, D. J., eds., 1998, Modern approaches to ore and environmental mineralogy: Ottawa, Ontario, Mineralogical Association of Cana$\mathrm{da}, 421 \mathrm{p}$.

Cánovas, C. R., Hubbard, G. G., Olías, M., Nieto, J. M., Black, S., and Coleman, M. L., 2008, Hydrochemical variations and contaminant load in the Río Tinto (Spain) during flood events: Journal of Hydrology, v. 350, p. 25-40.

Carmona, D. M., Faz Cano, Á., and Arocena, J. M., 2009, Cadmium, copper, lead, and zinc in secondary sulfate minerals in soils of mined areas in Southeast Spain: Geoderma, v. 150, no. 1-2, p. 150-157.

Clark, D. G., ed., 1980, The Indiana water resource-availability, uses, and needs: Indianapolis, Indiana Department of Natural Resources, 508 p.

Cravotta, C. A., III, 1994, Secondary iron-sulfate minerals as sources of sulfate and acidity, in Alpers, C. N., and Blowes, D. W., eds., Environmental geochemistry of sulfide oxidation: Washington, D.C., American Chemical Society Symposium Series, v. 550, p. 345-364.

Dagenhart, T. V., Jr., 1980, The acid mine drainage of Contrary Creek, Louisa County, Virginia-factors causing variations in stream water chemistry: Charlottesville, University of Virginia, master's thesis, $215 \mathrm{p}$.
Erd, R. C., and Greenburg, S. S., 1960, Minerals of Indiana: Indiana Geological Survey Bulletin 18, 74 p.

Hammarstrom, J. M., Seal, R. R., II, Meier, A. L., and Jackson, J. C., 2003, Weathering of sulfidic shale and copper mine waste-secondary minerals and metal cycling in Great Smoky Mountains National Park, Tennessee, and North Carolina, USA: Environmental Geology, v. 45, no. 1, p. 35-57.

Hammarstrom, J. M., Seal, R. R., II, Meier, A. L., and Kornfeld, J. M., 2005, Secondary sulfate minerals associated with acid drainage in the eastern US-recycling of metals and acidity in surficial environments: Chemical Geology, v. 215, no. 1-4, p. 407-431.

Harper, D., Hartke, E. J., Olyphant, G. A., and West, T. R., 1989, Research and reclamation feasibility studies at the Friar Tuck site, Sullivan and Greene Counties, Indiana, in Second annual report to the Indiana Division of Reclamation, part A-chemical analyses and hydrologic investigations: Indiana Geological Survey, 145 p., unpubl.

Harper, D., Hartke, E. J., West, T., and Olyphant, G. A., 1988, Research and reclamation feasibility studies at the Friar Tuck site, Sullivan and Greene Counties, Indiana: Indiana Geological Survey, First Annual Report to the Indiana Division of Reclamation, $161 \mathrm{p}$.

Harper, D., Olyphant, G. A., and Branam, T. D., 2012, Direct revegetation and the sustainability of reclaimed mine lands-the story of the Friar Tuck Site, Indiana, in Comer, J. B., ed., Effects of abandoned mine land reclamation on ground and surface water quality-research and case histories from Indiana: Indiana Geological Survey Special Report 72, p. 83-125.

Jambor, J. L., 1994, Mineralogy of sulfide-rich tailings and their oxidation products, in Jambor, J. L., and Blowes, D. W., eds., Environmental geochemistry of sulfide mine-wastes: Mineralogical Association of Canada Short Course Series, v. 22, p. 59-102.

Jambor, J. L., and Blowes, D. W., eds., 1994, The environmental geochemistry of sulfide mine-wastes: Mineralogical Association of Canada Short Course Series, v. 22, 438 p.

Jambor, J. L., Nordstrom, D. K., and Alpers, C. N., 2000, Metal-sulfate salts from sulfide mineral oxidation, in Alpers, C.N., Jambor, J.L., and Nordstrom, D.K., eds., Sulfate minerals-crystallography, geochemistry, and environmental significance: Washington, D.C., Mineralogical Society of America and Geochemical Society, Reviews in Mineralogy and Geochemistry 40, p. 303-350.

Jamieson, H. E., Alpers, C. N., Nordstrom, D. K., and Peterson, R. C., 1999, Substitution of $\mathrm{Zn}$ and other 
metals in iron-sulfate minerals at Iron Mountain, California, in Goldsack, D., Belzile, N., Yearwood, P., and Hall, G., eds., Conference Proceedings, Sudbury '99-Mining and the Environment II, Sept. 12-16, 1999, Sudbury, Ont., Canada: v. 1, p. 231-241.

Jamieson, H. E., Robinson, C., Alpers, C. N., McCleskey, R. B., Nordstrom, D. K., and Peterson, R. C., 2005, Major and trace element composition of copiapitegroup minerals and coexisting water from the Richmond mine, Iron Mountain, California: Chemical Geology, v. 215, p. 387-405.

Jerz, J. K., and Rimstidt, J. D., 2003, Efflorescent sulfate salts-paragenesis, relative stability, and environmental impact: American Mineralogist, v. 88, no. 11-12, p. 1,919-1,931.

Joeckel, R. M., and Ang Clement, B. J., 2005, Soils, surficial geology, and geomicrobiology of salinesodic wetlands, North Platte River Valley, Nebraska, USA: Catena, v. 61, p. 63-101.

Keith, D. C., Runnels, D. D., Esposito, K. J., Chermak, J. A., and Hannula, S. R., 1999, Efflorescent sulfate salts-chemistry, mineralogy, and effects of ARD streams, in $6^{\text {th }}$ International Conference on Tailings and Mine Waste '99, Fort Collins, Colo.: Rotterdam, Balkema, p. 573-579.

Keith, D. C., Runnells, D. D., Esposito, K. J., Chermak, J. A., Levy, D. B., Hannula, S. R., Watts, M., and Hall, L., 2001, Geochemical models of the impact of acidic groundwater and evaporative sulfate salts on Boulder Creek at Iron Mountain, California: Applied Geochemistry, v. 16, p. 947-961.

Kubisz, J., 1960, Magnesium szomolnokite (Fe,Mg) $\mathrm{SO}_{4} \mathrm{H}_{2} \mathrm{O}$ : Bulletin de $\mathrm{l}^{\prime}$ Academie Polonaise des Sciences-Serie des Sciences Geologiques et Geographiques, v. 8, p. 101-105.

Le Fur, Y., Coing-Boyat, J., and Bassi, G., 1966, Structure of the monoclinic monhydrate sulfates of the transition metals $\mathrm{MSO}_{4} \cdot \mathrm{H}_{2} \mathrm{O}(\mathrm{M}=\mathrm{Mn}, \mathrm{Fe}, \mathrm{Co}, \mathrm{Ni}$ and $\mathrm{Zn})$ : Comptes Rendus des Seances de l'Academie des Sciences (Paris)-Serie C, Sciences Chimiques, v. 262, p. 632-635 [in French].

McKibben, M. A., and Barnes, H. L., 1986, Oxidation of pyrite in low temperature acidic solutions-rate laws and surface textures: Geochimica et Cosmochimica Acta, v. 50, p. 1,509-1,520.

Melchiorre, E., Mills, J., Dale, D., Chapman, B., 2005 A new occurrence of xitieshanite $\left[\mathrm{Fe}^{3+}\left(\mathrm{SO}_{4}\right) \mathrm{Cl} \cdot 6 \mathrm{H}_{2} \mathrm{O}\right]$ crystals in acid-mine seepways, Green Valley, Vigo County, Indiana, U.S.A.: American Mineralogist, v. 90 , no. 10 , p. $1,518-1,521$.
Mrozek, S. A., Buck, B. J., Drohan, P. J., and Brock, A. L., 2006, Decorative landscaping rock as a source for heavy metal contamination, Las Vegas, Nevada: Soil and Sediment Contamination, v. 15, no. 5, p. $471-480$.

Nordstrom, D. K., and Alpers, C. N., 1999, Geochemistry of acid mine waters, in Plumlee, G. S., and Logsdon, M. J., eds., The environmental geochemistry of mineral deposits-processes, techniques, and health issues: Littleton, Colo., Society of Economic Geologists, Reviews in Economic Geology, v. 6A, p. 131-160.

Olyphant, G. A, Bayless, E. R., and Harper, D., 1992, Seasonal and weather-related controls on solute concentrations and acid drainage from a pyritic coalrefuse deposit in southwestern Indiana, U.S.A.: Journal of Contaminant Hydrology, v. 7, p. 219-236.

Olyphant, G. A., and Harper, D., 1995, Effects of direct revegetation on the hydrology, erosion and sediment yield of an abandoned deposit of coal-mine refuse: Geomorphology, v. 11, p. 261-272.

Plumlee, G. S., and Logsdon, M. L., eds., 1999, The environmental geochemistry of mineral depositsprocesses, techniques, and health issues: Littleton, Colo., Society of Economic Geologists, Reviews in Economic Geology, v. 6A, 583 p.

PRISM Climate Group, 2010, Documentation Web page: Oregon State University, <http://www.prism. oregonstate.edu/docs/index.phtml $>$, date accessed, Aug. 4, 2010.

Romero, A., González, I., and Galán, E., 2006, The role of efflorescent sulfates in the storage of trace elements in stream waters polluted by acid mine-drainagethe case of Peña del Hierro, southwestern Spain: Canadian Mineralogist, v. 44, p. 1,431-1,445.

Salvarredy-Aranguren, M. M., Probst, A., Roulet, M., and Isaure, M. P., 2008, Contamination of surface waters by mining wastes in the Milluni Valley (Cordillera Real, Bolivia)-mineralogical and hydrological influences: Applied Geochemistry, v. 23, no. 5, p. 1,299-1,324.

Singer, P. C., and Stumm, W., 1970, Acidic mine drainagethe rate-determining step: Science, v. 167, p. 1,121-1,123.

Smith, M. A., 1993, Multivariate analysis of temporal trends in groundwater chemistry and coal waste moisture content at a site experiencing acid mine drainage in southwestern Indiana: Bloomington, Indiana University, master's thesis, $251 \mathrm{p}$.

Süsse, P., 1972, Crystal structure and hydrogen bonding of copiapite: Zeitschrift für Kristallographie, v. 135, p. 34-35. 
Stewart, B. R., Daniels, W. L., Jackson, M. L., 1997, Evaluation of leachate quality from co-disposed coal fly ash and coal refuse: Journal of Environmental Quality, v. 26, p. 1,417-1,424.

Williamson, M. A., and Rimstidt, J. D., 1994, The kinetics and electrochemical rate-determining step of aqueous pyrite oxidation: Geochimica et Cosmochimica Acta, v. 58, p. 5,443-5,454.

Zodrow, E. L., Wiltshire, J., and McCandlish, K., 1979, Hydrated sulfates from Sydney coalfield, of Cape Breton, Nova Scotia. II. Pyrite and its alteration products: Canadian Mineralogist, v. 17, p. 63-70. 
INDIANA GEOLOGICAL SURVEY SPECIAL REPORT 72 


\title{
Potential Metal Attenuation by Eukaryote-Dominated Biofilm Communities in Acid Mine Drainage at the Green Valley Coal Mine Site, Indiana
}

\author{
Sandra S. Brake* and Stephen T. Hasiotis ${ }^{\dagger}$ \\ ${ }^{*}$ Department of Earth and Environmental Systems, Indiana State University \\ ${ }^{+}$Department of Geology, The University of Kansas
}

\begin{abstract}
This study of eukaryote-dominated microbial biofilms and iron-rich biolaminates in acid mine drainage at the abandoned Green Valley coal mine site in western Indiana focuses on the nature of the biofilms and their influence on the formation of the biolaminates, including the natural attenuation of contaminants. Iron-rich precipitates form continuously, encrusting the channel bottom, biofilms, and any material that falls into the effluent. Aluminum-rich chemical sediments also cover the channel bottom during periods of rapid increases in $\mathrm{pH}$ from increased discharge attributed to rainfall. Biofilm distribution and biological activity are likely influenced by seasonal variations in water temperature and light intensity, and by rapid changes in physicochemical conditions associated with increased hydrologic discharge.

Euglena mutabilis-dominated biofilm is the most abundant, covering up to 100 percent of the channel bottom during the spring and fall months. Diatom-dominated biofilm, consisting of a benthic species of the genus Nitzschia, covers up to 60 percent of the channel bottom in the summer when it is most productive at warmer water temperatures. Filamentous algae-dominated biofilm is least abundant $(<5$ percent channel coverage), present only during warmer months. These eukaryotic biofilms mediate acid mine drainage by: 1) sequestering iron within cells to form amorphous granules as a means of detoxification, 2) actively or passively accumulating acid mine drainage precipitates on cell walls, membranes, or mucilage, 3) driving precipitation of iron via oxygenic photosynthesis, and 4) releasing iron granules from within cell membranes and from iron-encrusted cell walls after death that act as nuclei for further iron precipitation.
\end{abstract}

\section{INTRODUCTION}

In 1999, Brake and others (2001a, 2001b, 2004) began studying the unique occurrence of eukaryotedominated, microbial biofilms and iron (Fe)-rich bio- laminates in acid mine drainage (AMD) at the abandoned Green Valley coal mine site (GVS) in western Indiana. The site provides an excellent natural laboratory to observe microbial biofilms in the absence of grazers and bioeroders that can oth- 
erwise damage and destroy microbial communities. This paper focuses on the nature of biofilms at the GVS and their influence on the formation of Ferich biolaminates. Our goal is to further elucidate the activity of eukaryotic microorganisms in AMD environments and evaluate the biological processes that result in natural attenuation of contaminants. Additionally, we can use our understanding of the preservation of these biofilms in the AMD biolaminates to improve our ability to interpret the geologic record of similar ancient ecosystems derived from natural acid rock drainage.

Acid mine drainage discharging from coal mining areas is highly enriched in $\mathrm{Fe}$ and sulfate $\left(\mathrm{SO}_{4}{ }^{2-}\right)$ derived from the oxidative dissolution of Fe-sulfide minerals (mainly pyrite, $\mathrm{FeS}_{2}$ ) contained in coal waste material stored at the surface. At $\mathrm{pH}$ less than 5, Fe-oxidizing microorganisms biologically accelerate this oxidative process by a factor of $\sim 10^{6}$ compared to abiotic oxidative processes (Singer and Stumm, 1970; Ehrlichand others, 1991;Schippersand others, 1996; Fowler and others, 1999; Kirby and others, 1999). Pyrite oxidation involves a complicated hydrobiogeochemical process, where bacteria mediate solubilization and Fe oxidation directly at the mineral surface. The main oxidizing agent for pyrite oxidation is dissolved ferric Fe (equation 1), produced when Fe-oxidizing bacteria oxidize reduced ferrous Fe (equation 2) generated in equation 1 (Marchand and Silverstein, 2003). The overall oxidation process is expressed in equation 3, which shows a net production of ferric $\mathrm{Fe}$, $\mathrm{SO}_{4}{ }^{2-}$, and acidity.

$$
\begin{aligned}
& \mathrm{FeS}_{2(\mathrm{~s})}+14 \mathrm{Fe}^{3+}+8 \mathrm{H}_{2} \mathrm{O} \rightarrow 15 \mathrm{Fe}^{2+}+ \\
& 2 \mathrm{SO}_{4}^{2-}+16 \mathrm{H}^{+} \\
& 15 \mathrm{Fe}^{2+}+3.75 \mathrm{O}_{2}+15 \mathrm{H}^{+} \rightarrow 15 \mathrm{Fe}^{3+}+7.5 \mathrm{H}_{2} \mathrm{O}
\end{aligned}
$$

Net reaction:

$$
\begin{aligned}
& \mathrm{FeS}_{2(\mathrm{~s})}+3.75 \mathrm{O}_{2}+0.5 \mathrm{H}_{2} \mathrm{O} \rightarrow \mathrm{Fe}^{3+}+ \\
& 2 \mathrm{SO}_{4}^{2-}+\mathrm{H}^{+}
\end{aligned}
$$

The acidity produced from pyrite oxidation facilitates leaching of other soluble minerals from the waste rock, resulting in elevated concentrations of such dissolved metals as aluminum (Al), copper $(\mathrm{Cu})$, zinc $(\mathrm{Zn})$, cadmium $(\mathrm{Cd})$, chromium $(\mathrm{Cr})$, nickel $(\mathrm{Ni})$, arsenic $(\mathrm{As})$, lead $(\mathrm{Pb})$, and cobalt $(\mathrm{Co})$ (Banks and others, 1997; Brake and others, 2001a; Sánchez-España and others, 2005). Al, in particular, is often highly elevated from leaching of Alrich shales present in coal waste material.
Both Fe and $\mathrm{Al}$ are removed from AMD via hydrolysis and precipitation of insoluble $\mathrm{Fe}-$ and Al-rich mineral phases. Fe removal is associated with hydrolysis of ferrous Fe, resulting in precipitation of ferric Fe oxyhydroxides and oxyhydroxysulfates. In very acidic $(\mathrm{pH}<3.0)$, high-sulfate environments, well-crystallized, straw-colored jarosite $\left(\mathrm{KFe}_{3}\left(\mathrm{SO}_{4}\right)_{2}(\mathrm{OH})_{6}\right)$ is the stable mineral phase (Schwertmann and others, 1995), whereas very fine $(0.5-10 \mu \mathrm{m}$ diameter), yellow schwertmannite $\left(\mathrm{Fe}_{8} \mathrm{O}_{8}\left(\mathrm{SO}_{4}\right)\left(\mathrm{OH}_{6}\right)\right)$ is stable in acidic water from $\mathrm{pH} 2.8$ to 4.5 (Bigham and others, 1992, 1996). Poorly crystalline, very fine, reddish, highly aggregated, spherical particles $(2-6 \mathrm{~nm})$ of ferrihydrite $\left(\mathrm{Fe}_{5} \mathrm{HO}_{8} \cdot 4 \mathrm{H}_{2} \mathrm{O}\right)$ or a mixture of ferrihydrite and goethite $(\alpha-\mathrm{FeOOH})$ forms in effluent with a $\mathrm{pH}$ greater than 5.0 (Bigham and others, 1992). At intermediate acidic $\mathrm{pH}$ values ( $\mathrm{pH}$ 4.5-6.5), Bigham and others (1996) found that precipitates were composed of a mixture of ferrihydrite and schwertmannite. Al phases in AMD consist of such amorphous $\mathrm{Al}$ hydroxysulfates as hydrobasaluminite $\left(\mathrm{Al}_{4}\left(\mathrm{SO}_{4}\right)(\mathrm{OH})_{10} \cdot 12-36\left(\mathrm{H}_{2} \mathrm{O}\right)\right)$ and basaluminite $\left(\mathrm{Al}_{4}\left(\mathrm{SO}_{4}\right)(\mathrm{OH})_{10} \cdot 5\left(\mathrm{H}_{2} \mathrm{O}\right)\right)$, which form at $\mathrm{pH} 4.5$ to 5.0 (Sánchez España and others, 2005, 2006). These Fe and Al precipitates generally have low crystallinity with high specific surface area (Bigham and others, 1996; Bigham and Nordstrom, 2000; Marina and others, 2005), making them efficient scavengers of trace elements from the AMD effluent (Dzombak and Morel, 1990; Smith, 1999; Sánchez España and others, 2006).

The elevated acidity and concentration of dissolved metals creates an extreme environment toxic to most aquatic organisms. Life under these extreme conditions is restricted to single-celled microorganisms that include such prokaryotes as bacteria and Archaea (Bond and others, 2000; Hallberg and Johnson, 2003; Coupland and Johnson, 2004; Druschel and others, 2004; Bruneel and others, 2006) and such eukaryotes as fungi, protozoa, and algae (Brake and others, 2001a, 2004; LópezArchilla and others, 2001). The majority of microbial studies on AMD systems focus on bacteria that catalyze redox reactions (Colmer and others, 1950; Kleinmann and Crerar, 1979; Suzuki and others, 1990; Edwards and others, 2000), dissolve minerals (Hallmann and others, 1992; Fowler and others, 1999; Pogliani and Donati, 2000), and mediate mineral precipitation (Lazaroff and others, 1982; Ferris and others, 1989; Bigham and others, 1990; Banfield and others, 2000; Kim and others, 2002). These microbial activities are important in the enhancement of metal extraction (Brierley and Brier- 
ley, 1999; Kai and others, 2000), desulfurization of coal (Bos and others, 1992), and treatment of mine waste (Sharp and Munster, 1986; Murayama and others, 1987; Ledin and Pedersen, 1996; Sen and Johnson, 1999). The function of eukaryotic microorganisms in mediating the physicochemical conditions of AMD environments is less well known and poorly documented.

\section{SITE DESCRIPTION AND HISTORY}

Mining activity at the GVS (fig. 1) took place from 1948 until 1962 and consisted of the extraction of coal from three coal seams via underground workings at the Green Valley Mine and the immediately adjacent Wabash Mine (Eggert and others, 1981). Mined coal seams included the Pennsylvanian Springfield Coal Member of the Petersburg Formation (Hartke and others, 1983; Eggert and Wier, 1986; Mastalerz and Harper, 1998; Tri-State Committee on Correlation, 2001) and the Survant and Seelyville Coal Members of the Linton Formation (Tri-State Committee on Correlation, 2001). Interbedded in the coal seams were carbonaceous pyritic shale and sandstone that were extracted along with the coal. Carbonates were a minor component of the stratigraphy and were rarely extracted. The coal units are characterized as high-volatile bituminous coals from 1 to $2.5 \mathrm{~m}(3.3-8.2 \mathrm{ft})$ thick, with the Springfield and Seelyville Members containing high concentrations of sulfur and the Survant Member containing low concentrations of sulfur (Hartke and others, 1983).

An estimated 1.2 million tons of coal were extracted from the Wabash Mine and 13.3 million tons from the Green Valley Mine (IDNR, 1985) with processing on site at a coal preparation facility. Mining and processing activities yielded approximately 5 million tons of waste material that was placed into five tailings ponds and two gob piles, with the latter measuring up to $17 \mathrm{~m}(55 \mathrm{ft})$ thick. The waste material covered an area of $\sim 25$ hectares (ha) ( $\sim 62$ acres) (Eggert and others, 1981). The GVS was abandoned when mining activities ceased. Levees and dams surrounding the gob piles and tailings ponds were subsequently breached by erosion, resulting in uncontrolled discharge of waste and contaminated water from the site with most of the material draining into West Little Sugar Creek located along the western margin of the site (fig. 1).
In 1994, the Indiana Department of Natural Resources, Division of Reclamation reclaimed the GVS. Waste piles and tailings ponds were recontoured and backfilled to create a single, low-relief mound covering about 67 ha (165 acres). The mound was covered with $19 \mathrm{~cm}$ (17.5 inches) of lime to neutralize acidity produced by the oxidation of waste material and then capped with about $1 \mathrm{~m}(3.3 \mathrm{ft})$ of soil from the Green Valley Fish and Wildlife area located east of the mine (Indiana Department of Natural Resources, Division of Reclamation, oral comm., 2000). The soil was later seeded with grasses and legumes to prevent erosion. Several ditches lined with carbonate riprap were constructed at various locations in the mound to divert surface-water runoff into West Little Sugar Creek. The longest ditch is herein referred to as the main effluent channel (see fig. 1).

Since construction, acidic seeps have developed adjacent to and within several of the ditches, and AMD now flows freely through the channels into West Little Sugar Creek. The limestone channel riprap is covered with Fe-rich precipitates, rendering the carbonate ineffective in buffering the acidity of the effluent.

Brake and others (2001a, 2001b) characterized AMD at the GVS as ranging in $\mathrm{pH}$ from 2.2 to 4.6 with high concentrations of total dissolved solids (TDS) (up to $22 \mathrm{~g} / \mathrm{L}$; Arango and others, 2002), including $\mathrm{SO}_{4}^{2-}$ (up to $63,000 \mathrm{mg} / \mathrm{L}$ ), $\mathrm{Fe}^{2+}$ (up to $2,300 \mathrm{mg} / \mathrm{L}$ ), $\mathrm{Fe}^{3+}$ (up to $10,000 \mathrm{mg} / \mathrm{L}$ ), $\mathrm{Al}$ (up to $3,100 \mathrm{mg} / \mathrm{L}$ ), $\mathrm{Cl}$ (up to $600 \mathrm{mg} / \mathrm{L}$ ), and elevated trace metals. Values of $\mathrm{pH}$ and concentration of dissolved constituents varies seasonally depending on amount of hydrologic input from snow melt and rainfall, with the lowest $\mathrm{pH}$ and highest concentrations of dissolved constituents occurring in summer when input from rainfall is low (Unger and others, 2004). When rainfall events exceed $2.5 \mathrm{~cm}$ (1 inch), $\mathrm{pH}$ increases above 4.0 and water in the ditches turns milky white with very fine suspended, amorphous Al precipitates that are most likely $\mathrm{Al}$ oxyhydroxysulfates that form at $\mathrm{pH} 4$ to 5 (Kim and Kim, 2003; Sanchez España and others, 2006). These Al oxyhydroxysulfates aggregate and settle to the channel bottom to form a bright white layer of Al-rich chemical sediments up to $5 \mathrm{~cm}$ (2 inches) thick.

Fe-rich precipitates form continuously in the GVS AMD system, encrusting the channel bottom and any material that falls into the acidic effluent, 
including twigs, leaves, insects, worms, amphibians, and reptiles. They also cover the Al-rich chemical sediments as the system recovers from rapid changes in physicochemical conditions associated with increased discharge. Consequently, we frequently see thin (<3-mm [ $<0.1$-inch] thick), white Al-rich lamina interbedded within the Fe-rich precipitates. Precipitates in the main channel are from 2 to $60 \mathrm{~cm}(0.8-23.6$ inches) thick and, in places, form small terraces. Pale greenish-blue soluble efflorescent salts, possibly melanterite $\left(\mathrm{FeSO}_{4}\right.$. $7 \mathrm{H}_{2} \mathrm{O}$ ) (see Nordstrom, 1982, and Pope and others, 2012 [this volume] for a list of common hydrated Fe sulfates in AMD environments), also develop in the summer at the water line as encrustations on carbonate riprap. Brake and others (2001c) analyzed the Fe-rich precipitates in the main channel and detected highly elevated concentrations of $\mathrm{Fe}_{\text {total }}$ $>\mathrm{Al}>\mathrm{K}>\mathrm{Ca}>\mathrm{Mg}>\mathrm{Na}>\mathrm{Mn}>\mathrm{Zn}>\mathrm{Cr}>\mathrm{Pb}>\mathrm{Cd}>\mathrm{Ni}$ $>\mathrm{Si}$ compared to suspended solids in uncontaminated sections of West Little Sugar Creek. In AMD environments, these elements are commonly attenuated from the acidic effluent via coprecipitation with, or adsorption to AMD precipitates (Morel and Gschwend, 1987; Rose and Ghazi, 1998). At GVS, some of these elements are also concentrated

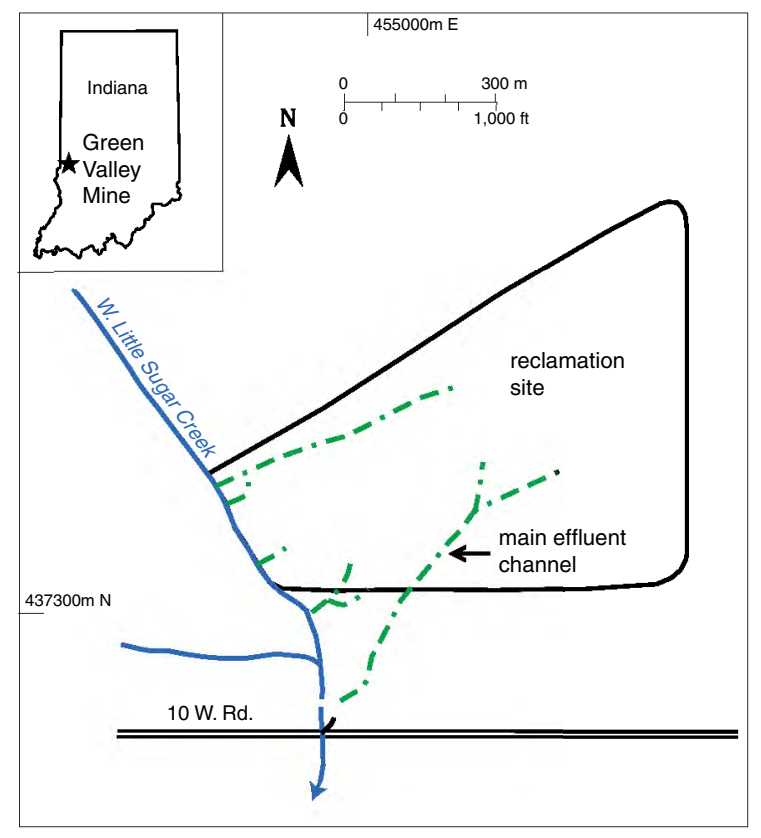

Figure 1. Map of Green Valley Mine in western Indiana showing location of the reclamation site and network of constructed channels (dashed and dotted lines). Channels divert run-off and acid mine drainage into West Little Sugar Creek. Map coordinates in meters, UTM zone 16. in the channel deposits as a consequence of biological activity associated with the biofilms.

\section{MICROBIAL BIOFILMS}

We have documented three distinct eukaryotedominated biofilms in AMD at the GVS: Euglena mutabilis-dominated, diatom-dominated, and filamentous algae-dominated biofilms. Distribution and biological activity of these biofilms appears to be influenced by seasonal variations in water temperature and light intensities, and by rapid changes in the physicochemical conditions of the environment associated with increased hydrologic discharge (Arango and others, 2002; Brake and Hasiotis, 2005). The following text describes each biofilm type based on data collected to date.

\section{E. mutabilis-dominated biofilm}

E. mutabilis-dominated biofilm (fig. 2) is the most abundant biofilm type in the AMD system at the GVS. It is easily identified in the field by its emerald green color. The biofilm is relatively thin, measuring less than $3 \mathrm{~mm}$ ( $0.1 \mathrm{inch}$ ) thick, and drapes over the contours of the underlying channel bottom.

E. mutabilis is an oxygenic photosynthesizing, acidophilic protozoan which, based on microscopic estimations, forms more than 90 percent of the biofilm biomass. Also present and collectively comprising less than 10 percent of the biomass are: 1) diatoms, the majority of which belong to a single species in the genus Nitzschia, 2) a few unidentified species of filamentous algae, 3) the acidophilic, photosynthetic green algae Chlamydomonas sp., 4) fungi, and 5) several types of bacteria (Brake and others, 2004). E. mutabilis, diatoms, algae, and Chlamydomonas are all phototrophs known to inhabit AMD systems (Lackey, 1938; Bennett, 1969; Hargreaves and Whitton, 1976; López-Archilla and others, 2001). Fungal species include at least six species of Penicillium, two species of Trichoderma, Cladosporium cladosporioides, a species of Acremonium, and a species of Mortierella (Shepard and others, 2004). Bacteria contribute the smallest fraction $(<1 \%)$ of the biomass because of their very small size (generally $<10 \mu \mathrm{m}$ ) compared to the much larger eukaryotic microorganisms. 
Brake and others (2002) reported a crude microbial stratification in the E. mutabilis biofilm consisting of two layers: an upper layer up to $2 \mathrm{~mm}$ (0.07 inch) thick dominated by E. mutabilis with minor amounts of fungal hyphae, Chlamydomonas, fungi, and bacteria, and a lower layer about $1 \mathrm{~mm}$ (0.04 inch) thick containing mainly bacterial species with lesser fungal hyphae and algal filaments. The presence of algal filaments in the lower layer suggests that the biofilm is primarily aerobic throughout. This layering differs from stromatolite-building microbial communities in marine environments where the lower layer in the microbial succession is typically composed of anaerobic bacteria, which includes sulfate-reducing bacteria and Archaea (Schopf, 1999). Brake and others (2001a) showed that the surface of the biofilm is commonly supersaturated in oxygen at up to $20.6 \mathrm{mg} / \mathrm{L}$ (oxygen-saturated water is at $8.25 \mathrm{mg} / \mathrm{L}$ at $25^{\circ} \mathrm{C}\left[77^{\circ} \mathrm{F}\right]$ and 1 atmosphere) (Langmuir, 1997). We have yet to establish the oxygen content downward within the biofilm to determine if the succession is more complex than indicated by preliminary microscopic observations.
The stability of the biofilm is dependent on the entwining nature of E. mutabilis and on the production of extracellular polymeric substances (EPS), or mucilage, by some of the microbial species within the biofilm. The layer is mainly held together by entwined E. mutabilis cells and by cells entwined around small amorphous Fe-rich particles. E. mutabilis lacks an emergent flagellum for locomotion like other Euglena species and instead uses its flexible cell membrane for motility. This allows it to entwine around other cells and around material within the biofilm. E. mutabilis also secretes a thin layer of EPS (Häder and Melkonian, 1983). In bacteria, the production of EPS is used, in part, to provide a strong adhesive force that inhibits removal of the cells from attached surfaces and promotes adhesion to other cells (Costerton and others, 1978, 1985; Dowd and others, 2000). E. mutabilis likely secretes EPS for similar purposes.

E. mutabilis-dominated biofilm is the only biofilm that occurs in the AMD channel year round. It covers up to 100 percent of the channel bottom during the spring and fall months when water

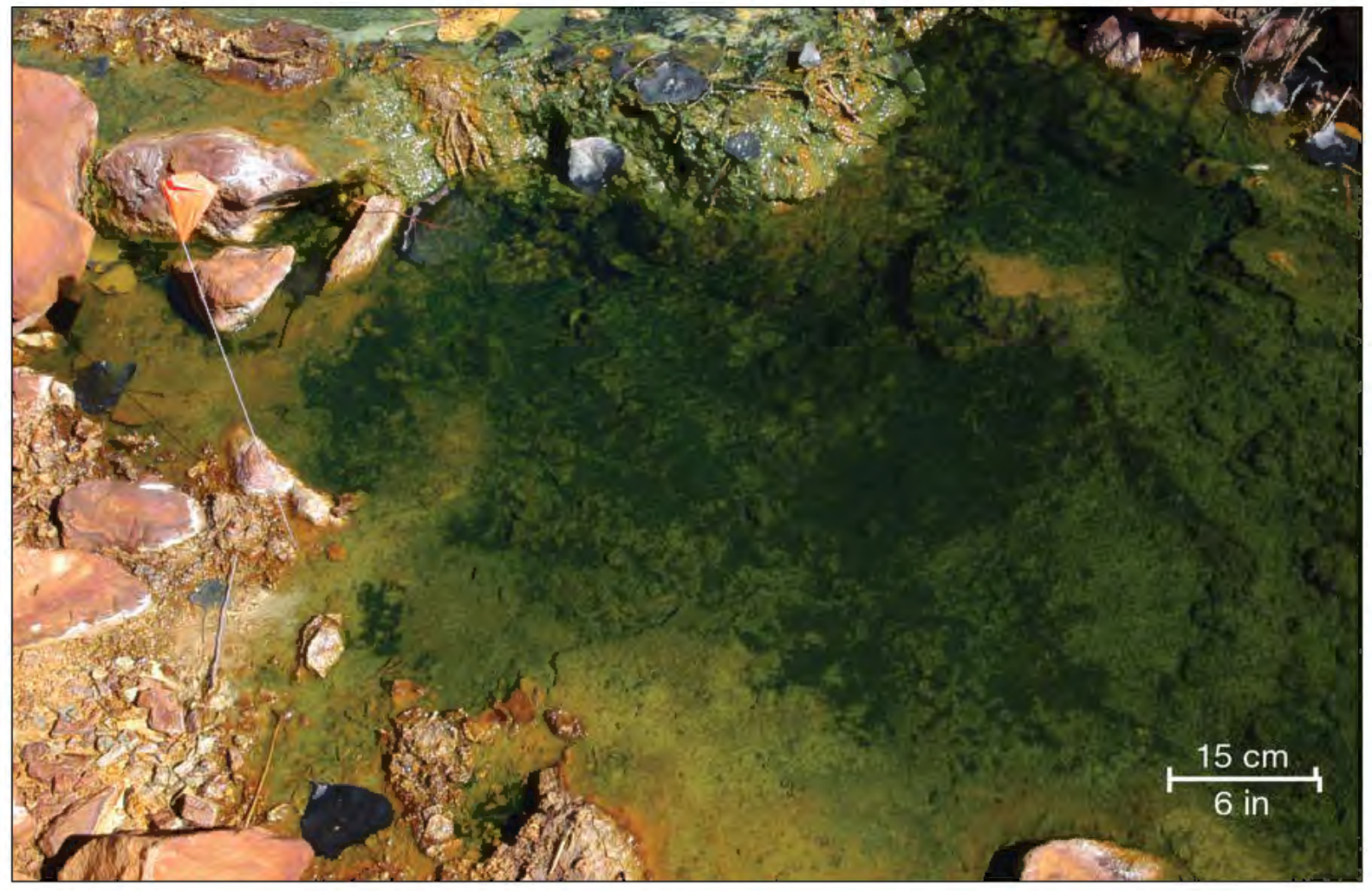

Figure 2. Photograph of emerald green E. mutabilis-dominated biofilm covering acid mine drainage channel at the Green Valley coal mine site. 
temperatures are between 13 to $28^{\circ} \mathrm{C}\left(55-82^{\circ} \mathrm{F}\right)$, and retreats to isolated patches during summer and winter months outside of this temperature range (Arango and others, 2002; Brake and Hasiotis, 2005). Within the GVS systems, we have detected no trends in distribution associated with $\mathrm{pH}$ and concentration of TDS. Rather, we hypothesize that water temperature is the main factor influencing biofilm distribution. The maximum distribution in the spring and fall suggests water temperature at those times is optimal for growth and reproduction. On the other hand, the isolated occurrence of E. mutabilis in the coldest and warmest months suggests that the extreme water temperatures provide less hospitable conditions for community maintenance. These isolated sites may serve as refugia from which E. mutabilis can expand when conditions are more optimal for growth (Hasiotis and others, 2001).

\section{Diatom-dominated biofilm}

Diatom-dominated biofilm (fig. 3) is easily distinguished from E. mutabilis biofilm in the field because of its olive-green color and greater thickness (up to $50 \mathrm{~mm}$ [1.9 inches]) when it reaches its optimum growth cycle. Diatoms make up more than 90 percent of the biofilm population, consisting primarily of one benthic, pennate diatom species belonging to the genus Nitzschia (Brake and others, 2004). Cells occur either individually or more often as chains of cells linked parallel to one another. Individual frustules are about $40 \mu \mathrm{m}$ long. Fe particles are often attached to individual cells and to linked segments (fig. 4). Also present in the biofilm and forming less than 10 percent of the population are Chlamydomonas sp., E. mutabilis, filamentous algae, fungi, and bacteria similar to those observed in the E. mutabilis biofilm. The presence of any microbial stratification has yet to be determined.

When the diatoms reach their optimum growth period, the biofilm is considerably thicker than the E. mutabilis biofilm because of the copious production of mucilage. This mucilage allows the biofilm to expand upward above the channel bottom. During the warmest months of the summer, the biofilm achieves its maximum thickness and has the appearance of an algal bloom (Brake and Hasiotis, 2005). At this time, the cells are loosely held together by mucilage and are easily dispersed with slight agitation of the water. Diatoms are known to use mucilage for gliding motility to place cells higher in the biofilm near the biofilm-water interface for nutrients and light (Hudson and Legendre, 1987; Cohn and Weitzell, 1996).

Distribution is likewise controlled by water temperature and seasonality; however, it differs significantly from that of E. mutabilis (Brake and Hasiotis, 2005). For example, the diatom biofilm is not present year round, being absent in the winter when water temperature and light intensity are at a minimum. It forms isolated patches in the spring and fall when E. mutabilis distribution is at a peak, and in the summer it expands from the patches to cover up to 60 percent of the channel bottom as E. mutabilis retreats to isolated patches. This suggests that diatoms are most productive when water temperatures are the warmest and light intensity the strongest.

\section{Filamentous algae-dominated biofilm}

The least abundant biofilm type is the filamentous algae-dominated biofilm community (fig. 5). This biofilm is distinguished by its yellowish-green color and presence of macroscopic strands or tassels of entwining algal filaments 2 to $20 \mathrm{~cm}(0.8-7.9$ inches) long. It is generally less than $5 \mathrm{~mm}(0.2$ inch) thick and mucilage aids in holding the biofilm together. Also present with the algae are very minor $(<10 \%)$ E. mutabilis, diatoms, Chlamydomonas sp., and bacteria (Brake and Hasiotis, 2005).

The biofilm is present during warmer months from spring through fall and absent in winter, similar to the diatom-dominated biofilm. It occurs only in isolated patches, generally covering less than 5 percent of the channel bottom and tends to form in areas where water cascades between carbonate riprap. Unlike the diatom- and E. mutabilis-dominated biofilms, the algae-dominated biofilm does not expand from its patches, suggesting that the AMD system never achieves sufficient conditions for accelerated growth and expansion. Its occurrence in areas of cascading water may be similar to some species of algae that prefer flowing water because it provides constant renewal of nutrient material needed by the algae and increases metabolism, causing the algae to respire more rapidly because of the higher oxygen content of the water (Whitford, 1960; Whitford and Schumacher, 1961). Other factors such as rainfall rate and texture of the chemical sediments may play a role in controlling distribution of the algaldominated biofilm. 


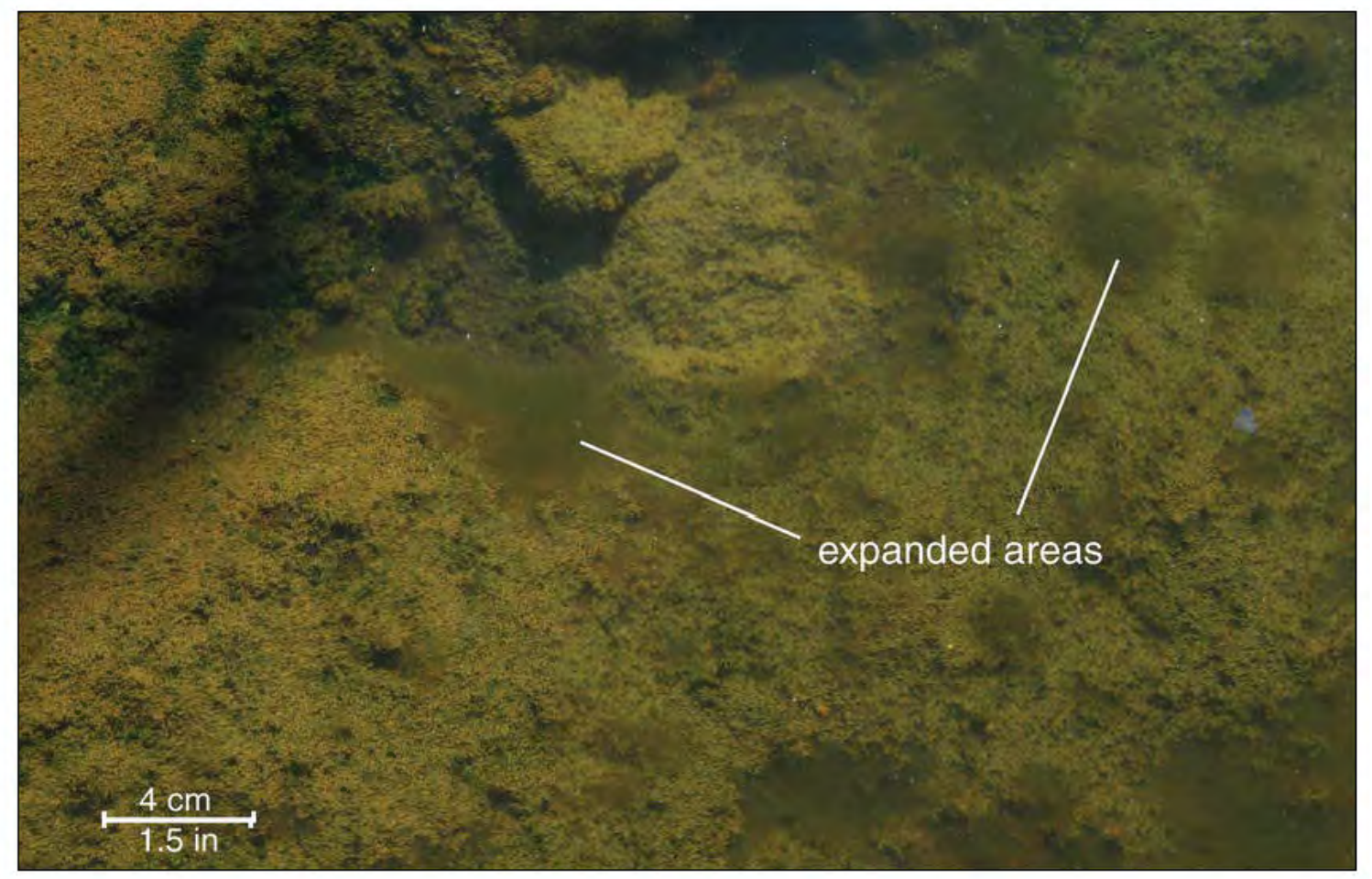

Figure 3. Photograph of patchy olive green diatom-dominated biofilm with small fuzzy-looking areas that represent sections of biofilm that have expanded upward. Areas appear fuzzy because of copious amounts of mucilage surrounding cells.

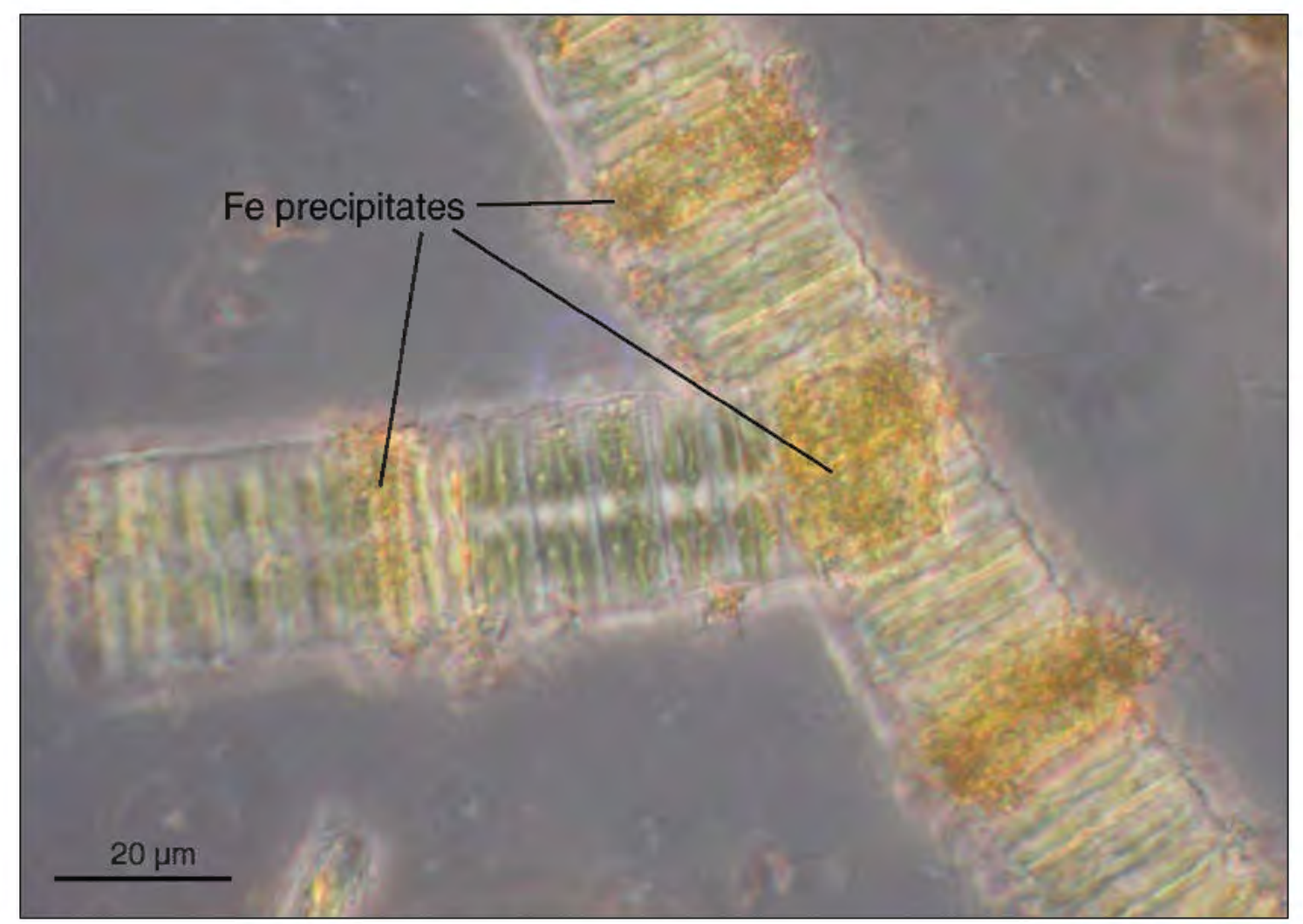

Figure 4. Transmitted light photomicrograph of linked diatoms with aggregated granular Fe particles attached to some segments. 


\section{CELLULAR SEQUESTRATION OF CONTAMINANTS}

Microorganisms living under extreme conditions in AMD are able to do so because of evolutionary adaptations to tolerate or adapt to adverse physicochemical conditions of their environment. Adverse conditions were the norm in the Archean and Proterozoic when microorganisms were the dominate life form in all environments, atmospheric oxygen was less than one-tenth of present-day, UV flux from the early Sun was higher, and metazoans had yet to evolve (Canuto and others, 1982; Schopf, 1999; Seckback, 2003; Westall and Drake, 2004; Westall, 2005). Under present-day extreme conditions, microorganisms continue to develop ways to mitigate the physicochemical conditions of their environment. In AMD environments, microorganisms have developed the ability to mitigate the toxic effects of high concentrations of dissolved metals and acidic conditions as a means of survival.

Research on AMD microorganisms has focused primarily on prokaryotes because they typically have greater diversity and numbers, and possess the ability to enhance metal dissolution and bio- precipitation (Bigham and others, 1992; Ledin and Pedersen, 1996; Warren and Ferris, 1998; Wood and others, 2001), the latter important in natural remediation (Ledin and Pedersen, 1996; Warren and Ferris, 1998; Johnson and others, 2002). Studies on eukaryotes in AMD environments, on the other hand, have focused mainly on identifying species diversity and biovolume, and on measuring the potential for metal uptake (for example, Rai and others, 1981; Winterbourn and others, 2000). The different approaches in research are likely because of fundamental differences between the two groups where chemolithotrophic bacteria have the ability to catalyze chemical reactions and produce complexing agents that affect speciation and mobility of metals (Ledin and Pedersen, 1996; Ehrlich, 2002) in contrast to eukaryotes that have developed biological defense mechanisms to cope with adverse conditions (Wood and Wang, 1985). Below we review potential metal uptake by some eukaryotic microorganisms as an adaptive strategy for survival in AMD environments having high TDS. This adaptive strategy has the potential to be useful in engineering of natural bioremediation systems.

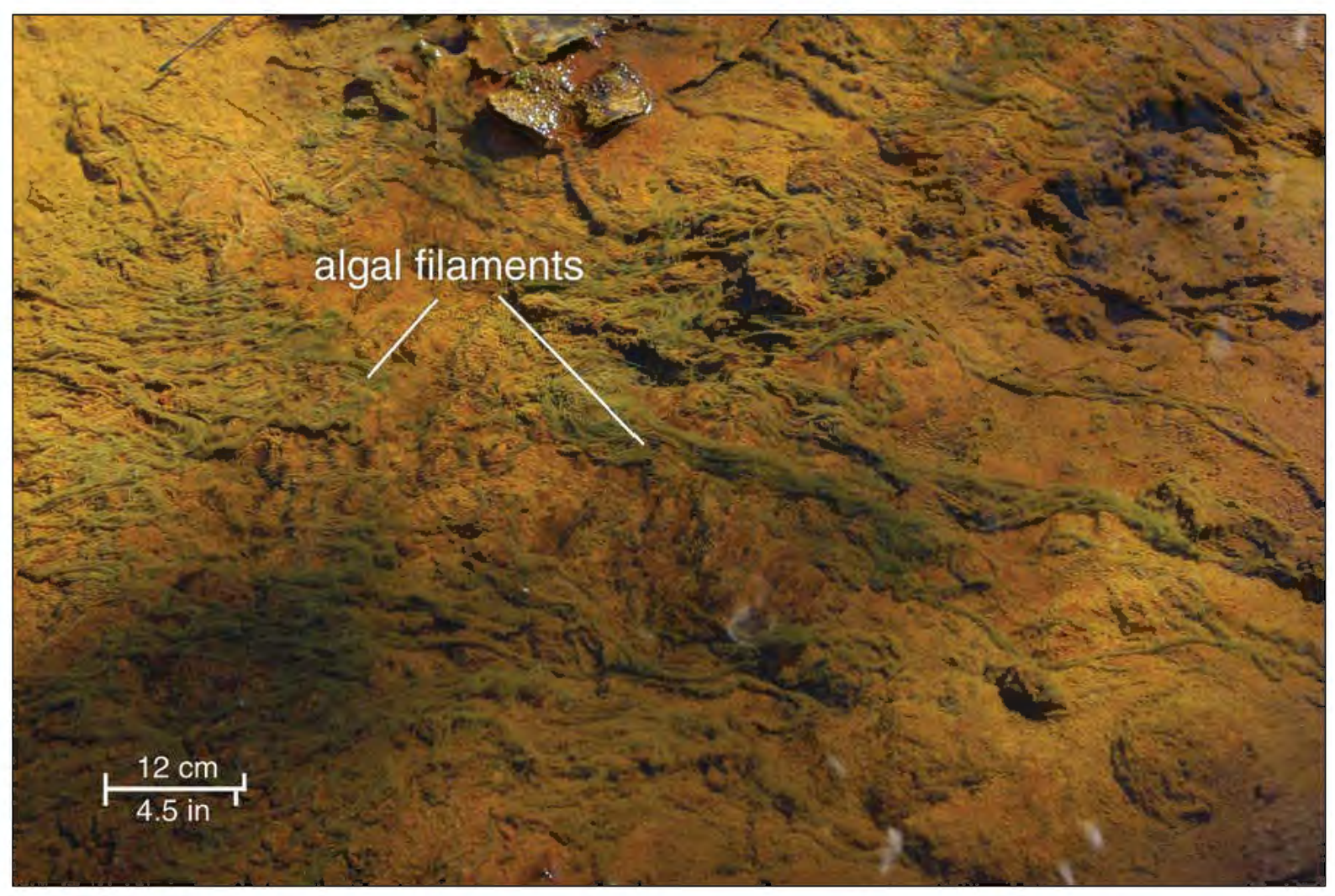

Figure 5. Photograph of filamentous algae-dominated biofilm consisting of long strands of entwined algal filaments. 
Rai and others (1981) provide a comprehensive review of heavy metal uptake and accumulation in algal species, including diatoms. They report that some species have the ability to adsorb metals onto the cell surface in both living and dead cells. In some cases, however, metals can be removed by repeated washing of algal cells in distilled water (Fujita and Hashizume, 1975). This process is probably a result of passive accumulation of dissolved metals onto the cell surface as opposed to metabolic intervention, and is responsible for only a small amount of heavy metal attenuation (Gadd and Griffiths, 1978). Similar metal adsorption has also been reported on fungal cell walls (Krantz-Rülcker and others, 1995).

Metabolic or energy-dependent sequestration of metals is thought to result in substantially higher uptake of dissolved metals by algal species (SchulzBaldes and Lewin, 1976; Gadd and Griffiths, 1978). This is achieved by diffusion-controlled uptake across the cell membrane and by binding metals to proteins within the cells (Silverberg and others, 1976). The EPS secreted by both bacteria and eukaryotes has also been shown to serve as a sorption barrier to protect the cells from the toxic effects of the heavy metals, resulting in high accumulations of heavy metals in the EPS layer (Ledin and Pedersen, 1996; Zavarzin, 2003).

Our evaluation of metal uptake by microorganisms at the GVS has focused primarily on $E$. $m u$ tabilis because it is the dominant eukaryote in the AMD system. E. mutabilis cells are elongate, 100 to $125 \mu \mathrm{m}$ long and 25 to $50 \mu \mathrm{m}$ wide, with numerous chloroplasts spaced evenly between the ends of the organism. The chloroplasts are separated by a nucleus near the center with a prominent red stigma located off-center.

The most interesting feature of E. mutabilis at the GVS is the occurrence of numerous (10-15) small $(<3-5 \mu \mathrm{m})$, irregularly shaped orange to dark-red amorphous granules (fig. 6) located within the cytoplasm (Brake and others, 2001a). Brake and others (2001a) initially hypothesized that the granules were composed of Fe. Arango (2002) ran several tests to determine the composition of the granules. For these tests, E. mutabilis cells were initially grown in Fe-rich and Fe-free media. The results of the experiment showed that granules were larger and more numerous in cells grown in the Fe-rich medium. Further testing indicated that the granules were not protein- or biomolecular-based Fe structures that sometimes occur in eukaryotic microorganisms. These conclusions are based on protein absorbance values of the granules compared to protein standard curves as well as the exposure of granules to phenol-chloroform to remove proteins, which did not change the structures of the granules (Arango, 2002). Staining techniques, using Turnbull's blue staining for $\mathrm{Fe}^{2+}$, confirmed the presence of $\mathrm{Fe}$ in the granules, and environmental scanning electron microscope with an energy dispersive system (ESEM-EDS) and scanning transmission electron microscope (STEM) analyses provided further evidence that the granules were indeed Fe-based and having smaller concentrations of potassium $(\mathrm{K})$, sulfur $(\mathrm{S})$, oxygen $(\mathrm{O})$, phosphorus $(\mathrm{P})$, silicon $(\mathrm{Si})$, aluminum $(\mathrm{Al})$, chlorine $(\mathrm{Cl})$, and calcium $(\mathrm{Ca})$. Semiquantitative ICPMS analysis of a small concentrate of the granules showed that selenium (Se), zinc $(\mathrm{Zn})$, cobalt $(\mathrm{Co})$, arsenic $(\mathrm{As})$, copper $(\mathrm{Cu})$, chromium $(\mathrm{Cr})$, vanadium $(\mathrm{V})$, zirconium $(\mathrm{Zr})$, thorium $(\mathrm{Th})$, niobium $(\mathrm{Nb})$, molybdenum $(\mathrm{Mo})$, silver $(\mathrm{Ag})$, lead $(\mathrm{Pb})$, and thalium (Tl) (in approximate order of abundance) were also present in the granules (Brake and others, 2002). These granules likely represent compartmentalized Fe and other elements converted to an inert form as a means of detoxification (for example, Gadd, 1990). This adaptation would prevent an internal build-up of the toxic elements. It has yet to be determined how metals cross the cell membrane, whether by diffusion, active transport, or binding (Gross, 2000; Gadd, 2009). We have yet to test metal uptake by the diatoms and filamentous algae; however, we anticipate that some of these species may possess the ability to sequester metals similar to other eukaryotic algae and diatoms living in AMD.

\section{CONTAMINANT ATTENUATION VIA FORMATION OF BIOLAMINATED DEPOSITS}

Both direct and indirect microbial processes of metal sequestration via precipitation, trapping, and binding chemical precipitates have been documented at the GVS. These processes are important in retarding the adverse conditions of AMD by attenuating contaminants before they are discharged into natural drainage systems.

Numerous studies have documented enzymatic processes in bacterial species that lead to biomineralization in marine, hot spring, and AMD 


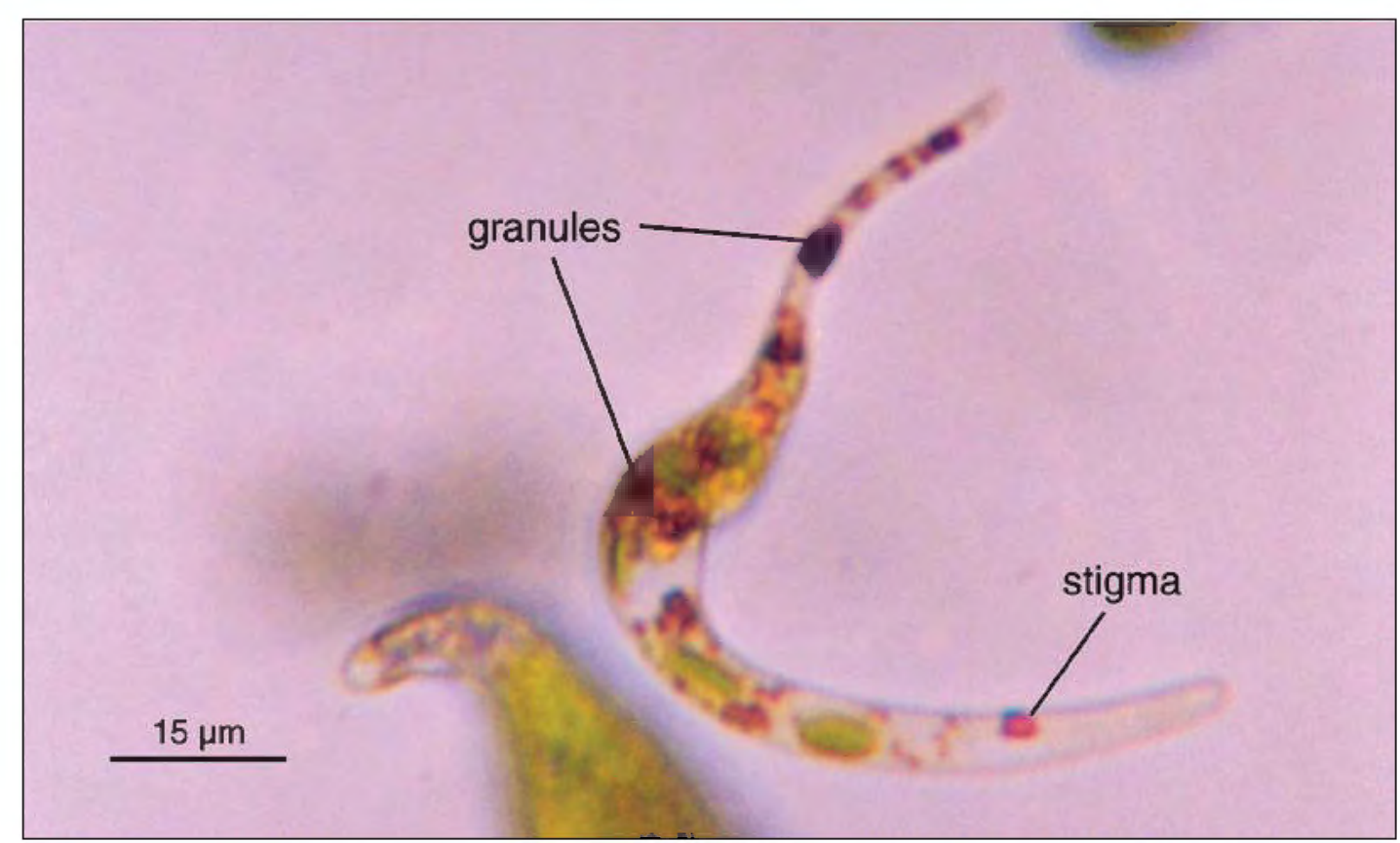

Figure 6. Photomicrograph of Euglena mutabilis showing elongate morphology and reddish Fe-rich intracellular granules. Red spot in lower right of cell represents stigma.

environments (for example, Lowenstam, 1981; Krumbein, 1986; Pentecost and Riding, 1986; Westall and others, 2003; Ferris and others, 2004; Inskeep and others, 2004). In bacteria, mineral precipitates are observed to occur as: 1) accretions on the external surface of cell walls, 2) minerals that develop on the inside surface of cell membranes, 3) precipitates extending through the capsule or external sheath surrounding cell walls, and 4) precipitates within the EPS matrix surrounding cells (Ferris and others, 2004). Enzymatic processes leading to biomineralization by eukaryotes is not as well documented, probably because eukaryotes are generally considered incapable of similarly mediating their environment for the purpose of biomineralization. Rather, literature on eukaryotes highlights nonenzymatic processes associated with mineral precipitation, mainly as passive precipitation on cell membranes that act as a nucleation media (for example, Winsborough and Golubic, 1987), as precipitates trapped in EPS surrounding the cells, and as abiotic precipitation driven by oxygenic photosynthesis (for example, Golubic, 1973; Pentecost and Riding, 1986; Ehrlich, 2002; Brake and others, 2004). Mann and others (1987), however, were able to demonstrate that a species of Euglena living in acid conditions was capable of nucleating microcrystalline Fe oxides within the cell and on the cell membrane. Likewise, Brake and others (2002) showed that E. mutabilis forms amorphous Fe deposits withinitscytoplasm. Thesestudiessuggestthatsome eukaryotic species have the capacity to enzymatically promote biomineralization.

Studies of the biofilms and Fe-rich precipitates at the GVS show that both prokaryotes and eukaryotes are directly and indirectly involved in the attenuation of contaminants, resulting in the formation of biolaminated deposits that cover the channel bottom. The biolaminates are situated directly below the biofilms and are soft and crumbly, ranging from 5 to $60 \mathrm{~cm}$ (1.9-23.6 inches) thick and extending fairly continuously along the entire width of the channel. They are composed of a succession of finely laminated, wavy layers that alternate with slightly thicker porous, spongelike layers (fig. 7). The wavy layers consist of amorphous granular $\mathrm{Fe}$ precipitates with interbedded decaying remnants of E. mutabilis biofilm. SEM analysis of this layer revealed interbedded layers of monospecific pennate diatom frustules oriented perpendicular to bedding and Fe-mineralized casts of bacterial cocci (Brake and Hasiotis, 2008). Microscopic analysis of the thicker spongelike layers shows that they contain Fe-coated diatom frustules, some of which display an upward branching morphology indicative of diatoms preserved in growth position, and remnants of fungal and algal filaments (Brake and others, 2004). These layers vary from less than 0.1 to 2.5 cm (0.04-1.0 inches) thick (Brake and others, 2002). 
We identify these biolaminated structures as stromatolites and conclude that they meet the criteria established by Awramik and others (1976) as being accretionary, organosedimentary structures composed of biologically derived laminae formed by microbial communities.

To date, we have identified several biological processes involved in the formation of the Ferich stromatolites at the GVS. These include: active or passive nucleation of $\mathrm{Fe}$ minerals on cells walls; intracellular storage of Fe compounds in the cytoplasm of E. mutabilis, which after death contributes to the solid material in the biolaminates; genertion of $\mathrm{O}_{2}$ via photosynthesis by E. mutabilis and other the phototropic eukaryotes that further facilitates oxidation and subsequent precipitation of reduced Fe; and trapping and binding of chemical precipitates via microbial motility with the use of EPS, which leads to accretion of chemical sediments.

We have observed the occurrence of minerals on cell walls and membranes in both the living biofilm and in the laminations of the stromatolites. In the living biofilms, Fe minerals were often attached to cells of diatoms that occurred in linked strands (see fig. 4). SEM-EDS analyses of the stromatolites revealed crystalline Fe-sulfate occurring as mineralized casts on lysed bacterial cocci (fig. 8) and Fe-oxyhydroxide minerals encrusting diatom frustules (fig. 9) (Brake and others, 2004; Brake and Hasiotis, 2008). Whether these precipitates represent active or passive nucleation on cell walls or cell membranes has yet to be determined. Because Fe precipitates form continuously in this environment, we hypothesize that some of the encrustations represent passive nucleation. We have yet to observe Fe encrustations on E. mutabilis, possibly because its flexible cell membrane precludes encrustation and subsequent preservation in the stromatolites.

We have, however, established that E. mutabilis contributes to the attenuation of metals via sequestration and intracellular formation of the Fe-rich granules discussed here (see fig. 6). Because the Fe granules are fairly inert, Brake and others (2002) hypothesized that upon cell death these granules likely contribute to the developing stromatolites and may serve as nucleation sites for further precipitation of authigenic Fe phases (for example, Konhauser and Ferris, 1996). Within the stromatolitic fabric, we see small spherical, amorphous Fe oxyhydroxides that are similar in size to the granules. Whether these particles represent spherical, amorphous, abiotically derived Fe precipitates, such as ferrihydrite or biologically derived Fe granules, has yet to be established.

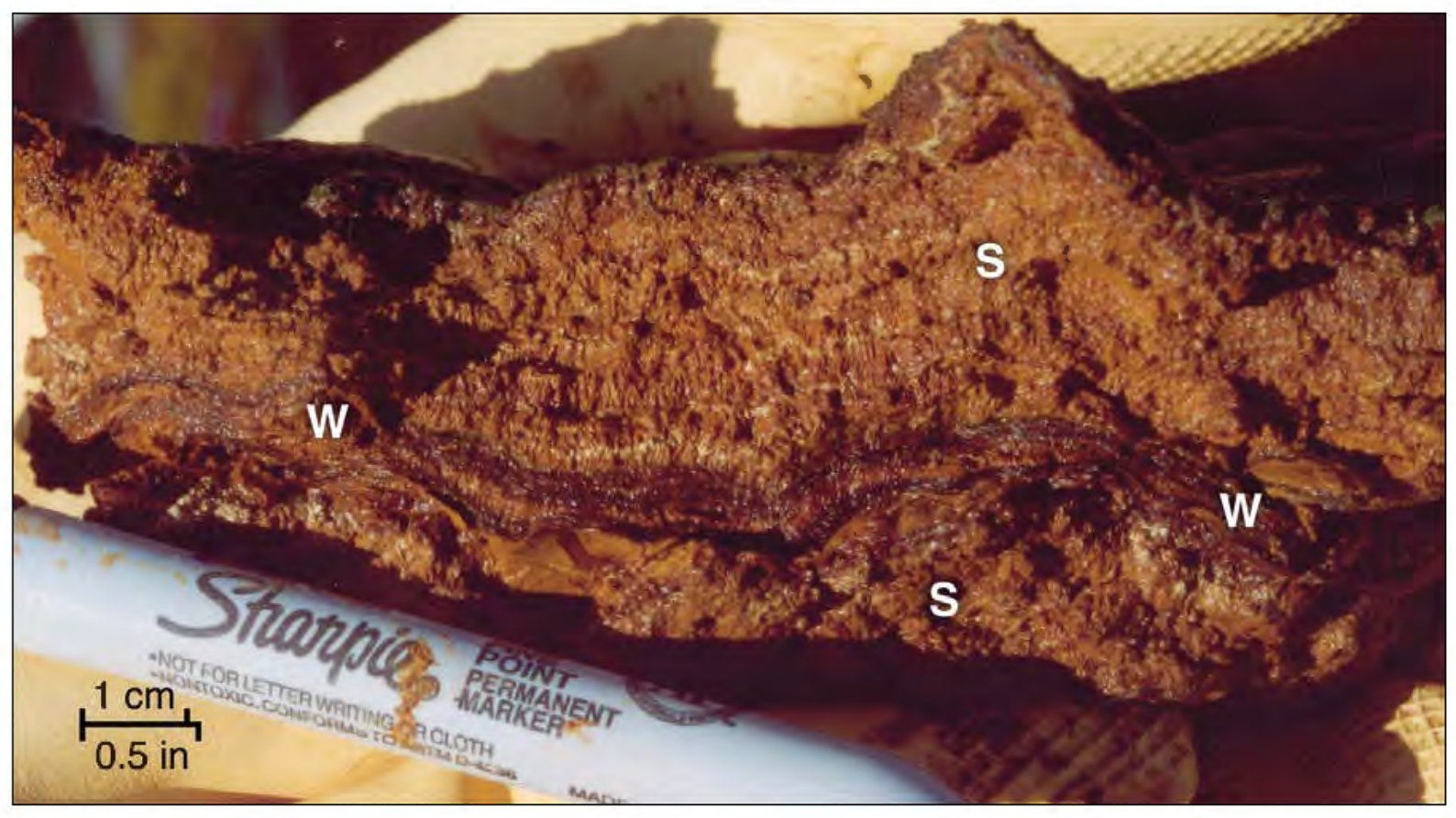

Figure 7. Photograph of sample of Fe-rich stromatolite showing thicker porous spongelike (S) layers alternating with thinner wavy (W) layer. 
The oxygenic photosynthetic activity of E. mutabilis and the other phototrophic eukaryotes in the biofilms may also indirectly contribute to the precipitation of Fe in the growing stromatolites. At the GVS, Brake and others (2001a) detected supersaturation of $\mathrm{O}_{2}$ (up to 200 percent saturation with the atmosphere) in areas with E. mutabilis biofilms. Similarly, Arango (2002) detected elevated concentrations of dissolved $\mathrm{O}_{2}$ in cultures of $E$. mutabilis grown in artificial AMD compared to $\mathrm{O}_{2}$ concentrations in artificial AMD without $E$. mutabilis. Ehrlich (2002) reported that photosynthesis associated with biofilms may promote ferrous Fe oxidation by creating conditions favorable for autooxidation by: 1 ) raising $\mathrm{pH}$ of the water in the areas of the biofilms, and 2) raising $\mathrm{O}_{2}$ levels in the water around the biofilm. In laboratory tests, Arango (2002) documented that ferrous Fe removal in artificial AMD media was accelerated in samples containing E. mutabilis cells as opposed to media without cells, suggesting that the biological activity of E. mutabilis plays an important role in attenuating Fe. Whether Fe removal was accelerated by internal sequestration or via precipitation from oxygenic photosynthesis is stillunder investigation.

Our studies at the GVS suggest that one of the main factors influencing attenuation of metals and contributing to the formation of stromatolites is the trapping and binding of the chemical sediments by EPS. Microscopic studies of E. mutabilis- and diatom-dominated biofilms at the GVS show amorphous Fe-rich precipitates trapped in mucilage and adhering to cells in the biofilms. E. mutabilis, in particular, uses its flexible cell membrane to wrap around Fe particles (Brake and others, 2002), further facilitating the trapping of particles within the biofilm layer. A similar process of trapping Fe hydroxides in EPS secreted by bacterial biofilms was documented by Boult and others (1997) in AMD-contaminated streams. Once the chemical sediment is trapped, we propose that the biofilm community binds the precipitated grains in the EPS produced for locomotion to form the biolaminated fabric of the stromatolites, similar to the biostabilization process that forms marine stromatolites (Noffke and Paterson, 2008). In the marine environment, the stromatolitic fabric is established when cyanobacteria and diatoms bind sediment in locomotion-produced EPS while placing cells higher in the mat to improve fitness with light (phototaxis) and nutrient availability (chemotaxis) as the driving forces in order to keep pace with sedimentation (Edgar and Pickett-Heaps, 1984; Paterson and others, 2003).

Likewise in the AMD environment, microorganisms in biofilms produce EPS for locomotion to

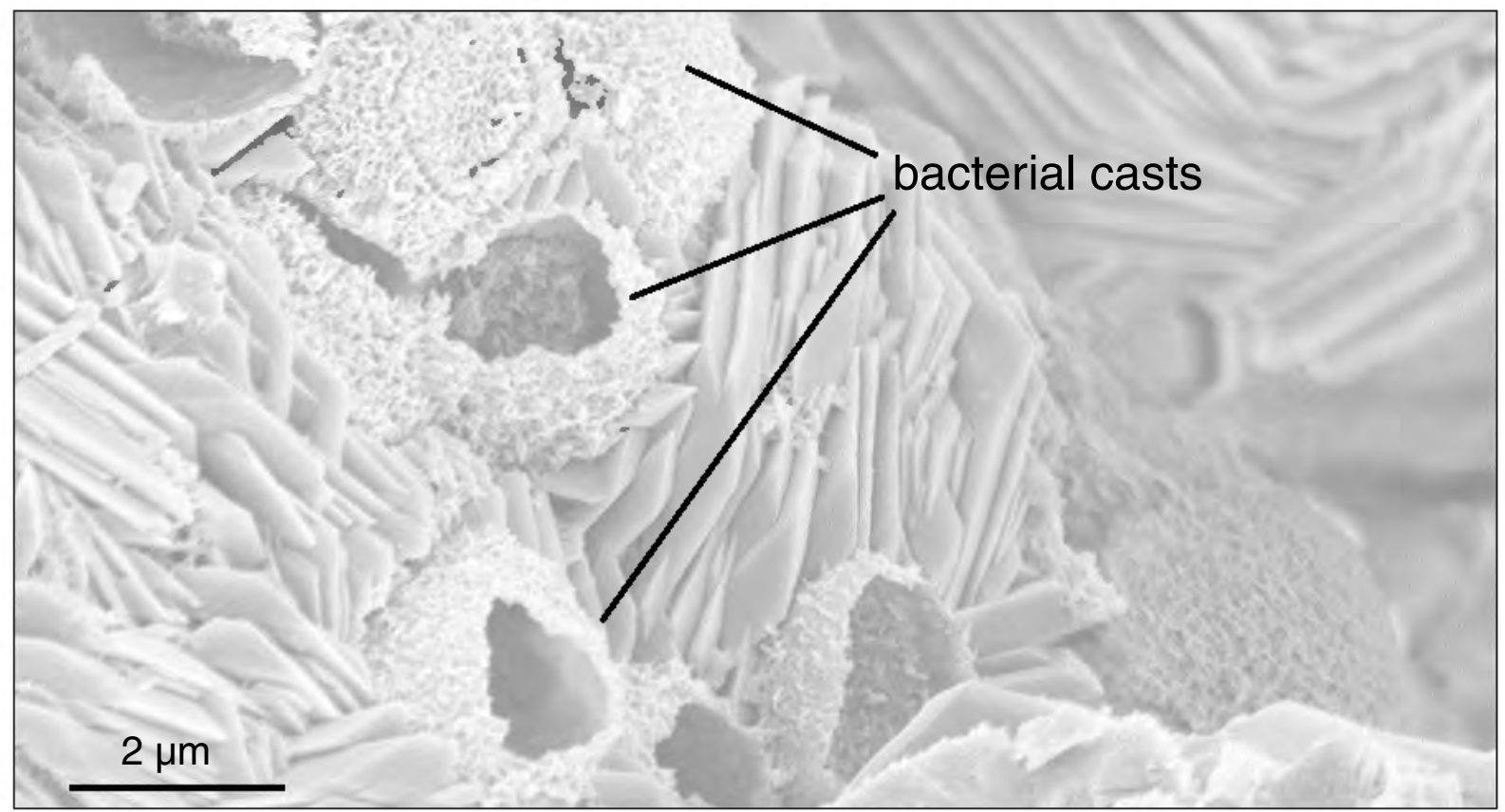

Figure 8. Scanning electron microscope micrograph showing crystallized casts of coccoid bacteria within a thinly laminated wavy layer (for example, $\mathrm{W}$ in fig. 7). 
keep pace with chemical sedimentation, particularly during times of increased Fe and Al precipitation associated with decreased acidity and increased hydrologic input from rainfall. We have observed the phototactic-chemotactic response of E. mutabilis and diatoms in the laboratory and in the field when the biofilms are rapidly covered with precipitates. Cells are able to move through the chemical sediment to reestablish a biofilm layer at the sediment-water interface within a few days of being covered. We consider that this process helps bind the chemical sediments and establishes the biolaminated structures observed in the AMD precipitates. In some cases, we have found decaying layers of E. mutabilis biofilm interbedded in the biolaminates, indicating that at least some of the microbial communities were unable to keep pace with high rates of chemical sedimentation.

\section{SUMMARY}

In general, the activity of eukaryotic microorganisms is neglected in the design of mine waste treatment systems. Our work at the GVS, however, dem- onstrates that eukaryotic microorganisms and eukaryote-dominated communities are capable of modulating their environment via processes that contribute to natural remediation of contaminants. This is accomplished by such activities as:

1. Taking in $\mathrm{Fe}$ and other contaminants to form granules or precipitates as a means of detoxifying the cytoplasm;

2. Actively or passively accumulating $\mathrm{Fe}$ precipitates on cell walls or membranes;

3. Driving precipitation of $\mathrm{Fe}$ and other elements from AMD via highly oxygenic photosynthetic activity;

4. Releasing Fe granules from within cell membranes and from Fe-encrusted cell walls upon death that act as nucleation sites for further precipitation of authigenic Fe minerals; and

5. Biostabilization of chemical sediments by trapping and binding via EPS that results in the building of stromatolites.

Even though increased discharge can lead to erosion of the chemical sediments and stromatolites, the sequestered metals remain in the solid phase and are not redissolved. Instead, the chemical sedi-



Figure 9. Scanning electron microscope micrograph of Fe-oxyhydroxides encrusting the smooth surface of linked diatom frustules. 
ments are redeposited elsewhere in the local drainage system and are biostabilized, buried, or reeroded. Future research should evaluate the use of the eukaryotes in bioremediation of polluted AMD wastewaters.

The GVS AMD system also provides an exceptional example of life's adaptation to an extreme environment. The microbial processes operating here may also have operated on early Earth, leading to the formation of such Fe-rich deposits as Precambrian banded Fe formations and the oxygenation of the atmosphere. Understanding the microbial processes operating at GVS will provide important insights into the possible role of eukaryotes in Earth's evolutionary history.

\section{ACKNOWLEDGMENTS}

Aspects of this work were supported by a grant to S. Brake from the Indiana Academy of Sciences. We would like to acknowledge the research contributions of our colleagues I. Arango, Chevron; J. Fang, University of Hawaii; M.A. McLean, Indiana State University; H. Dannelly, Indiana State University; S. Das Gupta, Iowa State University; H. Kaur, Indiana State University; and Scott Shepherd, Indiana State University. We also thank Charles Lee for providing access to the Green Valley mine site. Ron Smith, John Senko, Todd Royer, Walter Hasenmueller, John Comer, and Margaret Ennis provided insightful comments and suggestions that improved the clarity of the manuscript.

\section{REFERENCES}

Arango, I., 2002, Evaluation of the beneficial effects of the acidophilic alga Euglena mutabilis on acid mine drainage systems: Terre Haute, Indiana State University, master's thesis, $65 \mathrm{p}$.

Arango, I., Brake, S. S., and Dannelly, H. K., 2002, Seasonal influences on the distribution of a beneficial protozoan in acid mine drainage: Geological Society of America Abstracts with Programs, v. 34, no. 6, p. 493.

Awramik, S. M., Marguilis, L., and Barghoorn, E. S., 1976, Evolutionary processes in the formation of stromatolites, in Walter, M. R., ed., Stromatolites: New York, Elsevier, p. 149-162.
Banfield, J. F., Welch, S. A., Zhang, H., Ebert, T. T., Penn, R. L., 2000, Aggregation-based crystal growth and microstructure development in natural iron oxyhydroxide biomineralization products: Science, v. 289, no. 5480, p. 751-754.

Banks, D., Younger, P. L., Arnesen, R.-T., Iversen, E. R., and Banks, S. B., 1997, Mine-water chemistry-the good, the bad, and the ugly: Environmental Geology, v. 32, no. 3, p. 157-174.

Bennett, H. D., 1969, Algae in relation to mine water: Castanea, v. 34, no. 3, p. 306-328.

Bigham, J. M., and Nordstrom, D. K., 2000, Iron and aluminum hydroxysulfates from acid sulfate waters, in Alpers, C. N., Jambor, J. L., and Nordstrom, D. K., eds., Sulfate minerals-crystallography, geochemistry, and environmental significance: Reviews in Mineralogy and Geochemistry, v. 40, p. 351-403.

Bigham, J. M., Schwertmann, U., and Carlson, L., 1992, Mineralogy of precipitates formed by the biogeochemical oxidation of $\mathrm{Fe}(\mathrm{II})$ in mine drainage, in Skinner, H. C. W., and Fitzpatrick, R. W., eds., Biomineralization processes of iron and manganese: modern and ancient environments: Catena Supplement, v. 21, p. 219-232.

Bigham, J. M., Schwertmann, U., Carlson, L., Murad E., 1990, A poorly crystallized oxyhydroxysulfate of iron formed by bacterial oxidation of Fe(II) in acid mine waters: Geochimica et Cosmochimica Acta, v. 54 , no. 10 , p. $2,743-2,758$.

Bigham, J. M., Schwertmann, U., Traina, S. J., Winland, R. L., Wolf, M., 1996, Schwertmannite and the chemical modeling of iron in acid sulfate waters: Geochimica et Cosmochimica Acta, v. 60, no. 12, p. 2,111-2,121.

Bond, P. L., Druschel, G. K., and Banfield, J. F., 2000, Comparison of acid mine drainage microbial communities in physically and geochemically distinct ecosystems: Applied and Environmental Microbiology, v. 66, no. 11, p. 4,962-4,971.

Bos, P., Boogerd, F. C., and Kuenen, J. G., 1992, Microbial desulphurization of coal, in Mitchell, R., ed., Environmental microbiology: New York, Wiley-Liss, p. 357-403.

Boult, S., Johnson, M., and Curtis, C., 1997, Recognition of a biofilm at the sediment-water interface of an acid mine drainage-contaminated stream, and its role in controlling iron flux: Hydrologic Processes, v. 11, no. 4, p. 391-399.

Brake, S. S., Connors, K. A., and Romberger, S. B., 2001c, A river runs through it-impact of acid mine drainage on the geochemistry of West Little Sugar Creek pre- and post-reclamation at the Green Valley coal 
mine, Indiana, USA: Environmental Geology, v. 40, no. 11-12, p. 1,471-1,481.

Brake, S. S., Dannelly, H. K., and Connors, K. A., 2001a, Controls on the nature and distribution of an alga in coal mine-waste environments and its potential impact on water quality: Environmental Geology, v. 40, no. $4-5$, p. $458-469$.

Brake, S. S., Dannelly, H. K., and Connors, K. A., 2001b, Influence of water chemistry on the distribution of an acidophilic protozoan in an acid mine drainage system at the abandoned Green Valley coal mine, Indiana, USA: Applied Geochemistry, v. 16, no. 14, p. 1,641-1,652.

Brake, S. S., and Hasiotis, S. T., 2005, Eukaryotedominated biofilms in acid mine drainage: Geological Society of America Abstracts with Programs, v. 37, no. 7, p. 205.

Brake, S. S. and Hasiotis, S. T., 2008, Eukaryote-dominated biofilms in extreme environments-overlooked sources of information in the geologic record: PALAIOS, v. 23, p. 121-123.

Brake, S. S., Hasiotis, S. T., and Dannelly, H. K., 2004, Diatoms in acid mine drainage and their role in the formation of iron-rich stromatolites: Geomicrobiology Journal, v. 21, no. 5, p. 331-340.

Brake, S. S., Hasiotis, S. T., Dannelly, H. K., and Connors, K. A., 2002, Eukaryotic stromatolite builders in acid mine drainage-implications for Precambrian iron formations and oxygenation of the atmosphere?: Geology, v. 30, no. 7, p. 599-602.

Brierley, J. A., and Brierley, C. L., 1999, Present and future commercial applications of biohydrometallurgy, in Amils, R., and Ballester, A., eds., Biohydrometallurgy and the environment toward the mining of the 21st century-part A: Amsterdam, Elsevier, p. $81-89$.

Bruneel, O., Duran, R., Casiot, C., Elbaz-Poulichet, F., and Personné, J.-C., 2006, Diversity of microorganisms in Fe-As-rich acid mine drainage waters of Caroulès, France: Applied and Environmental Microbiology, v. 72, no. 1, p. 551-556.

Canuto, V. M., Augustsson, J. S., Levine, T. R., and Imhoff, C. L., 1982, UV radiation from the young sun and oxygen and ozone levels in the prebiological palaeoatmosphere: Nature, v. 296, no. 5860, p. $816-820$.

Cohn, S. A., and Weitzell, R. E., 1996, Ecological consideration of diatom cell motility, I. Characterization of motility and adhesion in four diatom species: Journal of Phycology, v. 32, no. 6, p. 928-939.

Colmer, A. R., Temple, K. L., Hinkle, H. E., 1950, Anionoxidizing bacterium from the acid drainage of some bituminous coal mines: Journal of Bacteriology, v. 59, no. 3, p. 317-328.
Costerton, J. W., Geesey, G. G., and Cheng, K.-J., 1978, How bacteria stick: Scientific American, v. 238, no. 1, p. 86-95.

Costerton, J. W., Marrie, T. J., and Cheng, K.-J., 1985, Phenomena of bacterial adhesion, in Savage, D. C., and Fletcher, M., eds., Bacterial adhesion-mechanisms and physiological significance: New York, Plenum Press, p. 3-43.

Coupland, K., and Johnson, D. B., 2004, Geochemistry and microbiology of an impounded subterranean acidic water body at Mynydd Parys, Anglesey, Wales: Geobiology, v. 2, no. 2, p. 77-86.

Dowd, S. E., Herman, D. C., and Maier, R. M., 2000, Aquatic and extreme environments, in Maier, R. M., Pepper, I. L., and Gerba, C. P., eds., Environmental microbiology: San Diego, Calif., Academic Press, p. 123-146.

Druschel, G. K., Baker, B. J., Gihring, T. M., and Banfield, J. F., 2004, Acid mine drainage biogeochemistry at Iron Mountain, California: Geochemical Transactions, v. 5, no. 2, p. 13-32.

Dzombak, D. A., and Morel, F. M. M., 1990, Surface complexation modeling-hydrous ferric oxide: Somerset, N.J., John Wiley and Sons, 393 p.

Edgar, L. A., and Pickett-Heaps, J. D., 1984, Diatom locomotion, in Round, F. E., and Chapman, D. J., eds., Progress in phycological research, v. 3: Bristol, Bristol Biopress, Ltd., p. 47-88.

Edwards, K. J., Bond, P. L., Gihring, T. M., Banfield, J. F., 2000, An Archeal iron-oxidizing extreme acidophile important in acid mine drainage: Science, v. 287 , no. 5,459 , p. 1,796-1,799.

Eggert, D. L., Hailer, J. G., Irwin, P. N., and Miller, L. V., 1981, Energy content, composition, and associated water chemistry of wastes in the coal-preparation plant of the Green Valley-Wabash Mine, Vigo County, Indiana, in Graves, D. H., ed., Symposium on Surface Mining Hydrology, Sedimentology and Reclamation, University of Kentucky, Lexington, Dec. 1981, p. 143-149.

Eggert, D. L, and Wier, C. E., 1986, Springfield Coal Member, in Shaver, R. H., and others, Compendium of Paleozoic rock-unit stratigraphy in Indiana-a revision: Indiana Geological Survey Bulletin 59, p. 149.

Ehrlich, H. L., 2002, Geomicrobiology: New York, Marcel Dekker, $768 \mathrm{p}$.

Ehrlich, H. L., Ingledew, W. J., and Salerno, J. C., 1991, Iron- and manganese-oxidizing bacteria, in Shively, J. M., and Barton, L. L., eds., Variation in autotrophic life: New York, Academic Press, p. 147-170.

Ferris, F. G., Tazaki, L., Fyfe, W. S., 1989, Iron oxides in acid mine drainage environments and their association with bacteria: Chemical Geology, v. 74, no. 3-4, p. 321-330. 
Ferris, F. G., Hallbeck, L., Kennedy, C. B., and Pedersen, K., 2004, Geochemistry of acidic Rio Tinto headwaters and role of bacteria in solid phase metal partitioning: Chemical Geology, v. 212, no. 3-4, p. 291-300.

Fowler, T. A., Holmes, P. R., and Crundwell, F. K., 1999, Mechanism of pyrite dissolution in the presence of Thiobacillus ferrooxidans: Applied Environmental Microbiology, v. 65, no. 7, p. 2,987-2,993.

Fujita, M., and Hashizume, K., 1975, Status of uptake of mercury by the fresh water diatom Synedra ulna: Water Research, v. 9, no. 10, p. 889-894.

Gadd, G. M., 2009, Biosorption-critical review of scientific rationale, environmental importance and significance for pollution treatment: Journal of Chemical Technology and Biotechnology, v. 84, no. 1, p. 13-28.

Gadd, G. M., 1990, Metal tolerance, in Edwards. C., ed., Microbiology of extreme environments: New York, McGraw-Hill, p. 178-209.

Gadd, G. M., and Griffiths, J. J., 1978, Microorganisms and heavy-metal toxicity: Microbial Ecology, v. 4, no. 4, p. 303-317.

Golubic, S., 1973, The relationship between blue-green algae and carbonate deposits, in Carr, N. G., and Whitton, B. A., eds., The biology of blue-green algae: London, Blackwell, p. 434-472.

Gross W., 2000, Ecophysiology of algae living in highly acidic environments: Hydrobiologia, v. 433, no. 1-3, p. 31-37.

Häder, D.-P., and Melkonian, M., 1983, Phototaxis in the gliding flagellate, Euglena mutabilis: Archives of Microbiology, v. 135, no. 1, p. 25-29.

Hallberg, K. B., and Johnson, D. B., 2003, Novel acidophiles isolated from moderately acidic mine drainage waters: Hydrometallurgy, v. 71, no. 1-2, p. 139-148.

Hallmann, R., Friedrich, A., Koops, H.-P., PomereningRöser, A., Rohde, D., Zenneck, C., and Sand, W., 1992, Physiological characteristics of Thiobacillus ferrooxidans and Leptospirillum ferrooxidans and physiochemical factors influencing microbial metal leaching: Geomicrobiology Journal, v. 10, no. 3-4, p. 193-206.

Hargreaves, J. W., and Whitton, B. A., 1976, Effect of pH on growth of acid stream algae: British Phycology Journal, v. 11, p. 215-223.

Hartke, E. J., Hailer, J. G., and Gordon, F. S., 1983, Environmental geology of Vigo County, Indiana-an aid to planning: Indiana Geological Survey Special Report 31, Environmental Study 18, 58 p.

Hasiotis, S. T., Brake, S. S., Dannelly, H. K., and Duncan, A., 2001, Eukaryote-dominated microbial communities that build iron-stromatolites in acid mine drainage, western Indiana-an analog for Proterozoic banded iron formations and oxygenation of the early atmosphere?: $32^{\text {nd }}$ Lunar and Planetary Science Conference, Houston, 2001, v. 32, p. 386.

Hudson, C., and Legendre, P., 1987, The ecological implications of growth forms in epibenthic diatoms: Journal of Phycology, v. 23, no. 3, p. 434-441.

Indiana Department of Natural Resources (IDNR), 1985, Feasibility study for reclamation of the Green Valley Mine site, Vigo County: Report submitted by Geoscience Research Associates, Inc., 94 p.

Inskeep, W. P., Macur, R. E., Harrison, G., Bostick, B. C., and Fendorf, S., 2004, Biomineralization of $\mathrm{As}(\mathrm{V})$ hydrous ferric oxyhydroxide in microbial mats of an acid-sulfate-chloride geothermal spring, Yellowstone National Park: Geochimica et Cosmochimica Acta, v. 68, no. 15, p. 3,141-3,155.

Johnson, D. B., Dziurla, M.-A., Kolmert, A., and Hallberg, K. B., 2002, The microbiology of acid mine drainage-genesis and biotreatment: South African Journal of Science, v. 98, no. 5-6, p. 249-255.

Kai, T., Suenaga, Y., Migita, A., and Takahashi, T., 2000, Kinetic model for simultaneous leaching of zinc sulfide and manganese dioxide in the presence of iron-oxidizing bacteria: Chemical Engineering Science, v. 55, no., 17, p. 3,429-3,436.

Kim, J. J., and Kim, S. J., 2003, Environmental, mineralogical, and genetic characterization of ochreous and white precipitates from acid mine drainages in Taebaeg, Korea: Environmental Science and Technology, v. 37, no. 1, p. 2,120-2,126.

Kim J. J., Kim, S. J., and Tazaki, K., 2002, Mineralogical characterization of microbial ferrihydrite and schwertmannite, and non-biogenic Al-sulfate precipitates from acid mine drainage in the Donghae mine area, Korea: Environmental Geology, v. 42, no. 1, p. 19-31.

Kirby, C. S., Thomas, H. M., Southam, G., and Donald, R., 1999, Relative contribution of abiotic and biologicalfactorsinFe(II) oxidationinminedrainage: Applied Geochemistry, v. 14, no. 4, p. 511-530.

Kleinmann, R. L. P., and Crerar, D. A., 1979, Thiobacillus ferrooxidans and the formation of acidity in simulated coal mine environments: Geomicrobiology Journal, v. 1, no. 4, p. 373-388.

Konhauser, K. O., and Ferris, F. G., 1996, Diversity of iron and silica precipitation by microbial mats in hydrothermal waters, Iceland-implications for Precambrian iron formations: Geology, v. 24, no. 4, p. 323-326.

Krantz-Rülcker, C., Frändberg, E., and Schnürer, J., 1995, Metal loading and enzymatic degradation of fungal cell walls and chitin: Biometals, v. 8, no. 1, p. 12-18. 
Krumbein, W. E., 1986, Biotransfer of minerals by microbes and microbial mats, in Leadbeater, B. S. C., and Riding, R., eds., Biomineralization in lower plants and animals: Oxford, Clarendon Press, Systematics Association Special Volume 30, p. 55-72.

Lackey, J. B., 1938, The flora and fauna of surface waters polluted by acid mine drainage: Public Health Report, v. 53, no. 34, p. 1,499-1,507.

Langmuir, D., 1997, Aqueous environmental geochemistry: Upper Saddle River, N.J., Prentice-Hall, 600 p.

Lazaroff, N., Sigal, W., and Wasserman, A., 1982, Iron oxidation and precipitation of ferric hydrosulfates by resting Thiobacillus ferrooxidans cells: Applied Environmental Microbiology, v. 43, no. 4, p. 924-938.

Ledin, M., and Pedersen, K., 1996, The environmental impact of mine wastes-roles of microorganisms and their significance in treatment of mine wastes: Earth-Science Reviews, v. 41, no. 1-2, p. 67-108.

López-Archilla, I., Marin, I., and Amils, R., 2001, Microbial community composition and ecology of an acidic aquatic environment-the Tinto River, Spain: Microbial Ecology, v. 41, no. 1, p. 20-35.

Lowenstam, H. A., 1981, Minerals formed by organisms: Science, v. 211, no. 4487, p. 1,126-1,131.

Mann, H., Tazaki, K., Fyfe, W. S., Beveridge, R. J., and Humphrey, R., 1987, Cellular lepidocrocite precipitation and heavy-metal sorption in Euglena sp. (unicellular alga)-implications for biomineralization: Chemical Geology, v. 63, no. 1-2, p. 39-43.

Marchand, E. A., and Silverstein, J., 2003, The role of enhanced heterotrophic bacterial growth on iron oxidation by Acidithiobacillus ferrooxidans: Geomicrobiology Journal, v. 20, no. 3, p. 231-244.

Marina, A., Marini, L., Ottonello, G., Zuccolini, M. V., 2005, The fate of major constituents and chromium and other trace elements when acid waters from the derelict Libiola mine (Italy) are mixed with stream waters: Applied Geochemistry, v. 20, no. 7, p. $1,368-1,390$.

Mastalerz, M., and Harper, D., 1998, Coal in Indianaa geologic overview: Indiana Geological Survey Special Report 60, $45 \mathrm{p}$.

Morel, F. M. M., and Gschwend, P. M., 1987, The role of colloids in the partitioning of solutes in natural waters, in Stumm, W., ed., Aquatic surface chemistry: New York, Wiley, p. 405-422.

Murayama, T., Konno, Y., Sakata, T., and Imaizumi, T., 1987, Application of immobilized Thiobacillus ferrooxidans for large-scale treatment of acid mine drainage, in Mosbach, K., ed., Methods in enzymology, v. 136: New York, Academic Press, p. 530-540.

Noffke, N., and Paterson, D., 2008, Microbial interactions with physical sediment dynamics, and their signif- icance for the interpretation of Earth's biological history: Geobiology, v. 6, no. 1, p. 1-4.

Nordstrom, D. K., 1982, Aqueous pyrite oxidation and the consequent formation of secondary iron minerals, in Hossner, L. R., Kittrick, H. A., and Fanning, D. F., eds., Acid sulfate weathering: Madison, Wisc., American Press, Soil Science, p. 37-56.

Paterson, D. M., Perkins, R., Consalvey, M., and Underwood, G. J. C., 2003, Ecosystem function, cell microcycling and the structure of transient biofilms, in Krumbein, W. E., Paterson, D. M., and Zavarzin, G. A., eds., Fossil and recent biofilms: Dordrecht, Kluwer Academic Publishers, p. 47-63.

Pentecost, A., and Riding, R., 1986, Calcification in cyanobacteria, in Leadbeater, B. S. C., and Riding, R., eds., Biomineralization in lower plants and animals: Oxford, Clarendon Press, Systematics Association Special Volume no. 30, p. 73-90.

Pogliani, C., and Donati, E., 2000, Enhancement of copper dissolution from a sulfide ore by using Thiobacillus ferrooxidans: Geomicrobiology Journal, v. 17 , no. 1, p. 35-42.

Pope, J. K., Bayless, E. R., Olyphant, G. A., and Branam, T. D., 2012, The role of efflorescent sulfate salts in Indiana's mine water quality, in Comer, J. B., ed., Effects of abandoned mine land reclamation on ground and surface water quality-research and case histories from Indiana: Indiana Geological Survey Special Report 72, p. 259-279.

Rai, L. C., Gaur, J. P., and Kumar, H. D., 1981, Phycology and heavy-metal pollution: Biological Review, v. 56, no. 2, p. 99-151.

Rose, S., and Ghazi, A. M., 1998, Experimental study of the stability of metals associated with iron oxyhydroxides precipitated in acid in drainage: Environmental Geology, v. 36, no. 3-4, p. 364-370.

Sánchez España, J., López Pamo, E., Santofimia-Pastor, E., Reyes-Andrés, J., and Martín-Rubí, J. A., 2006, The removal of dissolved metals by hydroxysulphate precipitates during oxidation and neutralization of acid mine waters, Iberian Pyrite Belt: Aquatic Geochemistry, v. 12, no. 3, p. 269-298.

Sánchez España, J., López Pamo, E., Santofimia, E. Aduvire, O., Reyes, J., and Barettino, D., 2005, Acid mine drainage in the Iberian Pyrite Belt (Odiel river watershed, Huelva, SW Spain)-geochemistry, mineralogy, and environmental implications: Applied Geochemistry, v. 20, no. 7, p. 1,320-1,356.

Schippers, A., Jozsa, P. G., and Sand, W., 1996, Sulfur chemistry in bacterial leaching of pyrite: Applied Environmental Microbiology, v. 62, no. 9, p. 3,424-3,431.

Schopf, J. W., 1999, Cradle of life: Princeton, N.J., Princeton University Press, 367 p. 
Schulz-Baldes M., and Lewin, R. A., 1976, Lead uptake in two marine phytoplankton organisms: Biological Bulletin, v. 150, no. 1, p. 118-127.

Schwertmann, U., Bigham, J. H., Murad, E., 1995, The first occurrence of schwertmannite in a natural stream environment: European Journal of Mineralogy, v. 7, no. 3, p. 547-552.

Seckbach, J., 2003, Life on the edge and beyond, in Krumbein, W. E., Paterson, D. M., and Zavarzin, G. A., eds., Fossil and recent biofilms: Dordrecht, Kluwer Academic Publishers, p. 401-414.

Sen, A. M., and Johnson, B., 1999, Acidophilic sulphatereducing bacteria-candidates for bioremediation of acid mine drainage, in Amils, R., and Ballester, A., eds., Biohydrometallurgy and the environment toward the mining of the 21st century, part A: Amsterdam, Elsevier, p. 709-718.

Sharp, R. J., and Munster, M. J., 1986, Biotechnological implications for microorganisms from extreme environments, in Herbert, R. A., and Codd, G. A., eds., Microbes in extreme environments: London, Academic Press, p. 215-295.

Shepherd, B. S., McLean, M. A., and Brake, S. S., 2004, Fungal diversity in eukaryote-dominated biofilms in acid mine drainage: Geological Society America Annual Meeting, Abstracts with Programs, v. 36, no. 5, p. 360.

Silverberg, B. A., Stokes, P. M., and Ferstenberg, L. B., 1976, Intranuclear complexes in a copper-tolerant green alga: Journal of Cell Biology, v. 69, no. 1, p. 210-214.

Singer, P. C., and Stumm, W., 1970, Acidic mine drainage-the rate-determining step: Science, v. 167, no. 3,921, p. 1,121-1,123.

Smith, K. S., 1999, Metal sorption on mineral surfacesan overview with examples relating to mineral deposits, in Plumlee, G. S., and Logdon, M. J., eds., The environmental geochemistry of mineral deposits, part A-processes, techniques, and health issues: Littleton, Colo., Society of Economic Geologists, Reviews in Economic Geology 6A, p. 161-182.

Suzuki, I., Takeuchi, T. L., Yuthasastrakosol, T. D., Oh, J. D., 1990, Ferrous iron and sulfur oxidation and ferric iron reduction activities of Thiobacillus ferrooxidans are affected by growth on ferrous iron, sulfur, or a sulfide ore: Applied Environmental Microbiology, v. 56, no. 6, p. 1,620-1,626.

Tri-State Committee on Correlation, 2001, Toward a more uniform stratigraphic nomenclature for rock units (formations and groups) of the Pennsylvanian System in the Illinois Basin: Illinois Basin Consortium Study 5, p. 13 and Plate 1.
Unger, D. L., Bird, J. R., Wolf, S. F., Mattox, J. M., and Brake, S. S., 2004, Effects of increased hydrologic input on AMD water chemistry at the Green Valley Mine, Indiana: 38th Annual Meeting of the NorthCentral Section Geological Society of America, St. Louis, 2004, v. 36, no. 3, p. 43.

Warren, L. A., and Ferris, F. G., 1998, Continuum between sorption and precipitation of $\mathrm{Fe}(\mathrm{III})$ on microbial surfaces: Environmental Science and Technology, v. 32 , no. 15 , p. 2,331-2,337.

Westall, F., 2005, Life on early Earth-a sedimentary view: Science, v. 308, no. 5,720, p. 366-367.

Westall, F., and Drake, F. D., 2004, Is life an unavoidable planetary phenomenon given the right conditions?, in Schellnhuber, H. J., Crutzen, P. J., Clark, W. C., Claussen, M., and Held, H., eds., Earth system analysis for sustainability: Cambridge, Mass., MIT Press, p. 53-71.

Westall, F., Walsh, M. M., Toporski, J., and Steele, A., 2003, Fossil biofilms and the search for life on Mars, in Krumbin, W. E., Paterson, D. M., and Zavarzin, G. A., eds., Fossil and recent biofilms: Dordrecht, Kluwer Academic Publishers, p. 447-465.

Whitford, L. A., 1960, The current effect and growth of fresh-water algae: Transactions of American Microscopic Society, v. 79, p. 302-309.

Whitford, L. A., and Schumacher, G. J., 1961, Effect of current on mineral uptake and respiration by a fresh-water alga: Limnology and Oceanography, v. 6 , no. 4, p. 423-425.

Winsborough, B. M., and Golubic, S., 1987, The role of diatoms in stromatolite growth-two examples from modern freshwater settings: Journal of Phycology, v. 23, no. 1, p. 195-201.

Winterbourn, M. J., McDiffett, W. F., and Eppley, S. J., 2000, Aluminum and iron burdens of aquatic biota in New Zealand streams contaminated by acid mine drainage-effect of trophic level: Science of the Total Environment, v. 254, no. 1, p. 45-54.

Wood, J. M., and Wang, H. K., 1985, Strategies for microbial resistance to heavy metals, in Stumm, W., ed., Chemical processes in lakes: New York, Wiley, p. 81-98.

Wood, T. A., Murray, K. R., and Burgess, J. G., 2001, Ferrous sulphate oxidation using Thiobacillus ferrooxidans cells immobilized on sand for the purpose of treating acid mine-drainage: Applied Microbiology and Biotechnology, v. 56, no. 3-4, p. 560-565.

Zavarzin, G. A., 2003, Diversity of cyano-bacterial mats, in Krumbein, W. E., Paterson, D. M., and Zavarzin, G. A., Fossil and recent biofilms; a natural history of life on Earth: Dordrecht, Kluwer Academic Publishers, p. 141-150. 


\title{
Sulfur Isotopes as Indicators of Remediation Efficacy in Constructed Wetlands Receiving Acid Mine Drainage
}

\author{
Adam E. Flege, ${ }^{*}$ J. Barry Maynard, ${ }^{\dagger}$ and Erika R. Elswick ${ }^{\ddagger}$ \\ ${ }^{*}$ Apex Companies, LLC \\ ${ }^{+}$Department of Geology, University of Cincinnati \\ $\ddagger$ Department of Geological Sciences, Indiana University
}

\begin{abstract}
Acid mine drainage containing high levels of sulfate, heavy metals, and acidity can be effectively remediated by constructed wetlands. One process contributing to remediation success is bacterial sulfate reduction. This wetland process raises $\mathrm{pH}$ and removes dissolved metals and sulfate from acid mine drainage. This paper documents the utility of sulfur isotope measurements as indicators of the extent of bacterial sulfate reduction, and, hence, of the effectiveness of wetland performance and design for this removal mechanism.
\end{abstract}

Four constructed wetland systems, Midwestern and Tecumseh in Indiana and Simco and Wills Creek in Ohio, were studied to determine sulfate reduction trends and remediation success. Influent, effluent, and intra-wetland water and soil samples were collected and analyzed for stable sulfur isotope ratios. The difference between inlet and outlet $\delta^{34} S$ for dissolved sulfate, $\Delta \delta^{34} S_{\text {in-out }}$ is a measure of the extent of bacterial sulfate reduction in the wetland system, with more negative numbers indicating more extensive reaction. Values from summer measurements at Tecumseh $(-2.3 \%$ o and Wills Creek (-1.1\%o) show relatively minor bacterial sulfate reduction activity, and are similar to winter values of $-1.9 \%$ ond $+0.1 \%$ o. In contrast, Simco $\left(\Delta \delta^{34} S_{\text {in-out }}=-9.8 \%\right)$ and Midwestern (-5.7\%o) show that a significant removal of dissolved sulfate by bacterial sulfate reduction in summer, but not in winter $\left(\Delta \delta^{34} S_{\text {in-out }}=-0.7 \%\right.$ o and $-0.2 \%$ o). Within-system trends for concentration of dissolved sulfate, $\delta^{34} S$ of sulfate in water, and of sulfide in soil confirm these conclusions. Abiotic sulfate, iron, and aluminum removal continue throughout the year by precipitation of minerals like gypsum and the formation of amorphous iron and aluminum hydroxides or sulfates. On a yearly basis, about twice as much sulfate is removed by abiotic precipitation as by bacterial sulfate reduction, although in the summer season, removal by the bacterial process predominates in successful wetlands. 


\section{INTRODUCTION}

Acid mine drainage (AMD), which contains, in addition to acidity, high levels of dissolved metals, especially iron (Fe) and manganese $(\mathrm{Mn})$, and of sulfate $\left(\mathrm{SO}_{4}\right)$, is one of the major problems resulting from coal mining. AMD is formed by the interaction of air and water with sulfides, primarily pyrite $\left(\mathrm{FeS}_{2}\right)$, exposed during coal mining processes. The oxidation of pyrite and consequent generation of acidity can be driven by oxygen or by ferric iron. The relevant chemical equations are (Stumm and Morgan, 1981; Plumlee, 1999):

$$
\begin{aligned}
& \mathrm{FeS}_{2}+{ }^{7} / 2 \mathrm{O}_{2}+\mathrm{H}_{2} \mathrm{O} \rightarrow \mathrm{Fe}^{2+}+2 \mathrm{SO}_{4}{ }^{2-}+2 \mathrm{H}^{+} \\
& \mathrm{Fe}^{2+}+\mathrm{H}^{+}+1 / 4 \mathrm{O}_{2} \rightarrow \mathrm{Fe}^{3+}+1 / 2 \mathrm{H}_{2} \mathrm{O} \\
& \mathrm{Fe}^{3+}+3 \mathrm{H}_{2} \mathrm{O} \rightarrow \mathrm{Fe}(\mathrm{OH})_{3}+3 \mathrm{H}^{+} \\
& \mathrm{FeS}_{2}+14 \mathrm{Fe}^{3+}+\mathrm{H}_{2} \mathrm{O} \rightarrow 15 \mathrm{Fe}^{2+}+2 \mathrm{SO}_{4}^{2-}+16 \mathrm{H}^{+}
\end{aligned}
$$

Equations 1-3 represent the oxygen pathway. Pyrite can also be oxidized by dissolved ferric iron $\left(\mathrm{Fe}^{3+}\right)$, as shown in equation 4. Thus, AMD will continue to form even under anoxic conditions when there is a supply of ferric iron. In both the first pathway (reaction $1 \rightarrow 2 \rightarrow 3$ ) and the second $(4 \rightarrow 2 \rightarrow 3)$, a net of 4 moles of $\mathrm{H}^{+}$are generated for each mole of pyrite oxidized.

The result of the reactions above is a solution of low $\mathrm{pH}$ with high concentrations of dissolved metals and sulfate. The introduction of this drainage into local surface and groundwater contaminates the soil and destroys biota. Kleinmann (1989) estimated that over 12,000 miles $(19,312 \mathrm{~km})$ of rivers and streams and over 180,000 acres (72,843 hectares) of lakes and reservoirs in the United States had been affected by AMD; therefore, treatment of AMD before it enters the local surface or groundwater system could help mitigate the effects of this source of pollution. U.S. regulations (Code of Federal Regulations, 2009, Title 40, part 434.3) set 7.0 ppm Fe and 4.0 ppm Mn as the limits for instantaneous discharges of mine wastewater to surface streams. A further restriction is that there can be no more than 3.5 ppm Fe and 2.0 ppm Mn in discharge water, averaged over 30 days.

Conventional treatment, such as neutralization with sodium hydroxide $(\mathrm{NaOH})$, involves costly chemicals and frequent maintenance of treatment equipment. Passive treatment involving constructed wetlands and biological processes for remediation has proven to be a cost-effective alternative to conventional treatment methods (see, for example, Ziemkiewicz and others, 2003), and is particularly appropriate in the case of abandoned mine lands. However, passive treatment costs can soar if the wetland is poorly designed or if the wetland is not properly maintained. Thus, design and implementation of constructed wetlands is critical to ensure that passive treatment will remain a cost-effective treatment strategy for AMD abatement.

\section{Sulfate reduction as a measure of treatment effectiveness}

Bacterial sulfate reduction (BSR) has proven to be an effective process for passive treatment of AMD from both coal and metal mines (see, for example, Fortin and others, 2000; Church and others, 2007; Riefler and others, 2008; Faulwetter and others, 2009). Under anoxic conditions, various facultative and obligate anaerobic bacteria use $\mathrm{SO}_{4}{ }^{2-}, \mathrm{NO}_{3}{ }^{-}$, and $\mathrm{CO}_{2}$ to oxidize simple organic compounds found in the soil (Singleton, 1993; Barton and Tomei, 1995, fig. 2; Mills, 1999; Thauer and others, 2007). The sulfate-reduction process involves oxidation of organic compounds (represented by $\mathrm{CH}_{2} \mathrm{O}$ ) to generate alkalinity $\left(\mathrm{HCO}_{3}^{-}\right)$, native sulfur $\left(\mathrm{S}^{0}\right)$, and hydrogen sulfide $\left(\mathrm{H}_{2} \mathrm{~S}\right)$, which can escape to the atmosphere, be re-oxidized in the water column, or precipitate as metal sulfides such as FeS, PbS, and CuS:

$$
\begin{aligned}
& 2 \mathrm{CH}_{2} \mathrm{O}+\mathrm{SO}_{4}^{2-} \rightarrow 2 \mathrm{HCO}_{3}-+\mathrm{H}_{2} \mathrm{~S} \\
& \mathrm{H}_{2} \mathrm{~S}+1 / 2 \mathrm{O}_{2} \rightarrow \mathrm{S}^{0}+\mathrm{H}_{2} \mathrm{O} \\
& \mathrm{Fe}^{2+}+\mathrm{H}_{2} \mathrm{~S} \rightarrow \mathrm{FeS}+2 \mathrm{H}^{+} \\
& \mathrm{FeS}+\mathrm{S}^{0} \rightarrow \mathrm{FeS}_{2}
\end{aligned}
$$

Thus, acidity, iron, and sulfate are removed by this process. Manganese is not removed because, unlike other metals such as $\mathrm{Fe}, \mathrm{Cu}$, and $\mathrm{Zn}$, its sulfides are soluble. $\mathrm{MnCO}_{3}$ can form at high $\mathrm{pH}$, but its precipitation is seldom achieved in constructed wetlands, and Mn removal is often poor (Clayton and others, 1999). From these reactions we see that reduced-valence sulfur in coal mine wetlands can occur as $\mathrm{S}^{0}$, FeS, or $\mathrm{FeS}_{2}$. 
Conditions in the wetland must be favorable to initiate the sulfate-reduction process. Dvorak and others (1992) identified six conditions as necessary: 1) anaerobic conditions in the soil; 2) a source of sulfate; 3) a source of organic carbon; 4) presence of sulfate-reducing bacteria; 5) physical retention of metal sulfide precipitates; and 6) influent $\mathrm{pH}$ of 5 to 6.

The AMD itself provides abundant sulfate, the decay of wetland vegetation and the flooded state of the wetland generates anaerobic conditions in the soil, the wetland vegetation provides the source of carbon and baffling of water flow to retain precipitates, and sulfate-reducing bacteria are ubiquitous. It is the sixth condition, involving a relatively neutral influent $\mathrm{pH}$, that is the most critical. The $\mathrm{pH}$ of influent AMD can be very low, in the range of 2 to $3 \mathrm{pH}$ units, and thus must be raised to meet the conditions necessary.

One common method for raising influent $\mathrm{pH}$ of the system is the use of an anoxic limestone drain (ALD). ALDs consist of cobble- to boulder-sized limestone fragments buried in shallow trenches and isolated from the atmosphere to promote anaerobic conditions. Exclusion of oxygen is necessary to prevent the formation of ferric hydroxides, which precipitate rapidly and armor the limestone, preventing it from continuing to neutralize the acid. The dissolution of limestone and the production of alkalinity follow the reactions (from Brodie and others, 1993):

$$
\begin{aligned}
& \mathrm{CaCO}_{3}+2 \mathrm{H}^{+} \rightarrow \mathrm{Ca}^{2+}+\mathrm{H}_{2} \mathrm{CO}_{3} \\
& \mathrm{CaCO}_{3}+\mathrm{H}_{2} \mathrm{CO}_{3} \rightarrow \mathrm{Ca}^{2+}+2 \mathrm{HCO}_{3}^{-}
\end{aligned}
$$

Note, however, that these reactions release large amounts of $\mathrm{Ca}^{2+}$ that can react with the sulfate in the AMD to produce a gypsum precipitate that will clog the pore space in the drain and passivate the limestone surfaces to further reaction with the AMD (Booth and others, 1997; Huminicki and Rimstidt, 2008; Soler and others, 2008):

$$
\mathrm{Ca}^{2+}+\mathrm{SO}_{4}^{2-}+2 \mathrm{H}_{2} \mathrm{O} \rightarrow \mathrm{CaSO}_{4} \cdot 2 \mathrm{H}_{2} \mathrm{O}
$$

The gypsum coatings on calcite form by epitaxial growth and hence are strongly adherent to limestone grains. AMD that is initially high in aluminum (Al) or ferric iron will also tend to produce clogging of ALDs through the precipitation of hydroxides or sulfates of these metals (Watzlaf and others, 2000; Ziemkiewicz and Simmons, 2001; Cravotta and Watzlaf, 2002; Cravotta, 2003).

In the process of bacterial sulfate reduction, the lighter sulfur isotopes, chiefly ${ }^{32} \mathrm{~S}$, are separated from the heavier, mostly ${ }^{34} \mathrm{~S}$, producing an isotopic fractionation. Sulfate-reducing bacteria incorporate more readily the ${ }^{32} \mathrm{~S}$ isotope, resulting in $\mathrm{H}_{2} \mathrm{~S}$ depleted in ${ }^{34} \mathrm{~S}$, relative to the source sulfate (see, for example, Seal, 2003, p. 320.) In closed systems, this process creates a fractionation trend that is often referred to as "Rayleigh distillation," in which there is an accumulation of residual SO that is enriched in ${ }^{34} \mathrm{~S}$, causing new aliquots of $\mathrm{H}_{2} \mathrm{~S}$ to also become progressively more enriched. Because the sulfate concentration in AMD is so high, it may be that we can treat constructed wetlands as closed systems for sulfate reduction. Any sulfur remobilized from the soil is likely to be swamped by the inlet sulfur. If so, then as the AMD-bearing water progresses through the wetland system, dissolved sulfate in systems with active BSR should become progressively enriched in ${ }^{34} \mathrm{~S}$, leading to more positive (heavier) values for $\delta^{34} \mathrm{~S}$, where

$$
\delta^{34} S=\left[1-\left({ }^{34} S / 22 S\right)_{\text {sample }}\left(\left({ }^{4} S / \beta 2 S\right)_{\text {standard }}\right] \times 1,000\right.
$$

and the units are permil (\%o). For the purposes of this paper, we also define two additional parameters:

$$
\begin{aligned}
& \Delta \delta^{34} S_{\text {ox-red }}=\delta^{34} S_{\text {oxidized S }}-\delta^{34} S_{\text {reduced } S} \\
& \Delta \delta^{34} S_{\text {in-out }}=\delta^{34} S_{\text {sulfate in }}-\delta^{34} S_{\text {sulfate out }}
\end{aligned}
$$

where $\Delta \delta^{34} S_{\text {ox-red }}$ is the numerical difference between the isotope ratios for oxidized and reduced sulfur and $\Delta \delta^{34} S_{\text {in-out }}$ is the numerical difference between the isotope ratios for sulfur dissolved in water flowing into and that flowing out of a wetland.

The extent of fractionation is controlled by the rate at which the bacteria reduce the sulfate. When reduction rates are slow, the bacteria discriminate more effectively against ${ }^{34} \mathrm{~S}$; when they are working quickly, they are indiscriminate in their choice of isotopes. In modern marine sediments, the relationship is:

$$
\log R=-0.084 \Delta \delta^{34} S_{\text {ox-red }}+0.36
$$


where $\mathrm{R}$ is the rate of reduction in moles/(liter $\mathrm{x}$ year) (see Maynard, 1980; Hsu and Maynard, 1999, and Potter and others, 2005, p. 273, for details).

Such variations in sulfur isotopes provide a valuable tool for tracing bacterial sulfate reduction, and there is a large literature on sulfur isotope behavior in modern and ancient marine sediments (see, for example, Canfield, 2001, and Newton and Bottrell, 2007). Very little has been published on sulfur isotopes in wetlands receiving AMD, however, despite this wealth of information from other systems. Hsu and Maynard (1999) presented data from a constructed wetland system in Ohio, and Seal (2010) has presented some preliminary data from a wetland system in Pennsylvania. Edraki and others (2005) used S isotopes to trace sources of acid drainage from a metal mine in Queensland, Australia, and related ${ }^{34} \mathrm{~S}$ enrichment downstream in the receiving drainage to seasonal sulfate reduction in weir pools. In this paper we expand the record of sulfur isotope chemistry of coal mine sites to three additional wetland systems and report further data on the one our group previously studied.

\section{Wetlands studied}

Sulfate reduction trends were examined in four constructed wetland systems-Midwestern in Pike County, Indiana; Tecumseh in Warrick County, Indiana; and Simco and Wills Creek in Coshocton County, Ohio-using $\mathrm{S}$ isotopes and water chemistry to determine the contribution of bacterial sulfate reduction to the treatment effectiveness of the wetlands.

\section{Midwestern}

The Midwestern wetland system $\left(210,000 \mathrm{ft}^{2}[20,000\right.$ $\left.\mathrm{m}^{2}\right]$ ) (fig. 1) was constructed to treat drainage from overburden spoil and pyritic coal-preparation refuse generated during mining of the Springfield Coal Member of the Pennsylvanian Petersburg Formation (IGS, 1999; see Smith and others, 2003, for a description of the substrates in each cell). Prior to construction of the wetland in 1997, rainwater infiltration and surface runoff from the refuse piles entered an unnamed tributary of the Patoka River. An anoxic limestone drain was constructed to capture flow from riprap drainage channels that collect surface runoff and drainage from the

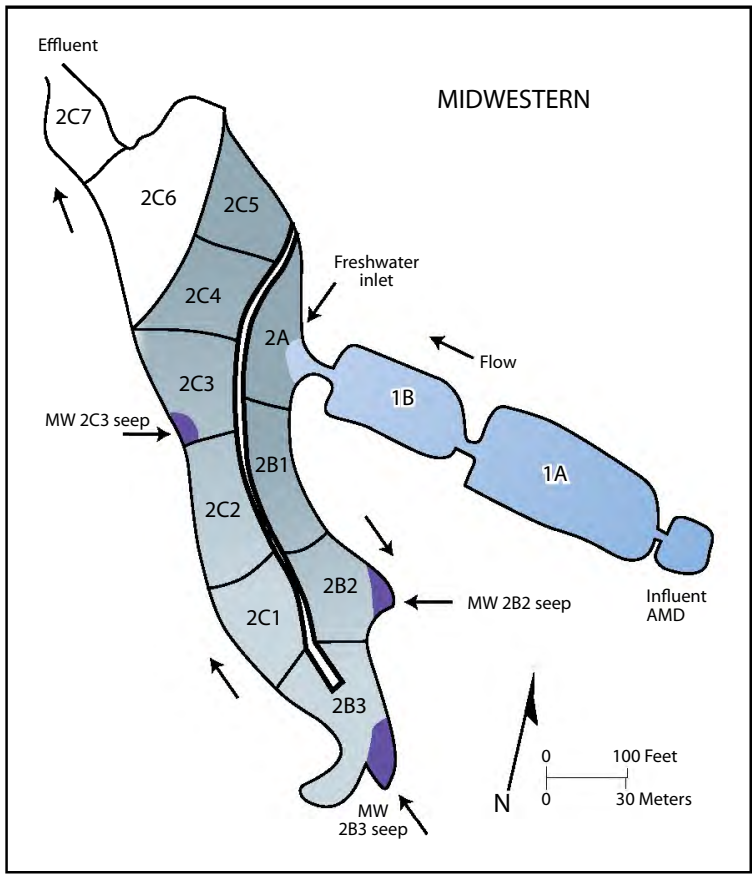

Figure 1. Diagram showing the configuration of the Midwestern wetland system.

refuse piles and AMD seeping from abandoned underground mine workings. A series of 13 wetland cells was designed to provide treatment for this drainage. Influent AMD is piped into the wetland through the ALD and into cell 1A, an anoxic pond filled with coarse gravel. AMD also enters the wetland from seeps into cells 2B2, 2B3, and $2 \mathrm{C} 3$. Water exits the wetland through cell $2 \mathrm{C} 7$. A general site description and a summary of waterquality measurements in surface and groundwater in the area are included in Branam and others (2012 [this volume]).

\section{Tecumseh}

Constructed in 1995, the Tecumseh wetland $\left(258,000 \mathrm{ft}^{2}\left[24,000 \mathrm{~m}^{2}\right]\right)$ had been operational for 5 years when we sampled it in 2000, but had already developed problems. It comprises five remediation cells through which AMD travels (fig. 2). Each cell contains internal embankments designed to act as baffles to maximize residence time and encourage water/substrate interaction. The original flow pattern was designed for acid drainage to enter wetland Cell 1 from a lake to the north through an ALD dam. However, the ALD had clogged and the influent AMD was rerouted to the west side of cell $4 \mathrm{~A}$. Water exits the wetland through the south end 
of cell 5. In 2003, our group excavated five trenches across the ALD and found it to be pervasively cemented with gypsum and iron carbonate (siderite).

\section{Simco}

Simco $\left(44,000 \mathrm{ft}^{2}\left[4,100 \mathrm{~m}^{2}\right]\right)$ is one of the oldest and most successful AMD wetlands in the country, and has been widely studied (Stark and others, 1988, 1990, 1994a, 1994b). Construction on the wetland was completed in November 1985. The system was designed to treat AMD discharging from underground and surface mining operations in Coshocton County, Ohio, in the Middle Kittanning coal seam of the Allegheny Series (Pennsylvanian) (Kolbash and Romanoski, 1989). When the mines were closed in 1978, a chemical treatment system using soda ash briquettes was implemented. The system was inadequate for the size of the ultimate discharge, however. Various strategies were considered, including sealing the mines with flue gas desulfurization sludge, but there were fears of contamination from this

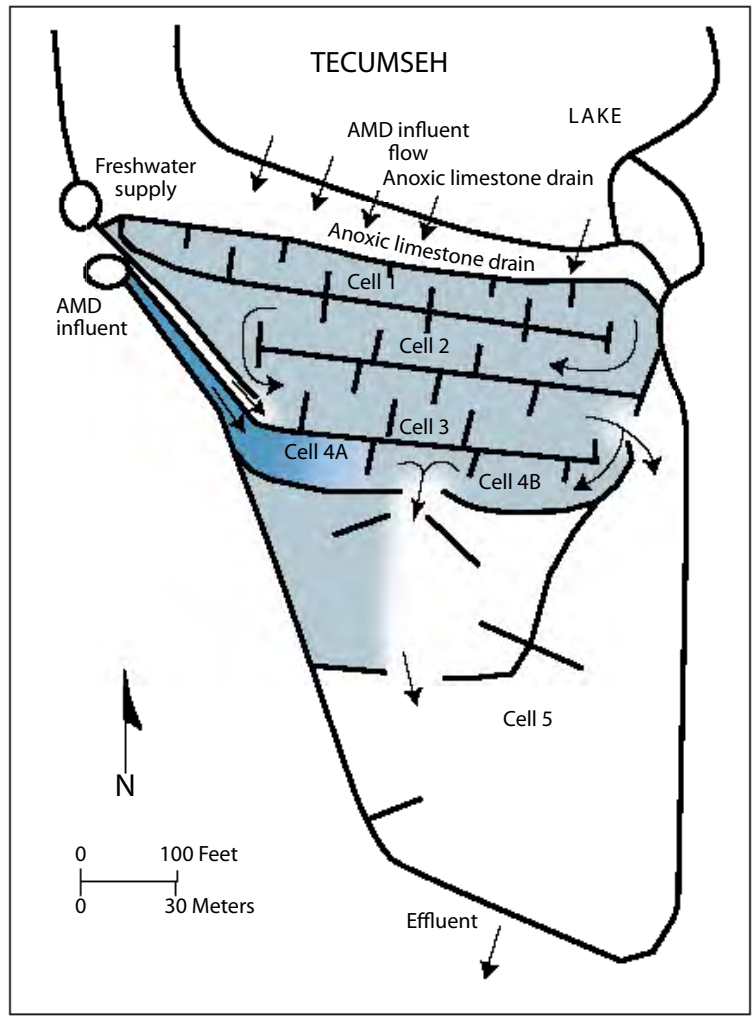

Figure 2. Diagram showing the configuration of the Tecumseh wetland system. source and a constructed wetland strategy was adopted. As initially designed, the wetland system consisted of three cells in sequence separated by small settling pools. An increased flow path within the cells was provided by a series of straw bales further dividing the wetland cells. A fourth cell was added in 1989 for a total area of $44,541 \mathrm{ft}^{2}$ $\left(4138 \mathrm{~m}^{2}\right)$ (fig. 3). Influent AMD is split in two, with half flowing into cell 1 and half flowing along a side channel into cell 2 . Water exits the wetland through the west end of cell 4. During one of our visits, cell 4 had been flooded by a beaver dam, illustrating the need for continuous maintenance, including wildlife control.

The principal contaminant in the AMD is a high concentration of iron. Influent $\mathrm{pH}$ has historically been around 6 to 7, buffered by limestone layers in the local bedrock. Removal of iron from the drainage since construction has been very successful, with an estimated 75 percent retention of all iron entering the wetland system (Stark and others, 1994b).

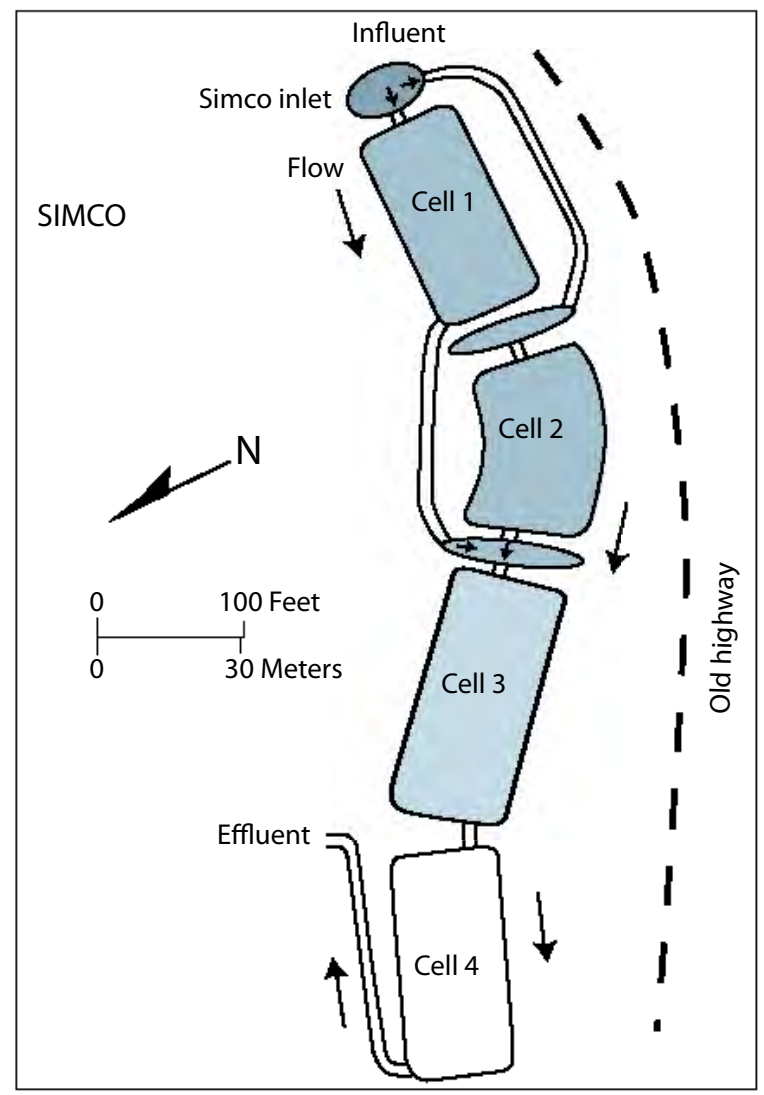

Figure 3. Diagram showing the configuration of the Simco wetland system. 


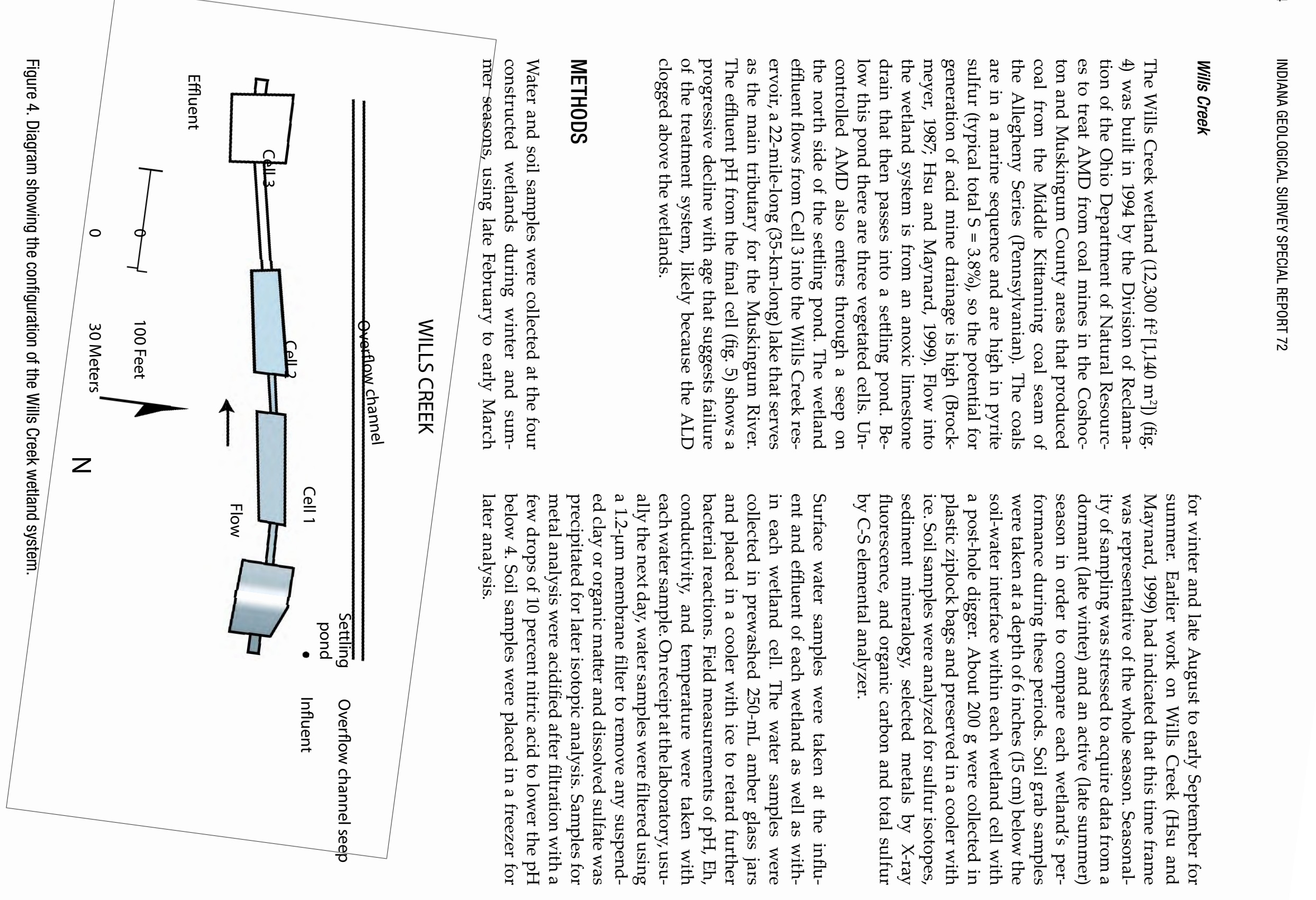




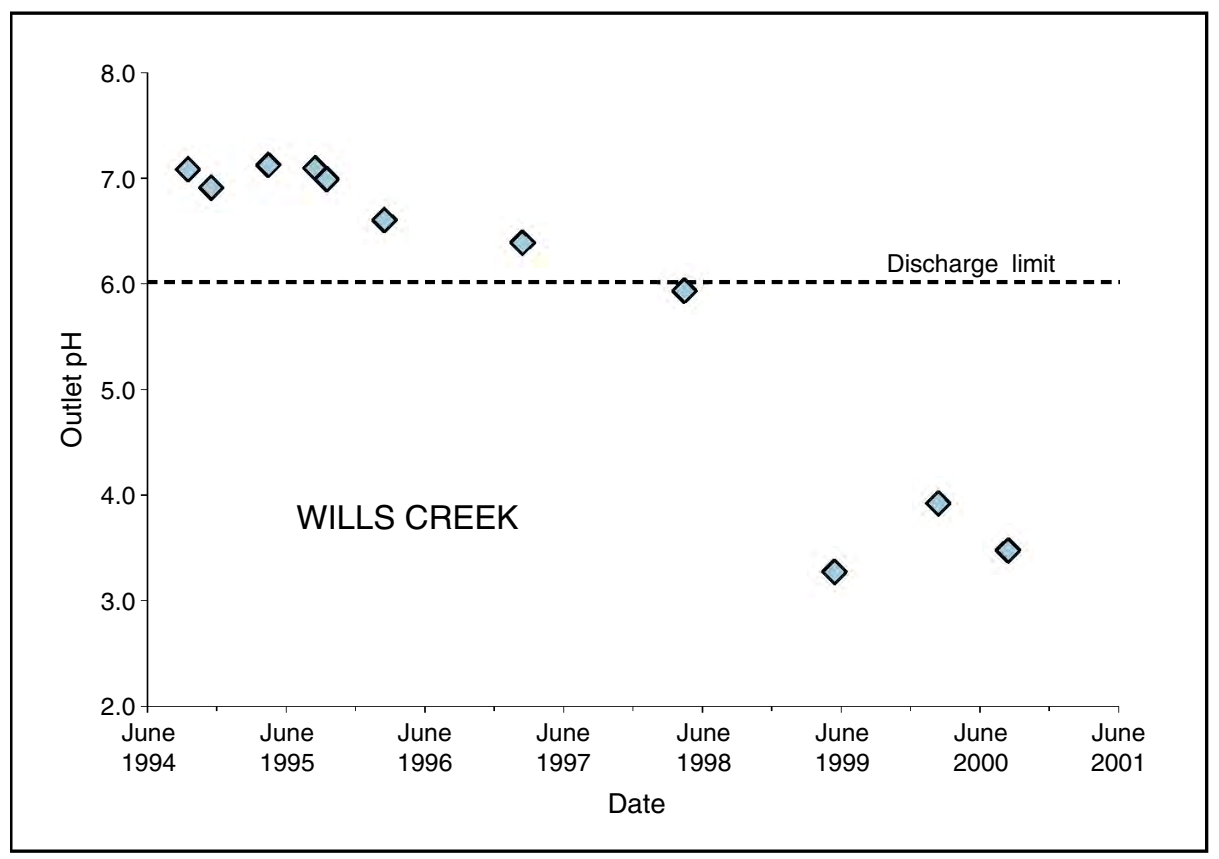

Figure 5. Graph showing decreasing $\mathrm{pH}$ values of effluent with time in the Wills Creek wetland, which indicates progressive failure of the system. Discharge limit refers to U.S. Environmental Protection Agency standards for receiving waters.

\section{Sulfur isotopes}

There are four stable sulfur isotope species that exist in nature $-{ }^{32} \mathrm{~S},{ }^{33} \mathrm{~S},{ }^{34} \mathrm{~S}$, and ${ }^{36} \mathrm{~S}$. The two most abundant isotopes are ${ }^{32} \mathrm{~S}$, making up 95.02 percent of the species, and ${ }^{34}$, which makes up 4.21 percent of the species. The isotopic fractionation, expressed as $\delta^{34} S$, of these two species was determined for soil and water samples from each wetland. Sulfur was extracted from the samples by a method originally developed by Canfield and others (1986) and modified by the biogeochemistry laboratory at Indiana University (Bruchert, 1998, fig. 2; Lefticariu and others, 2006). Sulfur from soils and sediments can be separated into five fractions: sulfate (mostly from gypsum), native $S, S$ bound to extractable organic matter, acid-volatile $S$ (mostly from $\mathrm{FeS}$ ), and chromium-reducible $S$ (mostly from $\mathrm{FeS}_{2}$ ). Native $S$ and pyrite $S$ dominate in the wetland soils studied and are the forms reported here.

After filtration of suspended solids, samples for analysis of dissolved sulfate were treated with two tablets of $\mathrm{NaOH}$ to raise the $\mathrm{pH}$ above 8 and to precipitate iron and aluminum hydroxides. Precipitation and subsequent filtration of the iron and aluminum insured a complete precipitation of barium sulfate in the subsequent steps and prevented the formation of amorphous iron and aluminum sulfates, which can polymerize in solution and clog the filtration system.

After removal of $\mathrm{Fe}$ and $\mathrm{Al}$, the $\mathrm{pH}$ of the sample was lowered to below 4 using nitric acid. Then barium sulfate $\left(\mathrm{BaSO}_{4}\right)$ was precipitated by titrating a 250-mL water sample with a solution of $100 \mathrm{~g} / \mathrm{L}$ barium chloride $\left(\mathrm{BaCl}_{2} \cdot 2 \mathrm{H}_{2} \mathrm{O}\right)$. A pH value of 4 or lower insured that $\mathrm{BaSO}_{4}$ would precipitate rather than barium carbonate $\left(\mathrm{BaCO}_{3}\right)$, which interferes with the gravimetric determination of sulfate. The barium chloride solution was added to each water sample until no further $\mathrm{BaSO}_{4}$ precipitation was observed. Samples were then filtered again using $1.2-\mu \mathrm{m}$ glass microfiber filters and the $\mathrm{BaSO}_{4}$ precipitate was washed repeatedly with distilled water to remove all traces of $\mathrm{Cl}$, which can damage the mass spectrometer inlet system. The washed precipitate was dried in a petri dish at $70^{\circ} \mathrm{C}$. The dried samples were then weighed and sulfate concentrations were calculated from:

$$
\mathrm{ppm} \mathrm{SO}_{4}=\left(\mathrm{mg} \mathrm{BaSO}{ }_{4} \times 411.5\right) /(250 \mathrm{~mL})
$$

For native $S$, pulverized samples were extracted for 24 hours with methylene chloride in a Soxhlet apparatus. This procedure removes native 
sulfur and sulfur bound to soluble organic matter. Extracting the organics also removes organic coatings from sulfide mineral grains and makes them easier to dissolve in subsequent steps. Any extracted native sulfur is reprecipitated as copper sulfide on activated copper granules in a receiving flask. The S-coated copper granules are then transferred to a closed reaction system where they are treated with $6 \mathrm{~N} \mathrm{HCl}$ under a nitrogen stream and heated to $90^{\circ} \mathrm{C}$. This process converts the copper sulfide to $\mathrm{H}_{2} \mathrm{~S}$, which is bubbled into a $\mathrm{AgNO}_{3}$ trap and precipitated as $\mathrm{Ag}_{2} \mathrm{~S}$. The precipitate was filtered through a $1.2-\mu \mathrm{m}$ glass microfiber filter, washed with $\mathrm{NH}_{4} \mathrm{OH}$ to remove traces of $\mathrm{AgCl}$, and then dried at $50^{\circ} \mathrm{C}$ overnight.

For sulfide $S$, the solid residue from the soxhlet extraction is, in turn, placed in the reaction system where it is reacted with $6 \mathrm{~N} \mathrm{HCl}$ at $90^{\circ} \mathrm{C}$. Any $\mathrm{H}_{2} \mathrm{~S}$ released is the acid-volatile sulfur (AVS) fraction, a minor component in these samples. Subsequently, a 1-M solution of chromous chloride $\left(\mathrm{CrCl}_{2}\right)$, prepared by reacting chromic chloride with zinc metal in $6 \mathrm{~N} \mathrm{HCl}$ under a nitrogen atmosphere, is added to the remaining residue and heated to $90^{\circ} \mathrm{C}$. This procedure breaks down pyrite. The $\mathrm{H}_{2} \mathrm{~S}$ released is recovered as $\mathrm{Ag}_{2} \mathrm{~S}$ as described above.

The resulting $\mathrm{Ag}_{2} \mathrm{~S}$ precipitate from the soil samples and the $\mathrm{BaSO}_{4}$ precipitate from the water samples are both ideally suited for subsequent $\mathrm{S}$ isotope determination. Sulfur isotopic ratios were determined at Indiana University using the Finnigan MAT 252 mass spectrometer with EA 1110 elemental analyzer as described by Studley and others (2002). In this procedure, amounts of $\mathrm{Ag}_{2} \mathrm{~S}$ or $\mathrm{BaSO}_{4}$ equivalent to 10 to 50 micrograms of sulfur are weighed into tin cups, covered with vanadium pentoxide as a catalyst in a weight ratio of 10:1 catalyst:sample, and oxidized to $\mathrm{SO}_{2}$ gas with $4 \mathrm{~mL}$ of oxygen. The combustion products are then fed directly into the mass spectrometer via a ConFlo II split interface. Sulfur isotope values are reported relative to Vienna Cañon Diablo Troilite and the precision is $\pm 0.2 \%$ based on replicate analyses of U.S. Geological Survey (USGS) standard SDO-1 and Carnegie Laboratories standard AA Pyrite. Duplicate runs on wetland soil samples yielded a precision of $\pm 0.5 \%$.

\section{Bulk chemistry and mineralogy}

Bulk chemistry of the soil samples was determined by X-ray fluorescence using the University of Cincinnati Rigaku 3070 spectrometer. Soil samples were powdered using a tungsten carbide ball mill and then pressed into thin pellets using a Spex 3624B X-Press 20-ton press. Samples were analyzed for percentage of Fe and Mn to determine the quantity of precipitated metals in the soil samples. Concentrations were calculated by regression using data from USGS rock and soil standards. Bulk mineralogy was determined on the same pressed powders using a Siemans D500 diffractometer with $\mathrm{CuK} \alpha$ radiation. Scans were conducted from 5 to 55 degrees with a step size of 0.2 degrees 2 theta and a count time of 10 seconds per step.

\section{Carbon and sulfur}

Carbon and sulfur were determined by analyzing powdered soil samples in a LECO Carbon-Sulfur 224 analyzer at Indiana University. The instrument was calibrated with the LECO calibration standard "Carbon and Sulfur in White Iron." For total $C$ and S, soils were dried and $250 \mathrm{mg}$ transferred to ceramic thimbles. The thimbles were then combusted with $\mathrm{O}_{2}$. Organic carbon was measured by reacting $250 \mathrm{mg}$ of dried soil overnight with 10 percent $\mathrm{HCl}$, then filtering on a baked glass fiber filter, which is then transferred to a combustion thimble and reacted as above.

\section{Dissolved metals}

Dissolved $\mathrm{Al}, \mathrm{Fe}$, and $\mathrm{Mn}$ were determined by a commercial laboratory, Brookside Laboratories, Inc., of New Knoxville, Ohio, using atomic absorption spectrophotometry.

\section{Chemical modeling}

Equilibrium models such as Wateq4f (Ball and Nordstrom, 1991) and PHREEQC (Parkhurst and Appelo, 1999) were used with the water chemistry data to predict which minerals might precipitate from water in AMD wetlands. Saturation state is 
indicated by the saturation index, SI (Ball and Nordstrom, 1991; Nordstrom and Alpers, 1999):

$$
\mathrm{SI}=\log \left[\mathrm{IAP} / \mathrm{K}_{\mathrm{sp}}\right]
$$

where $\mathrm{K}_{\mathrm{sp}}$ is the equilibrium solubility product and IAP is the ion activity product. IAP has the same algebraic form as $\mathrm{K}_{\mathrm{sp}^{\prime}}$ but uses measured instead of equilibrium values of activity. An SI value greater than 0 indicates supersaturation, whereas SI less than 0 indicates undersaturation. Because of uncertainties in the underlying thermodynamic values, SI values between -0.1 and +0.1 are effectively at saturation.

It must be stressed that equilibrium modeling is appropriate for some minerals found in constructed wetlands, but not for others. In their model of mineral reactions, Leavitt and others (2008) used equilibrium calculations for calcite, gypsum, and melanterite, but used kinetic parameters for jarosite, ferrihydrite, magnetite, and siderite. In general, carbonate minerals and most sulfate minerals can be effectively modeled using equilibrium on the time scale of days, making such calculations appropriate for constructed wetland systems, whereas slowly reacting Fe and Mn phases generally involve bacterial catalysis and cannot be handled in this way (see Robbins and others [1999]).

\section{RESULTS AND DISCUSSION: INDIVIDUAL WETLAND SYSTEMS}

\section{Midwestern}

Field parameters for water samples from the influent and effluent of each wetland cell showed overall improved water quality with passage through the wetland during three sampling rounds: winter and summer 2000, and winter 2001 (Table 1). Water samples were also collected at the two seeps entering cell 2B2 and cell 2B3 (fig. 1). Conductivity generally decreased with progression through the wetland for each season. Also, $\mathrm{pH}$ increased slightly from the influent to the effluent for each season, with the exception of the water in cell 2B2 and 2B3, which was affected by the AMD seeps. Generally, $\mathrm{pH}$ was above 6, indicating conditions favorable for sulfate reduction at most locations in the system.

\section{Table 1. Midwestern field measurements}

[W = winter*; $\mathrm{S}=$ summer* $^{*}$ mS = millisiemens. $]$

\begin{tabular}{|l|c|c|c|c|c|c|c|c|c|}
\hline \multirow{2}{*}{ Sample location } & \multicolumn{3}{|c|}{$\mathrm{pH}$} & \multicolumn{3}{c|}{ Temperature ${ }^{\circ} \mathrm{C}$} & \multicolumn{3}{c|}{ Conductivity (mS/cm) } \\
\cline { 2 - 11 } & W & S & W & W & S & W & W & S & W \\
& 2000 & 2000 & 2001 & 2000 & 2000 & 2001 & 2000 & 2000 & 2001 \\
\hline MWS-1A in & 6.5 & 6.3 & 6.3 & 17.0 & 17.4 & 9.4 & 3.69 & 3.64 & 2.82 \\
\hline MWS-1A out & 7.3 & - & - & 15.8 & - & - & - & - & - \\
\hline MWS-1B in & 6.7 & - & 6.1 & 11.6 & - & 9.6 & 2.83 & - & 2.69 \\
\hline MWS-1B out & 7.2 & 6.2 & 7.0 & 15.1 & 21.0 & 9.4 & 2.52 & 3.02 & 2.63 \\
\hline MWS-2A out & 7.2 & - & 6.0 & 16.5 & - & 6.7 & 2.26 & - & 2.28 \\
\hline MWS-2B2 seep & 4.5 & - & - & 12.4 & - & - & 2.27 & - & - \\
\hline MWS-2B2 out & 6.4 & 7.0 & 6.6 & 13.1 & 14.1 & 6.1 & 1.82 & 2.25 & 1.97 \\
\hline MWS-2B3 seep & 3.6 & - & 3.8 & 12.8 & - & 5.5 & - & - & - \\
\hline MWS-2B3 out & 5.5 & 7.1 & 6.6 & 12.1 & 15.2 & 5.4 & 1.78 & 2.06 & 1.74 \\
\hline MWS-2C1 out & 5.8 & 7.2 & 6.4 & 12.8 & 15.7 & 6.0 & 1.80 & 2.07 & 1.74 \\
\hline MWS-2C2 out & 6.3 & 7.2 & 6.4 & 13.6 & 15.6 & 5.2 & 1.78 & 2.09 & 1.66 \\
\hline MWS-2C3 out & 6.7 & 7.2 & 6.4 & 11.2 & 15.4 & 5.4 & 1.63 & 1.95 & 1.42 \\
\hline MWS-2C4 out & 6.9 & 6.9 & 6.4 & 11.8 & 14.7 & 4.8 & 1.52 & 1.86 & 1.43 \\
\hline MWS-2C5 out & 7.2 & 7.1 & 6.7 & 11.4 & 13.8 & 4.9 & 1.49 & 1.90 & 1.57 \\
\hline MWS-2C6 out & 7.3 & 7.1 & 6.7 & 10.9 & 18.1 & 5.5 & 1.34 & 2.05 & 1.54 \\
\hline
\end{tabular}

* Winter measurements were taken in late February or early March; summer measurements were taken in late August or early September. 
Sulfate concentrations decreased by approximately $1,000 \mathrm{ppm}$ from the influent to the effluent in each of the three sampling rounds (Table 2, fig. 6). In the winter, this decrease in dissolved sulfate is not accompanied by a significant change in $\delta^{34} S$ (fig. 7), suggesting that bacterial sulfate reduction is not the process responsible for the sulfate removal. In contrast, the late summer sampling shows ${ }^{34} \mathrm{~S}$ enrichment in the effluent $\mathrm{SO}_{4}$. Also note that $\delta^{34} \mathrm{~S}$ becomes progressively more positive as the water passes through the wetland except for a reversal in cell 2C3, likely caused by introduction of unreacted AMD from the seep on the margin of this cell.

In winter, the likely mechanism for sulfate remov$\mathrm{al}$ is the abiogenic precipitation of sulfate minerals such as gypsum $\left(\mathrm{CaSO}_{4} \cdot 2 \mathrm{H}_{2} \mathrm{O}\right)$. X-ray diffraction (XRD) measurements of soil samples showed the presence of small amounts of gypsum in wetland cells $1 \mathrm{~B}, 2 \mathrm{C} 2,2 \mathrm{C} 5$, and $2 \mathrm{C} 6$. Thus, sulfate removal through gypsum precipitation is occurring at Midwestern. Based on differences in concentration of water that enters cell $1 \mathrm{~B}$ (the first surface cell) and the exit to the surface drainage in cell $2 \mathrm{C} 7$, abiogenic formation of gypsum in winter removes about $800 \mathrm{mg} / \mathrm{L}$ of $\mathrm{SO}_{4}$. Assuming the same rate of gypsum precipitation in summer, the excess summer removal of $500 \mathrm{mg} / \mathrm{L}$ can reasonably be ascribed to bacterial sulfate reduction. Another sulfate likely to form in AMD wetlands is jarosite, $(\mathrm{K}, \mathrm{Na}) \mathrm{Fe}_{3}\left(\mathrm{SO}_{4}\right)_{2}(\mathrm{OH})_{6}$, as described by Gagliano and others (2004). We did not detect this phase in XRD, although it may be present in small amounts obscured by iron fluorescence or poor crystallinity. Another possibility is aluminum sulfate. We did find a small amount of alunite, $\mathrm{KAl}_{3}\left(\mathrm{SO}_{4}\right)_{2}(\mathrm{OH})_{6}$, in cell $2 \mathrm{C} 3$, but no other crystalline aluminum sulfates or hydroxides.

Metal concentrations, specifically iron $(\mathrm{Fe})$ and manganese $(\mathrm{Mn})$, show significant decreases as effluent travels through the wetland (Table 2). For Fe, removal in the summer of 2000 was 99 percent of the input at the influent to cell 1B, whereas for $\mathrm{Mn}$ it was 81 percent. In both cases most of the removal occurs early in cell $1 \mathrm{~B}$, but the seep into cell 2C3 introduces new effluent with high concentrations of $\mathrm{Fe}$ and $\mathrm{Mn}$ that are removed in subsequent cells. For comparison, Smith and others (2003) show removals of 99 and 39 percent. Fe was lowered to values well below the regulatory limits, but $\mathrm{Mn}$ remained slightly above the 30-day target of $2 \mathrm{mg} / \mathrm{L}$.

Table 2. Midwestern water results

$[\mathrm{W}=$ winter; $\mathrm{S}=$ summer. $]$

\begin{tabular}{|c|c|c|c|c|c|c|c|c|c|c|}
\hline \multirow{2}{*}{$\begin{array}{l}\text { Sample } \\
\text { location }\end{array}$} & \multicolumn{3}{|c|}{$\begin{array}{l}\text { Dissolved sulfate } \\
\text { (ppm) }\end{array}$} & \multicolumn{3}{|c|}{$\begin{array}{c}\delta^{34} \text { of dissolved } \\
\text { sulfate }(\% 0)\end{array}$} & \multicolumn{2}{|c|}{$\begin{array}{c}\mathrm{Fe} \\
(\mathrm{ppm})\end{array}$} & \multirow{2}{*}{$\begin{array}{c}\begin{array}{c}\mathrm{Mn} \\
(\mathrm{ppm})\end{array} \\
\mathrm{S} \\
2000\end{array}$} & \multirow{2}{*}{$\begin{array}{c}\begin{array}{c}\mathrm{Al} \\
(\mathrm{ppm})\end{array} \\
\begin{array}{c}\mathrm{S} \\
2000\end{array}\end{array}$} \\
\hline & $\begin{array}{c}W \\
2000\end{array}$ & $\begin{array}{c}S \\
2000\end{array}$ & $\begin{array}{c}W \\
2001\end{array}$ & $\begin{array}{c}W \\
2000\end{array}$ & $\begin{array}{c}S \\
2000\end{array}$ & $\begin{array}{c}W \\
2001\end{array}$ & $\begin{array}{c}W \\
2000\end{array}$ & $\begin{array}{c}S \\
2000\end{array}$ & & \\
\hline MWS- $1 A$ inlet & 1740 & 2470 & - & -5.31 & -5.03 & -4.88 & - & - & - & - \\
\hline MWS-1B inlet & 1600 & 2250 & 2118 & -5.37 & -4.79 & -4.73 & 45 & 107 & 11.4 & 0.49 \\
\hline MWS-1B outlet & 1540 & 1980 & 2048 & - & -2.69 & -3.87 & - & 1.09 & 3.09 & 0.46 \\
\hline MWS- $2 A$ outlet & 1350 & - & 1905 & -4.26 & - & -4.22 & - & - & - & - \\
\hline MWS-2B2 seep & 1990 & - & - & - & - & - & - & - & - & - \\
\hline MWS-2B2 outlet & 1230 & 1540 & 1719 & -5.01 & -1.23 & -4.40 & - & 0.92 & 5.87 & 0.57 \\
\hline MWS-2B3 seep & 1440 & - & - & -5.31 & - & - & - & - & - & - \\
\hline MWS-2B3 outlet & 1210 & 1360 & 1715 & -4.66 & -0.98 & -4.21 & - & 0.30 & 1.27 & 0.35 \\
\hline MWS-2C1 outlet & 1230 & 1370 & 1729 & -4.32 & -0.78 & -3.78 & - & 0.62 & 3.04 & 0.30 \\
\hline MWS-2C2 outlet & 1170 & 1140 & 1692 & -4.66 & -0.46 & -4.05 & - & 0.44 & 1.43 & 0.36 \\
\hline MWS-2C3 outlet & 1050 & 1370 & 1203 & -4.96 & -1.74 & -5.50 & - & 0.40 & 4.20 & 0.36 \\
\hline MWS-2C4 outlet & 903 & 1300 & 1381 & -5.35 & -2.04 & -4.49 & - & 7.03 & 4.68 & 0.36 \\
\hline MWS-2C5 outlet & 932 & 1220 & 1582 & -5.79 & 0.34 & -4.00 & - & 0.73 & 4.53 & 0.55 \\
\hline MWS-2C6 outlet & 873 & 989 & 1458 & -5.46 & 0.38 & -4.36 & - & 0.30 & 2.77 & 0.40 \\
\hline MWS-2C7 outlet & 831 & 1020 & 1282 & -5.56 & 0.27 & -4.31 & 0.30 & 0.66 & 2.08 & 0.49 \\
\hline
\end{tabular}




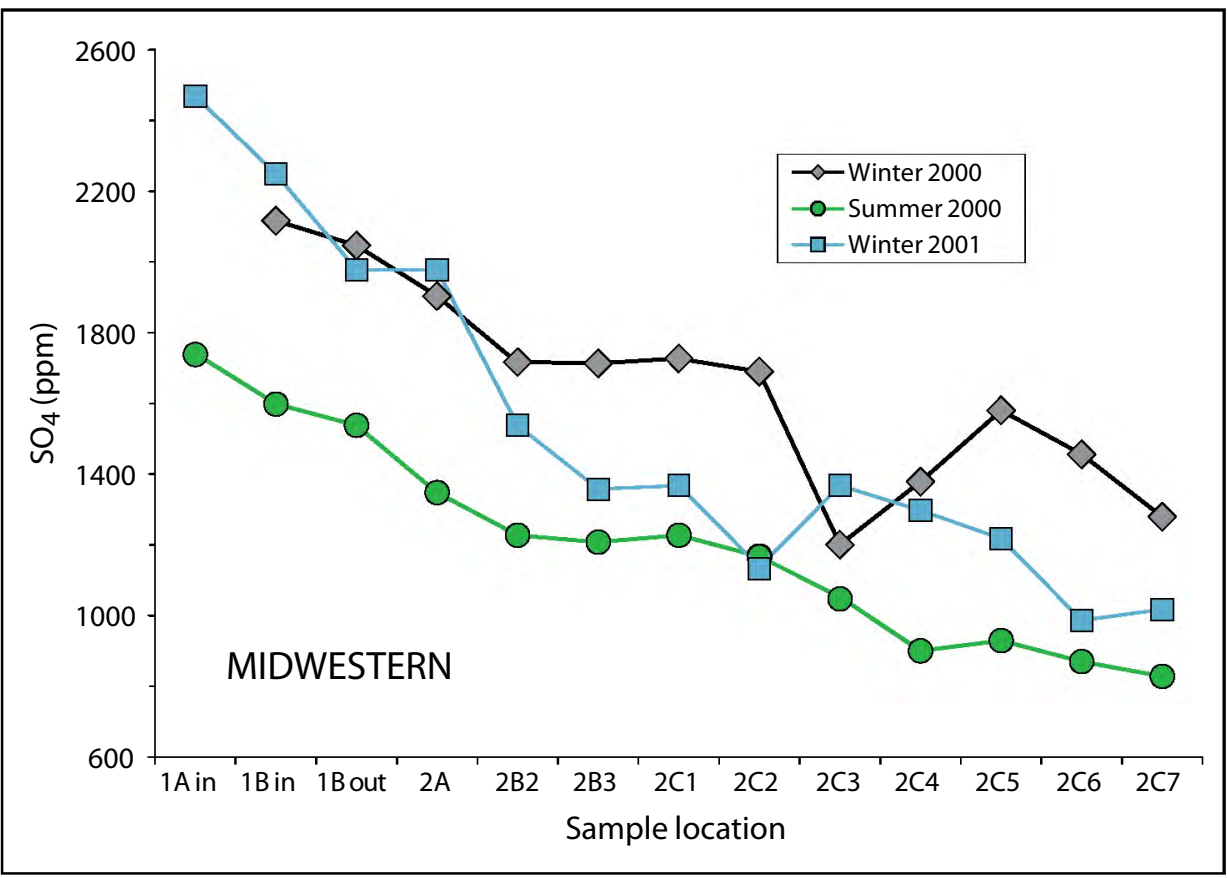

Figure 6. Graph showing dissolved $\mathrm{SO}_{4}$ at Midwestern, winter and summer 2000, winter 2001.

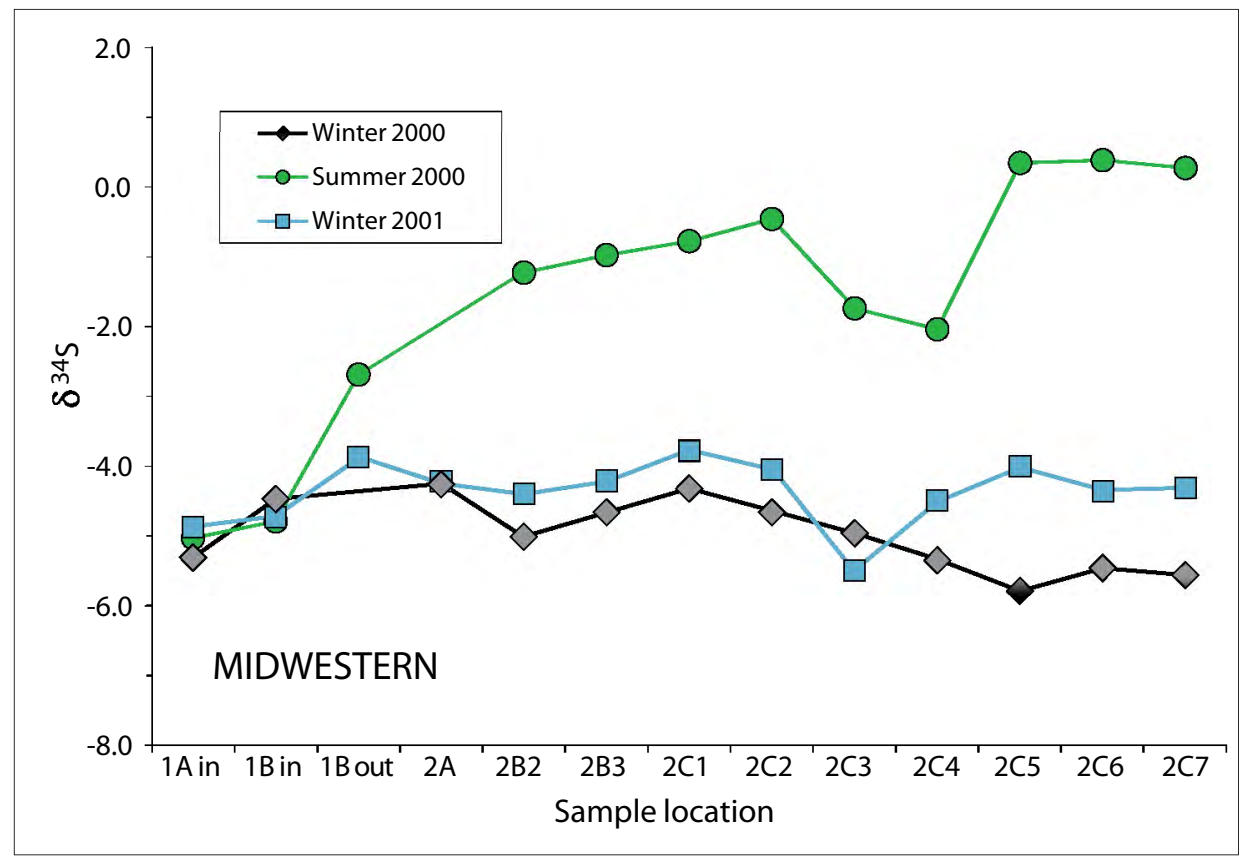

Figure 7. Graph showing $\delta^{34} \mathrm{~S}$ of dissolved $\mathrm{SO}_{4}$ at Midwestern, winter and summer 2000, winter 2001. 
Soil samples collected near the middle of each wetland cell during the late winter and summer of 2000 did not yield measureable pyrite sulfur but had abundant native sulfur. Earlier work on the Wills Creek wetland in Ohio (data of Hsu, 1998) showed a strong positive correlation of pyrite $S$ (chromium-reducible S [CrRS]) to native S:

$$
\mathrm{CrRS}=1.08^{*} \mathrm{~S}^{0}+1.07 \quad \mathrm{r}^{2}=0.94
$$

Therefore we used combined CrRS and $\mathrm{S}^{0}$, using equation 18 to adjust $S^{0}$ to CrRS equivalents, to represent reduced $S$ in the wetland systems. Midwestern soils had variable values of $\delta^{34} S$ for reduced $S$ (Table 3), but these values were consistently much more negative than corresponding values for dissolved $\mathrm{SO}_{4}$ in the overlying water (Table 2). The average of the sulfate sulfur values was $-3.1 \%$, whereas the average for the reduced sulfur was -21.1 , which is equivalent to a pyrite $S$ value of -21.7 using equation 18. Thus the sulfate-reduced sulfur spread- $\triangle \delta^{34} S_{\text {ox-red }}$-was $18.6 \%$, consistent with bacterial sulfate reduction as a major process of $S$ removal. Organic carbon contents of the soil samples ranged from 1 to 7 percent; total $S$ ranged from 0.4 to 1.6 percent; and the average $S / C$ ratio was 0.20 . $S$ and $C_{\text {org }}$ were only roughly correlated with an $\mathrm{r}^{2}$ of 0.37 .

Table 3. Midwestern soil results

[W = winter; $\mathrm{S}=$ summer.]

\begin{tabular}{|c|c|c|c|c|c|c|c|c|c|c|}
\hline \multirow{3}{*}{$\begin{array}{l}\text { Sample } \\
\text { Iocation }\end{array}$} & \multicolumn{2}{|c|}{$\begin{array}{c}\delta^{34} \text { of native } \\
\text { sulfur* }(\% 0)\end{array}$} & \multicolumn{4}{|c|}{ Soil metal content $(\% 0)$} & \multicolumn{4}{|c|}{ Soil C - S } \\
\hline & \multirow[t]{2}{*}{ W 2000} & \multirow[t]{2}{*}{ S 2000} & \multicolumn{2}{|c|}{ W 2000} & \multicolumn{2}{|c|}{ S 2000} & \multicolumn{2}{|c|}{ W 2000} & \multicolumn{2}{|c|}{ S 2000} \\
\hline & & & $\mathrm{Fe}$ & $\mathrm{Mn}$ & $\mathrm{Fe}$ & $\mathrm{Mn}$ & $\% \mathrm{C}_{\text {org }}$ & $\% \mathrm{~S}_{\text {tot }}$ & $\% \mathrm{C}_{\text {org }}$ & $\% \mathrm{~S}_{\text {tot }}$ \\
\hline MWS-1B inlet & -19.89 & - & 4.68 & 0.07 & - & - & 4.31 & 1.41 & - & - \\
\hline MWS-2A & -21.22 & -38.58 & 4.65 & 0.063 & 5.22 & 0.04 & 4.01 & 0.43 & 3.49 & 0.53 \\
\hline MWS-2B2 & -30.66 & -36.3 & - & - & 6.02 & 0.14 & 6.9 & 0.87 & 5.92 & 1.57 \\
\hline MWS-2B3 & -14.72 & -1.13 & 5.15 & 0.11 & - & - & 3.44 & 0.60 & 3.07 & 0.30 \\
\hline MWS-2C1 & -13.45 & - & 5.20 & 0.04 & - & - & 3.16 & 0.58 & - & - \\
\hline MWS-2C2 & - & - & 2.90 & 0.2 & - & - & - & - & - & - \\
\hline MWS-2C3 & - & - & 5.34 & 0.06 & - & - & - & - & - & - \\
\hline MWS-2C4 & - & - & 2.72 & 0.10 & - & - & - & - & - & - \\
\hline MWS-2C5 & - & - & 2.77 & 0.04 & - & - & - & - & - & - \\
\hline MWS-2C6 & - & - & 2.73 & 0.063 & - & - & - & - & - & - \\
\hline MWS-2C7 & -0.64 & - & 4.53 & 0.03 & - & - & 1.05 & 0.49 & 1.01 & 0.39 \\
\hline
\end{tabular}

*Pyrite $\mathrm{S}$ amounts were too low for isotope analysis.

\section{Tecumseh}

Field parameters from water samples collected at the influent and effluent of each wetland cell and at strategic locations in the wetland during the late winter and summer of 2000 show minimal changes in water quality through the wetland (Table 4), with the exception of low $\mathrm{pH}$ at the new AMD inlet in cell TCS-4A. The $\mathrm{pH}$ exiting the wetland system at the outlet from cell 5 is nearly identical to the $\mathrm{pH}$ in cells 1 and 2, so the AMD entering cell $4 \mathrm{~A}$ is effectively neutralized or diluted. Sulfate concentrations (Table 5) are similarly little changed through most of the wetland system except for very high values in cell 4A, again related to the inflow of additional AMD. Figure 8 shows that this additional sulfate is not reflected in the amounts of $\mathrm{SO}_{4}$ leaving the wetland system, which are identical to the values found in cells 1 and 2 . The decrease in dissolved $\mathrm{SO}_{4}$ from cell $4 \mathrm{~A}$ to cell 5 might be a result of bacterial sulfate reduction or might simply be the dilution of a relatively small volume of AMD by the much larger volume of clean water in the wetland system (Smith and others, 2003, p. 16).

Sulfur $\delta^{34} S$ values of dissolved sulfate exhibit a slight increase from cell 4 A to the outlet from cell 5 (Table 5), indicative of bacterial sulfate reduction. 
Table 4. Tecumseh field measurements

$[\mathrm{W}=$ winter; $\mathrm{S}=$ summer; $\mathrm{mS}=$ millisiemens $]$

\begin{tabular}{|l|c|c|c|c|c|c|}
\hline \multirow{2}{*}{$\begin{array}{c}\text { Sample } \\
\text { location }\end{array}$} & \multicolumn{2}{c|}{$\mathrm{pH}$} & \multicolumn{2}{c|}{ Temperature $^{\circ} \mathrm{C}$} & \multicolumn{2}{c|}{ Conductivity (mS/cm) } \\
\cline { 2 - 7 } & W 2000 & S 2000 & W 2000 & S 2000 & W 2000 & S 2000 \\
\hline TCS-1 inlet & 6.82 & 6.82 & 20.2 & 20.3 & 4.22 & 4.22 \\
\hline TCS-1 outlet & 6.57 & - & 13.8 & - & 2.64 & - \\
\hline TCS-2 outlet & 6.83 & 6.45 & 16.1 & 24.0 & 2.64 & 2.57 \\
\hline TCS-3 inlet & 7.11 & - & 15.1 & - & 2.59 & - \\
\hline TCS-3 2 ${ }^{\text {nd } \text { berm }}$ & 7.2 & - & 14.4 & - & 2.59 & - \\
\hline TCS-4A inlet & 4.6 & - & 14.0 & - & 4.73 & - \\
\hline TCS-4A middle & 3.42 & - & 14.1 & - & 3.99 & - \\
\hline TCS-4A outlet & 3.18 & 2.7 & 14.2 & 27.8 & 4.37 & 8.13 \\
\hline TCS-4B inlet & 6.53 & - & 14.1 & - & 2.61 & - \\
\hline TCS-4B oulet & 6.6 & 6.7 & 13.6 & 26.6 & 2.62 & 2.79 \\
\hline TCS-5 outlet & 6.81 & 6.07 & 17.9 & 27.4 & 2.44 & 2.7 \\
\hline
\end{tabular}

Table 5. Tecumseh water results

$[\mathrm{W}=$ winter; $\mathrm{S}=$ summer. $]$

\begin{tabular}{|l|c|c|c|c|c|c|}
\hline \multicolumn{1}{c}{$\begin{array}{c}\text { Sample } \\
\text { location }\end{array}$} & \multicolumn{2}{|c|}{ Dissolved sulfate (ppm) } & \multicolumn{2}{c|}{ 34 S of dissolved sulfate (\%) $^{3}$} & Fe (ppm) & Mn (ppm) \\
\cline { 2 - 7 } & W 2000 & S 2000 & W 2000 & S 2000 & W 2000 & S 2000 \\
\hline TCS-1 inlet & 1490 & - & -3.57 & - & 1.5 & 0.66 \\
\hline TCS-1 outlet & 1650 & - & -3.74 & - & - & \\
\hline TCS-2 outlet & 1760 & 1420 & -3.61 & -2.83 & 1.0 & 0.80 \\
\hline TCS-3 inlet & 1580 & - & -3.27 & - & - & - \\
\hline TCS-3 outlet & 1680 & - & -3.57 & - & - & - \\
\hline TCS-4A inlet & 2570 & - & -4.54 & - & - & - \\
\hline TCS-4A outlet & 5300 & 6530 & -5.38 & -4.63 & 547 & 5.79 \\
\hline TCS-4B inlet & 1660 & - & -3.58 & - & - & - \\
\hline TCS-4B outlet & 1640 & 1610 & -6.64 & -2.63 & $<1$ & 0.58 \\
\hline TCS-5 outlet & 1520 & 1450 & -3.46 & -2.28 & $<1$ & 0.32 \\
\hline
\end{tabular}

Compared to Midwestern, however, the amount of change in $\delta^{34} S$ is small and does not vary appreciably from winter to summer (fig. 9). Therefore, we conclude that there is some level of bacterial activity, but that the dominant effect on water quality is dilution.

Dissolved metal concentrations ( $\mathrm{Fe}$ and $\mathrm{Mn}$ ) are low throughout the system except in cell 4A (Table 5). Comparing cell $4 \mathrm{~A}$ with values measured at the outlet of cell 5 shows large decreases in both $\mathrm{Fe}$ and Mn. Both metals are well below the 30-day discharge limits in the water exiting the system. From our data we cannot estimate how much of the change is dilution and how much is precipitation in the wetland.

Soil samples collected near the outlet of each wetland cell (Table 6) show no consistent variation from cell to cell in $\delta^{34} S$ values for sulfides or in bulk chemistry (Flege, 2001, Appendix B). However, within cell $4 \mathrm{~A}$, the cell now receiving the AMD, there is a distinctly heavier population of pyrites. Pyrite $S$ in cells 1, 2, and 3 averaged $-35.3 \%$, whereas within cell $4 \mathrm{~A}$ it averaged $-12.6 \%$. Native $\mathrm{S}$ is similar to pyrite $S$ in cells 1,2 and 3, consistent with equation 18 . Note, however, the marked departure of pyrite $S$ and native $S$ values in cell $4 \mathrm{~A}$. 
We speculate that the pyrite $S$ represents an earlier population recording an initial episode of rapid bacterial activity, whereas the native $S$ represents the present situation of slower bacterial sulfate reduction inhibited by low $\mathrm{pH}$ values. Combining pyrite $S$ and native $S$, adjusted using equation 18 , yields overall reduced $\mathrm{S}$ with $\delta^{34} \mathrm{~S}$ values of -35.1 for cells 1, 2, and 3 and -24.2 for cell $4 \mathrm{~A}$. Cell 4B appears to be a mixture of these two $S$ sources. Average sulfate $\delta^{34} S$ for all cells was -3.61 with little variance. Thus the corresponding $\Delta \delta^{34} S_{\text {ox-red }}$ was $31.5 \%$ or for cells 1,2 , and 3 , and $20.6 \%$ or cell $4 \mathrm{~A}$. These values suggest that bacterial sulfate reduction has occurred very slowly in cells 1 through 3 ,

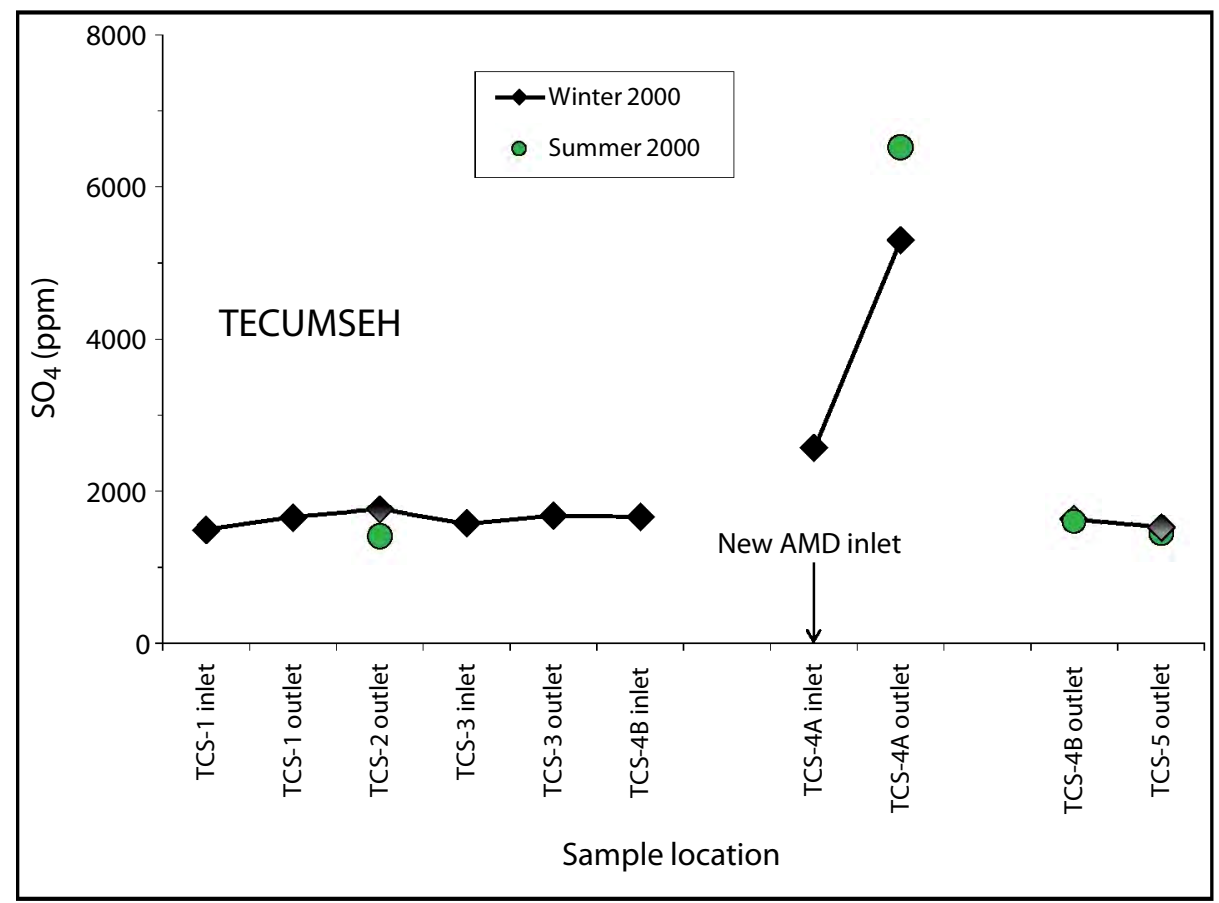

Figure 8. Graph showing dissolved $\mathrm{SO}_{4}$ at Tecumseh, winter and summer 2000.

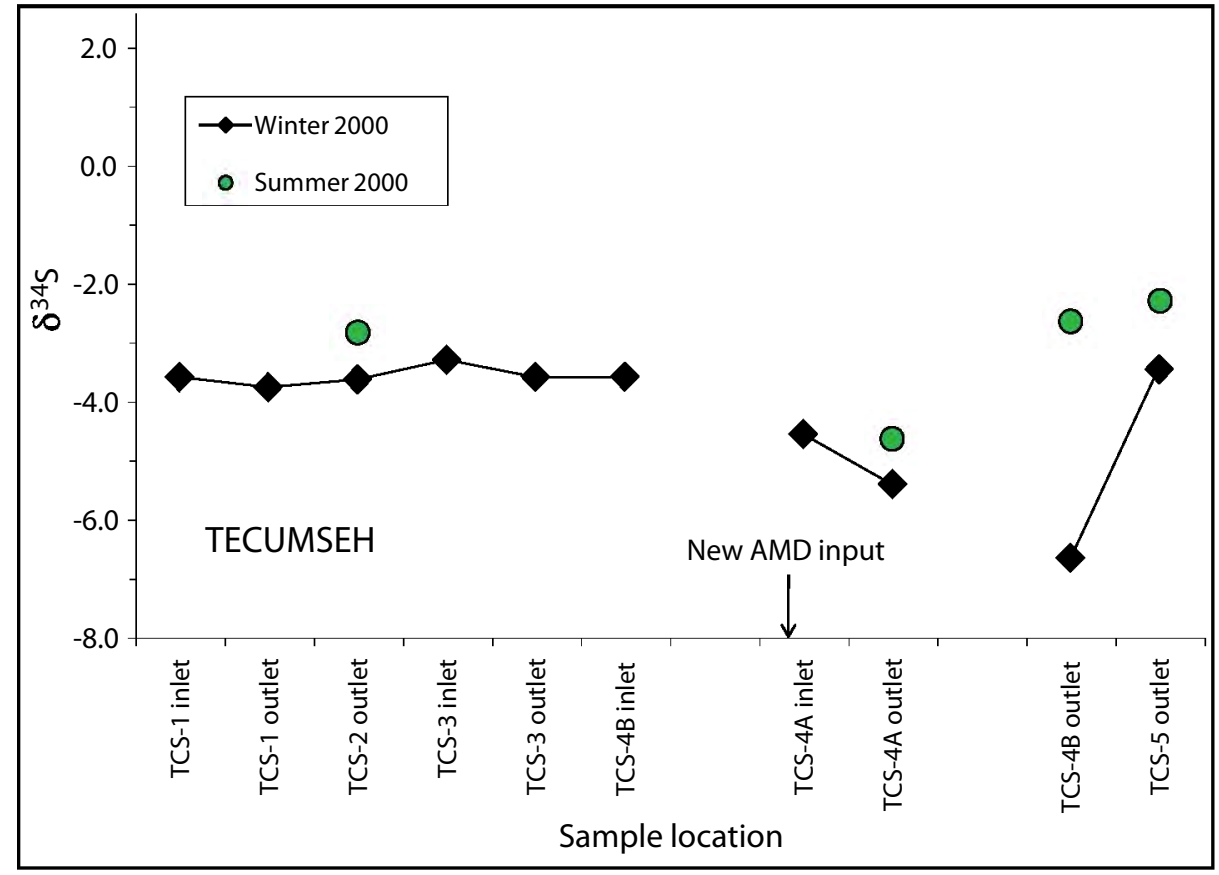

Figure 9. Graph showing $\delta^{34} \mathrm{~S}$ of dissolved $\mathrm{SO}_{4}$ at Tecumseh, winter and summer 2000. 
Table 6. Tecumseh soil results

$[\mathrm{W}=$ winter; $\mathrm{S}=$ summer. $]$

\begin{tabular}{|c|c|c|c|c|c|c|c|c|c|c|c|}
\hline \multirow{3}{*}{$\begin{array}{l}\text { Sample } \\
\text { location }\end{array}$} & \multirow{3}{*}{$\begin{array}{c}\begin{array}{c}\delta^{34} \mathrm{~S} \text { of } \\
\text { pyrite } \\
(\% 0)\end{array} \\
\text { W } 2000\end{array}$} & \multicolumn{2}{|c|}{$\begin{array}{c}\delta^{34} \mathrm{~S} \text { of } \\
\text { native S }(\%)\end{array}$} & \multicolumn{4}{|c|}{ Soil metal content $(\% \circ)$} & \multicolumn{4}{|c|}{ Soil C - S } \\
\hline & & \multirow{2}{*}{$\begin{array}{c}W \\
2000\end{array}$} & \multirow{2}{*}{$\begin{array}{c}S \\
2000\end{array}$} & \multicolumn{2}{|c|}{ W 2000} & \multicolumn{2}{|c|}{ S 2000} & \multicolumn{2}{|c|}{ W 2000} & \multicolumn{2}{|c|}{ W 2000} \\
\hline & & & & $\mathrm{Fe}$ & $\mathrm{Mn}$ & $\mathrm{Fe}$ & $\mathrm{Mn}$ & $\% \mathrm{C}_{\text {org }}$ & $\% \mathrm{~S}_{\text {tot }}$ & $\% \mathrm{C}_{\text {org }}$ & $\% \mathrm{~S}_{\text {tot }}$ \\
\hline TCS-1 outlet & -35.74 & -37.08 & - & 2.92 & 0.06 & - & - & 2.70 & 0.32 & - & - \\
\hline TCS-2 outlet & -37.67 & -36.28 & -31.46 & - & - & 23.22 & 0.06 & 3.98 & 1.47 & 4.01 & 1.02 \\
\hline TCS-3 $2^{\text {nd }}$ berm & -31.23 & -26.18 & - & - & - & 3.19 & 0.05 & 6.43 & 0.40 & - & - \\
\hline TCS-3 outlet & -36.58 & -40.77 & - & - & - & - & - & 4.41 & 0.49 & - & - \\
\hline TCS-4A inlet & -10.3 & - & - & 5.84 & 0.02 & - & - & 1.11 & 0.67 & 1.90 & 0.79 \\
\hline TCS-4A middle & -12.85 & -33.56 & - & - & - & - & - & 7.18 & 0.37 & - & - \\
\hline TCS-4A outlet & -14.68 & -32.78 & -35.23 & - & - & - & - & 2.97 & 0.28 & 2.06 & 0.65 \\
\hline TCS-4B outlet & -16.11 & -8.46 & -26.82 & - & - & 3.49 & 0.02 & 7.03 & 0.53 & 2.03 & 0.23 \\
\hline
\end{tabular}

but that, at least in the past, it has been significant in cell $4 \mathrm{~A}$. The much smaller $\Delta \delta^{34} \mathrm{~S}_{\text {ox-red }}$ values for cell $4 \mathrm{~A}$ indicates an appreciably faster rate of sulfate reduction compared to the other cells. From equation 15 applied to total reduced $\mathrm{S}$, rates were eight times faster in cell 4A. Organic carbon in the soils ranged from 1 to 7 percent, total $S$ from 0.2 to 1.5 percent, with $\mathrm{S} / \mathrm{C}$ averaging 0.16 . There was no correlation between the two variables.

\section{Simco}

Water quality improves through the Simco wetland, as measured by $\mathrm{pH}$ increase and conductivity decrease (Table 7). The change was greater in the summer season than in winter.

Dissolved sulfate concentrations fall slightly with progression through the wetland in winter, but summer sees a much greater decrease (Table 8, fig. 10). Sulfur isotopes of dissolved sulfate are essentially flat in winter, but show a sharp increase in $\delta^{34} S$ values during the summer (fig. 11). Thus Simco appears to have vigorous bacterial sulfate reduction in the summer, but shows no appreciable removal of $\mathrm{SO}_{4}$ during the winter. Unlike Midwestern, there appears to be no removal as gypsum.

The wetland system was very effective for Fe removal. Over 96 percent of Fe coming into the wetland is precipitated (Table 8). For Mn, however, removal is highly variable, ranging from -31 to +80 percent, but the concentrations discharged are below the EPA limit of $2 \mathrm{mg} / \mathrm{L}$ because the inlet $\mathrm{Mn}$ levels are low. For comparison, efficiencies of removal in the first 2 years of operation were reduced by 66 percent for Fe and increased by 25 percent for Mn (Kolbash and Romanoski, 1989).

Sulfur isotopic composition of soil samples showed no significant trend through the wetland (Table 9), but again the values are substantially more negative than for the overlying water. The $\Delta \delta^{34} S_{\text {ox-red }}$ averaged $+35.3 \%$ for pyrite-equivalent reduced $S$ values, the greatest spread among the wetlands studied, indicating a relatively slow average rate of sulfate reduction. Soil Fe contents were much higher than for the other wetlands, reflecting a long history of successful Fe removal. Mn, however, is low throughout. It is noteworthy that $\mathrm{C}_{\text {org }}$ is high for all the cells, ranging from 2 to 22 percent. This indicates vigorous growth of Typha sp., and a healthy, sustainable wetland system. Total $\mathrm{S}$ ranged from 0.1 to 2.4 percent and $S / C$ averaged $0.9 . C_{\text {org }}$ and $S_{\text {total }}$ had a weak positive correlation $\left(r^{2}=0.2\right)$.

\section{Wills Creek}

This treatment system was functioning when we began sampling it in 1994, but by 1999 was showing a decline in function, based on low effluent $\mathrm{pH}$ (fig. 5). Water samples showed little improvement in water quality throughout the wetland in 2000. Conductivity was virtually unchanged from influent to effluent and $\mathrm{pH}$ stayed relatively low throughout, showing a slight decrease in value from the influent to the effluent (Table 10). 
Table 7. Simco field measurements

[W = winter; $\mathrm{S}=$ summer; $\mathrm{mS}=$ millisiemens. $]$

\begin{tabular}{|l|c|c|c|c|c|c|c|c|c|}
\hline \multirow{2}{*}{$\begin{array}{c}\text { Sample } \\
\text { location }\end{array}$} & \multicolumn{4}{|c|}{$\mathrm{pH}$} & \multicolumn{3}{c|}{ Temperature ${ }^{\circ} \mathrm{C}$} & \multicolumn{3}{c|}{ Conductivity (mS/cm) } \\
\cline { 2 - 11 } & $\mathbf{W}$ & $\mathbf{S}$ & $\mathrm{W}$ & $\mathrm{W}$ & $\mathrm{S}$ & $\mathrm{W}$ & $\mathrm{W}$ & $\mathrm{S}$ & $\mathrm{W}$ \\
& $\mathbf{2 0 0 0}$ & $\mathbf{2 0 0 0}$ & $\mathbf{2 0 0 1}$ & $\mathbf{2 0 0 0}$ & $\mathbf{2 0 0 0}$ & $\mathbf{2 0 0 1}$ & $\mathbf{2 0 0 0}$ & $\mathbf{2 0 0 0}$ & 2001 \\
\hline Sim-1 inlet & 6.58 & 6.47 & 5.92 & 4.9 & - & 6.6 & 1.457 & 1.01 & 1.49 \\
\hline Sim-1 outlet & 6.55 & - & 6.40 & 3.5 & - & 3.6 & 1.352 & - & 0.898 \\
\hline Sim-2 inlet & 6.55 & - & 6.34 & 3.0 & - & 5.6 & 1.476 & - & 0.983 \\
\hline Sim-2 outlet & 6.62 & - & 6.57 & 4.1 & - & 7.2 & 1.424 & - & 0.867 \\
\hline Sim-3 inlet & 6.47 & 6.82 & 6.63 & 6.4 & - & 6.6 & 1.207 & 0.787 & 0.921 \\
\hline Sim-4 inlet & 6.61 & - & 6.74 & 3.0 & - & 2.8 & 1.389 & - & 0.915 \\
\hline Sim-4 outlet & 6.62 & 7.26 & 6.60 & 6.0 & 21.1 & 2.6 & 1.295 & 0.629 & 0.931 \\
\hline
\end{tabular}

Table 8. Simco water results

[W = winter; $\mathrm{S}=$ summer. $]$

\begin{tabular}{|c|c|c|c|c|c|c|c|c|c|c|c|c|c|}
\hline \multirow{2}{*}{$\begin{array}{l}\text { Sample } \\
\text { location }\end{array}$} & \multicolumn{3}{|c|}{ Dissolved sulfate (ppm) } & \multicolumn{3}{|c|}{$\begin{array}{c}\delta^{34} \mathrm{~S} \text { of } \\
\text { dissolved } \mathrm{SO}_{4}\end{array}$} & \multicolumn{3}{|c|}{$\begin{array}{c}\mathrm{Fe} \\
(\mathrm{ppm})\end{array}$} & \multicolumn{3}{|c|}{$\begin{array}{c}\mathrm{Mn} \\
(\mathrm{ppm})\end{array}$} & \multirow{2}{*}{$\begin{array}{c}\begin{array}{c}\mathrm{Al} \\
(\mathrm{ppm})\end{array} \\
\mathrm{W} \\
2001\end{array}$} \\
\hline & $\begin{array}{c}W \\
2000\end{array}$ & $\begin{array}{c}S \\
2000\end{array}$ & $\begin{array}{c}W \\
2001\end{array}$ & $\begin{array}{c}W \\
2000\end{array}$ & $\begin{array}{c}S \\
2000\end{array}$ & $\begin{array}{c}W \\
2001\end{array}$ & $\begin{array}{c}W \\
2000\end{array}$ & \begin{tabular}{|c|}
$S$ \\
2000 \\
\end{tabular} & $\begin{array}{c}W \\
2001 \\
\end{array}$ & $\begin{array}{c}W \\
2000\end{array}$ & \begin{tabular}{|c|} 
\\
2000 \\
\end{tabular} & $\begin{array}{c}W \\
2001\end{array}$ & \\
\hline Sim-1 inlet & 599 & 640 & 741 & -3.88 & -3.58 & -4.06 & 28.5 & 3.5 & 33.4 & 0.83 & 0.55 & 1.07 & 0.59 \\
\hline Sim-1 outlet & 595 & - & 775 & -2.99 & - & -3.57 & - & - & 0.61 & - & - & 1.11 & 0.21 \\
\hline Sim-2 inlet & 542 & - & 736 & -4.01 & - & -3.22 & - & - & - & - & - & - & \\
\hline Sim-2 outlet & 498 & - & 724 & -3.47 & - & -3.22 & - & - & 16.1 & - & - & 1.01 & $<0.2$ \\
\hline Sim-3 inlet & 610 & 430 & 714 & -3.62 & -2.29 & -3.26 & - & - & 10.3 & - & - & 0.96 & $<0.2$ \\
\hline Sim-4 inlet & 519 & - & 711 & -3.46 & - & -2.86 & - & - & - & - & - & - & \\
\hline Sim- 4 outlet & 542 & 290 & 708 & -3.27 & 6.26 & -3.28 & 0.11 & 0.13 & 2.56 & 1.09 & 0.11 & 0.90 & 0.23 \\
\hline
\end{tabular}

Sulfate concentrations, however, show a decrease in the winter sampling round, although not in summer (Table 11, fig. 12). Sulfate $\delta^{34} S$ values during both sampling seasons remain relatively constant, with a slight increase in the summer 2000 season (fig. 13). Some Fe removal was still occurring (62 percent of influent Fe was removed) and Mn was unchanged going through the wetland.

The soil samples we collected had $\delta^{34} S$ values similar to those reported by Hsu and Maynard (1999). In 2000, the average reduced sulfur (pyrite + FeS + native S) was $-29.5 \%$ o (Table 12) compared to -28.2 for 1995 through 1999. For the 5 years over which we collected samples from this wetland, cell 1 averaged $\Delta \delta^{34} S_{\text {ox-red }}$ of 17 , compared to 29 and 30 for cells 2 and 3 . Thus the most vigorous sulfate reduction occurred in cell 1 , which used mushroom compost as the original organic substrate (Hsu and
Maynard, 1999). This cell also had the highest average organic carbon content. Average $\mathrm{C}_{\text {org }}$ and total $\mathrm{S}$ for four sets of measurements from 1995 through 1997 were 7.2 percent for $C_{\text {org }}$ and 1.2 percent for $S_{\text {tot }}$ for the whole wetland system (Table 12). For these sampling rounds, $\mathrm{Fe}_{2} \mathrm{O}_{3}$ averaged 22.2 percent, $\mathrm{MnO}$ was 0.2 percent. The soil samples collected showed significant gypsum in the substrate of each wetland cell (Hsu, 1998). In addition, PHREEQC modeling of water chemistry (Parkhurst and Appelo, 1999) showed that the surface waters were at or very near saturation with respect to gypsum in cells 1 and 2 and in the settling pond (Hsu, 1998; Hsu and Maynard, 1999). Thus the low $\mathrm{pH}$ present in the Wills Creek system after 1999 seems to have inhibited bacterial sulfate reduction, and inorganic precipitation of ferric hydroxides and of gypsum are the dominant processes. 


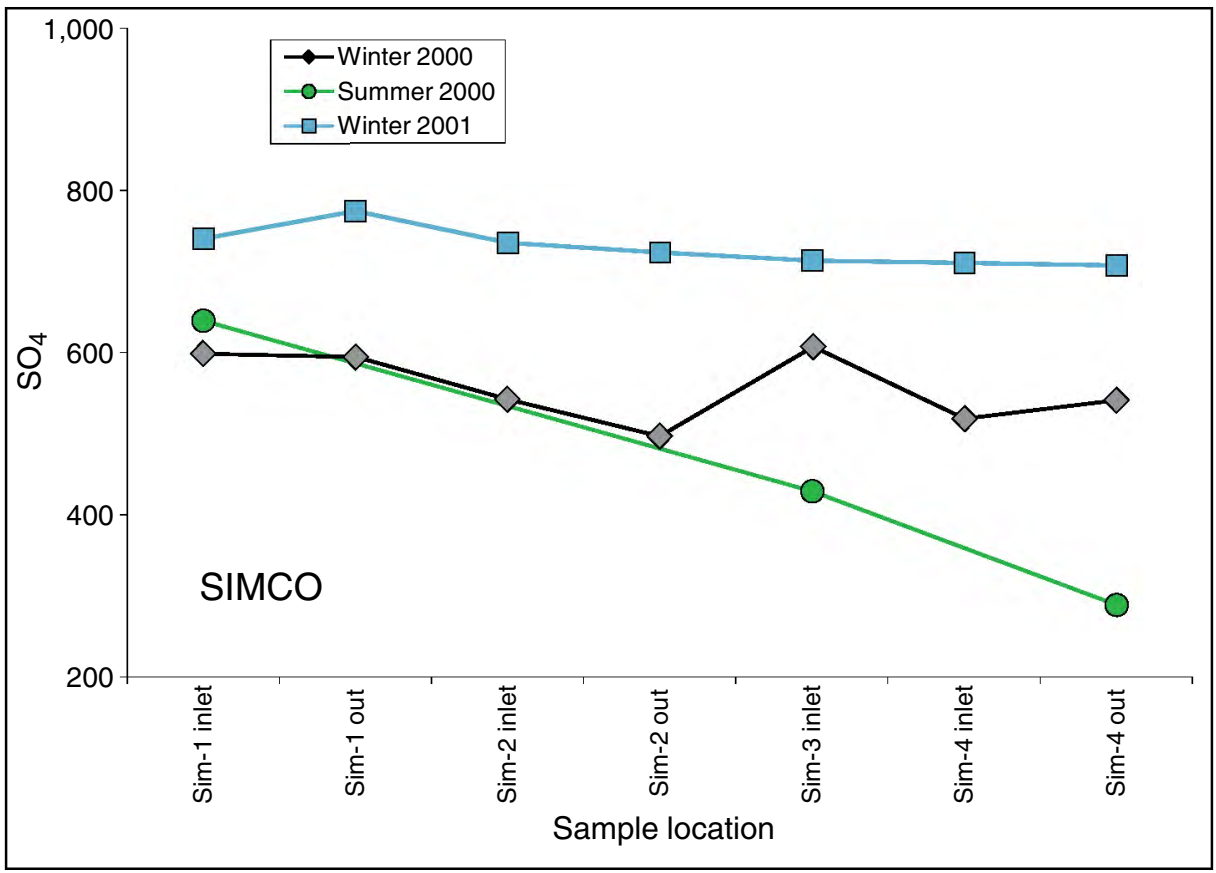

Figure 10. Graph showing dissolved $\mathrm{SO}_{4}$ at Simco, winter and summer 2000, winter 2001.

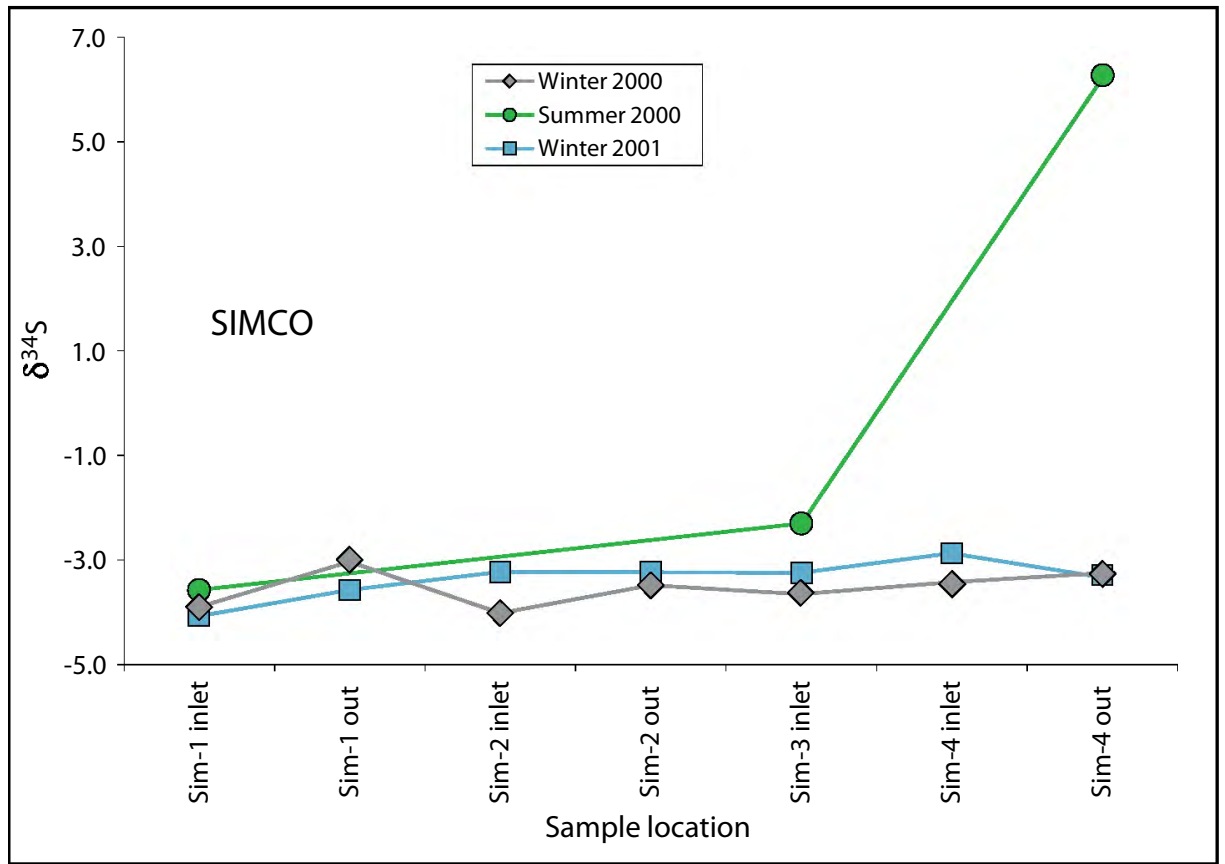

Figure 11. Graph showing $\delta^{34} \mathrm{~S}$ of dissolved $\mathrm{SO}_{4}$ at Simco, winter and summer 2000, winter 2001. 
Table 9. Simco soil results

$[\mathrm{W}=$ winter; $\mathrm{S}=$ summer. $]$

\begin{tabular}{|c|c|c|c|c|c|c|c|c|}
\hline \multirow{3}{*}{ Sample location } & \multicolumn{2}{|c|}{$\begin{array}{c}\delta^{34} S \text { of native } S^{\star} \\
(\% 0)\end{array}$} & \multirow{2}{*}{\multicolumn{2}{|c|}{$\begin{array}{c}\text { Soil metal content } \\
\text { W } 2000\end{array}$}} & \multicolumn{4}{|c|}{ Soil C - S } \\
\hline & \multirow[t]{2}{*}{ W 2000} & \multirow[t]{2}{*}{ S 2000} & & & \multicolumn{2}{|c|}{ W 2000} & \multicolumn{2}{|c|}{ S 2000} \\
\hline & & & $\% \mathrm{Fe}$ & $\% \mathrm{Mn}$ & $\% \mathrm{C}$ & $\% \mathrm{~S}$ & $\% \mathrm{C}$ & $\% \mathrm{~S}$ \\
\hline Sim inlet pond, begin & -41.68 & - & - & - & - & - & - & - \\
\hline Sim inlet pond, end & -38.59 & - & 17.16 & 0.10 & 4.22 & 0.14 & - & - \\
\hline Sim-1 begin & -33.42 & -34.66 & 15.89 & 0.03 & 3.90 & 0.21 & - & - \\
\hline Sim-1 end & -33.29 & -29.66 & 6.74 & 0.02 & 2.37 & 0.10 & - & - \\
\hline Sim-2 begin & -32.24 & - & 32.62 & 0.03 & 4.55 & 0.43 & - & - \\
\hline Sim-2 end & -9.15 & - & - & - & 5.15 & 0.33 & - & - \\
\hline Sim-3 begin & -37.42 & -37.22 & 40.47 & 0.08 & 9.14 & 0.47 & 3.42 & 0.20 \\
\hline Sim-3 end & -32.85 & - & 37.66 & 0.06 & 7.34 & 2.37 & - & - \\
\hline Sim-4 begin & -41.64 & - & 20.41 & 0.07 & 10.42 & 0.59 & - & - \\
\hline Sim-4 end & -47.31 & -41.39 & 12.60 & 0.04 & 21.64 & 1.26 & - & - \\
\hline
\end{tabular}

* Pyrite $\mathrm{S}$ amounts were too low for isotope analysis.

Table 10. Wills Creek field measurements

[W = winter; $\mathrm{S}=$ summer; $\mathrm{mS}=$ millisiemens. $]$

\begin{tabular}{|l|c|c|c|c|c|c|}
\hline \multirow{2}{*}{\multicolumn{1}{c}{$\begin{array}{c}\text { Sample } \\
\text { location }\end{array}$}} & \multicolumn{2}{c|}{$\mathrm{pH}$} & \multicolumn{2}{c|}{ Temperature $^{\circ} \mathrm{C}$} & \multicolumn{2}{c|}{ Conductivity (mS/cm) } \\
\cline { 2 - 7 } & W 2000 & S 2000 & W 2000 & S 2000 & W 2000 & S 2000 \\
\hline WC settling pond & 6.52 & - & 12.7 & - & 1.50 & - \\
\hline WC-1 inlet & 4.14 & 3.4 & 17.1 & 23.4 & 1.98 & 1.49 \\
\hline WC-1 outlet & 4.04 & - & 10.3 & - & 1.74 & - \\
\hline WC-2 outlet & 4.10 & 3.61 & 12.8 & 21.6 & 1.05 & 1.17 \\
\hline WC-3 outlet & 3.93 & 3.48 & 13.1 & 22.5 & 1.56 & 1.38 \\
\hline
\end{tabular}

Table 11. Wills Creek water results

[W = winter; $\mathrm{S}=$ summer. $]$

\begin{tabular}{|l|c|c|c|c|c|c|c|c|}
\hline \multirow{2}{*}{ Sample location } & \multicolumn{2}{|c|}{$\begin{array}{c}\text { Dissolved sulfate } \\
\text { (ppm) }\end{array}$} & \multicolumn{2}{c|}{$\begin{array}{c}\delta^{34} \text { S of dissolved } \\
\text { sulfate (\%) }\end{array}$} & \multicolumn{2}{c|}{$\begin{array}{c}\text { Fe } \\
\text { (ppm) }\end{array}$} & \multicolumn{2}{c|}{$\begin{array}{c}\text { Mn } \\
(\mathrm{ppm})\end{array}$} \\
\cline { 2 - 10 } & W 2000 & S 2000 & W 2000 & S 2000 & W 2000 & S 2000 & W 2000 & S 2000 \\
\hline WC settling pond & 2540 & - & - & - & - & - & - & - \\
\hline WC-1 inlet & - & 1050 & -3.36 & -3.96 & 12.6 & 10.1 & 8.45 & 6.72 \\
\hline WC-1 outlet & 1200 & - & -3.39 & - & - & - & - & - \\
\hline WC-2 outlet & 570 & 1060 & -3.32 & -1.67 & - & - & - & - \\
\hline WC-3 outlet & 797 & 975 & -3.48 & -2.87 & 4.2 & 4.3 & 7.91 & 6.9 \\
\hline
\end{tabular}




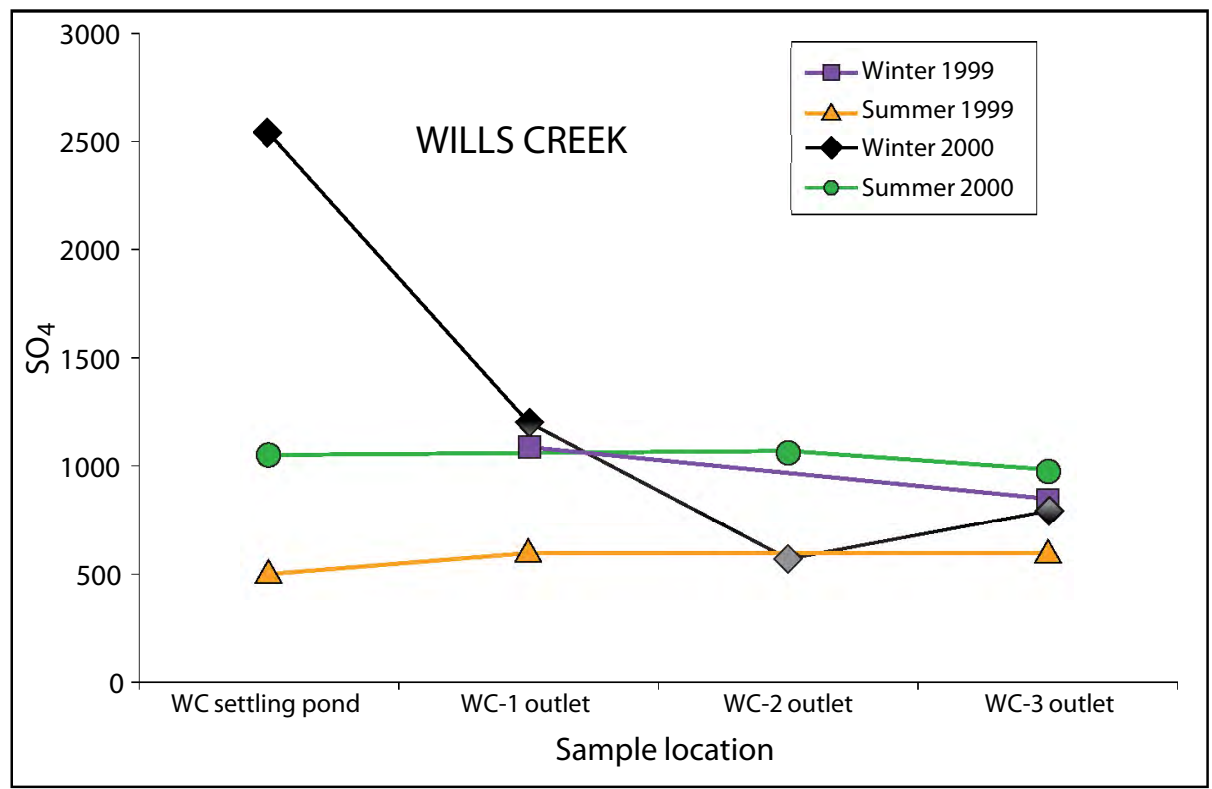

Figure 12. Graph showing dissolved $\mathrm{SO}_{4}$ at Wills Creek, winter and summer 2000.

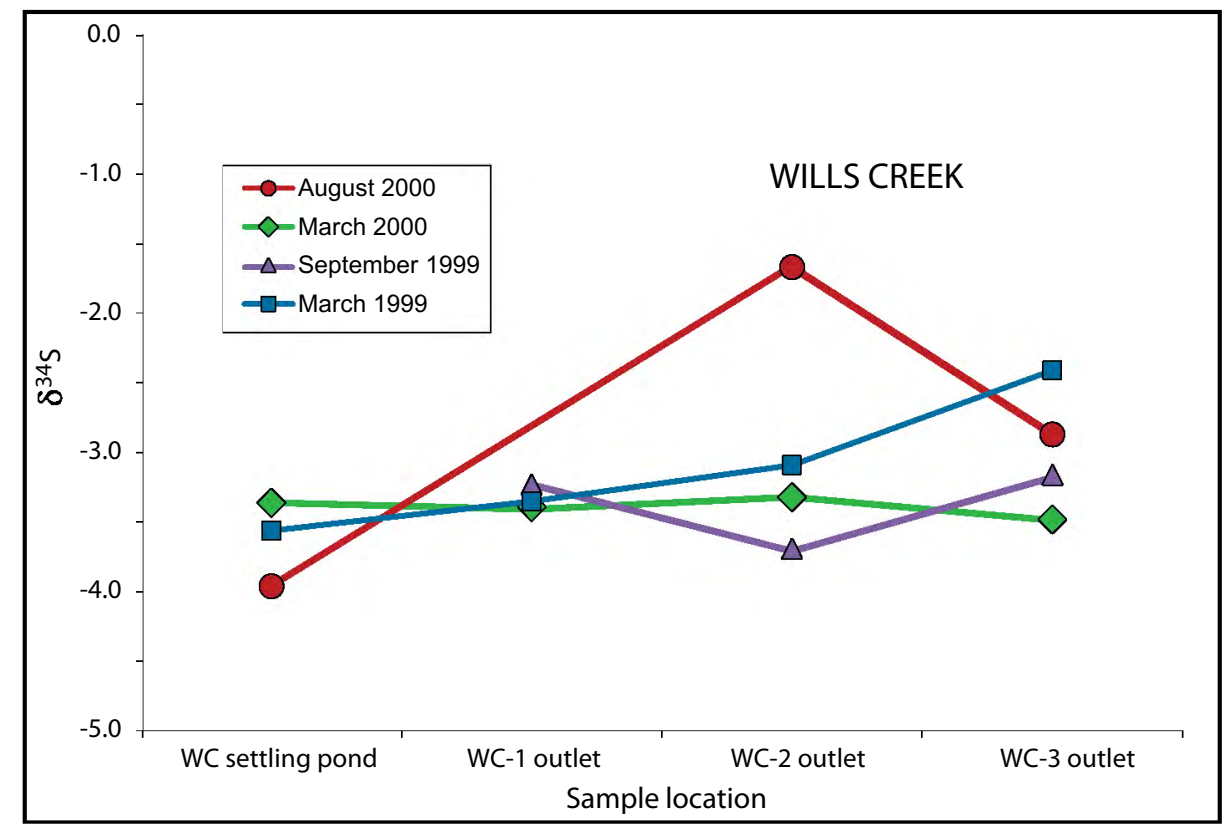

Figure 13. Graph showing $\delta^{34} \mathrm{~S}$ of dissolved $\mathrm{SO}_{4}$ at Wills Creek, winter and summer 2000. 
Table 12. Wills Creek soil results

$[\mathrm{W}=$ winter; $\mathrm{S}=$ summer $]$

\begin{tabular}{|l|c|c|c|c|c|c|c|}
\hline \multirow{2}{*}{$\begin{array}{c}\text { Sample } \\
\text { location }\end{array}$} & \begin{tabular}{c}
$\delta^{34} \begin{array}{c}\text { S of pyrite } \\
(\%)\end{array}$ \\
\cline { 2 - 8 }
\end{tabular} & \multicolumn{2}{c|}{$\begin{array}{c}\delta^{34} \text { S of native S } \\
(\%)\end{array}$} & \multicolumn{2}{c|}{$\begin{array}{c}\text { Metals } \\
\text { (avg 1995-1997) }\end{array}$} & \multicolumn{2}{c|}{$\begin{array}{c}\text { Soil C - S } \\
\text { (avg 1995-1997) }\end{array}$} \\
\cline { 2 - 8 } & W 2000 & W 2000 & S 2000 & $\% F e$ & $\% M n$ & $\% C_{\text {org }}$ & $\% \mathrm{~S}_{\text {tot }}$ \\
\hline WC-1 inlet & -31.1 & -31.7 & -24.31 & 18.25 & 0.13 & 12.80 & 1.27 \\
\hline WC-1 outlet & -6.61 & -6.10 & - & 9.79 & 0.08 & 9.42 & 1.15 \\
\hline WC-2 inlet & -17.14 & - & -31.66 & 12.73 & 0.12 & 4.26 & 0.72 \\
\hline WC-2 outlet & -36.06 & -27.63 & - & 22.52 & 0.15 & 6.31 & 1.18 \\
\hline WC-3 outlet & -28.94 & -41.77 & -36.04 & 14.34 & 0.16 & 3.17 & 1.75 \\
\hline
\end{tabular}

\section{DISCUSSION: COMPARISON OF THE FOUR SYSTEMS}

In Table 13 we compare the success of each of these four wetlands in treating AMD. As of 2001, $\mathrm{pH}$ was being raised and significant iron removal was taking place in three of the four cases. For Wills Creek, the system had largely failed and effluent $\mathrm{pH}$ and Fe did not meet water discharge standards. For Tecumseh, it is not clear to what extent the lowered Fe values are related to remediation by the wetlands and to what extent they are simply diluted by the much larger volumes of fresh water entering from other sources. Mn removal was considerably less efficient than for $\mathrm{Fe}$, but was still going on to an appreciable degree in the two Indiana wetlands, although not in the Ohio wetlands.

Sulfate removal occurred in all wetlands during both winter and summer. For the two most efficiently functioning systems (Midwestern and Simco), 23 percent of the inlet sulfate was removed in winter, 57 percent in summer. The two poorly functioning systems (Tecumseh and Wills Creek) showed no significant differences in summer versus winter removal. The large removal for winter 2000 at Wills Creek was anomalous: the 5 previous years averaged a gain of 7 percent in winter and a loss of 18 percent in summer (data of Hsu, 1998). The seasonal differences at Midwestern and Simco suggest biologically driven removal, most likely bacterial sulfate reduction. Confirmation of this supposition can be found in the sulfur isotopic data. The progressive enrichment of ${ }^{34} \mathrm{~S}$ in the residual sulfate pool as water passes through the Midwestern wetland system demonstrates that there is effective BSR in the summer, but not in winter (Table 2). For all the wetlands there is an increase in $\delta^{34} S_{\text {sulfate }}$ between the inlet and the outlet in summer (Table 13), which again indicates that
BSR is a significant process for sulfate removal. Dilution or sulfate-mineral precipitation would not cause the observed isotopic fractionation because the $\delta^{34} S$ ratios of dissolved sulfate would remain unchanged or become more negative. The average change is greater in summer, about $4.7 \%$, than in winter, about $0.7 \%$, which indicates that BSR activity is severely diminished in winter. Machemer and others (1993) also reported a seasonal fluctuation in sulfur metabolism in a constructed wetland receiving AMD, in their case reflected in a much greater production of isotopically light $\mathrm{H}_{2} \mathrm{~S}$ gas in the summer.

Sulfur isotopes can also provide insight into the relative performance of the wetlands. The summer season differences in $\delta^{34} S_{\text {sulfate }}$ between inlet and outlet, $\Delta \delta^{34} S_{\text {in-out' }}$ correlate strongly to the amount of sulfate removed by the wetlands in summer (fig. 14). On this basis we can rank the systems in the order Simco > Midwestern > Tecumseh > Wills Creek. Note that the input $\mathrm{pH}$ averaged 6.3 for the two most efficient wetlands, but only 3.6 for the two less efficient wetlands (Table 13). Thus the low inlet $\mathrm{pH}$ at Tecumseh and Wills Creek was most likely responsible for suppressing BSR, although it still occurred to some extent, perhaps related to local areas of higher $\mathrm{pH}$.

The small $\Delta \delta^{34} S_{\text {in-out }}$ in winter and the absence of a progressive increase in $\delta^{34} S$ as the water moves through the different cells indicate that the sulfatereducing bacteria are essentially inactive in colder weather. Therefore virtually all sulfate removal must be through abiotic mineral precipitation in winter. Furthermore, an appreciable fraction of sulfate must also be removed abiotically in summer (higher summer temperatures would enhance rather than inhibit abiotic reaction rates). There are a number of sparingly soluble sulfate minerals 

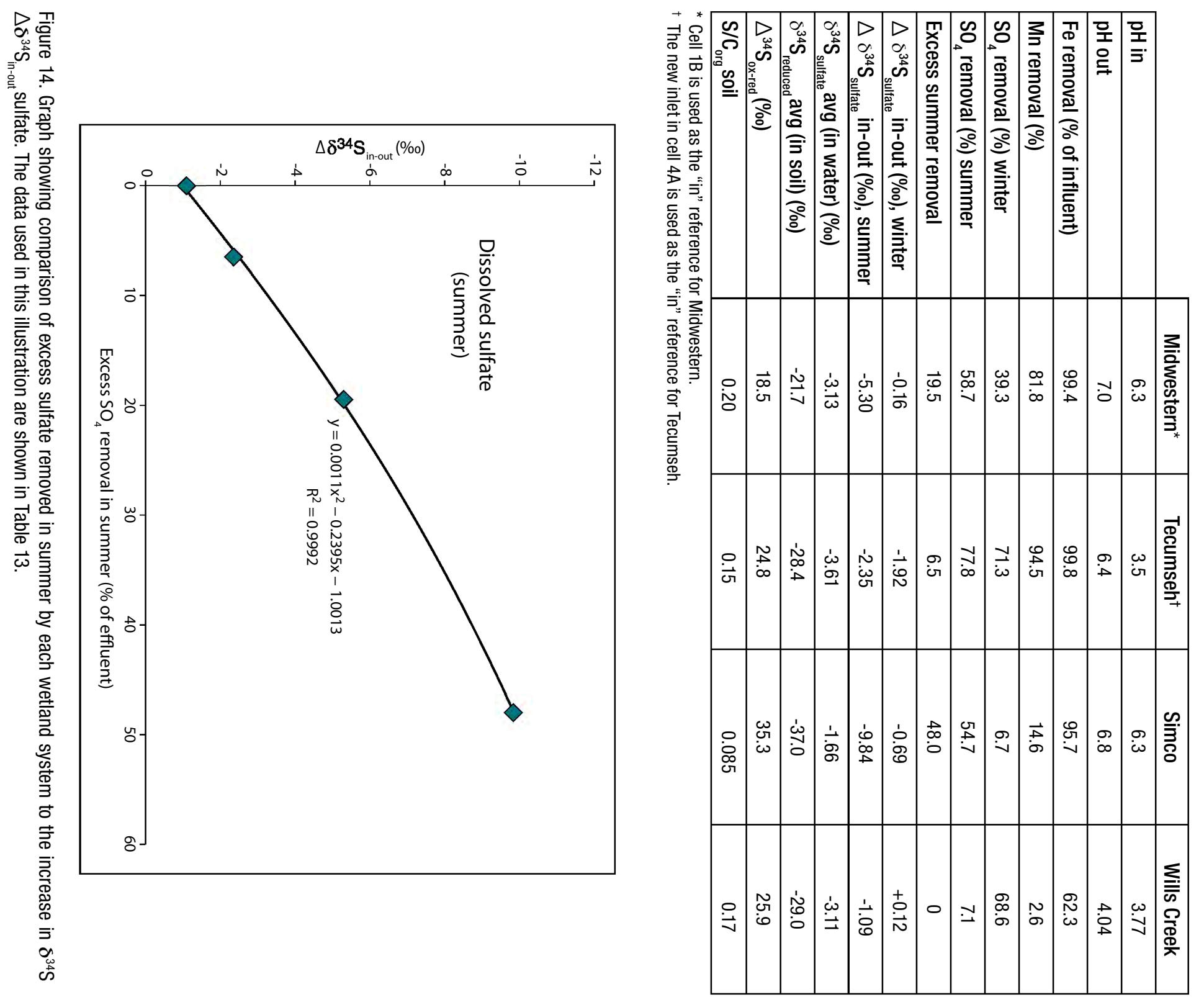
Table 14. Saturation state of inlet water from PHREEQC modeling

\begin{tabular}{|l|c|c|c|c|}
\hline \multirow{2}{*}{ Mineral } & \multirow{2}{*}{ Formula } & \multicolumn{3}{c|}{ Saturation index $^{\star}$} \\
\cline { 3 - 5 } & & MW summer & MW winter & Simco winter \\
\hline Al(OH) $)_{3}$ (amorphous) & $\mathrm{Al}(\mathrm{OH})_{3}$ & 0.00 & 0.57 & 0.85 \\
\hline Alunite & $\mathrm{KAl}_{3}\left(\mathrm{SO}_{4}\right)_{2}(\mathrm{OH})_{6}$ & 4.55 & 7.14 & 8.95 \\
\hline Basaluminite & $\mathrm{Al}_{4}(\mathrm{OH})_{10} \mathrm{SO}_{4}$ & 5.24 & 11.46 & 13.32 \\
\hline Calcite & $\mathrm{CaCO}{ }_{3}$ & 0.37 & 0.14 & -2.04 \\
\hline $\mathrm{Fe}(\mathrm{OH})_{3}$ (amorphous) & $\mathrm{Fe}(\mathrm{OH})_{3}$ & 5.02 & 5.78 & 4.85 \\
\hline Gypsum & $\mathrm{CaSO}_{4} \cdot 2_{2} \mathbf{O}$ & 0.01 & 0.02 & 0.75 \\
\hline Jarosite-K & $\mathrm{KFe}_{3}\left(\mathrm{SO}_{4}\right)_{2}(\mathrm{OH})_{6}$ & 8.94 & 9.85 & 8.09 \\
\hline Jarosite-Na & $\mathrm{NaFe}_{3}\left(\mathrm{SO}_{4}\right)_{2}(\mathrm{OH})_{6}$ & 5.59 & 6.41 & 5.56 \\
\hline Jurbanite & $\mathrm{Al}_{(0 H}\left(\mathrm{SO}_{4}\right)$ & -2.23 & -0.69 & 0.45 \\
\hline Rhodochrosite & $\mathrm{MnCO}_{3}$ & 1.16 & 1.03 & -1.59 \\
\hline
\end{tabular}

${ }^{*}$ All Fe treated as $\mathrm{Fe}^{3+}$.

of $\mathrm{Al}, \mathrm{Ca}$, and $\mathrm{Fe}$ that can form under the conditions found in these wetlands. For example, Hsu (1998) and Hsu and Maynard (1999) reported abundant gypsum from the Wills Creek wetland. Flege (2001) also found gypsum in the wetland soils at Midwestern. In a study of other wetlands, Gagliano and others (2004) documented the iron sulfates schwertmannite and jarosite as well as gypsum in an AMD wetland in Athens County, Ohio.

Computed mineral saturation indices (Table 14) indicate influents at the Midwestern and Simco wetland systems are close to saturation with respect to amorphous $\mathrm{Al}(\mathrm{OH})_{3^{\prime}}$ calcite, and gypsum. These compounds are likely to have come to equilibrium with the water in the anoxic limestone drain (in the case of Midwestern) or the local groundwater system (in the case of Simco) before emerging into the wetland. The abrupt increase in oxygen level when the AMD enters the wetland cells results in supersaturation of effluent with respect to all of the $\mathrm{Fe}^{3+}$ minerals, so iron would be expected to precipitate rapidly in the form of oxides and hydroxides. If some iron remains in the ferrous state, siderite would also be stable. In PHREEQC runs for Midwestern, siderite is saturated for any $\mathrm{Fe}^{2+}$ content above 7 percent of total Fe, which suggests that this mineral could also be a common host for $\mathrm{Fe}$, especially within anoxic drains. Various Al sulfate minerals also are above saturation. Using X-ray diffraction, we commonly found gypsum in the wetland soils, but could not detect any of the likely Fe or Al sulfates, except alunite in one sample (Flege, 2001). We speculate that phases like jarosite and basaluminite are present, but are too poorly crystalline or obscured by Fe fluorescence to be detected by X-ray diffraction.

We see from the above results that sulfur removal in AMD wetlands occurs in two general ways in successful wetland systems: 1) Bacterial transformation of sulfate to sulfide with subsequent conversion to solid reduced-valence sulfur minerals such as pyrite and native sulfur; 2) Abiotic precipitation of sulfate minerals from supersaturated solutions.

The first process is active only in warm weather, while the second can occur year-round. A variety of $\mathrm{Al}, \mathrm{Ca}$, and $\mathrm{Fe}$ sulfate minerals could be responsible for the abiotic removal of sulfate, but only gypsum was detected in X-ray diffraction measurements. On a yearly basis, about twice as much sulfate is removed by abiotic precipitation as by bacterial sulfate reduction in successful wetland systems, although in the summer season, removal by bacterial sulfate reduction predominates.

\section{ACKNOWLEDGMENTS}

This research was supported by a SMART grant from the Indiana Division of Reclamation. Comments by reviewers and detailed editing by John Comer of the Indiana Geological Survey greatly improved the manuscript. Tim Phillips of the University of Cincinnati drafted the schematic 
diagrams of the individual wetlands. We also thank David Nash and Jodi Shann of the University of Cincinnati for their help with conducting the research.

\section{REFERENCES}

Ball, J. W., and Nordstrom, D. K., 1991, User's manual for WATEQ4F with revised data base: U.S. Geological Survey Open-File Report 91-183, 189 p.

Barton, L. L., and Tomei, F. A., 1995, Characteristics and activities of sulfate-reducing bacteria, in Barton, L. L., ed., Sulfate-reducing bacteria, Biotechnology Handbook, v. 8: New York, Plenum Press, p. 1-32.

Booth, J., Hong, Q., Compton, R. G., Prout, K., and Payne, R. M., 1997, Gypsum overgrowths passivate calcite to acid attack: Journal of Colloid and Interface Science, v. 192, no. 1, p. 207-214.

Branam, T. D., Harper, D., Smith, R. T., and Naylor, S. C., 2012, Effectiveness of emerging reclamation methods for abating acid mine drainage from abandoned mine lands-Midwestern site, Indiana, in Comer, J. B., ed., Effects of abandoned mine land reclamation on ground and surface water qualityresearch and case histories from Indiana: Indiana Geological Survey Special Report 72, p. 125-146.

Brockmeyer, F., 1987, Investigation of sources of mine drainage pollution to Wills Creek Reservoir and their impact on its water quality-a report from the special studies section: Abandoned Mined Lands Program, Division of Reclamation, Ohio Department of Natural Resources.

Brodie, G. A., Britt C. R., Tomaszewski, T. M., and Taylor, H. N., 1993, Anoxic limestone drains to enhance performance of anaerobic acid drainage treatment wetlands-experiences of the Tennessee Valley Authority, in Moshiri, G. A., ed., Constructed wetlands for water quality improvement: Boca Raton, Fla., Lewis Publishers, p. 129-138.

Bruchert, V., 1998, Early diagenesis of sulfur in estuarine sediments-the role of sedimentary humic and fulvic acids: Geochimica et Cosmochimica Acta, v. 62 , no. 9 , p. 1,567-1,586.

Canfield, D. E., 2001, Biogeochemistry of sulfur isotopes, in Valley, J. W., and Cole, D. R., eds., Reviews in mineralogy and geochemistry 43-stable isotope geochemistry: Washington, D.C., Mineralogical Society of America, p. 607-636.

Canfield, D. E., Raiswell, R., Westrich, J. T., Reaves, C. M., and Berner, R. A., 1986, The use of chromium reduction in the analysis of reduced inorganic sulfur in sediments and shales: Chemical Geology, v. 54, nos. 1-2, p. 149-155.

Church, C. D., Wilkin, R. T., Alpers, C. N., Rye, R. O., and McCleskey, R. B., 2007, Microbial sulfate reduction and metal attenuation in $\mathrm{pH} 4$ acid mine water: Geochemical Transactions, v. 8, no. 10, 14 p.

Clayton, L. A., Bolis, J. L., Wildeman, T. R., and Updegraff, D. M., 1999, A case study on the aerobic and anaerobic removal of manganese by wetland processes, in Filipek, L. H., and Plumlee, G. S., eds., The environmental geochemistry of mineral deposits, part B-case studies and research topics: Littleton, Colo., Society of Economic Geologists, Reviews in Economic Geology, v. 6B, p. 515-526.

Code of Federal Regulations, 2009, Title 40, part 434.3: Government Publications Office Access Web site, $<$ http://ecfr.gpoaccess.gov/cgi/t/text/text-idx?c=ec fr\&rgn=div5\&view=text\&node=40:29.0.1.1.10\&id no $=40 \# 40: 29 \cdot 0 \cdot 1 \cdot 1 \cdot 10.3 .4 .4>$, date accessed, June 1, 2009.

Cravotta, C. A., 2003, Size and performance of anoxic limestone drains to neutralize acid mine drainage: Journal of Environmental Quality, v. 32, no. 4, p. 1,277-1,289.

Cravotta, C. A., and Watzlaf, G. R., 2002, Design and performance of limestone drains to increase $\mathrm{pH}$ and remove metals from acidic mine drainage, in Naftz, D. L., Morrison, S. J., Fuller, C. C., and Davis, J. A., eds., Handbook of groundwater remediation using permeable reactive barriers: San Diego, Calif., Academic Press, p. 19-66.

Dvorak, D. H., Hedin, R. S., Edenborn, H. M., and McIntrye, P. E., 1992, Treatment of metal contaminated water using bacterial sulfate reduction-results from pilot scale reactors: Biotechnology and Bioengineering, v. 40, no. 5, p. 609-616.

Edraki, M., Golding, S. D., Baublys, K. A., and Lawrence, M. G., 2005, Hydrochemistry, mineralogy and sulfur isotope geochemistry of acid mine drainage at the Mt. Morgan mine environment, Queensland, Australia: Applied Geochemistry, v. 20, no. 4, p. 789-905.

Faulwetter, J. L., Gagnon, V., Sandberg, C., Chazarenc, F., Burr, M. D., Brisson, J., Camper, A. K., and Stein, O. R., 2009, Microbial processes influencing performance of treatment wetlands-a review: Ecological Engineering, v. 35, no. 6, p. 987-1,004.

Flege, A. E., 2001, Sulfate reduction in five wetlands receiving acid mine drainage: Cincinnati, Ohio, University of Cincinnati, master's thesis, $148 \mathrm{p}$.

Fortin, D., Goulet, R., and Roy, M., 2000, Seasonal cycling of $\mathrm{Fe}$ and $\mathrm{S}$ in a constructed wetland-the role of sulfate-reducing bacteria: Geomicrobiology Journal, v. 17 , no. 3, p. 221-335. 
Gagliano, W. B., Brill, M. R., Bigham, J. L., Jones, F. S., and Traina, S. J., 2004, Chemistry and mineralogy of ochreous sediments in a constructed mine drainage wetland: Geochimica et Cosmochimica Acta, v. 68 , no. 9, p. 2,119-2,128.

Hsu, S. C., 1998, The use of sulfur isotopes to determine the effectiveness of sulfate-reduction in the remediation of acid mine drainage at Wills Creek constructed wetland: Cincinnati, Ohio, University of Cincinnati, master's thesis, $142 \mathrm{p}$.

Hsu, S. C., and Maynard, J. B., 1999, The use of sulfur isotopes to monitor the effectiveness of constructed wetlands in controlling acid mine drainage: Environmental Engineering and Policy, v. 1, no. 4, p. 223-233.

Huminicki, D. M. C., and Rimstidt, J. D., 2008, Neutralization of sulfuric acid solutions by calcite dissolution and the application to anoxic limestone drain design: Applied Geochemistry, v. 23, no. 2, p. $148-165$.

Indiana Geological Survey (IGS), 1999, Hydrology and water quality associated with the Midwestern Reclamation Site, Pike County, Indiana: Indiana Geological Survey Web site, <http://igs.indiana.edu/ survey/projects/midwest/midwest/midwhtml/ index.cfm> and <http://igs.indiana.edu/survey/ projects/midwestExtension/midw2html/index. cfm\#fig5>, date accessed, Dec. 18, 2009.

Kleinmann, R. L. P., 1989, Acid mine drainage-U.S. Bureau of Mines researches and develops control methods for both coal and metal mines: Engineering and Mining Journal, v. 190, p. 16I-16N.

Kolbash, R. L., and Romanoski, T. L., 1989, Simco/Windsor wetlands, in Proceedings of $20^{\text {th }}$ West Virginia Surface Mine Drainage Task Force Symposium: West Virginia Mine Drainage Task Force Web site, <http:// wvmdtaskforce.com/proceedings/89/89kol $/ 89 \mathrm{kol}$. htm $>$, date accessed, Feb. 2, 2010.

Leavitt, B., Stiles, J., and Lovett, R., 2008, Modeling AMD geochemistry in underground mines, in Proceedings of $30^{\text {th }}$ West Virginia Surface Mine Drainage Task Force Symposium: West Virginia Mine Drainage Task Force Web site, <http://wvmdtaskforce.com/ proceedings/2008.cfm $>$, date accessed, Feb. 2, 2010.

Lefticariu, L., Pratt, L. M., and Ripley, E. M., 2006, Mineralogic and sulfur isotopic effects accompanying oxidation of pyrite in millimolar solutions of hydrogen peroxide at temperatures from 4 to $150^{\circ} \mathrm{C}$ : Geochimica et Cosmochimica Acta, v. 70, no. 19, p. 4,889-4,905.

Machemer, S. D., Reynolds, J. S., Laudon, L. S., and Wildeman, T. R., 1993, Balance of $S$ in a constructed wetland built to treat acid mine drainage, Ida- ho Springs, Colorado, USA: Applied Geochemistry, v. 8 , no. 6 , p. 587-603.

Maynard, J. B., 1980, Sulfur isotopes of iron sulfides in Devonian-Mississippian shales of the Appalachian Basin-control by rate of sedimentation: American Journal of Science, v. 280, no. 8, p. 772-786.

Mills, A. L., 1999, The role of bacteria in environmental geochemistry, in Plumlee, G. S., and Logsdon, M. J., eds., The environmental geochemistry of mineral deposits, part A-processes, techniques, and health issues: Littleton, Colo., Society of Economic Geologists, Reviews in Economic Geology, v. 6A, p. 125-132.

Newton, R., and Bottrell, S., 2007, Stable isotopes of carbon and sulphur as indicators of environmental change-past and present: Journal of the Geological Society, v. 164, no. 4, p. 691-708.

Nordstrom, D. K., and Alpers, C. N., 1999, Geochemistry of acid mine waters, in Plumlee, G. S., and Logsdon, M. J., eds., The environmental geochemistry of mineral deposits-processes, techniques, and health issues: Littleton, Colo., Society of Economic Geologists, Reviews in Economic Geology, v. 6A, p. $133-160$.

Parkhurst, D. L., and Appelo, C. A. J., 1999, User's guide to PHREEQC (Version 2) -a computer program for speciation, batch-reaction, one-dimensional transport, and inverse geochemical calculations: U.S. Geological Survey Water Resources Investigations Report 99-4259, $312 \mathrm{p}$.

Plumlee, G. S., 1999, The environmental geology of mineral deposits, in Plumlee, G. S., and Logsdon, M. J., eds., The environmental geochemistry of mineral deposits-processes, techniques, and health issues: Littleton, Colo., Society of Economic Geologists, Reviews in Economic Geology, v. 6A, p. 71-116.

Potter, P. E., Maynard, J. B., and DePetris, P. J., 2005, Mud and mudstone: New York, Springer-Verlag, $297 \mathrm{p}$.

Riefler, R. G., Krohn, J., Stuart, B., and Socotch, C., 2008, Role of sulfur-reducing bacteria in a wetland system treating acid mine drainage: Science of the Total Environment, v. 394, nos. 2-3, p. 222-229.

Robbins, E. I., Cravotta, C. A., Savela, C. E., and Nord, G. L., 1999, Hydrobiogeochemical interactions in 'anoxic' limestone drains for neutralization of acid mine drainage: Fuel, v. 78, no. 2, p. 259-270.

Seal, R. R., 2003, Chapter 15, Stable-isotope geochemistry of mine waters and related solids, in Jambor, J. L., Blowes, D. W., and Ritchie, A. I. M., eds., Environmental aspects of mine wastes: Vancouver, B.C., Mineralogical Association of Canada, Short Course Series, v. 31, p. 303-334. 
Seal, R., 2010, Field calibration of stable isotopic fractionation associated with biotic and abiotic sulfate removal processes: U.S. Geological Survey, Crustal Imaging and Characterization Team (CICT). [Available at USGS Web site, <http://crustal.usgs.gov/ projects/aqueous_geochemistry/field_calibration. html $>$, date accessed, July 1, 2011]

Singleton, R., 1993, The sulfate-reducing bacteria-an overview, in Odom, J. M., and Singleton, R., eds., The sulfate-reducing bacteria-contemporary perspectives: New York, Springer-Verlag, p. 1-20.

Smith, R. T., Comer, J. B., Ennis, M. V., Branam, T. D., Butler, S. M., and Renton, P. M., 2003, Toxic metals removal in acid mine drainage treatment wetlands: Indiana Geological Survey Open-File Report 01-03, 52 p. [Available online at IU ScholarWorks Repository, <https://scholarworks.iu.edu/dspace/ handle/2022/1801>, date accessed, Feb. 2, 2010.]

Soler, J. M., Boi, M., Mogollón, J. L., Cama, J., Ayora, C., Nico, P. S., Tamura, N., and Kunz, M., 2008, The passivation of calcite by acid mine water-column experiments with ferric sulfate and ferric chloride solutions at $\mathrm{pH}$ 2: Applied Geochemistry, v. 23, no. 12, p. 3,579-3,588.

Stark, L. R., Brooks, R. P., Williams, F. M., Stevens, S. E., and Davis, L. K., 1994a, Water quality during storm events from two constructed wetlands receiving mine drainage: Water Resources Bulletin, v. 30, no. 4, p. 639-650.

Stark, L. R., Williams, F. M., Stevens, S. E., and Eddy, D. P., 1994b, Iron retention and vegetative cover at the Simco constructed wetland-an appraisal through year eight of operation, in Proceedings, International Land Reclamation and Mine Drainage Conference and $3^{\text {rd }}$ International Conference on the Abatement of Acidic Drainage, v. 1: Mine Drainage, Pittsburgh, Pa.

Stark, L. R., Kolbash, R. L., Webster, H. J., Stevens, S. E., Dionis, K. A., and Murphy, E. R., 1988, The Simco \#4 Wetland-biological patterns and performance of a wetland receiving mine drainage, in Mine drainage and surface mine reclamation, v. 1-mine water and mine waste: Bureau of Mines Information Circular 9183, p. 89-98.

Stark, L. R., Stevens, S. Edward, Jr., Webster, H. J., and Wenerick, W. R., 1990, Iron loading, efficiency and sizing in a constructed wetland receiving mine drainage, in Skousen, J., Sencindiver, J., and Samuel, D., eds., Proceedings of the 1990 Mining and Reclamation Conference and Exhibition, Charleston, West Virginia, April 23-26, 1990, p. 393-402.
Studley, S. A., Ripley, E. M., Elswick, E. R., Dorais, M. J., Fong, J., Finkelstein, D., and Pratt, L. M., 2002, Analysis of sulfides in whole rock matrices by elemental analyzer-continuous flow isotope ratio mass spectrometry: Chemical Geology, v. 192, nos. 1-2, p. 141-148.

Stumm, W., and Morgan, J. J., 1981, Aquatic chemistry, 2nd ed.: New York, Wiley Interscience, $780 \mathrm{p}$.

Thauer, R. K., Stackebrandt, E., and Hamilton, W. A., 2007, Energy metabolism and phylogenetic diversity of sulphate-reducing bacteria, in Barton, L. L., and Hamilton, W. A., eds., Sulphate-reducing bacteria: environmental and engineered systems: Cambridge, U.K., Cambridge University Press, p. 1-38.

Watzlaf, G. R., Schroeder, K. T., and Kairies, C. L., 2000, Long-term performance of anoxic limestone drains: Mine Water and the Environment, v. 19, p. 98-110.

Ziemkiewicz, P. F., and Simmons, J., 2001, Design and early field performance of AMD treatment systems under the Appalachian Clean Streams Initiative, in Proceedings of $22^{\text {nd }}$ West Virginia Surface Mine Drainage Task Force Symposium, p. 19-32.

Ziemkiewicz, P. F., Skousen, J. G., and Simmons, J., 2003, Long-term performance of passive acid mine drainage systems: Mine Water and the Environment, v. 22 , no. 3 , p. $118-129$. 


\title{
Passive Treatment of Low-pH, High-Aluminum Acid Mine Drainage: A Critical Review of Sulfate-Reducing Bioreactor Technology
}

\author{
Paul T. Behum \\ U.S. Office of Surface Mining Reclamation and Enforcement, Mid-Continent Region
}

\begin{abstract}
Passive treatment has been widely employed in the United States to abate acid mine drainage. Passive treatment is often preferred because of lower installation and operational costs compared to direct chemical treatment methods such as lime neutralization. Most passive technologies, however, are incapable of providing long-term treatment of drainage that has high aluminum content ( $>20 \mathrm{mg} / \mathrm{L})$. Aluminum-bearing acid mine drainage occurs at some abandoned mine sites in the Illinois Basin and is characterized by low $\mathrm{pH}(<3.0)$, high acidity $(>1,500 \mathrm{mg} / \mathrm{L}$ calcium carbonate equivalent), and high iron and manganese content $(>300 \mathrm{mg} / \mathrm{L}$ and $>30 \mathrm{mg} / \mathrm{L}$, respectively). Elevated levels of trace metals such as nickel and zinc $(>1 \mathrm{mg} / \mathrm{L})$ are also common in this drainage.
\end{abstract}

Sulfate-reducing bioreactors are a promising technology gaining application in treatment of acid mine drainage from both metal mines and coal mines that discharge low- $\mathrm{pH}$ high-aluminum drainage. In this process, organic carbon is oxidized and sulfate, the terminal electron acceptor, is reduced, producing hydrogen sulfide gas. The process requires anaerobic conditions and is mediated by sulfatereducing bacteria. The hydrogen sulfide gas readily dissolves in water and reacts with divalent metals $\mathrm{Fe}^{2+}, \mathrm{Ni}^{2+}$, and $\mathrm{Zn}^{2+}$ to form sulfide mineral precipitates, which are relatively stable if they remain under anoxic environmental conditions. A key component in the biozone of a sulfate-reducing bioreactor is cellulolytic bacteria, which degrade complex organic molecules to produce simple compounds such as acetate, which the sulfate-reducing bacteria use as a carbon source.

Sulfate-reducing bioreactors are constructed in two basic designs that perform as either passive or active treatment systems. Carbon sources for passive sulfate-reducing bioreactors are complex carbohydrates, such as agricultural waste (compost, hay, straw, corn stover, and manure) and timber production waste (sawdust, bark, and wood chips). Active and semipassive systems use continuous additions of simple liquid organic carbon sources that are easily metabolized by sulfate-reducing bacteria. Active systems are operated like industrial plants and require power and continuous monitoring, whereas semipassive systems are capable of extended unattended operation in remote areas. Lactate, ethanol, and methanol have been the most commonly used carbon sources for active and semipassive systems. Lactate, ethanol, 
and, to a lesser extent, methanol, are expensive. Methanol, however, is too poisonous to use safely in semipassive operations. Recent research evaluated the application of food and alternative fuel production waste as a substitute for the highcost carbon source materials. In particular, glycerol/methanol waste from biodiesel manufacture may be a low-cost alternative in the midwestern United States. Considerable research is focused on determining the design requirements and longevity of sulfate-reducing bioreactors. A discussion of the results of this research and recommendations for future study are included.

\section{INTRODUCTION}

The weathering of pyrite $\left(\mathrm{FeS}_{2}\right)$ contained in coal, overburden strata, and coal refuse has generated aluminum-bearing acid mine drainage (AMD) at a significant number of abandoned mine sites in the Illinois Basin. Pyrite oxidizes rapidly upon exposure to humid air or aerated water, and bacterial activity greatly increases the rate of pyrite oxidation (Evangelou, 1995). Acid mine drainage occurs where combined mineral and proton acidity exceeds naturally available alkalinity (Evangelou, 1995), and it is characterized by low $\mathrm{pH}$, high concentrations of sulfate, acidity, iron, and manganese, and elevated levels of trace metals such as nickel and zinc. The high concentration of sulfate $\left(\mathrm{SO}_{4}\right)$ is often used as an indicator of coal mining impacts. Acid mine drainage is similar to problematic metal mine discharge, referred to in the mining industry as "acid rock drainage" (ARD). However, ARD is also generated by the weathering of additional sulfide minerals such as pyrrhotite $\left(\mathrm{Fe}_{1-x} \mathrm{~S}\right)$, bornite $\left(\mathrm{Cu}_{5} \mathrm{FeS}_{4}\right)$, and arsenopyrite (FeAsS), and typically contains higher concentrations of metals such as arsenic, copper, lead, and zinc.

Sulfate is commonly the dominant anion in active coal mine drainage and, depending on the geology and anthropogenic impacts of the site, may include other major ions such as chloride, calcium, magnesium, sodium, potassium, and bicarbonate. Sulfate, being nonvolatile and relatively conservative in the natural environment, is not a regulated parameter of the National Pollutant Discharge Elimination System (NPDES) and, until recent scientific and regulatory concerns, was not considered a serious threat to ecosystems. However, it is an established pollutant of drinking water supplies. The federal standard for sulfate is 250 $\mathrm{mg} / \mathrm{L}$, a secondary maximum contaminant level (SMCL) that is not regulated or enforceable. The sulfate SMCL is usually applied to drinking water supplies from groundwater aquifers and surface water intakes. Elevated total dissolved solids (TDS) content, which for coal mine drainage, sulfate is a principal component, is believed to harm certain aquatic life such as mayflies (Paybins and others, 2000; Latimer, 1999); however, there is no consensus in the scientific community as to the extent of ecologic harm or the appropriate means to regulate high TDS discharges (Hedrick and Ras, 2002; Weber-Scannell and Duffy, 2007).

In the Illinois Basin, AMD has primarily been found at coal mines abandoned before passage of the Surface Mining Control and Reclamation Act (SMCRA) in 1977. Acid mine drainage is generated at these mine sites because of inadequate reclamation practices. However, since the enactment of SMCRA, mine operations are subject to performance standards that minimize AMD formation. Although AMD can be found throughout the coal basin, serious environmental impacts have historically occurred mostly in the southern part of the Illinois Basin, owing in part to geologic factors (namely, the presence of acid-forming overburden) and mining practices (namely, construction of haulage roads from coal waste materials).

Passive treatment has been widely employed in the United States to abate AMD (Faulkner and Skousen, 1994; Hedin and others, 1994a, b). Most passive technologies, however, are incapable of providing long-term treatment (10 years or more) of AMD that exhibits both a high aluminum content $(>20 \mathrm{mg} / \mathrm{L})$ and high acidity $(>300 \mathrm{mg} / \mathrm{L})$. However, this type of problematic, aluminumbearing AMD occurs at a significant number of 
abandoned mine sites in the Illinois coal basin. This paper is intended to provide a critical review of one technology-the sulfate-reducing bioreactor-that offers some potential in AMD remediation in the Midwest. The sulfate-reducing bioreactor is one of the bioremediation technologies, along with anaerobic wetlands and successive alkalinityproducing systems, that employs sulfate-reducing bacteria for treating acid mine drainage (Hedin and others, 1994a; Watzlaf, 1997; Doshi, 2006). The passive treatment system is often preferred because of the cost advantages of construction and operation for publicly funded land reclamation projects. However, both emerging active and semiactive sulfate-reducing bioreactor systems may successfully abate high sulfate discharges from certain types of operating and abandoned coal mines that have been difficult to treat using conventional passive AMD mitigation methods.

\section{GEOCHEMISTRY OF ACID MINE DRAINAGE}

\section{Pyrite oxidation}

The geochemistry of AMD is based primarily on the interactions of pyrite with oxygen, water, and bacteria. Similarly, reactive sulfide minerals, such as pyrite, that contain nickel, zinc, and other trace metals may also be distributed in coal and overburden rocks. The overall stoichiometric reaction describing pyrite oxidation is commonly given as:

$$
\mathrm{FeS}_{2(\mathrm{~s})}+15 / 4 \mathrm{O}_{2}+7 / 2 \mathrm{H}_{2} \mathrm{O}=\mathrm{Fe}(\mathrm{OH})_{3(\mathrm{~s})}+2 \mathrm{SO}_{4}{ }^{2-}+4 \mathrm{H}^{+}
$$

Reaction 1 from Stumm and Morgan (1981) has pyrite, oxygen $\left(\mathrm{O}_{2}\right)$, and water $\left(\mathrm{H}_{2} \mathrm{O}\right)$ as reactants and solid ferric hydroxide $\left(\mathrm{Fe}(\mathrm{OH})_{3}\right)$, sulfate $\left(\mathrm{SO}_{4}^{2-}\right)$, and hydrogen ions $\left(\mathrm{H}^{+}\right)$as products. Coal mine drainage having an abundance of dissolved, reduced iron-ferrous iron $\left(\mathrm{Fe}^{2+}\right)$-is at an intermediate stage (partially oxidized) in the series of reactions that, upon completion, forms the process known as pyrite oxidation (reactions $2-5$ ). Reaction 1 involves a series of steps (Stumm and Morgan, 1981).

$$
\begin{aligned}
& \mathrm{FeS}_{2}+7 / 2 \mathrm{O}_{2}+\mathrm{H}_{2} \mathrm{O} \rightarrow \mathrm{Fe}^{2+}+2 \mathrm{SO}_{4}^{2-}+2 \mathrm{H}^{+} \\
& \mathrm{Fe}^{2+}+1 / 4 \mathrm{O}_{2}+\mathrm{H}^{+}=\mathrm{Fe}^{3+}+1 / 2 \mathrm{H}_{2} \mathrm{O} \\
& \mathrm{FeS}_{2(\mathrm{~s})}+14 \mathrm{Fe}^{3+}+8 \mathrm{H}_{2} \mathrm{O}=15 \mathrm{Fe}^{2+}+2 \mathrm{SO}_{4}^{-2}+16 \mathrm{H}^{+}
\end{aligned}
$$

$$
\mathrm{Fe}^{3+}+3 \mathrm{H}_{2} \mathrm{O}=\mathrm{Fe}(\mathrm{OH})_{3(\mathrm{~s})}+3 \mathrm{H}^{+}
$$

In reaction 4 , dissolved ferric iron $\left(\mathrm{Fe}^{3+}\right)$ produced by reaction 3 is the oxidizing agent for pyrite. Kinetic studies show that at an acidic $\mathrm{pH}$ rates of pyrite oxidation by $\mathrm{Fe}^{3+}$ are much faster than oxidation by $\mathrm{O}_{2}$ (reaction 2) (Stumm and Morgan, 1981). Therefore, in well-established acid-generating environments, the typical sequence is pyrite oxidation by reaction 4 to produce $\mathrm{Fe}^{2+}$, which is then oxidized to $\mathrm{Fe}^{3+}$ by the bacterially aided reaction 3 (Stumm and Morgan, 1981). The powerful oxidant $\mathrm{Fe}^{3+}$ is then available for further pyrite oxidation. Although $\mathrm{O}_{2}$ is not directly consumed in the $\mathrm{Fe}^{3+}$-mediated pyrite-oxidizing step, it is still necessary for the generation of $\mathrm{Fe}^{3+}$ by reaction 3. Ferric iron is relatively insoluble in water having $\mathrm{pH}$ greater than between 2.3 to 3.5 (reaction 5). Although reaction 5 shows solid ferric hydroxide $\left(\mathrm{Fe}(\mathrm{OH})_{3(s)}\right)$ as an end product of pyrite weathering, ferric iron will also occur in AMD as a series of dissolved species, including $\mathrm{Fe}^{3+}, \mathrm{Fe}(\mathrm{OH})^{2+}$, and $\mathrm{Fe}(\mathrm{OH})_{2}^{+}$. Additional pyrite weathering and iron hydrolysis will continue to lower the $\mathrm{pH}$ until ferric iron remains in solution and is subsequently reduced by pyrite, which then again forms ferrous iron (reaction 4). This cyclic process continues until either the ferric iron or the pyrite is completely consumed. Oxidation of pyrite by ferric ion (reaction 4) produces 16 moles of $\mathrm{H}^{+}$compared to the 2 moles produced more slowly when oxygen combines with pyrite (reaction 2). It is important to note that for every mole of pyrite that is oxidized, two moles of sulfate are released.

Singer and Stumm (1970) emphasized that Acidithiobacillus ferrooxidans (syn. Thiobacillus ferrooxidans) act as a biologic equivalent to catalysts that increase the rate of reaction for the step where $\mathrm{Fe}^{2+}$ is oxidized to $\mathrm{Fe}^{3+}$ in an acidic environment. Reactions 2 and 3, which involve the oxidation of sulfur and iron by gaseous or dissolved $\mathrm{O}_{2}$, can be mediated by various species of sulfur- and iron-oxidizing bacteria, notably those of the genus Acidithiobacillus. These bacteria require only dissolved $\mathrm{CO}_{2}$ and $\mathrm{O}_{2}$, a reduced form of Fe or S, and minor N and P for their metabolism. Nicholson (1994) discovered that these bacteria boost pyritic oxidation rates by 10 to 100 times. Bigham and Nordstrom (2000) have postulated that the presence of a variety of bacteria species enhances pyrite oxidation more than any single bacteria species. This is understandable, because 95 percent of bacteria species that aid the pyrite 
oxidation process are species other than Acidithiobacillus ferrooxidans (Morin and Hutt, 2001).

\section{AMD metals chemistry}

Guy and others (1975) describe five complexation processes that control the speciation and mobility of metals in natural waters: 1) formation of aqueous metal-inorganic ion complexes, 2) formation of aqueous metal-organic ligand complexes, 3) metal sorption onto humic acid-clay colloids, 4) metal sorption onto hydrous oxide precipitates, and 5) metal sorption onto metal-clay colloids.

Iron, manganese, and aluminum are the most abundant metals in coal mine drainage (Deutsch, 1997) and the formation of dissolved metal complexes is an important chemical process that allows large concentrations of these metals to remain in aqueous solution. Complex formation also increases the solubility of trace metals (Evangelou, 1995; Hong and others, 1995; Sawyer and others, 2003). High concentrations of complexing agents increase the solubility of metal-bearing minerals by reducing the amount of "free" metal ions in the solution. Inorganic metal complexes form with ligands such as $\mathrm{Cl}, \mathrm{OH}-\mathrm{CO}_{3}{ }^{2-}$, and $\mathrm{SO}_{4}{ }^{2-}$. An example is the neutral ferrous iron sulfate complex, which forms by the reaction:

$$
\mathrm{Fe}^{2+}+\mathrm{SO}_{4}{ }^{2-}=\mathrm{FeSO}_{4}{ }^{0}
$$

Sawyer and others (2003) suggest that $\mathrm{FeSO}_{4}{ }^{0}$ is the most common iron complex in AMD discharged from mine pools with a reducing atmosphere. Partitioning of metal ions among various ligands is a function of the nature of those ligands and their concentrations (Sawyer and others, 2003). For example, multidentate organic ligands are more effective complexing agents that monodentate inorganic ions. Furthermore, ferric iron complexes commonly are less soluble than ferrous iron complexes. Complex-forming ions typically are removed from aqueous solution at a slower rate than noncomplex-forming metals because complexation decreases the concentration of the free metal ion that reacts with hydroxide or sulfide to form precipitates. Although ferrous iron normally can be oxidized to ferric iron in minutes, complex-stabilized ferrous iron may take months to oxidize (Vance, 1994).
Ferric iron will often bind to organics and form organic-iron hydroxide colloids or dissolved organic-iron complexes (Wieder and Lang, 1982; Evangelou, 1995). At low $\mathrm{pH}$, these colloids and complexes also include aluminum $\left(\mathrm{Al}^{3+}\right)$, which competes with $\mathrm{Fe}^{3+}$ for available complex sites in proportion to the relative abundances of the two metals in these waters (Perdue and others, 1976). Humic acid, fulvic acid, and tannic acid are examples of naturally occurring organic complex-forming compounds that are likely to be present in sulfate-reducing bioreactors (Wieder and Lang, 1982). Guy and others (1975) developed a simple model of metal fixation to colloidal organic particles. They found that humic acid particles (large molecules of phenolic and benzene carboxylic acids) contained acidic functional groups that chelate metal cations such as ferrous iron $\left(\mathrm{Fe}^{2+}\right)$. Hem (1972) suggested that there are few strong inorganic ferrous complexes but that both ferrousorganic ligand and ferric-organic ligand complexes are stronger and, therefore, more important in mine waters having elevated iron levels.

Mobility of metals in oxic environments is often controlled by adsorption onto humic acid-clay colloids, metal sorption onto hydrous oxides, and formation of metal-clay colloids (Evangelou, 1995; Hong and others, 1995). Oxides of $\mathrm{Fe}^{3+}$ and $\mathrm{Mn}^{4+}$, oxyhydroxides, and organics will acquire metal coatings as their binding sites are occupied. Hong and others (1995) found that trace metals will bind to amorphous $\mathrm{Fe}^{3+}$ oxyhydrate (in the order: $\mathrm{Cd} \approx \mathrm{Ni}<\mathrm{Co}<\mathrm{Zn}<<\mathrm{Cu} \approx \mathrm{Pb}$ ). Colloids may settle and become part of the sediment, which, if they are buried and stabilized, removes them from the aqueous system. Conversely, dissolved complexes remain in aqueous solution and would pass through the treatment systems unless there are other reactions that remove them. As an example, in anoxic sulfidic environments, iron will be removed as iron monosulfide and, ultimately, pyrite (Hong and others, 1995). Removal of ferrous iron as FeS would cause the ferrous sulfate complex to dissociate and release free $\mathrm{Fe}^{2+}$ ions into solution, driving the complex-forming reaction 6 to the left to maintain chemical equilibrium. Continued removal of $\mathrm{FeS}$ would eventually eliminate the neutral ferrous sulfate complex. Note that the overall removal rate may be slower for a metal ion complex because of the finite rates at which the complexes dissociate. 


\section{Biogeochemistry of sulfate reduction}

Sulfate-reducing bioreactors are a promising technology increasingly applied to treat problematic AMD from both metal mines and coal mines that discharge low-pH, high-aluminum drainage. Sulfate-reducing bioreactors provide an environment in which organic carbon is oxidized, and sulfate, the terminal electron acceptor, is reduced. The reduction of sulfate is microbial-mediated and the general reaction is:

$$
2 \mathrm{CH}_{2} \mathrm{O}_{(\mathrm{aq})}+14 \mathrm{SO}_{4}^{2-} \text { (aq) } \rightarrow 2 \mathrm{HCO}_{3 \text { (aq) }}^{-}+\mathrm{H}_{2} \mathrm{~S}_{(\text {(aq) }}
$$

where $\mathrm{CH}_{2} \mathrm{O}$ represents the simplified organic carbon source. The bicarbonate $\left(\mathrm{HCO}_{3}^{-}\right)$produced in the reaction helps to buffer AMD acidity.

The second product, hydrogen sulfide, readily dissolves in water and combines with divalent metals such as $\mathrm{Fe}, \mathrm{Ni}$, and $\mathrm{Zn}$ to form sulfide mineral precipitates. These sulfides are relatively stable under the $\mathrm{pH}, \mathrm{Eh}$, and temperature conditions of their formation. Reaction between hydrogen sulfide and a metal can be expressed by:

$$
\mathrm{H}_{2} \mathrm{~S}_{(\mathrm{aq})}+\mathrm{M}^{2+}{ }_{(\mathrm{aq})} \leftrightharpoons \mathrm{MS}{ }_{(\mathrm{s})}+2 \mathrm{H}^{+}{ }_{(\mathrm{aq})}
$$

where $\mathrm{M}$ is a divalent metal cation and MS is the sulfide mineral precipitant (Neculita and others, 2007a).

Reactions 7 and 8 usually lead to an increase in the alkalinity and $\mathrm{pH}$ of bioreactor discharge while simultaneously attenuating iron. Alkalinity and $\mathrm{pH}$ also rise because of the dissolution of limestone added to bioreactors to maintain a $\mathrm{pH}$ favorable for bacterial life. Sulfate-reducing bacteria such as Desulfovibrio desulfuricans reduce sulfate to sulfite by anaerobic respiration (Postgate, 1965).

\section{PASSIVE TREATMENT SYSTEMS}

\section{Passive sulfate-reducing bioreactors}

In passive sulfate-reducing bioreactors (fig. 1), AMD normally flows downward through a thin water layer into an underlying 4- to 6-ft-thick limestone-amended organic layer and is collected in an underdrain embedded in crushed limestone. Mine drainage is normally fed into the top of the treatment cell and drains out the bottom (fig. 1).
Microorganisms derive their carbon from complex carbohydrates in composted blends of agricultural waste (hay, straw, corn stover, mushroom compost, and manure), timber prduction wastes (sawdust, bark, and woochips), and yard waste (grass clippings and leaves). The organic materials are mixed with fine-grained (generally $<2 \mathrm{~mm}$ or $8 \mathrm{mesh}$ ) limestone blended into the compost layer to produce a sufficiently porous, permeable medium that provides both short-term and long-term carbon sources and alkalinity from both sulfate reduction (reaction 7) and limestone dissolution (reactions 9-12). Calcium ions and bicarbonate $\left(\mathrm{HCO}_{3}^{-}\right)$alkalinity is produced as products of these reactions.

Note that agricultural limestone varies considerably in quality and particle size distribution. The characteristics of individual stone sources must be considered (Illinois Department of Agriculture, 2010). Some of the agricultural and yard waste tends to readily decompose, releasing carbon over the short term. On the other hand, wood waste (namely, chips and sawdust) takes much longer to break down and releases carbon over the long term. Wood chips are also important in providing long-lasting matrix porosity that maintains adequate hydraulic conductivity in the mixed limestone-compost layer. Sulfate-reducing bioreactors typically use a 1-ft $(30.5-\mathrm{cm})$ layer of limestone or nonreactive gravel to serve as bedding for the underlying drain pipe network (fig. 1).

$$
\begin{aligned}
& \mathrm{CaCO}_{3} \rightarrow \mathrm{Ca}^{2+}+\mathrm{CO}_{3}^{2-} \\
& \mathrm{CaCO}_{3}+\mathrm{H}^{+} \rightarrow \mathrm{Ca}^{2+}+\mathrm{HCO}_{3}^{-} \\
& \mathrm{CaCO}_{3}+\mathrm{H}_{2} \mathrm{CO}_{3} \rightarrow \mathrm{Ca}^{2+}+2 \mathrm{HCO}_{3}^{-} \\
& \mathrm{CaCO}_{3}+\mathrm{H}_{2} \mathrm{O}+\mathrm{CO}_{2(\mathrm{~g})} \rightarrow \mathrm{Ca}^{2+}+2 \mathrm{HCO}_{3}^{-}
\end{aligned}
$$

\section{Successive alkalinity-producing systems}

Successive alkalinity-producing systems (SAPS) are a key passive technology that has been widely used in remediation of coal mine AMD (Kepler and McCleary, 1994; Watzlaf, 1997; Behum and others, 2002, 2008; Zagury and Neculita, 2007). Reducing and alkalinity-producing systems (RAPS) is one of many names applied to these vertical flow systems (Watzlaf, 1997; Thomas and Romanek, 2002a; Younger and others, 2002). Although generally similar to passive sulfate- 
reducing bioreactors, SAPS have some important design differences. The overlying water layer in a typical sulfate-reducing bioreactor is much thinner than in many RAPS-type systems (figs. 1 and 2). Normally, RAPS use a relatively thin organic layer (compost) 1.5 to $2 \mathrm{ft}(45.7-61 \mathrm{~cm})$ thick as a substrate for the bacteria. This layer promotes sulfate reduction, generation of alkalinity $\left(\mathrm{HCO}_{3}^{-}\right.$ from reaction 7 ), and the conditions for reduction of ferric iron to ferrous iron. A RAPS system also employs a relatively thick layer of limestone 2 to 3 $\mathrm{ft}(61-91 \mathrm{~cm})$ thick, which dissolves to produce additional alkalinity (fig. 2).

\section{Horizontal- and upward-flow bioreactors}

Historically, a number of passive systems have also been constructed as horizontal-flow and upward-flow bioreactors (Hedin and others, 1994a;
Kropfelova and others, 2009). Horizontal flow systems are termed "anaerobic wetlands" and have been constructed to treat both low- and highflow discharges. Most upward-flow bioreactors are constructed in a manner similar to the vertical flow systems, except the AMD or ARD is introduced into the base of the layered structure. Up-flow systems use hydraulic head to force metalladen drainage through the layered compost and limestone treatment bed (Gusek, 2005b; Martins and others, 2008). These designs have been termed "up-flow anaerobic packed bed" reactors (Jong and Parry, 2006) or "up-flow bio-column" reactors (Mondal and others, 2007). A report of a URS Corporation study (URS Corp., 2003) indicated that an effective bioreactor design used at the Elizabeth metal mine in Vermont sandwiched substrate between pipes set in inert gravel near the top and bottom of the basin (fig. 3). In this design, ARD flows into the bioreactor through one set of pipes

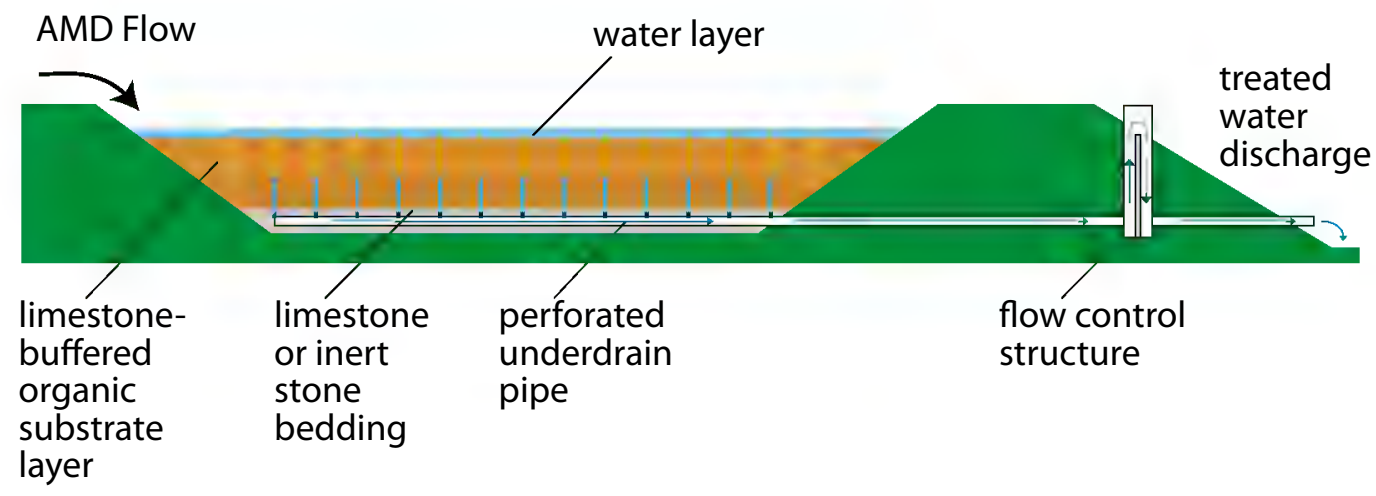

Figure 1. Cross section of a typical sulfate-reducing bioreactor (modified from Gusek and Wildeman, 2002).

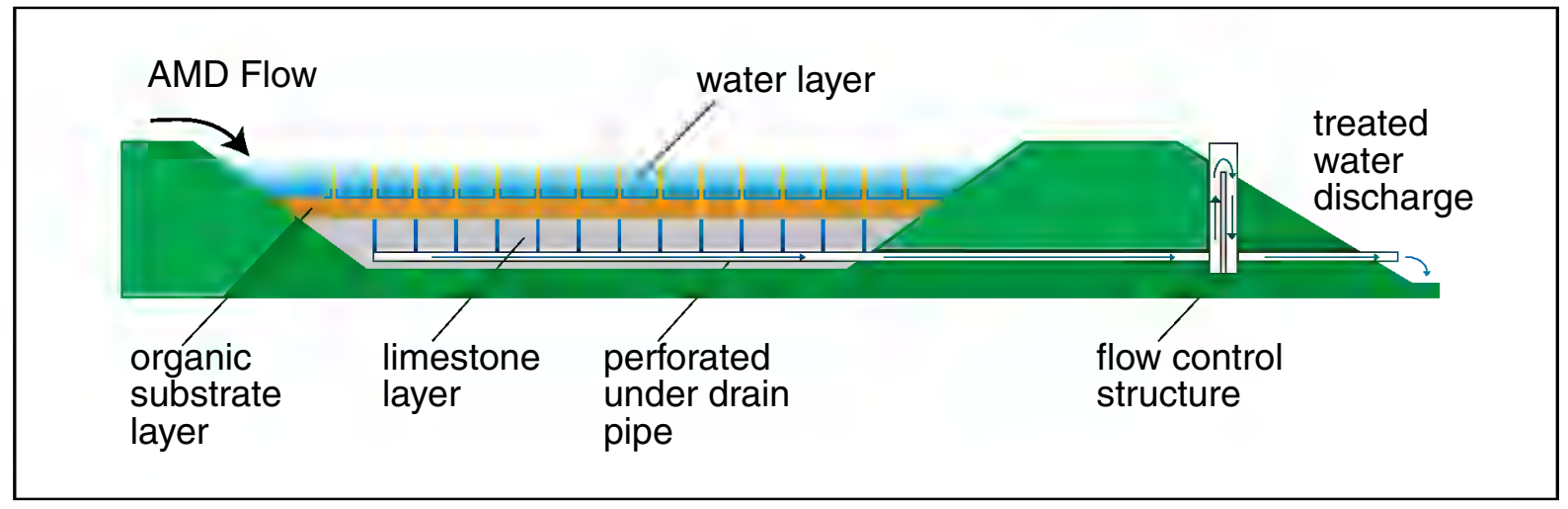

Figure 2. Cross section of a typical vertical flow wetland or reducing and alkalinity-producing system. 
and treated water flows out through the other. Flow direction can be reversed between downflow mode and up-flow mode. The ability to backflush may improve longevity by aiding in reducing the amount of clogging from compaction and precipitation. This design employs several geotextile materials that are inert to biological degradation and are intended to stabilize the structure and prevent clogging. These include geogrids and geofabric, which are constructed of woven of polyester yarn, and geonet, which is constructed of a heavier fiber woven similar to chain-link fencing (fig. 3).

\section{Design considerations}

Considerable research has evaluated various "compost" blends (Figueroa and others, 2004 and
2007; Gibert and others, 2004; Gusek, 2005a, b; Neculita and others, 2007a, b; McCauley and others, 2009; Clyde and others, 2010). In most cases, cellulosic wastes-wastes more resistant to weathering-are wood chips, sawdust, hay, alfalfa, corn stover, and walnut shells, and the materials less resistant to weathering are manure, stable cleanings, sewage sludge, spent mushroom compost, and yard waste compost. Often the particular blend is based on the price and availability of agricultural byproducts in the region where the sulfate-reducing bioreactor is constructed. For example, initial research into RAPS-type vertical flow cells (Watzlaf, 1997) demonstrated the use of spent mushroom compost, a material readily available in western Pennsylvania. Mushroom compost has the alkalinity (bicarbonate alkalinity produced in reactions 7 and 10-12), nutrient constituents, and hydraulic properties

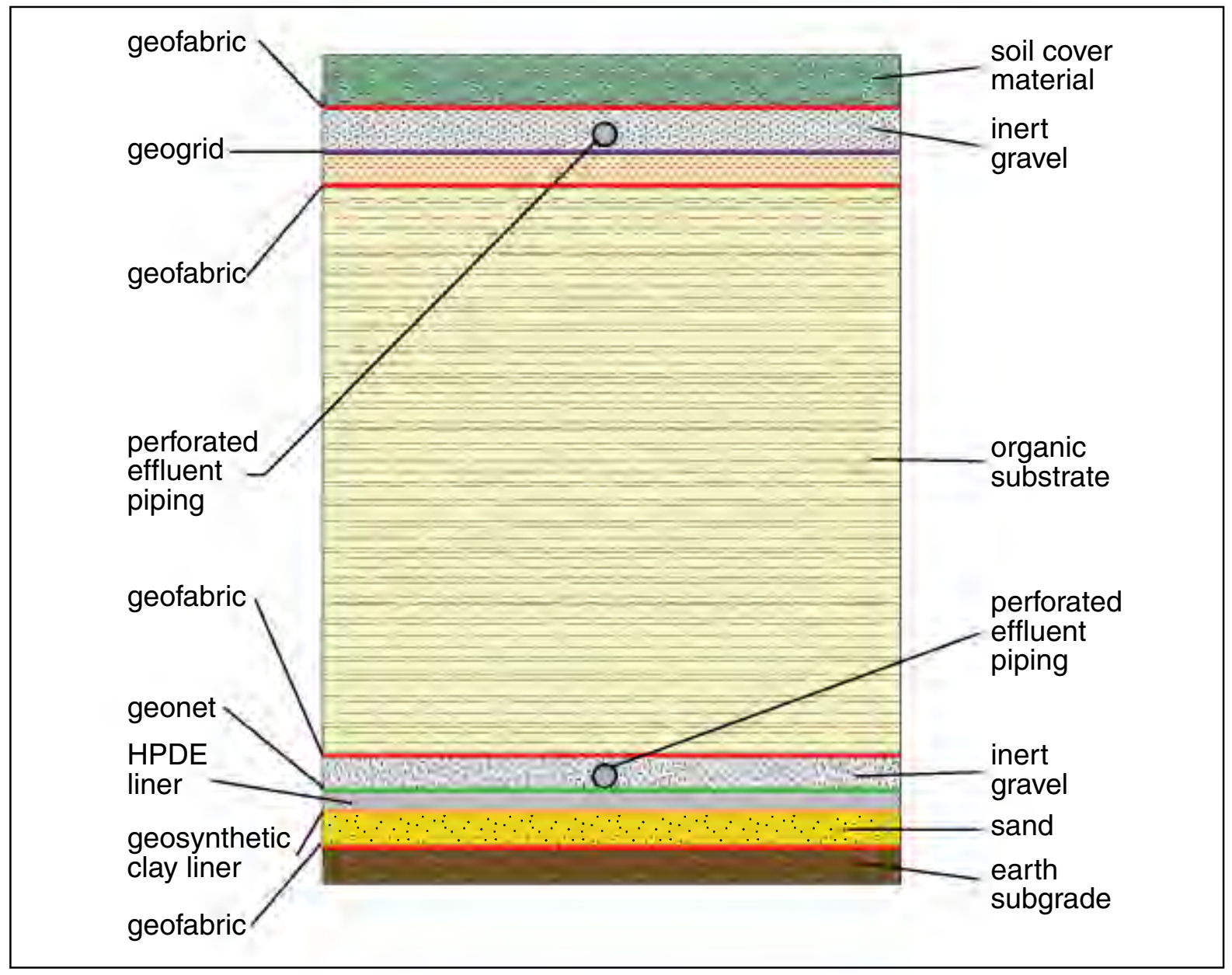

Figure 3. Cross section of the Elizabeth Mine bioreactor (modified from URS Corporation, 2003). HDPE = high-density polyethylene; geofabric is a HDPE-based woven fabric used to strengthen soil layers; geonet is a HPDE-based mesh used to enhance soil drainage; and geogrid is an extruded polymer structure used to distribute load in earthen structures. 
desirable for sulfate-reduction-based treatment. Gibert and others (2003) used municipal compost/ limestone/zero-valent (metallic) iron in a series of bench-scale (column) studies with simulated ARD in Spain. Zero-valent iron is sometimes used as a reductant, especially if the system is designed to treat Se- or As-bearing ARD from metal mines (Gibert and others, 2003; Wilkin and McNeil, 2003). Work by Gibert and others (2003) to evaluate organic substrate blends was followed by additional tests using sheep manure/ limestone blends (Gibert and others, 2008). In ARD using three reactive mixtures (Table 1) in relatively long-term (152 days) batch experiments, Neculita and others (2007b) succeeded in lowering the concentration of metals $(\mathrm{Fe}, \mathrm{Ni}, \mathrm{Cd}, \mathrm{Zn}$, and $\mathrm{Mn}$ ) by 91.8 to 99.8 percent and reducing all of the $\mathrm{SO}_{4}{ }^{2-}$ to $\mathrm{S}^{2-}$. The highest sulfate removal efficiencies were observed with 30 percent $(\mathrm{wt} / \mathrm{wt})$ cellulosic wastes (maple wood chips and sawdust; Table 1, Mixture 3). Using this mixture, sulfate decreased from $5,500 \mathrm{mg} / \mathrm{L}$ to $<1 \mathrm{mg} / \mathrm{L}$. Clyde and others (2010) conducted bench-scale tests to compare an organic waste blend $[\mathrm{V} / \mathrm{V}$ ratio $=55$ percent hemp chip/45 percent green yard waste compost/hemp chip (10 percent) mixture] to peat moss.

Gusek (2000, 2004, and 2005a) also discussed use of a variety of both cellulosic and organic wastes for bioreactor treatment of ARD, stressing the importance of a substrate mixture that will provide long-term permeability in full-scale applications.

The cellulose-degrading microorganisms and fungi that actively reduce $\mathrm{SO}_{4}{ }^{2-}$ require a favorable $\mathrm{pH}(>4.5)$ for efficient treatment. For this purpose, most solid substrate bioreactors mix into the substrate 20 to 30 percent by weight of fine-grained ( $<2 \mathrm{~mm}$ or 8 mesh) limestone or other material having a similar buffering capacity (Gusek, 2005a). To emphasize this requirement, some investigators have termed these systems "limestone-buffered organic substrate (LBOS) vertical flow wetlands" (Thomas and Romanek, 2002a, b; Thomas and others, 2004). The LBOS medium was made by mixing 25 percent limestone "screenings" with 75 percent organic material by volume. The screenings were high-calcium limestone (91.5 percent by weight $\mathrm{CaCO}_{3}$ ) with a nominal grain size of 1.23 $\mathrm{mm}$ ( 80 percent between 0.59 and $4.76 \mathrm{~mm}$ ). Thomas and Romanek (2002a) found that the LBOS effectively treated low- $\mathrm{pH}(<3.0)$, ferric iron-dominated AMD with very few limitations. However, detailed analysis of system pore water and compost mineralogy identified a thin (2-5 cm [0.78-1.96 inches]) transitional reaction layer in the upper part of the LBOS in which most of the acid neutralization and alkalinity generation occurred. This zone was composed of partially reacted limestone (32 percent reduction in neutralization potential [NP]) that graded upward into a weathered oxide zone. In the weathered oxide zone, the LBOS material was devoid of limestone amendment (85 percent reduction in NP) and was considered spent. Pore water chemistry indicated that the $\mathrm{pH}$, alkalinity, and calcium values in the weathered oxide zone above the reaction boundary were similar to the influent AMD. Below the transitional reaction zone was LBOS with unreacted limestone; this was termed the "sulfide zone." The LBOS in the sulfide zone and below represents the neutralizing potential available for future treatment. Alkalinity, $\mathrm{pH}$, and calcium content immediately below the reaction zone correspond to system effluent values. Thomas and Romanek, (2002a, 2002b) and Thomas and others (2004) suggested that the transitional reaction zone of an LBOS is capable of outperforming typical RAPS-type systems at comparable

Table 1. Test cell mixtures (weight percent) used by Neculita and others (2007b)

\begin{tabular}{|l|c|c|c|}
\hline \multicolumn{1}{|c|}{ Component } & Mixture 1 & Mixture 2 & Mixture 3 \\
\hline Maple wood chips & 3 & 2 & 10 \\
\hline Maple sawdust & 0 & 0 & 20 \\
\hline Poultry manure & 20 & 18 & 10 \\
\hline Leaf compost & 30 & 30 & 20 \\
\hline Urea (N source) & 3 & 3 & 3 \\
\hline Creek sediment (inoculants) & 37 & 15 & 15 \\
\hline Sand (porous medium) & 5 & 30 & 20 \\
\hline $\mathrm{CaCO}_{3}$ & 2 & 2 & 2 \\
\hline
\end{tabular}


loading rates when influent $\mathrm{pH}$ is low $(<3.0)$, and the limestone is fine grained ( $<2 \mathrm{~mm}$ or 8 mesh).

Rotting and others (2006, 2008a, b) investigated both bench- and field-scale bioreactors that featured additions of sand-sized high-calcium limestone. Their systems, termed "calcite dispersed alkalinity substrate," treated extremely acidic and metal-laden ARD in the Iberian Pyrite Belt. The "dispersed alkaline substrate" was also composed of a fine-grained alkaline reagent (calcite "sand") mixed with a coarse-grained and a slow-to-degrade matrix (wood chips). Rotting and others (2008b, p. 1,741) noted that: "the small grains provide a large reactive surface and dissolve almost completely before the growing layer of precipitates passivates the substrate, whereas the dispersion of nuclei for precipitation on the inert surfaces retards clogging."

Another investigation by Buccambuso and others (2007) applied a series of bench-scale microcosms (artificial, simplified ecosystems) termed the "solid-phase organic sulfate-reducing bioreactor" to remediate metal mine drainage. These microcosms were composed of varying mixtures of materials similar to those used in the United States for treatment of acidic coal mine drainage (Table 2). These test cells contained a considerable amount of dispersed limestone (20-30 percent) along with a mixture of organic material, some of which (manure, hay, and corn stover) would be easily degraded by fermentative bacteria and some of which (wood chips) would be suitable as a long-term matrix because of its slowness to break down. Wu and others (2009) conducted similar experiments using rice straw as the only component in a comparison with wood chips to evaluate agricultural waste materials readily available in their region. Similarly, Greben and others (2007) used grass cuttings (hay) as the cellulosic source in bench-scale testing of sulfate-reducing bioreactor treatment of AMD. Although straw or hay proved to be more effective than wood chips in the short term, the primary goal of passive systems is to provide long-term, unattended treatment. Cellulosic waste, such as sawdust and wood chips, helped maintain high permeability in the organic layer and, unlike easily degraded material such as straw, provides a more persistent carbon source for microorganisms.

When designing sulfate-reducing bioreactors, the metal loading rate must be considered to prevent excessive sulfide mineral accumulations and metal toxicity to the system's bacterial community. A report by the URS Corporation (2003) suggests a cumulative heavy metal (iron, copper, nickel, and zinc) flux limit of 0.15 moles $/ \mathrm{m}^{3} /$ day. To maintain an effective metal removal rate, the cumulative heavy metal loading into the system must be less than the rate of sulfate reduction to provide sufficient sulfide to precipitate metal sulfides. Note that aluminum and manganese, two metals abundant in coal mine drainage, are excluded from this calculation. Aluminum tends to form hydroxide or sulfate minerals and the solubility of manganese sulfide is too high to precipitate within a typical sulfate-reducing bioreactor.

\section{Bench and field-scale demonstrations}

To date, most sulfate-reducing bioreactor demonstrations treat ARD from metal mines that may or may not contain elevated aluminum. Acidic coal mine drainage is typically characterized by higher iron and aluminum content. High aluminum concentrations present the additional operational problem of clogging with precipitates, which can limit bioreactor longevity (Rose, 2004, 2006). Several research projects have investigated the application of sulfate-reducing bioreactors in treating AMD having elevated (>10 mg/L) aluminum (Tables 3 and 4).

Table 2. Test cell mixtures (weight percent) used by Buccambuso and others (2007)

\begin{tabular}{|l|c|c|c|c|}
\hline Component & Cell 3 & Cell 4 & Cell 5 & Cell 6 \\
\hline Wood chips & 50 & 50 & 35 & 35 \\
\hline Corn stover & 0 & 0 & 30 & 30 \\
\hline Limestone & 30 & 30 & 20 & 20 \\
\hline Hay (straw) & 10 & 10 & 0 & 0 \\
\hline Cow manure & 10 & 10 & 15 & 10 \\
\hline
\end{tabular}


Table 3. Influent water quality of sulfate-reducing bioreactor demonstration projects with elevated aluminum

\begin{tabular}{|c|c|c|c|c|c|}
\hline Parameter & $\begin{array}{c}\text { McCauley } \\
\text { and others, } 2009 \\
\text { (New Zealand AMD) }\end{array}$ & $\begin{array}{c}\text { Gibert and } \\
\text { others, } 2003 \\
\text { (simulated ARD) }\end{array}$ & $\begin{array}{c}\text { Thomas and } \\
\text { Romanek } \\
\text { 2000a, 2002b } \\
\text { (simulated ARD) }\end{array}$ & $\begin{array}{c}\text { Gusek and } \\
\text { Wildeman, } 2002 \\
\text { (Fran Mine) }\end{array}$ & $\begin{array}{c}\text { Lewis, } 2008 \\
\text { (Tab-Simco } \\
\text { Mine) }\end{array}$ \\
\hline $\mathrm{pH}$ & 2.61 & 3.0 & 2.4 & 2.3 & 2.9 \\
\hline $\mathrm{SO}_{4}{ }^{2-}(\mathrm{mg} / \mathrm{L})$ & 608 & 960 & 1,521 & 2,900 & 3,019 \\
\hline $\mathrm{Fe}(\mathrm{mg} / \mathrm{L})^{\star}$ & 65.8 & 10 & 147 & 407 & 433.3 \\
\hline $\mathrm{Al}\left(\mathrm{mg} / \mathrm{L}^{* *}\right.$ & 46.5 & 10 & 84 & 237 & 115 \\
\hline $\mathrm{Mn}(\mathrm{mg} / \mathrm{L})^{\star}$ & 1.65 & & & 42 & 35.8 \\
\hline $\mathrm{Ni}\left(\mathrm{mg} / \mathrm{L}^{*}\right.$ & 0.210 & & & 3.27 & 1.12 \\
\hline $\mathrm{Zn}(\mathrm{mg} / \mathrm{L})^{\star}$ & 1.27 & 20 & & 6.4 & 2.11 \\
\hline $\mathrm{Cu}(\mathrm{mg} / \mathrm{L})^{\star}$ & 0.199 & 20 & & 1.80 & 0.12 \\
\hline $\begin{array}{l}\text { Total acidity } \\
\left(\mathrm{mg} / \mathrm{L} \mathrm{CaCO}_{3}\right)\end{array}$ & & 450 & 1,304 & 2,800 & 1,471 \\
\hline
\end{tabular}

${ }^{*}$ All metals are dissolved.

Table 4. Performance of sulfate-reducing bioreactor demonstration projects treating mine drainage*

[D. = dissolved metals.]

\begin{tabular}{|c|c|c|c|c|c|}
\hline Parameter & $\begin{array}{c}\text { McCauley } \\
\text { and others, } \\
2009^{\dagger} \\
\text { (New Zealand AMD) }\end{array}$ & $\begin{array}{c}\text { Gibert and } \\
\text { others, } \\
2003 \text { and } 2004 \\
\text { (simulated ARD) }\end{array}$ & $\begin{array}{l}\text { Thomas and } \\
\text { Romanek, } \\
\text { 2002b } \\
\text { (simulated ARD) }\end{array}$ & $\begin{array}{c}\text { Gusek and } \\
\text { Wildeman, } 2002 \\
\text { (Fran Mine) }^{\dagger}\end{array}$ & $\begin{array}{l}\text { Lewis, 2008, } \\
\text { unpublished data } \\
\text { (Tab-Simco } \\
\text { Mine })^{\dagger}\end{array}$ \\
\hline $\begin{array}{l}\text { Bioreactor } \\
\text { discharge } \mathrm{pH}\end{array}$ & & 7.0 & 6.4 & 6.5 & 6.4 \\
\hline $\begin{array}{l}\text { Discharge } \\
\mathrm{SO}_{4}^{2-}(\mathrm{mg} / \mathrm{L})\end{array}$ & & & 1,192 & & 2,100 \\
\hline $\begin{array}{l}\mathrm{SO}_{4}{ }^{2-} \text { removal } \\
\text { rate (moles/ } \\
\mathrm{m}^{-3} / \text { day }^{-1} \text { ) }\end{array}$ & $\begin{array}{l}0.061-0.421 \\
\text { avg. }=0.308\end{array}$ & $0.17-0.44$ & $0.25-0.35$ & & 0.187 \\
\hline $\mathrm{SO}_{4}{ }^{2-}$ removal & $\begin{array}{c}2.7-98 \% \\
\text { avg. }=41.2 \%\end{array}$ & $18-27 \%$ & $20 \%$ & & $29.6 \%$ \\
\hline $\begin{array}{l}\text { Discharge } \\
\text { D. Fe (mg/L) }\end{array}$ & & & 15.0 & $0.37-45.7$ & 77.0 \\
\hline D. Fe removal & $94-99 \%$ & $>99 \%$ & $90 \%$ & & $82 \%$ \\
\hline $\begin{array}{l}\text { Discharge } \\
\text { D. Al (mg/L) }\end{array}$ & & $<0.01$ & 0.05 & $0.21-0.67$ & 0.11 \\
\hline D. Al removal & $>99 \%$ & $>99 \%$ & $>99 \%$ & $>99 \%$ & $>99 \%$ \\
\hline $\begin{array}{l}\text { Discharge } \\
\mathrm{Mn}(\mathrm{mg} / \mathrm{L})\end{array}$ & & & & $2.86-38.8$ & 30.73 \\
\hline D. Mn removal & $36.2 \% \max$. & & & $7.6-93.2 \%$ & $14.2 \%$ \\
\hline D. Ni (mg/L) & 0.210 & & & $0.03-0.28$ & $0.02(98 \%)$ \\
\hline D. Zn (mg/L) & 1.27 & $(>99 \%)$ & & $0.02-0.1$ & $0.09(96 \%)$ \\
\hline D. Cu (mg/L) & & $(>99 \%)$ & & $<0.01-0.01$ & $0.05(58 \%)$ \\
\hline
\end{tabular}

* Data shows the performance of the sulfate-reducing bioreactor component only.

${ }^{\dagger}$ Acidic coal mine drainage is treated. 
Gusek and Wildeman (2002) described a demonstration treatment system at the abandoned Fran Mine in Clinton County, Pa. The 30 to 40 gpm (114$151 \mathrm{Lpm})$ discharge from Fran Mine is considered one of the worst in Pennsylvania and exhibits high $\mathrm{Fe}, \mathrm{Al}$, and trace metals and low $\mathrm{pH}$ (Table 3). Bench-scale tests included five cells using various organic substrate mixtures operated over a 20-week period. The construction details of the test cells were not published. However, influent water had low $\mathrm{pH}$, high $\mathrm{Fe}(370 \mathrm{mg} / \mathrm{L}$ in the final 6 weeks of sampling), and high $\mathrm{Al}$ content (Table 3). Average effluent Fe ranged from $3.7 \mathrm{mg} / \mathrm{L}$ to $47.5 \mathrm{mg} / \mathrm{L}$ over the same 6-week period. With an average influent concentration of $237 \mathrm{mg} / \mathrm{L}$, aluminum dropped from a low of $0.21 \mathrm{mg} / \mathrm{L}$ to a high of $0.67 \mathrm{mg} / \mathrm{L}$ during this 6-week period (Gusek and Wildeman, 2002). An examination of the treatment matrix at the end of the study did not reveal any visible accumulations of aluminum hydroxide precipitate (reaction 13), even in the cell that contained 50 percent limestone by weight.

$$
\mathrm{Al}^{3+}+3 \mathrm{H}_{2} \mathrm{O} \leftrightharpoons \underset{\text { (gibbsite) }}{\mathrm{Al}\left((\mathrm{OH})_{3(\mathrm{~s})}\right.}+3 \mathrm{H}^{+}
$$

McCauley and others (2009) conducted a series of bench tests evaluating sulfate-reducing bioreactor treatment of coal mine drainage in New Zealand and found that mussel shells derived from industrial-scale seafood packaging outperformed limestone additions as alkaline source material. Suggested treatment design goals derived from this study include: 1) 0.3 moles of sulfate loading per $\mathrm{m}^{2}$ per day for high sulfate removal (94.1\%), 2) 0.4 moles of combined metal loading per $\mathrm{m}^{2}$ per day with partial sulfate removal $(46 \%)$, and 3) 0.8 moles of metal loading per $\mathrm{m}^{2}$ per day with low sulfate removal (16.6\%) (McCauley and others, 2009).

A large sulfate-reducing bioreactor was constructed in 2007 near Carbondale, Ill., at the abandoned Tab-Simco coal mine (fig. 4). Acid mine drainage enters the bioreactor from a collection ditch (bioreactor inlet, Figure 4 foreground) and a series of seeps (bioreactor seeps) along the southern side of the structure. The 21.1-gpm (79.9-Lpm) discharge (bioreactor outlet) from the bioreactor flows through a series of aeration structures (oxidation pond in Figure 4) to the receiving stream (system outlet).

This treatment system is being extensively studied by a research team from the state of Illinois, the Office of Surface Mining Reclamation and Enforcement (OSMRE), and Southern Illinois University Carbondale (Smith, 2002; Lewis, 2008; Lefticariu and others, 2009; Segid, 2010). Total iron and aluminum concentrations in the AMD are 433.3 and $115 \mathrm{mg} / \mathrm{L}$, respectively (Table 3). The 0.75 -acre (0.3-ha) Tab-Simco bioreactor was built

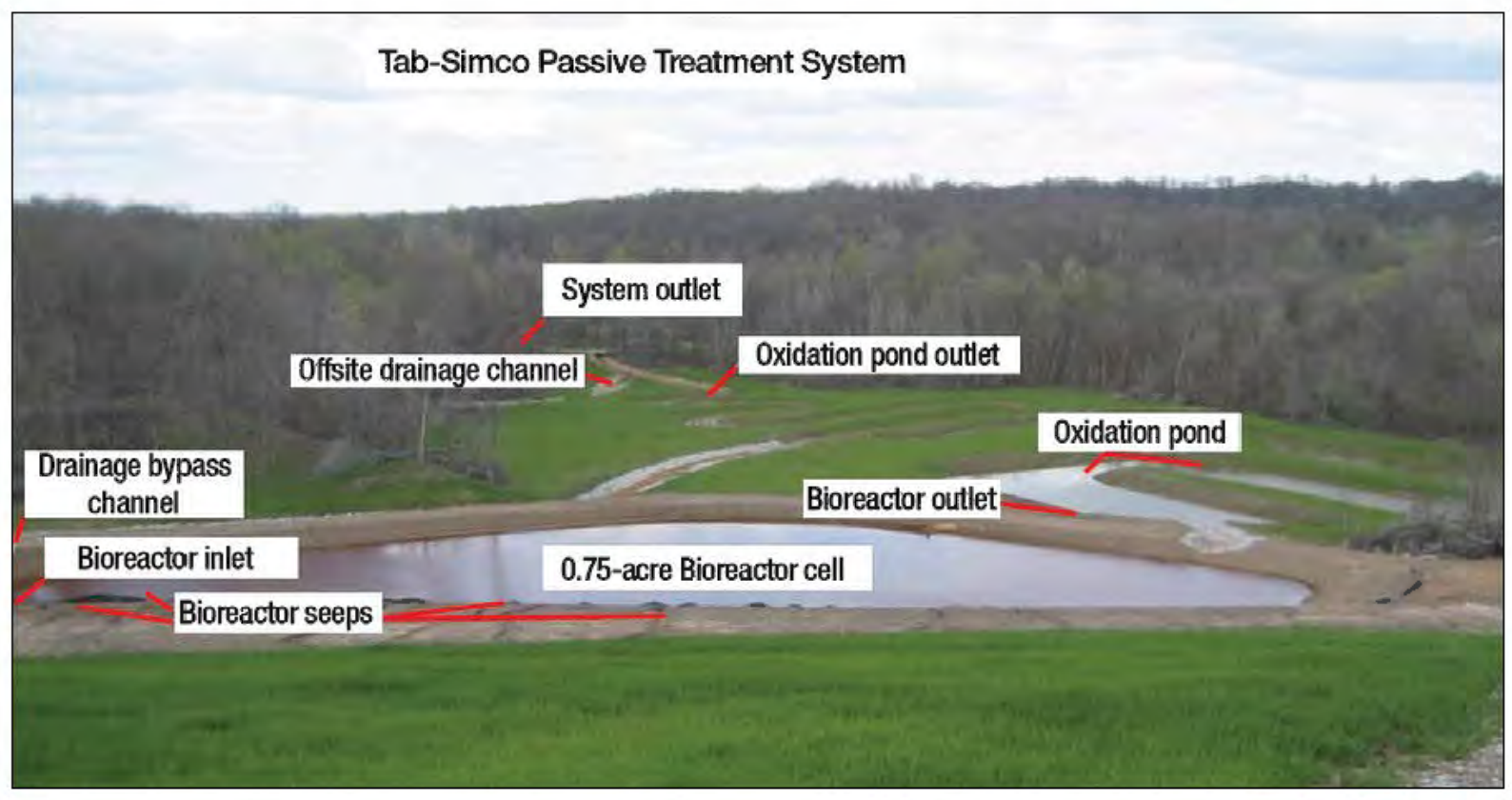

Figure 4. Photograph showing an overview of the Tab-Simco sulfate-reducing bioreactor-based treatment system. The view is to the north; flow is from the upland bioreactor through the oxidation pond toward the system outlet. 
using approximately 7,700 cubic yards (5,887 $\left.\mathrm{m}^{3}\right)$ of limestone-amended "compost"-53 percent wood chips, 27 percent straw, 11 percent seasoned municipal (yard waste) compost, and 9 percent agricultural ground limestone by volume (Lewis, 2008). This system has proven highly successful in treating poor-quality AMD.

Although the Tab-Simco system is smaller than originally planned because of the geotechnical constraints of the site (Lewis, 2008), nevertheless, $\mathrm{SO}_{4}$ loading of 0.61 moles $\mathrm{m}^{-3}$ day $^{-1}$ and a cumulative metal loading (excluding $\mathrm{Mn}$ ) of 0.232 moles $\mathrm{m}^{-3}$ day $^{-1}$ is consistent with design guidelines (Gusek, 2002, 2005b; MSE Technology Applications, 2006). Metal loading is somewhat higher than the cumulative heavy metal (iron, copper, nickel, and zinc) flux limit of 0.15 moles $/ \mathrm{m}^{3} /$ day recommended by the URS Corporation report (2003). In the first two years of operation, metal removal by the Tab-Simco bioreactor alone has been 81.8 percent for $\mathrm{Fe}, 99.9$ percent for $\mathrm{Al}, 98.5$ percent for $\mathrm{Ni}$, and 95.7 percent for $\mathrm{Zn}$. Subsequent Fe precipitation occurs in follow-up oxidation cells (fig. 5) with a median dissolved Fe concentration in discharge from the system of only $1.5 \mathrm{mg} / \mathrm{L}$. The median total iron is somewhat higher at $13.7 \mathrm{mg} / \mathrm{L}$, but the water quality is improved during periods of precipitation by dilution water from an offsite freshwater drainway (fig. 4, offsite drainage channel).

\section{Longevity}

Information concerning the longevity of vertical flow systems is limited to typical SAPS-type systems (fig. 2). Longevity of SAPS treating highaluminum drainage $(>20 \mathrm{mg} / \mathrm{L})$ is limited. Problems occur when the $\mathrm{pH}$ rises above 4.5 in the limestone layer. At this $\mathrm{pH}$, aluminum hydroxide will precipitate (reaction 13) and accumulate, eventually clogging the system. Regular flushing of the SAPS drain pipes may extend system life (Watzlaf and others, 2002; Weaver and others, 2004; Hedin Environmental, 2008). Within compost-amended sulfate-reducing bioreactors, Gusek and Wildeman (2002) suspected that aluminum precipitates as relatively insoluble aluminum sulfate minerals, such as alunite, by the following reaction.

$$
\begin{aligned}
& 3 \mathrm{Al}^{3+}+\mathrm{K}^{+}+6 \mathrm{H}_{2} \mathrm{O}+2 \mathrm{SO}_{4}^{2-} \leftrightharpoons \mathrm{KAl}_{3}(\mathrm{OH})_{6}\left(\mathrm{SO}_{4}\right)_{2} \\
& +6 \mathrm{H}^{+}
\end{aligned}
$$

Alunite is more compact than the bulky, amorphous $\mathrm{Al}(\mathrm{OH})_{3}$ (solid or colloid forms). Additional studies (X-ray diffraction) are needed to show whether this material is amorphous or crystalline gibbsite or alunite. Research by Thomas and Romanek (2002a, b), Rotting and others (2008b), and McCauley and others (2009) confirmed the presence of aluminum oxyhydrosulfates in deeper substrate zones of bench-scale bioreactor microcosms (reaction 15) (Thomas and Romanek, 2002b).

$$
\mathrm{Al}^{3+}+\mathrm{H}_{2} \mathrm{O}+\mathrm{H}_{2} \mathrm{SO}_{4} \leftrightharpoons \mathrm{Al}\left(\mathrm{SO}_{4}\right)(\mathrm{OH})+3 \mathrm{H}^{+}
$$

Iron is removed as iron hydroxides and oxyhydroxides in the upper oxidized zone, whereas the lower sulfidic zones contained black iron monosulfide (FeS) precipitates. Neculita and others (2007a) and Thomas and Romanek (2002b) identified precipitates containing iron and sulfur within a sulfidic zone within bench bioreactor test cells using backscattered scanning electron microscopy and electron microprobe techniques, respectively. Periodic flushing of a large sulfatereducing bioreactor and wetland passive treatment system at the Enos site in Indiana produced large plumes of black particles that are suspected to represent iron monosulfide (Behum and others, 2008, 2010). Additional discussion of this facility is presented by the author elsewhere in this publication (Behum and others, 2012, [this volume]).

\section{Performance}

Limited performance data are available for pilotand full-scale passive sulfate-reducing bioreactors treating coal mine drainage (Gusek, 2000; Gusek and Wildeman, 2002; Gusek, 2005b). Results from evaluations of the Fran and Tab-Simco mines are presented in Table 4. Empirical observations by Gusek (2005a) and McCauley and others (2009) suggested a design criteria of 1 cubic meter of bioreactor cell volume for each 0.3 to 0.4 moles of metal removed per day. Under these conditions, most metals except manganese are retained within the bioreactor (Doshi, 2006). Divalent metals Fe, Ni, Zn, and $\mathrm{Cu}$ are retained within the bioreactor primarily as sulfides, and in bench- and field-scale applications nearly complete removal of trace metals $\mathrm{Ni}, \mathrm{Zn}$, and $\mathrm{Cu}$ is observed (Gusek and Wildeman, 2002; Kuyucak and others, 2006; Zagury and Neculita, 2007). Additional metals are immobilized by cation exchange reactions with, or are adsorbed onto, organics and hydroxides. Most manganese 
passes though the bioreactor cell (Table 4) because of the higher solubility of MnS under circumneutral $\mathrm{pH}$ (Hedin and others, 1994a).

Performance of a sulfate-reducing bioreactor is dependent on the hydraulic retention time (HRT). At least 3 to 5 days has been suggested as sufficient time for $\mathrm{H}_{2} \mathrm{~S}$ to react with and precipitate divalent metals (URS, 2003; Kuyucak and others, 2006; Neculita and others, 2008a). A bench-scale study by Clyde and others (2010) showed that an HRT of 1.2 to 5 days was sufficient to remove $\mathrm{Fe}, \mathrm{Ni}, \mathrm{Cu}$, and $\mathrm{Zn}$ contaminants from simulated ARD. Neculita and others (2008b) found that sulfate-reducing bioreactors were effective treatment systems given HRTs of 7.3 and 10 days. Retention time is ultimately set by the loading rate of the inlet AMD and the design's metal removal rate as determined by bench- and pilot-scale testing. However, the designer must consider factors such as changes in influent AMD composition caused by increased or decreased rainfall, changes in the activity of the microbes, variations in the flow patterns (for example, channeling), and reductions in pore space because of metal accumulation. These conditions suggest inclusion of a safety factor, for example, increasing the size (retention time within the compost) by 30 percent where possible considering the availability of space and funding.

Considerable dissolved Fe (depending on the $\mathrm{pH}$ conditions of the cell) may pass through bioreactors where loading is high (Lewis, 2008) (Table 3). Bioreactor discharge bearing dissolved $\mathrm{Fe}$ would typically have high alkalinity (>200 mg/L) from limestone dissolution (reactions 9-12) and sulfate reduction (reaction 7) and circumneutral $\mathrm{pH}$. These are conditions that would promote rapid Fe precipitation (for example, reactions 3 and 5) in a downstream oxidation pond or surface flow (aerobic) wetlands. Tab-Simco bioreactor discharge, for example, has a median $\mathrm{pH}$ of 6.4 and net alkalinity of $150 \mathrm{mg} / \mathrm{L}$ (Lewis, 2008). McCauley and others (2009) reported an average sulfate removal

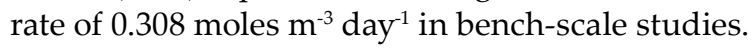
This value compares favorably with conventional design goals of 0.25 to 0.30 moles $\mathrm{m}^{-3} \mathrm{day}^{-1}$ (Gusek, 2002, 2005a; MSE Technology Applications, 2006). An even higher removal rate of 0.44 moles $^{-3}$ day $^{-1}$ was reported in the bench-scale test by Gibert and others (2004). Unpublished data from the TabSimco study gave a slightly lower sulfate removal rate of 0.187 moles $\mathrm{m}^{-3}$ day $^{-1}$. However, this

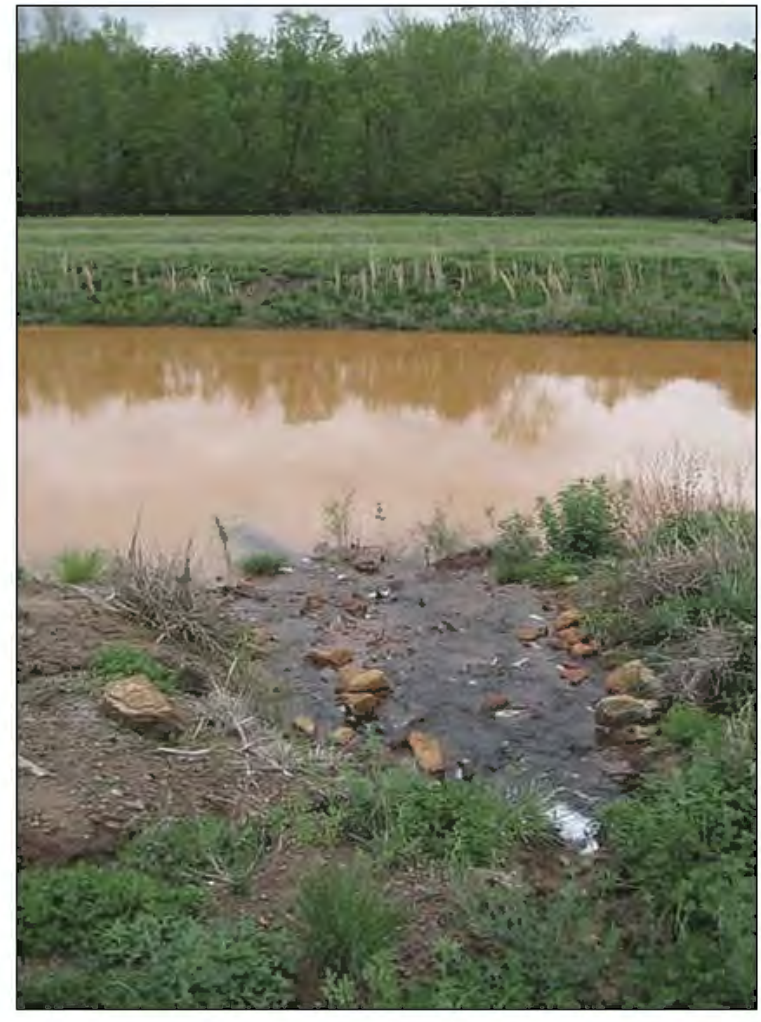

Figure 5. Photograph showing discharge of suspected iron monosulfide (black particulate material) from the Tab-Simco Bioreactor.

system is treating inlet water that has a high nitrate level (up to $300 \mathrm{mg} / \mathrm{L}$ ). Nitrate reduction is biologically favored compared to sulfate reduction by the particular strains for sulfate-reducing bacteria observed within the bioreactor. This would suppress sulfate removal by this system until nitrate is removed (Lefticariu and others, 2009).

McCauley and others (2009) provided the following criteria for the design of bioreactor size based on sulfate and cumulative metal loading rates (all divalent metals except manganese). The observed removal rates are also listed as 0.3 moles $\mathrm{m}^{-3}$ day $^{-1}$ for sulfate removal (mean reduction of $94.1 \%$ for the range $87.6-98.0 \%$ ); 0.4 moles $\mathrm{m}^{-3}$ day $^{-1}$ for cumulative, non-Mn metal removal (mean reduction of $99.0 \%$ with a range of $98.5-99.9 \%$ ); and partial sulfate removal (mean reduction of $46 \%$ with a range of 39.6-57.8\%); and 0.8 moles $\mathrm{m}^{-3}$ day $^{-1}$ for cumulative metal removal (mean reduction of $98.4 \%$ with a range of $98.2-98.6 \%$ ); and partial sulfate removal (mean reduction of $16.6 \%$ with a range of $11.9-19.2 \%)$. 
Research by Neculita and others (2007b) and Neculita and Zagury (2008) indicated that higher C/N ratios $(>10)$, chemical oxygen demand to sulfate ratios (COD: $\mathrm{SO}_{4}^{2-}=0.65-3.88$ ), and dissolved organic carbon to sulfate ratios (DOC: $\mathrm{SO}_{4}{ }^{2-}=0.32-1.78$ ) (Neculita and others, 2007a) are all associated with increased sulfate reduction and metal removal. The work of Neculita and others (2008a) and Clyde and others (2010) confirmed that C/N and DOC: $\mathrm{SO}_{4}^{-2}$ ratios could be used to indicate optimized sulfate reduction in bioreactors treating ARD or AMD when the substrate contained natural organic wastes.

\section{ACTIVE AND SEMIPASSIVE TREATMENT SYSTEMS}

Active or semipassive sulfate-reducing bioreactor systems use continuous additions of simple liquid carbon sources, including lactate, methanol, ethanol, and glycerol, that are easier for the bacteria to process. Some of these systems are part of industrial plant operations (Dijkman and others, 1999; Johnson and Hallberg, 2005), while others operate in remote areas in a semipassive operation (USEPA, 2006). The active-type sulfidogenic bioreactor technologies in full-scale deployment are the Biosulfide $^{\circledR}$ and the THIOPAQ ${ }^{\circledR}$ processes. Biosulfide technology is marketed by Bioteq (Vancouver, B.C., Canada) (Rowley and others, 1997). THIOPAQ is marketed overseas by Paques B.V. (Balk, Netherlands) (Boonstra and others, 1999) and, in North America, under license by Bioteq. Active and semipassive bioreactors add a liquid neutralization agent, such as sodium hydroxide $(\mathrm{NaOH})$, to raise bioreactor $\mathrm{pH}$ to a level favorable for sulfate-reducing bacteria activity (Zamzow and others, 2006).

Smaller semipassive systems have been developed in recent years to treat metal mine drainage in remote sites (Tsukamoto and others, 2004). Most semipassive bioreactors use alcohols such as ethanol or methanol as the carbon source for bacteria. However, pure alcohol-based feedstock is expensive and an alcohol-rich waste source is preferable. Considerable research has investigated the applicability of various feedstock including lactate, ethanol, methanol, and waste glycerin (glycerol). These compounds share the common attribute of providing a liquid feedstock that microorganisms can easily degrade to acetic acid $\left(\mathrm{CH}_{3} \mathrm{COOH}\right)$, a compound readily used by sulfate-reducing bacteria such as Desulfovibrio and Desulfotomaculum.

\section{Lactate}

The organic lactate anion $\left[\mathrm{CH}_{3} \mathrm{CH}(\mathrm{OH}) \mathrm{COO}^{-}\right.$ or $\mathrm{C}_{3} \mathrm{H}_{5} \mathrm{O}_{3}^{-}$] forms by dissolution of lactic acid (2-hydroxypropanoic acid, $\mathrm{C}_{3} \mathrm{H}_{6} \mathrm{O}_{3}$ ) in water and is one of the most widely used substrates for cultivating sulfate-reducing bacteria in laboratory-scale experiments. The reaction of lactate, sulfate, and protons yields acetic acid $\left(\mathrm{CH}_{3} \mathrm{COOH}\right)$, bicarbonate, and hydrogen sulfide.

$$
\begin{aligned}
& 2 \mathrm{C}_{3} \mathrm{H}_{5} \mathrm{O}_{3}^{-}+\mathrm{SO}_{4}{ }^{2-}+2 \mathrm{H}^{+} \rightarrow 2 \mathrm{CH}_{3} \mathrm{COOH} \\
& +2 \mathrm{HCO}_{3}^{-}+\mathrm{H}_{2} \mathrm{~S}_{(\mathrm{aq})} \\
& \mathrm{CH}_{3} \mathrm{COOH}+\mathrm{SO}_{4}{ }^{2-} \rightarrow 2 \mathrm{HCO}_{3}^{-}+\mathrm{H}_{2} \mathrm{~S}_{(\mathrm{aq})}
\end{aligned}
$$

El Bayoumy and others (1999) established the optimum conditions for sulfide production by sulfatereducing bacteria utilizing lactate in bench-scale experiments with an apparatus termed an "upflow, anaerobic fixed-film reactor" (UAFFR). The organic carbon source lactate, along with the required sulfate, nitrogen, and phosphorus as nutrients, was metered to a test UAFFR inoculated with sulfate-reducing bacteria. El Bayoumy and others (1999) found that anaerobic sulfide reduction was optimized using an organic loading rate of $6 \mathrm{~kg} \mathrm{~d}^{-1}$ $\mathrm{m}^{-3}$, while the ratio of theoretical oxygen demand (ThOD) to sulfate (ThOD: $\mathrm{SO}_{4}$ ) ranged from 1.5 to 2.25; a value of 2.0 is recommended. This study also identified optimum total nitrogen and phosphorus demands at 250 and $50 \mathrm{mg} / \mathrm{L}$, respectively. The initial decrease in sulfide production attributed to nitrogen toxicity was observed at a total nitrogen concentration above $600 \mathrm{mg} / \mathrm{L}$. The optimum ThOD:N:P for sulfide production and growth of sulfate-reducing bacteria in the UAFFR was 100:5:1. El Bayoumy and others (1999) suggest that sulfate removal can be estimated in a lactate-feed UAFFR using the equation:

$$
[\mathrm{S}]=120\left(1-\mathrm{e}^{-0.62(\mathrm{OLR})}\right)
$$

where [S] is the concentration of sulfate in $\mathrm{mg} / \mathrm{L}$ and OLR is the organic loading rate in $\mathrm{kg} \mathrm{d}^{-1} \mathrm{~m}^{-3}$. One problem with the full-scalefield use of lactate is its relatively high cost $(\$ 1.00 / \mathrm{lb}$ as sodium lactate). 
Methanol

Methanol or methyl alcohol $\left(\mathrm{CH}_{3} \mathrm{OH}\right)$ has advantages and disadvantages for use as a carbon source in a semipassive sulfate-reducing bioreactor. Advantages include: 1) low cost, 2) low freezing point, and 3) low viscosity $\left(0.69 \mathrm{mPa} \cdot \mathrm{s}\right.$ at $\left.10^{\circ} \mathrm{C}\right)$. The principal disadvantage is that methanol is extremely toxic. If ingested, as little as $10 \mathrm{~mL}$ can cause permanent blindness in humans and a likely fatal dose is only 100 to $125 \mathrm{~mL}$ (about $4 \mathrm{oz}$ ) (Vale, 2007). Therefore, the use of methanol is not warranted for nonsecure applications such as semipassive bioreactors. However, methanol may be appropriate for use in secured active treatment facilities that provide worker safety training. The bacterially mediated sulfate-reduction reaction with reagentgrade methanol as the carbon source is:

$$
4 \mathrm{CH}_{3} \mathrm{OH}+3 \mathrm{SO}_{4}^{2-}+\mathrm{H}^{+} \rightarrow 4 \mathrm{HCO}_{3}^{-}+3 \mathrm{H}_{2} \mathrm{~S}+2 \mathrm{H}_{2} \mathrm{O}
$$

Tsukamoto and Miller (1999) compared methanol to lactate for treating synthetic AMD in a benchscale study. The study was prompted by the premature failure of the compost-based bioreactor at the Leviathan metal mine, Alpine County, California. A field-scale evaluation at this site followed the bench-scale tests. In both cases, methanol additions were designed to remove 50 percent of the sulfate. Methanol additions in both laboratoryand field-scale tests demonstrated the suitability of methanol as a carbon source for sulfatereducing bacteria. Subsequent laboratory-scale tests used methanol-fed reaction columns to simulate a semiactive treatment system for treating the Leviathan mine drainage (Tsukamoto and others, 2004). Methanol was added at a rate to achieve 50 percent of stoichiometric sulfate removal from synthetic AMD with $900 \mathrm{mg} / \mathrm{L}$ sulfate. Methanol performance was compared to that of ethanol under test conditions of moderate $\mathrm{pH}$ (4.2), low $\mathrm{pH}$ (2.5-3.5), moderate temperature $\left(22^{\circ} \mathrm{C}\left[71.6^{\circ} \mathrm{F}\right]\right)$, and low temperature $\left(5^{\circ} \mathrm{C}-15^{\circ} \mathrm{C}\right.$ $\left.\left[41-59^{\circ} \mathrm{F}\right]\right)$. In all cases a period of acclimation was required for the bacteria, but the acclimation period for ethanol was lower. Both alcohols proved to be an effective carbon source and both averaged 42 percent sulfate removal following acclimation. During bench-scale tests efficient AMD treatment occurred at low-temperature $\left(5-15^{\circ} \mathrm{C}\left[41-59^{\circ} \mathrm{F}\right]\right)$ and low- $\mathrm{pH}(\mathrm{pH}=3.5)$ conditions. The low-temperature study (Tsukamoto and Miller, 1999) indicated that removal of 44.8 to 55.2 percent sulfate along with 98 percent iron was possible with methanol.
Low-pH experiments showed effective sulfate removal (41.9-58.1\%) and 97 percent iron removal in experimental methanol columns (Tsukamoto and Miller, 1999). A follow-up pilot-scale sulfatereducing bioreactor treated poor-quality AMD during cold winter conditions (influent $\mathrm{Fe}=242$ $\mathrm{mg} / \mathrm{L}$ and sulfate $=2005 \mathrm{mg} / \mathrm{L}$ ) (Tsukamoto and Miller, 1999) using methanol additions. Measurements of this test facility found a 30.7 percent sulfate removal and 93.4 percent iron removal.

\section{Ethanol}

Ethanol or ethyl alcohol $\left(\mathrm{C}_{2} \mathrm{H}_{5} \mathrm{OH}\right.$ or $\left.\mathrm{CH}_{3} \mathrm{CH}_{2} \mathrm{OH}\right)$ has one key advantage over methanol-it is relatively nontoxic. Ethanol is miscible in water so it readily mixes with AMD; it is resistant to freezing and also has low viscosity. On the other hand, ethanol costs much more than methanol and its miscibility in water means it could readily pollute groundwater, a concern when spilled in large quantities. Sulfate reduction with reagent-grade ethanol as the carbon source is:

$$
\begin{aligned}
& 2 \mathrm{CH}_{3} \mathrm{CH}_{2} \mathrm{OH}+3 \mathrm{SO}_{4}{ }^{2-}+2 \mathrm{H}^{+} \rightarrow 4 \mathrm{HCO}_{3}^{-}+ \\
& 3 \mathrm{H}_{2} \mathrm{~S}+2 \mathrm{H}_{2} \mathrm{O}
\end{aligned}
$$

Other microorganisms within the bioreactor may break ethanol down to acetate, which is more easily used by sulfate-reducing bacteria (Field and Sierra-Alverez, 2005):

$$
\begin{aligned}
& 2 \mathrm{CH}_{3} \mathrm{CH}_{2} \mathrm{OH}+\mathrm{SO}_{4}^{2-} \rightarrow 2 \mathrm{CH}_{3} \mathrm{COO}^{-}+ \\
& \mathrm{HS}^{-}+\mathrm{H}^{+}+2 \mathrm{H}_{2} \mathrm{O} \\
& \mathrm{CH}_{3} \mathrm{COO}^{-}+\mathrm{SO}_{4}^{2-} \rightarrow 2 \mathrm{HCO}_{3}^{-}+\mathrm{HS}^{-}
\end{aligned}
$$

Tsukamoto and Miller (1999) and Tsukamoto and others (2004) found that ethanol-based bioreactors were effective in removing iron and trace metals (namely, discharge $\mathrm{Fe}<3 \mathrm{mg} / \mathrm{L}$ and $\mathrm{Zn}<0.1 \mathrm{mg} / \mathrm{L}$ ) and were effective in colder climate conditions. Low-temperature studies $\left(\mathrm{T}=5-15^{\circ} \mathrm{C}\right.$; Tsukamoto and Miller, 1999) indicated that removal of 48.6 to 51.2 percent sulfate along with 98 percent iron was possible with ethanol. Low-pH (2.5-3.5) experiments showed effective sulfate removal (48.8-58.1\%) and up to 98 percent iron removal in experimental ethanol columns (Tsukamoto and Miller, 1999). Buccambuso and others (2007) conducted a largediameter 22-inch $(55.9-\mathrm{cm})$ laboratory column study of solid substrate and ethanol-fed sulfatereducing bioreactors and confirmed the acceptable 
metal and sulfate removal capabilities of ethanolfeed bioreactors. Zinc, the primary metal contaminant, was removed to $<0.1 \mathrm{mg} / \mathrm{L}$, which represented 95 percent removal. Sulfate removal ranged from 60 to 70 percent in warm weather periods to 18 to 35 percent in winter.

Fields and Sierra-Alverez (2005) used a mixture of ethanol and acetate as the electron-donor source in a series of laboratory column experiments that treated ARD having an influent $\mathrm{pH}$ as low as 4.5, $100 \mathrm{mg} / \mathrm{L}$ copper, $15 \mathrm{mg} / \mathrm{L}$ zinc, and $15 \mathrm{mg} / \mathrm{L}$ nickel. Sulfate reducers were able to precipitate these heavy metals with efficiencies greater than 99.5 percent. Sahinkaya and Yucesoy (2010) also conducted a bench-scale study of an ethanol-fed sulfidogenic bioreactor treating zinc- and copperbearing wastewater. In this study, more than 99 percent of the metals were removed with a $\mathrm{pH}$ as low as 3.0, a total metal loading of up to $500 \mathrm{mg} / \mathrm{L}$, and a COD/SO $/ 4$ ratio of 0.67. Costa and others (2009) successfully substituted low-cost ethanol-bearing wine production waste for distilled ethanol, removing 61 to 91 percent of the Fe and 97 percent for both $\mathrm{Zn}$ and $\mathrm{Cu}$. Similarly, Goncalves and others (2007) demonstrated in bench-scale tests that the use of low-cost stillage (ethanol distillery wastewater) as an acceptable sulfate-reducing bioreactor feedstock. In these experiments, synthetic ARD (50 to $70 \mathrm{mg} / \mathrm{L} \mathrm{Zn,} 2 \mathrm{mg} / \mathrm{L} \mathrm{Cd}$, and 400 $\mathrm{mg} / \mathrm{L}$ sulfate) was treated in upflow bioreactors to produce effluent that meets the goals of $5.0 \mathrm{mg} / \mathrm{L}$ for $\mathrm{Zn}$ and $0.2 \mathrm{mg} / \mathrm{L} \mathrm{Cd}$ and a 30 percent sulfate removal (Goncalves and others, 2007).

\section{Glycerol}

Zamzow and others (2006) demonstrated that glycerol-methanol waste from biodiesel manufacture should be considered for semiactive bioreactors. About 1 pound $(0.45 \mathrm{~kg})$ of glycerol $\left(\mathrm{C}_{3} \mathrm{H}_{5}(\mathrm{OH})_{3}\right.$ or $\mathrm{C}_{3} \mathrm{H}_{8} \mathrm{O}_{3}$ ), also known as glycerin, is created for every 10 pounds $(4.54 \mathrm{~kg})$ of biodiesel produced. Biodiesel production in the United States was 460 million gallons (1.74 billion L) in 2007 and 700 million gallons (2.65 billion L) in 2008. Biodiesel production is anticipated to grow. A report by the National Biodiesel Board (2008) projected that by 2010 about 60 new plants having production capacities of 1.3 billion gallons $\left(4.92 \times 10^{9} \mathrm{~L}\right)$ would open. At the current price of about 2.5 cents $/ \mathrm{lb}$ ( $\$ 0.011$ $\mathrm{US} / \mathrm{kg}$ ), waste glycerol is very competitively priced as a bioreactor feedstock. Given the highly reduced nature of carbon atoms in glycerol, additional advantages can be realized by using glycerol. The sulfate-reduction reaction with reagent-grade glycerol as the carbon source is:

$$
\begin{aligned}
& 4 \mathrm{C}_{3} \mathrm{H}_{8} \mathrm{O}_{3}+7 \mathrm{SO}_{4}{ }^{2-}+2 \mathrm{H}^{+} \rightarrow 12 \mathrm{HCO}_{3}{ }^{-} \\
& +7 \mathrm{H}_{2} \mathrm{~S}+4 \mathrm{H}_{2} \mathrm{O}
\end{aligned}
$$

Using rock-filled columns in a laboratory, Zamzow and others (2006) compared reagent-grade glycerol to biodiesel waste as a carbon source for sulfatereducing bacteria treating sulfate-rich mine waters. Each column processed water containing $900 \mathrm{mg} / \mathrm{L}$ sulfate and received reagent-grade glycerol or biodiesel waste in sufficient quantity to reduce 50 percent of the sulfate. Reagent-grade glycerol was added to form a concentration of $246 \mathrm{mg} / \mathrm{L}$, the level calculated to achieve a 50 percent sulfate reduction, and resulted in the production of $59 \mathrm{mg} / \mathrm{L}$ of soluble sulfide. A concentration of biodiesel waste corresponding to $246 \mathrm{mg} / \mathrm{L}$ of reagent-grade glycerol equivalent resulted in slightly greater sulfate reduction (55\%) and the formation of considerably more soluble sulfide $(92 \mathrm{mg} / \mathrm{L})$. Zamzow and others (2006) noted that whereas 4 moles of reagent-grade glycerol would remove 7 moles of sulfate (reaction 23), a greater volume of biodiesel waste, having only a 68 percent glycerol content, would be needed to achieve the same results. For treatment applications, biodiesel waste has several other advantages. First, it contains about 8 percent methanol and, second, it is alkaline, attributable to $\mathrm{KOH}$ or $\mathrm{NaOH}$ additions during fuel production, which reduces the cost of alkaline addition (Zamzow and others, 2006). These authors also noted the formation of propionic, acetic, formic, and lactic acids by the sulfate-reducing bacteria cultures. Acidity of the AMD was reduced by the inherent alkalinity of the biodiesel waste and conversion of organic carbon into bicarbonate by sulfate reduction (reaction 23). However, the toxicity of methanol in biodiesel waste may limit the use of this material in semipassive bioreactors (Vale, 2007). The potential ecotoxicity of biodiesel waste warrants additional testing before this otherwise promising carbon source is considered for use in field applications. 


\section{FACTORS THAT LIMIT BIOREACTOR FUNCTION}

\section{$\mathrm{pH}$}

Inlet $\mathrm{pH}$ is an important variable in sulfatereducing bioreactor performance. Most research indicates that circumneutral $\mathrm{pH}(>6$ and $<8)$ is required for efficient operation because optimum sulfate-reducing bacterial growth occurs in this $\mathrm{pH}$ range (Thomas and others, 2002b; Cao and others, 2009). More recent investigations both of natural systems (Church and others, 2007) and constructed bioreactors (Tsukamoto and others, 2004; Field and Sierra-Alvarez, 2005; Sierra-Alvarez and others, 2006; Jimenez-Rodriguez and others, 2009) indicated that low-pH $(<5)$ sulfidogenesis is possible, but may produce a lower sulfate and metal removal rate. In addition, the order of metal sulfide precipitate formation is also $\mathrm{pH}$ dependent (Sahinkaya and others, 2009). Sahinkaya and others (2009) conducted geochemical modeling of sulfide precipitation within sulfate-reducing bioreactors having sulfide concentrations of 4 and 8 mmol. These models suggest that iron sulfide will not begin to precipitate until above $\mathrm{pH} 4$, even with an excess of sulfide $(8 \mathrm{mmol})$. However, most of the iron sulfide will be precipitated by $\mathrm{pH}$ 5. The models indicated that trace metal sulfides having a solubility product lower than FeS $\left(3.7 \times 10^{-19}\right)$, such as NiS $\left(10^{-21}\right.$ to $\left.10^{-27}\right)$ and $\mathrm{ZnS}\left(1.2 \times 10^{-23}\right)$, will precipitate at lower optimum $\mathrm{pH}$ (1.0 and 1.5, respectively) (Sahinkaya and others, 2009). Therefore, $\mathrm{pH}$ may strongly influence the success of sulfatereducing bioreactors to remove particular contaminants. The impact of $\mathrm{pH}$ depends on competing geochemical conditions within the bioreactor, such as the amount of sulfide and the retention time. The latter condition relates to competition between the rate of precipitation (the kinetics of the reaction) and the flow rate of AMD through the system.

\section{Temperature}

Buccambuso and others (2007) found that in periods of cold temperature the rate of sulfate reduction was higher for ethanol-fed reactors than for solid substrate reactors. This implies that colder temperatures inhibit cellulose-fermenting microorganisms, which are necessary to degrade the solid organic substrate. Cellulose degradation seems to be the rate-limiting step for solid phase substrate bioreactors treating acid mine drainage (Logan and others, 2005). Kuyucak and others (2006) evaluated the performance of sulfate-reducing bioreactors constructed in northern Quebec Province, Canada, using a solid organic substrate blend to treat ARD. The key innovation of these systems was the addition of insulating soil covers to limit the impact of the region's cold climate on sulfate-reduction rates. No significant seasonal loss of performance was observed when the bioreactor was constructed with a soil cover.

Tsukamoto and others (2004) conducted laboratoryscale tests with methanol and ethanol at moderate $\left(22^{\circ} \mathrm{C}\left[71.6^{\circ} \mathrm{F}\right]\right)$ and low $\left(5-15^{\circ} \mathrm{C}\left[41-59^{\circ} \mathrm{F}\right]\right)$ temperatures. No effect on treatment performance was observed with these simple organic compounds used directly by sulfate-reducing bacteria as a carbon source. Again, this suggests that cellulosefermenting microorganisms are more sensitive to low temperature than sulfate-reducing bacteria. Consequently, solid substrate bioreactors would be more prone to performance reduction at low temperatures than systems using liquid feedstock for bacteria.

\section{Precipitation of micronutrients}

Iron is a required nutrient for sulfate-reducing bacteria (Postgate, 1965). When the sulfate-reducing bioreactor treating typical metal mines drainage is functioning at full efficiency, most iron is removed, reducing iron availability and, thereby, bacterial growth. This problem is not encountered in coal mine AMD where inlet iron values tend to be very high. Desulfovibrio also requires $\mathrm{Na}^{+}, \mathrm{K}^{+}, \mathrm{Mg}^{2+}, \mathrm{SO}_{4}{ }^{2-}$, $\mathrm{Cl}^{-}, \mathrm{HCO}_{3}^{-}, \mathrm{CO}_{3}{ }^{2-}$, and $\mathrm{H}_{2} \mathrm{PO}_{4}^{-}$as nutrients (Postgate, 1965). Cao and others (2009) demonstrated an increase in sulfate-reducing bacteria activity when $\mathrm{Mg}$ was added to a laboratory-scale system. Except for $\mathrm{HCO}_{3}{ }^{-}$and $\mathrm{CO}_{3}{ }^{2-}$, all these solutes are typically present in problematic high-aluminum coal mine AMD that is encountered in the Midwest. However, $\mathrm{HCO}_{3}{ }^{-}$and $\mathrm{CO}_{3}{ }^{2-}$ are provided in solid substrate bioreactors by the fine-grained limestone (up to $3 \%$ ) added to the "compost" mix.

\section{Nitrate inhibition}

Nitrate, or more correctly nitrite $\left(\mathrm{NO}_{2}^{-}\right)$, inhibits sulfate reduction even at low nitrate concentrations (Dalsgaard and Bak, 1994). Nitrate is present in many underground mine pools as a result of domestic sewage pollution and agricultural activi- 
ties (Ducatman and others, 2010). During bacterialaided denitrification of nitrate nitrogen is converted from valence state +5 to valence +3 . Denitrification by certain sulfate-reducing bacteria genera important in mine drainage remediation, such as Desulfovibrio, Desulfobacterium, and Desulfobulbus, reduce nitrate to ammonia. Nitrate will outcompete sulfate for electrons in the life process of the bacterium (Dalsgaard and Bak, 1994). Inhibition of sulfate reduction by nitrate was observed at the Tab-Simco compost-type sulfate-reducing bioreactor in Illinois (Lefticariu and others, 2009). However, nitrate in the inlet AMD at the Tab-Simco site promotes the growth of algae, which could provide an additional carbon source for the sulfate-reduction reaction. Cyclic growth patterns have been observed in these algal deposits. Periods of decreased growth (cyclic algae death) should add fresh organic material to the bioreactor.

\section{Ferrolysis}

Ferrolysis, or dissolution of iron, is a natural process that also may occur within a sulfate-reducing bioreactor. In these reactions, fine ferric oxide particulate matter is solubilized to $\mathrm{Fe}^{2+}$, which, in turn, displaces other cations, such as $\mathrm{Ca}^{2+}$ and $\mathrm{Mg}^{2+}$, in the mineral matrix of minerals such as calcite and dolomite (Hong and others, 1995). Ferrolysis would have the effect of increasing bioreactor iron-removal performance. Bioreactors have been observed to discharge large amounts of calcium and magnesium ions. Calcium discharge from the Tab-Simco compost bioreactor increased from 291 to $549 \mathrm{mg} / \mathrm{L}$, yet magnesium has decreased from 149 to $106 \mathrm{mg} / \mathrm{L}$. This reduction in magnesium concentration may be due to dilution by groundwater that appears in a series of small seeps along the eastern side of the bioreactor cell. Additional study is needed to determine if calcium and magnesium changes are due to limestone dissolution, ferrolysis, or dilution effects.

\section{Toxic metals}

Coal mine drainage may contain trace amounts of $\mathrm{As}, \mathrm{Cu}, \mathrm{Ni}, \mathrm{Zn}, \mathrm{Co}$, and $\mathrm{Cr}$. These elements are typically associated with pyrite and are released upon weathering. Thomas and others (2004) found that trace metal removal and retention in a laboratory bioreactor was dependent on $\mathrm{pH}$. Their simulated LBOS reactor removed trace metals along a
$\mathrm{pH}$ gradient between the inlet $\mathrm{pH}$ of $<3.0$ to the $\mathrm{pH}$ within the cell of $>6.5$ in the order: $\mathrm{As}>\mathrm{Cu}>\mathrm{Cr}>$ $\mathrm{Co}=\mathrm{Ni}=\mathrm{Zn}=\mathrm{Cd}>\mathrm{U}$. Thomas and others (2004) found metals sequestered at the higher $\mathrm{pH}$ will remobilize if low $\mathrm{pH}$ conditions are reestablished by exhaustion of the organic compost or other operational failures, such as channeling/short circuiting in the compost layer, which may lead to an increased flow rate and decreased treatment residence time. The order of remobilization is: $\mathrm{U}>\mathrm{Co}=\mathrm{Zn} \geq \mathrm{Cd}=\mathrm{Ni}>\mathrm{Cr}>$ As. Similarly, manganese may be remobilized by unanticipated low-pH conditions (Behum and others, 2010).

The relation between metal levels and bioreactor health is complex. Although heavy metals may act as nutrients and stimulate growth in low concentrations, Zagury and others (2005) suggested that high concentrations will either inhibit growth or be toxic to the sulfate-reducing bacteria and associated microorganisms. Synergetic detrimental effects have been identified with $\mathrm{Ni}$ and $\mathrm{Zn}$ or $\mathrm{Cu}$ and $\mathrm{Zn}$ (Neculita and others, 2007a). Both Rotting and others (2006) and Gibert and others (2008) found that zinc was incompletely removed from laboratory columns designed for sulfatereducing treatment. Gibert and others (2008) attributed this to: 1) the low rate of sulfate reduction in these experiments, 2) the lower rate of organic molecules-metal complex formation (namely, of binding sites that are already occupied), and 3) the $\mathrm{pH}$ of the bioreactor pore water being less than 7 , a $\mathrm{pH}$ level where many toxic metals are mobile. Geochemical modeling of test data by Gibert and others (2008) indicated that zinc formed an aqueous complex with sulfate $\left(\mathrm{ZnSO}_{4}{ }^{0}\right)$ and remained mobile below $\mathrm{pH}$ 7. Metal toxicity may be abated by the presence of strong chelators (organic acids), buffers $\left(\mathrm{HCO}_{3}^{-}\right)$, or reductants $\left(\mathrm{H}_{2} \mathrm{~S}\right)$.

The concentrations of trace metals that are toxic to microbes in sulfate-reducing bioreactors have been evaluated in several investigations. Utgikar and others (2001) determined the effective concentration that resulted in a 50 percent decrease in sulfate reduction (EC50) and the effective concentration that resulted in a 100 percent decrease in sulfate reduction (EC100) for copper and zinc. This study found that the EC50 was $10.5 \mathrm{mg} / \mathrm{L}$ for copper and $16.5 \mathrm{mg} / \mathrm{L}$ for zinc and EC100 was $12 \mathrm{mg} / \mathrm{L}$ for copper and $20 \mathrm{mg} / \mathrm{L}$ for zinc. Both values are well above copper and zinc concentrations observed in coal mine drainage. Ruhs and others (2005) studied the impact of zinc toxicity on cellulolytic 
bacteria within an experimental sulfate-reducing bioreactor with the concern that these critical bacteria may be more sensitive to metal toxicity. They suggested that metals are absorbed by negatively charged groups such as $\mathrm{COO}, \mathrm{PO}_{4}^{3-}$, and $\mathrm{O}^{2-}$ along the bacterial cell wall, but found that inhibition of bacterial growth correlated well with increasing zinc concentration within the concentration range of 0 to $40 \mathrm{mg} / \mathrm{L}$. Ruhs and others (2005) documented the negative effect of zinc on the growth of the cellulolytic-fermenting bacterium Cellulomonas flavigena. They also found that this effect was lower for high substrate biomass concentrations (lower metal-loading rate) and suggested that sulfatereducing bacteria inhibition attributable to metal (namely, zinc) toxicity may amplify other inhibitory events such as seasonal variations attributable to cold weather and nutrient cycles. Spring was suggested as a time of bioreactor stress when cold weather and nutrient starvation decreased sulfate-reducing and cellulose-fermenting bacteria growth and levels of inhibitory toxic metals such as zinc remained high or increased because of the wet season flushing of mine pools. In field-scale bioreactor applications highlighted in this paper (Table 4), significant amounts of nickel and zinc were removed to low levels at the pilot-scale Fran Mine (Gusek and Wildeman, 2002) and full-scale Tab-Simco bioreactors (Lewis, 2008; Segid, 2010). However, the levels of copper, nickel, and zinc in the AMD treated at these sites may be low enough to avoid any synergistic effects for the toxicity of these metals.

Hong and others (1995) discussed chemical interactions of trace metals in natural interstitial waters and their work can be used to help understand reactions that occur in sulfate-reducing bioreactors. Some chemical species will accumulate in the "sediment" (the solid substrate in the case of a treatment cell), while other constituents remain mobile and may be flushed from the treatment cell. For example, acidity-producing components FeS, FeNiS, and $\mathrm{FeS}_{2}$ are immobile, but the alkalinityproducing component $\mathrm{HCO}_{3}{ }^{-}$is mobile. Hong and others (1995) also noted that pyrite formed in anoxic sediments will adsorb divalent cations in the preferential order: $\mathrm{Co}^{2+}<\mathrm{Cd}^{2+}<\mathrm{Mn}^{2+}<\mathrm{Ni}^{2+}<\mathrm{Zn}^{2+}$. $\mathrm{X}$-ray testing of pyritic sediments indicated that $\mathrm{Zn}$ will eventually form discrete zinc sulfide minerals, whereas $\mathrm{Ni}$ and $\mathrm{Mn}$ are incorporated into the pyrite and the iron monosulfide structure. Organic acids, which are prevalent within bioreactors, will also form complexes with trace metals and could form a secondary source of metal toxicity. The probable order for organic complex formation reported by Hong and others (1995) is: $\mathrm{Hg}^{2+}<\mathrm{Cu}^{2+}<\mathrm{Pb}^{2+}<\mathrm{Zn}^{2+}<\mathrm{Ni}^{2+}<\mathrm{Co}^{2+}$. Understanding the role that these reactions play in mitigating or exacerbating the toxic effects of metals on the microbes in sulfate-reducing bioreactors will require further study.

Metal sulfides act as a bacterial growth inhibitor and the consequent reduction in sulfate-reducing bacteria population decreases the efficiency of the treatment system (Postgate, 1965). What is not clear from short-term bioreactor applications (Table 4) is the impact of accumulated sulfide precipitates on the toxicity within the sulfate-reducing biozone. Periodic flushing has been used successfully to maintain vertical flow RAPS-type systems by removing a portion of the aluminum and iron precipitates from the RAPS limestone bed (Weaver and others, 2004; Hedin Environmental, 2008). However, although sulfide discharges have been observed from passive systems (fig. 5), the ability of flushing to clear a significant amount of sulfide precipitate from a sulfate-reducing bioreactor has not been demonstrated.

\section{Premature failure}

Based on laboratory-scale columns studies, several investigators (Thomas and others, 1999; Waybrandt and others, 2002; Figueroa and others, 2004; Buccambuso and others, 2007) found that an initial high rate of sulfate-reduction in organic substratebased bioreactors was not sustainable. Four factors contributed to this change: 1 ) reduction in alkalinity owing to exhaustion or coating of the limestone amendments to the compost, 2) reduction in the availability of carbon that would be digestible by sulfate-reducing bacteria and cellulolytic-fermenting microorganisms, 3) plugging of the solid substrate by precipitates such as aluminum, and 4) short-circuiting or channeling of treatment flow. Thomas and others (1999) used substrate neutralization potential to predict longevity of organic substrate-based, anaerobic treatment cells. Bioreactors with fine-grained alkaline addition such as the LBOS or DAS designs extend longevity by restricting passivation created by the formation of $\mathrm{Fe}, \mathrm{Al}$, or gypsum coatings (Rose and others, 2007; Rotting and others, 2008a, b). Limestone grain size is a key factor because it is suggested that smaller grains may dissolve before passivation becomes a 
limiting factor. Thomas and Romanek (2002b) illustrated that sulfate minerals (for example, gypsum) largely accumulate as replacement of the limestone grains and not as a matrix infilling. However, excavations of failed vertical flow ponds have also shown zones of flow-blocking sulfide mineral accumulation. Therefore, sulfate-reducing bioreactor layers should be designed and constructed to minimize reduction in hydraulic conductivity that may be caused by sulfide precipitates. This may be accomplished by blending more easily degraded material (for example, straw) with long-lasting material (for example, wood chips) and minimizing compaction by equipment used to place the organic material. In addition to accounting for factors involving available alkalinity and hydraulic conductivity, it is important to provide a longterm source of organic material to maintain bacterial activity (Gusek, 2005a).

\section{SUGGESTIONS FOR RESEARCH}

More research is needed to investigate the importance of the many diverse processes operating in sulfate-reducing bioreactors so that future designs can be optimized to achieve maximum longevity and efficiency. Analytical methods for evaluating sulfate-reducing bioreactor function, performance, and efficiency can be improved. For example, most studies typically have not measured levels of dissolved sulfide in bioreactor discharge. Sulfide in the form of $\mathrm{H}_{2} \mathrm{~S}$ is generally toxic to aquatic life. Although abandoned coal mine drainage often has elevated iron group metals $(\mathrm{Fe}, \mathrm{Mn}$, and $\mathrm{Ni})$ that would quickly scavenge any remaining dissolved sulfide, the level of aqueous $\mathrm{S}^{2-}$ concentrations in passive treatment effluent is not well known. Colorimetric methods such as U.S. EPA Methylene Blue Method (376.2) (USEPA, 1983) or the Hach Method 8131 (Hach Co., 2002), could be used to measure sulfide levels in bioreactor discharge and improve the evaluation of bioreactor performance.

The magnitude of fractionation of the sulfate isotope is dependent on the rate of sulfate reduction (Seal, 2006). Isotope geochemistry has been applied in a study of sulfate reduction in a vertical flow pond (Bhattacharya and others, 2008) and sulfatereducing bioreactors (Segid, 2010; Flege and others, 2012 [this volume]). However, isotopic evaluation of sulfur and carbon could be used to address the rate of sulfate reduction and the contribution of this reaction to alkalinity generation. During sulfate reduction, bioreactor organisms preferentially metabolize the lighter carbon and sulfur isotopes with the lighter isotope used in the life process or biologically aided reaction and the heavier isotopes reporting to the discharge waters. The isotope geochemistry of carbon contained within the pore water (namely, as $\mathrm{HCO}_{3}{ }^{-}$) of a sulfate-reducing bioreactor is complex because it will reflect the signature of dissolved atmospheric $\mathrm{CO}_{2}$, as well as that of the carbon of the carbonate rock and organic matter of which the cell is constructed. However, because of the large isotope fractionation in biogenic carbon, the determination of $\mathrm{C}$ isotope ratios can be used to discriminate whether treatment system alkalinity (in the form of $\mathrm{HCO}_{3}^{-}$) is being produced from carbonate minerals with their characteristic heavier isotopic signature $\left(\delta^{13} \mathrm{C}=-1\right.$ to $+4 \%$ ) or is the result of metabolic processes that produce material having a characteristically much lighter isotopic signature $\left(\delta^{13} \mathrm{C}=\right.$ -23 to $-34 \%$; $\mathrm{C}_{3}$ plants). The values of atmospheric $\delta^{13} \mathrm{C}$ average around $-7.7 \%$ o (Faure, 2005). Carbon isotopes can also be used to discriminate between acid waters derived from the weathering of sulfides in terrains devoid of carbonate rock, which have a mean $\delta^{13} \mathrm{C}=-15 \%$ from neutral $\mathrm{pH}$ groundwater influenced by dissolution of carbonate rock with a $\delta^{13} \mathrm{C}=-9.7 \%$ (Mayo and others, 1992).

Determination of stable isotopes of sulfur can be used to evaluate the efficiency of metabolic activity of sulfate-reducing bacteria in reducing ambient sulfate. The sulfate-reducing bacteria preferentially metabolize the lighter ${ }^{32} \mathrm{~S}$ isotope, which is subsequently sequestered in metal-sulfide precipitates (reaction 8). Any sulfate remaining in the bioreactor and eventually discharged into local surface water is enriched in the heavier ${ }^{34} \mathrm{~S}$ isotope. During sulfate reduction by Desulfovibrio desulfuricans, isotopic fractionation will occur from 15 to $71 \%$ as compared to the inlet AMD (Seal, 2006). This difference can be exploited to evaluate RAPStype vertical flow ponds and sulfate-reducing bioreactor performance. Segid (2010) observed a change within the Tab-Simco bioreactor in $\delta^{34} \mathrm{~S}$ of dissolved sulfate from of $+6.9 \%$ o to $+9.2 \%$, which amounts to enrichment in ${ }^{34} S$ isotope $\left(\Delta^{34} S_{\text {out-in }}\right)$ of $2.3 \%$. This suggests bacterial sulfate reduction is ongoing and is consistent with the findings of a $\Delta^{34} S_{\text {out-in }}$ of 2 to $3 \%$ by Church and others (2007) in studies of sulfate-reducing bacteria activity in metal mine pool waters. By using sulfur isotope geochemistry and comparing the amount of 
calcium into and out of the bioreactor, Segid (2010) concluded that 60 percent of the produced alkalinity (bicarbonate alkalinity) was derived from sulfate reduction with the remainder from limestone dissolution. Branam (2009) used isotopic geochemistry to evaluate the temporal and spatial variability of sulfate reduction in a detailed evaluation of a demonstration bioreactor treating coal mine drainage in southern Indiana. The range of values within a given season was reflective of sample depth; Branam (2009) noted greater sulfate reduction (a higher $\Delta^{34} S_{\text {out-in }}$ ) in the deeper parts of the treatment cell. This finding is important when designing sulfate-reducing bioreactor cell geometry. Specifically, bioreactors that maximize the amount of organic substrate placed deeper in the cell should be more efficient in sulfate removal. More applications of isotope geochemistry to confirm the findings of Segid (2010) and Branam (2009) are warranted to better understand sulfatereducing bioreactor processes and performance.

The interactive role and interdependency of species in the microorganism community is poorly understood. For example, fungi can also metabolize inorganic sulfate to create sulfur-containing organic compounds. However, most bioreactor research on this topic has centered on the role of cellulose-degrading bacteria that produce the more simple organic compounds, such as acetate $\left(\mathrm{CH}_{3} \mathrm{COO}^{-}\right)$and lactate $\left[\mathrm{CH}_{3} \mathrm{CH}(\mathrm{OH}) \mathrm{COO}^{-}\right]$, which, in turn, are consumed by sulfate-reducing bacteria. The role the metal-reducing bacteria such as Gallionellaceaea, algae, fungi, and the more rare acidophilic protist Eugena mutabilis (Das and others, 2009; Lefticariu and others, 2009) is not completely understood. Research has identified a range of microenvironments within the typical sulfate-reducing bioreactor cell. These include acidic, oxic environments within the AMD pool that overlies the anaerobic sulfate-reducing bacteria-bearing zone with transitional environments in between (Lefticariu and others, 2009). Algae may be an important food source for sulfate-reducing bacteria in some existing systems, and there is a possibility that sulfate-reducing bacteria in bioreactors could be "fed" by harvested algae (Das and others, 2009). Abundant algae growth is present in the inlet waters of the Tab-Simco bioreactor because of the high nitrate content in these waters (Lefticariu and others, 2009). The interdependency of biologic activity throughout a multicomponent bioreactor system has not been fully evaluated. Although this discussion is focused on the sulfate- reducing bioreactors, other components are also critical to the overall success of the treatment system.

\section{CONCLUDING REMARKS}

Currently, the evaluation of sulfate-reducing bacteria-based treatment technology is a hot topic in environmental control research. At the time of this writing, Indiana University and the Indiana Geological Survey is undertaking a detailed evaluation of a pilot-scale anaerobic sulfatereducing bioreactor under contracts with the U.S. Office of Surface Mining Reclamation and Enforcement (OSMRE) and the Indiana Department of Natural Resources, Division of Reclamation (Branam, 2009). Additional research is also underway at the Tab-Simco compost bioreactor near Carbondale, Ill., by Southern Illinois University in cooperation with OSMRE and the Illinois Department of Natural Resources, Office of Mines and Minerals (Lewis, 2008; Lefticariu and others, 2009; Segid, 2010). The U.S. Environmental Protection Agency has spent considerable research funds on bioreactor technology for metal mine drainage treatment (Tsukamoto and Miller, 1999; Doshi, 2006; USEPA, 2006). Gusek (2001, 2005b) and Gusek and Wildeman (2002) have presented observations from numerous bench- to full-scale systems. However, most other efforts have been conducted by academic researchers at a laboratory scale.

A few studies have addressed the scale-up problems (namely, the increased complexity of hydrologic conditions at field sites) that must be expected when laboratory experimental designs are applied to a field setting (Gusek, 2005b; Kuyucak and others, 2006; Branam, 2009; Segid, 2010). Despite these limitations, research has identified the principal geochemical and biochemical mechanisms of the treatment process. These include bacterial degradation of cellulose to provide simple organic compounds such as acetate for use as a carbon sources for sulfate-reducing bacteria, which, in turn, reduce the acidity of the AMD by producing bicarbonate alkalinity and sequestering iron and trace metals $(\mathrm{Ni}, \mathrm{Zn}$, and $\mathrm{Cu})$ as sulfides and preventing acidity derived from metal hydrolysis. Nevertheless, more work is needed to define the role of supporting inorganic and organic processes such as: 1) the sequestration of iron by 
bacterial-aided low-pH iron oxidation in the upper portions of a bioreactor, 2) the degree of seasonal variation in limestone dissolution and sulfatereduction-derived alkalinity, and 3) the rate of progression of the $\mathrm{pH}$ and reduction-oxidation front within a bioreactor cell (Thomas and others, 2004). More research is also needed to define specific design criteria such as sulfate and pollutant metal removal rate, metal loading, system longevity, and the limiting environmental factors, such as $\mathrm{pH}$ and temperature. Because of concerns over longevity in solid substrate reactors, continued evaluation of both passive and semipassive bioreactors is warranted.

\section{ACKNOWLEDGMENTS}

I would like to acknowledge the support of the Office of Surface Mining Reclamation and Enforcement, Mid-Continent Region (OSMRE) for the preparation of this paper. Special thanks are given to the peer reviewers whose input greatly improved the presentation. These included James Gusek of Golder Associates, Inc., Lakewood, Colo., Ken Anderson, Southern Illinois University Carbondale (SIUC), and Brian Hicks (OSMRE). Liliana Lefticariu, SIUC, also provided valuable information on bioreactor geochemistry. Larry Lewis and Ron Kiser of the Illinois Department of Natural Resources, Office of Mines and Minerals provided unpublished information on the TabSimco treatment system.

\section{REFERENCES}

Behum, P. T., Hause, D. R., Stacy, M. A., and Branam, T. D., 2008, Passive treatment of acid mine drainage-the Enos Reclamation Project, Indiana-preliminary results, in Barnhisel, R. I., ed., Proceedings of the $25^{\text {th }}$ Annual Meeting of the American Society of Mining and Reclamation, Richmond, Va., June 1419: Lexington, Ky., American Society of Mining and Reclamation, p. 129-147.

Behum, P. T., Hause, D. R., Stacy, M. A., and Branam, T. D., 2010, Passive treatment of high volume net acidic mine drainage-the Enos Reclamation Project, Indiana: National Association of Abandoned Mine Lands Programs Conference, Scranton, Pa., Sept. 19-22, 2012.

Behum, P. T., Hause, D. R., Stacy, M. A., and Branam, T. D., 2012, Passive treatment of large-flow, net acid mine drainage-the Enos Reclamation Project, Indiana, in Comer, J. B., ed., Effects of abandoned mine land reclamation on ground and surface water quality-research and case histories from Indiana: Indiana Geological Survey Special Report 72, p. $165-186$.

Behum, P. T., Jr., Kim, K., Garnett, K. W., Meier, L., Glascock, A., Mueller, M., and Phillips, M., 2002, Rehabilitation of the Old Bevier passive treatment wetland, Macon County, Missouri, in Proceedings of the $24^{\text {th }}$ Annual National Association of Abandoned Mine Land Programs Conference, Sept. 15-18, 2002, Park City, Utah, 21 p.

Bhattacharya, J., Ji, S. W., Lee. H. S., Cheong, Y. W., Yim, G. J., Min, J. S., and Choi, Y. S., 2008, Treatment of acidic coal mine drainage-design and operational challenges of successive alkalinity producing systems: Mine Water and the Environment, v. 27, p. 12-19.

Bigham, J. M., and Nordstrom, D. K., 2000, Iron and aluminum hydroxysulfates from acid surface waters, in Jambor, J. L., Alpers, C. N., and Nordstrom, D. K., eds., Sulfate minerals-crystallography, geochemistry and environmental significance, Mineralogical Society of America Reviews in Mineralogy and Geochemistry, v. 40, p. 351-404.

Boonstra, J., van Lier, R., Janssen, G., Dijkman, H., and Buisman, C. J. N., 1999, Biological treatment of acid mine drainage, in Amils, A., and Ballester, R., eds., Biohydrometallurgy and the environment toward mining of the $21^{\text {st }}$ century, v. 9B: Amsterdam, Elsevier, p. 559-667.

Branam, T. D., 2009, Optimization of bioreactor cell design for treating low-flow acid mine drainage in the Midwest-model development and demonstration: Final report to the Office of Surface Mining Reclamation and Enforcement, 41 p. [Available at <http://www.techtransfer.osmre.gov/NTTMainSite/appliedscience/2006/Projects/SRBCtreatmentTBranam06FR.pdf $>$, date accessed, Nov. 11, 2011.]

Buccambuso, E., Ruhs, A., Figueroa, L., Gusek, J. J., Wildeman, T., Holmes, H., and Reisman, D., 2007, Ethanol-fed or solid-phase organic sulfate reducing bioreactors for the National Tunnel drainage, Clear Creek/Central City Superfund site, in Barnhisel, R. I., ed., $24^{\text {th }}$ National Meeting of the American Society of Mining and Reclamation, Gillette, Wyo., June 2-7: Lexington, Ky., American Society of Mining and Reclamation, p. 95-105.

Cao, J., Zhang, G., Mao, Z, Fang, Z., and Han, B., 2009, Influence of $\mathrm{Mg}^{2+}$ on the growth and activity of sulfate reducing bacteria: Hydrometallurgy, v. 95, p. $127-134$.

Church, C. D., Wilkin, R. T., Alpers, C. N., Rye, R. O., and McCleskey, R. B., 2007, Microbial sulfate reduc- 
tion and metal attenuation in $\mathrm{pH} 4$ acid mine water: Geochemical Transactions, v. 8, no. 10, 14 p. [Available at $<$ http://www.geochemicaltransactions.com/ content $/ 8 / 1 / 10>$, date accessed, Oct. 11, 2011.]

Clyde, E. J., Champagne, P., and Jamieson, H. E., 2010, The use of passive treatment alternatives for the mitigation of acidic drainage at the Williams Brothers mine, California-bench-scale study: Applied Geochemistry, v. 25, p. 958-971.

Costa, M. C., Santos, E. S., Barros, R. J., Pires, C., and Martins, M., 2009, Wine wastes as a carbon source for biological treatment of acid mine drainage: Chemosphere, v. 75, no. 6, p. 831-836.

Craig, H., 1957, Isotopic standards for carbon and oxygen and correction factors for mass-spectrometric analysis of carbon dioxide: Geochimica et Cosmochimica Acta, v. 12, p. 133-149.

Dalsgaard, T., and Bak, F., 1994, Nitrate reduction in a sulfate-reducing bacterium, Desulfovibrio desulfuricans, isolated from rice paddy soil-sulfide inhibition, kinetics and regulation: Applied and Environmental Microbiology, v. 60, p. 291-297.

Das, B. K., Roy, A., Koschorreck, M., Mandal, S. M., Wendt-Pottoff, K., and Bhattacharya, J., 2009, Occurrence and role of algae and fungi in acid mine drainage environment with special reference to metals and sulfate immobilization: Water Research, v. 43, p. $883-894$.

Deutsch, W. J., 1997, Groundwater geochemistry fundamentals and applications to contamination: Boca Raton, Fla., Lewis Publishers, 221 p.

Dijkman, H., Bayer, H. G., and Buisman, C. J. N, 1999, Biotechnology in the mining and metallurgical industries-cost savings through selective precipitation of metal sulfides: Copper 99 International Conference, Phoenix, Ariz., Oct. 10-13, p. 113-126.

Doshi, S. M., 2006, Bioremediation of acid mine drainage using sulfate reducing bacteria: U.S. Environmental Protection Agency, Office of Solid Waste and Emergency Response and Office of Superfund Remediation and Technology Innovation, $72 \mathrm{p}$.

Ducatman, A., Ziemkiewicz, P., Quaranta, J., Vandivort, T., Mack, B., and Van Aken, B., 2010, Coal slurry waste underground injection assessment, final report-phase II: Agreement No. G1090951, West Virginia Department of Health and Human Resources, Office of Environmental Health Services, July 20, 2010.

El Bayoumy, M. A., Bewtra, J. K., Ali, H. I., and Biswas, N., 1999, Sulfide production by sulfate reducing bacteria with lactate as feed in an upflow anaerobic fixed film reactor: Water, Air, and Soil Pollution, v. 112 , p. 67-84.

Evangelou, V. P., 1995, Pyrite oxidation and its control: Boca Raton, Florida, CRC Press, 293 p.
Faulkner, B. B., and Skousen, J. G., 1994, Treatment of acid mine drainage by passive treatment systems, in International Land Reclamation and Mine Drainage Conference and $3^{\text {rd }}$ International Conference on the Abatement of Acidic Drainage, Pittsburgh, Pa., April 24-29: U.S. Bureau of Mines Special Publication SP 06A-94, p. 250-257.

Faure, G., 2005, Isotopes-principles and applications, $3^{\text {rd }}$ ed.: Hoboken, N.J., John Wiley and Sons, 897 p.

Field, J. A., and Sierra-Alvarez, R., 2005, Permeable reactive biobarriers for the containment and remediation of acid mine drainage, final report: Tucson, Ariz., Water Resources Research Center, Federal Grant Number 01-HQ-GR-0113, 20 p.

Figueroa, L., Miller, A., Zaluski, M., and Bless, D., 2007, Evaluation of a two-stage passive treatment approach for mining influenced waters, in Barnhisel, R. I., ed., Proceedings of the $24^{\text {th }}$ National Meeting of the American Society for Mining and Reclamation, Gillette, Wy., June 2-7, Lexington, Ky., American Society for Mining and Reclamation, p. 238-247.

Figueroa, L., Seyler, J., and Wildeman, T., 2004, Characterization of organic substrates used for anaerobic bioremediation of mining impacted waters, in Jarvis, A., ed., Proceedings of the International Mine Water Association Conference, Newcastle, England, Sept. 20-25, p. 43-52.

Flege, A. B., Maynard, J. B., and Elswick, E. R., 2012, Sulfur isotopes as indicators of remediation efficacy in constructed wetlands receiving acid mine drainage, in Comer, J. B., ed., Effects of abandoned mine land reclamation on ground and surface water qualityresearch and case histories from Indiana: Indiana Geological Survey Special Report 72, p. 299-324.

Gibert, O., de Pablo, J., Cortina, J. L., and Ayora, C., 2003, Evaluation of municipal compost/limestone/iron mixtures as filling material for permeable barriers: Journal of Chemical Technology and Biotechnology, v. 78, p. 489-496.

Gibert, O., de Pablo, J., Cortina, J. L., and Ayora, C., 2004, Chemical characterization of natural organic substrates for biological mitigation of acid mine drainage: Water Research, v. 38, no. 19, p. 4,186-4,196.

Gibert, O., de Pablo, J., Cortina, J. L., and Ayora, C., 2008, Evaluation of a sheep manure/limestone mixture for in situ acid mine drainage treatment: Environmental Engineering Science, v. 25, no. 1, p. 43-52.

Goncalves, M. M. M., da Costa, A. C.A., Leite, S. G. F., and Sant'Anna, G. L., Jr., 2007, Heavy metal removal in synthetic wastewaters in an anaerobic bioreactor using stillage from ethanol distilleries as a carbon source: Chemosphere, v. 69, p. 1,815-1,830.

Greben, H. A., Baloyi, L. J., and Venter, S. N., 2007, Grass cellulose as cost-effective energy source for bio- 
logical sulphate removal: Water SA, v. 33, no. 5, p. 729-733.

Gusek, J. J., 2000, Reality check-passive treatment of mine drainage an emerging technology or proven methodology?, in Proceedings of the Society of Mining Engineers Annual Meeting, Salt Lake City, Utah, Feb. 28-March 1, 10 p.

Gusek, J. J., 2001, Why do some passive treatment systems fail while others work?, in Proceedings of the National Association of Abandoned Mine Land Programs, Athens, Ohio, Aug. 19-22.

Gusek, J. J., 2002, Sulfate-reducing bioreactor design and operating issues: Is this the passive treatment technology for your mine drainage?, in Proceedings of the National Meeting of the American Society of Mining and Reclamation, Park City, Utah, Sept. 1518, 14 p. [Available at <http://www.ogm.utah.gov/ amr/naamlp/ $>$, date accessed, Nov. 11, 2011.]

Gusek, J. J., 2004, Scaling up design challenges for large scale sulfate reducing bioreactors, in Proceedings of the National Association of Abandoned Mine Land Programs and $25^{\text {th }}$ Annual West Virginia Surface Mine Drainage Task Force Symposium, Morgantown, W. Va., April 18-24, p. 752-765.

Gusek, J. J., 2005a, Sulfate reducing bioreactor engineering principles: Mine Water Treatment Technology Conference, Pittsburgh, Pa., Aug. 15-18.

Gusek, J. J., 2005b, Selected case studies-applications of sulfate reducing bioreactors in the passive treatment of acid mine/rock drainage: Mine Water Treatment Technology Conference, Pittsburgh, Pa., Aug. 15-18.

Gusek, J. J., and Wildeman, T. R., 2002, Passive treatment of aluminum-bearing acid rock drainage, in Proceedings of the $23^{\text {rd }}$ Annual West Virginia Surface Mine Drainage Task Force Symposium, Morgantown, W. Va., April 16-17.

Guy, R. D., Chakrabarti, C. L., and Schramm, L.,1975, The application of a simple chemical model of natural waters to metal fixation in particulate matter: Canadian Journal of Chemistry, v. 53, p. 661-669.

Hach Company, 2002, Water analysis handbook, $4^{\text {th }}$ ed.: Loveland, Colorado, Hach Company, 1,260 p.

Hedin, R. S., Nairn, R. W., and Kleinmann, R. L. P., 1994a, Passive treatment of coal mine drainage: U.S. Bureau of Mines Information Circular 9389, $35 \mathrm{p}$.

Hedin, R. S., Watzlaf, G. R., and Nairn, R. W., 1994b, Passive treatment of acid mine drainage with limestone: Journal of Environmental Quality, v. 23, no. 6 , p. $1,338-1,345$.

Hedin Environmental, 2008, Optimizing the design and operation of self-flushing limestone systems for mine drainage treatment, final report: Western
Pennsylvania Coalition for Abandoned Mine Reclamation, Dec. 31, 80 p.

Hedrick, J., and Ras, R., 2002, Determination of aquatic impacts resulting from valley fill construction, in Proceedings of the $23^{\text {rd }}$ Annual Meeting West Virginia Surface Mine Drainage Task Force, Morgantown, W. Va., April 16-17, 4 p.

Hem, J. D., 1972, Chemical factors that influence the availability of iron and manganese in aqueous solutions: Geological Society of America Bulletin, v. 83 , p. $443-450$.

Hong, J., Camano, W., and Förstner, U., 1995, Interstitial waters, in Salbu, B., and Steinnes, E., eds., Trace elements in natural waters: Washington, D.C., CRC Press, p. 117-150.

Illinois Department of Agriculture, 2010, Illinois Voluntary Limestone Program Producer information: Illinois Department of Agriculture and Illinois Department of Transportation, Aug. 2010 edition, $12 \mathrm{p}$.

Jimenez-Rodriguez, A. M., Durán-Barrantes, M. M., Borja, R., Sanchez, E., Colmenarejo, M. F., and Raposo, F., 2009, Heavy metal removal from acid mine drainage water using biogenic hydrogen sulfide and effluent from anaerobic treatmenteffect of pH: Journal of Hazardous Materials, v. 165, p. 759-765.

Johnson, D. B., and Hallberg, K. B., 2005, Acid mine drainage options-a review: Total Environment, v. 338, p. 3-14.

Jong, T., and Parry, D. L., 2006, Microbial sulfate reduction under sequentially acidic conditions in an upflow anaerobic packed bed bioreactor: Water Research, v. 40, no. 13, p. 2,561-2,571.

Kepler, D. A., and McCleary, E. C., 1994, Successive alkalinity producing systems (SAPS) for the treatment of acidic mine drainage, in Proceedings of the International Land Reclamation and Mine Drainage Conference and the $3^{\text {rd }}$ International Conference of the Abatement of Acidic Drainage, Pittsburgh, Pa., April 1994, p. 195-204.

Kropfelova, L., Vymazal, J., Svehla, J., and Stochova, J., 2009, Removal of trace elements in three horizontal sub-surface flow constructed wetlands in the Czech Republic: Environmental Pollution, v. 157, no. 4, p. 1,186-1,194.

Kuyucak, N., Chabot, F., and Martschuk, J., 2006, Successful implementation and operation of a passive treatment system in an extremely cold climate, northern Quebec, Canada, in Barnhisel, R. I., ed., $7^{\text {th }}$ International Conference on Acid Rock Drainage, St. Louis, Mo., March 26-30: Lexington, Ky., American Society of Mining and Reclamation, p. 980-992. 
Latimer, H. A., 1999, An ecotoxicological evaluation of active coal mining, agricultural sedimentation and acid mine drainage in three tributaries of the Leading Creek Watershed, Meigs County, Ohio: Blacksburg, Virginia Polytechnic Institute and State University, master's thesis, $84 \mathrm{p}$.

Lefticariu, L., Behum, P. T., Jr., Bender, K. S., Burns, A. S., and Pugh, C. W., 2009, Biochemical evaluation of the Tab Simco mine drainage treatment system: $43^{\text {rd }}$ Annual Meeting of the Geological Society of America North-Central Section, Rockford, Ill., April 2-3, paper no. 6-9.

Lewis, L. L., 2008, Addressing acid mine drainage from complex conditions at the Tab Simco mine (Jackson County, Illinois), in Proceedings of the $30^{\text {th }}$ Annual National Association of Abandoned Mine Land Programs Conference, Durango, Colo., Oct. 26-29, $11 \mathrm{p}$.

Logan, M. V., Reardon, K. F., Figueroa, L. A., McLain, J. E., and Ahmann, D. M., 2005, Microbial community activities during establishment, performance, and decline of bench-scale passive treatment systems for mine drainage: Water Research, v. 39, p. 4,537-4,551.

Martins, M. S. F., Santos, E. S., Barros, R. J. J., and da Silva Costa, M. C. S., 2008, Treatment of acid mine drainage with sulphate-reducing bacteria using a twostage bioremediation process, in Rapantova, N., and Hrkal, Z., eds., Proceedings of the International Mine Water Congress, Karlsbad, Czech Republic, $4 \mathrm{p}$.

Mayo, A. L., Nielsen, P. J., Loucks, M., and Brimhall, W. H., 1992, The use of solute and isotopic chemistry to identify flow patterns and factors which limit acid mine drainage in the Wasatch Range, Utah: Groundwater, v. 30, no. 3, p. 243-249.

McCauley, C. A., O'Sullivan, A. D., Milke, M. W., Weber, P. A., and Trumm, D. A., 2009, Sulfate and metal removal in bioreactors treating acid mine drainage dominated with iron and aluminum: Water Research, v. 43, no. 4, p. 961-970.

Mondal, P., Majumder, C. B., and Mohanty, B., 2007, Treatment of arsenic-contaminated water in a laboratory scale up-flow bio-column reactor: Journal of Hazardous Materials, v. 153, p. 136-145.

Morin, K. A., and Hutt, N. M., 2001, Environmental geochemistry of minesite drainage- practical theory and case studies, digital ed.: Vancouver, Canada, MDAG Publishing.

MSE Technology Applications, Inc., 2006, Designing modular sulfate-reducing bacteria bioreactor to treat acid rock drainage (draft): Mine Waste Technology Program, Activity III, Project 24.
National Biodiesel Board, 2008, U.S. biodiesel production capacity: National Biodiesel Board, Sept. 29, 2008.

Neculita, C. M., and Zagury, G. J., 2008, Biological treatment of highly contaminated acid mine drainage in batch reactors-long term treatment and reactive mixture characterization: Journal of Hazardous Materials, v. 157, p. 358-366.

Neculita, C. M., Zagury, G. J., and Bussière, B., 2007a, Passive treatment of acid mine drainage in bioreactors using sulfate-reducing bacteria-critical review and research needs: Journal of Environmental Quality, v. 36, p. 1-16.

Neculita, C. M., Zagury, G. J., and Bussière, B., 2007b, Efficiency of three reactive mixtures of organic wastes for the treatment of highly contaminated acid mine drainage, in Proceedings of the $60^{\text {th }}$ Canadian Geotechnical Conference and 8th Joint Canadian Geotechnical Society and the Canadian National Chapter of the International Association of Hydrogeologists Groundwater Conference, Ottawa, Canada, Oct. 21-24, p. 1,530-1,537.

Neculita, C. M., Zagury, G. J., and Bussière, B., 2008a, Effectiveness of sulfate-reducing passive bioreactors for treating highly contaminated acid mine drainage-I. Effect of hydraulic retention time: Applied Geochemistry, v. 23, p. 3,442-3,451.

Neculita, C. M., Zagury, G. J., and Bussière, B., 2008b, Effectiveness of sulfate-reducing passive bioreactors for treating highly contaminated acid mine drainage-II. Metal removal mechanisms and potential mobility: Applied Geochemistry, v. 23, p. 3,545-3,560.

Nicholson, R. V., 1994, Iron-sulfide oxidation mechanisms-laboratory studies, in Jambor, J. L., and Blowes, D. W., eds., Environmental geochemistry of sulphide mine-wastes: Mineralogical Association of Canada, p. 163-183.

Paybins, K. S., Messinger, T., Eychaner, J. H., Chambers, D. B., and Kozer, M. D., 2000, Water quality in the Kanawha-New River basin, West Virginia, Virginia, and North Carolina, 1996-98: U.S. Geological Survey Circular 1204, 31 p.

Perdue, E. M., Beck, K. C., and Reuter, J. H., 1976, Organic complexes of iron and aluminum in natural waters: Nature, v. 260, p. 418-420.

Postgate, J. R., 1965, Recent advances in the study of sulfate-reducing bacteria: Bacterialological Reviews, v. 29 , no. 4 , p. $425-441$.

Rotting, T. S., Caraballo, M. A., Serrano, J. A., Ayora, C., and Carrera, J., 2006, Challenges of passive treatment of metal mine drainage in the Iberian Pyrite Belt (southern Spain)-preliminary studies, in Barnhisel, R. I., ed., Proceedings of the $7^{\text {th }}$ Inter- 
national Acid Rock Drainage Conference and the National Meeting of the American Society of Mining and Reclamation, St. Louis, Mo., March 26-30: Lexington, Ky., American Society of Mining and Reclamation, p. 1,753-1,767.

Rotting, T. S., Caraballo, M. A., Serrano, J. A., Ayora, C., and Carrera, J., 2008a, Field applications of calcite dispersed alkalinity substrate (calcite-DAS) for passive treatment of acid mine drainage with high $\mathrm{Al}$ and metal concentrations: Applied Geochemistry, v. 23 , p. $1,660-1,674$.

Rotting, T. S., Thomas, R. C., Ayora, C., and Carrera, J., 2008b, Passive treatment of acid mine drainage with high metal concentrations using dispersed alkaline substrate: Journal of Environmental Quality, v. 37, no. 5, p. 1,741-1,751.

Rose, A. W., 2004, Vertical flow systems-effects of time and acidity relations, in Barnhisel, R. I., ed., Proceedings of the American Society of Mining and Reclamation, Morgantown, W. Va., April 18-24, p. 1,595-1,615.

Rose, A. W, 2006, Long-term performance of vertical flow ponds-an update, in Barnhisel, R. I., ed., Proceedings of the $7^{\text {th }}$ International Conference on Acid Rock Drainage and the National Meeting of the American Society of Mining and Reclamation, St. Louis, Mo., March 26-30, p. 1,704-1,715.

Rose, A. W., Morrow, T., Dunn, M. and Denholm, C., 2007, Mode of gypsum precipitation in vertical flow ponds, in Barnhisel, R. I., ed., Proceedings of the 2007 Annual Meeting of the American Society of Mining and Reclamation, Gillette, Wyo., June 2-7, p. 678-691.

Rowley, M., Warkentin, D. D., and Sicotte, V., 1997, Site demonstration of the biosulfide process at the former Britannia mine: Proceedings of the 4th International Conference on Acid Rock Drainage, Vancouver, Canada, May 30-June 6, v. IV, p. 1,531-1,548.

Ruhs, A., Excoffon, J., Figueroa, L., and Wildeman, T. R., 2005, A study of zinc metal toxicity on the cellulolytic bacteria in anaerobic passive treatment systems, in Barnhisel, R. I., ed., Proceedings of the 2005 National Meeting of the American Society of Mining and Reclamation Billings, Mt., June 19-23, p. 985-998.

Sahinkaya, E., Gungor, M., Bayrakdar, A., Yucesoy, Z., and Yesilnacar, M. I., 2009, A model based on optimization study with OLI stream analyzer for separate metal recovery from acid mine drainage, in Proceedings of the $3^{\text {rd }}$ Annual AMIREG Conference, Sept. 7-8, 2009, Athens, Greece, 5 p.

Sahinkaya, E., and Yucesoy, Z., 2010, Biotreatment of acidic zinc- and copper-containing wastewater using ethanol-fed sulfidogenic anaerobic baffled reactor: Bioprocess and Biosystems Engineering, v. 33, p. 989-997.

Sawyer, C. N., McCarty, P. L., and Parkin, G. F., 2003, Chemistry for environmental engineering and science, $5^{\text {th }}$ ed.: New York, McGraw Hill, 752 p.

Seal, R. R., 2006, Sulfur isotope geochemistry of sulfide minerals: Reviews in Mineralogy and Geochemistry, v. 61, p. 633-677.

Segid, Y. T., 2010, Evaluation of the Tab-Simco acid mine drainage treatment system-water chemistry, performance and treatment processes: Carbondale, Southern Illinois University Carbondale, master's thesis, $82 \mathrm{p}$.

Sierra-Alvarez, R., Karri, S., Freeman, S., and Field, J. A., 2006, Biological treatment of heavy metals in acid mine drainage using sulfate reducing bioreactors: Water Science and Technology, v. 54, no. 2, p. 179-185.

Singer P. C., and Stumm, W., 1970, Acidic mine drainagerate-determining step: Science, v. 167, p. 1,121-1,123.

Skousen, J., Sextone, A., Garbutt, K., and Sencindiver, J., 1995, Passive treatment of acid mine drainage, in Skousen, J., and Ziemkiewicz, P., eds., Acid mine drainage control and treatment, $1^{\text {st }}$ ed.: West Virginia University, National Mine Land Reclamation Center, p. 199-210.

Smith, P. A., 2002, Characterization of an acid mine drainage site in Southern Illinois, in Proceedings of the 2002 National Meeting of the American Society of Mining and Reclamation, Lexington, Ky., June 9-13, p. 472-486.

Stumm, W., and Morgan, J. J., 1981, Aquatic geochemistry: New York, John Wiley and Sons, $470 \mathrm{p}$.

Thomas, B. T., Romanek, C. S., Coughlin, D. P., and Crowe, D. E., 1999, Treatment of acid mine drainage using anaerobic constructed treatment wetlandspredicting longevity and substrate neutralization potential, in Proceedings of the Sudbury '99 Mining and the Environment II Conference, Sudbury, Ontario, v. 2, p. 449-458.

Thomas, R. C., Romanek, C. S., and Paddock, L. S., 2004, Trace metal retention in LBOS-amended vertical flow wetlands treating low- $\mathrm{pH}$, ferric iron-dominated acid rock drainage, in Proceedings of the 2004 National Meeting of the American Society of Mining and Reclamation and 25 $5^{\text {th }}$ Annual West Virginia Surface Mine Drainage Task Force Symposium, Morgantown, W. Va., April 18-24, p. $1,862-1,893$.

Thomas, R. C., and Romanek, C. S., 2002a, Acid rock drainage in a vertical flow wetland I-acidity neutralization and alkalinity generation, in Proceedings of the $19^{\text {th }}$ Annual Meeting of the American Society of Mining and Reclamation, Lexington, Ky., June 9-13, p. 723-751. 
Thomas, R. C., and Romanek, C. S., 2002b, Passive treatment of low-pH, ferric-iron dominated acid rock drainage in a vertical flow wetland II-metal removal, in Proceedings of the $19^{\text {th }}$ Annual Meeting of the American Society of Mining and Reclamation, Lexington, Ky., June 9-13, p. 753-775.

Tsukamoto, T. K., and Miller, G. C., 1999, Methanol as a carbon source for microbiological treatment of acid mine drainage: Water Research, v. 36, no. 6, p. 1,365-1,370.

Tsukamoto, T. K., Killion, H. A., and Miller, G. C., 2004, Column experiments for microbial treatment of acid mine drainage-low-temperature, low-pH and matrix investigations: Water Research, v. 38, p. 1,405-1,418.

URS Corporation, 2003, Passive and semi-active treatment of acid rock drainage from metal mines-state of the practice: Portland, Maine, URS Corp. [prepared for U.S. Army Corps of Engineers].

U.S. Environmental Protection Agency (USEPA), 1983, Sulfide by colorimetric determination, in Methods for chemical analysis of water and wastes: EPA 600/4-79-020, 3 p.

U.S. Environmental Protection Agency (USEPA), 2006, Compost-free bioreactor treatment of acid rock drainage Leviathan Mine, California: Innovative Technology Report, National Risk Management Laboratory, Office of Research and Development, EPA/540/R-06/009, 82 p.

Utgikar, V. P., Chen, B., Chaudhary, N., Tabak, H.H., Haines, J.R., and Govind, R., 2001, Acute toxicity of heavy metals to acetate-utilizing mixed cultures of sulfate reducing bacteria-EC100 and EC50: Environmental Toxicology and Chemistry, v. 20, no. 12 , p. 2,662-2,669.

Vale, A., 2007, Methanol: Medicine, v. 35, no. 12, p. 633-634.

Vance, D. B., 1994, Iron-the environmental impact of a universal element: National Environmental Journal, v. 4, no. 3, p. 24-25.

Watzlaf, G. R., 1997, Passive treatment of acid mine drainage in down-flow limestone systems, in Brandt, J. E., ed., Proceedings of the $14^{\text {th }}$ Annual National Meeting of the American Society of Surface Mining and Reclamation, Austin, Texas, May 10-16, p. 611-622.

Watzlaf, G. R., Kairies, C. L., Schroeder, K. T., Danehy, T., and Beam, R., 2002, Quantitative results from the flushing of four reducing and alkalinity-producing systems, in Proceedings of the West Virginia Surface Mine Drainage Task Force Symposium, Morgantown, W. Va., April 16-17, 11 p.

Waybrant, K. R., Ptacek, C. J., and Blowes, D. W., 2002, Treatment of mine drainage using permeable reactive barriers-column experiments: Environmental Science and Technology, v. 36, p. 1,349-1,356.

Weaver, K. R., Langanese, K., and Hedin, R. S., 2004, Technology and design advancement in passive treatment system flushing, in Proceedings of the 2004 National Meeting of the American Society of Mining and Reclamation and $25^{\text {th }}$ West Virginia Surface Mine Drainage Task Force, Morgantown, W. Va., April 18-24, 15 p.

Weber-Scannell, P. K., and Duffy, L. K., 2007, Effects of total dissolved solids on aquatic organismsa review of literature and recommendation for Salmonid species: American Journal of Environmental Sciences, v. 3, no. 1, p. 1-6.

Wieder, R. K., and Lang, G. E., 1982, Modification of acid mine drainage in a freshwater wetland, in Symposium on Wetlands of the Unglaciated Appalachian Region: Morgantown, West Virginia University, p. $43-53$.

Wilkin, R. T., and McNeil, M. S., 2003, Laboratory evaluation of zero-valent iron to treat water impacted by acid mine drainage: Chemosphere, v. 53, p. 715-725.

Wu, J., Lu, J., Chen, T., He, Z., Su, Y., and Jin, X., 2009, In situ biotreatment of acidic mine drainage using straw as sole substrate: Environmental Earth Sciences, v. 60, no. 2, May 27, 2009, p. 421-429.

Younger, P. L., Banwart, S. A., and Hedin, R. S., 2002, Mine water hydrology, pollution remediation: Boston, Mass., Kluwer Academic Publications, $442 \mathrm{p}$.

Zagury, G. J., and Neculita, C., 2007, Passive treatment of acid mine drainage in bioreactors-short review, applications and research needs, in Proceedings of the $60^{\text {th }}$ Canadian Geotechnical Conference and 8th Joint Canadian Geotechnical Society and the Canadian National Chapter of the International Association of Hydrogeologists Groundwater Conference, Ottawa, Canada, Oct. 21-24, p. 1,439-1,446.

Zagury, G. J., Neculita, C., and Bussière, B., 2005, Passive biological treatment of acid mine drainage-challenges in the $21^{\text {st }}$ century, in Proceedings of the $2^{\text {nd }}$ Mines and Environment Symposium, Rouyn-Noranda, Canada, May 15-18, 2005.

Zamzow, K., Tsukamoto, T., and Miller, G., 2006, Waste from biodiesel manufacturing as an inexpensive carbon source for bioreactors treating acid mine drainage: Mine Water and the Environment, v. 25 , no. 3 , p. $163-170$. 
INDIANA GEOLOGICAL SURVEY SPECIAL REPORT 72 
홍 동

동

ํㅜㄹ

굴

क

훙

용

윽 을

용 웅

호음음

를

르므.

के

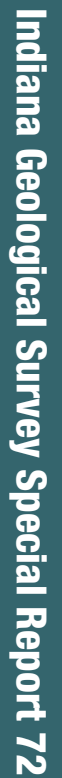

